\title{
The Remedial Investigation of Marine Sediment at the United Heckathorn Superfund Site
}
P. J. White
W. W. Gardiner
N. P. Kohn
J. Q. word

Battelle/Marine Sciences Laboratory

Sequim, Washington

February 1994

Prepared for the

U.S. Environmental Protection Agency

under a Related Services Agreement

with the U.S. Department of Energy

Contract DE-AC06-76RLO 1830

Pacific Northwest Laboratory

Operated for the U.S. Department of Energy

by Battelle Memorial Institute 


\title{
DISCLAIMER
}

This report was prepared as an account of work sponsored by an agency of the United States Government. Neither the United States Government nor any agency thereof, nor Battelle Memorial Institute, nor any of their employees, makes any warranty, expressed or implied, or assumes any legal liability or responsibility for theaccuracy, completeness, or usefulnessof any information, apparatus, product, or process disclosed, or represents that its use would not infringeprivately owned rights. Reference herein to any specific commercial product, process, or service by trade name, trademark, manufacturer, or otherwise does not necessarily constitute or imply its endorsement, recommendation, or favoring by the United States Government or any agency thereof, or Battelle Memorial Institute. The views and opinions of authors expressed herein do not necessarily state or reflect those of the United States Government or any agency thereof.

\author{
PACIFIC NORTHWEST LABORATORY \\ operated by \\ BATTELLEMEMORIAL INSTITUTE \\ for the \\ UNITED STATES DEPARTMENT OF ENERGY \\ under Contract DE-AC06-76RLO 7830
}

Printed in the United States of America

Available to DOE and DOE contractors from the

Office of Scientific and Technical Information, P.0. Box 62, Oak Ridge, TN 37831; prices available from (615) 576-8401. FTS 626-8401.

Available to the public from the National Technical Information Service, U.S. Department of Commerce, 5285 Port Royal Rd., Springfield, VA 22161. 
PNL-9383

UC-510

The Remedial Investigation

of Marine Sediment at the

United Heckathorn Superfund Site

P. J. White

N. P. Kohn

W. W. Gardiner

J. Q. Word

Battelle/Marine Sciences Laboratory

Sequim, Washington

February 1994

Prepared for the U.S. Environmental Protection Agency under a Related Services Agreement with the U.S. Department of Energy under Contract DE-AC06-76RLO 1830

Pacific Northwest Laboratory

Richland, Washington 

The former United Heckathom site in Richmond, California, was used to process and package chlorinated pesticides from the 1940 s to the mid-1960s. These activities resulted in the contamination of upland soils and marine sediment in the adjacent waterways. The site was placed on the National Priorities List by the U.S. Environmental Protection Agency (USEPA) in 1990. Battelle/Marine Sciences Laboratory (MSL) was requested by USEPA to conduct a remedial investigation and feasibility study (RI/FS) of the marine portion of the site. The purpose of this report is to present the results of the RI.

The objectives of this $\mathrm{Rl}$ are as follows: 1) determine the extent of pesticide contamination in inner Richmond Harbor; 2) estimate the total volume of contaminated sediment; 3) characterize the subsurface geology; 4) characterize the biological effects of contaminated sediment; and 5) characterize the quality of effluent derived from dewatered sediment through treatability testing. Sediment cores were collected from 53 stations in the Lauritzen Canal, Santa Fe Channel, Inner Harbor Channel, and Parr Canal. Vertical subsamples from each sediment core were analyzed for chlorinated pesticides. Sediment from selected cores was also analyzed for other contaminants. Sediment thickness and chemistry data were used to estimate volumes of sediment above various levels of contamination. Younger Bay Mud (YBM) sediment from multiple stations was mixed to form composite samples representing various segments of the study area. These composites were used for solid-phase toxicity and bioaccumulation tests, and the preparation of liquid-phase samples for treatability testing. The probable quality of effluent produced by dewatering sediment was evaluated by chemical and toxicological testing of suspended-particulate-phase (SPP) and elutriate samples.

The pesticides 4,4'-DDT, 4,4'-DDD, 4,4'-DDE, and dieldrin were found at higher concentrations and over a larger area relative to background levels for San Francisco Bay than other contaminants. Total DDT (sum of 4,4'-DDT, 4,4'-DDD, and 4,4'-DDE) concentrations were highest in sediment from the Lauritzen Canal (up to approximately 600,000 micrograms per kilogram $[\mu \mathrm{g} / \mathrm{kg}]$ dry weight) and decreased to background levels for San Francisco Bay (less than $20 \mu \mathrm{g} / \mathrm{kg}$ dry weight) near Point Potrero. Contamination was concentrated in the YBM; in general, only traces of contamination were detected in the underlying Older Bay Mud (OBM).

Sediment cleanup criteriahave not yet been established for the United Heckathorn site. The volume of YBM sediment exceeding both $1000 \mu \mathrm{g} / \mathrm{kg}$ and $500 \mu \mathrm{g} / \mathrm{kg}$ total DDT includes all sediment in the Lauritzen and Parr Canals and is estimated to be approximately $65,000 \mathrm{cu}$ yd. Sediment exceeding $100 \mu \mathrm{g} / \mathrm{kg}$ total DDT extends to the northern end of the Inner Harbor Channel, and has a volume of approximately $350,000 \mathrm{cu}$ yd. Sediment exceeding $50 \mu \mathrm{g} / \mathrm{kg}$ total 
DDT extends to the center of the Inner Harbor Channel and has a volume of approximately 600,000 cu yd.

Results of solid-phase toxicity and bioaccumulation tests indicate that the greatest biological impacts are associated with sediment from the Lauritzen Canal. Toxicity to the amphipod, Rhepoxynius abronius, and tissue residues in the clam, Macoma nasuta, decreased with increasing distance from the Lauritzen Canal. These results are consistent with data collected during USEPA's ecological risk assessment for the United Heckathorn site.

Concentrations of DDT and dieldrin in SPP and elutriate samples prepared from Lauritzen Canal sediment exceeded state and federal water quality criteriaby two to five orders of magnitude. Pesticide concentrations in SPP and elutriate samples prepared from composites outside the Lauritzen Canal were one to four orders of magnitude lower. The SPP and elutriate samples prepared from Lauritzen Canal sediment composites caused acute toxicity to the mysid, Holmesimysis costata, and chronic effects in mussel larvae, Mytilus galloprovincialis.

A strong gradient in pesticide concentrations indicates that the Lauritzen Canal is the source of contaminated sediment found in inner Richmond Harbor. A sharp drop in contaminant concentrations from the Lauritzen Canal to the Santa Fe Channel suggests that the rate of contaminant transport out of the Lauritzen Canal is relatively slow. If the highly contaminated sediments were removed from or confined to the Lauritzen Canal, contaminant concentrations in the Santa Fe and Inner Harbor Channels would probably slowly decrease over time.

The fine-grained nature and high water content of the YBM will be an important considerationin the evaluation of remedial alternatives because many remedial technologies are not effective at removing contaminants that are strongly bound to fine-grained particles (USEPA 1993). If YBM sediments are moved, a dredging technique that minimizes sediment resuspension should be selected. The OBM appears to be an excellent barrier to the downward migration of contaminants from recent sediment. Its firm to hard consistency prevents mixing with overlying sediment, and its low water content and relatively low permeability minimize the migration of contaminants by porewater diffusion.

Treatability testing results suggest that controlling for fine-grained particles would not be sufficient to reduce pesticide concentrations in effluent from a confined disposal facility to levels below state water quality objectives. Effluent from Lauritzen Canal sediment would be likely to require treatment with a filtration and carbon-adsorptionsystem capable of removing high concentrations of pesticides. Toxicity must be removed from an effluent prior to discharge to meet the state water quality objectives. A further evaluation might be required to identify reasonable steps necessary to reduce toxicity. 


\section{ACKNOWLEDGMENTS}

The authors thank Jeff Ward and Jim Coley for assistance with the field cruise; Rhonda Karis, Mike Barrows, Heather Mayhew, Lisa Karle, and Brian Gruendell for assistance with sample preparation and biological testing; Jenny Bridge, Larri Ann Bond, and Sharon RapachHenry for data entry, proofreading, and report preparation; Rob Cuello for data audit and quality assurance reviews; Laura Gully for text processing; and Ron Thom and Susan Thomas for their review of this report. 



\section{CONTENTS}

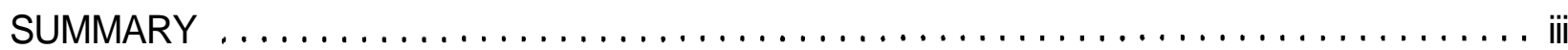

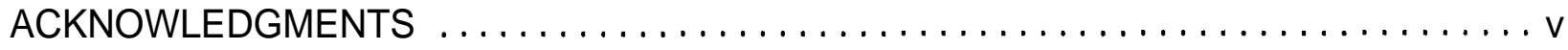

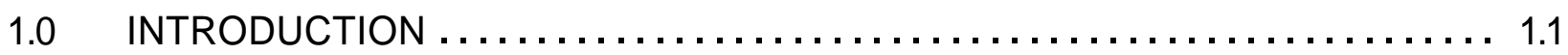

1.1 SITE BACKGROUND $\ldots \ldots \ldots \ldots \ldots \ldots \ldots \ldots \ldots \ldots \ldots \ldots \ldots \ldots \ldots \ldots \ldots, 1.1$

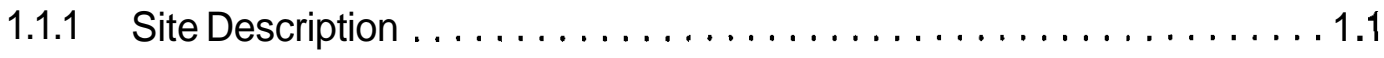

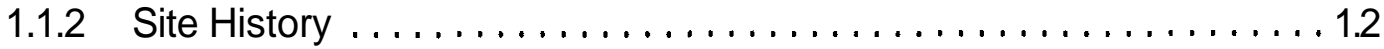

1.1.3 Previous Investigations $\ldots \ldots \ldots \ldots \ldots \ldots \ldots \ldots \ldots \ldots \ldots \ldots \ldots \ldots$

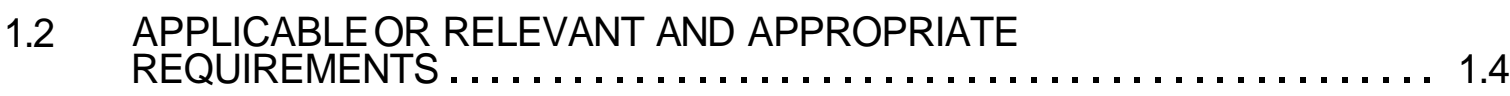

1.3 REMEDIAL INVESTIGATION OBJECTIVES $\ldots \ldots \ldots \ldots \ldots \ldots \ldots \ldots 1.5$

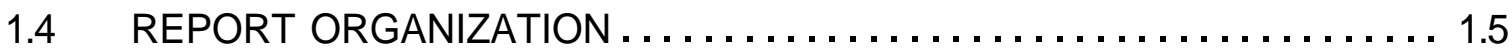

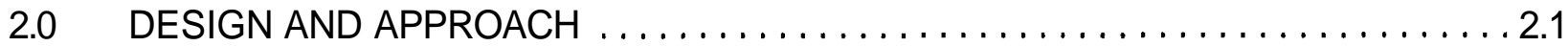

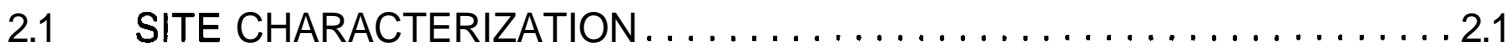

2.1.1 Field Investigation $\ldots \ldots \ldots \ldots \ldots \ldots \ldots \ldots \ldots \ldots \ldots \ldots \ldots \ldots \ldots \ldots \ldots$

2.1.2 Sample Analysis . . . . . . . . . . . . . . . . . . . . . . 2.2

2.1.3 Sediment Volume Calculations $\ldots \ldots \ldots \ldots \ldots \ldots \ldots \ldots \ldots \ldots . . . \ldots$

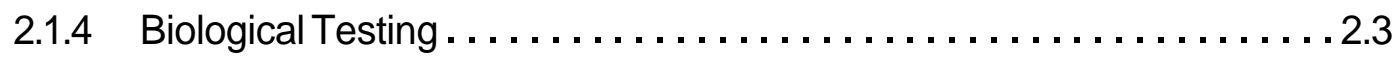

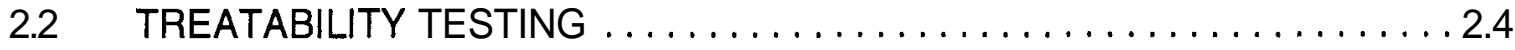

2.2.1 Chemical Analysis of SPP and Elutriate Samples . . . . . . . . . . 2.5

2.2.2 Biological Testing of SPP and Elutriate Samples $\ldots \ldots \ldots \ldots \ldots \ldots 2.5$

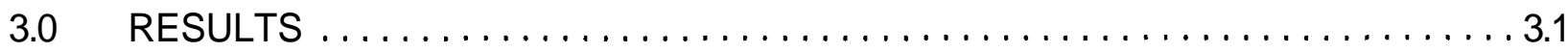

3.1 FIELD INVESTIGATION. . . . . . . . . . . . . . . . . . . . . 3.1

3.1.1 Sediment Core Sampling $\ldots \ldots \ldots \ldots \ldots \ldots \ldots \ldots \ldots \ldots \ldots \ldots \ldots \ldots$

3.1.2 Geology of Marine Sediment . ......................... 3.2

3.1.3 Shoreline Survey and Sediment Grab Sampling $\ldots \ldots \ldots \ldots \ldots \ldots .3$

3.1.4 Control Sediment and Seawater Sampling . . . . . . . . . . . . . . . . 3.3

3.1.5 Sample Preparation................................. 3.4 


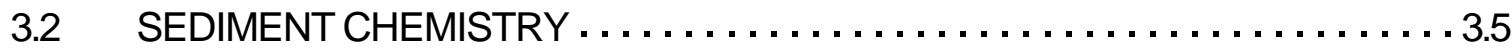

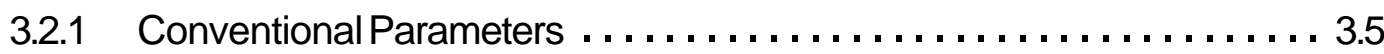

3.2.2 Chlorinated Pesticides . . . . . . . . . . . . . . . . . . . . . 3.5

3.2.2.1 Areal Distribution of Pesticides in Sediment . . . . . . . . . 3.6

3.2.2.2 Vertical Distribution of DDT in Sediment ............... 3.7

3.2.2.3 Distribution of Analogues in Total DDT ............. 3.10

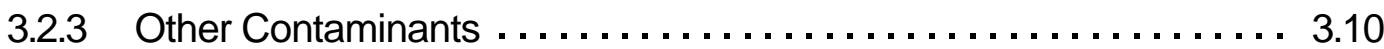

3.2.3.1 Oil and Grease and Total Petroleum Hydrocarbons . . . . . . 3.10

3.2.3.2 Polynuclear Aromatic Hydrocarbons . . . . . . . . . . . . . 3.11

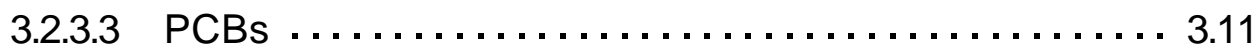

3.2.3.4 Metals $\ldots \ldots \ldots \ldots \ldots \ldots \ldots \ldots \ldots \ldots \ldots \ldots \ldots, 3.11$

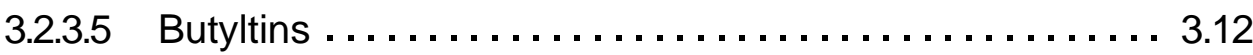

3.3 SEDIMENT VOLUMES $\ldots \ldots \ldots \ldots \ldots \ldots \ldots \ldots \ldots \ldots \ldots \ldots \ldots \ldots \ldots \ldots \ldots \ldots, 12$

3.4 SOLID-PHASE BIOLOGICAL TESTING $\ldots \ldots \ldots \ldots \ldots \ldots \ldots \ldots \ldots .13$

3.4.1 Composite Sediment Chemistry . . . . . . . . . . . . . . . . . 3.14

3.4.1.1 Conventional Parameters ..................... 3.14

3.4.1.2 Chlorinated Pesticides .......................... 3.14

3.4.1.3 Other Contaminants .......................... 3.15

3.4.2 10-Day Static Test With Rhepoxynius abronius .............. 3.16

3.4.3 28-Day Flow- Through Test With Macoma nasuta.............. 3.17

3.4.3.1 Chlorinated Pesticides and Lipid Content ............. 3.17

3.4.3.2 Other Contaminants . . . . . . . . . . . . . . . . . . . 3.18

3.4.3.3 Accumulation Factors $\ldots \ldots \ldots \ldots \ldots \ldots \ldots \ldots \ldots \ldots .19$

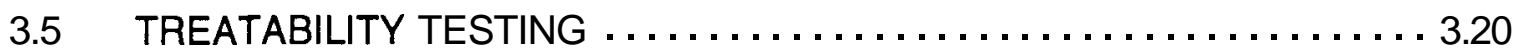

3.5.1 Suspended Particulate Phase and Elutriate Phase Chemistry . . . . . . 3.20

3.5.1.1 Chlorinated Pesticides . . . . . . . . . . . . . . . . . . 3.20

3.5.1.2 Other Contaminants .......................... 32 
3.5.2 96-Hour Static Test with Holmesimysis costata .............. 3.23

3.5.3 48-Hour Static Test with Larval Mytilus galloprovincialis .......... 3.24

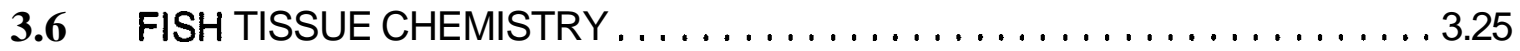

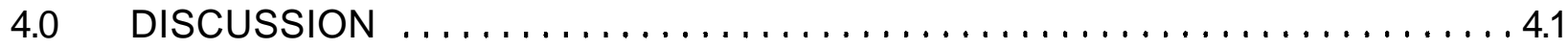

4.1 FIELD INVESTIGATION . . . . . . . . . . . . . . . . . . . . . . 4.1

4.2 SEDIMENT CHEMISTRY $\ldots \ldots \ldots \ldots \ldots \ldots \ldots \ldots \ldots \ldots \ldots \ldots .2$

4.2.1 Nature and Extent of Chlorinated Pesticide Contamination . . . . . . . . . . . 4.2

4.2.1.1 Areal and Vertical Distribution of Pesticides in Sediment ... . 4.3

4.2.1.2 Contaminant Fate and Transport $\ldots \ldots \ldots \ldots \ldots \ldots \ldots .4$

4.2.2 Other Contaminants . . . . . . . . . . . . . . . . . . . . . . . 4.6

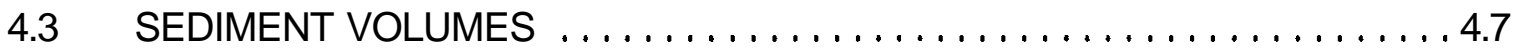

4.4 BIOLOGICAL EFFECTS OF CONTAMINATED SEDIMENT $\ldots \ldots \ldots \ldots .7$

4.4.1 Solid-Phase Acute Toxicity . . . . . . . . . . . . . . . . . . . . . . . . . 4.7

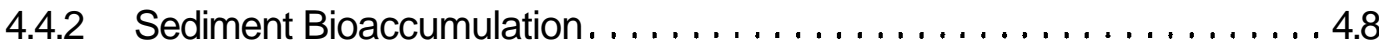

4.5 TREATABILITY TESTING $\ldots \ldots \ldots \ldots \ldots \ldots \ldots \ldots \ldots \ldots \ldots \ldots$

4.5.1 Contaminant Concentrations ....................... 4.10

4.5 .2 Toxicity of Effluent $\ldots \ldots \ldots \ldots \ldots \ldots \ldots \ldots \ldots \ldots \ldots \ldots, \ldots, 11$

5.0 SUMMARY AND CONCLUSIONS $\ldots \ldots \ldots \ldots \ldots \ldots \ldots \ldots \ldots \ldots \ldots \ldots \ldots$

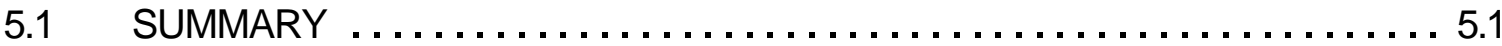

5.1.1 Subsurface Geology of Inner Richmond Harbor .............. 5.1

5.1.2 Areal and Vertical Extent of Marine Contamination ............... 5.1

5.1.3 Volume of Contaminated Sediment . . . . . . . . . . . . . . . . . . . . 5.2

5.1.4 Biological Effects of Contaminated Sediment . . . . . . . . . . . . . 5.2

5.1.5 Probable Quality of Effluent From Dewatered Sediment . . . . . . . . . 5.3

5.2 CONCLUSIONS $\ldots \ldots \ldots \ldots \ldots \ldots \ldots \ldots \ldots \ldots \ldots \ldots \ldots \ldots . ., \ldots \ldots \ldots$

5.2.1 Subsurface Geology of Inner Richmond Harbor . . . . . . . . . . . . 5.3

5.2.2 Areal and Vertical Extent of Marine Contamination . . . . . . . . . . . 5.4

5.2 .3 Volume of Contaminated Sediment . . . . . . . . . . . . . . . . . . . . 5.4 
5.2.4 Biological Effects of Contaminated Sediment ................ 5.4

5.2.5 Probable Quality of Effluent from Dewatered Sediment ........... 5.5

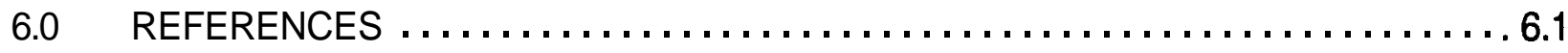

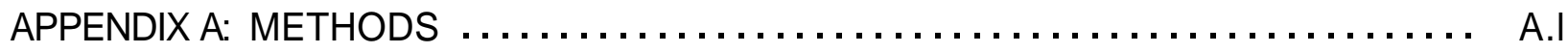

APPENDIX B: GEOLOGIC CORE DATA LOGS ....................... B. 1

APPENDIX C: SEDIMENT CHEMISTRY AND QUALITY ASSURANCE DATA . . . . . . C.I

APPENDIX D: BIOASSAY RESULTS FOR 10-DAY SOLID-PHASE TEST

WITH Rhepoxynius abronius ............................... D. 1

APPENDIX E: BIOASSAY RESULTS FOR 28-DAY SOLID-PHASE TEST WITH

Macomanasuta ........................................ E.I

APPENDIX F: TISSUE CHEMISTRY AND QUALITY ASSURANCE DATA FOR

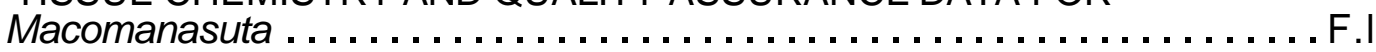

APPENDIX G: LIQUID-PHASE CHEMISTRY AND QUALITY ASSURANCE DATA . . . . . . G.I

APPENDIX H: BIOASSAY RESULTS FOR 96-HOUR SUSPENDED-PARTICULATEPHASE TEST AND 96-HOUR REFERENCE TOXICANT TEST

FOR Holmesimysis costata............................... H.1

APPENDIXI: BIOASSAY RESULTS FOR 48-HOUR SUSPENDED-PARTICULATE-

PHASE TEST AND 48-HOUR REFERENCE TOXICANT TEST FOR

Mytilus galloprovincialis .................................... 1.1

APPENDIX J: FISH TISSUE CHEMISTRY AND QUALITY ASSURANCE DATA ..........I 


\section{FIGURES}

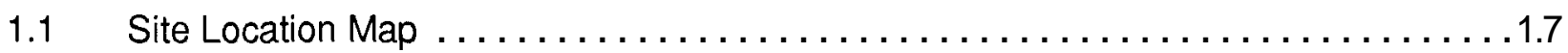

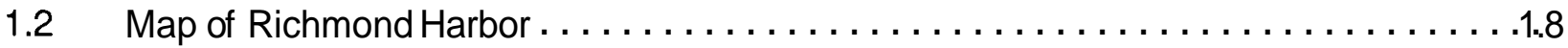

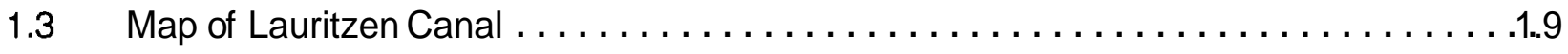

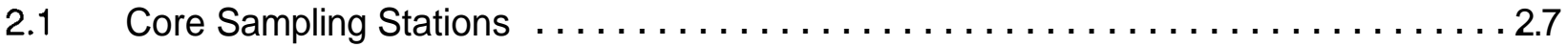

2.2 Sediment Sampling and Processing Procedure $\ldots \ldots \ldots \ldots \ldots \ldots \ldots \ldots \ldots \ldots \ldots \ldots \ldots \ldots$

2.3 Example of Vertical Core Segments. Station $L Z-1 \ldots \ldots \ldots \ldots \ldots \ldots \ldots \ldots \ldots \ldots$

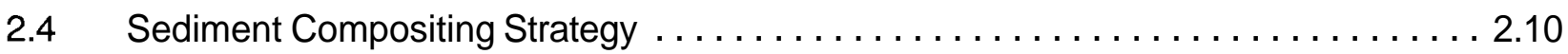

2.5 Suspended-Particulate Phase and Elutriate Preparation Procedure $\ldots \ldots \ldots \ldots \ldots 2.11$

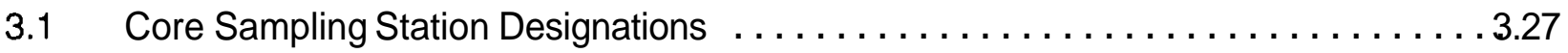

3.2 Elevation of the Mudline and YBM/OBM Contact in the Lauritzen Canal . . . . . . . . 3.28

3.3 Mudline Elevation in Santa Fe and Inner Harbor Channels . . . . . . . . . . . . . 3.29

3.4 Elevation of YBM/OBM Contact in Santa Fe and Inner Harbor Channels . . . . . . . . 3.30

3.5 Map of YBM Thickness . . . . . . . . . . . . . . . . . . . . . . . . . . . . 3.31

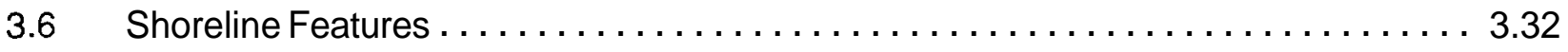

3.7 Approximate Locations of Channel Edge and Graving Dock Grab Sampling Sites . . 3.33

3.8 Distribution of DDT and Dieldrin in YBM, Log Scale . . . . . . . . . . . . . 3.35

3.9 Distribution of DDT and Dieldrin in YBM, Linear Scale $\ldots \ldots \ldots \ldots \ldots \ldots \ldots . . .37$

3.10 Distribution of Total DDT in YBM With Increasing Depth ...................3.39

3.11 Distribution of Total DDT Above and Below the YBM/OBM Contact ..............41

3.12 Cross-Sections of the Lauritzen Canal Showing Total DDT Concentrations . . . . . . . 3.43

3.13 Cross-Sections of the Santa Fe channel Showing Total DDT Concentrations . . . . . 3.45

3.14 Cross-Sections of Inner Harbor Channel Showing Total DDT Concentrations . . . . . 3.47

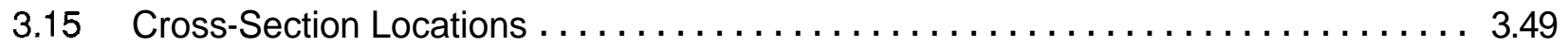

3.16 Boundaries of Sediment Volume Categories . ...................... 3.50 
3.23 Metals and Butyltins in Tissues of Macoma nasuta . . . . . . . . . . . . . . . . 3.80

3.24 Accumulation Factors for DDT Compounds. Dieldrin. Aroclor 1254. and PAHs in Macoma nasuta Tissue . . . . . . . . . . . . . . . . . . . . . . . . . . . . 3.81

3.25 Dieldrin and DDT Compounds in Liquid-Phase Samples . . . . . . . . . . . . . . . . . 3.82

3.26 Chlorinated Pesticides Other Than Dieldrin and DDT Compounds in Liquid-Phase

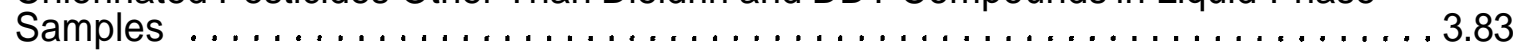

3.27 PAH. PCB. and Tributyltin in Liquid-Phase Samples ......................... 3.84

3.28 Metals in Liquid-Phase Samples ................................. 3.85

3.29 Results of the 96-Hour SPP Test with Holmesimysis costata . ............... 3.86

3.30 Results of the 96-Hour Elutriate Test with Holmesimysis costata . . . . . . . . . . . 3.87

3.31 Results of the 48-Hour SPP Test with Larval Mytilus galloprovincialis ........... 3.88

3.32 Results of the 48-Hour Elutriate Test with Larval Mytilus galloprovincialis . . . . . . . 3.89

4.1 Comparison of Total DDT in Marine Sediment With Previous Studies ........... 4.13

4.2 Relative Contribution of DDT Analogues to Total DDT in Upland and Marine Sediment Samples .......................................4.14

4.3 Concentrations of Contaminants in Sediments from San Francisco Bay and Apparent Effects Thresholds

4.4 Comparison of Action Levels With Contaminant Levels in M. nasuta Exposed to Sediment Composites

4.5 Comparison of Accumulation Factors for DDT and Dieldrin in M nasuta Tissue ............................................ 4

4.6 State and Federal Water Quality Objectives $\ldots \ldots \ldots \ldots \ldots \ldots \ldots \ldots \ldots .18$ 


\section{$1.0 \underline{\text { INTRODUCTION }}$}

The former United Heckathom site is located in Richmond Harbor on the eastern side of San Francisco Bay, California (Figure 1.1). The site was used by several operators to process and package chlorinated pesticides from the 1940s to the 1960s. These activities resulted in the contamination of upland and embankment soils and marine sediment in the adjacent waterways. The site was placed on the National Priorities List (NPL) by the U.S. Environmental Protection Agency (USEPA) in 1990, and became subject to the requirements of the Comprehensive Environmental Response, Compensation and Liability Act (CERCLA), also known as Superfund. Battelle/Marine Sciences Laboratory (MSL) was requested by USEPA to conduct a remedial investigation and feasibility study (RI/FS) of the marine portion of the site. The purpose of this report is to present the results of the RI of contaminated marine sediment in inner Richmond Harbor.

\subsection{SITE BACKGROUND}

The former United Heckathorn facility is located on the eastern shore of the Lauritzen Canal in Richmond, California (Figure 1.2). The site is currently an active marine shipping terminal owned by Levin Enterprises, Incorporated (formerly the Levin Metals Corporation) and operated by the Levin Richmond Terminal Corporation. The marine portion of the Superfund site includes all areas in Richmond Harbor that USEPA determines are adversely affected by contaminants from the former United Heckathom site.

\section{1 . IL Site Description}

The study area for the marine portion of the site includes the Lauritzen Canal, Santa Fe Channel, Richmond Inner Harbor Channel to Point Potrero, and Parr Canal (Figure 1.2). Historical maps indicate that the Richmond Harbor area was originally intertidal marshlands. Dredge and fill activities began prior to 1917 (CH2M Hill 1988). The upland area is $7 \mathrm{ft}$ to $11 \mathrm{ft}$ above mean lower low water (MLLW) and is generally level. The channel shorelines are generally armored with rip rap, sandy gravel fill, or pile-supported docks within a tidal zone that ranges between about $-2 \mathrm{ft}$ and $+7 \mathrm{ft}$ MLLW.

The Lauritzen Canal is approximately $1800 \mathrm{ft}$ long and varies in width from about $120 \mathrm{ft}$ at its north end to about $350 \mathrm{ft}$ at its south end. The depth of the canal ranges from approximately $-10 \mathrm{ft}$ to $-40 \mathrm{ft} \mathrm{MLLW}$. Portions of the canal have been periodically dredged; the most recent maintenance dredging occurred in December 1984 and January 1985, and included an area about $120 \mathrm{ft}$ in width on the eastern side of the channel from the Santa Fe Channel northward about $850 \mathrm{ft}$ (Figure 1.3). The canal was dredged to a depth of approximately $-41 \mathrm{ft} \mathrm{MLLW.} \mathrm{It} \mathrm{is} \mathrm{not}$ known when the northern and western portions of the canal were last dredged. Submerged 
debris in the northern part of the canal include a sunken barge and one tank $5 \mathrm{ft}$ in diameter and $5 \mathrm{ft}$ high. A 5-ft-diameter, reinforcedconcrete culvert enters the north end of the canal and provides storm drainage for the area north of the Lauritzen Canal.

The south end of the Lauritzen Canal enters the Santa Fe Channel. The Santa Fe Channel is approximately $4000 \mathrm{ft}$ long and $300 \mathrm{ft}$ wide. Approximately half of its length is maintained at a depth of $-35 \mathrm{ft}$ MLLW by the U.S. Army Corps of Engineers (USACE). The head of the channel and berth areas are maintained by the Port of Richmond or private owners; bathymetric maps provided by USACE indicate a depth of about $-32 \mathrm{ft}$ MLLW. The Santa Fe Channel connects at its east end with the Inner Harbor Channel, which flows into San Francisco Bay. The Inner Harbor Channel is maintained by USACE to a depth of - $35 \mathrm{ft} \mathrm{MLLW;} \mathrm{a}$ proposed deepening project will increase the depth of the channel to $-38 \mathrm{ft} \mathrm{MLLW.} \mathrm{The} \mathrm{Inner}$ Harbor Channel terminates at Point Potrero. Five former drydocks, known as the graving docks, are located at Point Potrero and are included in the study area for this RI.

The study area also includes the Parr Canal, which extends north from the north end of the Inner Harbor Channel. The Parr Canal is approximately $750 \mathrm{ft}$ long and $100 \mathrm{ft}$ wide. It is less than $10 \mathrm{ft}$ deep. It is armored on both shores with rip-rap. Little is known about its history. Aerial photographs indicate that it was wider during the 1940s and was gradually filled to its present width.

Marine sediment throughout inner Richmond Harbor consists of two geologic units: the Younger Bay Mud (YBM) and the underlying Older Bay Mud (OBM) (USACE 1979). The YBM is typically composed of black or dark gray, very soft to soft clay, silt, and fine-grained sand with a high water content. The YBM was deposited in estuarine and shallow marine environments as sea level rose following the last retreat of glacial ice, about 15,000 to 18,000 years ago (Prest 1969). The YBM is up to $70 \mathrm{ft}$ thick (USACE 1979) and is generally less than $10 \mathrm{ft}$ thick in inner Richmond Harbor. The underlying OBM consists of relatively dry, firm to hard silts and clays with variable amounts of sand. The marine portions of the OBM are finer-grained and generally olive or gray in color. It is believed that the OBM was deposited in shallow marine and terrestrial environments during the interglacial epoch immediately preceding the formation of the Wisconsin ice sheet, and was exposed and subjected to erosion during the first Wisconsonian glacial advance (USACE 1979). While exposed, the OBM sediments desiccated and consolidated. The OBM is up to $200 \mathrm{ft}$ thick. The OBM may be largely unaffected by anthropogenic contamination because of its pre-industrial age, low water content, and consolidated character.

\subsubsection{Site Historv}

An operational history of the United Heckathorn site is provided in a technical memorandum prepared for the California Department of Health Services (CDHS) (CH2M Hill 1988). Other reports provide additional information about site history and operations, 
hazardous materials used on the site, and spills and unauthorized releases (Harding Lawson Associates [HLA] 1984, 1986a, 1986b; CH2M Hill 1987). The most significant aspects of the site history are summarized below.

In the early 1940s, World War II shipbuilding operations were conducted in the area east of the Lauritzen Canal and north of Santa Fe Channel. The site was used from approximately 1945 to 1966 by several operators, including the Parr Richmond Terminal Company, the Universal Pigment and Chemical Company, R.J. Prentiss and Company, Heckathorn and Company, United Chemetrics, and Chemwest (collectively referred to as "United Heckathorn"). Operations on the site prior to 1958 are not well documented. In 1958, Montrose Chemical Corporation began shipping the pesticide dichlorodiphenyltrichlororethane(DDT) to United Heckathorn for processing and packaging. Formulation, processing, and packaging of DDT, dieldrin, and other pesticides continued on the site until 1965 or 1966. The United Heckathorn buildings were demolished by 1970 , and the site was apparently unused during the 1970s. In 1981, the site was purchased by the Levin Metals Corporation.

Little information about the types or quantities of materials used on the site or waste disposal methods is available. An inspection by the California Regional Water Pollution Control Board and California Department of Fish and Game (CDFG) in 1960 indicated that waste water was released directly from the United Heckathorn site into the Lauritzen Canal. These discharges included sewage and laboratory waste, industrial waste from the main plant and outside areas, and wastewater from the vats used to settle solids from DDT air mill wash waters. The discharges entered the canal via pipes on the wharf.

United Heckathorn was cited in 1960 for a release of DDT-laden waste water into the Lauritzen Canal (CH2M Hill 1988). In 1965, CDFG wardens identified a discharge of waste water which had overflowed from or bypassed the DDT settling vats. In addition, surface runoff carrying DDT residue from discarded bags into the canal was noted.

In 1980, the United Heckathorn site was inspected and sampled by the CDHS as part of the Abandoned Site Project. Chlorinated pesticides and metals were detected in soil samples, and the area was designated a state Superfund site in March 1982. In March 1990, USEPA listed the United Heckathorn site on the NPL of federal Superfund sites, and took over as lead agency in August 1990. Contaminated soils were removed from the upland area from 1990 through 1993 (Levine-Fricke 1991b, 1993)

\subsubsection{Previous Investiaations}

From 1983 through 1990, investigations were performed at the United Heckathorn site to characterize the nature and extent of contamination of upland soils, canal embankment sediment, marine sediment, and ground water (HLA 1986a; Levine-Fricke 1990,1991a, 1991b, 1993). Contamination of the upland area was well characterized as a result of these investigations, and 
soil from all known areas of highest contamination has been removed from the site. However, the nature and extent of marine contamination was not delineated. The results of previous investigations are discussed and evaluated in the work plan for this investigation (MSL 1992) and are summarized below.

HLA collected sediment samples from 19 locations in the Lauritzen Canal, most of them from less than $6 \mathrm{ft}$ below mudline. DDT concentrations of up to 765 parts per million (ppm) wet weight were detected. DDT concentrations were much higher in the soft, recent sediment than in the stiffer, underlying clay (presumed to be OBM). Levine-Fricke collected sediment core samples in the Lauritzen Canal and Santa Fe Channel, and found that DDT concentrations decreased from the tens of ppm at the head of the Lauritzen Canal to generally less than $1 \mathrm{ppm}$ at its mouth (Levine-Fricke 1990). In addition, DDT concentrations increased with depth in the sediment. DDT concentrations were generally less than 500 parts per billion (ppb) wet weight in the Santa Fe Channel sediment. Levine-Fricke also detected almost pure, crystalline DDT in embankment sediment immediately west of the site of the former United Heckathom buildings. Other chlorinated pesticides were detected in sediment from the Lauritzen Canal (e.g., aldrin and endrin); however, DDT, DDT analogues dichlorodiphenyldichloroethane (4,4'-DDD) and dichlorodiphenyldichloroethylene (4,4'-DDE), and dieldrin showed much higher concentrations and a wider distribution. Semivolatile and volatile organic compounds, organophosphorus pesticides, and metals were either not detected or detected at lower concentrations and over a more limited area than the chlorinated pesticides.

Five grab samples collected from the Parr Canal in 1985 showed DDT concentrations up to 9 ppm wet weight (HLA 1985). Dredged material disposal studies for inner Richmond Harbor showed DDT concentrations ranging from about 600 ppb dry weight in Santa Fe Channel to less than 5 ppb dry weight west of Point Potrero (Brown et al. 1990, Pinza et al. 1992). For comparison, a range of background values for total DDT in San Francisco Bay sediments is about 3 ppb to 20 ppb dry weight (Long et al. 1988). This range is based upon median values from a compilation of data from 13 studies conducted between 1971 and 1987, excluding areas of known contamination such as Richmond Harbor. Based on data from previous investigations, it appeared that pesticides from the former United Heckathom site had affected marine sediment as far south as the Inner Harbor Channel north of Point Potrero.

\subsection{APPLICABLEOR RELEVANT AND APPROPRIATE REQUIREMENTS}

The remedial action objective for the marine portion of the United Heckathom site is to attain a cleanup level that will allow full beneficial uses of site water, including fish and shellfish harvesting and protection of aquatic life. During the RI/FS process, remediation goals are established in part through the consideration of applicable or relevant and appropriate 
requirements (ARARs) that specify acceptable exposure levels for various constituents. After remediation is complete, concentrations of contaminants must not exceed federal and state environmental regulations, criteria, and standards that are determined to be legally applicable or relevant and appropriate to the site, unless waived by USEPA.

To date, no sediment cleanup criteria for pesticides in marine sediment at the United Heckathorn site have been established. The human health and ecological risk assessments for the site are currently in preparation by USEPA. A discussion of standards, criteria, and other information regarding toxicity used to assess ecological threats at the site is included in the Ecological Risk Assessment of the Marine Sediments at the United Heckathorn Superfund Site (draft)(a). These standards provide the basis for establishing cleanup levels at the site.

\subsection{REMEDIAL INVESTIGATION OBJECTIVES}

Previous investigations established the approximate areal extent of pesticide contamination in inner Richmond Harbor, but did not adequately delineate its vertical extent. As a result, alternatives for the remediation of contaminated marine sediment could not be analyzed in detail because the volume of contaminated sediment was not known. The objectives of the RI/FS of the marine portion of the Heckathorn site are the following:

- Determine the areal extent and depth of contamination in the Lauritzen Canal, Santa Fe Channel, Inner Harbor Channel, and Parr Canal.

- Determine the total volume of contaminated sediment at contamination ranges down to about 2 ppb dry weight.

- Characterize the subsurface geology (ie., depth to Older Bay Mud) throughout inner Richmond Harbor.

- Characterize the biological effects of contaminated sediment and quality of effluent derived from dewatered sediment.

- Analyze alternatives for removing, containing, and/or treating sediments to a cleanup level that will allow full beneficial uses of site waters, including fish and shellfish harvesting and protection of aquatic life and wildlife.

The first four objectives are addressed in this report. The analysis of remedial alternatives will be presented in a FS report.

\subsection{REPORT ORGANIZATION}

This $R \mid$ report is organized in six sections and ten appendixes. Section 1 is the introduction and provides background information for the RI. Section 2 describes the design and

(a) Lee, Henry et al. 1993. Ecological Risk Assessment of the Marine Sediments at the United Heckathorn Superfund Site (Draft). ERL-N: N269. Prepared by the U.S. Environmental Protection Agency, Newport, Oregon. 
approach used to accomplish the objectives of the RI. Section 3 presents the results of the investigation, including field observations, chemical and biological testing of sediment samples, and treatability testing of effluent from dewatered sediment. Section 4 discusses the nature and extent of marine contamination at the site, biological effects of contaminated sediment, and potential impacts of dredging and dewatering sediment during cleanup. Section 5 summarizes the results of the $\mathrm{Rl}$ and conclusions of the study. References are provided in Section 6. Figures and tables appear at the end of each section for the reader's convenience. Supporting data for the $\mathrm{RI}$ are included in the appendixes as follows:

Appendix A: Methods used in the RI, including the field investigation, sample preparation, chemical and biological testing, data analysis, and quality assurance

Appendix B: $\quad$ Geologic core data logs

Appendix C: $\quad$ Sediment chemistry and quality assurance data

Appendix D-E: Solid-phase toxicity test data

Appendix F: $\quad$ Macoma tissue chemistry and quality assurance data

Appendix G: Liquid-phase chemistry and quality assurance data

Appendix $\mathrm{H}$-I: $\quad$ Liquid-phase toxicity test data

Appendix J: $\quad$ Fish tissue chemistry and quality assurance data 


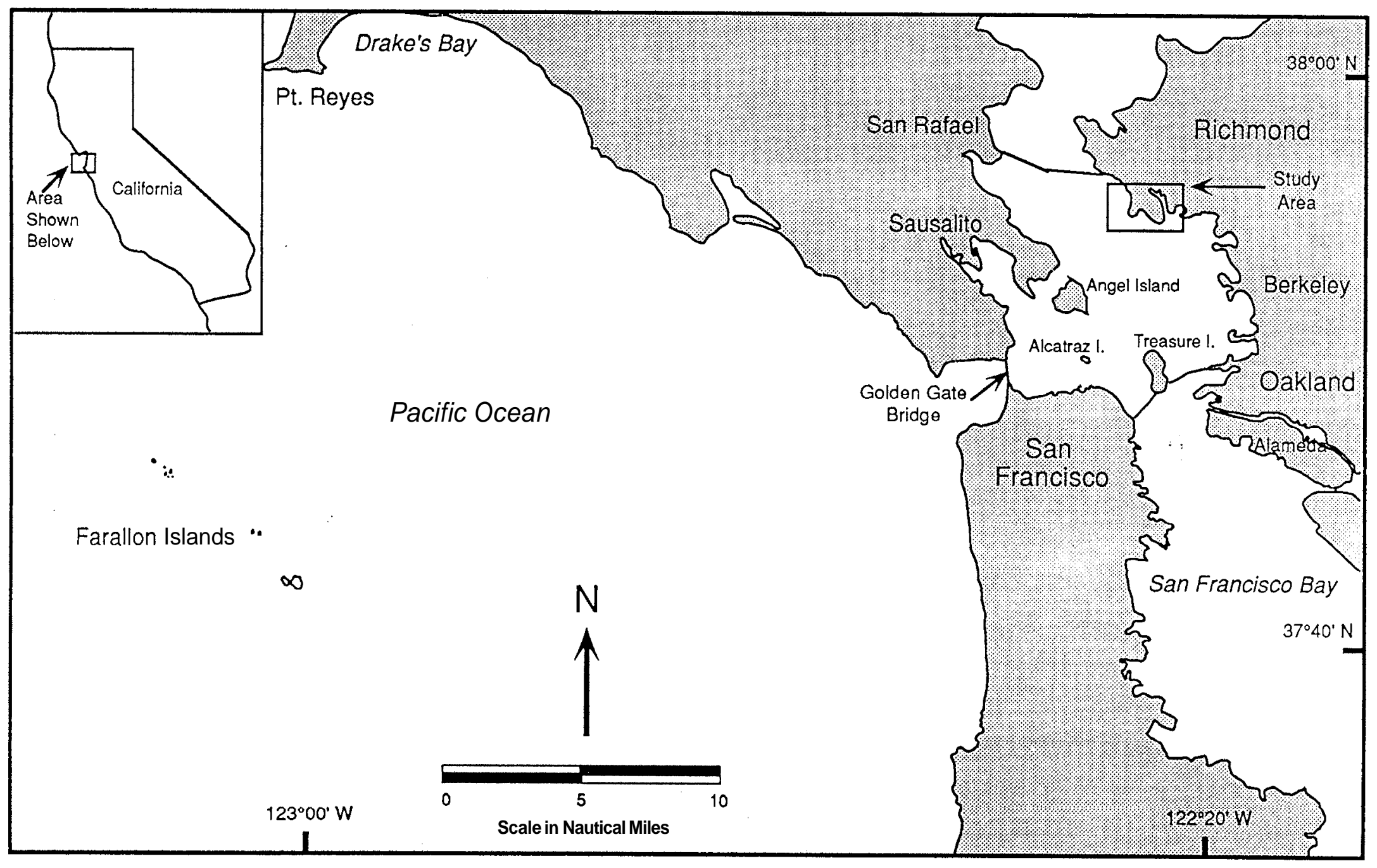

FIGURE 1.1. Site Location Map 


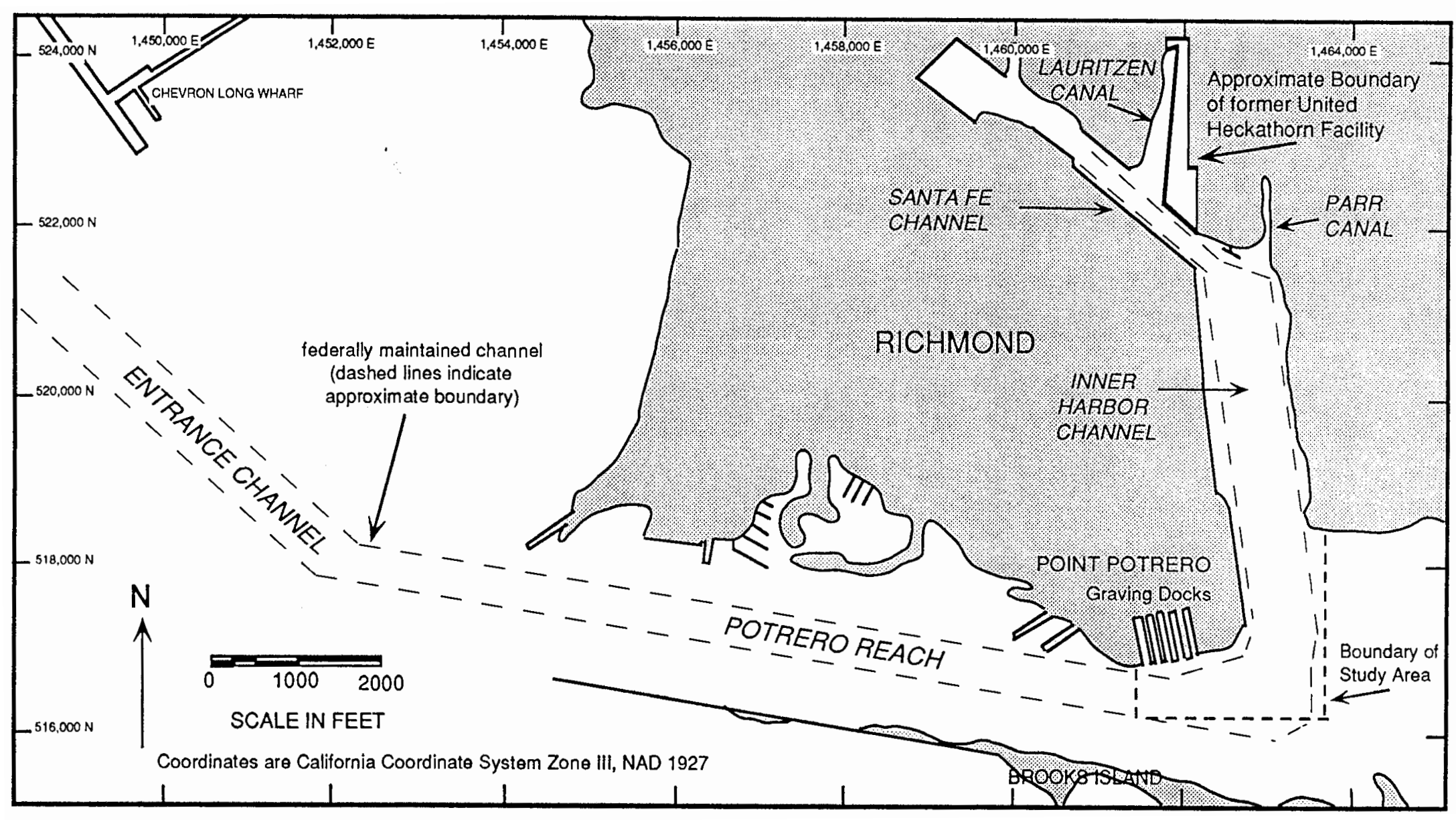

FIGURE 1.2. Map of Richmond Harbor 


\subsection{DESIGN AND APPROACH}

Tasks were developed to accomplish the RI objectives, after reviewing existing information and identifying data needed to characterizemarine contamination at the United Heckathom site. These tasks and the approach used to conduct the Rl are described below. Detailed descriptions of the methods used in the field and laboratory are provided in Appendix A.

\subsection{SITE CHARACTERIZATION}

The primary objective of the site characterization was to determine the areal and vertical extent of pesticide contamination of marine sediment with sufficient resolution to determine the volume of sediment over a specified cleanup level. The site characterization included a field investigation, chemical and biological analysis of sediment samples, and analysis of field and laboratory data. Each of these elements is described below.

\subsubsection{Field Investiaation}

The field sampling design was based upon the assumption that anthropogenic contamination is confined to the recent sediment of the YBM. The underlying OBM is highly consolidated and appears to act as a barrier to the downward migration of contaminants from the YBM. Sediment cores were collected to a depth of at least $2 \mathrm{ft}$ below the YBMIOBM contact at 53 stations in the Lauritzen Canal, Santa Fe Channel, Inner Harbor Channel, and Parr Canal (Figure 2.1). Sampling locations were spaced most closely in the Lauritzen Canal, where contaminant concentrations were the highest and the greatest variation was expected. Sampling stations were spaced progressively farther apart in the Santa Fe and Inner Harbor Channels, where sediment pesticide concentrations were lower and more uniform.

The sediment sampling and analysis procedure is illustrated in Figure 2.2 and described below. The 12-in. core barrel was used at each station to examine sediment lithology, identify the YBMIOBM contact, and collect sediment for biological testing. The 4-in. core barrel was used to collect cores for sediment chemistry. The vertical core sampling strategy was designed to define pesticide distribution with depth and to establish whether the OBM acts as a barrier to contaminant transport. Pesticides were analyzed in samples of the uppermost $1 \mathrm{ft}$ of the YBM, the $1 \mathrm{ft}$ of YBM immediately above the YBMIOBM contact, and the $1 \mathrm{ft}$ of OBM immediately below the contact (Figure 2.3). Samples were also collected in intervals of no greater than $2 \mathrm{ft}$ between the uppermost $1 \mathrm{ft}$ and the $1 \mathrm{ft}$ interval above the contact. The OBM from the $1 \mathrm{ft}$ to $2 \mathrm{ft}$ interval below the YBMIOBM contact was archived for future analysis, if necessary. Grain size distribution and total organic carbon (TOC) were also measured in each of the vertical samples to provide information about the availability of contaminants to marine organisms. 
Samples representing the entire thickness of the YBM at selected stations were analyzed for contaminants other than pesticides. All cores from the upper Santa Fe Channel and Parr Canal were analyzed because of the lack of existing data for these areas. Composite samples of YBM were collected from approximately half of the stations in the Lauritzen Canal and federal Santa Fe Channel. Composite samples of YBM were collected from three stations in the Inner Harbor Channel; existing data for the remainder of the channel are considered adequate. Two composite samples of the OBM (fine-grained and coarse-grained) were also analyzed for other contaminants.

Sediment samples representing different segments of the study area were collected for biological testing (Section 2.1.4). Composites of subsamples collected from the uppermost $1 \mathrm{ft}$ of YBM were prepared to represent the Lauritzen Canal, upper Santa Fe Channel, federal Santa Fe Channel, Inner Harbor Channel, and the graving docks at Point Potrero. Composite samples of YBM representing the 1-ft- to 4-ft- and 4-ft- to 7-ft-below-mudlineintervals in the Lauritzen Canal were also prepared. Samples of fine-grained and coarse-grainedsediment from San Francisco Bay were collected for use as grain-size controls in biological testing.

In addition to core sampling, a shoreline survey was conducted throughout the study area to document the nature of the channel banks and identify locations where grab samples of soft sediment could be collected. Sediment along the channel edges could not be sampled with the core barrel because the banks are generally armored with rip-rap or sheetpile. Grab samples ( 1 gal to 2 gal of sediment each) were collected at 16 stations and combined to form seven composite samples. These samples were analyzed for pesticides to assess whether the channel edges might act as a continuing source of contaminated sediment after dredging of the channels was complete. Seawater from Richmond Harbor was also collected during the field investigation for use in the treatability study (Section 2.2).

\subsubsection{Sample Analysis}

Sediment samples collected during the field investigation were prepared for chemical and biological testing, or archived for possible future analysis. In addition, tissue samples generated during bioaccumulation studies were chemically analyzed. Data quality objectives (DQOs) for sample analysis were specified in the Quality Assurance Project Plan (QAPP) for the RI (MSL 1992). Analytical data underwent quality control (QC) review by the Task Leader and the Quality Engineer prior to data evaluation to ensure that DQOs were met.

Analytical requirements for the sediment core samples are outlined in Figure 2.2. Vertical core samples and grab samples were analyzed for chlorinated pesticides, grain size, and total organic carbon (TOC). Composite samples of the YBM and OBM were analyzed for oil and grease, total petroleum hydrocarbons (TPH), polynuclear aromatic hydrocarbons (PAHs), polychlorinated biphenyls (PCBs), metals, and butyltins. Composite sediment samples for 
biological testing and grain-size control sediment from San Francisco Bay were analyzed for all of the above-referenced parameters.

A number of sediment samples were archived to minimize the need for additional field sampling. The following sediment samples were frozen and archived for possible future analysis:

- a duplicate of every sample

- OBM material from the $1 \mathrm{ft}$ to $2 \mathrm{ft}$ interval below the YBM/OBM contact to be analyzed if contamination was detected in the uppermost $1 \mathrm{ft}$ of the OBM

- native control sediments collected for biological testing (excluding the San Francisco Bay controls).

Tissue samples of organisms exposed to sediment composites in a laboratory bioaccumulation test were analyzed for chlorinated pesticides, PAHs, PCBs, metals, and butyltins (Section 2.1.4). The lipid content of the tissues was also measured to provide information about contaminant uptake. Tissue samples from organisms exposed to control sediment were archived. Ten whole fish tissue samples (Cymatogasteraggregata) that were collected by USEPA during the ecological risk assessment were analyzed for chlorinated pesticides, PCBs, PAHs, and phthalate esters.

\subsubsection{Sediment Volume Calculations}

The thickness of the YBM at each coring station was measured in both the 12-in. and 4-in. cores. These data were used to calculate approximate volumes of recent sediment (YBM) present in various segments of the study area and volumes of sediment above specified contaminant concentration levels. In addition, weighted average contaminant concentrations were determined for given volumes of sediment.

\subsubsection{Bioloaical Testing}

Solid-phase toxicity and bioaccumulation tests were conducted using composite sediment samples collected from segments throughout the study area to characterize the effects of contaminated sediment on marine organisms. Figure 2.4 shows the compositing strategy for toxicity testing. Solid-phase toxicity tests were conducted on sediment composites (treatments) of the uppermost $1 \mathrm{ft}$ of sediment from the following areas: the Lauritzen Canal (four treatments), upper Santa Fe Channel, federal Santa Fe Channel, Inner Harbor Channel (three treatments), and the graving docks. Two grain-size control treatments (fine-grained and coarse-grained) from San Francisco Bay were also tested. The amphipod, Rhepoxynius abronius, was exposed in each of five replicates for each sediment treatment under static conditions for 10 days. Native control sediment from West Beach, Washington, was used to validate test results, and cadmium chloride reference toxicant tests were performed to evaluate the relative sensitivity of the test stock of $R$. abronius used during the solid-phase toxicity testing. Data from solid-phase toxicity tests were analyzed using analysis of variance (ANOVA) to assess statistical differences in test 
organism survival between sediment treatments. Test results were compared to acute toxicity data collected during the ecological risk assessment of marine sediments at the United Heckathom site.

A 28-day bioaccumulation test was conducted using the bentnose clam, Macoma nasuta. YBM composites of the uppermost $1 \mathrm{ft}$ of sediment from the following areas were tested: the Lauritzen Canal, upper Santa Fe Channel, federal Santa Fe Channel, upper Inner Harbor Channel, and graving docks (Figure 2.4). Twenty-five M. nasuta were exposed in each of five replicates of each sediment treatment, plus two control treatments (M. nasuta native sediment from Sequim Bay, Washington, and a fine-grained control sediment from San Francisco Bay). Following 28 days of sediment exposure, the surviving M. nasuta were placed in clean-flowing seawater for two days to depurate (purge all sediment from the gut). The tissues from the test sediment treatments were sent to a laboratory for chemical analysis. Tissues from control organisms were frozen and archived for potential future analysis. A tissue sample from each replicate was analyzed for pesticides and lipid content. Tissues from the five replicates for each treatment were combined to form a composite sample that was analyzed for PAHs, PCBs, metals, and butyltins. Results were evaluated to determine the bioaccumulation of DDT and DDT analogues into the tissues of $M$. nasuta. Data were compared to tissue residues measured by USEPA in the ecological risk assessment for the site.

\subsection{TREATABILITY TESTING}

Treatability testing was conducted to assist in the evaluation of remedial alternatives. Preliminary remedial alternatives identified for analysis in this study include the no-action altemative, dredging of sediments followed by containment in a confined disposal facility or permitted upland disposal site, and filling of all or a portion of the Lauritzen Canal as an altemative confined disposal facility.

The probable quality of effluent produced by dewatering sediment during confined disposal operations was evaluated by chemical and toxicological testing of suspendedparticulate phase (SPP) and elutriate samples derived from sediment composites throughout the study area. The USACE modified elutriate test (Palerrno 1986; Palermo and Thackston 1988) was used to predict the dissolved and particulate-associated contaminant concentrations in effluent by simulating confined disposal conditions. In addition, the effect of activated carbon treatment on contaminant concentrations in effluent was evaluated. These results were also used to evaluate potential water quality impacts during dredging. Composite sediment samples of the YBM in the following areas were tested: Lauritzen Canal (four treatments), upper Santa Fe Channel, federal Santa Fe Channel, and Inner Harbor Channel (three treatments)(Figure 2.4). The Lauritzen Canal composites were composed of YBM sediment from the following intervals below the mudline: $0 \mathrm{ft}$ to $1 \mathrm{ft}, 1 \mathrm{ft}$ to $4 \mathrm{ft}$, and $4 \mathrm{ft}$ to $7 \mathrm{ft}$. The sediment treatments in Santa Fe 
Channel and Inner Harbor Channel were composed of the uppermost $1 \mathrm{ft}$ of sediment, which were also tested for solid-phase toxicity.

Procedures used to prepare SPP and elutriate samples are described in detail in Appendix A and summarized in Figure 2.5. A slurry was prepared to simulate the influent concentration of sediment entering a confined disposal facility. The slurry was centrifuged at low speed for approximately $15 \mathrm{~min}$ to simulate a 24 -h settling period. The supernatant after the lowspeed centrifugation represents the SPP. A portion of the SPP was centrifugedat high speed for $30 \mathrm{~min}$ to prepare the elutriate phase samples. The supematant after the high-speed centrifugation represents the dissolved phase.

\subsubsection{Chemical Analysis of SPP and Elutriate Samples}

The SPP and elutriate of the effluent from each composite were analyzed for pesticides, PAHs, PCBs, metals, and butyltins. Carbon-treated elutriate was analyzed for pesticides and TPH. SPP and elutriate chemical data were compared to applicable marine water quality criteria and used to predict whether treatment of effluent would be required during disposal operations.

\subsubsection{Bioloaical Testina of SPP and Elutriate Samples}

SPP and elutriate toxicity tests were conducted using mysids (Holmesimysis costata) and bivalve larvae (Mytilus galloprovincialis) to evaluate the potential impacts of effluent on marine organisms. In each test, organisms were exposed under static conditions to SPP and elutriate concentrations of $100 \%, 50 \%, 10 \%$, and $0 \%$ (control), with three replicates per concentration. In the 4-day mysid test, 10 organisms per replicate were exposed, and in the 2- to 3-day larval test, approximately 8,000 larvae per replicate were exposed. SPP and elutriate toxicity test results were analyzed by attempting to construct mean dose-response curves for each treatment. If survival in the control or diluted-water treatments was greater than survival in the $100 \%$ SPP or elutriate treatment, the data were evaluated statistically to determine whether the $100 \%$ treatment was significantly more toxic than the other treatments. If greater than $50 \%$ mortality occurred in any of the treatments, the median lethal concentration $\left(\mathrm{LC}_{50}\right)$ was calculated. If less than $50 \%$ mortality occurred in all treatments, the $\mathbf{L C}_{50}$ was assumed to be $100 \%$. For one composite with greater than $50 \%$ mortality in all treatments, mysids were exposed to additional SPP and elutriate dilutions of $0.01 \%, 0.1 \%$, and $1 \%$. The elutriate from this composite was also filtered through granular-activated carbon (GAC); mysids were exposed to filtered and unfiltered elutriate. The toxicity data will be used to identify remedial actions that will prevent negative impacts to marine organisms. 



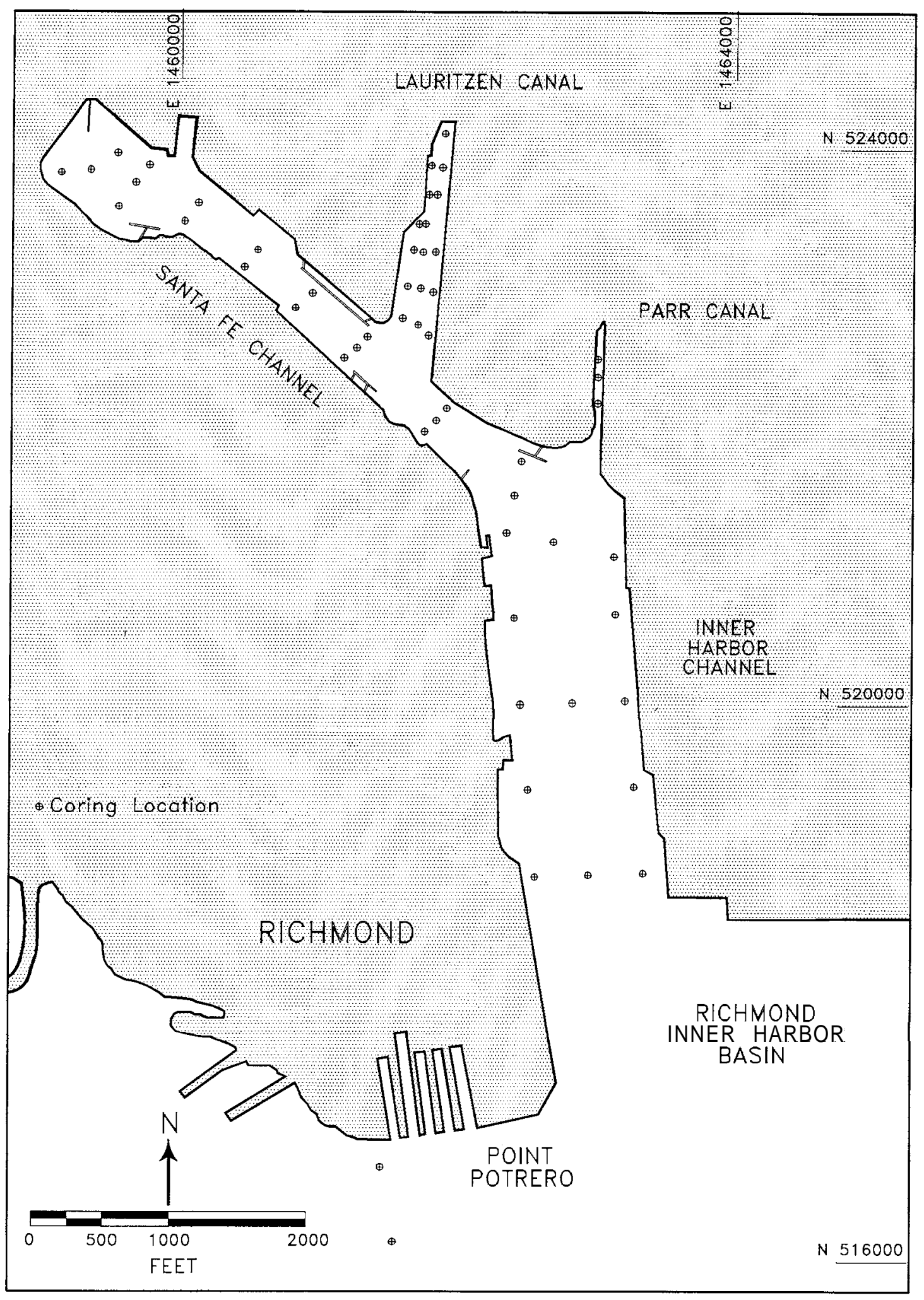

FIGURE 2.1. Core Sampling Stations

2. 7 
12-in. Core

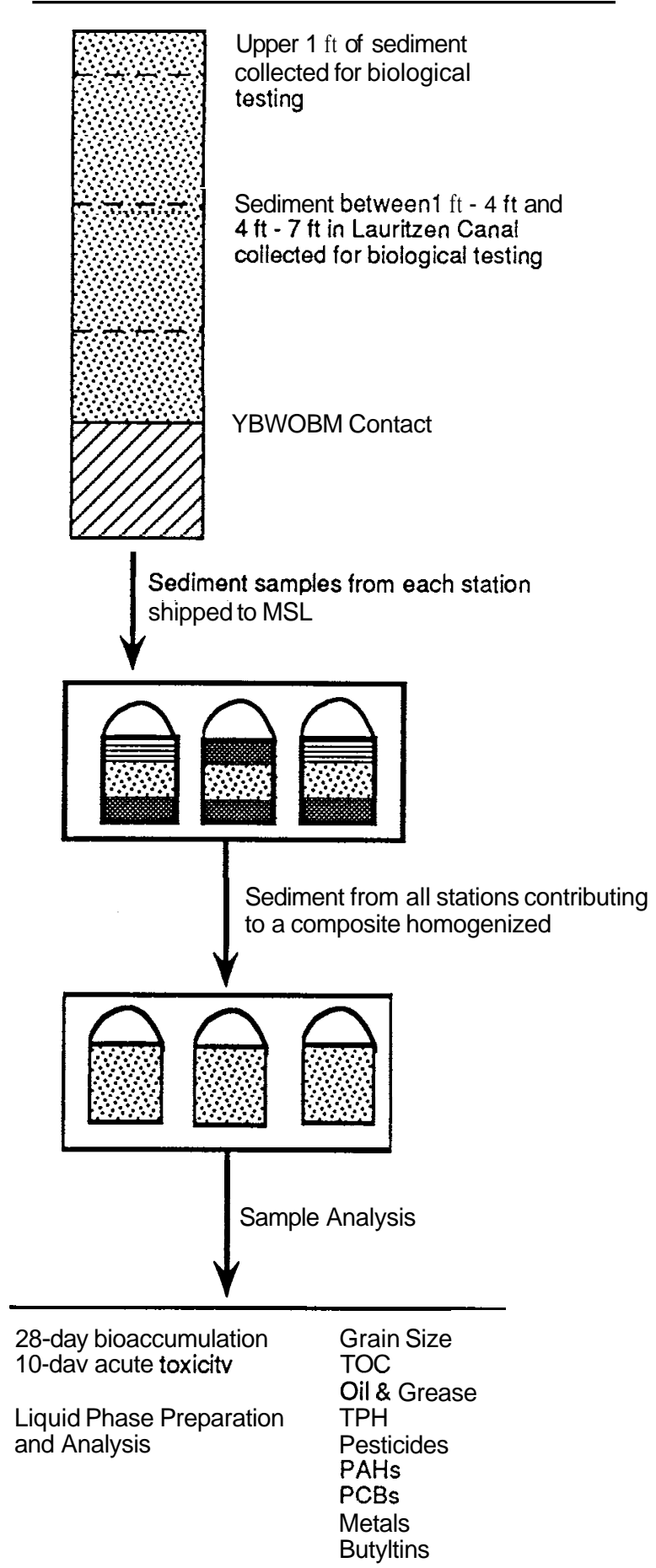

4-in. Core

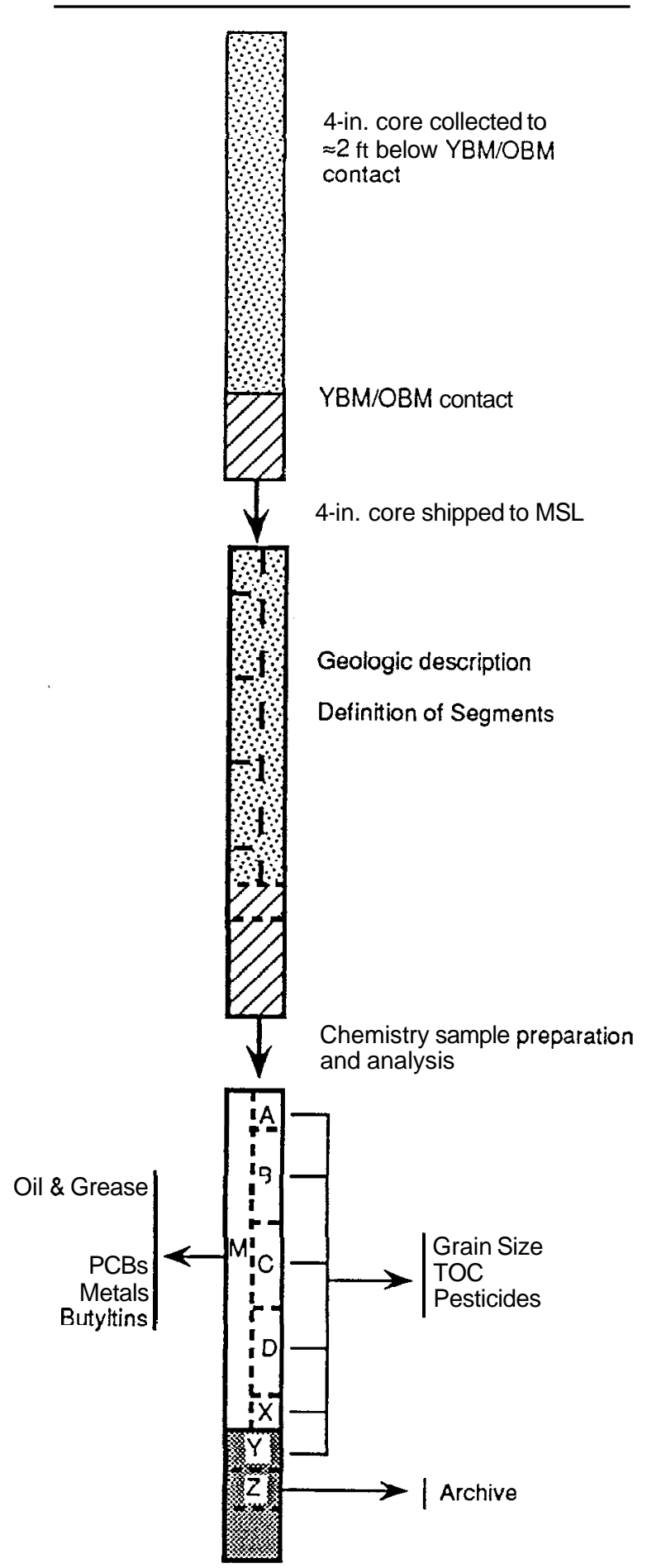

FIGURE 2.2. Sediment Sampling and Processing Procedure 

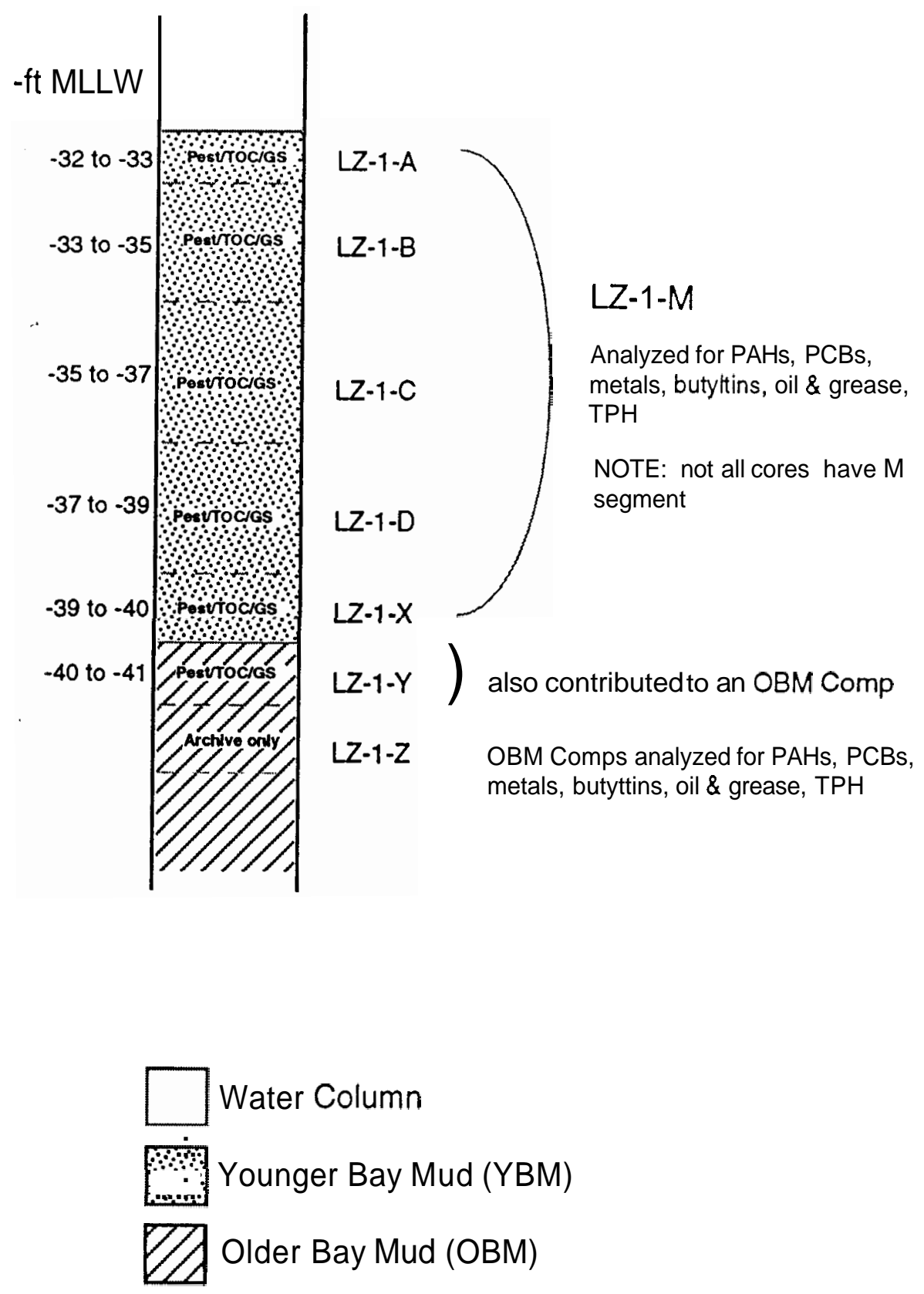

FIGURE 2.3. Example of Vertical Core Segments, Station LZ-1 


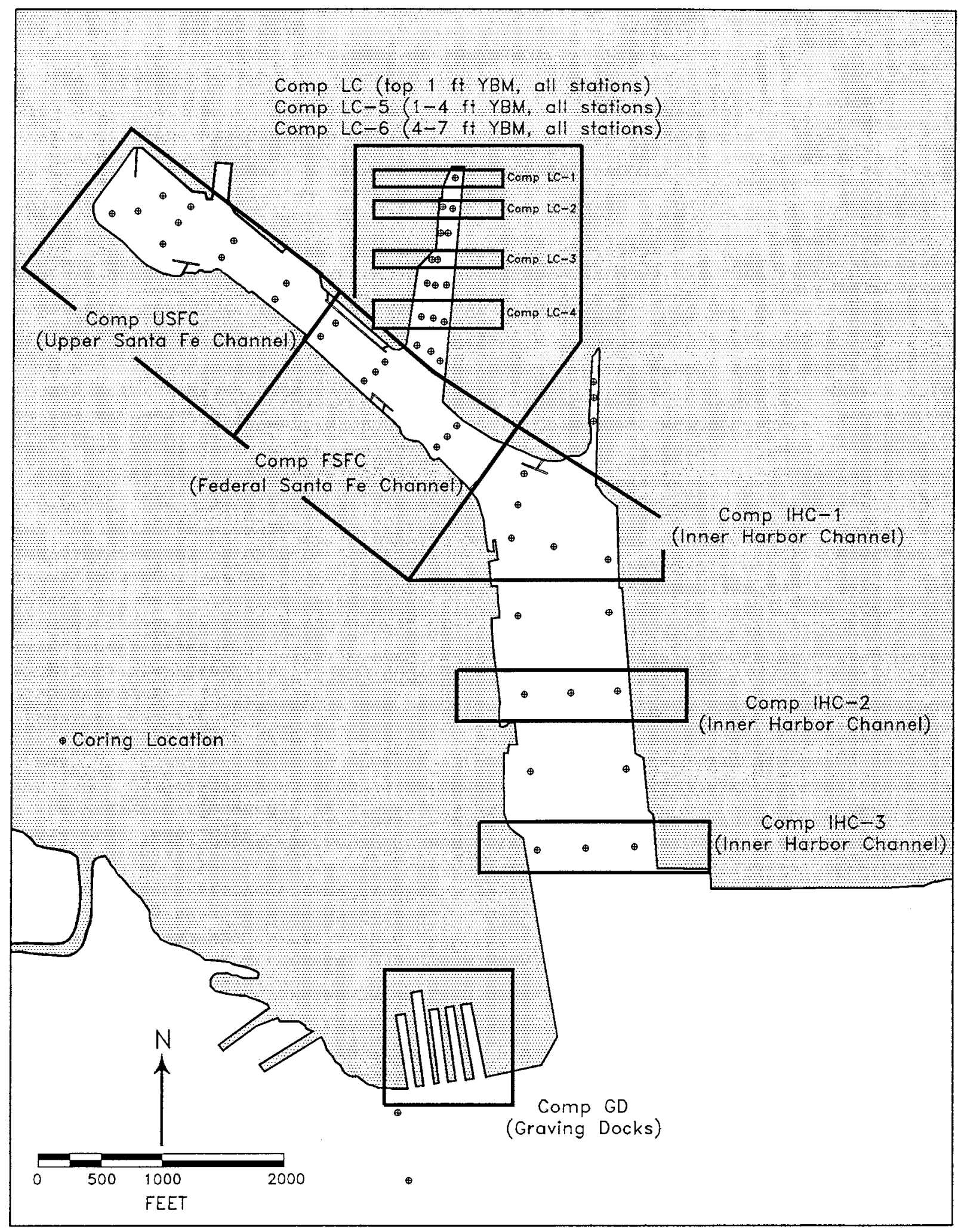

FIGURE 2.4. Sediment Cornpositing Strategy 


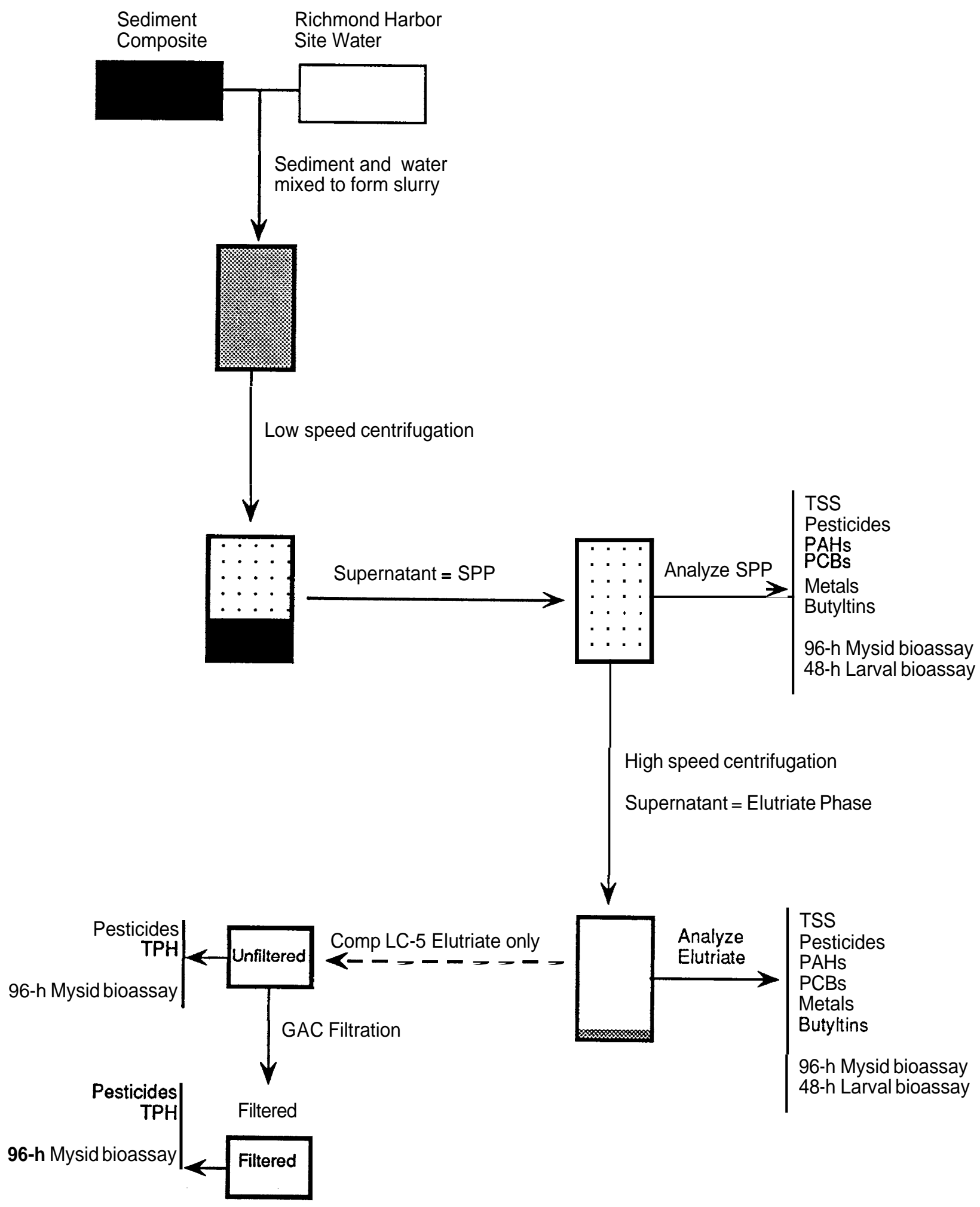

FIGURE 2.5. Suspended-Particulate Phase and Elutriate Preparation Procedure 



\section{0 $\underline{\text { RESULTS }}$}

The characterization of the marine portion of the United Heckathorn site was accomplished through a field investigation and chemical and biological analyses of sediment samples. In addition, treatability testing was conducted to support the evaluation of remedial alternatives. The results of the site characterization and treatability testing are presented in this section and discussed in Section 4.

\subsection{FIELD INVESTIGATION}

The field investigation for the United Heckathorn RI was conducted in Richmond Harbor from January 5 to 9,1993 . Samples were prepared for analysis the following week at the MSL in Sequim, Washington. The following sections present the results of the field investigation.

\subsubsection{Sediment Core Sampling}

Core samples were collected from 15 stations in Lauritzen Canal, 18 stations in Santa Fe Channel, 17 stations in the Inner Harbor Channel, and 3 stations in the Parr Canal (Figure 3.1). Station LZ-4 in the Lauritzen Canal was abandoned because debris in the canal prevented the penetration of the core barrel. A 12-in. core and a 4-in. core were collected at each station, with the exception of four Inner Harbor Channel stations and the Parr Canal stations, where only 4-in. cores were collected (Table 3.1). Three cores were collected from the Parr Canal by pushing a 4in.-diameter Lexan core liner into the sediment by hand from a small vessel.

Table 3.1 lists the coordinates, mudline elevation, YBM thickness, and elevation of the YBMIOBM contact measured at each station in the 12-in. and 4-in. cores. Differences in the thickness of YBM collected in the 12-in. and 4-in. core at each station are probably due to slightly different sampling locations (i.e., the 4-in. core barrel did not penetrate the sediment in the same place as the 12-in. core barrel). With the exception of Station LZ-4, the YBMIOBM contact was well defined in the 12-in. cores and the YBM was measured and collected for composite samples as planned. A minimum of $0.5 \mathrm{ft}$ of OBM was collected from all 4 -in. cores except those collected at Station SF-24 and the Parr Canal stations.

The elevation of the mudline and the YBMIOBM contact in the Lauritzen Canal is shown in Figure 3.2. The mudline is approximately - $10 \mathrm{ft} \mathrm{MLLW} \mathrm{in} \mathrm{the} \mathrm{northern} \mathrm{and} \mathrm{western} \mathrm{portions} \mathrm{of}$ the canal, which have not been dredged for a number of years. The channel depth increases to $-40 \mathrm{ft}$ MLLW adjacent to the Levin terminal on the southeastern shore of the canal. The surface of the OBM lies beneath approximately $5 \mathrm{ft}$ of YBM and roughly follows the configuration of the mudline. The contact is shallowest in the undredged portions of the Lauritzen Canal (-15 ft to 
$-20 \mathrm{ft} \mathrm{MLLW),} \mathrm{and} \mathrm{deepest} \mathrm{adjacent} \mathrm{to} \mathrm{the} \mathrm{Levin} \mathrm{terminal} \mathrm{(-45} \mathrm{ft} \mathrm{MLLW).} \mathrm{The} \mathrm{nature} \mathrm{of} \mathrm{the}$ contact indicates that the OBM was exposed during the initial dredging of the canal, and the YBM sediment has accumulated since that time.

The elevations of the mudline and YBM/OBM contact in the Santa Fe and Inner Harbor Channels are shown in Figures 3.3 and 3.4. The mudline elevation is $-29 \mathrm{ft}$ to $-34 \mathrm{ft} \mathrm{MLLW}$ in upper Santa Fe Channel, $-27 \mathrm{ft}$ to $-38 \mathrm{ft}$ MLLW in federal Santa Fe Channel, and $-34 \mathrm{ft}$ to $-38 \mathrm{ft}$ MLLW in Inner Harbor Channel. The YBM/OBM contact is -33 ft to - $37 \mathrm{ft}$ MLLW in upper Santa Fe Channel, and $-33 \mathrm{ft}$ to $-41 \mathrm{ft}$ MLLW in the federally maintained portion of the channel. The contact is $-37 \mathrm{ft}$ to $-43 \mathrm{ft} \mathrm{MLLW} \mathrm{in} \mathrm{Inner} \mathrm{Harbor} \mathrm{Channel.} \mathrm{As} \mathrm{in} \mathrm{the} \mathrm{Lauritzen} \mathrm{Canal,} \mathrm{the}$ surface of the OBM generally lies $4 \mathrm{ft}$ to $6 \mathrm{ft}$ beneath the mudline. The elevation of the YBMIOBM contact in the Parr Canal was not determined; however, probes taken along the length of the canal encountered a hard barrier at approximately $6 \mathrm{ft}$ below the mudline.

An isopach map of the YBM throughout the study area is provided in Figure 3.5. The thickness of the YBM is generally $4 \mathrm{ft}$ to $6 \mathrm{ft}$. The thickness of the YBM in the Lauritzen Canal ranges from approximately $8 \mathrm{ft}$ in the northern portion of the canal to less than $2 \mathrm{ft}$ in the center of the canal. The thickness of YBM in Santa Fe Channel varies from about $2 \mathrm{ft}$ to $8 \mathrm{ft}$, and is thicker in the upper channel and on the southern side of the channel across from the Lauritzen Canal. The YBM in the Inner Harbor Channel is generally $4 \mathrm{ft}$ to $6 \mathrm{ft}$ thick and is thicker on the east side of the channel.

\subsubsection{Geoloav of Marine Sediment}

The sediment cores were described by a geologist as specified in Appendix A. Core logs are provided in Appendix B. The YBM in the study area consisted of recent deposits of very soft black or very dark gray clay with lesser amounts of silt and minor sand and gravel. The sediment contained few roots and shell fragments, and locally had gas holes and a faint odor of sulfur. Sediments from the Lauritzen Canal, Parr Canal, and Stations SF-17 and SF-25 in Santa Fe Channel smelled of petroleum and had an oily appearance. A layer of light gray, granular material was encountered from approximately $1 \mathrm{ft}$ to $3 \mathrm{ft}$ below the mudline at Station $L Z-1$ and $1 \mathrm{ft}$ to $7 \mathrm{ft}$ below the mudline at Station LZ-8. The material reacted with hydrochloric acid, and analysis by $X$-ray fluorescence indicated that it contains $16 \%$ calcium by weight. This material may have been used in the preparation of pesticide formulations or discharged as a waste from a former concrete batch plant on the western shore of Lauritzen Canal. Samples from approximately $2 \mathrm{ft}$ below the mudline at Stations $\mathrm{LZ}-13$ and LZ-16 contained chunks of bauxite ore. These stations were located adjacent to the Levin terminal. Sediment from Parr Canal was black and contained abundant organic material.

The contact between the YBM and the OBM was generally sharp, with the very soft clay of the YBM overlying stiff to hard OBM. The contact was disrupted at some locations in the 
Lauritzen Canal, with a mixture of YBM and OBM sediment over an interval of up to several feet. Up to 4 in. of the OBM below the contact was discolored in some cores, indicating limited local alteration of the OBM by the overlying sediment. The OBM in the study area was composed primarily of silt, silty sand, and clay with minor gravel in shades of gray, brown, and olive. The lithology of the OBM was most variable in Lauritzen Canal; layering defined by changes in grain size was commonly observed. The OBM in the Santa Fe Channel and Inner Harbor Channel was composed of firm to hard, homogeneous silt and clay. The silt and clay in these areas was dark gray or olive brown and locally contains roots and gypsum nodules up to 6 in. in diameter.

\subsubsection{Shoreline Survev and Sediment Grab Sampling}

Shoreline properties and types of shoreline are shown in Figure 3.6. The construction of the banks of the Lauritzen Canal, Santa Fe Channel, and Inner Harbor Channel varies with the use of the shore property. Distinct changes in the appearance of the bank were commonly observed at property boundaries. Commercial properties with regular ship traffic generally maintain piers or docks extending into the water, and channel banks are generally modified with rip rap, sheet pile, or other concrete structures. These properties include the oil storage facilities of ARCO, GATX, Unocal, Castrol, Texaco, Time Oil, and California Oil. The shorelines adjacent to the Gold Bond and Castrol facilities are not armored or modified to the same degree as the other facilities in the area, and consist primarily of variable sizes of rock or cement debris. Richmond Harbor Terminals 2 and 3 and Point Potrero Marine Terminals 6 and 7 consist of concrete-faced bulkheads built over the natural shoreline. The Levin terminal on the east bank of the Lauritzen Canal consists of a pier supported by dense pilings; the natural shoreline is not visible. The upper end of the Santa Fe Channel is occupied by a marina with rows of covered slips, floating docks, and open moorage for small boats. The shoreline is generally armored or concealed by buildings.

Grab samples of soft surface sediment were collected from a small boat in areas where sampling could not be accomplished by coring (i.e., under piers and in very shallow water). Grab sampling locations are shown in Figure 3.7. Grab samples were combined to form seven composite samples representing the following areas: outer Richmond Harbor, east edge of the Inner Harbor Channel, west edge of the Inner Harbor Channel, west edge of the federal Santa Fe Channel, Santa Fe Channel marina, Parr Canal edge, and the graving docks. Grab sampling information is summarized in Table 3.2 .

\subsubsection{Control Sediment and Seawater Sampling}

Pipe-dredge samples representing relatively uncontaminated fine- and coarse-grained (sandy) sediment were collected from two locations in San Francisco Bay on January 6, 1993. The fine-grained control was collected approximately $0.5 \mathrm{mi}$ east of Brooks Island, and the coarsegrained control was collected approximately 3 mi west of Point Potrero. Both samples were used 
were used as grain-size control sediments in the 10-day acute bioassay, and the fine-grained San Francisco Bay Control was used in the 28-day bioaccumulation test. Native control sediment for M. nasuta was collected from the deepest part of Sequim Bay, Washington, on January 14, 1993. Native control sediment for R. abronius was collected at the time of amphipod collection (January 15, 1993) near West Beach, Whidbey Island, Washington. Control sample information is provided in Table 3.3.

Approximately $400 \mathrm{~L}$ of seawater were collected from the center of the Inner Harbor Channel on January 9, 1993. The site water was used to prepare and dilute SPP and elutriate samples. Collection of live clams (Macoma spp.) for chemical analysis from the area north of Brooks Island (Figure 1.2) was planned to measure ambient concentrations of pesticides in tissue; however, digging and raking in this area yielded few individuals and no significant population of clams.

\subsubsection{Sample Preparation}

Within 10 days of field sampling, 341 sediment samples were prepared for physical and chemical analysis and shipped to the appropriate analytical laboratories or archived at MSL. All samples were prepared, shipped, and analyzed within the required holding times, with exceptions noted in the quality control summaries provided in Appendix C. Table 3.4 summarizes sediment preparation and subsequent physical and chemical analyses. Complete sediment sample preparation information including preparation date, sample identification, length of core segment, depth interval, and analytical parameters is provided in Table C.1, Appendix C.

Thirteen composite and four control sediment composites were prepared for chemical and biological testing and preparation of liquid-phase samples. The sediment composites and associated testing program are listed in Table 3.5. SPP and elutriate samples were prepared from Comps LC, LC-5, LC-6, USFC, FSFC, IHC-1, IHC-2, and IHC-3 within 10 days of sediment collection. The liquid-phase samples were used for biological testing and shipped for chemical analysis within $24 \mathrm{~h}$ of preparation.

M. nasuta tissue samples were collected following the 28-day bioaccumulation test with Comps LC, USFC, FSFC, IHC-1, and GD. Tissue samples from each of the five exposure replicates were submitted for pesticide analysis; subsamples from each replicate were combined into one composite tissue sample per treatment for PAH, PCB, metals, and butyltin analyses. Tissue lipid content was measured in both the individual replicate samples and in the composite samples for each treatment. Tissues of $\mathrm{M}$ nasuta exposed to control sediments were collected and archived in the event that future analysis was required. 


\subsection{SEDIMENT CHEMISTRY}

Vertical core segments and channel edge grab samples were analyzed for chlorinated pesticides, grain size, and TOC. Composite YBM and OBM samples were analyzed for other contaminants (oil and grease, TPH, PAHs, PCBs, metals, and butyltins). Results of these analyses are presentedbelow. Analytical results for composite samples used in biological testing are presented in Section 3.4.1. All sediment chemistry data are presented in dry weight concentrations. Complete analytical results, including QC data, are tabulated in Appendix C. QC summaries for each type of analysis follow the data tables in Appendix C. In general, QC criteria for all analyses were met with the exception of the precision criteria for analytical and compositing duplicates. Analytical duplicates are two aliquots of one sample, and are intended to evaluate analytical precision. Compositing duplicates are the same sample submitted to the laboratory in two separate jars, and are intended to evaluate the effectiveness of sample compositing. The frequent differences in analytical and compositing duplicate measurements are likely to be due to the heterogeneous nature of the sediment samples because the precision between matrix spike and matrix spike duplicate measurements was generally within QC limits.

\subsubsection{Conventional Parameters}

Results for TOC, grain size, and percent moisture analyses of vertical core segments and channel edge grab samples, including quality control data, are provided in Tables C.2 through C.5, Appendix C. Table 3.6 summarizes the mean TOC content in samples of YBM and OBM from various segments of the study area. Samples of YBM from the Lauritzen Canal averaged about 2\% TOC . The average TOC content in samples of YBM from Santa Fe and Inner Harbor Channels was approximately $1 \%$, and samples from the Parr Canal averaged about $5 \%$. TOC content was more variable in sediment from the Lauritzen and Parr Canals than in sediment from the Santa Fe and Inner Harbor Channels. The OBM from all segments of the study area averaged about $0.2 \%$ TOC. Typical values for TOC in YBM from San Francisco Bay are less than $1 \%$ (Long and Morgan 1990).

Grain size distribution in the YBM and OBM is summarized in Table 3.6. Analyses show that both the YBM and OBM are predominately fine grained. The YBM throughout the study area was composed primarily of silty clay. The OBM was composed primarily of silt, with some silty sand, clay, and gravel. Samples of YBM ranged from $18 \%$ to $81 \%$ solids, with most samples containing $40 \%$ to $50 \%$ solids. The percent solids in OBM samples ranged from $71 \%$ to $87 \%$, with an average of $77 \%$.

\subsubsection{Chlorinated Pesticides}

Two hundred thirty-nine vertical core segments and channel edge grab samples were analyzed for chlorinated pesticides to delineate the areal and vertical extent of marine 
contamination. Complete results for these analyses, including QC data, are provided in Tables C.6 through C.10 and Table C.25, Appendix C. The QC summary on page C.I10 summarizes the results of the pesticide data review. The pesticides 4,4'-DDT and 4,4'-DDD were detected at low levels in the method blanks for six batches of samples; sample results less than five times the concentration in the associated blank were flagged as not detected in accordance with Laboratory Data Validation Functional Guidelines for Evaluating Organic Analyses (USEPA 1988). Otherwise, the pesticide data were of excellent quality.

The pesticides 4,4'-DDT and 4,4'-DDD showed the highest concentrations and widest distribution throughout the study area (Table 3.7). The pesticides 4,4'-DDE and dieldrin were also widely distributed but were detected at lower concentrations. Eight other pesticides were detected locally at lower concentrations. Analytical results for DDT, DDT analogues, and dieldrin are presented in Table 3.7 and discussed in the following sections. Samples designated A through $\mathrm{X}$ represent the $\mathrm{YBM}$ core sections, and samples designated $\mathrm{Y}$ or $\mathrm{Z}$ represent the OBM sections.

\subsubsection{Areal Distribution of Pesticides in Sediment}

Figures 3.8 and 3.9 present the average total DDT (sum of 4,4'-DDT, 4,4'-DDD, and $4,4^{\prime}-\mathrm{DDE}$ ) concentration in the YBM at each coring station. Total DDT concentrations are depicted on a log scale in Figure 3.8 and a linear scale in Figure 3.9. The maximum and median total DDT and maximum dieldrin concentrations throughout the study area are also shown. Pesticide concentrations were highest in the Lauritzen Canal, and decreased with increasing distance from the former United Heckathorn site. The highest total DDT concentration of $633,358 \mu \mathrm{g} / \mathrm{kg}$ was measured in a sample from $1 \mathrm{ft}$ to $3 \mathrm{ft}$ below the mudline at Station LZ-7. Pesticide concentrations of greater than $100,000 \mu \mathrm{g} / \mathrm{kg}$ were detected in sediment from eight stations in the northern and western portions of the canal. The most highly contaminated samples were collected from Stations LZ-1, LZ-2, LZ-6, and LZ-7. The median total DDT concentration was approximately $47,000 \mu \mathrm{g} / \mathrm{kg}$ at the head of the Lauritzen Canal, which has not been dredged in a number of years. The median concentration of total DDT decreased to about $14,000 \mu \mathrm{g} / \mathrm{kg}$ in the western, undredged portion of the canal, and to $1500 \mu \mathrm{g} / \mathrm{kg}$ in the dredged portion of the canal near the Levin terminal. Dieldrin concentrations were lower (maximum concentration of $16,000 \mu \mathrm{g} / \mathrm{kg}$ ), but exhibited the same geographic trend in relative concentration.

Total DDT concentrations in sediment decreased by at least two orders of magnitude from the Lauritzen Canal to the Santa Fe Channel. The median concentration of total DDT was $110 \mu \mathrm{g} / \mathrm{kg}$ in the upper Santa Fe Channel and $210 \mu \mathrm{g} / \mathrm{kg}$ in the federally maintained portion of the channel. DDT and dieldrin concentrations were higher in the federally maintained portion of the Santa Fe Channel, which includes the area downstream of the Lauritzen Canal. Total DDT and dieldrin concentrations decreased by another order of magnitude from the Santa Fe Channel to the 
Inner Harbor Channel. The median total DDT concentration was $60 \mu \mathrm{g} / \mathrm{kg}$ in the upper Inner Harbor Channel, and $10 \mu \mathrm{g} / \mathrm{kg}$ in the lower Inner Harbor Channel. The maximum total DDT concentration near Point Potrero was $19 \mu \mathrm{g} / \mathrm{kg}$, which is approximately equal to the median DDT concentration for the periphery of San Francisco Bay, excluding the Lauritzen Canal (Long et al. 1988).

Pesticide concentrations in Parr Canal sediment were lower than those measured in the Lauritzen Canal but greater than those measured in Santa Fe or Inner Harbor Channels. The maximum and median total DDT concentrations measured in Parr Canal sediment were $4080 \mu \mathrm{g} / \mathrm{kg}$ and $840 \mu \mathrm{g} / \mathrm{kg}$, respectively. The maximum dieldrin concentration was $170 \mathrm{pg} / \mathrm{kg}$.

Grab samples collected from channel edges throughout the study area showed the same geographic trend in pesticide concentrations as the core samples (Table 3.7). The highest total DDT concentration was measured in the Parr Canal edge sample $(1143 \mu \mathrm{g} / \mathrm{kg})$, followed by the west side of the Santa Fe Channel, Santa Fe Channel marina, east shore of the Inner Harbor Channel, west shore of the Inner Harbor Channel, and Outer Harbor Edge. The total DDT concentrations in channel edge samples were consistent with the median concentration measured in core samples from that area.

Table 3.8 summarizes pesticides other than DDT, DDT analogues, and dieldrin detected in core and grab samples from the study area. The following pesticides were detected at one or more stations: alpha-BHC, aldrin, trans-chlordane, endosulfan I, cis-chlordane, endrin, endosulfan II, and endrin aldehyde. These compounds were generally detected at concentrations of less than $3 \mu \mathrm{g} / \mathrm{kg}$ in samples from the Lauritzen Canal, Santa Fe Channel, and Inner Harbor Channel. Concentrations in samples from the Parr Canal ranged up to $68 \mu \mathrm{g} / \mathrm{kg}$. Other pesticides could be present in sediment from the Lauritzen Canal, but were not detected because they were either diluted below the detection limit during analyses of DDT and DDT analogues, or obscured by the signals from DDT and DDT analogues.

\subsubsection{Vertical Distribution of DDT in Sedimenf}

The vertical distribution of total DDT in sediment is illustrated in contaminant distribution maps representing increasing depth intervals throughout the study area. Figure 3.10 shows the concentration of total DDT in sediment with increasing depth below the mudline. Samples with total DDT concentrations of greater than $500 \mu \mathrm{g} / \mathrm{kg}$ were grouped into one category because of the large magnitude and range of values in these samples. The highest total DDT concentrations in the 0-ft- to 1-ft-below-mudline interval occurred in sediment from the Lauritzen Canal, with concentrations ranging from $471 \mu \mathrm{g} / \mathrm{kg}$ at Station LZ-14 to $111,625 \mu \mathrm{g} / \mathrm{kg}$ at Station LZ-6 (Table 3.7). Station LZ-6 was the only station with surface sediment exceeding 100,000 $\mu \mathrm{g} / \mathrm{kg}$ total DDT. The other Lauritzen Canal stations (excluding LZ-14 and LZ-16) had total DDT concentrations in the thousands and tens of thousands of $\mu \mathrm{g} / \mathrm{kg}$. Total DDT concentrations 
decreased to less than $400 \mu \mathrm{g} / \mathrm{kg}$ in surface sediment from the Santa Fe Channel, except at Stations SF-25 and SF-34, where total DDT was $749 \mu \mathrm{g} / \mathrm{kg}$ and $535 \mu \mathrm{g} / \mathrm{kg}$, respectively. Station SF-25 was adjacent to the Castrol Pier, and Station SF-34 was downstream of the Lauritzen Canal. Total DDT concentrations were higher in the portion of the Santa Fe Channel downstream of the Lauritzen Canal. Total DDT concentrations decreased to less than $50 \mu \mathrm{g} / \mathrm{kg}$ in the lower two-thirds of the Inner Harbor Channel surface sediment (except Station IH-42).

In general, total DDT concentrations were higher in sediment from the 1-ft- to 3-ft-belowmudline interval than in the surface sediment. Six stations in Lauritzen Canal had sediment exceeding $100,000 \mu \mathrm{g} / \mathrm{kg}$ total DDT in this interval (Table 3.7). As with the surface sediment, DDT concentrations decreased by several orders of magnitude in the Santa Fe Channel. However, a larger area of the federal Santa Fe Channel had sediment with greater than $400 \mu \mathrm{g} / \mathrm{kg}$ total DDT in this interval than is found in the surface sediment. Sediment from the upper Santa Fe Channel was less contaminated than in the federally maintained portion of the channel. The highest DDT concentrations in the federal Santa Fe Channel were found upstream of the mouth of the Lauritzen Canal. The channel is shallower above the Lauritzen Canal than below it, and it is likely that some sediment from the lower portion of the channel was removed during maintenance dredging in 1985. Total DDT concentrations of less than $50 \mu \mathrm{g} / \mathrm{kg}$ were restricted to sediment in the lower one-third of the Inner Harbor Channel.

The distribution of total DDT in sediment from the 3-ft- to 5-ft-below-mudlineinterval was similar to the distribution in the 1-ft- to 3-ft-below-mudline interval. Total DDT concentrations generally decreased in sediment from the Lauritzen Canal and upper Santa Fe Channel, and increased in the federal Santa Fe Channel and upper Inner Harbor Channel (data were not available in areas where the YBM/OBM contact was less than $2 \mathrm{ft}$ below mudline). Pockets of sediment with greater than $100,000 \mu \mathrm{g} / \mathrm{kg}$ total DDT occurred at the head of Lauritzen Canal (Stations LZ-1 and LZ-2) and at Stations LZ-8 and LZ-10 (Table 3.7). The federal Santa Fe Channel above the Lauritzen Canal contained a greater volume of sediment with greater than $500 \mu \mathrm{g} / \mathrm{kg}$ total DDT in this interval. Total DDT concentrations decreased to less than $100 \mu \mathrm{g} / \mathrm{kg}$ by the center of Inner Harbor Channel, and to less than $50 \mu \mathrm{g} / \mathrm{kg}$ at Stations IH-47 through IH-51

Figure 3.11 shows the distribution of total DDT in sediment in the intervals $1 \mathrm{ft}$ above and $1 \mathrm{ft}$ below the YBM/OBM contact, regardless of its depth below mudline. The maximum total DDT concentration above the contact was approximately $130,000 \mu \mathrm{g} / \mathrm{kg}$ at Station $\mathrm{LZ}-11$ (Table 3.7). The base of the YBM contained greater than $500 \mu \mathrm{g} / \mathrm{kg}$ total DDT at all stations in the Lauritzen Canal except LZ-7 and LZ-14, and at Station SF-28. Sediment with greater than $100 \mu \mathrm{g} / \mathrm{kg}$ total DDT extends from approximately the middle of Inner Harbor Channel north. Below the YBM/OBM contact, total DDT concentrations were less than $50 \mu \mathrm{g} / \mathrm{kg}$ everywhere except in the Lauritzen Canal, and in a small area of the federal Santa Fe Channel north of it. 
Total DDT concentrations of greater than $100 \mathrm{yg} / \mathrm{kg}$ were measured at six stations in the Lauritzen Canal (Stations LZ-1, LZ-2, LZ-3, LZ-5, LZ-9, and LZ-11). Archived samples from the 1-ft to 2-ft interval below the contact at these stations (and Station LZ-6) were analyzed; results for all but two of these samples showed less than $50 \mathrm{yg} / \mathrm{kg}$ total DDT (these samples are specified with a "Z" in Table 3.7). The samples from Stations LZ-2 and LZ-5 contained $181 \mu \mathrm{g} / \mathrm{kg}$ and $66 \mathrm{yglkg}$ total DDT, respectively.

Table 3.9 lists the total DDT concentrations and percent solids in samples from $1 \mathrm{ft}$ above and $1 \mathrm{ft}$ below the YBMIOBM contact in the Lauritzen Canal. The total DDT concentrations in sediment decreased across the contact by factors ranging from about 4 to 36,000 . The solids content averaged about $60 \%$ in the YBM samples and $80 \%$ in the OBM samples. The greatest change was observed at Station $\mathrm{LZ}-10$, where the concentration of total DDT decreased from over $120,000 \mu \mathrm{g} / \mathrm{kg}$ to $7.4 \mu \mathrm{g} / \mathrm{kg}$. At Station LZ-10, the YBM sample was $49 \%$ solids; whereas, the OBM sample, a silt, was $81 \%$ solids.

Cross sections showing the thickness of the YBM and distribution of total DDT along and across the Lauritzen Canal, Santa Fe Channel, and Inner Harbor Channel are presented in Figures 3.12 through 3.14, respectively. Cross-section locations are shown on Figure 3.15. The Lauritzen Canal cross sections (Figure 3.12) show total DDT concentrations on a log scale because they span seven orders of magnitude. The YBM was thickest at the head and on the western side of the central part of the canal; total DDT concentrations were also highest in these areas. Distinct layers of contaminated sediment were not discernible, and DDT concentrations varied over short vertical distances within the cores. DDT concentrations were higher in buried sediment. Although sediment concentrations were highly variable on a small scale, a large-scale pattern was evident. Sediment contamination decreases toward the mouth of the Lauritzen Canal and below the YBMIOBM contact.

The Santa Fe Channel cross sections (Figure 3.13) show total DDT concentrations on a linear scale. The YBM was thicker at the head of the channel, and on the south side of the channel across from the Lauritzen Canal. Again, distinct layers of contaminated sediment were not discernible and DDT concentrations were variable on a small scale. The highest total DDT concentrations were found adjacent to the Lauritzen Canal , and decreased toward the head of the Santa Fe Channel and the Inner Harbor Channel. Sediment with total DDT exceeding $500 \mu \mathrm{g} / \mathrm{kg}$ was found just above the YBMIOBM contact at Stations SF-28 and SF-29, and at the surface at Stations SF-34 and SF-25 (SF-25 is not shown on the cross sections). Concentrations of total DDT in the OBM did not exceed $25 \mathrm{yglkg}$, and are generally less than $2 \mu \mathrm{g} / \mathrm{kg}$.

Cross sections of the Inner Harbor Channel (Figure 3.14) show that the YBM thickness and concentration of total DDT were more uniform than in the Santa Fe Channel and Lauritzen 
Canal. Total DDT concentrations exceeded $200 \mu \mathrm{g} / \mathrm{kg}$ only at the head of the channel, and decreased to less than $50 \mu \mathrm{g} / \mathrm{kg}$ by the south end of the channel.

\subsubsection{Distribution of Analogues in Total DDT}

Table 3.10 shows the average relative percent of each DDT analogue contributing to total DDT. The $2,4^{\prime}$ isomers of DDT were not analyzed in this study; however, these compounds were not detected at significant concentrations in marine sediment samples collected during the ecological risk assessment. The compound 4,4'-DDD contributed the most to total DDT, from $55 \%$ in sediment from the Lauritzen Canal to approximately $70 \%$ in upper Santa Fe Channel, Inner Harbor Channel, and Parr Canal sediment. The relative percent contribution of 4,4'-DDT was highest in sediment from the Lauritzen Canal (42\%), and progressively decreased in the federal Santa Fe Channel, Inner Harbor Channel, Parr Canal, and upper Santa Fe Channel (12\%). The compound $4,4^{\prime}-\mathrm{DDE}$ comprised less than $5 \%$ of total DDT in sediment from the Lauritzen Canal (except samples of gray, granular material collected at Stations $\mathbf{Z Z - 1}$ and $\mathbf{L Z}-8$, in which $4,4^{\prime}-\mathrm{DDE}$ constituted $50 \%$ of the total DDT). The relative percent of $4,4^{\prime}-\mathrm{DDE}$ increased to $10 \%$ or more in sediment outside Lauritzen Canal.

\subsubsection{Other Contaminants}

Composite samples of YBM sediment from selected stations and fine-grained and coarsegrained composite samples of OBM sediment were analyzed for oil and grease, total petroleum hydrocarbons, PAHs, PCBs, metals, and butyltins to identify contaminants other than pesticides. Sample locations are shown in Figure 3.1. Results of these analyses are presented in the following sections.

\subsubsection{Oil and Grease and Total Petroleum Hvdrocarbons}

Oil and grease and TPH were measured to estimate the amount of hydrocarbons in the sediment and the relative contribution of petroleum products to the hydrocarbons. Complete analytical results for TPH and oil and grease, including QC data, are provided in Tables C. II and C.12, Appendix C. The QC summaries for these analyses are on pages C.115 and C.117. The specified holding times for oil and grease and TPH analyses were exceeded because the samples required reanalysis. However, the sediment samples were stored frozen until reanalysis and the concentrations of hydrocarbons should not have decreased significantly during this time.

Oil and grease concentrations in the YBM ranged from $190 \mathrm{mg} / \mathrm{kg}$ to $26,000 \mathrm{mg} / \mathrm{kg}$ (Table 3.11). Concentrations were highest in samples from the Lauritzen and Parr Canals. TPH results indicate that petroleum products constituted the majority of the hydrocarbons in the Lauritzen Canal, Santa Fe Channel, and Parr Canal samples. TPH was not detected in composite YBM samples from the Inner Harbor Channel. Neither oil and grease nor TPH were detected in the OBM composite samples. 


\subsubsection{Polvnuclear Aromatic Hvdrocarbons}

Composite sediment samples were analyzed for $16 \mathrm{PAH}$ compounds. Complete analytical results, including $Q C$ data, for individual PAH compounds are provided in Tables $\mathrm{C} .13$ through C.18, Appendix C. The QC summary for PAH analyses is on page C.119.

PAH data are summarized as high-molecular-weight PAHs (HPAH) and low-molecularweight PAHs (LPAH) in Table 3.11. Total PAH concentrations in YBM composite samples ranged from $195 \mu \mathrm{g} / \mathrm{kg}$ to $32,118 \mathrm{pg} \mathrm{kg}$. Concentrations of HPAHs exceeded those of LPAHs in all samples except LZ-1 M. PAH concentrations exceeded $20,000 \mu \mathrm{g} / \mathrm{kg}$ at three stations: $\mathrm{LZ}-13$, SF-25, and PC-53. Station LZ-13 was adjacent to the Levin terminal in the Lauritzen Canal. The odor of naphtha was reported by samplers in this core; a spill of naphthenic acid occurred near this location in 1951 (CH2M Hill 1988). Station SF-25 was located adjacent to the Castrol pier. The uppermost $1 \mathrm{ft}$ of sediment from this core was very oily in appearance. This station corresponded to a station sampled as part of the ecological risk assessment; surface sediments collected from this area contained $149,000 \mu \mathrm{g} / \mathrm{kg}$ total PAHs. The sediment at the Parr Canal Station PC-53 was also very oily in appearance. PAH concentrations were also elevated at Station $L Z-1$ at the head of Lauritzen Canal $(12,500 \mathrm{pg} / \mathrm{kg})$. PAHs were detected at concentrations of $143 \mu \mathrm{g} / \mathrm{kg}$ and $35 \mu \mathrm{g} / \mathrm{kg}$ in the coarse and fine OBM composites, respectively.

\subsubsection{PCBs}

Complete analytical results for PCBs, including QC data, are provided in Tables C.19 and C.20, Appendix C. The QC summary is on page C.121. Aroclor 1254 was the only PCB detected in samples from the United Heckathorn study area (Table 3.11). PCB concentrations in the YBM composite samples ranged from $5 \mathrm{pglkg}$ to $1982 \mathrm{pglkg}$. The highest values were measured in samples from the Parr Canal, with concentrations of $675 \mathrm{pglkg}, 1982 \mu \mathrm{g} / \mathrm{kg}$, and $568 \mu \mathrm{g} / \mathrm{kg}$ at Stations PC-52, PC-53, and PC-54, respectively. PCB concentrations were greater than $200 \mathrm{pglkg}$ in samples from all Lauritzen Canal stations except LZ-13 and LZ-15. PCBs were not detected in the OBM composite samples.

\subsubsection{Metals}

Sediment samples were analyzed for 10 metals: silver, arsenic, cadmium, chromium, copper, mercury, nickel, lead, selenium, and zinc. Complete results for metals analyses, including QC data, are provided in Tables C. 21 and C.22, Appendix C. The QC summary for metals analyses is on page C.123.

Results for metals analyses are presented in Table 3.12. With the exception of chromium, concentrations of metals, particularly lead, zinc, and mercury, were generally higher in YBM samples than in the two OBM composite samples. The concentration of chromium in the coarse 
OBM composite was higher than all but one YBM sample. The OBM likely contains material eroded from the chromium-rich ultramafic rocks exposed in the Bay area.

In general, concentrations of six metals (arsenic, chromium, copper, mercury, nickel, and selenium) in the composite YBM samples showed little spatial variation throughout the study area. Arsenic concentrations ranged from less than $7 \mathrm{mg} / \mathrm{kg}$ to $26.6 \mathrm{mg} / \mathrm{kg}$. Chromium concentrations ranged from $166 \mathrm{mg} / \mathrm{kg}$ to $3990 \mathrm{mg} / \mathrm{kg}$. The highest concentration was observed at Station LZ-13, which was located adjacent to the Levin Terminal pier where metal ore is offloaded. Copper concentrations ranged from $50 \mathrm{mg} / \mathrm{kg}$ to $212 \mathrm{mg} / \mathrm{kg}$. Mercury concentrations ranged from $0.31 \mathrm{mg} / \mathrm{kg}$ to $2.18 \mathrm{mg} / \mathrm{kg}$, with the highest concentrations measured in samples from the head of the Lauritzen Canal. Nickel values ranged from $83 \mathrm{mg} / \mathrm{kg}$ to $124 \mathrm{mg} / \mathrm{kg}$. Selenium concentrations ranged from $0.26 \mathrm{mg} / \mathrm{kg}$ to $0.60 \mathrm{mg} / \mathrm{kg}$.

Concentrations of silver, cadmium, lead, and zinc were elevated in samples from the Lauritzen and Parr Canals. Silver concentrations ranged from $0.16 \mathrm{mg} / \mathrm{kg}$ to $1.62 \mathrm{mg} / \mathrm{kg}$, with the highest measured in samples from the head of the Lauritzen Canal (Stations LZ-1 and LZ-3). Cadmium concentrations ranged from $0.39 \mathrm{mg} / \mathrm{kg}$ to $3.17 \mathrm{mg} / \mathrm{kg}$, and were higher at three stations in the Lauritzen Canal (LZ-1, LZ-3, and LZ-11) and all three stations in the Parr Canal. Lead concentrations ranged from $23 \mathrm{mg} / \mathrm{kg}$ to $849 \mathrm{mg} / \mathrm{kg}$. Lead concentrations were much higher in samples from the head of the Lauritzen Canal (over $200 \mathrm{mg} / \mathrm{kg}$ at Stations LZ-1 and LZ-3), and were greater than $800 \mathrm{mg} / \mathrm{kg}$ at two stations in the Parr Canal. Zinc concentrations ranged from $105 \mathrm{mg} / \mathrm{kg}$ to $709 \mathrm{mg} / \mathrm{kg}$, with the highest concentrations measured in samples from Stations PC-52 and PC-53 in the Parr Canal.

\subsubsection{Butyltins}

Complete analytical results for butyltins, including QC data, are provided in Tables C.23 and C.24, Appendix C. The QC summary for butyltin analyses is found on page C.125. Analytical results for butyltin analyses are provided in Table 3.12. Tributyltin concentrations in the YBM composite samples ranged from $5.1 \mu \mathrm{g} / \mathrm{kg}$ to $85.5 \mu \mathrm{g} / \mathrm{kg}$. Dibutyltin concentrations ranged from $3.6 \mu \mathrm{g} / \mathrm{kg}$ to $56.3 \mu \mathrm{g} / \mathrm{kg}$ dry weight. The highest butyltin concentrations were measured in samples from at Stations SF-18 and SF-19, at the upper end of the Santa Fe Channel. These stations were adjacent to a marina. Traces of tributyltin were detected in both OBM composite samples; dibutyltin was not detected in either sample.

\subsection{SEDIMENT VOLUMES}

The volume of marine sediment potentially requiring remediation was estimated based on the areal and vertical distribution of DDT contamination. Cleanup criteria for marine sediment at the United Heckathom site have not yet been established; therefore, sediment volumes above 
various contaminant levels were calculated. The volume of YBM in each category includes sediment down to the YBM/OBM contact because significant contamination appears to be restricted to the YBM, and distinct layers of contaminated sediment were not identified within the YBM. The 12-in. core data for YBM thickness were used to estimate sediment volumes because they are believed to be more accurate than the 4-in. core data (the soft sediment is less likely to be influenced by friction along the inner surface of the wider barrel as it advances through soft sediment). The boundary for each category includes all stations with an average total DDT concentration exceeding the specified level. The average total DDT concentration was calculated for sediment in each category using the method described in Section A.5, Appendix A. The weighted average contaminant concentrations assume that the sediment within the given volume is homogenized.

Sediment volumes and average contaminant concentrations are summarized in Table 3.13. The volume estimates are an average of three values calculated using different surface modeling programs (with the exception of the Parr Canal, which is a single estimate). The standard deviation associated with each estimate is also provided. The volumes of YBM with total DDT concentrations above $1000 \mu \mathrm{g} / \mathrm{kg}, 500 \mu \mathrm{g} / \mathrm{kg}, 100 \mu \mathrm{g} / \mathrm{kg}$, and $50 \mu \mathrm{g} / \mathrm{kg}$ were estimated. A map showing the boundary for each category is provided in Figure 3.16.

The $1000-\mu \mathrm{g} / \mathrm{kg}$ and $500-\mu \mathrm{g} / \mathrm{kg}$ boundaries both include all recent sediment in the Lauritzen and Parr Canals. Small areas of sediment with a total DDT concentration of greater than $500 \mu \mathrm{g} / \mathrm{kg}$ were found in the Santa Fe Channel (near the contact at Stations SF-28 and SF-29, and at the surface at Stations SF-34 and SF-25); these areas were not included in the $500-\mu \mathrm{g} / \mathrm{kg}$ volume estimate. The $100-\mu \mathrm{g} / \mathrm{kg}$ boundary is located at the northern end of the Inner Harbor Channel, and the $50-\mu \mathrm{g} / \mathrm{kg}$ boundary is located at the center of the Inner Harbor Channel. The total volumes and average contaminant concentrations of sediment exceeding $50 \mu \mathrm{g} / \mathrm{kg}$ and $100 \mathrm{yg} / \mathrm{kg}$ total DDT were calculated including and excluding Lauritzen Canal sediment because of its relatively small volume and highly contaminated nature.

The volume of sediment exceeding a total DDT concentration of $50 \mu \mathrm{g} / \mathrm{kg}$ is approximately $600,000 \mathrm{cu}$ yd. Approximately $60 \%$ of this sediment has an average total DDT concentration above $100 \mu \mathrm{g} / \mathrm{kg}, 10 \%$ above $500 \mu \mathrm{g} / \mathrm{kg}$, and $10 \%$ above $1000 \mu \mathrm{g} / \mathrm{kg}$. The weighted average total DDT concentration in the $100-\mu \mathrm{g} / \mathrm{kg}$ and $50-\mu \mathrm{g} / \mathrm{kg}$ categories decreases by one to two orders of magnitude if the Lauritzen Canal sediment is excluded.

\subsection{SOLID-PHASE BIOLOGICAL TESTING}

Solid-phase toxicity and bioaccumulation tests were conducted with sediment composites from inner Richmond Harbor to characterize the biological effects of contaminated sediment. A 
solid-phase toxicity test with the amphipod, $R$. abronius, was conducted using Comps LC-1, LC-2, LC-3, LC-4, LC-5, USFC, FSFC, IHC-1, IHC-2, IHC-3, GD, two San Francisco Bay grain-size controls, and a native control. All of these composites except Comp LC-5 represent the uppermost $1 \mathrm{ft}$ of sediment throughout the study area. After toxicity of SPP and elutriate from Comp LC-5 to mysids was observed, this composite was added to the solid-phase test. The bioaccumulation test was conducted using Comps LC, USFC, FSFC, IHC-1, GD, a San Francisco Bay fine-grained control, and a native control. Composite sediment chemistry data, acute toxicity data for $\mathrm{R}$. abronius, and results of the bioaccumulationtest with $\mathrm{M}$ nasuta are presented in the following sections.

\subsubsection{Composite Sediment Chemistry}

The 13 sediment composites and two San Francisco Bay grain-size control sediments prepared for biological testing were analyzed for grain size, TOC, oil and grease, total petroleum hydrocarbons, chlorinated pesticides, PCBs, PAHs, metals, and butyltins (Tables 3.14 to 3.17). Complete sediment chemistry data for the composites and controls, including QC data, are reported in Appendix C. All sediment chemistry data are reported in dry weight concentrations.

\subsubsection{Conventional Parameters}

The sediment composites were predominantly fine grained; silt and clay comprised at least $62 \%$ of the total solids in all composites and over $90 \%$ in composites from the Inner Harbor Channel and graving docks. The fine-grained San Francisco Bay control C-SFBF, at $91 \%$ silt and clay, was an appropriate grain-size control for the solid-phase bioassays. TOC was $1 \%$ to $2 \%$ in all composites except Comps LC-1 and IHC-1, with TOC contents of about $5 \%$ (Table 3.14). The San Francisco Bay coarse-grained control sediment (83\% sand) had much less TOC $(0.05 \%)$ than the other composites.

\subsubsection{Chlorinated Pesticides}

Chlorinated pesticide concentrations in the sediment composites were consistent with pesticide concentrations in the contributing core segments (Section 3.2.2). The pesticides 4,4'-DDT, 4,4'-DDD, 4,4'-DDE, and dieldrin were detected in most composites (Table 3.15). Concentrations of 4,4'-DDT in Lauritzen Canal composites, except for Comp LC-4, were at least two orders of magnitude greater than concentrations in Santa Fe Channel composites. Inner Harbor Channel composites were one order of magnitude lower than Santa Fe Channel composites. Only traces of pesticides were detected in the graving docks composite and the San Francisco Bay grain-size control sediments. Individual values for the upper $1 \mathrm{ft}$ of sediment from Comp LC-4 stations (samples LZ-11 A, LZ-12 A, and LZ-13 A) indicate that the actual 4,4'-DDT concentration may be greater than $1000 \mathrm{yglkg}$ instead of the $461 \mathrm{yglkg}$ reported for the 
composite (Table 3.7). Total DDT was nearly $90,000 \mu \mathrm{g} / \mathrm{kg}$ in the YBM at depth in the Lauritzen Canal (Comps LC-5 and LC-6).

\subsubsection{Other Contaminants}

Analytical results for oil and grease, TPH, PAHs, and PCBs in sediment composites are provided in Table 3.16. Oil and grease ranged from $4310 \mathrm{mg} / \mathrm{kg}$ to $290 \mathrm{mg} / \mathrm{kg}$, which was higher than the San Francisco Bay controls. Concentrations were highest in composites from the Lauritzen Canal. TPH data indicate that petroleum hydrocarbons constituted the majority of the oil and grease.

Both LPAHs and HPAHs were found in relatively high concentrations in composites from the Lauritzen Canal and Santa Fe Channel, indicating that these compounds have not undergone extensive weathering (Table 3.16). Total PAHs were highest in Comp LC-4 $(21,566 \mu \mathrm{g} / \mathrm{kg})$; most appeared to be contributed by Station LZ-13 (32,118 yglkg). Station LZ-13 was located on the east side of Lauritzen Canal, in the active berthing area for the Levin Terminal. The PAHs in Comp USFC (9233 $\mu \mathrm{g} / \mathrm{kg}$ total PAH) appear to be contributed by sediment from SF-25 (24,199 $\mu \mathrm{g} / \mathrm{kg}$ total PAH), where concentrations of individual PAH compounds were thousands of times higher than at other contributing stations. Total PAH in sediment composites decreased with increasing distance from the Lauritzen Canal, with the lowest concentrations less than or equal to $1000 \mu \mathrm{g} / \mathrm{kg}$ in the Inner Harbor Channel and graving dock composites.

Aroclor 1254 was detected in most composites (Table 3.16). Most Aroclor 1254 concentrations were two orders of magnitude lower than total DDT concentrations in the composites. Estimated concentrations were below the method detection limits in the Inner Harbor Channel and graving docks composites. Comp LC-1 from the head of Lauritzen Canal had over $1000 \mathrm{yg} / \mathrm{kg}$ Aroclor 1254; the other Lauritzen Canal composites had concentrations of $200 \mu \mathrm{g} / \mathrm{kg}$ to $300 \mu \mathrm{g} / \mathrm{kg}$. Concentrations of Aroclor 1254 were much lower in the dredged portions of the study area (federal Santa Fe Channel, Inner Harbor Channel).

In general, concentrations of metals were highest in Lauritzen Canal composites, and decreased with increasing distance from the canal (Table 3.17). Nearly all metals were higher in Lauritzen, Santa Fe, and Inner Harbor Channel composites than in the San Francisco Bay control sediment. Cadmium, chromium, copper, mercury, lead, and zinc were elevated the most relative to the San Francisco Bay controls. The values for these metals probably reflect the industrial uses of the waterways. The unusually high chromium concentrations in Comp LC-6 (1540 mg/kg) could be attributed to sediment from Station LZ-13, which had $3990 \mathrm{mg} / \mathrm{kg}$ chromium (Table 3.12). 
Tributyltin in all sediment composites except Comp LC-4 ranged from below detection to $83.6 \mu \mathrm{g} / \mathrm{kg}$ dry weight (Table 3.17). The extremely high value of $210 \mu \mathrm{g} / \mathrm{kg} \mathrm{TBT}$ for Comp LC-4 does not agree with the much lower TBT measured in YBM from contributing Stations $L Z-11$ and LZ-13 $(5.3 \mu \mathrm{g} / \mathrm{kg}$ and $37.5 \mu \mathrm{g} / \mathrm{kg}$ respectively)(Table 3.12). The YBM from the other contributing station, LZ-12, was not analyzed for TBT. It is possible that a TBT source such as a paint chip could have been in the sample. Excluding Comp LC-4, butyltin concentrations were highest in the northern, undredged portion of Lauritzen Canal, and decreased with distance and with depth.

\subsubsection{0-Day Static Test With Rhepoxynius abronius}

The acute toxicity of surface sediments in the Heckathom study area to the burrowing amphipod, $R$. abronius, was evaluated in a 10-day static toxicity test as described in Section A.3.2. Twenty R. abronius were exposed in each of 5 replicates of 11 composites, 2 San Francisco Bay grain-size controls, and a native control. Five additional replicates of the native control were tested with Comp LC- 5 when this composite was added to the experiment one week after initiation of the test. Complete survival data for all replicates are reported in Appendix D, Table D.1. Water quality monitoring and reference toxicant data are also tabulated in Appendix D.

The $R$. abronius test was validated by $96 \%$ and $99 \%$ survival in the native control C-WB and C-WB Rerun, respectively (Table 3.18). In the reference toxicant test with cadmium chloride, an $\mathrm{LC}_{50}$ of $0.90 \mathrm{mg} / \mathrm{L} \mathrm{Cd}$ was estimated using the trimmed Spearman-Karber method ( $11 \%$ trim). This $L_{50}$ is comparable to the $0.92 \mathrm{mg} / \mathrm{L}$ value cited for Cd toxicity to $R$. abronius in the standard guide to conducting toxicity tests with marine amphipods (ASTM 1990). These results indicate that the test population of $R$. abronius responded as expected. Water quality parameters were within acceptable ranges throughout the test except for on the last day, when $\mathrm{pH}$ in three replicates of Comp LC-1 exceeded the acceptable range.

The results of the R. abronius test, Tukey's HSD Test $(a=0.05)$, and ANOVA are summarized in Tables 3.18 and 3.19. R. abronius survival is not significantly different in treatments that share a letter under the statistical grouping column in Table 3.18. Overall, $R$. abronius survival corresponded with the degree of sediment contamination: the highest mortality was observed in Lauritzen Canal composites, and mortality decreased with increasing distance from the canal. Survival was $0 \%$ in Comps LC-1, LC-2, LC-3, and LC-5, which was significantly different from all other treatments. Comp LC-4, from the mouth of Lauritzen Canal, and all other composites showed $74 \%$ to $92 \%$ survival and were not significantly different from each other or from the fine-grained San Francisco Bay Control. Some of the difference between Comps LC-4, FSFC, and IHC-3 and the coarse-grained San Francisco Bay Control is probably due to the sensitivity of $R$. abronius to fine-grained sediment (DeWitt et al. 1988). 


\subsubsection{8-Dav Flow-Throuah Test With Macoma nasuta}

The 28-day exposure of the bentnose clam, $M$ nasuta, to sediment composites from inner Richmond Harbor was conducted to evaluate bioaccumulation of contaminants. Five Heckathom sediment composites and two control sediments were tested as described in Section A.3.3. Twenty-five $M$. nasuta were exposed in each of five replicates of each treatment. After the 28-day exposure and 48-h depuration period, tissue samples from each replicate were analyzed for pesticides and lipids. Composite tissue samples were prepared by combining a subsample from each of the five replicates to measure concentrations of PAHs, PCBs, metals, and butyltins.

Complete survival data for the 28-day M. nasutatest are reported in Appendix E, Table E.1. Water quality parameters remained within acceptable ranges throughout the 28-day test (Appendix E, Table E.2). The test was validated by $98 \%$ survival in the Sequim Bay control sediment C-SB. Survival in the fine-grained San Francisco Bay control was $98 \%$. Survival in the composites ranged from $94 \%$ to $96 \%$, indicating that the sediments were not acutely toxic to adult $M$. nasuta.

All tissue chemistry and quality control data are reported in Appendix F; chemistry results are reported on a wet weight and dry weight basis. Nearly all QC criteria were met for the analyses. No analytical duplicates were analyzed for PAHs, PCBs, metals, and butyltins, because these parameters were measured in only five samples.

\subsubsection{Chlorinated Pesticides and Lipid Content}

Thirteen chlorinated pesticides were detected in the tissue samples. Pesticide results are reported in dry weight in Tables 3.20 and 3.21. Measured lipid values and the calculated BlighDyer equivalents are also reported in dry weight in Table 3.20. The lipid content of tissue samples ranged from $3.1 \%$ to $15.5 \%$ (1.4\% to $7.1 \%$ in Bligh-Dyer equivalents). The average lipid content was $6.2 \%$ (2.8\% in Bligh-Dyer equivalents).

Dieldrin, 4,4'-DDT, 4,4'-DDE, and 4,4'-DDD were detected in all $M$. nasuta tissue samples at higher concentrations than any other pesticides (Table 3.20). These pesticides showed a clear pattern of decreasing concentrations in M. nasutawith increasing distance from the Lauritzen Canal, with at least an order of magnitude of reduction outside of Lauritzen Canal. The mean concentration of total DDT in clams exposed to Comp LC was approximately $35,000 \mu \mathrm{g} / \mathrm{kg}$; mean total DDT in tissue decreased to $725 \mu \mathrm{g} / \mathrm{kg}$ in Comps FSFC and USFC, and to approximately $200 \mu \mathrm{g} / \mathrm{kg}$ in upper Inner Harbor Channel (Comp IHC-1). Pinza et al. (1992) measured approximately $100 \mu \mathrm{g} / \mathrm{kg}$ total DDT in M. nasuta exposed to composites from the southern part of Inner Harbor Channel. Mean total DDT in M. nasuta exposed to graving docks sediment was $36 \mu \mathrm{g} / \mathrm{kg}$. 
The distribution of DDT analogues as percentage of total DDT was different in tissues than in composite sediment samples. In $\mathrm{M}$ nasutatissue, 4,4'-DDD made up the highest percentage (generally around $80 \%$ ) of total DDT; 4,4 '-DDT the least (1\% to $5 \%$ ) except in M nasuta exposed to Lauritzen Canal sediment (5\% to 14\%). In sediment composites, 4,4'-DDT contributed a similar amount or more than $4,4^{\prime}-\mathrm{DDD}$ to total DDT.

Dieldrin concentrations in tissue were an order of magnitude lower than total DDT, but showed the same spatial pattem of decreasing concentrations with increasing distance from Lauritzen Canal (Table 3.20). The mean M. nasuta dieldrin concentration of $10 \mu \mathrm{g} / \mathrm{kg}$ for Comp IHC-1 was slightly higher than the $6 \mathrm{pglkg}$ to $7 \mathrm{pglkg}$ in $\mathrm{M}$ nasuta exposed to southern Inner Harbor Channel sediments measured by Pinza et al. (1992). Dieldrin in M nasuta exposed to Comp GD was 3 pglkg dry weight.

Table 3.21 lists the chlorinated pesticides other than dieldrin and DDT compounds that were detected in $\mathrm{M}$ nasuta. Endrin was detected in three replicates of Comp LC. Aldrin, transchlordane, cis-chlordane, and endosulfan I were detected at more than 10 times the detection limit in the 5 replicates of Comp LC, but were either undetected or close to the detection limit in $\mathrm{M}$ nasuta exposed to other composites. The following compounds were detected in several samples, at concentrations below the target detection limit of $2 \mu \mathrm{g} / \mathrm{kg}$ wet weight: a-BHC, g-BHC, endosulfan II, endosulfan sulfate.

\subsubsection{Other Contaminants}

Concentrations of PAHs and the PCB Aroclor 1254 detected in composite M nasuta tissue samples are reported in Table 3.22. The PAH data are summarized as total LPAH and HPAH; values for individual compounds are provided in Appendix F. Bioaccumulation of PAHs was greater than pesticides in all areas except Lauritzen Canal, where tissue pesticide concentrations were an order of magnitude higher. Total PAHs were highest in $\mathrm{M}$ nasuta exposed to Comp USFC and Comp LC, with about $5500 \mathrm{pglkg}$. Total PAH concentrations decreased to between $500 \mathrm{pglkg}$ and $2000 \mathrm{pglkg}$ in M nasuta exposed to other composites. HPAHs, especially pyrene, fluoranthene, and the benzofluoranthenes, constituted a higher proportion of total PAH in M nasuta exposed to Comp LC. In Comp USFC, LPAHs (primarily phenanthrene, anthracene, and fluorene) made a greater contribution to total PAH (approximately $20 \%$ ). The relative proportions of LPAH and HPAH in $M$. nasutatissues reflect the distribution of PAH compounds in the sediment composites. Aroclor 1254 was highest in $\mathrm{M}$ nasuta exposed to Comp LC, with a concentration of $308 \mu \mathrm{g} / \mathrm{kg}$. M. nasuta exposed to Comps USFC and FSFC had approximately $180 \mathrm{pg} / \mathrm{kg}$ Aroclor 1254 . Tissue PCB concentrations in $\mathrm{M}$ nasuta exposed to Comps IHC-1 and GD decreased to $91 \mu \mathrm{g} / \mathrm{kg}$ and $55 \mathrm{pg} \mathrm{kg}$, respectively. These tissue PCB concentrations reflect relative PCB concentrations in sediment composites (Table 3.16). 
Metals and butyltins in M. nasutatissues are reported in Table 3.23. Tissue metal concentrations showed little variation (within 2-fold) between composites, and were very similar to the mean M nasutametal concentrations reported by Pinza et al. (1992) for M nasuta exposed to sediments from other parts of Richmond Harbor. M nasutatissue butyltin concentrations also did not vary significantly between composites (2.4-fold). The similarity of metal and butyltin concentrations between tissue composites does not reflect the variability of the sediment composite concentrations (Table 3.17).

\subsubsection{Accumulation Factors}

The composite sediment chemistry and bioaccumulation data collected in this study were used to calculate accumulation factors, which describe the preference of contaminants (particularly nonpolar organic compounds) for organism lipids relative to sediment organic carbon. They are important variables in modeling bioaccumulation of sediment-bound contaminants with a high affinity for organic carbon and lipids. The simplest definition of an accumulation factor is the ratio of the tissue contaminant concentration (normalized to lipid content) of an organism to the contaminant concentration (normalized to organic carbon) in sediment to which the organism was exposed (Lee et al. 1989), as shown below:

$$
A F=\frac{C t / L}{C s / T O C}
$$

where $\mathrm{AF}=$ accumulation factor in $\mathrm{g}$ organic carbon $/ \mathrm{g}$ lipid

$\mathrm{Ct}=$ tissue contaminant concentration in $\mathrm{ng} / \mathrm{g}$ dry weight

$\mathrm{L} \quad=\quad$ tissue lipid content in $\mathrm{g} / \mathrm{g}$ dry weight

Cs $=$ sediment contaminant concentration in $\mathrm{ng} / \mathrm{g}$ dry weight

TOC $=$ sediment organic carbon in $\mathrm{g} / \mathrm{g}$ dry weight.

Accumulation factors calculated for DDT analogues and total DDT, dieldrin, PCB Aroclor 1254, and PAHs are listed in Table 3.24. The accumulation factors for M nasutatissue for DDT compounds did not appear related to sediment concentration, except that the accumulation factors were higher when sediment concentrations were very low (e.g., Comp GD). This was also true for Aroclor 1254 and PAHs. The high TOC in Comp IHC-1 (5.2\% vs. $1.2 \%$ to $1.9 \%$ in other composites) also contributed to higher accumulation factors for all compounds. 


\subsection{IREATABILITY TESTING}

Treatability testing was conducted to support the evaluation of selected remedial alternatives for contaminated marine sediment. SPP and elutriate phase samples were prepared and analyzed to predict the probable quality of effluent from dewatering sediment; test results were also used to evaluate the potential effects of dredging contaminated sediment. Two liquid phases were prepared from eight sediment composites and tested as described in Appendix A. The eight composites were Comps LC, LC-5, LC-6, USFC, FSFC, IHC-1, IHC-2, and IHC-3. These samples represent the uppermost $1 \mathrm{ft}$ of sediment from various sections of the project area (Comps LC, USFC, FSFC, IHC-1, IHC-2, and IHC-3), as well as the 1- to 4-ft- and 4- to 7-ftbelow-mudline intervals of YBM in the Lauritzen Canal (Comps LC-5 and LC-6, respectively). SPP and elutriate samples prepared from each composite were chemically analyzed and tested for acute toxicity to mysids and bivalve larvae. Additional dilutions of liquid-phase samples and GAC-filtered elutriate from Comp LC-5 were also tested. The Richmond Harbor site water used to prepare and dilute SPP and elutriate phases was analyzed, as was a procedural blank of site water carried through the SPP and elutriate preparation process. Liquid-phase chemistry and toxicity test results are discussed below.

\subsubsection{Suspended Particulate Phase and Elutriate Phase Chemistry}

The liquid phases of eight sediment composites were chemically analyzed for total suspended solids (TSS), chlorinatedpesticides, PCBs, PAHs, metals, and butyltins (Tables 3.25 to 3.28). GAC-filtered elutriate from Comp LC-5 was analyzed for pesticides and TPH. Complete liquid-phase chemistry and analytical QC data are reported in Appendix G. Data quality was acceptable for all water analyses except butyltins. The butyltin blanks were contaminated with dibutyltin; therefore, only tributyltin results are reported in this section.

TSS in SPP samples ranged from $34 \mathrm{mg} / \mathrm{L}$ to $62 \mathrm{mg} / \mathrm{L}$ (Table 3.25). As expected, TSS were reduced $80 \%$ to $100 \%$ by centrifugation to the elutriate phase in most samples; however, TSS were reduced by only $65 \%$ and $39 \%$ in Cornps LC- 5 and LC-6, respectively. Oily surface films observed on these samples may have retained particles during centrifugation.

\subsubsection{Chlorinated Pesticides}

Liquid-phase sample results for DDT, DDT analogues, and dieldrin are presented in Table 3.25. The procedural blank is site water that was carried through the SPP and elutriate preparation process. The procedural blank had higher concentrations of pesticides (particularly 4,4'-DDD) and PAHs than the site water sample. Reanalysis confirmed the concentrations of pesticides in the procedural blank. Two possible causes for the irregularity are as follows: 1) the site water was not homogeneous, or 2) cross-contaminationoccurred during sample preparation. The site water used to prepare SPP and elutriate samples was collected from Inner Harbor 
Channel in 2020 -liter containers, and was not homogenized before sample preparation. The site water used to prepare the procedural blank was decanted from a different container than the site water sample that was analyzed directly. All Teflon containers used in SPP and elutriate preparation were decontaminated between composites following procedures described in Appendix $A$; however, the wash, rinse, and acid bath may not have been adequate to remove all traces of contaminants. Consequently, sample results that are less than five times the concentration in the procedural blank might be attributed to the site water or cross-contamination during sample preparation. The five times criteria was applied in accordance with the guidelines for blank contamination provided in Laboratory Data Validation Functional Guidelines for Evaluating Organics Analyses (USEPA 1988). Pesticides detected in samples from the following composites might be derived from the site water or cross-contamination, and not from the sediment: Comps USFC (except 4,4'-DDE), FSFC (except 4,4'-DDE in the SPP), IHC-1, IHC-2 (except 4,4'-DDT in the elutriate), and IHC-3. Pesticide concentrations (except 4,4'-DDD) were near or below the method detection limit in most of these samples.

Pesticide concentrations in SPP and elutriate samples from the Lauritzen Canal composites greatly exceeded the concentrations in the procedural blank. Dieldrin and DDT compounds were present in liquid-phase samples from Lauritzen Canal at concentrations ranging from about $450 \mathrm{ng} / \mathrm{L}$ to $300,000 \mathrm{ng} / \mathrm{L}$ (Table 3.25). Concentrations of 4,4'-DDD were the highest of all the pesticides and were an order of magnitude higher than 4,4'-DDT, 4,4'-DDE, and dieldrin concentrations. Pesticide concentrations increased with the depth of the composite from which the liquid phase was prepared: highest in Comp LC-6, followed by Comp LC-5 and then Comp LC. Concentrations were reduced by $15 \%$ to $90 \%$ in the elutriate with the exception of Comps LC- 6 , USFC, and IHC-2, where elutriate concentrations were more than twice as high as in the SPP. Higher concentrations in the elutriate were observed even though the TSS concentrations were reduced (39\% to 100\%) during elutriate preparation. Reanalysis confirmed the initial values. The reason for higher contaminant concentrations in elutriate samples is not clear, but may be explained in part by sample inhomogeneity. Analytical duplicates of SPP and elutriate samples showed a $50 \%$ to $94 \%$ differencein pesticide concentrations, indicating that aliquots of liquid from the same sample container were not homogeneous, even after mixing.

Elutriate from Comp LC-5 was filtered through GAC as described in Appendix A to test whether treatment would reduce contaminant concentrations. GAC filtration of Comp LC-5 elutriate reduced the total DDT concentration by $23 \%$, and dieldrin by $27 \%$. TPH was analyzed in the unfiltered and filtered elutriate of Comp LC-5. Filtration reduced the TPH in the elutriate from $16 \mathrm{mg} / \mathrm{L}$ to $14 \mathrm{mg} / \mathrm{L}$, or by $12.5 \%$.

Table 3.26 shows pesticides other than dieldrin and DDT that were detected in liquidphase samples. These compounds were only detected in Lauritzen Canal samples. Most 
notably, chlordane isomers were detected at concentrations from $10 \mathrm{ng} / \mathrm{L}$ to $1240 \mathrm{ng} / \mathrm{L}$. GAC filtration appeared to effectively remove trans-chlordane from the Comp LC-5 elutriate.

\subsubsection{Other Contaminants}

As with pesticides, PAHs were detected in the procedural blank at concentrations higher than those detected in the site water (Table 3.27). Therefore, sample results less than five times the concentration in the procedural blank might be attributed to the site water or to crosscontamination during SPP and elutriate sample preparation. PAH results for SPP and elutriate samples from Comps FSFC, IHC-1, IHC-2, and IHC-3 are less than five times the PAH concentrations in the procedural blank.

PAH concentrations in SPP and elutriate samples from the Lauritzen Canal and upper Santa $\mathrm{Fe}$ Channel composites are at least an order of magnitude higher than the others (Table 3.27). Total PAHs in these liquid-phase samples ranged from $1120 \mathrm{ng} / \mathrm{L}$ to $40,812 \mathrm{ng} / \mathrm{L}$. The highest concentrations were found in Comp LC-6 elutriate and SPP, followed by Comp LC-5, Comp USFC, and Comp LC. PAHs in the liquid phase of Comps LC and LC-5 composites consisted mostly of HPAH. In Comp LC-6 liquid-phase samples, LPAH and HPAH contributed about equally to total PAH. In contrast, the PAHs in Comp USFC liquid-phase samples were primarily LPAH. This distribution of LPAH and HPAH in the liquid phase is similar to the distribution in the solid phase (sediment), especially for Comp LC-6 (Table 3.16). LPAHs were not the primary contributor of PAH in Comp USFC sediment, but they did account for a higher percentage of total PAH than in other composites. In most cases, PAH concentrations were reduced by removal of particulates (centrifugation to elutriate phase). Exceptions were Comp LC-6 and Comp IHC-2, where PAHs were higher in the elutriate phase.

The PCB Aroclor 1254 was detected in liquid-phase samples (Table 3.27). Aroclor 1254 was present in SPP samples only; it appeared to be effectively removed by centrifugation. Aroclor 1254 was only present in the SPP from surface (upper $1 \mathrm{ft}$ of YBM) composites, decreasing in concentration from about $350 \mathrm{ng} / \mathrm{L}$ in Comp LC SPP to $64 \mathrm{ng} / \mathrm{L}$ in Comp IHC-1 SPP. Aroclor 1254 was not detected in SPP from composites at depth (Comps LC-5 and LC-6) or further out the Inner Harbor Channel (Comps IHC-2 and IHC-3).

Tributyltin ranged from less than $10 \mathrm{ng} / \mathrm{L}$ to $40.5 \mathrm{ng} / \mathrm{L}$ in Comp LC-5 (Table 3.27). Most values were not much higher than the $27.2 \mathrm{ng} / \mathrm{L}$ measured in the site water, indicating a relatively small contribution from sediments. Centrifugation to the elutriate phase reduced TBT levels somewhat in the liquid phases of Comps LC, LC-5, and USFC. TBT levels were similar or increased between SPP and elutriate of other composites.

Of the 10 priority pollutant metals measured in liquid-phase samples, only arsenic and mercury were consistently detected at higher levels than was found in Richmond Harbor site 
water (Table 3.28). In general, metals concentrations were reduced by centrifugation to elutriate phase, particularly chromium, copper, mercury, and lead. Notable exceptions were arsenic in Comps LC-5 and FSFC, cadmium and selenium in Comp USFC, and zinc in Comp IHC-1. In those cases, metals concentrations were slightly higher in elutriate than in SPP.

\subsubsection{6-Hour Static Test with Holmesimvsis costata}

The 96-h mysid test was conducted following the procedures described in Appendix A. $H$. costata were exposed to eight SPP and eight elutriate treatments at concentrations of $0 \%$, $10 \%, 50 \%$, and $100 \%$. In addition, lower concentrations of Comp LC-5 SPP and elutriate were tested, as were the unfiltered and GAC-filtered elutriate of Comp LC-5. Complete survival data for all replicates are reported in Appendix $\mathrm{H}$, Tables $\mathrm{H} . \mathrm{I}$ and $\mathrm{H}$. 3. Water quality monitoring and reference toxicant data are also tabulated in Appendix $\mathrm{H}$.

All SPP and elutriate tests with $H$. costata were validated by greater than $90 \%$ control (0\% SPP or elutriate) survival for each composite dilution series (Tables 3.29 and 3.30). Water quality parameters were within acceptable ranges throughout the test, with the exception of $\mathrm{pH}$, which was slightly elevated in several $100 \%$ elutriate and SPP replicates. However, these values were within the acceptable $\mathrm{pH}$ range (6.5-8.5) for marine life listed in USEPA's Quality Criteria for Water 1986 (USEPA 1987). The $\mathrm{pH}$ was elevated above 8.5 in the 100\% SPP and elutriate from Comps LC- 5 and L-6, but were within the suggested pH range of 6.5 to 9.0 for estuarine organisms (USEPA 1987). Results of the reference toxicant tests showed that H. costata were sensitive to copper, with $\mathrm{LC}_{50} \mathrm{~S}$ of $92 \mu \mathrm{g} / \mathrm{L}$ and $109 \mu \mathrm{g} / \mathrm{L}$ for the two populations of organisms tested. The close agreement of the $\mathrm{LC}_{50} \mathrm{~s}$ demonstrates a consistent response to copper for the two populations. These values were higher than previous $\mathbf{L C}_{50} \mathbf{s}$ found both in the literature (27 $\mu \mathrm{g} / \mathrm{L}$, Hunt et al. 1989), and at this laboratory (50 $\mu \mathrm{g} / \mathrm{L})$, indicating that these populations may have been less sensitive to toxicants.

H. costatawere sensitive to SPP prepared from all eight sediment composites. T-test comparisons $(a=0.05)$ showed that all $100 \%$ SPP treatments had statistically significantly higher mortality than the $0 \%$ SPP controls. However, results for the composites outside of the Lauritzen Canal might be influenced by possible cross-contamination during sample preparation (Sections 3.5.1.1 and 3.5.1.2). H. costata exposed to SPP prepared with Comps LC, LC-5, and LC-6 sediment experienced $100 \%$ mortality in all concentrations, with LC $_{50}$ S of less than $10 \%$ SPP. Comp LC- 5 SPP was retested at lower concentrations ( $0.01 \%, 0.1 \%$ and $1 \%)$; an LC $_{50}$ was estimated at $0.38 \%$ SPP.

Similar results were seen in the $H$. costata tests with elutriate preparations: $H$. costata mortality in each of the $100 \%$ elutriate treatments was significantly higher than its respective control. Again, results for composites outside of the Lauritzen Canal might be influenced by 
procedural cross-contamination. As with the SPP, exposure to Comps LC, LC-5, and LC-6 elutriates resulted in $100 \%$ mortality in the $10 \%, 50 \%$, and $100 \%$ concentrations and LC $_{50} \mathrm{~S}$ of less than $10 \%$ elutriate. With the additional $0.01 \%, 0.1 \%$, and $1 \%$ elutriate concentrations, the LC $_{50}$ for Comp LC- 5 elutriate was estimated to be $0.8 \%$ elutriate. Carbon filtration of Comp LC- 5 elutriate did not reduce its toxicity to $\mathrm{H}$ wstata.

\subsubsection{8-Hour Static Test with Larval Mytilus galloprovincialis}

The 48-h larval bivalve test was conducted following the procedures described in Appendix A. Larvae of the bivalve, $\mathrm{M}$ galloprovincialis, were exposed to four concentrations $(0 \%, 10 \%, 50 \%$, and $100 \%)$ of eight SPP and eight elutriate treatments. Complete survival and normal development data for all replicates are reported in Appendix I, Tables 1.1 and 1.3. Water quality and reference toxicant test data are also reported in Appendix I.

All SPP and elutriate tests with $M$. galloprovincialis were validated by greater than $90 \%$ survival in controls ( $0 \%$ SPP or elutriate), except the Comp USFC elutriate control which had 89.3\% survival (Tables 3.31 and 3.32). The high percentage of normally developed larvae in the controls ( $87.9 \%$ to $100 \%)$ also indicate that the organisms responded as expected. Water quality parameters were within acceptable ranges throughout the test, with the exception of $\mathrm{pH}$ which was slightly elevated in several $100 \%$ elutriate and SPP samples. The $\mathrm{pH}$ values were less than 8.5 for all 100\% concentrations except for Comps LC-5 and LC-6 100\% SPP and elutriate, which were less than $\mathrm{pH} 9.0$.

Reference toxicant tests indicated that the $\mathrm{M}$ galloprovincialis larvae used in these tests were sensitive to copper, with $\mathrm{LC}_{50}$ S ranging from $9.9 \mu \mathrm{g} / \mathrm{L}$ to $27.7 \mu \mathrm{g} / \mathrm{L}$. Median effective concentrations $\left(E_{50} \mathrm{~S}\right)$ based on normal larval development ranged from $7.5 \mu \mathrm{g} / \mathrm{L}$ to $8.9 \mu \mathrm{g} / \mathrm{L}$. These values are within the range of responses ( $\mathrm{LC}_{50} \mathrm{~s} 5.8 \mu \mathrm{g} / \mathrm{L}$ to $35.0 \mu \mathrm{g} / \mathrm{L} \mathrm{Cu}$; EC $\mathrm{E}_{50} \mathrm{~s} 5.7 \mu \mathrm{g} / \mathrm{L}$ to $21.0 \mu \mathrm{g} / \mathrm{L} \mathrm{Cu}$ ) previously reported both by MSL and other scientists (Dinnel et al. 1983; USEPA 1985). The close range of responses to copper indicates that all batches of larvae used in these tests produced a similar response.

In the SPP test with larval $\mathrm{M}$ galloprovincialis, statistically significant survival differences were observed between $0 \%$ and 100\% SPP of Comps LC-5 and LC-6 (Table 3.31). SPP from composites outside of Lauritzen Canal showed no significant differences in survival between the $100 \%$ and $0 \%$ concentrations. Although survival in Comp USFC 100\% SPP was much lower than in the $0 \%$ SPP, the difference was not statistically significant because the variance between replicates was very high. Despite the significantly lower survival in 100\% SPP and elutriate of most Lauritzen Canal composites, mortality did not exceed $50 \%$ relative to controls, and $\mathbf{L C}_{50}$ s for both SPP and elutriate of all composites were greater than $100 \%$. 
Exposure to SPP composites affected normal larval development. Normal development is a more sensitive indicator of liquid-phase toxicity than survival because larvae with abnormal or delayed development at 48-h are much less likely to survive to adulthood in the natural environment. Statistically significant differences in normal development between $0 \%$ and $100 \%$ concentrations were observed in the SPP of all except Comp USFC (Table 3.31). However, results for composites outside of the Lauritzen Canal might be affected by procedural crosscontamination. $\mathrm{EC}_{50}$ s based on the percent normal were $21.2 \%$ and $23.1 \%$ SPP for Comps LC- 5 and LC-6, and Comp LC had an EC $_{50}$ of $70.1 \%$ SPP. The larval test results were similar to the mysid test (Table 3.29) in that removal of the suspended particles did not appear to reduce toxicity.

M. galloprovincialisresponse to elutriate was similar to its response to SPP. Statistically significant survival differences were observed between $0 \%$ and $100 \%$ elutriate of Comps LC, LC-5, and LC-6 (Table 3.32). Elutriate from composites outside of Lauritzen Canal showed no significant differences in survival between the $100 \%$ and $0 \%$ concentrations. In elutriate from all composites, mortality did not exceed $50 \%$ relative to controls; therefore, $\mathbf{L C}_{50} \mathrm{~S}$ were greater than $100 \%$.

Exposure to elutriates resulted in statistically significant differences in normal larval development between $0 \%$ and $100 \%$ concentrations of all composites (Table 3.32). As with the other tests, results for composites outside of the Lauritzen Canal might be influenced by sample cross-contamination. $\mathrm{EC}_{50}$ s for Comps LC- 5 and LC- 6 were $21.4 \%$ and $19.8 \%$ elutriate, nearly identical to the SPP $\mathrm{EC}_{50} \mathrm{~S}$. Comp LC had an $\mathrm{EC}_{50}$ of $69.5 \%$, again similar to the SPP $\mathrm{EC}_{50}$. The larval test results were similar to the mysid test (Table 3.30) in that removal of suspended particles by centrifugation did not appear to reduce toxicity.

\subsection{EISH TISSUE CHEMISTRY}

Ten whole fish tissue samples of shiner surfperch (Cymatogaster aggregata) were analyzed for chlorinated pesticides, PCBs, PAHs, and phthalate esters. The samples were collected by USEPA for the ecological risk assessment of marine sediments at the United Heckathorn site. Complete analytical results, including QC data, are provided in Appendix J. 


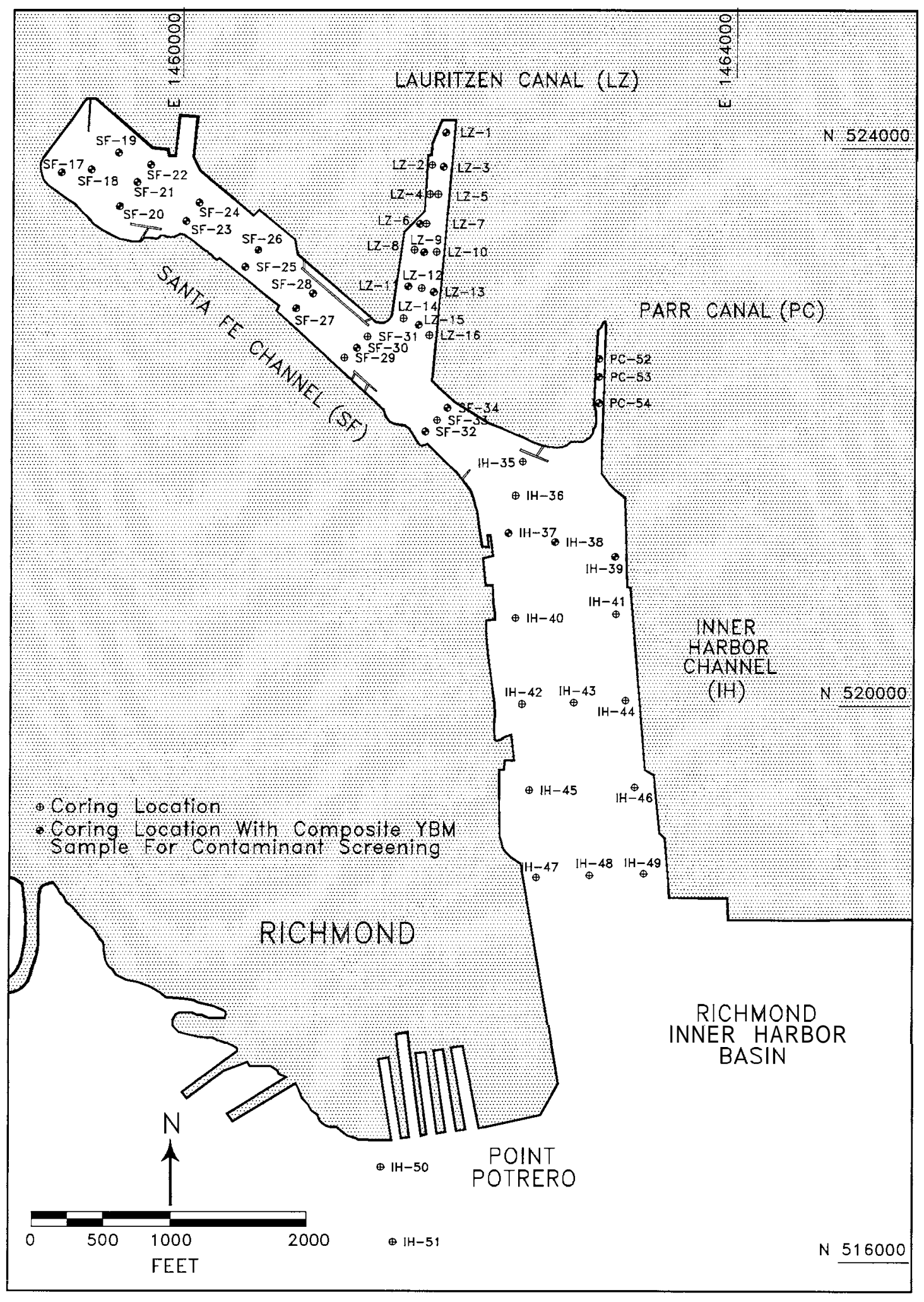

FIGURE 3.1. Core Sampling Station Designations 


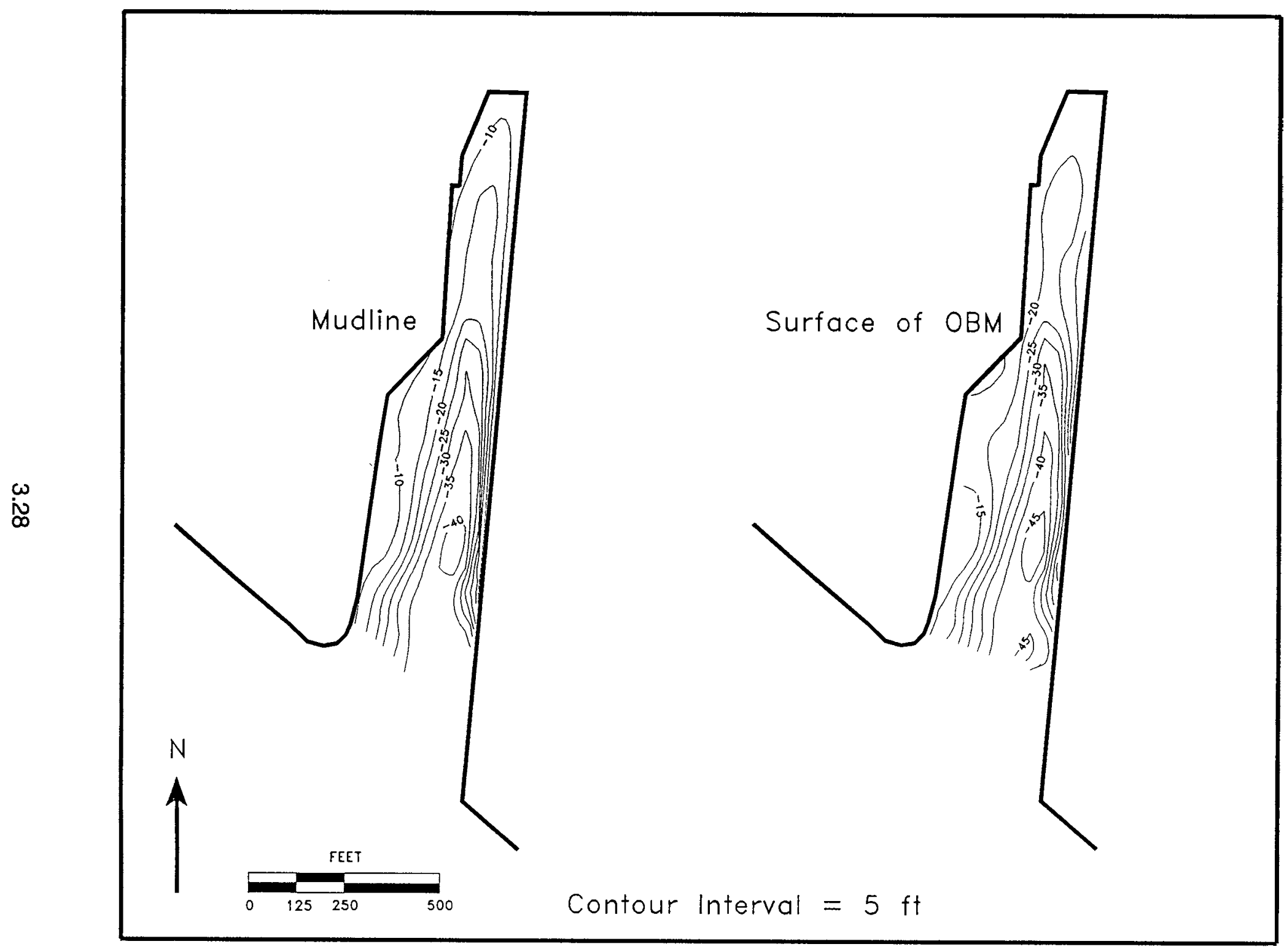

FIGURE 3.2. Elevation of the Mudline and YBM/OBM Contact in the Lauritzen Canal 


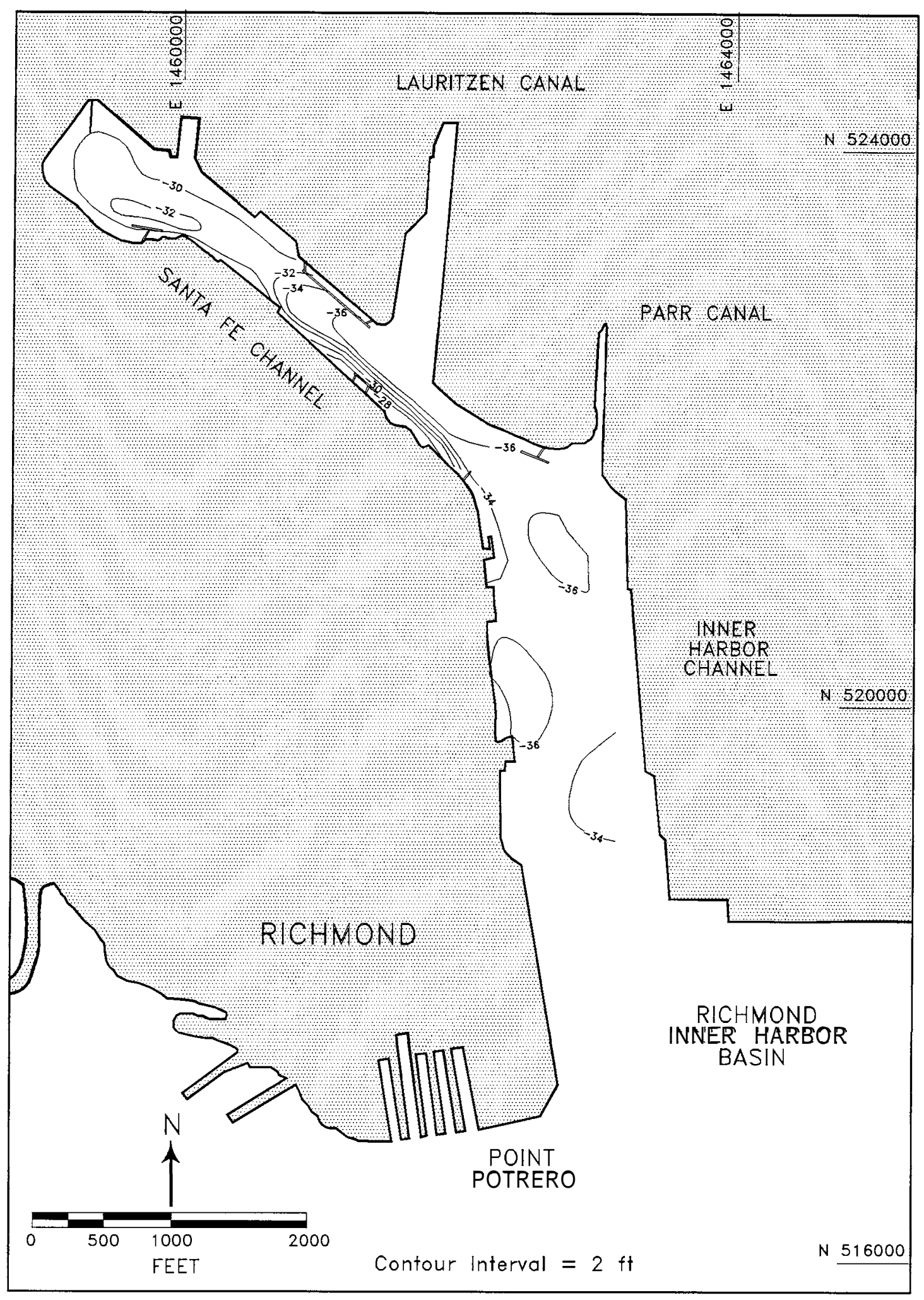

FIGURE 3.3. Mudline Elevation in Santa Fe and Inner Harbor Channels 


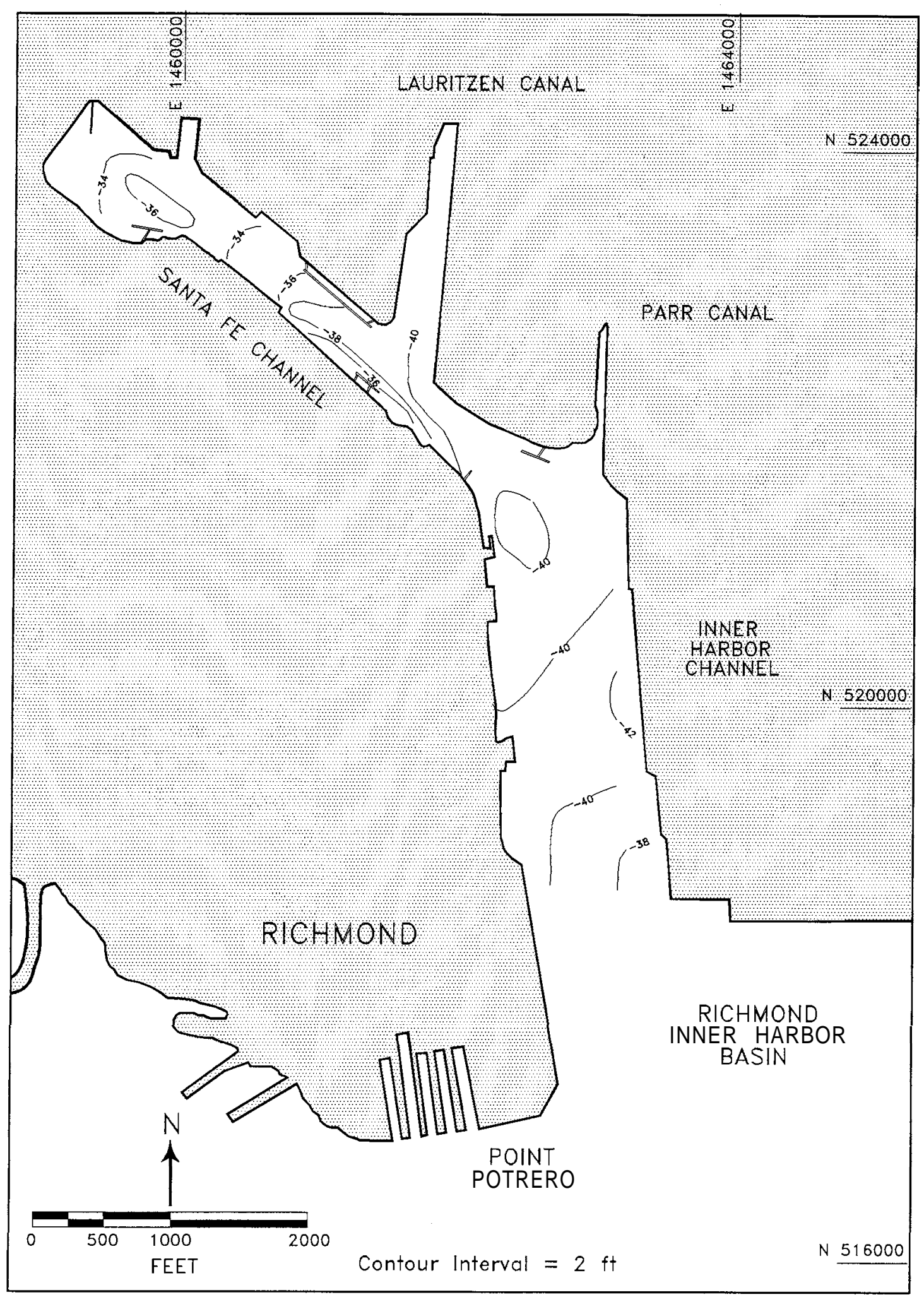

FIGURE 3.4. Elevation of YBM/OBM Contact in Santa Fe and Inner Harbor Channels 


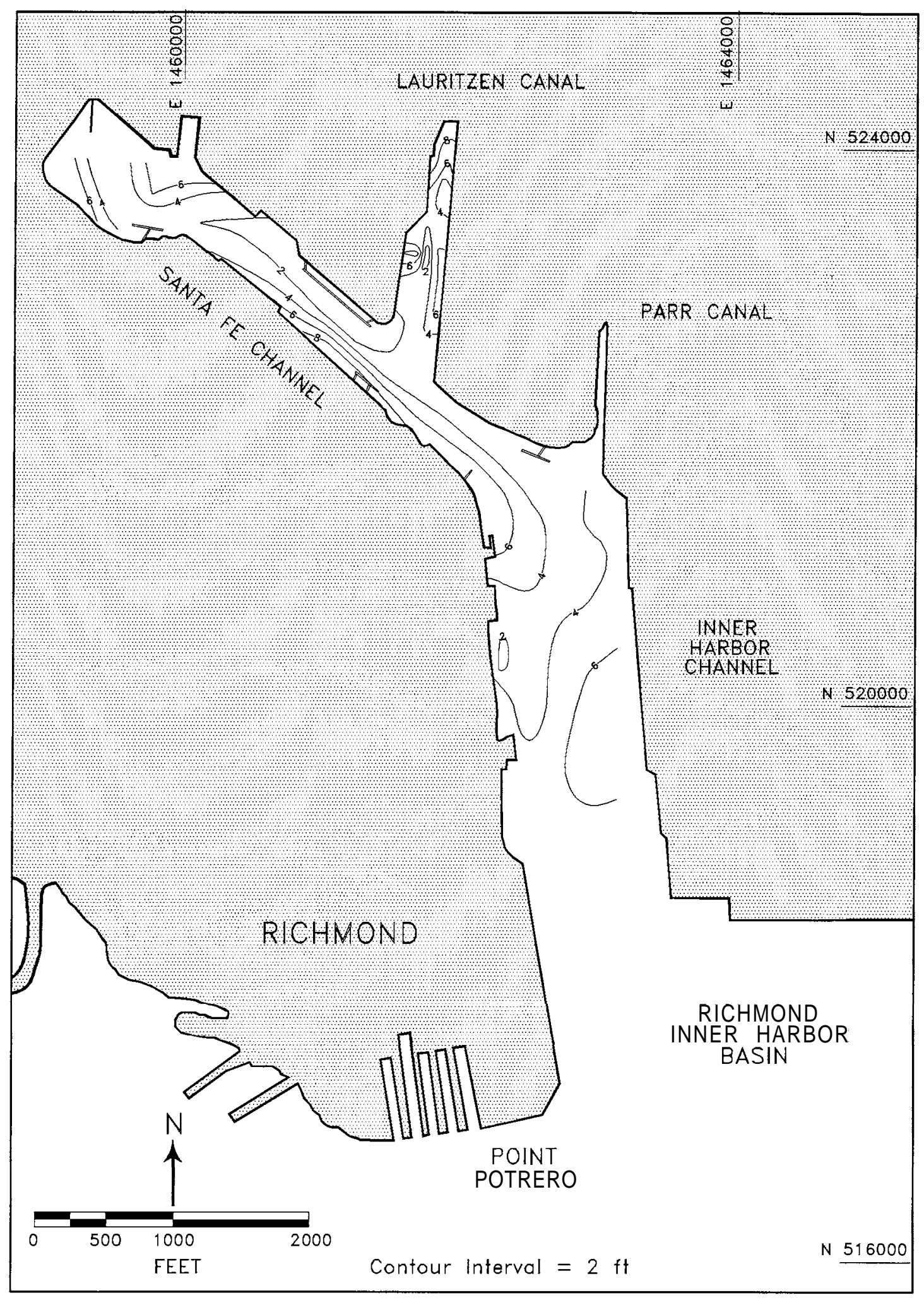

FIGURE 3.5. Map of YBM Thickness 


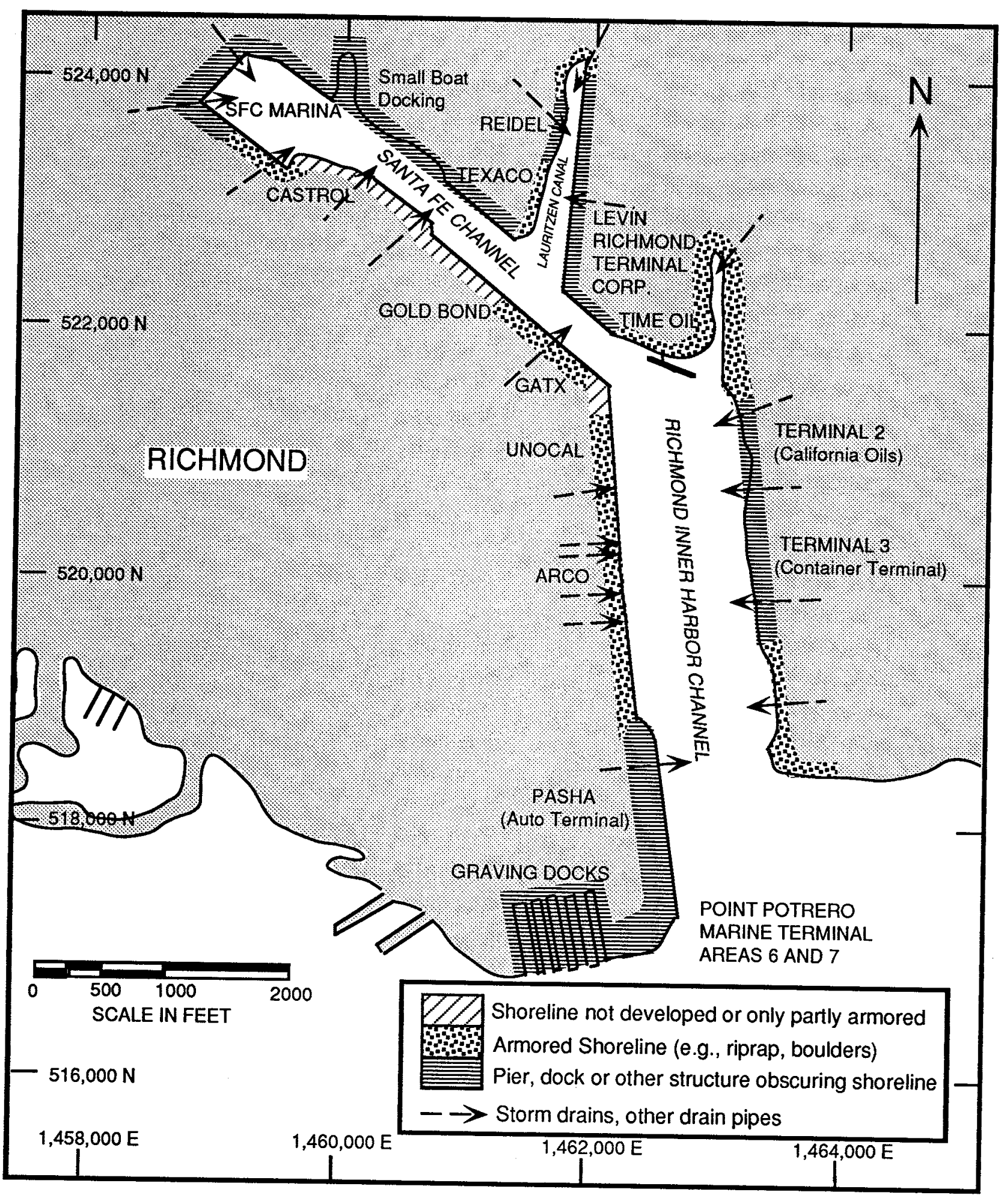

FIGURE 3.6. Shoreline Features 


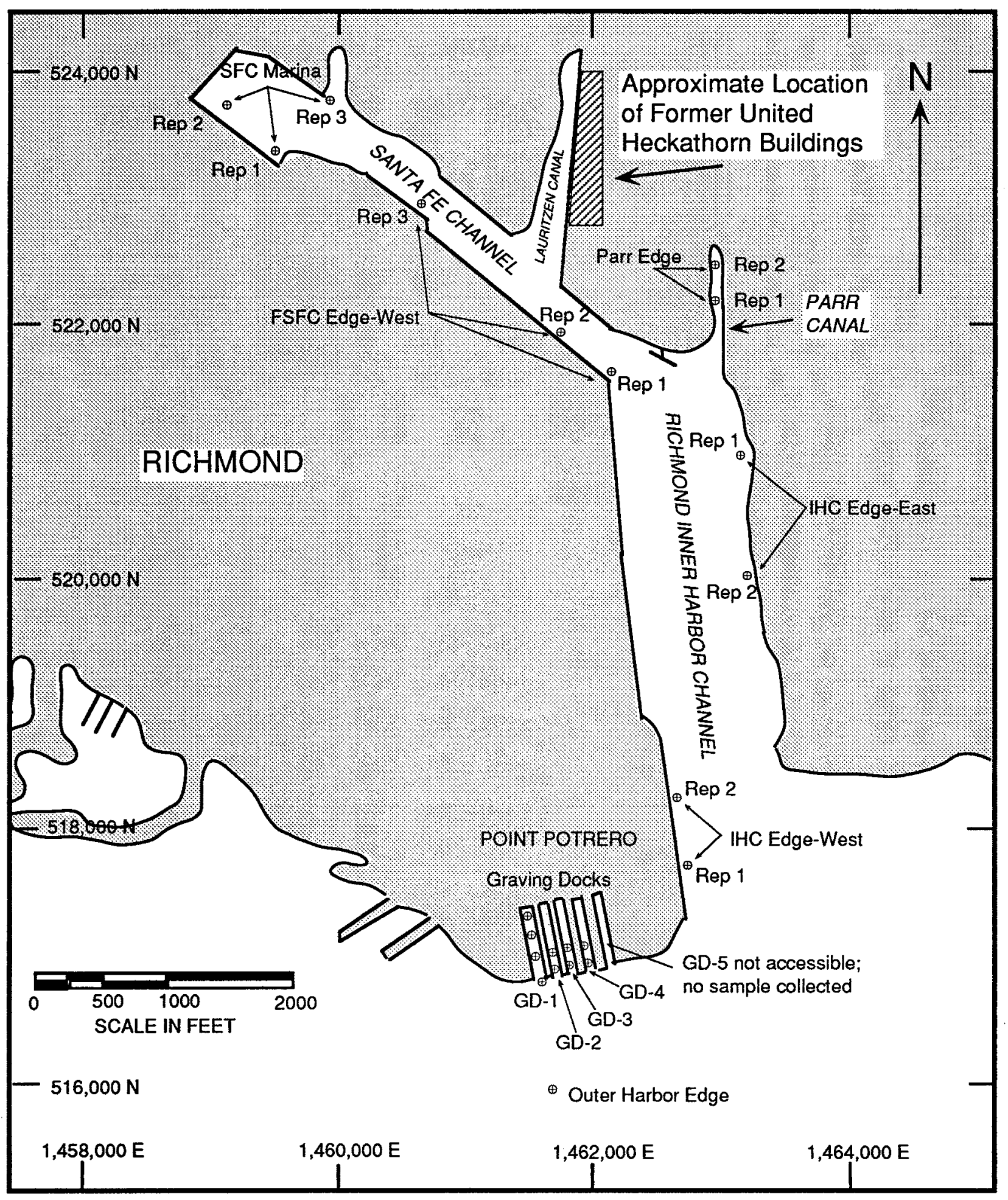

FIGURE 3.7. Approximate Locations of Channel Edge and Graving Dock Grab Sampling Sites 


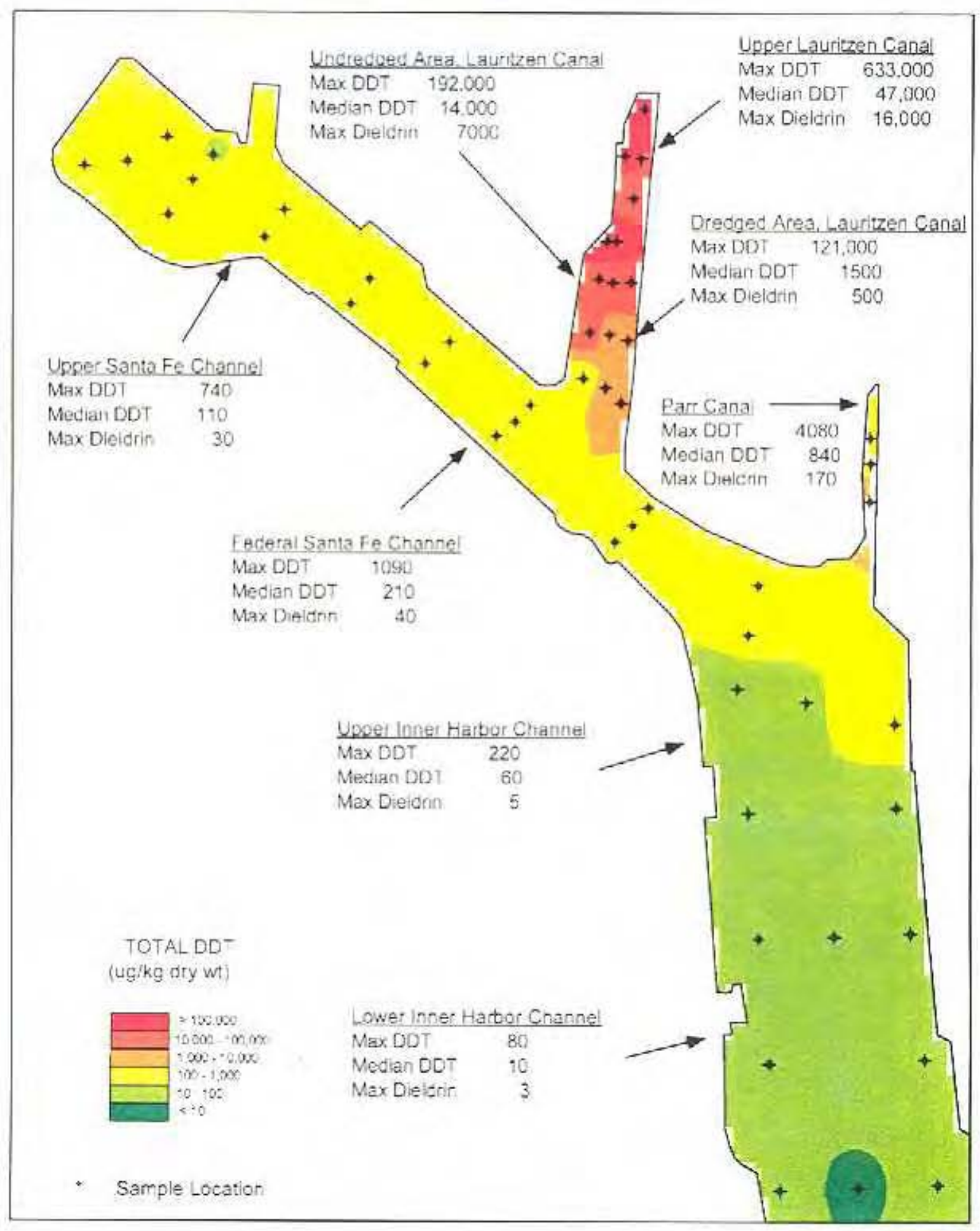

FIGURE 3.8. Distribution of DDT and Dieldnn in YBM, Log Scaie 


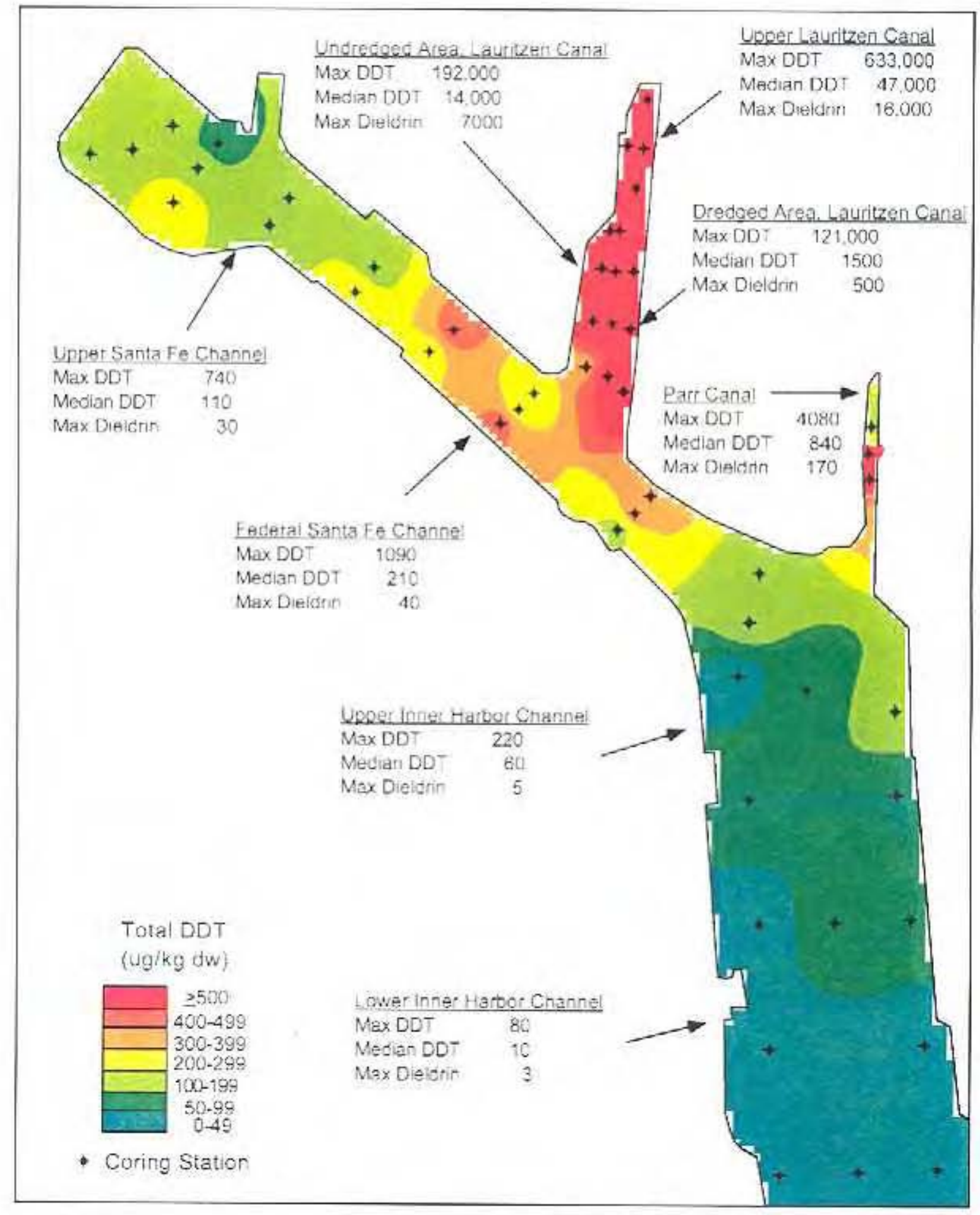

FIGURE 3.9. Distribution of DDT and Dieldrin in Y8M, Linear Scale 


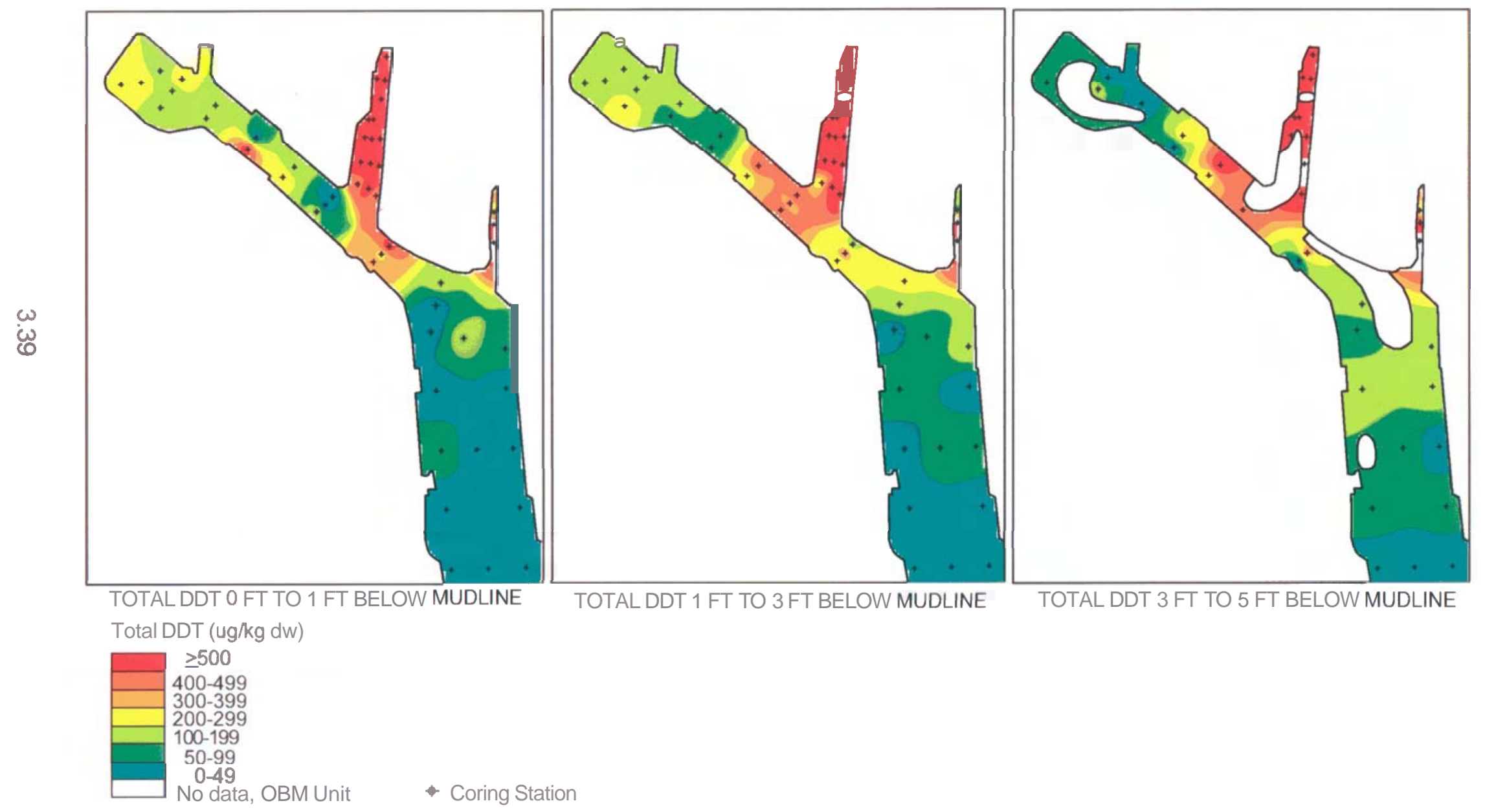

ElGURE_3.10. Distribution of Total DDT in YBM With Increasing Depth 


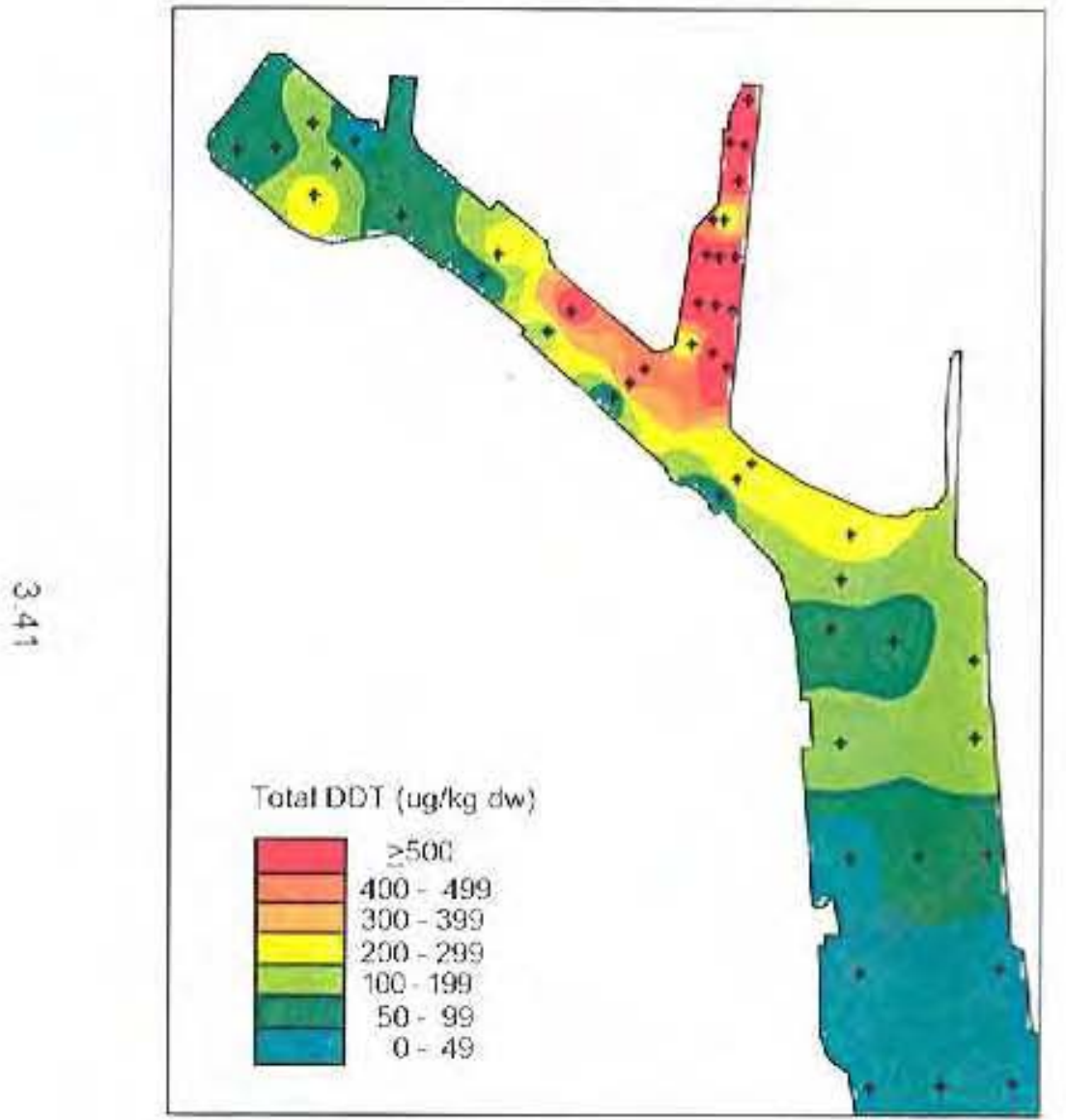

TOTAL ODI 1 FT ABOVE YBMIOBM CONTACT

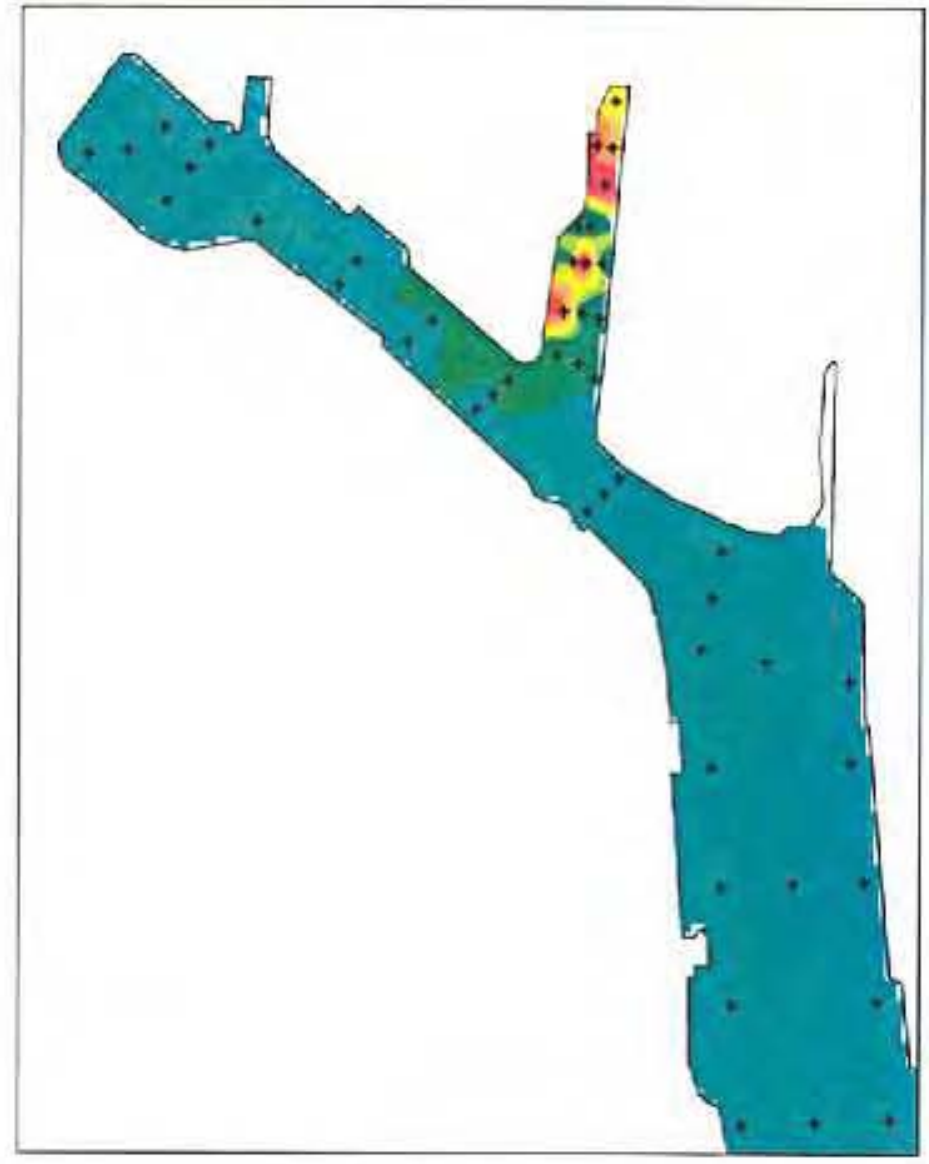

TOTAL DDT : FT BELOW YBM/OBM CONTACT

+ Coring Station

FIGURE 3.11 Distribution of Total DDT Above and Below the YBM/OBM Cantact 


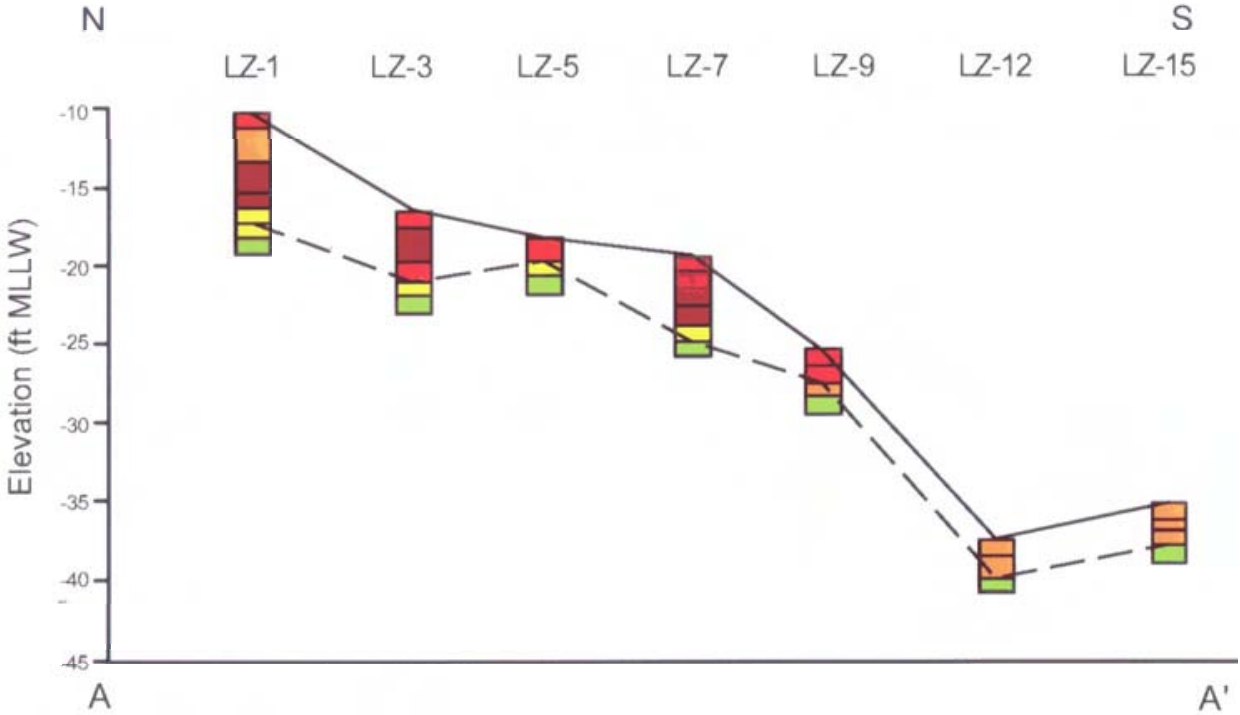

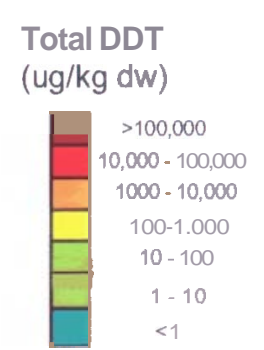

Vertical Exaggeration $=25 \mathrm{X}$

- - YBM/OBM Contact
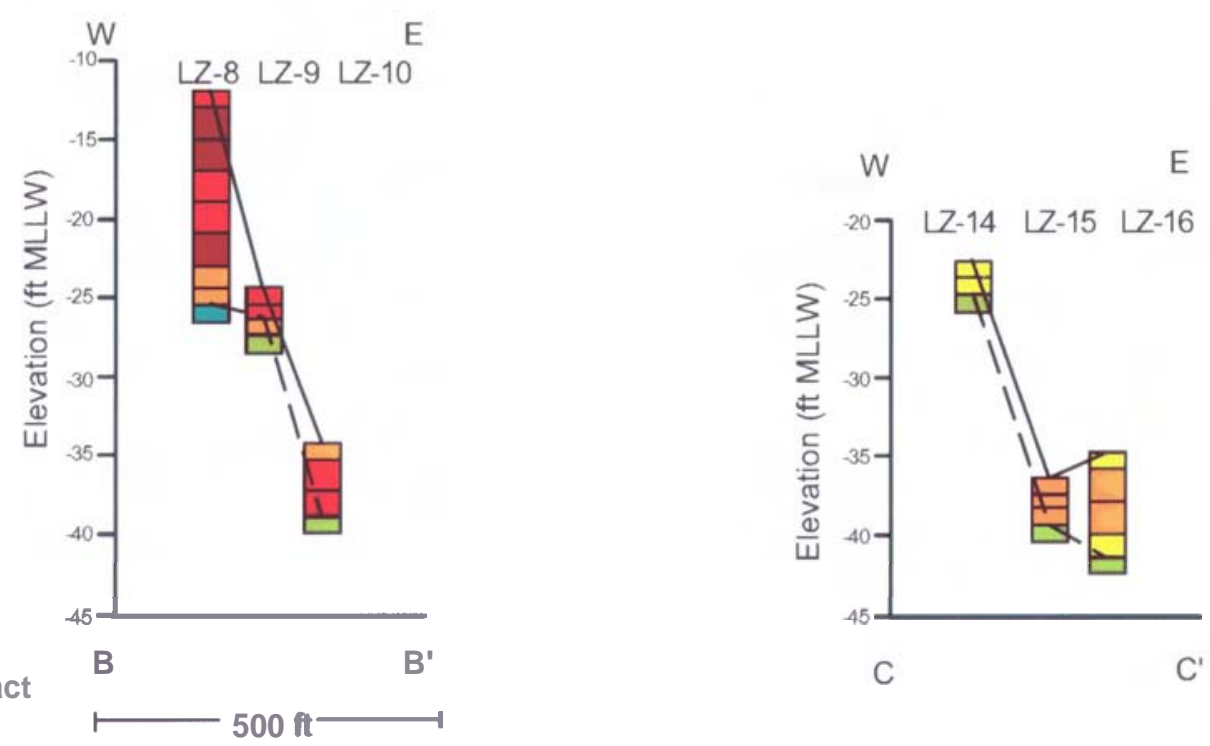

FGURE 3.12. Cross-Sections of the Lauritzen Canal Showing Total DDT Concentrations 

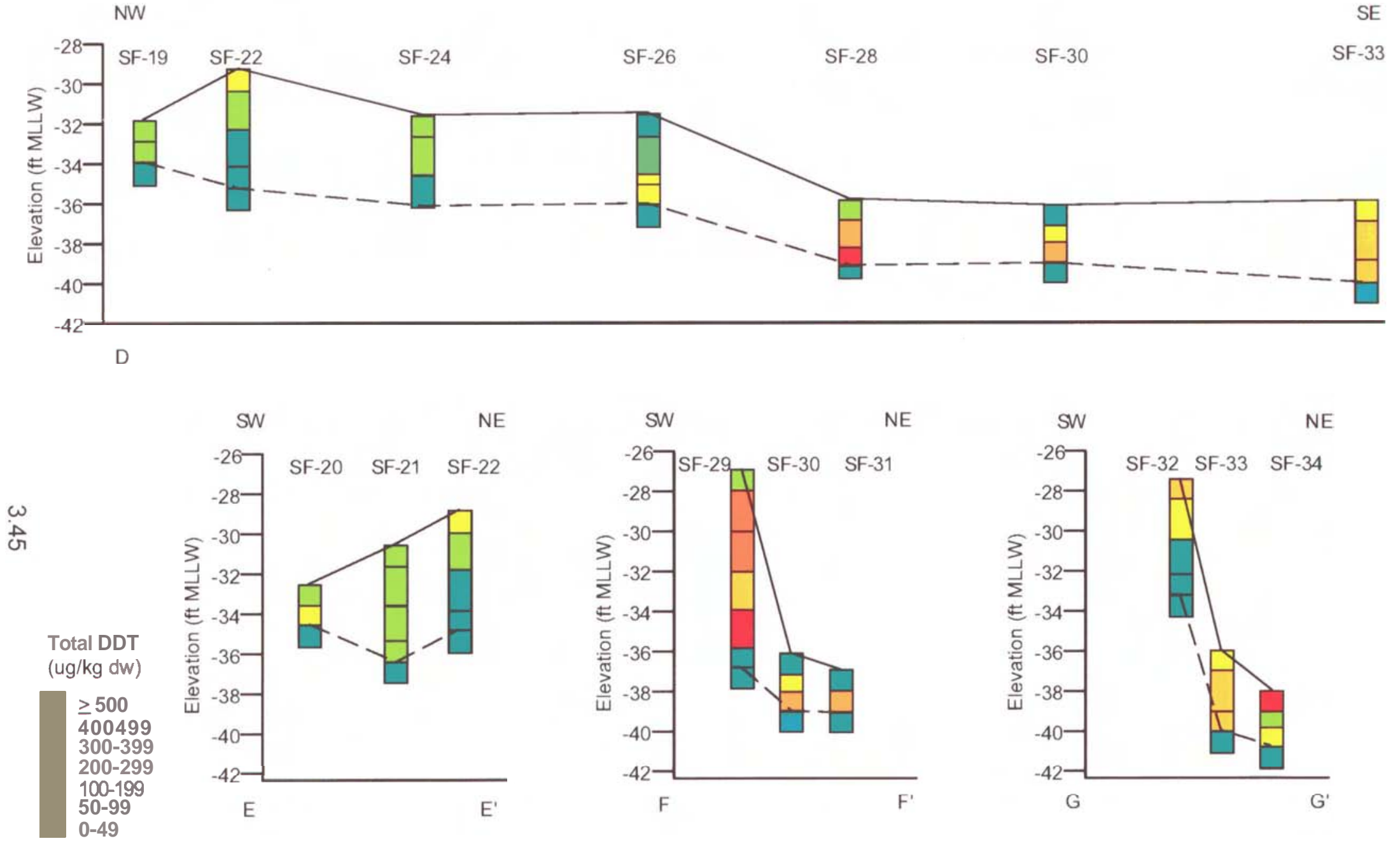

Vertical Exaggeration $=50 \mathrm{X}$

- - YBM/OBM contact $\longmapsto 500 \mathrm{ft} \longrightarrow$

FIGURE 3.13. Cross-Sections of the Santa Fe Channel Showing Total DDT Concentrations 
N

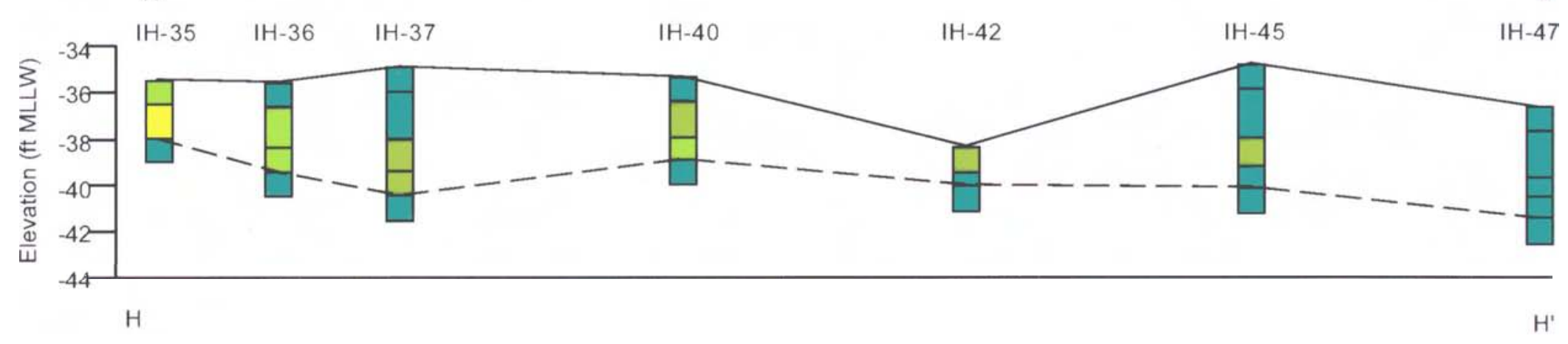

$\omega$

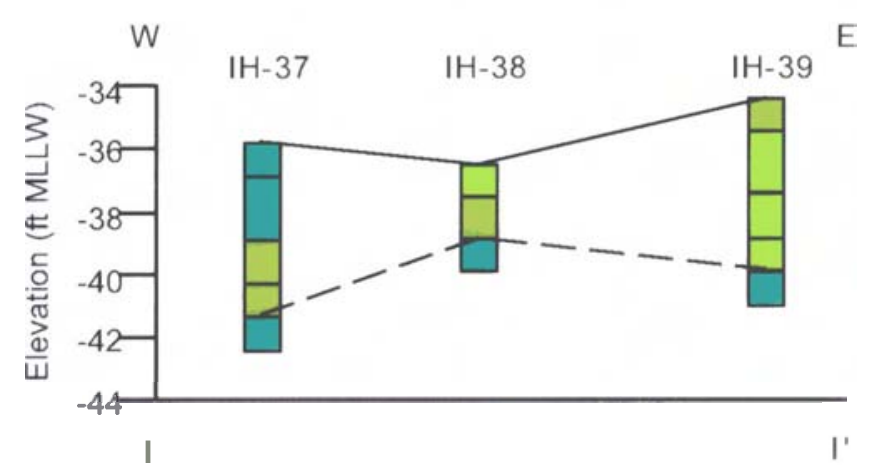

Total DDT

(ug/kg dw)

$\square 200-299$

$100-199$
$50-99$

0. 49

$\longmapsto 500 \mathrm{ft} \longrightarrow$

Vertical Exaggeration $=50 \mathrm{X}$

- - - YBM/OBM contact

ElGURE 3.14. Cross-Sections of Inner Harbor Channel Showing Total DDT Concentrations 


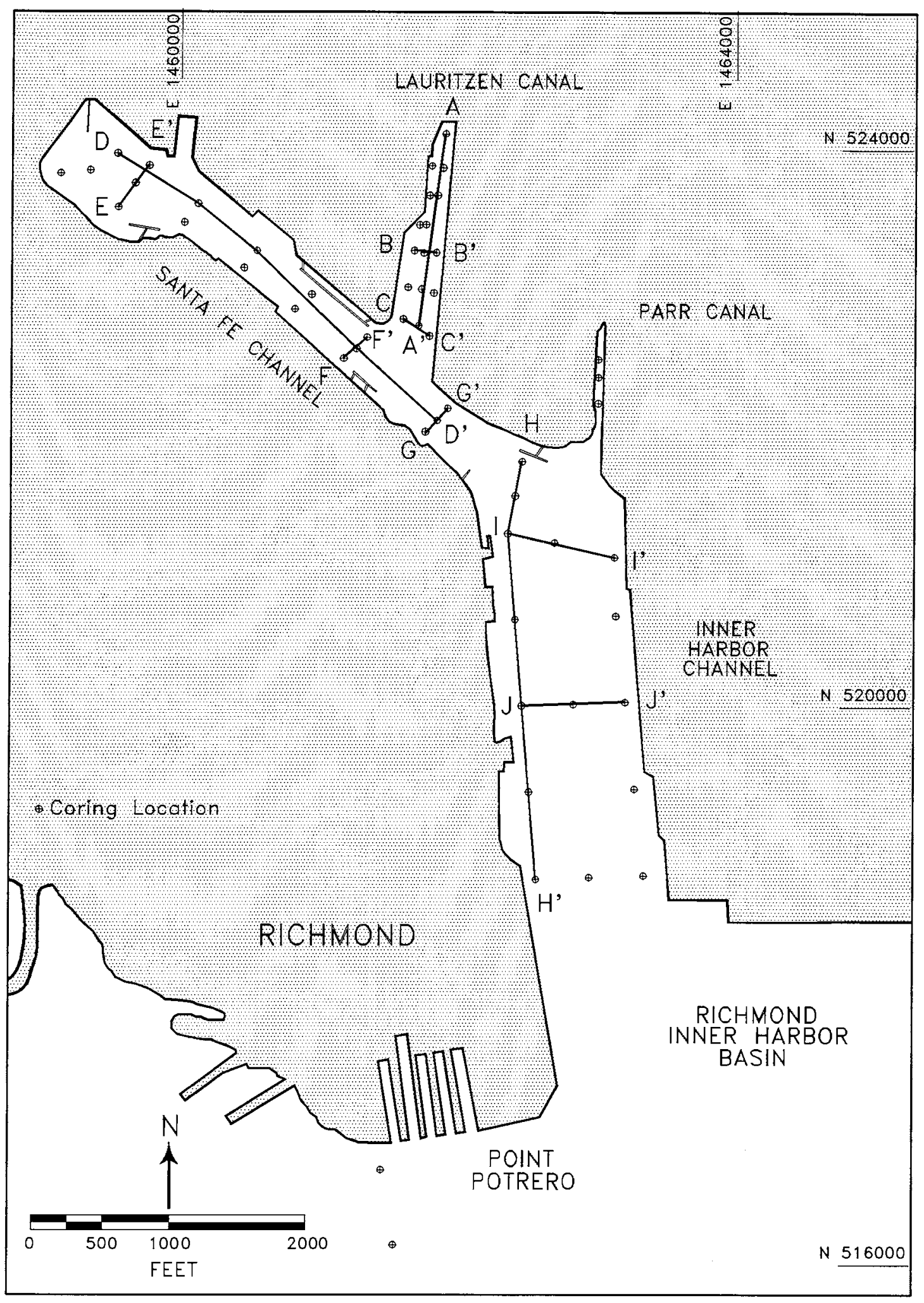

FIGURE 3.15. Cross-Section Locations 


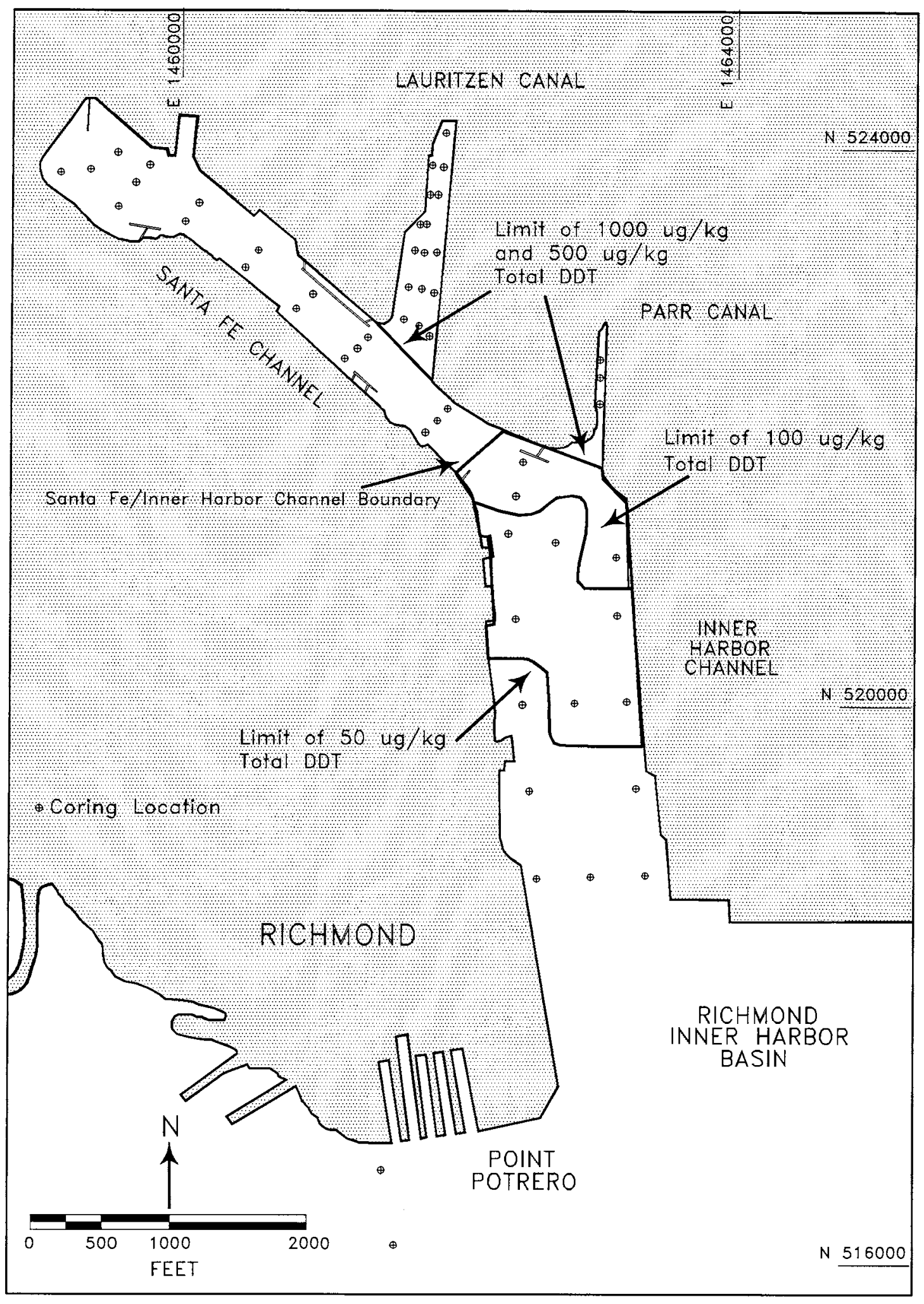

FIGURE 3.16. Boundaries of Sediment Volume Categories 
TABLE 3.1. Core Sampling Site Locations, Mudline Elevations, and Thickness of Younger Bay Mud

\section{Battelle}

Station Desianation

Date

Collected

Lauritzen Canal

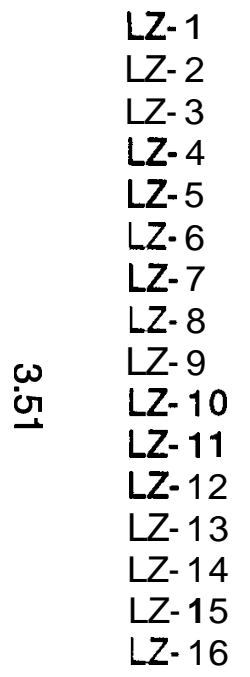

$\begin{array}{ll}\mathbf{5 2 4 , 0 3 1} & \mathbf{1}, \mathbf{4 6 1 , 8 9 8} \\ \mathbf{5 2 3 , 8 0 1} & \mathbf{1 , 4 6 1 , 7 9 9} \\ \mathbf{5 2 3 , 7 8 7} & \mathbf{1 , 4 6 1 , 8 8 0} \\ \mathbf{5 2 3 , 5 9 0} & 1,461,784 \\ \mathbf{5 2 3 , 5 9 1} & \mathbf{1 , 4 6 1 , 8 4 3} \\ \mathbf{5 2 3 , 3 7 9} & 1,461,712 \\ \mathbf{5 2 3 , 3 8 0} & 1,461,760 \\ \mathbf{5 2 3 , 1 9 3} & 1,461,674 \\ \mathbf{5 2 3 , 1 7 6} & 1,461,743 \\ \mathbf{5 2 3 , 1 7 8} & 1,461,833 \\ \mathbf{5 2 2 , 9 3 0} & 1,461,630 \\ \mathbf{5 2 2 , 9 1 7} & 1,461,727 \\ \mathbf{5 2 2 , 8 8 9} & \mathbf{1 , 4 6 1 , 8 1 6} \\ \mathbf{5 2 2 , 7 0 1} & 1,461,597 \\ \mathbf{5 2 2 , 6 5 4} & 1,461,708 \\ \mathbf{5 2 2 , 5 8 0} & 1,461,785\end{array}$

Upper Santa Fe Channe

$\begin{array}{ll}\text { SF-17 } & \text { 7-Jan-93 } \\ \text { SF-18 } & \text { 7-Jan-93 } \\ \text { SF-19 } & \text { 7-Jan-93 } \\ \text { SF-20 } & \text { 7-Jan-93 } \\ \text { SF-21 } & \text { 7-Jan-93 } \\ \text { SF-22 } & \text { 7-Jan-93 } \\ \text { SF-23 } & \text { 7-Jan-93 } \\ \text { SF-24 } & \text { 7-Jan-93 } \\ \text { SF-25 } & \text { 8-Jan-93 } \\ \text { SF-26 } & \text { 8-Jan-93 }\end{array}$

$\begin{array}{ll}\mathbf{5 2 3 , 7 4 7} & \mathbf{1 , 4 5 9 , 1 3 4} \\ \mathbf{5 2 3 , 7 6 8} & \mathbf{1 , 4 5 9 , 3 4 4} \\ \mathbf{5 2 3 , 8 8 9} & \mathbf{1 , 4 5 9 , 5 4 1} \\ \mathbf{5 2 3 , 5 0 5} & \mathbf{1 , 4 5 9 , 5 4 7} \\ \mathbf{5 2 3 , 6 7 8} & \mathbf{1 , 4 5 9 , 6 6 8} \\ \mathbf{5 2 3 , 8 0 2} & \mathbf{1 , 4 5 9 , 7 6 8} \\ \mathbf{5 2 3 , 3 9 7} & 1,460,023 \\ \mathbf{5 2 3 , 5 2 9} & \mathbf{1 , 4 6 0 , 1 2 0} \\ \mathbf{5 2 3 , 0 6 8} & \mathbf{1 , 4 6 0 , 4 5 2} \\ \mathbf{5 2 3 , 1 9 1} & \mathbf{1 , 4 6 0 , 5 4 5}\end{array}$

California State Plane (Zone III) Coordinates North East

\begin{tabular}{|c|c|c|c|}
\hline \multicolumn{2}{|c|}{ 12-in. Core } & \multicolumn{2}{|c|}{ 4-in Core } \\
\hline & YBM/OBM & & YBM/OBM \\
\hline $\begin{array}{l}\text { Thickness } \\
\text { of YBM ( } \mathrm{ft})\end{array}$ & $\begin{array}{l}\text { Contact } \\
\text { (ft MLLW }\end{array}$ & $\begin{array}{l}\text { Thickness } \\
\text { of YBM (ft) }\end{array}$ & $\begin{array}{l}\text { Contact } \\
\text { fftMLLW }\end{array}$ \\
\hline
\end{tabular}

$-10.2$

$-12.1$

$-16.5$

$-12.6$

$-18.3$

$-12.3$

$-19.4$

$-12.3$

$-25.4$

$-34.7$

$-12.0$

$-37.5$

$-34.9$

$-23.1$

$-36.7$

$-35.2$

$\begin{array}{llll}8.5 & -18.7 & 7.0 & -17.2 \\ 8.1 & -20.2 & 4.8 & -16.9 \\ 5.9 & -22.4 & 4.2 & -20.7\end{array}$

No core collected; subsurface debris in channel

$\begin{array}{lrrr}2.0 & -20.3 & 1.2 & -19.5 \\ 4.0 & -16.3 & 4.9 & -17.2 \\ 5.0 & -24.4 & 5.3 & -24.7 \\ 8.5 & -20.8 & 13.4 & -25.7 \\ 1.0 & -26.4 & 2.0 & -27.4 \\ 6.0 & -40.7 & 4.3 & -39.0 \\ 2.3 & -14.3 & 1.7 & -13.7 \\ 3.3 & -40.8 & 2.2 & -39.7 \\ 6.6 & -41.5 & 6.2 & -41.1 \\ 1.5 & -24.6 & 1.9 & -25.0 \\ 4.3 & -41.0 & 2.8 & -39.5 \\ 3.0 & -38.2 & 7.4 & -42.6\end{array}$

$-29.4$

$-31.6$

$-31.9$

$-32.7$

$-30.8$

$-28.9$

$-34.2$

$-31.4$

$-29.5$

$-31.4$

$\begin{array}{ll}7.3 & -36.7 \\ 1.7 & -33.3 \\ 2.0 & -33.9 \\ 2.8 & -35.5 \\ 6.0 & -36.8 \\ 6.9 & -35.8 \\ 2.0 & -36.2 \\ 2.9 & -34.3 \\ 4.2 & -33.7 \\ 1.9 & -33.3\end{array}$

$\begin{array}{lr}4.3 & -33.7 \\ 2.8 & -34.4 \\ 2.1 & -34.0 \\ 2.1 & -34.8 \\ 5.6 & -36.4 \\ 6.1 & -35.0 \\ 2.7 & -36.9 \\ 5.0 & \text { N/A(a) } \\ 4.4 & -33.9 \\ 4.7 & -36.1\end{array}$


TABLE 3.1. (contd)

$\begin{array}{lc}\begin{array}{c}\text { Battelle } \\ \text { Station }\end{array} & \text { Date } \\ \text { Desianation } & \text { Collected }\end{array}$

Federal Santa Fe Channel

$\begin{array}{ll}\text { SF-27 } & \text { 8-Jan-93 } \\ \text { SF-28 } & \text { 8-Jan-93 } \\ \text { SF-29 } & \text { 8-Jan-93 } \\ \text { SF-30 } & \text { 8-Jan-93 } \\ \text { SF-31 } & \text { 8-Jan-93 } \\ \text { SF-32 } & \text { 7-Jan-93 } \\ \text { SF-33 } & \text { 7-Jan-93 }\end{array}$

in Inner Harbor Channel

$\begin{array}{ll}\mathbb{H}-35 & \text { 8-Jan-93 } \\ \mathbb{H}-36 & \text { 8-Jan-93 } \\ \mathbb{H}-37 & \text { 8-Jan-93 } \\ \mathbb{H}-38 & \text { 8-Jan-93 } \\ \mathbb{H}-39 & \text { 8-Jan-93 } \\ \mathbb{H}-40(\text { b) } & \text { 9-Jan-93 } \\ \mathbb{H}-41 \text { (b) } & \text { 9-Jan-93 } \\ \mathbb{H}-42 & \text { 9-Jan-93 } \\ \mathbb{H}-43 & 9-\mathrm{Jan}-93 \\ \mathbb{H}-44 & 9-\operatorname{Jan}-93 \\ \mathbb{H}-45(\mathrm{~b}) & \text { 9-Jan-93 } \\ \mathbb{H}-46(\mathrm{~b}) & \text { 9-Jan-93 } \\ \mathbb{H}-47 & \text { 9-Jan-93 } \\ \mathbb{H}-48 & \text { 9-Jan-93 } \\ \mathbb{H}-49 & \text { 9-Jan-93 } \\ \mathbb{H}-50 & \text { 4-Jan-93 } \\ \mathbb{H}-51 & \text { 4-Jan-93 }\end{array}$

California State Plane (Zone III) Coordinates North East

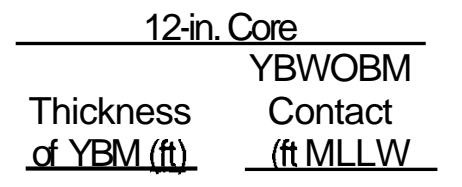

521,677 521,431

521,163

521,096

520,990

520,548

520,575

519,928

519,939

519,953

519,310

519,331

518,685

518,699

518,711

516,597

516,060

$\begin{array}{ll}1,460,819 & -35.3 \\ 1,460,940 & -35.6 \\ 1,461,172 & -27.1 \\ 1,461,263 & -36.1 \\ 1,461,339 & -36.9 \\ 1,461,758 & -27.5 \\ 1,461,843 & -35.9 \\ 1,461,920 & -38.0\end{array}$

$1,461,920$

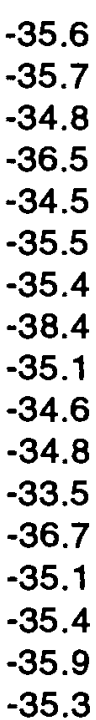

4.5
1.0
8.3
2.5
1.8
7.0
4.3
2.5

$$
\begin{aligned}
& -39.8 \\
& -36.6 \\
& -35.4 \\
& -38.6 \\
& -38.7 \\
& -34.5 \\
& -40.2
\end{aligned}
$$

$-40.5$

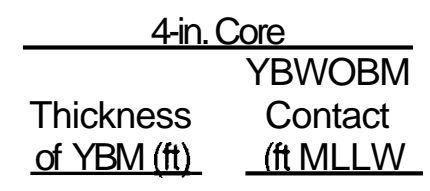

$\begin{array}{lr}2.5 & -38.1 \\ 5.1 & -40.8 \\ 7.0 & -41.8 \\ 3.3 & -39.8 \\ 5.0 & -39.5 \\ \text { NA(c) } & \text { NA } \\ \text { NA } & \text { NA } \\ 1.8 & -40.2 \\ 6.0 & -41.1 \\ 8.0 & -42.6 \\ \text { NA } & \text { NA } \\ \text { NA } & \text { NA } \\ 3.8 & -40.5 \\ 3.7 & -38.8 \\ 1.2 & -36.6 \\ 3.3 & -39.2 \\ 4.4 & -39.7\end{array}$

$\begin{array}{ll}2.4 & -38.0 \\ 3.7 & -39.4 \\ 5.5 & -40.3 \\ 2.2 & -38.7 \\ 5.5 & -40.0 \\ 3.5 & -39.0 \\ 5.0 & -40.4 \\ 1.6 & -40.0 \\ 4.0 & -39.1 \\ 8.0 & -42.6 \\ 5.3 & -40.1 \\ 6.0 & -39.5 \\ 4.8 & -41.5 \\ 4.4 & -39.5 \\ 3.7 & -39.1 \\ 4.8 & -40.7 \\ 3.0 & -38.3\end{array}$

$-40.3$

$-39.3$

$-36.9$

$-38.9$

$-38.9$

$-33.2$

$-40.1$

$-40.8$ 
TABLE 3.1 . (contd)

\begin{tabular}{|c|c|c|c|c|c|c|c|c|}
\hline \multirow{4}{*}{$\begin{array}{c}\text { Battelle } \\
\text { Station } \\
\text { Desianation }\end{array}$} & \multirow{4}{*}{$\begin{array}{c}\text { Date } \\
\text { Collected }\end{array}$} & \multirow{2}{*}{\multicolumn{2}{|c|}{ California State Plane }} & \multirow{4}{*}{$\begin{array}{c}\text { Mudline } \\
\text { (ft MLLWW }\end{array}$} & \multicolumn{2}{|c|}{ 12-ln. core } & \multicolumn{2}{|c|}{ 4-In. core } \\
\hline & & & & & & YBM/OBM & & YBM/OBM \\
\hline & & (Zone III) & oordinates & & Thickness & Contact & Thickness & Contact \\
\hline & & - & & & OI TDivi III) & MIIVILLVV & & \\
\hline \multicolumn{9}{|l|}{ Parr Canal } \\
\hline PC- 52(b) & 9-Jan-93 & 522,411 & $1,463,012$ & -3.8 & NA & NA & $>4.1$ & N/A \\
\hline PC- 53(b) & 9-Jan-93 & 522,282 & $1,463,014$ & -3.5 & NA & NA & $>3.4$ & N/A \\
\hline PC- 54(b) & 9-Jan-93 & 522,095 & $1,463,011$ & -2.8 & NA & NA & $>3.6$ & N/A \\
\hline
\end{tabular}


TABLE 3.2. Sampling Information for Channel Edge and Graving Dock Grabs in Richmond Harbor

\begin{tabular}{|c|c|c|c|c|c|c|c|}
\hline & & Date & Location (G) & NAD 83)(a) & Water Depth & Sampler & \\
\hline Station & licate & Sampled & Latitude & Longitude & (ftMLLW) & Type & Comments \\
\hline Outer Harbor Edge & 1 & 6-Jan-93 & N $37^{\circ} 54.13^{\prime}$ & W $122^{\circ} 22.07^{\prime}$ & 10.0 & Pipe dredge & Loosely compacted clay \\
\hline IHC Edge-West & 1 & 6-Jan-93 & N $37^{\circ} 54.30^{\prime}$ & W $122^{\circ} 21.82^{\prime}$ & 38.5 & Pipe dredge & Loosely compacted silt, clay \\
\hline IHC Edge-West & 2 & 6-Jan-93 & N $37^{\circ} 54.43^{\prime}$ & $W 122^{\circ} 21.79^{\prime}$ & 39.5 & Pipe dredge & Very loosely compacted clay \\
\hline FSFC Edge-West & 1 & 6-Jan-93 & N $37^{\circ} 55.16^{\prime}$ & $W 122^{\circ} 22.06^{\prime}$ & 41.0 & Pipe dredge & Loosely compacted silt \\
\hline FSFC Edge-West & 2 & 6-Jan-93 & N $37^{\circ} 55.18^{\prime}$ & W $122^{\circ} 22.09^{\prime}$ & 37.5 & Pipe dredge & Clay \\
\hline FSFC Edge-West & 3 & 6-Jan-93 & N $37^{\circ} 55.28^{\prime}$ & W $122^{\circ} 22.22^{\prime}$ & 27.0 & Pipe dredge & N/A(b) \\
\hline SFC Marina & 1 & 6-Jan-93 & N $37^{\circ} 55.39^{\prime}$ & W $122^{\circ} 22.50^{\prime}$ & 37.5 & Ponar Grab & Silt, clay \\
\hline SFC Marina & 2 & 6-Jan-93 & N $37^{\circ} 55.40^{\prime}$ & $W 122^{\circ} 22.55^{\prime}$ & 36.5 & Ponar Grab & Silt, clay \\
\hline SFC Marina & 3 & 6-Jan-93 & N $37^{\circ} 55.44^{\prime}$ & $W 122^{\circ} 22.49^{\prime}$ & 36.5 & Ponar Grab & Silt, clay \\
\hline Parr Edge & 1 & 6-Jan-93 & N $37^{\circ} 55.10^{\prime}$ & $W 122^{\circ} 21.72^{\prime}$ & 9.0 & Ponar Grab & $\begin{array}{l}\text { Clay; blackened sediment, oil } \\
\text { sheen }\end{array}$ \\
\hline Parr Edge & 2 & 6-Jan-93 & N $37^{\circ} 55.14^{\prime}$ & W $122^{\circ} 21.73^{\prime}$ & 9.5 & Ponar Grab & Clay \\
\hline IHC Edge-East & 1 & 6-Jan-93 & N $37^{\circ} 54.90^{\prime}$ & W $122^{\circ} 21.69^{\prime}$ & 39.5 & Ponar Grab & Clay \\
\hline IHC Edge-East & 2 & 6-Jan-93 & N $37^{\circ} 54.72^{\prime}$ & $W 122^{\circ} 21.66^{\prime}$ & 37.5 & Ponar Grab & Clay \\
\hline GD-1 & 1 & 6-Jan-93 & N $37^{\circ} 54.34 '$ & W 122" 22.02' & 19.5 & Pipe dredge & Watery clay \\
\hline GD-1 & 2 & 6-Jan-93 & N $37^{\circ} 54.31^{\prime}$ & W $122^{\circ} 22.02^{\prime}$ & 20.0 & Pipe dredge & Watery clay \\
\hline GD-1 & 3 & 6-Jan-93 & N $37^{\circ} 54.33^{\prime}$ & W $122^{\circ} 22.04^{\prime}$ & 22.0 & Pipe dredge & Loosely compacted clay \\
\hline GD-1 & 4 & 6-Jan-93 & N $37^{\circ} 54.32^{\prime}$ & W $122^{\circ} 22.04^{\prime}$ & 21.0 & Pipe dredge & Loosely compacted clay \\
\hline GD-2 & 1 & 6-Jan-93 & N $37^{\circ} 54.27^{\prime}$ & W $122^{\circ} 22.02^{\prime}$ & 29.0 & Pipe dredge & Loosely compacted clay \\
\hline GD-2 & 2 & 6-Jan-93 & N $37^{\circ} 54.28^{\prime}$ & W $122^{\circ} 21.98^{\prime}$ & 26.5 & Pipe dredge & Loosely compacted clay \\
\hline GD-3 & 1 & 6-Jan-93 & N $37^{\circ} 54.33^{\prime}$ & W $122^{\circ} 21.98^{\prime}$ & 32.0 & Pipe dredge & $\begin{array}{l}\text { Loosely compacted clay; slight } \\
\text { oil sheen }\end{array}$ \\
\hline GD-3 & 2 & 6-Jan-93 & N $37^{\circ} 54.33^{\prime}$ & W $122^{\circ} 21.99^{\prime}$ & 32.0 & Pipe dredge & $\begin{array}{l}\text { Loosely compacted clay; slight } \\
\text { oil sheen }\end{array}$ \\
\hline GD-4 & 1 & 6-Jan-93 & N 37" $54.30^{\prime}$ & W 122 $21.92^{\prime}$ & 21.5 & Pipe dredge & Loosely compacted clay \\
\hline GD-4 & 2 & 6-Jan-93 & N $37^{\circ} 54.29^{\prime}$ & W $122^{\circ} 21.92^{\prime}$ & 23.0 & Pipe dredge & $\begin{array}{l}\text { Loosely compacted clay; some } \\
\text { shell debris }\end{array}$ \\
\hline
\end{tabular}

(a) Global Positioning System, North American Datum 1983.

(b) N/A Not available. 
TABLE 3.3. Sampling Information for Control Sediments

\begin{tabular}{|c|c|c|c|c|c|c|c|}
\hline \multirow[b]{2}{*}{ Station } & \multirow[b]{2}{*}{ Replicate } & \multirow{2}{*}{$\begin{array}{c}\text { Date } \\
\text { Sampled }\end{array}$} & \multicolumn{2}{|c|}{ Location (GPS NAD 83)(a) } & \multirow{2}{*}{$\begin{array}{l}\text { Water Depth } \\
\text { (ft MLLW) }\end{array}$} & \multirow{2}{*}{$\begin{array}{c}\text { Sampler } \\
\text { Type }\end{array}$} & \multirow[b]{2}{*}{ Comments } \\
\hline & & & Latitude & Lonaitude & & & \\
\hline C-SFBF & 1 & $6-J a n-93$ & N $37^{\circ} 54.00^{\prime}$ & W $122^{\circ} 20.70^{\prime}$ & 11.5 & Pipe dredge & Silt, clay; \\
\hline C-SFBF & 2 & 6-Jan-93 & N $37^{\circ} 54.02^{\prime}$ & W $122^{\circ} 20.80^{\prime}$ & 11.5 & Pipe dredge & polychaete \\
\hline C-SFBF & 3 & 6-Jan-93 & N $37^{\circ} 54.01^{\prime}$ & W $122^{\circ} 20.80^{\prime}$ & 11.5 & Pipe dredge & tubes present in \\
\hline C-SFBF & 4 & 6-Jan-93 & N $37^{\circ} 54.03^{\prime}$ & W $122^{\circ} 20.77^{\prime}$ & 11.5 & Pipe dredge & all replicates; \\
\hline C-SFBF & 5 & 6-Jan-93 & N $37^{\circ} 54.03^{\prime}$ & W $122^{\circ} 20.70^{\prime}$ & 11.5 & Pipe dredge & shell debris in \\
\hline C-SFBF & 6 & 6-Jan-93 & N $37^{\circ} 54.02^{\prime}$ & W $122^{\circ} 20.80^{\prime}$ & 11.5 & Pipe dredge & Rep 3 \\
\hline C-SFBC & 1 & 6-Jan-93 & N $37^{\circ} 54.46^{\prime}$ & W 122 $26.25^{\prime}$ & 43.5 & Pipe dredge & $\begin{array}{l}\text { Medium-coarse } \\
\text { sand }\end{array}$ \\
\hline C-SB & NA & 14-Jan-93 & $\begin{array}{l}\text { Center of Sec } \\
\text { N 48 } 03.70^{\prime}\end{array}$ & $\begin{array}{l}\lim \text { Bay (approx. } \\
\left.\text { W } 123^{\circ} 01.50^{\prime}\right)\end{array}$ & 80 & Ponar Grab & $\begin{array}{l}\text { Silt; polychaetes } \\
\text { present }\end{array}$ \\
\hline C-WB & NA & 15-Jan-93 & $\begin{array}{l}50 \text { yd off We } \\
\text { N } 48^{\circ} 23.83^{\prime}\end{array}$ & $\begin{array}{l}\text { Beach (approx. } \\
\left.\text { W } 122^{\circ} 40.00^{\prime}\right)\end{array}$ & 12 & $\begin{array}{l}\text { Amphipod } \\
\text { Dredge }\end{array}$ & Medium sand \\
\hline
\end{tabular}

(a) Global Positioning System, North American Datum 1983. 
TABLE 3.4. Summary of Sediment Sample Preparation and Analysis

\begin{tabular}{|c|c|c|c|c|c|c|}
\hline & & \\
\hline & $\begin{array}{c}\text { Total } \\
\text { Number of } \\
\text { Samples }\end{array}$ & $\begin{array}{c}\text { Chlorinated } \\
\text { Pesticides }\end{array}$ & $\begin{array}{l}\text { Grain } \\
\text { Size }\end{array}$ & TOC & $\begin{array}{c}\text { PAH, PCB } \\
\text { metals, } \\
\text { butultins }\end{array}$ & $\begin{array}{c}\text { Oil \& } \\
\text { Grease, } \\
\text { TPH }\end{array}$ \\
\hline
\end{tabular}

Vertical Searnents From 4-in. Cores

$\begin{array}{lrrrrrrr}\text { A...X(YBM) and } Y(\mathrm{OBM}) & 236 & 236 & 236 & 236 & 0 & 0 & 236 \\ Z \text { (OBM) } & 46 & 0 & 0 & 0 & 0 & 0 & 46 \\ \text { M (all YBM in a core) } & 31 & 0 & 0 & 0 & 31 & 31 & 31\end{array}$

Grab Samples From

Channel Edaes$$
7
$$

OBM Composites From

Combined 4-in. Cores

Composites From 12-in. Cores
Cornp LC

Comp LC-1

Comp LC-2

Comp LC-3

Comp LC-4

Cornp LC-5

Comp LC-6

Comp USFC

Cornp FSFC

Cornp IHC-1

Cornp IHC-2

Comp IHC-3
7

2

1
1
1
2
1
1
1
1
1
1
2
1

Gravina Dock Composite

Comp GD

Control Sediments

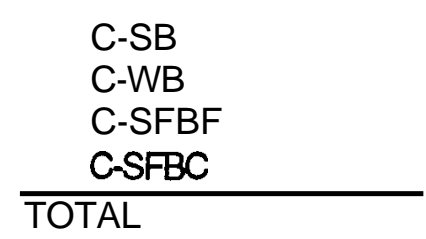

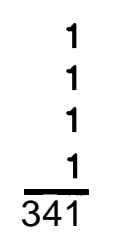

$\begin{array}{r}0 \\ 0 \\ 1 \\ 1 \\ \hline 48\end{array}$

$\begin{array}{rr}0 & 1 \\ 0 & 1 \\ 1 & 1 \\ 1 & \frac{1}{341}\end{array}$


TABLE 3.5. Samples for Biological Testing and Related Chemical Analysis

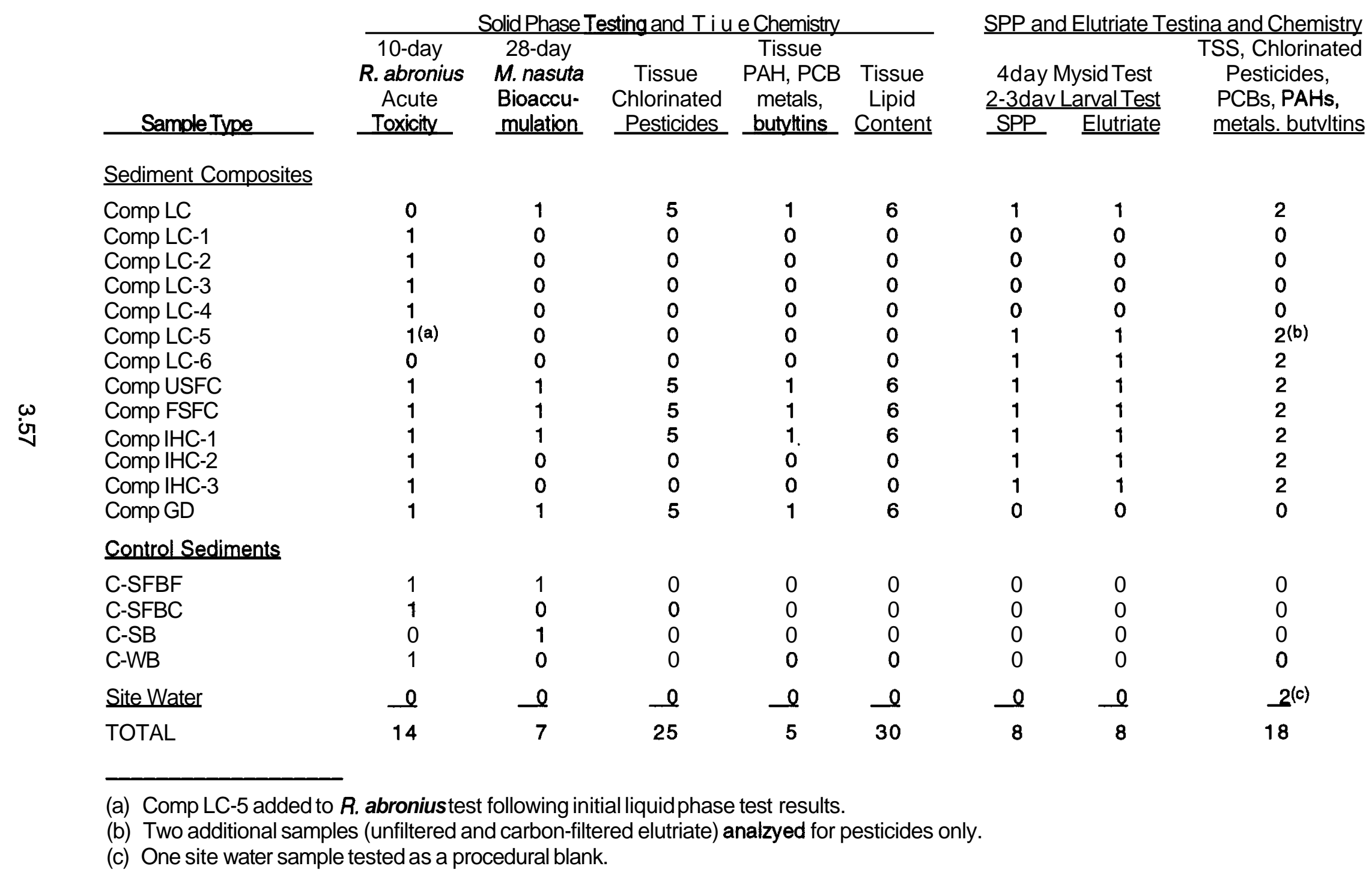


TABLE 3.6. Mean Total Organic Carbon, Percent Solids, and Grain Size Distribution in Vertical Core Segments and Channel Edge Grab Samples

\begin{tabular}{|c|c|c|c|c|c|c|c|}
\hline Location & $\begin{array}{c}\text { Sediment } \\
\text { Type } \\
\end{array}$ & $\begin{array}{c}\text { Mean } \\
\text { Percent TOC } \\
\text { dry weiaht) }\end{array}$ & $\begin{array}{l}\text { Mean } \\
\text { Percent } \\
\text { Solids } \\
\end{array}$ & $\begin{array}{l}\text { Mean } \\
\text { Percent } \\
\text { Gravel } \\
\end{array}$ & $\begin{array}{l}\text { Mean } \\
\text { Percent } \\
\text { Sand }\end{array}$ & $\begin{array}{c}\text { Mean } \\
\text { Percent } \\
\text { Silt } \\
\end{array}$ & $\begin{array}{c}\text { Mean } \\
\text { Percent } \\
\text { Clay } \\
\end{array}$ \\
\hline $\begin{array}{l}\text { Lauritzen Canal } \\
\text { Santa Fe Channel } \\
\text { Inner Harbor Channel } \\
\text { Parr Canal } \\
\text { Lauritzen Canal } \\
\text { Santa Fe Channel } \\
\text { Inner Harbor Channel }\end{array}$ & $\begin{array}{l}\text { YBM } \\
\text { YBM } \\
\text { YBM } \\
\text { YBM } \\
\text { OBM } \\
\text { OBM } \\
\text { OBM }\end{array}$ & $\begin{array}{l}1.91 \\
1.14 \\
1.14 \\
5.19 \\
0.12 \\
0.23 \\
0.21\end{array}$ & $\begin{array}{l}49 \\
47 \\
45 \\
45 \\
80 \\
77 \\
76\end{array}$ & $\begin{array}{l}6 \\
2 \\
0 \\
4 \\
8 \\
1 \\
5\end{array}$ & $\begin{array}{c}26 \\
11 \\
5 \\
24 \\
42 \\
30 \\
16\end{array}$ & $\begin{array}{l}25 \\
28 \\
32 \\
37 \\
31 \\
37 \\
41\end{array}$ & $\begin{array}{l}42 \\
59 \\
62 \\
34 \\
20 \\
32 \\
38\end{array}$ \\
\hline
\end{tabular}


TABLE 3.7. Dieldrin and DDT Compounds in Vertical Core Segments and Channel Edge Grab Samples

\begin{tabular}{|c|c|c|c|c|c|c|c|}
\hline \multirow{2}{*}{\multicolumn{2}{|c|}{$\begin{array}{l}\text { Sediment } \\
\text { Sample ID }\end{array}$}} & \multirow{3}{*}{$\begin{array}{c}\frac{T_{\text {Thickness }}}{(\mathrm{ft})} \\
1.0\end{array}$} & \multicolumn{5}{|c|}{ Pesticide Concentration ( $\mu \mathrm{g} / \mathrm{kg}$ drv weiaht) } \\
\hline & & & \multirow{2}{*}{$\frac{\text { Dieldrin }}{401.65 \mathrm{~J}(\mathrm{~b})}$} & \multirow{2}{*}{$\frac{4,4^{\prime}-\mathrm{DDT}}{13843.61}$} & \multirow{2}{*}{$\frac{4,4-D D E}{2865.23}$} & \multirow{2}{*}{$\frac{4,4^{\prime}-\mathrm{DDD}}{11228.33}$} & \multirow{2}{*}{$\begin{array}{c}\begin{array}{c}\text { Total } \\
\text { DDT(a) }\end{array} \\
27937.2\end{array}$} \\
\hline$L Z-1$ & A & & & & & & \\
\hline LZ-1 & B & 2.0 & $205.94 \mathrm{~J}$ & 595.70 & 4855.60 & $363.48 \mathrm{~J}$ & 5814.8 \\
\hline$L Z-1$ & C & 2.0 & 10304.57 & 30541.48 & 7915.53 & 322304.49 & 360761.5 \\
\hline LZ-1 & $\mathrm{D}$ & 1.0 & $723.37 \mathrm{~J}$ & $700.53 \mathrm{~J}$ & $1441.28 \mathrm{~J}$ & 136929.91 & 139071.7 \\
\hline$L Z-1$ & $\mathrm{X}$ & 1.0 & $25.92 \mathrm{~J}$ & $41.32 \mathrm{~J}$ & $15.44 \mathrm{~J}$ & 487.21 & 544.0 \\
\hline LZ-1 & $Y$ & 1.0 & 1.50 & 1.77 & 1.71 & 140.22 & 143.7 \\
\hline$L Z-1$ & $\mathbf{Z}$ & 1.0 & $N M(c)$ & $0.23 \mathrm{~J}$ & $0.10 \mathrm{~J}$ & 6.70 & 7.0 \\
\hline LZ-2 & A & 1.0 & $311.02 \mathrm{~J}$ & 43298.77 & $462.14 \mathrm{~J}$ & 11414.95 & 55175.9 \\
\hline LZ-2 & B & 2.0 & $685.75 \mathrm{~J}$ & 111047.83 & $989.25 \mathrm{~J}$ & 21516.06 & 133553.1 \\
\hline LZ-2 & $\mathrm{C}$ & 0.8 & $4344.56 \mathrm{~J}$ & 45332.96 & $3656.61 \mathrm{~J}$ & 212115.89 & 261105.5 \\
\hline LZ-2 & $x$ & 1.0 & $439.81 \mathrm{~J}$ & 6827.19 & $345.82 \mathrm{~J}$ & 103190.29 & 110363.3 \\
\hline LZ-2 & $Y$ & 1.0 & 12.43 & 188.34 & 10.54 & 776.60 & 975.5 \\
\hline$L Z-2$ & $Z$ & 1.0 & NM & 15.36 & 1.45 & 164.24 & 181.1 \\
\hline LZ-3 & A & 1.0 & $882.34 \mathrm{~J}$ & 41784.21 & $826.31 \mathrm{~J}$ & 29781.44 & 72392.0 \\
\hline$L Z-3$ & B & 2.0 & $2271.21 \mathrm{~J}$ & 38901.66 & $2366.27 \mathrm{~J}$ & 112717.87 & 153985.8 \\
\hline LZ-3 & $x$ & 1.2 & 519.38 & 2323.78 & $165.91 \mathrm{~J}$ & 17054.30 & 19544.0 \\
\hline$L Z-3$ & $Y$ & 1.0 & 3.69 & 60.93 & 2.20 & 189.28 & 252.4 \\
\hline$L Z-3$ & Z & 1.0 & NM & 7.76 & $0.57 \mathrm{~J}$ & 28.32 & 36.7 \\
\hline LZ-5 & A & 1.2 & $467.28 \mathrm{~J}$ & 29641.09 & $378.69 \mathrm{~J}$ & 14791.94 & 44811.7 \\
\hline$L Z-5$ & $Y$ & 1.0 & 17.09 & 476.54 & 10.23 & 445.10 & 931.9 \\
\hline$L Z-5$ & Z & 1.0 & NM & 27.84 & 0.99 & 37.37 & 66.2 \\
\hline$L Z-6$ & A & 1.0 & $930.71 \mathrm{~J}$ & 92956.22 & $842.97 \mathrm{~J}$ & 17825.73 & 111624.9 \\
\hline$L Z-6$ & B & 2.0 & $1894.04 \mathrm{~J}$ & 161331.74 & $2573.81 \mathrm{~J}$ & 113865.44 & 277771.0 \\
\hline$L Z-6$ & C & 0.9 & $155.14 \mathrm{~J}$ & 12496.97 & $447.25 \mathrm{~J}$ & 33972.04 & 46916.3 \\
\hline LZ-6 & $x$ & 1.0 & $41.59 \mathrm{~J}$ & $141.28 \mathrm{~J}$ & $16.34 \mathrm{~J}$ & 670.27 & 827.9 \\
\hline LZ-6 & $Y$ & 1.0 & 0.98 & 37.33 & 0.73 & 54.78 & 92.8 \\
\hline LZ-6 & $Z$ & 0.7 & $\mathbf{N M}$ & $0.37 \mathrm{~J}$ & $0.03 \mathrm{~J}$ & $1.04 U(d)$ & 0.4 \\
\hline LZ-7 & A & 1.0 & 1311.68 & 38600.63 & $857.32 \mathrm{~J}$ & 37505.99 & 76963.9 \\
\hline LZ-7 & $B$ & 2.0 & 15971.27 & 334563.58 & 6274.29 & 292520.38 & 633358.3 \\
\hline LZ-7 & C & 1.3 & 1475.77 & 48493.85 & $739.18 \mathrm{~J}$ & 68456.14 & 117689.2 \\
\hline$L Z-7$ & $x$ & 1.0 & $6.63 \mathrm{~J}$ & 69.40 & $2.42 \mathrm{~J}$ & 101.19 & 173.0 \\
\hline LZ-7 & $Y$ & 1.0 & $0.45 \mathrm{~J}$ & 1.85 & $0.19 \mathrm{~J}$ & 9.73 & 11.8 \\
\hline LZ-8 & A & 1.0 & $409.19 \mathrm{~J}$ & 26511.54 & $415.45 \mathrm{~J}$ & 8983.00 & 35910.0 \\
\hline LZ-8 & $\mathrm{B}$ & 2.0 & $2344.70 \mathrm{~J}$ & 53736.21 & 4511.69 & 101508.55 & 159756.5 \\
\hline LZ-8 & C & 2.0 & $1576.51 \mathrm{~J}$ & 59262.41 & 27663.04 & 50720.09 & 137645.5 \\
\hline LZ-8 & D & 2.0 & $778.95 \mathrm{~J}$ & 22355.96 & 31498.99 & 13787.46 & 67642.4 \\
\hline LZ-8 & $E$ & 2.0 & $435.71 \mathrm{~J}$ & 34123.38 & 41767.87 & 5786.51 & 81677.8 \\
\hline LZ-8 & $\mathrm{F}$ & 2.0 & 6980.94 & 45252.16 & $2275.90 \mathrm{~J}$ & 143993.28 & 191521.3 \\
\hline LZ-8 & $\mathbf{G}$ & 1.4 & $28.61 \mathrm{~J}$ & 1029.47 & $24.66 \mathrm{~J}$ & 873.30 & 1927.4 \\
\hline$L Z-8$ & $x$ & 1.0 & $7.96 \mathrm{~J}$ & 957.42 & $10.88 \mathrm{~J}$ & 98.51 & 1066.8 \\
\hline LZ-8 & $Y$ & 1.0 & $0.04 \mathrm{~J}$ & $0.73 \mathrm{U}$ & $0.68 U$ & $0.67 \mathrm{~J}$ & 0.7 \\
\hline
\end{tabular}


TABLE 3.7. (contd)

\begin{tabular}{|c|c|c|c|c|c|c|c|}
\hline \multirow{2}{*}{\multicolumn{2}{|c|}{$\begin{array}{l}\text { Sediment } \\
\text { Samole ID } \\
\end{array}$}} & \multirow{3}{*}{$\begin{array}{c}\frac{T}{\text { Thickness }} \text { (ft) } \\
1.0\end{array}$} & \multicolumn{5}{|c|}{ Pesticide Concentration (ug/kg dry woight) } \\
\hline & & & \multirow{2}{*}{$\frac{\text { Dieldrin }}{343.16 \mathrm{~J}}$} & \multirow{2}{*}{$\begin{array}{r}4,4^{1}-\mathrm{DDT} \\
27403.36\end{array}$} & \multirow{2}{*}{$\begin{array}{l}4,4^{1}-\mathrm{DDE} \\
356.27 \mathrm{~J}\end{array}$} & \multirow{2}{*}{$\begin{array}{l}4.4^{\prime}-\mathrm{DDD} \\
9862.51\end{array}$} & \multirow{2}{*}{$\begin{array}{c}\text { Total } \\
\text { DDT(a) } \\
\\
37622.1\end{array}$} \\
\hline LZ-9 & A & & & & & & \\
\hline LZ-9 & $X$ & 1.0 & $281.94 \mathrm{~J}$ & 13956.56 & $219.06 \mathrm{~J}$ & 5695.97 & 19871.6 \\
\hline LZ-9 & Y & 1.0 & 52.07 & 1001.17 & 36.81 & 866.52 & 1904.5 \\
\hline LZ-9 & Z & 1.0 & NM & 0.98 & $0.07 \mathrm{~J}$ & $0.88 \cup$ & 1.1 \\
\hline LZ-10 & A & 1.0 & $48.85 \mathrm{~J}$ & 2951.54 & $55.40 \mathrm{~J}$ & 1116.28 & 4123.2 \\
\hline $\mathrm{LZ}-10$ & B & 2.0 & 339.79 & 12591.73 & 331.07 & 12061.52 & 24984.3 \\
\hline LZ-10 & $X$ & 1.3 & $530.10 \mathrm{~J}$ & 89109.29 & $1010.44 \mathrm{~J}$ & 30415.95 & 120535.7 \\
\hline LZ-10 & $Y$ & 1.0 & 0.94 & 1.04 & $0.67 \cup$ & 6.36 & 7.4 \\
\hline LZ-11 & A & 1.0 & $124.92 \mathrm{~J}$ & 2258.61 & $149.67 \mathrm{~J}$ & 5368.23 & 7776.5 \\
\hline LZ-11 & $X$ & 0.7 & $2246.89 \mathrm{~J}$ & 19837.68 & $2399.22 \mathrm{~J}$ & 106725.42 & 128962.3 \\
\hline$L Z-11$ & $Y$ & 1.0 & 38.90 & 79.61 & 15.99 & 559.06 & 654.7 \\
\hline LZ-11 & Z & 1.0 & NM & $0.42 \mathrm{~J}$ & $0.11 \mathrm{~J}$ & $3.57 \mathrm{U}$ & 0.5 \\
\hline LZ-12 & A & 1.0 & $43.97 \mathrm{~J}$ & 1400.33 & $62.04 \mathrm{~J}$ & 1213.26 & 2675.6 \\
\hline LZ-12 & $X$ & 1.2 & $43.51 \mathrm{~J}$ & 528.55 & $59.84 \mathrm{~J}$ & 959.08 & 1547.5 \\
\hline LZ-12 & $Y$ & 1.0 & $0.65 \mathrm{~J}$ & 8.58 & 0.73 & 20.43 & 29.7 \\
\hline LZ-13 & A & 1.0 & $99.10 \mathrm{~J}$ & 1538.68 & 177.46 & 1430.44 & 3146.6 \\
\hline LZ-13 & B & 2.0 & $80.79 \mathrm{~J}$ & 472.40 & 140.78 & 1402.63 & 2015.8 \\
\hline LZ-13 & C & 2.0 & $108.19 \mathrm{~J}$ & 4781.08 & 233.24 & 2298.08 & 7312.4 \\
\hline LZ-13 & $X$ & 1.2 & 237.35 & 1915.71 & 481.78 & 4793.95 & 7191.4 \\
\hline LZ-13 & $Y$ & 1.0 & $0.67 \mathrm{U}$ & $0.08 \mathrm{~J}$ & $0.68 \mathrm{U}$ & $0.15 \mathrm{~J}$ & 0.2 \\
\hline LZ-14 & A & 1.0 & $25.05 \mathrm{~J}$ & $187.93 \mathrm{U}$ & $25.34 \mathrm{~J}$ & 445.61 & 471.0 \\
\hline LZ-14 & $X$ & 0.9 & $4.55 \mathrm{~J}$ & 82.34 & 8.16 & 110.30 & 200.8 \\
\hline LZ-14 & $Y$ & 1.0 & $0.13 \mathrm{~J}$ & $0.26 \mathrm{~J}$ & $0.06 \mathrm{~J}$ & 1.18 & 1.5 \\
\hline LZ-15 & A & 1.0 & $31.90 \mathrm{~J}$ & 414.80 & $45.35 \mathrm{~J}$ & 711.72 & 1171.9 \\
\hline LZ-15 & B & 0.8 & $31.30 \mathrm{~J}$ & 641.43 & $54.73 \mathrm{~J}$ & 683.41 & 1379.6 \\
\hline$L Z-15$ & $X$ & 1.0 & $42.62 \mathrm{~J}$ & 1460.35 & $60.60 \mathrm{~J}$ & 883.31 & 2404.3 \\
\hline LZ-15 & $Y$ & 1.0 & $0.40 \mathrm{~J}$ & 8.99 & $0.37 \mathrm{~J}$ & 9.24 & 18.6 \\
\hline LZ-16 & A & 1.0 & $7.47 \mathrm{~J}$ & 169.60 & 22.62 & 276.92 & 469.1 \\
\hline LZ-16 & B & 2.0 & $74.90 \mathrm{~J}$ & 167.08 & 139.81 & 946.84 & 1253.7 \\
\hline LZ-16 & $\mathrm{C}$ & 2.0 & 164.25 & 1574.53 & 266.24 & 2598.46 & 4439.2 \\
\hline$L Z-16$ & $D$ & 1.4 & $39.98 \mathrm{~J}$ & 646.93 & 75.19 & 690.96 & 1413.1 \\
\hline LZ-16 & $X$ & 1.0 & 34.63 & 163.49 & 96.94 & 627.30 & 887.7 \\
\hline LZ-16 & $Y$ & 0.5 & $0.04 \mathrm{~J}$ & $0.39 \mathrm{~J}$ & $0.09 \mathrm{~J}$ & $0.69 \mathrm{~J}$ & 1.2 \\
\hline SF-17 & A & 1.0 & 11.37 & $10.06 \mathrm{U}$ & 64.72 & 193.13 & 257.9 \\
\hline SF-17 & B & 2.3 & 11.03 & $7.19 \mathrm{U}$ & 60.14 & 137.80 & 197.9 \\
\hline SF-17 & $X$ & 1.0 & 2.06 & $1.77 \mathrm{U}$ & 7.82 & 60.00 & 67.8 \\
\hline SF-17 & $Y$ & 0.8 & $0.02 \mathrm{~J}$ & $0.76 \mathrm{U}$ & $0.06 \mathrm{~J}$ & $0.88 \cup$ & 0.1 \\
\hline
\end{tabular}


TABLE 3.7. (contd)

\begin{tabular}{|c|c|c|c|c|c|c|c|}
\hline \multirow{2}{*}{\multicolumn{2}{|c|}{$\begin{array}{l}\text { Sediment } \\
\text { Sample ID } \\
\end{array}$}} & \multirow[b]{2}{*}{$\begin{array}{c}\text { Thickness } \\
\text { (ft) }\end{array}$} & \multicolumn{5}{|c|}{ Pesticide Concentration (ug/kg dry weight) } \\
\hline & & & Dieldrin & 4.4'-DDT & 4,4-DDE & 4, $4^{t}-\mathrm{DDD}$ & $\begin{array}{l}\text { Total } \\
\text { DDT(a) } \\
\end{array}$ \\
\hline SF-18 & A & 1.0 & 7.90 & 86.21 & 21.16 & 109.78 & 217.2 \\
\hline SF-18 & B & 0.8 & 12.36 & $19.28 \mathrm{U}$ & 18.14 & 135.47 & 153.6 \\
\hline SF-18 & $\mathrm{X}$ & 1.0 & 4.66 & $2.97 \mathrm{U}$ & 10.56 & 78.94 & 89.5 \\
\hline SF-18 & $Y$ & 1.0 & $0.73 \mathrm{U}$ & $0.08 \mathrm{~J}$ & $0.03 \mathrm{~J}$ & $0.92 U$ & 0.1 \\
\hline SF-19 & A & 1.0 & 3.90 & $12.68 \mathrm{U}$ & 10.37 & 112.35 & 122.7 \\
\hline SF-19 & $\mathrm{X}$ & 1.1 & 7.22 & $16.16 \mathrm{U}$ & 22.80 & 94.90 & 117.7 \\
\hline SF-19 & $Y$ & 1.0 & $0.69 \mathrm{U}$ & $0.75 \mathrm{U}$ & $0.70 \mathrm{U}$ & $0.87 \mathrm{U}$ & 0.0 \\
\hline SF-20 & $\mathbf{A}$ & 1.0 & 3.83 & $13.82 \mathrm{U}$ & 11.01 & 116.55 & 127.6 \\
\hline SF-20 & $x$ & 1.1 & 11.20 & 50.66 & 26.57 & 191.09 & 268.3 \\
\hline SF-20 & $Y$ & 1.0 & $0.77 \mathrm{U}$ & $0.31 \mathrm{~J}$ & 2.28 & $10.41 U$ & 2.3 \\
\hline SF-21 & A & 1.0 & 4.54 & 40.57 & 11.20 & 83.71 & 135.5 \\
\hline SF-21 & $B$ & 2.0 & 4.29 & 5.50 & 11.05 & 119.36 & 135.9 \\
\hline SF-21 & $C$ & 1.6 & 7.09 & 22.57 & 13.30 & 102.96 & 138.8 \\
\hline SF-21 & $x$ & 1.0 & 6.74 & 3.39 & 25.19 & 89.02 & 117.6 \\
\hline SF-21 & $Y$ & 1.0 & $0.69 \cup$ & $0.07 \mathrm{~J}$ & $0.70 \mathrm{U}$ & $0.21 \mathrm{~J}$ & 0.3 \\
\hline SF-22 & A & 1.0 & 10.88 & 14.17 & 42.85 & 144.00 & 201.0 \\
\hline SF-22 & B & 2.0 & 9.89 & 6.12 & 47.48 & 135.50 & 189.1 \\
\hline SF-22 & $C$ & 2.1 & $1.06 \mathrm{U}$ & $0.11 \mathrm{~J}$ & $0.11 \mathrm{~J}$ & $0.22 \mathrm{~J}$ & 0.4 \\
\hline SF-22 & $x$ & 1.0 & $0.88 U$ & $0.96 \mathrm{U}$ & $0.89 \mathrm{U}$ & $0.07 \mathrm{~J}$ & 0.1 \\
\hline SF-22 & $Y$ & 1.0 & $0.70 \mathrm{U}$ & $0.06 \mathrm{~J}$ & $0.71 \mathrm{U}$ & $0.06 \mathrm{~J}$ & 0.1 \\
\hline SF-23 & A & 1.0 & 2.49 & 50.23 & 12.37 & 93.41 & 156.0 \\
\hline SF-23 & $B$ & 0.7 & 4.05 & 16.75 & 11.52 & 75.15 & 103.4 \\
\hline SF-23 & $x$ & 1.0 & 3.21 & $4.06 \mathrm{U}$ & 10.48 & 53.69 & 64.2 \\
\hline SF-23 & $Y$ & 1.0 & $0.02 \mathrm{~J}$ & $0.05 \mathrm{~J}$ & $0.04 \mathrm{~J}$ & $0.31 \mathrm{~J}$ & 0.4 \\
\hline SF-24 & A & 1.0 & 6.25 & 29.36 & 17.06 & 118.56 & 165.0 \\
\hline SF-24 & B & 2.0 & 4.34 & 12.12 & 13.62 & 129.30 & 155.0 \\
\hline SF-24 & $C$ & 1.8 & $0.81 \mathrm{~J}$ & $0.63 \mathrm{~J}$ & 2.65 & 18.57 & 21.9 \\
\hline SF-25 & A & 1.0 & 33.04 & 10.68 & 290.07 & 440.33 & 741.1 \\
\hline SF-25 & B & 2.4 & 2.67 & 19.24 & 8.08 & 51.28 & 78.6 \\
\hline SF-25 & $x$ & 1.0 & $0.72 \mathrm{U}$ & $0.78 \mathrm{U}$ & $0.72 \cup$ & $0.59 \mathrm{~J}$ & 0.6 \\
\hline SF-25 & $Y$ & 1.0 & $0.69 \mathrm{U}$ & $0.75 \cup$ & $0.70 \mathrm{U}$ & $0.87 \cup$ & 0.0 \\
\hline SF-26 & A & 1.0 & $0.53 \mathrm{~J}$ & $1.42 \mathrm{U}$ & 3.50 & 5.77 & 9.3 \\
\hline SF-26 & B & 2.0 & 2.90 & 18.28 & 7.16 & 54.43 & 79.9 \\
\hline SF-26 & $\mathrm{C}$ & 0.7 & 12.60 & 35.40 & 28.92 & 180.37 & 244.7 \\
\hline SF-26 & $x$ & 1.0 & 11.77 & 54.72 & 25.71 & 172.42 & 252.9 \\
\hline SF-26 & $Y$ & 1.0 & $0.69 \mathrm{U}$ & $0.75 \mathrm{U}$ & $0.70 \mathrm{U}$ & $0.38 \mathrm{~J}$ & 0.4 \\
\hline
\end{tabular}


TABLE 3.7. (contd)

\begin{tabular}{|c|c|c|c|c|c|c|c|}
\hline \multirow{2}{*}{\multicolumn{2}{|c|}{$\begin{array}{l}\text { Sediment } \\
\text { Sample ID } \\
\end{array}$}} & \multirow{3}{*}{$\frac{\begin{array}{c}\text { Thickness } \\
\text { (ft) }\end{array}}{1.0}$} & \multicolumn{5}{|c|}{ Pesticida Concentration ( $\mu \mathrm{g} / \mathrm{kg}$ drv weight) } \\
\hline & & & \multirow{2}{*}{$\begin{array}{c}\text { Dieldrin } \\
1.65\end{array}$} & \multirow{2}{*}{$\begin{array}{r}\text { 4.4'-DDT } \\
98.26\end{array}$} & \multirow{2}{*}{$\begin{array}{c}\text { 4.4'-DDE } \\
3.40\end{array}$} & \multirow{2}{*}{$\begin{array}{r}\text { 4.4'-DDD } \\
124.65\end{array}$} & \multirow{2}{*}{$\begin{array}{l}\begin{array}{l}\text { Total } \\
\text { DDT(a) }\end{array} \\
226.3\end{array}$} \\
\hline SF-27 & A & & & & & & \\
\hline SF-27 & B & 2.0 & 4.97 & 129.07 & 10.74 & 119.43 & 259.2 \\
\hline SF-27 & C & 1.0 & 8.71 & 94.02 & 20.33 & 225.39 & 339.7 \\
\hline SF-27 & $x$ & 1.0 & 12.26 & 32.90 & 12.58 & 135.42 & 180.9 \\
\hline SF-27 & Y & 1.0 & $0.67 U$ & $0.73 \mathrm{U}$ & $0.68 \mathrm{U}$ & $0.50 \mathrm{~J}$ & 0.5 \\
\hline SF-28 & A & 1.0 & 3.80 & 19.17 & 19.13 & 96.19 & 134.5 \\
\hline SF-28 & B & 1.7 & 12.86 & 188.41 & 26.87 & 278.67 & 494.0 \\
\hline SF-28 & $x$ & 1.0 & 17.40 & 168.56 & 33.14 & 335.56 & 537.3 \\
\hline SF-28 & Y & 0.5 & $0.53 \mathrm{~J}$ & 0.77 & 1.37 & 12.17 & 14.3 \\
\hline SF-29 & A & 1.0 & 1.83 & 125.24 & 3.59 & 32.85 & 161.7 \\
\hline SF-29 & B & 2.0 & 6.55 & 277.91 & 20.50 & 147.01 & 445.4 \\
\hline SF-29 & C & 2.0 & 12.10 & 111.03 & 21.87 & 283.52 & 416.4 \\
\hline SF-29 & D & 2.0 & 8.83 & 181.17 & 36.18 & 163.16 & 380.5 \\
\hline SF-29 & $E$ & 1.8 & 29.65 & 109.13 & 121.33 & 863.54 & 1094.0 \\
\hline SF-29 & $\mathrm{x}$ & 1.0 & 0.92 & 3.68 & 3.15 & 23.65 & 30.5 \\
\hline SF-29 & $\mathbf{Y}$ & 1.0 & $0.68 \cup$ & $0.74 \mathrm{U}$ & $0.16 \mathrm{~J}$ & 1.07 & 1.2 \\
\hline SF-30 & A & 1.0 & $1.02 \mathrm{~J}$ & 13.80 & 2.20 & 32.56 & 48.6 \\
\hline SF-30 & B & 0.8 & 4.71 & 48.85 & 20.25 & 164.72 & 233.8 \\
\hline SF-30 & $x$ & 1.0 & 10.96 & 101.54 & 32.21 & 299.76 & 433.5 \\
\hline SF-30 & $Y$ & 1.0 & $0.19 \mathrm{~J}$ & $0.74 \mathrm{U}$ & $0.09 \mathrm{~J}$ & 1.17 & 1.3 \\
\hline SF-31 & A & 1.0 & $0.58 \mathrm{~J}$ & 16.19 & 1.28 & 14.17 & 31.6 \\
\hline SF-31 & $x$ & 1.0 & 19.99 & 103.70 & 24.67 & 325.51 & 453.9 \\
\hline SF-31 & Y & 1.0 & 1.36 & $0.34 \mathrm{~J}$ & 1.75 & 21.15 & 23.2 \\
\hline SF-32 & A & 1.0 & 9.87 & 80.76 & 41.24 & 205.26 & 327.3 \\
\hline SF-32 & B & 2.0 & 5.51 & 50.70 & 23.56 & 129.13 & 203.4 \\
\hline SF-32 & C & 1.7 & $0.78 \mathrm{U}$ & $0.23 \mathrm{~J}$ & $0.09 \mathrm{~J}$ & $0.61 \mathrm{~J}$ & 0.9 \\
\hline SF-32 & $x$ & 1.0 & $0.87 \mathrm{U}$ & $0.94 U$ & $0.88 U$ & $0.48 \mathrm{~J}$ & 0.5 \\
\hline SF-32 & $Y$ & 1.0 & $0.66 \mathrm{U}$ & $0.72 U$ & $0.67 U$ & $0.08 \mathrm{~J}$ & 0.1 \\
\hline SF-33 & A & 1.0 & 10.11 & 76.28 & 26.95 & 173.46 & 276.7 \\
\hline SF-33 & B & 2.2 & 11.83 & 153.73 & 31.95 & 198.05 & 383.7 \\
\hline SF-33 & $x$ & 1.0 & 16.70 & 69.32 & 62.85 & 217.76 & 349.9 \\
\hline SF-33 & $Y$ & 1.0 & $0.10 \mathrm{~J}$ & 1.85 & $0.03 \mathrm{~J}$ & $0.62 \mathrm{~J}$ & 2.5 \\
\hline SF-34 & A & 1.0 & 36.59 & 38.70 & 193.73 & 302.60 & 535.0 \\
\hline SF-34 & B & 0.8 & 2.43 & 24.86 & 9.42 & 65.98 & 100.3 \\
\hline SF-34 & $\mathrm{x}$ & 1.0 & 5.50 & 108.51 & 13.79 & 125.95 & 248.3 \\
\hline SF-34 & $Y$ & 1.0 & $0.03 \mathrm{~J}$ & $0.72 U$ & $0.04 \mathrm{~J}$ & $0.83 \cup$ & 0.0 \\
\hline IH-35 & A & 1.0 & 2.18 & 24.22 & 7.51 & 68.47 & 100.2 \\
\hline IH-35 & $\mathrm{X}$ & 1.4 & 3.78 & 91.79 & 12.85 & 113.37 & 218.0 \\
\hline IH-35 & Y & 1.0 & $0.06 \mathrm{~J}$ & $0.77 \cup$ & $0.08 \mathrm{~J}$ & $0.87 \mathrm{~J}$ & 1.0 \\
\hline
\end{tabular}


TABLE 3.7. (contd)

\begin{tabular}{|c|c|c|c|c|c|c|c|}
\hline \multirow{2}{*}{\multicolumn{2}{|c|}{$\begin{array}{l}\text { Sediment } \\
\text { Samole ID } \\
\end{array}$}} & \multirow{3}{*}{$\begin{array}{c}\frac{\begin{array}{c}\text { Thickness } \\
(\mathrm{ft})\end{array}}{1.0} \\
\end{array}$} & \multicolumn{5}{|c|}{ Pesticide Concentration (ug/kg dry weight) } \\
\hline & & & \multirow{2}{*}{$\begin{array}{l}\text { Dieldrin } \\
0.86 \mathrm{~J}\end{array}$} & \multirow{2}{*}{$\begin{array}{r}4.4^{\prime}-\mathrm{DDT} \\
13.30\end{array}$} & \multirow{2}{*}{$\begin{array}{c}4,4^{\prime}-\mathrm{DDE} \\
1.93\end{array}$} & \multirow{2}{*}{$\begin{array}{r}4,4^{\prime}-\mathrm{DDD} \\
29.34\end{array}$} & \multirow{2}{*}{$\begin{array}{r}\begin{array}{l}\text { Total } \\
\text { DDT(a) }\end{array} \\
\\
44.6\end{array}$} \\
\hline $\mathrm{IH}-36$ & A & & & & & & \\
\hline $\mathrm{IH}-36$ & B & 1.7 & 5.43 & 64.91 & 12.90 & 110.16 & 188.0 \\
\hline $\mathrm{IH}-36$ & $x$ & 1.0 & 4.70 & 8.70 & 20.19 & 134.94 & 163.8 \\
\hline $\mathrm{IH}-36$ & $Y$ & 1.0 & $0.13 \mathrm{~J}$ & $0.16 \mathrm{~J}$ & $0.15 \mathrm{~J}$ & 1.18 & 1.5 \\
\hline IH-37 & A & 1.0 & $0.43 \mathrm{~J}$ & $1.11 \mathrm{~J}$ & $0.86 \mathrm{~J}$ & 6.96 & 8.9 \\
\hline IH-37 & B & 2.0 & $1.02 \mathrm{~J}$ & 6.21 & 2.64 & 26.56 & 35.4 \\
\hline $\mathrm{IH}-37$ & C & 1.5 & 1.39 & 16.63 & 2.80 & 38.99 & 58.4 \\
\hline $\mathrm{IH}-37$ & $\mathrm{x}$ & 1.0 & 1.88 & 6.69 & 7.92 & 56.10 & 70.7 \\
\hline $\mathrm{IH}-\mathbf{3 7}$ & $\mathbf{Y}$ & 1.0 & $0.12 \mathrm{~J}$ & $0.76 U$ & $0.71 U$ & $0.16 \mathrm{~J}$ & 0.2 \\
\hline $\mathrm{IH}-38$ & A & 1.0 & 3.19 & 39.69 & 7.31 & 71.60 & 118.6 \\
\hline $\mathrm{IH}-38$ & $\mathbf{x}$ & 1.2 & 2.18 & 5.91 & 5.31 & 71.54 & 82.8 \\
\hline $1 \mathrm{H}-38$ & $Y$ & 1.0 & $0.10 \mathrm{~J}$ & $0.76 U$ & $0.70 \cup$ & $0.21 \mathrm{~J}$ & 0.2 \\
\hline IH-39 & A & 1.0 & 1.38 & 33.83 & 5.97 & 57.28 & 97.1 \\
\hline IH-39 & B & 2.0 & 2.71 & 23.87 & 12.45 & 66.56 & 102.9 \\
\hline IH-39 & C & 1.5 & 3.98 & 37.37 & 18.69 & 109.02 & 165.1 \\
\hline IH-39 & $x$ & 1.0 & 5.09 & 47.63 & 22.33 & 127.69 & 197.7 \\
\hline IH-39 & $Y$ & 1.0 & $0.07 \mathrm{~J}$ & $0.73 U$ & $0.06 \mathrm{~J}$ & $0.52 \mathrm{~J}$ & 0.6 \\
\hline $\mathrm{HH}-40$ & A & 1.0 & $0.92 \mathrm{~J}$ & 4.92 & 3.38 & 32.98 & 41.3 \\
\hline $\mathrm{IH}-40$ & B & 1.5 & $1.10 \mathrm{~J}$ & 16.22 & 3.17 & 32.70 & 52.1 \\
\hline $\mathrm{IH}-40$ & $x$ & 1.0 & 1.61 & 68.27 & 3.79 & 43.70 & 115.8 \\
\hline $\mathrm{IH}-40$ & $Y$ & 1.0 & $0.09 \mathrm{~J}$ & $0.76 \mathrm{U}$ & $0.71 \cup$ & $0.12 \mathrm{~J}$ & 0.1 \\
\hline $\mathrm{IH}-41$ & A & 1.0 & 1.19 & 21.65 & 3.73 & 24.16 & 49.5 \\
\hline $\mid H-41$ & B & 2.0 & $1.13 \mathrm{~J}$ & 1.75 & 3.24 & 19.22 & 24.2 \\
\hline $\mathrm{IH}-41$ & C & 1.0 & 3.22 & 34.51 & 9.18 & 98.66 & 142.4 \\
\hline $\mid H-41$ & $x$ & 1.0 & 3.07 & 13.99 & 9.05 & 78.73 & 101.8 \\
\hline $\mathrm{IH}-41$ & $Y$ & 1.0 & $0.68 \mathrm{U}$ & $0.73 \mathrm{U}$ & $0.68 \mathrm{U}$ & $0.09 \mathrm{~J}$ & 0.1 \\
\hline $\mathrm{IH}-42$ & A & 1.0 & 1.72 & 4.42 & 6.28 & 40.53 & 51.2 \\
\hline $\mid H-42$ & $x$ & 0.6 & $1.10 \mathrm{~J}$ & 1.55 & 3.93 & 21.52 & 27.0 \\
\hline $\mathrm{IH}-42$ & $\mathrm{Y}$ & 1.0 & $0.68 \mathrm{U}$ & $0.75 \mathrm{U}$ & $0.69 \mathrm{U}$ & $0.09 \mathrm{~J}$ & 0.1 \\
\hline $\mathrm{IH}-43$ & A & 1.0 & $1.18 \mathrm{U}$ & $1.29 \mathrm{U}$ & $0.09 \mathrm{~J}$ & $0.31 \mathrm{~J}$ & 0.4 \\
\hline $\mid H-43$ & B & 2.0 & 2.13 & 18.44 & 5.58 & 49.03 & 73.1 \\
\hline $\mathrm{IH}-43$ & $x$ & 1.0 & 1.66 & 12.82 & 5.63 & 37.17 & 55.6 \\
\hline $\mathrm{IH}-43$ & $Y$ & 1.0 & $0.10 \mathrm{~J}$ & $0.75 \mathrm{U}$ & $0.70 \mathrm{U}$ & $0.17 \mathrm{~J}$ & 0.2 \\
\hline $\mid H-44$ & A & 1.0 & $1.03 \mathrm{~J}$ & 14.60 & 3.10 & 17.82 & 35.5 \\
\hline $\mathrm{HH}-44$ & B & 2.0 & 2.15 & 14.07 & 6.26 & 60.74 & 81.1 \\
\hline $\mid H-44$ & C & 2.0 & 1.27 & 3.05 & 3.74 & 18.33 & 25.1 \\
\hline $\mathrm{HH}-44$ & D & 2.0 & 1.53 & 8.73 & 6.43 & 35.28 & 50.4 \\
\hline $\mid H-44$ & $x$ & 1.0 & 3.24 & 4.45 & 19.18 & 50.74 & 74.4 \\
\hline $\mathrm{H}-44$ & $Y$ & 1.0 & $0.04 \mathrm{~J}$ & $0.08 \mathrm{~J}$ & $0.08 \mathrm{~J}$ & $0.53 \mathrm{~J}$ & 0.7 \\
\hline
\end{tabular}


IABLE 3.7. (contd)

\begin{tabular}{|c|c|c|c|c|c|c|c|}
\hline \multirow{2}{*}{\multicolumn{2}{|c|}{$\begin{array}{l}\text { Sediment } \\
\text { Samole ID }\end{array}$}} & \multirow[b]{2}{*}{$\begin{array}{c}\text { Thickness } \\
\text { (ft) }\end{array}$} & \multicolumn{5}{|c|}{ Pesticide Concentration (ug/kg dry weight) } \\
\hline & & & \multirow{2}{*}{$\begin{array}{l}\text { Dieldrin } \\
0.42 \mathrm{~J}\end{array}$} & \multirow{2}{*}{$\begin{array}{r}\text { 4.4'-DDT } \\
2.72\end{array}$} & 4,4'-DDE & \multirow{2}{*}{$\begin{array}{r}4,4^{\prime}-\mathrm{DDD} \\
8.53\end{array}$} & \multirow{2}{*}{$\begin{array}{l}\text { Total } \\
\text { DDT(a) } \\
\\
\\
\mathbf{1 2 . 8}\end{array}$} \\
\hline$H-45$ & A & 1.0 & & & 1.55 & & \\
\hline $\mathrm{IH}-45$ & $\mathrm{~B}$ & 2.0 & $1.15 \mathrm{~J}$ & 3.13 & 2.55 & 20.65 & 26.3 \\
\hline $1 \mathrm{H}-45$ & $\mathrm{C}$ & 1.3 & 2.21 & 10.48 & 7.45 & 61.17 & 79.1 \\
\hline $\mathrm{IH}-45$ & $x$ & 1.0 & $0.45 \mathrm{~J}$ & 7.42 & $1.00 \mathrm{~J}$ & 8.60 & 17.0 \\
\hline $\mathrm{IH}-45$ & $Y$ & 1.0 & $0.02 \mathrm{~J}$ & $0.76 U$ & $0.05 \mathrm{~J}$ & $0.39 \mathrm{~J}$ & 0.4 \\
\hline $\mathrm{IH}-46$ & A & 1.0 & 1.33 & 7.33 & 1.41 & 8.70 & 17.4 \\
\hline $\mathrm{IH}-46$ & B & 2.0 & $0.52 \mathrm{~J}$ & 10.66 & 1.29 & 8.49 & 20.4 \\
\hline$I H-46$ & C & 2.0 & 1.32 & 52.75 & 3.15 & 18.80 & 74.7 \\
\hline $\mathrm{IH}-46$ & $x$ & 1.0 & $0.60 \mathrm{~J}$ & $0.18 \mathrm{~J}$ & 2.03 & 10.98 & 13.2 \\
\hline $\mathrm{IH}-46$ & $Y$ & 1.0 & $0.10 \mathrm{~J}$ & $0.76 U$ & $0.71 U$ & $0.19 \mathrm{~J}$ & 0.2 \\
\hline $\mathrm{IH}-47$ & A & 1.0 & $0.17 \mathrm{~J}$ & $0.70 \mathrm{~J}$ & $0.46 \mathrm{~J}$ & 1.63 & 2.8 \\
\hline $\mathrm{lH}-47$ & $\mathrm{~B}$ & 2.0 & $0.94 \mathrm{~J}$ & 8.39 & 1.91 & 14.11 & 24.4 \\
\hline $\mathrm{IH}-47$ & $C$ & 0.8 & $0.59 \mathrm{~J}$ & $0.24 \mathrm{~J}$ & 1.75 & 9.17 & 11.2 \\
\hline $1 \mathrm{H}-47$ & $x$ & 1.0 & $0.44 \mathrm{~J}$ & $0.29 \mathrm{~J}$ & 1.50 & 8.68 & 10.5 \\
\hline $\mathrm{IH}-47$ & $Y$ & 1.0 & $0.68 \mathrm{U}$ & $0.74 \mathrm{U}$ & $0.69 \mathrm{U}$ & $0.10 \mathrm{~J}$ & 0.1 \\
\hline $\mathrm{IH}-48$ & A & 1.0 & $0.24 \mathrm{~J}$ & $0.31 \mathrm{~J}$ & $0.61 \mathrm{~J}$ & 3.55 & 4.5 \\
\hline $\mathrm{IH}-48$ & B & 2.4 & $0.42 \mathrm{~J}$ & $0.36 \mathrm{~J}$ & $1.11 \mathrm{~J}$ & 7.43 & 8.9 \\
\hline $\mathrm{IH}-48$ & $x$ & 1.0 & $0.62 \mathrm{~J}$ & 1.85 & $0.88 \mathrm{~J}$ & 5.74 & 8.5 \\
\hline $\mathrm{IH}-48$ & $Y$ & 1.0 & $0.11 \mathrm{~J}$ & $0.74 U$ & $0.69 \mathrm{U}$ & $0.19 \mathrm{~J}$ & 0.2 \\
\hline $\mathbb{H}-49$ & A & 1.0 & $0.21 \mathrm{~J}$ & $0.37 \mathrm{~J}$ & $0.64 \mathrm{~J}$ & 2.28 & 3.3 \\
\hline $\mathrm{IH}-49$ & $\mathrm{~B}$ & 1.7 & $1.20 \mathrm{~J}$ & 3.90 & 2.74 & 16.45 & 23.1 \\
\hline $\mathrm{IH}-49$ & $x$ & 1.0 & $0.96 \mathrm{~J}$ & $0.83 \mathrm{~J}$ & 2.84 & 22.01 & 25.7 \\
\hline $\mathrm{IH}-49$ & $Y$ & 0.8 & $0.10 \mathrm{~J}$ & $0.79 \mathrm{U}$ & $0.73 \mathrm{U}$ & $0.21 \mathrm{~J}$ & 0.2 \\
\hline $\mathrm{IH}-50$ & A & 1.0 & $0.21 \mathrm{~J}$ & $0.26 \mathrm{~J}$ & $0.36 \mathrm{~J}$ & 9.58 & 10.2 \\
\hline $\mathrm{IH}-50$ & $B$ & 2.0 & $0.25 \mathrm{~J}$ & $0.88 \mathrm{~J}$ & $1.14 \mathrm{~J}$ & 3.08 & 5.1 \\
\hline $\mathrm{IH}-50$ & C & 0.8 & $0.38 \mathrm{~J}$ & 8.13 & 1.95 & 8.67 & 18.8 \\
\hline $\mathrm{HH}-50$ & $x$ & 1.0 & $0.25 \mathrm{~J}$ & $0.70 \mathrm{~J}$ & 1.27 & 5.33 & 7.3 \\
\hline $\mathrm{HH}-50$ & $Y$ & 1.0 & $0.60 \mathrm{U}$ & $0.65 U$ & $0.61 U$ & $0.08 \mathrm{~J}$ & 0.1 \\
\hline $\mid \mathrm{H}-51$ & A & 1.0 & $0.48 \mathrm{~J}$ & $0.65 \mathrm{~J}$ & 2.10 & 6.34 & 9.1 \\
\hline $\mid \mathrm{H}-51$ & B & 1.0 & $1.03 \mathrm{U}$ & $0.18 \mathrm{~J}$ & $0.49 \mathrm{~J}$ & 1.78 & 2.5 \\
\hline $\mathrm{IH}-51$ & $x$ & 1.0 & $0.56 \mathrm{~J}$ & $0.61 \mathrm{~J}$ & 2.51 & 10.38 & 13.5 \\
\hline $\mathrm{IH}-51$ & $Y$ & 1.0 & $0.01 \mathrm{~J}$ & $0.74 \mathrm{U}$ & $0.69 \mathrm{U}$ & $0.08 \mathrm{~J}$ & 0.1 \\
\hline PC-52 & A & 1.0 & 7.91 & 45.90 & 30.86 & 123.52 & 200.3 \\
\hline PC-52 & B & 2.0 & 6.94 & 2.15 & 21.37 & 75.16 & 98.7 \\
\hline PC-52 & C & 1.1 & 18.58 & 10.51 & 48.94 & 155.05 & 214.5 \\
\hline PC-53 & A & 1.0 & 29.38 & 122.85 & 102.12 & 617.02 & 842.0 \\
\hline PC-53 & $B$ & 1.4 & 39.32 & 52.46 & 81.86 & 526.74 & 661.1 \\
\hline PC-53 & $\mathrm{C}$ & 1.0 & 44.57 & 119.98 & 179.57 & 1142.75 & 1442.3 \\
\hline
\end{tabular}


TABLE 3.7. (contd)

\begin{tabular}{llll}
$\begin{array}{l}\text { Sediment } \\
\text { Samole ID }\end{array}$ & & \multicolumn{1}{c}{$\begin{array}{c}\text { Thicknnes } \\
\text { (tt) }\end{array}$} \\
\cline { 1 - 1 } & & \\
PC-54 & A & & 1.0 \\
PC-54 & B & & 1.6 \\
PC-54 & C & & 1.0 \\
& & \\
SFC Marina & & NA \\
FSFC Edge-West & NA \\
Parr Canal Edge & NA \\
IHC Edge-East & NA \\
IHC Edge-West & NA \\
Outer Harbor Edge & NA \\
& &
\end{tabular}

\begin{tabular}{|c|c|c|c|c|}
\hline Dieldrin & 4.4'-DDT & 4.4'-DDE & 4.4'-DDD & $\begin{array}{l}\text { Total } \\
\text { DDT(a) }\end{array}$ \\
\hline 36.29 & 192.79 & 85.50 & 690.05 & 968.3 \\
\hline 44.86 & 433.31 & 131.83 & 1005.82 & 1571.0 \\
\hline 167.79 & 721.50 & 370.35 & 2986.02 & 4077.9 \\
\hline 1.98 & 8.67 & 7.17 & 46.54 & 62.4 \\
\hline 5.66 & 90.83 & 23.44 & 140.83 & 255.1 \\
\hline 11.55 & 758.73 & 56.54 & 327.83 & 1143.1 \\
\hline $1.77 \mathrm{~J}$ & 4.33 & 4.81 & 28.01 & 37.2 \\
\hline $0.47 \mathrm{~J}$ & $0.90 \mathrm{~J}$ & $0.84 \mathrm{~J}$ & 2.68 & 4.4 \\
\hline $1.15 \mathrm{U}$ & $0.49 \mathrm{~J}$ & $0.36 \mathrm{~J}$ & 1.70 & 2.6 \\
\hline
\end{tabular}

(a) Sum of 4,4'-DDT, 4,4'-DDE, and 4,4'-DDD. Undetected analytes are assigned a value of 0.

(b) J Analyte detected below method detection limit but above instrument detection limit.

(c) NM Analyte not measured in sample.

(d) U Analyte undetected above given concentration; some detection limits are elevated because of sample dilutions of $1: 10$ to $1: 5000$.

(e) NA Not applicable. 
TABLE 3. 8. Pesticides Other Than DDT, DDD, DDE, and Dieldrin in Vertical Core Segments and Channel Edge Grab Samples

\begin{tabular}{|c|c|c|c|c|c|c|c|c|}
\hline \multirow[b]{2}{*}{$\begin{array}{l}\text { Sediment } \\
\text { Treatment }\end{array}$} & \multicolumn{8}{|c|}{ Concentrations in $\mu \mathrm{o} / \mathrm{kg}$ dry weiaht } \\
\hline & Alpha-BHC & Aldrin & $\begin{array}{c}\text { trans- } \\
\text { Chlordane } \\
\end{array}$ & $\begin{array}{l}\text { Endo- } \\
\text { sulfan I }\end{array}$ & $\begin{array}{l}\text { Cis- } \\
\text { Chlordane } \\
\end{array}$ & Endrin & $\begin{array}{c}\text { Endo- } \\
\text { sulfan II }\end{array}$ & $\begin{array}{c}\text { Endrin- } \\
\text { Aldehyde }\end{array}$ \\
\hline $\begin{array}{l}\text { LZ-9Y } \\
\text { LZ-11Y } \\
\text { LZ-16 C } \\
\text { SF-17 A } \\
\text { SF-17 B } \\
\text { SF-18 B } \\
\text { SF-20 X } \\
\text { SF-22 A } \\
\text { SF-22 B } \\
\text { SF-24 A } \\
\text { SF-26 C } \\
\text { SF-26 X } \\
\text { SF-27 A } \\
\text { SF-28 B } \\
\text { SF-28 X } \\
\text { SF-29 C } \\
\text { SF-29 D } \\
\text { SF-29 E } \\
\text { SF-31 X } \\
\text { SF-32 A } \\
\text { SF-33 A } \\
\text { SF-33 X } \\
\text { SF-34 A } \\
\text { IH-44 X } \\
\text { IH-46 A } \\
\text { PC-52 A } \\
\text { PC-52 B } \\
\text { PC-52 C } \\
\text { PC-53 A } \\
\text { PC-53 B } \\
\text { PC-53 C } \\
\text { PC-54 A } \\
\text { PC-54 B } \\
\text { PC-54 C }\end{array}$ & $\begin{array}{l}0.83 \\
0.74 \\
\text { ND } \\
\text { ND } \\
\text { ND } \\
\text { ND } \\
\text { ND } \\
\text { ND } \\
\text { ND } \\
\text { ND } \\
0.96 \\
\text { ND } \\
\text { ND } \\
0.66 \\
1.01 \\
1.01 \\
0.98 \\
2.07 \\
0.82 \\
\text { ND } \\
0.66 \\
\text { ND } \\
\text { ND } \\
\text { ND } \\
\text { ND } \\
\text { ND } \\
\text { ND } \\
1.37 \\
\text { ND } \\
\text { ND } \\
9.14 \\
\text { ND } \\
\text { ND } \\
8.55\end{array}$ & $\begin{array}{l}1.29 \\
\text { ND } \\
\text { ND } \\
\text { ND } \\
\text { ND } \\
\text { ND } \\
\text { ND } \\
\text { ND } \\
\text { ND } \\
\text { ND } \\
\text { ND } \\
\text { ND } \\
\text { ND } \\
\text { ND } \\
\text { ND } \\
\text { ND } \\
\text { ND } \\
\text { ND } \\
\text { ND } \\
\text { ND } \\
\text { ND } \\
\text { ND } \\
\text { ND } \\
\text { ND } \\
\text { ND } \\
\text { ND } \\
\text { ND } \\
\text { ND } \\
\text { ND } \\
\text { ND } \\
\text { ND } \\
\text { ND } \\
\text { ND } \\
\text { ND }\end{array}$ & $\begin{array}{r}0.81 \\
N D \\
N D \\
2.09 \\
1.54 \\
1.89 \\
1.45 \\
2.25 \\
1.34 \\
1.44 \\
\text { ND } \\
\text { ND } \\
\text { ND } \\
\text { ND } \\
1.37 \\
\text { ND } \\
\text { ND } \\
\text { ND } \\
\text { ND } \\
1.53 \\
\text { ND } \\
1.33 \\
2.62 \\
N D \\
N D \\
6.15 \\
10.24 \\
24.95 \\
17.64 \\
14.65 \\
68.52 \\
17.85 \\
34.59 \\
\text { ND }\end{array}$ & $\begin{array}{l}\text { ND(a) } \\
\text { ND } \\
\text { ND } \\
\text { ND } \\
\text { ND } \\
\text { ND } \\
\text { ND } \\
\text { ND } \\
\text { ND } \\
\text { ND } \\
1.38 \\
1.09 \\
N D \\
N D \\
N D \\
N D \\
N D \\
N D \\
\text { ND } \\
\text { ND } \\
\text { ND } \\
\text { ND } \\
\text { ND } \\
N D \\
N D \\
N D \\
N D \\
N D \\
3.34 \\
3.13 \\
7.31 \\
2.19 \\
N D \\
\text { ND }\end{array}$ & $\begin{array}{l}\text { ND } \\
\text { ND } \\
\text { ND } \\
\text { ND } \\
\text { ND } \\
\text { ND } \\
\text { ND } \\
\text { ND } \\
\text { ND } \\
\text { ND } \\
\text { ND } \\
\text { ND } \\
\text { ND } \\
\text { ND } \\
N D \\
N D \\
N D \\
N D \\
\text { ND } \\
\text { ND } \\
\text { ND } \\
\text { ND } \\
N D \\
N D \\
N D \\
5.65 \\
8.24 \\
19.50 \\
21.58 \\
44.20 \\
56.72 \\
20.07 \\
26.01 \\
5.44\end{array}$ & $\begin{array}{r}1.15 \\
\text { ND } \\
116.53 \\
N D \\
N D \\
N D \\
N D \\
N D \\
N D \\
N D \\
N D \\
N D \\
N D \\
N D \\
N D \\
N D \\
N D \\
N D \\
N D \\
N D \\
N D \\
N D \\
N D \\
N D \\
2.19 \\
N D \\
N D \\
N D \\
N D \\
N D \\
N D \\
N D \\
N D \\
3.77\end{array}$ & $\begin{array}{l}\text { ND } \\
\text { ND } \\
\text { ND } \\
\text { ND } \\
\text { ND } \\
\text { ND } \\
\text { ND } \\
\text { ND } \\
\text { ND } \\
\text { ND } \\
\text { ND } \\
\text { ND } \\
\text { ND } \\
\text { ND } \\
\text { ND } \\
\text { ND } \\
\text { ND } \\
\text { ND } \\
1.83 \\
\text { ND } \\
\text { ND } \\
\text { ND } \\
1.12 \\
\text { ND } \\
2.93 \\
\text { ND } \\
\text { ND } \\
\text { ND } \\
9.31 \\
\text { ND } \\
6.69 \\
9.78 \\
\text { ND }\end{array}$ & $\begin{array}{l}\text { ND } \\
\text { ND } \\
\text { ND } \\
\text { ND } \\
\text { ND } \\
\text { ND } \\
\text { ND } \\
\text { ND } \\
\text { ND } \\
\text { ND } \\
\text { ND } \\
\text { ND } \\
2.23 \\
\text { ND } \\
\text { ND } \\
\text { ND } \\
\text { ND } \\
\text { ND } \\
\text { ND } \\
\text { ND } \\
\text { ND } \\
\text { ND } \\
\text { ND } \\
\text { ND } \\
\text { ND } \\
\text { ND } \\
\text { ND } \\
\text { ND } \\
\text { ND } \\
\text { ND } \\
\text { ND } \\
\text { ND } \\
\text { ND } \\
\text { ND }\end{array}$ \\
\hline
\end{tabular}

(a) ND Not detected above the target detection limit. 
TABLE 3.9. Total DDT Concentrations and Percent Solids in Samples Above and Below the YBM/OBM Contact

\begin{tabular}{|c|c|c|c|c|}
\hline \multirow[b]{2}{*}{ Treatment } & \multicolumn{2}{|c|}{$1 \mathrm{ft}$ Above YBM/OBM Contact } & \multicolumn{2}{|c|}{$1 \mathrm{ft}$ Below YBM/OBM Contact } \\
\hline & $\begin{array}{l}\text { Total DDT(a) } \\
\text { (ug/kg dry) }\end{array}$ & $\%$ Solids & $\begin{array}{l}\text { Total DDT } \\
(\mu \mathrm{g} / \mathrm{kg} \text { dry) }\end{array}$ & $\%$ Solids \\
\hline $\begin{array}{l}\text { LZ-1 } \\
\text { LZ-2 } \\
\text { LZ-3 } \\
\text { LZ-5 } \\
\text { LZ-6 } \\
\text { LZ-7 } \\
\text { LZ-8 } \\
\text { LZ-9 } \\
\text { LZ-10 } \\
\text { LZ-11 } \\
\text { LZ-12 } \\
\text { LZ-13 } \\
\text { LZ-14 } \\
\text { LZ-15 } \\
\text { LZ-16 }\end{array}$ & $\begin{array}{r}544 \\
110,363 \\
19,544 \\
44,812 \\
828 \\
173 \\
1,067 \\
19,872 \\
120,536 \\
128,962 \\
1,548 \\
7,191 \\
201 \\
2,404 \\
888\end{array}$ & $\begin{array}{l}52 \\
52 \\
57 \\
55 \\
70 \\
65 \\
73 \\
50 \\
49 \\
59 \\
40 \\
59 \\
81 \\
46 \\
76\end{array}$ & $\begin{array}{c}144 \\
976 \\
252 \\
932 \\
93 \\
12 \\
0.7 \\
1,905 \\
7.4 \\
655 \\
30 \\
0.2 \\
1.5 \\
19 \\
1.2\end{array}$ & $\begin{array}{l}75 \\
78 \\
78 \\
75 \\
80 \\
78 \\
80 \\
84 \\
81 \\
86 \\
78 \\
80 \\
85 \\
80 \\
79\end{array}$ \\
\hline Mean & 30,596 & 59 & 335 & 80 \\
\hline
\end{tabular}

(a) Sum of 4,4'-DDT, 4,4'-DDD, and 4,4'-DDE. 
TABLE 3.10. Relative Contribution of DDT Metabolites to Total DDT

\begin{tabular}{|c|c|c|c|}
\hline Location & $\begin{array}{r}\text { Percent } \\
4.4^{\prime}-\mathrm{DDT} \\
\end{array}$ & $\begin{array}{r}\text { Percent } \\
4.4^{\prime}-\mathrm{DDE} \\
\end{array}$ & $\begin{array}{r}\text { Percent } \\
4.4^{\prime}-\mathrm{DDD} \\
\end{array}$ \\
\hline $\begin{array}{l}\text { Lauritzen Canal(a) } \\
\text { Fedreral Santa Fe Channel } \\
\text { Inner Harbor Channel } \\
\text { Parr Canal } \\
\text { Upper Santa Fe Channel }\end{array}$ & $\begin{array}{l}42 \% \\
30 \% \\
21 \% \\
14 \% \\
12 \%\end{array}$ & $\begin{array}{r}3 \% \\
9 \% \\
11 \% \\
14 \% \\
15 \%\end{array}$ & $\begin{array}{l}55 \% \\
61 \% \\
68 \% \\
72 \% \\
73 \%\end{array}$ \\
\hline
\end{tabular}

(a) Excluding samples LZ-1B, LZ-8C, LZ-8D, and LZ-8E. 
TABLE 3.11. Oil and Grease, Total Petroleum Hydrocarbons, PAHs, and Aroclor 1254 in YBM from Selected Cores and in OBM Composites

\begin{tabular}{|c|c|c|c|c|c|c|c|}
\hline \multirow{2}{*}{\multicolumn{2}{|c|}{$\begin{array}{l}\text { Sediment } \\
\text { Treatment }\end{array}$}} & \multicolumn{2}{|c|}{ mo/kg dn weiaht } & \multicolumn{4}{|c|}{ ugkg d w weight } \\
\hline & & Oil and Grease & $\mathrm{TPH}$ & Iotal LPAH & Iotal HPAH & Total & Aroclor 1254 \\
\hline LZ-1 & M & 26,000 & 22,900 & $7,819.1$ & $4,684.4$ & 12,503 & 310.86 \\
\hline LZ-3 & $M$ & 2,100 & 1,800 & 773.6 & $5,281.0$ & 6,055 & 465.88 \\
\hline LZ-6 & $M$ & 1,700 & 1,400 & $1,538.1$ & $2,999.9$ & 4,538 & 280.07 \\
\hline LZ-9 & $M$ & 770 & 490 & 587.2 & $2,324.6$ & 2,912 & 201.07 \\
\hline LZ-11 & $M$ & 940 & 600 & 606.0 & $1,294.4$ & 1,900 & 236.45 \\
\hline LZ-13 & $M$ & 670 & 470 & $11,693.1$ & $20,424.9$ & 32,118 & 108.41 \\
\hline LZ-15 & $M$ & 400 & 240 & 84.8 & 665.0 & 750 & $44.80 \mathrm{U}(\mathrm{a})$ \\
\hline SF-17 & M & 340 & 400 & 76.4 & 724.2 & 801 & 78.18 \\
\hline SF-18 & M & 510 & 360 & 143.6 & $1,331.7$ & 1,475 & 125.69 \\
\hline SF-19 & M & 520 & 370 & 34.7 & 286.9 & 322 & $25.68 \mathrm{~J}(\mathrm{~b})$ \\
\hline SF-20 & M & 450 & 370 & 93.2 & 855.6 & 949 & $44.05 \mathrm{~J}$ \\
\hline SF-21 & $\mathbf{M}$ & 300 & 290 & 34.8 & 288.1 & 323 & $37.77 \mathrm{~J}$ \\
\hline SF-22 & $\mathbf{M}$ & 220 & 170 & 110.3 & $1,249.8$ & 1,360 & 91.46 \\
\hline SF-23 & $M$ & 190 & 330 & 62.4 & 366.4 & 429 & $21.43 \mathrm{~J}$ \\
\hline SF-24 & M & 240 & 330 & 46.1 & 555.4 & 602 & 49.83 \\
\hline SF-25 & M & 520 & 520 & $9,714.2$ & $14,484.4$ & 24,199 & 109.92 \\
\hline SF-26 & M & 370 & 250 & 77.3 & 509.8 & 587 & $14.70 \mathrm{~J}$ \\
\hline SF-27 & $M$ & 390 & 450 & 21.6 & 173.1 & 195 & $4.82 \mathrm{~J}$ \\
\hline SF-28 & $M$ & 200 & 130 & 228.8 & $1,626.7$ & 1,856 & 59.36 \\
\hline SF-30 & $M$ & 400 & 170 & 63.9 & 501.1 & 565 & $11.80 \mathrm{~J}$ \\
\hline SF-32 & $M$ & 250 & 150 & 87.6 & 557.6 & 645 & $17.35 \mathrm{~J}$ \\
\hline SF-34 & $M$ & 310 & 210 & 190.6 & $1,637.2$ & 1,828 & 58.62 \\
\hline IH-37 & $M$ & 250 & $90 \mathrm{U}$ & 62.0 & 566.2 & 628 & $13.76 \mathrm{~J}$ \\
\hline IH-38 & $M$ & 270 & $90 \mathrm{U}$ & 23.4 & 191.1 & 215 & $6.21 \mathrm{~J}$ \\
\hline IH-39 & $M$ & 246 & $90 \mathrm{U}$ & 80.0 & 805.9 & 886 & $30.60 \mathrm{~J}$ \\
\hline PC-52 & $M$ & 19,800 & 14,800 & $1,726.8$ & $5,056.0$ & 6,783 & 675.00 \\
\hline PC-53 & M & 14,200 & 11,200 & $6,789.3$ & $19,696.1$ & 26,485 & $1,981.91$ \\
\hline PC-54 & M & 3,700 & 2,300 & 562.3 & $4,170.7$ & 4,733 & 567.81 \\
\hline $\begin{array}{l}\text { OBM Co } \\
\text { OBM Co }\end{array}$ & $\begin{array}{l}\text { omp } \\
\text { omp. }\end{array}$ & $\begin{array}{l}30 \mathrm{U} \\
30 \mathrm{U}\end{array}$ & $\begin{array}{l}30 \mathrm{U} \\
30 \mathrm{U}\end{array}$ & $\begin{array}{l}14.8 \\
42.2\end{array}$ & $\begin{array}{r}20.4 \\
101.0\end{array}$ & $\begin{array}{r}35 \\
143\end{array}$ & $\begin{array}{l}21.71 \mathrm{U} \\
24.15 \mathrm{U}\end{array}$ \\
\hline
\end{tabular}

(a) U Analyte undetected above given concentration.

(b) J Analyte detected below method detection limit but above instrument detection limit. 
TABLE 3.12. Metals and Butyltins in Younger Bay Mud from Selected Cores and in Older Bay Mud Composites

Sediment

\begin{tabular}{|c|c|}
\hline $\begin{array}{l}L Z-1 \\
L Z-3 \\
L Z-6 \\
L Z-9 \\
L Z-11 \\
L Z-13 \\
L Z-15\end{array}$ & $\begin{array}{l}M \\
M \\
M \\
M \\
M \\
M \\
M\end{array}$ \\
\hline $\begin{array}{l}\text { SF-17 } \\
\text { SF-18 } \\
\text { SF-19 } \\
\text { SF-20 } \\
\text { SF-21 } \\
\text { SF-22 } \\
\text { SF-23 } \\
\text { SF-24 } \\
\text { SF-25 } \\
\text { SF-26 }\end{array}$ & $\begin{array}{l}M \\
M \\
M \\
M \\
M \\
M \\
M \\
M \\
M \\
M\end{array}$ \\
\hline $\begin{array}{l}\text { SF-27 } \\
\text { SF-28 } \\
\text { SF-30 } \\
\text { SF-32 } \\
\text { SF-34 }\end{array}$ & $\begin{array}{l}M \\
M \\
M \\
M \\
M\end{array}$ \\
\hline $\begin{array}{l}\mathrm{IH}-37 \\
\mathrm{lH}-38 \\
\mathrm{IH}-39\end{array}$ & $\begin{array}{l}M \\
M \\
M\end{array}$ \\
\hline $\begin{array}{l}P C-52 \\
\text { PC-53 } \\
\text { PC-54 }\end{array}$ & $\begin{array}{l}M \\
M \\
M\end{array}$ \\
\hline
\end{tabular}

OBM Comp - Fine OBM Comp - Coarse

\begin{tabular}{l} 
\\
\hline $\mathrm{Ag}$ \\
\hline 1.62 \\
1.27 \\
0.60 \\
0.59 \\
0.70 \\
0.42 \\
0.41 \\
\\
0.57 \\
0.53 \\
0.62 \\
0.52 \\
0.55 \\
0.45 \\
0.48 \\
0.47 \\
0.39 \\
0.74 \\
0.51 \\
0.43 \\
0.51 \\
0.16 \\
0.34 \\
0.47 \\
0.48 \\
0.58 \\
0.98 \\
0.87 \\
0.60 \\
0.13 \\
0.10 \\
\end{tabular}

Metal Concentration (moka drv weiahtl

\begin{tabular}{ll}
\hline $\mathrm{Ag}$ & $\mathrm{As}$ \\
& \\
1.62 & 16.4 \\
1.27 & 15.5 \\
0.60 & 15.7 \\
0.59 & 18.4 \\
0.70 & 15.1 \\
0.42 & 20.1 \\
0.41 & 15.6
\end{tabular}

$\begin{array}{rr}0.57 & 14.1 \\ 0.53 & 15.0\end{array}$

$53 \quad 15.0$

$62 \quad 14.5$

$\begin{array}{ll}14.5 \\ 55 & 17.0\end{array}$

17.0

26.6

16.8

13.4
17.6

15.4

11.6
14.3

14.8

14.8
14.2

13.0
15.5

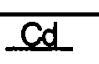

$\mathrm{Cr}$
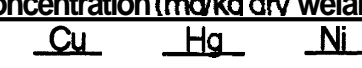

$\mathrm{Pb}$

$2.12 \quad 177$

\section{8}

2.18

$\begin{array}{ll}1.87 & 224 \\ 1.28 & 237\end{array}$

134
113

1.70

0.96

0.78

1.41

0.55

0.53

\section{1}

102
105

105
102

93

$1.70 \quad 235$

1.023990

212

122

$0.92 \quad 166$

104

1.39

1.13

98

$\begin{array}{ll}0.74 & 176 \\ 0.73 & 170\end{array}$

$0.50 \quad 168$

$0.60 \quad 170$

$1.21 \quad 173$

$0.54 \quad 177$

$\begin{array}{ll}0.54 & 177 \\ 0.66 & 180\end{array}$

$0.78 \quad 200$

$0.88 \quad 196$

$0.67 \quad 187$

$\begin{array}{ll}0.50 & 181\end{array}$

$0.47 \quad 211$

$0.39 \quad 199$

$\begin{array}{ll}0.77 & 241\end{array}$

101
104

106
95

1.11
0.76

0.99

1.18

103

116

116

116
106
104

$\begin{array}{lll}89 & 0.69 & 104\end{array}$

$\begin{array}{lll}114 & 1.01 & 112\end{array}$

$\begin{array}{rr}65 & 0.92 \\ 107 & 1.25\end{array}$

91
108

$\begin{array}{lll}86 & 0.85 & 104\end{array}$

69
100

0.85
0.61

0.61

93
110

$\begin{array}{ll}50 & 0.31\end{array}$

0.33

83
97

$0.47 \quad 183$

$0.50 \quad 177$

73

0.52
0.47

$0.47 \quad 117$

112
117
115

15.7

7.0 U(b) 3.17

$6.8 \cup \quad 3.06$

245
233
266

138

0.92
0.80

0.71

86

85
86

$\begin{array}{ll}6.8 & 0.54\end{array}$

170

$\begin{array}{ll}29 & 0.09 \\ 16 & 0.08\end{array}$

76
64

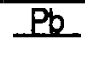

223
222

120
79

79

79
102

96

69

75
67

67
59

59
66

66
66

$\begin{array}{ll}66 & 0.45 \\ 49 & 0.45\end{array}$

$60 \quad 0.45$

46
71

0.45
0.49

0.39

$\begin{array}{ll}61 & 0.36 \\ 43 & 0.40\end{array}$

62
23

33

$$
0.40
$$$$
0.26
$$$$
0.40
$$$$
\begin{aligned}
& 56 \\
& 49
\end{aligned}
$$

0.36$$
0.40
$$
$\begin{array}{lll}849 & 0.45 & 709\end{array}$
$807 \quad 0.41 \quad 707$

323

0.40

$\begin{array}{ll}17 & 0.21\end{array}$

9

$0.10 \mathrm{U}$
Butyltins

fuok ko dru weiahtl

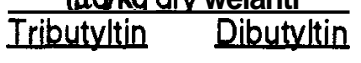

$13.2 \quad 11.6$

$17.6 \quad 15.0$

10.8

22.0

$5.3 \mathrm{~J}(\mathrm{a})$

37.5

24.9

10.6

23.6

$4.5 \mathrm{~J}$

21.9

12.4

$19.6 \quad 27.2$

$85.5 \quad 50.5$

$39.0 \quad 56.3$

$29.9 \quad 45.9$

$12.2 \quad 16.7$

$19.9 \quad 13.9$

$23.6 \quad 31.8$

$27.2 \quad 28.7$

$17.2 \quad 11.0$

$13.2 \quad 10.4$

$28.0 \quad 16.0$

$\begin{array}{ll}13.1 & 16.7\end{array}$

$16.0 \quad 14.7$

$7.9 \mathrm{~J} \quad 3.6 \mathrm{~J}$

120

3.6
7.6

$5.1 \mathrm{~J}$

7.6

8.1

6.7

$28.0 \mathrm{D1}(\mathrm{c}) \quad 8.3 \mathrm{D} 1$

20.2 D1 $15.9 \mathrm{D}$

$36.3 \quad 28.7$

$2.8 \mathrm{~J} \quad 5.0 \mathrm{U}$

$3.5 \mathrm{~J} \quad 5.0 \mathrm{U}$

(a) J Analyte detected below method detection limit but above instrument detection limit.

(b) U Analyte undetected above given concentration.

(c) D1 Sample diluted 1:10 
TABLE 3.13. Estimated Volume of Younger Bay Mud and Average DDT Concentration

\begin{tabular}{|c|c|c|c|}
\hline Category & $\begin{array}{c}\text { Average } \\
\text { Vdume } \\
\text { (cubic yards) } \\
\end{array}$ & $\begin{array}{l}\text { Standard } \\
\text { Deviation }\end{array}$ & $\begin{array}{c}\text { Average } \\
\text { Total DDT(a) } \\
\text { (ua/kg dry weight) }\end{array}$ \\
\hline Lauritzen Canal & 54,376 & 16,513 & 73,112 \\
\hline Parr Canal(b) & 10,000 & NA & 1,000 \\
\hline Santa Fe Channel & 232,780 & 40,747 & 204 \\
\hline Inner Harbor Channel >100 $\mu \mathrm{g} / \mathrm{kg}$ (c) & 63,686 & 25,633 & 135 \\
\hline Inner Harbor Channel >50 $\mu \mathrm{g} / \mathrm{kg}$ (d) & 296,001 & 45,604 & 87 \\
\hline Total YBM >1000 $\mu \mathrm{g} / \mathrm{kg}$ & 64,376 & $N A(\theta)$ & 61,910 \\
\hline Total YBM > $500 \mu \mathrm{g} / \mathrm{kg}$ & 64,376 & NA & 61,910 \\
\hline Total YBM > $100 \mu \mathrm{g} / \mathrm{kg}$ & 360,842 & NA & 11,201 \\
\hline $\begin{array}{l}\text { Total YBM > } 100 \mu \mathrm{g} / \mathrm{kg} \text {, } \\
\text { excluding Lauritzen Canal }\end{array}$ & 306,466 & NA & 216 \\
\hline Total YBM > $50 \mu \mathrm{g} / \mathrm{kg}$ & 593,157 & NA & 6,843 \\
\hline $\begin{array}{l}\text { Total YBM > }>50 \mu \mathrm{g} / \mathrm{kg} \text {, } \\
\text { excluding Lauritzen Canal }\end{array}$ & 538,781 & NA & 154 \\
\hline \multicolumn{4}{|c|}{$\begin{array}{l}\text { (a) Sum of 4,4'-DDT, 4,4'-DDD, and 4,4'-DDE; Undetected analytes are assigned } \\
\text { (b) Single estimate assuming a uniform YBM thickness of } 6 \mathrm{ft} \text {. } \\
\text { (c) Includes stations with average total DDT concentration greater than } 100 \mu \mathrm{g} / \mathrm{kg} \text {. } \\
\text { (d) Includes stations with average total DDT concentration greater than } 50 \mu \mathrm{g} / \mathrm{kg} \text {. } \\
\text { (e) NA Not applicable. }\end{array}$} \\
\hline
\end{tabular}


TABLE 3.14. Conventional Parameters in Sediment Composites

\begin{tabular}{|c|c|c|c|c|c|}
\hline \multirow[b]{2}{*}{$\begin{array}{l}\text { Sediment } \\
\text { Treatment }\end{array}$} & \multicolumn{5}{|c|}{ Percent DN Weiaht } \\
\hline & $\begin{array}{c}\text { Gravel } \\
>2000 \\
\end{array}$ & $\begin{array}{c}\text { Sand } \\
62.5-2000 \\
\end{array}$ & S.9-62.5 & $\begin{array}{l}\text { Clay } \\
<3.9\end{array}$ & TOC \\
\hline $\begin{array}{l}\text { Comp LC } \\
\text { Comp LC-1 } \\
\text { Comp LC-2 } \\
\text { Comp LC--3 } \\
\text { Comp LC-4 } \\
\text { Comp LC-5 } \\
\text { Comp LC-6 } \\
\text { Comp USFC } \\
\text { Comp FSFC } \\
\text { Comp IHC-1 } \\
\text { Comp IHC-2 } \\
\text { Comp IHC-3 } \\
\text { Comp GD }\end{array}$ & $\begin{array}{l}7 \\
5 \\
1 \\
7 \\
4 \\
5 \\
4 \\
2 \\
3 \\
1 \\
0 \\
0 \\
1\end{array}$ & $\begin{array}{r}25 \\
23 \\
23 \\
31 \\
20 \\
26 \\
28 \\
9 \\
17 \\
5 \\
3 \\
2 \\
5\end{array}$ & $\begin{array}{l}27 \\
26 \\
34 \\
25 \\
27 \\
30 \\
34 \\
26 \\
27 \\
30 \\
19 \\
33 \\
36\end{array}$ & $\begin{array}{l}41 \\
46 \\
42 \\
37 \\
49 \\
39 \\
34 \\
63 \\
53 \\
64 \\
78 \\
65 \\
58\end{array}$ & $\begin{array}{l}1.90 \\
5.24 \\
1.93 \\
1.62 \\
1.90 \\
1.77 \\
1.89 \\
1.43 \\
1.24 \\
5.24 \\
1.26 \\
1.20 \\
1.81\end{array}$ \\
\hline $\begin{array}{l}\text { C-SFBF } \\
\text { C-SFBC }\end{array}$ & $\begin{array}{l}0 \\
9\end{array}$ & $\begin{array}{r}9 \\
83\end{array}$ & $\begin{array}{r}60 \\
5\end{array}$ & $\begin{array}{r}31 \\
3\end{array}$ & $\begin{array}{l}0.82 \\
0.05\end{array}$ \\
\hline
\end{tabular}


TABLE 3.15. Dieldrin and DDT Compounds in Sediment Composites

\begin{tabular}{|c|c|c|c|c|c|}
\hline \multirow[b]{2}{*}{$\begin{array}{l}\text { Sediment } \\
\text { Sample ID }\end{array}$} & \multicolumn{5}{|c|}{ Pesticide Concentration ( $\mu \mathrm{g} / \mathrm{kg}$ dry weight) } \\
\hline & Dieldrin & 4,4'-DDT & 4,4'-DDD & 4,4'-DDE & $\begin{array}{l}\text { Total } \\
\text { DDT(a) }\end{array}$ \\
\hline $\begin{array}{l}\text { Comp LC } \\
\text { Comp LC-1 } \\
\text { Comp LC-2 } \\
\text { Comp LC-3 } \\
\text { Comp LC-4 } \\
\text { Comp LC-5 } \\
\text { Comp LC-6 } \\
\text { Comp USFC } \\
\text { Comp FSFC } \\
\text { Comp IHC-1 } \\
\text { Comp IHC-2 } \\
\text { Comp IHC-3 } \\
\text { Comp GD }\end{array}$ & $\begin{array}{c}480.57 \mathrm{~J}(\mathrm{~b}) \\
318.51 \\
1696.20 \mathrm{~J} \\
209.81 \mathrm{~J} \\
34.46 \mathrm{~J} \\
1568.82 \\
1515.15 \\
13.71 \\
9.50 \\
0.66 \mathrm{~J} \\
1.21 \mathrm{~J} \\
1.00 \mathrm{~J} \\
0.30 \mathrm{~J}\end{array}$ & $\begin{array}{r}32776.54 \\
11993.68 \\
140212.86 \\
13996.72 \\
460.72 \\
41560.53 \\
15974.54 \\
106.58 \\
191.41 \\
7.29 \\
1.69 \\
6.81 \\
1.38 \mathrm{U}(c)\end{array}$ & $\begin{array}{r}20658.65 \\
13762.32 \\
75700.61 \\
7814.17 \\
611.27 \\
45625.72 \\
71441.35 \\
288.38 \\
188.63 \\
8.73 \\
15.85 \\
12.16 \\
0.97 \mathrm{~J}\end{array}$ & $\begin{array}{c}461.32 \mathrm{~J} \\
1245.70 \\
1982.00 \mathrm{~J} \\
211.42 \mathrm{~J} \\
40.30 \mathrm{~J} \\
974.08 \mathrm{~J} \\
1207.27 \\
86.25 \\
30.50 \\
1.24 \\
2.52 \\
1.70 \\
1.28 \mathrm{U}\end{array}$ & $\begin{array}{r}53886.5 \\
27001.7 \\
217895.5 \\
22022.3 \\
1112.3 \\
88160.3 \\
88623.2 \\
481.2 \\
410.5 \\
17.3 \\
20.1 \\
20.7 \\
1.0\end{array}$ \\
\hline $\begin{array}{l}\text { C-SFBF } \\
\text { C-SFBC }\end{array}$ & $\begin{array}{l}0.98 \mathrm{U} \\
0.01 \mathrm{~J}\end{array}$ & $\begin{array}{l}0.62 \mathrm{~J} \\
0.71 \mathrm{U}\end{array}$ & $\begin{array}{l}2.48 \\
0.82 \mathrm{U}\end{array}$ & $\begin{array}{l}0.99 \mathrm{U} \\
0.01 \mathrm{~J}\end{array}$ & $\begin{array}{l}3.1 \\
0.0\end{array}$ \\
\hline
\end{tabular}

(a) Sum of 4,4'-DDT, 4,4'-DDE, and 4,4'-DDD. Undetected analytes are assigned a value of 0.

(b) J Analyte detected below method detection limit but above instrument detection limit.

(c) $U$ Analyte undetected above given concentration; some detection limits are elevated because of sample dilutions of $1: 10$ to $1: 5000$. 
TABLE 3.16. PAH, PCB, Oil and Grease, and TPH in Sediment Composites

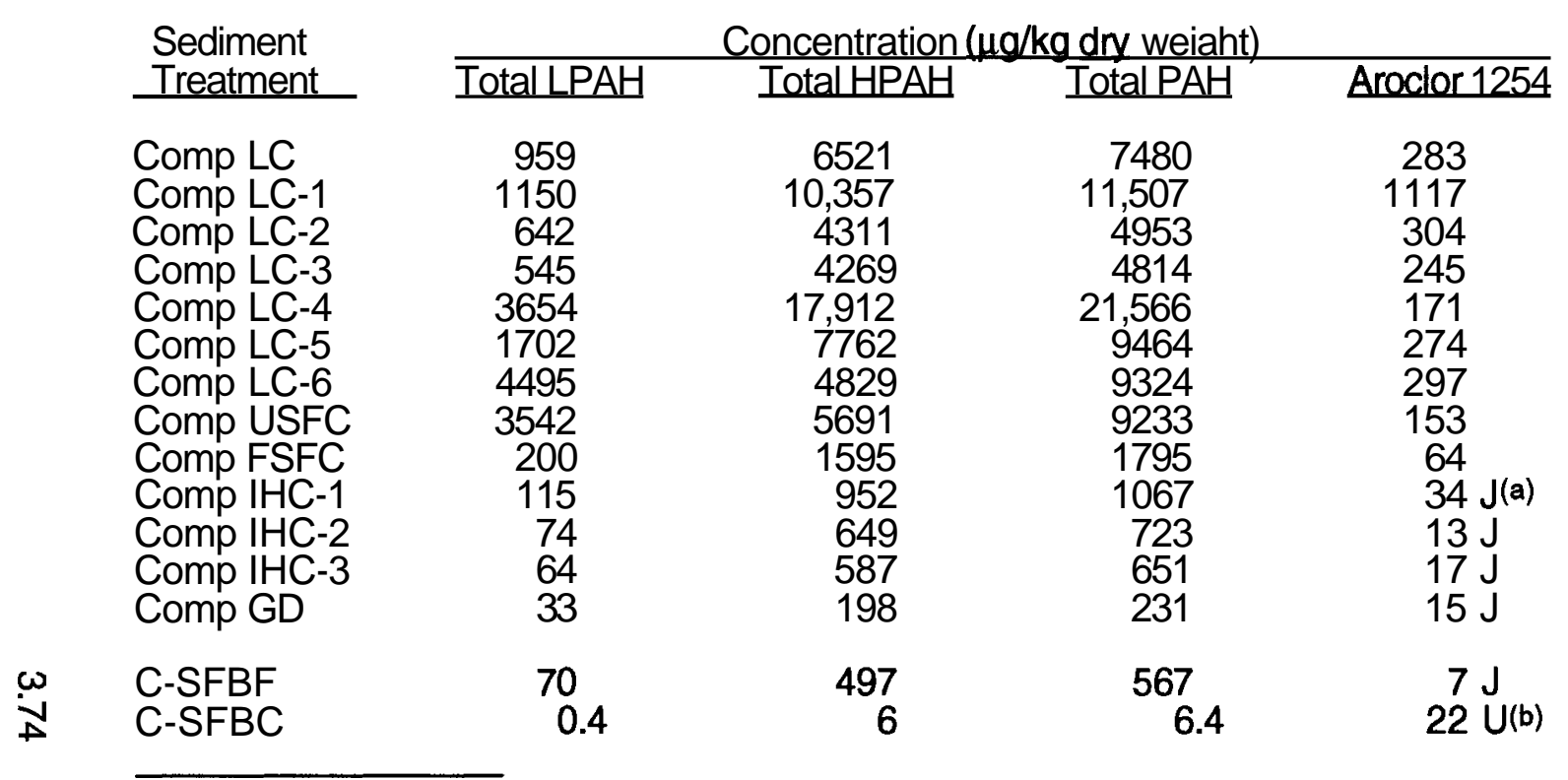

\begin{tabular}{cr}
\multicolumn{2}{c}{ Concentration (mg/kg dry weiaht) } \\
Oil and Grease & TPH \\
1000 & 840 \\
4310 & 3960 \\
2600 & 2300 \\
1340 & 1080 \\
630 & 480 \\
1200 & 1000 \\
2200 & 2000 \\
910 & 660 \\
450 & 330 \\
390 & 290 \\
380 & 180 \\
290 & 190 \\
480 & 290 \\
260 & \\
110 & 160 \\
& 69
\end{tabular}

(a) $\mathrm{J}$ Analyte detected below method detection limit but above instrument detection limit.

(b) U Analyte undetected above given concentration. 
TABLE 3.17. Metals and Butyltins in Sediment Composites

\begin{tabular}{|c|c|c|c|c|c|c|c|c|c|c|c|c|}
\hline Sediment & & & & letal Co & entratic & ng/kgd & veight & & & & Butvltins (ug & Iry weight \\
\hline Treatment & $\mathrm{Ag}$ & $A S$ & Cd & $\mathrm{Cr}$ & $\mathrm{Cu}$ & $\mathrm{Hg}$ & $\underline{\mathrm{Ni}}$ & $\mathrm{Pb}$ & Se & $\mathrm{Zn}$ & Iributvltin & Dibutvltir \\
\hline Comp LC & 0.42 & $4.6 \mathrm{U}(\mathrm{a})$ & 0.94 & 273 & 97 & 1.12 & 93 & 314 & 0.50 & 238 & 33.7 & 28.1 \\
\hline Comp LC-1 & 0.67 & 16.1 & 2.06 & 285 & 202 & 1.27 & 106 & 225 & 0.75 & 517 & 83.6 & 85.6 \\
\hline Comp LC-2 & 0.75 & 19.1 & 1.37 & 273 & 171 & 0.98 & 103 & 152 & 0.55 & 444 & 60.7 & 56.9 \\
\hline Comp LC-3 & 0.40 & 14.4 & 0.90 & 242 & 119 & 0.69 & 92 & 119 & 0.41 & 313 & 30.3 & 31.4 \\
\hline Comp LC-4 & 0.37 & 14.4 & 0.55 & 248 & 118 & 0.59 & 100 & 54 & 0.45 & 201 & $209.6 \mathrm{D}(\mathrm{b})$ & 55.9 C \\
\hline Comp LC-5 & 0.60 & 19.7 & 1.25 & 326 & 214 & 0.83 & 92 & 92 & 0.65 & 244 & 14.9 & 13.0 \\
\hline Comp LC-6 & 0.95 & 12.1 & 1.54 & 1540 & 100 & 1.37 & 101 & 372 & 0.51 & 369 & $6.0 \mathrm{~J}(\mathrm{c})$ & 5.3 \\
\hline Comp USFC & 0.66 & 9.3 & 1.02 & 143 & 92 & 1.48 & 81 & 66 & 0.45 & 213 & 39.3 & 37.4 \\
\hline Comp FSFC & 0.44 & 15.9 & 0.65 & 221 & 91 & 0.52 & 113 & 53 & 0.35 & 199 & 18.0 & 12.3 \\
\hline Comp IHC-1 & 0.43 & 15.7 & 0.42 & 200 & 85 & 0.54 & 114 & 46 & 0.40 & 194 & 13.3 & 7.6 \\
\hline Comp IHC-2 & 0.36 & 17.0 & 0.29 & 209 & 76 & 0.48 & 130 & 43 & 0.40 & 187 & 8.7 & $4.0 \mathrm{~J}$ \\
\hline Comp IHC-3 & 0.37 & 16.8 & 0.36 & 203 & 67 & 0.46 & 115 & 42 & 0.26 & 171 & $7.3 \mathrm{~J}$ & $3.7 \mathrm{~J}$ \\
\hline Comp GD & 0.36 & 13.9 & 0.21 & 192 & 71 & 0.44 & 106 & 36 & 0.31 & 172 & 16.6 & 5.7 \\
\hline $\begin{array}{l}\text { C-SFBF } \\
\text { C-SFBC }\end{array}$ & 0.20 & 13.7 & 0.25 & 191 & 36 & 0.25 & 90 & 20 & 0.26 & 108 & $5.9 \mathrm{~J}$ & $\begin{array}{c}19.6 \\
501\end{array}$ \\
\hline C-SFBC & 0.05 & 9.8 & 0.10 & 383 & 11 & 0.03 & 84 & 11 & 0.11 & 77 & $2.7 \mathrm{~J}$ & \\
\hline
\end{tabular}

(a) U Analyte undetected above given concentration.

(b) D Sample diluted 1:2.

(c) J Analyted detected below the method detection limit but above the instrument detection limit. 
TABLE 3.18. Results of the 10-day Rhepoxynius abronius Test

\begin{tabular}{|c|c|c|c|}
\hline $\begin{array}{l}\text { Sediment } \\
\text { Treatment }\end{array}$ & $\begin{array}{c}\text { Mean } \\
\text { Proportion } \\
\text { Survival } \\
\end{array}$ & $\begin{array}{l}\text { Standard } \\
\text { Deviation }\end{array}$ & $\begin{array}{l}\text { Statistical } \\
\text { Grouping(a) }\end{array}$ \\
\hline $\begin{array}{l}\text { Comp LC-1 } \\
\text { Comp LC-2 } \\
\text { Comp LC-3 } \\
\text { Comp LC-5 } \\
\text { Comp LC-4 } \\
\text { Comp FSFC } \\
\text { Comp IHC-3 } \\
\text { Comp USFC } \\
\text { Comp IHC-1 } \\
\text { Comp IHC-2 } \\
\text { Comp GD } \\
\text { C-SFBF } \\
\text { C-SFBC }\end{array}$ & $\begin{array}{l}0.00 \\
0.00 \\
0.00 \\
0.00 \\
0.74 \\
0.74 \\
0.85 \\
0.88 \\
0.89 \\
0.89 \\
0.92 \\
0.92 \\
1.00\end{array}$ & $\begin{array}{l}0.00 \\
0.00 \\
0.00 \\
0.00 \\
0.11 \\
0.26 \\
0.09 \\
0.08 \\
0.11 \\
0.05 \\
0.08 \\
0.06 \\
0.00\end{array}$ & $\begin{array}{l}A \\
A \\
A \\
A \\
B \\
B \\
B \\
B C \\
B C \\
B C \\
B C \\
B C \\
C\end{array}$ \\
\hline $\begin{array}{l}\text { C-WB } \\
\text { C-WB Rerun }\end{array}$ & $\begin{array}{l}0.96 \\
0.99\end{array}$ & $\begin{array}{l}0.09 \\
0.02\end{array}$ & $\begin{array}{l}\text { NA(b) } \\
\text { NA }\end{array}$ \\
\hline
\end{tabular}

(a) Derived from Tukey's HSD Test, $\mathrm{a}=0.05$.

(b) NA Not applicable; treatment not included in statistical analysis.

TABLE 3.19. ANOVA Data for 10-day Rhepoxynius abroniusTest

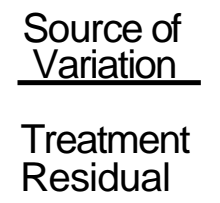

$\begin{array}{cc}\begin{array}{c}\text { Sum of } \\ \text { Sauares }\end{array} & \text { d.f.(a) } \\ 22.845 & 12 \\ 1.219 & 52\end{array}$

$\begin{gathered}\text { Mean } \\ \text { Sauares }\end{gathered}$
1.904
0.023

F-ratio
81.230
NA(b)

$\frac{\begin{array}{c}\text { Significance } \\ \text { Level }\end{array}}{\begin{array}{c}0.0001 \\ \text { NA }\end{array}}$

(a) Degrees of freedom.

(b) NA Not applicable. 
TABLE 3.20. Lipids, Dieldrin, and DDT Compounds in Tissues of Macoma nasuta

\begin{tabular}{|c|c|c|c|c|c|c|c|c|}
\hline \multirow{3}{*}{$\begin{array}{l}\text { Sediment } \\
\text { Ireatment }\end{array}$} & \multirow[b]{3}{*}{ Beplicate } & \multicolumn{2}{|c|}{ Lipids (percent drv weight) } & \multirow{2}{*}{\multicolumn{5}{|c|}{ Pesticide Concentration (uakka dw weight) }} \\
\hline & & & Bligh-Dyer & & & & & \\
\hline & & Measured & Equivalent & Dieldrin & 4.4'-DDE & 4.4'-DDD & 4'-DDT- & TotalDDT(a) \\
\hline Comp LC & 1 & 3.11 & 1.43 & 1895.18 & 1543.08 & 29898.65 & 2727.61 & 34169.3 \\
\hline Comp LC & 2 & 5.05 & 2.32 & 1504.59 & 1894.71 & 32894.79 & 2478.44 & 37267.9 \\
\hline Comp LC & 3 & 6.81 & 3.13 & 3054.35 & 2396.20 & 46507.78 & 2778.19 & 51682.2 \\
\hline Comp LC & 4 & 8.53 & 3.92 & 2353.21 & 2761.38 & 12632.04 & 2436.72 & 17830.1 \\
\hline Comp LC & 5 & 3.91 & 1.80 & 1518.68 & 1784.88 & 31119.74 & 2219.08 & 35123.7 \\
\hline Comp USFC & 1 & 5.11 & 2.35 & 36.08 & 96.92 & 662.04 & 9.43 & 768.4 \\
\hline Comp USFC & 2 & 3.79 & 1.74 & 32.07 & 102.22 & 654.49 & 6.95 & 763.7 \\
\hline Comp USFC & 3 & 5.64 & 2.59 & 40.55 & 114.84 & 694.56 & 8.54 & 817.9 \\
\hline Comp USFC & 4 & 4.48 & 2.06 & 31.84 & 87.63 & 583.51 & 9.21 & 680.4 \\
\hline Comp USFC & 5 & 4.15 & 1.91 & 27.71 & 79.63 & 510.09 & 11.01 & 600.7 \\
\hline Comp FSFC & 1 & 10.94 & 5.03 & 51.28 & 288.66 & 752.40 & 2.04 & 1043.1 \\
\hline Comp FSFC & 2 & 10.89 & 5.00 & 37.42 & 246.82 & 576.64 & 5.79 & 829.3 \\
\hline Comp FSFC & 3 & 5.07 & 2.33 & 27.68 & 220.62 & 589.83 & 3.48 & 813.9 \\
\hline Comp FSFC & 4 & 7.33 & 3.37 & 43.19 & 193.73 & 479.14 & 4.80 & 677.7 \\
\hline Comp FSFC & 5 & 4.38 & 2.01 & 21.28 & 112.97 & 147.49 & $1.28 \mathrm{~J}(\mathrm{~b})$ & 261.7 \\
\hline Comp IHC-1 & 1 & 15.51 & 7.13 & 6.95 & 26.31 & 121.83 & 2.13 & 150.3 \\
\hline Comp IHC-1 & 2 & 4.48 & 2.06 & 9.32 & 31.67 & 140.71 & 9.67 & 182.1 \\
\hline Comp IHC-1 & 3 & 3.97 & 1.82 & 10.68 & 26.54 & 141.25 & 3.98 & 171.8 \\
\hline Comp IHC-1 & 4 & 7.30 & 3.36 & 12.67 & 30.78 & 168.45 & $0.95 \mathrm{~J}$ & 200.2 \\
\hline Comp IHC-1 & 5 & 4.32 & 1.99 & 11.87 & 31.24 & 204.23 & 4.09 & 239.6 \\
\hline Comp GD & 1 & 4.86 & 2.23 & 3.28 & 6.47 & 64.66 & 4.40 & 75.5 \\
\hline Comp GD & 2 & 4.37 & 2.01 & 1.75 & 4.52 & 14.21 & $0.83 \mathrm{~J}$ & 19.6 \\
\hline Comp GD & 3 & 10.93 & 5.02 & 1.94 & 4.55 & 21.59 & 1.69 & 27.8 \\
\hline Comp GD & 4 & 4.95 & 2.27 & 1.70 & 4.85 & 33.12 & 1.70 & 39.7 \\
\hline Comp GD & 5 & 4.46 & 2.05 & 1.66 & 4.34 & 12.81 & $0.43 \mathrm{~J}$ & 17.6 \\
\hline
\end{tabular}

(a) Sum of 4,4'-DDT, 4,4'-DDE, and 4,4'-DDD.

(b) J Analyte detected below method detection limit but above instrument detection limit. 


\section{TABLE 3.21. Detected Pesticides Other Than Dieldrin and DDT Compounds in Tissues of Macoma nasuta}

\begin{tabular}{|c|c|c|c|c|c|c|}
\hline \multirow[b]{2}{*}{$\begin{array}{l}\text { Sediment } \\
\text { Treatment }\end{array}$} & \multirow[b]{2}{*}{ Beplicate } & \multicolumn{5}{|c|}{ esticide Concentration ( $(\mu \mathrm{g} / \mathrm{kg}$ dry wejoht) } \\
\hline & & Exdrin & Aldrin & $\begin{array}{c}\text { trans- } \\
\text { chlordane }\end{array}$ & $\begin{array}{c}\text { cis- } \\
\text { chlordane }\end{array}$ & Endosulfan \\
\hline Comp LC & 1 & $0.34 \mathrm{U}(\mathrm{a})$ & 7.66 & 1091.57 & 49.88 & 55.76 \\
\hline Comp LC & 2 & 13.39 & 4.20 & 114.01 & 51.67 & 67.08 \\
\hline Comp LC & 3 & $0.51 U$ & 11.07 & 2117.50 & 76.50 & 77.18 \\
\hline Comp LC & 4 & 12.77 & 4.04 & 114.51 & 63.44 & 62.01 \\
\hline Comp LC & 5 & 11.16 & 5.21 & 98.28 & 46.80 & 59.08 \\
\hline Comp USFC & 1 & $0.86 U$ & $0.69 \mathrm{U}$ & 2.57 & 2.14 & 2.57 \\
\hline Comp USFC & 2 & $0.65 U$ & $0.56 U$ & 2.04 & 1.11 & 1.85 \\
\hline Comp USFC & 3 & $0.60 \mathrm{U}$ & $0.52 \mathrm{U}$ & 2.85 & 1.81 & 2.59 \\
\hline Comp USFC & 4 & $0.61 \mathrm{U}$ & $0.53 U$ & $1.49 \mathrm{U}$ & 1.23 & 1.58 \\
\hline Comp USFC & 5 & $0.73 \mathrm{U}$ & $0.55 U$ & $1.65 \mathrm{~J}(\mathrm{~b})$ & 1.28 & 1.83 \\
\hline Comp FSFC & 1 & $0.82 U$ & $0.61 \mathrm{U}$ & 5.72 & 3.06 & 5.21 \\
\hline Comp FSFC & 2 & $0.66 U$ & $0.57 U$ & 3.13 & 2.37 & 3.80 \\
\hline Comp FSFC & 3 & $0.92 U$ & $0.73 \mathrm{U}$ & $2.29 \mathrm{U}$ & $1.37 U$ & $2.29 U$ \\
\hline Comp FSFC & 4 & $1.37 \mathrm{U}$ & $1.08 \mathrm{U}$ & 5.00 & 2.15 & $2.55 \mathrm{~J}$ \\
\hline Comp FSFC & 5 & $0.64 \mathrm{U}$ & $0.46 \mathrm{U}$ & $1.55 \mathrm{U}$ & $0.91 U$ & $1.55 U$ \\
\hline Comp IHC-1 & 1 & $0.40 \mathrm{U}$ & $0.29 U$ & 0.98 & 0.69 & $0.52 \mathrm{~J}$ \\
\hline Comp IHC-1 & 2 & $0.49 \mathrm{U}$ & $0.42 \mathrm{U}$ & 1.54 & 1.12 & $0.63 \mathrm{~J}$ \\
\hline Comp IHC-1 & 3 & $0.36 \mathrm{U}$ & $0.30 \mathrm{U}$ & $0.66 \mathrm{~J}$ & 0.66 & $0.48 \mathrm{~J}$ \\
\hline Comp IHC-1 & 4 & $0.60 \mathrm{U}$ & $0.52 \mathrm{U}$ & $1.47 \mathrm{U}$ & 1.29 & $1.29 \mathrm{~J}$ \\
\hline Comp IHC-1 & 5 & $0.48 U$ & $0.34 \mathrm{U}$ & 1.91 & 1.36 & $0.68 \mathrm{~J}$ \\
\hline Comp GD & 1 & $0.60 \mathrm{U}$ & $0.52 \mathrm{U}$ & $0.52 \mathrm{~J}$ & $0.52 \mathrm{~J}$ & $0.09 \mathrm{~J}$ \\
\hline Comp GD & 2 & $0.65 U$ & $0.55 U$ & $1.57 \mathrm{U}$ & $0.65 \mathrm{~J}$ & $0.74 \mathrm{~J}$ \\
\hline Comp GD & 3 & $0.67 \mathrm{U}$ & $0.51 U$ & $0.51 \mathrm{~J}$ & $0.51 \mathrm{~J}$ & $0.08 \mathrm{~J}$ \\
\hline Comp GD & 4 & $0.57 U$ & $0.40 \mathrm{U}$ & $0.48 \mathrm{~J}$ & $0.32 \mathrm{~J}$ & $1.29 \mathrm{U}$ \\
\hline Comp GD & 5 & $0.51 U$ & $0.36 U$ & $1.16 \mathrm{U}$ & $0.58 \mathrm{~J}$ & $1.16 \mathrm{U}$ \\
\hline
\end{tabular}

(a) U Analyte undetected above given concentration.

(b) J Analyte detected below method detection limit but above instrument detection limit. 
TABLE 3.22. PAH and PCB in Tissues of Macoma nasuta

\begin{tabular}{|c|c|c|c|c|c|c|}
\hline \multirow[b]{2}{*}{$\begin{array}{l}\text { Sediment } \\
\text { Treatment }\end{array}$} & \multicolumn{2}{|c|}{$\begin{array}{l}\text { Total Lipids } \\
\text { (percent drv weight) }\end{array}$} & \multicolumn{4}{|c|}{ Concentration ( $\mu \mathrm{g} / \mathrm{kg}$ dry weiaht) } \\
\hline & Measured & $\begin{array}{l}\text { Bligh-Dyer } \\
\text { Equivalent }\end{array}$ & $\begin{array}{l}\text { Total } \\
\text { LPAH }\end{array}$ & $\begin{array}{l}\text { Total } \\
\text { HPAH } \\
\end{array}$ & $\begin{array}{l}\text { Total } \\
\text { PAH } \\
\end{array}$ & $\begin{array}{c}\text { Aroclor } \\
1254 \\
\end{array}$ \\
\hline $\begin{array}{l}\text { Comp LC } \\
\text { Comp USFC } \\
\text { Comp FSFC } \\
\text { Comp IHC-1 } \\
\text { Comp GD }\end{array}$ & $\begin{array}{l}5.25 \\
5.22 \\
7.57 \\
7.46 \\
9.11\end{array}$ & $\begin{array}{l}2.41 \\
2.40 \\
3.48 \\
3.43 \\
4.18\end{array}$ & $\begin{array}{r}63.9 \\
1094.4 \\
149.1 \\
23.9 \\
155.0\end{array}$ & $\begin{array}{r}5367.9 \\
4476.9 \\
1667.2 \\
550.9 \\
873.1\end{array}$ & $\begin{array}{r}5432 \\
5571 \\
1816 \\
575 \\
1028\end{array}$ & $\begin{array}{r}307.9 \\
181.4 \\
178.8 \\
90.7 \\
55.0\end{array}$ \\
\hline
\end{tabular}


TABLE 3.23. Metals and Butyltins in Tissues of Macoma nasuta

\begin{tabular}{|c|c|c|c|c|c|c|c|c|c|c|c|c|}
\hline \multirow{2}{*}{$\begin{array}{l}\text { Sediment } \\
\text { Treatment }\end{array}$} & \multicolumn{10}{|c|}{ Metal Concentration (mg/kg drw weight) } & \multicolumn{2}{|c|}{ Butyltins ( $\mu \mathrm{g} / \mathrm{kg} \mathrm{dr} v$ weight) } \\
\hline & $\mathrm{Ag}$ & As & cd & $\mathrm{Cr}$ & $\mathrm{Cu}$ & $\mathrm{Hg}$ & $\mathrm{Ni}$ & $\mathrm{Pb}$ & $\mathrm{Se}$ & $\mathrm{Zn}$ & Tributvltin & Dibutvltin \\
\hline Comp LC & 0.63 & 28.1 & 0.40 & 1.69 & 24.6 & 0.131 & 3.7 & 2.82 & 1.84 & 103 & 41.8 & 26.0 \\
\hline Comp USFC & 0.66 & 30.3 & 0.29 & 2.06 & 24.1 & 0.136 & 5.1 & 2.35 & 1.85 & 98.5 & 43.9 & 26.8 \\
\hline Comp FSFC & 0.59 & 25.5 & 0.39 & 2.20 & 21.8 & 0.131 & 3.1 & 1.88 & 1.80 & 125 & 39.2 & 60.4 \\
\hline Comp IHC-1 & 0.50 & 32.7 & 0.45 & 2.67 & 20.4 & 0.138 & 4.9 & 2.47 & 1.48 & 96.8 & 19.7 & 26.9 \\
\hline Comp GD & 0.47 & 28.2 & 0.33 & 2.85 & 18.9 & 0.138 & 4.1 & 1.66 & 2.06 & 122 & 47.2 & 26.8 \\
\hline
\end{tabular}




\section{TABLE 3.24. Accumulation Factors for DDT Compounds, Dieldrin, Aroclor 1254, and PAHs in}

Macoma nasuta Tissue

\begin{tabular}{|c|c|c|c|c|c|c|c|c|c|}
\hline \multirow[b]{2}{*}{ Treatment } & \multicolumn{9}{|c|}{ Accumulation Factor (g OC/glipid)(a) } \\
\hline & $\begin{array}{l}\text { Total } \\
\text { DDT (b) } \\
\end{array}$ & 4.4'-DDT & 4.4'-DDD & 4.4'-DDE & Dieldrin & Arocior 1254 & $\begin{array}{l}\text { Total } \\
\text { PAH } \\
\end{array}$ & $\underline{\mathrm{LPAH}}$ & $\underline{\mathrm{HPAH}}$ \\
\hline Comp LC & 0.515 & 0.061 & 1.168 & 3.546 & $3.39(c)$ & 0.857 & 0.572 & 0.052 & 0.649 \\
\hline Comp USFC & 0.900 & 0.051 & 1.284 & 0.665 & 1.46 & 0.707 & 0.360 & 0.184 & 0.469 \\
\hline Comp FSFC & 0.630 & 0.006 & 0.962 & 2.485 & 1.36 & 0.996 & 0.361 & 0.266 & 0.373 \\
\hline Comp IHC-1 & 16.68 & 0.873 & 27.19 & 36.12 & $23.8(c)$ & 4.077 & 0.824 & 0.318 & 0.885 \\
\hline Comp GD & 15.59 & 0.567 & 13.07 & 1.656 & $2.98(c)$ & 1.585 & 1.925 & 2.032 & 1.908 \\
\hline
\end{tabular}

(a) Factors for DDT compounds and dieldrin calculated using mean tissue contaminant concentration and mean lipid content of five replicates.

(b) Sum of 4,4'-DDT, 4,4'-DDD, and 4,4'-DDE.

(c) Sediment concentration was below method detection limit but above instrument detection limit. 
TABLE 3.25. Dieldrin and DDT Compounds in Liquid-Phase Samples

Liquid Phase

Treatment

Site Water

Procedural Blank

Comp LC SPP

Comp LC Elutriate

Comp LC-5 SPP

Comp LC-5 Elutriate

Comp LC-5 Elutriate UF(d)

Comp LC-5 Elutriate $F(f)$

Comp LC-6 SPP

Comp LC-6 Elutriate

Comp USFC SPP

Comp USFC Elutriate

Comp FSFC SPP

Cornp FSFC Elutriate

Comp IHC-1 SPP

Comp IHC-1 Elutriate

Comp IHC-2 SPP

Comp IHC-2 Elutriate

Comp IHC-3 SPP

Comp IHC-3 Elutriate TSS (mo/L)

Die

14
8
41
8

$\begin{array}{rr}57 & 4,653 \\ 20 & 3,332 \\ \text { NM(e) } & 2,966 \\ \text { NM } & 2,159 \\ & \\ 59 & 5,351 \\ 36 & 9,636\end{array}$

$0.42 \mathrm{~J}(\mathrm{~b})$

$7.15 \mathrm{~J}$ Pesticide Concentration (nol)
$4.4^{\prime}$-DDT

4.4'-DDT

$4.4^{\prime}-\mathrm{DDE}$

Total DDT(a)

62

8

$8.31 \mathrm{JB}(\mathrm{g})$

$22.89 \mathrm{~B}$

$0.76 \mathrm{~J}$
$6.33 \mathrm{~J}$

$2.74 \mathrm{~J}$

$8.09 U(c)$

3.5

$448 \quad 701$

546

701
310

249

$5.20 \mathrm{~J}$

260

42

2

$11.28 \mathrm{JB}$

$5.43 \mathrm{JB}$

2,228

9,542

611

522

10,854

2,070

2,902

1,419

78,634

7,578

54,427

4,495

3,529

941

42,986

2,811

88,441

60,341

47,603

36,607

$2,764 \quad 117,169 \quad 4,964$

$6,801 \quad 283,065 \quad 10,615$

124,897

300,481

$\begin{array}{rrrrr}4.75 \mathrm{JB} & 101.44 \mathrm{~B} & 41.35 & 147.5 \mathrm{~B} \\ 18.45 \mathrm{~B} & 882.17 \mathrm{~B} & 29.93 & 930.6 \mathrm{~B} \\ & & & & \\ 9.33 \mathrm{JB} & 203.86 \mathrm{~B} & 37.52 & 250.7 \mathrm{~B} \\ 1.53 \mathrm{JB} & 41.18 \mathrm{~B} & 4.09 \mathrm{JB} & 46.8 \mathrm{~B} \\ & & & & \\ 1.12 \mathrm{JB} & 22.07 \mathrm{~B} & 3.24 \mathrm{JB} & 26.4 \mathrm{~B} \\ 0.45 \mathrm{JB} & 17.00 \mathrm{JB} & 0.69 \mathrm{JB} & 18.1 \mathrm{~B} \\ & & & & \\ 3.49 \mathrm{JB} & 61.11 \mathrm{~B} & 2.62 \mathrm{JB} & 67.2 \mathrm{~B} \\ 125.89 & 663.67 \mathrm{~B} & 20.29 \mathrm{~B} & 809.9 \mathrm{~B} \\ & & & & \\ 1.05 \mathrm{JB} & 15.02 \mathrm{~B} & 0.85 \mathrm{JB} & 16.9 \mathrm{~B} \\ 1.03 \mathrm{JB} & 18.94 \mathrm{~B} & 0.75 \mathrm{JB} & 20.7 \mathrm{~B}\end{array}$

(a) Sum of 4,4'-DDT, 4,4'-DDE, and 4,4'-DDD; undetected analytes assigned value of zero.

(b) J Analyte detected below method detection limit (MDL), but above instrument detection limit (IDL).

(c) U Analyte undetected above given concentration.

(d) UF Unfiltered elutriate.

(e) NM Not measured.

(f) F Granular-activated-carbon-filteredelutriate.

(g) B Sample result less than five times the concentration in the procedural blank. 
TABLE 3.26. Chlorinated Pesticides Other Than Dieldrin and DDT Compounds in Liquid-Phase Samples

\begin{tabular}{|c|c|c|c|c|c|c|}
\hline \multirow[b]{2}{*}{$\begin{array}{l}\text { Liquid Phase } \\
\text { Treatment }\end{array}$} & \multicolumn{6}{|c|}{ Pesticide Concentration (ngl) } \\
\hline & $\begin{array}{l}\text { Alpha } \\
\text { BHC }\end{array}$ & $\begin{array}{l}\text { Beta } \\
\text { BHC }\end{array}$ & Endrin & $\begin{array}{c}\text { trans- } \\
\text { Chlordane } \\
\end{array}$ & $\begin{array}{c}\text { cis- } \\
\text { Chlordane }\end{array}$ & $\begin{array}{l}\text { Endosulfan } \\
\text { Sulfate } \\
\end{array}$ \\
\hline $\begin{array}{l}\text { Site Water } \\
\text { Procedural Blank }\end{array}$ & $\begin{array}{l}5.12 \mathrm{U}(\mathrm{a}) \\
5.12 \mathrm{U}\end{array}$ & $\begin{array}{l}4.57 \mathrm{U} \\
4.57 \mathrm{U}\end{array}$ & $\begin{array}{l}9.31 \mathrm{U} \\
9.31 \mathrm{U}\end{array}$ & $\begin{array}{l}6.33 \mathrm{U} \\
0.76 \mathrm{~J}(\mathrm{~b})\end{array}$ & $\begin{array}{l}9.18 \mathrm{U} \\
0.16 \mathrm{~J}\end{array}$ & $\begin{array}{l}8.19 U \\
8.19 U\end{array}$ \\
\hline $\begin{array}{l}\text { Comp LC SPP } \\
\text { Comp LC Elutriate }\end{array}$ & $\begin{array}{l}158.71 \\
171.02\end{array}$ & $\begin{array}{r}6.39 \\
10.16\end{array}$ & $\begin{array}{l}15.53 \\
9.31 \mathrm{U}\end{array}$ & $\begin{array}{r}182.04 \\
40.79\end{array}$ & $\begin{array}{l}46.96 \\
10.03\end{array}$ & $\begin{array}{l}8.19 U \\
8.19 U\end{array}$ \\
\hline $\begin{array}{l}\text { Comp LC-5 SPP } \\
\text { Comp LC-5 Elutriate } \\
\text { Comp LC-5 Elutriate UF(c) } \\
\text { Comp LC-5 Elutriate F(d) }\end{array}$ & $\begin{array}{l}23.39 \\
16.81 \\
5.12 \mathrm{U} \\
5.12 \mathrm{U}\end{array}$ & $\begin{array}{l}4.57 U \\
4.57 U \\
4.57 U \\
4.57 U\end{array}$ & $\begin{array}{l}9.31 U \\
9.31 U \\
9.31 U \\
9.31 U\end{array}$ & $\begin{array}{l}435.47 \\
275.20 \\
246.10 \\
6.33 \mathrm{U}\end{array}$ & $\begin{array}{r}189.15 \\
129.82 \\
70.60 \\
65.16\end{array}$ & $\begin{array}{r}58.67 \\
94.81 \\
101.90 \\
8.04 \mathrm{~J}\end{array}$ \\
\hline $\begin{array}{l}\text { Comp LC-6 SPP } \\
\text { Comp LC-6 Elutriate }\end{array}$ & $\begin{array}{l}5.12 \mathrm{U} \\
5.12 \mathrm{U}\end{array}$ & $\begin{array}{l}4.57 U \\
4.57 U\end{array}$ & $\begin{array}{l}9.31 U \\
9.31 U\end{array}$ & $\begin{array}{l}1114.35 \\
1240.78\end{array}$ & $\begin{array}{l}710.01 \\
400.06\end{array}$ & $\begin{array}{l}8.19 \mathrm{U} \\
8.19 \mathrm{U}\end{array}$ \\
\hline $\begin{array}{l}\text { Comp USFC SPP } \\
\text { Comp USFC Elutriate }\end{array}$ & $\begin{array}{l}5.12 \mathrm{U} \\
5.12 \mathrm{U}\end{array}$ & $\begin{array}{l}4.57 \mathrm{U} \\
4.57 \mathrm{U}\end{array}$ & $\begin{array}{l}9.31 \mathrm{U} \\
9.31 \mathrm{U}\end{array}$ & $\begin{array}{l}3.19 \mathrm{JB}(\theta) \\
2.78 \mathrm{JB}\end{array}$ & $\begin{array}{l}9.18 \mathrm{U} \\
0.77 \mathrm{JB}\end{array}$ & $\begin{array}{l}8.19 \mathrm{U} \\
8.19 \mathrm{U}\end{array}$ \\
\hline $\begin{array}{l}\text { Comp FSFC SPP } \\
\text { Comp FSFC Elutriate }\end{array}$ & $\begin{array}{l}6.40 \cup \\
5.12 \cup\end{array}$ & $\begin{array}{l}5.71 \mathrm{U} \\
4.57 \mathrm{U}\end{array}$ & $\begin{array}{r}11.64 \mathrm{U} \\
9.31 \mathrm{U}\end{array}$ & $\begin{array}{l}7.91 \mathrm{U} \\
6.33 \mathrm{U}\end{array}$ & $\begin{array}{r}11.48 \mathrm{U} \\
9.18 \mathrm{U}\end{array}$ & $\begin{array}{r}10.24 U \\
8.19 U\end{array}$ \\
\hline $\begin{array}{l}\text { Comp IHC-1 SPP } \\
\text { Comp IHC-1 Elutriate }\end{array}$ & $\begin{array}{l}5.12 \mathrm{U} \\
5.12 \mathrm{U}\end{array}$ & $\begin{array}{l}4.57 U \\
4.57 U\end{array}$ & $\begin{array}{l}9.31 \mathrm{U} \\
9.31 \mathrm{U}\end{array}$ & $\begin{array}{l}0.54 \mathrm{JB} \\
6.33 \mathrm{U}\end{array}$ & $\begin{array}{l}9.18 \mathrm{U} \\
9.18 \mathrm{U}\end{array}$ & $\begin{array}{l}8.19 \mathrm{U} \\
8.19 \mathrm{U}\end{array}$ \\
\hline $\begin{array}{l}\text { Comp IHC-2 SPP } \\
\text { Comp IHC-2 Elutriite }\end{array}$ & $\begin{array}{l}5.12 \mathrm{U} \\
5.12 \mathrm{U}\end{array}$ & $\begin{array}{l}4.57 \mathrm{U} \\
4.57 \mathrm{U}\end{array}$ & $\begin{array}{l}9.31 \mathrm{U} \\
9.31 \mathrm{U}\end{array}$ & $\begin{array}{l}6.33 \mathrm{U} \\
6.33 \mathrm{U}\end{array}$ & $\begin{array}{l}9.18 \mathrm{U} \\
9.18 \mathrm{U}\end{array}$ & $\begin{array}{l}8.19 \mathrm{U} \\
8.19 \mathrm{U}\end{array}$ \\
\hline $\begin{array}{l}\text { Comp IHC-3 SPP } \\
\text { Comp IHC-3 Elutriate }\end{array}$ & $\begin{array}{l}5.12 \cup \\
5.12 \cup\end{array}$ & $\begin{array}{l}4.57 U \\
4.57 U\end{array}$ & $\begin{array}{l}9.31 \mathrm{U} \\
9.31 \mathrm{U}\end{array}$ & $\begin{array}{l}6.33 U \\
6.33 U\end{array}$ & $\begin{array}{l}9.18 \mathrm{U} \\
9.18 \mathrm{U}\end{array}$ & $\begin{array}{l}8.19 U \\
8.19 U\end{array}$ \\
\hline
\end{tabular}

(a) $\cup$ Analyte was not present above the associated value.

(b) J Analyte detected below method detection limit (MDL), but above instrument detection limit (IDL).

(c) UF Unfiltered elutriate.

(d) F Granular-activated-carbon-filteredelutriate.

(e) B Sample result less than five times the concentration in the procedural blank. 
TABLE 3.27. PAH, PCB, and Tributyltin in Liquid-Phase Samples

\begin{tabular}{|c|c|c|c|c|c|}
\hline \multirow[b]{2}{*}{$\begin{array}{l}\text { Liquid Phase } \\
\text { Sample }\end{array}$} & \multicolumn{5}{|c|}{ Concentration (ngL) } \\
\hline & $\begin{array}{l}\text { Total } \\
\text { LPAH }\end{array}$ & $\begin{array}{l}\text { Total } \\
\text { HPAH }\end{array}$ & $\begin{array}{l}\text { Total } \\
\mathrm{PAH}\end{array}$ & $\begin{array}{c}\text { Aroclor } \\
1254 \\
\end{array}$ & Tributyltin \\
\hline Site Water & 25.7 & 49.9 & 76 & $25 U(a)$ & 27.2 \\
\hline ProceduralBlank & 40.8 & 119.5 & 160 & $25 U$ & 24.9 \\
\hline Comp LC SPP & 413.7 & $2,829.5$ & 3,243 & 350 & 38.8 \\
\hline Comp LC ELUT & 311.4 & 809.0 & 1,120 & $25 \mathrm{U}$ & 29.8 \\
\hline Comp LC-5 SPP & $2,516.3$ & $9,715.0$ & 12,231 & $25 \mathrm{U}$ & 40.5 \\
\hline Comp LC-5 ELUT & $2,676.9$ & $7,265.7$ & 9,943 & $25 U$ & 28.3 \\
\hline Comp LC-5 Elutriate, UF(b) & $2,503.2$ & $7,735.6$ & 10,239 & $25 U$ & $N M(c)$ \\
\hline Comp LC-5 Elutriate, F(d) & 586.9 & $4,255.4$ & 4,842 & $25 U$ & NM \\
\hline Comp LC-6 SPP & $9,371.7$ & $11,299.8$ & 20,671 & $25 U$ & $10.0 \mathrm{U}$ \\
\hline Comp LC-6 ELUT & $19,492.1$ & $21,320.3$ & 40,812 & $25 U$ & 12.2 \\
\hline Comp USFC SPP & $7,086.7$ & $3,868.6$ & 10,955 & 224 & 35.6 \\
\hline Comp USFC ELUT & 7,332.6 & $1,284.2$ & 8,617 & $25 U$ & 24.6 \\
\hline Comp FSFC SPP & $110.3 \mathrm{~B}(\theta)$ & $572.9 \mathrm{~B}$ & $683 \mathrm{~B}$ & 124 & 17.1 \\
\hline Comp FSFC ELUT & $25.0 \mathrm{~B}$ & $129.1 \mathrm{~B}$ & $154 \mathrm{~B}$ & $25 U$ & 16.9 \\
\hline Comp IHC-1 SPP & $48.7 \mathrm{~B}$ & $176.6 \mathrm{~B}$ & $225 B$ & 64 & 13.9 \\
\hline Comp IHC-1 ELUT & $19.7 \mathrm{~B}$ & $51.2 \mathrm{~B}$ & $71 \mathrm{~B}$ & $25 U$ & 26.1 \\
\hline Comp IHC-2 SPP & 26.4 B & $168.6 \mathrm{~B}$ & $195 B$ & $25 U$ & $10.0 \mathrm{U}$ \\
\hline Comp IHC-2 ELUT & $164.9 \mathrm{~B}$ & $147.6 \mathrm{~B}$ & $312 B$ & $25 U$ & 13.4 \\
\hline Comp IHC-3 SPP & $68.3 \mathrm{~B}$ & $182.0 \mathrm{~B}$ & $250 \mathrm{~B}$ & $25 U$ & 12.7 \\
\hline Comp IHC-3 ELUT & $60.5 \mathrm{~B}$ & $139.6 \mathrm{~B}$ & $200 \mathrm{~B}$ & $25 U$ & 12.5 \\
\hline
\end{tabular}

(a) U Analyte undetected above given concentration.

(b) UF Unfiltered elutriate.

(c) NM Not measured.

(d) F GAC-filtered elutriate.

(e) B Sample result less than five times the concentration in the procedural blank. 
TABLE 3.28. Metals in Liquid-Phase Samples

\begin{tabular}{|c|c|c|c|c|c|c|c|c|c|c|}
\hline Liquid Phase & & & & & al Cons & tration & & & & \\
\hline Treatment & $\mathrm{Ag}$ & As & $\mathrm{Cd}$ & $\mathrm{Cr}$ & $\mathrm{Cu}$ & Ia & $\mathrm{Ni}$ & $\mathrm{Pb}$ & $\mathrm{Se}$ & $\mathrm{Zn}$ \\
\hline $\begin{array}{l}\text { Site Water } \\
\text { Procedural Blank }\end{array}$ & $\begin{array}{l}0.02 U^{(a)} \\
0.02 U^{-1}\end{array}$ & $\begin{array}{l}1.61 \\
0.99\end{array}$ & $\begin{array}{l}0.092 \\
0.103\end{array}$ & $\begin{array}{l}2.11 \\
0.33\end{array}$ & $\begin{array}{l}3.28 \\
2.40\end{array}$ & $\begin{array}{l}0.016 \\
0.005\end{array}$ & $\begin{array}{l}4.32 \\
3.56\end{array}$ & $\begin{array}{l}3.72 \\
0.25\end{array}$ & $\begin{array}{l}2.3 U \\
2.3 U\end{array}$ & $\begin{array}{l}21.4 \\
15.2\end{array}$ \\
\hline $\begin{array}{l}\text { Comp LC SPP } \\
\text { Comp LC Elutriate }\end{array}$ & $\begin{array}{l}0.02 U \\
0.02 U\end{array}$ & $\begin{array}{l}7.48 \\
3.96\end{array}$ & $\begin{array}{l}0.072 \\
0.048\end{array}$ & $\begin{array}{l}1.31 \\
0.62\end{array}$ & $\begin{array}{l}3.60 \\
1.35\end{array}$ & $\begin{array}{l}0.036 \\
0.010\end{array}$ & $\begin{array}{l}2.67 \\
2.04\end{array}$ & $\begin{array}{l}3.45 \\
0.79\end{array}$ & $\begin{array}{l}2.3 U \\
2.3 U\end{array}$ & $\begin{array}{l}8.97 \\
3.43\end{array}$ \\
\hline $\begin{array}{l}\text { Comp LC-5 SPP } \\
\text { Comp LC-5 Elutriate }\end{array}$ & $\begin{array}{l}0.022 \\
0.02 \mathrm{U}\end{array}$ & $\begin{array}{l}16.9 \\
19.1\end{array}$ & $\begin{array}{l}0.110 \\
0.067\end{array}$ & $\begin{array}{l}3.47 \\
0.98\end{array}$ & $\begin{array}{l}5.48 \\
1.84\end{array}$ & $\begin{array}{l}0.063 \\
0.018\end{array}$ & $\begin{array}{l}4.36 \\
3.33\end{array}$ & $\begin{array}{l}4.48 \\
1.92\end{array}$ & $\begin{array}{l}2.3 U \\
2.3 U\end{array}$ & $\begin{array}{l}17.3 \\
13.2\end{array}$ \\
\hline $\begin{array}{l}\text { Comp LC-6 SPP } \\
\text { Comp LC-6 Elutriate }\end{array}$ & $\begin{array}{l}0.16 \\
0.056\end{array}$ & $\begin{array}{l}10.9 \\
14.8\end{array}$ & $\begin{array}{l}0.121 \\
0.090\end{array}$ & $\begin{array}{l}1.75 \\
1.18\end{array}$ & $\begin{array}{l}5.28 \\
2.62\end{array}$ & $\begin{array}{l}0.148 \\
0.067\end{array}$ & $\begin{array}{l}2.80 \\
2.61\end{array}$ & $\begin{array}{l}3.01 \\
2.40\end{array}$ & $\begin{array}{l}2.3 U \\
2.3 U\end{array}$ & $\begin{array}{l}9.37 \\
5.54\end{array}$ \\
\hline $\begin{array}{l}\text { Comp USFC SPP } \\
\text { Comp USFC Elutriate }\end{array}$ & $\begin{array}{l}0.02 U \\
0.02 U\end{array}$ & $\begin{array}{l}7.47 \\
4.62\end{array}$ & $\begin{array}{l}0.042 \\
0.054\end{array}$ & $\begin{array}{l}1.34 \\
0.33\end{array}$ & $\begin{array}{l}2.66 \\
0.954\end{array}$ & $\begin{array}{l}0.033 \\
0.011\end{array}$ & $\begin{array}{l}1.58 \\
1.30\end{array}$ & $\begin{array}{l}1.92 \\
0.533\end{array}$ & $\begin{array}{l}2.3 \mathrm{U} \\
3.1\end{array}$ & $\begin{array}{l}12.9 \\
2.11\end{array}$ \\
\hline $\begin{array}{l}\text { Comp FSFC SPP } \\
\text { Comp FSFC Elutriate }\end{array}$ & $\begin{array}{l}0.02 U \\
0.02 U\end{array}$ & $\begin{array}{l}4.26 \\
5.07\end{array}$ & $\begin{array}{l}0.179 \\
0.025\end{array}$ & $\begin{array}{l}1.18 \\
0.26\end{array}$ & $\begin{array}{l}2.94 \\
0.858\end{array}$ & $\begin{array}{l}0.024 \\
0.007\end{array}$ & $\begin{array}{l}2.16 \\
1.10\end{array}$ & $\begin{array}{l}1.44 \\
0.295\end{array}$ & $\begin{array}{l}2.3 U \\
2.3 U\end{array}$ & $\begin{array}{l}8.71 \\
3.96\end{array}$ \\
\hline $\begin{array}{l}\text { Comp IHC-1 SPP } \\
\text { Comp IHC-1 Elutriate }\end{array}$ & $\begin{array}{l}0.02 U \\
0.02 U\end{array}$ & $\begin{array}{l}8.17 \\
4.22\end{array}$ & $\begin{array}{l}0.035 \\
0.026\end{array}$ & $\begin{array}{l}1.08 \\
0.31\end{array}$ & $\begin{array}{l}2.52 \\
0.953\end{array}$ & $\begin{array}{l}0.021 \\
0.007\end{array}$ & $\begin{array}{l}2.36 \\
2.16\end{array}$ & $\begin{array}{l}2.11 \\
0.25\end{array}$ & $\begin{array}{l}2.3 \mathrm{U} \\
2.3 \mathrm{U}\end{array}$ & $\begin{array}{l}4.09 \\
5.28\end{array}$ \\
\hline $\begin{array}{l}\text { Comp IHC-2 SPP } \\
\text { Comp IHC-2 Elutriate }\end{array}$ & $\begin{array}{l}0.02 U \\
0.02 U\end{array}$ & $\begin{array}{l}7.99 \\
3.00\end{array}$ & $\begin{array}{l}0.02 \mathrm{U} \\
0.02 \mathrm{U}\end{array}$ & $\begin{array}{l}1.36 \\
0.08\end{array}$ & $\begin{array}{l}3.11 \\
0.757\end{array}$ & $\begin{array}{l}0.012 \\
0.004\end{array}$ & $\begin{array}{l}3.66 \\
1.41\end{array}$ & $\begin{array}{l}1.29 \\
0.162\end{array}$ & $\begin{array}{l}2.3 \mathrm{U} \\
2.3 \mathrm{U}\end{array}$ & $\begin{array}{l}4.49 \\
2.38\end{array}$ \\
\hline $\begin{array}{l}\text { Comp IHC-3 SPP } \\
\text { Comp IHC-3 Elutriate }\end{array}$ & $\begin{array}{l}0.02 U \\
0.02 U\end{array}$ & $\begin{array}{l}7.46 \\
3.33\end{array}$ & $\begin{array}{l}0.02 U \\
0.02 U\end{array}$ & $\begin{array}{l}1.03 \\
0.23\end{array}$ & $\begin{array}{l}1.99 \\
0.611\end{array}$ & $\begin{array}{l}0.015 \\
0.004\end{array}$ & $\begin{array}{l}2.97 \\
1.52\end{array}$ & $\begin{array}{l}0.915 \\
0.137\end{array}$ & $\begin{array}{l}2.3 \mathrm{U} \\
2.3 \mathrm{U}\end{array}$ & $\begin{array}{l}29.6 \\
1.45\end{array}$ \\
\hline
\end{tabular}

(a) U Analyte undetected above given concentration. 
TABLE 3.29. Results of the 96-Hour SPP Test with Holmesimysis costata

\begin{tabular}{|c|c|c|c|c|}
\hline $\begin{array}{l}\text { Sediment } \\
\text { Treatment }\end{array}$ & $\begin{array}{l}\text { Concentration } \\
\text { (Percent SPP) } \\
\end{array}$ & $\begin{array}{c}\text { Mean } \\
\text { Percent } \\
\text { Surviving } \\
\end{array}$ & $\begin{array}{c}\text { Survival in } 100 \% \text { SPP } \\
\text { Significantly Lower Than } \\
\text { Survival in 0\% SPP(a) } \\
\end{array}$ & $\begin{array}{c}96-\mathrm{h} \mathrm{LC} \\
\text { (Percent SPP) } \\
\end{array}$ \\
\hline $\begin{array}{l}\text { Comp LC } \\
\text { Comp LC } \\
\text { Comp LC } \\
\text { Comp LC }\end{array}$ & $\begin{array}{r}0 \\
10 \\
50 \\
100\end{array}$ & $\begin{array}{r}93 \\
0 \\
0 \\
0\end{array}$ & Yes $(\mathrm{t}$ calc $=28.000$ ) & $<10$ \\
\hline $\begin{array}{l}\text { Comp LC-5 } \\
\text { Comp LC-5 } \\
\text { Comp LC-5 } \\
\text { Comp LC-5 } \\
\text { Comp LC-5 } \\
\text { Comp LC-5 } \\
\text { Comp LC-5 }\end{array}$ & $\begin{array}{r}0 \\
0.01 \\
0.1 \\
1 \\
10 \\
50 \\
100\end{array}$ & $\begin{array}{r}93 \\
97 \\
83 \\
20 \\
0 \\
0 \\
0\end{array}$ & Yes (t calc=28.000) & 0.38 \\
\hline $\begin{array}{l}\text { Comp LC-6 } \\
\text { Comp LC-6 } \\
\text { Comp LC-6 } \\
\text { Comp LC-6 }\end{array}$ & $\begin{array}{r}0 \\
10 \\
50 \\
100\end{array}$ & $\begin{array}{r}90 \\
0 \\
0 \\
0\end{array}$ & Yes (t calc=2.700 E8) & $<10$ \\
\hline $\begin{array}{l}\text { Comp USFC } \\
\text { Comp USFC(b) } \\
\text { Comp USFC(b) } \\
\text { Comp USFC(b) }\end{array}$ & $\begin{array}{r}0 \\
10 \\
50 \\
100\end{array}$ & $\begin{array}{l}93 \\
67 \\
47 \\
20\end{array}$ & Yes $(\mathrm{t}$ calc $=11.000)$ & 38.8 \\
\hline $\begin{array}{l}\text { Comp FSFC } \\
\text { Comp FSFC(b) } \\
\text { Comp FSFC(b) } \\
\text { Comp FSFC(b) }\end{array}$ & $\begin{array}{r}0 \\
10 \\
50 \\
100\end{array}$ & $\begin{array}{l}97 \\
93 \\
77 \\
63\end{array}$ & Yes $(\mathrm{t}$ calc $=7.071)$ & $>100$ \\
\hline $\begin{array}{l}\text { Comp IHC-1 } \\
\text { Comp IHC-1(b) } \\
\text { Comp IHC-1(b) } \\
\text { Comp IHC-1(b) }\end{array}$ & $\begin{array}{r}0 \\
10 \\
50 \\
100\end{array}$ & $\begin{array}{l}93 \\
90 \\
80 \\
67\end{array}$ & Yes $(\mathrm{t}$ calc $=7.071)$ & $>100$ \\
\hline $\begin{array}{l}\text { Comp IHC-2 } \\
\text { Comp IHC-2(b) } \\
\text { Comp IHC-2(b) } \\
\text { Comp IHC-2(b) }\end{array}$ & $\begin{array}{r}0 \\
10 \\
50 \\
100\end{array}$ & $\begin{array}{l}93 \\
87 \\
77 \\
67\end{array}$ & Yes ( $\mathrm{t}$ calc=3.578) & $>100$ \\
\hline $\begin{array}{l}\text { Comp IHC-3 } \\
\text { Comp IHC-3(b) } \\
\text { Comp IHC-3(b) } \\
\text { Comp IHC-3(b) }\end{array}$ & $\begin{array}{r}0 \\
10 \\
50 \\
100\end{array}$ & $\begin{array}{l}93 \\
93 \\
77 \\
57\end{array}$ & Yes $(\mathrm{t}$ calc=3.889) & $>100$ \\
\hline
\end{tabular}

(a) Evaluated in 1-tailed t-test $(a=0.05$, df $=4$, critical t value $=2.132$ ).

(b) Results may be influenced by possible cross-contamination during sample preparation. 
TABLE 3.30. Results of the 96-Hour Elutriate Test with Holmesimysis costata

\begin{tabular}{|c|c|c|c|c|}
\hline $\begin{array}{l}\text { Sediment } \\
\text { Treatment } \\
\end{array}$ & $\begin{array}{c}\text { Concentration } \\
\text { (Percent Elutriate) }\end{array}$ & $\begin{array}{l}\text { Mean } \\
\text { Percent } \\
\text { Surviving } \\
\end{array}$ & $\begin{array}{l}\text { Survival in } 100 \% \text { SPP } \\
\text { Significantly Lower Than } \\
\text { Survival in 0\% Elutriate(a) }\end{array}$ & $\begin{array}{l}96-h L^{2} C_{50} \\
\text { (Percent } \\
\text { Elutriate) } \\
\end{array}$ \\
\hline $\begin{array}{l}\text { Comp LC } \\
\text { Comp LC } \\
\text { comp LC } \\
\text { comp LC }\end{array}$ & $\begin{array}{r}0 \\
10 \\
50 \\
100\end{array}$ & $\begin{array}{r}93 \\
0 \\
0 \\
0\end{array}$ & Yes $(\mathrm{t}$ calc $=14.000)$ & $<10$ \\
\hline $\begin{array}{l}\text { comp LC-5 } \\
\text { comp LC-5 } \\
\text { comp LC-5 } \\
\text { Comp LC-5 } \\
\text { Comp LC-5 } \\
\text { comp LC-5 } \\
\text { Comp LC-5 }\end{array}$ & $\begin{array}{c}0 \\
0.01 \\
0.1 \\
1 \\
10 \\
50 \\
100\end{array}$ & $\begin{array}{r}97 \\
97 \\
90 \\
43 \\
0 \\
0 \\
0\end{array}$ & Yes (t calc $=29.000)$ & 0.80 \\
\hline $\begin{array}{l}\text { Comp LC-5 Unfiltered } \\
\text { Comp LC-5 Unfiltered }\end{array}$ & $\begin{array}{r}0 \\
100\end{array}$ & $\begin{array}{r}97 \\
0\end{array}$ & Yes (t calc $=29.000$ ) & $N A(b)$ \\
\hline $\begin{array}{l}\text { Comp LC-5 Filtered } \\
\text { Comp LC-5 Filtered }\end{array}$ & $\begin{array}{r}0 \\
100\end{array}$ & $\begin{array}{r}97 \\
0\end{array}$ & Yes (t calc=29.000) & NA \\
\hline $\begin{array}{l}\text { Comp LC-6 } \\
\text { Comp LC-6 } \\
\text { Comp LC6 } \\
\text { comp LC-6 }\end{array}$ & $\begin{array}{r}0 \\
10 \\
50 \\
100\end{array}$ & $\begin{array}{r}93 \\
0 \\
0 \\
0\end{array}$ & Yes $(\mathrm{t}$ calc $=28.000)$ & $<10$ \\
\hline $\begin{array}{l}\text { USFC } \\
\text { USFC(c) } \\
\text { USFC(c) } \\
\text { USFC(c) }\end{array}$ & $\begin{array}{r}0 \\
10 \\
50 \\
100\end{array}$ & $\begin{array}{l}90 \\
67 \\
50 \\
20\end{array}$ & Yes (t calc=6.062) & 47.2 \\
\hline $\begin{array}{l}\text { FSFC } \\
\text { FSFC(c) } \\
\text { FSFC(c) } \\
\text { FSFC(c) }\end{array}$ & $\begin{array}{r}0 \\
10 \\
50 \\
100\end{array}$ & $\begin{array}{l}93 \\
93 \\
80 \\
73\end{array}$ & Yes (t calc=3.578) & $>100$ \\
\hline $\begin{array}{l}\text { Comp IHC-1 } \\
\text { Comp IHC-1(c) } \\
\text { Comp IHC-1(c) } \\
\text { Comp IHC-1(c) }\end{array}$ & $\begin{array}{r}0 \\
10 \\
50 \\
100\end{array}$ & $\begin{array}{r}100 \\
90 \\
83 \\
67\end{array}$ & Yes (t calc=10.000) & $>100$ \\
\hline $\begin{array}{l}\text { Comp IHC-2 } \\
\text { Comp IHC-2(c) } \\
\text { Comp IHC-2(c) } \\
\text { Comp IHC-2(c) }\end{array}$ & $\begin{array}{r}0 \\
10 \\
50 \\
100\end{array}$ & $\begin{array}{l}93 \\
90 \\
73 \\
63\end{array}$ & Yes (t calc=6.364) & $>100$ \\
\hline $\begin{array}{l}\text { Comp IHC-3 } \\
\text { Comp IHC-3(c) } \\
\text { Comp IHC-3(c) } \\
\text { Comp IHC-3(c) }\end{array}$ & $\begin{array}{r}0 \\
10 \\
50 \\
100\end{array}$ & $\begin{array}{l}97 \\
87 \\
77 \\
53\end{array}$ & Yes (t calc=9.192) & $>100$ \\
\hline
\end{tabular}

(a) Evaluated in 1-tailed t-test $(a=0.05$, $d f=4$, criticalt value $=2.132)$.

(b) NA Not applicable; insufficient data to estimate $\mathbf{L C}_{50}$.

(c) Results may be influenced by possible cross-contamination during sample preparation. 
TABLE 3.31. Results of the 48-Hour SPP Test with Larval Mytilus galloprovincialis

\begin{tabular}{|c|c|c|c|c|c|c|c|}
\hline $\begin{array}{l}\text { Sediment } \\
\text { Treatment } \\
\end{array}$ & $\begin{array}{l}\text { Concentration } \\
\text { [Percent SPP] }\end{array}$ & $\begin{array}{l}\text { Mean } \\
\text { Percent } \\
\text { Normal } \\
\end{array}$ & $\begin{array}{l}\text { Normal in } 100 \% \text { SPP } \\
\text { Significantly Lower Than } \\
\text { Normal in 0\% SPP(a) } \\
\end{array}$ & $\begin{array}{c}96-h E_{50} \\
\text { (Percent SPP) } \\
\end{array}$ & $\begin{array}{c}\text { Mean } \\
\text { Percent } \\
\text { Survival } \\
\end{array}$ & $\begin{array}{l}\text { Survival in } 100 \% \text { SPP } \\
\text { Significantly Lower Than } \\
\text { Survival in 0\% SPP (a) }\end{array}$ & $\begin{array}{c}96-h L^{2} C_{50} \\
\text { [Percent SPP) }\end{array}$ \\
\hline $\begin{array}{l}\text { Comp LC } \\
\text { Comp LC } \\
\text { Comp LC } \\
\text { Comp LC }\end{array}$ & $\begin{array}{r}0 \\
10 \\
50 \\
100\end{array}$ & $\begin{array}{r}94.8 \\
93.7 \\
92.4 \\
0.3\end{array}$ & Yes $(\mathrm{t}$ calc $=35.10)$ & 70.1 & $\begin{array}{l}96.1 \\
95.7 \\
93.7 \\
88.4\end{array}$ & No (t calc=1.114) & $>100$ \\
\hline $\begin{array}{l}\text { Comp LC-5 } \\
\text { Comp LC-5 } \\
\text { Comp LC-5 } \\
\text { Comp LC-5 }\end{array}$ & $\begin{array}{r}0 \\
10 \\
50 \\
100\end{array}$ & $\begin{array}{r}99.5 \\
93.8 \\
0.3 \\
0.0\end{array}$ & Yes (t calc $=149.00)$ & 21.2 & $\begin{array}{l}99.7 \\
94.6 \\
62.7 \\
81.9\end{array}$ & Yes (t calc=11.300) & $>100$ \\
\hline $\begin{array}{l}\text { Comp LC-6 } \\
\text { Comp LC-6 } \\
\text { Comp LC-6 } \\
\text { Comp LC-6 }\end{array}$ & $\begin{array}{r}0 \\
10 \\
50 \\
100\end{array}$ & $\begin{array}{r}97.0 \\
98.4 \\
0.0 \\
0.4\end{array}$ & Yes ( $\mathrm{t}$ calc=65.59) & 23.1 & $\begin{array}{l}97.5 \\
99.2 \\
82.5 \\
66.8\end{array}$ & Yes ( $\mathrm{t}$ calc $=4.383$ ) & $>100$ \\
\hline $\begin{array}{l}\text { Comp USFC } \\
\text { Comp USFC(b) } \\
\text { Comp USFC(b) } \\
\text { Comp USFC(b) }\end{array}$ & $\begin{array}{r}0 \\
10 \\
50 \\
100\end{array}$ & $\begin{array}{l}98.9 \\
95.5 \\
99.9 \\
83.9\end{array}$ & No (t calc=1.828) & $>100$ & $\begin{array}{r}99.3 \\
96.3 \\
100.0 \\
100.0\end{array}$ & No & $>100$ \\
\hline $\begin{array}{l}\text { Comp FSFC } \\
\text { Comp FSFC(p) } \\
\text { Comp FSFC(p) } \\
\text { Comp FSFC(p) }\end{array}$ & $\begin{array}{r}0 \\
10 \\
50 \\
100\end{array}$ & $\begin{array}{l}96.9 \\
86.6 \\
93.5 \\
13.6\end{array}$ & Yes ( $\mathrm{t}$ calc=53.30) & 73.2 & $\begin{array}{l}97.7 \\
89.0 \\
95.3 \\
88.4\end{array}$ & No (t calc=1.583) & $>100$ \\
\hline $\begin{array}{l}\text { Comp IHC-1 } \\
\text { Comp IHC-1(b) } \\
\text { Comp IHC-1(b) } \\
\text { Comp IHC-1(b) }\end{array}$ & $\begin{array}{r}0 \\
10 \\
50 \\
100\end{array}$ & $\begin{array}{r}98.9 \\
93.2 \\
75.1 \\
0.1\end{array}$ & Yes (t calc=148.00) & 57.2 & $\begin{array}{l}99.3 \\
94.5 \\
84.5 \\
95.9\end{array}$ & No (t calc=1.372) & $>100$ \\
\hline $\begin{array}{l}\text { Comp IHC-2 } \\
\text { Comp IHC-2(b) } \\
\text { Comp IHC-2(b) } \\
\text { Comp IHC-2(b) }\end{array}$ & $\begin{array}{r}0 \\
10 \\
50 \\
100\end{array}$ & $\begin{array}{r}97.5 \\
90.1 \\
80.5 \\
0.2\end{array}$ & Yes ( $t$ calc $=36.09$ ) & 62.2 & $\begin{array}{l}98.0 \\
90.9 \\
84.1 \\
94.0\end{array}$ & No (i calc=1.109) & $>100$ \\
\hline $\begin{array}{l}\text { Comp IHC-3 } \\
\text { Comp IHC-3(b) } \\
\text { Comp IHC-3(b) } \\
\text { Comp IHC-3(b) }\end{array}$ & $\begin{array}{r}0 \\
10 \\
50 \\
100\end{array}$ & $\begin{array}{r}94.0 \\
90.8 \\
0.1 \\
0.0\end{array}$ & Yes (t calc=20.51) & 21.4 & $\begin{array}{l}95.3 \\
91.9 \\
95.3 \\
84.9\end{array}$ & No (t calc=1.356) & $>100$ \\
\hline
\end{tabular}

(a) Evaluated in 1-tailedt-test $(a=0.05$, df $=4$, criticalt value $=2.132)$.

(b) Results may be influenced by possible cross-contamination during sample preparation. 
TABLE 3.32. Results of the 48-Hour Elutriate Test with Larval Mytilus galloprovincialis

\begin{tabular}{|c|c|c|c|c|c|c|c|}
\hline $\begin{array}{l}\text { Sediment } \\
\text { Treatment } \\
\end{array}$ & $\begin{array}{l}\text { Concentration } \\
\text { (Percent } \\
\text { Elutriate) } \\
\end{array}$ & $\begin{array}{l}\text { Mean } \\
\text { Percent } \\
\text { Normal } \\
\end{array}$ & $\begin{array}{l}\text { Normal in } 100 \% \text { Elutriate } \\
\text { Significantly Lower Than } \\
\text { Normal in } 0 \% \text { Elutriate(a) } \\
\end{array}$ & $\begin{array}{l}\text { 96-h } \mathrm{EC}_{50} \\
\text { (Percent } \\
\text { Elutriate) } \\
\end{array}$ & $\begin{array}{l}\text { Mean } \\
\text { Percent } \\
\text { Survival } \\
\end{array}$ & $\begin{array}{l}\text { Survival in } 100 \% \text { Elutriate } \\
\text { Significantly Lower Than } \\
\text { Survival in } 0 \% \text { Elutriate(a) }\end{array}$ & $\begin{array}{l}\text { 96-h LC } \mathrm{LC}_{50} \\
\text { (Percent } \\
\text { Elutriate) } \\
\end{array}$ \\
\hline $\begin{array}{l}\text { Cornp LC } \\
\text { Cornp LC } \\
\text { Cornp LC } \\
\text { Cornp LC }\end{array}$ & $\begin{array}{r}0 \\
10 \\
50 \\
100\end{array}$ & $\begin{array}{r}97.6 \\
91.8 \\
92.9 \\
0.7\end{array}$ & Yes (t calc $=40.73$ ) & 69.5 & $\begin{array}{l}97.9 \\
93.9 \\
94.5 \\
73.6\end{array}$ & Yes ( $\mathrm{t}$ calc $=6.478)$ & $>100$ \\
\hline $\begin{array}{l}\text { Cornp LC-5 } \\
\text { Cornp LC-5 } \\
\text { Cornp LC-5 } \\
\text { Cornp LC-5 }\end{array}$ & $\begin{array}{r}0 \\
10 \\
50 \\
100\end{array}$ & $\begin{array}{r}98.6 \\
93.6 \\
0.4 \\
0.0\end{array}$ & Yes (t calc=111.88) & 21.4 & $\begin{array}{l}99.0 \\
95.8 \\
67.4 \\
57.3\end{array}$ & Yes ( $\mathrm{t}$ calc=3.233) & $>100$ \\
\hline $\begin{array}{l}\text { Cornp LC-6 } \\
\text { Cornp LC-6 } \\
\text { Cornp LC-6 } \\
\text { Cornp LC-6 }\end{array}$ & $\begin{array}{r}0 \\
10 \\
50 \\
100\end{array}$ & $\begin{array}{r}100.0 \\
86.7 \\
0.1 \\
0.0\end{array}$ & Yes (t calc=3.000 E8) & 19.8 & $\begin{array}{r}100.0 \\
94.3 \\
70.4 \\
67.9\end{array}$ & Yes (t calc=2.893) & $>100$ \\
\hline $\begin{array}{l}\text { Cornp USFC } \\
\text { Cornp USFC(b) } \\
\text { Cornp USFC(b) } \\
\text { Comp USFC(b) }\end{array}$ & $\begin{array}{r}0 \\
10 \\
50 \\
100\end{array}$ & $\begin{array}{l}87.9 \\
98.6 \\
89.0 \\
14.3\end{array}$ & Yes (t calc=9.432) & 75.8 & $\begin{array}{l}89.3 \\
98.6 \\
92.0 \\
80.5\end{array}$ & No (t calc=0.7453) & $>100$ \\
\hline $\begin{array}{l}\text { Comp FSFC } \\
\text { Cornp FSFC(b) } \\
\text { Cornp FSFC(b) } \\
\text { Cornp FSFC(b) }\end{array}$ & $\begin{array}{r}0 \\
10 \\
50 \\
100\end{array}$ & $\begin{array}{r}91.5 \\
94.1 \\
92.2 \\
0.1\end{array}$ & Yes ( $\mathrm{t}$ calc $=39.29$ ) & 70.7 & $\begin{array}{l}93.8 \\
95.2 \\
92.8 \\
59.0\end{array}$ & No $(\mathrm{t} c a l c=1.477$ ) & $>100$ \\
\hline $\begin{array}{l}\text { Cornp IHC-1 } \\
\text { Cornp IHC-1(b) } \\
\text { Cornp IHC-1(b) } \\
\text { Cornp IHC-1(b) }\end{array}$ & $\begin{array}{r}0 \\
10 \\
50 \\
100\end{array}$ & $\begin{array}{r}95.5 \\
89.5 \\
75.0 \\
0.0\end{array}$ & Yes (t calc=41.00) & 64.0 & $\begin{array}{l}96.9 \\
90.1 \\
88.4 \\
81.1\end{array}$ & No (t calc=1.026) & $>100$ \\
\hline $\begin{array}{l}\text { Cornp IHC-2 } \\
\text { Cornp IHC-2(b) } \\
\text { Cornp IHC-2(b) } \\
\text { Cornp IHC-2(b) }\end{array}$ & $\begin{array}{r}0 \\
10 \\
50 \\
100\end{array}$ & $\begin{array}{r}100.0 \\
100.0 \\
100.0 \\
0.3\end{array}$ & Yes $(\mathrm{t}$ calc $=149.0$ ) & 71.0 & $\begin{array}{l}100.0 \\
100.0 \\
100.0 \\
100.0\end{array}$ & No & $>100$ \\
\hline $\begin{array}{l}\text { Cornp IHC-3 } \\
\text { Cornp IHC-3(b) } \\
\text { Cornp IHC-3(b) } \\
\text { Cornp IHC-3(b) }\end{array}$ & $\begin{array}{r}0 \\
10 \\
50 \\
100\end{array}$ & $\begin{array}{r}97.1 \\
100.0 \\
0.1 \\
0.0\end{array}$ & Yes (t calc=55.18) & 22.9 & $\begin{array}{r}98.4 \\
100.0 \\
91.6 \\
95.2\end{array}$ & No (t calc=0.605) & $>100$ \\
\hline
\end{tabular}

(a) Evaluated in 1-tailed t-test $(a=0.05$, df $=4$, critical t value $=2.132$ ).

(b) Results may be influenced by possible cross-contamination during sample preparation. 



\subsection{DISCUSSION}

This section summarizes the results of the RI and discusses the physical characteristics of marine sediment at the United Heckathorn site, nature and extent of marine contamination, biological effects of contaminated sediment, and potential impacts of dredging and dewatering sediment during site remediation.

\subsection{FIELD INVESTIGATION}

The sampling strategy employed in the site characterization was based upon the assumption that the OBM would be present throughout the study area, and that anthropogenic contamination would be restricted to the overlying recent sediment of the YBM. Consequently, one of the RI objectives was to identify the depth to OBM throughout inner Richmond Harbor. The OBM was penetrated at every coring location, except the three stations in Parr Canal that were cored by hand. The elevation of the YBM/OBM contact ranged from -15 ft to -20 ft MLLW in the shallow portions of the Lauritzen Canal to approximately-40 $\mathrm{ft}$ MLLW in the Inner Harbor Channel. The thickness of the YBM varied from less than $2 \mathrm{ft}$ to over $8 \mathrm{ft}$ throughout the study area, with the thickest sediment in shallow areas that have not been dredged for some time. The YBM averaged $4 \mathrm{ft}$ to $6 \mathrm{ft}$ over most of the study area. This relatively constant YBM thickness suggests uniform sediment deposition in areas with similar dredging histories. The elevation of the OBM in the Parr Canal is not known; however, probes taken along the length of the canal encountered a hard surface at approximately $6 \mathrm{ft}$ below the mudline.

The YBM in inner Richmond Harbor was on average more than $50 \%$ clay, and had an average solids content of $\mathbf{4 7 \%}$. These physical characteristics will be an important consideration in the selection of a remedial alternative. The USEPA guidance document Selecting Remediation Techniques for Contaminated Sediment (USEPA 1993) notes that many remedial technologies cannot effectively remove contaminants that are strongly bound to small particles, whereas others cannot successfully process fines. Treatment technologies such as dechlorination, soil washing, solvent extraction, incineration, and thermal desorption are not effective for sediment with high clay content. Solidification or stabilization are not feasible for clays because of the small particle size. The high water content and small particle size of the YBM sediment will increase the time required to dewater it. If contaminated sediments are removed or otherwise disturbed as part of a remedial action, a dredging technique that minimizes the resuspension of fine particulate matter should be selected.

The physical and chemical characteristics of the OBM indicate that it forms an excellent barrier to the migration of contaminants from recent sediment. The OBM consisted primarily of silty sand in the shallower portions of Lauritzen Canal, and finer-grained sandy silt and silt in the 
deeper part of the channel. The OBM in the Santa Fe and Inner Harbor channels was generally a homogeneous, firm to hard silt and clay unit that is probably continuous beneath the coarsergrained sediment observed at shallower depths in the Lauritzen Canal. The OBM had an average of about $80 \%$ solids throughout the study area. The low water content and relatively low permeability of silt and clay minimize the likelihood of contamination by porewater diffusion, and its highly consolidated, unfractured character precludes the possibility of contaminationby mixing with recent sediment. The concentrations of pesticides in sediment decreased significantly below the YBM/OBM contact, even in the coarser-grained OBM underlying the highly contaminated sediment in the northern and western portions of the Lauritzen Canal. Sediment chemistry is discussed further in Section 4.2.

The shoreline survey and analysis of grab samples from channel edges outside of the Lauritzen Canal identified few areas with soft sediment that would be difficult to remove by dredging, and that could potentially act as sources of contamination after remediation is complete. The majority of the shoreline is armored with riprap, sheetpile, or concrete-faced bulkheads. In areas where soft sediment was identified and sampled, no pockets of highly contaminated sediment were identified, except along the edge of the Parr Canal. The Parr Canal is restricted in area, has a narrow mouth, and is not likely to be a sediment source to Richmond Harbor. Grab samples were not collected from the edges of the Lauritzen Canal. Many of the core locations were close to the banks of the channel, and pesticide concentrations in most of these samples were extremely high. Therefore, if sediment were dredged from the Lauritzen Canal as part of a remedial action, highly contaminated sediment along the shoreline could be missed. The shoreline sediment could recontaminate adjacent areas.

\subsection{SEDIMENT CHEMISTRY}

The nature and extent of marine contaminationare discussed in this section. As expected, the occurrence of pesticides, particularly DDT and dieldrin, was more widespread and at higher concentrations relative to San Francisco Bay background levels than the other measured contaminants. Other contaminants were detected in the YBM; however, average concentrations were generally comparable to background values for the periphery of San Francisco Bay (Long et al. 1988).

\subsubsection{Nature and Extent of Chlorinated Pesticide Contamination}

Sediment pesticide concentrationswere highest in the Lauritzen Canal and decreased to background levels for San Francisco Bay near Point Potrero. Significant contamination was concentrated in the recent sediment of the YBM. Pesticide distribution in sediment, and contaminant fate and transport are discussed in the following sections. 


\section{Areal and Vertical Distribution of Pesticides in Sedinnent}

The spatial trend in sediment pesticide concentrations delineated in this study is consistent with past data for Richmond Harbor (Table 4.1). A strong concentration gradient exists from the Lauritzen Canal to the Santa Fe Channel; the gradient is less steep from the Santa Fe Channel to the Inner Harbor Channel. The most highly-contaminated sediment was located in the shallow portions of the Lauritzen Canal, with total DDT concentrations in the tens to hundreds of parts per million (ppm). Total DDT concentrations dropped by an order of magnitude (to less than $10 \mathrm{ppm}$ ) in the dredged portion of the canal near the Levin terminal. The total DDT concentrations dropped by another order of magnitude (to less than $1 \mathrm{ppm}$ ) in the Santa Fe Channel. The most contaminated sediment in the Santa Fe Channel was located adjacent to the Lauritzen Canal; total DDT concentrations decreased toward the upper Santa Fe Channel and the Inner Harbor Channel. Total DDT concentrations decreased to less than $100 \mu \mathrm{g} / \mathrm{kg}$ by the center of the Inner Harbor Channel, $50 \mu \mathrm{g} / \mathrm{kg}$ by the south end of the channel, and $20 \mu \mathrm{g} / \mathrm{kg}$ by Point Potrero. Pesticide concentrations in sediment from the Parr Canal were lower than in the Lauritzen Canal sediment, but higher than in the Santa Fe and Inner Harbor Channel sediment. These data are consistent with data from previous studies in Richmond Harbor and with the ecological risk assessment for the Heckathorn site, although the median pesticide concentrations detected in Lauritzen Canal sediment in this study were higher (Table 4.1). Samples from previous studies were primarily collected from surface sediment, and results of this study show that the most highly contaminated sediments in the Lauritzen Canal are below the mudline surface.

Dieldrin was detected throughout the study area at much lower concentrations than was DDT. It showed the same spatial trend in relative concentration as DDT, with a maximum concentration of $16,000 \mu \mathrm{g} / \mathrm{kg}$ at the head of the Lauritzen Canal, $37 \mu \mathrm{g} / \mathrm{kg}$ in Santa Fe Channel, and $5.4 \mu \mathrm{g} / \mathrm{kg}$ in Inner Harbor Channel. Dieldrin was identified at concentrations near the detection limit in most samples from Inner Harbor Channel. Eight other pesticides were detected locally at lower concentrations.

The strong DDT and dieldrin concentration gradients indicate that the Lauritzen Canal is the source of contamination to the Santa Fe and Inner Harbor Channels. The primary source of DDT and dieldrin appears to be waste discharges to the canal during pesticide processing activities at the United Heckathorn site. In 1991, Parametrix reported the presence of four large steel tanks and a sunken barge near the north end of the Lauritzen Canal (Parametrix 1991). In August 1993, USEPA divers located one steel tank and a barge. Sediment collected from the barge and tank contained a maximum of $9000 \mu \mathrm{g} / \mathrm{kg}$ total DDT, indicating that the contents of these vessels are not a source of DDT to the Lauritzen Canal. 
Significantpesticide contamination was concentrated in the YBM; samples from the OBM generally contained only traces of pesticides. In the Lauritzen Canal, the average concentration of total DDT in sediment decreased by two orders of magnitude from the base of the YBM to the top of the OBM, from about $30,000 \mu \mathrm{g} / \mathrm{kg}$ to $300 \mu \mathrm{g} / \mathrm{kg}$ (51 $\mu \mathrm{g} / \mathrm{kg}$ if four values of greater than $500 \mu \mathrm{g} / \mathrm{kg}$ are disregarded). OBM samples from the 1-ft to 2 -ft interval below the contact showed a further reduction in contamination (three samples had $1 \mu \mathrm{g} / \mathrm{kg}$ or less total DDT, and four had between $7 \mu \mathrm{g} / \mathrm{kg}$ and $181 \mu \mathrm{g} / \mathrm{kg}$ ). Some (and possibly most) of the pesticides detected in the OBM samples from the Lauritzen Canal are believed to originate from contamination during sample preparation. Extreme care was taken to avoid sampling OBM that was in contact with the core liner; however, it is possible that a small amount of contamination by the very soft and highly contaminated overlying sediment occurred during the splitting and opening of the cores. The concentrations of pesticides in the uppermost $1 \mathrm{ft}$ of OBM in the Santa Fe and Inner Harbor Channels were near the detection limit.

Vertical stratification in contaminant concentrations in the YBM was generally not well developed. In the shallow portions of the Lauritzen Canal, contaminant concentrations increased, and then decreased with increasing depth. The most highly contaminated sediment was generally found from $1 \mathrm{ft}$ to $5 \mathrm{ft}$ below the mudline. In the Santa Fe Channel, the most contaminated sediment was found down-channel of the mouth of the Lauritzen Canal in the surface sediment, and just up-channel of the mouth in deeper sediment. Contaminant concentrations were generally higher in deeper sediment in the Inner Harbor Channel. The reduced level of contamination in surface sediment throughout most of the site suggests that the primary source of contamination to the system is no longer present. The need for occasional maintenance dredging indicates that net deposition occurs in inner Richmond Harbor. Accumulation of sediment buries previously deposited contaminated material and may result in a decrease in contamination in surface sediment over time if the source of contamination no longer exists. The higher surface concentrations in the Santa Fe Channel downstream of the Lauritzen Canal relative to subsurface sediment may be due to the removal of sediment from this area as part of maintenance dredging of the Lauritzen Canal in 1985.

\subsubsection{Contaminant Fate and Transport}

DDT is essentially non-volatile, almost insoluble in water, and has very high soil adsorption constant. It is highly persistent in the environment. Dieldrin and DDT analogues have similar properties. The dominant transport mechanism for DDT is the migration of fine-grained sediment because DDT tends to bind to silt- and clay-sized particles. Contaminants can also move vertically in sediment by desorption, transport in porewater, and subsequent adsorption (porewater diffusion), or can disperse in the dissolved state by desorbing from sediment, being transportedin solution, and later adsorbing back onto sediment. Porewater diffusion and 
dissolved-phase transport are not likely to be important processes at the Heckathom site because of the extremely low solubility of pesticides. Thus, DDT-contaminated sediment can leave the site by 1) exposure of contaminated sediment at the surface by vertical mixing, 2) resuspension of contaminated sediment, 3) transport, and 4) deposition.

The progressive burial of previously contaminated sediment does not necessarily prevent the dispersion of contaminants. Physical and biological processes can mix surface and subsurface sediment. Physical mixing due to wave resuspension is probably not significant in the protected waters of inner Richmond Harbor. Ship wakes and propeller wash resuspend and mix sediment. Sediment can also be disturbed and subsequently mixed by the grounding of ship keels and propellers, or by liquefaction and slumping. Biological activity (bioturbation) can mix sediment over an interval of millimeters to tens of centimeters, depending upon the resident species. Consequently, the exposure of previously contaminated sediment at the surface depends upon the relative rates of deposition and vertical mixing.

For the transport of contaminated sediment to occur, the particles must first be resuspended. Sediment and associated contaminants in inner Richmond Harbor are likely resuspended by ship wakes and propeller wash, dredging or construction activities, and biologic processes. Once suspended, the sediments are transported by wind or tidal currents, causing dispersal of the contaminants. Current speeds in Richmond Harbor are generally slow and are seldom capable of eroding fine sediment in the absence of other disturbances. Over the past 50 years, the periodic resuspension and transport of sediment out of the Lauritzen Canal have led to the gradual contamination of the Santa Fe Channel, and subsequently of the Inner Harbor Channel. If contaminated sediment were removed from or confined in the Lauritzen Canal, contaminant concentrations in Santa Fe and Inner Harbor Channels would be likely to slowly decrease over time.

The YBM in the Lauritzen Canal is contaminated throughout. Although the vertical profile of contamination has been defined, it is not possible to reconstruct the depositional history of the site without knowing the sediment deposition and mixing rates, and the relative importance of various sediment resuspension and transport processes. It is clear that surface sediments in the canal are still highly contaminated 27 years after activities at the United Heckathom site ceased. The sharp drop in contaminant levels from the Lauritzen Canal to the Santa Fe Channel indicates that sediment is being transported out of the canal at a very slow rate.

DDT, DDT analogues, and dieldrin are more persistent in the environment than other chlorinated pesticides (Gould 1972). DDT may be broken down by chemical and biological means to 4,4'-DDD, 4,4'-DDE, and other compounds. 4,4'-DDD was also manufactured as an insecticide; it is not known whether it was processed at the United Heckathom facility. DDT in sediment is converted primarily to DDE under aerobic conditions, and to DDD in anaerobic 
conditions (Murty 1986). Table 4.2 summarizes the relative percentage of DDT analogues contributing to total DDT in samples from the upland and embankment areas near the former United Heckathorn facility (Levine-Fricke 1990), marine sediment samples collected in this study, and marine sediment samples collected during the ecological risk assessment of the Heckathorn site. The results from this study and the ecological risk assessment are in good agreement. The marine sediment contained a lower percentage of 4,4'-DDT relative to the upland and embankment samples, indicating that DDT is being degraded in the marine environment. The degradation is likely occurring under anaerobic conditions in the Lauritzen Canal, as evidenced by the large percentage of 4,4'-DDD relative to 4,4'-DDE (although some of the 4,4'-DDD may have been directly released in waste discharges from the United Heckathorn facility).

The percentage of 4,4'-DDE in Lauritzen Canal sediment is similar to its contribution in the upland and embankment samples, with the exception of samples of gray material (primarily calcium carbonate) collected from Stations $L Z-1$ and $L Z-8$. These samples had relative percentages of $18 \%$ and $50 \%$ of $4,4^{\prime}-\mathrm{DDD}$ and $4,4^{\prime}-\mathrm{DDE}$, respectively. Conditions in this sediment apparently enhanced the formation of DDE. In sediment outside of the Lauritzen Canal, the relative percent of 4,4'-DDT decreased, indicating that degradation has proceeded to a greater degree in these sediments. The relative percent of 4,4'-DDE increased in these sediments to between $10 \%$ and $20 \%$, although $4,4^{\prime}-D D D$ remained the dominant DDT compound. The increase in 4,4'-DDE may reflect slightly more aerobic conditions.

\subsubsection{Other Contaminants}

Table 4.3 summarizes the median concentrations of contaminants other than pesticides detected in samples of the YBM from this study and a 1992 dredged material disposal study for Richmond Harbor (Pinza et al. 1992). These data are compared to median concentrations for the periphery of San Francisco Bay, as tabulated in National Oceanic and Atmospheric Administration (NOAA) Technical Memorandum NOS OMA 41 (Long et al. 1988). The NOAA data are median values from a compilation of data from 13 studies conducted between 1971 and 1987, excluding areas of known contamination, and are considered background conditions for the periphery of San Francisco Bay in the following discussion. Also provided for comparison are Apparent Effects Threshold (AET) concentrations for San Francisco Bay, which are contaminant concentrations above which significantly toxic effects were always observed (Long and Markel 1992). These values are based on the evaluation of matching sediment chemistry and bioassay data from numerous studies, and do not represent regulatory criteria or standards.

Metals concentrations in Richmond Harbor measured in 1992 and 1993 were generally consistent with those in sediment along the periphery of San Francisco Bay. Chromium, mercury, and lead concentrations exceeded background conditions, but were below the AET. The median copper concentration measured in this study was approximately equal to the AET. The median 
concentrations of total PAHs and PCBs measured in this study were less than the median for the periphery of San Francisco Bay, and far below the AETs. Butyltin concentrations were higher than measured in 1992; however, only samples from the upper Lauritzen Canal and upper Santa Fe Channel had higher concentrations than those measured in other industrialized waterways of San Francisco Bay such as Oakland Inner Harbor (up to $48 \mu \mathrm{g} / \mathrm{kg}$ near Todd Shipyards) (Ward et al. 1992). Compilations of sediment chemistry and solid-phase toxicity data for butyltins are not currently available.

Although the median concentrations of metals, PAHs, and PCBs were within expected ranges for an industrialized area, sediment in the upper Lauritzen Canal and Parr Canal had higher concentrations of these contaminants than elsewhere in Richmond Harbor. Sediment in the Lauritzen and Parr Canals had extremely high pesticide concentrations as well. In general, metals, PAHs, PCBs, and butyltins were not present at elevated concentrations or over a large area compared to chlorinated pesticides.

\subsection{SEDIMENT VOLUMES}

The cleanup criteria for total DDT in sediment at the United Heckathom site have not yet been established; however, the volume of sediment requiring remediation can be estimated from the data generated in this study once the cleanup level has been established. Volumes of sediment were estimated with total DDT concentrations exceeding $1000 \mu \mathrm{g} / \mathrm{kg}, 500 \mu \mathrm{g} / \mathrm{kg}$, $100 \mu \mathrm{g} / \mathrm{kg}$, and $50 \mu \mathrm{g} / \mathrm{kg}$. The cleanup level for pesticides in sediment at the Heckathorn site is likely to fall within the range of these four concentrations. These concentrations yielded, respectively, approximately 65,000-, 65,000-, 350,000-, and 600,000-cu-yd in-place volumes. These estimates will be used to evaluate the feasibility of various remedial alternatives.

\subsection{BIOLOGICAL EFFECTS OF CONTAMINATED SEDIMENT}

Results of the solid-phase and bioaccumulation tests were consistent with data from the ecological risk assessment and another previous study (Pinza et al. 1992). The greatest biological impact was associated with sediment from the Lauritzen Canal; toxicity and levels of bioaccumulation decreased with increasing distance from the United Heckathom site. Test results are discussed in the following sections.

\subsubsection{Solid-Phase Acute Toxicity}

Lauritzen Canal sediment, except for the surface $1 \mathrm{ft}$ from the south end of the canal, was acutely toxic ( $0 \%$ survival) to the amphipod, R. abronius. R. abronius survival was reduced, but not extreme ( $74 \%$ survival), in the southern portion of Lauritzen Canal and in the federal portion of Santa Fe Channel. Acute toxicity decreased with distance from Lauritzen Canal, with $85 \%$ to $89 \%$ survival in upper Santa Fe Channel and in Richmond Inner Harbor Channel. Part of the 
reduced survival outside of Lauritzen Canal may also be attributed to an inappropriate habitat for the amphipods: a fine-grained control sediment from San Francisco Bay resulted in $92 \%$ R. abronius survival while a coarse-grained control sediment resulted in $100 \%$ survival. The grain-size distribution of Santa Fe and Inner Harbor Channel sediments was similar to or finer than the fine-grained control.

\subsubsection{Sediment Bioaccumulation}

Wet weight concentrations of contaminants in tissues of M. nasuta were compared to available Food and Drug Administration (FDA) action levels for fish and shellfish consumption and to National Academy of Sciences (NAS) action levels for fish consumption by marine birds or mammals (Table 4. 4). Most tissue concentrations of contaminants were well below the FDA limits. The maximum dieldrin level in $\mathrm{M}$ nasuta exposed to Comp LC exceeded the $0.3 \mathrm{mg} / \mathrm{kg}$ (wet weight) limit. M nasuta exposed to Comp LC- 5 exceeded the $5 \mathrm{mg} / \mathrm{kg}$ FDA limit for total DDT. No FDA action levels for fish and shellfish consumption have been established for PAHs, PCBs, butyltins, or metals other than methyl mercury. Dieldrin, DDT, and DDT analogues in $M$ nasuta exposed to Comp LC were well in excess of the NAS action levels for those compounds in fish. M nasuta exposed to Comps USFC and FSFC also exceeded the NAS action level for DDT and DDT analogues. Nearly all Comp USFC and FSFC M. nasuta replicates had dieldrin concentrations of $3 \mu \mathrm{g} / \mathrm{kg}$ to $5 \mu \mathrm{g} / \mathrm{kg}$ wet weight, but the NAS limit of $5 \mu \mathrm{g} / \mathrm{kg}$ was exceeded in just one replicate of Comp FSFC.

Average total DDT levels in M. nasuta are comparable to those reported in the ecological risk assessment and another previous investigation (HLA 1986a). The bioaccumulation results from this study confirm the conclusions of USEPA's ecological assessment of laboratory bioaccumulation. Dieldrin and DDT compounds were available in a form that could be bioaccumulated by shellfish, and tissue pesticide levels dropped by at least an order of magnitude from Lauritzen Canal to the Santa Fe Channel, and by at least two orders of magnitude in Inner Harbor Channel. The distribution of DDT analogues in tissues, expressed as a percentage of the total DDT, was similar to that measured by USEPA. The primary analogue present in M nasutawas 4,4-DDD (approximately $85 \%$ in MSL study and $95 \%$ in USEPA study), while DDE made up a small proportion (10\% to $14 \%$ in MSL study and about $4 \%$ in USEPA study), and DDT made the smallest contribution to total DDT in tissues ( $1 \%$ to $5 \%$ in MSL study, less than $1 \%$ in USEPA study). The ratio of DDT analogues was different in tissue than in sediments, in which 4,4'-DDT contributed a similar amount or more than 4,4'-DDD to total DDT.

In the ecological risk assessment, USEPA estimated that $30 \%$ to $50 \%$ of the steady-state concentration of most DDT analogues in $\mathrm{M}$ nasuta was reached at 28 days of exposure. Only $9 \%$ of the steady-state concentration of $4,4^{\prime}-$ DDT was reached at 28 days. The accumulation 
factors (AFs) calculated using data from this study can be compared to USEPA's AFs if the tissue pesticide concentrations are corrected from 28-day values to steady-state values. The correction factors, provided by USEPA, are based on comparison of 28-day values to 42-, 60-, and 90-day values. Table 4.5 shows both MSL and USEPA AFs, with all 28-day data corrected to steadystate values. The AFs were generally comparable for the Lauritzen Canal and Santa Fe Channel; the MSL values were slightly higher in some cases. The AFs from this study were much higher than USEPA's for the Inner Harbor Channel, probably because the detection limits for sediment analyses achieved by MSL were low in comparison to USEPA's.

Literature values for AFs typically used for equilibrium partitioning models of bioaccumulation range from 1 to 4 (USEPAIUSACE 1991; McFarland 1984; Rubinstein et al. 1987). The steady-state AFs of MSL and USEPA show that an AF of 4 may underestimate maximum tissue concentration for some compounds, especially those obtained from sediment with low contaminant concentrations. A more ecologically protective approach would be to use a higher AF value. The MSL data show that even with very low sediment concentrations, $M$ nasuta can accumulate pesticides well beyond what would be predicted by the sediment concentration and TOC. However, in the case of extremely high AFs for the Inner Harbor Channel and graving docks, it is likely that some assumptions of the equilibrium partitioning model were not met (e.g., the chemical behaved conservatively, sediment was the only source of the chemical, no metabolic degradation or transformation of the chemical occurred, the desorption rate of the chemical from TOC did not vary with the sediment concentration of TOC).

\subsection{IREATABILITY TESTING}

Several potential remedial alternatives under consideration for the Heckathom site require dredging and dewatering of marine sediment. The purpose of treatability testing was to provide a preliminary evaluation of potential problems associated with the dredging and dewatering of contaminated sediment in Richmond Harbor, and the effectiveness of various effluent treatment methods. The effluent from dewatering sediment would represent a short-term point discharge to a receiving water body. Any discharge from a confined disposal facility could not cause a violation of'water quality standards applicable to San Francisco Bay. CERCLA requires that remedial actions at a Superfund site meet all ARARs of federal and state environmental laws, unless a waiver is justified. Potential ARARs include the following standards:

- State of California Water Quality Objectives. The State of California Enclosed Bays and Estuaries Plan identifies numerical water quality objectives for contaminants pursuant to the requirements of Section 303 of the Clean Water Act. The values are based upon USEPA's Ambient Water Quality Criteria. These objectives apply to all surface waters of San Francisco Bay. Toxicity objectives state that there shall be no acute toxicity in ambient waters, including mixing zones, and that there shall be no chronic toxicity in ambient waters outside mixing zones. Narrative water quality objectives under the plan state that enclosed bay and estuarine communities and populations shall not be degraded 
as a result of the waste discharge, and that concentrations of toxic pollutants in the water column shall not adversely affect beneficial uses.

- $\quad$ USEPA Ambient Water Quality Criteria. CERCLA requires that remedial actions meet water quality criteria established under Section 304 or 303 of the Clean Water Act, where relevant and appropriate.

The analytical results for liquid-phase samples and results of toxicity testing are compared to these potential ARARs in the following sections.

\subsubsection{Contaminant Concentrations}

Federal and state water quality criteria and objectives are identified in Table 4.6. The federal marine chronic criteria and state water quality objectives for DDT, dieldrin, and other pesticides are below the detection limit for the water analyses. Pesticide concentrations in all liquid-phase samples prepared from Lauritzen Canal composites exceeded the criteria for DDT and dieldrin by large factors. Chlordane isomers exceeded both acute and chronic water quality criteria in nearly all Lauritzen Canal liquid-phase samples. Options for the treatment of effluent from Lauritzen Canal sediment include control for fine particulates, dilution to achieve water quality criteria, or treatment with a GAC-adsorption system. Concentrations of pesticides in elutriate samples exceeded water quality criteria; therefore, controlling for fine-particulates by increasing the settling time of the effluent would not be likely to sufficiently improve its quality. Effluent would require more than a thousand-folddilution to decrease concentrations to acceptable levels, which is not likely to be practical.

Treatment by GAC-adsorption reduced DDT and dieldrin concentrations in elutriate from Comp LC- 5 by approximately $25 \%$; however, additional testing is needed to assess whether this type of treatment is capable of reducing contaminant concentrations to acceptable levels. Additional testing could identify the most effective adsorbent material, quantity of adsorbent material needed, and optimal flow rate of effluent through the adsorbent material. Based on available data, GAC-adsorption may be a feasible option for the treatment of effluent from dewatered sediment from the Lauritzen Canal, depending upon the volume of effluent requiring treatment.

Pesticide concentrations in effluent from sediments outside the Lauritzen Canal were much lower; however, procedural blank contamination prevented a determination of whether they would exceed state water quality objectives. The site water used to prepare the liquid-phase samples exceeded the state water quality objective of $1 \mathrm{ng} / \mathrm{L}$ total DDT.

Concentrations of PCBs, copper, and mercury also exceeded marine water quality criteria in some instances. Where detected in liquid-phase samples, Aroclor 1254 concentrations exceeded federal marine chronic water quality criteria for PCBs (30 $\mathrm{ng} / \mathrm{L})$, but were lower than the marine acute criteria $(10,000 \mathrm{ng} / \mathrm{L})$. Concentrations of copper in the site water exceeded both 
acute and chronic water quality criteria, as did copper in SPP of Comps LC, LC-5, LC-6, FSFC, and IHC-2. Of those, only Comp LC-5 had an unusually high sediment copper concentration $(214 \mathrm{mg} / \mathrm{kg}$, or twice the concentration in the other sediment composites). Four SPP samples (Comps LC, LC-5, LC-6, and USFC) also exceeded the chronic water quality criterion for mercury.

\subsubsection{Toxicity of Effluent}

The presence of dieldrin, DDT, DDT analogues, and PAHs in the procedural blank at higher concentrations than those measured in site water indicates that liquid-phase samples could have been contaminated during the SPP and elutriate preparation process. Toxicity results for liquid-phase samples prepared from Lauritzen Canal sediment were not likely to have been influenced by potential cross-contaminationbecause pesticide and PAH concentrations in these samples greatly exceeded the concentrations in the procedural blank. However, toxicity results for liquid-phase samples prepared from sediment outside the Lauritzen Canal could have been influenced by potential cross-contamination because contaminant concentrations in the liquidphase samples and procedural blank are generally comparable. Consequently, the potential effects of effluent from Santa Fe and Inner Harbor Channel sediments on marine organisms are uncertain.

SPP and elutriate prepared from Lauritzen Canal sediment composites produced statistically significant reductions in survival of the test organism $\mathrm{H}$ costata. Survival of the mysid in the 100\% SPP and elutriate prepared from each Lauritzen Canal sediment composite was $0 \%$. Survival of mussel larvae was statistically significantly reduced in the $100 \%$ SPP and elutriate from Comps LC-5 and LC-6, and in elutriate from Comp LC. The California Enclosed Bays and Estuaries Plan defines acute toxicity as less than $90 \%$ survival $50 \%$ of the time, and less than $70 \%$ survival $10 \%$ of the time, of standard test organisms in undiluted effluent in a 96-hour static or continuous-flow test. Based on this definition, effluent from a confined disposal facility containing sediment from the Lauritzen Canal would likely not meet the water quality objective of no acute toxicity in ambient waters, including mixing zones. The process of dredging in the Lauritzen Canal is also likely to produce toxic effects in the water column by the resuspension of fine-grained sediment.

Chronic effects on mussel larvae were observed with SPP and elutriate prepared from all Lauritzen Canal composites. The state water quality objective for chronic toxicity is $1.0 \mathrm{TUc}$, where TUc equals 100/No Observed Effect Level (NOEL). NOEL is the maximum percent of test water that causes no observed effect on a test organism, as determined in a critical life stage toxicity test. Chronic toxicity in SPP and elutriate from all Lauritzen Canal sediment composites exceeded this criteria. Effluent from a confined disposal facility containing Lauritzen Canal 
sediment would likely require additional treatment beyond the removal of fine particles to meet this objective. 
TABLE 4.1. Comparison of Total DDT in Marine Sediment With Previous Studies

\begin{tabular}{|c|c|c|c|c|c|c|}
\hline Location & $\begin{array}{l}\text { This Stu } \\
\text { Median } \\
\text { Total DDT } \\
(\mu \mathrm{g} / \mathrm{kg}) \\
\end{array}$ & $\underline{n(c)}$ & $\begin{array}{l}\text { Previous Stu } \\
\text { Median } \\
\text { Total DDT } \\
(\mu \mathrm{g} / \mathrm{kg})\end{array}$ & dies(a) & $\begin{array}{c}\text { Ecoloaical Risk } \\
\text { Median } \\
\text { Total DDT } \\
(\mu \mathrm{g} / \mathrm{kg}) \\
\end{array}$ & ssment(b) \\
\hline $\begin{array}{l}\text { Upper Lauritzen Canal } \\
\text { Western Lauritzen Canal } \\
\text { Dredged Area, Lauritzen Canal } \\
\text { Santa Fe Channel } \\
\text { Inner Harbor Channel }\end{array}$ & $\begin{array}{c}46,916 \\
13,824 \\
1480 \\
131 \\
19.6\end{array}$ & $\begin{array}{l}27 \\
18 \\
22 \\
76 \\
74\end{array}$ & $\begin{array}{l}11,000(d) \\
975(d) \\
282(d) \\
250(d) \\
25\end{array}$ & $\begin{array}{r}51 \\
8 \\
23 \\
35 \\
28\end{array}$ & $\begin{array}{c}36,917(e) \\
\text { NA(f) } \\
\text { NA } \\
626 \\
60\end{array}$ & $\begin{array}{r}4 \\
\text { NA } \\
\text { NA } \\
6 \\
6\end{array}$ \\
\hline
\end{tabular}

(a) HLA 1986a, Levine-Fricke 1990, Brown et al. 1990, Pinza et al. 1992.

(b) Lee, Henry et al. 1993. Ecological Risk Assessment of the Marine Sediments at the United Heckathorn Superfund Site (Draft). ERLN: N269. Prepared by the U.S. Environmental Protection Agency, Newport, Oregon.

(c) $\mathrm{n}$ Number of samples.

(d) Wet weight concentrations converted to dry weight concentrations assuming 55\% moisture content.

+ (e) Entire Lauritzen Canal.

$\vec{\omega}$ (f) NA Not applicable. 
TABLE 4.2. Relative Contribution of DDT Analogues to Total DDT in Upland and Marine Sediment Samples

\begin{tabular}{|c|c|c|c|}
\hline Location & $\begin{array}{r}\text { Average } \\
\text { Percent } \\
\text { 4.4'-DDT } \\
\end{array}$ & $\begin{array}{r}\text { Average } \\
\text { Percent } \\
4.4^{\prime} \text {-DDE } \\
\end{array}$ & $\begin{array}{r}\text { Average } \\
\text { Percent } \\
4.4^{\prime}-\text { DDD } \\
\end{array}$ \\
\hline Upland and Embankment Samples(a) & 73 & 7 & 20 \\
\hline $\begin{array}{l}\text { Lauritzen Canal } \\
\text { This study } \\
\text { Ecological Risk Assessment(b) }\end{array}$ & $\begin{array}{l}42 \\
44\end{array}$ & $\begin{array}{l}3 \\
3\end{array}$ & $\begin{array}{l}55 \\
53\end{array}$ \\
\hline $\begin{array}{l}\text { Santa Fe/Inner Harbor Channels } \\
\text { This study } \\
\text { Ecological Risk Assessment }\end{array}$ & $\begin{array}{l}21 \\
23\end{array}$ & $\begin{array}{l}12 \\
17\end{array}$ & $\begin{array}{l}68 \\
60\end{array}$ \\
\hline
\end{tabular}

(a) Levine-Fricke 1990. Data for 2,4'-DDT not included.

(b) Lee, Henry et al. 1993. Ecological Risk Assessment of the Marine Sediments at the United Heckathorn Superfund Site (Draft). ERL-N: N269. Prepared by the U.S. Environmental Protection Agency, Newport, Oregon. 
TABLE 4.3. Concentrations of Contaminants in Sediments from San Francisco Bay and Apparent Effects Thresholds

\begin{tabular}{|c|c|c|c|c|}
\hline Contaminants & $\begin{array}{r}\text { San Francisco Bay } \\
\text { Periphery Median } \\
\text { (Long et al. 1988) } \\
\end{array}$ & $\begin{array}{c}\text { Richmond Inner Harbor, } \\
1991 \text { Median(a) } \\
\text { (Pinza et al.. 1992) } \\
\end{array}$ & $\begin{array}{c}\text { United Heckathorn Site } \\
1993 \text { Median(b) } \\
\text { (this study) } \\
\end{array}$ & $\begin{array}{c}\text { Apparent Effects } \\
\text { Threshold } \\
\text { LLong and Markel. 1992) } \\
\end{array}$ \\
\hline \multicolumn{5}{|l|}{$\begin{array}{l}\text { Trace Metals } \\
\text { (pom drv weight) }\end{array}$} \\
\hline $\begin{array}{l}\mathrm{Ag} \\
\mathrm{As} \\
\mathrm{Cd} \\
\mathrm{Cr} \\
\mathrm{Cu} \\
\mathrm{Hg} \\
\mathrm{Ni} \\
\mathrm{Pb} \\
\mathrm{Se} \\
\mathrm{Zn}\end{array}$ & $\begin{array}{c}1.2 \\
\text { NA(c) } \\
0.76 \\
66 \\
55 \\
0.40 \\
\text { NA } \\
43 \\
\text { NA } \\
\text { NA }\end{array}$ & $\begin{array}{c}0.34 \\
12.3 \\
0.43 \\
200 \\
62 \\
0.34 \\
114 \\
33.4 \\
0.83 \\
137\end{array}$ & $\begin{array}{c}0.53 \\
15.3 \\
0.76 \\
194 \\
103 \\
0.83 \\
104 \\
67 \\
0.41 \\
216\end{array}$ & $\begin{array}{c}>8.6 \\
>72 \\
1.7 \\
>240 \\
98 \\
1.2 \\
\mathrm{NA} \\
120 \\
0.2 \\
230\end{array}$ \\
\hline \multicolumn{5}{|l|}{$\begin{array}{c}\text { Organic } \\
\text { Compounds } \\
\text { (ppo dry weiaht) }\end{array}$} \\
\hline $\begin{array}{l}\text { Total PAH } \\
\text { Total PCB } \\
\text { TBT } \\
\text { DBT }\end{array}$ & $\begin{array}{r}4600 \\
221 \\
N A \\
N A\end{array}$ & $\begin{array}{l}968 \\
38 \\
2.5 \\
2.4\end{array}$ & $\begin{array}{c}1155 \\
59 \\
18.6 \\
14.9\end{array}$ & $\begin{array}{r}>15,000 \\
260 \\
\text { NA } \\
\text { NA }\end{array}$ \\
\hline
\end{tabular}


TABLE 4.4. Comparison of Action Levels With Contaminant Levels in M nasuta Exposed to Sediment Composites

Contaminant

Methyl Mercury

Chlordane

DDT and metabolites (i)

Dieldrin + Aldrin

Dieldrin

Endrin

Heptachlor + Heptachlor Epoxide

Toxaphene

PCBs
FDA NAS Action Level(a) Action Level(b) ( $\mu \mathrm{g} / \mathrm{kg}$ wet weight) $(\mu \mathrm{g} / \mathrm{kg}$ wet weight)

$1000(c)$

$300(f)$

$5000(f)$

$300(f)$

$300(f)$

NA(j)

$300(f)$

5000 (f)

2000(k)

\section{$N A(d)$}

50

50

5

5

5

5

50

500
Concentration Range

in $\mathrm{M}$ nasuta (ug/ka wet weight)

$\begin{array}{ccc}16 & \text { to } 20(\theta) \\ \text { ND(g) } & \text { to } 260(h) \\ 2 & \text { to } & 7090 \\ 0.2 & \text { to } & 395 \\ 0.2 & \text { to } & 393 \\ \text { ND } & \text { to } & 1.7 \\ \text { ND } & \text { to } & 1.4 \\ & \text { ND } & \\ 7 & \text { to } 44\end{array}$

(a) Action Levels for Poisonous or Deleterious Substances in Human Food and Animal Feed, Department of Health and Human Services, Public Health Service, Food and Drug Administration, Washington D.C. Current as of August 1992.

(b) National Academy of Sciences and National Academy of Engineering, EPA-R3-73-033, March 1973. Values apply to whole fish consumption by birds and mammals in the marine environment.

(c) Edible portion of fish, shellfish, crustaceans, and other aquatic animals.

(d) NA Not applicable.

(e) Value is for total mercury; methyl mercury is fraction of total but was not analyzed separately.

(9 Edible portion of fish.

(g) ND Not detected.

(h) Sum of cis- and trans-chlordane.

(i) $\mathrm{DDT}+\mathrm{DDD}+\mathrm{DDE}$

(j) Action level for endrin revoked, Federal Register July 28, 1993.

(k) Tolerance level for fish and shellfish, 21CFR109.30(a)(7). 
TABLE 4.5. Comparison of Accumulation Factors for DDT and Dieldrin M nasutaTissue

Accumulation Factors (all data corrected to steady state)

\begin{tabular}{|c|c|c|c|c|c|c|}
\hline \multirow[b]{2}{*}{ Compound } & \multicolumn{2}{|c|}{ Lauritzen Canal } & \multicolumn{2}{|c|}{ Upper Santa Fe Channel } & \multicolumn{2}{|c|}{ Upper Inner Harbor Channel } \\
\hline & MS__(a)_ & USEPA_b) & MSL & USEPA & MSL & USEPA \\
\hline $4,4^{\prime}-\mathrm{DDE}$ & 7.45 & $0.52-3.94$ & 1.40 & $0.29-2.09$ & 75.9 & $0.59-1.45$ \\
\hline $4,4^{\prime}-$-DDD & 3.50 & $0.41-4.78$ & 3.85 & $0.32-2.87$ & 81.6 & $0.31-1.00$ \\
\hline 4,4'-DDT & 0.66 & $0.01-0.57$ & 0.55 & 0.89-1.39 & 9.4 & $0.24-1.83$ \\
\hline Total DDT(c) & 1.49 & $0.18-3.26$ & 2.61 & $0.19-2.45$ & 48.4 & $0.30-0.96$ \\
\hline Dieldrin & 5.76 & $0.40-3.22$ & 2.49 & $0.60-5.50$ & 40.5 & $0.50-1.40$ \\
\hline
\end{tabular}
(a) This study.
(b) Lee, Henry et al. 1993. Ecological Risk Assessment of the Marine Sediments at the United Heckathorn Superfund Site (Draft). ERL-N: N269. Prepared by the U.S. Environmental Protection Agency, Newport, Oregon.
(c) Sum of 4,4'-DDT, 4, 4'-DDD, and 4,4'-DDE. 
TABLE 4.6. State and Federal Water Quality Objectives

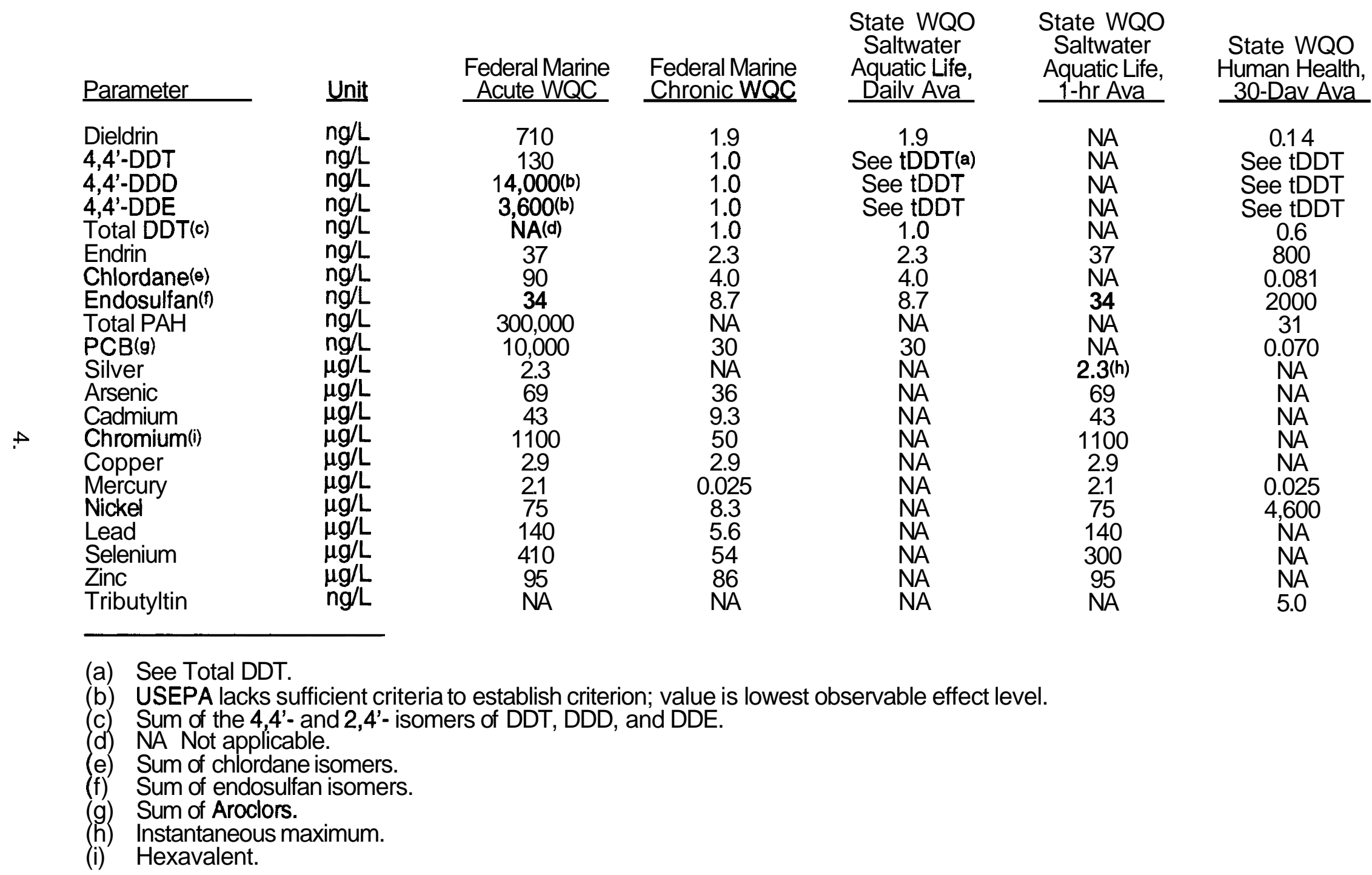




\subsection{SUMMARY AND CONCLUSIONS}

This section summarizes the results and conclusions of the RI of marine sediment at the United Heckathom site. The summary and conclusions are presented in terms of the study objectives stated in Section 1.3.

\subsection{SUMMARY}

The areal and vertical extent of pesticide contamination in marine sediment at the United Heckathom site has been delineated as a result of this RI. The volume and nature of sediment requiring remediation can be characterized from the $\mathrm{RI}$ data after sediment cleanup criteria have been established. Biological testing results from this study were consistent with the results of the ecological risk assessment for the United Heckathorn site. Treatability testing characterized the probable quality of effluent from dewatered sediment; test results will be used to evaluate remedial alternatives for contaminated sediment. $\mathrm{RI}$ results are summarized below.

\subsubsection{Subsurface Geoloav of Inner Richmond Harbor}

The OBM was present below the YBM throughout inner Richmond Harbor. The elevation of the YBM/OBM contact ranged from approximately $-15 \mathrm{ft}$ MLLW in the shallow portions of the Lauritzen Canal to $-40 \mathrm{ft}$ MLLW in the Inner Harbor Channel. The YBM varied in thickness from approximately $2 \mathrm{ft}$ to $8 \mathrm{ft}$ throughout the site, with an average thickness of $4 \mathrm{ft}$ to $6 \mathrm{ft}$. It had an average clay content of greater than $50 \%$, and an average solids content of $47 \%$. The OBM consisted primarily of silty sand in the shallow part of Lauritzen Canal, and homogeneous, unfractured silt and clay in the deeper part of Lauritzen Canal, the Santa Fe Channel, and the Inner Harbor Channel. The homogeneous silt and clay unit is likely to be continuous under the entire Lauritzen Canal. The OBM had an average of $77 \%$ solids, and was firm to very hard in consistency. It is highly consolidated and does not mix with the overlying sediment.

\subsubsection{Areal and Vertical Extent of Marine Contamination}

The pesticides 4,4'-DDT, 4,4'-DDD, 4,4'-DDE, and dieldrin were found at higher concentrations and over a larger area relative to San Francisco Bay background levels than other contaminants in inner Richmond Harbor. The median total DDT concentration decreased from $47,000 \mu \mathrm{g} / \mathrm{kg}$ to $1500 \mu \mathrm{g} / \mathrm{kg}$ from the head of the Lauritzen Canal to its mouth, and to $131 \mu \mathrm{g} / \mathrm{kg}$ and $20 \mu \mathrm{g} / \mathrm{kg}$ in the Santa Fe and Inner Harbor Channels, respectively. The median total DDT concentration in the Parr Canal was $840 \mu \mathrm{g} / \mathrm{kg}$. Maximum total DDT concentrations in sediment were less than $20 \mu \mathrm{g} / \mathrm{kg}$ by Point Potrero. The maximum dieldrin concentrations measured in sediment were $16,000 \mu \mathrm{g} / \mathrm{kg}$ at the head of the Lauritzen Canal, $500 \mu \mathrm{g} / \mathrm{kg}$ at its mouth, $37 \mu \mathrm{g} / \mathrm{kg}$ in the Santa Fe Channel, $5 \mu \mathrm{g} / \mathrm{kg}$ in the Inner Harbor Channel, and $170 \mu \mathrm{g} / \mathrm{kg}$ in the Parr Canal. 
Total DDT concentrations in sediment generally decreased by two orders of magnitude from the base of the YBM to the top of the OBM in the Lauritzen Canal. OBM samples from all but four stations the Lauritzen Canal had less than $20 \mathrm{pglkg}$ total DDT. The total DDT concentrations in the OBM in Santa Fe and Inner Harbor Channels were generally less than $1 \mathrm{pglkg}$. Vertical stratification of contamination within the YBM was not well-defined; however, the highest levels of contamination were generally found in sediment from $1 \mathrm{ft}$ to $5 \mathrm{ft}$ below the mudline.

Other contaminants were detected in sediment from inner Richmond Harbor; however, median concentrations were generally comparable to background values for the periphery of San Francisco Bay. Elevated concentrations of PAHs, PCBs, and metals were detected in sediment from the head of the Lauritzen Canal and the Parr Canal; both of these areas had extremely high pesticide concentrations as well.

\subsubsection{Volume of Contaminated Sediment}

The volumes of sediment exceeding $1000 \mathrm{pg} / \mathrm{kg}, 500 \mu \mathrm{g} / \mathrm{kg}, 100 \mathrm{pg} / \mathrm{kg}$, and $50 \mathrm{pg} / \mathrm{kg}$ total DDT were estimated because cleanup criteria for total DDT in sediment at the Heckathom site have not yet been establishedand are likely to fall within this range of concentrations. Sediment volumes include the YBM down to the YBMIOBM contact. The volume exceeding $1000 \mathrm{pg} / \mathrm{kg}$ and $500 \mu \mathrm{g} / \mathrm{kg}$ total DDT includes all YBM sediment in the Lauritzen and Parr canals, and is estimated as approximately $65,000 \mathrm{cu}$ yd. Pockets of sediment exceeding $500 \mu \mathrm{g} / \mathrm{kg}$ total DDT were found in the Santa Fe Channel near the YBMIOBM contact up-channel and across from the mouth of the Lauritzen Canal, and in surface sediment adjacent to the Castrol pier and downstream of the mouth of the Lauritzen Canal. Sediment exceeding $100 \mathrm{pg} / \mathrm{kg}$ total DDT extends to the northern end of the Inner Harbor Channel, and has a volume of approximately 350,000 cu yd. Sediment exceeding $50 \mathrm{pg} / \mathrm{kg}$ total DDT extends to the center of the Inner Harbor Channel and has a volume of approximately $600,000 \mathrm{cu}$ yd. The volume of YBM in the Parr Canal is approximately $10,000 \mathrm{cu}$ yd. Weighted average total DDT concentrations for each category of sediment (including and excluding sediment from the Lauritzen Canal) were estimated and will be used to evaluate remedial alternatives for the site.

\subsubsection{BioloaicalEffects of Contaminated Sediment}

Lauritzen Canal sediment, with the exception of sediment from the south end of the canal, was acutely toxic ( $0 \%$ survival) to the amphipod, R. abronius. Sediment from the south end of the Lauritzen Canal and the federal Santa Fe Channel was less toxic ( $74 \%$ survival). Survival in sediment from the upper Santa Fe and Inner Harbor Channel was 85\% to $89 \%$. The average total DDT concentration in the tissue of M nasuta decreased from approximately 35,000 pglkg (dry weight) in the Lauritzen Canal to 700 pglkg in the Santa Fe Channel, and to $200 \mathrm{pg} / \mathrm{kg}$ in the Inner Harbor Channel. 


\subsubsection{Probable Quality of Effluent From Dewatered Sediment}

Concentrations of DDT, DDT analogues, and dieldrin in SPP and elutriate samples prepared from Lauritzen Canal sediment exceeded state and federal water quality criteria by two to five orders of magnitude. Elutriate concentrations were $15 \%$ to $90 \%$ lower than those in SPP samples (with the exception of two composites with higher elutriate concentrations). GAC treatment of the elutriate from one Lauritzen Canal composite resulted in about a $25 \%$ reduction in total DDT and dieldrin concentrations. Pesticide and PAH concentrations in SPP and elutriate prepared from composites outside the Lauritzen Canal were one to three orders of magnitude lower; however, potential cross-contamination during sample preparation prevented a determination of whether water quality criteria were exceeded.

The SPP and elutriate samples prepared from all sediment composites from the Lauritzen Canal caused statistically significant acute toxicity to the mysid $\mathrm{H}$ costata. The elutriate sample prepared from Comp LC and the SPP and elutriate samples prepared from Comps LC-5 and LC-6 (all from the Lauritzen Canal) caused statistically significant reductions in survival of bivalve larvae. Chronic effects in mussel larvae were observed with SPP and elutriate prepared from all Lauritzen Canal sediment composites. Toxicity test results for SPP and elutriate samples prepared from Santa Fe and Inner Harbor Channel sediment composites were not reliable because of potential cross-contaminationduring sample preparation.

\section{$5.2 \quad$ CONCLUSIONS}

The conclusions of the RI of marine sediment at the United Heckathom site are summarized below.

\subsubsection{Subsurface Geoloav of Inner Richmond Harbor}

The fine-grained nature and high water content of the YBM in inner Richmond Harbor will be an important consideration in the evaluation of remedial alternatives because many remedial technologies are not effective at removing contaminants that are strongly bound to fine-grained particles (USEPA 1993). In addition, if YBM sediments are dredged as part of a remedial action, a dredging technique that minimizes sediment resuspension should be selected.

The physical characteristics of the OBM indicate that it should form an excellent barrier to the downward migration of contaminants from recent sediment. Its firm to hard consistency prevents mixing of the OBM with overlying sediment, and its low water content and relatively low permeability minimize the migration of contaminants by porewater diffusion.

The shoreline survey identified few areas with soft sediment that could potentially act as a continuing source of contamination after site remediation is complete. Contaminated sediment 
might be left in place along the shorelines of the Lauritzen and Parr Canals if sediments were dredged as part of a remedial action.

\subsubsection{Areal and Vertical Extent of Marine Contamination}

The pesticides 4,4'-DDT, 4,4'-DDD, 4,4'-DDE, and dieldrin were found at higher concentrations and over a larger area relative to San Francisco Bay background than any other contaminants in inner Richmond Harbor. Concentrations were highest in sediment from the Lauritzen Canal and decreased to backgroundlevels for San Francisco Bay in Inner Harbor Channel. A strong concentration gradient exists within the Lauritzen Canal and from the Lauritzen Canal to the Santa Fe Channel. A smaller concentration gradient exists from the federally maintained portion of the Santa Fe Channel to the upper Santa Fe Channel, and from the federal Santa Fe Channel to the Inner Harbor Channel. Significant pesticide contamination was concentrated in the YBM sediment.

The strong gradient in pesticide concentrations indicates that the Lauritzen Canal is the source of contaminated sediment to inner Richmond Harbor. The pesticide contamination in Lauritzen Canal sediment is apparently due to waste discharges to the canal during pesticide processing activities at the former United Heckathom facility. The lower contaminant concentrations in the uppermost $1 \mathrm{ft}$ of sediment compared to deeper sediment suggest that the primary source of contamination to the system is no longer present. The surface sediment is periodically resuspended by some type of disturbance and transported out of the canal by wind or tidal currents. The sharp drop in contaminant concentrations from the Lauritzen Canal to the Santa Fe Channel suggests that the rate of contaminant transport out of the Lauritzen Canal is relatively slow. If the highly contaminated sediments were removed from or confined to the Lauritzen Canal, contaminant concentrations in the Santa Fe and Inner Harbor Channels would be likely to slowly decrease over time.

\subsubsection{Volume of Contaminated Sediment}

Assuming that the cleanup criteria for total DDT in sediment at the United Heckathorn site falls between $50 \mu \mathrm{g} / \mathrm{kg}$ and $1000 \mu \mathrm{g} / \mathrm{kg}$, the volume of sediment requiring remediation is between approximately $65,000 \mathrm{cu}$ yd and $600,000 \mathrm{cu}$ yd. The average total DDT concentrations of sediment above $50 \mu \mathrm{g} / \mathrm{kg}$ and $100 \mu \mathrm{g} / \mathrm{kg}$ total DDT decreased by an order of magnitude if the sediment from the Lauritzen Canal was excluded.

\subsubsection{Bioloaical Effects of Contaminated Sediment}

Results of solid-phase toxicity and bioaccumulation tests indicate that the greatest biological impacts were associated with sediment from the Lauritzen Canal, and that toxicity and tissue residues in clams decreased with increasing distance from the Lauritzen Canal. These 
results are consistent with data reported in USEPA's ecological risk assessment for the United Heckathom site.

\subsubsection{Probable Quality of Effluent from Dewatered Sediment}

The pesticide concentrations measured in SPP and elutriate samples prepared from Lauritzen Canal sediment composites suggest that controlling for fine-grained particles would not be sufficient to reduce pesticide concentrations in effluent from a confined disposal facility to levels below the state numerical water quality objectives. Dilution would not be practical for effluent from Lauritzen Canal sediment because a dilution factor of thousands to hundreds of thousands would be required. The effluent would be likely to require treatment with a filtration and carbonadsorption system capable of removing high concentrations of pesticides. Additional testing is required to evaluate the feasibility of this type of system.

The SPP and elutriate samples prepared from Lauritzen Canal sediment composites produced statistically significant acute toxicity to $\mathrm{H}$ costata and chronic toxicity to $\mathrm{M}$ galloprovincialis. Toxicity must be removed from an effluent prior to discharge to meet the state water quality objective of no acute toxicity in ambient water, including mixing zones. Further evaluation might be required to identify reasonable steps necessary to reduce toxicity. 



\subsection{REFERENCES}

ASTM (American Society for Testing and Materials). 1990. Standard Guide for Conducting 10day Static Sediment Toxicity Tests with Marine and Estuarine Amphipods. ASTM Designation: E 1367-90. American Society for Testing and Materials, Philadelphia, PA.

Brown, B., N. P. Kohn, E. A. Crecelius, J. A. Ward, B. N. Bjornstad. 1990. Environmental Evaluations for Deepening of Richmond Harbor and Santa Fe Channels. PNL-7614. Prepared for the U.S. Army Corps of Engineers, San Francisco District by Marine Sciences Laboratory, Sequim, Washington, published by Pacific Northwest Laboratory, Richland, Washington.

CH2M Hill. 1987. Work Plan/Revised Remedial Action Plan, Richmond Terminal Corporation Site. Prepared for the California Department of Health Services.

CH2M Hill. 1988. Site Characterization Technical Memorandum, Levin Richmond Terminal Corporation Site. Prepared for California Department of Health Services.

DeWitt, T. H., G. R. Ditsworth, and R. C. Swartz. 1988. "Effects of Natural Sediment Features on Survival of the Phoxocephalid Amphipod, Rhepoxynius abronius." Marine Environmental Research 25:99-124.

Dinnel, P., Q. Stober, J. Link, M. Letourneau, W. Roberts, S. Felton, and R. Nakatani. 1983. Methodology and Validation of a Sperm Cell Toxicity Test for Testing Toxic Substances in Marine Waters. Final Report FRI-UW-8306, Fisheries Research Institute, University of Washington, Seattle.

Gould, R. F., ed. 1972. Fate of Organic Pesticides in the Aquatic Environment. Advances in Chemistry Series III. American Chemical Society, Washington D.C.

HLA (Harding Lawson Associates). 1984. Preliminary Site Characterization, Former United Heckathorn Site, Richmond, California. Prepared for the Levin Richmond Terminal Corporation. Novato, California.

HLA (Harding Lawson Associates). 1985. Site Characterization and Remedial Action Plan, Parr Canal Site, Richmond, California. Novato, California.

HLA (Harding Lawson Associates). 1986a. Revised Draft Site Characterizationand Remedial Action Plan, Former United Heckathorn Site, Richmond, California. Novato, California.

HLA (Harding Lawson Associates). 1986b. Interim Remedial Actions, Train Scale Excavation, United Heckathorn Site, Richmond, California. Novato, California.

Hunt, J. W., B. S. Anderson, S. L. Turpen, A. R. Coulon, M. Martin, F. H. Palmer, and J. J. Janik. 1989. "Marine Bioassay Project Fourth Report: Experimental Evaluation of Effluent Toxicity Testing Protocols with Giant Kelp, Mysids, Red Abalone, and Topsmelt." Environmental Science and Technology 11(7):714-719.

Levine-Fricke. 1990. Remedial Investigation, United Heckathorn Site, Richmond, California. Emeryville, California.

Levine-Fricke. 1991a. Feasibility Study Report, United Heckathorn Site, Richmond, California. Emeryville, California.

Levine-Fricke. 1991b. Removal of Pesticide-AffectedSoil, United Heckathorn Site, Richmond, California. Emeryville, California. 
Levine-Fricke. 1993. Removal of Hot Spot Soils from the United Heckathorn Site, Richmond, California. Emeryville, California.

Long, E. and L. Morgan. 1990. The Potential for Biological Effects of Sediment-Sorbed Contaminants Tested in the National Status and Trends Program. NOAA Technical Memorandum NOS OMA 52.

Long, E. and R. Mardel. 1992. An Evaluation of the Extent and Magnitude of Biological Effects Associated With Chemical Contaminants in San Francisco Bay, California. NOAA Technical Memorandum NOS ORCA 64.

Long, E., D. MacDonald, M. Baker Matta, K. VanNess, M. Buchman, and H. Harris. 1988. Status and Trends in Concentrations of Contaminants and Measures of Biological Stress in San Francisco Bay. NOAA Technical Memorandum NOS OMA 41.

MacFarland, V. A. 1984. "Activity-based evaluation of potential bioaccumulation from sediments." Proc. Am. Soc. Civ. Eng. 1:461-467.

MSL (Battelle/Marine Sciences Laboratory). 1992. Final Work Plan, Remedial Investigation and Feasibility Study of Marine Sediment at the United Heckathorn Superfund Site. Prepared for the United States Environmental Protection Agency.

Murty, A.S. 1986. Toxicity of Pesticides to Fish, Volume I. CRC Press, Inc., Boca Raton, Florida.

Palermo, M. R. 1986. Development of a Modified Elutriate Test for Predicting the Quality of Effluent From Confined Dredged Material Disposal Areas. Technical Report D-86-4, U.S Army Engineer Waterways Experiment Station, Vicksburg, Mississippi.

Palermo, M. R. and E. L. Thackston, 1988. "Test For Dredged Material Effluent Quality." Journal of Environmental Engineering. American Society of Civil Engineers, Vol 114.

Parametrix. 1991. Site Reconnaissanceat the United Heckathorn Site, Lauritzen Canal. Prepared for United Heckathorn, Richmond, California. Bellevue, Washington.

Pinza, M. R., J. A. Ward, H. L. Mayhew, J. Q. Word, D. K. Niyogi, and N. P. Kohn. 1992. Ecological Evaluation of Proposed Dredged Material From Richmond Harbor. PNL-8389. Prepared for the U.S. Army Corps of Engineers, San Francisco District by Battelle/Marine Sciences Laboratory, Sequim, Washington, published by the Pacific Northwest Laboratory, Richland, Washington.

Prest, V. K. 1969. "Retreat of Wisconsin and Recent Ice in North America." Geol. Surv. Can. Map 1257A, Scale 1:5,000,000.

Rubinstein, N. I., J. L. Lake, R. J. Pruell, H. Lee, II, B. Taplin, J. Heltshe, R. Bowen, and S. Pavignano. 1987. Predicting Bioaccumulation of Sediment Associated Organic Contaminants: Development of a Regulatory Tool for Dredged Material Evaluation. Tech. Rep. D-87. U. S. Army Engineer Waterways Experiment Station, Vicksburg, Mississippi.

USACE (United States Army Corps of Engineers). 1979. Dredge Disposal Study for San Francisco Bay and Estuary, Appendix B: Pollutant Distribution Study. San Francisco, California. 
USEPA (United States Environmental Protection Agency). 1985. Ambient Water Quality Criteria for Copper, 1984. EPA 440/5-84-031. January 1985. Office of Water Regulations and Standards, Criteria and Standards Division, Washington D.C.

USEPA (United States Environmental Protection Agency). 1987. Quality Criteria for Water, 1986. EPA 44015-86-001. May 1987. Office of Water Regulations and Standards, Criteria and Standards Division, Washington D.C.

USEPA (United States Environmental Protection Agency). 1988. Laboratory Data Validation Functional Guidelines for Evaluating Organics Analyses. Prepared for the Hazardous Site Evaluation Division, U.S. Environmental Protection Agency. February 1988.

USEPA (United States Environmental Protection Agency (USEPA) 1993. Selecting Remediation Techniques for Contaminated Sediment, EPA-823-B93-001. Office of Water, Office of Science and Technology, Standards and Applied Science Division and Office of Research and Development, Risk Reduction Engineering Laboratory. Washington, D.C. and Cincinatti, Ohio.

USEPA/USACE (United States Environmental Protection Agency and United States Army Corps of Engineers). 1991. Evaluation of Dredged Material Proposed for Ocean Disposal, Testing Manual. EPA-68-C8-0105. Washington, D.C.

Ward, J. A., J. Q. Word, M. R. Pinza, H. L Mayhew, E. S. Barrows, and L. F. Lefkovitz. 1992. Ecological Evaluation of Proposed Discharge of Dredged Material from Oakland Harbor into Ocean Waters, Phase 111 A of -42-Foot Project. (Volumes I and II). PNL-8302. Prepared by the Battelle/Marine Sciences Laboratory, Sequim, Washington. Published by the Pacific Northwest Laboratory, Richland, Washington. 

APPENDIX A

METHODS 



\section{APPENDIX A}

\section{METHODS}

Methods used in the laboratory to prepare and analyze samples collected in the field are described in Sections A.I through A.4. Data analysis procedures are summarized in Section A.5, and quality assurance/quality control $(\mathrm{QA} / \mathrm{QC})$ procedures are specified in Section A.6.

\section{A.1 SEDIMENT CHEMISTRY SAMPLE PREPARATION}

Procedures used in the laboratory to prepare sediment samples for chemical testing are discussed below. The glassware and equipment preparation procedures also apply to all equipment used in the biological testing laboratory. To assure that holding time limits for chemical analyses were met, sediment cores were processed and samples prepared in the same order in which they were collected.

\section{A.I.I Laboratorv Glassware and Equipment Prenaration}

All glassware, stainless steel or titanium utensils, Nalgene, Teflon, and other laboratory containers and equipment were cleaned according to stringent procedures to avoid contamination of samples. Glassware (including test containers, aquaria, and sediment transfer dishes) was washed with warm, soapy water, rinsed five times with deionized water, then soaked in a $\mathbf{5 \%}$ reagent grade nitric acid bath for a minimum of $4 \mathrm{~h}$. After soaking, glassware was rinsed with deionized water five times and allowed to dry. Polyvinyl chloride (PVC), Nalgene, and Teflon tools were also washed and soaked in acid baths in the same manner as was glassware. The only exception was chemistry sample containers (glass with Teflon-lined lids) that were purchased already cleaned.

Stainless steel bowls, spoons, spatulas, and other utensils were washed with warm, soapy water, rinsed five times with deionized water, and allowed to air dry. They were then rinsed with methylene chloride under a fume hood, where they remained until the methylene chloride had evaporated.

Neoprene stoppers and polyethylene sheets or other porous materials were washed with warm, soapy water and rinsed five times with deionized water. These items were then "seasoned" by continuous soaking in 0.45 -pm-filtered seawater for at least 2 days prior to use. Large pieces of laboratory equipment, such as the epoxy-coated mixer used to mix sediment and epoxy-coated boards used to hold cores for geologic descriptions, were washed with a mild soap solution and thoroughly rinsed with tap water followed by deionized water. 


\section{A.1.2 Geoloaic Descriotion of Sediment Cores}

The subsurface geology throughout the study area was described by the geologic characteristics of each 4-in. core sample. The description protocol was consistent with ASTM Method D2488-84 (ASTM 1984). Each core section was removed from storage, scored longitudinally with a circular saw, and cut open with a stainless steel linoleum knife. The core was then carefully opened to expose the sediment stratigraphy. The geologist measured and described the sediment, and recorded the following characteristics on a core data log form: lithology, color, consistency, cementation, structure, maximum particle size, odor, and any other notable characteristics. Care was taken not to disturb or disrupt the sediment during description. The geologist determined and marked the YBMIOBM boundary based on color, consistency, and sediment type. The geologist also measured and marked the vertical segments for sample preparation. The vertical segments were defined as follows: 1) Segment A - the top $1 \mathrm{ft}$ of YBM; 2) Segment $X$ - the $1 \mathrm{ft}$ of $Y B M$ above the YBMIOBM contact; 3) Segment $Y$ - the $1 \mathrm{ft}$ of OBM below the YBMIOBM contact; 4) Segments B, C...G - intermediate YBM samples in $\leq 2 \mathrm{ft}$ increments; 5) Segment $M$ - the entire length of YBM; and 6) Segment $Z$ - the OBM $1 \mathrm{ft}$ to $2 \mathrm{ft}$ below the YBMIOBM contact (see Figure 2.3). If the sediment at the YBMIOBM contact was disturbed or not well defined, it was not included in the chemistry sample. Selected cores were photographed in color.

\section{A.1.3 Preoaration of Sediment Samples}

Following geologic description and demarcation of segments for subsampling, the 4-in. cores were moved to a sediment preparation table. The number, lengths, and corresponding depths of the segments were recorded and assigned sample identification codes, and the appropriate analysis jars were labeled. The sediment from each marked segment was carefully transferred to a clean glass baking dish or a stainless steel bowl, using a clean stainless steel spatula. Extreme care was taken to avoid removing sediment in contact with the Lexan core liner and Lexan shavings. Each channel-edge grab sample was emptied from its epoxy-coatedpail into a clean, labeled stainless steel bowl. Each core segment or grab sample was homogenized to uniform color and consistency using stainless a steel spoon or spatula. Aliquots of homogenized sample were placed in the appropriate, labeled jars. The filled jars were placed on ice in coolers. An inventory of samples in each cooler was maintained on chain-of-custody forms. Samples were shipped daily to analytical laboratories; any coolers not shipped were stored at $4^{\circ} \pm 2^{\circ} \mathrm{C}$ in MSL's cold room until the following day. In addition to the samples prepared for immediate study, the following samples were archived for possible future analysis: duplicates of every sediment sample, OBM from $1 \mathrm{ft}$ to $2 \mathrm{ft}$ below the YBMIOBM contact, and control sediments used for biological testing only. 


\section{A2 SOLID-PHASE BIOLOGICAL TESTING}

Procedures used to prepare for and conduct solid-phase bioassays are described in this section. Two solid-phase tests were used to characterize the acute toxicity and bioaccumulation potential of the uppermost $1 \mathrm{ft}$ of YBM in the study area: a 10-day static acute toxicity test using the amphipod, $R$. abronius, and a 28-day flow-through bioaccumulation test with the bent-nose clam, M nasuta.

\section{A.2.1 Preparation of Sediment for Testing}

Sediment from selected stations was combined into a composite sample for biological testing. Sediments were transferred from 5-gal pails into a mixer coated with a special epoxy paint (TNEMEC Epoxy converter 83-83-B). The mixer homogenized the large volume of sediment necessary for biological testing. Minimal amounts of $0.45-\mu \mathrm{m}$-filtered seawater were added as needed to achieve a homogeneous consistency. After mixing, the composite samples were returned to the labeled, epoxy-coated metal pails. Aliquots for chemical analyses were placed in cleaned and labeled sample jars. The composite sediment chemistry samples were placed on ice in coolers along with the individual core sediment chemistry samples as described in Section A.1.3. The remaining pail(s) of composite sediment sample were stored at $4^{\circ} \pm 2^{\circ} \mathrm{C}$ in MSL's cold room.

The control sediments were stored in their sampling containers at $4^{\circ} \pm 2^{\circ} \mathrm{C}$ until sieving. The sediments were placed on 1- or 2-mm stainless steel mesh and press-sieved (no water added) into clean stainless steel bowls or epoxy-coated pails. Any organisms collected on the sieves were discarded, and any large particles were returned to the sieved sediment. The sieved sediment was then mixed thoroughly by hand in the bowl or pail using a stainless steel spoon. Homogenized control sediments were stored in clean bowls or pails at $4^{\circ} \pm 2^{\circ} \mathrm{C}$ until needed for testing. A 500-mL aliquot of sediment was archived for possible future analysis. Between sieving of reference sediments, all equipment was thoroughly rinsed with $0.45-\mu \mathrm{m}$ filtered seawater to avoid cross-contaminationbetween samples. All control sediments were sieved, homogenized, and used for biological testing within the 6-week holding limit from the sampling date.

\section{A.2.2 10-Dav Static Test with Rhepoxynius abronius}

R. abronius amphipods were captured by MSL staff near West Beach, Whidbey Island, Washington, using a specially-designed anchor dredge deployed from a 17-ft Boston Whaler. Sediment brought up with the dredge was sieved through a 2-mm mesh screen to remove large debris and predatory organisms. Amphipods were kept in coolers partially filled with native sediment and seawater until they were delivered to a holding tank at the MSL. The amphipods were held in a large tank containing their native sediment and flowing $15^{\circ} \mathrm{C}$ seawater. Organisms 
were not fed during the holding period, because food was available from the holding sediment. The amphipods were held for one week before test initiation.

The 10-day test was conducted in 1-quart glass jars placed in random positions on a water table maintained at $15^{\circ} \mathrm{C}$. After the test sediment was mixed (Section A.2.1), it was added to the jars to a depth of $2 \mathrm{~cm}$. Each jar was slowly filled with $0.45-\mathrm{pm}$-filtered seawater to the test volume of $750 \mathrm{~mL}$, placed on the water table to stabilize the temperature, and covered with a PVC lid with an aeration pipette connected to an overhead air manifold. After the sediment in the jars was allowed to settle ovemight, initial water quality parameters were measured in each container and recorded on water quality forms.

The test was initiated by adding 20 R. abronius to each test container. Amphipods were gently sieved from the holding tank into clean seawater and counted into small transfer containers. The number of organisms was confirmed before they were transferred into the test container. The date and time of initiation were recorded on data forms. Amphipods were observed daily during the test, and the number of organisms floating on the surface, swimming in the jar, or resting on the sediment surface was recorded on observation forms. Amphipods floating on the surface were gently pushed below the water surface with a pipette tip and observed as they either burrowed or did not burrow into the sediment.

Water temperature, salinity, $\mathrm{pH}$, and dissolved oxygen (DO) were measured daily in one replicate of each treatment and in all containers at initiation and termination of the bioassay. Acceptable ranges for water quality parameters during the experiment were as follows:

$\begin{array}{ll}\text { DO } & 16.0 \mathrm{mg} / \mathrm{L} \\ \mathrm{pH} & \text { ambient } \pm 0.5 \text { unit } \\ \text { salinity } & 30 \mathrm{e} .0 \mathrm{ppt} \\ \text { temperature } & 15.0^{\prime \prime} \pm 2.0^{\circ} \mathrm{C}\end{array}$

At the end of the test (Day 10), the contents of each jar were sieved through a $0.5-\mathrm{mm}$ Nytex screen to collect the R. abronius. Organisms were placed in clean seawater in a glass dish labeled with the treatment and replicate number. The number of live and dead organisms in each dish was counted, and the presence or absence of body parts recovered at the end of the test was noted. If a R. abronius did not respond to gentle probing after several minutes of observation, the organism was considered dead. At least $10 \%$ of the mortality counts were confirmed by a second analyst.

To assess the sensitivity of $R$. abronius response to a known contaminant, a reference toxicant test with cadmium was conducted. The reference toxicant test was a static $96-\mathrm{h}$ exposure to four concentrations of cadmium chloride $(0.5,1.0,2.0,4.0$ milligrams per liter [mg/L] as cadmium) in the absence of sediment. Three 750-ml replicates of each concentration, including a 
seawater control, were placed randomly on the water table. The test was initiated, monitored, and terminated in a manner similar to that of the 10-day sediment test.

\section{A.2.3 28-Day Flow-Throuah Test with Macoma nasuta}

M. nasutawere collected from the intertidal zones of beaches in Discovery Bay, near Gardiner, Washington, by Gunstone and Johnson commercial suppliers. The clams were held in large tanks of clean sediment with flow-through $15^{\circ} \mathrm{C}$ seawater. Temperature, $\mathrm{pH}$, DO, and salinity of water in each holding tank water were monitored daily. The $\mathrm{M}$ nasuta were not fed during the holding or testing periods, because the organisms were able to obtain food from the sediment.

The flow-through test with $M$. nasuta was conducted in 10-gal glass aquaria placed in random positions on water tables. Each sediment treatment had five replicate aquaria, each containing 25 M. nasuta. Each aquarium was partially filled (about $8 \mathrm{~L}$ of sand-filteredseawater) via the flow-through system. Test sediment was added to a depth of $3 \mathrm{~cm}$ by measuring out the required amount $(3870 \mathrm{~mL})$ in a clean glass container and using seawater to wash and distribute the sediment evenly in the tank. After the sediment was allowed to settle overnight, the flowthrough and aeration systems were started, and the flows adjusted to deliver $125 \pm 10 \mathrm{~mL} / \mathrm{min}$ of seawater to each aquarium.

Initial water quality parameters were measured in every replicate before $25 \mathrm{M}$. nasuta were added to each tank. The initiation time and date were noted on each aquarium and on a data sheet. Salinity, temperature, $\mathrm{DO}$, and $\mathrm{pH}$ were measured daily in at least one replicate of each treatment and recorded on water quality data sheets. The acceptable ranges for water quality parameters during the experiment were as follows:

$\begin{array}{ll}\mathrm{DO} & 26.0 \mathrm{mg} / \mathrm{L} \\ \mathrm{pH} & \text { ambient } \mathrm{H} .5 \text { unit } \\ \text { salinity } & 30 \pm 2.0 \mathrm{ppt} \\ \text { temperature } & 15.0^{\circ} \pm 2.0^{\circ} \mathrm{C} \\ \text { flow rates } & 125 \pm 10 \mathrm{~mL} / \mathrm{min} .\end{array}$

The number of $M$. nasuta on the sediment surface and the number of those with their siphons exposed were observed and recorded daily. Dead organisms were removed, but not replaced. At the end of the 28-day exposure, water quality measurements were taken in all tanks and the contents of each aquarium were gently passed through a 1.0-mm Nytex screen to recover the $\mathrm{M}$ nasuta. The organisms were placed in glass baking dishes labeled with the treatment number, and the number of dead and live $M$. nasuta was determined. Those with 
unresponsive or gaping shells were considered dead. At least $10 \%$ of the mortality counts were confirmed by a second analyst.

To ensure that tissue chemistry results would not be biased by contaminants associated with sediment grains in the digestive tract, surviving $\mathrm{M}$ nasuta were allowed to depurate, or void the digestive tract, for $48 \mathrm{~h}$ following the 28-day exposure. The surviving $M$. nasuta were placed in a clean depuration aquarium (without sediment). After $48 \mathrm{~h}$ of depuration, the $\mathrm{M}$ nasuta shells were cleaned with a scrub brush to minimize potential contamination of tissues during the dissection process. The tissues were then removed using titanium instruments and transferred to labeled containers for chemical analysis. The tissue samples were immediately sent to the analytical laboratory, where they were frozen until analysis.

\section{A.3 LIQUID-PHASE BIOLOGICAL TESTING}

The following sections describe the procedures used to prepare suspended-particulate phase (SPP) and elutriate samples, and to conduct acute toxicity tests with mysids (Holmesimysis costata) and larval mussels (Mytilus galloprovincialis). The toxicity testing procedures for SPP and elutriate samples are identical.

\section{A.3.1 Preparation of Suspended-Particulate and Elutriate Phase Samples}

The procedures used to prepare SPP and elutriate samples were adapted from those described in Development of a Modified Elutriate Test for Estimating the Quality of Effluent from Confined Disposal Areas (Palermo 1986). Figure 2.5 provides a graphical representation of the liquid-phase preparation and testing steps. Basically, a sediment-water slurry representative of the influent into a confined disposal area is created. The slurry is agitated under aerobic conditions, then allowed to settle undisturbed for $24 \mathrm{~h}$. The supernatant (SPP) is decanted for testing or for filtration to remove particles (elutriate phase). Low-speed centrifugation was substituted for 24-h settling because it saved preparation time. A pilot study indicated that the low-speed centrifugation resulted in a worse case scenario because fewer particulates were removed. High-speed centrifugation was substituted for filtration in the elutriate preparation step because the incompatibility of filter materials needed for the variety of chemical analyses (metals, pesticides, PAHs, butyltins) precluded the use of a single filtration system. The most important elements of the procedure were not changed: using a slurry (influent) concentration of 150 grams (g) dry sediment per liter of seawater, agitation under aerobic conditions, and the solid-liquid contact time (agitation time).

SPP was prepared by creating a $150 \mathrm{~g} / \mathrm{L}$ dry weight sediment-to-water slurry in $1-\mathrm{L}$ glass jars with Teflon-lined lids. Seawater from Richmond Harbor, used to make the slurry, was salinityadjusted to $30 \mathrm{ppt}$ with concentratedbrine. The proportion dry weight of each sediment composite was determined by drying five replicates of 10 to $20 \mathrm{~g}$ wet sediment each at $105^{\circ} \mathrm{C}$ for 
$2 \mathrm{~h}$. The dried sediment was cooled in a desiccator and reweighed; the dry weight was divided by the wet weight to obtain the proportion dry weight. Once the appropriate mass of wet sediment, calculated by dividing $150 \mathrm{~g}$ by the proportion of dry weight, was weighed into each jar, each was filled to $1 \mathrm{~L}$ with unfiltered Richmond Harbor seawater.

The jars of slurry were capped, placed on a shaker table, and agitated for $30 \mathrm{~min}$ at a rate of 120 to $150 \mathrm{cycles} / \mathrm{min}$. After shaking, the slurry was poured into $500-\mathrm{mL}$ Teflon containers with tightly fitting lids. These containers were placed in a centrifuge and spun for 10 to $15 \mathrm{~min}$ at approximately $1750 \mathrm{rpm}$. After this low-speed centrifugation, the supernatant SPP was poured into clean, labeled, 1-gal glass jars. When all SPP for a treatment was prepared, the appropriate containers for chemical analysis were filled and immediately stored at $4^{\circ} \pm 2^{\circ} \mathrm{C}$. The sample for metals analysis was acidified to $\mathrm{pH}<2$ with $0.1 \mathrm{~mL}$ of concentrated (18N) nitric acid.

Elutriate phase samples were immediately prepared from about 2 gal of the SPP liquid, while the remaining volume was stored at $4^{\circ} \pm 2^{\circ} \mathrm{C}$ to be used for toxicity tests within $24 \mathrm{~h}$. To prepare the elutriate, SPP was poured into $250-\mathrm{mL}$ Teflon bottles and centrifuged for $30 \mathrm{~min}$ at $2000 \mathrm{rpm}$. The supernatant (elutriate) was carefully poured into clean, labeled, 1-gal glass jars with Teflon-lined lids. When all elutriate for a treatment was prepared, the appropriate containers for chemical analysis were filled and immediately stored at $4^{\circ} \pm 2^{\circ} \mathrm{C}$. Samples were shipped to analytical laboratories within one day of preparation. Between preparation of SPP and elutriate from different sediment treatments, all glass and Teflon containers were appropriately cleaned according to procedures described in Section A.I _ I .

Approximately $8 \mathrm{~L}$ of additional elutriate from one composite was prepared to test whether filtration through a granular activated carbon (GAC) system would reduce the concentrations of organic contaminants. Half of the elutriate was filtered; the unfilteredportion was used as a control. In addition, Richmond Harbor site water was filtered and used as a control. The filtering system consisted of a 1.3-in.-diameter stainless steel cylinder with a stainless steel mesh screen at its base. The cylinder was filled with an 8-in. column of GAC (approximately $200 \mathrm{~mL}$ ) and capped with a glass wool plug. The flow rate through the column was adjusted to $2 \mathrm{~L} / \mathrm{h}$ with a teflon stopcock. The unfiltered and filtered elutriate samples were analyzed for pesticides and for acute toxicity to mysids.

\section{A.3.2 96-Hour Static Test with Holmesimvsis costata}

H. costata were received from Brezina and Associates in Dillon Beach, California, and were held in a 10-gal flow-through aquarium maintained at test temperature $\left(16^{\circ} \mathrm{C} \pm 2^{\circ} \mathrm{C}\right)$ for at least $48 \mathrm{~h}$ prior to testing. Water quality parameters were monitored daily, and $H$. costata were fed concentrated brine shrimp twice daily. 
The $\mathrm{H}$. costata tests were conducted in $400-\mathrm{mL}$ glass jars labeled with sediment treatment code, concentration, position number, and replicate number. Appropriate volumes of $100 \%$ SPP or elutriate and Richmond Harbor site water were combined in a clean, $1000-\mathrm{mL}$ glass graduated cylinder to make $0 \%, 10 \%, 50 \%$, and $100 \%$ SPP or elutriate concentrations for $\mathrm{H}$. costatatesting. The effect of filtering elutriate through GAC was also evaluated by testing both filtered and unfiltered $100 \%$ elutriate from one sediment treatment. A total of $600 \mathrm{~mL}$ of each concentration was prepared, from which the $200-\mathrm{mL}$ test volume was poured into each replicate chamber. Each chamber was then placed in its randomly assigned position on a controlled-temperature water table $\left(16^{\circ} \mathrm{C} \pm 2^{\circ} \mathrm{C}\right)$ and allowed to equilibrate to test temperature. Aeration was provided through glass pipettes connected to an overhead air manifold by silastic tubing.

After the concentrations were prepared and placed on the water table, each container was gently aerated, and water quality parameters were measured in all replicates of each sediment treatment. To initiate the test, $\mathrm{H}$ costata were transferredfrom the holding tank to test chambers with wide-bore pipettes. Ten individuals were added to each chamber to produce a test population of 30 individuals per concentration (120 individuals per treatment). Test initiation time and date were documented on data forms. After test initiation, water quality parameters were measured daily in one replicate concentration of each sediment treatment. Acceptable water quality parameters for this test were:

$\begin{array}{ll}\mathrm{DO} & 24.0 \mathrm{mg} / \mathrm{l} \\ \mathrm{pH} & \text { ambient k0.5 units } \\ \text { salinity } & 32 \pm 2.0 \mathrm{ppt} \\ \text { temperature } & 16^{\circ} \pm 2.0^{\circ} \mathrm{C}\end{array}$

Although the test plan called for a salinity of $32 \pm 2 \mathrm{ppt}$, the test was conducted at $30 \pm 2$ ppt because the SPP and elutriate had been prepared with Richmond Harbor water adjusted to the latter salinity. The test results should not be affected by this variation because $\mathrm{H}$. costata can tolerate a wide range of salinity. Observations of test organisms were performed at test initiation and at $4 \mathrm{~h}, 24 \mathrm{~h}, 48 \mathrm{~h}$, and $72 \mathrm{~h}$ using a light table to enhance visibility of the organisms. During the 96-h exposure, H. costata were fed $<24$-h-old brine shrimp daily. Excess food was removed with a small pipette; care was taken not to disturb test animals. Molted exoskeletons and any particulates from the liquid-phase solutions were also removed.

Prior to test termination, water quality parameters were measured in all replicates. At $96 \mathrm{~h}$, the number of live versus dead animals was recorded for each test container. An organism was considered dead if it did not respond to gentle probing. As a quality control check, a second observer confirmed surviving test organisms on at least $10 \%$ of the termination counts. 
A 96-h reference toxicant test was also conducted with each batch of $\mathrm{H}$. costata to establish the health and expected response of the test organisms. The reference toxicant test was conducted in the same manner as the liquid-phase tests. $H$. costata were exposed to a seawater control plus four concentrations of copper $(0.4 \mathrm{mg} / \mathrm{L}, 0.2 \mathrm{mg} / \mathrm{L}, 0.1 \mathrm{mg} / \mathrm{L}$, and $0.05 \mathrm{mg} / \mathrm{L})$ using three replicates of each treatment.

\section{A.3.3 48-Hour Static Test with Larval Mvtilus aalloprovincialis (formerly M. edulis)}

Adult bay mussels (M. galloprovincialis) were obtained from Carlsbad Aquafarms in Carlsbad, California. Mussels were held in flowing unfiltered Sequim Bay seawater at ambient temperatures for approximately five days. Chambers for the bivalve larvae test were $500-\mathrm{mL}$ glass jars labeled with sediment treatment code, concentration, position number, and replicate number. Concentrations of both SPP and elutriate $(0 \%, 10 \%, 50 \%$, and $100 \%)$ were prepared with unfiltered Richmond Harbor site water in a 100-mL graduated cylinder. Three hundred $\mathrm{mL}$ of test solution was poured directly into each test chamber. Test chambers were placed in random positions on a water table and each chamber was provided with gentle aeration. After test chambers reached testing temperatures $\left(16^{\circ} \mathrm{C} \pm 2^{\circ} \mathrm{C}\right)$, initial water quality was measured in all replicates.

Spawning was induced by placing the mussels into $15^{\circ} \mathrm{C}$, filtered Sequim Bay seawater and then rapidly raising the holding water temperature to $20^{\circ} \mathrm{C}$. Spawning occurred within $1 \mathrm{~h}$ of temperature elevation. Males and females were isolated in individual jars with filtered Sequim Bay seawater and allowed to shed gametes for approximately $45 \mathrm{~min}$. Eggs from each female were then filtered through a $75-\mu \mathrm{m}$ Nytex screen into separate jars to remove feces, detritus, and byssal fibers. Sperm from at least three males were pooled and $10 \mathrm{~mL}$ of sperm solution was then added to the egg stocks. Egg-sperm solutions were mixed every 10 min with a perforated plunger. Fertilization proceeded for $1 \mathrm{~h}$, then fertilization success (percent fertilized) was determined by removing a subsample and observing the number of multi-cell stage embryos. Fertilization was considered successful if greater than $90 \%$ of the eggs were in the multi-cell stage. To prevent polyspermy, egg stocks with greater than $90 \%$ fertilization were rinsed on a 20- $\mu \mathrm{m}$ Nytex screen to remove excess sperm. Stock embryo solution density was estimated by removing a $0.1-\mathrm{mL}$ subsample and counting all multi-cell embryos, then multiplying by 10 to yield embryo density (embryos $/ \mathrm{mL}$ ). Stock solution was diluted or concentrated to yield 7,500 to 9,000 embryos $/ \mathrm{mL}$. The test was initiated by introducing $1 \mathrm{~mL}$ of stock solution into each test chamber, to produce test embryo densities of $25-30$ embryos $/ \mathrm{mL}$. Test initiation date and time were recorded on data sheets. Following initiation, $10-\mathrm{mL}$ subsamples were removed from each container and preserved in $10 \%$ formaldehyde to determine the actual embryo stocking density. 
Water quality parameters were measured in one replicate per treatment daily throughout the test. Acceptable ranges for water quality parameters were:

$\begin{array}{ll}\text { DO } & 24.0 \mathrm{mgh} \\ \mathrm{pH} & \text { ambient } \pm 0.5 \text { units } \\ \text { salinity } & 30 \mathrm{ppt} \pm 2 \mathrm{ppt} \\ \text { temperature } & 16^{\circ} \pm 2^{\circ} \mathrm{C}\end{array}$

The bivalve test was terminated after $48 \mathrm{~h}$, at which time greater than $90 \%$ of the larvae in the controls had reached the $\mathrm{D}$-cell stage. Final water quality parameters were recorded for all replicates. Each chamber was then homogenized with a perforated plunger, and a 10-mL subsample removed and preserved with $1 \mathrm{~mL}$ of $50 \%$ formalin in seawater in a labeled, $20-\mathrm{mL}$ scintillation vial. Samples were scored for the appearance of normal D-shaped larvae, abnormal and blastula larvae, and total number of larvae. At least $10 \%$ of the counts were confirmed by a second observer.

Four 48-h reference toxicant tests were conducted with the SPP and elutriate tests to establish the health and expected response of the test organisms. Because not all SPP and elutriate treatments could be tested concurrently, a separate reference toxicant test was performed each day a set of tests was initiated to compare gamete sensitivity to a known toxicant. The reference toxicant test was set up and conducted in the same manner as the liquidphase tests. M. galloprovincialislarvae were exposed to a filtered Sequim Bay seawater control plus copper sulfate concentrations of $1 \mu \mathrm{g} / \mathrm{L}, 4 \mu \mathrm{g} / \mathrm{L}, 16 \mu \mathrm{g} / \mathrm{L}, 64 \mu \mathrm{g} / \mathrm{L}$, and $256 \mu \mathrm{g} / \mathrm{L}$ as copper, with three replicates per concentration in each test.

\section{A.4 ANALYTICAL CHEMISTRY}

The following sections briefly describe the methods used for the chemical analysis of sediment, tissue and water samples. Analyses follow established USEPA procedures as applicable. Vertical subsamples from sediment cores, grab samples, composite sediment samples for biological testing, and selected control sediments were analyzed for conventional parameters (percent solids, grain size, and total organic carbon), and chlorinated pesticides. Composite sediment samples from selected stations were analyzed for oil and grease, total petroleum hydrocarbons, PCBs, PAHs, metals, and butyltins. All M nasuta tissue samples were analyzed for chlorinated pesticides and percent lipids. Composite samples representing $\mathrm{M}$ nasuta tissues exposed to each sediment treatment were analyzed for PCBs, PAHs, metals, and butyltins. SPP and elutriate water samples were analyzed for chlorinated pesticides, PCBs, PAHs, metals, and butyltins. In addition, two water samples were analyzed for total petroleum hydrocarbons. Quality control samples included method blanks, matrix spike (MS) and matrix spike duplicate (MSD) samples, compositing duplicates (sediment only), and analytical 
duplicates. The method blanks, MS, and MSD samples were used to evaluate analytical accuracy. Compositing duplicates were used to evaluate the effect of compositing on the reproducibility of sample results. Analytical duplicates were used to evaluate analytical precision, as were the MS and MSD where applicable.

\section{A.4.1 Conventional Sediment Measurements}

Conventional sediment measurements consist of percent solids, grain size, and total organic carbon (TOC). Percent solids and grain size analysis were conducted by Soil Technology, Inc., of Bainbridge Island, Washington. The test samples were split into representative water content and grain size test samples. Percent solids was determined by oven-drying the samples at $105^{\circ} \pm 5^{\circ} \mathrm{C}$ for at least $8 \mathrm{~h}$ followed by cooling in a desiccator. The ratio of dry weight to wet weight was multiplied by 100 to determine the percent solids.

Four grain-size fractions were determined by a combination of sieve and hydrometer techniques. These methods are consistent with ASTM D-2217 (ASTM 1985) and ASTM D422 (ASTM 1972). Sediment was washed with distilled water through a U.S. No. $230(62.5 \mu \mathrm{m})$ sieve into a hydrometer cylinder to separate the fine (silt and clay) fraction from the coarse (sand and gravel) fraction. The coarse fraction was oven-dried and shaken through U.S. No. 10 (2 mm) and No. 230 sieves. The sediments retained in the sieves were weighed and recorded. The fraction passing the No. 230 sieve was added to the hydrometer cylinder, which is used to analyze the siltclay portion of the sample. The silt/clay boundary was interpolated using the 2-h and 4-h hydrometer readings plotted in a graphical format. Duplicate analysis at a frequency of 1 per 20 samples was performed as a quality control measure.

TOC is the amount of non-volatile, partially volatile, volatile, and particulate organic carbon compounds in a sample. Analysis of TOC was performed by Global Geochemistry in Canoga Park, Califomia. Each sediment sample was dried and ball-milled to a fine powder. Inorganic carbon in the sample was removed by acidification before combustion. The TOC in sediment was then determined by measuring the carbon dioxide released during combustion of the sample (SW-846 Method 9060, USEPA 1986), and reported as percent of dry weight. Quality control measures to assess precision included duplicate analysis at a frequency of 1 per 20 samples. MS samples are not applicable to the combustion method of TOC analysis.

\section{A.4.2 Chlorinated Pesticides}

Analyses for chlorinated pesticides in sediment, tissue, and water samples were performed by Battelle Ocean Sciences (BOS) in Duxbury, Massachusetts. Chlorinated pesticides were quantified by gas chromatography with electron capture detection (GC/ECD) following USEPA SW-846 Method 8080 (USEPA 1986). Chlorinated pesticides were extracted from sediment samples following the low-level methods for extraction of pesticides from soil 
(SW-846). The procedure involved a methylene chloride/acetone mixture extraction using sonication (for sediments) or a Tekmar tissuemizer (for tissues). Water samples were extracted with methylene chloride in a separatory funnel. A portion of the methylene chloride extract was solvent- exchanged to hexane, and interferences were removed through Florisil and gel permeation chromatography (GPC) cleanup. Analytical quantification was performed using GC/ECD analysis, with second column qualitative confirmation.

Three surrogate compounds [DBOFB, CL5(112), and CL5(103)] were added to each sample before extraction to assess extraction efficiency. Quality control samples included a method blank, duplicate, MS, and MSD analysis at a minimum frequency of 1 per 20 samples. The matrix spiking solution consisted of six pesticide compounds.

\section{A.4.3 Oil and Grease and Total Petroleum Hvdrocarbons}

Total oil and grease includes vegetable oils, animal fats, soaps, waxes, and any other carbon-hydrogen material extractable by the solvent Freon. Total petroleum hydrocarbons comprise the nonpolar mineral fraction of total oil and grease that is not removed by silica gel absorption. These analyses were performed by Analytical Resources, Inc., of Seattle, Washington. Infrared spectrophotometry (IR) was used to determine concentrations of oil and grease (Method 413.2, USEPA 1979) and total petroleum hydrocarbons (Method 418.1, USEPA 1979). A 20-g aliquot of sample was dried with an excess of anhydrous sodium sulfate, then extracted with Freon. For total oil and grease, sample extracts were scanned from 4000 to $600 \mathrm{~cm}^{-1}$ on an infrared spectrophotometer and the peak height measured at $2930 \mathrm{~cm}^{-1}$. This wavelength represents the $-\mathrm{CH}_{2}$ configurations of hydrocarbons and was the standard used to determine oil and grease. For total petroleum hydrocarbons, silica gel was added to the extract to remove the more polar animal- and vegetable-based oils. The extract was then shaken and allowed to settle. An aliquot was then removed and scanned in the same manner as for the oil and grease sample. The relationship of peak height to oil concentration was determined by regressing the peak height versus a known concentration of fuel oil. Quality control samples included method blanks, MS/MSD samples, and analytical duplicates.

\section{A.4.4 Polvnuclear Aromatic Hvdrocarbons and Polychlorinated Biphenyls}

Sediment, tissue and water samples were analyzed for 16 PAHs listed in USEPA Method 610 (USEPA 1986) and for PCBs as Aroclors. Analyses were performed by BOS. These compounds were extracted with the solvent methylene chloride, following the methods used by NOAA for its Status and Trends monitoring program. The surrogate compounds naphthalene-d8, acenaphthene-d10, and benzo(a)pyrene-d12 were added to all samples for PAH analysis prior to extraction to assess extraction efficiency. The surrogate compounds DBOFB, CL5(112), and 
CL5(103) were added to samples for PCB analysis. A portion of the extract was used for PAH analysis by gas chromatography/mass spectroscopy in the Selective Ion Mode (GC/MS SIM) following USEPA SW-846 Method 8270 (USEPA 1986). Tissue extracts were run through a phenogel size-exclusion high pressure liquid chromatograph (HPLC) prior to analysis to remove any additional interferences. PCBs were quantified by gas chromatography with electron capture detection (GC/ECD) following USEPA SW-846 Method 8080 (USEPA 1986). Quality control samples included a method blank, MS, MSD, and analytical duplicate for each batch of samples.

\section{A.4.5 Metals}

Ten metals were measured in sediments and tissues: silver (Ag), arsenic (As), cadmium $(\mathrm{Cd})$, chromium $(\mathrm{Cr})$, copper $(\mathrm{Cu})$, mercury $(\mathrm{Hg})$, nickel $(\mathrm{Ni})$, lead $(\mathrm{Pb})$, selenium $(\mathrm{Se})$, and zinc (Zn). Samples of sediment, $M$. nasuta tissue, and water were analyzed using four methods: 1) energy-diffusive $x$-ray fluorescence (XRF);2) Zeeman graphite-furnace atomic absorption spectroscopy (GFAA), following USEPA SW-846 Method 7000 (USEPA 1986) and the method of Bloom and Crecelius (1984); 3) cold-vapor atomic absorption spectroscopy (CVAA), according to USEPA SW-846 Method 7471 (USEPA 1986) and the method of Bloom and Crecelius (1983); and 4) inductively coupled plasma mass spectrometry (ICP/MS), following USEPA Method 200.8 (USEPA 1990). Analyses were performed by the Pacific Northwest Laboratory (PNL) in Richland, Washington, and the MSL. The analytical methods for each sample matrix and the corresponding metals for which each method was used are presented in Table A.1.

To prepare sediment and tissues for analysis, samples were freeze-dried, then blended in a Spex mixer-mill. Approximately $5 \mathrm{~g}$ of mixed sample was ground in a ceramic ball mill. The XRF analysis was performed on a $0.5-\mathrm{g}$ aliquot of this dried, ground material pressed into a pellet with a diameter of $2 \mathrm{~cm}$. For GFAA, CVAA, and ICP/MS analyses, $0.2-$ to $0.5-\mathrm{g}$ aliquots of dried homogeneous sample went through an acid digestion process to separate and isolate the metals from the matrix. Sediment samples were digested with a mixture of nitric, perchloric, and hydrofluoric acids. Tissues were digested using nitric and perchloric acids.

Quality control measures for metals analyses included analysis of blanks, matrix spikes (blanks and spikes are not applicable to XRF technique), and duplicate analyses for each batch of up to 20 samples, and analysis of a standard reference material (SRM) for metals analyzed by XRF at a frequency of at least 1 per 20 samples. The SRM for sediment was SRM 1646 (obtained from the National Institute of Standards and Technology). The tissue SRM was an oyster tissue, 1566a, obtained from National Research Council of Canada. 
TABLE A.1. Analytical Method and Corresponding Metal for Each Sample Matrix

\begin{tabular}{|c|c|c|}
\hline \multicolumn{3}{|c|}{ Sediment } \\
\hline XRF & F A A & CVAA \\
\hline As & $\mathrm{Ag}$ & $\mathrm{Hg}$ \\
\hline $\mathrm{Cu}$ & $\mathrm{Cd}$ & \\
\hline $\mathrm{Cr}$ & $\mathrm{Se}$ & \\
\hline $\mathrm{Ni}$ & & \\
\hline $\mathrm{Pb}$ & & \\
\hline $\mathrm{Zn}$ & & \\
\hline
\end{tabular}

\begin{tabular}{lcc}
\multicolumn{3}{c}{ Mnasuatissue } \\
\hline XBE & CVAA & GFAA \\
$\mathrm{As}$ & $\mathrm{Hg}$ & $\mathrm{Ag}$ \\
$\mathrm{Cu}$ & & $\mathrm{Cd}$ \\
$\mathrm{Se}$ & & $\mathrm{Cr}$ \\
$\mathrm{Zn}$ & & $\mathrm{Pb}$ \\
$\mathrm{Ni}$ & &
\end{tabular}

\begin{tabular}{|c|c|c|c|}
\hline \multicolumn{4}{|c|}{ Water. } \\
\hline$\underline{\mathrm{HAA}}$ & GFAA & $\mathrm{ICP} / \mathrm{MS}$ & CVAF \\
\hline$\overline{\text { As }}$ & $\mathrm{Cr}$ & $\mathrm{Ag}$ & $\overline{\mathrm{Hg}}$ \\
\hline & $\mathrm{Se}$ & Cd & \\
\hline & $\mathrm{Zn}$ & $\mathrm{Cu}$ & \\
\hline & & $\mathrm{Ni}$ & \\
\hline & & $\mathrm{Pb}$ & \\
\hline
\end{tabular}

\section{A.4.6. Butyltins}

Butyltin compounds in sediment, tissue and water were analyzed using gas chromatographylflame photometric detection (GC/FPD) following the methods of Unger et al. (1986). Butyltins were analyzed at MSL. Wet samples were extracted with methylene chloride and tropolone using a roller under ambient conditions. Water samples were extracted with methylene chloride using a separatory funnel. The surrogate compound tripentyltin chloride was added before extraction to assess extraction efficiency. The di- and tributyltin compounds extracted from the sediment and tissues were derivatized to a less volatile, more thermally stable form (nonionic n-hexyl or n-pentyl derivatives). The extracts were passed through a florisil liquid chromatography column for cleanup, and the butyltins were quantified by GCIFPD. Samples were spiked with di- and tributyltins prior to extraction to assess the accuracy of the procedure. Method blanks and analytical duplicates were analyzed with each batch of samples.

\section{A.4.7 Lipid Content}

The percent lipid content in $M$. nasuta tissue samples was determined by BOS. This investigation required that lipid weights be determined by the method of Bligh and Dyer (1959), as recommended by Lee et al. (1989) to ensure comparability of data from various bioaccumulationstudies. The Bligh and Dyer method calls for a separate extraction of tissue from the extraction prepared for chemical analysis, which requires a large volume of tissue mass.

BOS used its standard method for lipid determination and calibrated its results to the Bligh and Dyer method to conserve sample material. Prior to the analysis of tissue samples, a composite of 30 tissue samples was analyzed in triplicate by both the BOS and Bligh and Dyer methods. An 
algebraic relationship between the results of the two methods was determined using the following formula:

Bligh and Dyer Lipid Weight $(\mathrm{g})=$ BOS Lipid Weight $(\mathrm{g})$ X Correction Factor

where the Correction Factor is 0.4594 (average Bligh and Dyer Weight/average BOS Weight).

This conversion factor was used to convert lipid weights obtained by BOS to Bligh and Dyer "equivalent" lipids weights.

\section{A.4.8 Total Suspended Solids}

SPP and elutriate water samples were analyzed for total suspended solids. Well-mixed water samples were filtered through a standard glass fiber filter and the filter, containing nonfilterable residue, was dried in a tared crucible for at least $4 \mathrm{~h}$ at $105^{\circ} \pm 5^{\circ} \mathrm{C}$. The crucible was cooled in a desiccator, then weighed. The increase in crucible weight represents the total suspended solids.

\section{A.5 DATA ANALYSIS}

This section describes the methods used to estimate sediment volumes and average total DDT concentrations in sediment. Survey and elevation data for the mudline and depth to OBM (as measured in the 12-in. cores) were compiled and used to calculate the thickness of the YBM at each station. These data were used to generate models of the YBM thickness in the following discrete segments of the study area: the Lauritzen Canal, Santa Fe Channel, the northern portion of the Inner Harbor Channel, and the Inner Harbor Channel north of Stations $\mathrm{IH}-42, \mathrm{IH}-45$, and $\mathrm{IH}$ 46. A 50-ft grid spacing was used to model the YBM thickness in the Lauritzen Canal and Santa Fe Channel; a 100-ft grid spacing was used for the Inner Harbor Channel. Grids were created using three different computer surface modeling programs: Surfer, Surface III+, and Quicksurf. In Surfer and Surface III+, the YBM thickness at each grid node was calculated from the data points using a distance-weighted averaging algorithm and nearest neighbor search. The weighting varied inversely with the square of the distance between the grid node and the nearest data points. In Quicksurf, a triangulatedirregular network (TIN) was constructed from the data points using the Delauney criterion, and a grid was created by calculating a polynomial equation for each TIN face and evaluating the equation for each grid node on the face. The volume of YBM in each segment of the study area was estimated in each modeling program by integrating the 3-dimensional solid formed by a planar lower surface with zero thickness, and an upper surface consisting of the grid of YBM thickness. The mean and standard deviation of the three volume estimates yielded by these programs were reported. 
The weighted average total DDT concentration in the YBM at each coring station was calculated using the following formula:

$$
\mathrm{C}_{\mathrm{av}}=\frac{\Sigma(\mathrm{C} \times \mathrm{T})}{\Sigma T}
$$

where $\mathrm{C}_{\mathrm{av}}=$ average total DDT concentration at station

$\mathrm{C}=$ total DDT concentration in sample

$\mathrm{T}=$ thickness of YBM sample segment

The weighted average total DDT concentration for the YBM in each segment of the study area was calculated by generating two grids of equal size for each segment using the Surfer modeling program. One grid contained estimated values for YBM thickness at each grid node, and the other contained weighted average total DDT concentrations at each grid node. The two grids were multiplied, and the resultant values were summed and divided by the total thickness of YBM using the following formula:

$$
\mathrm{C}_{\mathrm{vol}}=\Sigma(\mathrm{C} \times \mathrm{T})
$$

$\Sigma T$

where $C_{\mathrm{vol}}=$ average total DDT concentration of volume of sediment

$\mathrm{C}=$ average total DDT concentration at each grid node

$\mathrm{T}=$ Thickness of YBM at each grid node

\section{A.6 QUALITY ASSURANCE/OUALITY CONTROL PROCEDURES}

The quality assurance/quality control (QAVC) procedures followed in this investigation were documented by PNL Quality Engineering Division in the Quality Assurance Project Plan (QAPP). Laboratory notebooks (Data Accumulation Notebooks) were assigned to each portion of the study and served as records of day-to-day activities during sample preparation and toxicity testing. All entries in the laboratory notebooks were signed, dated, and reviewed by the project manager. The following discussion summarizes QAQC procedures followed for sediment sampling, biological testing, and chemical testing.

\section{A.6.1 Sample Trackina and Storage}

All sediment samples were accompanied by chain-of-custody forms from the time of collection to receipt at MSL. After sample compositing, a new set of custody forms was initiated for the sediment subsamples requiring chemical analyses. These accompanied the samples to 
the appropriate laboratory, where the forms were signed and returned to the MSL project manager. Custody forms were also initiated for all tissue samples upon completion of the biological testing. These forms accompanied the samples to the appropriate laboratory for chemical analyses.

All sediment collected for these studies was stored in glass, Lexan containers, or steel drums lined with 9-C-4-A-phenolic epoxy, a non-contaminating coating. Sediment samples were stored at $4^{\circ} \pm 2^{\circ} \mathrm{C}$ prior to biological testing. Subsamples of sediment for chemical analyses and archival were obtained prior to biological testing. These subsamples were stored frozen (approximately $-20^{\circ} \mathrm{C}$ ) until chemical analyses were performed. Samples for grain size and organic analyses were held at $4^{\circ} \pm 2^{\circ} \mathrm{C}$. Samples for metals analysis were freeze dried upon receipt at the laboratory and held less than six months.

\section{A.6.2 Quality Control Procedures for Sediment and Tissue Chemistry}

QAVC guidelines specific to this project are described in the QAPP for this project. These QC guidelines include the following, where applicable:

- $\quad$ analysis of a method blank with each batch

- analysis of surrogate internal standards with each sample analyzed for organic compounds

- analysis of MS/MSD at a frequency of $5 \%$ (as applicable)

- duplicate analyses at a frequency of $5 \%$.

Accuracy can be measured by analyzing MS and surrogate spikes of known concentrations. The MS samples were analyzed for selected metals and organic parameters. Percent recoveries were calculated based on the differences between the amount spiked and the amount recovered in the sample. Surrogate compounds were added in known amounts to samples analyzed for PCBs, pesticides, PAHs, and butyltins. Surrogate compounds were added to samples prior to extraction, and their recoveries were a measurement of the efficiency or procedural accuracy of the analysis.

Measurements of precision were obtained through replicate analysis of selected sediment samples. Replicate analyses quantify the repeatability of the measurements as well as intersample variability and efficiency of compositing. The measurements of precision are the industrial statistic (I-stat) and relative percent difference (RPD) for duplicate analyses. The I-stat is defined as the absolute value of the difference between duplicate measurements divided by the sum of the duplicates. The RPD is defined as the absolute value of the difference between two duplicate measurements, divided by the mean of the duplicates, multiplied by 100 . All instrument printouts and other raw data generated using MSL analytical instruments are filed at MSL for future reference. Procedures and related data were written into the appropriate Data 
Accumulation Notebooks. Copies of data generated by offsite analytical facilities are maintained at the MSL.

\section{A.6.3 Toxicoloaical Testina Qualitv Control Procedures}

Appropriate procedures for organism care were maintained from collection through testing. Organisms shipped to MSL were gradually acclimated to test conditions and kept in their native sediment whenever possible. Animals were fed if necessary before biological testing. Selection of species was consistent with the 1991 Implementation Manual. Representatives of all test organisms were taxonomically identified by qualified experts at MSL before use in testing. During testing, water quality parameters were measured to ensure that acceptable experimental conditions were maintained. These conditions included a stable temperature $\left( \pm 2.0^{\circ} \mathrm{C}\right)$, minimum DO representing at least $60 \%$ saturation ( $40 \%$ in some cases) and controlled levels of light each day. Salinity and $\mathrm{pH}$ were permitted to vary within narrow ranges, as defined in the Toxicological Testing Plan. Water quality instruments were calibrated according to the manufacturer's specification or PNL protocols.

\section{A.7 REFERENCES}

ASTM (American Society for Testing and Materials). 1972. "Standard Method for Particle-Size Analysis of Soils: Procedure D422." American Society for Testing and Materials. Philadelphia, Pennsylvania.

ASTM (American Society for Testing and Materials). 1984. "Standard Practice for Description and Identification of Soils (visual-manual procedure): Procedure D2488-84." American Society for Testing and Materials. Philadelphia, Pennsylvania.

ASTM (American Society for Testing and Materials). 1985. "Standard Method for Wet Preparation of Soil Samples for Particle-Size Analysis of Soils: Procedure D2217." American Society for Testing and Materials. Philadelphia, Pennsylvania.

Bligh, E. G. and W. J. Dyer. 1959. "A Rapid Method of Total Lipid Extraction and Purification." Canadian Journal of Biochemical of Physiology 37:911-917.

Bloom N. S. and E. A. Crecelius. 1983. "Determination of Mercury in Seawater at Sub-Nanogram per Liter Levels." Marine Chemistry 14:49-59.

Bloom, N. S. and E. A. Crecelius. 1984. "Distribution of Silver, Mercury, Lead, Copper, and Cadmium in Central Puget Sound Sediments." Marine Chemistry21:377-390.

Lee, H., B. Boese, J. Pelletier, M. Winsor, D. Specht, R. Randall. 1989. "EPA Guidance Manual: Bedded Sediment Bioaccumulation Tests." EPA/600/x-89/302 ERLN-N111. U.S. Environmental Protection Agency, Pacific Ecosystems Branch, Bioaccumulation Team. Newport, Oregon.

Palermo, M. R. 1986. "Development of a Modified Elutriate Test for Predicting the Quality of Effluent From Confined Dredged Material Disposal Areas." Technical Report D-86-4, U.S Army Engineer Waterways Experiment Station, Vicksburg, Mississippi.

Unger, M., W. Maclntyre, J. Greaves, and R. Huggett. 1986. "GC Determination of Butyltins in Natural Waters by Flame Photometric Detection of Hexyl Derivatives with Mass Spectrometric Confirmation." Chemosphere 15(4):461-470. 
USEPA (United States Environmental Protection Agency). 1986. "Test Methods for Evaluating Solid Waste: Physical/Chemical Methods." EPA-955-001-00000, U.S. Environmental Protection Agency, Government Printing Office, Washington D.C.

USEPA (United States Environmental Protection Agency). 1979. "Test Methods for Evaluating Solid Waste: Physical/Chemical Methods." EPA-600-4-79-020 Methods 413.2, 418.1, Environmental Monitoring and Support Laboratory, Cincinnati, Ohio.

USEPA (United States Environmental Protection Agency). 1990. "Determination of Metals and Trace Elements by Inductively-Coupled Plasma Mass Spectrometry, March 1990." Method 200.8. March 1990 Government Printing Office, Washington D.C. 

APPENDIX B

GEOLOGIC CORE DATA LOGS 



\section{KEY TO CORE DATA LOGS}

\section{LITHOLOGY}

\begin{tabular}{|c|c|}
\hline & Clav \\
\hline$\equiv$ & \\
\hline & Silt \\
\hline 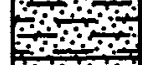 & Sandy silt/silty sand \\
\hline n & Sand \\
\hline $0_{0}^{\circ}$ & Pebbles \\
\hline 2 & Shells \\
\hline$\lambda \lambda$ & Roots/organic matter \\
\hline
\end{tabular}

\section{TYPE}

GW Well-graded gravels, gravel-sand mixtures

GP Poorly-graded gravels, gravel-sand mixtures

GM Silty gravels, gravel-sand-siltmixtures

GC Clayey gravels, gravel-sand-clay mixtures

SW Well-graded sands, gravelly sands

SP Poorly-graded sands, gravelly sands

SM Silty sands, sand-silt mixtures

SC Clayey sands, sand-clay mixtures

ML Silts and very fine sands, silty or clayey fine sands, or clayey silts, with slight plasticity

CL Clays of low to medium plasticity, gravelly clays, sandy clays, silty clays, lean clays

$\mathrm{MH}$ Silts or fine sandy silts with moderate plasticity

$\mathrm{CH}$ Clays of high plasticity, fat clays
CEMENTATION

$\mathrm{N}=$ Not cemented

$\mathrm{W}=$ Weakly cemented

$M=$ Moderately cemented

$\mathrm{S}=$ Strongly cemented

\section{STRUCTURE}

$\mathrm{H}=$ Homogeneous

$\mathrm{S}=$ Stratified

$\mathrm{L}=$ laminated

$\mathrm{M}=$ Mottled

\section{HCI REACTION}

$\mathrm{N}=$ None

$\mathrm{W}=$ Weak

$\mathrm{S}=$ Strong

MAXIMUM PARTICLE SIZE

$\mathrm{CS}=$ Coarse sand

$\mathrm{MS}=$ Medium sand

$\mathrm{FS}=$ Fine sand

VFS $=$ Very fine sand

$\mathrm{Z}=$ silt

ODOR

$\mathrm{N}=$ None

$\mathrm{S}=$ Sulfide

$\mathrm{P}=$ Petroleum
COLOR

Selected from Munsell Soil Color Chart

\section{CONSISTENCY}

Penetration of thumb:

$<0.25 \mathrm{~cm}=$ hard

$0.25-2.0 \mathrm{~cm}=$ firm

$2.0-4.0 \mathrm{~cm}=\mathrm{soft}$

$>4.0 \mathrm{~cm}=$ very soft

B.i

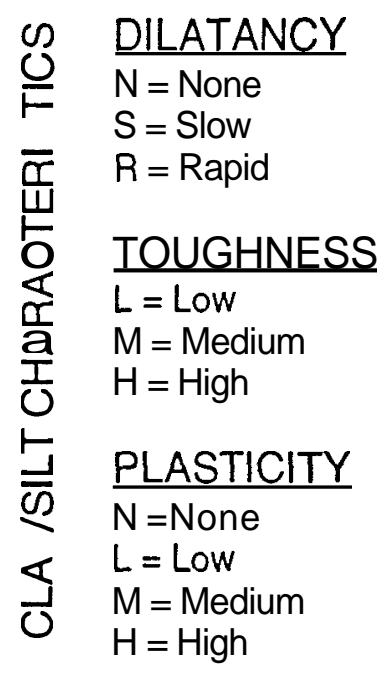



Project: Heckathorn

Core Data Log

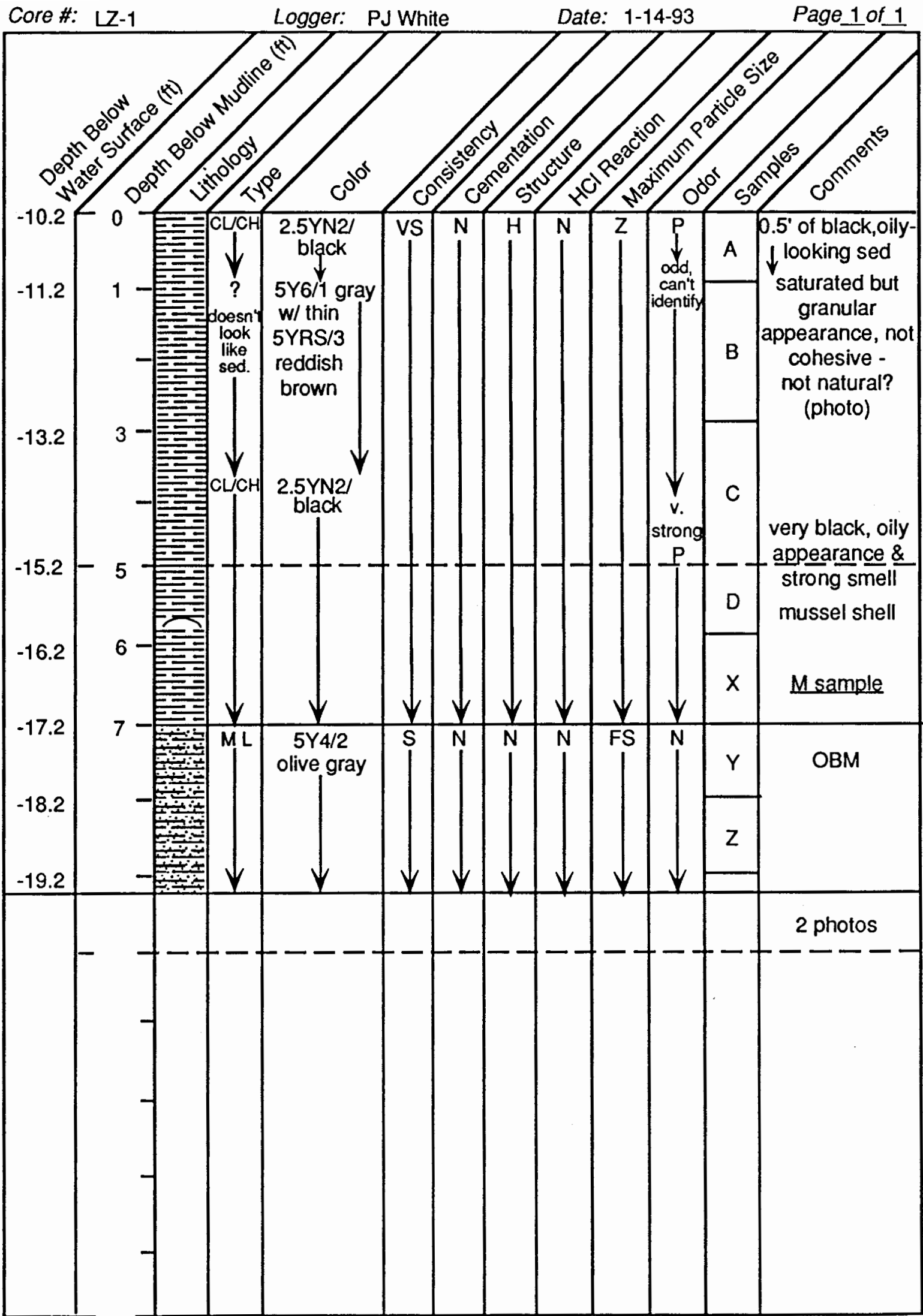

B.1 


\section{Core Data Log}

Project: Heckathom

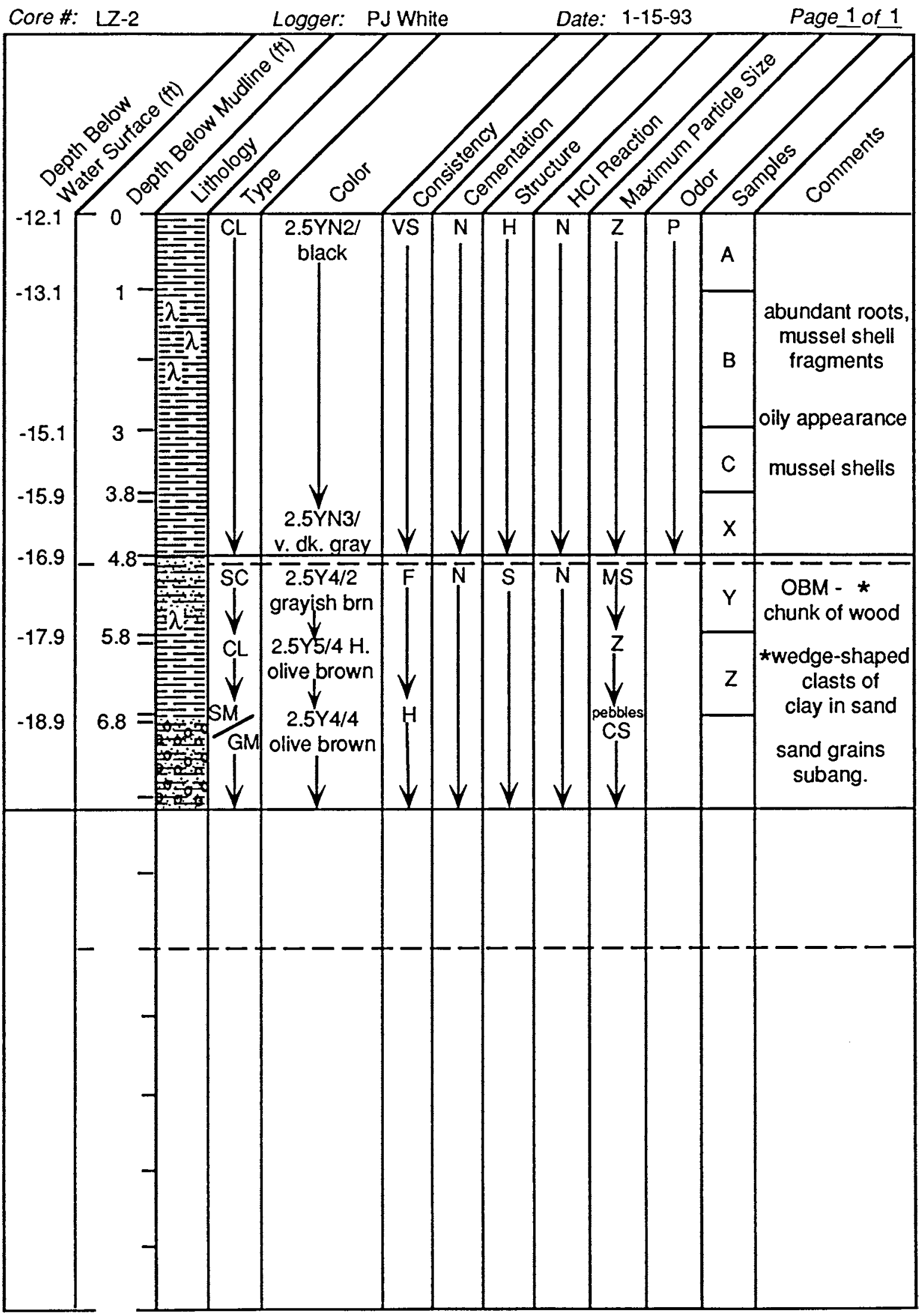

B. 2 
Project: Heckathorn

\section{Core Data Log}

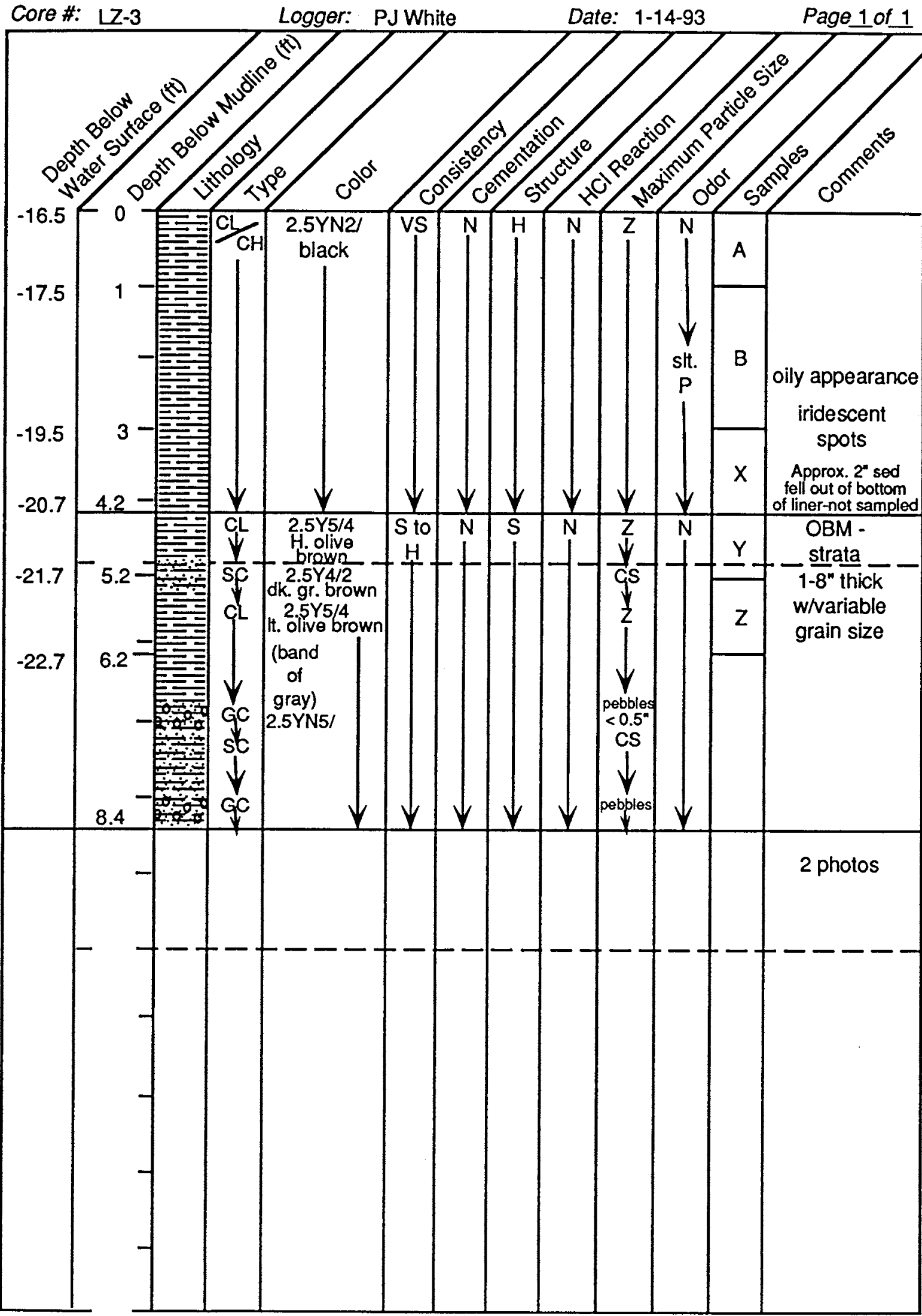

B. 3 


\section{Core Data Log}

Project: Heckathom

Core \#: LZ-5 Logger: PJ White Date: 1-15-93 Page 1 of 1

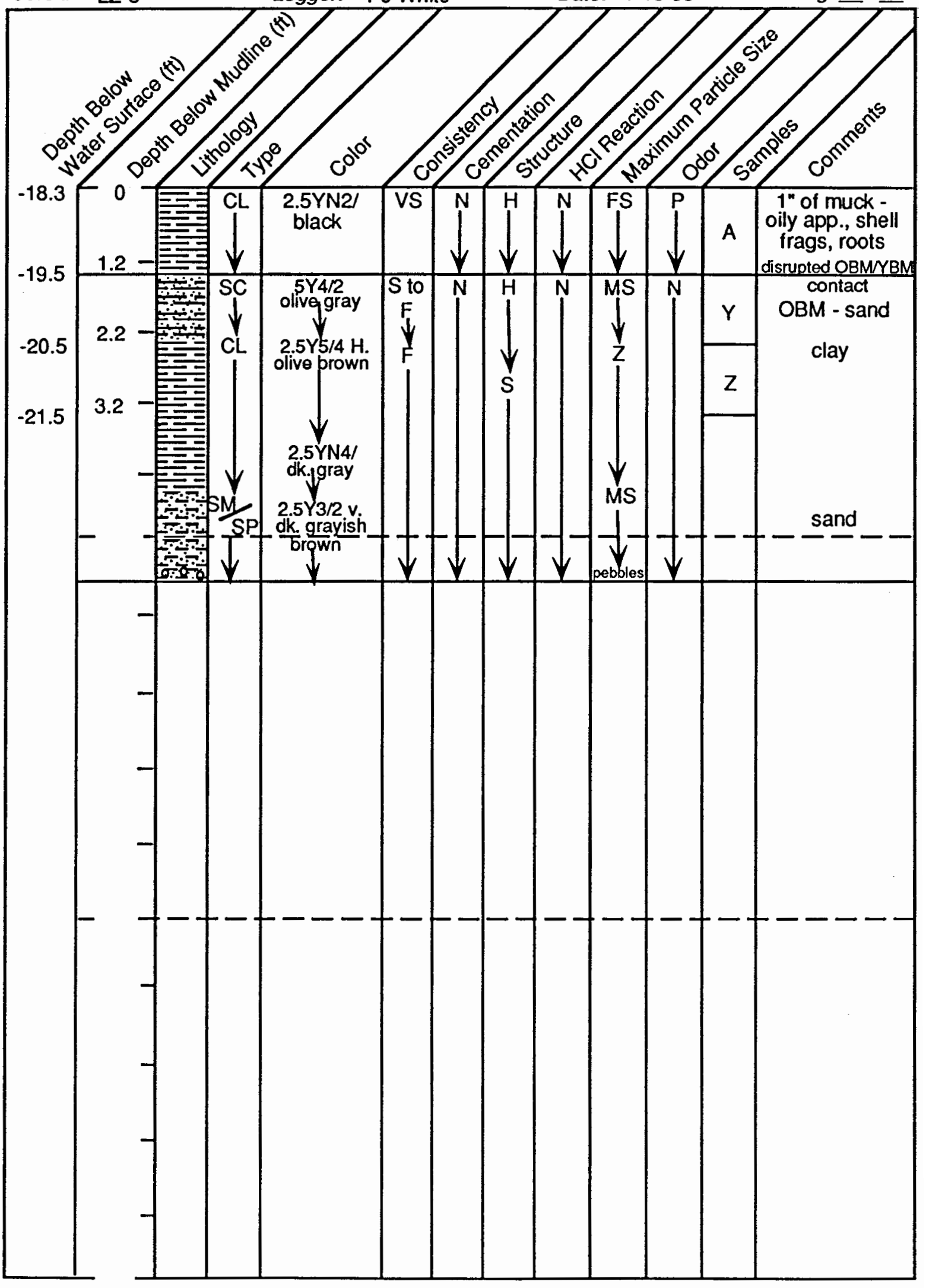




\section{Core Data Log}

Project: Heckathom

Core \#: LZ-6 Logger: PJ White

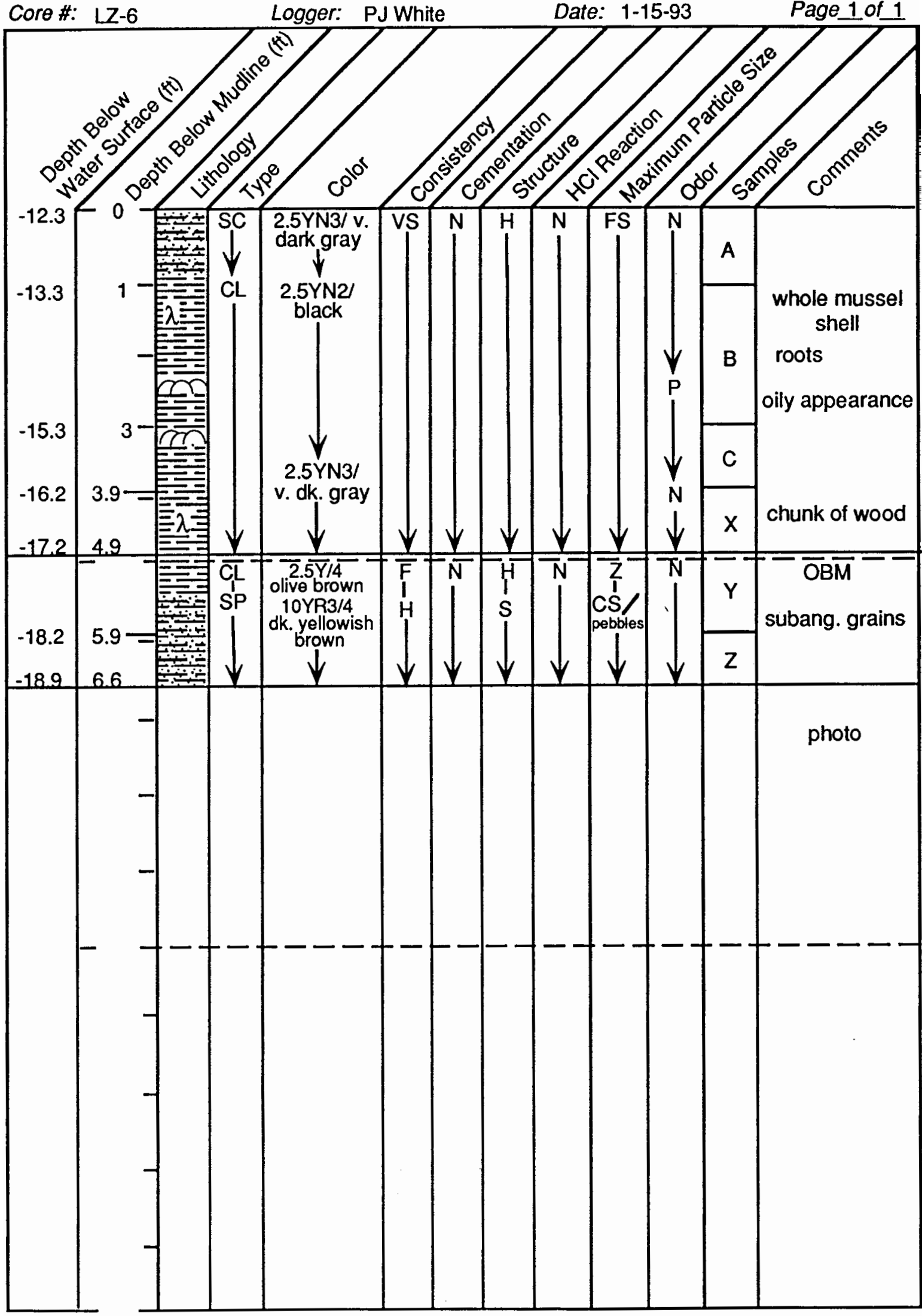

B. 5 
Core Data Log

Project: Heckathom

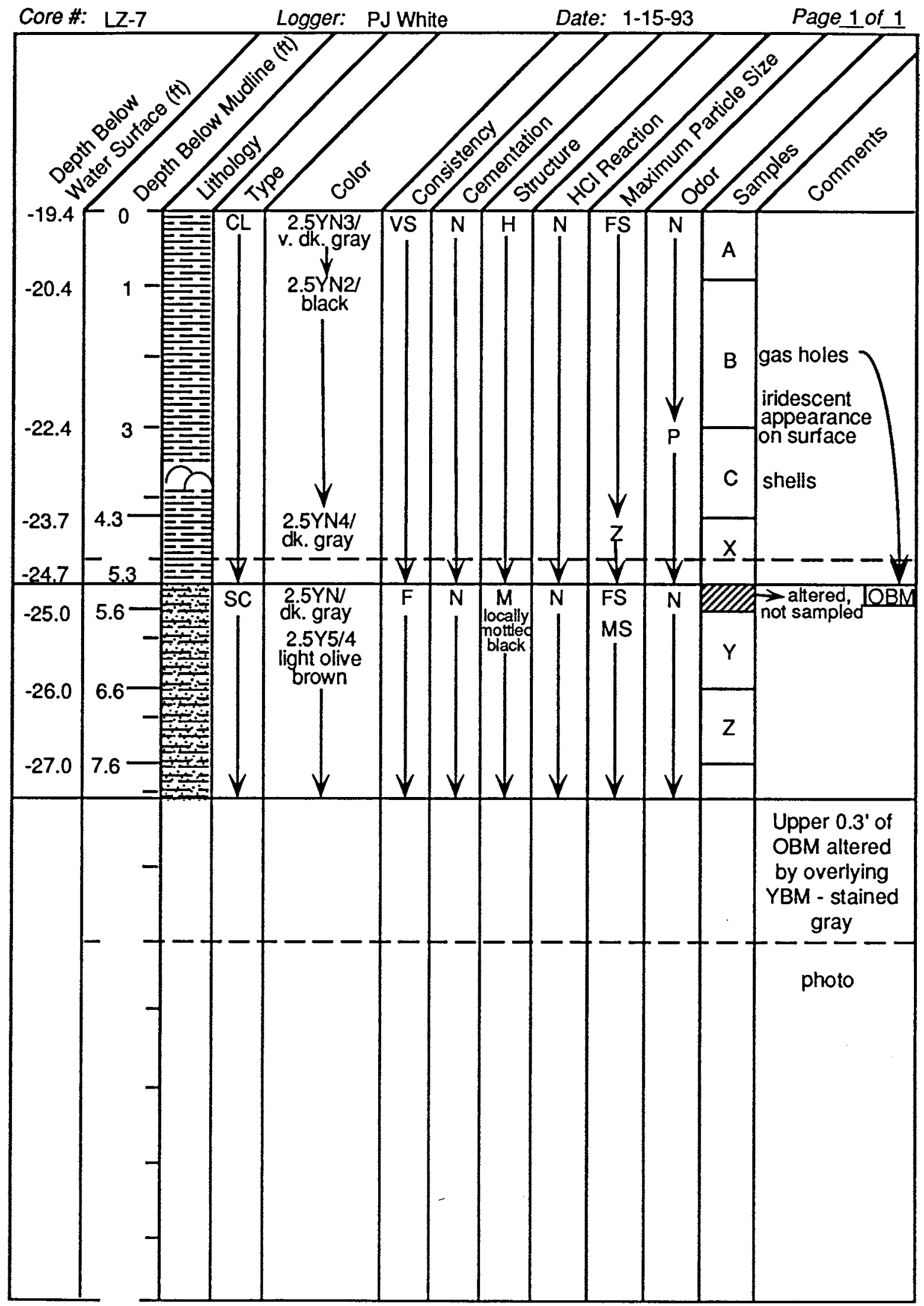

B. 6 
Project: Heckathorn

Core Data Log

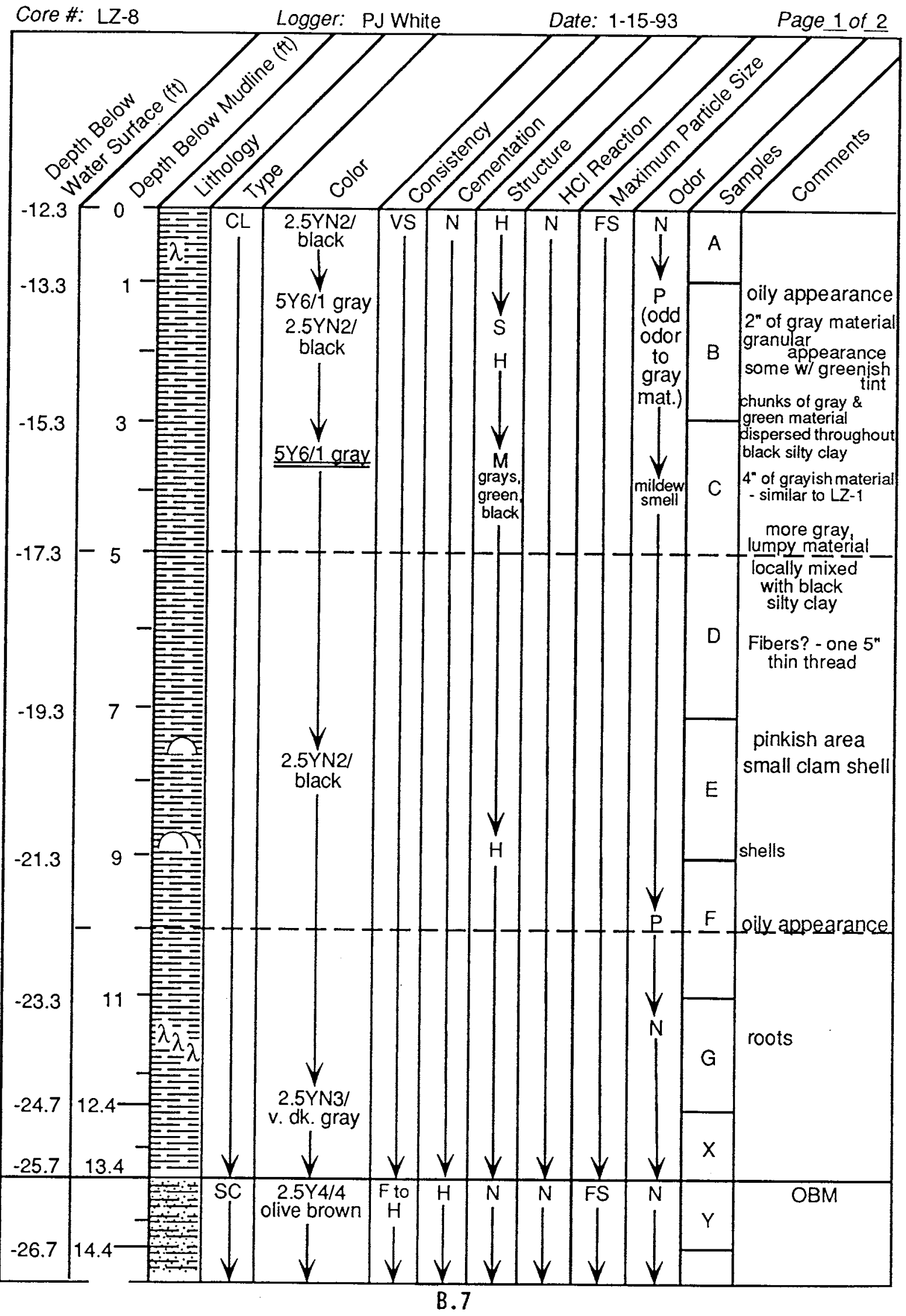


Core Data Log

Project: Heckathorn

Core \#: LZ-8 (cont'd) Logger: PJ White

Date: $1-15-93$

Page_2of 2

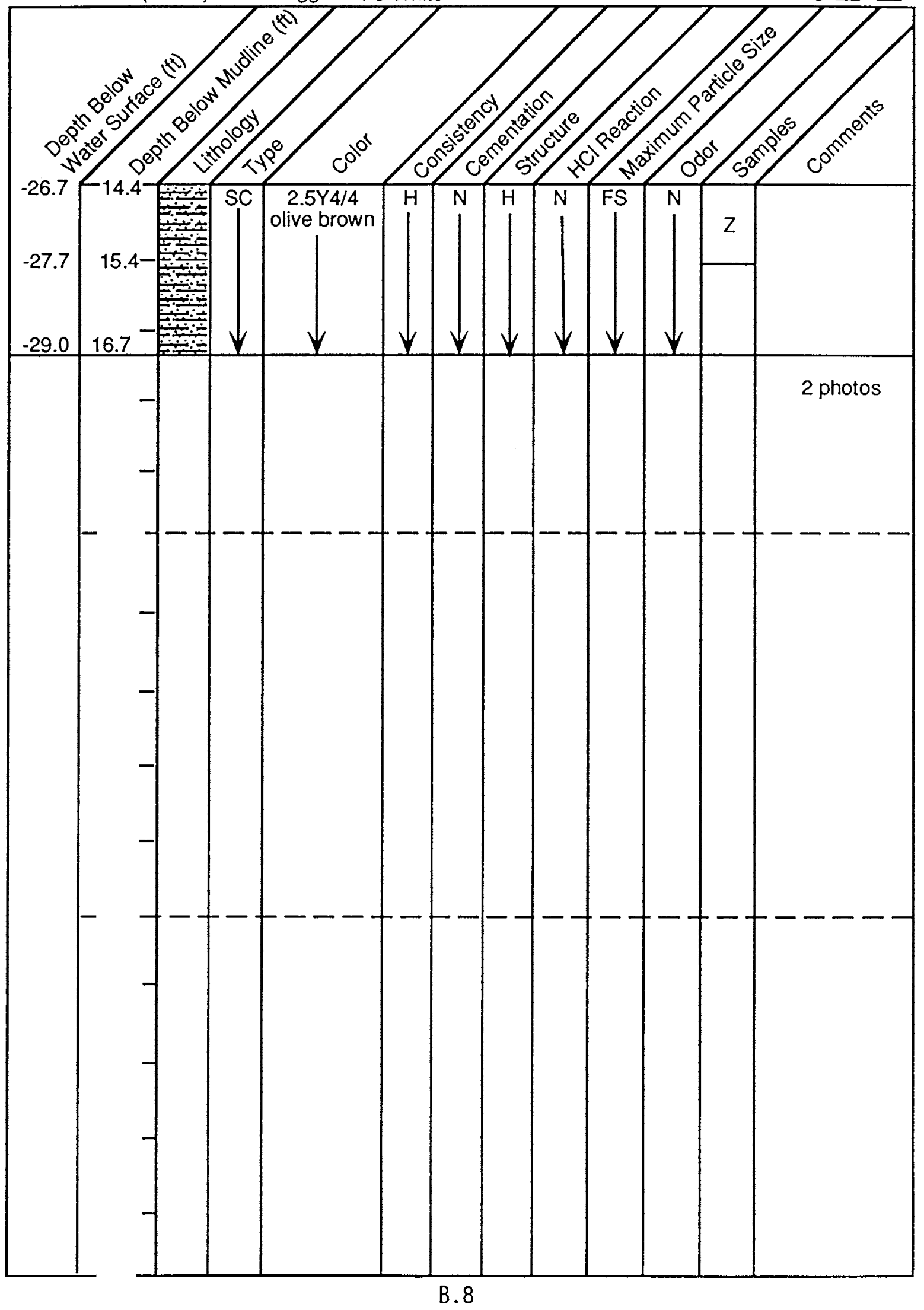




\section{Core Data Log}

Project: Heckathorn

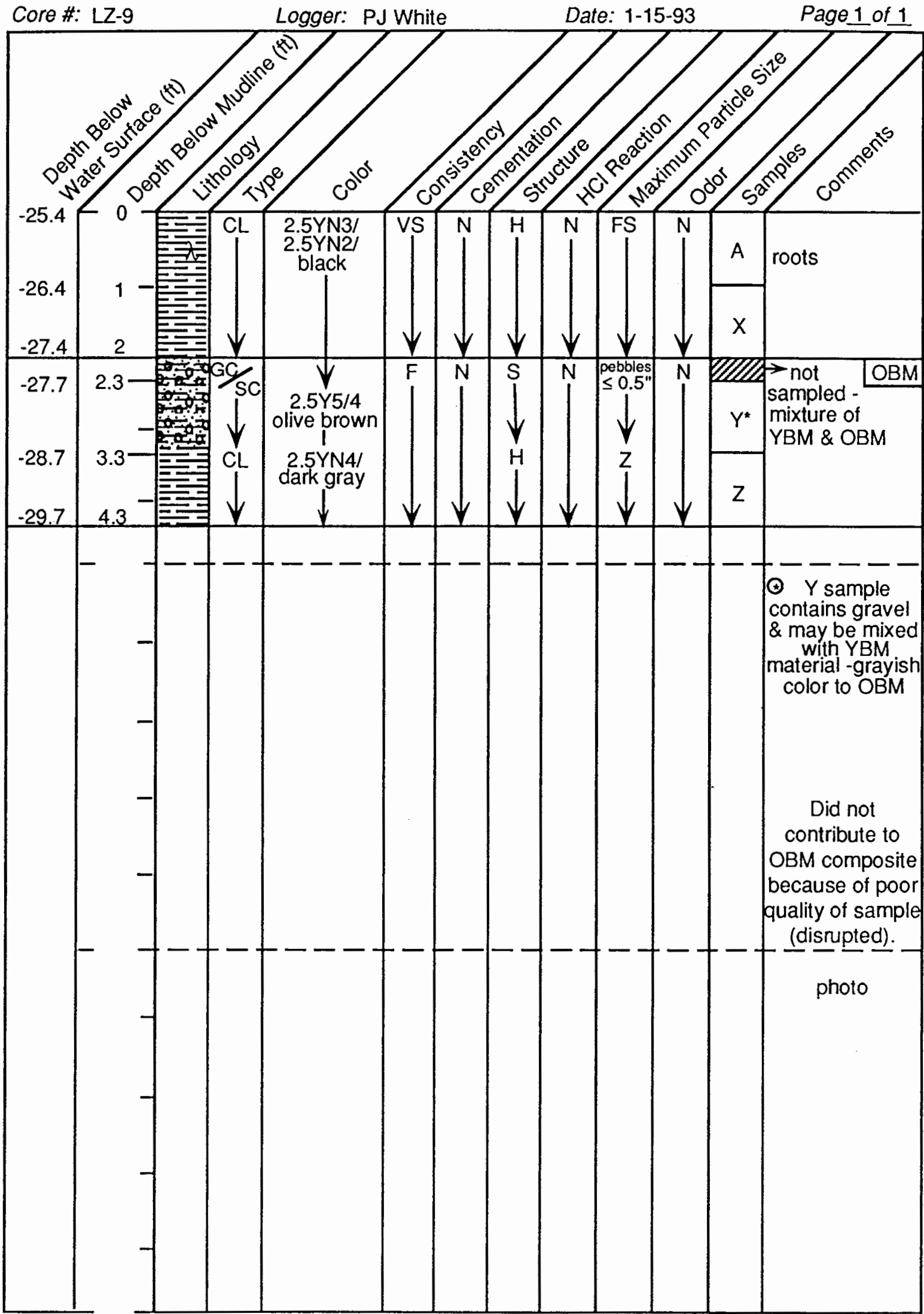


Project: Heckathorn

\section{Core Data Log}

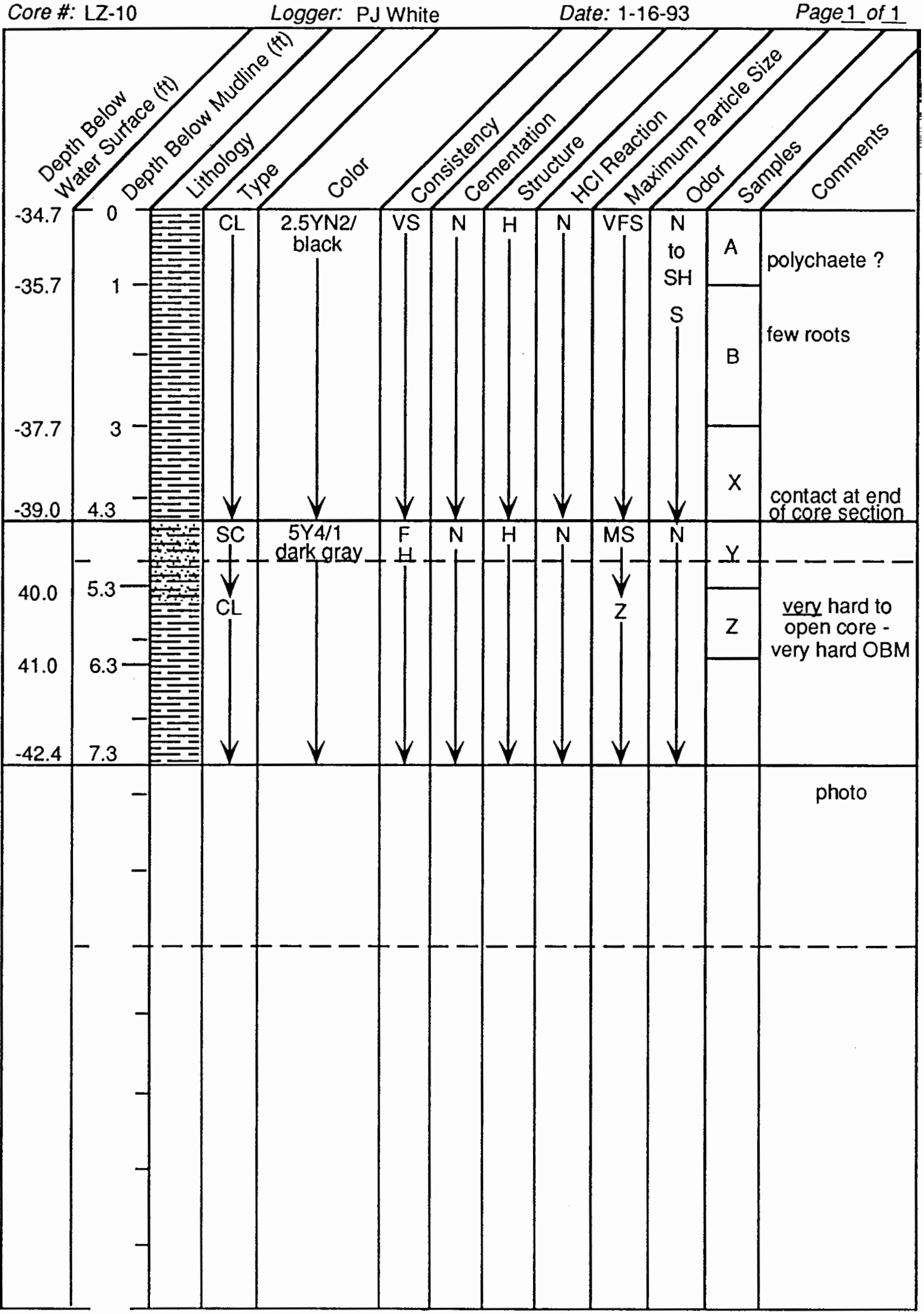




\section{Core Data Log}

Project: Heckathorn

Core \#: LZ-11 Logger: PJ White Date: 1-15-93 Page 1 of 1

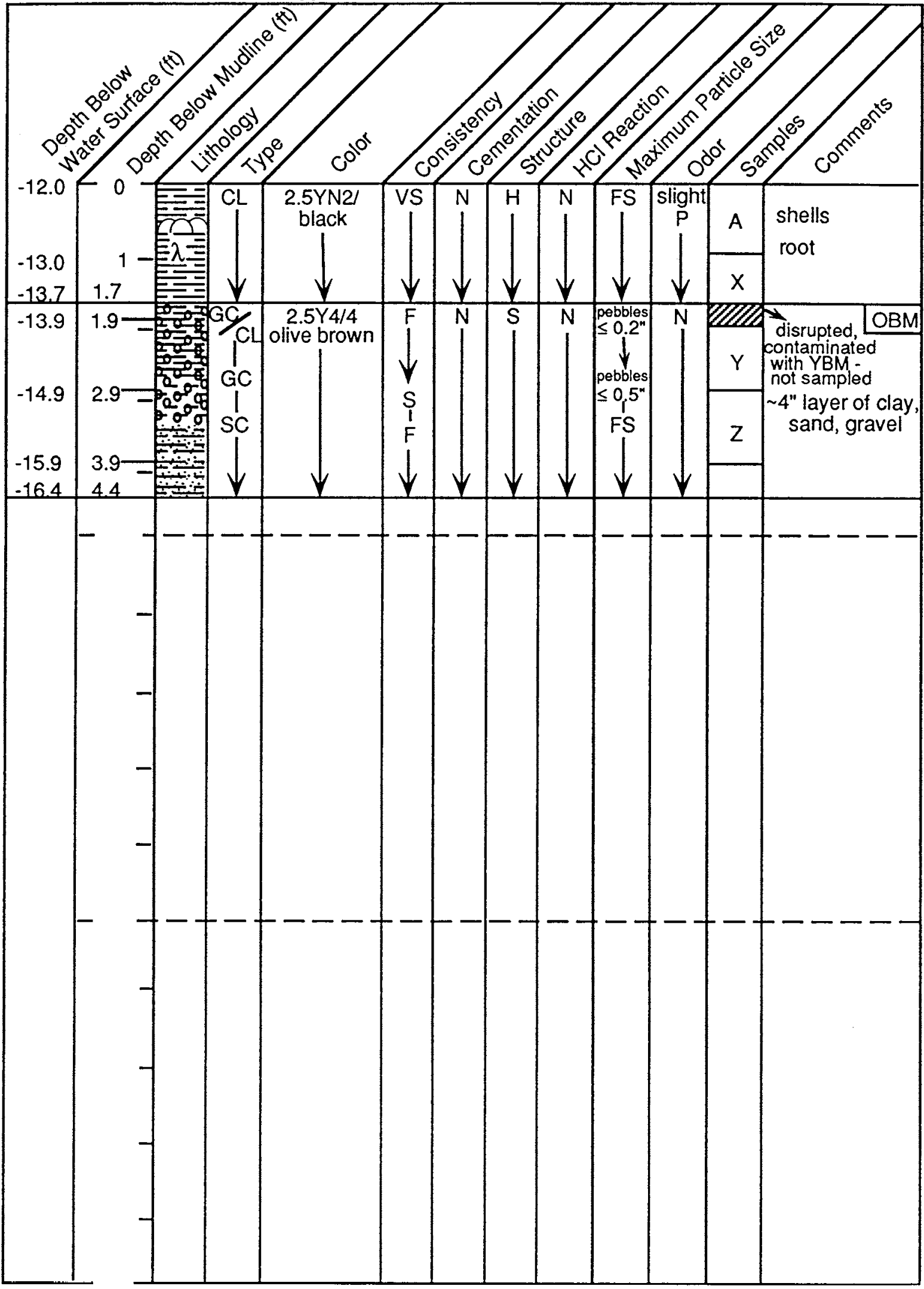

B. 11 
Project: Heckathorn

\section{Core Data Log}

Core \#: LZ-12

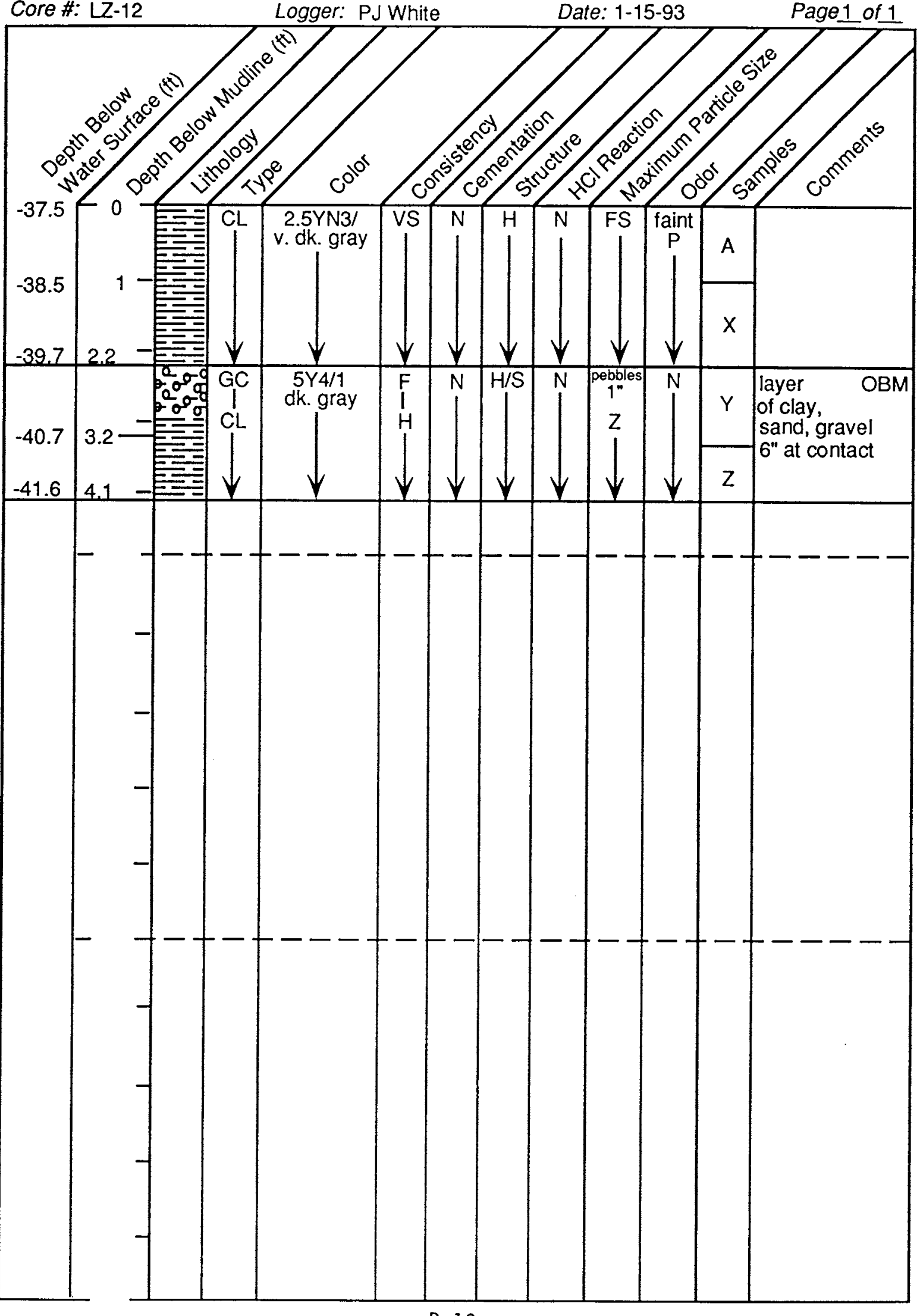

B. 12 
Project: Heckathorn

Core Data Log

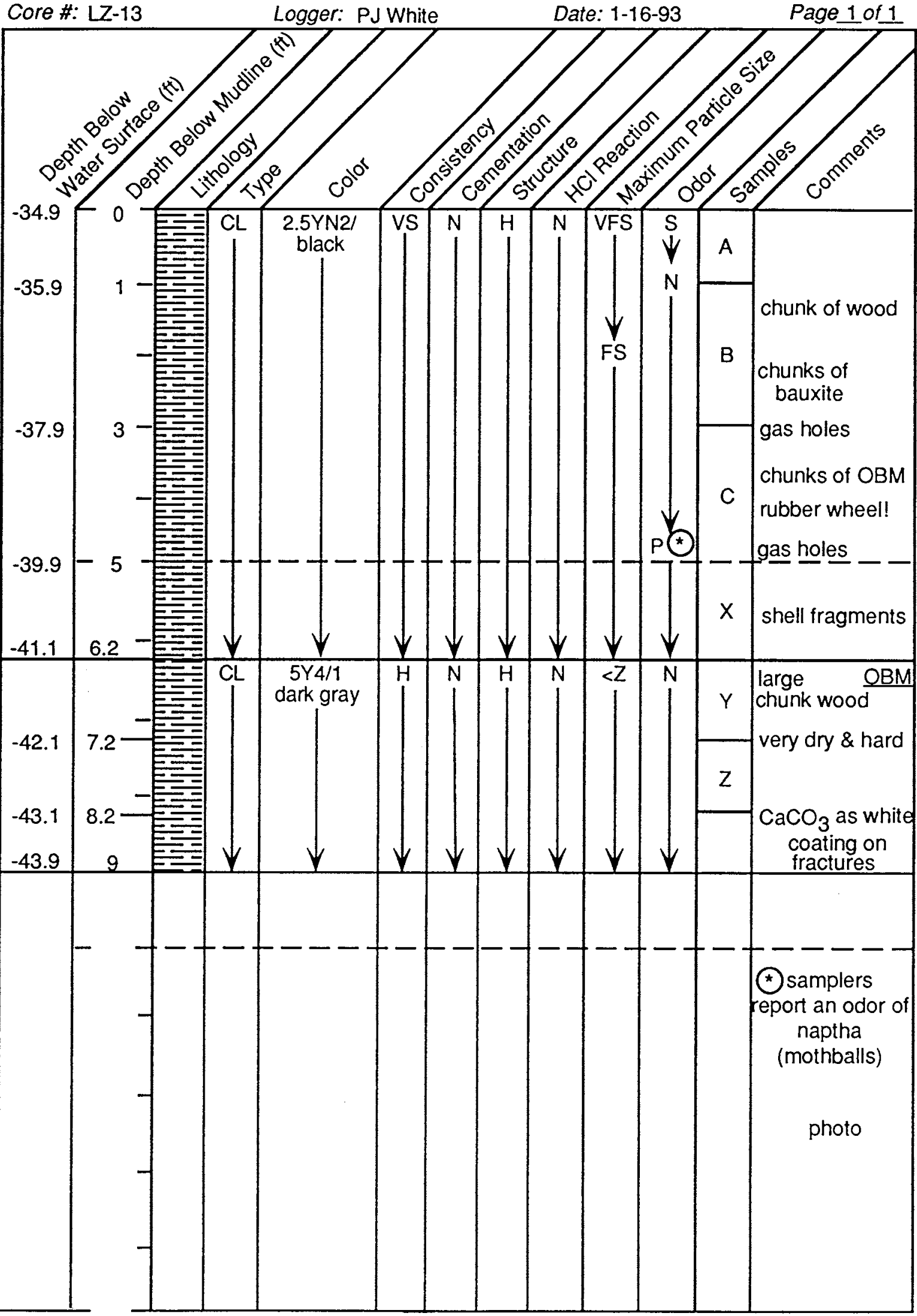

B. 13 


\section{Core Data Log}

Project: Heckathorn

Core \#: LZ-14 
Project: Heckathorn

Core Data Log

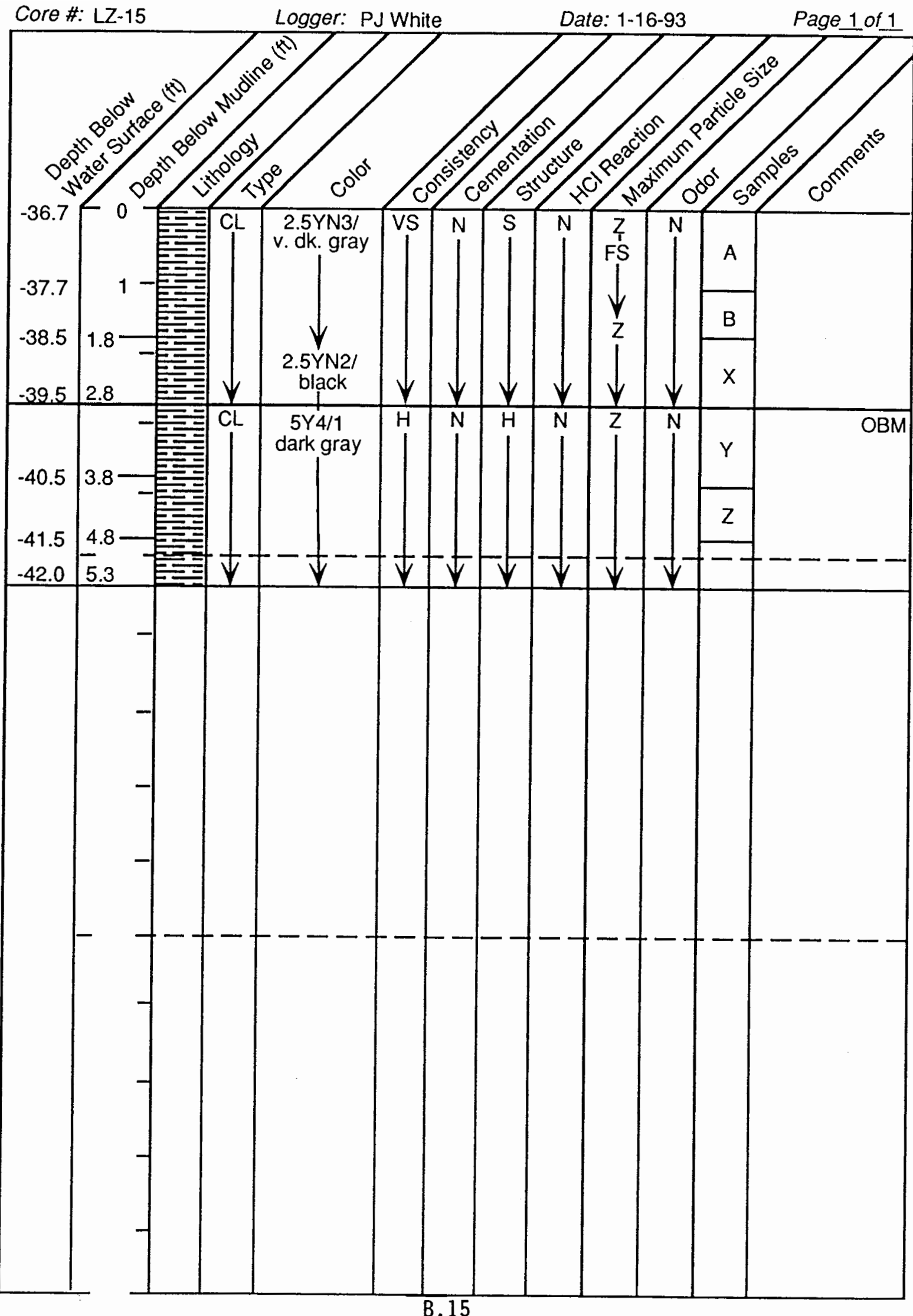


Project: Heckathorn

Core Data Log

Core \#: LZ-16 Logger: PJ White Date: 1-16-93 Page 1 of 1

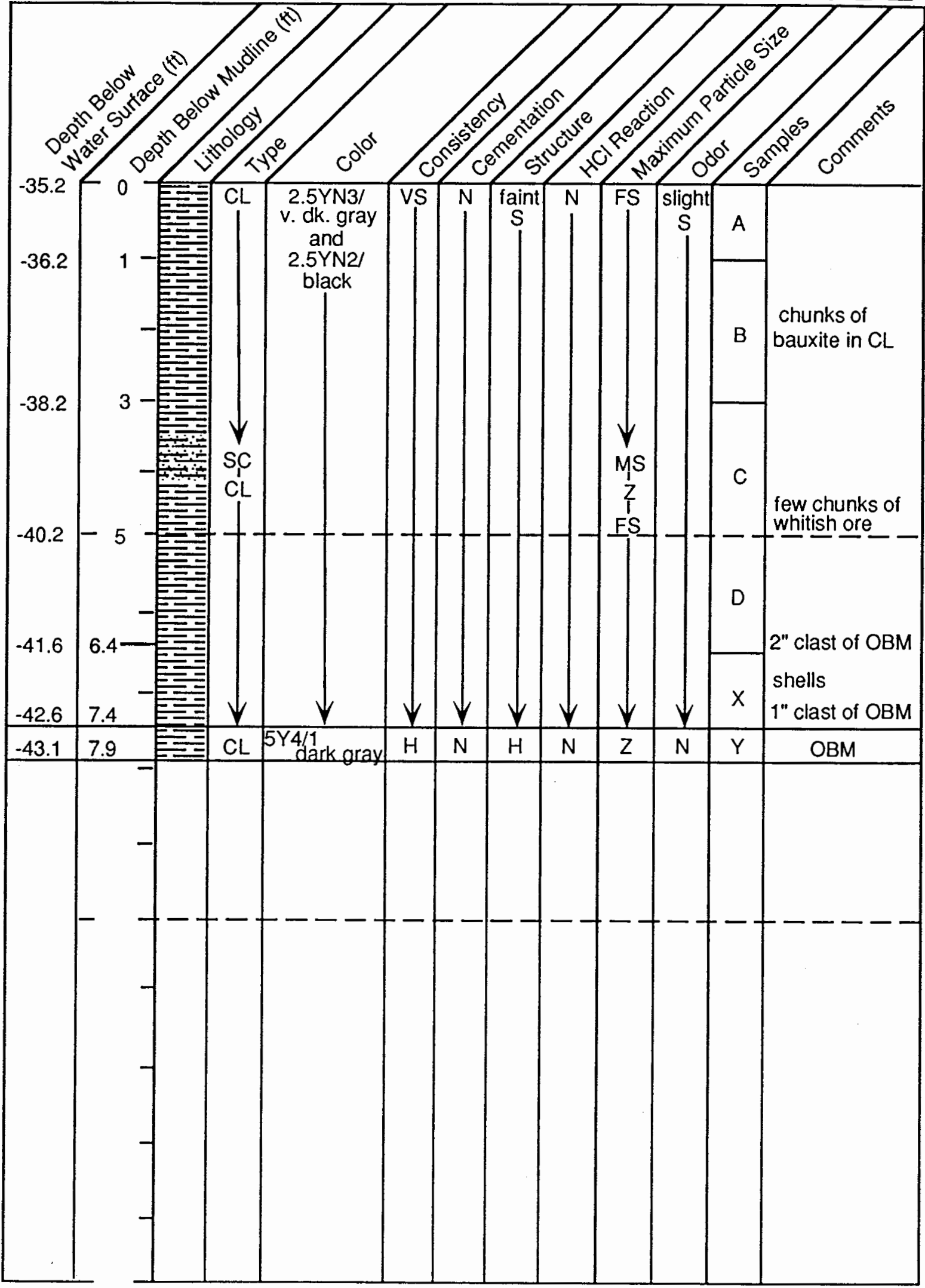


Project: Heckathorn

\section{Core Data Log}

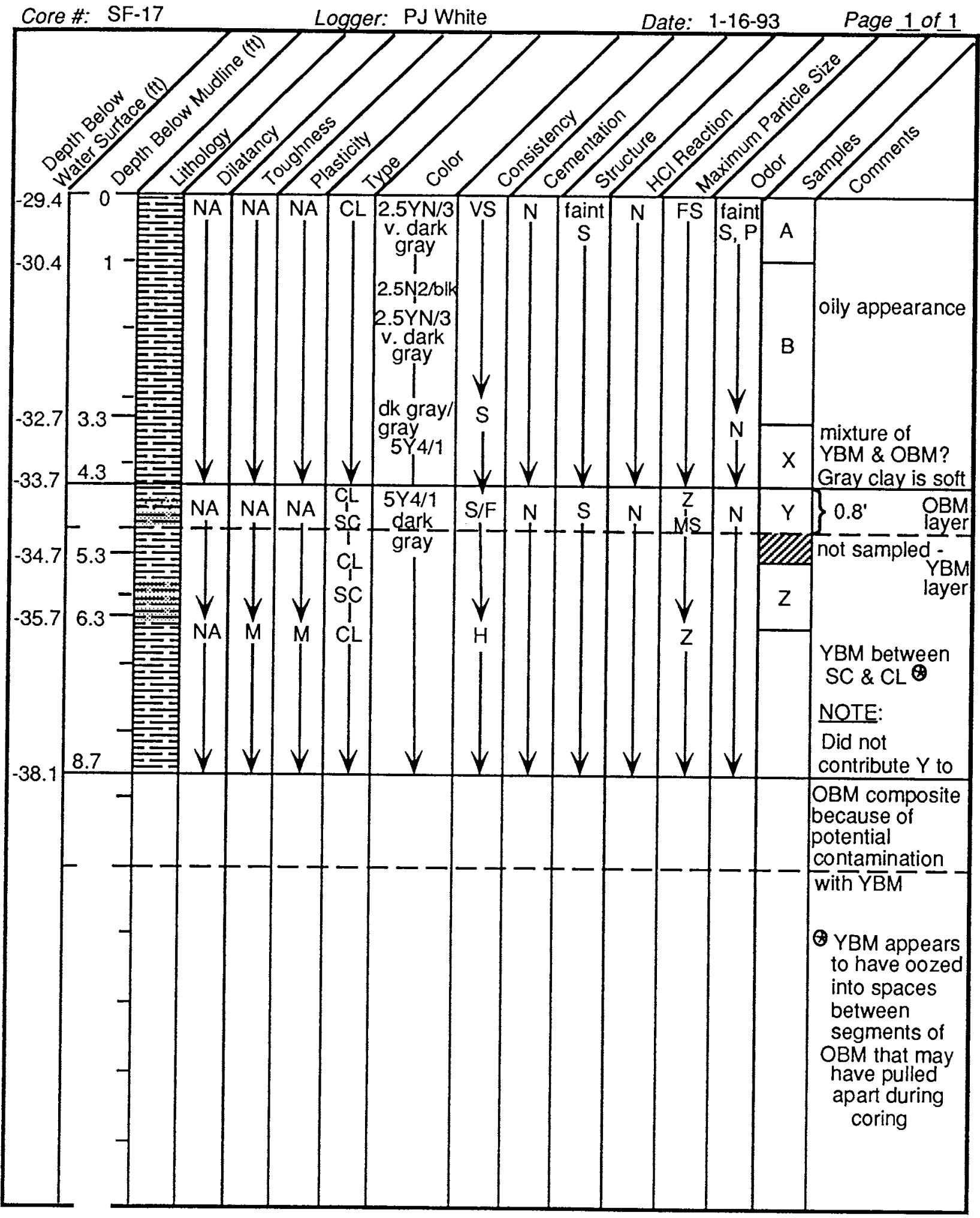


Project: Heckathorn

\section{Core Data Log}
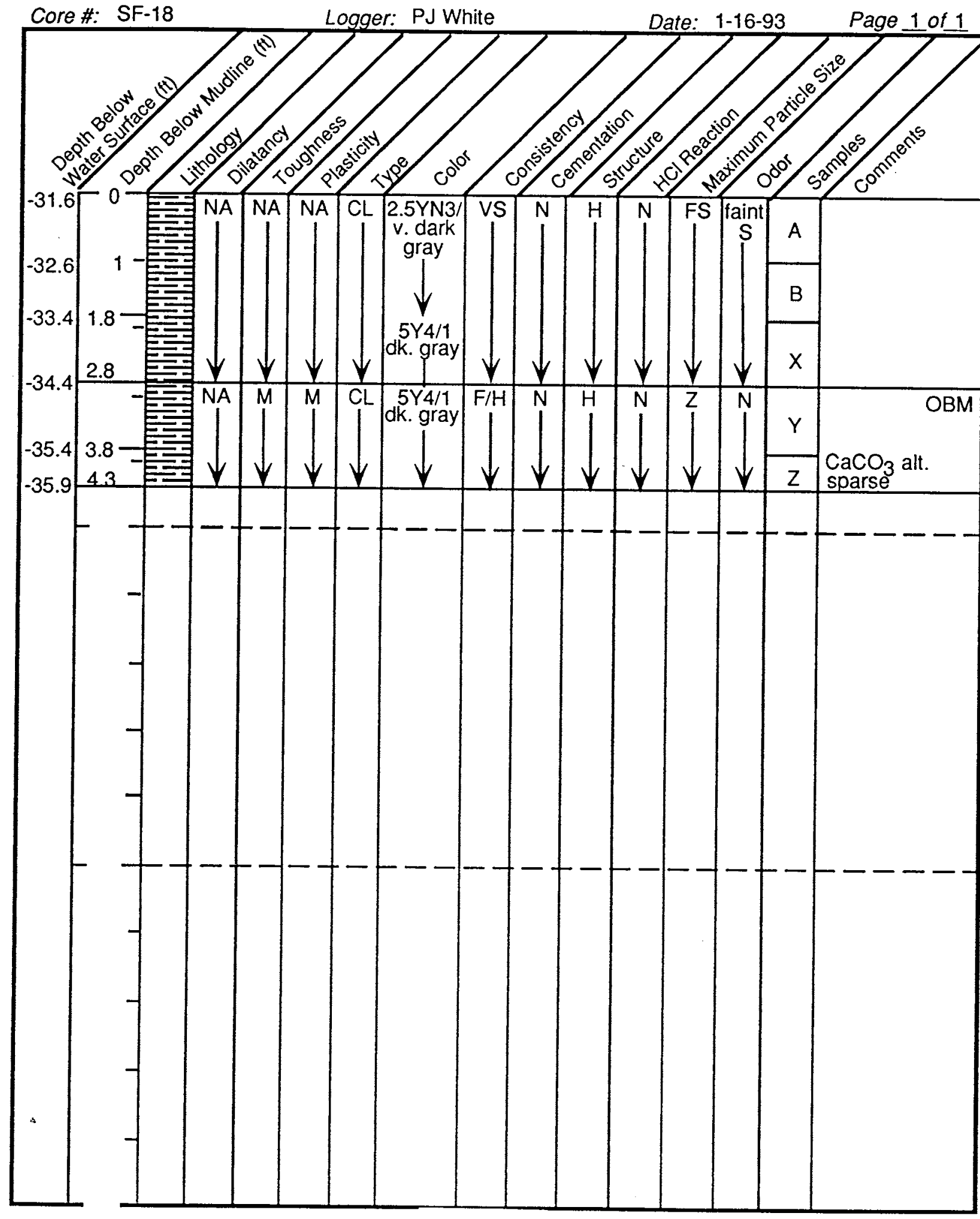

B. 18 
Project: Heckathorn

\section{Core Data Log}

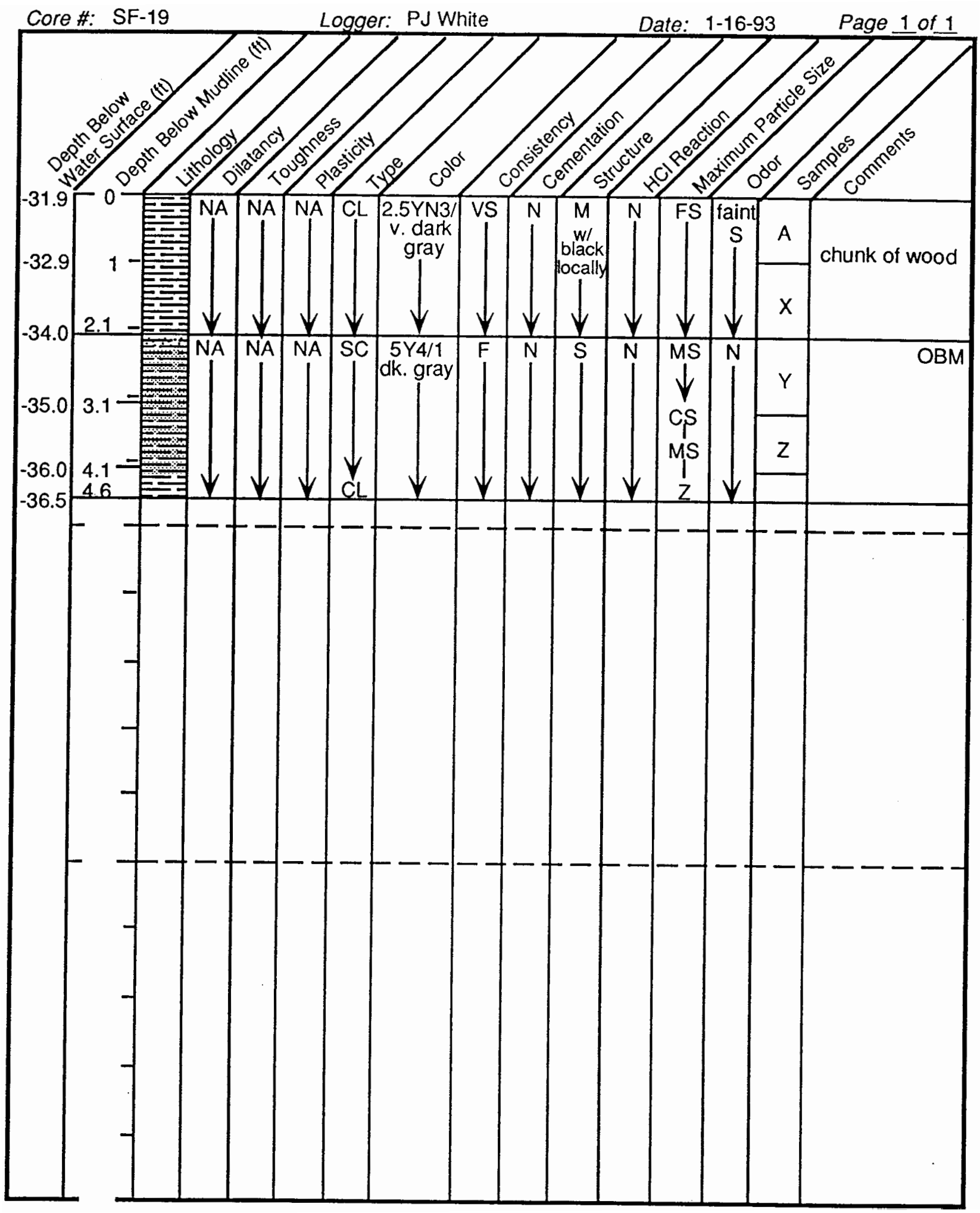

B. 19 
Project: Heckathorn

\section{Core Data Log}

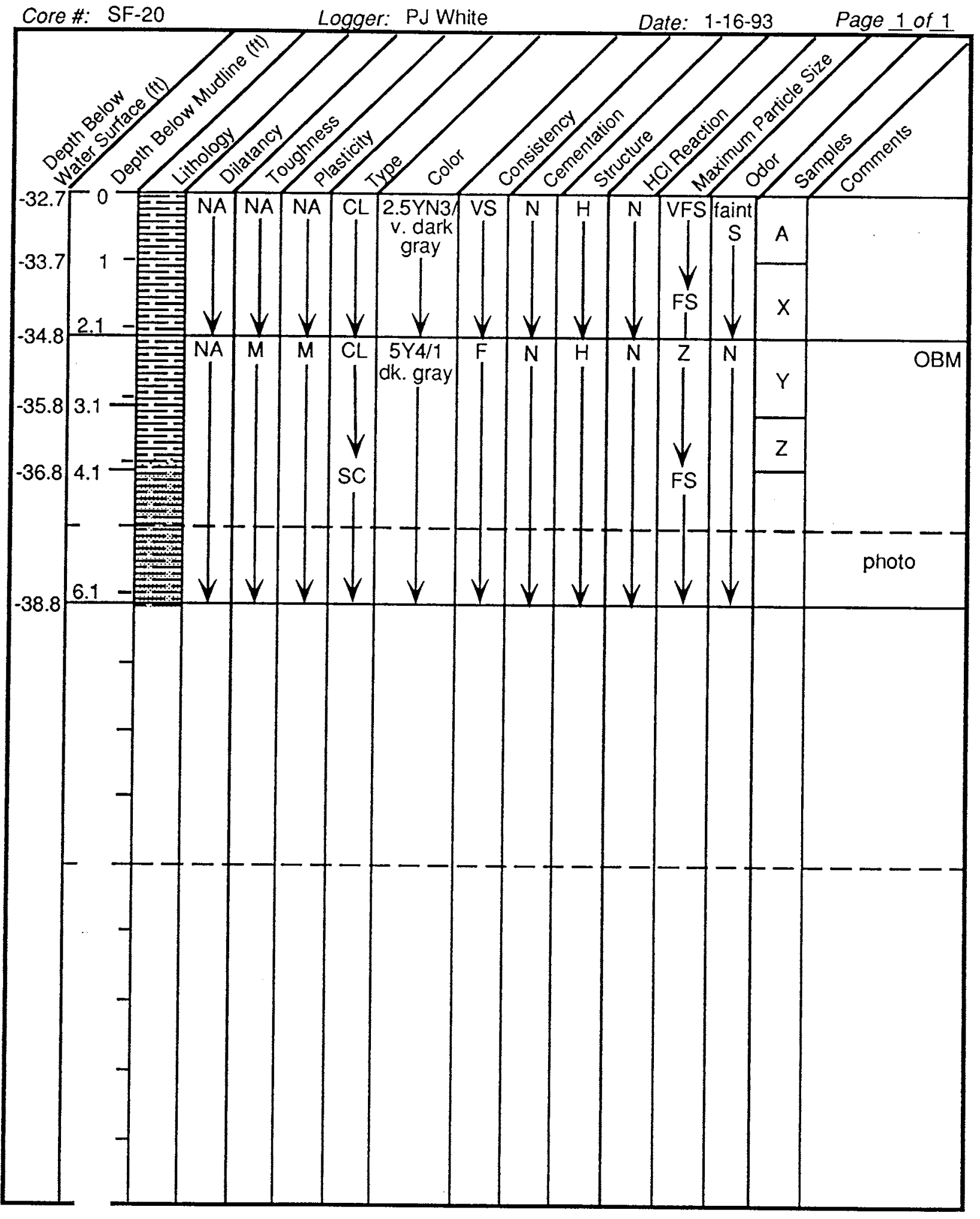


Project: Heckathorn

Core Data Log

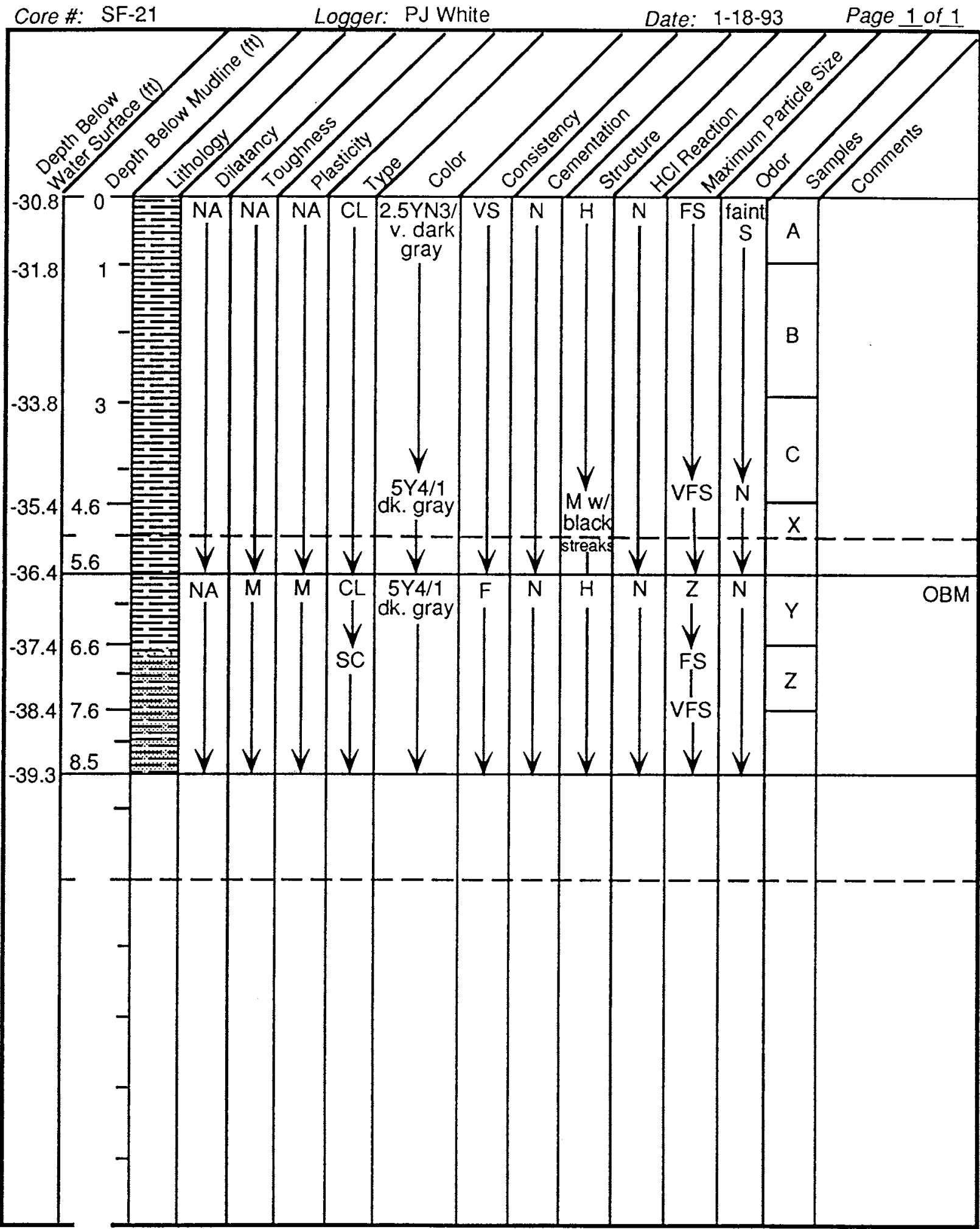

B. 21 
Project: Heckathorn

\section{Core Data Log}

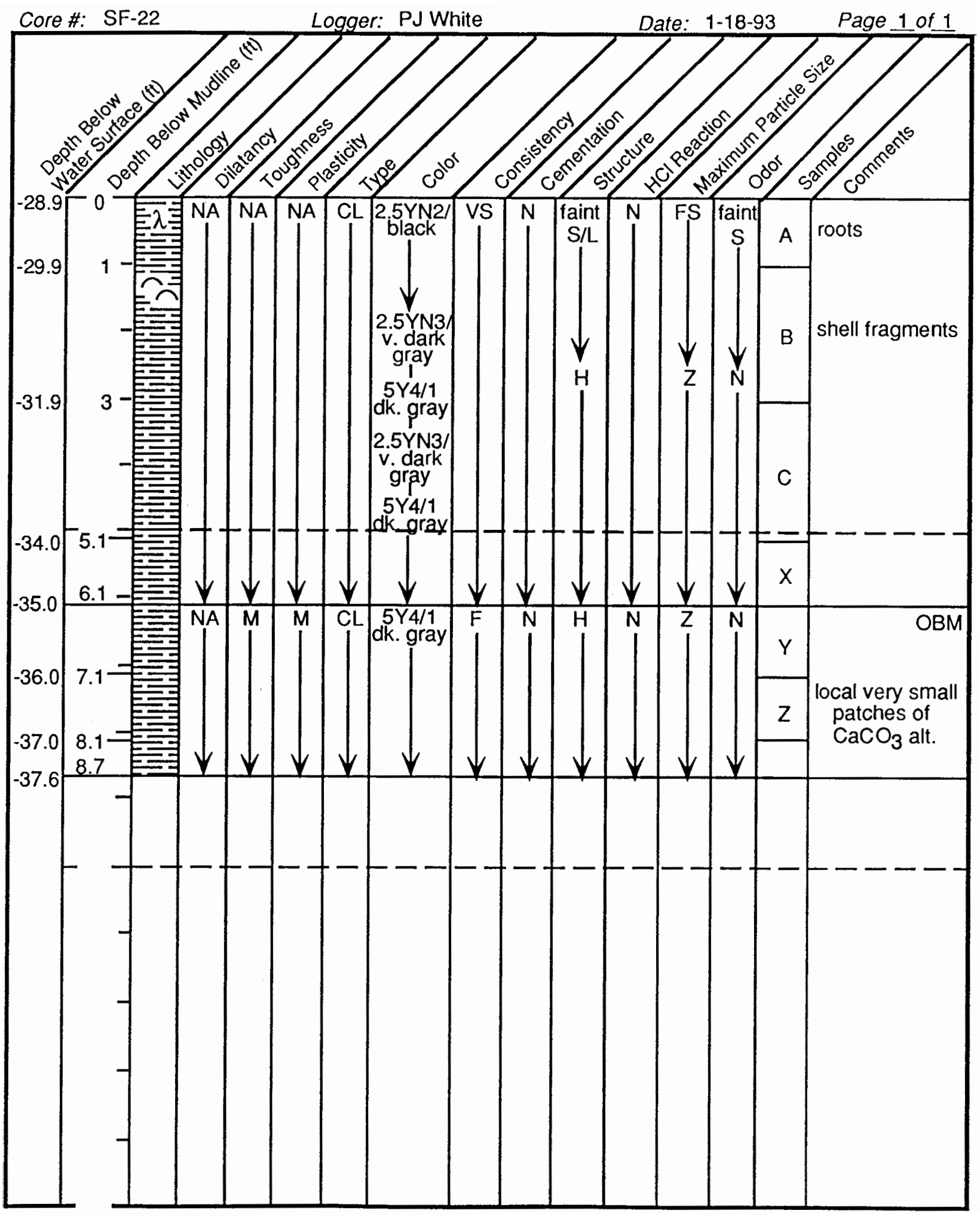

B. 22 
Project: Heckathorn

\section{Core Data Log}

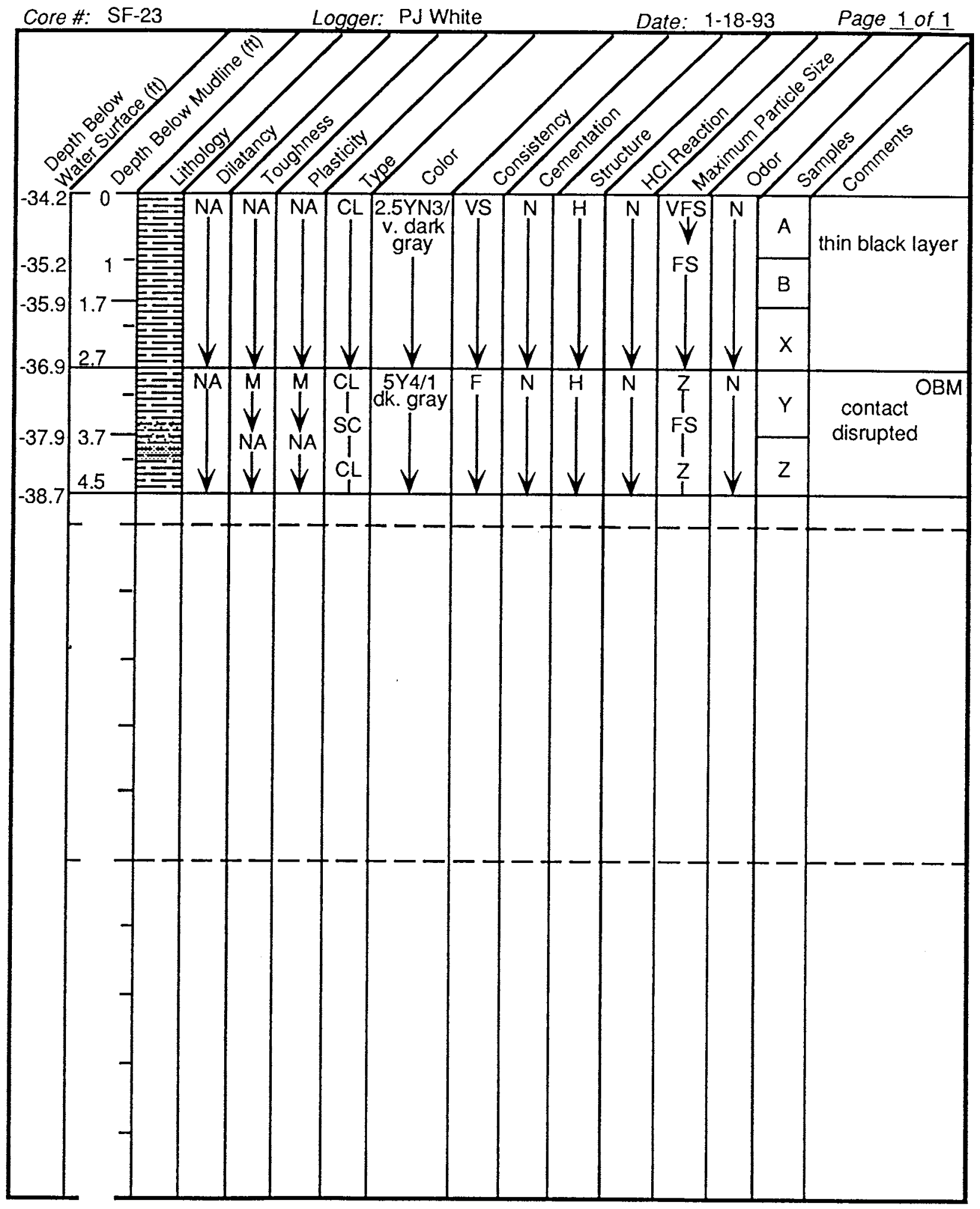


Project: Heckathorn

Core Data Log

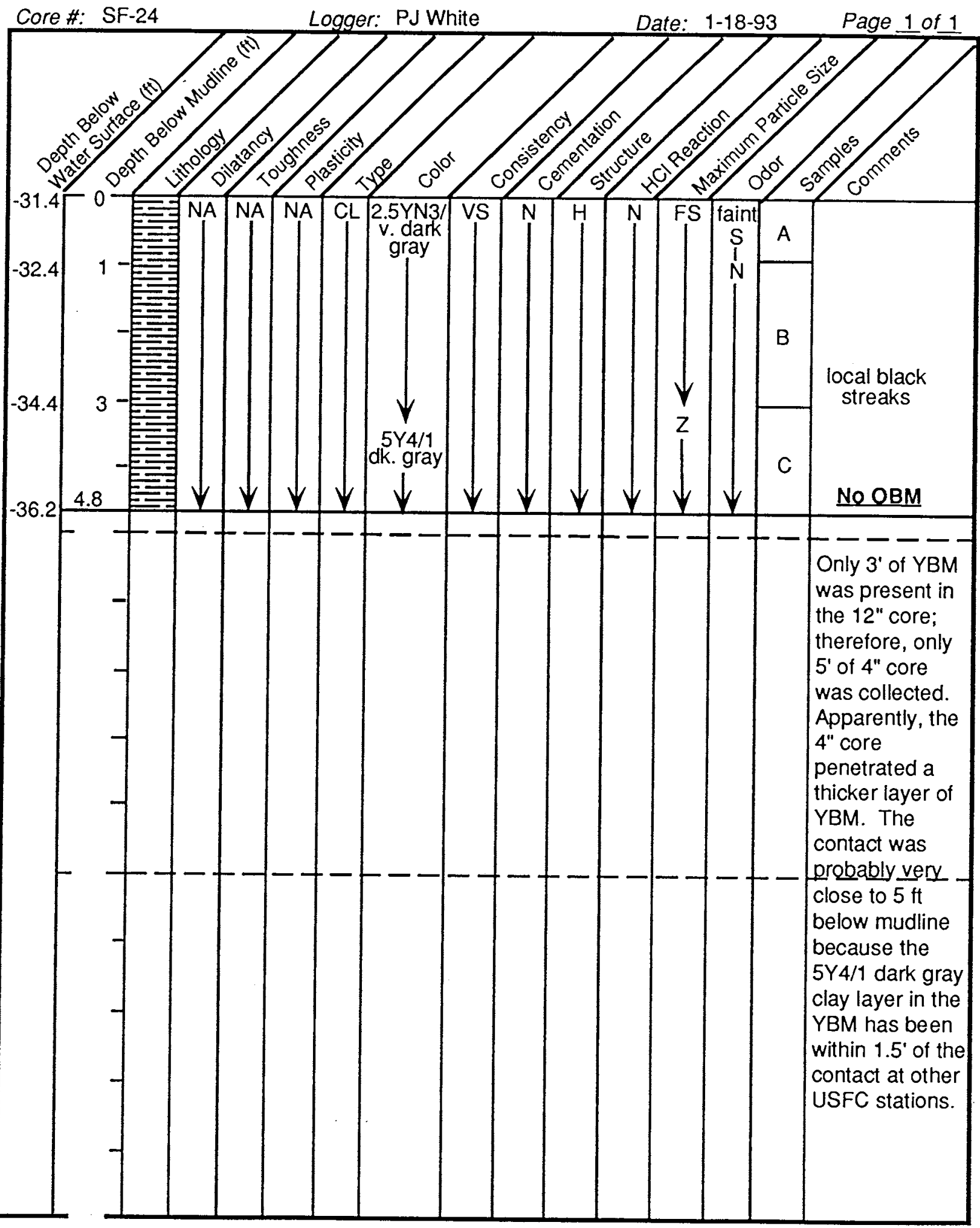


Project: Heckathorn

Core Data Log

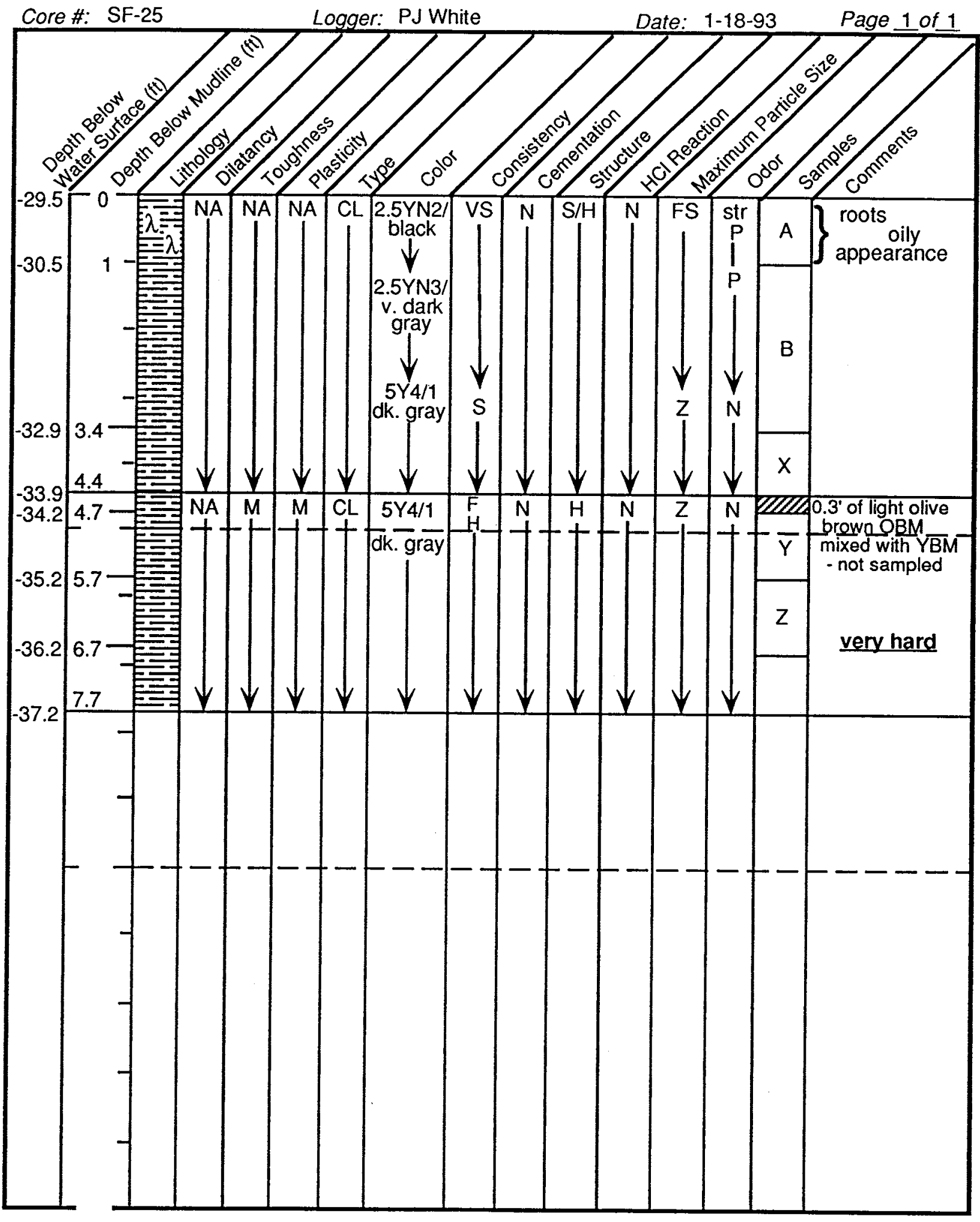

B. 25 
Project: Heckathorn

\section{Core Data Log}

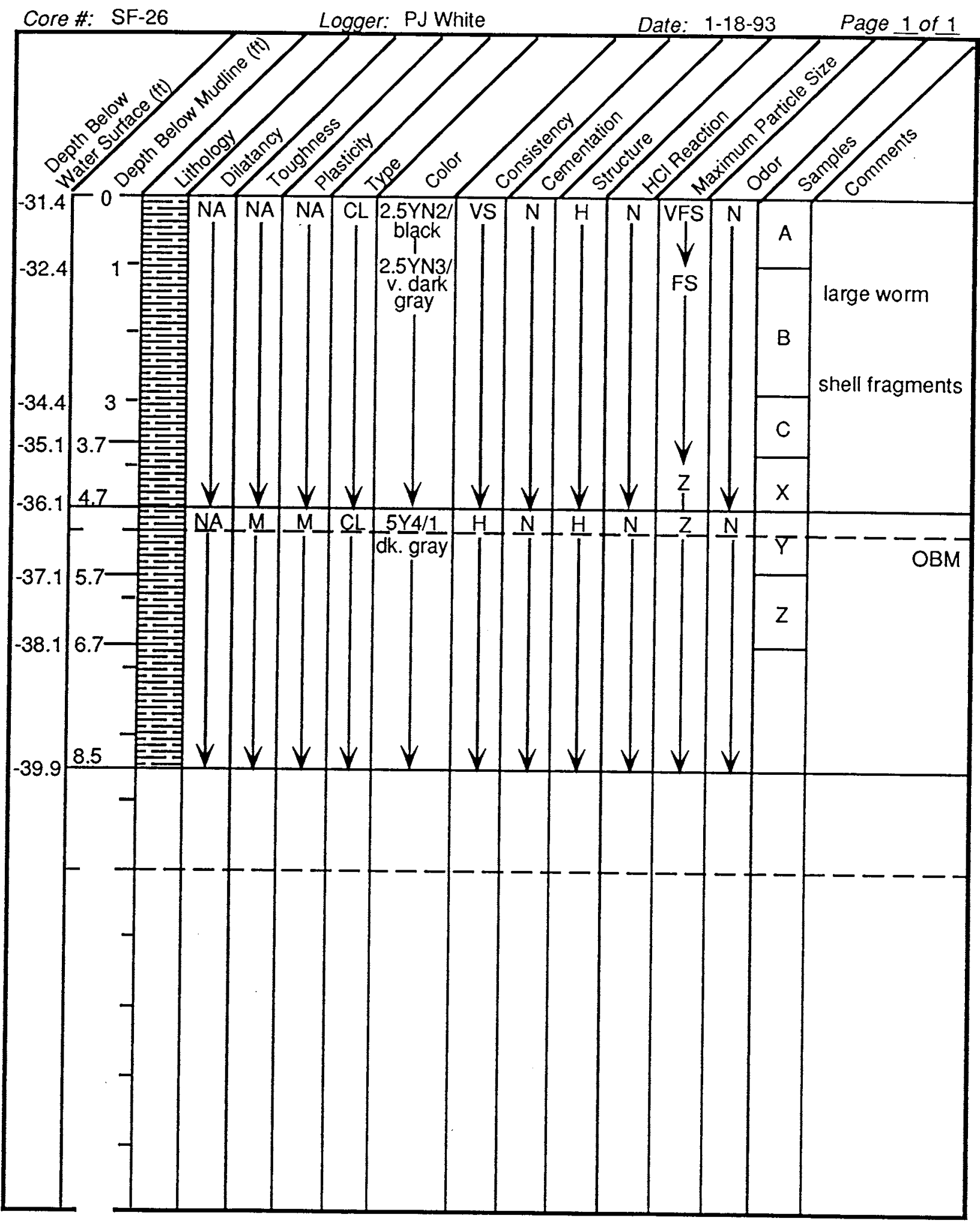

B. 26 
Project: Heckathorn

\section{Core Data Log}

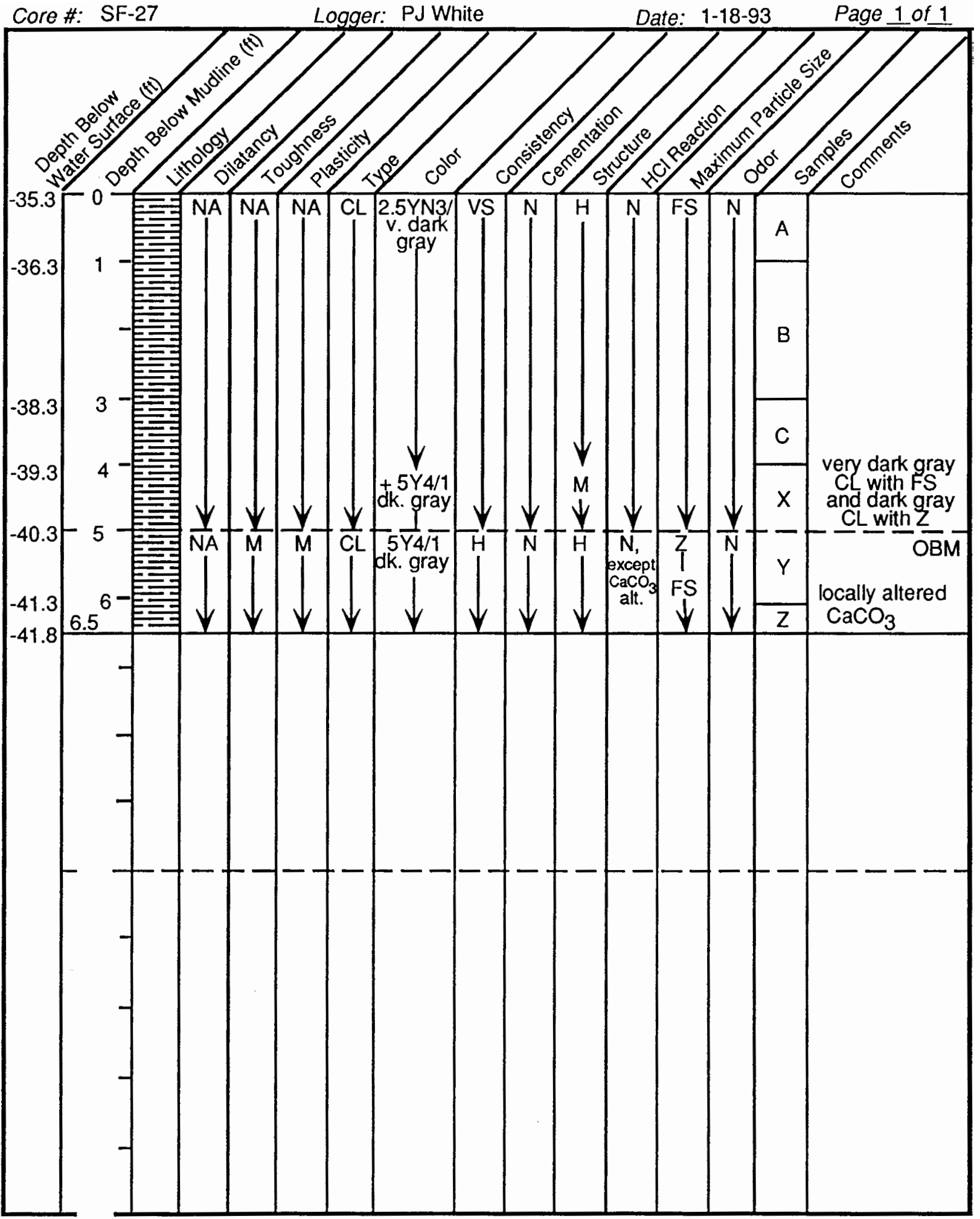

B. 27 
Core Data Log

Project: Heckathorn

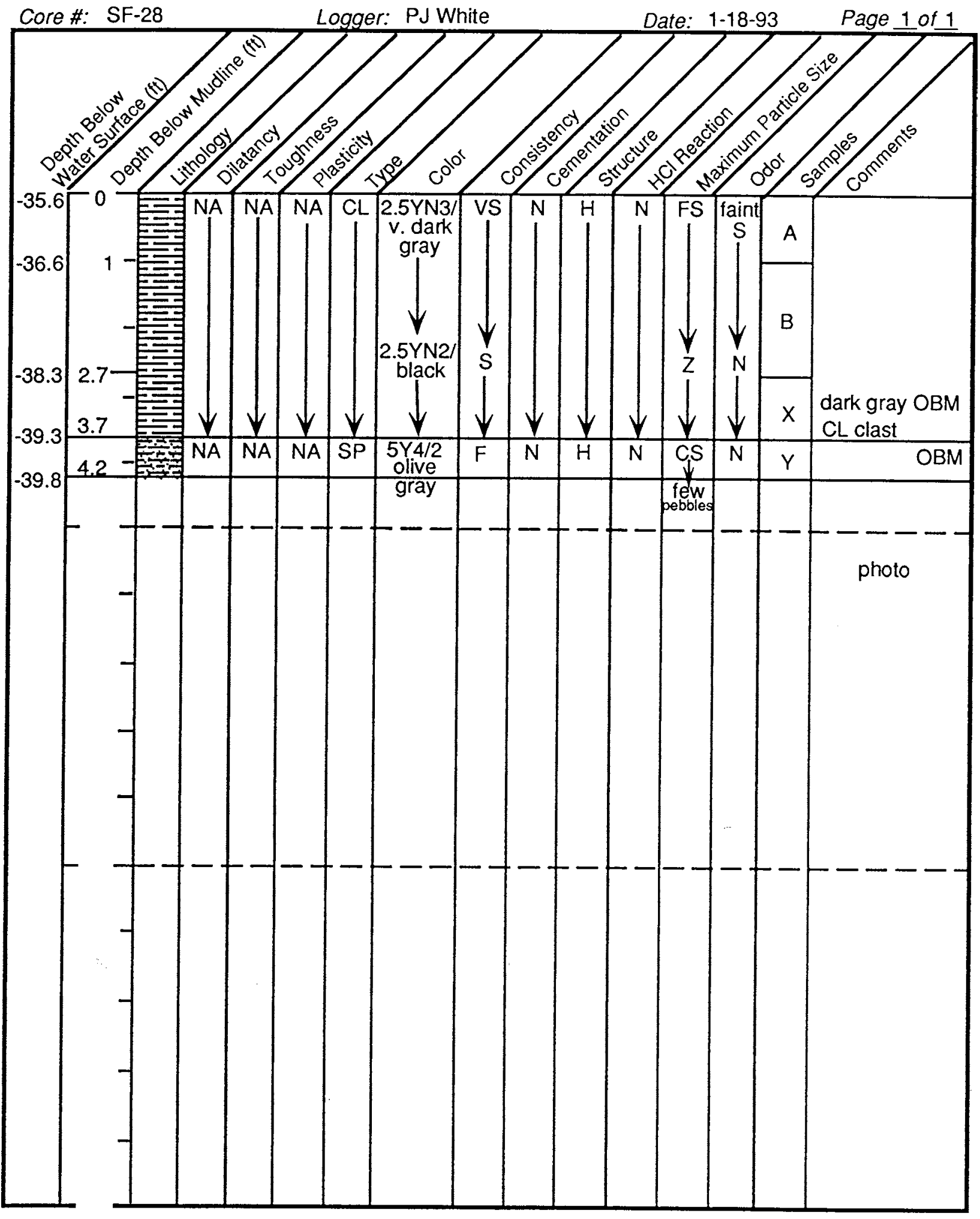

B. 28 
Project: Heckathorn

Core Data Log

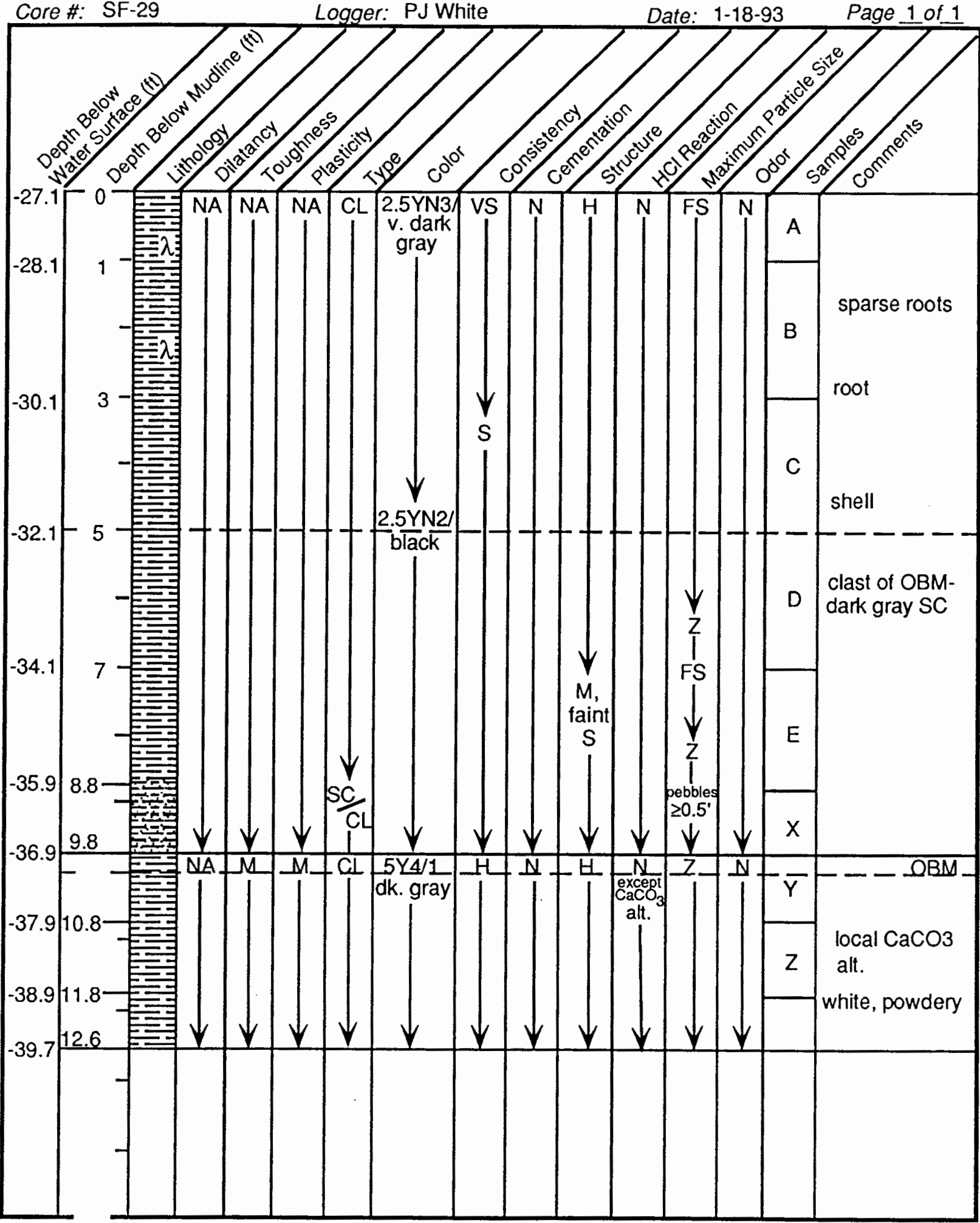

B. 29 
Project: Heckathorn

Core Data Log

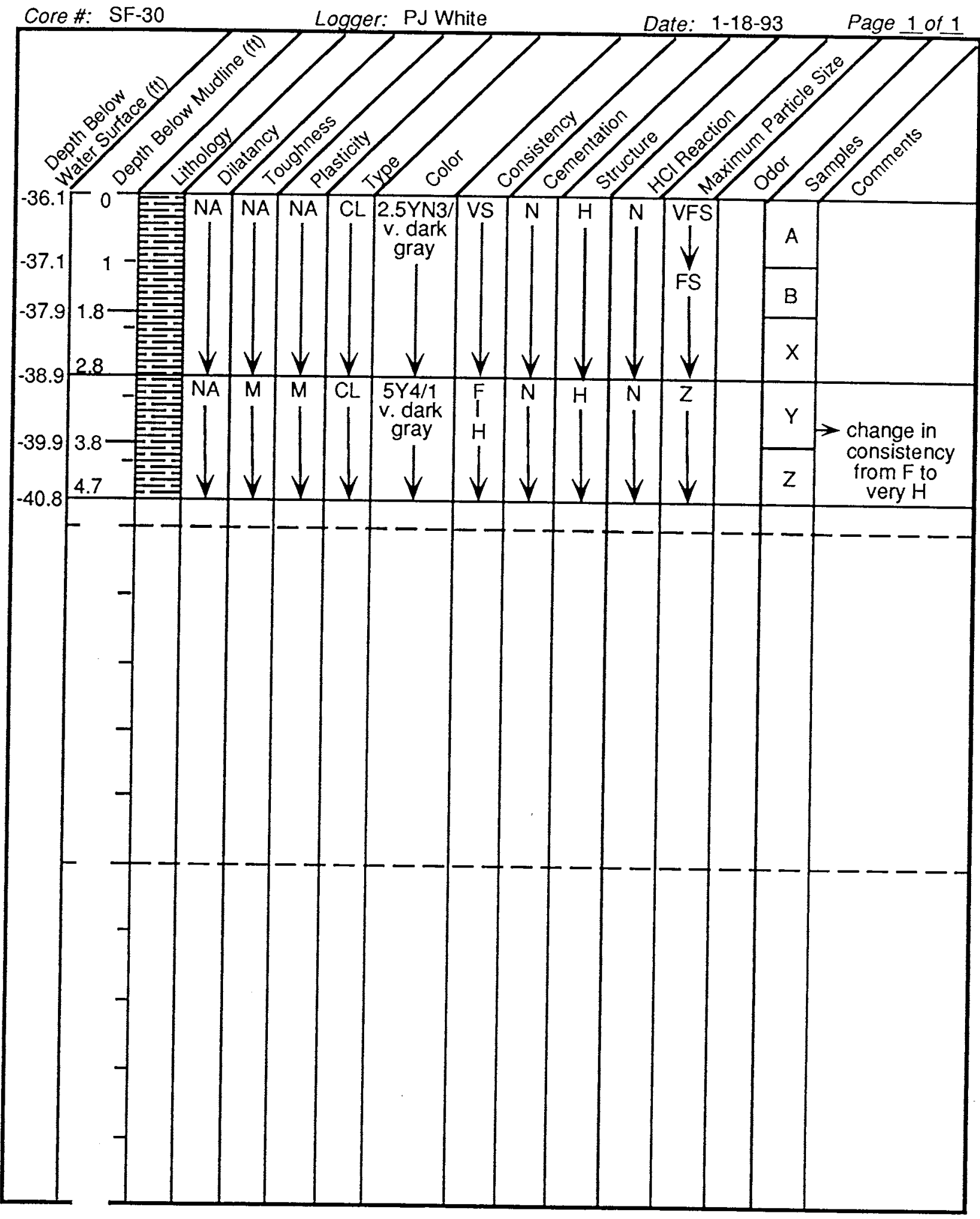

B. 30 
Project: Heckathorn

Core Data Log

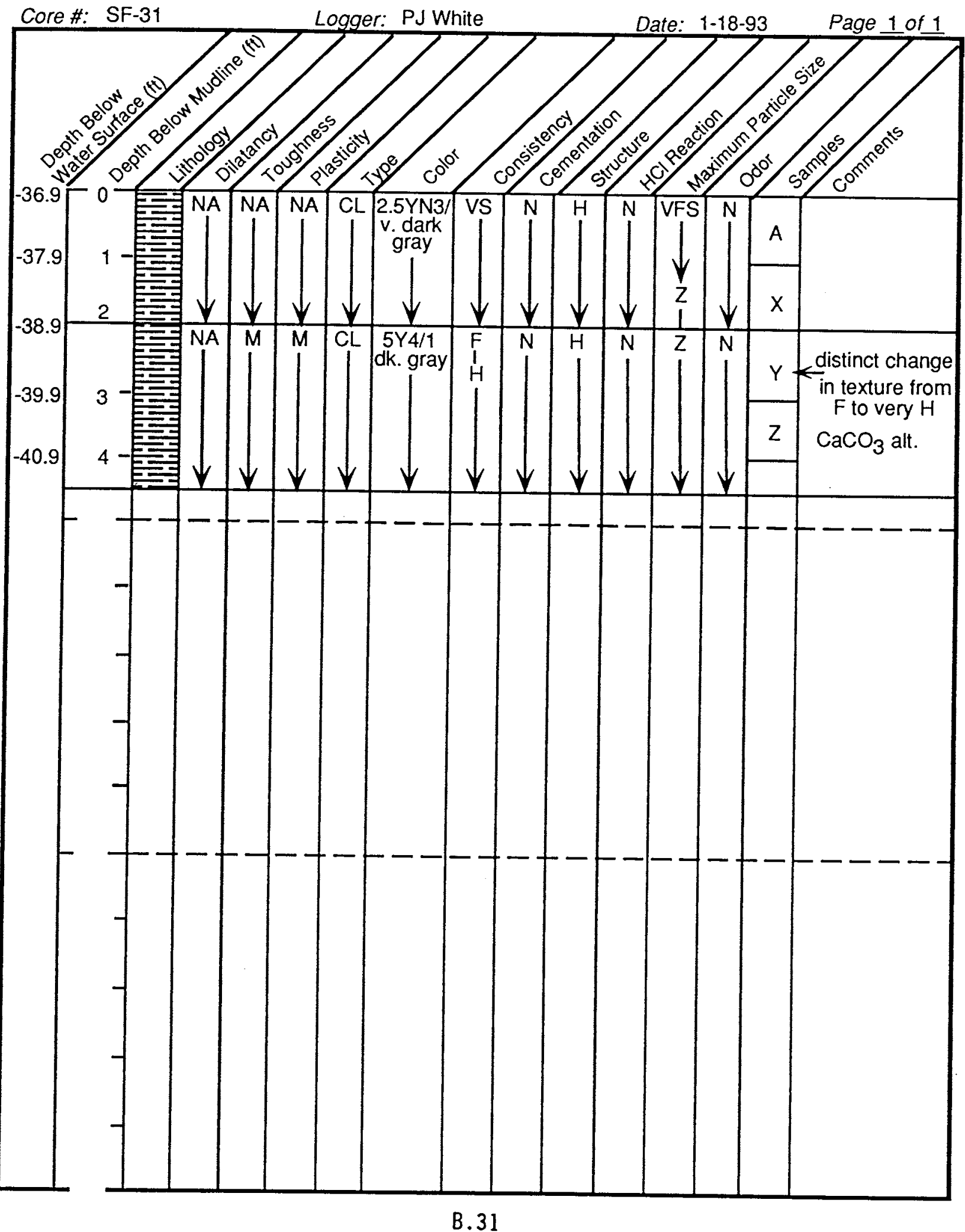


Project: Heckathorn

\section{Core Data Log}

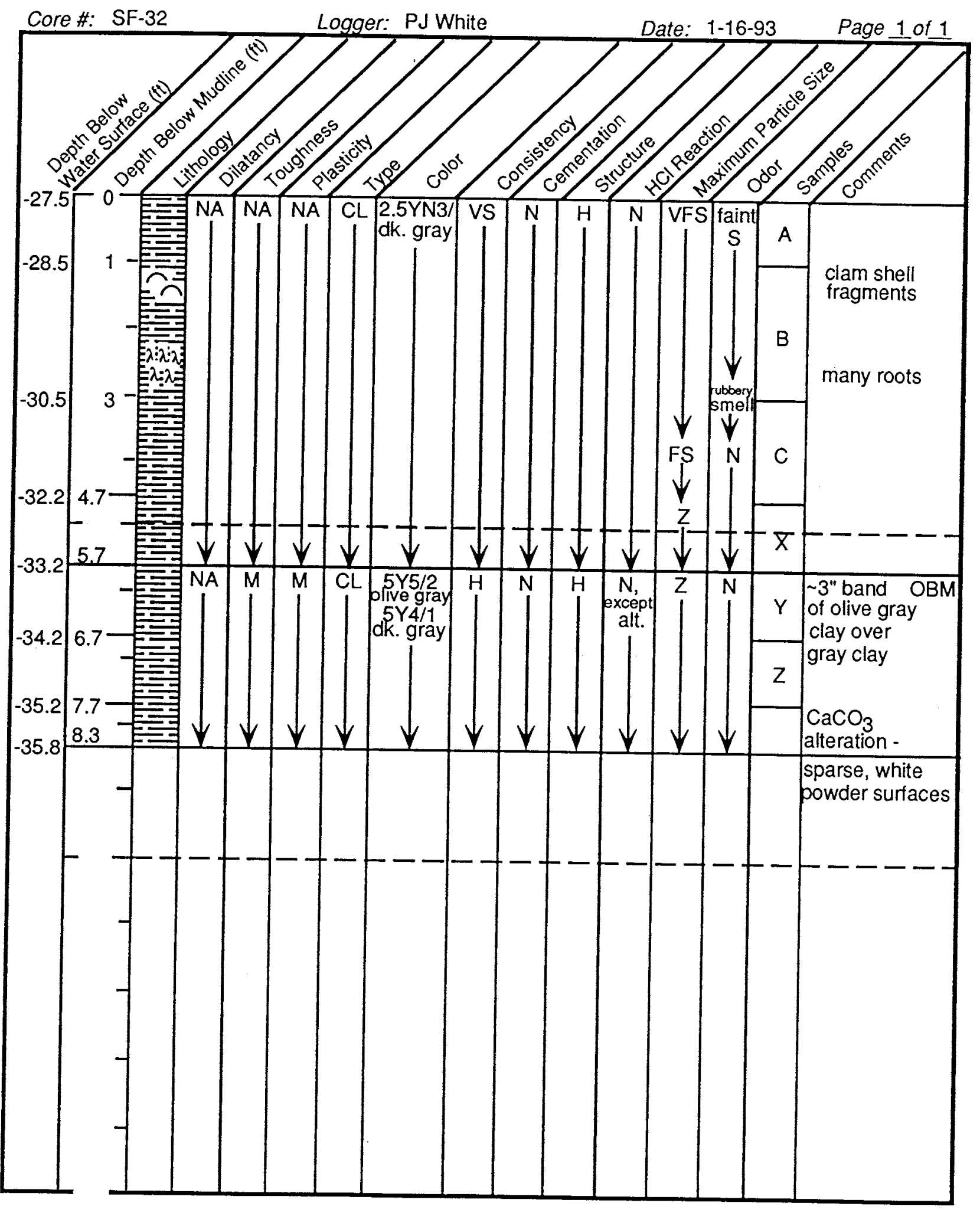

B. 32 
Project: Heckathorn

\section{Core Data Log}

core \#: SF-33

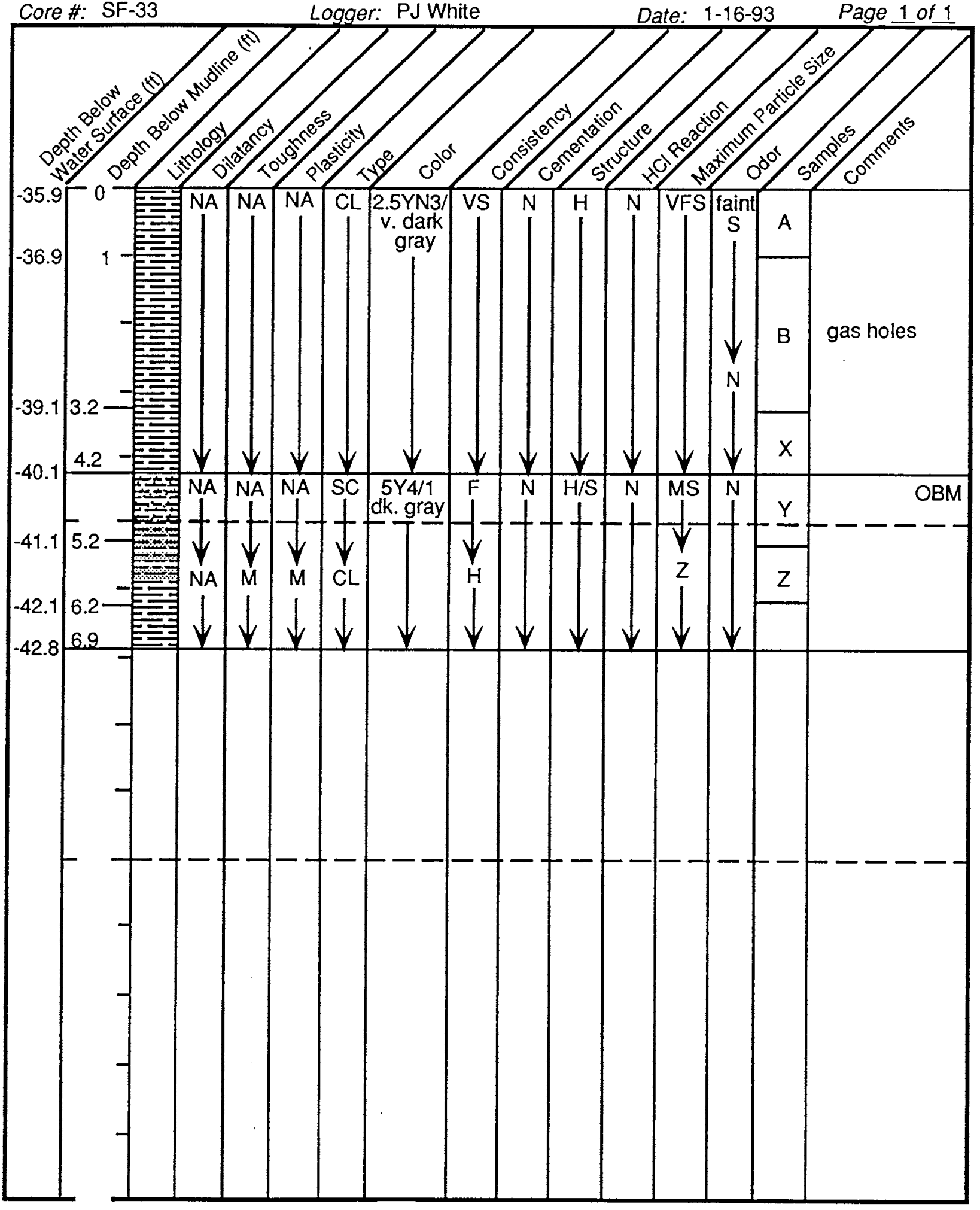

B. 33 
Project: Heckathorn

\section{Core Data Log}

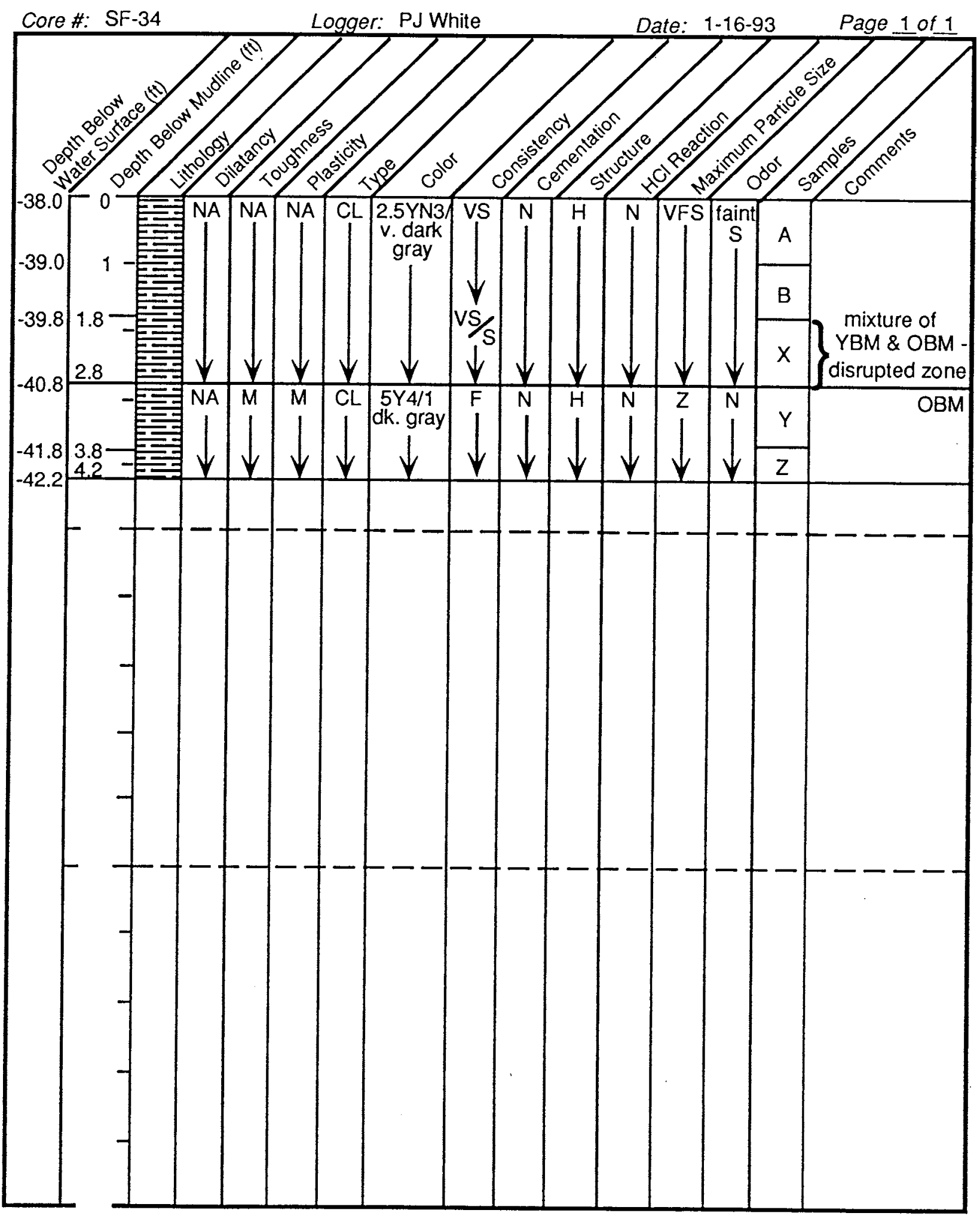

\section{B. 34}


Core Data Log

Project: Heckathorn

Core \#: IH-35

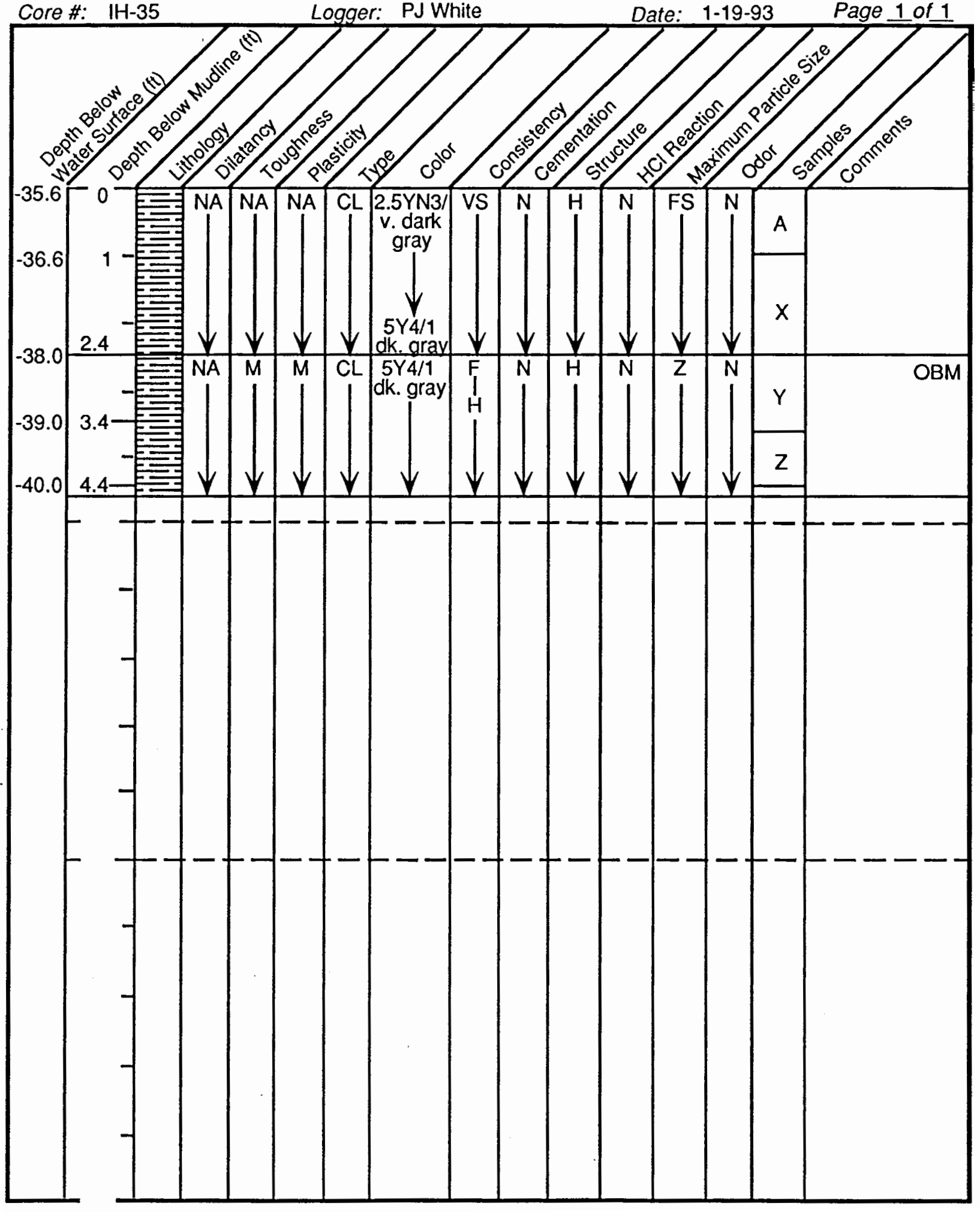

B. 35 
Project: Heckathorn

\section{Core Data Log}

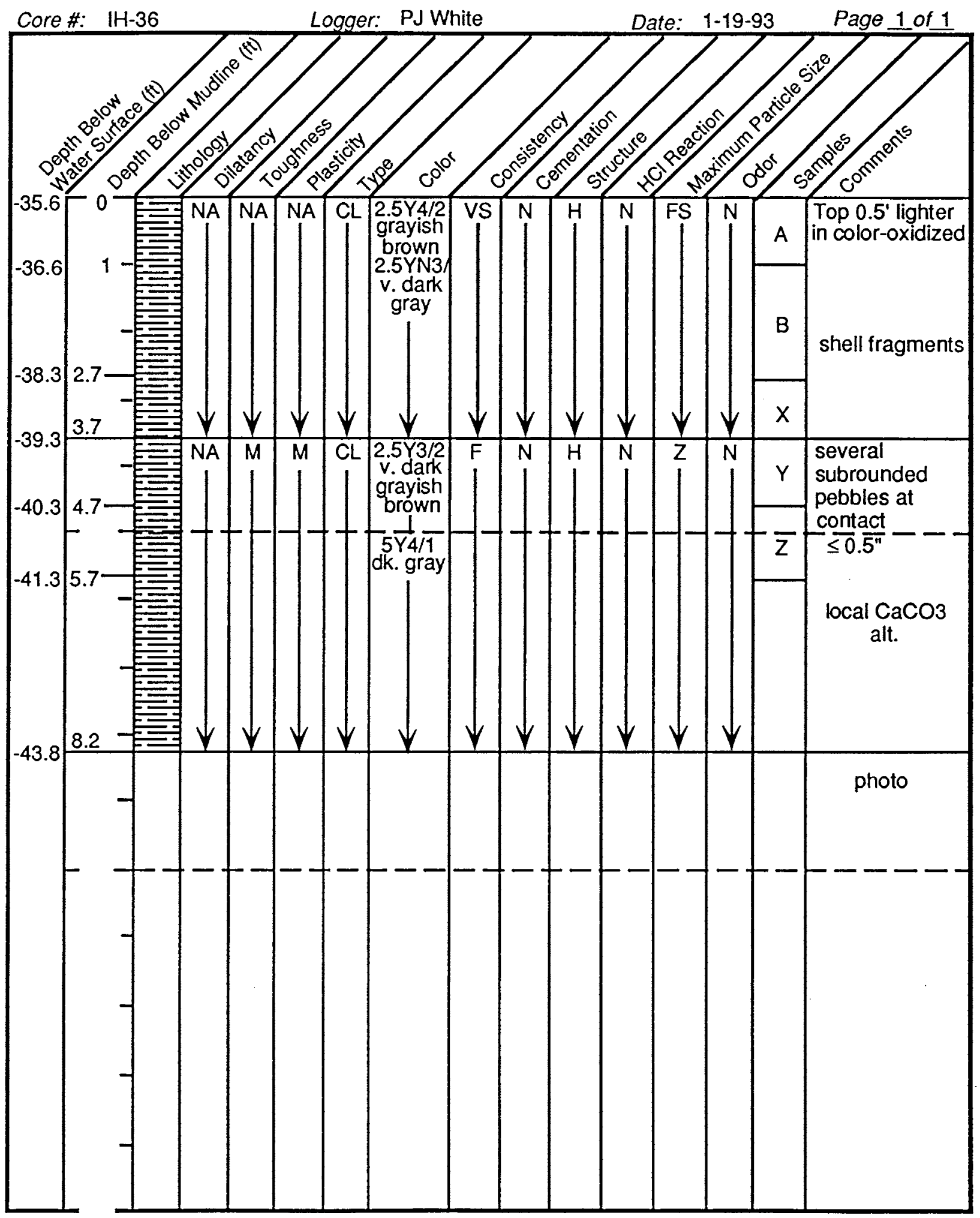


Project: Heckathorn

Core Data Log

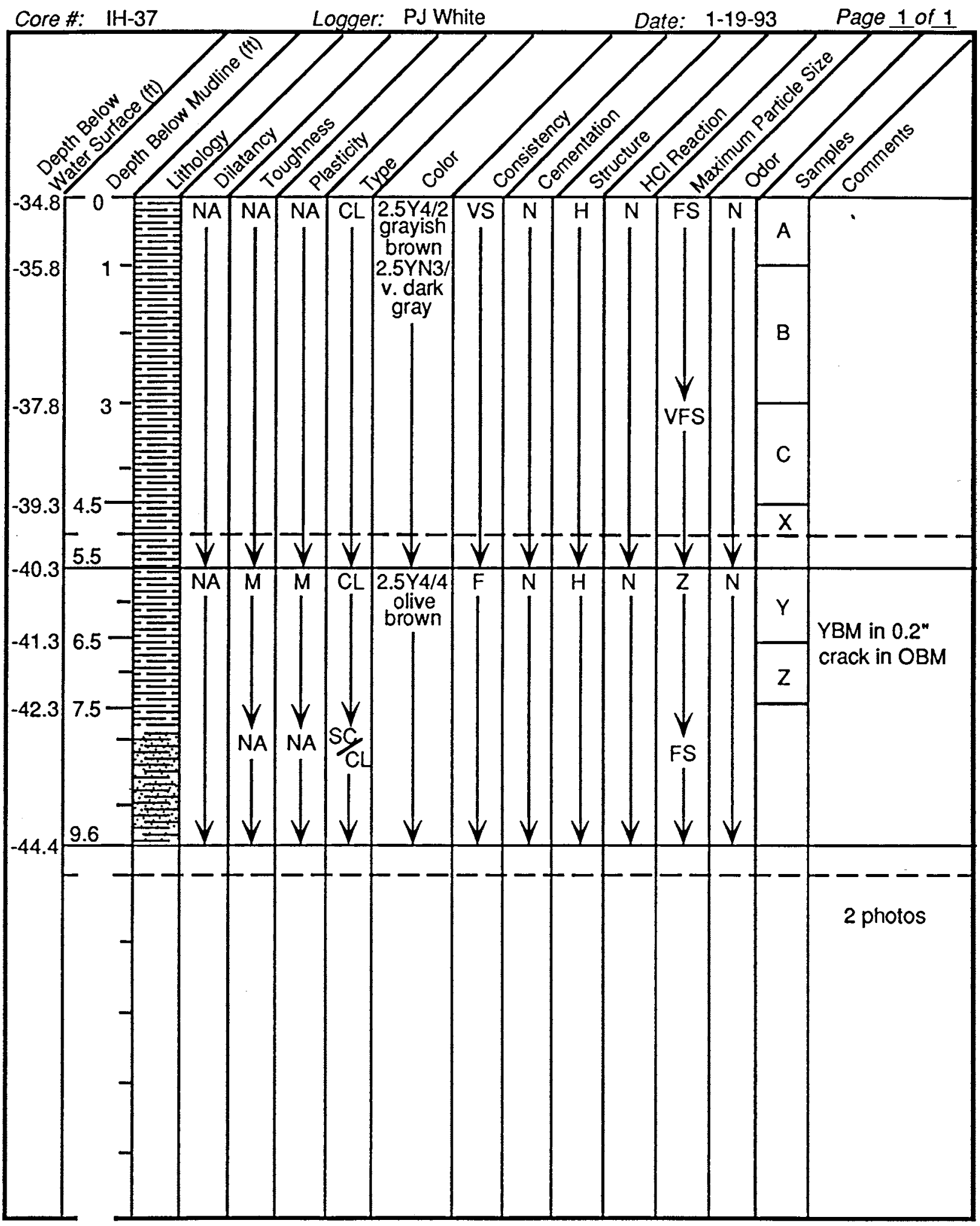

B. 37 
Project: Heckathorn

Core Data Log

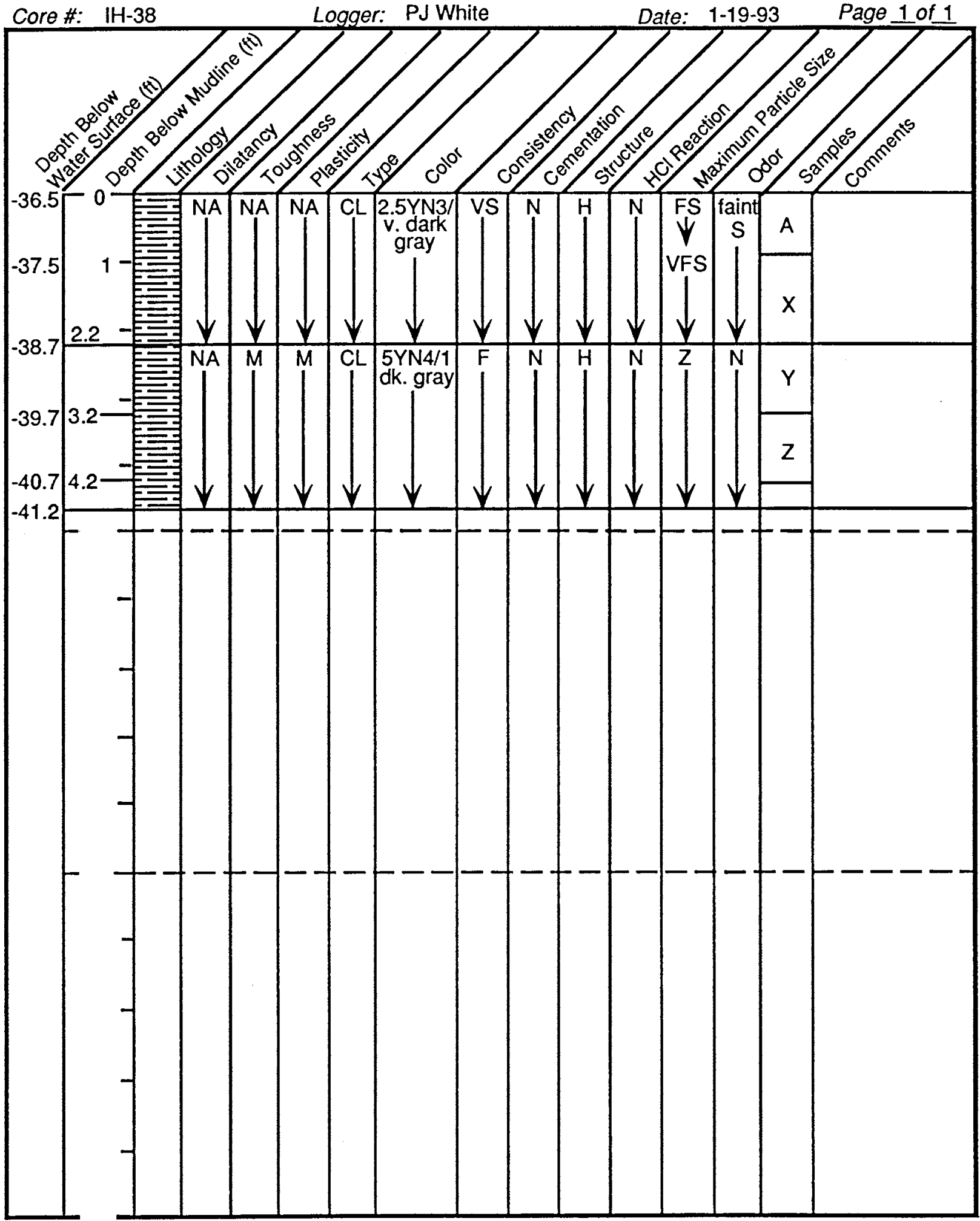

B. 38 
Project: Heckathorn

\section{Core Data Log}

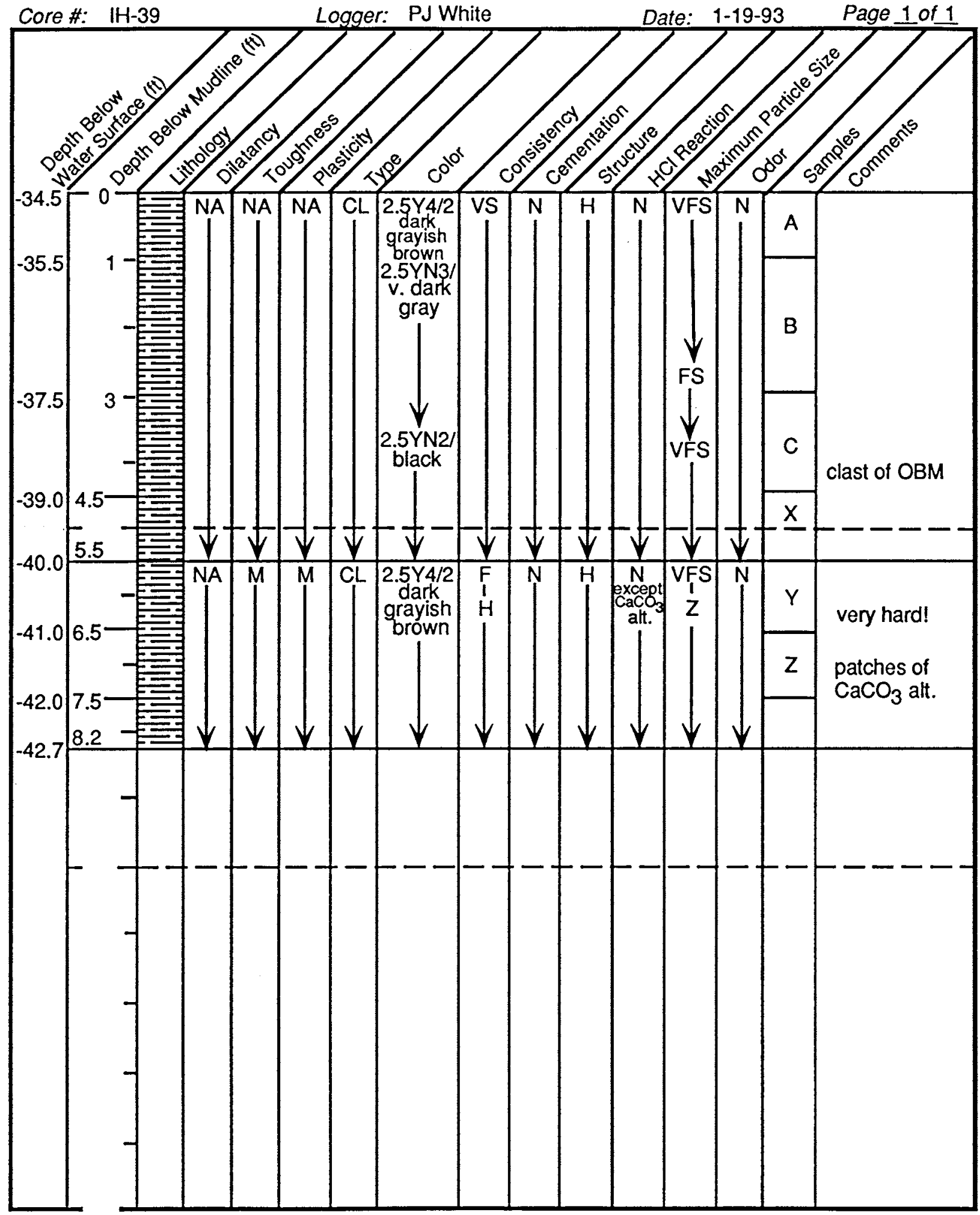

B. 39 
Project: Heckathorn

Core Data Log

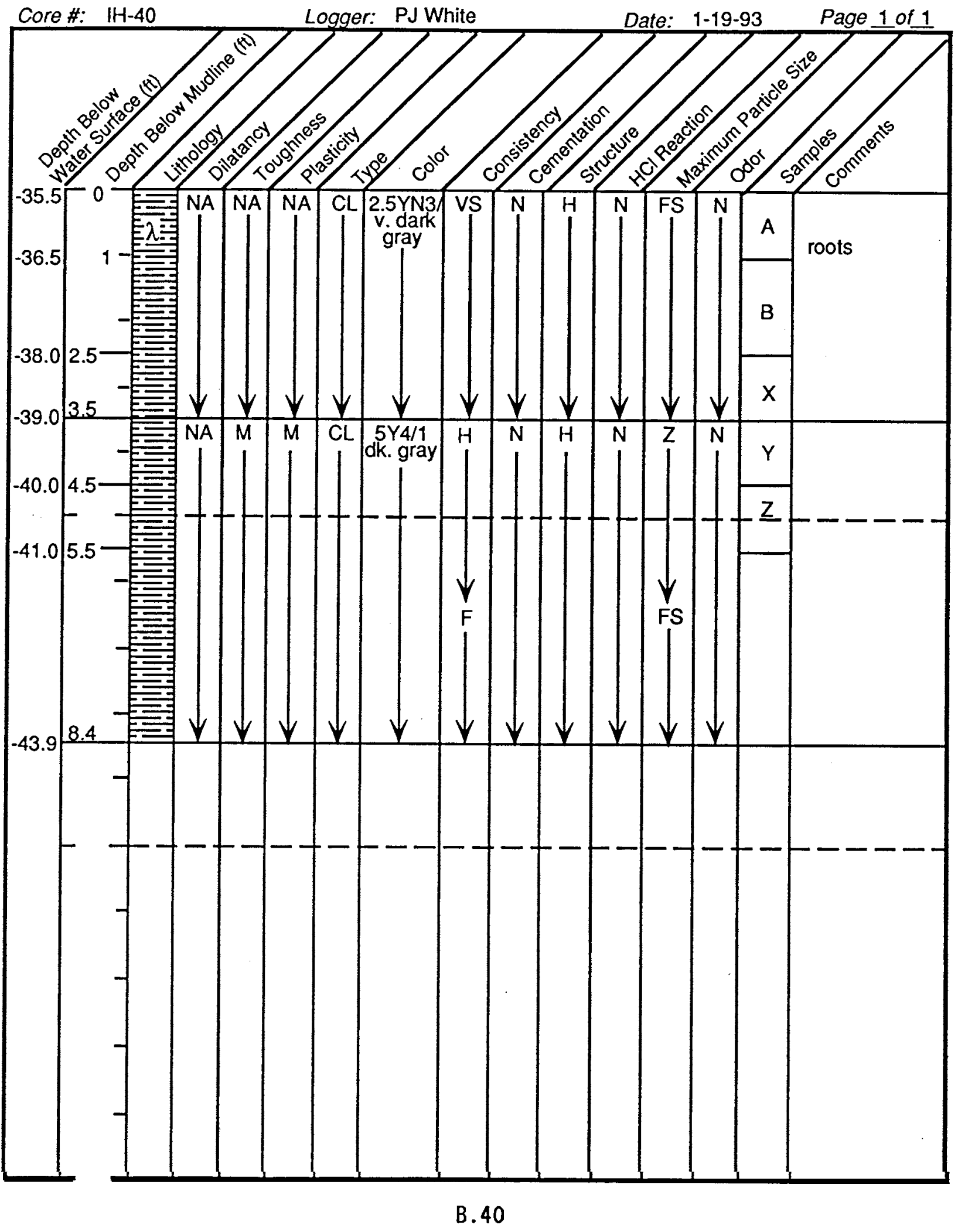


Project: Heckathorn

Core Data Log

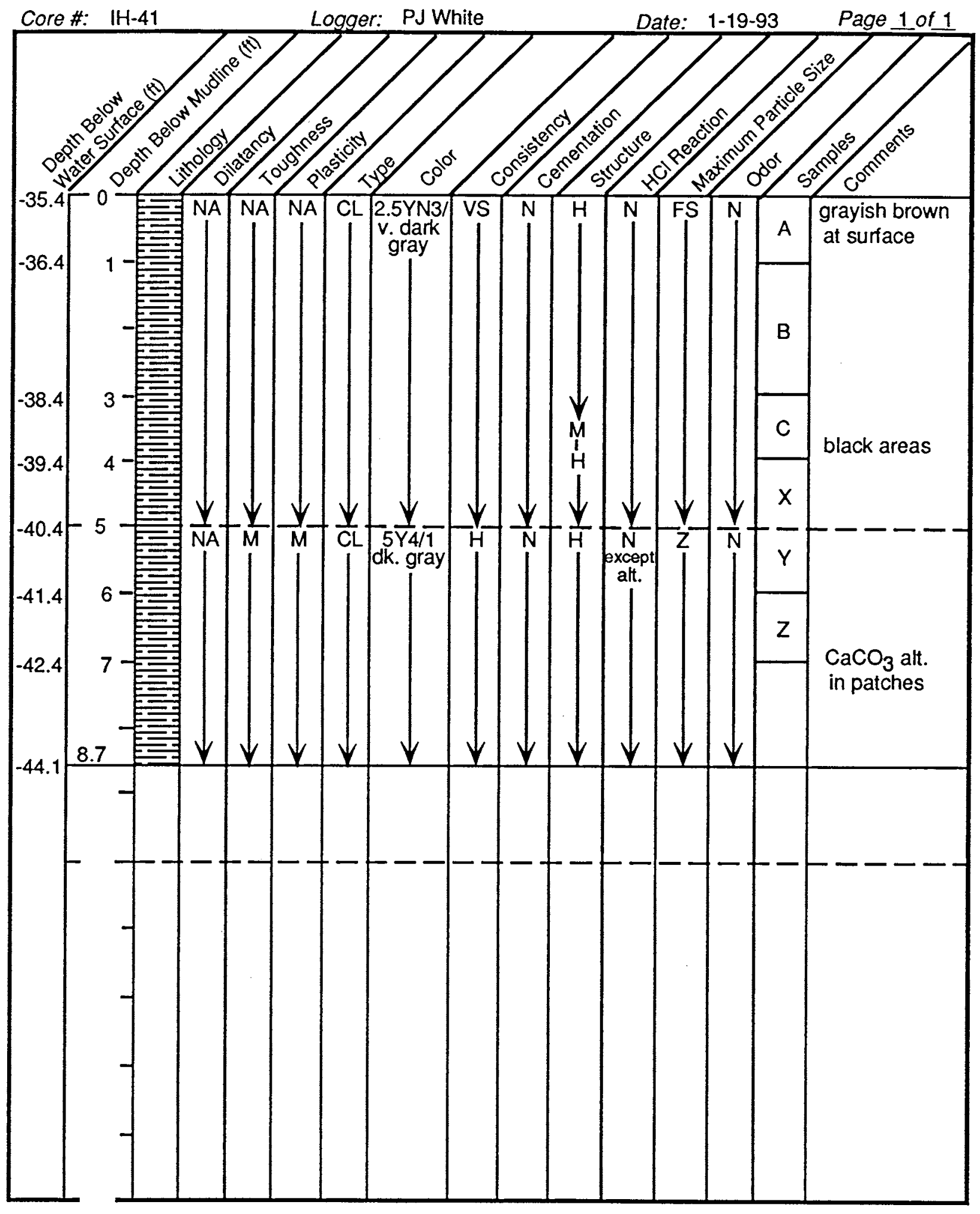


Project: Heckathorn

Core Data Log

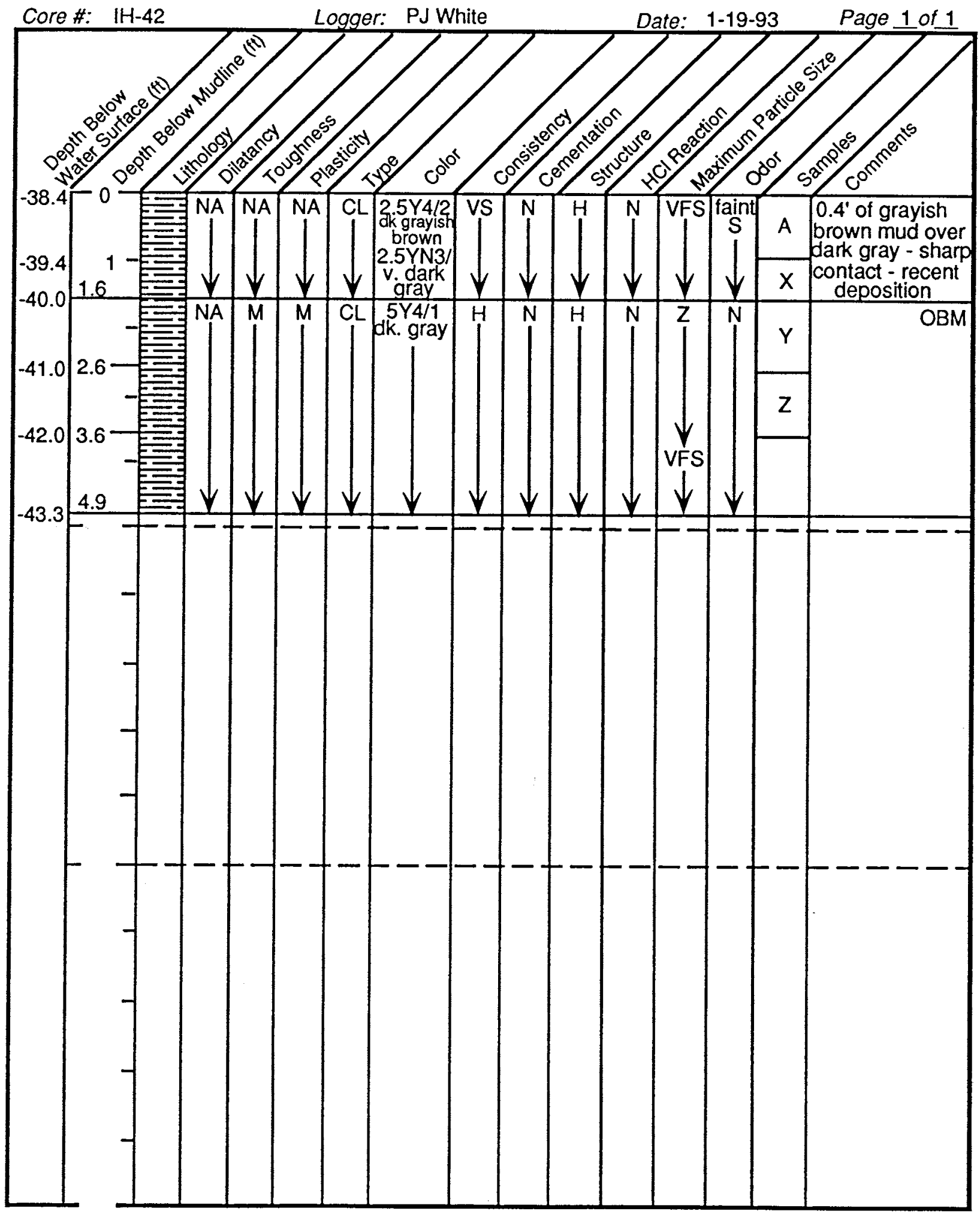

B. 42 
Project: Heckathorn

Core Data Log

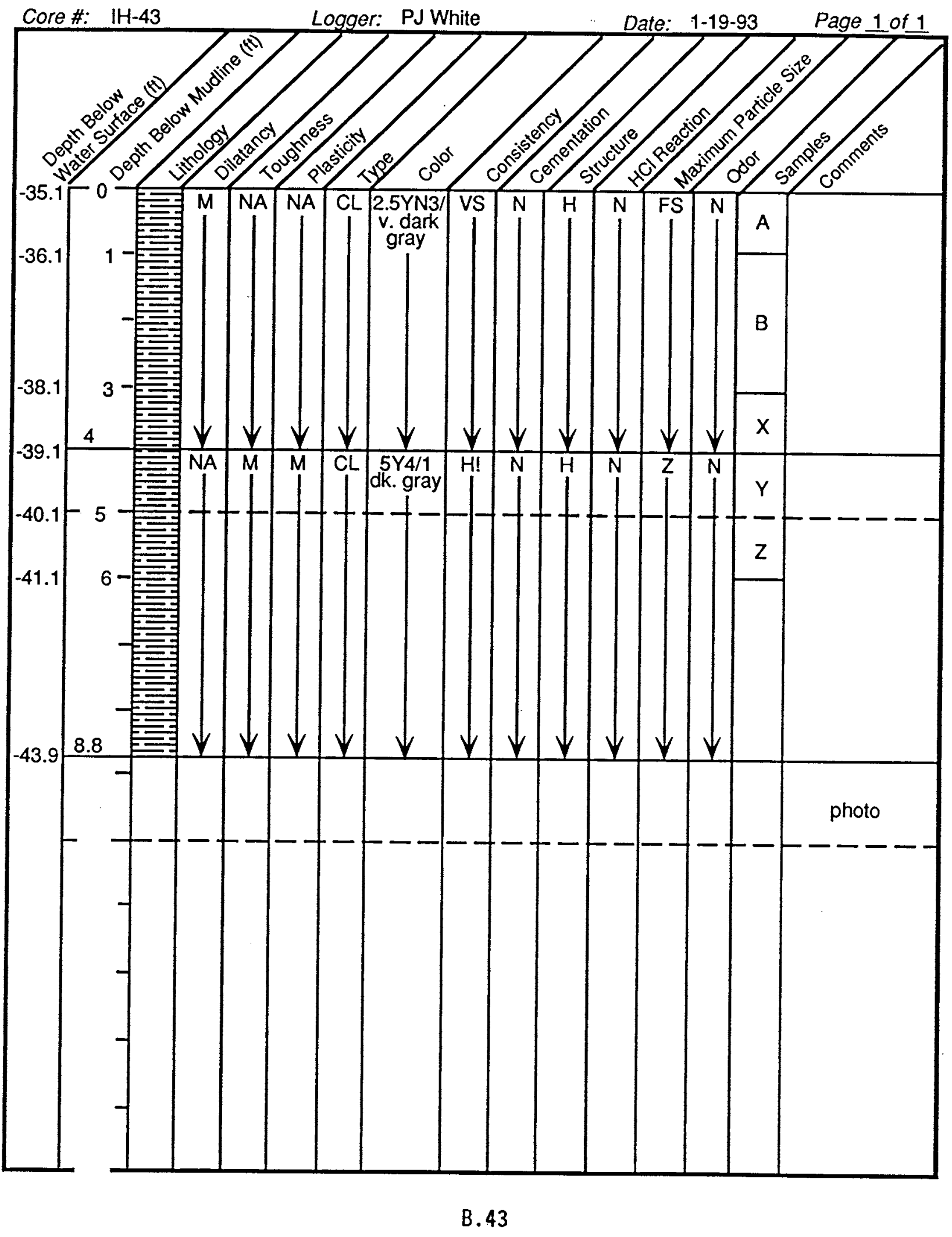




\section{Core Data Log}

Project: Heckathorn

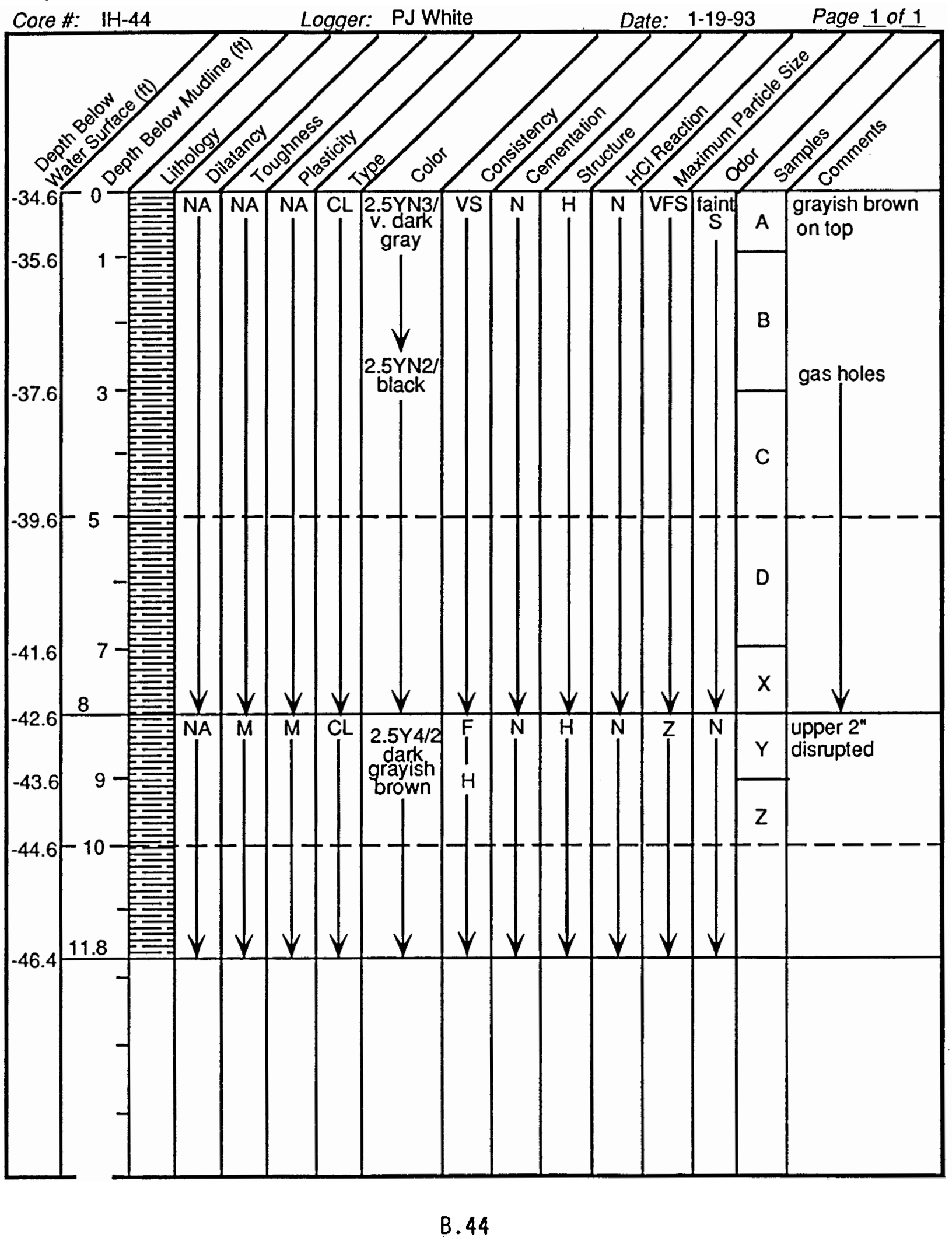


Project: Heckathorn

Core Data Log

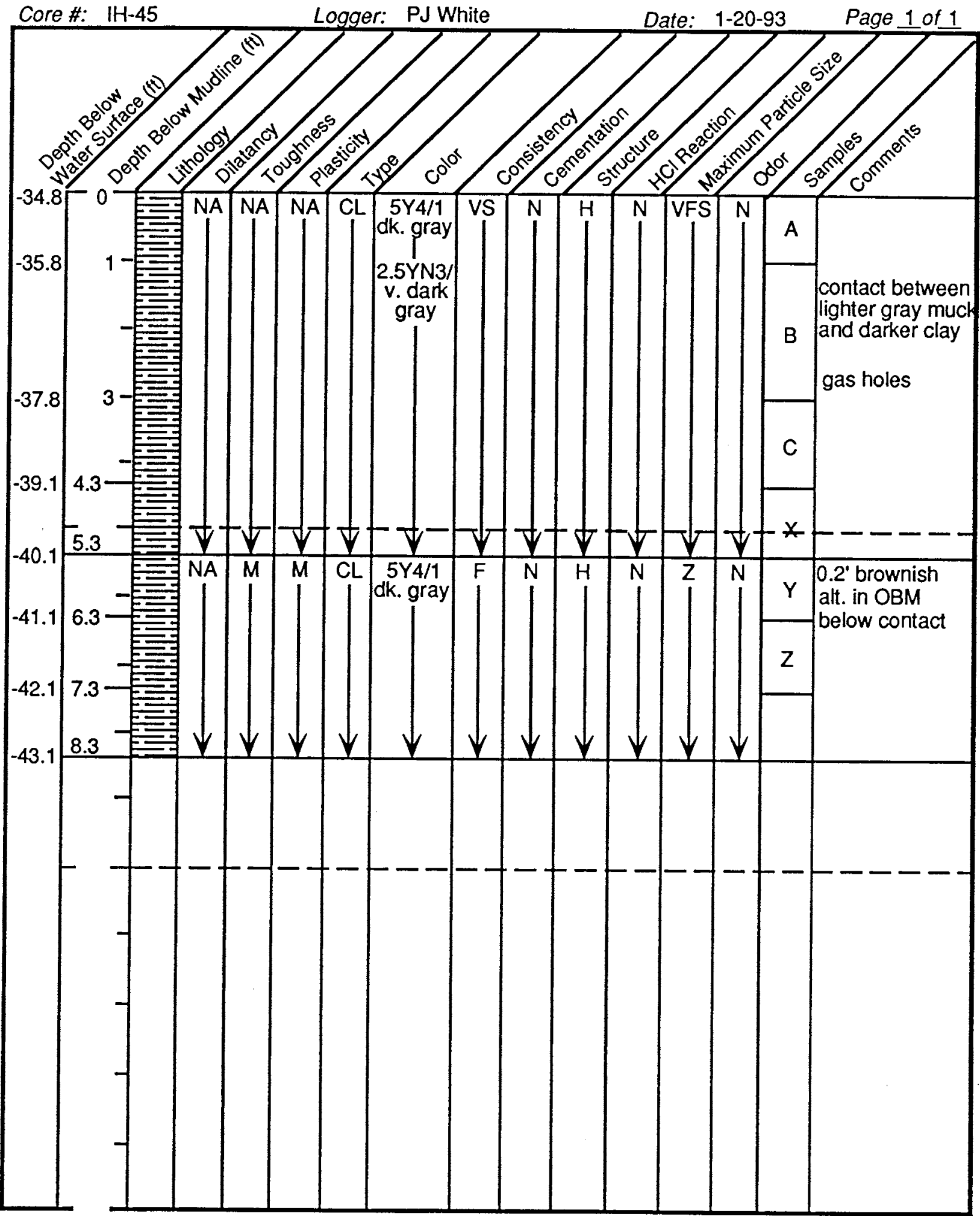

B. 45 
Project: Heckathorn

\section{Core Data Log}

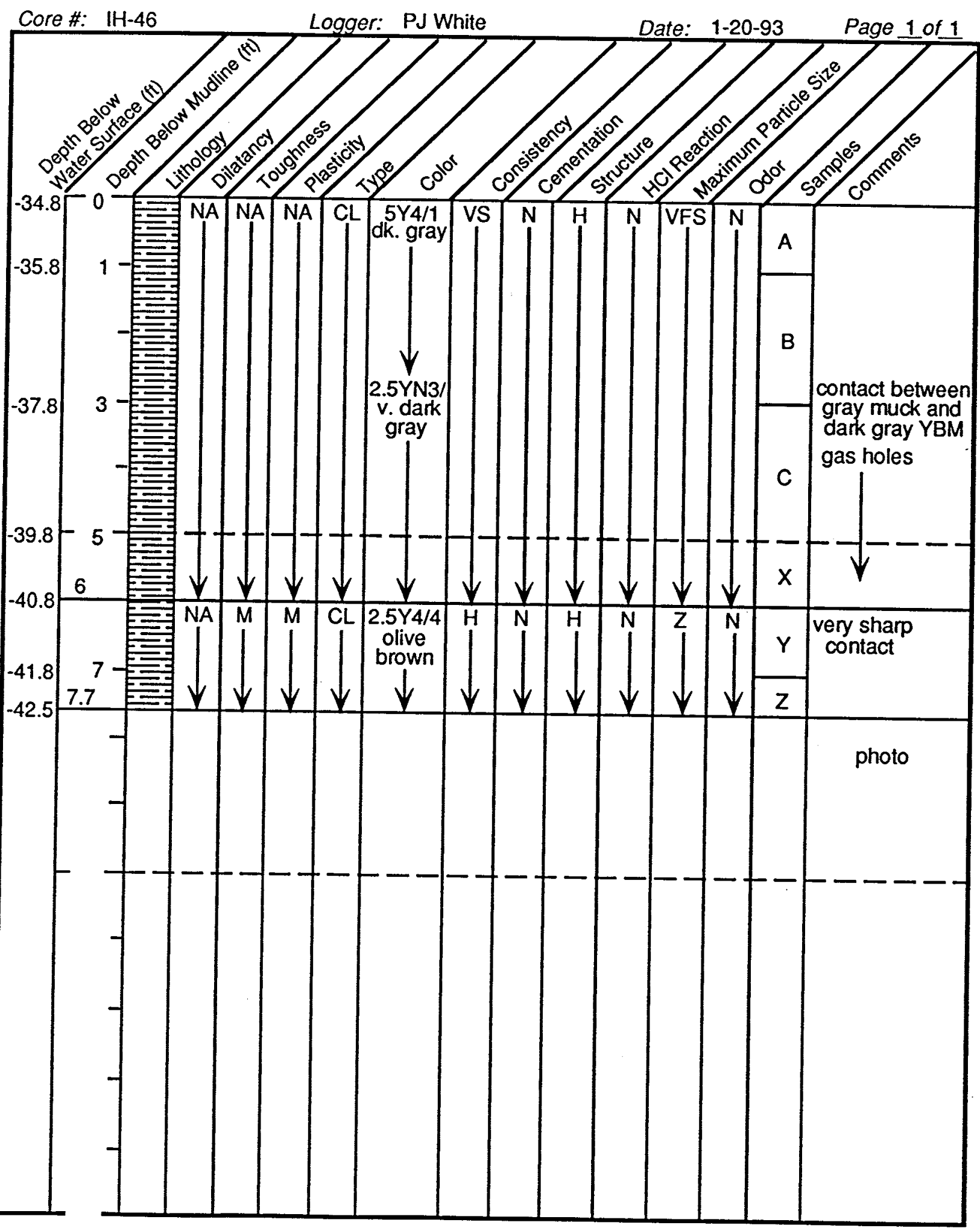

B. 46 


\section{Project: Heckathorn}

\section{Core Data Log}

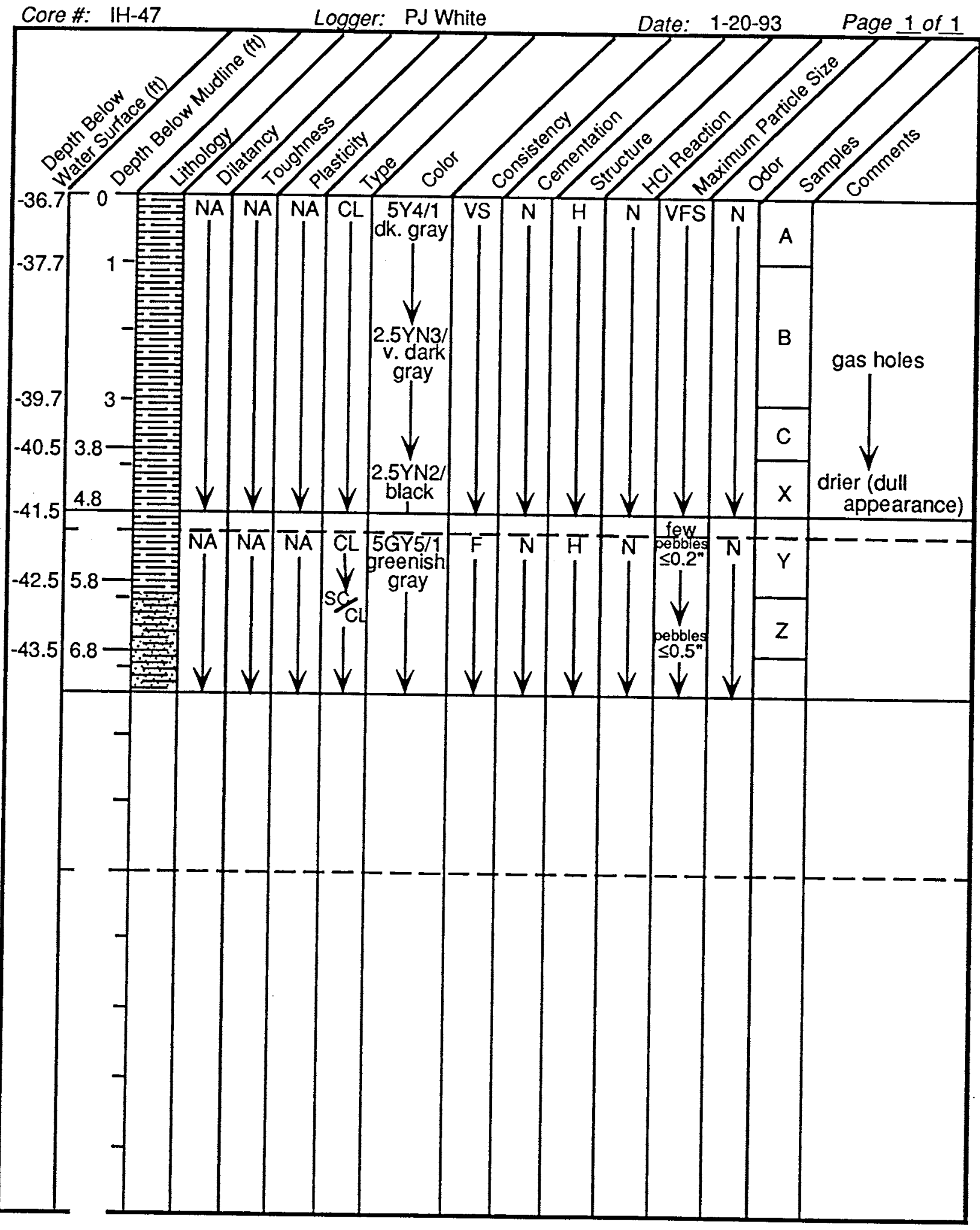


Project: Heckathorn

\section{Core Data Log}

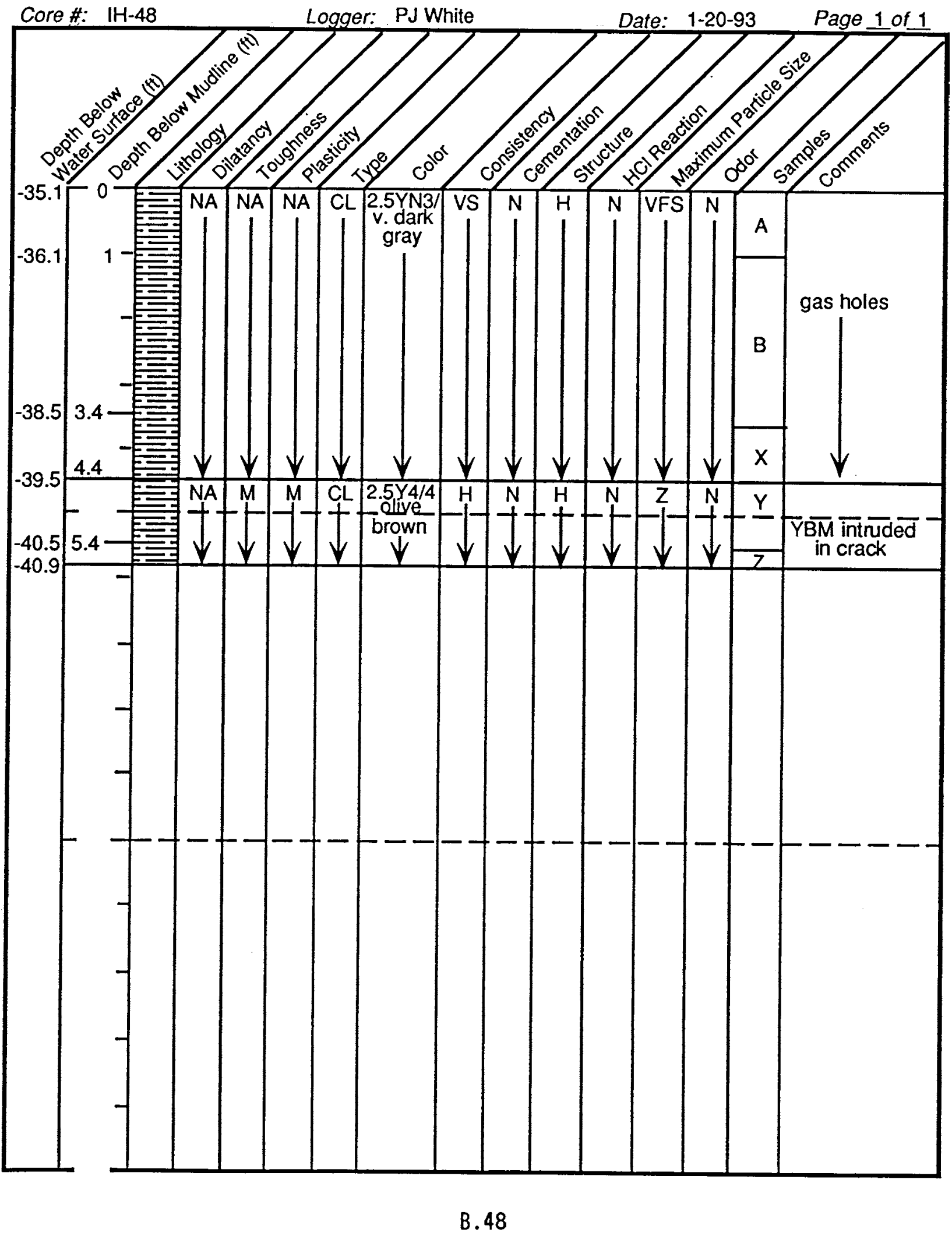


Project: Heckathorn

Core Data Log

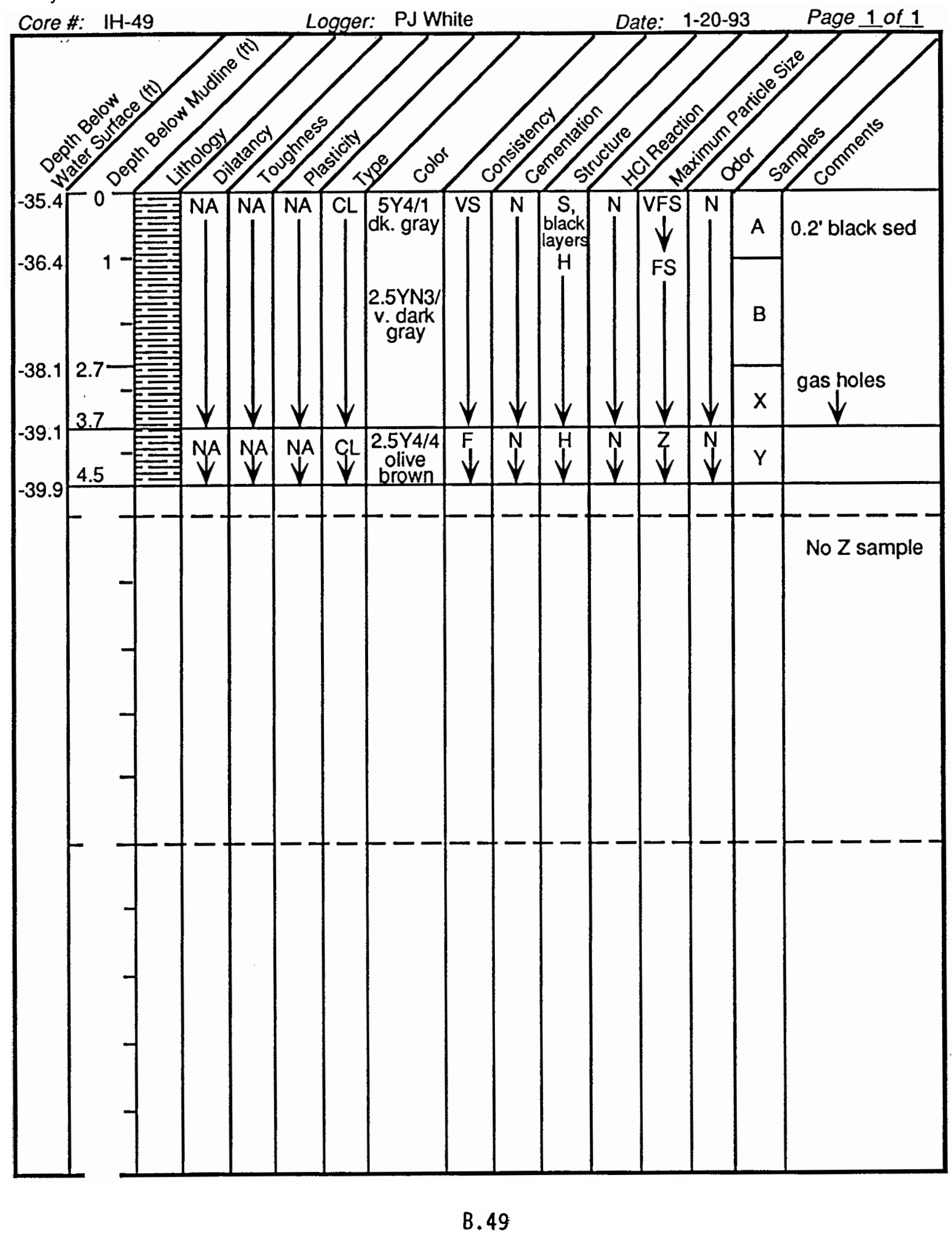


Project: Heckathorn

\section{Core Data Log}

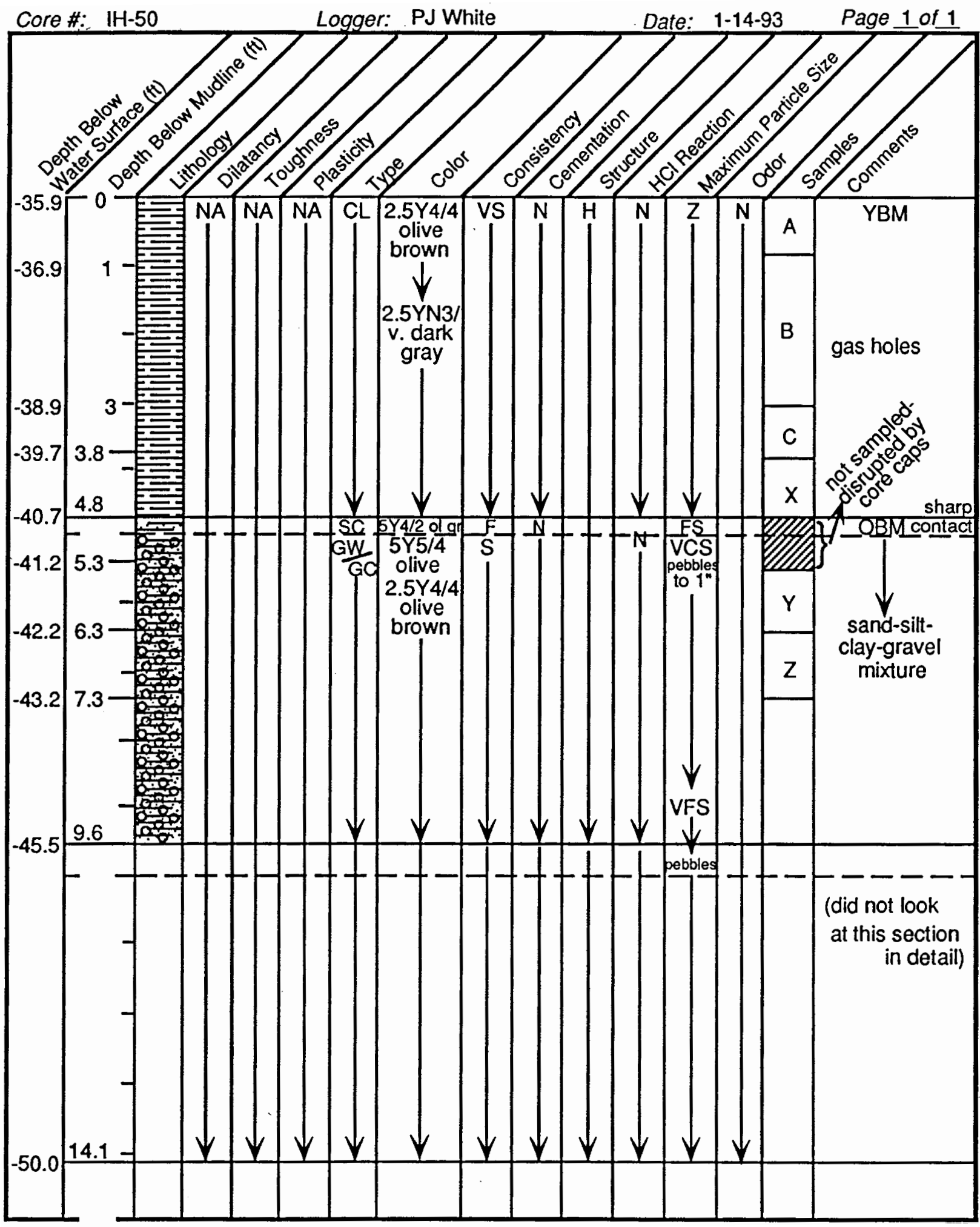

B. 50 


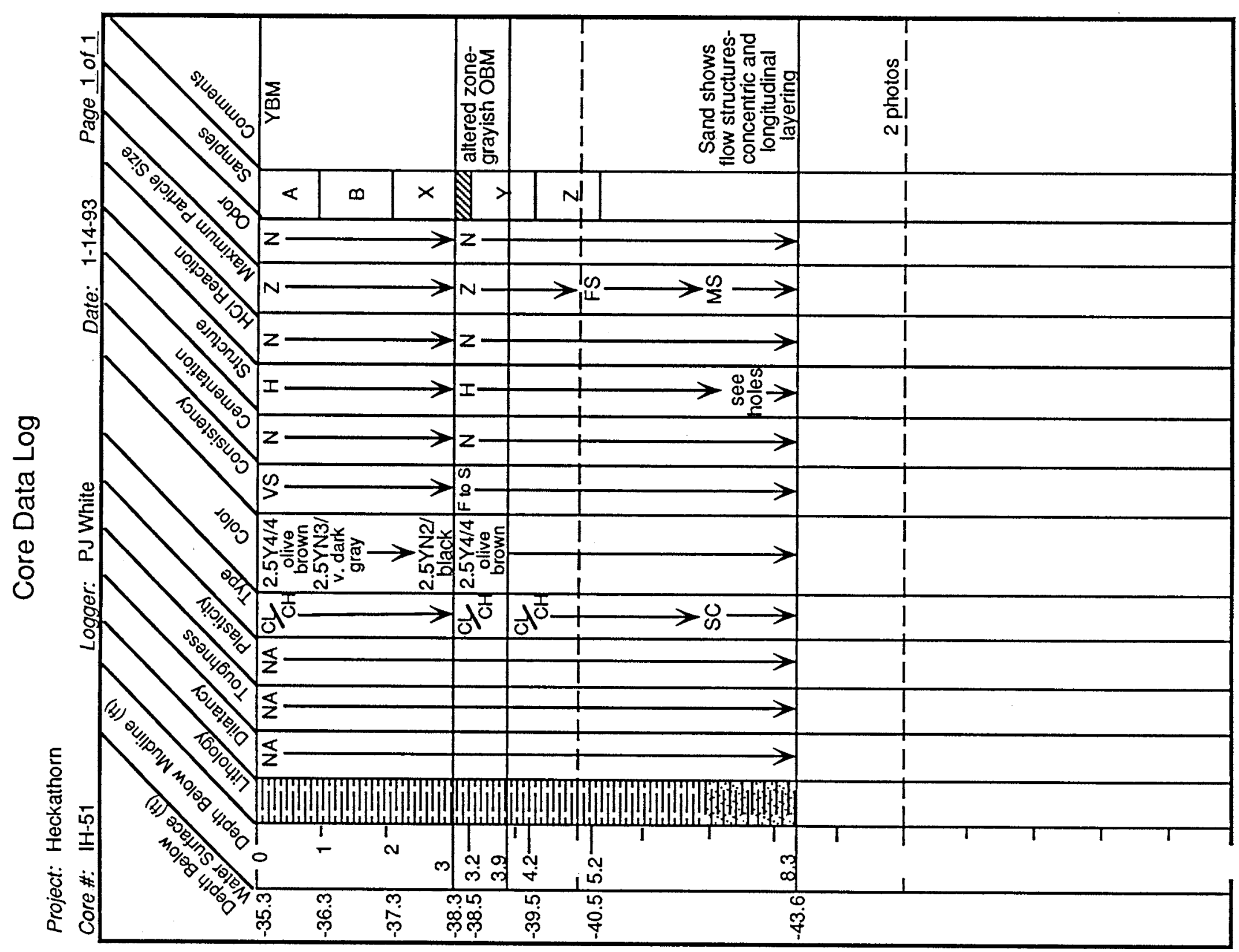


Project: Heckathorn

\section{Core Data Log}

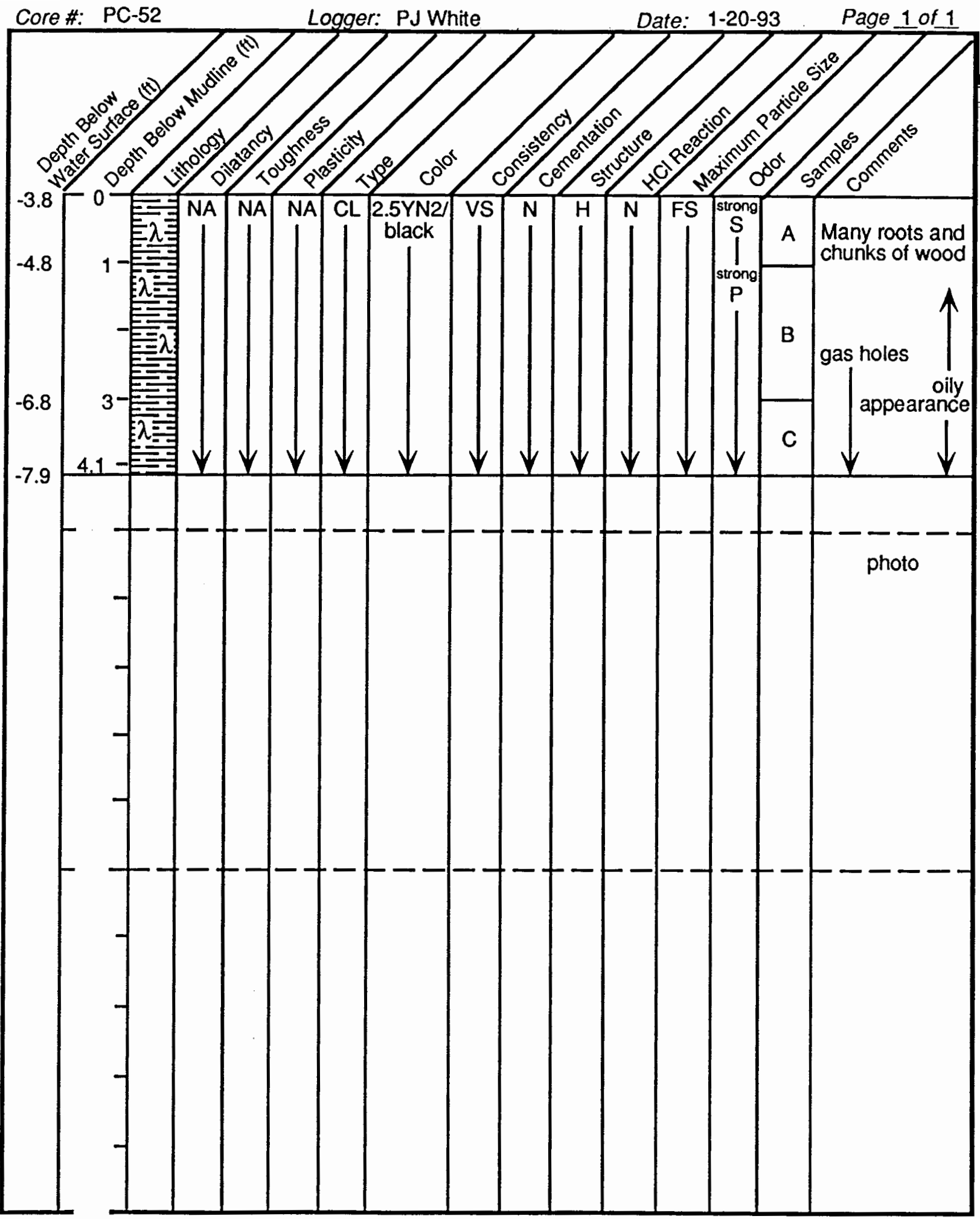

\section{B. 52}


Project: Heckathorn

Core Data Log

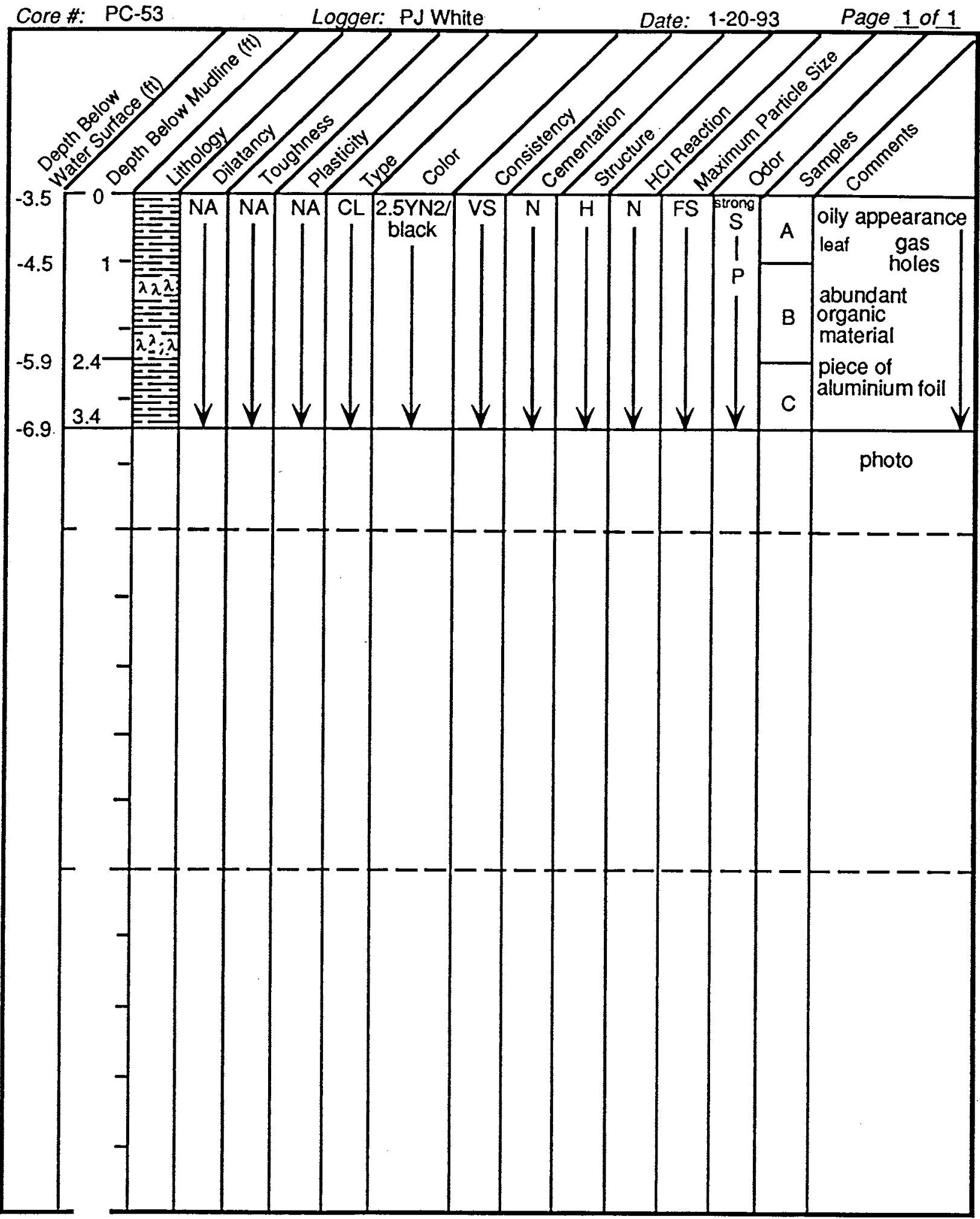

B. 53 
Project: Heckathorn

\section{Core Data Log}

Core \#: PC-54

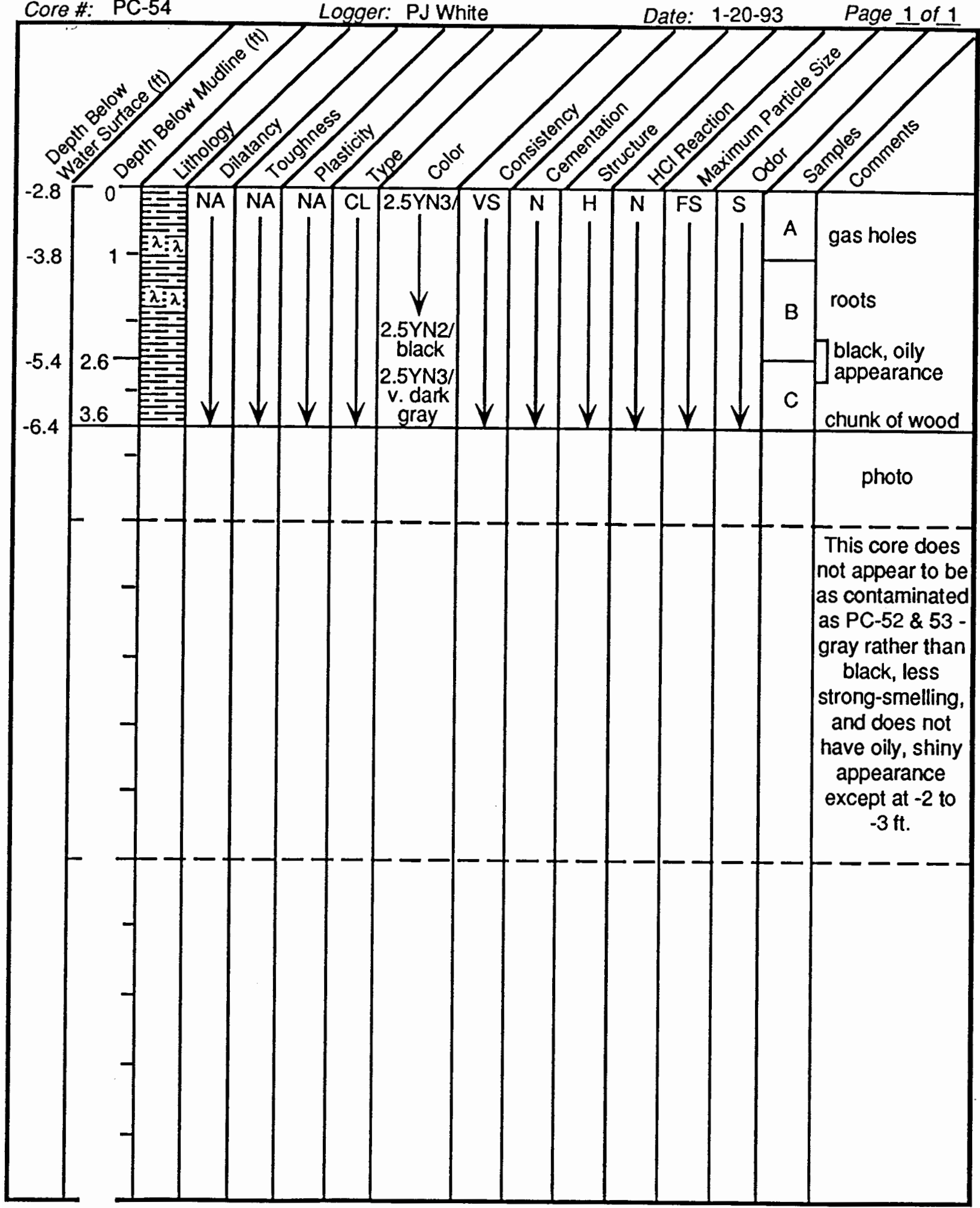

B. 54 
APPENDIX C

SEDIMENT CHEMISTRY AND QUALITY ASSURANCE DATA 

TABLE C. 1. Sediment Samples Prepared from 4-in. Cores and Channel Edge Grab Samples, United Heckathorn Remedi al Investigation

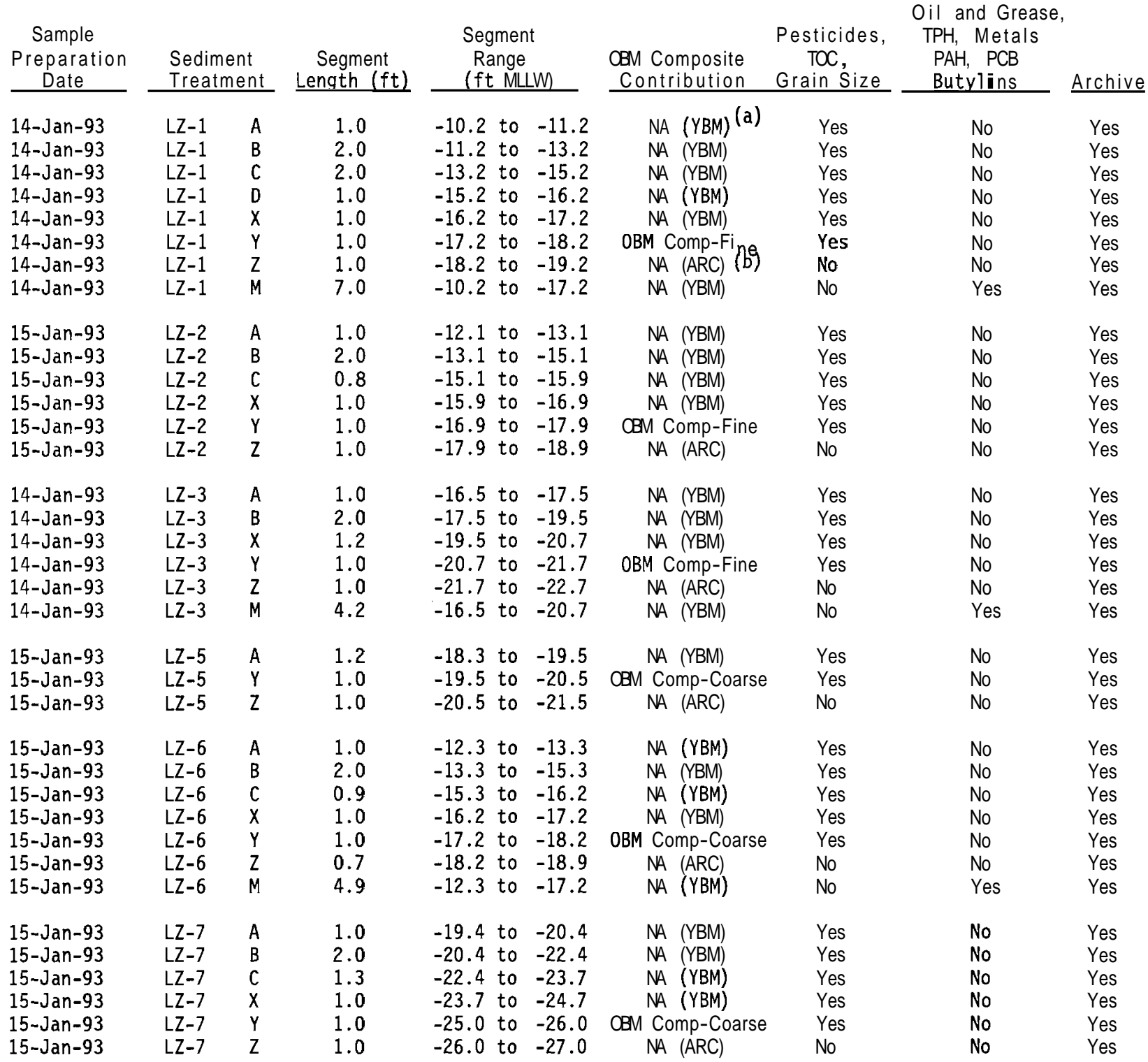


TABLE C.1. (contd)

\begin{tabular}{|c|c|c|c|c|c|c|c|c|c|c|}
\hline $\begin{array}{c}\text { Sample } \\
\text { Preparation } \\
\text { Date } \\
\end{array}$ & $\begin{array}{l}\text { Sedime } \\
\text { Treatm }\end{array}$ & & $\begin{array}{c}\text { Segment } \\
\text { Lenqth ( } f t)\end{array}$ & & & & $\begin{array}{l}\text { CBM Composite } \\
\text { Contribution }\end{array}$ & $\begin{array}{c}\text { Pesticides, } \\
\text { TOC, } \\
\text { Grain Size }\end{array}$ & $\begin{array}{c}\text { Oil and Grease, } \\
\text { TPH, Metals } \\
\text { PAH, PCB } \\
\text { Butvlins } \\
\end{array}$ & Archiv \\
\hline $\begin{array}{l}15-J a n-93 \\
15-J a n-93 \\
15-J a n-93 \\
15-J a n-93 \\
15-J a n-93 \\
15-J a n-93 \\
15-J a n-93 \\
15-J a n-93 \\
15-J a n-93 \\
15-J a n-93 \\
15-J a n-93\end{array}$ & $\begin{array}{l}\text { LZ-8 } \\
\text { LZ-8 } \\
\text { LZ-8 } \\
\text { LZ-8 } \\
\text { LZ-8 } \\
\text { LZ-8 } \\
\text { LZ-8 } \\
\text { LZ-8 } \\
\text { LZ-8 } \\
\text { LZ-8 } \\
\text { LZ-8 }\end{array}$ & $\begin{array}{l}A \\
B \\
B \\
C \\
D \\
E \\
F \\
G \\
X \\
Y \\
Z\end{array}$ & $\begin{array}{l}1.0 \\
2.0 \\
\text { Composit } \\
2.0 \\
2.0 \\
2.0 \\
2.0 \\
1.4 \\
1.0 \\
1.0 \\
1.0\end{array}$ & $\begin{array}{l}-12.3 \\
-13.3 \\
\text { ing Du } \\
-15.3 \\
-17.3 \\
-19.3 \\
-21.3 \\
-23.3 \\
-24.7 \\
-25.7 \\
-26.7\end{array}$ & $\begin{array}{l}\text { to } \\
\text { to } \\
\text { aplic } \\
\text { to } \\
\text { to } \\
\text { to } \\
\text { to } \\
\text { to } \\
\text { to } \\
\text { to } \\
\text { to }\end{array}$ & $\begin{array}{l}-13.3 \\
-15.3 \\
\text { cate } \\
-17.3 \\
-19.3 \\
-21.3 \\
-23.3 \\
-24.7 \\
-25.7 \\
-26.7 \\
-27.7\end{array}$ & $\begin{array}{c}\text { NA (YBM) } \\
\text { NA (YBM) } \\
\text { NA (YBM) } \\
\text { NA (YBM) } \\
\text { NA (YBM) } \\
\text { NA (YBM) } \\
\text { NA (YBM) } \\
\text { NA (YBM) } \\
\text { NA (YBM) } \\
\text { OBM Comp-Fine } \\
\text { NA (ARC) }\end{array}$ & $\begin{array}{l}\text { Yes } \\
\text { Yes } \\
\text { Yes } \\
\text { Yes } \\
\text { Yes } \\
\text { Yes } \\
\text { Yes } \\
\text { Yes } \\
\text { Yes } \\
\text { Yes } \\
\text { No }\end{array}$ & $\begin{array}{l}\text { No } \\
\text { No } \\
\text { No } \\
\text { No } \\
\text { No } \\
\text { No } \\
\text { No } \\
\text { No } \\
\text { No } \\
\text { No } \\
\text { No }\end{array}$ & $\begin{array}{l}\text { Yes } \\
\text { Yes } \\
\text { Yes } \\
\text { Yes } \\
\text { Yes } \\
\text { Yes } \\
\text { Yes } \\
\text { Yes } \\
\text { Yes } \\
\text { Yes } \\
\text { Yes }\end{array}$ \\
\hline $\begin{array}{l}15-J a n-93 \\
15-J a n-93 \\
15-J a n-93 \\
15-J a n-93 \\
15-J a n-93\end{array}$ & $\begin{array}{l}\text { LZ-9 } \\
\text { LZ-9 } \\
\text { LZ-9 } \\
\text { LZ-9 } \\
\text { LZ-9 }\end{array}$ & $\begin{array}{l}A \\
X \\
Y \\
Z \\
M\end{array}$ & $\begin{array}{l}1.0 \\
1.0 \\
1.0 \\
1.0 \\
2.0\end{array}$ & $\begin{array}{l}-25.4 \\
-26.4 \\
-27.7 \\
-28.7 \\
-25.4\end{array}$ & $\begin{array}{l}\text { to } \\
\text { to } \\
\text { to } \\
\text { to } \\
\text { to }\end{array}$ & $\begin{array}{l}-26.4 \\
-27.4 \\
-28.7 \\
-29.7 \\
-27.4\end{array}$ & $\begin{array}{l}\text { NA (YBM) } \\
\text { NA (YBM) } \\
\text { No Contribution } \\
\text { NA (ARC) } \\
\text { NA (YBM) }\end{array}$ & $\begin{array}{l}\text { Yes } \\
\text { Yes } \\
\text { Yes } \\
\text { No } \\
\text { No }\end{array}$ & $\begin{array}{l}\text { No } \\
\text { No } \\
\text { No } \\
\text { No } \\
\text { Yes }\end{array}$ & $\begin{array}{l}\text { Yes } \\
\text { Yes } \\
\text { Yes } \\
\text { Yes } \\
\text { Yes }\end{array}$ \\
\hline $\begin{array}{l}16-J a n-93 \\
16-J a n-93 \\
16-J a n-93 \\
16-J a n-93 \\
16-J a n-93\end{array}$ & $\begin{array}{l}\text { LZ-10 } \\
\text { LZ-10 } \\
\text { LZ-10 } \\
\text { LZ-10 } \\
\text { LZ-10 }\end{array}$ & $\begin{array}{l}A \\
B \\
X \\
Y \\
Z\end{array}$ & $\begin{array}{l}1.0 \\
2.0 \\
1.3 \\
1.0 \\
1.0\end{array}$ & $\begin{array}{l}-34.7 \\
-35.7 \\
-37.7 \\
-39.0 \\
-40.0\end{array}$ & $\begin{array}{l}\text { to } \\
\text { to } \\
\text { to } \\
\text { to } \\
\text { to }\end{array}$ & $\begin{array}{l}-35.7 \\
-37.7 \\
-39.0 \\
-40.0 \\
-41.0\end{array}$ & $\begin{array}{c}\text { NA (YBM) } \\
\text { NA (YBM) } \\
\text { NA (YBM) } \\
\text { @B Comp-Fine } \\
\text { NA (ARC) }\end{array}$ & $\begin{array}{l}\text { Yes } \\
\text { Yes } \\
\text { Yes } \\
\text { Yes } \\
\text { No }\end{array}$ & $\begin{array}{l}\text { No } \\
\text { No } \\
\text { No } \\
\text { No } \\
\text { No }\end{array}$ & $\begin{array}{l}\text { Yes } \\
\text { Yes } \\
\text { Yes } \\
\text { Yes } \\
\text { Yes }\end{array}$ \\
\hline $\begin{array}{l}15-J a n-93 \\
15-J a n-93 \\
15-J a n-93 \\
15-J a n-93 \\
15-J a n-93\end{array}$ & $\begin{array}{l}\text { LZ-11 } \\
\text { LZ-11 } \\
\text { LZ-11 } \\
\text { LZ-11 } \\
\text { LZ-11 }\end{array}$ & $\begin{array}{l}A \\
X \\
Y \\
Z \\
M\end{array}$ & $\begin{array}{l}1.0 \\
0.7 \\
1.0 \\
1.0 \\
1.7\end{array}$ & $\begin{array}{l}-12.0 \\
-13.0 \\
-13.9 \\
-14.9 \\
-12.0\end{array}$ & $\begin{array}{l}\text { to } \\
\text { to } \\
\text { to } \\
\text { to } \\
\text { to }\end{array}$ & $\begin{array}{l}-13.0 \\
-13.7 \\
-14.9 \\
-15.9 \\
-13.7\end{array}$ & $\begin{array}{c}\text { NA (YBM) } \\
\text { NA (YBM) } \\
\text { CBM Comp-Coarse } \\
\text { NA (ARC) } \\
\text { NA (YBM) }\end{array}$ & $\begin{array}{l}\text { Yes } \\
\text { Yes } \\
\text { Yes } \\
\text { No } \\
\text { No }\end{array}$ & $\begin{array}{l}\text { No } \\
\text { No } \\
\text { No } \\
\text { No } \\
\text { Yes }\end{array}$ & $\begin{array}{l}\text { Yes } \\
\text { Yes } \\
\text { Yes } \\
\text { Yes } \\
\text { Yes }\end{array}$ \\
\hline $\begin{array}{l}16-J a n-93 \\
16-J a n-93 \\
16-J a n-93 \\
16-J a n-93\end{array}$ & $\begin{array}{l}\text { LZ-12 } \\
\text { LZ-12 } \\
\text { LZ-12 } \\
\text { LZ-12 }\end{array}$ & $\begin{array}{l}A \\
X \\
Y \\
Z\end{array}$ & $\begin{array}{l}1.0 \\
1.2 \\
1.0 \\
0.9\end{array}$ & $\begin{array}{l}-37.5 \\
-38.5 \\
-39.7 \\
-40.7\end{array}$ & $\begin{array}{l}\text { to } \\
\text { to } \\
\text { to } \\
\text { to }\end{array}$ & $\begin{array}{l}-38.5 \\
-39.7 \\
-40.7 \\
-41.6\end{array}$ & $\begin{array}{c}\text { NA (YBM) } \\
\text { NA (YBM) } \\
\text { œBM Comp-Coarse } \\
\text { NA (ARC) }\end{array}$ & $\begin{array}{l}\text { Yes } \\
\text { Yes } \\
\text { Yes } \\
\text { No }\end{array}$ & $\begin{array}{l}\text { No } \\
\text { No } \\
\text { No } \\
\text { No }\end{array}$ & $\begin{array}{l}\text { Yes } \\
\text { Yes } \\
\text { Yes } \\
\text { Yes }\end{array}$ \\
\hline $\begin{array}{l}16-J a n-93 \\
16-J a n-93 \\
16-J a n-93 \\
16-J a n-93 \\
16-J a n-93 \\
16-J a n-93 \\
16-J a n-93\end{array}$ & $\begin{array}{l}\text { LZ-13 } \\
\text { LZ-13 } \\
\text { LZ-13 } \\
\text { LZ-13 } \\
\text { LZ-13 } \\
\text { LZ-13 } \\
\text { LZ-13 }\end{array}$ & $\begin{array}{l}A \\
B \\
C \\
X \\
Y \\
Z \\
M\end{array}$ & $\begin{array}{l}1.0 \\
2.0 \\
2.0 \\
1.2 \\
1.0 \\
1.0 \\
6.2\end{array}$ & $\begin{array}{l}-34.9 \\
-35.9 \\
-37.9 \\
-39.9 \\
-41.1 \\
-42.1 \\
-34.9\end{array}$ & $\begin{array}{l}\text { to } \\
\text { to } \\
\text { to } \\
\text { to } \\
\text { to } \\
\text { to } \\
\text { to }\end{array}$ & $\begin{array}{l}-35.9 \\
-37.9 \\
-39.9 \\
-41.1 \\
-42.1 \\
-43.1 \\
-41.1\end{array}$ & $\begin{array}{c}\text { NA (YBM) } \\
\text { NA (YBM) } \\
\text { NA (YBM) } \\
\text { NA (YBM) } \\
\text { CBM Comp-Fine } \\
\text { NA (ARC) } \\
\text { NA (YBM) }\end{array}$ & $\begin{array}{l}\text { Yes } \\
\text { Yes } \\
\text { Yes } \\
\text { Yes } \\
\text { Yes } \\
\text { No } \\
\text { No }\end{array}$ & $\begin{array}{l}\text { No } \\
\text { No } \\
\text { No } \\
\text { No } \\
\text { No } \\
\text { No } \\
\text { Yes }\end{array}$ & $\begin{array}{l}\text { Yes } \\
\text { Yes } \\
\text { Yes } \\
\text { Yes } \\
\text { Yes } \\
\text { Yes } \\
\text { Yes }\end{array}$ \\
\hline $\begin{array}{l}15-J a n-93 \\
15-J a n-93 \\
15-J a n-93 \\
15-J a n-93\end{array}$ & $\begin{array}{l}\text { LZ-14 } \\
\text { LZ-14 } \\
\text { LZ-14 } \\
\text { LZ-14 }\end{array}$ & $\begin{array}{l}A \\
X \\
Y \\
Z\end{array}$ & $\begin{array}{l}1.0 \\
0.9 \\
1.0 \\
1.0\end{array}$ & $\begin{array}{l}-23.1 \\
-24.1 \\
-25.0 \\
-26.0\end{array}$ & $\begin{array}{l}\text { to } \\
\text { to } \\
\text { to } \\
\text { to }\end{array}$ & $\begin{array}{l}-24.1 \\
-25.0 \\
-26.0 \\
-27.0\end{array}$ & $\begin{array}{c}\text { NA (YBM) } \\
\text { NA (YBM) } \\
\text { CBM Comp-Coarse } \\
\text { NA (ARC) }\end{array}$ & $\begin{array}{l}\text { Yes } \\
\text { Yes } \\
\text { Yes } \\
\text { No }\end{array}$ & $\begin{array}{l}\text { No } \\
\text { No } \\
\text { No } \\
\text { No }\end{array}$ & $\begin{array}{l}\text { Yes } \\
\text { Yes } \\
\text { Yes } \\
\text { Yes }\end{array}$ \\
\hline
\end{tabular}


TABLE C.1. (contd)

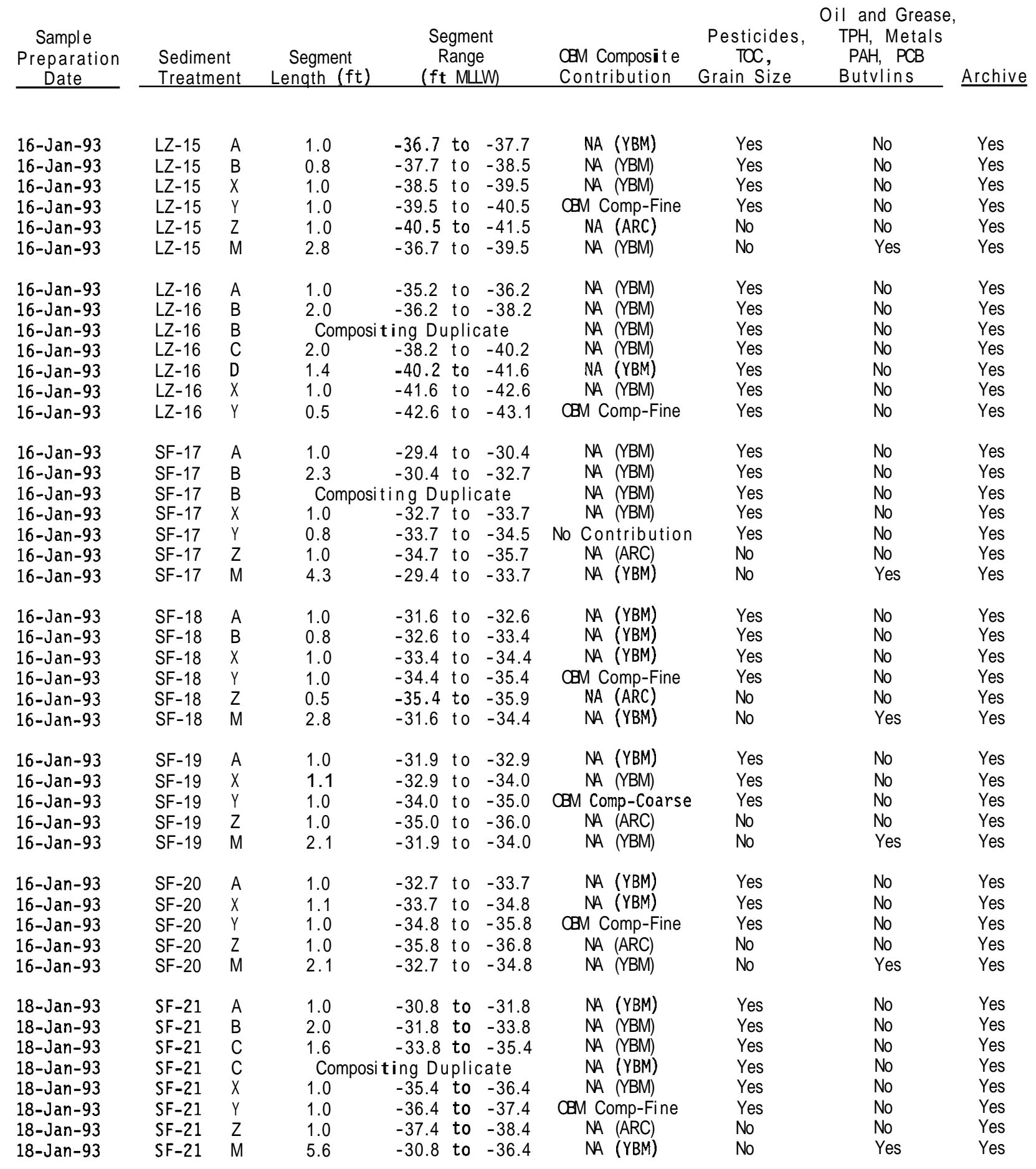


TABLE C.1. (contd)

\begin{tabular}{|c|c|c|c|c|c|c|c|c|c|c|}
\hline $\begin{array}{c}\text { Sample } \\
\text { Preparation } \\
\text { Date } \\
\end{array}$ & \multicolumn{2}{|c|}{$\begin{array}{l}\text { Sediment } \\
\text { Treatment }\end{array}$} & \multicolumn{4}{|c|}{$\begin{array}{c}\text { Segment } \\
\text { Range } \\
\text { (ft MนW) } \\
\end{array}$} & $\begin{array}{l}\text { CBM Composite } \\
\text { Contribution }\end{array}$ & $\begin{array}{c}\text { Pesticides, } \\
\text { TOC, } \\
\text { Grain Size } \\
\end{array}$ & $\begin{array}{c}\text { Oil and Grease, } \\
\text { TPH, Metals } \\
\text { PAH, PCB } \\
\text { Butylins } \\
\end{array}$ & $\underline{\text { Archive }}$ \\
\hline $\begin{array}{l}18-J a n-93 \\
18-J a n-93 \\
18-J a n-93 \\
18-J a n-93 \\
18-J a n-93 \\
18-J a n-93 \\
18-J a n-93\end{array}$ & $\begin{array}{l}\text { SF-22 } \\
\text { SF-22 } \\
\text { SF-22 } \\
\text { SF-22 } \\
\text { SF-22 } \\
\text { SF-22 } \\
\text { SF-22 }\end{array}$ & $\begin{array}{l}A \\
B \\
C \\
X \\
Y \\
Z \\
M\end{array}$ & $\begin{array}{l}1.0 \\
2.0 \\
2.1 \\
1.0 \\
1.0 \\
1.0 \\
6.1\end{array}$ & $\begin{array}{l}-28.9 \\
-29.9 \\
-31.9 \\
-34.0 \\
-35.0 \\
-36.0 \\
-28.9\end{array}$ & $\begin{array}{l}\text { to } \\
\text { to } \\
\text { to } \\
\text { to } \\
\text { to } \\
\text { to } \\
\text { to }\end{array}$ & $\begin{array}{l}-29.9 \\
-31.9 \\
-34.0 \\
-35.0 \\
-36.0 \\
-37.0 \\
-35.0\end{array}$ & $\begin{array}{c}\text { NA (YBM) } \\
\text { NA (YBM) } \\
\text { NA (YBM) } \\
\text { NA (YBM) } \\
\text { OBM Comp-Fine } \\
\text { NA (ARC) } \\
\text { NA (YBM) }\end{array}$ & $\begin{array}{l}\text { Yes } \\
\text { Yes } \\
\text { Yes } \\
\text { Yes } \\
\text { Yes } \\
\text { No } \\
\text { No }\end{array}$ & $\begin{array}{l}\text { No } \\
\text { No } \\
\text { No } \\
\text { No } \\
\text { No } \\
\text { No } \\
\text { Yes }\end{array}$ & $\begin{array}{l}\text { Yes } \\
\text { Yes } \\
\text { Yes } \\
\text { Yes } \\
\text { Yes } \\
\text { Yes } \\
\text { Yes }\end{array}$ \\
\hline $\begin{array}{l}18-J a n-93 \\
18-J a n-93 \\
18-J a n-93 \\
18-J a n-93 \\
18-J a n-93 \\
18-J a n-93\end{array}$ & $\begin{array}{l}\text { SF-23 } \\
\text { SF-23 } \\
\text { SF-23 } \\
\text { SF-23 } \\
\text { SF-23 } \\
\text { SF-23 }\end{array}$ & $\begin{array}{l}A \\
B \\
X \\
Y \\
Z \\
M\end{array}$ & $\begin{array}{l}1.0 \\
0.7 \\
1.0 \\
1.0 \\
0.8 \\
2.7\end{array}$ & $\begin{array}{l}-34.2 \\
-35.2 \\
-35.9 \\
-36.9 \\
-37.9 \\
-34.2\end{array}$ & $\begin{array}{l}\text { to } \\
\text { to } \\
\text { to } \\
\text { to } \\
\text { to } \\
\text { to }\end{array}$ & $\begin{array}{l}-35.2 \\
-35.9 \\
-36.9 \\
-37.9 \\
-38.7 \\
-36.9\end{array}$ & $\begin{array}{c}\text { NA (YBM) } \\
\text { NA (YBM) } \\
\text { NA (YBM) } \\
\text { CBM Comp-Fine } \\
\text { NA (ARC) } \\
\text { NA (YBM) }\end{array}$ & $\begin{array}{l}\text { Yes } \\
\text { Yes } \\
\text { Yes } \\
\text { Yes } \\
\text { No } \\
\text { No }\end{array}$ & $\begin{array}{l}\text { No } \\
\text { No } \\
\text { No } \\
\text { No } \\
\text { No } \\
\text { Yes }\end{array}$ & $\begin{array}{l}\text { Yes } \\
\text { Yes } \\
\text { Yes } \\
\text { Yes } \\
\text { Yes } \\
\text { Yes }\end{array}$ \\
\hline $\begin{array}{l}18-J a n-93 \\
18-J a n-93 \\
18-J a n-93 \\
18-J a n-93\end{array}$ & $\begin{array}{l}\text { SF-24 } \\
\text { SF-24 } \\
\text { SF-24 } \\
\text { SF-24 }\end{array}$ & $\begin{array}{l}A \\
B \\
C \\
M\end{array}$ & $\begin{array}{l}1.0 \\
2.0 \\
1.8 \\
4.8\end{array}$ & $\begin{array}{l}-31.4 \\
-32.4 \\
-34.4 \\
-31.4\end{array}$ & $\begin{array}{l}\text { to } \\
\text { to } \\
\text { to } \\
\text { to }\end{array}$ & $\begin{array}{l}-32.4 \\
-34.4 \\
-36.2 \\
-36.2\end{array}$ & $\begin{array}{ll}\text { NA } & (\mathrm{YBM}) \\
\mathrm{NA} & (\mathrm{YBM}) \\
\mathrm{NA} & (\mathrm{YBM}) \\
\mathrm{NA} & (\mathrm{YBM})\end{array}$ & $\begin{array}{l}\text { Yes } \\
\text { Yes } \\
\text { Yes } \\
\text { No }\end{array}$ & $\begin{array}{l}\text { No } \\
\text { No } \\
\text { No } \\
\text { Yes }\end{array}$ & $\begin{array}{l}\text { Yes } \\
\text { Yes } \\
\text { Yes } \\
\text { Yes }\end{array}$ \\
\hline $\begin{array}{l}18-J a n-93 \\
18-J a n-93 \\
18-J a n-93 \\
18-J a n-93 \\
18-J a n-93 \\
18-J a n-93\end{array}$ & $\begin{array}{l}\text { SF-25 } \\
\text { SF-25 } \\
\text { SF-25 } \\
\text { SF-25 } \\
\text { SF-25 } \\
\text { SF-25 }\end{array}$ & $\begin{array}{l}A \\
B \\
X \\
Y \\
Z \\
M\end{array}$ & $\begin{array}{l}1.0 \\
2.4 \\
1.0 \\
1.0 \\
1.0 \\
4.4\end{array}$ & $\begin{array}{l}-29.5 \\
-30.5 \\
-32.9 \\
-34.2 \\
-35.2 \\
-29.5\end{array}$ & $\begin{array}{l}\text { to } \\
\text { to } \\
\text { to } \\
\text { to } \\
\text { to } \\
\text { to }\end{array}$ & $\begin{array}{l}-30.5 \\
-32.9 \\
-33.9 \\
-35.2 \\
-36.2 \\
-33.9\end{array}$ & $\begin{array}{c}\text { NA (YBM) } \\
\text { NA (YBM) } \\
\text { NA (YBM) } \\
\text { CBM Comp-Fine } \\
\text { NA (ARC) } \\
\text { NA (YBM) }\end{array}$ & $\begin{array}{l}\text { Yes } \\
\text { Yes } \\
\text { Yes } \\
\text { Yes } \\
\text { No } \\
\text { No }\end{array}$ & $\begin{array}{l}\text { No } \\
\text { No } \\
\text { No } \\
\text { No } \\
\text { No } \\
\text { Yes }\end{array}$ & $\begin{array}{l}\text { Yes } \\
\text { Yes } \\
\text { Yes } \\
\text { Yes } \\
\text { Yes } \\
\text { Yes }\end{array}$ \\
\hline $\begin{array}{l}18-J a n-93 \\
18-J a n-93 \\
18-J a n-93 \\
18-J a n-93 \\
18-J a n-93 \\
18-J a n-93 \\
18-J a n-93\end{array}$ & $\begin{array}{l}\text { SF-26 } \\
\text { SF-26 } \\
\text { SF-26 } \\
\text { SF-26 } \\
\text { SF-26 } \\
\text { SF-26 } \\
\text { SF-26 }\end{array}$ & $\begin{array}{l}A \\
B \\
C \\
X \\
Y \\
Z \\
M\end{array}$ & $\begin{array}{l}1.0 \\
2.0 \\
0.7 \\
1.0 \\
1.0 \\
1.0 \\
4.7\end{array}$ & $\begin{array}{l}-31.4 \\
-32.4 \\
-34.4 \\
-35.1 \\
-36.1 \\
-37.1 \\
-31.4\end{array}$ & $\begin{array}{l}\text { to } \\
\text { to } \\
\text { to } \\
\text { to } \\
\text { to } \\
\text { to } \\
\text { to }\end{array}$ & $\begin{array}{l}-32.4 \\
-34.4 \\
-35.1 \\
-36.1 \\
-37.1 \\
-38.1 \\
-36.1\end{array}$ & $\begin{array}{c}\text { NA (YBM) } \\
\text { NA (YBM) } \\
\text { NA (YBM) } \\
\text { NA (YBM) } \\
\text { CBM Comp-Fine } \\
\text { NA (ARC) } \\
\text { NA (YBM) }\end{array}$ & $\begin{array}{l}\text { Yes } \\
\text { Yes } \\
\text { Yes } \\
\text { Yes } \\
\text { Yes } \\
\text { No } \\
\text { No }\end{array}$ & $\begin{array}{l}\text { No } \\
\text { No } \\
\text { No } \\
\text { No } \\
\text { No } \\
\text { No } \\
\text { Yes }\end{array}$ & $\begin{array}{l}\text { Yes } \\
\text { Yes } \\
\text { Yes } \\
\text { Yes } \\
\text { Yes } \\
\text { Yes } \\
\text { Yes }\end{array}$ \\
\hline $\begin{array}{l}18-J a n-93 \\
18-J a n-93 \\
18-J a n-93 \\
18-J a n-93 \\
18-J a n-93 \\
18-J a n-93 \\
18-J a n-93 \\
18-J a n-93\end{array}$ & $\begin{array}{l}S F-27 \\
S F-27 \\
S F-27 \\
S F-27 \\
S F-27 \\
S F-27 \\
S F-27 \\
S F-27\end{array}$ & $\begin{array}{l}A \\
B \\
B \\
C \\
X \\
Y \\
Z \\
M\end{array}$ & $\begin{array}{l}1.0 \\
2.0 \\
\text { Cornpos } \\
1.0 \\
1.0 \\
1.0 \\
0.5 \\
5.0\end{array}$ & $\begin{array}{l}-35.3 \\
-36.3 \\
\text { ting Dup } \\
-38.3 \\
-39.3 \\
-40.3 \\
-41.3 \\
-35.3\end{array}$ & $\begin{array}{l}\text { to } \\
\text { to } \\
\text { iplic } \\
\text { to } \\
\text { to } \\
\text { to } \\
\text { to } \\
\text { to }\end{array}$ & $\begin{array}{l}-36.3 \\
-38.3 \\
\text { ate } \\
-39.3 \\
-40.3 \\
-41.3 \\
-41.8 \\
-40.3\end{array}$ & $\begin{array}{c}\text { NA (YBM) } \\
\text { NA (YBM) } \\
\text { NA (YBM) } \\
\text { NA (YBM) } \\
\text { NA (YBM) } \\
\text { CBM Comp-Fine } \\
\text { NA (ARC) } \\
\text { NA (YBM) }\end{array}$ & $\begin{array}{l}\text { Yes } \\
\text { Yes } \\
\text { Yes } \\
\text { Yes } \\
\text { Yes } \\
\text { Yes } \\
\text { No } \\
\text { No }\end{array}$ & $\begin{array}{l}\text { No } \\
\text { No } \\
\text { No } \\
\text { No } \\
\text { No } \\
\text { No } \\
\text { No } \\
\text { Yes }\end{array}$ & $\begin{array}{l}\text { Yes } \\
\text { Yes } \\
\text { Yes } \\
\text { Yes } \\
\text { Yes } \\
\text { Yes } \\
\text { Yes } \\
\text { Yes }\end{array}$ \\
\hline $\begin{array}{l}18-J a n-93 \\
18-J a n-93 \\
18-J a n-93 \\
18-J a n-93 \\
18-J a n-93\end{array}$ & $\begin{array}{l}\text { SF-28 } \\
\text { SF-28 } \\
\text { SF-28 } \\
\text { SF-28 } \\
\text { SF-28 }\end{array}$ & $\begin{array}{l}\text { A } \\
B \\
X \\
Y \\
M\end{array}$ & $\begin{array}{l}1.0 \\
1.7 \\
1.0 \\
0.5 \\
3.7\end{array}$ & $\begin{array}{l}-35.6 \\
-36.6 t \\
-38.3 \\
-39.3 \\
-35.6\end{array}$ & $\begin{array}{l}\text { to } \\
\text { to } \\
\text { to } \\
\text { to } \\
\text { to }\end{array}$ & $\begin{array}{l}-36.6 \\
-38.3 \\
-39.3 \\
-39.8 \\
-39.3\end{array}$ & $\begin{array}{c}\text { NA (YBM) } \\
\text { NA (YBM) } \\
\text { NA (YBM) } \\
\text { CBM Comp-Coarse } \\
\text { NA (YBM) }\end{array}$ & $\begin{array}{l}\text { Yes } \\
\text { Yes } \\
\text { Yes } \\
\text { Yes } \\
\text { No }\end{array}$ & $\begin{array}{l}\text { No } \\
\text { No } \\
\text { No } \\
\text { No } \\
\text { Yes }\end{array}$ & $\begin{array}{l}\text { Yes } \\
\text { Yes } \\
\text { Yes } \\
\text { Yes } \\
\text { Yes }\end{array}$ \\
\hline
\end{tabular}


TABLE C.1. (contd)

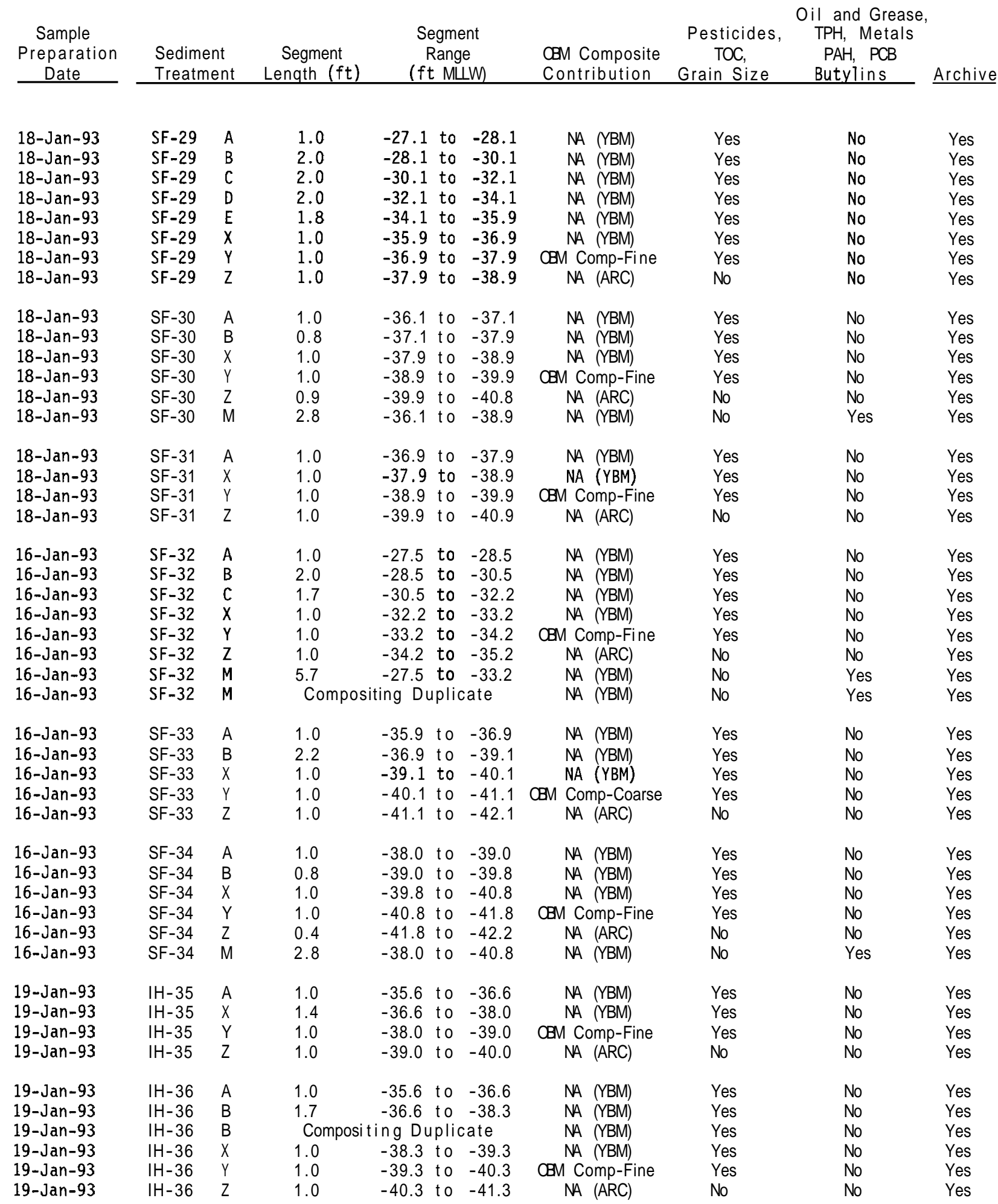


TABLE C.1. (contd)

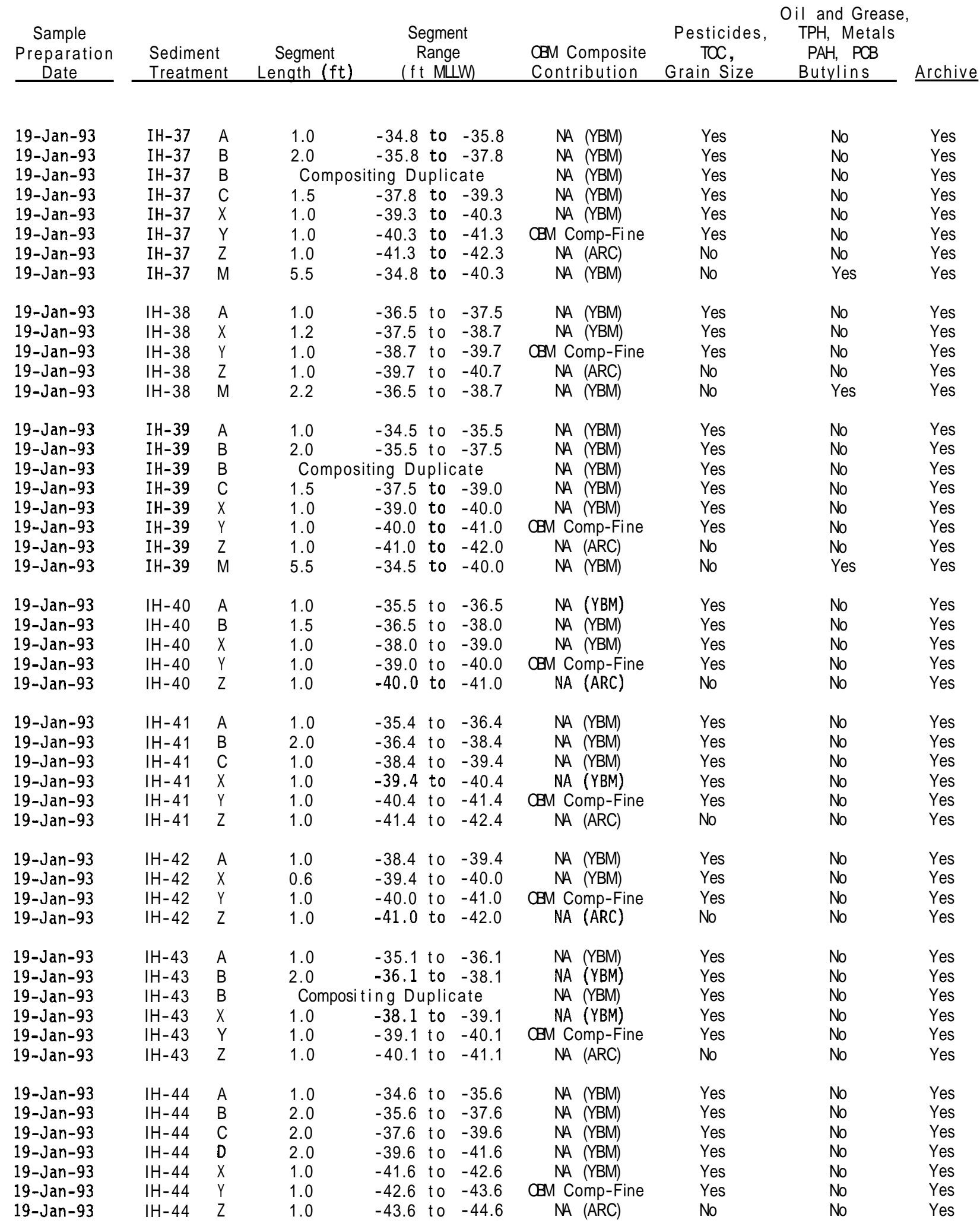


TABLE C.1. (contd)

\begin{tabular}{|c|c|c|c|c|c|c|c|c|c|c|}
\hline $\begin{array}{c}\text { Sample } \\
\text { Preparation } \\
\text { Date } \\
\end{array}$ & $\begin{array}{l}\text { Sedim } \\
\text { Treatn }\end{array}$ & & $\begin{array}{c}\text { Segment } \\
\text { Lenqth (ft) }\end{array}$ & & & & $\begin{array}{l}\text { CBM Composite } \\
\text { Contribution }\end{array}$ & $\begin{array}{c}\text { Pesticides, } \\
\text { TOC, } \\
\text { Grain Size }\end{array}$ & $\begin{array}{l}\text { il and Grease, } \\
\text { TPH, Metals } \\
\text { PAH, PCB } \\
\text { Butylins } \\
\end{array}$ & $\underline{\text { Archive }}$ \\
\hline $\begin{array}{l}20-J a n-93 \\
20-J a n-93 \\
20-J a n-93 \\
20-J a n-93 \\
20-J a n-93 \\
20-J a n-93\end{array}$ & $\begin{array}{l}\mathrm{IH}-45 \\
\mathrm{IH}-45 \\
\mathrm{IH}-45 \\
\mathrm{IH}-45 \\
\mathrm{IH}-45 \\
\mathrm{IH}-45\end{array}$ & $\begin{array}{l}A \\
B \\
C \\
X \\
Y \\
Z\end{array}$ & $\begin{array}{l}1.0 \\
2.0 \\
1.3 \\
1.0 \\
1.0 \\
1.0\end{array}$ & $\begin{array}{l}-34.8 \\
-35.8 \\
-37.8 \\
-39.1 \\
-40.1 \\
-41.1\end{array}$ & $\begin{array}{l}\text { to } \\
\text { to } \\
\text { to } \\
\text { to } \\
\text { to } \\
\text { to }\end{array}$ & $\begin{array}{l}-35.8 \\
-37.8 \\
-39.1 \\
-40.1 \\
-41.1 \\
-42.1\end{array}$ & $\begin{array}{c}\text { NA (YBM) } \\
\text { NA (YBM) } \\
\text { NA (YBM) } \\
\text { NA (YBM) } \\
\text { CBM Comp-Fine } \\
\text { NA (ARC) }\end{array}$ & $\begin{array}{l}\text { Yes } \\
\text { Yes } \\
\text { Yes } \\
\text { Yes } \\
\text { Yes } \\
\text { No }\end{array}$ & $\begin{array}{l}\text { No } \\
\text { No } \\
\text { No } \\
\text { No } \\
\text { No } \\
\text { No }\end{array}$ & $\begin{array}{l}\text { Yes } \\
\text { Yes } \\
\text { Yes } \\
\text { Yes } \\
\text { Yes } \\
\text { Yes }\end{array}$ \\
\hline $\begin{array}{l}20-J a n-93 \\
20-J a n-93 \\
20-J a n-93 \\
20-J a n-93 \\
20-J a n-93 \\
20-J a n-93\end{array}$ & $\begin{array}{l}\mathrm{IH}-46 \\
\mathrm{IH}-46 \\
\mathrm{IH}-46 \\
\mathrm{IH}-46 \\
\mathrm{IH}-46 \\
\mathrm{IH}-46\end{array}$ & $\begin{array}{l}A \\
B \\
C \\
X \\
Y \\
Z\end{array}$ & $\begin{array}{l}1.0 \\
2.0 \\
2.0 \\
1.0 \\
1.0 \\
0.7\end{array}$ & $\begin{array}{l}-34.8 \\
-35.8 \\
-37.8 \\
-39.8 \\
-40.8 \\
-41.8\end{array}$ & $\begin{array}{l}\text { to } \\
\text { to } \\
\text { to } \\
\text { to } \\
\text { to } \\
\text { to }\end{array}$ & $\begin{array}{l}-35.8 \\
-37.8 \\
-39.8 \\
-40.8 \\
-41.8 \\
-42.5\end{array}$ & $\begin{array}{c}\text { NA (YBM) } \\
\text { NA (YBM) } \\
\text { NA (YBM) } \\
\text { NA (YBM) } \\
\text { CBM Comp-Fine } \\
\text { NA (ARC) }\end{array}$ & $\begin{array}{l}\text { Yes } \\
\text { Yes } \\
\text { Yes } \\
\text { Yes } \\
\text { Yes } \\
\text { No }\end{array}$ & $\begin{array}{l}\text { No } \\
\text { No } \\
\text { No } \\
\text { No } \\
\text { No } \\
\text { No }\end{array}$ & $\begin{array}{l}\text { Yes } \\
\text { Yes } \\
\text { Yes } \\
\text { Yes } \\
\text { Yes } \\
\text { Yes }\end{array}$ \\
\hline $\begin{array}{l}20-J a n-93 \\
20-J a n-93 \\
20-J a n-93 \\
20-J a n-93 \\
20-J a n-93 \\
20-J a n-93\end{array}$ & $\begin{array}{l}\mathrm{IH}-47 \\
\mathrm{IH}-47 \\
\mathrm{IH}-47 \\
\mathrm{IH}-47 \\
\mathrm{IH}-47 \\
\mathrm{IH}-47\end{array}$ & $\begin{array}{l}A \\
B \\
C \\
X \\
Y \\
Z\end{array}$ & $\begin{array}{l}1.0 \\
2.0 \\
0.8 \\
1.0 \\
1.0 \\
1.0\end{array}$ & $\begin{array}{l}-36.7 \\
-37.7 \\
-39.7 \\
-40.5 \\
-41.5 \\
-42.5\end{array}$ & $\begin{array}{l}\text { to } \\
\text { to } \\
\text { to } \\
\text { to } \\
\text { to } \\
\text { to }\end{array}$ & $\begin{array}{l}-37.7 \\
-39.7 \\
-40.5 \\
-41.5 \\
-42.5 \\
-43.5\end{array}$ & $\begin{array}{c}\text { NA (YBM) } \\
\text { NA (YBM) } \\
\text { NA (YBM) } \\
\text { NA (YBM) } \\
\text { CBM Comp-Fine } \\
\text { NA (ARC) }\end{array}$ & $\begin{array}{l}\text { Yes } \\
\text { Yes } \\
\text { Yes } \\
\text { Yes } \\
\text { Yes } \\
\text { No }\end{array}$ & $\begin{array}{l}\text { No } \\
\text { No } \\
\text { No } \\
\text { No } \\
\text { No } \\
\text { No }\end{array}$ & $\begin{array}{l}\text { Yes } \\
\text { Yes } \\
\text { Yes } \\
\text { Yes } \\
\text { Yes } \\
\text { Yes }\end{array}$ \\
\hline $\begin{array}{l}20-J a n-93 \\
20-J a n-93 \\
20-J a n-93 \\
20-J a n-93 \\
20-J a n-93\end{array}$ & $\begin{array}{l}\text { IH-48 } \\
\text { IH-48 } \\
\text { IH-48 } \\
\text { IH-48 } \\
\text { IH-48 }\end{array}$ & $\begin{array}{l}A \\
B \\
X \\
Y \\
Z\end{array}$ & $\begin{array}{l}1.0 \\
2.4 \\
1.0 \\
1.0 \\
0.4\end{array}$ & $\begin{array}{l}-35.1 \\
-36.1 \\
-38.5 \\
-39.5 \\
-40.5\end{array}$ & $\begin{array}{l}\text { to } \\
\text { to } \\
\text { to } \\
\text { to } \\
\text { to }\end{array}$ & $\begin{array}{l}-36.1 \\
-38.5 \\
-39.5 \\
-40.5 \\
-40.9\end{array}$ & $\begin{array}{c}\text { NA (YBM) } \\
\text { NA (YBM) } \\
\text { NA (YBM) } \\
\text { CBM Comp-Fine } \\
\text { NA (ARC) }\end{array}$ & $\begin{array}{l}\text { Yes } \\
\text { Yes } \\
\text { Yes } \\
\text { Yes } \\
\text { No }\end{array}$ & $\begin{array}{l}\text { No } \\
\text { No } \\
\text { No } \\
\text { No } \\
\text { No }\end{array}$ & $\begin{array}{l}\text { Yes } \\
\text { Yes } \\
\text { Yes } \\
\text { Yes } \\
\text { Yes }\end{array}$ \\
\hline $\begin{array}{l}20-J a n-93 \\
20-J a n-93 \\
20-J a n-93 \\
20-J a n-93\end{array}$ & $\begin{array}{l}\text { IH }-49 \\
\text { IH-49 } \\
\text { IH-49 } \\
\text { IH-49 }\end{array}$ & $\begin{array}{l}A \\
B \\
X \\
Y\end{array}$ & $\begin{array}{l}1.0 \\
1.7 \\
1.0 \\
0.8\end{array}$ & $\begin{array}{l}-35.4 \\
-36.4 \\
-38.1 \\
-39.1\end{array}$ & $\begin{array}{l}\text { to } \\
\text { to } \\
\text { to } \\
\text { to }\end{array}$ & $\begin{array}{l}-36.4 \\
-38.1 \\
-39.1 \\
-39.9\end{array}$ & $\begin{array}{c}\text { NA (YBM) } \\
\text { NA (YBM) } \\
\text { NA (YBM) } \\
\text { CBM Comp-Fine }\end{array}$ & $\begin{array}{l}\text { Yes } \\
\text { Yes } \\
\text { Yes } \\
\text { Yes }\end{array}$ & $\begin{array}{l}\text { No } \\
\text { No } \\
\text { No } \\
\text { No }\end{array}$ & $\begin{array}{l}\text { Yes } \\
\text { Yes } \\
\text { Yes } \\
\text { Yes }\end{array}$ \\
\hline $\begin{array}{l}14-J a n-93 \\
14-J a n-93 \\
14-J a n-93 \\
14-J a n-93 \\
14-J a n-93 \\
14-J a n-93\end{array}$ & $\begin{array}{l}\mathrm{IH}-50 \\
\mathrm{IH}-50 \\
\mathrm{IH}-50 \\
\mathrm{IH}-50 \\
\mathrm{IH}-50 \\
\mathrm{IH}-50\end{array}$ & $\begin{array}{l}A \\
B \\
C \\
X \\
Y \\
Z\end{array}$ & $\begin{array}{l}1.0 \\
2.0 \\
0.8 \\
1.0 \\
1.0 \\
1.0\end{array}$ & $\begin{array}{l}-35.9 \\
-36.9 \\
-38.9 \\
-39.7 \\
-41.2 \\
-42.2\end{array}$ & $\begin{array}{l}\text { to } \\
\text { to } \\
\text { to } \\
\text { to } \\
\text { to } \\
\text { to }\end{array}$ & $\begin{array}{l}-36.9 \\
-38.9 \\
-39.7 \\
-40.7 \\
-42.2 \\
-43.2\end{array}$ & $\begin{array}{c}\text { NA (YBM) } \\
\text { NA (YBM) } \\
\text { NA (YBM) } \\
\text { NA (YBM) } \\
\text { CBM Comp-Coarse } \\
\text { NA (ARC) }\end{array}$ & $\begin{array}{l}\text { Yes } \\
\text { Yes } \\
\text { Yes } \\
\text { Yes } \\
\text { Yes } \\
\text { No }\end{array}$ & $\begin{array}{l}\text { No } \\
\text { No } \\
\text { No } \\
\text { No } \\
\text { No } \\
\text { No }\end{array}$ & $\begin{array}{l}\text { Yes } \\
\text { Yes } \\
\text { Yes } \\
\text { Yes } \\
\text { Yes } \\
\text { Yes }\end{array}$ \\
\hline $\begin{array}{l}14-J a n-93 \\
14-J a n-93 \\
14-J a n-93 \\
14-J a n-93 \\
14-J a n-93\end{array}$ & $\begin{array}{l}\text { IH }-51 \\
\text { IH }-51 \\
\text { IH }-51 \\
\text { IH }-51 \\
\text { IH }-51\end{array}$ & $\begin{array}{l}A \\
B \\
X \\
Y \\
Z\end{array}$ & $\begin{array}{l}1.0 \\
1.0 \\
1.0 \\
1.0 \\
1.0\end{array}$ & $\begin{array}{l}-35.3 \\
-36.3 \\
-37.3 \\
-38.5 \\
-39.5\end{array}$ & $\begin{array}{l}\text { to } \\
\text { to } \\
\text { to } \\
\text { to } \\
\text { to }\end{array}$ & $\begin{array}{l}-36.3 \\
-37.3 \\
-38.3 \\
-39.5 \\
-40.5\end{array}$ & $\begin{array}{c}\text { NA (YBM) } \\
\text { NA (YBM) } \\
\text { NA (YBM) } \\
\text { CBM Comp-Fine } \\
\text { NA (ARC) }\end{array}$ & $\begin{array}{l}\text { Yes } \\
\text { Yes } \\
\text { Yes } \\
\text { Yes } \\
\text { No }\end{array}$ & $\begin{array}{l}\text { No } \\
\text { No } \\
\text { No } \\
\text { No } \\
\text { No }\end{array}$ & $\begin{array}{l}\text { Yes } \\
\text { Yes } \\
\text { Yes } \\
\text { Yes } \\
\text { Yes }\end{array}$ \\
\hline $\begin{array}{l}20-J a n-93 \\
20-J a n-93 \\
20-J a n-93 \\
20-J a n-93\end{array}$ & $\begin{array}{l}P C-52 \\
P C-52 \\
P C-52 \\
P C-52\end{array}$ & $\begin{array}{l}\text { A } \\
B \\
C \\
M\end{array}$ & $\begin{array}{l}1.0 \\
2.0 \\
1.1 \\
4.1\end{array}$ & $\begin{array}{l}-3.8 \\
-4.8 \\
-6.8 \\
-3.8\end{array}$ & $\begin{array}{l}\text { to } \\
\text { to } \\
\text { to } \\
\text { to }\end{array}$ & $\begin{array}{l}-4.8 \\
-6.8 \\
-7.9 \\
-7.9\end{array}$ & $\begin{array}{ll}\text { NA } & (\mathrm{YBM}) \\
\mathrm{NA} & (\mathrm{YBM}) \\
\mathrm{NA} & (\mathrm{YBM}) \\
\mathrm{NA} & (\mathrm{YBM})\end{array}$ & $\begin{array}{l}\text { Yes } \\
\text { Yes } \\
\text { Yes } \\
\text { No }\end{array}$ & $\begin{array}{l}\text { No } \\
\text { No } \\
\text { No } \\
\text { Yes }\end{array}$ & $\begin{array}{l}\text { Yes } \\
\text { Yes } \\
\text { Yes } \\
\text { Yes }\end{array}$ \\
\hline $\begin{array}{l}20-J a n-93 \\
20-J a n-93 \\
20-J a n-93 \\
20-J a n-93\end{array}$ & $\begin{array}{l}P C-53 \\
P C-53 \\
\text { PC-53 } \\
\text { PC-53 }\end{array}$ & $\begin{array}{l}A \\
B \\
C \\
M\end{array}$ & $\begin{array}{l}1.0 \\
1.4 \\
1.0 \\
3.4\end{array}$ & $\begin{array}{l}-3.5 \\
-4.5 \\
-5.9 \\
-3.5\end{array}$ & $\begin{array}{l}\text { to } \\
\text { to } \\
\text { to } \\
\text { to }\end{array}$ & $\begin{array}{l}-4.5 \\
-5.9 \\
-6.9 \\
-6.9\end{array}$ & $\begin{array}{l}\text { NA }(\mathrm{YBM}) \\
\mathrm{NA}(\mathrm{YBM}) \\
\mathrm{NA}(\mathrm{YBM}) \\
\mathrm{NA}(\mathrm{YBM})\end{array}$ & $\begin{array}{l}\text { Yes } \\
\text { Yes } \\
\text { Yes } \\
\text { No }\end{array}$ & $\begin{array}{l}\text { No } \\
\text { No } \\
\text { No } \\
\text { Yes }\end{array}$ & $\begin{array}{l}\text { Yes } \\
\text { Yes } \\
\text { Yes } \\
\text { Yes }\end{array}$ \\
\hline
\end{tabular}


TABLE C.1. (contd)

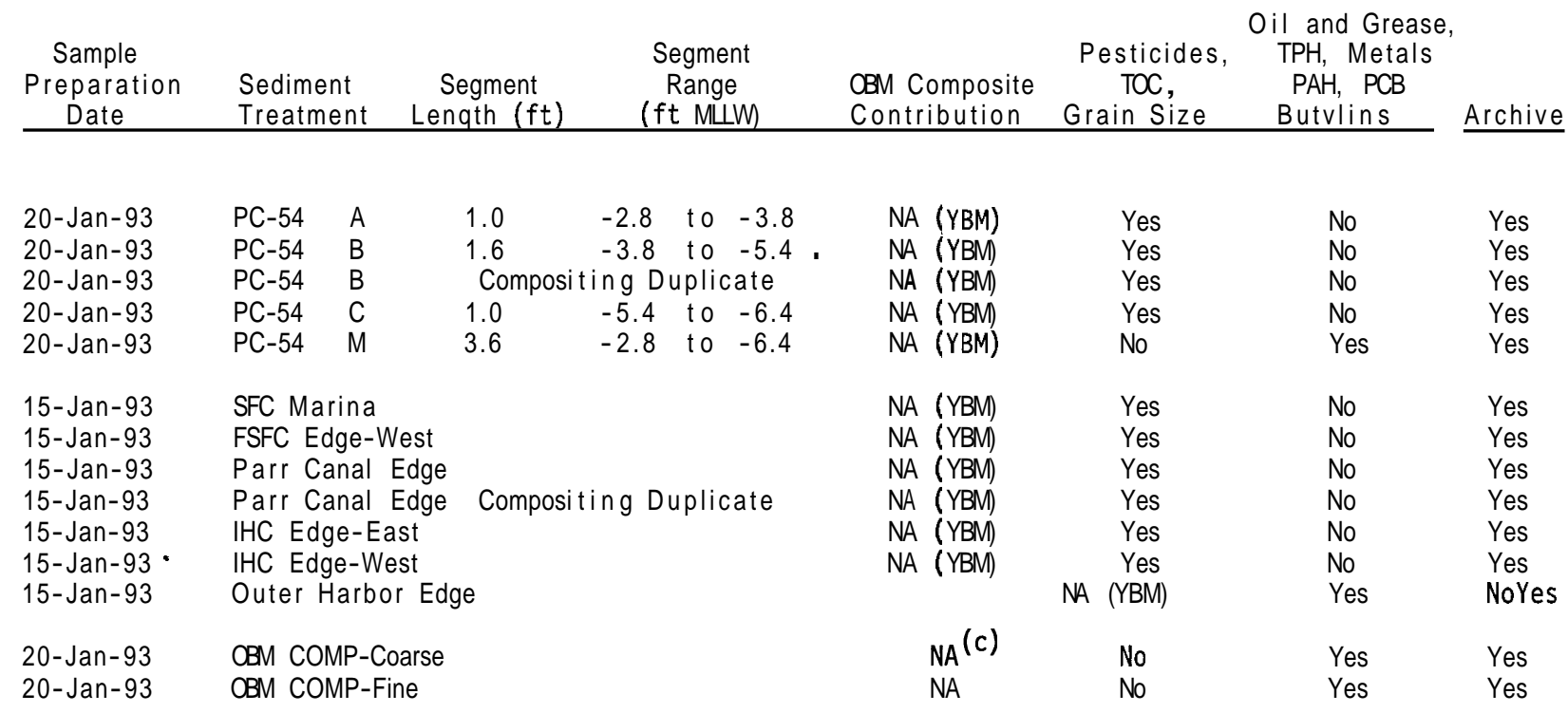
(a) NA (YBM) Not applicable; sample consists entirely of Younger Bay Mud.
(b) NA (ARC) Not applicable; sample was for archive only.
(c) NA Not applicable.

\section{C.8}


TABLE C.2. Sediment Grain Size and Percent Solids, Including Quality Control Data, United Heckathorn Remedial Investigation

Sediment

Treatment

LZ-1 A

LZ-1 B

LZ-1 C

LZ-1 $\quad D$

LZ-1 X

LZ-1 $\quad Y$

LZ-2 A

LZ-2 B

$\mathrm{LZ}-2$ C $\mathrm{C}$

LZ-2 $X$

LZ-2 Y

LZ-3 A

LZ-3 B

LZ-3 $X$

LZ-3 Y

LZ-5 A

LZ-5 Y

LZ-6 A

LZ-6 B

LZ-6 C

LZ-6 $\quad X$

LZ-6 Y

$\begin{array}{ll}\text { LZ-7 } & \text { A } \\ \text { LZ-7 } & \text { B } \\ \text { LZ-7 } & \text { C } \\ \text { LZ-7 } & \text { X } \\ \text { LZ-7 } & \text { Y } \\ & \\ \text { LZ-8 } & \text { A } \\ \text { LZ-8 } & \text { B } \\ \text { LZ-8 } & \text { C } \\ \text { LZ-8 } & \text { D } \\ \text { LZ-8 } & \text { E } \\ \text { LZ-8 } & F \\ \text { LZ-8 } & \text { G } \\ \text { LZ-8 } & \text { X } \\ \text { LZ-8 } & \text { Y }\end{array}$

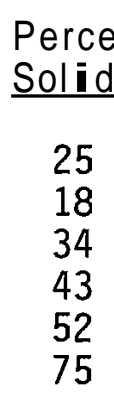

46

48

41

52

78

41

40

57

78

55

75

62

57

54

70

80

47

43

49

65

78

49

34

26

22

25

49

55

73

80
Fractional Percent (dry weight)

\begin{tabular}{cccc}
\hline Gravel & Sand & Silt & Clay \\
$\underline{\mu \mathrm{m}>2000}$ & $\underline{62.5-2000}$ & $\underline{3.9-62.5}$ & $\underline{3.9}$ \\
\hline
\end{tabular}

21

14

33

31

39

29

18

33

34

33

26

27

34

32

36

34

32

23

20

31

35

17

24

42

39

41

39

20

21

26

13

21

36

39

31

29
47

50

35

42

43

23

46

36

48

44

18

51

43

31

36

39

16

31

34

38

27

15

47

42

40

31

8

44

45

36

36

31

44

38

20 
TABLE C.2. (contd)

Sediment

Treatment

LZ-9 A

LZ-9 X

LZ-9 Y

LZ-10 A

LZ-10 B

LZ-10 X

LZ-10 Y

LZ-11 A

LZ-11 X

LZ-11 Y

LZ-12 A

LZ-12 X

LZ-12 Y

LZ-13 A

LZ-13 B

LZ-13 C

LZ-13 X

LZ-13 Y

LZ-14 A

LZ-14 X

LZ-14 Y

LZ-15 A

LZ-15 B

LZ-15 X

LZ-15 Y

LZ-16 A

LZ-16 B

LZ-16 C

LZ-16 D

LZ-16 X

LZ-16 Y

SF-17 A

SF-17 B

$\mathrm{SF}-17 \mathrm{X}$

SF-17 Y
Fractional Percent (dry weight)

Percent $\underline{\text { Solids }}$

44

50

84

42

44

49

81

61

59

86

41

40

78

35

60

64

59

80

77

81

85

37

41

46

80

37

51

55

73

76

79

40

44

61

75

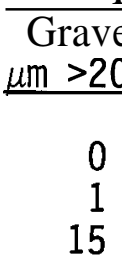

11

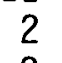

2

3

31

5
39

0

0

3

1

31

6

3

45

34

31

0

0

1

1
19

19

2
5

38

1

1
7
0
1

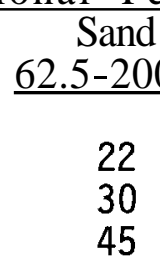

Silt

3.9-62.5

27

29

24

13

26

25

36

10

23

15

25

21

46

20

17

25

28

45

$\begin{array}{rr}8 & 14 \\ 15 & 10 \\ 1 & 1\end{array}$

21

25

30

45

22

20

30

21

15

41

29

22

39

39
73

67

59

39

67

42

37

24

15

41

64

64

42
34

26 
TABLE C.2. (contd)

Sediment

Treatment

SF-18 A

SF-18 B

$S F-18 X$

SF-18 Y

SF-19 A

SF-19X

SF-19 Y

SF-20 A

SF $-20 X$

$S F-20 Y$

$S F-21 A$

$S F-21 \quad B$

$\mathrm{SF}-21 \mathrm{C}$

$S F-21 X$

SF-21 $Y$

SF-22 A

$\mathrm{SF}-22 \mathrm{~B}$

SF-22 C

$\mathrm{SF}-22 \mathrm{X}$

$S F-22 Y$

$\mathrm{SF}-23 \mathrm{~A}$

$S F-23$ B

$\mathrm{SF}-23 \mathrm{X}$

$S F-23 Y$

$\mathrm{SF}-24 \mathrm{~A}$

SF-24 B

$\mathrm{SF}-24 \mathrm{C}$

SF-25 A

$S F-25 \quad B$

$S F-25 X$

$S F-25 Y$

SF-26 A

SF-26 B

SF-26 C

$\mathrm{SF}-26 \mathrm{X}$

SF-26 Y
Percent

Solids

40

40

46

74

38

43

76

37

40

74

37

40

45

54

73

41

47

48

58

75

37

42

54

77

39

41

48

44

53

71

76

35

42

46

52

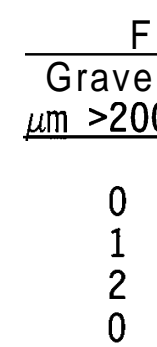

Fra

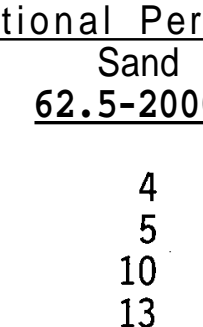

13

9
9
77

5

3

19

3

3
10

10

13

13

3

0

5
9

4

9
23

23
33

4

4
1

23

15

17

11

5
5
6
8
16
Silt

3.9-62.5

$20 \quad 76$

$25 \quad 69$

23

46

65

41

18

26

14

73

65

9

14

19

37

81

78

43

$22 \quad 75$

$16 \quad 81$

$25 \quad 63$

$34 \quad 54$

$43 \quad 43$

$19 \quad 67$

33

39

49

57

24

28

30

36

26

27

33

20

32

46

36

29

28

33

41

41
63

61

45

34

72

63

46

30

70

69

66

39

44

36

53

65

67

61

51

43 
TABLE C.2. (contd)

Sediment

Treatment

$\mathrm{SF}-27 \mathrm{~A}$

SF -27 B

SF $-27 C$

$\mathrm{SF}-27 \mathrm{X}$

SF-27 Y

$\mathrm{SF}-28 \mathrm{~A}$

$\mathrm{SF}-28 \mathrm{~B}$

$\mathrm{SF}-28 \mathrm{X}$

$S F-28 Y$

SF-29 A

SF-29 B

SF-29 C

$S F-29 D$

$S F-29 E$

$S F-29 X$

SF-29 Y

$\mathrm{SF}-30 \mathrm{~A}$

SF-30 B

$S F-30 X$

$S F-30 Y$

SF-31 A

$S F-31 X$

$S F-31 Y$

$\mathrm{SF}-32 \mathrm{~A}$

$\mathrm{SF}-32 \mathrm{~B}$

$S F-32 C$

$S F-32 X$

SF-32 Y

SF-33 A

$S F-33 B$

$S F-33 X$

$S F-33 Y$

SF-34 A

$\mathrm{SF}-34 \mathrm{~B}$

$S F-34 X$

$S F-34 Y$

Fractional Percent (dry weight)

Percent

$\underline{\text { Sol ids }}$

38

43

44

56

79

51

58

64

87

40

43

44

51

50

75

75

38

41

44

76

39

60

76

51

52

61

56

77

51

54

64

80

42

46

67

76

$\begin{array}{r}\text { Grave } \\ \mu \mathrm{m}>20\end{array}$
0
0
0
1
1

1

6

2
16

0

0

1

1

31

1

0

6

0

3
1
1

36

8

1

2

1
1
5
1

1

0

3
Silt

3.9-62.5

35

34

31

37

37

35

34

39

21

13

8

14

11

39

22

10

27

7
22

22

7
11
16

21

14

24

14

23

16

20

27

61

11

9

22

20
31

34

33

34

32

15

33

24

0

28

49

17

46

46

241

$28 \quad 50$

$40 \quad 35$

$37 \quad 47$

$39 \quad 38$

$28 \quad 55$

$29 \quad 50$

$29 \quad 39$

$29 \quad 9$

$24 \quad 64$

$25 \quad 66$

$35 \quad 40$

$38 \quad 41$ 
IABLE C.2. (contd)

Sediment

Treatment

IH -35 A

IH $-35 X$

IH-35 Y

IH-36 A

IH-36 B

IH-36 X

IH-36 Y

IH-37 A

IH-37 B

IH-37 C

IH $-37 \mathrm{X}$

IH-37 Y

IH-38 A

IH-38X

IH-38 Y

IH-39 A

IH-39 B

IH-39 C

IH-39X

IH-39 Y

IH-40 A

IH-40 B

IH-40 X

IH-40 Y

IH-41 A

IH-41 B

IH-41 C

IH-41 X

IH-41 Y

IH-42 A

IH-42 X

IH-42 Y

IH-43 A

IH-43 B

IH $-43 X$

IH-43 Y
Fractional Percent (dry weight)

Percent

Sol ids

41

60

76

42

52

61

75

39

41

44

51

74

43

49

76

38

44

51

50

79

40

44

47

74

39

43

47

50

77

49

48

74

43

44

49

78

Grave
$\mu \mathrm{m}>20$
0
0
0
0
1
1
2

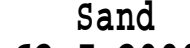

$\underline{62.5-2000}$

6
27
17

3. 9-62.5

26

37

58

27

32

31

34

30

24

25

28

42

68

36

25

65

58

47

47

13

19

22

33

45

64

71

67

58

39

73

54

47

29

32

35

33

42

66

63

58

59

34

18

24

30

29

78

71

62

49

27

69

23

26

27

42

73

69

64

13

31

45

29

60

$29 \quad 56$

14

26

29

72

36

68

60

35 
TABLE C.2. (contd)

Sediment

Treatment

IH-44 A

IH-44 B

IH-44 C

IH-44 D

IH-44 X

IH-44 Y

IH-45 A

IH-45 B

IH-45 C

IH-45 X

IH-45 Y

IH-46 A

IH-46 B

IH-46 C

IH-46 X

IH-46 Y

IH-47 A

IH-47 B

IH-47 C

IH-47 X

IH-47 Y

IH-48 A

IH-48 B

IH-48 X

IH-48 Y

IH-49 A

IH-49 B

IH-49X

IH-49 Y

IH-50 A

IH-50 B

IH-50 C

IH $-50 X$

IH-50 Y

IH-51 A

IH-51 B

IH-51 X

IH-51 Y

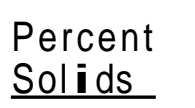

40

44

43

45

47

74

41

44

44

46

76

40

45

45

45

75

40

43

42

54

82

44

44

45

77

38

41

45

71

41

46

49

51

84

44

49

54

74 \begin{tabular}{lll}
\multicolumn{4}{c}{ Fractional Percent (dry weight) } \\
\hline Gravel Sand & Silt & Clay
\end{tabular} $\underline{\mu \mathrm{m}>2000} \quad \underline{62.5-2000} \quad \underline{3.9-62.5} \quad \leq 3.9$

$27 \quad 71$

$26 \quad 72$

$29 \quad 68$

$36 \quad 59$

$36 \quad 57$

$45 \quad 36$

$28 \quad 67$

$30 \quad 63$

$31 \quad 65$

$32 \quad 62$

$63 \quad 25$

$36 \quad 61$

$37 \quad 60$

$35 \quad 61$

$34 \quad 62$

$57 \quad 35$

$21 \quad 77$

$29 \quad 68$

$33 \quad 62$

$33 \quad 55$

$33 \quad 29$

$35 \quad 62$

$39 \quad 58$

$35 \quad 62$

$46 \quad 39$

$31 \quad 66$

$38 \quad 60$

$29 \quad 66$

$50 \quad 43$

$43 \quad 54$

$33 \quad 65$

$32 \quad 64$

$\begin{array}{rrrr}2 & 6 & 33 & 59 \\ 58 & 35 & 2 & 5\end{array}$

$\begin{array}{lllll}0 & 3 & 41 & 56\end{array}$

$\begin{array}{lllll}0 & 4 & 42 & 54\end{array}$

$\begin{array}{lllll}74 & 0 & 16 & 31 & 53\end{array}$ 
TABLE C.2. (contd)

Sediment

Treatment

PC-52 A

$P C-52$ B

PC-52 C

PC-53 A

$P C-53$ B

PC-53 C

PC-54 A

PC-54 B

PC-54 C

SFC Marina

FSFC Edge-West

Parr Canal Edge

IHC Edge-East

IHC Edge-West

Outer Harbor Edge

Comp LC

Comp LC-1

Comp LC-2

Comp LC-3

Comp LC-4

Comp LC-5

Comp LC-6

Comp USFC

Comp FSFC

Comp IHC-1

Comp IHC-2

Comp IHC-3

Comp GD

C-SFBF

C-SFBC \begin{tabular}{llll} 
& \multicolumn{3}{c}{ Fractional Percent (dry weight) } \\
\cline { 2 - 4 } Percent & Gravel Sand & Silt & Clay
\end{tabular} Solids $\quad \underline{\mu \mathrm{m}>2000} \quad \underline{62.5-2000} \quad \underline{3.9-62.5} \quad \underline{\leq 3.9}$

41

44

51

42

43

49

44

50

57

32

25

32

35

34

47

51

36

42

52

46

50

49

42

47

42

41

43

35

54

70

1
2
1
1
1
0

0

1

13

\section{0}

0

5

0

0

7

5

1

4

5

4

2

3

1

0

0

1

0
25

29

28

26

28

26

24

29

22

6

13

28

4

8

1

25

23

23

31

20

26

28

9
17

5

3

2

9

83
41

39

44

41

34

40

37

38

32

33

30

27

32

37

34

39

32

33

25

24

69

63

34

63

46

35

27

26

34

25

27

30

34

26

27

30

19

33

36

60
5
41

46

42

37

49

39

34

63

53

64

78

65

58

31 
TABLE C.3. Quality Control Data for Sediment Grain Size and Percent Solids Data, United Heckathorn Remedial Investigation

\begin{tabular}{|c|c|c|c|c|c|}
\hline \multirow[b]{2}{*}{$\begin{array}{l}\text { Sediment } \\
\text { Treatment } \\
\end{array}$} & \multirow[b]{2}{*}{$\begin{array}{l}\text { Percent } \\
\text { Solids } \\
\end{array}$} & \multicolumn{4}{|c|}{ Fractional Percent (dry weight) } \\
\hline & & $\begin{array}{c}\text { Gravel } \\
\mu \mathrm{m}>2000 \\
\end{array}$ & $\begin{array}{c}\text { Sand } \\
62.5-2000 \\
\end{array}$ & $\begin{array}{c}\text { Silt } \\
3.9-62.5 \\
\end{array}$ & $\begin{array}{l}\text { Clay } \\
\leq 3.9 \\
\end{array}$ \\
\hline \multicolumn{6}{|l|}{ Analvtical Duplicates } \\
\hline $\begin{array}{l}\text { Comp IHC-1 } \\
\text { Comp IHC-1 Duplicate } \\
\text { RPD } \\
\text { I-Stat }\end{array}$ & $\begin{array}{l}42 \\
42\end{array}$ & $\begin{array}{c}1 \\
0 \\
200 \%(a) \\
1.00\end{array}$ & $\begin{array}{c}5 \\
6 \\
18 \% \\
0.09\end{array}$ & $\begin{array}{c}30 \\
32 \\
\quad 6 \% \\
0.03\end{array}$ & $\begin{array}{c}64 \\
62 \\
\quad 3 \% \\
0.02\end{array}$ \\
\hline $\begin{array}{l}\text { IH-50 C } \\
\text { IH-50 C Duplicate } \\
\text { RPD } \\
\text { I-Stat }\end{array}$ & $\begin{array}{l}49 \\
50\end{array}$ & $\begin{array}{c}0 \\
1 \\
200 \% \text { (a) } \\
1.00\end{array}$ & $\begin{array}{l}4 \\
4 \\
0 \% \\
0.00\end{array}$ & $\begin{array}{c}32 \\
34 \\
\quad 6 \% \\
0.03\end{array}$ & $\begin{array}{r}64 \\
61 \\
5 \% \\
0.02\end{array}$ \\
\hline $\begin{array}{l}\text { IH-51 A } \\
\text { IH-51 A Duplicate } \\
\text { RPD } \\
\text { I-Stat }\end{array}$ & $\begin{array}{l}44 \\
44\end{array}$ & $\begin{array}{l}0 \\
0 \\
0 \% \\
0.00\end{array}$ & $\begin{array}{c}3 \\
3 \\
0 \% \\
0.00\end{array}$ & $\begin{array}{l}41 \\
37 \\
10 \% \\
0.05\end{array}$ & $\begin{array}{c}56 \\
60 \\
7 \% \\
0.03\end{array}$ \\
\hline $\begin{array}{l}\text { LZ-13 A } \\
\text { LZ-13 A Duplicate } \\
\text { RPD } \\
\text { I-Stat }\end{array}$ & $\begin{array}{l}35 \\
35\end{array}$ & $\begin{array}{l}1 \\
2 \\
67 \% \text { (a) } \\
0.33\end{array}$ & $\begin{array}{l}14 \\
16 \\
13 \% \\
0.07\end{array}$ & $\begin{array}{c}20 \\
19 \\
5 \% \\
0.03\end{array}$ & $\begin{array}{c}65 \\
63 \\
3 \% \\
0.02\end{array}$ \\
\hline $\begin{array}{l}\text { LZ-12 X } \\
\text { LZ-12 X Duplicate } \\
\text { RPD } \\
\text { I-Stat }\end{array}$ & $\begin{array}{l}40 \\
40\end{array}$ & $\begin{array}{c}0 \\
0 \\
0 \% \\
0.00\end{array}$ & $\begin{array}{c}9 \\
10 \\
11 \% \\
0.05\end{array}$ & $\begin{array}{l}21 \\
19 \\
10 \% \\
0.05\end{array}$ & $\begin{array}{c}70 \\
71 \\
1 \% \\
0.01\end{array}$ \\
\hline $\begin{array}{l}\text { LZ-15 A } \\
\text { LZ-15 A Duplicate } \\
\text { RPD } \\
\text { I-Stat }\end{array}$ & $\begin{array}{l}37 \\
37\end{array}$ & $\begin{array}{l}0 \\
0 \\
0 \% \\
0.00\end{array}$ & $\begin{array}{c}6 \\
5 \\
18 \% \\
0.09\end{array}$ & $\begin{array}{c}21 \\
21 \\
0 \% \\
0.00\end{array}$ & $\begin{array}{c}73 \\
74 \\
1 \% \\
0.01\end{array}$ \\
\hline $\begin{array}{l}\text { SF-34 B } \\
\text { SF-34 B Duplicate } \\
\text { RPD } \\
\text { I-Stat }\end{array}$ & $\begin{array}{l}46 \\
45\end{array}$ & $\begin{array}{l}0 \\
0 \\
0 \% \\
0.00\end{array}$ & $\begin{array}{l}9 \\
9 \\
0 \% \\
0.00\end{array}$ & $\begin{array}{c}25 \\
23 \\
\quad 8 \% \\
0.04\end{array}$ & $\begin{array}{c}66 \\
68 \\
3 \% \\
0.01\end{array}$ \\
\hline $\begin{array}{l}\text { SF-24 B } \\
\text { SF-24 B Duplicate } \\
\text { RPD } \\
\text { I-Stat }\end{array}$ & $\begin{array}{l}41 \\
41\end{array}$ & $\begin{array}{c}0 \\
0 \\
0 \% \\
0.00\end{array}$ & $\begin{array}{c}4 \\
4 \\
0 \% \\
0.00\end{array}$ & $\begin{array}{c}27 \\
28 \\
\quad 4 \% \\
0.02\end{array}$ & $\begin{array}{c}69 \\
68 \\
1 \% \\
0.01\end{array}$ \\
\hline
\end{tabular}


TABLE C.3. (contd)

Sediment

Treatment

SF-22 C Dupl icate

RPD

I-Stat

IH -46 B

IH-46 B Duplicate

RPD

I-Stat

$\mathrm{SF}-30 \mathrm{X}$

SF-30 X Duplicate

RPD

I-Stat

$\mathrm{IH}-44 \mathrm{C}$

IH-44 C Duplicate

RPD

I-Stat

IH-47 C

IH-47 C Duplicate

RPD

I-Stat

IH-44 B

IH-44 B Duplicate

RPD

I-Stat
$\mathrm{SF}-22 \mathrm{C}$

Percent

Solids

48

48

45

45

44

44

43

43

42

42

44

43

Compositing Duplicates

LZ-8 B

LZ-8 B Cdup $^{(b)}$

RPD

I-Stat

LZ-16 B

LZ-16 B Colup

RPD

I-Stat

$\mathrm{SF}-17 \mathrm{~B}$

SF-17 B Cdup

RPD

I-Stat
Fractional Percent (dry weight)
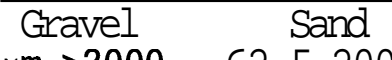

Silt

$\underline{\mu \mathrm{m}>2000} \quad \underline{62.5-2000}$

$3.9-62.5$

$\mathrm{Cl}$ ay

$<3.9$

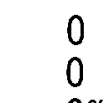

0.00

0
1
$200 \%(a)$
1.00

39

37

61

0.03

0.01

$2 \%$

0.00

$\begin{array}{cccc}0 & 3 & 37 & 60 \\ 0 & 3 & 35 & 62 \\ 0 \% & 0 \% & 6 \% & 3 \% \\ 0.00 & 0.00 & 0.03 & 0.02\end{array}$

0

7

28

29

$13 \%$

0.00

0.07

0.02

0.02

65

63

$3 \%$

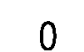

3
3
$0 \%$

0.00

29
29
$0 \%$
0.00

68

68

0.00

5

$0 \%$

0.00

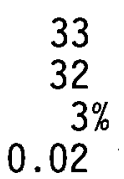

0.00

0.00

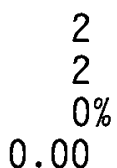

26
29
$11 \%$
0.05

0.01

$\begin{array}{cc}0 & 2 \\ 0 & 2 \\ 0 \% & 0 \% \\ 0.00 & 0.00\end{array}$

0.05

0.02 
TABLE C.3. (contd)

Sediment
Treatment
SF-21 C
SF-21 C Cdup
RPD
I-Stat
SF-27 B
SF-27 B Cdup
RPD
I-Stat
IH-36 B
IH-36 B Cdup
RPD
I-Stat
IH-37 B
IH-37 B Cdup
RPD
I-Stat
IH-39 B
IH-39 B Cdup
RPD
I-Stat
IH-43 B
IH-43 B Cdup
RPD
I-Stat
PC-54 B
PC-54 B Cdup
RPD
I-Stat
Parr Canal Edge
Parr Canal Edge Cdup
RPD
I-Stat
Comp LC
Comp LC Cdup
RPD
I-Stat

Percent
Solids Solids $\quad \mu \mathrm{m}>2000$

45

45

43

43

52

50

41

41

44
44

44

44

50

52

32

41

51

50

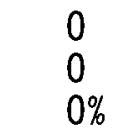

0.00

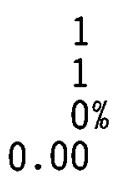

0.00

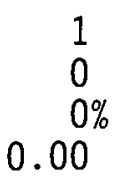

0.00

0.82

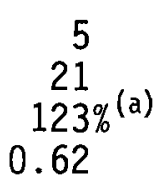

\begin{tabular}{lll}
\multicolumn{2}{c}{ Fractional Percent (dry weight) } \\
\hline Gravel Sand & Silt & Clay
\end{tabular} $\underline{\mu \mathrm{m}>2000} \quad \underline{62.5-2000} \quad \underline{3.9-62.5} \quad \leq 3.9$
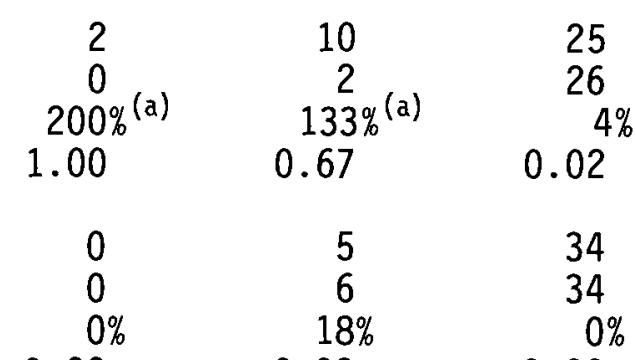

63

72

0.67

0.00

$13 \%$

0.07

0.09

5
6
$18 \%$
.09

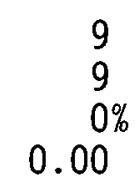
32
31
0.02

\section{4}

20

$18 \%$

0.09

0.00

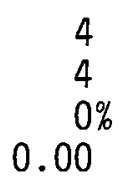

32

30

0.03

0.03

61

60

$2 \%$

0.01

58

59

$2 \%$

0.01

$\begin{array}{cc}29 & 68 \\ 28 & 69 \\ 4 \% & 1 \% \\ 0.02 & 0.01\end{array}$

0.00

\section{8}

35

$8 \%$

0.04

$13 \%$

0.04

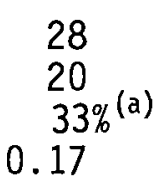

33
33
$0 \%$
0.00

0.07

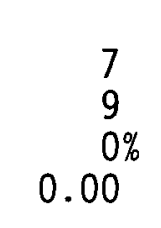

0.17

26

$4 \%$

0.02
27
24
$12 \%$
.06

41

41

$0 \%$

0.00

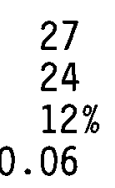


TABLE C.3. (contd)

Sediment

Treatment

Comp IHC-2

Comp IHC-2 Cdup

$\mathrm{RPD}$

I-Stat

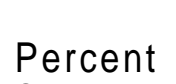

Solids

41
41

Fractional Percent (dry weight)

\begin{tabular}{|c|c|c|c|}
\hline $\begin{array}{c}\begin{array}{c}\text { Gravel } \\
\mu \mathrm{m}>2000\end{array} \\
\end{array}$ & $\begin{array}{c}\text { Sand } \\
62.5-2000 \\
\end{array}$ & $\begin{array}{c}\text { Silt } \\
3.9-62.5 \\
\end{array}$ & $\begin{array}{l}\text { Clay } \\
\leq 3.9 \\
\end{array}$ \\
\hline $\begin{array}{c}0 \\
0 \\
0 \% \\
0.00\end{array}$ & $\begin{array}{c}3 \\
3 \\
0 \% \\
0.00\end{array}$ & $\begin{array}{c}19 \\
32 \\
51 \%(a) \\
0.25\end{array}$ & $\begin{array}{c}78 \\
65 \\
18 \% \\
0.09\end{array}$ \\
\hline
\end{tabular}

(a) Value exceeds relative precision goal of $\leq 20 \%$.

(b) Compositing duplicate. 
TABLE C.4. Sediment Total Organic Carbon (TOC), United Heckathorn Remedial Investigation

Sediment

Treatment

Target $D^{(a)}$

Achieved DL High

Achieved DL Low

LZ-1 A

LZ-1 B

LZ-1 C

LZ-1 $D$

LZ-1 X

LZ-1 Y

LZ-2 A

LZ-2 B

LZ-2 C

LZ-2 X

LZ-2 Y

LZ-3 A

LZ-3 B

LZ-3 X

LZ-3 Y

LZ-5 A

LZ-5 Y

LZ-6 A

LZ-6 B

LZ-6 C

LZ-6 X

LZ-6 Y

LZ-7 A

LZ-7 B

LZ-7 C

LZ-7 X

LZ-7 Y

LZ-8 A

LZ-8 B

LZ-8 C

LZ-8 D

LZ-8 E

LZ-8 F

LZ-8 G

LZ-8 X

LZ-8 Y

\author{
TOC \\ (percent dry weight)
}

0.1

0.009

0.001

3.08

0.40

3.62

8.75

2.22

0.32

2.77

2.12

3.33

2.97

0.15

2.53

2.50

1.51

0.11

1.17

0.13

1.10

1.80

2.47

0.51

0.02

1.94

2.96

3.02

0.83

0.06

1.99

1.82

0.74

0.26

0.26

3.27

1.40

0.55

0.04 
TABLE C.4. (contd)

Sediment

Treatment

$\begin{array}{ll}L Z-9 & A \\ L Z-9 & X \\ L Z-9 & Y\end{array}$

LZ-10 A

$L Z-10$ B

LZ $-10 X$

$L Z-10 Y$

LZ-11 A

$L Z-11 \quad X$

LZ-11 Y

LZ-12 A

LZ $-12 X$

LZ-12 Y

LZ-13 A

LZ-13 B

LZ-13 C

LZ $-13 X$

LZ-13 Y

LZ-14 A

LZ-14 X

LZ-14 Y

LZ-15 A

LZ-15 B

$L Z-15 X$

LZ-15 Y

LZ-16 A

LZ-16 B

LZ-16 C

LZ-16 D

LZ-16 X

$L Z-16 Y$

SF-17 A

$S F-17 \quad B$

$S F-17 X$

SF-17 $Y$
TOC

(percent dry weight)

1.84

1.38

0.12

1.88

2.10

1.39

0.11

0.94

1.51

0.08

1.87

1.67

0.12

3.22

2.80

1.78

1.79

0.15

1.22

0.23

0.04

1.65

1.53

1.31

0.13

2. 14

2.04

1.55

0.74

0.63

0.21

1.62

1.42

0.49

0.13 
TABLE C.4. (contd)

\begin{tabular}{|c|c|}
\hline $\begin{array}{l}\text { Sediment } \\
\text { Treatment }\end{array}$ & $\begin{array}{c}T O C \\
\text { (percent drv weight) }\end{array}$ \\
\hline $\begin{array}{ll}S F-18 & A \\
S F-18 & B \\
S F-18 & X \\
S F-18 & Y\end{array}$ & $\begin{array}{l}1.50 \\
1.55 \\
1.01 \\
0.20\end{array}$ \\
\hline $\begin{array}{l}\text { SF-19 A } \\
\text { SF-19 X } \\
\text { SF-19 Y }\end{array}$ & $\begin{array}{l}1.35 \\
1.27 \\
0.06\end{array}$ \\
\hline $\begin{array}{l}S F-20 \mathrm{~A} \\
\text { SF-20 X } \\
\text { SF-20 Y }\end{array}$ & $\begin{array}{l}1.37 \\
1.36 \\
0.17\end{array}$ \\
\hline $\begin{array}{ll}S F-21 & A \\
S F-21 & B \\
S F-21 & C \\
S F-21 & X \\
S F-21 & Y\end{array}$ & $\begin{array}{l}1.33 \\
1.44 \\
1.16 \\
0.63 \\
0.19\end{array}$ \\
\hline $\begin{array}{ll}S F-22 & A \\
S F-22 & B \\
S F-22 & C \\
S F-22 & X \\
S F-22 & Y\end{array}$ & $\begin{array}{l}1.67 \\
1.03 \\
0.90 \\
0.41 \\
0.26\end{array}$ \\
\hline $\begin{array}{ll}S F-23 & A \\
S F-23 & B \\
S F-23 & X \\
S F-23 & Y\end{array}$ & $\begin{array}{l}1.35 \\
1.25 \\
0.69 \\
0.18\end{array}$ \\
\hline $\begin{array}{ll}\text { SF-24 } & A \\
\text { SF-24 } & B \\
\text { SF-24 } & \text { C }\end{array}$ & $\begin{array}{l}1.45 \\
1.66 \\
1.00\end{array}$ \\
\hline $\begin{array}{ll}S F-25 & A \\
S F-25 & B \\
S F-25 & X \\
S F-25 & Y\end{array}$ & $\begin{array}{l}2.34 \\
0.87 \\
0.22 \\
0.22\end{array}$ \\
\hline $\begin{array}{ll}S F-26 & A \\
\text { SF-26 } & B \\
S F-26 & C \\
S F-26 & X \\
S F-26 & Y\end{array}$ & $\begin{array}{l}1.61 \\
1.10 \\
1.26 \\
0.92 \\
0.22\end{array}$ \\
\hline
\end{tabular}


TABLE C.4. (contd)

\begin{tabular}{|c|c|}
\hline $\begin{array}{l}\text { Sediment } \\
\text { Treatment }\end{array}$ & $\begin{array}{c}\text { TOC } \\
\text { (percent dry weight) }\end{array}$ \\
\hline $\begin{array}{ll}S F-27 & A \\
S F-27 & B \\
S F-27 & C \\
S F-27 & X \\
S F-27 & Y\end{array}$ & $\begin{array}{l}1.32 \\
1.17 \\
1.29 \\
0.62 \\
0.07\end{array}$ \\
\hline $\begin{array}{ll}S F-28 & A \\
S F-28 & B \\
S F-28 & X \\
S F-28 & Y\end{array}$ & $\begin{array}{l}1.14 \\
0.78 \\
0.58 \\
0.10\end{array}$ \\
\hline $\begin{array}{ll}\text { SF-29 } & A \\
\text { SF-29 } & B \\
\text { SF-29 } & C \\
\text { SF-29 } & D \\
\text { SF-29 } & \text { E } \\
\text { SF-29 } & X \\
\text { SF-29 } & \text { Y }\end{array}$ & $\begin{array}{l}1.28 \\
1.30 \\
1.21 \\
1.00 \\
1.10 \\
0.32 \\
0.16\end{array}$ \\
\hline 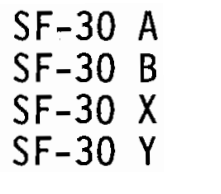 & $\begin{array}{l}1.43 \\
1.33 \\
1.23 \\
0.18\end{array}$ \\
\hline $\begin{array}{ll}\text { SF-31 } & A \\
\text { SF-31 } & X \\
\text { SF-31 } & Y\end{array}$ & $\begin{array}{l}1.25 \\
0.55 \\
0.23\end{array}$ \\
\hline $\begin{array}{ll}S F-32 & A \\
S F-32 & B \\
S F-32 & C \\
S F-32 & X \\
S F-32 & Y\end{array}$ & $\begin{array}{l}1.25 \\
1.32 \\
0.83 \\
1.12 \\
0.10\end{array}$ \\
\hline $\begin{array}{ll}S F-33 & A \\
S F-33 & B \\
S F-33 & X \\
S F-33 & Y\end{array}$ & $\begin{array}{l}1.02 \\
0.89 \\
0.63 \\
0.08\end{array}$ \\
\hline $\begin{array}{ll}S F-34 & A \\
S F-34 & B \\
S F-34 & X \\
S F-34 & Y\end{array}$ & $\begin{array}{l}1.33 \\
1.21 \\
0.12 \\
1.36\end{array}$ \\
\hline $\begin{array}{ll}\mathrm{IH}-35 & A \\
\mathrm{IH}-35 & \mathrm{X} \\
\mathrm{IH}-35 & \mathrm{Y}\end{array}$ & $\begin{array}{l}1.32 \\
0.54 \\
0.15\end{array}$ \\
\hline
\end{tabular}


TABLE C.4. (contd)

Sediment
Treatment

IH-36 A

IH-36 B

IH-36 X

IH-36 Y

IH-37 A

IH-37 B

IH-37 C

IH-37 X

IH-37 $Y$

IH-38 A

IH $-38 X$

IH-38 Y

IH-39 A

IH-39 B

IH-39 C

IH-39X

IH-39 Y

IH-40 A

IH-40 B

IH $-40 X$

IH-40 Y

IH-41 A

IH-41 B

IH-41 C

IH-41 X

IH-41 Y

IH-42 A

IH-42 X

IH-42 Y

IH-43 A

IH -43 B

IH $-43 X$

IH-43 Y

IH-44 A

IH-44 B

IH-44 C

IH-44 D

IH-44X

IH-44 Y

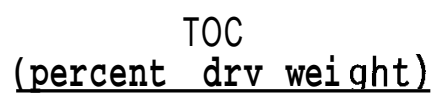

1.15

0.69

0.60

0.18

0.80

0.73

1.15

0.02

0.08

1.76

0.88

1.37

1.27

1.21

1.09

0.95

0.13

1.23

1.16

1.05

0.15

1.28

1.26

1.22

1.17

0.20

1.04

1.14

0.32

1.20

1.17

1.08

0.15

1.24

1.27

1. 30

1.28

1.08

0.14 
TABLE C.4. (contd)

\begin{tabular}{|c|c|}
\hline $\begin{array}{l}\text { Sediment } \\
\text { Treatment }\end{array}$ & $\begin{array}{c}\text { TOC } \\
\text { (percent dry weight) }\end{array}$ \\
\hline $\begin{array}{ll}\text { IH-45 } & \text { A } \\
\text { IH-45 } & \text { B } \\
\text { IH-45 } & \text { C } \\
\text { IH-45 } & X \\
\text { IH-45 } & Y\end{array}$ & $\begin{array}{l}1.21 \\
1.35 \\
0.97 \\
1.21 \\
0.14\end{array}$ \\
\hline $\begin{array}{ll}\text { IH-46 } & \text { A } \\
\text { IH-46 } & \text { B } \\
\text { IH-46 } & \text { C } \\
\text { IH-46 } & \text { X } \\
\text { IH-46 } & \text { Y }\end{array}$ & $\begin{array}{l}1.24 \\
1.25 \\
1.25 \\
1.26 \\
0.09\end{array}$ \\
\hline $\begin{array}{ll}\text { IH }-47 & \text { A } \\
\text { IH-47 } & \text { B } \\
\text { IH-47 } & \mathrm{C} \\
\text { IH-47 } & \text { X } \\
\text { IH }-47 & \text { Y }\end{array}$ & $\begin{array}{l}1.23 \\
1.19 \\
1.15 \\
1.13 \\
0.17\end{array}$ \\
\hline $\begin{array}{ll}\mathrm{IH}-48 & \mathrm{~A} \\
\mathrm{IH}-48 & \mathrm{~B} \\
\mathrm{IH}-48 & \mathrm{X} \\
\mathrm{IH}-48 & \mathrm{Y}\end{array}$ & $\begin{array}{l}1.17 \\
1.16 \\
1.19 \\
0.07\end{array}$ \\
\hline $\begin{array}{ll}\text { IH-49 } & \text { A } \\
\text { IH-49 } & \text { B } \\
\text { IH-49 } & X \\
\text { IH-49 } & Y\end{array}$ & $\begin{array}{l}1.16 \\
1.23 \\
1.19 \\
0.09\end{array}$ \\
\hline $\begin{array}{ll}I H-50 & A \\
I H-50 & B \\
I H-50 & C \\
I H-50 & X \\
I H-50 & Y\end{array}$ & $\begin{array}{l}1.17 \\
1.18 \\
1.24 \\
1.22 \\
0.05\end{array}$ \\
\hline $\begin{array}{ll}\text { IH }-51 & A \\
\text { IH-51 } & \text { B } \\
\text { IH-51 } & X \\
\text { IH-51 } & Y\end{array}$ & $\begin{array}{l}1.30 \\
1.26 \\
1.15 \\
0.03\end{array}$ \\
\hline $\begin{array}{ll}P C-52 & A \\
P C-52 & B \\
P C-52 & C\end{array}$ & $\begin{array}{l}5.54 \\
5.69 \\
5.53\end{array}$ \\
\hline $\begin{array}{l}P C-53 \\
P C-53 \\
P C \\
P C-53\end{array}$ & $\begin{array}{l}7.47 \\
8.74 \\
5.98\end{array}$ \\
\hline
\end{tabular}


TABLE C.4. (contd)

Sediment
Treatment
PC-54 A
PC-54 B
PC-54 C
SFC Marina
FSFC Edge-West
Parr Canal Edge
IHC Edge-East
IHC Edge-West
Outer Harbor Edge
Comp LC
Comp LC-1
Comp LC-2
Comp LC-3
Comp LC-4
Comp LC-5
Comp LC-6
Comp USFC
Comp FSFC
Comp IHC-1
Comp IHC-2
Comp IHC-3
Comp GD
C-SFBF
C-SFBC

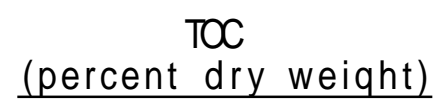

5.09

3.26

0.85

1.76

2.01

3.71

1.49

1.32

0.99

1.90

5.24

1.93

1.62

1.90

1.77

1.89

1.43

1.24

5.24

1.26

1.20

1.81

0.82

0.05

(a) DL Detection Timit. 
TABLE C.5. Quality Control Data for Total Organic Carbon (TOC), United Heckathorn Remedial Investigation

Sediment Treatment

Method Blanks

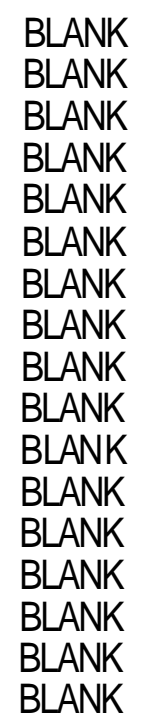

Analytical Duplicates

$\begin{array}{ll}\text { LZ-3 A } & 2.53 \\ \text { LZ-3 A Duplicate } & 2.54 \\ \text { RPD } & 0 \% \\ \text { I-Stat } & 0.00 \\ \text { LZ-6 Y } & 0.02 \\ \text { LZ-6 Y Duplicate } & 0.03 \\ \text { RPD } & 40 \% \text { (a) } \\ \text { I-Stat } & 0.20 \\ \text { LZ-8 G } & 0.26 \\ \text { LZ-8 G Duplicate } & 0.24 \\ \text { RPD } & 8 \% \\ \text { I-Stat } & 0.04 \\ \text { LZ-9 X } & 1.38 \\ \text { LZ-9 X Duplicate } & 1.37 \\ \text { RPD } & 1 \% \\ \text { I-Stat } & 0.00 \\ \text { LZ-13 C } & 1.78 \\ \text { LZ-13 C Dupl icate } & 1.72 \\ \text { RPD } & 3 \% \\ \text { I-Stat } & 0.02\end{array}$

\author{
$\mathrm{TOC}$ \\ (percent drv weight)
}

0.001

0.007

0.003

0.003

0.001

0.001

0.004

0.009

0.001

0.001

0.001

0.001

0.001

0.001

0.001

0.003

0.004

0.02

.03 
TABLE C.5. (contd)

\begin{tabular}{|c|c|}
\hline Sediment Treatment & $\begin{array}{c}\text { TOC } \\
\text { (percent dry weight) }\end{array}$ \\
\hline $\begin{array}{l}\text { LZ-16 B } \\
\text { LZ-16 B Duplicate } \\
\text { RPD } \\
\text { I-Stat }\end{array}$ & $\begin{array}{l}2.04 \\
1.82 \\
11 \%(a) \\
0.06\end{array}$ \\
\hline $\begin{array}{l}\text { SF-18 X } \\
\text { SF-18 X Duplicate } \\
\text { RPD } \\
\text { I-Stat }\end{array}$ & $\begin{array}{l}1.01 \\
1.00 \\
1 \% \\
0.00\end{array}$ \\
\hline $\begin{array}{l}\text { SF-20 A } \\
\text { SF-20 A Duplicate } \\
\text { RPD } \\
\text { I-Stat }\end{array}$ & $\begin{array}{l}1.37 \\
1.42 \\
4 \% \\
0.02\end{array}$ \\
\hline $\begin{array}{l}\text { SF-24 B } \\
\text { SF-24 B Duplicate } \\
\text { RPD } \\
\text { I-Stat }\end{array}$ & $\begin{array}{l}1.66 \\
1.66 \\
0 \% \\
0.00\end{array}$ \\
\hline $\begin{array}{l}\text { SF-25 A } \\
\text { SF-25 A Duplicate } \\
\text { RPD } \\
\text { I-Stat }\end{array}$ & $\begin{array}{l}2.34 \\
2.14 \\
9 \% \\
0.04\end{array}$ \\
\hline $\begin{array}{l}\text { SF-27 } \\
\text { SF-27 } \\
\text { BPD Duplicate } \\
\text { I-Stat }\end{array}$ & $\begin{array}{l}1.17 \\
1.14 \\
3 \% \\
0.01\end{array}$ \\
\hline $\begin{array}{l}\text { SF-29 D } \\
\text { SF-29 D Duplicate } \\
\text { RPD } \\
\text { I-Stat }\end{array}$ & $\begin{array}{l}1.00 \\
0.98 \\
2 \% \\
0.01\end{array}$ \\
\hline $\begin{array}{l}\text { SF-30 Y } \\
\text { SF-30 Y Duplicate } \\
\text { RPD } \\
\text { I-Stat }\end{array}$ & $\begin{array}{l}0.18 \\
0.18 \\
0 \% \\
0.00\end{array}$ \\
\hline $\begin{array}{l}\text { SF-33 A } \\
\text { SF-33 A Duplicate } \\
\text { RPD } \\
\text { I-Stat }\end{array}$ & $\begin{array}{l}1.02 \\
1.01 \\
1 \% \\
0.00\end{array}$ \\
\hline
\end{tabular}


TABLE C.5. (contd)

\begin{tabular}{|c|c|}
\hline Sediment Treatment & $\begin{array}{c}\text { TOC } \\
\text { (percent dry weight) }\end{array}$ \\
\hline $\begin{array}{l}\text { IH-37 Y } \\
\text { IH-37 Y Duplicate } \\
\text { RPD } \\
\text { I-Stat }\end{array}$ & $\begin{array}{l}0.08 \\
0.08 \\
0 \% \\
0.00\end{array}$ \\
\hline $\begin{array}{l}\text { IH-39 B } \\
\text { IH-39 B Duplicate } \\
\text { RPD } \\
\text { I-Stat }\end{array}$ & $\begin{array}{l}1.27 \\
1.28 \\
1 \% \\
0.00\end{array}$ \\
\hline $\begin{array}{l}\text { IH-41 X } \\
\text { IH-41 X Duplicate } \\
\text { RPD } \\
\text { I-Stat }\end{array}$ & $\begin{array}{l}1.17 \\
1.15 \\
2 \% \\
0.01\end{array}$ \\
\hline $\begin{array}{l}\text { IH-42 A } \\
\text { IH-42 A Duplicate } \\
\text { RPD } \\
\text { I-Stat }\end{array}$ & $\begin{array}{l}1.04 \\
1.10 \\
6 \% \\
0.03\end{array}$ \\
\hline $\begin{array}{l}\text { IH-45 B } \\
\text { IH-45 B Duplicate } \\
\text { RPD } \\
\text { I-Stat }\end{array}$ & $\begin{array}{l}1.35 \\
1.30 \\
\quad 4 \% \\
0.02\end{array}$ \\
\hline $\begin{array}{l}\text { IH-48 Y } \\
\text { IH-48 Y Duplicate } \\
\text { RPD } \\
\text { I-Stat }\end{array}$ & $\begin{array}{l}0.07 \\
0.07 \\
0 \% \\
0.00\end{array}$ \\
\hline $\begin{array}{l}\text { IH-49 A } \\
\text { IH-49 A Duplicate } \\
\text { RPD } \\
\text { I-Stat }\end{array}$ & $\begin{array}{l}1.16 \\
1.27 \\
9 \% \\
0.05\end{array}$ \\
\hline $\begin{array}{l}\text { IH-50 A } \\
\text { IH-50 A Duplicate } \\
\text { RPD } \\
\text { I-Stat }\end{array}$ & $\begin{array}{l}1.17 \\
1.25 \\
7 \% \\
0.03\end{array}$ \\
\hline $\begin{array}{l}\text { PC-53 B } \\
\text { PC-53 B Duplicate } \\
\text { RPD } \\
\text { I-Stat }\end{array}$ & $\begin{array}{l}8.74 \\
8.55 \\
2 \% \\
0.01\end{array}$ \\
\hline
\end{tabular}


TABLE C.5. (contd)

\begin{tabular}{|c|c|}
\hline Sediment Treatment & $\begin{array}{l}\text { TOC } \\
\text { (percent dry weight) }\end{array}$ \\
\hline $\begin{array}{l}\text { SFC Marina } \\
\text { SFC Marina Duplicate } \\
\text { RPD } \\
\text { I-Stat }\end{array}$ & $\begin{array}{l}1.76 \\
1.78 \\
1 \% \\
0.01\end{array}$ \\
\hline $\begin{array}{l}\text { Comp LC } \\
\text { Comp LC Duplicate } \\
\text { RPD } \\
\text { I-Stat }\end{array}$ & $\begin{array}{l}1.76 \\
1.88 \\
7 \% \\
0.03\end{array}$ \\
\hline $\begin{array}{l}\text { Comp USFC } \\
\text { Comp USFC Duplicate } \\
\text { RPD } \\
\text { I-Stat }\end{array}$ & $\begin{array}{l}1.43 \\
1.43 \\
0 \% \\
0.00\end{array}$ \\
\hline $\begin{array}{l}\text { Comp IHC-2 } \\
\text { Comp IHC-2 Duplicate } \\
\text { RPD } \\
\text { I-Stat }\end{array}$ & $\begin{array}{l}1.26 \\
1.28 \\
2 \% \\
0.01\end{array}$ \\
\hline \multicolumn{2}{|l|}{ Compositing Duplicates } \\
\hline $\begin{array}{l}\text { LZ-8 B } \\
\text { LZ-8 B } \text { Cdup }^{(\mathrm{b})} \\
\text { RPD } \\
\text { I-Stat }\end{array}$ & $\begin{array}{l}1.82 \\
1.71 \\
6 \% \\
0.03\end{array}$ \\
\hline $\begin{array}{l}\text { LZ-16 } \mathrm{B} \\
\text { LZ-16 } \mathrm{B} \text { Cdup } \\
\text { RPD } \\
\text { I-Stat }\end{array}$ & $\begin{array}{l}2.04 \\
4.16 \\
\quad 68 \%(a) \\
0.34\end{array}$ \\
\hline $\begin{array}{l}\text { SF-17 B } \\
\text { SF-17 B Cdup } \\
\text { RPD } \\
\text { I-Stat }\end{array}$ & $\begin{array}{l}1.42 \\
1.42 \\
0 \% \\
0.00\end{array}$ \\
\hline $\begin{array}{l}\text { SF-21 C } \\
\text { SF-21 C Cdup } \\
\text { RPD } \\
\text { I-Stat }\end{array}$ & $\begin{array}{l}1.16 \\
1.33 \\
14 \%(a) \\
0.07\end{array}$ \\
\hline $\begin{array}{l}\text { SF-27 B } \\
\text { SF-27 B Cdup } \\
\text { RPD } \\
\text { I-Stat }\end{array}$ & $\begin{array}{l}1.17 \\
1.14 \\
3 \% \\
0.01\end{array}$ \\
\hline
\end{tabular}


TABLE C.5. (contd)

\begin{tabular}{|c|c|}
\hline Sediment Treatment & $\begin{array}{c}T O \\
\text { (percent drv weight) } \\
\end{array}$ \\
\hline $\begin{array}{l}\mathrm{IH}-36 \text { B } \\
\mathrm{IH}-36 \text { B Cdup } \\
\text { RPD } \\
\text { I-Stat }\end{array}$ & $\begin{array}{l}0.69 \\
0.82 \\
17 \%(a) \\
0.09\end{array}$ \\
\hline $\begin{array}{l}\text { IH-37 B } \\
\text { IH-37 B Cdup } \\
\text { RPD } \\
\text { I-Stat }\end{array}$ & $\begin{array}{l}0.73 \\
1.29 \\
55 \%(a) \\
0.28\end{array}$ \\
\hline $\begin{array}{l}\text { IH-39 B } \\
\text { IH-39 B Cdup } \\
\text { RPD } \\
\text { I-Stat }\end{array}$ & $\begin{array}{l}1.21 \\
1.27 \\
5 \% \\
0.02\end{array}$ \\
\hline $\begin{array}{l}\mathrm{IH}-43 \text { B } \\
\text { IH-43 B Cdup } \\
\text { RPD } \\
\text { I-Stat }\end{array}$ & $\begin{array}{l}1.17 \\
1.16 \\
1 \% \\
0.00\end{array}$ \\
\hline $\begin{array}{l}\text { PC-54 B } \\
\text { PC-54 B Cdup } \\
\text { RPD } \\
\text { I-Stat }\end{array}$ & $\begin{array}{l}3.26 \\
2.13 \\
42 \%(a) \\
0.21\end{array}$ \\
\hline $\begin{array}{l}\text { Parr Canal Edge } \\
\text { Parr Canal Edge Cdup } \\
\text { RPD } \\
\text { I-Stat }\end{array}$ & $\begin{array}{l}3.71 \\
3.37 \\
10 \% \\
0.05\end{array}$ \\
\hline $\begin{array}{l}\text { Comp LC } \\
\text { Comp LC Cdup } \\
\text { RPD } \\
\text { I-Stat }\end{array}$ & $\begin{array}{l}1.90 \\
1.76 \\
8 \% \\
0.04\end{array}$ \\
\hline $\begin{array}{l}\text { Comp IHC-2 } \\
\text { Comp IHC-2 Cdup } \\
\text { RPD } \\
\text { I-Stat }\end{array}$ & $\begin{array}{l}1.26 \\
1.24 \\
2 \% \\
0.01\end{array}$ \\
\hline $\begin{array}{l}\text { (a) Value exceeds re } \\
\text { (b) Compositing dupl }\end{array}$ & goal of $\leq 10 \%$. \\
\hline
\end{tabular}


TABLE C.6. Chlorinated Pesticides (elution order, Alpha-BHC to Endosulfan I) in Younger Bay Mud from Selected Cores and Sediment Composites, United Heckathorn Remedia I Investigation

Sediment

Treatment

Target $D L^{(a)}$

Achieved DL High

Achieved DL Low

$L Z-1 \quad A$

$L Z-1 \quad B$

$\mathrm{LZ}-1 \quad \mathrm{C}$

LZ-1 D

LZ-1 X

LZ-1 Y

17-2 A

LZ-2 B

LZ-2 C

LZ-2 X

$\stackrel{?}{\omega}$

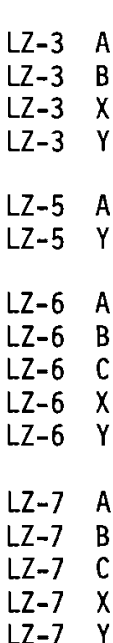

Batch

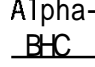

2 407.67

0.41

$372.45 \mathrm{u}^{(\mathrm{b})}$

$216.83 \mathrm{U}$

$4644.75 \mathrm{U}$

$1731.23 \mathrm{U}$

$68.22 \mathrm{U}$

$0.48 \mathrm{U}$

$734.90 \mathrm{U}$

$1483.74 \mathrm{U}$

$3225.33 \mathrm{U}$

$688.68 \mathrm{U}$

$0.18 \mathrm{~J}$

$835.24 \mathrm{U}$

$1735.34 \mathrm{U}$

$315.38 \mathrm{U}$

$0.08 \mathrm{~J}$

$326.87 \mathrm{U}$

$0.24 \mathrm{~J}$

$1125.39 \mathrm{U}$

$2515.80 \mathrm{U}$

$328.24 \mathrm{U}$

$99.01 \mathrm{U}$

$0.13 \mathrm{~J}$

$759.36 \mathrm{U}$

$4076.69 \mathrm{U}$

$699.23 \mathrm{U}$

$5.47 \mathrm{U}$

$0.02 \mathrm{~J}$
Pesticides $(\mu \mathrm{g} / \mathrm{kg}$ dry weight $)$

Hepta-

Aldrin

Epoxide

trans-

Chlordane

$\begin{array}{cc}2 & 2 \\ 602.76 & 547.65\end{array}$

0.61

2

2

0.56

547.65
0.56

623.60
0.63

223.60

2

2

0.67

$500.34 \mathrm{U} \quad 569.73 \mathrm{U}$

0.63

0.62

$550.68 \mathrm{U} \quad 500.34 \mathrm{U}$

$569.73 \mathrm{U}$

$556.12 \mathrm{U}$

$6867.44 \mathrm{U} \quad 6239.66 \mathrm{U} \quad 6239.66 \mathrm{U} \quad 7104.98 \mathrm{U}$

$2559.68 \mathrm{U} \quad 2325.69 \mathrm{U}$

$331.68 \mathrm{U}$

$7104.98 \mathrm{U}$

$323.76 \mathrm{U}$

$2648.22 \mathrm{U}$

$91.65 \mathrm{U} \quad 104.36 \mathrm{U}$

$0.73 \mathrm{U}$

$104.36 \mathrm{U}$

$2584.98 \mathrm{U}$

$101.87 \mathrm{U}$

$0.71 \mathrm{U}$

$0.64 \mathrm{U}$

$0.64 \mathrm{U}$

$987.25 \mathrm{U} \quad 1124.16 \mathrm{U}$

$1086.58 \mathrm{U} \quad 987.25 \mathrm{U}$

$4768.78 \mathrm{U}$

$1993.22 \mathrm{U}$

$0.71 \mathrm{U}$

$2269.65 \mathrm{U}$

$4933.73 \mathrm{U}$

$1124.16 \mathrm{U}$

$1097.32 \mathrm{U}$

$2269.65 \mathrm{U} \quad 2215.45 \mathrm{U}$

$4933.73 \mathrm{U}$

(332.84 U

$0.70 \mathrm{U}$

$0.70 \mathrm{U}$

$1028.30 \mathrm{U}$

$\begin{array}{rr}0.08 \mathrm{~J} & 0.06 \mathrm{~J}\end{array}$

$0.16 \mathrm{~J}$

$1234.94 \mathrm{U} \quad 1122.04 \mathrm{U} \quad 1122.04 \mathrm{U}$

$466.30 \mathrm{U}$

$1277.65 \mathrm{U}$

$1277.65 \mathrm{U}$

$0.69 \mathrm{U}$

$2654.52 \mathrm{U}$

$482.43 \mathrm{U}$

$1247.14 \mathrm{U}$

$423.68 \mathrm{U}$

$0.70 \mathrm{U}$

$482.43 \mathrm{U}$

$2591.13 \mathrm{U}$

$470.91 \mathrm{U}$

$0.68 \mathrm{U}$

$483.28 \mathrm{U} \quad 439.10 \mathrm{U}$

$500.00 \mathrm{U}$

$488.06 U$

$0.70 \mathrm{U}$

$500.00 \mathrm{U}$
$0.28 \mathrm{~J}$

$0.69 \mathrm{U}$

$1663.93 \mathrm{U}$

$1721.48 \mathrm{U}$

$1721.48 \mathrm{U}$

$1680.37 U$

$3848.36 \mathrm{U}$

2059.71

$490.11 \mathrm{U}$

$440.95 \mathrm{U}$

$440.95 \mathrm{U}$

$151.45 \mathrm{U}$

$502.10 \mathrm{U}$

$147.83 U$

$0.04 \mathrm{~J}$

$0.04 \mathrm{~J}$

$0.08 \mathrm{~J}$

$0.65 \mathrm{U}$

$0.37 \mathrm{~J}$

$0.63 U$

$109.24 \mathrm{~J}(\mathrm{c})$

J $\quad 602.04$

$0.19 \mathrm{~J} \quad 0.77 \mathrm{U}$

$1187.92 \mathrm{U}$

$1187.92 \mathrm{U}$

$2398.37 \mathrm{U} \quad 2398.37 \mathrm{U}$

$5213.55 \mathrm{U} \quad 5213.55 \mathrm{U}$

$\begin{array}{rr}1113.21 \mathrm{U} & 1113.21 \mathrm{U} \\ 0.63 \mathrm{~J} & 0.74 \mathrm{U}\end{array}$

$0.74 \mathrm{U}$

$1350.11 \mathrm{U}$

$1350.11 \mathrm{U}$

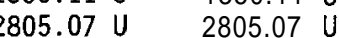

$509.79 \mathrm{U} \quad 509.79 \mathrm{U}$

$0.36 \mathrm{~J} \quad 0.74 \mathrm{U}$

$\begin{array}{lll}1122.75 \mathrm{U} & 1020.11 \mathrm{U} & 1020.11 \mathrm{U}\end{array}$

$1161.58 \mathrm{U}$

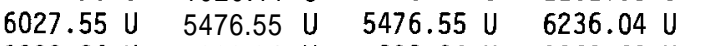

$939.34 \mathrm{U}$

$1069.60 \mathrm{U}$

$1161.58 \mathrm{U}$

$1133.84 \mathrm{U}$

$528.36 \mathrm{U}$

$528.36 \mathrm{U}$

$$
0.63 \mathrm{~J}
$$

$0.74 \mathrm{U}$

$1819.12 U \quad 1819.12 U$

$4066.63 \mathrm{U} \quad 4066.63 \mathrm{U}$

$530.58 \mathrm{U} \quad 530.58 \mathrm{U}$

$160.04 \mathrm{U} \quad 160.04 \mathrm{U}$

$0.09 \mathrm{~J} \quad 0.68 \mathrm{U}$

$8.09 \mathrm{U}$

$7.35 \mathrm{U}$

$7.35 \mathrm{U}$

$8.37 \mathrm{U}$

$6087.12 U$

$1227.46 \mathrm{U}$

$0.59 \mathrm{U}$

$0.67 \mathrm{U}$

$044.06 U$

-1
-72

$6589.72 \mathrm{U}$

$1130.27 \mathrm{U}$

8.84

$8.84 \mathrm{U}$
$0.71 \mathrm{U}$ 
TABLE C.6. (contd)

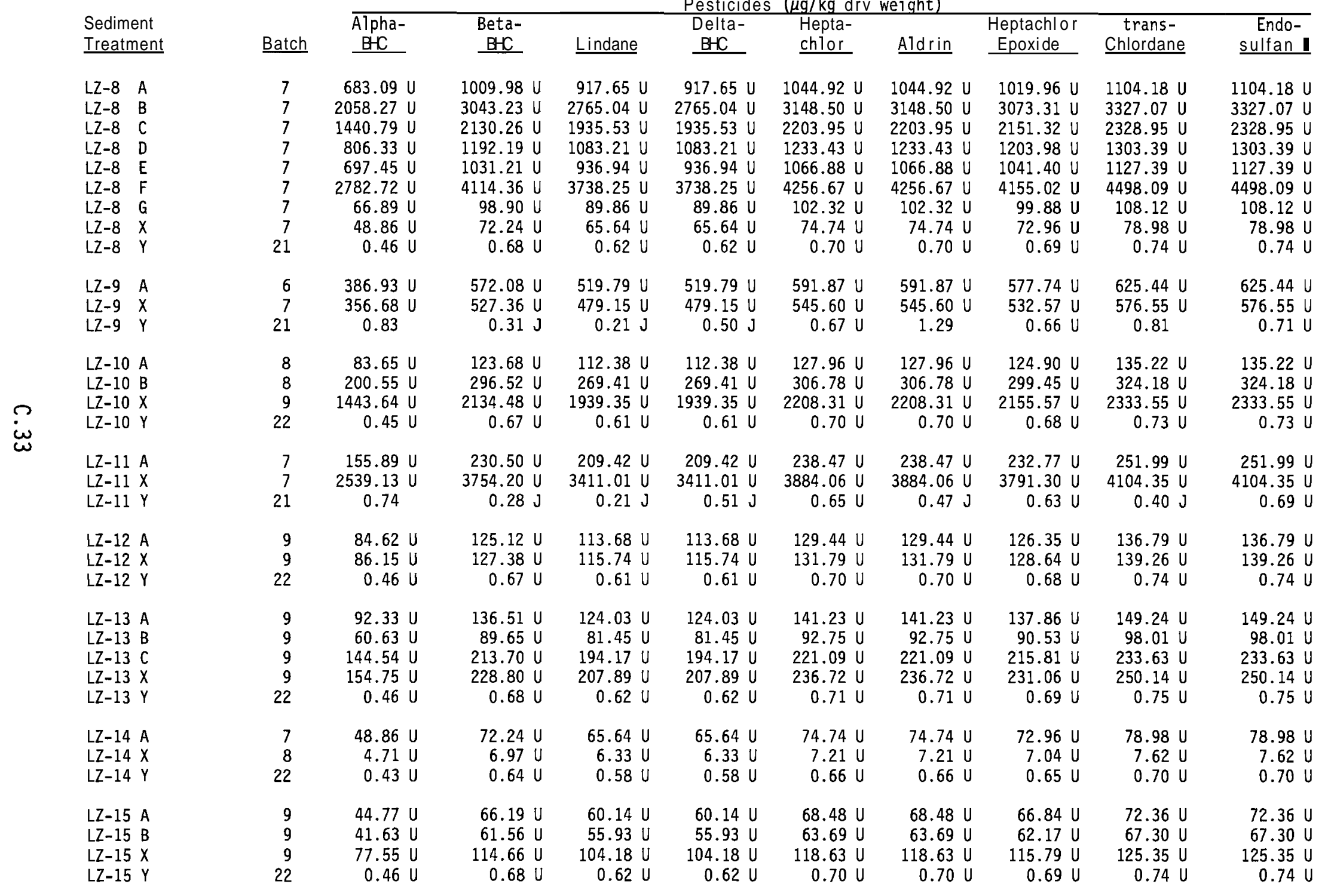


TABLE C.6. (contd)

Sediment

Treatmen

LZ-16 A

LZ -16 B

LZ-16 C

LZ-16 D

LZ-16 X

$L Z-16 Y$

SF-17 A

$S F-17 \quad B$

$\mathrm{SF}-17 X$

SF-17 $Y$

SF-18 A

$S F-18$ B

SF-18 X

SF-18 Y

$\stackrel{?}{\omega}$

SF-19 A

$S F-19 Y$

$S F-20 A$

$S F-20 X$
$S F-20 Y$

SF-21 A

$S F-21 B$

$S F-21 C$

$S F-21 X$

$S F-21 Y$

SF-22 A

$\mathrm{SF}-22 \mathrm{~B}$

SF-22 C

$\mathrm{SF}-22 X$

SF-22 Y

SF-23 A

$S F-23 B$

$\mathrm{SF}-23 \mathrm{X}$

SF-23 $Y$

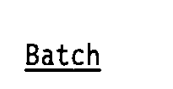

Alpha-

9.13

$73.74 \mathrm{U}$

$63.04 \mathrm{U}$

$50.02 \mathrm{U}$

4.98 U

$0.45 \mathrm{U}$

$0.58 \mathrm{~J}$

$0.09 \mathrm{~J}$

$0.48 U$

$0.31 \mathrm{~J}$

$0.35 \mathrm{~J}$

$0.35 \cdot \mathrm{J}$

$0.50 \mathrm{U}$

$0.35 \mathrm{~J}$

$0.48 \mathrm{U}$

$0.27 \mathrm{~J}$

$0.36 \mathrm{~J}$
$0.05 \mathrm{~J}$

$0.33 \mathrm{~J}$

$0.30 \mathrm{~J}$

$0.50 \mathrm{~J}$

$0.25 \mathrm{~J}$

$0.48 \mathrm{U}$

$0.52 \mathrm{~J}$

$0.46 \mathrm{~J}$

$0.73 \mathrm{U}$

$0.61 \mathrm{U}$

$0.48 U$

$0.26 \mathrm{~J}$

$0.55 \mathrm{~J}$

$0.28 \mathrm{~J}$

$0.48 \mathrm{U}$
BetaBHC

$109.02 \mathrm{U}$

$93.21 \mathrm{U}$

$73.96 \mathrm{U}$

$0.66 \mathrm{U}$

$1.28 \mathrm{U}$

$1.16 \mathrm{U}$

$0.87 \mathrm{U}$

$0.71 \mathrm{U}$

$1.24 \mathrm{U}$

$1.25 \mathrm{U}$

$1.16 \mathrm{U}$

$0.74 \mathrm{U}$

$1.28 \mathrm{U}$

$0.71 \mathrm{U}$

$1.37 \mathrm{U}$

$1.22 \mathrm{U}$
$0.72 \mathrm{U}$

$1.24 \mathrm{U}$

$1.18 \mathrm{U}$

$1.21 \mathrm{U}$

$1.02 \mathrm{U}$

$0.70 \mathrm{U}$

$1.26 \mathrm{U}$

$1.07 \mathrm{U}$

$1.08 \mathrm{U}$

$0.90 \mathrm{U}$

$0.71 \mathrm{U}$

$1.35 \mathrm{U}$

$0.20 \mathrm{~J}$

$0.92 \mathrm{U}$

$0.71 \mathrm{U}$
Pesticides ( $\mu \mathrm{g} / \mathrm{kg}$ dry weight)

Delta- Hepta-

Hepta-

$12.26 \mathrm{U}$

$99.06 \mathrm{U}$

$84.69 \mathrm{U}$

$67.20 \mathrm{U}$

$6.68 \mathrm{U}$

$13.96 \mathrm{U}$

$112.79 \mathrm{U}$

$96.43 \mathrm{U}$

$\begin{array}{rr}67.20 \mathrm{U} & 76.52 \mathrm{U} \\ 6.68 \mathrm{U} & 7.61 \mathrm{U}\end{array}$

$0.69 \mathrm{U}$

$1.16 \mathrm{~V}$

$0.60 \mathrm{U}$

$1.33 \mathrm{U}$

$1.16 \mathrm{U}$

$1.06 \mathrm{U}$

$1.20 \mathrm{U}$

$0.90 \mathrm{U}$

$0.65 \mathrm{U}$

$0.74 \mathrm{U}$

$1.12 \mathrm{U}$

$1.12 \mathrm{U}$

$1.28 \mathrm{U}$

$1.13 \mathrm{U}$

$1.29 \mathrm{U}$

$1.13 \mathrm{U}$

$0.67 \mathrm{U}$

$1.05 \mathrm{U}$

$1.20 \mathrm{U}$

$0.77 \mathrm{U}$

$1.16 \mathrm{U}$

$0.64 \mathrm{U}$

$1.16 \mathrm{U}$

$1.10 \mathrm{U}$

$1.32 \mathrm{U}$

$1.26 \mathrm{U}$

$1.25 \mathrm{U} \quad 1.25 \mathrm{U}$

$1.11 \mathrm{U}$
$0.66 \mathrm{U}$

$1.25 \mathrm{U}$
$1.11 \mathrm{U}$

$1.42 \mathrm{U}$

$0.66 \mathrm{U}$

$1.27 \mathrm{U}$
$0.75 \mathrm{U}$

$1.12 \mathrm{U}$

$1.12 \mathrm{U}$

$1.28 \mathrm{U}$

$1.08 \mathrm{U}$

$1.10 \mathrm{U}$

$0.92 \mathrm{U}$

$1.10 \mathrm{U}$

$0.92 \mathrm{U}$

$1.22 \mathrm{U}$

$1.25 \mathrm{U}$

$1.05 \mathrm{U}$

$0.73 \mathrm{U}$

$1.14 U$

$1.30 \mathrm{U}$

$1.14 \mathrm{U}$

$0.97 \mathrm{U}$

$0.98 \mathrm{U}$

$0.82 \mathrm{U}$

$0.65 \mathrm{U}$

$0.82 \mathrm{U}$

$1.11 \mathrm{U}$

$1.12 \mathrm{U}$

$0.93 \mathrm{U}$

$0.74 \mathrm{U}$

$1.23 \mathrm{U}$

$1.40 \mathrm{U}$

$1.23 \mathrm{~V}$

$1.03 \mathrm{U}$

$0.84 \mathrm{~V}$

$0.84 \mathrm{U}$

$1.17 \mathrm{U}$

$0.95 \mathrm{U}$

$0.73 \mathrm{U}$

$0.64 \mathrm{U}$

Aldri

$13.96 \mathrm{U}$ $112.79 \mathrm{U}$

$96.43 \mathrm{U}$

$76.52 \mathrm{U}$

$7.61 \mathrm{U}$

$0.69 \mathrm{U}$

$1.33 \mathrm{U}$

$1.20 \mathrm{U}$
$0.90 \mathrm{U}$

$0.74 \mathrm{U}$

$1.28 \mathrm{U}$

$1.29 \mathrm{U}$

$0.77 \mathrm{U}$

$1.32 \mathrm{U}$

$1.26 \mathrm{U}$

$0.73 \mathrm{U}$

$1.42 \mathrm{U}$

$1.27 U$
$0.75 U$

$1.28 \mathrm{U}$

$1.22 \mathrm{U}$

$1.25 \mathrm{U}$

$1.05 \mathrm{U}$
$0.73 \mathrm{U}$

$1.30 \mathrm{U}$

$1.11 \mathrm{U}$

$1.12 \mathrm{U}$

$0.93 \mathrm{U}$

$1.40 \mathrm{U}$

$1.17 \mathrm{U}$

$0.95 \mathrm{U}$

$0.73 U$
Heptachlor

poxide

$13.63 \mathrm{U}$

$110.10 \mathrm{U}$

$94.13 \mathrm{U}$
$74.69 \mathrm{U}$

$7.43 \mathrm{U}$

$0.67 \mathrm{U}$

$1.29 \mathrm{U}$

$1.17 \mathrm{U}$

$0.88 \mathrm{U}$

$0.72 \mathrm{U}$

$1.25 \mathrm{U}$

$1.26 \mathrm{U}$

$1.17 \mathrm{U}$

$0.75 \mathrm{U}$

$1.29 \mathrm{U}$

$1.23 \mathrm{U}$

$0.71 \mathrm{U}$

$1.39 \mathrm{U}$

$1.24 \mathrm{U}$
$0.73 \mathrm{U}$

$1.25 \mathrm{U}$

$1.25 \mathrm{U}$
$1.20 \mathrm{U}$

$1.22 \mathrm{U}$

$1.03 \mathrm{U}$

$0.71 \mathrm{U}$

$1.27 \mathrm{U}$

$1.08 \mathrm{U}$

$1.09 \mathrm{U}$

$0.91 \mathrm{U}$

$0.72 U$

$1.36 \mathrm{U}$

$1.14 \mathrm{U}$

$0.93 \mathrm{U}$

$0.71 \mathrm{U}$

$1.24 \mathrm{U}$

$1.01 \mathrm{U}$
$0.77 \mathrm{U}$

2.25
1.34

1.34
$1.18 \mathrm{U}$

$0.98 \mathrm{U}$

$.78 \mathrm{U}$

$0.92 \mathrm{~J}$
$0.74 \mathrm{~J}$

$0.84 \mathrm{~J}$

$.92 \mathrm{~J}$

$1.24 \mathrm{U}$
$0.77 \mathrm{U}$

sulfan

$14.75 \mathrm{U}$

$119.19 \mathrm{U}$

$101.90 \mathrm{U}$

$80.86 U$

$0.73 \mathrm{U}$

$1.40 \mathrm{U}$
$1.27 \mathrm{U}$

$0.96 U$

$0.78 \mathrm{U}$

$1.35 \mathrm{U}$

$1.36 \mathrm{U}$

1.26

$0.81 \mathrm{U}$

$1.39 \mathrm{U}$

$0.77 \mathrm{~V}$

$1.50 \mathrm{U}$

$1.34 \mathrm{U}$
$0.79 \mathrm{U}$

$1.35 \mathrm{U}$

$1.29 \mathrm{U}$

$1.33 \mathrm{U}$ 
TABLE C.6. (contd)

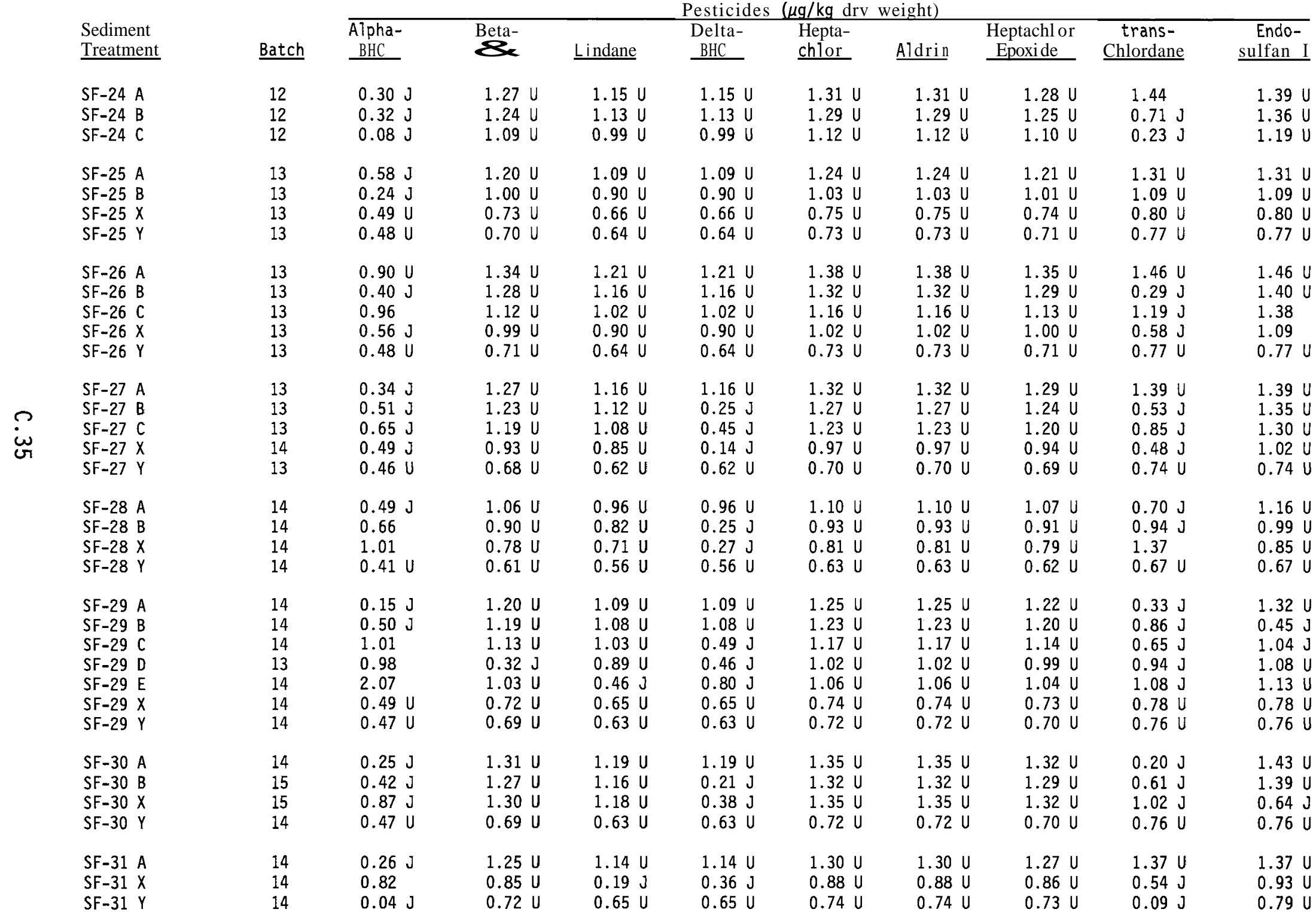


TABLE C.6. (contd)

Sediment Treatment

SF-32 A

SF-32 B

SF-32 C

$S F-32 X$

$S F-32 Y$

SF-33 A

SF-33 B

$S F-33 X$

SF-33 $Y$

SF-34 A

SF-34 B

SF $-34 X$

SF-34 $Y$

o

IH-35 A

IH-35 $Y$

IH-36 A

IH-36 B

IH-36 X

IH-36 Y

IH-37 A

IH-37 B

IH-37 C

IH-37 $X$

IH-37 Y

IH-38 A

IH-38 X

IH-38 $Y$

IH-39 A

IH-39 B

IH-39 C

IH-39X

IH-39 $Y$

\begin{tabular}{lllllll}
\hline \multicolumn{1}{c}{ Pesticides $(\mu \mathrm{g} / \mathrm{kg}$ dry weight $)$} \\
$\begin{array}{l}\text { Alpha- } \\
\text { BHC }\end{array}$ & Beta- & Delta- & Hepta- & Heptachlor & trans- & Endo- \\
\hline
\end{tabular}

$\begin{array}{ll}0.51 \mathrm{~J} & 1.01 \mathrm{U} \\ 0.35 \mathrm{~J} & 1.02 \mathrm{U} \\ 0.54 \mathrm{U} & 0.80 \mathrm{U} \\ 0.60 \mathrm{U} & 0.89 \mathrm{U} \\ 0.46 \mathrm{U} & 0.68 \mathrm{U}\end{array}$

$0.23 \mathrm{~J}$

$0.20 \mathrm{~J}$

$0.73 \mathrm{U}$

$0.80 \mathrm{U}$
$0.61 \mathrm{U}$

$0.21 \mathrm{~J}$

$1.05 \mathrm{U}$

$1.05 \mathrm{U}$

$1.05 \mathrm{U}$

$1.05 \mathrm{U}$

$0.73 \mathrm{U}$

$0.83 \mathrm{U}$

$0.80 \mathrm{U}$

$0.92 \mathrm{U}$
$0.70 \mathrm{U}$

$0.92 \mathrm{U}$

$0.70 \mathrm{U}$

$0.23 \mathrm{~J}$

$0.30 \mathrm{~J}$

$0.98 \mathrm{U}$

0.66

$0.94 \mathrm{U}$

$0.87 \mathrm{U}$

$0.07 \mathrm{~J}$

$0.62 \mathrm{U}$

$0.39 \mathrm{~J}$
$0.76 \mathrm{U}$

$0.99 \mathrm{U}$

$0.98 \mathrm{U}$

$0.99 \mathrm{U}$

$0.86 \mathrm{U}$

$0.71 \mathrm{U}$

$0.71 \mathrm{U}$

$1.06 \mathrm{U}$

$0.66 \mathrm{U}$

$1.21 \mathrm{U}$

$0.28 \mathrm{~J}$

$1.06 \mathrm{U}$

$1.21 \mathrm{U}$

$1.06 \mathrm{U}$

$0.75 \mathrm{U}$

$0.70 \mathrm{U}$

$0.28 \mathrm{~J}$
$0.46 \mathrm{U}$

$0.73 \mathrm{U}$

$0.61 \mathrm{U}$

$0.61 \mathrm{U}$

$1.15 \mathrm{U}$

$1.01 \mathrm{U}$
$0.79 \mathrm{U}$

$0.65 \mathrm{U}$

$0.79 \mathrm{U}$

$0.65 \mathrm{U}$

$0.74 \mathrm{U}$

$1.15 \mathrm{U}$

$0.90 \mathrm{U}$

$1.24 \mathrm{U}$

$1.09 \mathrm{U}$

$1.09 \mathrm{U}$

$1.00 \mathrm{U}$

$0.91 \mathrm{U}$
$0.78 \mathrm{U}$

$0.91 \mathrm{U}$

$1.24 \mathrm{U}$
$1.04 \mathrm{U}$

$1.24 \mathrm{U}$

$0.88 \mathrm{U}$

$1.04 \mathrm{U}$
$0.88 \mathrm{U}$

$0.88 U$
$0.74 U$

$1.02 \mathrm{U}$

$1.03 \mathrm{U}$

$0.81 \mathrm{U}$

$0.89 \mathrm{U}$
$0.68 \mathrm{U}$

1.53

$1.11 \mathrm{U}$

$0.87 \mathrm{U}$
$0.97 \mathrm{U}$

$0.74 \mathrm{U}$

$1.11 \mathrm{U}$

$0.95 \mathrm{U}$

$1.03 \mathrm{U}$

$0.96 \mathrm{U}$

$0.84 \mathrm{U}$

$0.69 \mathrm{U}$

$1.04 \mathrm{U}$

1.33

$0.75 \mathrm{U}$

$1.18 \mathrm{U}$

2.62

$1.12 \mathrm{U}$

$0.80 \mathrm{U}$

$0.74 \mathrm{U}$

$1.22 \mathrm{U}$

$0.79 \mathrm{U}$

$0.35 \mathrm{~J}$

$0.60 \mathrm{~J}$

$0.70 \mathrm{~J}$

$0.78 \mathrm{U}$

$0.72 \mathrm{U}$

$1.15 \mathrm{U}$

$1.15 \mathrm{U}$

$1.15 \mathrm{U}$

$1.07 \mathrm{U}$

$1.31 \mathrm{U}$

$1.31 \mathrm{U}$
$1.31 \mathrm{U}$

$1.15 \mathrm{U}$

$1.07 \mathrm{U}$
$0.94 \mathrm{U}$

$1.31 \mathrm{U}$

$1.28 \mathrm{U}$

$1.38 \mathrm{U}$

$0.30 \mathrm{~J}$

$0.25 \mathrm{~J}$

$0.39 \mathrm{~J}$

$1.08 \mathrm{U}$

$1.08 \mathrm{U}$

$1.05 \mathrm{U}$

$0.36 \mathrm{~J}$
$0.48 \mathrm{U}$

$0.71 \mathrm{U}$

$0.65 \mathrm{U}$

$0.65 \mathrm{U}$

$0.74 \mathrm{U}$

$1.15 \mathrm{U}$

$1.15 \mathrm{U}$

$1.31 \mathrm{U}$

$0.74 \mathrm{U}$

.78

$0.74 \mathrm{~J}$

$0.64 \mathrm{~J}$

$0.77 \mathrm{U}$

$1.05 \mathrm{~J}$

$0.49 \mathrm{~J}$

$1.17 \mathrm{~J}$
$0.75 \mathrm{U}$

$0.99 \mathrm{U}$

$1.13 \mathrm{U}$

$0.87 \mathrm{U}$

$0.63 \mathrm{U}$

$0.71 \mathrm{U}$

$0.69 \mathrm{U}$

$1.11 \mathrm{U}$

$0.97 U$

$0.74 \mathrm{U}$

$1.03 \mathrm{U}$

$1.04 \mathrm{U}$

$0.91 U$

$0.75 \mathrm{U}$

$1.28 \mathrm{U}$

$1.12 \mathrm{U}$

$0.80 \mathrm{U}$

$0.74 U$

$1.22 \mathrm{U}$

$0.79 \mathrm{U}$

$1.31 \mathrm{U}$

$0.44 \mathrm{~J}$

$0.44 \mathrm{~J}$

$0.78 \mathrm{U}$

$1.38 \mathrm{U}$

$0.06 \mathrm{~J}$

$0.07 \mathrm{~J}$

$0.78 \mathrm{U}$

$0.27 \mathrm{~J}$

$0.30 \mathrm{~J}$

$0.77 \mathrm{U}$

$0.22 \mathrm{~J}$

$0.38 \mathrm{~J}$

$0.44 \mathrm{~J}$
$0.47 \mathrm{U}$

$0.63 \mathrm{U}$

$0.75 \mathrm{U}$ 
TABLE C.6. (contd)

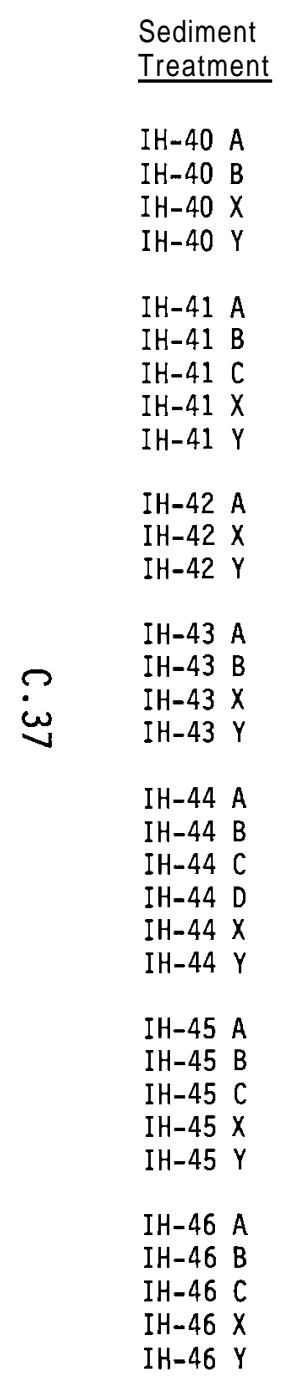

\begin{tabular}{|c|c|c|c|c|c|c|c|c|c|}
\hline & & & & Pesticide & $\mathrm{ug} / \mathrm{kg} \mathrm{drv}$ & eight) & & & \\
\hline Batch & $\begin{array}{l}\text { Alpha- } \\
\text { BHC } \\
\end{array}$ & $\begin{array}{l}\text { Beta- } \\
\text { BHC }\end{array}$ & $\underline{\text { Lindane }}$ & $\begin{array}{l}\text { Delta- } \\
\text { BHC }\end{array}$ & $\begin{array}{l}\text { Hepta- } \\
\text { chior }\end{array}$ & Aldrin & $\begin{array}{l}\text { Heptachlor } \\
\text { Epoxide }\end{array}$ & $\begin{array}{c}\text { trans- } \\
\text { Chlordane } \\
\end{array}$ & $\begin{array}{c}\text { Endo- } \\
\text { sulfan } 1\end{array}$ \\
\hline $\begin{array}{l}16 \\
25 \\
16 \\
17\end{array}$ & $\begin{array}{l}0.85 \mathrm{U} \\
0.79 \mathrm{U} \\
0.57 \mathrm{~J} \\
0.48 \mathrm{U}\end{array}$ & $\begin{array}{l}1.25 \mathrm{U} \\
1.16 \mathrm{U} \\
1.15 \mathrm{U} \\
0.71 \mathrm{U}\end{array}$ & $\begin{array}{l}1.14 \mathrm{U} \\
1.06 \mathrm{U} \\
1.04 \mathrm{U} \\
0.65 \mathrm{U}\end{array}$ & $\begin{array}{l}1.14 U \\
1.06 U \\
1.04 U \\
0.65 U\end{array}$ & $\begin{array}{l}1.30 \mathrm{U} \\
1.20 \mathrm{U} \\
1.19 \mathrm{U} \\
0.74 \mathrm{U}\end{array}$ & $\begin{array}{l}1.30 \mathrm{U} \\
1.20 \mathrm{U} \\
1.19 \mathrm{U} \\
0.74 \mathrm{U}\end{array}$ & $\begin{array}{l}1.27 \mathrm{U} \\
1.18 \mathrm{U} \\
1.16 \mathrm{U} \\
0.72 \mathrm{U}\end{array}$ & $\begin{array}{l}0.85 \mathrm{~J} \\
0.22 \mathrm{~J} \\
0.34 \mathrm{~J} \\
0.78 \mathrm{U}\end{array}$ & $\begin{array}{l}0.07 \mathrm{~J} \\
1.27 \mathrm{U} \\
0.15 \mathrm{~J} \\
0.78 \mathrm{U}\end{array}$ \\
\hline $\begin{array}{l}18 \\
18 \\
16 \\
16 \\
17\end{array}$ & $\begin{array}{l}0.29 \mathrm{~J} \\
0.36 \mathrm{~J} \\
0.48 \mathrm{~J} \\
0.35 \mathrm{~J} \\
0.47 \mathrm{~J}\end{array}$ & $\begin{array}{l}1.22 \mathrm{U} \\
1.20 \mathrm{U} \\
1.08 \mathrm{U} \\
1.08 \mathrm{U} \\
0.69 \mathrm{U}\end{array}$ & $\begin{array}{l}0.13 \mathrm{~J} \\
1.09 \mathrm{U} \\
0.98 \mathrm{U} \\
0.98 \mathrm{U} \\
0.63 \mathrm{U}\end{array}$ & $\begin{array}{l}1.11 U \\
1.09 U \\
0.98 U \\
0.98 U \\
0.63 U\end{array}$ & $\begin{array}{l}1.26 U \\
1.24 U \\
1.11 U \\
1.12 U \\
0.71 U\end{array}$ & $\begin{array}{l}1.26 U \\
1.24 U \\
1.11 U \\
1.12 U \\
0.71 U\end{array}$ & $\begin{array}{l}1.23 U \\
1.21 U \\
1.09 U \\
1.09 U \\
0.70 U\end{array}$ & $\begin{array}{l}0.40 \mathrm{~J} \\
0.27 \mathrm{~J} \\
0.74 \mathrm{~J} \\
0.80 \mathrm{~J} \\
0.75 \mathrm{U}\end{array}$ & $\begin{array}{l}1.33 \mathrm{U} \\
1.32 \mathrm{U} \\
0.34 \mathrm{~J} \\
0.25 \mathrm{~J} \\
0.75 \mathrm{U}\end{array}$ \\
\hline $\begin{array}{l}18 \\
18 \\
17\end{array}$ & $\begin{array}{l}0.15 \mathrm{~J} \\
0.14 \mathrm{~J} \\
0.47 \mathrm{U}\end{array}$ & $\begin{array}{l}1.11 U \\
1.14 U \\
0.70 U\end{array}$ & $\begin{array}{l}0.09 \mathrm{~J} \\
0.13 \mathrm{~J} \\
0.63 \mathrm{U}\end{array}$ & $\begin{array}{l}1.01 U \\
1.04 U \\
0.63 U\end{array}$ & $\begin{array}{l}1.15 U \\
1.18 U \\
0.72 U\end{array}$ & $\begin{array}{l}1.15 \mathrm{U} \\
1.18 \mathrm{U} \\
0.72 \mathrm{U}\end{array}$ & $\begin{array}{l}1.12 \mathrm{U} \\
1.15 \mathrm{U} \\
0.71 \mathrm{U}\end{array}$ & $\begin{array}{l}0.53 \mathrm{~J} \\
0.34 \mathrm{~J} \\
0.76 \mathrm{U}\end{array}$ & $\begin{array}{l}1.22 U \\
1.25 U \\
0.76 U\end{array}$ \\
\hline $\begin{array}{l}25 \\
18 \\
18 \\
17\end{array}$ & $\begin{array}{l}0.82 \mathrm{U} \\
0.30 \mathrm{~J} \\
0.23 \mathrm{~J} \\
0.48 \mathrm{U}\end{array}$ & $\begin{array}{l}1.21 \mathrm{U} \\
1.22 \mathrm{U} \\
1.09 \mathrm{U} \\
0.70 \mathrm{U}\end{array}$ & $\begin{array}{l}1.10 \mathrm{U} \\
0.13 \mathrm{~J} \\
0.16 \mathrm{~J} \\
0.64 \mathrm{U}\end{array}$ & $\begin{array}{l}1.10 \mathrm{U} \\
1.11 \mathrm{U} \\
0.99 \mathrm{U} \\
0.64 \mathrm{U}\end{array}$ & $\begin{array}{l}1.25 \mathrm{U} \\
1.26 \mathrm{U} \\
1.13 \mathrm{U} \\
0.73 \mathrm{U}\end{array}$ & $\begin{array}{l}1.25 U \\
1.26 U \\
1.13 U \\
0.73 U\end{array}$ & $\begin{array}{l}1.22 U \\
1.23 U \\
1.10 U \\
0.71 U\end{array}$ & $\begin{array}{l}1.32 \mathrm{U} \\
0.53 \mathrm{~J} \\
0.56 \mathrm{~J} \\
0.77 \mathrm{U}\end{array}$ & $\begin{array}{l}1.32 \mathrm{U} \\
1.33 \mathrm{U} \\
1.19 \mathrm{U} \\
0.77 \mathrm{U}\end{array}$ \\
\hline $\begin{array}{l}18 \\
18 \\
18 \\
18 \\
25 \\
17\end{array}$ & $\begin{array}{l}0.83 \mathrm{U} \\
0.27 \mathrm{~J} \\
0.80 \mathrm{U} \\
0.32 \mathrm{~J} \\
0.76 \mathrm{U} \\
0.48 \mathrm{U}\end{array}$ & $\begin{array}{l}1.23 \mathrm{U} \\
1.27 \mathrm{U} \\
1.18 \mathrm{U} \\
1.17 \mathrm{U} \\
1.12 \mathrm{U} \\
0.71 \mathrm{U}\end{array}$ & $\begin{array}{l}0.16 \mathrm{~J} \\
0.17 \mathrm{~J} \\
0.12 \mathrm{~J} \\
0.10 \mathrm{~J} \\
1.02 \mathrm{U} \\
0.65 \mathrm{U}\end{array}$ & $\begin{array}{l}1.12 \mathrm{U} \\
1.16 \mathrm{U} \\
1.07 \mathrm{U} \\
1.06 \mathrm{U} \\
0.24 \mathrm{~J} \\
0.65 \mathrm{U}\end{array}$ & $\begin{array}{l}1.27 \mathrm{U} \\
1.32 \mathrm{U} \\
1.22 \mathrm{U} \\
1.21 \mathrm{U} \\
1.16 \mathrm{U} \\
0.74 \mathrm{U}\end{array}$ & $\begin{array}{l}1.27 U \\
1.32 U \\
1.22 U \\
1.21 U \\
1.16 U \\
0.74 U\end{array}$ & $\begin{array}{l}1.24 \mathrm{U} \\
1.29 \mathrm{U} \\
1.19 \mathrm{U} \\
1.18 \mathrm{U} \\
1.13 \mathrm{U} \\
0.72 \mathrm{U}\end{array}$ & $\begin{array}{l}0.38 \mathrm{~J} \\
0.51 \mathrm{~J} \\
0.38 \mathrm{~J} \\
0.56 \mathrm{~J} \\
0.38 \mathrm{~J} \\
0.78 \mathrm{U}\end{array}$ & $\begin{array}{l}1.35 U \\
1.39 U \\
1.29 U \\
1.28 U \\
1.23 U \\
0.78 U\end{array}$ \\
\hline $\begin{array}{l}19 \\
18 \\
18 \\
19 \\
17\end{array}$ & $\begin{array}{l}0.86 \mathrm{U} \\
0.81 \mathrm{U} \\
0.41 \mathrm{~J} \\
0.80 \mathrm{U} \\
0.48 \mathrm{U}\end{array}$ & $\begin{array}{l}1.27 \mathrm{U} \\
1.19 \mathrm{U} \\
1.07 \mathrm{U} \\
1.18 \mathrm{U} \\
0.71 \mathrm{U}\end{array}$ & $\begin{array}{l}1.15 \mathrm{U} \\
0.10 \mathrm{~J} \\
0.20 \mathrm{~J} \\
1.07 \mathrm{U} \\
0.65 \mathrm{U}\end{array}$ & $\begin{array}{l}1.15 U \\
1.08 \mathrm{U} \\
0.97 \mathrm{U} \\
1.07 \mathrm{U} \\
0.65 \mathrm{U}\end{array}$ & $\begin{array}{l}1.31 \mathrm{U} \\
1.23 \mathrm{U} \\
1.10 \mathrm{U} \\
1.22 \mathrm{U} \\
0.74 \mathrm{U}\end{array}$ & $\begin{array}{l}1.31 \mathrm{U} \\
1.23 \mathrm{U} \\
1.10 \mathrm{U} \\
1.22 \mathrm{U} \\
0.74 \mathrm{U}\end{array}$ & $\begin{array}{l}1.28 \mathrm{U} \\
1.20 \mathrm{U} \\
1.08 \mathrm{U} \\
1.19 \mathrm{U} \\
0.72 \mathrm{U}\end{array}$ & $\begin{array}{l}1.38 \mathrm{U} \\
0.20 \mathrm{~J} \\
0.45 \mathrm{~J} \\
1.29 \mathrm{U} \\
0.78 \mathrm{U}\end{array}$ & $\begin{array}{l}1.38 \mathrm{U} \\
1.30 \mathrm{U} \\
1.17 \mathrm{U} \\
1.29 \mathrm{U} \\
0.78 \mathrm{U}\end{array}$ \\
\hline $\begin{array}{l}19 \\
19 \\
19 \\
19 \\
17\end{array}$ & $\begin{array}{l}0.79 \mathrm{U} \\
0.77 \mathrm{U} \\
0.81 \mathrm{U} \\
0.79 \mathrm{U} \\
0.48 \mathrm{U}\end{array}$ & $\begin{array}{l}1.17 U \\
1.14 U \\
1.19 U \\
1.17 U \\
0.71 U\end{array}$ & $\begin{array}{l}1.06 \mathrm{U} \\
1.03 \mathrm{U} \\
1.08 \mathrm{U} \\
1.06 \mathrm{U} \\
0.65 \mathrm{U}\end{array}$ & $\begin{array}{l}1.06 \mathrm{U} \\
1.03 \mathrm{U} \\
1.08 \mathrm{U} \\
1.06 \mathrm{U} \\
0.65 \mathrm{U}\end{array}$ & $\begin{array}{l}1.21 \mathrm{U} \\
1.18 \mathrm{U} \\
1.23 \mathrm{U} \\
1.21 \mathrm{U} \\
0.74 \mathrm{U}\end{array}$ & $\begin{array}{l}1.21 \mathrm{U} \\
1.18 \mathrm{U} \\
1.23 \mathrm{U} \\
1.21 \mathrm{U} \\
0.74 \mathrm{U}\end{array}$ & $\begin{array}{l}1.18 U \\
1.15 U \\
1.20 U \\
1.18 U \\
0.72 U\end{array}$ & $\begin{array}{l}0.20 \mathrm{~J} \\
0.28 \mathrm{~J} \\
1.30 \mathrm{U} \\
0.53 \mathrm{~J} \\
0.78 \mathrm{U}\end{array}$ & $\begin{array}{l}1.28 U \\
1.24 U \\
1.30 U \\
0.25 \mathrm{~J} \\
0.78 \mathrm{U}\end{array}$ \\
\hline
\end{tabular}


TABLE C.6. (contd)

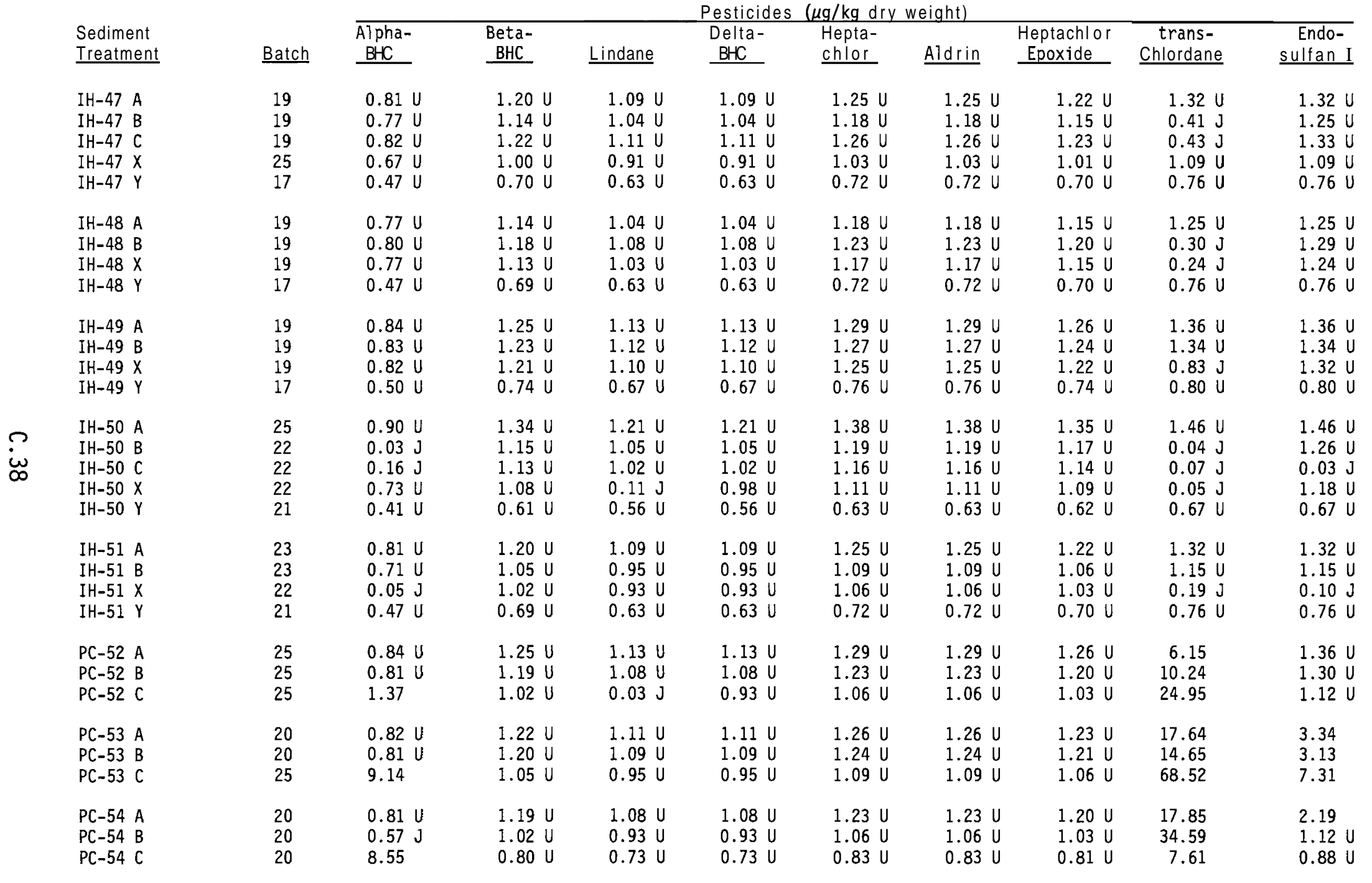


TABLE C.6. (contd)

Sediment

Treatment

SFC Marina

FSFC Edge-West

Parr Canal Edge

IHC Edge-East

IHC Edge-West

Outer Harbor Edge

Comp LC

Comp LC-1

Comp LC-2

Comp LC-3

Comp LC-4

Comp LC-5

Comp LC-6

Comp USFC

Comp FSFC

Comp IHC-1

๘ $\quad$ Comp IHC-2

Comp G

C-SFBF
C-SFBC

\section{Batch}

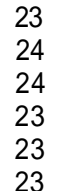

23
24
24
23
23
23

23

8
6

3

4

23
24

24
23

23
23
23

23

23

21
21

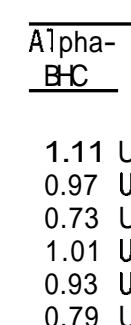

$382.60 \mathrm{U}$

$97.33 \mathrm{U}$

$654.08 \mathrm{U}$

$163.04 \mathrm{U}$

$77.06 \mathrm{U}$

$739.86 \mathrm{U}$

$742.88 \mathrm{U}$

$0.81 \mathrm{U}$

$0.51 \mathrm{~J}$

$0.82 \mathrm{U}$

$0.87 \mathrm{U}$

$0.73 \mathrm{U}$

$0.27 \mathrm{~J}$

$0.68 \mathrm{U}$

$0.45 \mathrm{U}$

Beta-

BHC

$1.65 \mathrm{U}$

$1.44 \mathrm{U}$
$1.09 \mathrm{U}$

$1.09 \mathrm{U}$

$1.37 \mathrm{U}$

$1.17 \mathrm{U}$

$565.69 \mathrm{U}$

$143.91 \mathrm{U}$

$445.62 \mathrm{U}$
$241.07 \mathrm{U}$

$113.93 \mathrm{U}$

$1093.92 \mathrm{U}$

$1098.37 \mathrm{U}$

$1.20 \mathrm{U}$
$1.08 \mathrm{U}$

$1.21 \mathrm{U}$

$1.28 \mathrm{U}$

$1.08 \mathrm{U}$

$1.29 \mathrm{U}$

$1.00 \mathrm{U}$

$0.66 \mathrm{U}$
Pesticide

Delta- Hepta-

$0.37 \mathrm{~J}$

$1.31 \mathrm{U}$

$0.99 \mathrm{U}$

$1.35 \mathrm{U}$

$1.25 \mathrm{U}$

$1.06 \mathrm{U}$

$513.98 \mathrm{U}$ $130.76 \mathrm{U}$

$2222.05 \mathrm{U}$

$219.03 \mathrm{U}$

$993.92 \mathrm{U}$

$997.96 \mathrm{U}$

$1.09 \mathrm{U}$
$0.98 \mathrm{U}$

$0.98 \mathrm{U}$
$1.10 \mathrm{U}$

$1.16 \mathrm{U}$

$0.98 \mathrm{U}$

$1.17 \mathrm{U}$

$0.91 \mathrm{U}$

$0.60 \mathrm{U}$
$\mathrm{BHC}$

$1.50 \mathrm{U}$

$1.31 \mathrm{U}$

$0.99 \mathrm{U}$

$1.35 \mathrm{U}$

$1.25 U$

\section{$513.98 \mathrm{U}$}

$130.76 \mathrm{U}$

$2222.05 \mathrm{U}$
$219.03 \mathrm{U}$

$103.52 \mathrm{U}$

$993.92 \mathrm{U}$

$997.96 \mathrm{U}$

$1.09 \mathrm{U}$

$1.09 \mathrm{~J}$
$0.37 \mathrm{~J}$

$1.10 \mathrm{U}$

$1.16 \mathrm{U}$

$0.98 U$

$1.17 \mathrm{U}$

$0.91 \mathrm{U}$

$0.60 \mathrm{U}$
Hepta-

$1.70 \mathrm{U}$

$1.49 \mathrm{U}$

$1.12 \mathrm{U}$

$1.54 \mathrm{U}$

$1.42 \mathrm{U}$

$1.21 \mathrm{U}$

$585.26 \mathrm{U}$

$148.89 \mathrm{U}$

$2530.21 \mathrm{U}$

$249.40 \mathrm{U}$

$117.87 \mathrm{U}$

$1131.76 \mathrm{U}$

$1136.36 \mathrm{U}$

$1.25 \mathrm{U}$

$1.25 \mathrm{U}$
$1.12 \mathrm{U}$

$1.25 \mathrm{U}$

$1.33 \mathrm{U}$

$1.11 \mathrm{U}$

$1.34 \mathrm{U}$

$1.03 \mathrm{U}$

$0.68 \mathrm{U}$

Ald rin

$1.70 \mathrm{U}$
$1.49 \mathrm{U}$
$1.12 \mathrm{U}$
$1.54 \mathrm{U}$
$1.42 \mathrm{U}$
$1.21 \mathrm{U}$

$585.26 \mathrm{U}$

$148.89 \mathrm{U}$

$2530.21 \mathrm{U}$

$249.40 \mathrm{U}$

$117.87 \mathrm{U}$
$151.84 \mathrm{~J}$

$1136.36 \mathrm{U}$

$1.25 \mathrm{U}$

$1.25 U$
$1.12 \mathrm{U}$

$1.25 \mathrm{U}$

$1.33 \mathrm{U}$

$1.11 \mathrm{U}$

$1.34 \mathrm{U}$

$1.03 \mathrm{U}$

$0.68 \mathrm{U}$

0.68

D Detection limit; detection limits are elevated in some batches because of sample dilutions.

(b) U Analyte was not present above the associated value.

(c) J Analyted detected below method detection limit (MDL), but above instrument detection Iimit (IDL).

Heptachlor trans- Endo-

\section{$1.66 \mathrm{U}$}

$1.45 \mathrm{U}$

$1.10 \mathrm{U}$

$1.50 \mathrm{U}$

$1.39 \mathrm{U}$

$1.18 \mathrm{U}$

$571.28 \mathrm{U}$

$145.33 \mathrm{U}$

$2469.79 \mathrm{U}$
$243.45 \mathrm{U}$

$115.06 \mathrm{U}$

$1104.73 \mathrm{U}$

$109.23 \mathrm{U}$

$1.22 \mathrm{U}$

$1.22 \mathrm{U}$

$1.29 \mathrm{U}$

$1.09 \mathrm{U}$

$1.30 \mathrm{U}$

$1.01 \mathrm{U}$

$0.67 \mathrm{U}$

$1.09 \mathrm{U}$
$0.72 \mathrm{U}$

$1.57 \mathrm{U}$

$1.19 \mathrm{U}$

$1.50 \mathrm{U}$

$1.28 \mathrm{U}$

$618.45 \mathrm{U}$

$49.41 \mathrm{~J}$

$2673.72 \mathrm{U}$

263.55
124.56

$1195.95 \mathrm{U}$

$200.81 \mathrm{U}$

$1.32 \mathrm{U}$

$0.73 \mathrm{~J}$
$1.32 \mathrm{U}$

$1.40 \mathrm{U}$

$1.18 \mathrm{U}$

$1.80 \mathrm{U}$

$1.57 \mathrm{~V}$

$1.19 \mathrm{U}$

$0.65 \mathrm{~J}$

$1.28 \mathrm{U}$

$618.45 \mathrm{U}$

$157.33 \mathrm{U}$

$2673.72 \mathrm{U}$

$263.55 \mathrm{U}$

$124.56 \mathrm{U}$
$1195.95 \mathrm{U}$

$1200.81 \mathrm{U}$

$1.32 \mathrm{U}$

$1.18 \mathrm{U}$

$1.32 \mathrm{U}$

$1.40 \mathrm{U}$

$1.18 \mathrm{U}$

$1.41 \mathrm{U}$

$1.09 \mathrm{U}$

$0.72 \mathrm{U}$ 
TABLE C.7. Chlorinated Pesticides (elution order, cis-Chlordane to Toxaphene) in Younger Bay Mud from Selected Cores and Sediment Composites, United Heckathorn Remedial Investigation

\begin{tabular}{|c|c|c|c|c|c|c|c|c|c|c|c|c|}
\hline \multirow{2}{*}{\multicolumn{2}{|c|}{$\begin{array}{l}\text { Sediment } \\
\text { Treatment } \\
\end{array}$}} & \multicolumn{10}{|c|}{ Pesticides $(\mu \mathrm{g} / \mathrm{kg}$ dry weight) } & \multirow[b]{2}{*}{ Toxaphene } \\
\hline & & Batch & $\begin{array}{c}\text { cis- } \\
\text { Chlordane }\end{array}$ & Dieldrin & $4,4^{\prime}-\mathrm{DDE}$ & Endrin & $\begin{array}{c}\text { Endo- } \\
\text { sulfan II } \\
\end{array}$ & $4,4^{\prime}-D D D$ & $\begin{array}{c}\text { Endrin } \\
\text { Aldehyde } \\
\end{array}$ & $\begin{array}{c}\begin{array}{c}\text { Endosul fan } \\
\text { Sulfate }\end{array} \\
\end{array}$ & 4.4'-DDT & \\
\hline $\begin{array}{l}\text { Targe } \\
\text { Achie } \\
\text { Achie }\end{array}$ & $\begin{array}{l}\text { DL } \\
\text { ved } D L \text { High } \\
\text { ved } D L \text { Low }\end{array}$ & & $\begin{array}{r}2 \\
590.84 \\
0.60\end{array}$ & $\begin{array}{r}2 \\
590.84 \\
0.60\end{array}$ & $\begin{array}{r}2 \\
598.66 \\
0.61\end{array}$ & $\begin{array}{r}2 \\
685.03 \\
0.69\end{array}$ & $\begin{array}{r}2 \\
602.38 \\
0.61\end{array}$ & $\begin{array}{r}2 \\
745.72 \\
0.76\end{array}$ & $\begin{array}{r}2 \\
653.76 \\
0.66\end{array}$ & $\begin{array}{r}2 \\
568.88 \\
0.58\end{array}$ & $\begin{array}{r}2 \\
642.96 \\
0.65\end{array}$ & $\begin{array}{c}30 \\
20750.19 \\
21.04\end{array}$ \\
\hline $\begin{array}{l}\text { LZ-1 } \\
\text { LZ-1 } \\
\text { LZ-1 } \\
\text { LZ-1 } \\
\text { LZ-1 } \\
\text { LZ-1 }\end{array}$ & $\begin{array}{l}A \\
B \\
C \\
D \\
X \\
Y\end{array}$ & $\begin{array}{r}3 \\
3 \\
3 \\
3 \\
3 \\
21\end{array}$ & $\begin{array}{r}539.80 \mathrm{U}^{(\mathrm{b}} \\
314.26 \mathrm{U} \\
6731.71 \mathrm{U} \\
2509.09 \mathrm{U} \\
98.88 \mathrm{U} \\
0.12 \mathrm{~J}\end{array}$ & $\begin{array}{r}401.65 \mathrm{~J}(\mathrm{c} \\
205.94 \mathrm{~J} \\
10304.57 \\
723.37 \mathrm{~J} \\
25.92 \mathrm{~J} \\
1.50\end{array}$ & $\begin{array}{c}2865.23 \\
4855.60 \\
7915.53 \\
1441.28 \mathrm{~J} \\
15.44 \mathrm{~J} \\
1.71\end{array}$ & $\begin{array}{r}625.85 U \\
364.36 U \\
7804.88 U \\
2909.09 U \\
114.64 \\
0.80 U\end{array}$ & 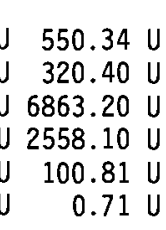 & $\begin{array}{r}11228.33 \\
363.48 \mathrm{~J} \\
322304.49 \\
136929.91 \\
487.21 \\
140.22\end{array}$ & $\begin{array}{r}597.28 U \\
347.72 U \\
7448.57 U \\
2776.28 U \\
109.41 U \\
0.77 \mathrm{U}\end{array}$ & $\begin{array}{r}519.73 \mathrm{U} \\
302.57 \mathrm{U} \\
6481.44 \mathrm{U} \\
2415.81 \mathrm{U} \\
95.20 \mathrm{U} \\
0.67 \mathrm{U}\end{array}$ & $\begin{array}{r}13843.61 \\
595.70 \\
30541.48 \\
700.53 \mathrm{~J} \\
41.32 \mathrm{~J} \\
1.77\end{array}$ & $\begin{array}{r}18957.48 \\
11036.63 \\
236415.69 \\
88118.58 \\
3472.59 \\
24.29\end{array}$ \\
\hline $\begin{array}{l}\text { LZ-2 } \\
\text { LZ-2 } \\
\text { LZ-2 } \\
\text { LZ-2 } \\
\text { LZ-2 }\end{array}$ & $\begin{array}{l}A \\
B \\
C \\
X \\
Y\end{array}$ & $\begin{array}{r}4 \\
4 \\
4 \\
4 \\
21\end{array}$ & $\begin{array}{r}1065.10 \mathrm{U} \\
2150.41 \mathrm{U} \\
4674.52 \mathrm{U} \\
998.11 \mathrm{U} \\
0.34 \mathrm{~J}\end{array}$ & $\begin{array}{r}311.02 \mathrm{~J} \\
685.75 \mathrm{~J} \\
4344.56 \mathrm{~J} \\
439.81 \mathrm{~J} \\
12.43\end{array}$ & $\begin{array}{r}462.14 \mathrm{~J} \\
989.25 \mathrm{~J} \\
3656.61 \mathrm{~J} \\
345.82 \mathrm{~J} \\
10.54\end{array}$ & $\begin{array}{c}1234.90 \\
2493.22 \\
5419.73 \\
1157.23 \\
0.77\end{array}$ & 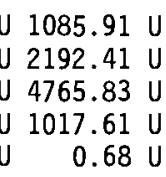 & $\begin{array}{r}11414.95 \\
21516.06 \\
212115.89 \\
103190.29 \\
776.60\end{array}$ & $\begin{array}{r}1178.52 \mathrm{U} \\
2379.40 \mathrm{U} \\
5172.31 \mathrm{U} \\
1104.40 \mathrm{U} \\
0.74 \mathrm{U}\end{array}$ & $\begin{array}{r}1025.50 \mathrm{U} \\
2070.46 \mathrm{U} \\
4500.74 \mathrm{U} \\
961.01 \mathrm{U} \\
0.64 \mathrm{U}\end{array}$ & $\begin{array}{r}43298.77 \\
111047.83 \\
45332.96 \\
6827.19 \\
188.34\end{array}$ & $\begin{array}{r}37406.04 \\
75521.68 \\
164167.89 \\
35053.46 \\
23.40\end{array}$ \\
\hline $\begin{array}{l}\text { LZ-3 } \\
\text { LZ-3 } \\
\text { LZ-3 } \\
\text { LZ-3 }\end{array}$ & $\begin{array}{l}A \\
B \\
X \\
Y\end{array}$ & $\begin{array}{r}4 \\
4 \\
4 \\
21\end{array}$ & $\begin{array}{r}1210.53 \mathrm{U} \\
2515.06 \mathrm{U} \\
457.09 \mathrm{U} \\
0.13 \mathrm{~J}\end{array}$ & $\begin{array}{c}882.34 \mathrm{~J} \\
2271.21 \mathrm{~J} \\
519.38 \\
3.69\end{array}$ & $\begin{array}{r}826.31 \mathrm{~J} \\
2366.27 \mathrm{~J} \\
165.91 \mathrm{~J} \\
2.20\end{array}$ & $\begin{array}{r}1403.51 \\
2916.01 \\
529.95 \\
0.12\end{array}$ & 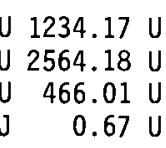 & $\begin{array}{r}29781.44 \\
112717.87 \\
17054.30 \\
189.28\end{array}$ & $\begin{array}{r}1339.44 \mathrm{U} \\
2782.88 \mathrm{U} \\
505.76 \mathrm{U} \\
0.73 \mathrm{U}\end{array}$ & $\begin{array}{r}1165.52 U \\
2421.55 \mathrm{U} \\
440.09 \mathrm{U} \\
0.64 \mathrm{U}\end{array}$ & $\begin{array}{r}41784.21 \\
38901.66 \\
2323.78 \\
60.93\end{array}$ & $\begin{array}{r}42513.35 \\
88328.05 \\
16052.71 \\
23.19\end{array}$ \\
\hline $\begin{array}{l}\text { LZ-5 } \\
\text { LZ-5 }\end{array}$ & $\begin{array}{l}A \\
Y\end{array}$ & $\begin{array}{r}6 \\
21\end{array}$ & $\begin{array}{r}473.73 \mathrm{U} \\
0.19 \mathrm{~J}\end{array}$ & $\begin{array}{c}467.28 \mathrm{~J} \\
17.09\end{array}$ & $\begin{array}{c}378.69 \mathrm{~J} \\
10.23\end{array}$ & $\begin{array}{r}549.25 \mathrm{~L} \\
0.77 \mathrm{I}\end{array}$ & $\begin{array}{rr}U & 482.99 U \\
U & 0.68 U\end{array}$ & $\begin{array}{r}14791.94 \\
445.10\end{array}$ & $\begin{array}{r}524.18 \mathrm{U} \\
0.74 \mathrm{U}\end{array}$ & $\begin{array}{r}456.12 \mathrm{U} \\
0.64 \mathrm{U}\end{array}$ & $\begin{array}{r}29641.09 \\
476.54\end{array}$ & $\begin{array}{r}16637.31 \\
23.41\end{array}$ \\
\hline $\begin{array}{l}\text { LZ-6 } \\
\text { LZ-6 } \\
\text { LZ-6 } \\
\text { LZ-6 } \\
\text { LZ-6 }\end{array}$ & $\begin{array}{l}A \\
B \\
C \\
X \\
Y\end{array}$ & $\begin{array}{r}6 \\
6 \\
6 \\
6 \\
21\end{array}$ & $\begin{array}{r}1631.04 \mathrm{U} \\
3646.18 \mathrm{U} \\
475.72 \mathrm{U} \\
143.49 \mathrm{U} \\
0.03 \mathrm{~J}\end{array}$ & $\begin{array}{r}930.71 \mathrm{~J} \\
1894.04 \mathrm{~J} \\
155.14 \mathrm{~J} \\
41.59 \mathrm{~J} \\
0.98\end{array}$ & $\begin{array}{r}842.97 \mathrm{~J} \\
2573.81 \mathrm{~J} \\
447.25 \mathrm{~J} \\
16.34 \mathrm{~J} \\
0.73\end{array}$ & $\begin{array}{r}1891.06 \\
4227.46 \\
551.56 \\
166.37 \\
0.71\end{array}$ & 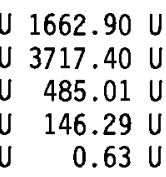 & $\begin{array}{r}17825.73 \\
113865.44 \\
33972.04 \\
670.27 \\
54.78\end{array}$ & $\begin{array}{r}1804.73 \mathrm{U} \\
4034.46 \mathrm{U} \\
526.38 \mathrm{U} \\
158.77 \mathrm{U} \\
0.68 \mathrm{U}\end{array}$ & $\begin{array}{r}1570.40 \mathrm{U} \\
3510.63 \mathrm{U} \\
458.03 \mathrm{U} \\
138.16 \mathrm{U} \\
0.59 \mathrm{U}\end{array}$ & $\begin{array}{r}92956.22 \\
161331.74 \\
12496.97 \\
141.28 \mathrm{~J} \\
37.33\end{array}$ & $\begin{array}{r}57281.60 \\
128052.84 \\
16707.13 \\
5039.33 \\
21.54\end{array}$ \\
\hline $\begin{array}{l}\text { LZ-7 } \\
\text { LZ-7 } \\
\text { LZ-7 } \\
\text { LZ-7 } \\
\text { LZ-7 }\end{array}$ & $\begin{array}{l}A \\
B \\
C \\
X \\
Y\end{array}$ & $\begin{array}{r}6 \\
6 \\
6 \\
6 \\
21\end{array}$ & $\begin{array}{r}1100.55 \mathrm{U} \\
5908.41 \mathrm{U} \\
1013.41 \mathrm{U} \\
7.93 \mathrm{U} \\
0.64 \mathrm{U}\end{array}$ & $\begin{array}{r}1311.68 \\
15971.27 \\
1475.77 \\
6.63 \mathrm{~J} \\
0.45 \mathrm{~J}\end{array}$ & $\begin{array}{r}857.32 \mathrm{~J} \\
6274.29 \\
739.18 \mathrm{~J} \\
2.42 \mathrm{~J} \\
0.19 \mathrm{~J}\end{array}$ & $\begin{array}{r}1276.01 \\
6850.34 \\
1174.97 \mathrm{l} \\
9.19 \\
0.74\end{array}$ & 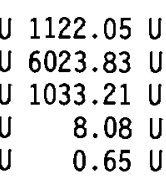 & $\begin{array}{r}37505.99 \\
292520.38 \\
68456.14 \\
101.19 \\
9.73\end{array}$ & $\begin{array}{r}1217.75 \mathrm{U} \\
6537.60 \mathrm{U} \\
1121.33 \mathrm{U} \\
8.77 \mathrm{U} \\
0.71 \mathrm{U}\end{array}$ & $\begin{array}{r}1059.64 \mathrm{U} \\
5688.76 \mathrm{U} \\
975.73 \mathrm{U} \\
7.63 \mathrm{U} \\
0.61 \mathrm{U}\end{array}$ & $\begin{array}{r}38600.63 \\
334563.58 \\
48493.85 \\
69.40 \\
1.85\end{array}$ & $\begin{array}{r}38651.18 \\
207501.86 \\
35590.68 \\
278.40 \\
22.41\end{array}$ \\
\hline
\end{tabular}


TABLE C.7. (contd)

Sediment Treatment

LZ-8 A

$L Z-8 \quad B$

$L Z-8 \quad C$

LZ -8 D

LZ-8

LZ-8 F

$17-8 \quad G$

$17-8 \quad x$

LZ-8 Y

LZ-9 A

LZ-9 $X$

LZ-9 Y

LZ-10 A

$L Z-10$

ᄂ LZ-10X

$? \quad$ LZ-10Y

LZ-11 A

LZ $-11 X$

LZ-11 $Y$

$\mathrm{LZ}-12 \mathrm{~A}$
$\mathrm{~L}-12 \mathrm{X}$

z $-12 x$

LZ-13 A

LZ-13 B

LZ-13 C

LZ $-13 x$

LZ-13 Y

LZ-14 A

$L Z-14 X$

LZ-14 Y

L7-15 A

LZ -15 B

LZ- $15 X$

LZ-15 Y

Pesticides $(\mu \mathrm{g} / \mathrm{kg}$ dry weight)

\begin{tabular}{|c|c|c|c|c|c|c|c|c|c|c|}
\hline atch & $\begin{array}{c}\text { cis- } \\
\text { Chlordane } \\
\end{array}$ & ieldrin & $\underline{4,4^{\prime}-D D E}$ & Endrin & $\begin{array}{c}\text { Endo- } \\
\text { sulfan II }\end{array}$ & $4,4^{\prime}-D D D$ & $\begin{array}{c}\text { Endrin } \\
\text { Aldehyde }\end{array}$ & $\begin{array}{c}\text { Endosul fan } \\
\text { Sulfate }\end{array}$ & $4,4^{\prime}-$ DDT & Toxaphene \\
\hline $\begin{array}{r}7 \\
7 \\
7 \\
7 \\
7 \\
7 \\
7 \\
7 \\
21\end{array}$ & $\begin{array}{r}990.02 \mathrm{U} \\
2983.08 \mathrm{U} \\
2088.16 \mathrm{U} \\
1168.63 \mathrm{U} \\
1010.83 \mathrm{U} \\
4033.04 \mathrm{U} \\
96.95 \mathrm{U} \\
70.82 \mathrm{U} \\
0.67 \mathrm{U}\end{array}$ & $\begin{array}{r}409.19 \mathrm{~J} \\
2344.70 \mathrm{~J} \\
1576.51 \mathrm{~J} \\
778.95 \mathrm{~J} \\
435.71 \mathrm{~J} \\
6980.94 \\
28.61 \mathrm{~J} \\
7.96 \mathrm{~J} \\
0.04 \mathrm{~J}\end{array}$ & $\begin{array}{r}415.45 \mathrm{~J} \\
4511.69 \\
27663.04 \\
31498.99 \\
41767.87 \\
2275.90 \mathrm{~J} \\
24.66 \mathrm{~J} \\
10.88 \mathrm{~J} \\
0.68 \mathrm{U}\end{array}$ & $\begin{array}{r}1147.85 \\
3458.65 \\
2421.05 \\
1354.93 \\
1171.97 \\
4675.98 \\
112.40 \\
82.11 \\
0.77\end{array}$ & 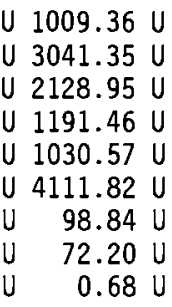 & $\begin{array}{r}8983.00 \\
101508.55 \\
50720.09 \\
13787.46 \\
5786.51 \\
143993.28 \\
873.30 \\
98.51 \\
0.67 \mathrm{~J}\end{array}$ & $\begin{array}{r}1095.45 \mathrm{U} \\
3300.75 \mathrm{U} \\
2310.53 \mathrm{U} \\
1293.08 \mathrm{U} \\
1118.47 \mathrm{U} \\
4462.52 \mathrm{U} \\
107.27 \mathrm{U} \\
78.36 \mathrm{U} \\
0.74 \mathrm{U}\end{array}$ & $\begin{array}{r}953.21 \mathrm{U} \\
2872.18 \mathrm{U} \\
2010.53 \mathrm{U} \\
1125.18 \mathrm{U} \\
973.25 \mathrm{U} \\
3883.10 \mathrm{U} \\
93.34 \mathrm{U} \\
68.18 \mathrm{U} \\
0.64 \mathrm{U}\end{array}$ & $\begin{array}{r}26511.54 \\
53736.21 \\
59262.41 \\
22355.96 \\
34123.38 \\
45252.16 \\
1029.47 \\
957.42 \\
0.73 \mathrm{U}\end{array}$ & $\begin{array}{r}34769.18 \mathrm{U} \\
104765.04 \mathrm{U} \\
73335.53 \mathrm{U} \\
41041.97 \mathrm{U} \\
35500.00 \mathrm{U} \\
141639.14 \mathrm{U} \\
3404.70 \mathrm{U} \\
2487.06 \mathrm{U} \\
23.41 \mathrm{U}\end{array}$ \\
\hline $\begin{array}{r}6 \\
7 \\
21\end{array}$ & $\begin{array}{r}560.78 \mathrm{U} \\
516.94 \mathrm{U} \\
0.39 \mathrm{~J}\end{array}$ & $\begin{array}{c}343.16 \mathrm{~J} \\
281.94 \mathrm{~J} \\
52.07\end{array}$ & $\begin{array}{c}356.27 \mathrm{~J} \\
219.06 \mathrm{~J} \\
36.81\end{array}$ & $\begin{array}{r}650.18 \\
599.35 \\
1.15\end{array}$ & $\begin{array}{r}571.73 \mathrm{U} \\
527.04 \mathrm{U} \\
0.65 \mathrm{U}\end{array}$ & & $\begin{array}{r}620.49 \mathrm{U} \\
571.99 \mathrm{U} \\
0.71 \mathrm{U}\end{array}$ & $\begin{array}{r}539.93 \mathrm{U} \\
497.72 \mathrm{U} \\
0.62 \mathrm{U}\end{array}$ & & $\begin{array}{r}19694.35 \\
18154.72 \\
22.45\end{array}$ \\
\hline $\begin{array}{r}8 \\
8 \\
9 \\
22\end{array}$ & $\begin{array}{r}121.24 \mathrm{U} \\
290.66 \mathrm{U} \\
2092.29 \mathrm{U} \\
0.01 \mathrm{~J}\end{array}$ & $\begin{array}{c}48.85 \mathrm{~J} \\
339.79 \\
530.10 \mathrm{~J} \\
0.94\end{array}$ & $\begin{array}{r}55.40 \mathrm{~J} \\
331.07 \\
1010.44 \mathrm{~J} \\
0.67 \mathrm{U}\end{array}$ & $\begin{array}{r}140.57 \\
337.00 \\
2425.84 \\
0.76\end{array}$ & 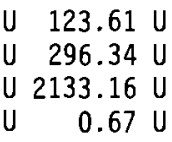 & $\begin{array}{r}1116.28 \\
12061.52 \\
30415.95 \\
6.36\end{array}$ & $\begin{array}{r}134.15 \mathrm{U} \\
321.61 \mathrm{U} \\
2315.10 \mathrm{U} \\
0.73 \mathrm{U}\end{array}$ & $\begin{array}{r}116.73 \mathrm{U} \\
279.85 \mathrm{U} \\
2014.50 \mathrm{U} \\
0.63 \mathrm{U}\end{array}$ & & $\begin{array}{r}4257.83 \\
10207.88 \\
73480.55 \\
23.13\end{array}$ \\
\hline $\begin{array}{r}7 \\
7 \\
21\end{array}$ & $\begin{array}{r}225.94 \mathrm{U} \\
3680.00 \mathrm{U} \\
0.62 \mathrm{U}\end{array}$ & $\begin{array}{c}124.92 \mathrm{~J} \\
246.89 \mathrm{~J} \\
38.90\end{array}$ & $\begin{array}{r}149.67 \mathrm{~J} \\
2399.22 \mathrm{~J} \\
15.99\end{array}$ & $\begin{array}{r}261.96 \\
4266.67 \\
0.31\end{array}$ & $\begin{array}{lr}U & 230.35 U \\
U & 3751.88 \mathrm{U} \\
\mathrm{J} & 0.63 \mathrm{U}\end{array}$ & $\begin{array}{r}5368.23 \\
06725.42 \\
559.06\end{array}$ & $\begin{array}{r}250.00 \mathrm{U} \\
4071.88 \mathrm{U} \\
0.68 \mathrm{U}\end{array}$ & $\begin{array}{r}217.54 \mathrm{U} \\
3543.19 \mathrm{U} \\
0.59 \mathrm{U}\end{array}$ & & $\begin{array}{r}7934.94 \\
129240.58 \\
21.64\end{array}$ \\
\hline $\begin{array}{r}9 \\
9 \\
22\end{array}$ & $\begin{array}{r}122.64 \mathrm{U} \\
124.86 \mathrm{U} \\
0.02 \mathrm{~J}\end{array}$ & $.65 \mathrm{~J}$ & $\begin{array}{c}62.04 \mathrm{~J} \\
59.84 \mathrm{~J} \\
0.73\end{array}$ & $\begin{array}{r}142.19 \\
144.77 \\
0.77\end{array}$ & $\begin{array}{r}125.04 \mathrm{U} \\
127.30 \mathrm{U} \\
0.67 \mathrm{U}\end{array}$ & & $\begin{array}{r}135.70 \mathrm{U} \\
138.16 \mathrm{U} \\
0.73 \mathrm{U}\end{array}$ & $\begin{array}{r}118.08 \mathrm{U} \\
120.22 \mathrm{U} \\
0.64 \mathrm{U}\end{array}$ & & $\begin{array}{r}307.19 U \\
385.13 U \\
23.20 U\end{array}$ \\
\hline $\begin{array}{r}9 \\
9 \\
9 \\
9 \\
22\end{array}$ & $\begin{array}{r}133.81 \mathrm{U} \\
87.87 \mathrm{U} \\
209.48 \mathrm{U} \\
224.28 \mathrm{U} \\
0.67 \mathrm{U}\end{array}$ & $\begin{array}{r}99.10 \mathrm{~J} \\
80.79 \mathrm{~J} \\
108.19 \mathrm{~J} \\
237.35 \\
0.67 \mathrm{U}\end{array}$ & $\begin{array}{r}177.46 \\
140.78 \\
233.24 \\
481.78 \\
0.68 \mathrm{U}\end{array}$ & $\begin{array}{r}155.14 \\
101.88 \\
242.87 \\
260.03 \\
0.78\end{array}$ & $\begin{array}{r}136.42 \mathrm{U} \\
89.59 \mathrm{U} \\
213.57 \mathrm{U} \\
228.66 \mathrm{U} \\
0.68 \mathrm{U}\end{array}$ & $\begin{array}{r}1430.44 \\
1402.63 \\
2298.08 \\
4793.95 \\
0.15 \mathrm{~J}\end{array}$ & $\begin{array}{r}148.06 \mathrm{U} \\
97.23 \mathrm{U} \\
231.78 \mathrm{U} \\
248.16 \mathrm{U} \\
0.74 \mathrm{U}\end{array}$ & $\begin{array}{r}128.84 \mathrm{U} \\
84.61 \mathrm{U} \\
201.69 \mathrm{U} \\
215.94 \mathrm{U} \\
0.65 \mathrm{U}\end{array}$ & $\begin{array}{r}1538.68 \\
472.40 \\
4781.08 \\
1915.71 \\
0.08 \mathrm{~J}\end{array}$ & $\begin{array}{l}9.41 U \\
6.10 U \\
6.78 U \\
6.63 U \\
3.56 U\end{array}$ \\
\hline $\begin{array}{r}7 \\
8 \\
22\end{array}$ & $\begin{array}{r}70.82 \mathrm{U} \\
6.83 \mathrm{U} \\
0.63 \mathrm{U}\end{array}$ & $\begin{array}{r}25.05 \mathrm{~J} \\
4.55 \mathrm{~J} \\
0.13 \mathrm{~J}\end{array}$ & $\begin{array}{c}25.34 \mathrm{~J} \\
8.16 \\
0.06 \mathrm{~J}\end{array}$ & $\begin{array}{r}82.11 \\
7.92 \\
0.73\end{array}$ & $\begin{array}{r}72.20 \mathrm{U} \\
6.96 \mathrm{U} \\
0.64 \mathrm{U}\end{array}$ & $\begin{array}{r}445.61 \\
110.30 \\
1.18\end{array}$ & $\begin{array}{r}78.36 \mathrm{U} \\
7.56 \mathrm{U} \\
0.70 \mathrm{U}\end{array}$ & $\begin{array}{r}68.18 \mathrm{U} \\
6.57 \mathrm{U} \\
0.60 \mathrm{U}\end{array}$ & $\begin{array}{r}187.93 \mathrm{U} \\
82.34 \\
0.26 \mathrm{~J}\end{array}$ & $\begin{array}{r}2487.06 U \\
239.82 U \\
22.06 U\end{array}$ \\
\hline $\begin{array}{r}9 \\
9 \\
9 \\
22\end{array}$ & $\begin{array}{r}64.88 \mathrm{U} \\
60.34 \mathrm{U} \\
112.39 \mathrm{U} \\
0.67 \mathrm{U}\end{array}$ & $\begin{array}{r}31.90 \mathrm{~J} \\
31.30 \mathrm{~J} \\
42.62 \mathrm{~J} \\
0.40 \mathrm{~J}\end{array}$ & $\begin{array}{r}45.35 \mathrm{~J} \\
54.73 \mathrm{~J} \\
60.60 \mathrm{~J} \\
0.37 \mathrm{~J}\end{array}$ & $\begin{array}{r}75.22 \\
69.96 \\
130.31 \\
0.77\end{array}$ & $\begin{array}{r}66.15 \mathrm{U} \\
61.52 \mathrm{U} \\
114.59 \mathrm{U} \\
0.68 \mathrm{U}\end{array}$ & $\begin{array}{r}711.72 \\
683.41 \\
883.31 \\
9.24\end{array}$ & $\begin{array}{r}71.79 U \\
66.77 U \\
124.36 U \\
0.74 U\end{array}$ & $\begin{array}{r}62.47 \mathrm{U} \\
58.10 \mathrm{U} \\
108.22 \mathrm{U} \\
0.64 \mathrm{U}\end{array}$ & $\begin{array}{r}414.80 \\
641.43 \\
1460.35 \\
8.99\end{array}$ & $\begin{array}{r}2278.62 \\
2119.20 \\
3947.24 \\
23.37\end{array}$ \\
\hline
\end{tabular}


TABLE C.7. (contd)

Pesticides $(\mu \mathrm{g} / \mathrm{kg}$ dry weight)

\begin{tabular}{|c|c|c|c|c|c|c|c|c|c|c|c|}
\hline \multirow{2}{*}{$\begin{array}{l}\text { Sediment } \\
\text { Treatment }\end{array}$} & \multirow[b]{2}{*}{ Batch } & \multicolumn{9}{|c|}{ Pesticides $(\mu \mathrm{g} / \mathrm{kg}$ dry weight) } & \multirow[b]{2}{*}{ Toxaphene } \\
\hline & & $\begin{array}{c}\text { cis- } \\
\text { Chlordane } \\
\end{array}$ & Dieldrin & $\underline{4,4^{\prime}-D D E}$ & Endrin & $\begin{array}{l}\text { Endo- } \\
\text { sulfan II } \\
\end{array}$ & 4.4'-DDD & $\begin{array}{c}\text { Endrin } \\
\text { Aldehyde } \\
\end{array}$ & $\begin{array}{c}\begin{array}{c}\text { Endosulfan } \\
\text { Sulfate }\end{array} \\
\end{array}$ & $\underline{4,4^{\prime}-\mathrm{DDT}}$ & \\
\hline $\begin{array}{ll}\text { LZ-16 } & A \\
\text { LZ-16 } & B \\
\text { LZ-16 } & C \\
\text { LZ-16 } & D \\
\text { LZ-16 } & X \\
\text { LZ-16 } & Y\end{array}$ & $\begin{array}{r}8 \\
9 \\
9 \\
9 \\
8 \\
22\end{array}$ & $\begin{array}{r}13.23 \mathrm{U} \\
106.87 \mathrm{U} \\
18.50 \mathrm{~J} \\
72.50 \mathrm{U} \\
7.21 \mathrm{U} \\
0.65 \mathrm{U}\end{array}$ & $\begin{array}{r}7.47 \mathrm{~J} \\
74.90 \mathrm{~J} \\
164.25 \\
39.98 \mathrm{~J} \\
34.63 \\
0.04 \mathrm{~J}\end{array}$ & $\begin{array}{r}22.62 \\
139.81 \\
266.24 \\
75.19 \\
96.94 \\
0.09 \mathrm{~J}\end{array}$ & $\begin{array}{r}15.33 \mathrm{U} \\
123.91 \mathrm{U} \\
116.53 \\
84.06 \mathrm{U} \\
8.36 \mathrm{U} \\
0.76 \mathrm{U}\end{array}$ & $\begin{array}{r}13.48 \mathrm{U} \\
108.96 \mathrm{U} \\
93.15 \mathrm{U} \\
73.92 \mathrm{U} \\
7.35 \mathrm{U} \\
0.66 \mathrm{U}\end{array}$ & $\begin{array}{r}276.92 \\
946.84 \\
2598.46 \\
690.96 \\
627.30 \\
0.69 \mathrm{~J}\end{array}$ & $\begin{array}{r}14.63 \mathrm{U} \\
118.25 \mathrm{U} \\
101.09 \mathrm{U} \\
80.22 \mathrm{U} \\
7.98 \mathrm{U} \\
0.72 \mathrm{U}\end{array}$ & $\begin{array}{r}12.73 \mathrm{U} \\
102.90 \mathrm{U} \\
87.97 \mathrm{U} \\
69.80 \mathrm{U} \\
6.94 \mathrm{U} \\
0.63 \mathrm{U}\end{array}$ & $\begin{array}{r}169.60 \\
167.08 \\
1574.53 \\
646.93 \\
163.49 \\
0.39 \mathrm{~J}\end{array}$ & $\begin{array}{r}464.46 \mathrm{U} \\
3753.20 \mathrm{U} \\
3208.69 \mathrm{U} \\
2546.14 \mathrm{U} \\
253.23 \mathrm{U} \\
22.89 \mathrm{U}\end{array}$ \\
\hline $\begin{array}{l}S F-18 \text { A } \\
\text { SF-18 } \\
\text { SF-18 } \\
\text { SF-18 } \\
Y\end{array}$ & $\begin{array}{l}11 \\
11 \\
11 \\
11\end{array}$ & $\begin{array}{l}0.61 \mathrm{~J} \\
0.85 \mathrm{~J} \\
0.50 \mathrm{~J} \\
0.73 \mathrm{U}\end{array}$ & $\begin{array}{r}7.90 \\
12.36 \\
4.66 \\
0.73 \mathrm{U}\end{array}$ & $\begin{array}{r}21.16 \\
18.14 \\
10.56 \\
0.03 \mathrm{~J}\end{array}$ & $\begin{array}{ll}0.12 \mathrm{~J} \\
0.22 \mathrm{~J} \\
0.21 \mathrm{~J} \\
0.84 \mathrm{U}\end{array}$ & $\begin{array}{l}1.24 \mathrm{U} \\
1.24 \mathrm{U} \\
1.16 \mathrm{U} \\
0.74 \mathrm{U}\end{array}$ & $\begin{array}{r}109.78 \\
135.47 \\
78.94 \\
0.92 \mathrm{U}\end{array}$ & $\begin{array}{l}1.34 \mathrm{U} \\
1.35 \mathrm{U} \\
1.25 \mathrm{U} \\
0.80 \mathrm{U}\end{array}$ & $\begin{array}{l}1.17 \mathrm{U} \\
1.18 \mathrm{U} \\
1.09 \mathrm{U} \\
0.70 \mathrm{U}\end{array}$ & $\begin{array}{r}86.21 \\
19.28 \mathrm{U} \\
2.97 \mathrm{U} \\
0.79 \mathrm{U}\end{array}$ & $\begin{array}{l}42.55 \cup \\
42.87 \mathrm{U} \\
39.81 \mathrm{U} \\
25.48 \mathrm{U}\end{array}$ \\
\hline $\begin{array}{l}S F-19 A \\
S F-19 X \\
S F-19 Y\end{array}$ & $\begin{array}{l}11 \\
11 \\
11\end{array}$ & $\begin{array}{l}0.45 \mathrm{~J} \\
0.48 \mathrm{~J} \\
0.69 \mathrm{U}\end{array}$ & $\begin{array}{l}3.90 \\
7.22 \\
0.69 U\end{array}$ & $\begin{array}{c}10.37 \\
22.80 \\
0.70 \mathrm{U}\end{array}$ & $\begin{array}{l}0.12 \mathrm{~J} \\
0.17 \mathrm{~J} \\
0.80 \mathrm{U}\end{array}$ & $\begin{array}{l}1.28 \mathrm{U} \\
1.21 \mathrm{U} \\
0.71 \mathrm{U}\end{array}$ & $\begin{array}{r}112.35 \\
94.90 \\
0.87 \mathrm{U}\end{array}$ & $\begin{array}{l}1.38 \mathrm{U} \\
1.32 \mathrm{U} \\
0.77 \mathrm{U}\end{array}$ & $\begin{array}{l}1.20 \mathrm{U} \\
1.15 \mathrm{U} \\
0.67 \mathrm{U}\end{array}$ & $\begin{array}{r}12.68 \mathrm{U} \\
16.16 \mathrm{U} \\
0.75 \mathrm{U}\end{array}$ & $\begin{array}{l}43.92 \mathrm{U} \\
41.81 \mathrm{U} \\
24.30 \mathrm{U}\end{array}$ \\
\hline $\begin{array}{l}S F-20 A \\
\text { SF-20 X } \\
\text { SF-20 Y }\end{array}$ & $\begin{array}{l}11 \\
11 \\
11\end{array}$ & $\begin{array}{l}0.39 \mathrm{~J} \\
0.63 \mathrm{~J} \\
0.04 \mathrm{~J}\end{array}$ & $\begin{array}{r}3.83 \\
11.20 \\
0.43 \mathrm{~J}\end{array}$ & $\begin{array}{r}11.01 \\
26.57 \\
2.28\end{array}$ & $\begin{array}{l}0.16 \mathrm{~J} \\
0.13 \mathrm{~J} \\
0.82 \mathrm{U}\end{array}$ & $\begin{array}{l}1.37 \mathrm{U} \\
1.22 \mathrm{U} \\
0.72 \mathrm{U}\end{array}$ & $\begin{array}{l}116.55 \\
191.09 \\
10.41 U\end{array}$ & $\begin{array}{l}1.49 \mathrm{U} \\
1.33 \mathrm{U} \\
0.78 \mathrm{U}\end{array}$ & $\begin{array}{l}1.29 \mathrm{U} \\
1.15 \mathrm{U} \\
0.68 \mathrm{U}\end{array}$ & $\begin{array}{c}13.82 \mathrm{U} \\
50.66 \\
0.77 \mathrm{U}\end{array}$ & $\begin{array}{l}47.23 \mathrm{U} \\
42.13 \mathrm{U} \\
24.85 \mathrm{U}\end{array}$ \\
\hline $\begin{array}{ll}S F-21 & A \\
S F-21 & B \\
S F-21 & C \\
S F-21 & X \\
S F-21 & Y\end{array}$ & $\begin{array}{l}12 \\
12 \\
12 \\
12 \\
12\end{array}$ & $\begin{array}{l}0.41 \mathrm{~J} \\
0.38 \mathrm{~J} \\
0.42 \mathrm{~J} \\
0.41 \mathrm{~J} \\
0.69 \mathrm{U}\end{array}$ & $\begin{array}{l}4.54 \\
4.29 \\
7.09 \\
6.74 \\
0.69 U\end{array}$ & $\begin{array}{r}11.20 \\
11.05 \\
13.30 \\
25.19 \\
0.70 \mathrm{U}\end{array}$ & $\begin{array}{l}0.09 \mathrm{~J} \\
0.15 \mathrm{~J} \\
0.26 \mathrm{~J} \\
0.10 \mathrm{~J} \\
0.80 \mathrm{U}\end{array}$ & $\begin{array}{l}1.24 U \\
1.18 U \\
1.21 U \\
1.02 U \\
0.70 U\end{array}$ & $\begin{array}{r}83.71 \\
119.36 \\
102.96 \\
89.02 \\
0.21 \mathrm{~J}\end{array}$ & $\begin{array}{l}1.34 \mathrm{U} \\
1.28 \mathrm{U} \\
1.32 \mathrm{U} \\
1.10 \mathrm{U} \\
0.76 \mathrm{U}\end{array}$ & $\begin{array}{l}1.17 \mathrm{U} \\
1.12 \mathrm{U} \\
1.14 \mathrm{U} \\
0.96 \mathrm{U} \\
0.67 \mathrm{U}\end{array}$ & $\begin{array}{r}40.57 \\
5.50 \\
22.57 \\
3.39 \\
0.07 \mathrm{~J}\end{array}$ & $\begin{array}{l}42.58 \text { U } \\
40.74 \text { U } \\
41.75 \text { U } \\
34.99 \text { U } \\
24.26 \text { U }\end{array}$ \\
\hline $\begin{array}{ll}S F-22 & A \\
S F-22 & B \\
S F-22 & C \\
S F-22 & X \\
S F-22 & Y\end{array}$ & $\begin{array}{l}12 \\
12 \\
12 \\
12 \\
12\end{array}$ & $\begin{array}{l}0.80 \mathrm{~J} \\
0.45 \mathrm{~J} \\
1.06 \mathrm{U} \\
0.88 \mathrm{U} \\
0.70 \mathrm{U}\end{array}$ & $\begin{array}{r}10.88 \\
9.89 \\
1.06 U \\
0.88 U \\
0.70 \mathrm{U}\end{array}$ & $\begin{array}{r}42.85 \\
47.48 \\
0.11 \mathrm{~J} \\
0.89 \mathrm{U} \\
0.71 \mathrm{U}\end{array}$ & $\begin{array}{l}0.25 \mathrm{~J} \\
0.10 \mathrm{~J} \\
1.23 \mathrm{U} \\
1.02 \mathrm{U} \\
0.81 \mathrm{U}\end{array}$ & $\begin{array}{l}1.26 \mathrm{U} \\
1.07 \mathrm{U} \\
1.08 \mathrm{U} \\
0.90 \mathrm{U} \\
0.71 \mathrm{U}\end{array}$ & $\begin{array}{r}144.00 \\
135.50 \\
0.22 \mathrm{~J} \\
0.07 \mathrm{~J} \\
0.06 \mathrm{~J}\end{array}$ & $\begin{array}{l}1.36 U \\
1.16 U \\
1.17 U \\
0.97 U \\
0.77 U\end{array}$ & $\begin{array}{l}1.19 \mathrm{U} \\
1.01 \mathrm{U} \\
1.02 \mathrm{U} \\
0.85 \mathrm{U} \\
0.67 \mathrm{U}\end{array}$ & $\begin{array}{l}14.17 \\
6.12 \\
0.11 \mathrm{~J} \\
0.96 \mathrm{U} \\
0.06 \mathrm{~J}\end{array}$ & $\begin{array}{l}43.27 \mathrm{U} \\
36.89 \mathrm{U} \\
37.21 \mathrm{U} \\
30.90 \mathrm{U} \\
24.47 \mathrm{U}\end{array}$ \\
\hline $\begin{array}{ll}S F-23 & A \\
S F-23 & B \\
S F-23 & X \\
S F-23 & Y\end{array}$ & $\begin{array}{l}12 \\
13 \\
13 \\
12\end{array}$ & $\begin{array}{l}0.29 \mathrm{~J} \\
0.36 \mathrm{~J} \\
0.25 \mathrm{~J} \\
0.69 \mathrm{U}\end{array}$ & $\begin{array}{l}2.49 \\
4.05 \\
3.21 \\
0.02 \mathrm{~J}\end{array}$ & $\begin{array}{r}12.37 \\
11.52 \\
10.48 \\
0.04 \mathrm{~J}\end{array}$ & $\begin{array}{l}0.10 \mathrm{~J} \\
0.26 \mathrm{~J} \\
1.05 \mathrm{U} \\
0.80 \mathrm{U}\end{array}$ & $\begin{array}{l}1.35 \mathrm{U} \\
1.13 \mathrm{U} \\
0.92 \mathrm{U} \\
0.71 \mathrm{U}\end{array}$ & $\begin{array}{c}93.41 \\
75.15 \\
53.69 \\
0.31 \mathrm{~J}\end{array}$ & $\begin{array}{l}1.47 \mathrm{U} \\
1.23 \mathrm{U} \\
1.00 \mathrm{U} \\
0.77 \mathrm{U}\end{array}$ & $\begin{array}{l}1.28 \mathrm{U} \\
1.07 \mathrm{U} \\
0.87 \mathrm{U} \\
0.67 \mathrm{U}\end{array}$ & $\begin{array}{r}50.23 \\
16.75 \\
4.06 \mathrm{U} \\
0.05 \mathrm{~J}\end{array}$ & $\begin{array}{l}46.52 \mathrm{U} \\
39.03 \mathrm{U} \\
31.74 \mathrm{U} \\
24.35 \mathrm{U}\end{array}$ \\
\hline
\end{tabular}


TABLE C.7. (contd)

\begin{tabular}{|c|c|c|c|c|c|c|c|c|c|c|c|}
\hline & & & & & sticides & $(\mu \mathrm{q} / \mathrm{kq} \mathrm{dry}$ & weight) & & & & \\
\hline $\begin{array}{l}\text { Sediment } \\
\text { Treatment } \\
\end{array}$ & Batch & $\begin{array}{c}\text { cis- } \\
\text { Chlordane }\end{array}$ & Dieldrin & $\underline{4,4^{\prime}-\mathrm{DDE}}$ & Endrin & $\begin{array}{c}\text { Endo- } \\
\text { sulfan II } \\
\end{array}$ & $4,4^{\prime}-D D D$ & $\begin{array}{c}\text { Endrin } \\
\text { Aldehyde } \\
\end{array}$ & $\begin{array}{c}\text { Endosulfan } \\
\text { Sulfate } \\
\end{array}$ & $\underline{4,4^{\prime}-\mathrm{DDT}}$ & Toxaphene \\
\hline $\begin{array}{ll}S F-24 & A \\
S F-24 & B \\
S F-24 & C\end{array}$ & $\begin{array}{l}12 \\
12 \\
12\end{array}$ & $\begin{array}{l}0.43 \mathrm{~J} \\
0.32 \mathrm{~J} \\
0.08 \mathrm{~J}\end{array}$ & $\begin{array}{l}6.25 \\
4.34 \\
0.81 \mathrm{~J}\end{array}$ & $\begin{array}{r}17.06 \\
13.62 \\
2.65\end{array}$ & $\begin{array}{l}0.15 \mathrm{~J} \\
0.14 \mathrm{~J} \\
1.23 \mathrm{U}\end{array}$ & $\begin{array}{l}1.27 \mathrm{U} \\
1.24 \mathrm{U} \\
1.09 \mathrm{U}\end{array}$ & $\begin{array}{r}118.56 \\
129.30 \\
18.57\end{array}$ & $\begin{array}{l}1.38 \mathrm{U} \\
1.35 \mathrm{U} \\
1.18 \mathrm{U}\end{array}$ & $\begin{array}{l}1.20 \mathrm{U} \\
1.17 \mathrm{U} \\
1.03 \mathrm{U}\end{array}$ & $\begin{array}{c}29.36 \\
12.12 \\
0.63 \mathrm{~J}\end{array}$ & $\begin{array}{l}43.75 \mathrm{U} \\
42.77 \mathrm{U} \\
37.41 \mathrm{U}\end{array}$ \\
\hline $\begin{array}{ll}S F-25 & A \\
S F-25 & B \\
S F-25 & X \\
S F-25 & Y\end{array}$ & $\begin{array}{l}13 \\
13 \\
13 \\
13\end{array}$ & $\begin{array}{l}1.18 \mathrm{U} \\
0.21 \mathrm{~J} \\
0.72 \mathrm{U} \\
0.69 \mathrm{U}\end{array}$ & $\begin{array}{l}33.04 \\
2.67 \\
0.72 \mathrm{U} \\
0.69 \mathrm{U}\end{array}$ & $\begin{array}{r}290.07 \\
8.08 \\
0.72 \mathrm{U} \\
0.70 \mathrm{U}\end{array}$ & $\begin{array}{l}1.37 \mathrm{U} \\
1.13 \mathrm{U} \\
0.83 \mathrm{U} \\
0.80 \mathrm{U}\end{array}$ & $\begin{array}{l}1.20 \mathrm{U} \\
1.00 \mathrm{U} \\
0.73 \mathrm{U} \\
0.70 \mathrm{U}\end{array}$ & $\begin{array}{r}440.33 \\
51.28 \\
0.59 \mathrm{~J} \\
0.87 \mathrm{U}\end{array}$ & $\begin{array}{l}1.30 \mathrm{U} \\
1.08 \mathrm{U} \\
0.79 \mathrm{U} \\
0.76 \mathrm{U}\end{array}$ & $\begin{array}{l}1.13 \mathrm{U} \\
0.94 \mathrm{U} \\
0.69 \mathrm{U} \\
0.66 \mathrm{U}\end{array}$ & $\begin{array}{c}10.68 \\
19.24 \\
0.78 \mathrm{U} \\
0.75 \mathrm{U}\end{array}$ & $\begin{array}{l}41.38 \mathrm{U} \\
34.28 \mathrm{U} \\
25.12 \mathrm{U} \\
24.20 \mathrm{U}\end{array}$ \\
\hline $\begin{array}{ll}S F-26 & A \\
S F-26 & B \\
S F-26 & C \\
S F-26 & X \\
S F-26 & Y\end{array}$ & $\begin{array}{l}13 \\
13 \\
13 \\
13 \\
13\end{array}$ & $\begin{array}{l}1.31 \mathrm{U} \\
1.25 \mathrm{U} \\
1.10 \mathrm{U} \\
0.41 \mathrm{~J} \\
0.69 \mathrm{U}\end{array}$ & $\begin{array}{r}0.53 \mathrm{~J} \\
2.90 \\
12.60 \\
11.77 \\
0.69 \mathrm{U}\end{array}$ & $\begin{array}{r}3.50 \\
7.16 \\
28.92 \\
25.71 \\
0.70 \mathrm{U}\end{array}$ & $\begin{array}{l}1.52 \mathrm{U} \\
1.45 \mathrm{U} \\
1.28 \mathrm{U} \\
1.12 \mathrm{U} \\
0.80 \mathrm{U}\end{array}$ & $\begin{array}{l}1.33 \mathrm{U} \\
1.28 \mathrm{U} \\
1.12 \mathrm{U} \\
0.99 \mathrm{U} \\
0.71 \mathrm{U}\end{array}$ & $\begin{array}{r}5.77 \\
54.43 \\
180.37 \\
172.42 \\
0.38 \mathrm{~J}\end{array}$ & $\begin{array}{l}1.45 \mathrm{U} \\
1.39 \mathrm{U} \\
1.22 \mathrm{U} \\
1.07 \mathrm{U} \\
0.77 \mathrm{U}\end{array}$ & $\begin{array}{l}1.26 \mathrm{U} \\
1.21 \mathrm{U} \\
1.06 \mathrm{U} \\
0.93 \mathrm{U} \\
0.67 \mathrm{U}\end{array}$ & $\begin{array}{c}1.42 \mathrm{U} \\
18.28 \\
35.40 \\
54.72 \\
0.75 \mathrm{U}\end{array}$ & $\begin{array}{l}45.99 \mathrm{U} \\
43.99 \mathrm{U} \\
38.68 \mathrm{U} \\
33.98 \mathrm{U} \\
24.30 \mathrm{U}\end{array}$ \\
\hline $\begin{array}{ll}S F=27 & A \\
S F-27 & B \\
S F-27 & C \\
S F-27 & X \\
S F-27 & Y\end{array}$ & $\begin{array}{l}13 \\
13 \\
13 \\
14 \\
13\end{array}$ & $\begin{array}{l}1.25 \mathrm{U} \\
0.23 \mathrm{~J} \\
0.37 \mathrm{~J} \\
0.34 \mathrm{~J} \\
0.67 \mathrm{U}\end{array}$ & $\begin{array}{r}1.65 \\
4.97 \\
8.71 \\
12.26 \\
0.67 \mathrm{U}\end{array}$ & $\begin{array}{r}3.40 \\
10.74 \\
20.33 \\
12.58 \\
0.68 \mathrm{U}\end{array}$ & $\begin{array}{l}1.45 U \\
1.40 U \\
1.35 U \\
1.06 U \\
0.77 U\end{array}$ & $\begin{array}{l}1.27 \mathrm{U} \\
1.23 \mathrm{U} \\
1.19 \mathrm{U} \\
0.93 \mathrm{U} \\
0.68 \mathrm{U}\end{array}$ & $\begin{array}{r}124.65 \\
119.43 \\
225.39 \\
135.42 \\
0.50 \mathrm{~J}\end{array}$ & $\begin{array}{l}2.23 \\
1.34 \mathrm{U} \\
1.29 \mathrm{U} \\
1.01 \mathrm{U} \\
0.74 \mathrm{U}\end{array}$ & $\begin{array}{l}1.20 \mathrm{U} \\
1.16 \mathrm{U} \\
1.12 \mathrm{U} \\
0.88 \mathrm{U} \\
0.64 \mathrm{U}\end{array}$ & $\begin{array}{r}98.26 \\
129.07 \\
94.02 \\
32.90 \\
0.73 \mathrm{U}\end{array}$ & $\begin{array}{l}43.82 \text { U } \\
42.38 \text { U } \\
40.92 \text { U } \\
32.16 \text { U } \\
23.41 \text { U }\end{array}$ \\
\hline $\begin{array}{ll}S F-28 & A \\
S F-28 & B \\
S F-28 & X \\
S F-28 & Y\end{array}$ & $\begin{array}{l}14 \\
14 \\
14 \\
14\end{array}$ & $\begin{array}{l}0.24 \mathrm{~J} \\
0.34 \mathrm{~J} \\
0.51 \mathrm{~J} \\
0.60 \mathrm{U}\end{array}$ & $\begin{array}{r}3.80 \\
12.86 \\
17.40 \\
0.53 \mathrm{~J}\end{array}$ & $\begin{array}{r}19.13 \\
26.87 \\
33.14 \\
1.37\end{array}$ & $\begin{array}{l}1.20 U \\
1.03 U \\
0.88 U \\
0.70 U\end{array}$ & $\begin{array}{l}1.06 U \\
0.90 U \\
0.78 U \\
0.61 U\end{array}$ & $\begin{array}{r}96.19 \\
278.67 \\
335.56 \\
12.17\end{array}$ & $\begin{array}{l}1.15 \mathrm{U} \\
0.98 \mathrm{U} \\
0.84 \mathrm{U} \\
0.66 \mathrm{U}\end{array}$ & $\begin{array}{l}1.00 \mathrm{U} \\
0.85 \mathrm{U} \\
0.73 \mathrm{U} \\
0.58 \mathrm{U}\end{array}$ & $\begin{array}{r}19.17 \\
188.41 \\
168.56 \\
0.77\end{array}$ & $\begin{array}{l}36.50 \mathrm{U} \\
31.07 \mathrm{U} \\
26.80 \mathrm{U} \\
21.10 \mathrm{U}\end{array}$ \\
\hline $\begin{array}{ll}S F-29 & A \\
S F-29 & B \\
S F-29 & C \\
S F-29 & D \\
S F-29 & E \\
S F-29 & X \\
S F-29 & Y\end{array}$ & $\begin{array}{l}14 \\
14 \\
14 \\
13 \\
14 \\
14 \\
14\end{array}$ & $\begin{array}{l}0.08 \mathrm{~J} \\
0.35 \mathrm{~J} \\
0.32 \mathrm{~J} \\
0.66 \mathrm{~J} \\
0.67 \mathrm{~J} \\
0.06 \mathrm{~J} \\
0.68 \mathrm{~J}\end{array}$ & $\begin{array}{r}1.83 \\
6.55 \\
12.10 \\
8.83 \\
29.65 \\
0.92 \\
0.68 \mathrm{U}\end{array}$ & $\begin{array}{r}3.59 \\
20.50 \\
21.87 \\
36.18 \\
121.33 \\
3.15 \\
0.16 \mathrm{~J}\end{array}$ & $\begin{array}{l}1.37 U \\
1.35 U \\
1.29 U \\
1.12 U \\
1.17 U \\
0.82 U \\
0.79 U\end{array}$ & $\begin{array}{l}1.20 \mathrm{U} \\
1.19 \mathrm{U} \\
1.13 \mathrm{U} \\
0.98 \mathrm{U} \\
1.03 \mathrm{U} \\
0.72 \mathrm{U} \\
0.69 \mathrm{U}\end{array}$ & $\begin{array}{r}32.85 \\
147.01 \\
283.52 \\
163.16 \\
863.54 \\
23.65 \\
1.07\end{array}$ & $\begin{array}{l}1.31 \mathrm{U} \\
1.29 \mathrm{U} \\
1.23 \mathrm{U} \\
1.07 \mathrm{U} \\
1.12 \mathrm{U} \\
0.78 \mathrm{U} \\
0.75 \mathrm{U}\end{array}$ & $\begin{array}{l}1.14 \mathrm{U} \\
1.12 \mathrm{U} \\
1.07 \mathrm{U} \\
0.93 \mathrm{U} \\
0.97 \mathrm{U} \\
0.68 \mathrm{U} \\
0.65 \mathrm{U}\end{array}$ & $\begin{array}{c}125.24 \\
277.91 \\
111.03 \\
181.17 \\
109.13 \\
3.68 \\
0.74 \mathrm{U}\end{array}$ & $\begin{array}{l}41.44 U \\
40.95 U \\
39.03 U \\
33.90 U \\
35.43 U \\
24.72 U \\
23.84 U\end{array}$ \\
\hline $\begin{array}{l}S F-30 A \\
S F-30 \quad B \\
S F-30 X \\
S F-30 Y\end{array}$ & $\begin{array}{l}14 \\
15 \\
15 \\
14\end{array}$ & $\begin{array}{l}0.06 \mathrm{~J} \\
0.23 \mathrm{~J} \\
0.37 \mathrm{~J} \\
0.68 \mathrm{U}\end{array}$ & $\begin{array}{c}1.02 \mathrm{~J} \\
4.71 \\
10.96 \\
0.19 \mathrm{~J}\end{array}$ & $\begin{array}{r}2.20 \\
20.25 \\
32.21 \\
0.09 \mathrm{~J}\end{array}$ & $\begin{array}{l}1.49 \mathrm{U} \\
1.45 \mathrm{U} \\
0.39 \mathrm{~J} \\
0.79 \mathrm{U}\end{array}$ & $\begin{array}{l}1.31 \mathrm{U} \\
1.27 \mathrm{U} \\
1.30 \mathrm{U} \\
0.69 \mathrm{U}\end{array}$ & $\begin{array}{r}32.56 \\
164.72 \\
299.76 \\
1.17\end{array}$ & $\begin{array}{l}1.42 \mathrm{U} \\
1.38 \mathrm{U} \\
1.41 \mathrm{U} \\
0.75 \mathrm{U}\end{array}$ & $\begin{array}{l}1.23 \mathrm{U} \\
1.20 \mathrm{U} \\
1.23 \mathrm{U} \\
0.65 \mathrm{U}\end{array}$ & $\begin{array}{r}13.80 \\
48.85 \\
101.54 \\
0.74 \cup\end{array}$ & $\begin{array}{l}44.98 U \\
43.82 U \\
44.84 U \\
23.82 U\end{array}$ \\
\hline
\end{tabular}


TABLE C.7. (contd)

\begin{tabular}{|c|c|c|c|c|c|c|c|c|c|c|c|}
\hline \multirow{2}{*}{$\begin{array}{l}\text { Sediment } \\
\text { Treatment } \\
\end{array}$} & \multirow[b]{2}{*}{ Batch } & \multicolumn{8}{|c|}{ Pesticides $(\mu \mathrm{g} / \mathrm{kg}$ dry weight) } & \multirow[b]{2}{*}{$\underline{4,4^{\prime}-\mathrm{DDT}}$} & \multirow[b]{2}{*}{$\underline{\text { Toxaphene }}$} \\
\hline & & $\begin{array}{c}\text { cis- } \\
\text { Chlordane } \\
\end{array}$ & Dieldrin & $\underline{4,4^{\prime}-\mathrm{DDE}}$ & Endrin & $\begin{array}{l}\text { Endo- } \\
\text { sulfan II }\end{array}$ & $4,4^{\prime}-D D D$ & $\begin{array}{c}\text { Endrin } \\
\text { Aldehyde } \\
\end{array}$ & $\begin{array}{c}\begin{array}{c}\text { Endosulfan } \\
\text { Sulfate }\end{array} \\
\end{array}$ & & \\
\hline $\begin{array}{ll}S F-32 & A \\
S F-32 & B \\
S F-32 & C \\
S F-32 & X \\
S F=32 & Y\end{array}$ & $\begin{array}{l}24 \\
24 \\
24 \\
24 \\
22\end{array}$ & $\begin{array}{l}0.78 \mathrm{~J} \\
0.47 \mathrm{~J} \\
0.78 \mathrm{U} \\
0.87 \mathrm{U} \\
0.66 \mathrm{U}\end{array}$ & $\begin{array}{l}9.87 \\
5.51 \\
0.78 \cup \\
0.87 \cup \\
0.66 \cup\end{array}$ & $\begin{array}{r}41.24 \\
23.56 \\
0.09 \mathrm{~J} \\
0.88 \mathrm{U} \\
0.67 \mathrm{U}\end{array}$ & $\begin{array}{l}1.15 U \\
1.15 U \\
0.91 U \\
1.01 U \\
0.77 U\end{array}$ & $\begin{array}{l}1.83 \\
1.01 \mathrm{U} \\
0.80 \mathrm{U} \\
0.89 \mathrm{U} \\
0.68 \mathrm{U}\end{array}$ & $\begin{array}{r}205.26 \\
129.13 \\
0.61 \mathrm{~J} \\
0.48 \mathrm{~J} \\
0.08 \mathrm{~J}\end{array}$ & $\begin{array}{l}1.10 U \\
1.10 U \\
0.87 U \\
0.96 U \\
0.73 U\end{array}$ & $\begin{array}{l}0.95 U \\
0.96 U \\
0.75 U \\
0.84 U \\
0.64 U\end{array}$ & $\begin{array}{r}80.76 \\
50.70 \\
0.23 \mathrm{~J} \\
0.94 \mathrm{U} \\
0.72 \mathrm{U}\end{array}$ & $\begin{array}{l}34.81 U \\
34.94 U \\
27.54 U \\
30.49 U \\
23.30 U\end{array}$ \\
\hline $\begin{array}{l}S F-33 \text { A } \\
S F-33 \text { B } \\
S F-33 X \\
S F-33 Y\end{array}$ & $\begin{array}{l}24 \\
24 \\
25 \\
22\end{array}$ & $\begin{array}{l}0.21 \mathrm{~J} \\
0.29 \mathrm{~J} \\
0.40 \mathrm{~J} \\
0.67 \mathrm{U}\end{array}$ & $\begin{array}{c}10.11 \\
11.83 \\
16.70 \\
0.10 \mathrm{~J}\end{array}$ & $\begin{array}{r}26.95 \\
31.95 \\
62.85 \\
0.03 \mathrm{~J}\end{array}$ & $\begin{array}{l}1.07 \mathrm{U} \\
1.08 \mathrm{U} \\
0.31 \mathrm{~J} \\
0.78 \mathrm{U}\end{array}$ & $\begin{array}{l}0.94 U \\
0.95 U \\
0.83 U \\
0.69 U\end{array}$ & $\begin{array}{r}173.46 \\
198.05 \\
217.76 \\
0.62 \mathrm{~J}\end{array}$ & $\begin{array}{l}1.02 \mathrm{U} \\
1.03 \mathrm{U} \\
0.90 \mathrm{U} \\
0.74 \mathrm{U}\end{array}$ & $\begin{array}{l}0.89 U \\
0.90 U \\
0.79 U \\
0.65 U\end{array}$ & $\begin{array}{r}76.28 \\
153.73 \\
69.32 \\
1.85\end{array}$ & $\begin{array}{l}32.46 U \\
32.79 U \\
28.71 U \\
23.60 U\end{array}$ \\
\hline $\begin{array}{ll}S F-34 & A \\
S F-34 & B \\
S F-34 & X \\
S F-34 & Y\end{array}$ & $\begin{array}{l}24 \\
24 \\
23 \\
11\end{array}$ & $\begin{array}{l}0.82 \mathrm{~J} \\
1.00 \mathrm{U} \\
0.15 \mathrm{~J} \\
0.66 \mathrm{U}\end{array}$ & $\begin{array}{r}36.59 \\
2.43 \\
5.50 \\
0.03 \mathrm{~J}\end{array}$ & $\begin{array}{r}193.73 \\
9.42 \\
13.79 \\
0.04 \mathrm{~J}\end{array}$ & $\begin{array}{l}1.33 \mathrm{U} \\
1.16 \mathrm{U} \\
0.83 \mathrm{U} \\
0.77 \mathrm{U}\end{array}$ & $\begin{array}{l}1.17 \mathrm{U} \\
1.02 \mathrm{U} \\
0.73 \mathrm{U} \\
0.67 \mathrm{U}\end{array}$ & $\begin{array}{r}302.60 \\
65.98 \\
125.95 \\
0.83 \mathrm{U}\end{array}$ & $\begin{array}{l}1.27 \mathrm{U} \\
1.11 \mathrm{U} \\
0.79 \mathrm{U} \\
0.73 \mathrm{U}\end{array}$ & $\begin{array}{l}1.10 \mathrm{U} \\
0.97 \mathrm{U} \\
0.69 \mathrm{U} \\
0.64 \mathrm{U}\end{array}$ & $\begin{array}{r}38.70 \\
24.86 \\
108.51 \\
0.72 \mathrm{U}\end{array}$ & $\begin{array}{l}40.24 \mathrm{U} \\
35.28 \mathrm{U} \\
25.11 \mathrm{U} \\
23.21 \mathrm{U}\end{array}$ \\
\hline $\begin{array}{l}\text { IH }-35 \text { A } \\
\text { IH-35 X } \\
\text { IH-35 Y }\end{array}$ & $\begin{array}{l}15 \\
15 \\
17\end{array}$ & $\begin{array}{l}0.13 \mathrm{~J} \\
0.22 \mathrm{~J} \\
0.71 \mathrm{U}\end{array}$ & $\begin{array}{l}2.18 \\
3.78 \\
0.06 \mathrm{~J}\end{array}$ & $\begin{array}{r}7.51 \\
12.85 \\
0.08 \mathrm{~J}\end{array}$ & $\begin{array}{l}1.27 \mathrm{U} \\
0.99 \mathrm{U} \\
0.82 \mathrm{U}\end{array}$ & $\begin{array}{l}1.12 \mathrm{U} \\
0.87 \mathrm{U} \\
0.72 \mathrm{U}\end{array}$ & $\begin{array}{r}68.47 \\
113.37 \\
0.87 \mathrm{~J}\end{array}$ & $\begin{array}{l}1.21 \mathrm{U} \\
0.95 \mathrm{U} \\
0.78 \mathrm{U}\end{array}$ & $\begin{array}{l}1.05 \mathrm{U} \\
0.82 \mathrm{U} \\
0.68 \mathrm{U}\end{array}$ & $\begin{array}{l}24.22 \\
91.79 \\
0.77 \mathrm{U}\end{array}$ & $\begin{array}{l}38.41 \mathrm{U} \\
30.08 \mathrm{U} \\
24.76 \mathrm{U}\end{array}$ \\
\hline $\begin{array}{ll}\mathrm{IH}-36 & \mathrm{~A} \\
\mathrm{IH}-36 & \mathrm{~B} \\
\mathrm{IH}-36 & \mathrm{X} \\
\mathrm{IH}-36 & \mathrm{Y}\end{array}$ & $\begin{array}{l}15 \\
15 \\
15 \\
17\end{array}$ & $\begin{array}{l}0.06 \mathrm{~J} \\
0.20 \mathrm{~J} \\
0.22 \mathrm{~J} \\
0.70 \mathrm{~V}\end{array}$ & $\begin{array}{l}0.86 \mathrm{~J} \\
5.43 \\
4.70 \\
0.13 \mathrm{~J}\end{array}$ & $\begin{array}{r}1.93 \\
12.90 \\
20.19 \\
0.15 \mathrm{~J}\end{array}$ & $\begin{array}{l}1.36 \mathrm{U} \\
1.14 \mathrm{U} \\
0.97 \mathrm{U} \\
0.81 \mathrm{U}\end{array}$ & $\begin{array}{l}1.20 \mathrm{U} \\
1.00 \mathrm{U} \\
0.85 \mathrm{U} \\
0.71 \mathrm{U}\end{array}$ & $\begin{array}{r}29.34 \\
110.16 \\
134.94 \\
1.18\end{array}$ & $\begin{array}{l}1.30 \mathrm{U} \\
1.09 \mathrm{U} \\
0.93 \mathrm{U} \\
0.78 \mathrm{U}\end{array}$ & $\begin{array}{l}1.13 \mathrm{U} \\
0.95 \mathrm{U} \\
0.81 \mathrm{U} \\
0.67 \mathrm{U}\end{array}$ & $\begin{array}{c}13.30 \\
64.91 \\
8.70 \\
0.16 \mathrm{~J}\end{array}$ & $\begin{array}{l}41.25 U \\
34.53 \mathrm{U} \\
29.44 \mathrm{U} \\
24.62 \mathrm{U}\end{array}$ \\
\hline $\begin{array}{ll}\mathrm{IH}-37 & \mathrm{~A} \\
\mathrm{IH}-37 & \mathrm{~B} \\
\mathrm{IH}-37 & \mathrm{C} \\
\mathrm{IH}-37 & \mathrm{X} \\
\mathrm{IH}-37 & \mathrm{Y}\end{array}$ & $\begin{array}{l}15 \\
15 \\
15 \\
15 \\
17\end{array}$ & $\begin{array}{l}1.24 \mathrm{U} \\
0.07 \mathrm{~J} \\
0.07 \mathrm{~J} \\
0.14 \mathrm{~J} \\
0.70 \mathrm{U}\end{array}$ & $\begin{array}{l}0.43 \mathrm{~J} \\
1.02 \mathrm{~J} \\
1.39 \\
1.88 \\
0.12 \mathrm{~J}\end{array}$ & $\begin{array}{l}0.86 \mathrm{~J} \\
2.64 \\
2.80 \\
7.92 \\
0.71 \mathrm{U}\end{array}$ & $\begin{array}{l}1.44 \mathrm{U} \\
1.44 \mathrm{U} \\
1.33 \mathrm{U} \\
1.18 \mathrm{U} \\
0.81 \mathrm{U}\end{array}$ & $\begin{array}{l}1.26 U \\
1.27 \mathrm{U} \\
1.17 \mathrm{U} \\
1.04 \mathrm{U} \\
0.71 \mathrm{U}\end{array}$ & $\begin{array}{r}6.96 \\
26.56 \\
38.99 \\
56.10 \\
0.16 \mathrm{~J}\end{array}$ & $\begin{array}{l}1.37 \mathrm{U} \\
1.38 \mathrm{U} \\
1.27 \mathrm{U} \\
1.13 \mathrm{U} \\
0.77 \mathrm{U}\end{array}$ & $\begin{array}{l}1.19 \mathrm{U} \\
1.20 \mathrm{U} \\
1.11 \mathrm{U} \\
0.98 \mathrm{U} \\
0.67 \mathrm{U}\end{array}$ & $\begin{array}{c}1.11 \mathrm{~J} \\
6.21 \\
16.63 \\
6.69 \\
0.76 \mathrm{U}\end{array}$ & $\begin{array}{l}43.54 \mathrm{U} \\
43.75 \mathrm{U} \\
40.39 \mathrm{U} \\
35.80 \mathrm{U} \\
24.53 \mathrm{U}\end{array}$ \\
\hline $\begin{array}{ll}I H-38 & A \\
I H-38 & X \\
I H-38 & Y\end{array}$ & $\begin{array}{l}16 \\
16 \\
17\end{array}$ & $\begin{array}{l}0.32 \mathrm{~J} \\
0.20 \mathrm{~J} \\
0.69 \mathrm{U}\end{array}$ & $\begin{array}{l}3.19 \\
2.18 \\
0.10 \mathrm{~J}\end{array}$ & $\begin{array}{l}7.31 \\
5.31 \\
0.70 \mathrm{U}\end{array}$ & $\begin{array}{l}1.43 U \\
1.29 U \\
0.81 U\end{array}$ & $\begin{array}{l}1.26 U \\
1.13 U \\
0.71 U\end{array}$ & $\begin{array}{l}71.60 \\
71.54 \\
0.21 \mathrm{~J}\end{array}$ & $\begin{array}{l}1.37 \mathrm{U} \\
1.23 \mathrm{U} \\
0.77 \mathrm{U}\end{array}$ & $\begin{array}{l}1.19 \mathrm{U} \\
1.07 \mathrm{U} \\
0.67 \mathrm{U}\end{array}$ & $\begin{array}{r}39.69 \\
5.91 \\
0.76 \mathrm{U}\end{array}$ & $\begin{array}{l}43.44 \mathrm{U} \\
39.06 \mathrm{U} \\
24.40 \mathrm{U}\end{array}$ \\
\hline $\begin{array}{ll}\mathrm{IH}-39 & \mathrm{~A} \\
\mathrm{IH}-39 & \mathrm{~B} \\
\mathrm{IH}-39 & \mathrm{C} \\
\mathrm{IH}-39 & \mathrm{X} \\
\mathrm{IH}-39 & \mathrm{Y}\end{array}$ & $\begin{array}{l}16 \\
16 \\
16 \\
16 \\
17\end{array}$ & $\begin{array}{l}0.21 \mathrm{~J} \\
0.22 \mathrm{~J} \\
0.19 \mathrm{~J} \\
0.33 \mathrm{~J} \\
0.67 \mathrm{U}\end{array}$ & $\begin{array}{l}1.38 \\
2.71 \\
3.98 \\
5.09 \\
0.07 \mathrm{~J}\end{array}$ & $\begin{array}{r}5.97 \\
12.45 \\
18.69 \\
22.33 \\
0.06 \mathrm{~J}\end{array}$ & $\begin{array}{l}1.43 \mathrm{U} \\
1.34 \mathrm{U} \\
1.08 \mathrm{U} \\
1.24 \mathrm{U} \\
0.78 \mathrm{U}\end{array}$ & $\begin{array}{l}1.26 U \\
1.18 U \\
0.95 U \\
1.09 U \\
0.69 U\end{array}$ & $\begin{array}{r}57.28 \\
66.56 \\
109.02 \\
127.69 \\
0.52 \mathrm{~J}\end{array}$ & $\begin{array}{l}1.37 U \\
1.28 U \\
1.03 U \\
1.18 U \\
0.75 U\end{array}$ & $\begin{array}{l}1.19 \mathrm{U} \\
1.11 \mathrm{U} \\
0.90 \mathrm{U} \\
1.03 \mathrm{U} \\
0.65 \mathrm{U}\end{array}$ & $\begin{array}{r}33.83 \\
23.87 \\
37.37 \\
47.63 \\
0.73 \cup\end{array}$ & $\begin{array}{l}43.44 U \\
40.65 U \\
32.80 \mathrm{U} \\
37.58 \mathrm{U} \\
23.69 \mathrm{U}\end{array}$ \\
\hline
\end{tabular}


TABLE C.7. (contd)

\begin{tabular}{|c|c|c|c|c|c|c|c|c|c|c|c|}
\hline & & & & & sticides & $(\mu \mathrm{g} / \mathrm{kg}$ dry & weight) & & & & \\
\hline $\begin{array}{l}\text { Sediment } \\
\text { Treatment } \\
\end{array}$ & Batch & $\begin{array}{c}\text { cis- } \\
\text { Chlordane } \\
\end{array}$ & Dieldrin & $\underline{4,4^{\prime}-D D E}$ & Endrin & $\begin{array}{l}\text { Endo- } \\
\text { sulfan II }\end{array}$ & $4,4^{\prime}-D D D$ & $\begin{array}{c}\text { Endrin } \\
\text { Aldehyde } \\
\end{array}$ & $\begin{array}{c}\begin{array}{c}\text { Endosulfan } \\
\text { Sulfate }\end{array} \\
\end{array}$ & $\underline{4,4^{\prime}-\mathrm{DDT}}$ & Toxaphene \\
\hline $\begin{array}{ll}\text { IH-40 A } \\
\text { IH-40 } \\
\text { IH-40 X } \\
\text { IH-40 Y }\end{array}$ & $\begin{array}{l}16 \\
25 \\
16 \\
17\end{array}$ & $\begin{array}{l}0.11 \mathrm{~J} \\
0.12 \mathrm{~J} \\
0.11 \mathrm{~J} \\
0.70 \mathrm{U}\end{array}$ & $\begin{array}{l}0.92 \mathrm{~J} \\
1.10 \mathrm{~J} \\
1.61 \\
0.09 \mathrm{~J}\end{array}$ & $\begin{array}{l}3.38 \\
3.17 \\
3.79 \\
0.71 U\end{array}$ & $\begin{array}{l}1.42 \mathrm{U} \\
1.32 \mathrm{U} \\
1.30 \mathrm{U} \\
0.81 \mathrm{U}\end{array}$ & $\begin{array}{l}1.25 \mathrm{U} \\
1.16 \mathrm{U} \\
1.15 \mathrm{U} \\
0.71 \mathrm{U}\end{array}$ & $\begin{array}{r}32.98 \\
32.70 \\
43.70 \\
0.12 \mathrm{~J}\end{array}$ & $\begin{array}{l}1.36 \mathrm{U} \\
1.26 \mathrm{U} \\
0.61 \mathrm{~J} \\
0.77 \mathrm{U}\end{array}$ & $\begin{array}{l}1.18 \mathrm{U} \\
1.10 \mathrm{U} \\
1.08 \mathrm{U} \\
0.67 \mathrm{U}\end{array}$ & $\begin{array}{r}4.92 \\
16.22 \\
68.27 \\
0.76 \mathrm{U}\end{array}$ & $\begin{array}{l}43.14 \mathrm{U} \\
40.07 \mathrm{U} \\
39.44 \mathrm{U} \\
24.60 \mathrm{U}\end{array}$ \\
\hline $\begin{array}{ll}\text { IH-41 } & \text { A } \\
\text { IH-41 } & \text { B } \\
\text { IH-41 } & \text { C } \\
\text { IH-41 } & X \\
\text { IH-4I } & Y\end{array}$ & $\begin{array}{l}18 \\
18 \\
16 \\
16 \\
17\end{array}$ & $\begin{array}{l}0.14 \mathrm{~J} \\
0.08 \mathrm{~J} \\
0.31 \mathrm{~J} \\
0.23 \mathrm{~J} \\
0.68 \mathrm{U}\end{array}$ & $\begin{array}{l}1.19 \\
1.13 \mathrm{~J} \\
3.22 \\
3.07 \\
0.68 \mathrm{U}\end{array}$ & $\begin{array}{l}3.73 \\
3.24 \\
9.18 \\
9.05 \\
0.68 U\end{array}$ & $\begin{array}{l}1.38 U \\
1.37 U \\
1.22 U \\
1.23 U \\
0.78 U\end{array}$ & $\begin{array}{l}1.22 \mathrm{U} \\
1.20 \mathrm{U} \\
1.07 \mathrm{U} \\
1.08 \mathrm{U} \\
0.69 \mathrm{U}\end{array}$ & $\begin{array}{c}24.16 \\
19.22 \\
98.66 \\
78.73 \\
0.09 \mathrm{~J}\end{array}$ & $\begin{array}{l}1.32 \mathrm{U} \\
1.30 \mathrm{U} \\
1.17 \mathrm{U} \\
1.17 \mathrm{U} \\
0.75 \mathrm{U}\end{array}$ & $\begin{array}{l}1.15 \mathrm{U} \\
1.14 \mathrm{U} \\
1.01 \mathrm{U} \\
1.02 \mathrm{U} \\
0.65 \mathrm{U}\end{array}$ & $\begin{array}{c}21.65 \\
1.75 \\
34.51 \\
13.99 \\
0.73 \mathrm{U}\end{array}$ & $\begin{array}{l}41.91 \mathrm{U} \\
41.41 \mathrm{U} \\
37.01 \mathrm{U} \\
37.21 \mathrm{U} \\
23.72 \mathrm{U}\end{array}$ \\
\hline $\begin{array}{l}\text { IH-42 A } \\
\text { IH-42 X } \\
\text { IH-42 Y }\end{array}$ & $\begin{array}{l}18 \\
18 \\
17\end{array}$ & $\begin{array}{l}0.22 \mathrm{~J} \\
0.16 \mathrm{~J} \\
0.68 \mathrm{U}\end{array}$ & $\begin{array}{l}1.72 \\
1.10 \mathrm{~J} \\
0.68 \mathrm{U}\end{array}$ & $\begin{array}{l}6.28 \\
3.93 \\
0.69 U\end{array}$ & $\begin{array}{l}1.27 \mathrm{U} \\
1.30 \mathrm{U} \\
0.79 \mathrm{U}\end{array}$ & $\begin{array}{l}1.11 \mathrm{U} \\
1.14 \mathrm{U} \\
0.70 \mathrm{U}\end{array}$ & $\begin{array}{r}40.53 \\
21.52 \\
0.09 \mathrm{~J}\end{array}$ & $\begin{array}{l}1.21 \mathrm{U} \\
1.24 \mathrm{U} \\
0.76 \mathrm{U}\end{array}$ & $\begin{array}{l}1.05 \mathrm{U} \\
1.08 \mathrm{U} \\
0.66 \mathrm{U}\end{array}$ & $\begin{array}{l}4.42 \\
1.55 \\
0.75 \mathrm{U}\end{array}$ & $\begin{array}{l}38.33 \mathrm{U} \\
39.25 \mathrm{U} \\
24.04 \mathrm{U}\end{array}$ \\
\hline $\begin{array}{ll}\mathrm{IH}-43 & \mathrm{~A} \\
\mathrm{IH}-43 & \mathrm{~B} \\
\mathrm{IH}-43 & \mathrm{X} \\
\mathrm{IH}-43 & \mathrm{Y}\end{array}$ & $\begin{array}{l}25 \\
18 \\
18 \\
17\end{array}$ & $\begin{array}{l}1.18 \mathrm{U} \\
0.25 \mathrm{~J} \\
0.23 \mathrm{~J} \\
0.69 \mathrm{U}\end{array}$ & $\begin{array}{l}1.18 \mathrm{U} \\
2.13 \\
1.66 \\
0.10 \mathrm{~J}\end{array}$ & $\begin{array}{l}0.09 \mathrm{~J} \\
5.58 \\
5.63 \\
0.70 \mathrm{U}\end{array}$ & $\begin{array}{l}1.37 U \\
1.38 U \\
1.24 U \\
0.80 U\end{array}$ & $\begin{array}{l}1.21 \mathrm{U} \\
1.22 \mathrm{U} \\
1.09 \mathrm{U} \\
0.70 \mathrm{U}\end{array}$ & $\begin{array}{r}0.31 \mathrm{~J} \\
49.03 \\
37.17 \\
0.17 \mathrm{~J}\end{array}$ & $\begin{array}{l}1.31 \mathrm{U} \\
1.32 \mathrm{U} \\
1.18 \mathrm{U} \\
0.76 \mathrm{U}\end{array}$ & $\begin{array}{l}1.14 \mathrm{U} \\
1.15 \mathrm{U} \\
1.03 \mathrm{U} \\
0.66 \mathrm{U}\end{array}$ & $\begin{array}{r}1.29 \mathrm{U} \\
18.44 \\
12.82 \\
0.75 \mathrm{U}\end{array}$ & $\begin{array}{l}41.56 \mathrm{U} \\
41.94 \mathrm{U} \\
37.61 \mathrm{U} \\
24.18 \mathrm{U}\end{array}$ \\
\hline $\begin{array}{ll}\text { IH-44 } & \text { A } \\
\text { IH-44 } & \text { B } \\
\text { IH-44 } & \text { C } \\
\text { IH-44 } & \text { D } \\
\text { IH-44 } & \text { X } \\
\text { IH-44 } & \text { Y }\end{array}$ & $\begin{array}{l}18 \\
18 \\
18 \\
18 \\
25 \\
17\end{array}$ & $\begin{array}{l}0.12 \mathrm{~J} \\
0.21 \mathrm{~J} \\
0.18 \mathrm{~J} \\
0.12 \mathrm{~J} \\
0.23 \mathrm{~J} \\
0.70 \mathrm{U}\end{array}$ & $\begin{array}{l}1.03 \mathrm{~J} \\
2.15 \\
1.27 \\
1.53 \\
3.24 \\
0.04 \mathrm{~J}\end{array}$ & $\begin{array}{r}3.10 \\
6.26 \\
3.74 \\
6.43 \\
19.18 \\
0.08 \mathrm{~J}\end{array}$ & $\begin{array}{l}1.40 U \\
1.45 U \\
1.34 U \\
1.33 U \\
1.28 U \\
0.81 U\end{array}$ & $\begin{array}{l}1.23 \mathrm{U} \\
1.27 \mathrm{U} \\
1.18 \mathrm{U} \\
1.17 \mathrm{U} \\
1.12 \\
0.71 \mathrm{U}\end{array}$ & $\begin{array}{r}17.82 \\
60.74 \\
18.33 \\
35.28 \\
50.74 \\
0.53 \mathrm{~J}\end{array}$ & $\begin{array}{l}1.34 \mathrm{U} \\
1.38 \mathrm{U} \\
1.28 \mathrm{U} \\
1.27 \mathrm{U} \\
1.22 \mathrm{U} \\
0.77 \mathrm{U}\end{array}$ & $\begin{array}{l}1.16 \mathrm{U} \\
1.20 \mathrm{U} \\
1.11 \mathrm{U} \\
1.10 \mathrm{U} \\
1.06 \mathrm{U} \\
0.67 \mathrm{U}\end{array}$ & $\begin{array}{r}14.60 \\
14.07 \\
3.05 \\
8.73 \\
4.45 \\
0.08 \mathrm{~J}\end{array}$ & $\begin{array}{l}42.42 \mathrm{U} \\
43.82 \mathrm{U} \\
40.48 \mathrm{U} \\
40.24 \mathrm{U} \\
38.65 \mathrm{U} \\
24.59 \mathrm{U}\end{array}$ \\
\hline $\begin{array}{ll}\mathrm{IH}-45 & \mathrm{~A} \\
\mathrm{IH}-45 & \mathrm{~B} \\
\mathrm{IH}-45 & \mathrm{C} \\
\mathrm{IH}-45 & \mathrm{X} \\
\mathrm{IH}-45 & \mathrm{Y}\end{array}$ & $\begin{array}{l}19 \\
18 \\
18 \\
19 \\
17\end{array}$ & $\begin{array}{l}0.06 \mathrm{~J} \\
0.14 \mathrm{~J} \\
0.16 \mathrm{~J} \\
1.15 \mathrm{U} \\
0.70 \mathrm{U}\end{array}$ & $\begin{array}{l}0.42 \mathrm{~J} \\
1.15 \mathrm{~J} \\
2.21 \\
0.45 \mathrm{~J} \\
0.02 \mathrm{~J}\end{array}$ & $\begin{array}{l}1.55 \\
2.55 \\
7.45 \\
1.00 \mathrm{~J} \\
0.05 \mathrm{~J}\end{array}$ & $\begin{array}{l}1.44 U \\
1.35 U \\
1.21 U \\
1.34 U \\
0.81 U\end{array}$ & $\begin{array}{l}1.27 \mathrm{U} \\
1.19 \mathrm{U} \\
1.07 \mathrm{U} \\
1.18 \mathrm{U} \\
0.71 \mathrm{U}\end{array}$ & $\begin{array}{r}8.53 \\
20.65 \\
61.17 \\
8.60 \\
0.39 \mathrm{~J}\end{array}$ & $\begin{array}{l}1.37 \mathrm{U} \\
1.29 \mathrm{U} \\
1.16 \mathrm{U} \\
1.28 \mathrm{U} \\
0.77 \mathrm{U}\end{array}$ & $\begin{array}{l}1.19 U \\
1.13 U \\
1.01 U \\
1.11 U \\
0.67 U\end{array}$ & $\begin{array}{r}2.72 \\
3.13 \\
10.48 \\
7.42 \\
0.76 \quad U\end{array}$ & $\begin{array}{l}43.58 \mathrm{U} \\
41.04 \mathrm{U} \\
36.76 \mathrm{U} \\
40.51 \mathrm{U} \\
24.52 \mathrm{U}\end{array}$ \\
\hline $\begin{array}{ll}\text { IH-46 } & A \\
\text { IH-46 } & B \\
\text { IH-46 } & \text { C } \\
\text { IH-46 } & X \\
\text { IH-46 } & Y\end{array}$ & $\begin{array}{l}19 \\
19 \\
19 \\
19 \\
17\end{array}$ & $\begin{array}{l}0.06 \mathrm{~J} \\
0.06 \mathrm{~J} \\
1.17 \mathrm{U} \\
1.15 \mathrm{U} \\
0.70 \mathrm{U}\end{array}$ & $\begin{array}{l}1.33 \\
0.52 \mathrm{~J} \\
1.32 \\
0.60 \mathrm{~J} \\
0.10 \mathrm{~J}\end{array}$ & $\begin{array}{l}1.41 \\
1.29 \\
3.15 \\
2.03 \\
0.71 \mathrm{U}\end{array}$ & $\begin{array}{l}2.19 \\
1.29 \mathrm{U} \\
1.35 \mathrm{U} \\
1.33 \mathrm{U} \\
0.81 \mathrm{U}\end{array}$ & $\begin{array}{l}0.37 \mathrm{~J} \\
1.14 \mathrm{U} \\
1.19 \mathrm{U} \\
1.17 \mathrm{U} \\
0.71 \mathrm{U}\end{array}$ & $\begin{array}{r}8.70 \\
8.49 \\
18.80 \\
10.98 \\
0.19 \mathrm{~J}\end{array}$ & $\begin{array}{l}1.27 U \\
1.23 U \\
1.29 U \\
1.27 U \\
0.77 U\end{array}$ & $\begin{array}{l}1.10 \mathrm{U} \\
1.07 \mathrm{U} \\
1.12 \mathrm{U} \\
1.10 \mathrm{U} \\
0.67 \mathrm{U}\end{array}$ & $\begin{array}{r}7.33 \\
10.66 \\
52.75 \\
0.18 \mathrm{~J} \\
0.76 \mathrm{U}\end{array}$ & $\begin{array}{l}40.30 \mathrm{U} \\
39.11 \mathrm{U} \\
41.01 \mathrm{U} \\
40.30 \mathrm{U} \\
24.49 \mathrm{U}\end{array}$ \\
\hline
\end{tabular}


TABLE C. $7 . \quad$ (contd)

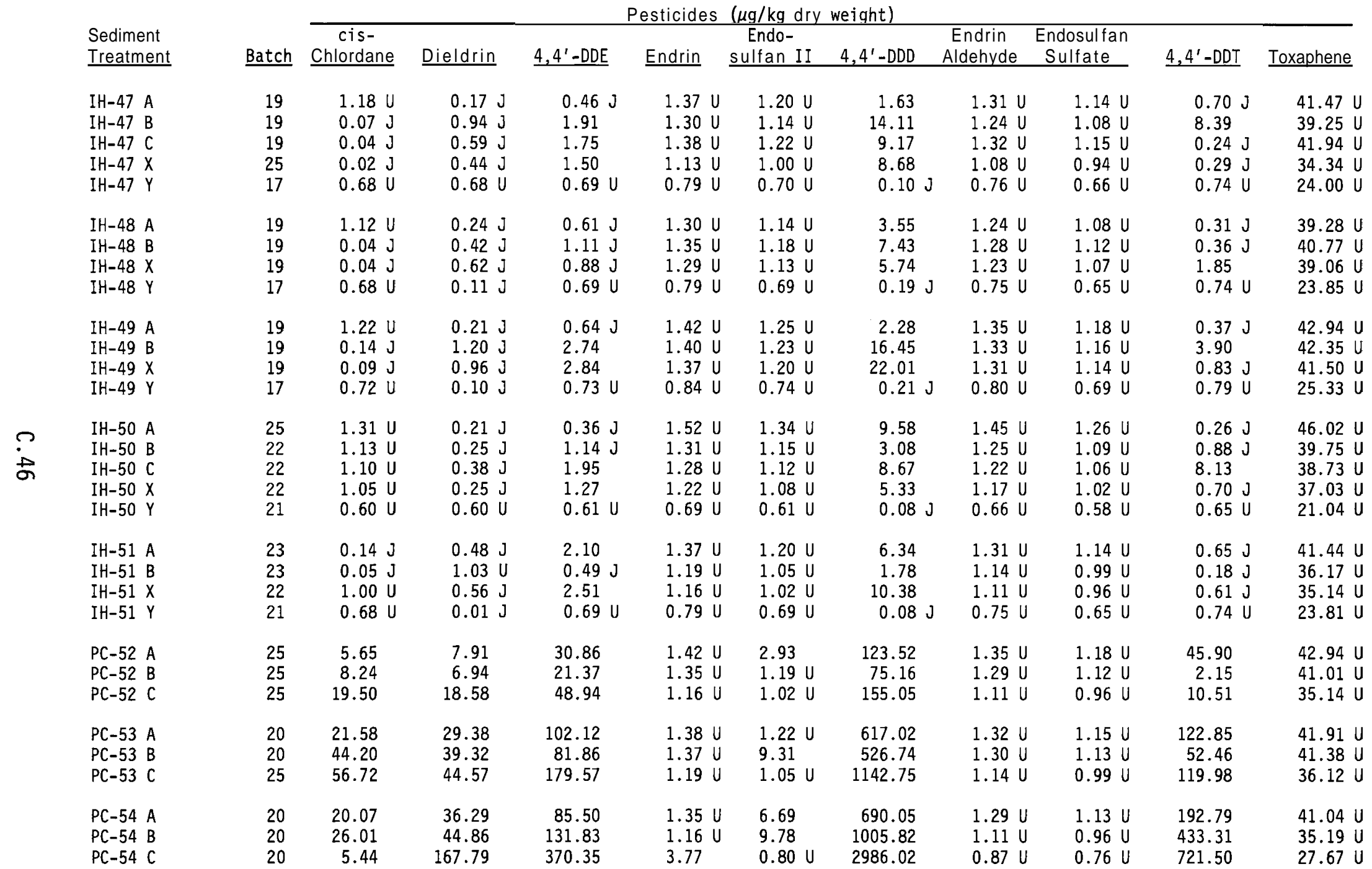


TABLE C.7. (contd)

\begin{tabular}{|c|c|c|c|c|c|c|c|c|c|c|c|}
\hline \multirow{2}{*}{$\begin{array}{l}\text { Sediment } \\
\text { Treatment }\end{array}$} & \multirow[b]{2}{*}{ Batch } & \multicolumn{8}{|c|}{$\frac{\text { Pesticides }(\mu \mathrm{g} / \mathrm{kg} \text { dry weight })}{\text { Endo- }}$} & \multirow[b]{2}{*}{$\underline{4,4^{\prime}-\mathrm{DDT}}$} & \multirow[b]{2}{*}{ Toxaphene } \\
\hline & & $\begin{array}{c}\text { cis- } \\
\text { Chlordane } \\
\end{array}$ & Dieldrin & $\underline{4,4^{\prime}-\mathrm{DDE}}$ & Endrin & $\begin{array}{c}\text { Endo- } \\
\text { sulfan II }\end{array}$ & $4,4^{\prime}-D D D$ & $\begin{array}{c}\text { Endrin } \\
\text { Aldehyde } \\
\end{array}$ & $\begin{array}{c}\text { Endosulfan } \\
\text { Sulfate } \\
\end{array}$ & & \\
\hline $\begin{array}{l}\text { SFC Marina } \\
\text { FSFC Edge-West } \\
\text { Parr Canal Edge } \\
\text { IHC Edge-East } \\
\text { IHC Edge-West } \\
\text { Outer Harbor Edge }\end{array}$ & $\begin{array}{l}23 \\
24 \\
24 \\
23 \\
23 \\
23\end{array}$ & $\begin{array}{l}0.18 \mathrm{~J} \\
1.41 \mathrm{U} \\
4.30 \mathrm{U} \\
1.46 \mathrm{U} \\
1.35 \mathrm{U} \\
0.07 \mathrm{~J}\end{array}$ & $\begin{array}{r}1.98 \\
5.66 \\
11.55 \\
1.77 \mathrm{~J} \\
0.47 \mathrm{~J} \\
1.15 \mathrm{U}\end{array}$ & $\begin{array}{r}7.17 \\
23.44 \\
56.54 \\
4.81 \\
0.84 \mathrm{~J} \\
0.36 \mathrm{~J}\end{array}$ & $\begin{array}{l}1.87 \mathrm{U} \\
1.64 \mathrm{U} \\
1.23 \mathrm{U} \\
1.69 \mathrm{U} \\
1.56 \mathrm{U} \\
1.33 \mathrm{U}\end{array}$ & $\begin{array}{l}1.65 \mathrm{U} \\
1.44 \mathrm{U} \\
1.09 \mathrm{U} \\
1.49 \mathrm{U} \\
1.37 \mathrm{U} \\
1.17 \mathrm{U}\end{array}$ & $\begin{array}{r}46.54 \\
140.83 \\
327.83 \\
28.01 \\
2.68 \\
1.70\end{array}$ & $\begin{array}{l}1.79 \mathrm{U} \\
1.56 \mathrm{U} \\
1.18 \mathrm{U} \\
1.62 \mathrm{U} \\
1.49 \mathrm{U} \\
1.27 \mathrm{U}\end{array}$ & $\begin{array}{l}1.55 \mathrm{U} \\
1.36 \mathrm{U} \\
1.03 \mathrm{U} \\
1.41 \mathrm{U} \\
1.30 \mathrm{U} \\
1.10 \mathrm{U}\end{array}$ & $\begin{array}{r}8.67 \\
90.83 \\
758.73 \\
4.33 \\
0.90 \mathrm{~J} \\
0.49 \mathrm{~J}\end{array}$ & $\begin{array}{l}56.70 \mathrm{U} \\
49.59 \mathrm{U} \\
37.41 \mathrm{U} \\
51.27 \mathrm{U} \\
47.31 \mathrm{U} \\
40.24 \mathrm{U}\end{array}$ \\
\hline $\begin{array}{l}\text { C-SFBF } \\
\text { C-SFBC }\end{array}$ & $\begin{array}{l}21 \\
21\end{array}$ & $\begin{array}{l}0.98 U \\
0.65 U\end{array}$ & $\begin{array}{l}0.98 \mathrm{U} \\
0.01 \mathrm{~J}\end{array}$ & $\begin{array}{l}0.99 \mathrm{U} \\
0.01 \mathrm{~J}\end{array}$ & $\begin{array}{l}1.14 \mathrm{U} \\
0.75 \mathrm{U}\end{array}$ & $\begin{array}{l}1.00 \mathrm{U} \\
0.66 \mathrm{U}\end{array}$ & $\begin{array}{l}2.48 \\
0.82 U\end{array}$ & $\begin{array}{l}1.08 U \\
0.72 U\end{array}$ & $\begin{array}{l}0.94 U \\
0.62 U\end{array}$ & $\begin{array}{l}0.62 \mathrm{~J} \\
0.71 \mathrm{U}\end{array}$ & $\begin{array}{l}34.40 u \\
22.76 \mathrm{l}\end{array}$ \\
\hline
\end{tabular}

(a) DL Detection limit; detection limits are elevated in some batches because of sample dilutions.

(b) U Analyte was not present above the associated value.

(c) J Analyte detected below method detection limit (MDL), but above instrument detection limit (IDL). 
TABLE C.8. Qualit y Control Data for Chlorinated Pesticides (elution order, Alpha-BHC to Endosulfan I) in Younger Bay Mud from Selected Cores and Sediment Composites, United Heckathorn Remedial Investigation

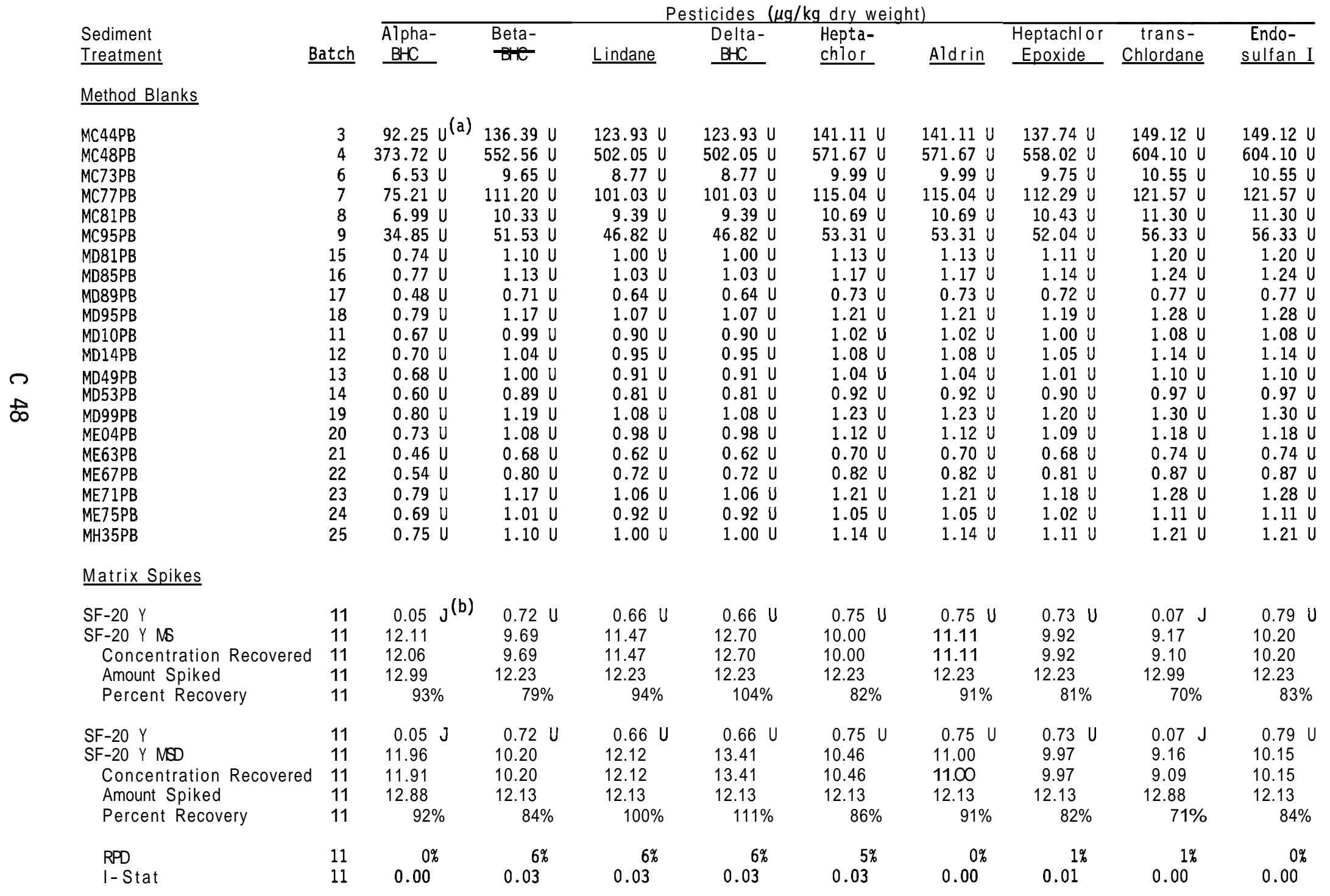


TABLE C.8. (contd)

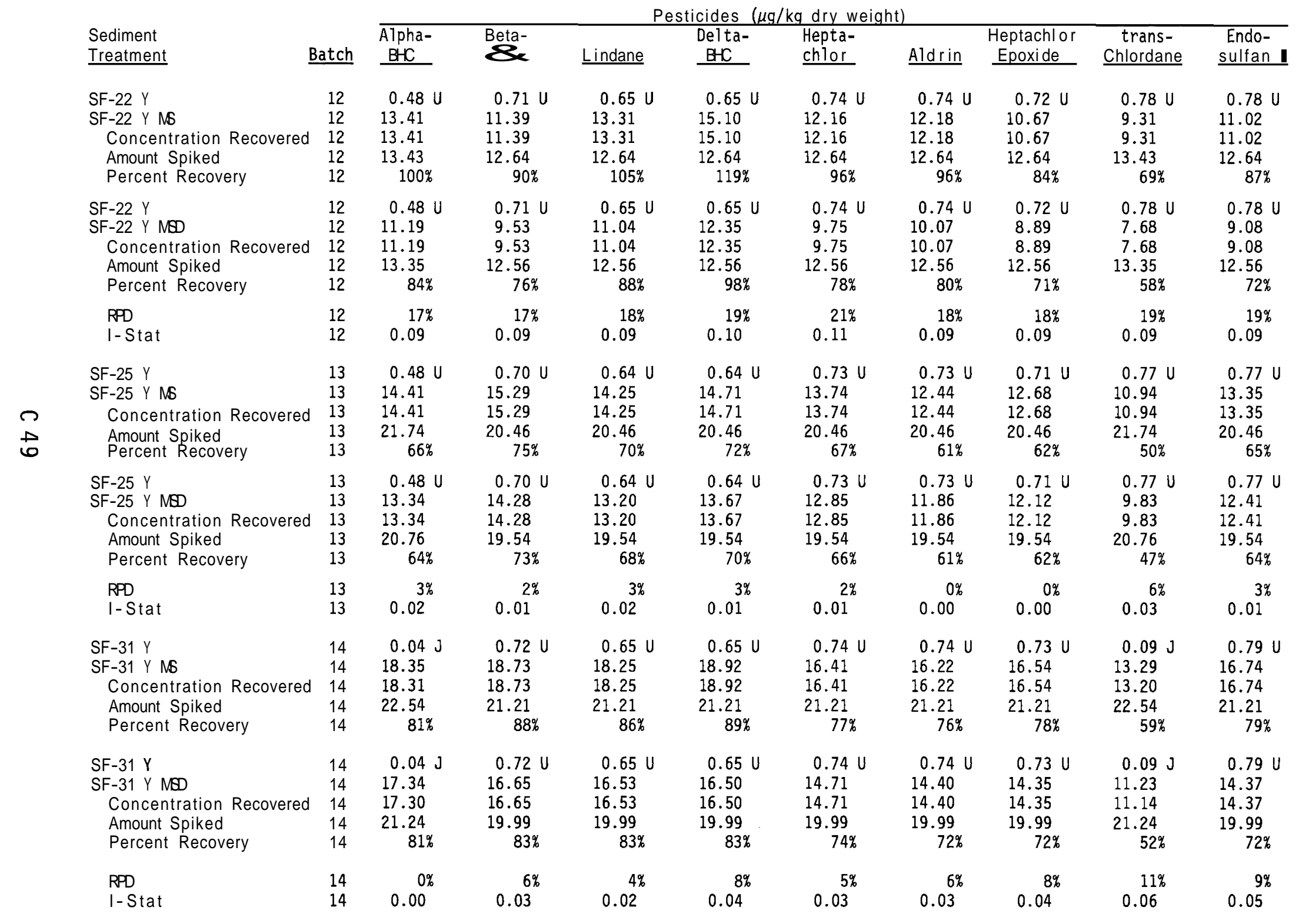


TABLE C.8. (contd)

\begin{tabular}{|c|c|c|c|c|c|c|c|c|c|c|}
\hline & & & & & icides $(\mu$ & g dry wei & & & & \\
\hline $\begin{array}{l}\text { Sediment } \\
\text { Treatment } \\
\end{array}$ & Batch & $\begin{array}{l}\text { Alpha- } \\
\text { BHC } \\
\end{array}$ & $\begin{array}{l}\text { Beta- } \\
\mathrm{BHC} \\
\end{array}$ & $\underline{\text { Lindane }}$ & $\begin{array}{l}\text { Delta- } \\
\text { BHC } \\
\end{array}$ & $\begin{array}{l}\text { Hepta- } \\
\text { chlor } \\
\end{array}$ & $\underline{\text { Aldrin }}$ & $\begin{array}{l}\text { Heptachlor } \\
\text { Epoxide }\end{array}$ & $\begin{array}{c}\text { trans- } \\
\text { Chlordane }\end{array}$ & $\begin{array}{c}\text { Endo- } \\
\text { sulfan I }\end{array}$ \\
\hline $\begin{array}{l}\mathrm{IH}-35 \text { Y } \\
\text { IH-35 Y NS } \\
\text { Concentration Recovered } \\
\text { Amount Spiked } \\
\text { Percent Recovery }\end{array}$ & $\begin{array}{l}15 \\
15 \\
15 \\
15 \\
15\end{array}$ & $\begin{array}{c}0.49 \mathrm{U} \\
9.49 \\
9.49 \\
13.47 \\
70 \%\end{array}$ & $\begin{array}{c}0.72 \mathrm{U} \\
9.95 \\
9.95 \\
12.68 \\
78 \%\end{array}$ & $\begin{array}{c}0.65 \mathrm{U} \\
8.53 \\
8.53 \\
12.68 \\
67 \%\end{array}$ & $\begin{array}{c}0.65 \mathrm{U} \\
8.42 \\
8.42 \\
12.68 \\
66 \%\end{array}$ & $\begin{array}{c}0.74 U \\
8.71 \\
8.71 \\
12.68 \\
69 \%\end{array}$ & $\begin{array}{c}0.74 \mathrm{U} \\
7.96 \\
7.96 \\
12.68 \\
63 \%\end{array}$ & $\begin{array}{c}0.73 \mathrm{U} \\
8.26 \\
8.26 \\
12.68 \\
65 \%\end{array}$ & $\begin{array}{c}0.79 \mathrm{U} \\
6.73 \\
6.73 \\
13.47 \\
50 \%\end{array}$ & $\begin{array}{c}0.79 \mathrm{U} \\
8.17 \\
8.17 \\
12.68 \\
64 \%\end{array}$ \\
\hline $\begin{array}{l}\text { IH-35 Y } \\
\text { IH-35 Y MSD } \\
\text { Concentration Recovered } \\
\text { Amount Spiked } \\
\text { Percent Recovery }\end{array}$ & $\begin{array}{l}15 \\
15 \\
15 \\
15 \\
15\end{array}$ & $\begin{array}{c}0.49 \mathrm{U} \\
8.68 \\
8.68 \\
13.65 \\
64 \%\end{array}$ & $\begin{array}{c}0.72 \mathrm{U} \\
9.22 \\
9.22 \\
12.85 \\
72 \%\end{array}$ & $\begin{array}{c}0.65 \mathrm{U} \\
7.82 \\
7.82 \\
12.85 \\
61 \%\end{array}$ & $\begin{array}{c}0.65 \mathrm{U} \\
7.79 \\
7.79 \\
12.85 \\
61 \%\end{array}$ & $\begin{array}{c}0.74 \mathrm{U} \\
8.28 \\
8.28 \\
12.85 \\
64 \%\end{array}$ & $\begin{array}{c}0.74 \mathrm{U} \\
7.32 \\
7.32 \\
12.85 \\
57 \%\end{array}$ & $\begin{array}{c}0.73 \quad \mathrm{U} \\
7.62 \\
7.62 \\
12.85 \\
59 \%\end{array}$ & $\begin{array}{c}0.79 \mathrm{U} \\
6.19 \\
6.19 \\
13.65 \\
45 \%\end{array}$ & $\begin{array}{c}0.79 \mathrm{U} \\
7.32 \\
7.32 \\
12.85 \\
57 \%\end{array}$ \\
\hline $\begin{array}{l}\text { RPD } \\
\text { I-Stat }\end{array}$ & $\begin{array}{l}15 \\
15\end{array}$ & $\begin{array}{l}10 \% \\
0.05\end{array}$ & 0.04 & $\begin{array}{l}10 \% \\
0.05\end{array}$ & 0.05 & 0.03 & $\begin{array}{l}10 \% \\
0.05\end{array}$ & $0.05 \%$ & $\begin{array}{l}10 \% \\
0.05\end{array}$ & $\begin{array}{l}12 \% \\
0.06\end{array}$ \\
\hline $\begin{array}{l}\text { IH-38 Y } \\
\text { IH-38 Y NS } \\
\text { Concentration Recovered } \\
\text { Amount Spiked } \\
\text { Percent Recovery }\end{array}$ & $\begin{array}{l}16 \\
16 \\
16 \\
16 \\
16\end{array}$ & $\begin{array}{c}0.48 \mathrm{U} \\
10.52 \\
10.52 \\
13.13 \\
80 \%\end{array}$ & $\begin{array}{c}0.71 U \\
10.89 \\
10.89 \\
12.36 \\
88 \%\end{array}$ & $\begin{array}{c}0.64 \mathrm{U} \\
9.35 \\
9.35 \\
12.36 \\
76 \%\end{array}$ & $\begin{array}{c}0.64 U \\
9.81 \\
9.81 \\
12.36 \\
79 \%\end{array}$ & $\begin{array}{c}0.73 \mathrm{U} \\
9.77 \\
9.77 \\
12.36 \\
79 \%\end{array}$ & $\begin{array}{c}0.73 \mathrm{U} \\
8.43 \\
8.43 \\
12.36 \\
68 \%\end{array}$ & $\begin{array}{c}0.72 \quad U \\
8.98 \\
8.98 \\
12.36 \\
73 \%\end{array}$ & $\begin{array}{c}0.77 \mathrm{U} \\
7.33 \\
7.33 \\
13.13 \\
56 \%\end{array}$ & $\begin{array}{c}0.77 \mathrm{U} \\
8.88 \\
8.88 \\
12.36 \\
72 \%\end{array}$ \\
\hline $\begin{array}{l}\text { IH-38 Y } \\
\text { IH-38 Y MSD } \\
\text { Concentration Recovered } \\
\text { Amount Spiked } \\
\text { Percent Recovery }\end{array}$ & $\begin{array}{l}16 \\
16 \\
16 \\
16 \\
16\end{array}$ & $\begin{array}{r}0.48 \mathrm{U} \\
11.15 \\
11.15 \\
13.55 \\
82 \%\end{array}$ & $\begin{array}{r}0.71 \mathrm{U} \\
11.24 \\
11.24 \\
12.75 \\
88 \%\end{array}$ & $\begin{array}{c}0.64 U \\
9.89 \\
9.89 \\
12.75 \\
78 \%\end{array}$ & $\begin{array}{c}0.64 U \\
10.23 \\
10.23 \\
12.75 \\
80 \%\end{array}$ & $\begin{array}{c}0.73 \mathrm{U} \\
9.98 \\
9.98 \\
12.75 \\
78 \%\end{array}$ & $\begin{array}{c}0.73 \mathrm{U} \\
8.87 \\
8.87 \\
12.75 \\
70 \%\end{array}$ & $\begin{array}{c}0.72 \quad U \\
9.26 \\
9.26 \\
12.75 \\
73 \%\end{array}$ & $\begin{array}{c}0.77 \mathrm{U} \\
7.43 \\
7.43 \\
13.55 \\
55 \%\end{array}$ & $\begin{array}{c}0.77 \mathrm{U} \\
9.01 \\
9.01 \\
12.75 \\
71 \%\end{array}$ \\
\hline $\begin{array}{l}\text { RPD } \\
\text { I-Stat }\end{array}$ & $\begin{array}{l}16 \\
16\end{array}$ & 0.01 & 0.00 & 0.01 & 0.01 & $0.00^{1 \%}$ & 0.01 & $0.00^{0 \%}$ & $0.01^{2 \%}$ & 0.01 \\
\hline $\begin{array}{l}\mathrm{IH}-49 \text { Y } \\
\text { IH-49 Y MS } \\
\text { Concentration Recovered } \\
\text { Amount Spiked } \\
\text { Percent Recovery }\end{array}$ & $\begin{array}{l}17 \\
17 \\
17 \\
17 \\
17\end{array}$ & $\begin{array}{c}0.50 \mathrm{U} \\
14.59 \\
14.59 \\
14.06 \\
104 \%\end{array}$ & $\begin{array}{r}0.74 \mathrm{U} \\
11.67 \\
11.67 \\
13.23 \\
88 \%\end{array}$ & $\begin{array}{l}0.67 \mathrm{U} \\
13.35 \\
13.35 \\
13.23 \\
101 \%\end{array}$ & $\begin{array}{c}0.67 \mathrm{U} \\
14.64 \\
14.64 \\
13.23 \\
111 \%\end{array}$ & $\begin{array}{c}0.76 \mathrm{U} \\
12.57 \\
12.57 \\
13.23 \\
95 \%\end{array}$ & $\begin{array}{c}0.76 \mathrm{U} \\
13.90 \\
13.90 \\
13.23 \\
105 \%\end{array}$ & $\begin{array}{c}0.74 \mathrm{U} \\
10.84 \\
10.84 \\
13.23 \\
82 \%\end{array}$ & $\begin{array}{c}0.80 \mathrm{U} \\
10.24 \\
10.24 \\
14.06 \\
73 \%\end{array}$ & $\begin{array}{l}0.80 \mathrm{U} \\
12.48 \\
12.48 \\
13.23 \\
94 \%\end{array}$ \\
\hline $\begin{array}{l}\text { IH-49 Y } \\
\text { IH-49 Y MSD } \\
\text { Concentration Recovered } \\
\text { Amount Spiked } \\
\text { Percent Recovery }\end{array}$ & $\begin{array}{l}17 \\
17 \\
17 \\
17 \\
17\end{array}$ & $\begin{array}{c}0.50 \mathrm{U} \\
12.80 \\
12.80 \\
14.08 \\
91 \%\end{array}$ & $\begin{array}{r}0.74 U \\
11.22 \\
11.22 \\
13.25 \\
85 \%\end{array}$ & $\begin{array}{r}0.67 \mathrm{U} \\
12.46 \\
12.46 \\
13.25 \\
94 \%\end{array}$ & $\begin{array}{c}0.67 \mathrm{U} \\
13.95 \\
13.95 \\
13.25 \\
105 \%\end{array}$ & $\begin{array}{r}0.76 \mathrm{U} \\
11.83 \\
11.83 \\
13.25 \\
89 \%\end{array}$ & $\begin{array}{c}0.76 \mathrm{U} \\
12.93 \\
12.93 \\
13.25 \\
98 \%\end{array}$ & $\begin{array}{c}0.74 \mathrm{U} \\
10.72 \\
10.72 \\
13.25 \\
81 \%\end{array}$ & $\begin{array}{c}0.80 \mathrm{U} \\
9.78 \\
9.78 \\
14.08 \\
69 \%\end{array}$ & $\begin{array}{c}0.80 \mathrm{U} \\
11.89 \\
11.89 \\
13.25 \\
90 \%\end{array}$ \\
\hline
\end{tabular}


TABLE C.8. (contd)

\begin{tabular}{|c|c|c|c|c|c|c|c|c|c|c|}
\hline & & & & & icides $(\mu$ & g dry wei & & & & \\
\hline $\begin{array}{l}\text { Sediment } \\
\text { Treatment } \\
\end{array}$ & Batch & $\begin{array}{l}\text { Alpha- } \\
\text { BHC }\end{array}$ & $\begin{array}{l}\text { Beta- } \\
\text { BHC }\end{array}$ & $\underline{\text { Lindane }}$ & $\begin{array}{l}\text { Delta- } \\
\text { BHC } \\
\end{array}$ & $\begin{array}{l}\text { Hepta- } \\
\text { chlor } \\
\end{array}$ & $\underline{\text { Aldrin }}$ & $\begin{array}{l}\text { Heptachlor } \\
\text { Epoxide } \\
\end{array}$ & $\begin{array}{c}\text { trans- } \\
\text { Chlordane } \\
\end{array}$ & $\begin{array}{l}\begin{array}{r}\text { Endo- } \\
\text { sulfan I }\end{array} \\
\end{array}$ \\
\hline $\begin{array}{l}\mathrm{IH}-43 \text { Y } \\
\mathrm{IH}-43 \text { Y MS } \\
\text { Concentration Recovered } \\
\text { Amount Spiked } \\
\text { Percent Recovery }\end{array}$ & $\begin{array}{l}18 \\
18 \\
18 \\
18 \\
18\end{array}$ & $\begin{array}{r}0.48 U \\
12.54 \\
12.54 \\
13.12 \\
96 \%\end{array}$ & $\begin{array}{l}0.70 \mathrm{U} \\
11.57 \\
11.57 \\
12.35 \\
94 \%\end{array}$ & $\begin{array}{l}0.64 U \\
12.36 \\
12.36 \\
12.35 \\
100 \%\end{array}$ & $\begin{array}{c}0.64 \mathrm{U} \\
13.96 \\
13.96 \\
12.35 \\
113 \%\end{array}$ & $\begin{array}{c}0.73 \mathrm{U} \\
12.59 \\
12.59 \\
12.35 \\
102 \%\end{array}$ & $\begin{array}{c}0.73 \mathrm{U} \\
12.33 \\
12.33 \\
12.35 \\
100 \%\end{array}$ & $\begin{array}{c}0.71 U \\
10.69 \\
10.69 \\
12.35 \\
87 \%\end{array}$ & $\begin{array}{l}0.77 U \\
10.25 \\
10.25 \\
13.12 \\
78 \%\end{array}$ & $\begin{array}{l}0.77 \mathrm{U} \\
11.19 \\
11.19 \\
12.35 \\
91 \%\end{array}$ \\
\hline $\begin{array}{l}\mathrm{IH}-43 \text { Y } \\
\mathrm{IH}-43 \text { Y MSD } \\
\text { Concentration Recovered } \\
\text { Amount Spiked } \\
\text { Percent Recovery }\end{array}$ & $\begin{array}{l}18 \\
18 \\
18 \\
18 \\
18\end{array}$ & $\begin{array}{r}0.48 U \\
12.53 \\
12.53 \\
13.32 \\
94 \%\end{array}$ & $\begin{array}{c}0.70 \mathrm{U} \\
10.90 \\
10.90 \\
12.54 \\
87 \%\end{array}$ & $\begin{array}{l}0.64 U \\
12.08 \\
12.08 \\
12.54 \\
96 \%\end{array}$ & $\begin{array}{c}0.64 \mathrm{U} \\
13.11 \\
13.11 \\
12.54 \\
105 \%\end{array}$ & $\begin{array}{r}0.73 \mathrm{U} \\
11.93 \\
11.93 \\
12.54 \\
95 \%\end{array}$ & $\begin{array}{l}0.73 \mathrm{U} \\
11.74 \\
11.74 \\
12.54 \\
94 \%\end{array}$ & $\begin{array}{c}0.71 \mathrm{U} \\
9.97 \\
9.97 \\
12.54 \\
80 \%\end{array}$ & $\begin{array}{c}0.77 U \\
9.44 \\
9.44 \\
13.32 \\
71 \%\end{array}$ & $\begin{array}{l}0.77 \mathrm{U} \\
10.66 \\
10.66 \\
12.54 \\
85 \%\end{array}$ \\
\hline $\begin{array}{l}\text { RPD } \\
\text { I-Stat }\end{array}$ & $\begin{array}{l}18 \\
18\end{array}$ & 0.01 & 0.04 & $0.02^{4 \%}$ & 0.04 & $0.03^{7 \%}$ & 0.03 & 0.04 & $\begin{array}{l}10 \% \\
0.05\end{array}$ & 0.03 \\
\hline $\begin{array}{l}\mathrm{IH}-46 \text { Y } \\
\text { IH-46 Y MS } \\
\text { Concentration Recovered } \\
\text { Amount Spiked } \\
\text { Percent Recovery }\end{array}$ & $\begin{array}{l}19 \\
19 \\
19 \\
19 \\
19\end{array}$ & $\begin{array}{r}0.48 \mathrm{U} \\
9.23 \\
9.23 \\
13.32 \\
69 \%\end{array}$ & $\begin{array}{c}0.71 \mathrm{U} \\
9.89 \\
9.89 \\
12.54 \\
79 \%\end{array}$ & $\begin{array}{c}0.65 U \\
8.98 \\
8.98 \\
12.54 \\
72 \%\end{array}$ & $\begin{array}{c}0.65 \mathrm{U} \\
9.02 \\
9.02 \\
12.54 \\
72 \%\end{array}$ & $\begin{array}{c}0.74 \mathrm{U} \\
9.47 \\
9.47 \\
12.54 \\
76 \%\end{array}$ & $\begin{array}{c}0.74 \mathrm{U} \\
8.48 \\
8.48 \\
12.54 \\
68 \%\end{array}$ & $\begin{array}{c}0.72 \mathrm{U} \\
8.98 \\
8.98 \\
12.54 \\
72 \%\end{array}$ & $\begin{array}{c}0.78 U \\
8.02 \\
8.02 \\
13.32 \\
60 \%\end{array}$ & $\begin{array}{c}0.78 \mathrm{U} \\
8.12 \\
8.12 \\
12.54 \\
65 \%\end{array}$ \\
\hline $\begin{array}{l}\text { IH-46 Y } \\
\text { IH-46 Y MSD } \\
\text { Concentration Recovered } \\
\text { Amount Spiked } \\
\text { Percent Recovery }\end{array}$ & $\begin{array}{l}19 \\
19 \\
19 \\
19 \\
19\end{array}$ & $\begin{array}{c}0.48 \mathrm{U} \\
9.17 \\
9.17 \\
13.51 \\
68 \%\end{array}$ & $\begin{array}{c}0.71 \mathrm{U} \\
9.45 \\
9.45 \\
12.72 \\
74 \%\end{array}$ & $\begin{array}{c}0.65 U \\
8.75 \\
8.75 \\
12.72 \\
69 \%\end{array}$ & $\begin{array}{c}0.65 \mathrm{U} \\
8.90 \\
8.90 \\
12.72 \\
70 \%\end{array}$ & $\begin{array}{c}0.74 \mathrm{U} \\
9.22 \\
9.22 \\
12.72 \\
72 \%\end{array}$ & $\begin{array}{c}0.74 \mathrm{U} \\
8.41 \\
8.41 \\
12.72 \\
66 \%\end{array}$ & $\begin{array}{c}0.72 \mathrm{U} \\
8.77 \\
8.77 \\
12.72 \\
69 \%\end{array}$ & $\begin{array}{c}0.78 \mathrm{U} \\
8.00 \\
8.00 \\
13.51 \\
59 \%\end{array}$ & $\begin{array}{l}0.78 \mathrm{U} \\
11.68 \\
11.68 \\
12.72 \\
92 \%\end{array}$ \\
\hline $\begin{array}{l}\text { RPD } \\
\text { I-Stat }\end{array}$ & $\begin{array}{l}19 \\
19\end{array}$ & 0.01 & 0.03 & $0.02^{4 \%}$ & 0.01 & 0.02 & 0.01 & $0.02^{4 \%}$ & 0.01 & $\begin{array}{l}35 \%(c) \\
0.17^{3}\end{array}$ \\
\hline $\begin{array}{l}\mathrm{IH}-45 \text { Y } \\
\mathrm{IH}-45 \text { Y NS } \\
\text { Concentration Recovered } \\
\text { Amount Spiked } \\
\text { Percent Recovery }\end{array}$ & $\begin{array}{l}20 \\
20 \\
20 \\
20 \\
20\end{array}$ & $\begin{array}{c}0.48 U \\
8.49 \\
8.49 \\
12.80 \\
66 \%\end{array}$ & $\begin{array}{c}0.71 \mathrm{U} \\
8.57 \\
8.57 \\
12.05 \\
71 \%\end{array}$ & $\begin{array}{c}0.65 \mathrm{U} \\
7.17 \\
7.17 \\
12.05 \\
60 \%\end{array}$ & $\begin{array}{c}0.65 \mathrm{U} \\
6.74 \\
6.74 \\
12.05 \\
56 \%\end{array}$ & $\begin{array}{c}0.74 \mathrm{U} \\
7.97 \\
7.97 \\
12.05 \\
66 \%\end{array}$ & $\begin{array}{c}0.74 \mathrm{U} \\
6.00 \\
6.00 \\
12.05 \\
50 \%\end{array}$ & $\begin{array}{c}0.72 \mathrm{U} \\
6.61 \\
6.61 \\
12.05 \\
55 \%\end{array}$ & $\begin{array}{c}0.78 \mathrm{U} \\
6.26 \\
6.26 \\
12.80 \\
49 \%\end{array}$ & $\begin{array}{c}0.78 \mathrm{U} \\
8.41 \\
8.41 \\
12.05 \\
70 \%\end{array}$ \\
\hline $\begin{array}{l}\mathrm{IH}-45 \text { Y } \\
\text { IH-45 Y MSD } \\
\text { Concentration Recovered } \\
\text { Amount Spiked } \\
\text { Percent Recovery }\end{array}$ & $\begin{array}{l}20 \\
20 \\
20 \\
20 \\
20\end{array}$ & $\begin{array}{c}0.48 \mathrm{U} \\
9.52 \\
9.52 \\
12.85 \\
74 \%\end{array}$ & $\begin{array}{c}0.71 \mathrm{U} \\
9.43 \\
9.43 \\
12.10 \\
78 \%\end{array}$ & $\begin{array}{c}0.65 \mathrm{U} \\
7.99 \\
7.99 \\
12.10 \\
66 \%\end{array}$ & $\begin{array}{c}0.65 \mathrm{U} \\
7.71 \\
7.71 \\
12.10 \\
64 \%\end{array}$ & $\begin{array}{c}0.74 \mathrm{U} \\
8.72 \\
8.72 \\
12.10 \\
72 \%\end{array}$ & $\begin{array}{c}0.74 \mathrm{U} \\
6.77 \\
6.77 \\
12.10 \\
56 \%\end{array}$ & $\begin{array}{c}0.72 \mathrm{U} \\
7.56 \\
7.56 \\
12.10 \\
62 \%\end{array}$ & $\begin{array}{c}0.78 \mathrm{U} \\
6.84 \\
6.84 \\
12.85 \\
53 \%\end{array}$ & $\begin{array}{c}0.78 \mathrm{U} \\
7.64 \\
7.64 \\
12.10 \\
63 \%\end{array}$ \\
\hline
\end{tabular}


TABLE C.8. (contd)

\begin{tabular}{|c|c|c|c|c|c|c|c|c|c|c|}
\hline & & & & & cides $(\mu \mathrm{g} /$ & dry weigh & & & & \\
\hline $\begin{array}{l}\text { Sediment } \\
\text { Treatment } \\
\end{array}$ & Batch & $\begin{array}{l}\text { Alpha- } \\
\text { BHC } \\
\end{array}$ & $\begin{array}{l}\text { Beta- } \\
\text { BHC } \\
\end{array}$ & $\underline{\text { Lindane }}$ & $\begin{array}{l}\text { Delta- } \\
\text { BHC }\end{array}$ & $\begin{array}{l}\text { Hepta- } \\
\text { chlor }\end{array}$ & Aldrin & $\begin{array}{l}\text { Heptachlor } \\
\text { Epoxide }\end{array}$ & $\begin{array}{c}\text { trans- } \\
\text { Chlordane }\end{array}$ & $\begin{array}{l}\begin{array}{c}\text { Endo- } \\
\text { sulfan I }\end{array} \\
\end{array}$ \\
\hline $\begin{array}{l}\text { IH-50 Y } \\
\text { IH-50 Y MS } \\
\text { Concentration Recovered } \\
\text { Amount Spiked } \\
\text { Percent Recovery }\end{array}$ & $\begin{array}{l}21 \\
21 \\
21 \\
21 \\
21\end{array}$ & $\begin{array}{c}0.41 \mathrm{U} \\
6.79 \\
6.79 \\
11.89 \\
57 \%\end{array}$ & $\begin{array}{c}0.61 \mathrm{U} \\
7.29 \\
7.29 \\
11.19 \\
65 \%\end{array}$ & $\begin{array}{l}0.56 \mathrm{U} \\
6.01 \\
6.01 \\
11.19 \\
54 \%\end{array}$ & $\begin{array}{l}0.56 \mathrm{U} \\
5.71 \\
5.71 \\
11.19 \\
51 \%\end{array}$ & $\begin{array}{c}0.63 \mathrm{U} \\
7.20 \\
7.20 \\
11.19 \\
64 \%\end{array}$ & $\begin{array}{c}0.63 \mathrm{U} \\
5.00 \\
5.00 \\
11.19 \\
45 \%\end{array}$ & $\begin{array}{c}0.62 \mathrm{U} \\
5.72 \\
5.72 \\
11.19 \\
51 \%\end{array}$ & $\begin{array}{r}0.67 \mathrm{U} \\
5.19 \\
5.19 \\
11.89 \\
44 \%\end{array}$ & $\begin{array}{l}0.67 \mathrm{U} \\
5.71 \\
5.71 \\
11.19 \\
51 \%\end{array}$ \\
\hline $\begin{array}{l}\text { IH-50 Y } \\
\text { IH-50 Y MSD } \\
\text { Concentration Recovered } \\
\text { Amount Spiked } \\
\text { Percent Recovery }\end{array}$ & $\begin{array}{l}21 \\
21 \\
21 \\
21 \\
21\end{array}$ & $\begin{array}{l}0.41 \mathrm{U} \\
8.21 \\
8.21 \\
11.81 \\
70 \%\end{array}$ & $\begin{array}{c}0.61 \mathrm{U} \\
7.93 \\
7.93 \\
11.12 \\
71 \%\end{array}$ & $\begin{array}{r}0.56 \mathrm{U} \\
7.02 \\
7.02 \\
11.12 \\
63 \%\end{array}$ & $\begin{array}{r}0.56 \mathrm{U} \\
6.46 \\
6.46 \\
11.12 \\
58 \%\end{array}$ & $\begin{array}{c}0.63 \mathrm{U} \\
7.75 \\
7.75 \\
11.12 \\
70 \%\end{array}$ & $\begin{array}{c}0.63 \mathrm{U} \\
5.91 \\
5.91 \\
11.12 \\
53 \%\end{array}$ & $\begin{array}{c}0.62 \mathrm{U} \\
6.28 \\
6.28 \\
11.12 \\
56 \%\end{array}$ & $\begin{array}{c}0.67 \mathrm{U} \\
5.69 \\
5.69 \\
11.81 \\
48 \%\end{array}$ & $\begin{array}{l}0.67 \mathrm{U} \\
6.34 \\
6.34 \\
11.12 \\
57 \%\end{array}$ \\
\hline $\begin{array}{l}\text { RPD } \\
\text { I-Stat }\end{array}$ & $\begin{array}{l}21 \\
21\end{array}$ & $\begin{array}{l}20 \% \\
0.10\end{array}$ & 0.05 & $\begin{array}{l}16 \% \\
0.08\end{array}$ & $\begin{array}{l}13 \% \\
0.06\end{array}$ & 0.04 & $\begin{array}{l}17 \% \\
0.09\end{array}$ & $\begin{array}{l}10 \% \\
0.05\end{array}$ & $\begin{array}{l}10 \% \\
0.05\end{array}$ & $\begin{array}{l}11 \% \\
0.06\end{array}$ \\
\hline $\begin{array}{l}\text { LZ-14 Y } \\
\text { LZ-14 Y NS } \\
\text { Concentration Recovered } \\
\text { Amount Spiked } \\
\text { Percent Recovery }\end{array}$ & $\begin{array}{l}22 \\
22 \\
22 \\
22 \\
22\end{array}$ & $\begin{array}{c}0.43 U \\
8.68 \\
8.68 \\
12.09 \\
72 \%\end{array}$ & $\begin{array}{c}0.64 U \\
8.52 \\
8.52 \\
11.37 \\
75 \%\end{array}$ & $\begin{array}{c}0.58 \mathrm{U} \\
7.59 \\
7.59 \\
11.37 \\
67 \%\end{array}$ & $\begin{array}{c}0.58 \mathrm{~V} \\
6.91 \\
6.91 \\
11.37 \\
61 \%\end{array}$ & $\begin{array}{c}0.66 \mathrm{U} \\
8.70 \\
8.70 \\
11.37 \\
77 \%\end{array}$ & $\begin{array}{c}0.66 U \\
6.03 \\
6.03 \\
11.37 \\
53 \%\end{array}$ & $\begin{array}{c}0.65 \mathrm{U} \\
6.83 \\
6.83 \\
11.37 \\
60 \%\end{array}$ & $\begin{array}{c}0.70 \mathrm{U} \\
5.92 \\
5.92 \\
12.09 \\
49 \%\end{array}$ & $\begin{array}{c}0.70 \mathrm{U} \\
6.67 \\
6.67 \\
11.37 \\
59 \%\end{array}$ \\
\hline $\begin{array}{l}\text { LZ-14 Y } \\
\text { LZ-14 Y MSD } \\
\text { Concentration Recovered } \\
\text { Amount Spiked } \\
\text { Percent Recovery }\end{array}$ & $\begin{array}{l}22 \\
22 \\
22 \\
22 \\
22\end{array}$ & $\begin{array}{c}0.43 \mathrm{U} \\
7.37 \\
7.37 \\
12.00 \\
61 \%\end{array}$ & $\begin{array}{c}0.64 \mathrm{U} \\
7.37 \\
7.37 \\
11.29 \\
65 \%\end{array}$ & $\begin{array}{c}0.58 \mathrm{U} \\
6.50 \\
6.50 \\
11.29 \\
58 \%\end{array}$ & $\begin{array}{c}0.58 \mathrm{U} \\
5.93 \\
5.93 \\
11.29 \\
53 \%\end{array}$ & $\begin{array}{c}0.66 \mathrm{U} \\
7.35 \\
7.35 \\
11.29 \\
65 \%\end{array}$ & $\begin{array}{c}0.66 \mathrm{U} \\
5.17 \\
5.17 \\
11.29 \\
46 \%\end{array}$ & $\begin{array}{c}0.65 \mathrm{U} \\
5.82 \\
5.82 \\
11.29 \\
52 \%\end{array}$ & $\begin{array}{c}0.70 \mathrm{U} \\
5.00 \\
5.00 \\
12.00 \\
42 \%\end{array}$ & $\begin{array}{c}0.70 \mathrm{U} \\
5.74 \\
5.74 \\
11.29 \\
51 \%\end{array}$ \\
\hline $\begin{array}{l}\text { RPD } \\
\text { I-Stat }\end{array}$ & $\begin{array}{l}22 \\
22\end{array}$ & $\begin{array}{c}16 \% \\
0.08\end{array}$ & $\begin{array}{l}14 \% \\
0.07\end{array}$ & $\begin{array}{l}15 \% \\
0.07\end{array}$ & $\begin{array}{l}15 \% \\
0.07\end{array}$ & $\begin{array}{l}16 \% \\
0.08\end{array}$ & $\begin{array}{l}15 \% \\
0.07\end{array}$ & $\begin{array}{l}15 \% \\
0.08\end{array}$ & $\begin{array}{c}16 \% \\
0.08\end{array}$ & $\begin{array}{l}14 \% \\
0.07\end{array}$ \\
\hline $\begin{array}{l}\text { LZ-14 Y } \\
\text { LZ-14 Y MS } \\
\text { Concentration Recovered } \\
\text { Amount Spiked } \\
\text { Percent Recovery }\end{array}$ & $\begin{array}{l}23 \\
23 \\
23 \\
23 \\
23\end{array}$ & $\begin{array}{c}0.43 \text { U } \\
8.38 \\
8.38 \\
11.94 \\
70 \%\end{array}$ & $\begin{array}{c}0.64 \mathrm{U} \\
9.72 \\
9.72 \\
11.24 \\
86 \%\end{array}$ & $\begin{array}{c}0.58 \mathrm{U} \\
8.37 \\
8.37 \\
11.24 \\
74 \%\end{array}$ & $\begin{array}{c}0.58 \mathrm{U} \\
8.43 \\
8.43 \\
11.24 \\
75 \%\end{array}$ & $\begin{array}{c}0.66 \mathrm{U} \\
9.00 \\
9.00 \\
11.24 \\
80 \%\end{array}$ & $\begin{array}{c}0.66 \mathrm{U} \\
7.41 \\
7.41 \\
11.24 \\
66 \%\end{array}$ & $\begin{array}{c}0.65 \mathrm{U} \\
8.50 \\
8.50 \\
11.24 \\
76 \%\end{array}$ & $\begin{array}{c}0.70 \mathrm{U} \\
7.12 \\
7.12 \\
11.94 \\
60 \%\end{array}$ & $\begin{array}{c}0.70 \mathrm{U} \\
10.92 \\
10.92 \\
11.24 \\
97 \%\end{array}$ \\
\hline $\begin{array}{l}\text { LZ-14 Y } \\
\text { LZ-14 Y MSD } \\
\text { Concentration Recovered } \\
\text { Amount Spiked } \\
\text { Percent Recovery }\end{array}$ & $\begin{array}{l}23 \\
23 \\
23 \\
23 \\
23\end{array}$ & $\begin{array}{c}0.43 \mathrm{U} \\
5.37 \\
5.37 \\
12.10 \\
44 \%\end{array}$ & $\begin{array}{c}0.64 U \\
6.98 \\
6.98 \\
11.39 \\
61 \%\end{array}$ & $\begin{array}{c}0.58 \cup \\
5.58 \\
5.58 \\
11.39 \\
49 \%\end{array}$ & $\begin{array}{c}0.58 \cup \\
5.72 \\
5.72 \\
11.39 \\
50 \%\end{array}$ & $\begin{array}{c}0.66 \mathrm{U} \\
6.44 \\
6.44 \\
11.39 \\
57 \%\end{array}$ & $\begin{array}{c}0.66 \mathrm{U} \\
5.01 \\
5.01 \\
11.39 \\
44 \%\end{array}$ & $\begin{array}{c}0.65 \cup \\
6.29 \\
6.29 \\
11.39 \\
55 \%\end{array}$ & $\begin{array}{c}0.70 \mathrm{U} \\
4.90 \\
4.90 \\
12.10 \\
40 \%\end{array}$ & $\begin{array}{c}0.70 \mathrm{U} \\
7.72 \\
7.72 \\
11.39 \\
68 \%\end{array}$ \\
\hline
\end{tabular}


TABLE C.8. (contd)

\begin{tabular}{|c|c|c|c|c|c|c|c|c|c|c|}
\hline \multirow[b]{2}{*}{$\begin{array}{l}\text { Sediment } \\
\text { Treatment }\end{array}$} & \multirow[b]{2}{*}{ Batch } & \multicolumn{8}{|c|}{ Pesticides $(\mu \mathrm{g} / \mathrm{kg}$ dry weight $)$} & \multirow[b]{2}{*}{$\begin{array}{c}\text { Endo- } \\
\text { sulfan I }\end{array}$} \\
\hline & & $\begin{array}{l}\text { Alpha- } \\
\text { BHC }\end{array}$ & $\begin{array}{c}\text { Beta- } \\
\text { BHC } \\
\end{array}$ & $\underline{\text { Lindane }}$ & $\begin{array}{l}\text { Delta- } \\
\text { BHC }\end{array}$ & $\begin{array}{l}\text { Hepta- } \\
\text { chlor } \\
\end{array}$ & Aldrin & $\begin{array}{c}\text { Heptachl or } \\
\text { Epoxide } \\
\end{array}$ & $\begin{array}{c}\text { trans- } \\
\text { Chlordane } \\
\end{array}$ & \\
\hline $\begin{array}{l}\text { LZ-14 Y } \\
\text { LZ-14 Y MS } \\
\text { Concentration Recovered } \\
\text { Amount Spiked } \\
\text { Percent Recovery }\end{array}$ & $\begin{array}{l}24 \\
24 \\
24 \\
24 \\
24\end{array}$ & $\begin{array}{c}0.43 \mathrm{U} \\
8.84 \\
8.84 \\
11.85 \\
75 \%\end{array}$ & $\begin{array}{c}0.64 \mathrm{U} \\
9.45 \\
9.45 \\
11.15 \\
85 \%\end{array}$ & $\begin{array}{c}0.58 \mathrm{U} \\
8.58 \\
8.58 \\
11.15 \\
77 \%\end{array}$ & $\begin{array}{c}0.58 \mathrm{U} \\
8.37 \\
8.37 \\
11.15 \\
75 \%\end{array}$ & $\begin{array}{c}0.66 \mathrm{U} \\
8.44 \\
8.44 \\
11.15 \\
76 \%\end{array}$ & $\begin{array}{c}0.66 \mathrm{U} \\
7.04 \\
7.04 \\
11.15 \\
63 \%\end{array}$ & $\begin{array}{c}0.65 \mathrm{U} \\
8.41 \\
8.41 \\
11.15 \\
75 \%\end{array}$ & $\begin{array}{c}0.70 \mathrm{U} \\
6.88 \\
6.88 \\
11.85 \\
58 \%\end{array}$ & $\begin{array}{c}0.70 \mathrm{U} \\
11.77 \\
11.77 \\
11.15 \\
106 \%\end{array}$ \\
\hline $\begin{array}{l}\text { LZ-14 Y } \\
\text { LZ-14 Y MSD } \\
\text { Concentration Recovered } \\
\text { Amount Spiked } \\
\text { Percent Recovery }\end{array}$ & $\begin{array}{l}24 \\
24 \\
24 \\
24 \\
24\end{array}$ & $\begin{array}{c}0.43 \mathrm{U} \\
9.63 \\
9.63 \\
11.89 \\
81 \%\end{array}$ & $\begin{array}{c}0.64 \mathrm{U} \\
9.95 \\
9.95 \\
11.19 \\
89 \%\end{array}$ & $\begin{array}{c}0.58 \mathrm{U} \\
9.34 \\
9.34 \\
11.19 \\
83 \%\end{array}$ & $\begin{array}{c}0.58 \mathrm{U} \\
9.06 \\
9.06 \\
11.19 \\
81 \%\end{array}$ & $\begin{array}{c}0.66 \mathrm{U} \\
8.91 \\
8.91 \\
11.19 \\
80 \%\end{array}$ & $\begin{array}{c}0.66 \mathrm{U} \\
7.76 \\
7.76 \\
11.19 \\
69 \%\end{array}$ & $\begin{array}{c}0.65 \mathrm{U} \\
8.83 \\
8.83 \\
11.19 \\
79 \%\end{array}$ & $\begin{array}{c}0.70 \mathrm{U} \\
7.20 \\
7.20 \\
11.89 \\
61 \%\end{array}$ & $\begin{array}{c}0.70 \mathrm{U} \\
11.60 \\
11.60 \\
11.19 \\
104 \%\end{array}$ \\
\hline $\begin{array}{l}\text { RPD } \\
\text { I-Stat }\end{array}$ & $\begin{array}{l}24 \\
24\end{array}$ & 0.04 & 0.02 & 0.04 & $\begin{array}{c}8 \% \\
0.04\end{array}$ & $\begin{array}{l}5 \% \\
0.03\end{array}$ & 0.05 & 0.02 & 0.02 & 0.01 \\
\hline $\begin{array}{l}\text { IH-50 A } \\
\text { IH-50 A MS } \\
\text { Concentration Recovered } \\
\text { Amount Spiked } \\
\text { Percent Recovery }\end{array}$ & $\begin{array}{l}25 \\
25 \\
25 \\
25 \\
25\end{array}$ & $\begin{array}{c}0.90 \mathrm{U} \\
11.77 \\
11.77 \\
25.33 \\
46 \%\end{array}$ & $\begin{array}{l}1.34 \mathrm{U} \\
12.37 \\
12.37 \\
23.84 \\
52 \%\end{array}$ & $\begin{array}{l}1.21 \mathrm{U} \\
11.01 \\
11.01 \\
23.84 \\
46 \%\end{array}$ & $\begin{array}{l}1.21 \mathrm{U} \\
10.25 \\
10.25 \\
23.84 \\
43 \%\end{array}$ & $\begin{array}{l}1.38 \mathrm{U} \\
12.33 \\
12.33 \\
23.84 \\
52 \%\end{array}$ & $\begin{array}{l}1.38 \mathrm{U} \\
11.10 \\
11.10 \\
23.84 \\
47 \%\end{array}$ & $\begin{array}{l}1.35 \mathrm{U} \\
10.15 \\
10.15 \\
23.84 \\
43 \%\end{array}$ & $\begin{array}{c}1.46 \mathrm{U} \\
9.36 \\
9.36 \\
25.83 \\
36 \%(\mathrm{~d})\end{array}$ & $\begin{array}{l}1.46 \mathrm{U} \\
11.51 \\
11.51 \\
23.84 \\
48 \%\end{array}$ \\
\hline $\begin{array}{l}\text { IH-50 A } \\
\text { IH-50 A MSD } \\
\text { Concentration Recovered } \\
\text { Amount Spiked } \\
\text { Percent Recovery }\end{array}$ & $\begin{array}{l}25 \\
25 \\
25 \\
25 \\
25\end{array}$ & $\begin{array}{c}0.90 \mathrm{U} \\
11.79 \\
11.79 \\
25.46 \\
46 \%\end{array}$ & $\begin{array}{l}1.34 \mathrm{U} \\
13.45 \\
13.45 \\
23.96 \\
56 \%\end{array}$ & $\begin{array}{l}1.21 \mathrm{U} \\
11.87 \\
11.87 \\
23.96 \\
50 \%\end{array}$ & $\begin{array}{l}1.21 \mathrm{U} \\
11.36 \\
11.36 \\
23.96 \\
47 \%\end{array}$ & $\begin{array}{l}1.38 \mathrm{U} \\
13.08 \\
13.08 \\
23.96 \\
55 \%\end{array}$ & $\begin{array}{l}1.38 \mathrm{U} \\
12.05 \\
12.05 \\
23.96 \\
50 \%\end{array}$ & $\begin{array}{c}1.35 \mathrm{U} \\
11.40 \\
11.40 \\
23.96 \\
48 \%\end{array}$ & $\begin{array}{c}1.46 \mathrm{U} \\
10.38 \\
10.38 \\
25.96 \\
40 \%\end{array}$ & $\begin{array}{l}1.46 \mathrm{U} \\
13.30 \\
13.30 \\
23.96 \\
56 \%\end{array}$ \\
\hline $\begin{array}{l}\text { RPD } \\
\text { I-Stat }\end{array}$ & $\begin{array}{l}25 \\
25\end{array}$ & $0.0 \%$ & $\begin{array}{l}8 \% \\
0.04\end{array}$ & 0.04 & $\begin{array}{l}10 \% \\
0.05\end{array}$ & 0.03 & 0.04 & $\begin{array}{l}11 \% \\
0.06\end{array}$ & $\begin{array}{l}10 \% \\
0.05\end{array}$ & $\begin{array}{l}14 \% \\
0.07\end{array}$ \\
\hline \multicolumn{11}{|l|}{ Analvtical Duplicates } \\
\hline $\begin{array}{l}\text { LZ-1 D } \\
\text { LZ-1 D Duplicate } \\
\quad \text { RPD } \\
\text { I-Stat }\end{array}$ & $\begin{array}{l}3 \\
3 \\
3 \\
3\end{array}$ & $\begin{array}{c}1731.23 \cup \\
1767.55 \\
\text { NA } \\
\text { NA }\end{array}$ & $\begin{array}{c}2559.68 \mathrm{U} \\
2613.40 \mathrm{U} \\
\text { NA } \\
\text { NA }\end{array}$ & $\begin{array}{c}2325.69 \mathrm{U} \\
2374.50 \mathrm{U} \\
\text { NA } \\
\text { NA }\end{array}$ & $\begin{array}{c}2325.69 \mathrm{U} \\
2374.50 \mathrm{U} \\
\text { NA } \\
\text { NA }\end{array}$ & $\begin{array}{c}2648.22 \mathrm{U} \\
2703.79 \mathrm{U} \\
\text { NA } \\
\text { NA }\end{array}$ & $\begin{array}{c}2648.22 \mathrm{U} \\
2703.79 \mathrm{U} \\
\text { NA } \\
\text { NA }\end{array}$ & $\begin{array}{c}2584.98 \mathrm{U} \\
2639.23 \mathrm{U} \\
\text { NA } \\
\text { NA }\end{array}$ & $\begin{array}{c}2798.42 \mathrm{U} \\
2857.14 \mathrm{U} \\
\text { NA } \\
\text { NA }\end{array}$ & $\begin{array}{c}2798.42 \mathrm{U} \\
2857.14 \mathrm{U} \\
\text { NA } \\
\text { NA }\end{array}$ \\
\hline $\begin{array}{l}\text { LZ-2 B } \\
\text { LZ-2 B Duplicate } \\
\text { RPD } \\
\text { I-Stat }\end{array}$ & $\begin{array}{l}4 \\
4 \\
4 \\
4\end{array}$ & $\begin{array}{c}1483.74 \text { U } \\
367.94 \mathrm{U} \\
\text { NA } \\
\text { NA }\end{array}$ & $\begin{array}{c}2193.77 \mathrm{U} \\
544.02 \mathrm{U} \\
\text { NA } \\
\text { NA }\end{array}$ & $\begin{array}{c}1993.22 \mathrm{U} \\
494.29 \mathrm{U} \\
\text { NA } \\
\text { NA }\end{array}$ & $\begin{array}{c}1993.22 \mathrm{U} \\
494.29 \mathrm{U} \\
\text { NA } \\
\text { NA }\end{array}$ & $\begin{array}{c}2269.65 \mathrm{U} \\
562.84 \mathrm{U} \\
\text { NA } \\
\text { NA }\end{array}$ & $\begin{array}{r}2269.65 \mathrm{U} \\
562.84 \mathrm{U} \\
\text { NA } \\
\text { NA }\end{array}$ & $\begin{array}{r}2215.45 \mathrm{U} \\
549.40 \mathrm{U} \\
\text { NA } \\
\text { NA }\end{array}$ & $\begin{array}{r}2398.37 \mathrm{U} \\
594.76 \mathrm{U} \\
\text { NA } \\
\text { NA }\end{array}$ & $\begin{array}{r}2398.37 \mathrm{U} \\
594.76 \mathrm{U} \\
\text { NA } \\
\text { NA }\end{array}$ \\
\hline
\end{tabular}


TABLE C.8. (contd)

Sediment

Treatment

LZ-5 A

LZ-5 A Duplicate

RPD

I-Stat

LZ-11 A

LZ-11 A Duplicate RPD

I-Stat

Comp LC-3

Comp LC-3 Duplicate RPD

I-Stat

LZ-13 X

$\cap \quad$ LZ-13 X Duplicate

$\begin{array}{ll}\rightarrow & \text { RPD } \\ \rightarrow & \text { l-Stat }\end{array}$

IH-37X

IH-37 X Duplicate

RPD

I-Stat

IH- $41 X$

IH-41X Duplicate

RPD

IH-49 Y

IH-49 Y Duplicate

RPD

IH-41 A

IH-41 A Duplicate

RPD

I-Stat
Pesticides $(\mu \mathrm{g} / \mathrm{kg}$ dry weight

\begin{tabular}{|c|c|c|c|c|c|c|c|c|c|}
\hline Bateh & $\begin{array}{l}\text { Alpha- } \\
\text { - }\end{array}$ & $\begin{array}{l}\text { Beta- } \\
\text { BHC }\end{array}$ & $\underline{\text { Lindane }}$ & $\begin{array}{c}\text { Delta- } \\
\text { BHC } \\
\end{array}$ & $\begin{array}{l}\text { Hepta- } \\
\text { chlor }\end{array}$ & Aldrin & $\begin{array}{l}\text { Heptachlor } \\
\text { Epoxide }\end{array}$ & $\begin{array}{c}\text { trans- } \\
\text { Chlordane }\end{array}$ & $\begin{array}{c}\text { Endo- } \\
\text { sulfan }\end{array}$ \\
\hline $\begin{array}{l}6 \\
6 \\
6 \\
6\end{array}$ & $\begin{array}{c}326.87 \mathrm{U} \\
323.20 \mathrm{U} \\
\text { NA } \\
\text { NA }\end{array}$ & $\begin{array}{c}483.28 \text { U } \\
477.86 U \\
\text { NA } \\
\text { NA }\end{array}$ & $\begin{array}{c}439.10 \mathrm{U} \\
434.18 \mathrm{U} \\
\text { NA } \\
\text { NA }\end{array}$ & $\begin{array}{c}439.10 \mathrm{U} \\
434.18 \mathrm{U} \\
\text { NA } \\
\text { NA }\end{array}$ & $\begin{array}{c}500.00 \mathrm{U} \\
494.39 \mathrm{U} \\
\text { NA } \\
\text { NA }\end{array}$ & $\begin{array}{c}500.00 \mathrm{U} \\
494.39 \mathrm{U} \\
\text { NA } \\
\text { NA }\end{array}$ & $\begin{array}{c}488.06 U \\
482.59 U \\
\text { NA } \\
\text { NA }\end{array}$ & $\begin{array}{c}528.36 U \\
522.43 U \\
\text { NA } \\
\text { NA }\end{array}$ & $\begin{array}{c}528.36 \mathrm{U} \\
522.43 \mathrm{U} \\
\text { NA } \\
\text { NA }\end{array}$ \\
\hline $\begin{array}{l}7 \\
7 \\
7 \\
7\end{array}$ & $\begin{array}{c}155.89 \cup \\
157.33 \cup \\
N A \\
N A\end{array}$ & $\begin{array}{r}230.50 \text { U } \\
232.61 \text { U } \\
\text { NA } \\
\text { NA }\end{array}$ & $\begin{array}{c}209.42 \text { U } \\
211.35 \mathrm{U} \\
\text { NA } \\
\text { NA }\end{array}$ & $\begin{array}{r}209.42 \mathrm{U} \\
211.35 \mathrm{U} \\
\text { NA } \\
\text { NA }\end{array}$ & $\begin{array}{c}238.47 U \\
240.66 U \\
\text { NA } \\
\text { NA }\end{array}$ & $\begin{array}{r}238.47 U \\
240.66 U \\
\text { NA } \\
\text { NA }\end{array}$ & $\begin{array}{c}232.77 U \\
234.91 U \\
\text { NA } \\
\text { NA }\end{array}$ & $\begin{array}{c}251.99 U \\
254.31 U \\
\text { NA } \\
\text { NA }\end{array}$ & $\begin{array}{c}251.99 \mathrm{U} \\
254.31 \mathrm{U} \\
\text { NA } \\
\text { NA }\end{array}$ \\
\hline $\begin{array}{l}8 \\
8\end{array}$ & $\begin{array}{l}163.04 U \\
386.08 U\end{array}$ & $\begin{array}{r}241.07 \mathrm{U} \\
49.37 \mathrm{U}\end{array}$ & $\begin{array}{r}219.03 \mathrm{U} \\
1862.03 \mathrm{U}\end{array}$ & $\begin{array}{r}219.03 \mathrm{U} \\
1862.03 \mathrm{U}\end{array}$ & $\begin{array}{r}249.40 \mathrm{U} \\
2120.25 \mathrm{U}\end{array}$ & $\begin{array}{r}249.40 \mathrm{U} \\
2120.25 \mathrm{U}\end{array}$ & $\begin{array}{r}243.45 \mathrm{U} \\
2069.62 \mathrm{U}\end{array}$ & $\begin{array}{r}263.55 \mathrm{U} \\
2240.51 \mathrm{U}\end{array}$ & $\begin{array}{r}263.55 \mathrm{U} \\
2240.51 \mathrm{U}\end{array}$ \\
\hline
\end{tabular}

$386.08 \mathrm{U}$

$49.37 U-1862.03 U$

2120.25

NA 2069.62

NA

NA
NA

NA

$154.75 \mathrm{U}$

NA NA

NA

NA

NA

NA

NA

$\begin{array}{lll}148.37 \mathrm{U} & 219.38 \mathrm{U} & 199.32 \mathrm{U}\end{array}$

$\begin{array}{ll}207.89 \mathrm{U} & 236.72 \mathrm{U} \\ 199.32 \mathrm{U} & 226.96 \mathrm{U}\end{array}$

$236.72 \mathrm{U} \quad 231.06 \mathrm{U}$

$250.14 \mathrm{U} \quad 250.14 \mathrm{U}$ $\begin{array}{llll}226.96 & 221.54 \cup \quad 239.84 U & 239.84\end{array}$

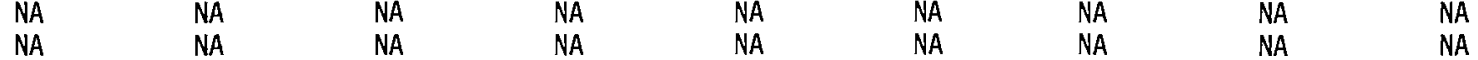

$\begin{array}{lllllllll}0.36 \mathrm{~J} & 1.04 \mathrm{U} & 0.94 \mathrm{U} & 0.94 \mathrm{U} & 1.08 \mathrm{U} & 1.08 \mathrm{U} & 1.05 \mathrm{U} & 0.39 \mathrm{~J} & 0.29 \mathrm{~J}\end{array}$

$1.05 \mathrm{U} \quad 0.95 \mathrm{U}$

$0.94 \mathrm{U}$
$0.95 \mathrm{U}$

$1.08 \mathrm{U}$
$1.08 \mathrm{U}$

$1.08 \mathrm{U}$

$1.06 \mathrm{U}$

$0.29 \mathrm{~J}$
$0.20 \mathrm{~J}$

0.09

NA

NA

NA

NA

NA

$56 \%$

0.18

$\begin{array}{lll}0.35 \mathrm{~J} & 1.08 \mathrm{U} & 0.98\end{array}$

$0.46 \mathrm{~J} \quad 1.06 \mathrm{U}$

$27 \%$

NA

$0.98 \mathrm{U}$

$1.12 \mathrm{U}$

$0.96 \mathrm{U}$

$0.96 \mathrm{U}$

1. 10 UA

$1.12 \mathrm{U} \quad 1.09 \mathrm{U}$

$\begin{array}{ll}1.12 \mathrm{U} & 1.09 \mathrm{U} \\ 1.10 \mathrm{U} & 1.07 \mathrm{U}\end{array}$

$0.80 \mathrm{~J}$

0.18

0.

NA

NA

NA

NA

NA

0.89

$0.25 \mathrm{~J}$

0.05

$25 \%$

$0.74 U$

$0.67 \mathrm{U}$

$0.67 \mathrm{U}$

$0.76 U$

$0.76 \mathrm{U}$

$0.74 U$

$0.80 \mathrm{U}$

0.12

$0.49 \mathrm{U}$
NA

NA

NA

NA

NA

0.75
NA

$0.73 \mathrm{U}$
NA

0.80

$0.80 \mathrm{U}$

NA

NA

NA

$.79 \mathrm{U}$

NA

$0.13 \mathrm{~J}$

$1.11 \mathrm{U}$

$1.26 \mathrm{U}$

$0.33 \mathrm{~J}$

1.22 U

$0.17 \mathrm{~J}$

$27 \%$

$1.11 \mathrm{U}$
$1.10 \mathrm{U}$

$1.10 \mathrm{U}$
$\mathrm{NA}$
$\mathrm{NA}$

$1.25 \mathrm{U}$
NA

NA

$1.26 \mathrm{U} \quad 1.23 \mathrm{U}$

$1.25 \mathrm{U} \quad 1.22 \mathrm{U}$

$\begin{array}{ll}\text { NA } & \text { NA } \\ \text { NA } & \text { NA }\end{array}$

$0.40 \mathrm{~J} \quad 1.33 \mathrm{U}$

$0.54 \mathrm{~J} \quad 1.32 \mathrm{U}$

$30 \%$
0.15 
TABLE C.8. (contd)

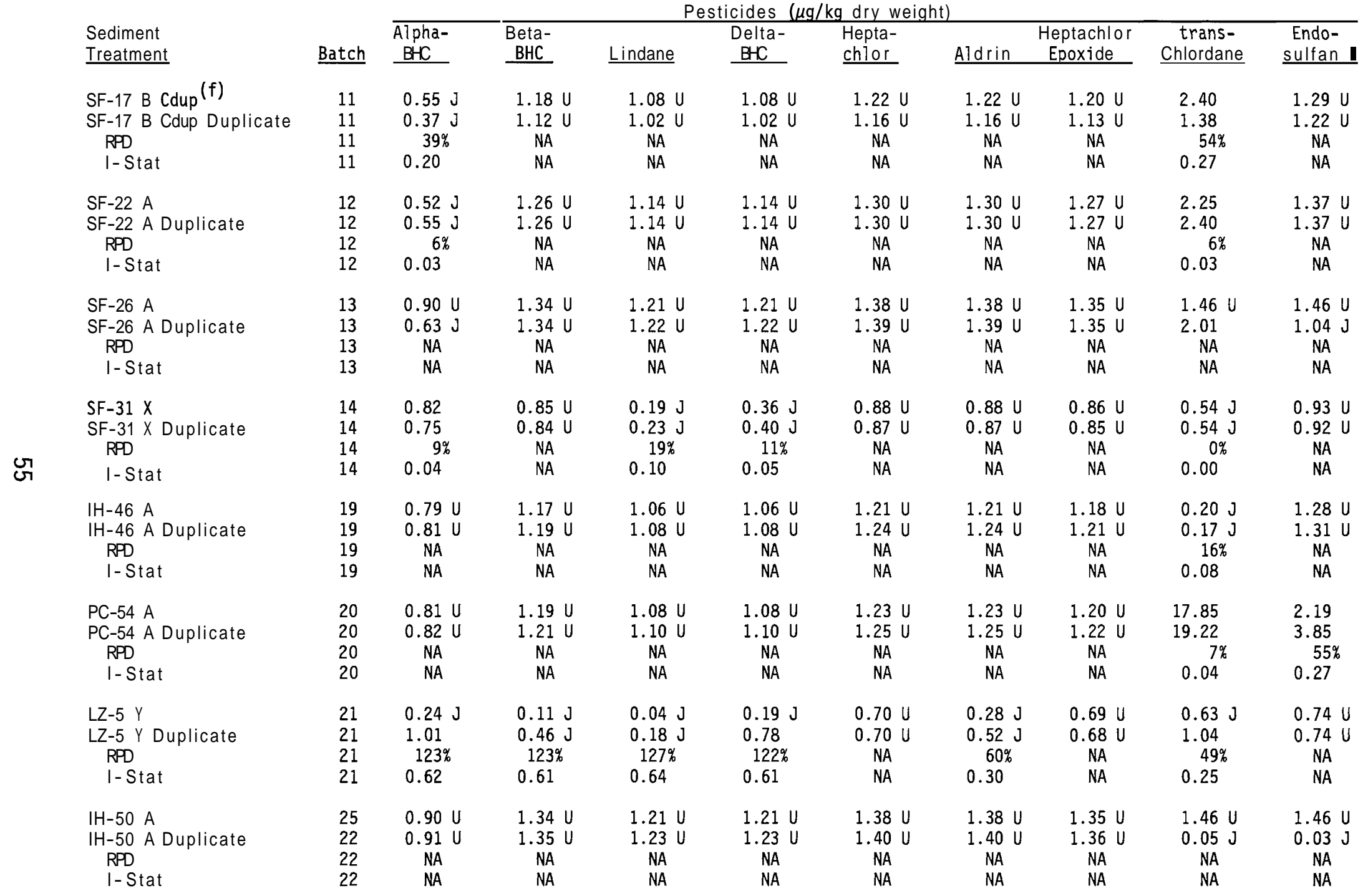


TABLE C.8. (contd)

Sediment

Treatment

Comp USFC

Comp USFC Duplicate

RPD

I- Stat

SF-33 X

SF-33 X Duplicate

$\mathrm{RPD}$

$\mathrm{IH}-40 \mathrm{~B}$

IH-40 B Duplicate

$$
\mathrm{RPD}
$$

I-Stat

\section{Compositing Duplicates}

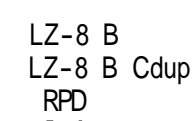

I-Stat

LZ-16 B

LZ-16 B Cdup

RPD

I-Stat

$\mathrm{SF}-17 \mathrm{~B}$

SF-17 B Cdup

RPD
I- Sta

SF-21 C

SF-21 C Cdup

RPD

I- Stat

SF-27 B

SF-27 B Cdup

RPD

I-Stat

23
23
23
23
25
24
24
24
25
25
25
25

$\begin{array}{cc}\begin{array}{c}\text { Alpha- } \\ \text { BHC }\end{array} & \begin{array}{l}\text { Beta- } \\ \text { BHC }\end{array} \\ 0.81 \mathrm{U} & 1.20 \mathrm{U} \\ 0.80 \mathrm{U} & \begin{array}{c}1.19 \mathrm{U} \\ \text { NA }\end{array} \\ \text { NA } & \text { NA } \\ 0.43 \mathrm{~J} & 0.83 \mathrm{U} \\ 1.15 & 0.82 \mathrm{U} \\ 91 \% & \text { NA } \\ 0.46 & \text { NA } \\ 0.79 \mathrm{U} & 1.16 \mathrm{U} \\ 0.09 \mathrm{~J} & 1.13 \mathrm{U} \\ \text { NA } & \text { NA } \\ \text { NA } & \text { NA }\end{array}$

Lindane

ch7or

A]drin $\begin{gathered}\text { Heptachlor } \\ \text { Epoxide }\end{gathered}$

$\begin{array}{ll}1.09 \mathrm{U} & 1.09 \mathrm{U} \\ 1.08 \mathrm{U} & 1.08 \mathrm{U} \\ \text { NA } & \text { NA } \\ \text { NA } & \text { NA }\end{array}$

$1.25 \mathrm{U}$

$1.25 \mathrm{U}$

$1.22 \mathrm{U}$
$1.20 \mathrm{U}$

$1.32 \mathrm{~V}$

1.30

$1.32 \mathrm{U}$

NA

NA

NA

NA

$\mathrm{NA}$

NA

$0.07 \mathrm{~J}$
$0.33 \mathrm{~J}$

$0.76 \mathrm{U} \quad 0.86 \mathrm{U}$

$0.86 U$

$0.84 \mathrm{U}$

1.33

$0.89 \mathrm{U}$

$0.91 \mathrm{U}$

$130 \%$

NA

$0.85 \mathrm{U}$
NA
NA

NA

0.83
NA
NA

NA

.89 U

NA NA

NA

NA

0.22

0.19

$15 \%$

0.07

$1.27 \mathrm{U}$

$1.02 \mathrm{U}$

$1.02 \mathrm{U}$

$1.20 \mathrm{U}$
$1.17 \mathrm{U}$

$1.17 \mathrm{U}$

$1.14 \mathrm{U}$

NA

NA

(n) $\begin{array}{lllll}2058.27 & \mathrm{U} & 3043.23 \mathrm{U} & 2765.04 \mathrm{U} & 276 \\ 1045.85 \mathrm{U} & 1546.32 \mathrm{U} & 1404.97 \mathrm{U} & 140\end{array}$

NA 1546.32 U 1404.97

$2765.04 \mathrm{U}$

$3148.50 \cup$

$3148.50 \mathrm{U} 3073.31 \mathrm{U}$

$3327.07 \mathrm{U} \quad 3327.07 \mathrm{U}$ NA NA

NA

NA

NA

$\begin{array}{rr}\text { NA } & \text { NA } \\ \text { NA } & \text { NA }\end{array}$

NA

NA

$\begin{array}{cc}73.74 \text { U } & 109.02 \mathrm{U} \\ 33.75 \mathrm{U} & 49.91 \mathrm{U} \\ \text { NA } & \text { NA } \\ \text { NA } & \text { NA }\end{array}$

$99.06 \mathrm{U}$

$99.06 \mathrm{U}$

$12.79 \mathrm{U} 112.79$

79 U $\quad 110.10 \mathrm{~V}$

$119.19 \mathrm{U} \quad 119.19 \mathrm{U}$ $45.35 \mathrm{U}$

$45.35 \mathrm{U}$

(12.79

$112.79 \mathrm{U}$
$51.63 \mathrm{U}$

$110.10 \mathrm{U}$
$50.40 \mathrm{U}$

50.40
NA
NA

54.56

NA

$54.56 \mathrm{U}$

NA

NA

NA

NA

$\begin{array}{ccccccccc}0.58 \mathrm{~J} & 1.16 \mathrm{U} & 1.06 \mathrm{U} & 1.06 \mathrm{U} & 1.20 \mathrm{U} & 1.20 \mathrm{U} & 1.17 \mathrm{U} & 1.54 & 1.27 \mathrm{U} \\ 0.55 \mathrm{~J} & 1.18 \mathrm{U} & 1.08 \mathrm{U} & 1.08 \mathrm{U} & 1.22 \mathrm{U} & 1.22 \mathrm{U} & 1.20 \mathrm{U} & 2.40 & 1.29 \mathrm{U} \\ 5 \% & \text { NA } & \text { NA } & \text { NA } & \text { NA } & \text { NA } & \text { NA } & 44 \% & \text { NA }\end{array}$

0.03 NA

NA

NA

NA

NA

NA

$44 \%$

$0.50 \mathrm{~J} \quad 1.21$

$1.10 \mathrm{U}$

$1.10 \mathrm{U}$

$1.25 \mathrm{U}$

$1.25 \mathrm{U} \quad 1.22 \mathrm{~V}$

0.22

$0.84 \mathrm{~J} \quad 1.33 \mathrm{~J}$$$
0.51
$$$$
0.50
$$$$
2 \%
$$$$
1.23 \mathrm{U}
$$$$
1.23 \mathrm{U}
$$

$1.12 \mathrm{U}$

NA

$1.26 \mathrm{U}$
NA

$1.26 \mathrm{U}$

$1.23 \mathrm{U}$

0.01

NA

NA

$0.25 \mathrm{~J}$
$1.09 \mathrm{U}$

$1.27 \mathrm{U}$

$1.25 \mathrm{U}$

$1.27 \mathrm{U}$

$1.25 \mathrm{U}$

$1.24 \mathrm{U}$

NA

NA

NA

NA
NA

$1.14 \mathrm{~J} \quad 1.33 \mathrm{~J}$

0.15

$0.53 \mathrm{~J} \quad 1.35 \mathrm{U}$

$0.69 \mathrm{~J} \quad 0.63 \mathrm{~J}$

0.13

NA 
TABLE C.8. (contd)

\begin{tabular}{|c|c|c|c|c|c|c|c|c|c|c|}
\hline \multirow{2}{*}{$\begin{array}{l}\text { Sediment } \\
\text { Treatment } \\
\end{array}$} & \multirow[b]{2}{*}{ Batch } & \multicolumn{6}{|c|}{$\frac{\text { Pesticides }(\mu \mathrm{g} / \mathrm{kg} \text { dry weight })}{\text { Delta- }}$} & \multirow[b]{2}{*}{$\begin{array}{l}\text { Heptachlor } \\
\text { Epoxide } \\
\end{array}$} & \multirow[b]{2}{*}{$\begin{array}{c}\text { trans- } \\
\text { Chlordane } \\
\end{array}$} & \multirow[b]{2}{*}{$\begin{array}{l}\text { Endo- } \\
\text { sulfan }\end{array}$} \\
\hline & & $\begin{array}{l}\text { Alpha- } \\
\text { BHC } \\
\end{array}$ & $\begin{array}{l}\text { Beta- } \\
\text { BHC }\end{array}$ & $\underline{\text { Lindane }}$ & $\begin{array}{l}\text { Delta- } \\
\mathrm{BHC} \\
\end{array}$ & $\begin{array}{l}\text { Hepta- } \\
\text { chlor } \\
\end{array}$ & Aldrin & & & \\
\hline $\begin{array}{l}\text { IH-36 B } \\
\text { IH-36 B Cdup } \\
\text { RPD } \\
\text { I-Stat }\end{array}$ & $\begin{array}{l}15 \\
15 \\
15 \\
15\end{array}$ & $\begin{array}{l}0.60 \mathrm{~J} \\
0.62 \mathrm{~J} \\
3 \% \\
0.02\end{array}$ & $\begin{array}{c}1.00 \mathrm{U} \\
0.98 \mathrm{U} \\
\mathrm{NA} \\
\mathrm{NA}\end{array}$ & $\begin{array}{l}0.91 U \\
0.89 \mathrm{U} \\
\text { NA } \\
\text { NA }\end{array}$ & $\begin{array}{c}0.91 \mathrm{U} \\
0.89 \mathrm{U} \\
\text { NA } \\
\text { NA }\end{array}$ & $\begin{array}{c}1.04 \mathrm{U} \\
1.01 \mathrm{U} \\
\mathrm{NA} \\
\mathrm{NA}\end{array}$ & $\begin{array}{c}1.04 \mathrm{U} \\
1.01 \mathrm{U} \\
\mathrm{NA} \\
\mathrm{NA}\end{array}$ & $\begin{array}{c}1.01 \mathrm{U} \\
0.99 \mathrm{U} \\
\text { NA } \\
\text { NA }\end{array}$ & $\begin{array}{l}0.60 \mathrm{~J} \\
1.02 \mathrm{~J} \\
52 \% \\
0.26\end{array}$ & $\begin{array}{l}0.44 \mathrm{~J} \\
0.53 \mathrm{~J} \\
19 \% \\
0.09\end{array}$ \\
\hline $\begin{array}{l}\text { IH-37 B } \\
\text { IH-37 B Cdup } \\
\text { RPD } \\
\text { I-Stat }\end{array}$ & $\begin{array}{l}15 \\
15 \\
15 \\
15\end{array}$ & $\begin{array}{c}0.86 U \\
0.84 U \\
\text { NA } \\
\text { NA }\end{array}$ & $\begin{array}{c}1.27 \mathrm{U} \\
1.25 \mathrm{U} \\
\text { NA } \\
\text { NA }\end{array}$ & $\begin{array}{l}1.15 \mathrm{U} \\
1.13 \mathrm{U} \\
\mathrm{NA} \\
\mathrm{NA}\end{array}$ & $\begin{array}{l}1.15 \mathrm{U} \\
1.13 \mathrm{U} \\
\mathrm{NA} \\
\mathrm{NA}\end{array}$ & $\begin{array}{c}1.31 \mathrm{U} \\
1.29 \mathrm{U} \\
\text { NA } \\
\text { NA }\end{array}$ & $\begin{array}{c}1.31 \mathrm{U} \\
1.29 \mathrm{U} \\
\text { NA } \\
\text { NA }\end{array}$ & $\begin{array}{c}1.28 \mathrm{U} \\
1.26 \mathrm{U} \\
\text { NA } \\
\text { NA }\end{array}$ & $\begin{array}{l}0.30 \mathrm{~J} \\
0.37 \mathrm{~J} \\
21 \% \\
0.10\end{array}$ & $\begin{array}{l}0.06 \mathrm{~J} \\
0.05 \mathrm{~J} \\
18 \% \\
0.09\end{array}$ \\
\hline $\begin{array}{l}\text { IH-39 B } \\
\text { IH-39 B Cdup } \\
\text { RPD } \\
\text { I-Stat }\end{array}$ & $\begin{array}{l}16 \\
16 \\
16 \\
16\end{array}$ & $\begin{array}{l}0.49 \mathrm{~J} \\
0.43 \mathrm{~J} \\
13 \% \\
0.07\end{array}$ & $\begin{array}{c}1.18 \mathrm{U} \\
1.19 \mathrm{U} \\
\mathrm{NA} \\
\mathrm{NA}\end{array}$ & $\begin{array}{c}1.07 \mathrm{U} \\
0.14 \mathrm{~J} \\
\text { NA } \\
\text { NA }\end{array}$ & $\begin{array}{c}1.07 \mathrm{U} \\
1.08 \mathrm{U} \\
\text { NA } \\
\text { NA }\end{array}$ & $\begin{array}{c}1.22 \mathrm{U} \\
1.23 \mathrm{U} \\
\text { NA } \\
\text { NA }\end{array}$ & $\begin{array}{c}1.22 \mathrm{U} \\
1.23 \mathrm{U} \\
\text { NA } \\
\text { NA }\end{array}$ & $\begin{array}{c}1.19 \mathrm{U} \\
1.20 \mathrm{U} \\
\text { NA } \\
\text { NA }\end{array}$ & $\begin{array}{l}0.55 \mathrm{~J} \\
1.06 \mathrm{~J} \\
63 \% \\
0.32\end{array}$ & $\begin{array}{l}0.45 \mathrm{~J} \\
0.66 \mathrm{~J} \\
38 \% \\
0.19\end{array}$ \\
\hline $\begin{array}{l}\mathrm{IH}-43 \text { B } \\
\mathrm{IH}-43 \text { B Cdup } \\
\mathrm{RPD} \\
\text { I-Stat }\end{array}$ & $\begin{array}{l}18 \\
18 \\
18 \\
18\end{array}$ & $\begin{array}{l}0.30 \mathrm{~J} \\
0.31 \mathrm{~J} \\
3 \% \\
0.02\end{array}$ & $\begin{array}{c}1.22 \mathrm{U} \\
1.17 \mathrm{U} \\
\text { NA } \\
\text { NA }\end{array}$ & $\begin{array}{l}0.13 \mathrm{~J} \\
0.15 \mathrm{~J} \\
14 \% \\
0.07\end{array}$ & $\begin{array}{c}1.11 \mathrm{U} \\
1.06 \mathrm{U} \\
\text { NA } \\
\text { NA }\end{array}$ & $\begin{array}{c}1.26 \mathrm{U} \\
1.21 \mathrm{U} \\
\text { NA } \\
\text { NA }\end{array}$ & $\begin{array}{l}1.26 \mathrm{U} \\
1.21 \mathrm{U} \\
\mathrm{NA} \\
\mathrm{NA}\end{array}$ & $\begin{array}{l}1.23 \mathrm{U} \\
1.18 \mathrm{U} \\
\mathrm{NA} \\
\mathrm{NA}\end{array}$ & $\begin{array}{l}0.53 \mathrm{~J} \\
0.68 \mathrm{~J} \\
25 \% \\
0.12\end{array}$ & $\begin{array}{l}1.33 \mathrm{U} \\
1.28 \mathrm{U} \\
\text { NA } \\
\text { NA }\end{array}$ \\
\hline $\begin{array}{l}\text { Parr Canal Edge } \\
\text { Parr Canal Edge Cdup } \\
\text { RPD } \\
\text { I-Stat }\end{array}$ & $\begin{array}{l}24 \\
24 \\
24 \\
24\end{array}$ & $\begin{array}{l}0.73 \mathrm{U} \\
0.87 \mathrm{U} \\
\text { NA } \\
\text { NA }\end{array}$ & $\begin{array}{l}1.09 \mathrm{U} \\
1.29 \mathrm{U} \\
\text { NA } \\
\text { NA }\end{array}$ & $\begin{array}{l}0.99 \mathrm{U} \\
1.17 \mathrm{U} \\
\text { NA } \\
\text { NA }\end{array}$ & $\begin{array}{l}0.99 \mathrm{U} \\
1.17 \mathrm{U} \\
\text { NA } \\
\text { NA }\end{array}$ & $\begin{array}{l}1.12 \mathrm{U} \\
1.34 \mathrm{U} \\
\text { NA } \\
\text { NA }\end{array}$ & $\begin{array}{c}1.12 \mathrm{U} \\
1.34 \mathrm{U} \\
\mathrm{NA} \\
\mathrm{NA}\end{array}$ & $\begin{array}{l}1.10 \mathrm{U} \\
1.30 \mathrm{U} \\
\mathrm{NA} \\
\mathrm{NA}\end{array}$ & $\begin{array}{l}1.19 U \\
2.32 \\
\text { NA } \\
\text { NA }\end{array}$ & $\begin{array}{l}1.19 \mathrm{U} \\
1.41 \mathrm{U} \\
\text { NA } \\
\text { NA }\end{array}$ \\
\hline $\begin{array}{l}\text { Comp LC } \\
\text { Comp LC Cdup } \\
\text { RPD } \\
\text { I-Stat }\end{array}$ & $\begin{array}{l}3 \\
3 \\
3 \\
3\end{array}$ & $\begin{array}{c}382.60 \mathrm{U} \\
370.93 \mathrm{U} \\
\text { NA } \\
\text { NA }\end{array}$ & $\begin{array}{c}565.69 \text { U } \\
548.44 U \\
\text { NA } \\
\text { NA }\end{array}$ & $\begin{array}{c}513.98 \mathrm{U} \\
498.31 \mathrm{U} \\
\text { NA } \\
\text { NA }\end{array}$ & $\begin{array}{c}513.98 \mathrm{U} \\
498.31 \mathrm{U} \\
\text { NA } \\
\text { NA }\end{array}$ & $\begin{array}{c}585.26 \text { U } \\
567.41 \mathrm{U} \\
\text { NA } \\
\text { NA }\end{array}$ & $\begin{array}{c}585.26 \mathrm{U} \\
567.41 \mathrm{U} \\
\text { NA } \\
\text { NA }\end{array}$ & $\begin{array}{c}571.28 \mathrm{U} \\
553.86 \mathrm{U} \\
\text { NA } \\
\text { NA }\end{array}$ & $\begin{array}{c}618.45 U \\
599.59 U \\
\text { NA } \\
\text { NA }\end{array}$ & $\begin{array}{c}618.45 U \\
599.59 U \\
\text { NA } \\
\text { NA }\end{array}$ \\
\hline $\begin{array}{l}\text { Comp IHC-2 } \\
\text { Comp IHC-2 Cdup } \\
\text { RPD } \\
\text { I-Stat }\end{array}$ & $\begin{array}{l}23 \\
23 \\
23 \\
23\end{array}$ & $\begin{array}{c}0.87 \text { U } \\
0.82 U \\
N A \\
N A\end{array}$ & $\begin{array}{c}1.28 \mathrm{U} \\
1.21 \mathrm{U} \\
\text { NA } \\
\text { NA }\end{array}$ & $\begin{array}{c}1.16 \mathrm{U} \\
1.10 \mathrm{U} \\
\text { NA } \\
\text { NA }\end{array}$ & $\begin{array}{c}1.16 \mathrm{U} \\
1.10 \mathrm{U} \\
\text { NA } \\
\text { NA }\end{array}$ & $\begin{array}{c}1.33 \mathrm{U} \\
1.25 \mathrm{U} \\
\text { NA } \\
\text { NA }\end{array}$ & $\begin{array}{c}1.33 \mathrm{U} \\
1.25 \mathrm{U} \\
\text { NA } \\
\text { NA }\end{array}$ & $\begin{array}{c}1.29 \mathrm{U} \\
1.22 \mathrm{U} \\
\mathrm{NA} \\
\mathrm{NA}\end{array}$ & $\begin{array}{c}1.40 \mathrm{U} \\
1.33 \mathrm{U} \\
\mathrm{NA} \\
\mathrm{NA}\end{array}$ & $\begin{array}{c}1.40 \mathrm{U} \\
1.33 \mathrm{U} \\
\mathrm{NA} \\
\mathrm{NA}\end{array}$ \\
\hline $\begin{array}{l}\text { (a) U Analyte was no } \\
\text { (b) J Analyte detect } \\
\text { (c) Value exceeds rel } \\
\text { (d) Recovery outside } \\
\text { (e) NA Not applicable. } \\
\text { (f) Compositing dupli }\end{array}$ & $\begin{array}{l}\text { resent } \\
\text { below m } \\
\text { ve prec } \\
\text { quality }\end{array}$ & control & $\begin{array}{l}\text { ssociated } \\
\text { tion limit } \\
\text { of } \leq 30 \% \text {. } \\
\text { ige }(40 \%-1\end{array}$ & $\begin{array}{l}\text { ue. } \\
\text { (DL), but } \\
\text { duplicat } \\
\% \text { ). }\end{array}$ & $\begin{array}{l}\text { e instru } \\
\text { one sam }\end{array}$ & $\begin{array}{l}\text { detecti } \\
\text { oncentr }\end{array}$ & imit (I & 10 times & MDL. & \\
\hline
\end{tabular}


TABLE C.9. Quality Control Data for Chlorinated Pesticides (elution order, cis-Chlordane to Toxaphene) in Younger Bay Mud from Selected Cores and Sediment Composites, United Heckathorn Remedi al Investigation

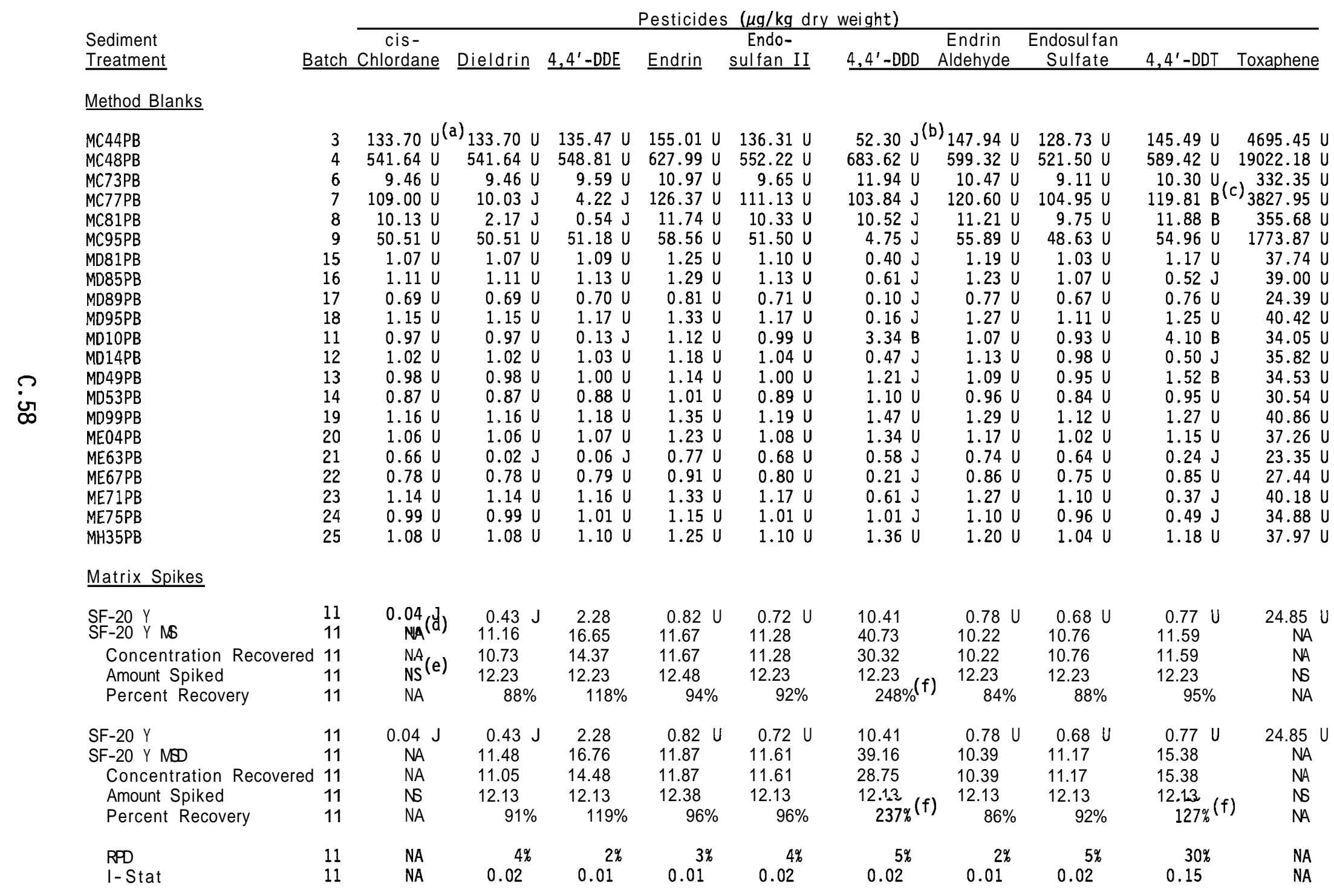


TABLE C.9. (contd)

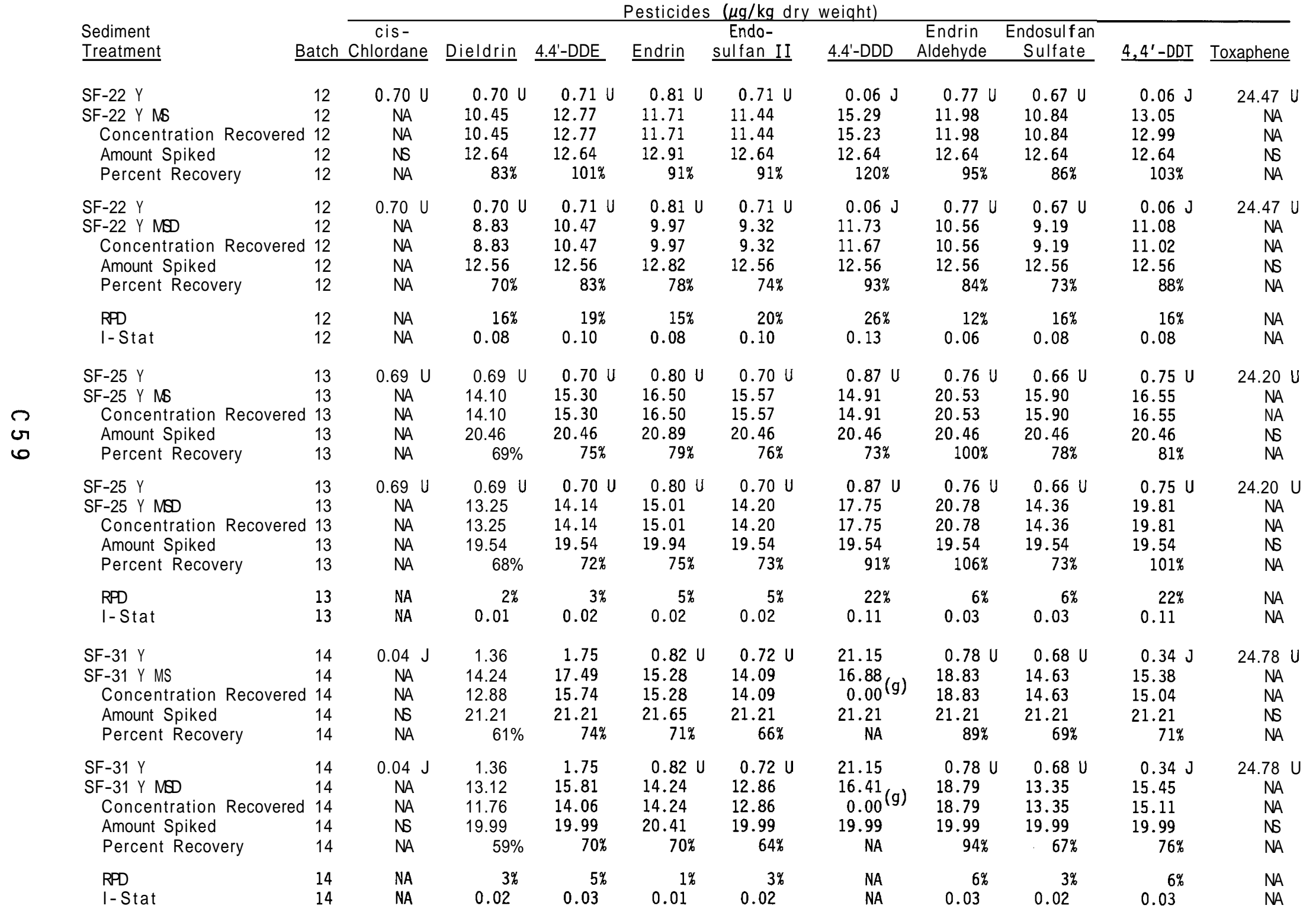


TABLE C.9. (contd)

Sediment

$\underline{\text { Treatment }}$

Pesticides ( $\mu \mathrm{g} / \mathrm{kg}$ dry weight)

\begin{tabular}{|c|c|c|c|c|c|c|c|c|c|c|c|}
\hline $\begin{array}{l}\text { Sediment } \\
\text { Treatment } \\
\end{array}$ & Batch & $\begin{array}{c}\text { cis- } \\
\text { Chlordane }\end{array}$ & Dieldrin & $4,4^{\prime}-\mathrm{DDE}$ & Endrin & $\begin{array}{l}\begin{array}{c}\text { Endo- } \\
\text { sulfan II }\end{array} \\
\end{array}$ & $\underline{4,4^{\prime}-D D D}$ & $\begin{array}{c}\text { Endrin } \\
\text { Aldehyde } \\
\end{array}$ & $\begin{array}{c}\text { Endosulfan } \\
\text { Sulfate } \\
\end{array}$ & $\underline{4,4^{\prime}-D D T}$ & Toxaphene \\
\hline $\begin{array}{l}\text { IH-35 Y } \\
\text { IH-35 Y NS } \\
\text { Concentration Recovered } \\
\text { Amount Spiked } \\
\text { Percent Recovery }\end{array}$ & $\begin{array}{r}15 \\
15 \\
d \quad 15 \\
15 \\
15\end{array}$ & $\begin{array}{l}0.71 \text { U } \\
\text { NA } \\
\text { NA } \\
\text { NS } \\
\text { NA }\end{array}$ & $\begin{array}{c}0.06 \mathrm{~J} \\
8.64 \\
8.58 \\
12.68 \\
68 \%\end{array}$ & $\begin{array}{c}0.08 \mathrm{~J} \\
8.76 \\
8.68 \\
12.68 \\
68 \%\end{array}$ & $\begin{array}{l}0.82 U \\
10.05 \\
10.05 \\
12.95 \\
78 \%\end{array}$ & $\begin{array}{c}0.72 U \\
9.68 \\
9.68 \\
12.68 \\
76 \%\end{array}$ & $\begin{array}{c}0.87 \mathrm{~J} \\
12.88 \\
12.01 \\
12.68 \\
95 \%\end{array}$ & $\begin{array}{l}0.78 U \\
10.84 \\
10.84 \\
12.68 \\
85 \%\end{array}$ & $\begin{array}{c}0.68 \mathrm{U} \\
9.08 \\
9.08 \\
12.68 \\
72 \%\end{array}$ & $\begin{array}{l}0.77 \mathrm{U} \\
12.77 \\
12.77 \\
12.68 \\
101 \%\end{array}$ & $\begin{array}{l}24.76 \text { U } \\
\text { NA } \\
\text { NA } \\
\text { NS } \\
\text { NA }\end{array}$ \\
\hline $\begin{array}{l}\text { IH-35 Y } \\
\text { IH-35 Y MSD } \\
\text { Concentration Recovered } \\
\text { Amount Spiked } \\
\text { Percent Recovery }\end{array}$ & $\begin{array}{r}15 \\
15 \\
\text { d } 15 \\
15 \\
15\end{array}$ & $\begin{array}{l}0.71 \mathrm{U} \\
\text { NA } \\
\text { NA } \\
\text { NS } \\
\text { NA }\end{array}$ & $\begin{array}{c}0.06 \mathrm{~J} \\
7.86 \\
7.80 \\
12.85 \\
61 \%\end{array}$ & $\begin{array}{c}0.08 \mathrm{~J} \\
8.02 \\
7.94 \\
12.85 \\
62 \%\end{array}$ & $\begin{array}{l}0.82 U \\
9.18 \\
9.18 \\
13.11 \\
70 \%\end{array}$ & $\begin{array}{c}0.72 U \\
8.87 \\
8.87 \\
12.85 \\
69 \%\end{array}$ & $\begin{array}{c}0.87 \mathrm{~J} \\
9.95 \\
9.08 \\
12.85 \\
71 \%\end{array}$ & $\begin{array}{l}0.78 U \\
11.84 \\
11.84 \\
12.85 \\
92 \%\end{array}$ & $\begin{array}{c}0.68 \mathrm{U} \\
8.32 \\
8.32 \\
12.85 \\
65 \%\end{array}$ & $\begin{array}{c}0.77 \mathrm{U} \\
9.86 \\
9.86 \\
12.85 \\
77 \%\end{array}$ & $\begin{array}{l}24.76 U \\
\text { NA } \\
\text { NA } \\
\text { NS } \\
\text { NA }\end{array}$ \\
\hline $\begin{array}{l}\text { RPD } \\
\text { I-Stat }\end{array}$ & $\begin{array}{l}15 \\
15\end{array}$ & $\begin{array}{l}\text { NA } \\
\text { NA }\end{array}$ & $\begin{array}{l}11 \% \\
0.05\end{array}$ & $\begin{array}{l}10 \% \\
0.05\end{array}$ & $\begin{array}{l}10 \% \\
0.05\end{array}$ & $\begin{array}{l}10 \% \\
0.05\end{array}$ & $\begin{array}{l}29 \% \\
0.15\end{array}$ & 0.04 & $\begin{array}{l}10 \% \\
0.05\end{array}$ & $\begin{array}{l}27 \% \\
0.14\end{array}$ & $\begin{array}{l}\text { NA } \\
\text { NA }\end{array}$ \\
\hline $\begin{array}{l}\text { IH-38 Y } \\
\text { IH-38 Y MS } \\
\text { Concentration Recovered } \\
\text { Amount Spiked } \\
\text { Percent Recovery }\end{array}$ & $\begin{array}{r}16 \\
16 \\
d 16 \\
16 \\
16\end{array}$ & $\begin{array}{l}0.69 \text { U } \\
N A \\
N A \\
N S \\
N A\end{array}$ & $\begin{array}{c}0.10 \mathrm{~J} \\
7.65 \\
7.55 \\
12.36 \\
61 \%\end{array}$ & $\begin{array}{c}0.70 \cup \\
8.37 \\
8.37 \\
12.36 \\
68 \%\end{array}$ & $\begin{array}{c}0.81 U \\
9.03 \\
9.03 \\
12.62 \\
72 \%\end{array}$ & $\begin{array}{c}0.71 U \\
8.35 \\
8.35 \\
12.36 \\
68 \%\end{array}$ & $\begin{array}{c}0.21 \mathrm{~J} \\
11.25 \\
11.04 \\
12.36 \\
89 \%\end{array}$ & $\begin{array}{l}0.77 \mathrm{U} \\
10.73 \\
10.73 \\
12.36 \\
87 \%\end{array}$ & $\begin{array}{c}0.67 \mathrm{U} \\
8.14 \\
8.14 \\
12.36 \\
66 \%\end{array}$ & $\begin{array}{c}0.76 U \\
9.83 \\
9.83 \\
12.36 \\
80 \%\end{array}$ & $\begin{array}{c}24.40 U \\
\text { NA } \\
\text { NA } \\
\text { NS } \\
\text { NA }\end{array}$ \\
\hline $\begin{array}{l}\text { IH-38 Y } \\
\text { IH-38 Y MSD } \\
\text { Concentration Recovered } \\
\text { Amount Spiked } \\
\text { Percent Recovery }\end{array}$ & $\begin{array}{r}16 \\
16 \\
d \quad 16 \\
16 \\
16\end{array}$ & $\begin{array}{l}0.69 \mathrm{U} \\
\text { NA } \\
\text { NA } \\
\text { NS } \\
N A\end{array}$ & $\begin{array}{c}0.10 \mathrm{~J} \\
8.32 \\
8.22 \\
12.75 \\
64 \%\end{array}$ & $\begin{array}{c}0.70 \mathrm{U} \\
9.01 \\
9.01 \\
12.75 \\
71 \%\end{array}$ & $\begin{array}{c}0.81 \mathrm{U} \\
9.24 \\
9.24 \\
13.02 \\
71 \%\end{array}$ & $\begin{array}{c}0.71 \mathrm{U} \\
8.85 \\
8.85 \\
12.75 \\
69 \%\end{array}$ & $\begin{array}{r}0.21 \mathrm{~J} \\
11.77 \\
11.56 \\
12.75 \\
91 \%\end{array}$ & $\begin{array}{r}0.77 \mathrm{U} \\
11.14 \\
11.14 \\
12.75 \\
87 \%\end{array}$ & $\begin{array}{c}0.67 \mathrm{U} \\
8.62 \\
8.62 \\
12.75 \\
68 \%\end{array}$ & $\begin{array}{c}0.76 \mathrm{U} \\
9.98 \\
9.98 \\
12.75 \\
78 \%\end{array}$ & $\begin{array}{l}\text { 24. } 40 \text { U } \\
\text { NA } \\
\text { NA } \\
\text { NS } \\
\text { NA }\end{array}$ \\
\hline $\begin{array}{l}\text { RPD } \\
\text { I-Stat }\end{array}$ & $\begin{array}{l}16 \\
16\end{array}$ & $\begin{array}{l}\text { NA } \\
\text { NA }\end{array}$ & 0.03 & $0.02^{4 \%}$ & $0.00^{1 \%}$ & 0.01 & $0.01 \%$ & $0.00^{1 \%}$ & 0.01 & 0.01 & $\begin{array}{l}\text { NA } \\
\text { NA }\end{array}$ \\
\hline $\begin{array}{l}\text { IH-49 Y } \\
\text { IH-49 Y NS } \\
\text { Concentration Recovered } \\
\text { Amount Spiked } \\
\text { Percent Recovery }\end{array}$ & $\begin{array}{l}17 \\
17 \\
17 \\
17 \\
17\end{array}$ & $\begin{array}{l}0.72 \mathrm{U} \\
\text { NA } \\
\text { NA } \\
\text { NS } \\
\text { NA }\end{array}$ & $\begin{array}{l}0.10 \mathrm{~J} \\
12.66 \\
12.56 \\
13.23 \\
95 \%\end{array}$ & $\begin{array}{l}0.73 \mathrm{U} \\
14.54 \\
14.54 \\
13.23 \\
110 \%\end{array}$ & $\begin{array}{c}0.84 U \\
13.73 \\
13.73 \\
13.50 \\
102 \%\end{array}$ & $\begin{array}{c}0.74 U \\
12.49 \\
12.49 \\
13.23 \\
94 \%\end{array}$ & $\begin{array}{c}0.21 \mathrm{~J} \\
15.35 \\
15.14 \\
13.23 \\
114 \%\end{array}$ & $\begin{array}{c}0.80 \mathrm{U} \\
13.26 \\
13.26 \\
13.23 \\
100 \%\end{array}$ & $\begin{array}{c}0.69 \mathrm{U} \\
12.47 \\
12.47 \\
13.23 \\
94 \%\end{array}$ & $\begin{array}{l}0.79 \mathrm{U} \\
15.36 \\
15.36 \\
13.23 \\
116 \%\end{array}$ & $\begin{array}{c}25.33 \mathrm{U} \\
\text { NA } \\
\text { NA } \\
\text { NS } \\
\text { NA }\end{array}$ \\
\hline $\begin{array}{l}\text { IH-49 Y } \\
\text { IH-49 Y MSD } \\
\text { Concentration Recovered } \\
\text { Amount Spiked } \\
\text { Percent Recovery }\end{array}$ & $\begin{array}{l}17 \\
17 \\
17 \\
17 \\
17\end{array}$ & $\begin{array}{c}0.72 \mathrm{U} \\
N A \\
N A \\
N S \\
N A\end{array}$ & $\begin{array}{r}0.10 \mathrm{~J} \\
11.50 \\
11.40 \\
13.25 \\
86 \%\end{array}$ & $\begin{array}{c}0.73 \mathrm{U} \\
13.46 \\
13.46 \\
13.25 \\
102 \%\end{array}$ & $\begin{array}{c}0.84 \mathrm{U} \\
12.51 \\
12.51 \\
13.53 \\
92 \%\end{array}$ & $\begin{array}{c}0.74 \mathrm{U} \\
12.09 \\
12.09 \\
13.25 \\
91 \%\end{array}$ & $\begin{array}{c}0.21 \mathrm{~J} \\
13.57 \\
13.36 \\
13.25 \\
101 \%\end{array}$ & $\begin{array}{c}0.80 \mathrm{U} \\
13.07 \\
13.07 \\
13.25 \\
99 \%\end{array}$ & $\begin{array}{c}0.69 \mathrm{U} \\
11.61 \\
11.61 \\
13.25 \\
88 \%\end{array}$ & $\begin{array}{c}0.79 \mathrm{U} \\
13.79 \\
13.79 \\
13.25 \\
104 \%\end{array}$ & $\begin{array}{c}25.33 \mathrm{U} \\
\text { NA } \\
\text { NA } \\
\text { NS } \\
\text { NA }\end{array}$ \\
\hline $\begin{array}{l}\text { RPD } \\
\text { I-Stat }\end{array}$ & $\begin{array}{l}17 \\
17\end{array}$ & $\begin{array}{l}\text { NA } \\
\text { NA }\end{array}$ & $\begin{array}{l}10 \% \\
0.05\end{array}$ & $\begin{array}{l}8 \% \\
0.04\end{array}$ & $\begin{array}{l}10 \% \\
0.05\end{array}$ & $\begin{array}{l}3 \% \\
0.02\end{array}$ & $\begin{array}{l}13 \% \\
0.06\end{array}$ & 0.01 & $\begin{array}{l}7 \% \\
0.04\end{array}$ & $\begin{array}{l}11 \% \\
0.05\end{array}$ & $\begin{array}{l}N A \\
N A\end{array}$ \\
\hline
\end{tabular}




\section{TABLE C.9. (contd)}

Sediment

Treatment

$\mathrm{IH}-43 \quad \mathrm{Y}$

$\mathrm{IH}-43$ Y MS

Concentration Recovered 18

Amount Spiked

Percent Recovery 18

$\mathrm{IH}-43 \mathrm{Y}$

$\mathrm{IH}-43$ Y MSD

Concentration Recovered 18

Amount Spiked

Percent Recovery

RPD

I- Stat

$\mathrm{IH}-46 \mathrm{Y}$

$\mathrm{IH}-46$ y MS

Concentration Recovered 19

の $\quad$ Amount Spiked $\quad 19$

$$
\begin{array}{ll}
\text { IH-46 Y } & 19 \\
\text { IH-46 Y MSD } & 19 \\
\text { Concentration Recovered } & 19 \\
\text { Amount Spiked } & 19 \\
\text { Percent Recovery } & 19 \\
\text { RPD } & 19 \\
\text { I-Stat } & 19
\end{array}
$$

$\mathrm{IH}-45 \mathrm{Y}$

$\mathrm{IH}-45$ Y MS

Concentration Recovered 20

Amount Spiked

Percent Recovery 20

$\mathrm{IH}-45 \mathrm{Y}$

IH-45 Y MSD

Concentration Recovered 20

Amount Spiked

Percent Recovery

RPD

I-Stat

\section{\begin{tabular}{cccc}
\hline Cis- \\
Batch Chlordane Dieldrin
\end{tabular} 4,4'-DDE Endrin $\begin{gathered}\text { Endo- } \\
\text { sulfan II }\end{gathered}$}

$0.69 \mathrm{U} \quad 0.10 \mathrm{~J}$

$\begin{array}{llll}12.35 & 12.35 & 12.61 & 12.35\end{array}$

NA

$88 \%$

$110 \%$

$88 \%$

$99 \%$

$\begin{array}{rr}0.69 \mathrm{U} & 0.10 \mathrm{~J} \\ \mathrm{NA} & 10.76\end{array}$

$0.70 \mathrm{U}$
13.42

$0.80 \mathrm{U} \quad 0.70 \mathrm{U}$

$\begin{array}{lllll}\text { NA } & 10.66 & 13.42 & 11.68 & 12.10\end{array}$

$11.68 \quad 12.10$

NS

12.54

12.80

12.54

$\begin{array}{lrrrr}\text { NA } & 4 \% & 2 \% & 3 \% & 3 \%\end{array}$

NA

0.02

0.01

0.02

0.01

$0.70 \mathrm{U}$

$0.71 \mathrm{U}$

$0.81 \mathrm{U} \quad 0.71 \mathrm{U}$

0.71
12.01

10.32
10.22

11.33

11.36

12.01

NA

2.54
$81 \%$

2.80

12.54

12.54
$96 \%$

$0.70 \mathrm{U} \quad 0.10 \mathrm{~J}$

$0.71 \mathrm{U}$

$0.81 \mathrm{U} \quad 0.71 \mathrm{U}$

$\begin{array}{lll}10.96 & 11.02 & 12.34 \\ 10.96 & 11.02 & 12.34\end{array}$

9.96
12.72

10.96

12.34
12.34
12.72

NS

NA $\quad 78 \%$

12.72

$12.98 \quad 12.72$

$85 \% \quad 97 \%$

NA $\quad 4 \%$

$3 \%$

$6 \% \quad 1 \%$

$\begin{array}{ll}0.70 \mathrm{U} & 0.02 \mathrm{~J}\end{array}$

$0.05 \mathrm{~J}$

$0.81 \mathrm{U}$

$0.71 \mathrm{U}$

NA

NA

0.02
6.17
6.15

6.15
12.05

NA

2.05

6.27
6.22

7.10

7.10

8.17

$58 \% \quad 12.05$

$0.70 \mathrm{U} \quad 0.02 \mathrm{~J}$

NA

NS

NA

$0.02 \mathrm{~J} \quad 0.05 \mathrm{~J}$

$6.88 \quad 7.15$

6.86
12.10

7.10
12.10

$0.81 \mathrm{U} \quad 0.71 \mathrm{U}$

8.10

0.71
8.82

$8.10 \quad 8.82$

$12.35 \quad 12.10$

NA
NA
$59 \%$

$13 \% \quad 73 \%$

$11 \%$

0.06
0.06

0.04

\section{(a)}

Endosulfan

$\begin{array}{lll}0.17 \mathrm{~J} & 0.76 \mathrm{U} & 0.66 \mathrm{U}\end{array}$

$15.85 \mathrm{~J} \quad 0.76 \mathrm{U}$

12.16
12.16

15.68

12.06

$\begin{array}{lrr}15.68 & 12.06 & 12.16 \\ 12.35 & 12.35 & 12.35 \\ 127 \%(f) & 98 \% & 98 \%\end{array}$

13.76
13.76

12.35

$\begin{array}{rrr}0.17 \mathrm{~J} & 0.76 \mathrm{U} & 0.66 \mathrm{U}\end{array}$

$0.75 \mathrm{U}$

13.87

$\begin{array}{lll}0.17 & 12.23 & 11.98 \\ 15.18 & 12.23 & 11.98\end{array}$

12.54 (f) $12.54 \quad 12.54$

13.87

$121 \%(f) \quad 98 \% \quad 96 \%$

0.02

0.00

0.02

12.54

$111 \%$

0.00

$\begin{array}{lll}0.19 \mathrm{~J} & 0.77 \mathrm{U} & 0.67 \mathrm{U}\end{array}$

$0.76 \mathrm{U}$

11.40

11.40

$12.41-10.33$

6.70

12.54

12.54

$99 \%$

$82 \%$

$53 \%$

12.63

$0.77 \mathrm{U}$

0.67

0.76

11.14

11.76
11.76

11.38
11.38

12.72

$98 \%$

12.72

12.72

12.72

$1 \%$

$6 \%$

$92 \%$

$89 \%$

0.01

0.03

$54 \%^{(h)}$
0.27

$2 \%$

$0.39 \mathrm{~J}$

0.77 U

$0.67 \mathrm{U}$

$10.28 \quad 7.95$

$\begin{array}{lll}6.88 & 10.28 & 7.95\end{array}$

$\begin{array}{lll}12.05 & 12.05 & 12.05\end{array}$

$57 \%$

$85 \%$

12.05
$66 \%$

0.76

7.00

7.00

12.05

$\begin{array}{lrl}0.39 \mathrm{~J} & 0.77 \mathrm{U} & 0.67 \mathrm{U} \\ 8.43 & 10.96 & 7.99\end{array}$

0.76

8.43

0.67
7.99

0.76

10.96

7.99

7.91
7.91

12.10

$66 \%$

$91 \%$

12. 10

12.10

$65 \%$

$15 \%$

$6 \%$

$0 \%$

0.06

0.06
NA

$24.18 U$

NA

NS

NA

NS

NA

$24.49 \mathrm{U}$

NA

NA

NA

$24.49 \mathrm{U}$

NA

NS

NA

NA

$24.52 \mathrm{U}$

NA

NS

NA

$24.52 U$

NA

NS

NA

NA 
TABLE C.9. (contd)

Sediment

Treatment

IH-50 Y

Concentration Recovered 21

Concentration Recovered 21
Amount Spiked

Percent Recovery

$\mathrm{IH}-50 \mathrm{Y}$

$\mathrm{IH}-50$ Y MBD

Concentration Recovered 21

Amount Spiked

Percent Recovery

RPD

I-Stat

LZ-14 Y

LZ-14 Y NS

Concentration Recovered 22

o Amount Spiked 22

LZ-14 Y

LZ-14 Y MSD

Concentration Recovered 22

Amount Spiked

Percent Recovery 22

RPD

I-Stat

LZ-14 Y

LZ-14 Y MS

Concentration Recovered 23

Amount Spiked

Percent Recovery 23

LZ-14 Y

LZ-14 Y MSD

Concentration Recovered 23 Amount Spiked

Percent Recovery

RPD

I-Stat

Pesticides $(\mu \mathrm{g} / \mathrm{kg}$ dry weight)

cis- Endo- Endrin Endosulfan

Batch Chlordane Dieldrin 4,4'-DDE Endrin sulfan II 4.4'-DDD Aidehvde Sulfate $\underline{4,4^{\prime}-\text { DDT }} \underline{\text { TOxaphene }}$

0.60
$N A$
$N A$
$N A$

NA $\quad 5.20$ U

$\begin{array}{llll}5.20 & 5.53 & 6.86 & 6.63\end{array}$

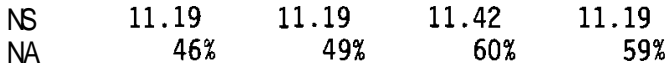

$0.60 \mathrm{U} \quad 0.60 \mathrm{U}$

NA

NA

$\begin{array}{lllll}\text { NS } & 11.12 & 11.12 & 11.35 & 11.12\end{array}$

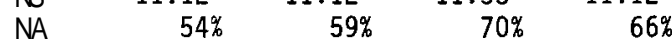

$\begin{array}{lllll}\text { NA } & 15 \% & 18 \% & 15 \% & 11 \% \\ \text { NA } & 0.08 & 0.09 & 0.08 & 0.05\end{array}$

0.63

NA

NA

$0.63 \mathrm{U} \quad 0.13 \mathrm{~J}$

NA

NA $\quad 5.19$

NS $\quad 11.29$

NA $\quad 46 \%$

$\begin{array}{ll}\text { NA } & 11 \% \\ \text { NA } & 0.05\end{array}$

$0.63 \mathrm{U} \quad 0.13 \mathrm{~J}$

$\begin{array}{lll}\mathrm{NA} & 9.31 & 9.06 \mathrm{~J}\end{array}$

NA $\quad 9.18$

$\begin{array}{ll}\text { NS } & 11.24 \\ \text { NA } & 82 \%\end{array}$

$\begin{array}{cl}0.63 \mathrm{U} & 0.13 \mathrm{~J} \\ \mathrm{NA} & 7.08\end{array}$

$\begin{array}{ll}\text { NA } & 7.08 \\ \text { NA } & 6.95\end{array}$

NS $\quad 11.39$

NA

NA

$0.73 \mathrm{U} \quad 0.64 \mathrm{U}$

$\begin{array}{ll}0.16 & 7.25\end{array}$

1.61

$64 \%$

$0.06 \mathrm{~J}$

$0.73 \mathrm{U}$

$0.64 \mathrm{U}$

5.60

7.00

6.27

$\begin{array}{lll}11.29 & 11.53 & 11.29\end{array}$

$49 \%$

$61 \% \quad 11.29$

$13 \% \quad 15 \% \quad 14 \%$

0.73 U $\quad 0.64 \mathrm{U}$

0.73

0.64
11.12

$\begin{array}{lll}9.32 & 10.34 & 11.12\end{array}$

11.24

11.48

11.24

6.94

$61 \%$

11.39
$60 \%$

11.63

11.39

0.14

$\begin{array}{lll}31 \%(\mathrm{~h}) & 29 \% & 28 \% \\ 0.16 & 0.14 & 0.14\end{array}$
$0.08 \mathrm{~J}$

8.07

7.99

11.19
$71 \%$

0.66

6.67

6.67

11.19
$60 \%$

$0.58 \mathrm{U}$

6.93

6.93

$0.08 \mathrm{~J}$

$0.66 \mathrm{U}$

$62 \%$

9.31

9.23

11.12

7.22

7.22

11.12

0.58
7.70
7.70

11.12

$15 \%$

0.08

0.04

$9 \% \quad 11 \%$

1.18
10.61

10.61
9.43

0.70

0.70
7.05

7.05
7.05

11.37

$83 \%$

1.18

9.34
8.16

8.16
11.29

$72 \%$

$14 \%$
0.07

1.18

1.18
11.51

10.33

11.24
$92 \%$

11.37

$0.70 \mathrm{U}$

0.70
6.28

6.28
6.28

11.29

$56 \%$

$11 \%$
0.05

$0.70 \mathrm{U}$

12.18

12.18

11.24

0.05

$0.60 \mathrm{U}$

7.31

7.31
11.37

$64 \%$

0.65

7.56

7.56
11.19

$68 \%$

$0.65 \mathrm{U}$

8.65

8.65

11.12

$14 \%$

0.07

$0.26 \mathrm{~J}$

10.01

9.75

$86 \%$

$0.60 \mathrm{U}$

6.45

$0.26 \mathrm{~J}$

0.26
7.99

7.73
11.29

11.29

1.29

$12 \%$

$22 \%$

0.11

$0.60 \mathrm{U}$

10.64

10.64

$0.26 \mathrm{~J}$

10.37

10.11

11.24

$\begin{array}{lllll}0.06 \mathrm{~J} & 0.73 \mathrm{U} & 0.64 \mathrm{U} & 1.18 \\ 6.94 & 7.85 & 8.46 & 8.83\end{array}$

$0.70 \mathrm{U}$

$0.60 \mathrm{U}$

$9.12 \quad 8.05$

0.26

8.15

7.89

11.39

7.65
11.39

11.39

11.39

$71 \%$

$31 \%(h)$

$30 \%$
0.15

0.15

$26 \%$

0.13
$21.04 \mathrm{U}$

NA

NA

NA

$21.04 \mathrm{U}$

NA

NS

NA

NA

$22.06 \mathrm{U}$

NA

NS

NA

$22.06 \mathrm{U}$

NA

NS

NA

NA

$22.06 \mathrm{U}$

NA

NA

NS

$22.06 \mathrm{U}$

NA

NA

NS

NA 
TABLE C.9. (contd)

Sediment

Treatment

LZ-5 A

LZ-5 A Duplicate

RPD

I-Stat

LZ-11 A

LZ-11 A Duplicate

RPD

I- Stat

Comp LC-3

Comp LC-3 Dupl icate RPD

I-Stat

LZ-13X

LZ-13 X Duplicate

RPD
I-Stat

o

IH-37 X
IH-37 X Duplicate
RPD
I-Stat
IH-41 X
IH-41 X Duplicate
RPD
I-Stat
IH-49 Y
IH-49 Y Duplicate
RPD
I-Stat
IH-41 A
IH-41 A Duplicate
RPD
I-Stat
SF-17 B Cdup (j)
SF-17 B Cdup Duplicate
RPD
I-Stat

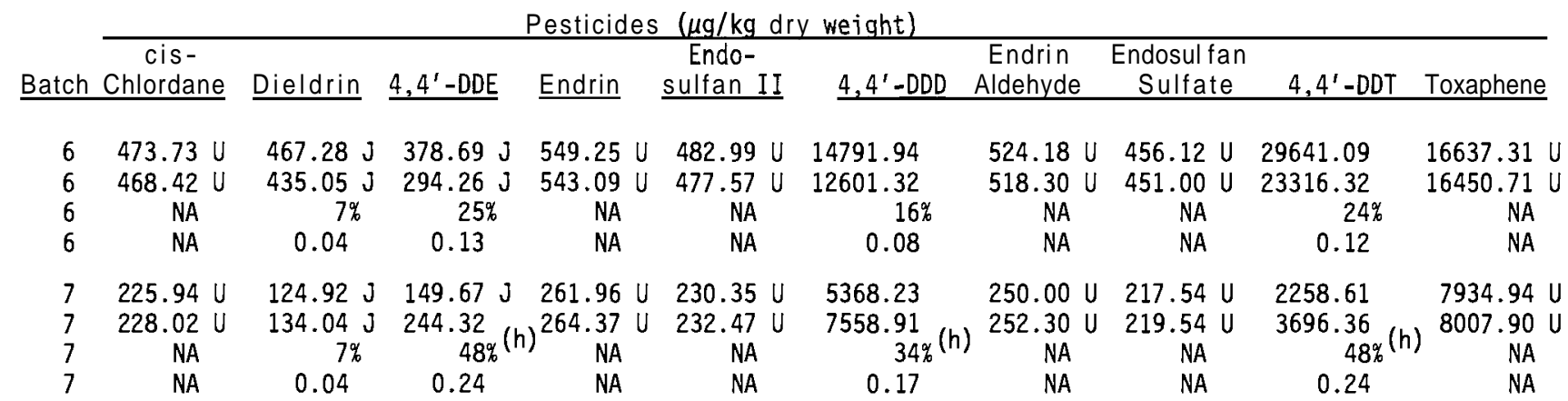

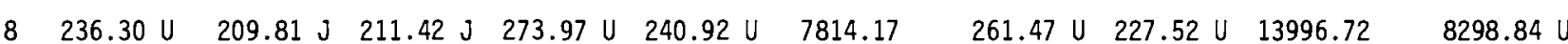

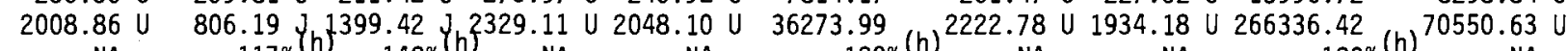

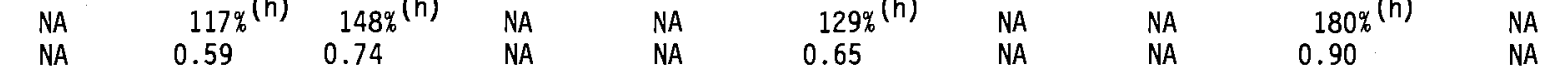

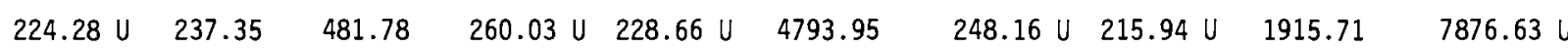

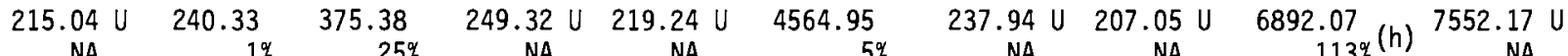

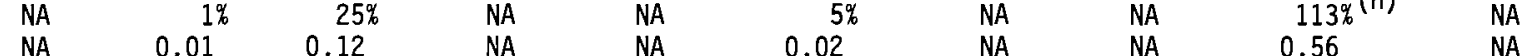

$\begin{array}{llllllllll}0.14 \mathrm{~J} & 1.88 & 7.92 & 1.18 \mathrm{U} & 1.04 \mathrm{U} & 56.10 & 1.13 \mathrm{U} & 0.98 \mathrm{U} & 6.69 & 35.80 \mathrm{U}\end{array}$

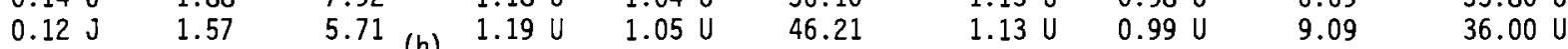

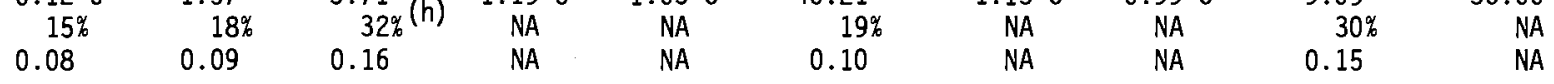

$\begin{array}{llllllllll}0.23 \mathrm{~J} & 3.07 & 9.05 & 1.23 \mathrm{U} & 1.08 \mathrm{U} & 78.73 & 1.17 \mathrm{U} & 1.02 \mathrm{U} & 13.99 & 37.21 \mathrm{U}\end{array}$

$\begin{array}{llllllllll}0.27 \mathrm{~J} & 3.49 & 9.80 & 1.20 \mathrm{U} & 1.06 \mathrm{U} & 88.51 & 1.15 \mathrm{U} & 1.00 \mathrm{U} & 41.60 \mathrm{o}(\mathrm{h}) & 36.50 \mathrm{U} \\ 16 \% & 13 \% & 8 \% & \mathrm{NA} & \mathrm{NA} & 12 \% & \mathrm{NA} & \mathrm{NA} & 99 \% & \mathrm{NA}\end{array}$

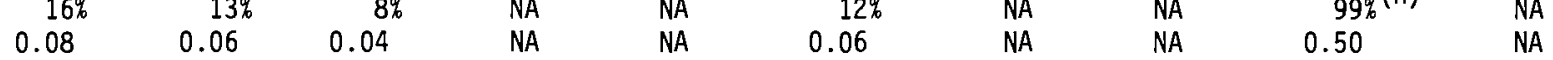

$\begin{array}{lllllllllll}0.72 \mathrm{U} & 0.10 \mathrm{~J} & 0.73 \mathrm{U} & 0.84 \mathrm{U} & 0.74 \mathrm{U} & 0.21 \mathrm{~J} & 0.80 \mathrm{U} & 0.69 \mathrm{U} & 0.79 \mathrm{U} & 25.33 \mathrm{U}\end{array}$

$\begin{array}{llllllllll}0.71 \mathrm{U} & 0.11 \mathrm{~J} & 0.72 \mathrm{U} & 0.83 \mathrm{U} & 0.73 \mathrm{U} & 0.18 \mathrm{~J} & 0.79 \mathrm{U} & 0.69 \mathrm{U} & 0.77 \mathrm{U} & 25.00 \mathrm{U}\end{array}$

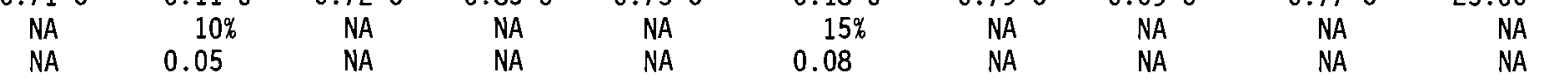

$\begin{array}{llllllllll}0.14 \mathrm{~J} & 1.19 & 3.73 & 1.38 \mathrm{U} & 1.22 \mathrm{U} & 24.16 & 1.32 \mathrm{U} & 1.15 \mathrm{U} & 21.65 & 41.91 \mathrm{U}\end{array}$

$\begin{array}{llllllllll}0.15 \mathrm{~J} & 1.30 & 4.28 & 1.37 \mathrm{U} & 1.20 \mathrm{U} & 29.63 & 1.31 \mathrm{U} & 1.14 \mathrm{U} & 14.68 \mathrm{~h}(\mathrm{~h}) & 41.50 \mathrm{U}\end{array}$

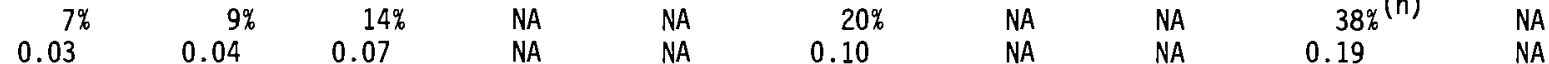

$\begin{array}{llllllllll}0.88 \mathrm{~J} & 16.75 & 65.97 & 0.26 \mathrm{~J} & 1.18 \mathrm{U} & 183.59 & 1.28 \mathrm{U} & 1.12 \mathrm{U} & 9.63 \mathrm{U} & 40.74 \mathrm{U}\end{array}$

$\begin{array}{llllllllll}0.60 \mathrm{~J} & 9.98 & \text { (h) } 42.80 & \text { (h) } 0.14 \mathrm{~J} & 1.12 \mathrm{U} & 127.77 \text { (h) } & 1.21 \mathrm{U} & 1.05 \mathrm{U} & 5.81 \mathrm{U} & 38.46 \mathrm{U}\end{array}$

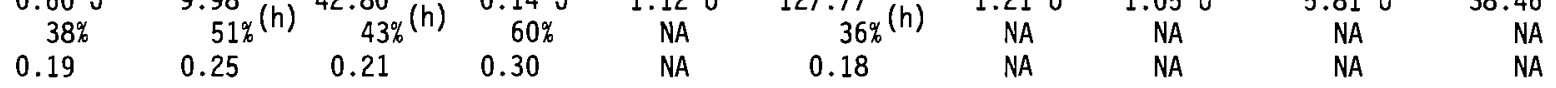


TABLE C.9. (contd)

Sediment

Ireatment

Pesticides $(\mu \mathrm{g} / \mathrm{kg}$ dry weight)

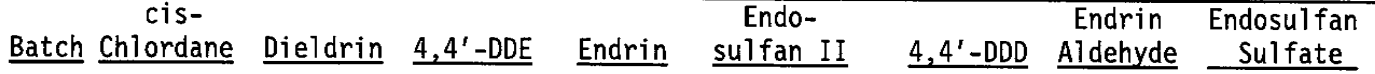

$\underline{4,4^{\prime}-\text { DDT }}$ Toxaphene

$\begin{array}{ll}\text { LZ-14 Y } & 24 \\ \text { LZ-14 Y MS } & 24\end{array}$

Concentration Recovered 24

Amount Spiked

Percent Recovery

$0.63 U$
NA
NA
NS
NA

$0.13 \mathrm{~J}$
9.87

$0.06 \mathrm{~J}$

$\begin{array}{lll}8.52 & 10.75 & 0.64\end{array}$

1.18

LZ-14 Y

LZ-14 Y MSD

$0.63 \mathrm{U}$

$87 \%$

11.09

12.14
11.15

$0.70 \mathrm{U}$

10.69

$0.60 \mathrm{U}$

$0.26 \mathrm{~J}$

$22.06 \mathrm{U}$

Concentration Recovered 24

Amount Spiked

$\begin{array}{ccc}11.15 & 11.39 & 11.15 \\ 76 \% & 94 \% & 99 \%\end{array}$

$\begin{array}{lll}10.69 & 10.44 & 13.17 \\ 10.69 & 10.44 & 12.91\end{array}$

$109 \%$

$96 \%$

11.15
$94 \%$

11.15
$116 \%$

NA

$0.06 \mathrm{~J} \quad 0.73 \mathrm{U} \quad 0.64 \mathrm{U}$

1.18
12.39

$0.70 \mathrm{U} \quad 0.60 \mathrm{U}$
12.08

$0.26 \mathrm{~J}$

$12.08 \quad 11.68$

9.60

11.21

$\begin{array}{lrrrr}\text { NA } & 10.57 & 8.86 & 11.51 & 11.66\end{array}$

NS $\quad 11.19$

Percent Recovery

NA

$94 \%$

RPD

I-Stat

NA

$79 \% \quad 101 \% \quad 104 \%$

$100 \%$

$11.19 \quad 11.19$

9.34

11.19

$\begin{array}{ccc}8 \% & 12 \% & 11 \% \\ 0.04 & 0.06 & 0.05\end{array}$

$32 \%(h)$
0.16

IH-50 A

IH-50 A MS

$1.31 \mathrm{U}$

0.04

$0.02^{4 \%}$

$\begin{array}{ll}7 \% & 5 \% \\ 0.03 & 0.02\end{array}$

9.58

$0.21 \mathrm{~J}$

$\begin{array}{rrr}0.36 \mathrm{~J} & 1.52 \mathrm{U} \quad 1.34 \mathrm{U}\end{array}$

NA 10.53

12.72

12.94

14.31

23.84

$\begin{array}{lll}12.36 & 12.94 & 14.31\end{array}$

Amount Spiked

Percent Recovery

NS

$43 \%$

$52 \%$

$53 \%$

23.84
$60 \%$

NA
23.84
NA

1.45

$1.26 \mathrm{U}$

$0.26 \mathrm{~J}$

12.56

$14.22 \quad 15.47$

12.56
12.30

$23.84 \quad 23.84$

23.84

IH-50 A
IH-50 A MSD

$1.31 \mathrm{U}$

$0.21 \mathrm{~J}$

$0.36 \mathrm{~J} \quad 1.52 \mathrm{U} \quad 1.34 \mathrm{U}$

Concentration Recovered 25

Amount Spiked

Percent Recovery

NA

11.21

12.69

14.00

15.29

$\begin{array}{lllll}\text { NS } & 23.96 & 23.96 & 24.46 & 23.96\end{array}$

12.33

$14.00 \quad 15.29$

RPD

I-Stat

$46 \%$

$51 \%$

9.58
$M$

$1.45 \mathrm{U}$

$65 \%$

$52 \%$

23. 96

$\begin{array}{ll}17.07 & 16.78\end{array}$

$0.26 \mathrm{~J}$

12.78

$17.07-16.78 \quad 12.52$

$23.96 \quad 23.96$

23.96

$18 \% \quad 8 \%$

$52 \%$

$6 \%$

NA

0.09

0.04

0.01

$2776.28 \cup 2415.81 \mathrm{U}$

$700.53 \mathrm{~J} \quad 88118.58 \mathrm{U}$

2509.09 U $723.37 \mathrm{~J} 1441.28 \mathrm{~J} 2909.09$ U $2558.10 \mathrm{U} 136929.91$

$2561.74 \mathrm{U} \quad 702.24 \mathrm{~J} 1126.94 \mathrm{~J} 2970.14 \mathrm{U} 2611.78 \mathrm{U} 105507.48$

2834.54 U 2466.51 U

$521.64 \mathrm{~J} 89967.72 \mathrm{U}$

LZ-1 D Duplicate

RPD

LZ-2 B

LZ-2 B Duplicate

RPD

I-Stat

$42150.41 \mathrm{U} \quad 685.75 \mathrm{~J} \quad 989.25 \mathrm{~J} 2493.22 \mathrm{U} 2192.41 \mathrm{U} 21516.06$

NA

NA

$29 \%$

NA

$2379.40 \cup 2070.46$ U $111047.83 \mathrm{~J} 75521.68 \mathrm{U}$

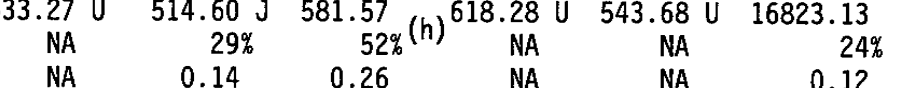
590.05 U 513.44 U 22448.59 (h) 18728.16 U NA

$\begin{array}{ccc}\text { NA } & 133 \%(h) & \text { NA } \\ \text { NA } & 0.66 & \text { NA }\end{array}$ 
TABLE C.9. (contd)

Sediment

Treatment

SF-22 A

SF-22 A Duplicate RPD

I-Stat

SF-26 A

SF-26 A Duplicate

RPD

I-Stat

SF-31X

SF-31 X Duplicate RPD

I-Stat

$\mathrm{IH}-46$ A

IH-46 A Duplicate

n $\quad$ PPD

G $\quad P C-54 A$

PC-54 A Duplicate

RPD

I-Stat

LZ-5 Y

LZ-5 Y Duplicate

RPD

I-Stat

IH-50 A

IH-50 A Duplicate

RPD

I-Stat

Comp USFC

Comp USFC Duplicate RPD

I-Stat

SF-33 $X$

SF-33 X Duplicate

RPD

I-Stat

cis-

Batch Chlordane Dieldrin 4,4'-DDE

Pesticides $(\mu \mathrm{g} / \mathrm{kg}$ dry weight Endo-

\section{$\underline{4.4^{\prime}-D D D}$}

Endosulfan

$$
\begin{aligned}
& 12 \\
& 12 \\
& 12 \\
& 12 \\
& 1 \\
& 13 \\
& 1 \\
& 1
\end{aligned}
$$

$\begin{array}{ccc}0.80 \mathrm{~J} & 10.88 & 42.85 \\ 0.84 \mathrm{~J} & 10.69 & 39.21 \\ 5 \% & 2 \% & 9 \%\end{array}$

$0.25 \mathrm{~J} 1.26 \mathrm{U}$

$\begin{array}{llll}0.25 \mathrm{~J} & 1.26 \mathrm{U} & 144.00\end{array}$

144.00
142.65

0.02

0.01

0.04

0.02

NA

$0.00^{1 \%}$

.

Sulfate

4,4'-DDT Toxaphene

$1.31 \mathrm{U}$
$0.68 \mathrm{~J}$
NA
NA

$0.53 \mathrm{~J} \quad 3.50$

$1.52 v \quad 1.33 v$

5.77

1.34 U 203.39

$\begin{array}{cc}9.27 & 31.52 \\ 178 \% & (h) \\ 0.89 & 0.80 \%\end{array}$

1.52

NA

$189 \%(h)$

1.36

$1.19 \mathrm{U}$

14.17

16.44

$43.27 \mathrm{U}$

NA

$0.47 \mathrm{~J}$

24.67

NA

NA

0.94

$\begin{array}{lllll}0.97 & U & 0.85 & U & 325.51\end{array}$

$\begin{array}{ccc}0.43 \mathrm{~J} & 17.77 & 22.99 \\ 9 \% & 12 \% & \end{array}$

0.04

$\begin{array}{ll}12 \% & 7 \% \\ 0.06 & 0.04\end{array}$

NA

0.84 U

311.28
$4 \%$

0.02

$\begin{array}{lll}1.41 & 2.19 & 0.37 \mathrm{~J}\end{array}$

$0.04 \mathrm{~J}$

1.33

8.70
4.72

8.70
4.72
$59 \%(h)$
0.30

NA

$$
0.30
$$

NA

NA

0.07

$43.21 U$

0.20

0.68

$58 \%$

NA

$1.45 \mathrm{U} \quad 1.26 \mathrm{U}$

$1.45 \mathrm{U} \quad 1.27 \mathrm{U}$

$1.42 \mathrm{U}$

$4.35 \mathrm{U}$

NA

NA

45.990

$46.18 \mathrm{U}$

NA NA

$0.92 \mathrm{U} \quad 0.80 \mathrm{U}$

103.70

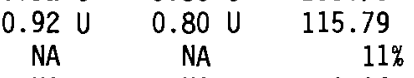

NA

NA

0.06

$1.27 \mathrm{U} \quad 1.10 \mathrm{U}$

$1.29 \mathrm{U} \quad 1.13 \mathrm{U}$

20.07

$36.29 \quad 85.50$

$1.35 \cup \quad 6.69$

690.05

NA

NA

2.59 (h)

0.48

23.52

$0.08 \%$

$\begin{array}{cc}41.78 & 85.30 \\ 0.07 & 0.00\end{array}$

6.87

649.24

$1.13 \mathrm{U}$

192.79

267.05 (h)

0.16

$0.19 \mathrm{~J}$

$0.07 \quad 0.00$

NA 0.01

0.03

31

1.14

476.54

$0.39 \mathrm{~J}$

$17.09 \quad 10.23$

$0.77 \mathrm{U} \quad 0.68 \mathrm{U}$

445.10

0.74

0.64

0.34

$75 \%$
0.30 $\frac{33.42}{106 \%}(h)$

NA

NA

931.71 (h)

$0.74 \mathrm{U}$

$.64 \mathrm{U}$

$\begin{array}{lc}.64 \text { U } & 1055.28 \\ \text { NA } & 76 \%(h)\end{array}$

NA $\quad 0.38$

$1.31 \mathrm{U}$

0.35

NA

$0.26 \mathrm{~J}$

$0.95 \mathrm{~J}$

$114 \%$

$3.94(h)$

$1.45 \mathrm{U} \quad 1.26 \mathrm{~V}$

$.27 \mathrm{U}$

NA

0.57

NA

$29.27 \mathrm{U}$

$29.05 \mathrm{U}$

NA

$40.30 \mathrm{~V}$

$41.10 \mathrm{U}$

NA

$41.04 \mathrm{U}$

$41.53 \mathrm{U}$

NA

$23.41 \mathrm{U}$

$23.31 \mathrm{U}$

NA

NA

0.05

$0.45 \%$

NA

0.42

NA

$1.14 \mathrm{U}$

$\begin{array}{llllll}0.63 \mathrm{~J} & 13.71 & 86.25 & 1.37 \mathrm{U} & 1.20 \mathrm{U} & 288.38\end{array}$

$0.42 \mathrm{~J}$

8.45

$\begin{array}{ll}86.25 & 1.37 \mathrm{U} \\ 61.15 & 1.35 \mathrm{U}\end{array}$

$1.20 \mathrm{U}$

0.20

0.2

24

NA

0.00

177.75 (h)

106.58

20.55 (h)

$0.40 \mathrm{~J}$

16.70
37.02

$62.85 \quad 0.31 \mathrm{~J}$

0.83

0.24

NA

NA

$135 \%$

69.32

141.99

$70 \%$

37.02
$76 \%$

$89.07 \mathrm{~h}$

0.93
$N A$

$\begin{array}{ll}0.82 \text { U } & 400.34\end{array}$

0.90
0.89

$0.79 \mathrm{U}$

0.77

NA

$\begin{array}{ll}59 \% & \text { NA } \\ 0.30 & \text { NA }\end{array}$

NA

$\begin{array}{ll}0.38 & 0.17\end{array}$

0.35 (n) 0.38 -

0.35 
TABLE C.9. (contd)

Sediment

Treatment

$\mathrm{IH}-40 \mathrm{~B}$

IH-40 B Duplicate

RPD

I-Stat

Compositing Dupl icates

LZ-8 B

LZ-8 B Cdup

RPD

I-Stat

LZ-16 B

LZ-16 B Cdup

RPD

I-Stat

$? \quad \mathrm{SF}-17 \mathrm{~B}$

of $\quad$ SF-17 B Cdup

I-Stat

SF-21 C

SF-21 C Cdup

RPD

I-Stat

SF-27 B

SF-27 B Cdup

RPD
I-Stat

IH-36 B

IH-36 B Cdup

RPD

I-Stat

IH-37 B

$\mathrm{IH}-37$ B Cdup

RPD

I-Stat

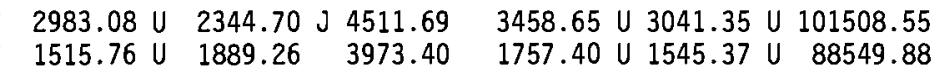
$\begin{array}{llllll}\text { NA } & 22 \% & 13 \% & \text { NA } & \text { NA } & 14 \%\end{array}$

$0.11 \quad 0.06$

NA

NA

0.07

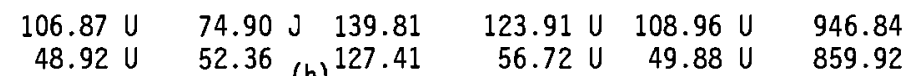

$52.36(h) 127.41$

$\begin{array}{ll}72 & U \\ N A & 49.88 \\ & \text { NA }\end{array}$

NA $\quad 10 \%$

0.05

NA

$0.18 \quad 0.05$

NA

$\begin{array}{llllll}0.69 \mathrm{~J} & 11.03 & 60.14 & 0.14 \mathrm{~J} & 1.16 \mathrm{U} & 137.80 \\ 0.88 \mathrm{~J} & 16.75 & 65.97 & 0.26 \mathrm{~J} & 1.18 \mathrm{U} & 183.59\end{array}$

$24 \% \quad 41 \%$ (h) $\quad 9 \%$

$0.26 \mathrm{~J}$
$60 \%$
0.30

NA

0.14

0.21

0.05

$0.26 \mathrm{~J}$

$\begin{array}{llllll}0.42 \mathrm{~J} & 7.09 & 13.30 & 0.26 \mathrm{~J} & 1.21 \mathrm{U} & 102.96 \\ 0.53 \mathrm{~J} & 7.96 & 15.72 & 0.34 \mathrm{~J} & 1.22 \mathrm{U} & 125.83\end{array}$

$1.21 \mathrm{U}$

$\begin{array}{ll}U & 102.96\end{array}$

$23 \%$

$12 \%$

$17 \%$

0.13

NA

$20 \%$

0.12

4.97

10.74
17.70

$1.40 \mathrm{U}$

0.10

$0.38 \mathrm{~J}$

$49 \%$

7.85

$\begin{array}{lll} & 1.23 \mathrm{U} & 119.43\end{array}$

0.25

0.22

$49 \%$

NA

$1.20 \mathrm{U}$
NA
NA

200.07

$0.20 \mathrm{~J}$

$0.33 \mathrm{~J}$

5.43
6.90

6.90

0.25

0.12

12.90

0.25

$\begin{array}{ll}1.00 \mathrm{U} & 110.16 \\ 0.98 \mathrm{U} & 200.59\end{array}$

1.02

1.11

NA

$0.05 \mathrm{~J}$

0.81

2.64

\begin{abstract}
NA
\end{abstract}
$1.44 \mathrm{U}$

$33 \%$

$23 \%$
0.11

1.93

1.42
NA

$1.27 \mathrm{U}$
$1.24 \mathrm{U}$

0.16

200.59 (h)

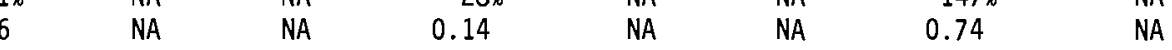

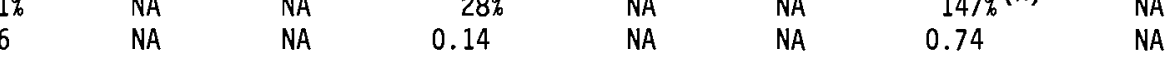

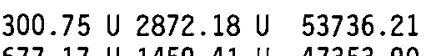
$677.17 \cup 1459.41 \cup \quad 47353.90 \quad 53233.05$ U

$\begin{array}{llll}\text { NA } & \text { NA } & 13 \% & \text { NA } \\ \text { NA } & \text { NA } & 0.06 & \text { NA }\end{array}$

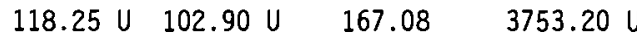
$54.13 \cup \quad 47.10 \mathrm{U} \quad 111.87$ (h) $1718.09 \mathrm{U}$

NA $\quad$ NA $\quad 40 \%$ (h) 11 NA

$\begin{array}{lll}N A & 0.20 & \text { NA }\end{array}$

$\begin{array}{llll}1.26 \mathrm{U} & 1.10 \mathrm{U} & 7.19 \mathrm{U} & 40.04 \mathrm{U}\end{array}$

$\begin{array}{llll}1.28 \mathrm{U} & 1.12 \mathrm{U} & 9.63 \mathrm{U} & 40.74 \mathrm{U}\end{array}$

$\begin{array}{llll}\text { NA } & \text { NA } & \text { NA } & \text { NA } \\ \text { NA } & \text { NA } & \text { NA } & \text { NA }\end{array}$

$\begin{array}{llll}1.32 \mathrm{U} & 1.14 \mathrm{U} & 22.57 & 41.75 \mathrm{U}\end{array}$

$\begin{array}{llll}1.32 \mathrm{U} & 1.15 \mathrm{U} & 18.76 & 41.91 \mathrm{U}\end{array}$

NA NA $\quad 18 \% \quad$ NA

$1.34 \mathrm{U}=1.16 \mathrm{U} \quad 129.07$

$\begin{array}{llll}1.34 & 1.16 \cup & 129.07 & 42.38\end{array}$

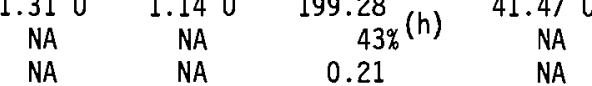

$\begin{array}{llll}1.09 U & 0.95 U & 64.91 & 34.53 \mathrm{U}\end{array}$

$\begin{array}{llll}.06 \mathrm{U} & 0.33 \mathrm{~J} & 38.36 & (\mathrm{~h}) \quad 33.68 \mathrm{U}\end{array}$

NA NA $\quad 51 \%$ (h) NA

$26.56 \quad 1.38 \mathrm{U}-1.20 \mathrm{U}-6.21-43.75 \mathrm{U}$

$20.02 \quad 1.35 \cup \quad 1.18 \cup \quad 41.02 \quad 43.75 U$

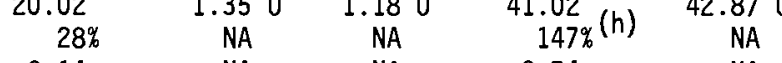


TABLE C.9. (contd)

Sediment

Treatment

Pesticides ( $\mu \mathrm{g} / \mathrm{kg}$ dry weight)

\begin{tabular}{|c|c|c|c|c|c|c|c|c|}
\hline $\begin{array}{c}\text { cis- } \\
\text { Batch Chlordane }\end{array}$ & Dieldrin & $\underline{4.4^{\prime}-\mathrm{DDE}}$ & Endrin & $\begin{array}{c}\text { Endo- } \\
\text { sulfan II }\end{array}$ & $4,4^{\prime}-D D D$ & $\begin{array}{c}\text { Endrin } \\
\text { Aldehyde }\end{array}$ & $\begin{array}{c}\text { Endosulfan } \\
\text { Sulfate }\end{array}$ & Toxaphene \\
\hline
\end{tabular}

$\mathrm{IH}-39 \mathrm{~B}$

IH-39 B Cdup

RPD

I-Stat

$\mathrm{IH}-43 \mathrm{~B}$

IH-43 B Cdup

RPD

I-Stat

PC-54 B

PC-54 B Cdup

RPD

I-Stat

Parr Canal Edge

Parr Canal Edge Cdup

\section{16}

PPD

I

Comp LC

Comp LC Cdup

PPD

I-Stat

Comp IHC-2

Comp IHC-2 Cdup

RPD

I-Stat

$0.22 \mathrm{~J}$
$0.36 \mathrm{~J}$
$48 \%$
0.24
$0.25 \mathrm{~J}$
$0.24 \mathrm{~J}$
$4 \%$
0.02
26.01
20.63
$23 \%$
0.12
4.30
6.32
$38 \%(\mathrm{~h})$
0.19

$2.71 \quad 12.45$

$1.34 \mathrm{U}$

$1.18 \mathrm{U}$

66.56

$1.28 \mathrm{~V}$

111

23.87

$40.65 \mathrm{U}$

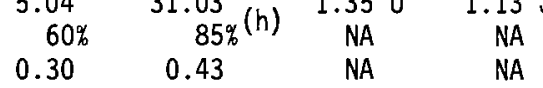

$108.02(h)$

1.29
NA

$1.12 \mathrm{U}$

37.64

$40.98 \mathrm{U}$

$\begin{array}{lll}2.13 & 5.58 & 1.38 \mathrm{U}\end{array}$

(NA

0.24

NA

NA

0.22

NA

$2.17 \quad 5.71$

$1.33 \mathrm{U}$

$1.22 \mathrm{U}$
$1.17 \mathrm{U}$

49.03
48.11

$1.32 \mathrm{U} \quad 1.15 \mathrm{U}$

18.44

$2 \% \quad 2 \%$

NA

NA

$2 \%$

1.27
NA

$1.10 \mathrm{U} \quad 16.03$

$41.94 \mathrm{U}$

NA

NA

.30

$\begin{array}{lllll}44.86 & 131.83 & 1.16 \mathrm{U} & 9.78 & 1005.82\end{array}$

$1.11 \mathrm{U} \quad 0.96 \mathrm{U}$

0.07

NA

$554.51 \mathrm{U}$

$537.60 \mathrm{U}$

$6 \% \quad 122.72 \%$

$1.17 \mathrm{U}$

$1.03 \cup \quad 651.79$

$0.96 \mathrm{U} \quad 433.31$

$35.19 \mathrm{U}$

$\begin{array}{lllll}0.03 & 0.04 & \mathrm{NA} & \mathrm{NA} & 0.21\end{array}$

NA

$0.97 \mathrm{U} \quad 302.01$

$35.39 \mathrm{U}$

$\begin{array}{lllll}11.55 & 56.54 & 1.23 \mathrm{U} & 1.09 \mathrm{U} & 327.83\end{array}$

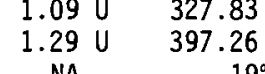

$\begin{array}{ccccc}54 \%(\mathrm{~h}) & 17 \% & \text { NA } & \text { NA } & 19 \% \\ 0.27 & 0.08 & \text { NA } & \text { NA } & 0.10\end{array}$

NA

NA

$36 \%$
0.18

NA

NA

NA

$480.57 \mathrm{~J} \quad 461.32 \mathrm{~J} \quad 642.91 \mathrm{U} \quad 565.34 \mathrm{U} \quad 20658.65$

$1.40 \mathrm{U}$

$1.03 \mathrm{U}$

758.73

$37.41 \mathrm{U}$

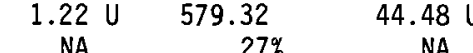

NA

NA

NA

613.56 U 533.89 U 32766.54

$19474.14 \mathrm{U}$

$\begin{array}{ccccc}8 \% & 6 \% & \text { NA } & \text { NA } & 2 \% \\ 0.04 & 0.03 & \text { NA } & \text { NA } & 0.01\end{array}$

594.85 U 517.62 U 27993.74

$18880.42 U$

NA

$\begin{array}{llcl}0.04 & 0.03 & N A & N A \\ 1.21 \mathrm{~J} & 2.52 & 1.46 \mathrm{U} & 1.28\end{array}$

NA

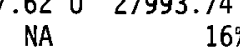

0.08

NA

$0.16 \mathrm{~J}$

$0.82 \mathrm{~J} \quad 1.88$

$1.38 \mathrm{U} \quad 1.21 \mathrm{U}$

15.85

NA

1.69

NA

$38 \%$
0.19

0.15

NA

NA

$10.32 \mathrm{~h}(\mathrm{~h})$

$1.21 \mathrm{U}$

$1.14 \mathrm{U}$

2.47

$41.75 \mathrm{U}$

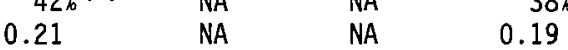

(a) $U$ Analyte was not present above the associated value.

(b) J Analyte detected below method detection limit (MDL), but above instrument detection limit (IDL).

(c) B Procedural blank ng amount greater than MDL

(d) NA Not applicable.

(e) NS Not spiked.

(f) Recovery outside of quality control range (40\%-120\%).

(g) Negative values reported as zero.

(h) Value exceeds relative precision goal of $\leq 30 \%$. For duplicates, one sample concentration must be $>10$ times the MDL

(i) M Matrix interference.

(j) Compositing duplicate. 
TABLE C.I0. Surrogate Recoveries for Chlorinated Pesticides in Younger Bay Mud from Selected Cores and Sediment Composites, United Heckathorn Remedial Investigation

Sediment

Treatment

LZ-1 A

$\mathrm{LZ}-1 \quad \mathrm{~B}$

$\mathrm{LZ}-1$ C

LZ-1 0

LZ-1 $X$

LZ-1 $\quad Y$

LZ-2 A

LZ-2 B

LZ-2 C

LZ-2 X

LZ-2 Y

LZ-3 A

LZ-3 B

LZ-3 X

LZ-3 Y

$\begin{array}{ll}L Z-5 & A \\ \text { LZ }-5 & Y\end{array}$

LZ-6 A

LZ-6 B

LZ-6 C

LZ-6 X

LZ-6 Y

LZ-7 A

LZ-7 B

LZ-7 C

LZ-7 X

LZ-7 Y

LZ-8 A

LZ-8 B

LZ-8 C

LZ-8 D

LZ-8 E

LZ-8 F

LZ-8 G

LZ-8 X

LZ-8 Y

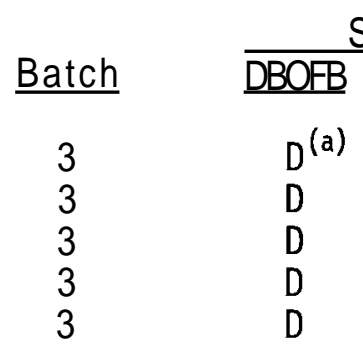

106.63
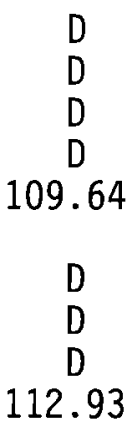

10489

6
21

6

6

6

6

21

\section{6}

6

6

6

21

\section{7}

7

7

7
7
7

7
7

7

7

101.85

D

D
Surrogate Percent Recoveries

$\underline{\mathrm{CL} 5(112) \quad \underline{C L 5(103)}}$

$\begin{array}{cc}D & D \\ D & D \\ D & D \\ D & D \\ D & D \\ 76.99 & 63.88\end{array}$

$\begin{array}{cc}D & D \\ D & D \\ D & D \\ D & D \\ 108.45 & 68.22\end{array}$

$\begin{array}{ll}D & D \\ D & D \\ D & D\end{array}$

$83.23 \quad 66.83$

D D

$102.13 \quad 67.78$

$\begin{array}{cc}D & D \\ D & D \\ D & D \\ D & D \\ 81.64 & 67.00\end{array}$

$D \quad D$

D D

$\begin{array}{lll}D & D \\ D & D\end{array}$

$77.06 \quad 63.71$

$\begin{array}{lll}106.98 & 77.06 & 63.71\end{array}$

D D

$D \quad D$

$\begin{array}{ll}D & D \\ D & D\end{array}$

D $\quad D$

D D

D $D$

$79.94 \quad 63.94$ 
TABLE C. 10. (contd)

Sediment

Treatment

LZ-9 A

LZ-9 X

LZ-9 Y

LZ-10 A

LZ-10 B

LZ-10 X

LZ-10 Y

LZ-11 A

LZ-11 X

LZ-11 Y

LZ-12 A

LZ-12 X

LZ-12 Y

LZ-13 A

LZ-13 B

LZ-13 C

LZ-13X

LZ-13 Y

LZ-14 A

LZ-14 X

LZ-14 Y

LZ-15 A

LZ-15 B

LZ-15 X

LZ-15 Y

LZ-16 A

LZ-16 B

LZ-16 C

LZ-16 D

LZ-16 X

LZ-16 Y

SF-17 A

$\mathrm{SF}-17 \mathrm{~B}$

$S F-17 X$

SF-17 $Y$ $\underline{\text { Batch }}$

6

21

8
8
9

22

7

21

9

9

22

\section{(9)}

9

22

7
8
22

22

9

22

8

9

9

8

22

11

11

11

11
Surroqate Percent Recoveries

$\underline{\mathrm{DBOFB}} \underline{\mathrm{CL5}(112)} \underline{\mathrm{CL} 5(103)}$
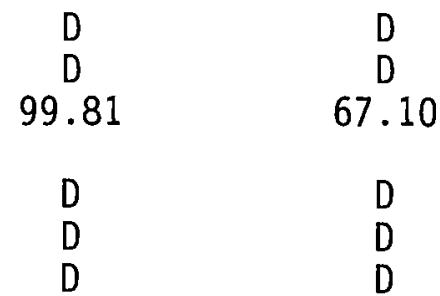

81.78

D

108.57

$\begin{array}{cc}D & D \\ D & D \\ 103.15 & 70.93\end{array}$

113.06

D

83.43

D

111.88

83.43

69.67

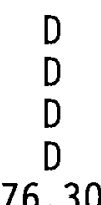

D

D

D

67.74

112.03

76.30

D

D

98.80

D

80.49

69.85

D

$\mathrm{D}$

80.32

D

69.33

101.54

D

D

D

D

76.64

$D$
$D$
$D$
$D$
$D$

66.95

86.74

59.60

56.44

72.40
51.90

45.98

46.49

66.93 
TABLE C. $10 . \quad$ (contd)

Sediment

$\underline{\text { Treatment }}$

SF-18 A

SF-18 B

$S F-18 X$

SF-18 $Y$

SF-19 A

SF-19X

SF-19 Y

SF-20 A

$S F-20 X$

SF-20 Y

SF-21 A

SF-21 B

SF-21 C

SF-21 $X$

SF-21 Y

SF-22 A

$\mathrm{SF}-22 \mathrm{~B}$

SF-22 C

SF-22 X

SF-22 $Y$

SF-23 A

$\mathrm{SF}-23 \mathrm{~B}$

$\mathrm{SF}-23 \mathrm{X}$

$\mathrm{SF}-23 \mathrm{Y}$

SF-24 A

SF-24 B

SF-24 C

SF-25 A

SF-25 B

SF-25X

SF-25 Y

SF-26 A

SF-26 B

SF-26 C

$\mathrm{SF}-26 \mathrm{X}$

SF-26 Y

Batch \begin{tabular}{c}
\multicolumn{2}{c}{ Surroqate Percent Recoveries } \\
\cline { 2 - 2 }
\end{tabular}

11

11

11

11

94.02

58.75

85.85

92.16

11

11

11

$$
93.70
$$

82.52

97.09

11

11

11

89.96

83.16

93.95

$12 \quad 90.61$

$12 \quad 70.67$

12

12

12

57.29

83.40

102.81

69.61

102.05

88.93

98.51

96.37

93.72

100.74

92.10

103.66

76.19

53.27

86.13

102.09

90.16

105.23

108.28

98.04

102.10

97.74

98.89

93.43
74.00

56.19

73.74

61.26

70.30

67.74

59.92

67.81

69.98

70.63

70.03

60.63

58.52

63.93

71.96

69.62

77.66

52.53

67.44

68.73

68.37

71.67

77.46

68.36

62.84

48.95

60.91

87.04

73.53

69.47

74.77

63.77

75.90

81.46

81.89

75.35
55.38

$38.39^{(b)}$

52.05

58.77

55.53

50.55

55.21

53.27

49.04

59.12

54.19

45.78

$39.49^{(b)}$

50.62

62.61

42.70

62.36

47.71

60.90

59.58

54.81

65.30

66.15

65.13

44.05

$34.57^{(\mathrm{b})}$

52.72

71.69

61.69

67.06

67.86

63.77

69.01

61.89

62.40

63.54 
TABLE C. $10 . \quad$ (contd)

Sediment

Treatment

SF-27 A

SF-27 B

SF $-27 \mathrm{C}$

$\mathrm{SF}-27 \mathrm{X}$

SF-27 $Y$

SF-28 A

SF-28 B

SF-28 X

SF-28 Y

SF-29 A

SF-29 B

SF-29 C

SF-29 D

SF-29 E

SF $-29 X$

SF-29 Y

SF-30 A

$S F-30 B$

$S F-30 X$

SF-30 Y

SF-31 A

$S F-31 X$

SF-31 Y

SF-32 A

SF-32 B

SF-32 C

SF-32 $X$

SF-32 Y

SF-33 A

SF-33 B

SF-33X

SF-33 Y

SF-34 A

SF-34 B

SF-34X

SF-34 Y

IH-35 A

IH-35 X

IH-35 Y

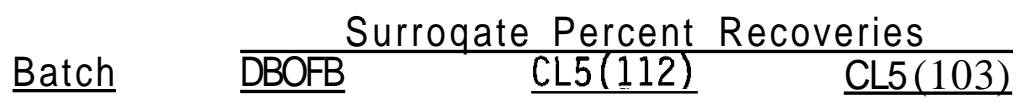

$\begin{array}{lrrr}13 & 104.21 & 75.67 & 69.49 \\ 13 & 115.93 & 75.51 & 67.80 \\ 13 & 92.29 & 75.55 & 58.68 \\ 14 & 88.46 & 65.32 & 56.84 \\ 13 & 98.39 & 67.13 & 64.27\end{array}$

$14 \quad 116.36$

97.66

113.35

$123.31^{(b)}$

76.67

82.96

104.82

72.20

68.65

80.02

78.99

98.13

109.08

74.16

68.68

68.29

57.25

61.37

73.33

104.47

76.15

109.00

93.85

115.09

110.77

66.70

52.53

81.09

66.72

64.09

61.45

49.04

71.11

58.97

66.31

66.78

93.67

50.70

73.27

105.23

59.73

106.64

68.78

62.78

40.04

49.16

66.15

93.88

113.24
$122.08^{(b)}$

66.41

78.94

45.87

71.57

80.24

62.16

70.60

81.81

80.49

59.88

67.14

65.11

$39.30^{(b)}$

65.87

41.09

65.00

69.25

40.13

45.88

44.32

66.91

94.16

72.93

92.41

77.09

64.90

62.95

64.00

63.99

63.83

59.85

70.99

59.51

72.22 
TABLE C. $10 . \quad$ (contd)

Sediment

$\underline{\text { Treatment }}$

IH-36 A

IH-36 B

IH-36 X

IH -36 Y

IH -37 A

IH -37 B

IH -37 C

IH-37 X

IH-37 $Y$

IH-38 A

IH-38 X

IH-38 Y

IH-39 A

IH-39 B

IH-39 C

IH-39X

IH-39 Y

IH-40 A

IH-40 B

IH-40 X

IH-40 Y

IH-41 A

IH-41 B

IH-41 C

IH-41 X

IH-41 Y

IH-42 A

IH-42 X

IH-42 Y

IH-43 A

IH-43 B

IH-43 X

IH-43 Y

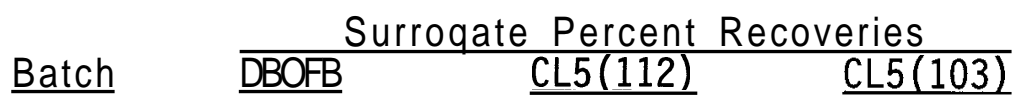

$\begin{array}{rrrl}15 & 102.89 & 71.51 & 67.02 \\ 15 & 57.65 & 49.71 & 38.76^{(b)} \\ 15 & 84.35 & 83.52 & 55.98 \\ 17 & 106.41 & 81.72 & 71.67 \\ 15 & 85.47 & 61.67 & 58.30 \\ 15 & 90.17 & 62.68 & 53.83 \\ 15 & 85.49 & 59.87 & 59.66 \\ 15 & 80.88 & 55.83 & 52.61 \\ 17 & 109.86 & 83.69 & 73.08 \\ 16 & 81.52 & 58.89 & 49.98 \\ 16 & 68.15 & 46.84 & 38.72^{(b)} \\ 17 & 109.12 & 82.59 & 68.97 \\ 16 & 99.36 & 63.97 & 54.52 \\ 16 & 96.26 & 67.18 & 62.27 \\ 16 & 65.35 & 58.18 & 43.12 \\ 16 & 59.20 & 56.49 & 33.88^{(b)} \\ 17 & 98.40 & 79.51 & 66.65\end{array}$

16
25 $\quad 83.70$

$\begin{array}{lr}25 & 70.31 \\ 16 & 105.42\end{array}$

$17 \quad 100.77$

$18 \quad 104.71$

$18 \quad 119.06$

$16 \quad 89.53$

$16 \quad 75.61$

$17 \quad 107.05$

$18 \quad 82.49$

$18 \quad 90.42$

$17 \quad 83.38$

$25 \quad 81.05$

$18 \quad 95.07$

$18 \quad 90.69$

17
51.48

53.62

68.87

77.07

70.61

73.47

60.97

55.74

78.50

61.07

65.32

68.63

59.15

68.87

66.92

80.86
53.73

48.33

62.66

66.35

61.31

67.29

47.50

44.63

70.99

50.82

55.15

58.37

57.47

56.39

53.96

68.42 
TABLE C. $10 . \quad$ (contd)

Sediment

Treatment

IH-44 A

IH-44 B

IH-44 C

IH-44 D

IH-44 X

IH-44 Y

IH-45 A

IH-45 B

IH-45 C

IH-45 X

IH-45 Y

IH-46 A

IH-46 B

IH-46 C

IH-46 X

IH-46 Y

IH-47 A

IH-47 B

IH-47 C

IH $-47 \quad X$

IH-47 $Y$

IH-48 A

IH-48 B

IH-48 X

IH -48 Y

IH-49 A

IH-49 B

IH-49 X

IH-49 Y

IH-50 A

IH -50 B

IH $-50 \mathrm{C}$

IH $-50 X$

IH-50 Y

IH-51 A

IH-51 B

IH-51 X

IH-51 Y

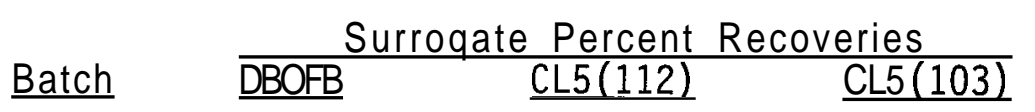

$\begin{array}{lccc}18 & 83.08 & 57.53 & 49.61 \\ 18 & 103.30 & 73.33 & 59.54 \\ 18 & 96.93 & 70.89 & 59.85 \\ 18 & 88.20 & 64.88 & 53.27 \\ 25 & 121.77^{\text {b) }} & 70.58 & 90.84 \\ 17 & 89.39 & 66.05 & 60.92 \\ 19 & 51.21 & 41.92 & 41.11 \\ 18 & 105.07 & 75.16 & 66.62 \\ 18 & 91.00 & 66.40 & 55.27 \\ 19 & 90.23 & 65.79 & 59.43 \\ 17 & 108.41 & 83.24 & 71.86 \\ 19 & 96.69 & 75.85 & 64.22 \\ 19 & 91.08 & 77.62 & 61.49 \\ 19 & 49.91 & 45.41 & 40.51 \\ 19 & 82.88 & 64.47 & 58.17 \\ 17 & 84.17 & 64.80 & 57.01\end{array}$

$19 \quad 98.90$

$19 \quad 67.53$

$19 \quad 92.75$

$25 \quad 78.77$

$17 \quad 108.19$

$19 \quad 90.00$

$19 \quad 83.12$

$19 \quad 96.95$

$17 \quad 107.92$

$19 \quad 102.14$

$19 \quad 67.51$

$19 \quad 47.44$

$17 \quad 106.59$

$25 \quad 72.44$

$22 \quad 58.49$

22

22

21

62.83

55.43

106.88

$23 \quad 101.36$

$23 \quad 89.32$

22

21
89.85

104.49
67.06

55.70

69.90

62.20

84.12

61.38

62.47

72.35

80.44

78.64

65.63

42.62

78.84

57.02

45.51

48.13

45.39

81.12

79.26

71.38

64.47

80.46
65.75

50.14

61.92

50.05

68.38

60.51

58.97

64.07

71.00

67.51

49.20

40.47

68.49

52.95

42.52

45.25

43.43

64.61

61.73

58.53

55.16

69.20 
TABLE C.10. (contd)

Sediment

Treatment

$P C-52$ A

$P C-52$ B

$\mathrm{PC}-52 \mathrm{C}$

PC-53 A

$P C-53 \quad B$

$P C-53 C$

PC-54 A

PC-54 B

PC-54 C

SFC Marina

FSFC Edge-West

Parr Canal Edge

IHC Edge-East

IHC Edge-West

Outer Harbor Edge

Comp LC

Comp LC-1

Comp LC-2

Comp LC-3

Comp LC-4

Comp LC-5

Comp LC-6

Comp USFC

Comp FSFC

Comp IHC-1

Comp IHC-2

Comp IHC-3

Comp GD

C-SFBF

C-SFBC

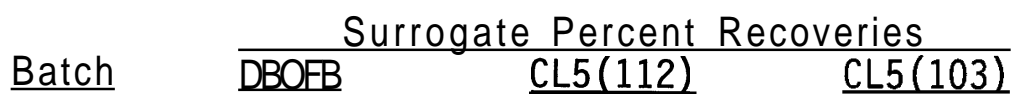

$\begin{array}{llll}25 & 44.20 & 39.16^{(\mathrm{b})} & 36.43^{(\mathrm{b})} \\ 25 & 5.94^{(\mathrm{b})} & 11.09^{(\mathrm{b})} & 11.99^{(\mathrm{b})} \\ 25 & 14.34^{(\mathrm{b})} & 17.20^{(\mathrm{b})} & 17.78^{(\mathrm{b})} \\ 20 & 84.51 & 60.06 & 72.15 \\ 20 & 40.38 & 47.01 & 44.00 \\ 25 & 51.30 & 46.67 & 94.97 \\ 20 & 52.46 & 50.29 & 45.03 \\ 20 & 47.00 & 55.04 & 38.89^{(\mathrm{b})} \\ 20 & 41.64 & \mathrm{M}^{(\mathrm{c})} & 59.65\end{array}$

23

24

24

23

23

23

3

8

8

8

6

3

4
23

24

23

23

23

23

21

21

93.64
$126.77^{(b)}$
80.76
94.67
95.82
114.09

D

D

D

D

D

D

63.50

69.24

115.00

89.17

66.35

107.07

95.03

95.13
65.47

82.87

45.39

75.94

68.19

79.04

$D$
$D$
$D$
$D$
$D$
$D$
$D$

64.83

73.91

82.87

68.76

63.91

79.90

69.27

82.08
57.76

69.80

55.25

71.85

58.78

72.68

D

D

D

D

D

D

D

$36.34^{(b)}$

54.07

74.44

59.96

45.70

66.62

61.87

64.94

Qualit v Control Samples

Method Blanks

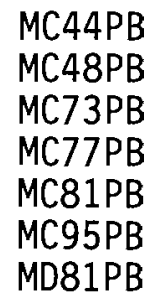

15

$D$
$D$
$D$
$D$
$D$
$D$
92.89

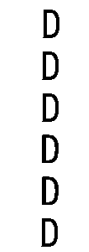

D
D
D
D
D
D

74.17

63.48 
TABLE C. $10 . \quad$ (contd)

Sediment

Treatment

MD85PB

MD89PB

MD95PB

MD10PB

MD14PB

MD49PB

MD53PB

MD99PB

ME04PB

ME63PB

ME67PB

ME71PB

ME75PB

MH35PB

Matrix Spikes

SF-20 Y NS

SF-20 Y MSD

SF-22 Y NS

SF-22 Y MSD

SF-25 Y MS

SF-25 Y MSD

SF-31 Y NS

SF-31 Y MSD

IH-35 Y NS

$\mathrm{IH}-35$ Y MSD

IH-38 Y MS

IH-38 Y MSD

IH-49 Y NS

$\mathrm{IH}-49$ Y MSD

IH-43 Y MS

$\mathrm{IH}-43$ Y MSD

IH-46 Y MS

$\mathrm{IH}-46$ Y MSD

$\mathrm{IH}-45$ Y MS

IH-45 Y MSD
Batch

16

17

18

11

12

13

14

19

20

21

22

23

24

25
Surrogate Percent Recoveries

DBOFB $\quad \underline{C L 5(112)} \quad \underline{C L 5(103)}$

98.78

106.29

113.66

87.09

95.74

81.78

109.35

$123.78^{(b)}$

108.81

50.99

41.75

92.44

97.85

77.53

72.87

81.12

82.44

70.24

68.10

73.65

68.87

78.74

82.04

57.31

$39.27^{(b)}$

81.29

82.60

56.92
66.35

71.97

72.45

63.13

60.81

62.14

68.25

76.47

76.90

47.65

$35.46^{(b)}$

59.02

62.21

53.31
11

11

12

12

13

13

14

14

17

17

17

17

17

17

17

17

17

17

17

17
91

96

101

86

78

78

100

97

86

79

107

99

107

99

106

99

90

92

87

97
77

80

72

63

72

72

67

66

76

70

81

74

81

74

76

74

87

84

70

75
64

66

64

55

57

59

66

62

65

60

66

63

66

63

71

66

61

59

65 
TABLE C. $10 . \quad$ (contd)

Sediment

$\underline{\text { Treatment }}$

$\mathrm{IH}-50$ Y NS

IH-50 Y MSD

LZ-14 Y NS

LZ-14 Y MSD

LZ-14 Y NS

LZ-14 Y MSD

LZ-14 Y NS

LZ-14 Y MSD

$\mathrm{IH}-50$ A NS

$\mathrm{IH}-50$ A MSD
21

21

22

22

22

22

22

22

25

25

Analvtical Duplicates

LZ-1 D Duplicate

LZ-2 B Duplicate

LZ-5 A Duplicate

LZ-11 A Duplicate

Comp LC-3 Duplicate

LZ-13 X Duplicate

$\mathrm{IH}-37 \times$ Duplicate

$\mathrm{IH}-41 \times$ Duplicate

$\mathrm{IH}-49$ Y Duplicate

IH-41 A Dupl jcate

SF-17 B Cdup (d) Duplicate

SF-22 A Duplicate

SF-26 A Duplicate

SF-31 X Duplicate

IH-46 A Duplicate

PC-54 A Duplicate

LZ-5 Y Duplicate

IH-50 A Duplicate

Comp USFC Duplicate

SF-33 X Duplicate

$\mathrm{IH}-40$ B Duplicate

3

$$
4
$$

\section{6}

7

8

9

15

16

17

18

11

12

13

14

19

20

21

22

23

24

25

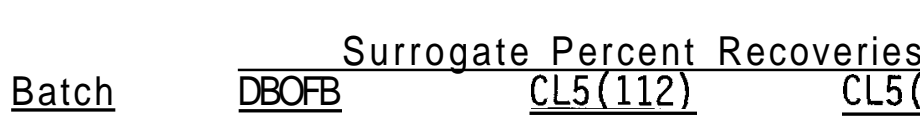

TABLE C.10. (contd)

\begin{tabular}{rcc}
\multicolumn{3}{c}{ Surrogate Percent } \\
\cline { 1 - 2 } DBOFB & CL5(112) & $\underline{C L 5(103)}$ \\
90 & 70 & 64 \\
107 & 78 & 66 \\
106 & 71 & 67 \\
91 & 64 & 58 \\
87 & 81 & 63 \\
51 & 68 & 49 \\
87 & 81 & 60 \\
95 & 89 & 63 \\
72 & 61 & 58 \\
76 & 64 & 62
\end{tabular}

90

107

106

87

2

25

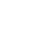

D
D
D
D
D
D

86.51

89.40

108.19

103.95

87.11

89.10

104.30

93.34

89.38

65.84

104.05

103.06

48.38

80.72

58.37

$\begin{array}{ll}\mathrm{D} & \mathrm{D} \\ \mathrm{D} & \mathrm{D} \\ \mathrm{D} & \mathrm{D} \\ \mathrm{D} & \mathrm{D} \\ \mathrm{D} & \mathrm{D} \\ \mathrm{D} & \mathrm{D}\end{array}$

63.35

63.35

78.29

67.49

70.52

78.06

78.30

90.66

70.97

$153.87^{(\mathrm{b})}$

74.26

40.73

106.39

45.52
$57.14 \quad 62.62$
58.32

54.30

71.37

59.06

53.98

49.33

61.58

56.23

62.62

52.91

63.23

$29.54^{(b)}$

51.23

40.81

Compositing Duplicates

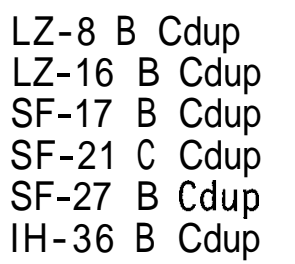

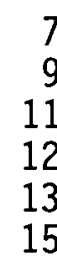

$D$
$D$
65.51
69.45
112.40
85.91

$\begin{array}{cc}D & D \\ D & D \\ 59.80 & 43.60 \\ 71.80 & 46.73 \\ 87.09 & 69.93 \\ 77.90 & 52.71\end{array}$


TABLE C.11. $0 \mathrm{il}$ and Grease and Total Petroleum Hydrocarbons in Younger Bay Mud from Selected Cores and Sediment Composites, United

Heckathorn Remedial Investigation

\begin{tabular}{|c|c|c|c|}
\hline $\begin{array}{l}\text { Sediment } \\
\text { Treatment }\end{array}$ & $\begin{array}{l}\text { Total Solids } \\
\text { (Percent) }\end{array}$ & $\begin{array}{c}0 \mathrm{il} \text { and Grease } \\
\text { (ma/kg drv weiaht) }\end{array}$ & $\begin{array}{l}\text { Total Petroleum } \\
\text { Hydrocarbons } \\
\text { (ma/kg drv weight) }\end{array}$ \\
\hline $\begin{array}{l}\text { Target } \mathrm{DL}^{(\mathrm{a})} \\
\text { Achieved DL High } \\
\text { Achieved DL Low }\end{array}$ & $\begin{array}{l}N A^{(b)} \\
N A \\
N A\end{array}$ & $\begin{array}{l}20 \\
30 \\
20\end{array}$ & $\begin{array}{l}20 \\
90 \\
30\end{array}$ \\
\hline $\begin{array}{ll}\text { LZ-1 } & M \\
\text { LZ-3 } & M \\
\text { LZ-6 } & M \\
\text { LZ-9 } & M \\
\text { LZ-11 } & M \\
\text { LZ-13 } & M \\
\text { LZ-15 } & M\end{array}$ & $\begin{array}{l}32.27 \\
44.75 \\
61.26 \\
48.08 \\
63.67 \\
48.00 \\
40.48\end{array}$ & $\begin{array}{r}26,000 \\
2,100 \\
1,700 \\
770 \\
940 \\
670 \\
400\end{array}$ & $\begin{array}{r}22,900 \\
1,800 \\
1,400 \\
490 \\
600 \\
470 \\
240\end{array}$ \\
\hline $\begin{array}{ll}\text { SF-17 } & M \\
\text { SF-18 } & M \\
\text { SF-19 } & M \\
\text { SF-20 } & M \\
\text { SF-21 } & M \\
\text { SF-22 } & M \\
\text { SF-23 } & M \\
\text { SF-24 } & M \\
\text { SF-25 } & M \\
\text { SF-26 } & M\end{array}$ & $\begin{array}{l}46.41 \\
42.05 \\
41.62 \\
38.10 \\
45.19 \\
48.72 \\
45.61 \\
43.47 \\
54.68 \\
44.31\end{array}$ & $\begin{array}{l}340 \\
510 \\
520 \\
450 \\
300 \\
220 \\
190 \\
240 \\
520 \\
370\end{array}$ & $\begin{array}{l}400 \\
360 \\
370 \\
370 \\
290 \\
170 \\
330 \\
330 \\
520 \\
250\end{array}$ \\
\hline $\begin{array}{l}\text { SF-27 } M \\
\text { SF-28 } \\
\text { SF-30 } \\
\text { SF-32 } \\
\text { SF-34 } \\
\text { SF- }\end{array}$ & $\begin{array}{l}44.66 \\
53.61 \\
40.96 \\
54.53 \\
51.48\end{array}$ & $\begin{array}{l}390 \\
200 \\
400 \\
250 \\
310\end{array}$ & $\begin{array}{l}450 \\
130 \\
170 \\
150 \\
210\end{array}$ \\
\hline $\begin{array}{l}I H-37 M \\
I H-38 M \\
I H-39 M\end{array}$ & $\begin{array}{l}43.50 \\
43.31 \\
45.36\end{array}$ & $\begin{array}{l}250 \\
270 \\
246\end{array}$ & $\begin{array}{l}90 U^{(c)} \\
90 U \\
90 U\end{array}$ \\
\hline $\begin{array}{l}\text { PC-52 M } \\
\text { PC-53 M } \\
\text { PC-54 M }\end{array}$ & $\begin{array}{l}44.75 \\
44.66 \\
50.86\end{array}$ & $\begin{array}{r}19,800 \\
14,200 \\
3,700\end{array}$ & $\begin{array}{r}14,800 \\
11,200 \\
2,300\end{array}$ \\
\hline $\begin{array}{ll}\text { Comp LC } \\
\text { Comp LC-1 } \\
\text { Comp LC-2 } \\
\text { Comp LC-3 } \\
\text { Comp LC-4 } \\
\text { Comp LC-5 } \\
\text { Comp LC-6 }\end{array}$ & $\begin{array}{l}49.90 \\
36.14 \\
42.07 \\
51.37 \\
43.33 \\
47.89 \\
49.14\end{array}$ & $\begin{array}{r}1,000 \\
4,310 \\
2,600 \\
1,340 \\
630 \\
1,200 \\
2,200\end{array}$ & $\begin{array}{r}840 \\
3,960 \\
2,300 \\
1,080 \\
480 \\
1,000 \\
2,000\end{array}$ \\
\hline
\end{tabular}


TABLE C. 11. (contd)

$\begin{array}{lccc}\begin{array}{c}\text { Sediment } \\ \text { Treatment }\end{array} & \begin{array}{c}\text { Total Solids } \\ \text { (Percent) }\end{array} & \begin{array}{c}\text { O il and Grease } \\ \text { (mq/kq drv weight) }\end{array} & \begin{array}{c}\text { Total Petroleum } \\ \text { Hydrocarbons } \\ \text { (mq/kq drv weight) }\end{array} \\ \text { Comp USFC } & 41.52 & 910 & 660 \\ \text { Comp FSFC } & 46.88 & 450 & 330 \\ \text { Comp IHC-1 } & 41.70 & 390 & 290 \\ \text { Comp IHC-2 } & 39.78 & 380 & 180 \\ \text { Comp IHC-3 } & 42.15 & 290 & 190 \\ \text { Comp GD } & 36.77 & 480 & 290 \\ \text { C-SFBF } & 53.93 & 260 & 160 \\ \text { C-SFBC } & 81.13 & 110 & 69 \\ \text { CBM Comp - Fine } & 80.03 & 30 \mathrm{U} & 30 \mathrm{U} \\ \text { CBM Comp - Coarse } & 75.70 & 30 \mathrm{U} & 30 \mathrm{U} \\ \end{array}$
(a) DL Detection limit.
(b) NA Not applicable.
(c) U Analyte was not present above the associated value. 
TABLE C.12. Quality Control Data for $0 \mathrm{il}$ and Grease and Total Petroleum Hydrocarbons, United Heckathorn Remedial Investigation

\begin{tabular}{|c|c|c|c|}
\hline Sediment Treatment & $\begin{array}{l}\text { Total Solids } \\
\text { (Percent) }\end{array}$ & $\begin{array}{c}\text { Oil and Grease } \\
\text { (mg/kg } \\
\text { dry weight) }\end{array}$ & $\begin{array}{c}\text { Total Petroleum } \\
\text { Hydrocarbons } \\
(\mathrm{mg} / \mathrm{kg} \\
\text { dry weight) }\end{array}$ \\
\hline
\end{tabular}

Method Blanks

Blank
Blank
Blank
Matrix Spikes
Comp LC
Comp LC NS
Concentration Recovered
Amount Spiked
Percent Recovery
LZ-15 M
LZ-15 M NS
Concentration Recovered
Amount Spiked
Percent Recovery
SF-32 M Cdup (d)
SF-32 M Cdup NS
Concentration Recovered
Amount Spiked
Percent Recovery

NA
Na
NA

$20 U^{(b)}$

$20 \mathrm{U}$

$20 \mathrm{U}$

$20 \mathrm{U}$

$20 \mathrm{U}$

49.90

49.90

$\mathrm{NS}^{(c)}$

$20 \mathrm{U}$

Analytical Duplicates

$\begin{array}{lrcc}\text { Comp LC } & 49.90 & 1000 & 840 \\ \text { Comp LC Duplicate } & \text { NA } & 1000 & 770 \\ \text { RPD } & \text { NA } & 0 \% & 9 \% \\ \text { I-Stat } & \text { NA } & 0.00 & 0.04 \\ & 40.48 & 400 & 240 \\ \text { LZ-15 M } & \text { NA } & 520 & 410 \\ \text { LZ-15 M Duplicate } & \text { NA } & 26 \% & 52 \% \\ \text { RPD } & \text { NA } & 0.13 & 0.26 \\ \text { I-Stat } & & & \\ \text { SF-32 M Cdup } & 54.57 & 280 & 260 \\ \text { SF-32 M Cdup Duplicate } & \text { NA } & 390 & 190 \\ \text { RPD } & \text { NA } & 33 \%(\mathrm{e}) & 31 \% \\ \text { I-Stat } & \text { NA } & 0.16 & 0.16\end{array}$

40.48

40.48

NA

NS

1000

50900

49900

44100

$113 \%$

840

NA

NA

NS

NA

NA

400
86100
85700
81300
$105 \%$

240

NA

NA

NS

54.57

54.57

NA

NS

280

48500

48220

48900

$99 \%$

260

NA

NA

NS

NA

Comp LC

Comp LC Duplicate

RPD

NA

(

NA

60

S

NA

49.90

$1000 \quad 840$

$0 \% \quad 9 \%$

0.00

240

NA $\quad 520$ (e) 410

$26 \%(\mathrm{e})$

$52 \%(\mathrm{e})$

54.57

NA

280
390
$33 \%(e)$
0.16

260

$31 \%$ (e)

0.16 
TABLE C. $12 . \quad$ (contd)

\begin{tabular}{|c|c|c|c|}
\hline$\underline{\text { Sediment Treatment }}$ & $\begin{array}{l}\text { Total Solids } \\
\text { (Percent) }\end{array}$ & $\begin{array}{c}0 \text { il and Grease } \\
\text { (mg/kg } \\
\text { drv weight) } \\
\end{array}$ & $\begin{array}{r}\text { Total Pet } \\
\text { Hydrocarb } \\
\text { (mg/ks } \\
\text { drv weic } \\
\end{array}$ \\
\hline \multicolumn{4}{|c|}{ Compositing Duplicates } \\
\hline $\begin{array}{l}\text { Comp LC } \\
\text { Comp LC Cdup } \\
\text { RPD } \\
\text { I-Stat }\end{array}$ & $\begin{array}{c}49.90 \\
48.50 \\
3 \% \\
0.01\end{array}$ & $\begin{array}{l}1000 \\
760 \\
27 \%(\mathrm{e}) \\
0.14\end{array}$ & $\begin{array}{c}840 \\
820 \\
2 \% \\
0.01\end{array}$ \\
\hline $\begin{array}{l}\text { Comp IHC-2 } \\
\text { Comp IHC-2 Cdup } \\
\text { RPD } \\
\text { I-Stat }\end{array}$ & $\begin{array}{c}39.78 \\
40.41 \\
2 \% \\
0.01\end{array}$ & $\begin{array}{l}380 \\
230 \\
\quad 49 \%(\mathrm{e}) \\
0.25\end{array}$ & $\begin{array}{c}180 \\
180 \\
0 \% \\
0.00\end{array}$ \\
\hline $\begin{array}{l}\text { SF-32 M } \\
\text { SF-32 M Cdup } \\
\text { RPD } \\
\text { I-Stat }\end{array}$ & $\begin{array}{l}54.53 \\
54.57 \\
0 \% \\
0.00\end{array}$ & $\begin{array}{l}250 \\
280 \\
11 \% \\
0.06\end{array}$ & $\begin{array}{l}150 \\
260 \\
54 \%(\mathrm{e}) \\
0.27\end{array}$ \\
\hline
\end{tabular}

\footnotetext{
(a) NA Not applicable.

(b) $U$ Analyte was not present above the associated value.

(c) NS Not spiked.

(d) Compositing duplicate.

(e) Value exceeds relative precision goal of $\leq 20 \%$.
} 
TABLE C.13. Total Polynuclear Aromatic Hydrocarbons (PAHs) in Younger Bay Mud from Selected Cores and Sediment Composites, United Heckathorn Remedial Investigation

Sediment

Treatment

LZ-1 $M$

LZ-3 $\quad M$

LZ-6 $\quad M$

LZ-9 M

LZ-11 $M$

LZ-13 $M^{(a)}$

LZ-15 M

SF-17 M

SF-18 M

SF-19 M

SF-20 M

SF-21 M

SF-22 M

$\mathrm{SF}-23 \mathrm{M}$

SF-24 M

$\mathrm{SF}-25 \mathrm{M}$

SF-26 M

SF-27 M

$\mathrm{SF}-28 \mathrm{M}$

SF-30 M

SF-32 M

SF-34 M

IH-37 M

IH-38 M

IH-39 M

PC-52 M

PC-53 M

PC-54 M

Comp LC

Comp LC-1

Comp LC-2

Comp LC-3

Comp LC-4

Comp LC-5

Comp LC-6

Comp USFC

Comp FSFC

\begin{tabular}{|c|c|c|}
\hline $\begin{array}{l}\text { Total } \\
\text { LPAHs }\end{array}$ & $\begin{array}{l}\text { Total } \\
\text { HPAHs } \\
\end{array}$ & $\begin{array}{r}\text { Total } \\
\text { PAHs } \\
\end{array}$ \\
\hline $\begin{array}{r}7819.1 \\
773.6 \\
1538.1 \\
587.2 \\
606.0 \\
11693.1 \\
84.8\end{array}$ & $\begin{array}{r}4684.4 \\
5,281.0 \\
2999.9 \\
2324.6 \\
1294.4 \\
20424.9 \\
665.0\end{array}$ & $\begin{array}{r}12503 \\
6,055 \\
4538 \\
2912 \\
1900 \\
32118 \\
750\end{array}$ \\
\hline $\begin{array}{r}76.4 \\
143.6 \\
34.7 \\
93.2 \\
34.8 \\
110.3 \\
62.4 \\
46.1 \\
9714.2 \\
77.3\end{array}$ & $\begin{array}{r}724.2 \\
1331.7 \\
286.9 \\
855.6 \\
288.1 \\
1249.8 \\
366.4 \\
555.4 \\
14484.4 \\
509.8\end{array}$ & $\begin{array}{r}801 \\
1475 \\
322 \\
949 \\
323 \\
1360 \\
429 \\
602 \\
24199 \\
587\end{array}$ \\
\hline $\begin{array}{r}21.6 \\
228.8 \\
63.9 \\
87.6 \\
190.6\end{array}$ & $\begin{array}{r}173.1 \\
1626.7 \\
501.1 \\
557.6 \\
1637.2\end{array}$ & $\begin{array}{r}195 \\
1856 \\
565 \\
645 \\
1828\end{array}$ \\
\hline $\begin{array}{l}62.0 \\
23.4 \\
80.0\end{array}$ & $\begin{array}{l}566.2 \\
191.1 \\
805.9\end{array}$ & $\begin{array}{l}628 \\
215 \\
886\end{array}$ \\
\hline $\begin{array}{r}1726.8 \\
6789.3 \\
562.3\end{array}$ & $\begin{array}{r}5056.0 \\
19696.1 \\
4170.7\end{array}$ & $\begin{array}{r}6783 \\
26485 \\
4733\end{array}$ \\
\hline $\begin{array}{r}959.4 \\
1150.2 \\
641.6 \\
544.9 \\
3654.4 \\
1701.9 \\
4494.9 \\
3542.2 \\
200.4\end{array}$ & $\begin{array}{r}6520.8 \\
10356.6 \\
4311.3 \\
4269.1 \\
17912.2 \\
7761.6 \\
4828.9 \\
5691.5 \\
1594.9\end{array}$ & $\begin{array}{r}7480 \\
11507 \\
4953 \\
4814 \\
21567 \\
9464 \\
9324 \\
9234 \\
1795\end{array}$ \\
\hline
\end{tabular}


TABLE C. $13 . \quad$ (contd)

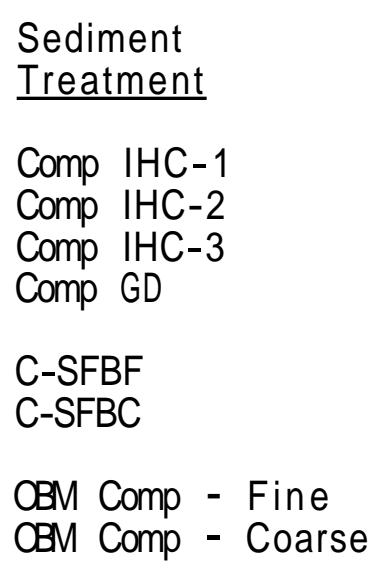

\begin{tabular}{|c|c|c|}
\hline $\begin{array}{l}\text { Total } \\
\text { LPAHs }\end{array}$ & $\begin{array}{l}\text { on }(\mu \mathrm{g} / \mathrm{k} \\
\text { Total } \\
\text { HPAHs }\end{array}$ & $\begin{array}{r}\text { Total } \\
\text { PAHs }\end{array}$ \\
\hline $\begin{array}{r}115.4 \\
73.9 \\
64.4 \\
32.8\end{array}$ & $\begin{array}{l}952.4 \\
649.2 \\
587.0 \\
198.1\end{array}$ & $\begin{array}{r}1068 \\
723 \\
651 \\
231\end{array}$ \\
\hline $\begin{array}{r}70.2 \\
0.4\end{array}$ & $\begin{array}{r}497.4 \\
6.2\end{array}$ & $\begin{array}{r}568 \\
7\end{array}$ \\
\hline $\begin{array}{l}14.8 \\
42.2\end{array}$ & $\begin{array}{r}20.4 \\
101.0\end{array}$ & $\begin{array}{r}35 \\
143\end{array}$ \\
\hline
\end{tabular}

(a) Recoveries of al1 three surrogate compounds were below acceptable quality control range $(40 \%-120 \%)$ in original and repeat analyses. Repeat analysis data are reported here. 
TABLE C. 14. Low Molecular Weight Polynuclear Aromatic Hydrocarbons (LPAHs) in Younger Bay Mud from Selected Cores and Sediment Composites, United Heckathorn Remedial Investigation

PAH Concentration ( $\mu \mathrm{g} / \mathrm{kg}$ dry weight)

\begin{tabular}{|c|c|c|c|c|c|c|c|c|c|c|c|}
\hline \multicolumn{2}{|c|}{$\begin{array}{l}\text { Sediment } \\
\text { Treatment }\end{array}$} & Batch & $\begin{array}{c}\text { Naphtha- } \\
\text { Iene }\end{array}$ & $\begin{array}{c}\text { 2-Methyl- } \\
\text { naphtha- } \\
\text { lene }\end{array}$ & \multicolumn{2}{|l|}{$\begin{array}{c}\text { I-Methyl- } \\
\text { naphtha- } \\
\text { lene }\end{array}$} & $\begin{array}{l}\text { Acenaph- } \\
\text { thylene }\end{array}$ & $\begin{array}{l}\text { Acenaph- } \\
\text { thene }\end{array}$ & Fluorene & $\begin{array}{l}\text { Phenan- } \\
\text { threne }\end{array}$ & $\begin{array}{c}\text { Anthra- } \\
\text { cene }\end{array}$ \\
\hline $\begin{array}{l}\text { Targe } \\
\text { Achiev } \\
\text { Achiev }\end{array}$ & $\begin{array}{l}\text { t }(a) \\
\text { ved } D \text { High } \\
\text { ved } D L \text { Low }\end{array}$ & & $\begin{array}{l}20 \\
13.09 \\
5.13\end{array}$ & $\begin{array}{l}20 \\
13.09 \\
5.13\end{array}$ & $\begin{array}{l}20 \\
13.09 \\
5.13\end{array}$ & & $\begin{array}{l}20 \\
8.76 \\
3.43\end{array}$ & $\begin{array}{c}20 \\
11.37 \\
4.46\end{array}$ & $\begin{array}{l}20 \\
11.07 \\
4.34\end{array}$ & $\begin{array}{r}20 \\
11.60 \\
4.54\end{array}$ & $\begin{array}{l}20 \\
10.06 \\
3.94\end{array}$ \\
\hline $\begin{array}{l}\text { LZ-1 } \\
\text { LZ-3 } \\
\text { LZ-6 } \\
\text { LZ-9 } \\
\text { LZ-11 } \\
\text { LZ-13 } \\
\text { LZ-15 }\end{array}$ & $\begin{array}{l}M \\
M \\
M \\
M \\
M \\
M \\
M\end{array}$ & $\begin{array}{r}2 \\
2 \\
2 \\
2 \\
2 \\
25 \\
1\end{array}$ & $\begin{array}{r}1071.47 \\
118.69 \\
272.78 \\
110.57 \\
208.48 \\
2155.16 \\
12.14\end{array}$ & $\begin{array}{r}1579.39 \\
79.24 \\
151.98 \\
69.75 \\
51.73 \\
1752.44 \\
10.82\end{array}$ & $\begin{array}{r}1005.06 \\
39.29 \\
83.52 \\
35.15 \\
40.47 \\
1025.62 \\
3.87\end{array}$ & ${ }_{J}(c)$ & $\begin{array}{r}116.42 \\
14.95 \\
12.83 \\
11.05 \\
4.90 \\
152.81 \\
2.79 \mathrm{~J}\end{array}$ & $\begin{array}{r}553.59 \\
38.19 \\
139.99 \\
40.09 \\
54.83 \\
894.38 \\
3.73 \mathrm{~J}\end{array}$ & $\begin{array}{r}842.99 \\
76.07 \\
198.97 \\
52.91 \\
49.16 \\
1203.51 \\
5.28\end{array}$ & $\begin{array}{r}2274.00 \\
221.72 \\
493.03 \\
170.12 \\
129.31 \\
2779.13 \\
29.19\end{array}$ & $\begin{array}{r}376.16 \\
185.46 \\
184.95 \\
97.59 \\
67.09 \\
1730.05 \\
16.94\end{array}$ \\
\hline $\begin{array}{l}S F-17 \\
S F-18 \\
S F-19 \\
S F-20 \\
S F-21 \\
S F-22 \\
S F-23 \\
S F-24 \\
S F-25 \\
S F-26\end{array}$ & $\begin{array}{l}M \\
M \\
M \\
M \\
M \\
M \\
M \\
M \\
M \\
M\end{array}$ & $\begin{array}{l}2 \\
2 \\
2 \\
2 \\
2 \\
2 \\
2 \\
2 \\
2 \\
5\end{array}$ & $\begin{array}{r}10.72 \\
18.68 \\
5.50 \\
10.82 \\
6.23 \\
17.94 \\
9.17 \\
5.15 \\
243.79 \\
25.21\end{array}$ & $\begin{array}{r}5.72 \mathrm{~J} \\
10.27 \mathrm{~J} \\
2.67 \mathrm{~J} \\
7.18 \mathrm{~J} \\
2.87 \mathrm{~J} \\
5.86 \mathrm{~J} \\
3.63 \mathrm{~J} \\
2.53 \mathrm{~J} \\
63.64 \\
5.21 \mathrm{~J}\end{array}$ & $\begin{array}{c}2.21 \\
4.55 \\
1.01 \\
3.99 \\
1.25 \\
2.84 \\
1.56 \\
1.17 \\
59.78 \\
1.84\end{array}$ & & $\begin{array}{r}3.21 \mathrm{~J} \\
5.57 \mathrm{~J} \\
1.41 \mathrm{~J} \\
3.17 \mathrm{~J} \\
1.64 \mathrm{~J} \\
5.02 \mathrm{~J} \\
2.13 \mathrm{~J} \\
2.61 \mathrm{~J} \\
104.15 \\
1.95 \mathrm{~J}\end{array}$ & $\begin{array}{r}3.00 \mathrm{~J} \\
4.57 \mathrm{~J} \\
1.10 \mathrm{~J} \\
2.80 \mathrm{~J} \\
1.40 \mathrm{~J} \\
3.82 \mathrm{~J} \\
1.45 \mathrm{~J} \\
1.50 \mathrm{~J} \\
919.82 \\
3.98 \mathrm{~J}\end{array}$ & $\begin{array}{r}3.76 \\
8.07 \\
1.57 \\
4.15 \\
1.36 \\
6.06 \\
4.12 \\
2.11 \\
1073.32 \\
4.25\end{array}$ & $\begin{array}{r}30.85 \\
62.26 \\
15.10 \\
42.67 \\
13.41 \\
42.85 \\
26.25 \\
21.89 \\
4992.25 \\
22.42\end{array}$ & $\begin{array}{r}16.92 \\
29.63 \\
6.34 \\
18.44 \\
6.63 \\
25.88 \\
14.05 \\
9.14 \\
2257.40 \\
12.46\end{array}$ \\
\hline $\begin{array}{l}\text { SF }-27 \\
\text { SF-28 } \\
\text { SF-30 } \\
\text { SF-32 } \\
\text { SF }-34\end{array}$ & & $\begin{array}{r}5 \\
23 \\
5 \\
2 \\
2\end{array}$ & $\begin{array}{r}4.33 \mathrm{~J} \\
43.73 \\
9.28 \mathrm{~J} \\
10.88 \\
24.28\end{array}$ & $\begin{array}{r}1.66 \mathrm{~J} \\
23.82 \\
6.51 \mathrm{~J} \\
6.64 \mathrm{~J} \\
20.67\end{array}$ & $\begin{array}{r}0.95 \\
10.72 \\
2.80 \\
2.50 \\
8.56\end{array}$ & & $\begin{array}{l}1.04 \mathrm{~J} \\
5.27 \\
2.70 \mathrm{~J} \\
2.14 \mathrm{~J} \\
7.26\end{array}$ & $\begin{array}{rl}0.73 & \mathrm{~J} \\
10.04 & \\
2.15 & \mathrm{~J} \\
3.61 & \mathrm{~J} \\
6.95 \mathrm{~J}\end{array}$ & $\begin{array}{r}0.95 \\
18.97 \\
3.33 \\
6.44 \\
11.28\end{array}$ & $\begin{array}{r}8.56 \\
84.08 \\
23.46 \\
30.31 \\
62.56\end{array}$ & $\begin{array}{l}3.42 \mathrm{~J} \\
32.17 \\
13.70 \\
25.08 \\
49.01\end{array}$ \\
\hline $\begin{array}{l}\text { IH }-37 \\
\text { IH }-38 \\
\text { IH-39 }\end{array}$ & & $\begin{array}{l}5 \\
5 \\
5\end{array}$ & $\begin{array}{r}9.24 \mathrm{~J} \\
4.50 \mathrm{~J} \\
10.33\end{array}$ & $\begin{array}{l}5.24 \mathrm{~J} \\
2.10 \mathrm{~J} \\
5.26 \mathrm{~J}\end{array}$ & $\begin{array}{l}2.41 \\
0.91 \\
2.44\end{array}$ & & $\begin{array}{l}3.09 \mathrm{~J} \\
1.09 \mathrm{~J} \\
3.31 \mathrm{~J}\end{array}$ & $\begin{array}{l}2.67 \mathrm{~J} \\
1.11 \mathrm{~J} \\
3.04 \mathrm{~J}\end{array}$ & $\begin{array}{l}3.25 \\
1.07 \\
4.26\end{array}$ & $\begin{array}{r}23.70 \\
8.70 \\
31.34\end{array}$ & $\begin{array}{r}12.42 \\
3.96 \mathrm{~J} \\
20.03\end{array}$ \\
\hline $\begin{array}{l}P C-52 \\
P C-53 \\
P C-54\end{array}$ & & $\begin{array}{l}5 \\
5 \\
5\end{array}$ & $\begin{array}{r}105.05 \\
549.00 \\
50.23\end{array}$ & $\begin{array}{r}104.06 \\
149.80 \\
24.82\end{array}$ & $\begin{array}{l}98.11 \\
87.43 \\
10.63\end{array}$ & & $\begin{array}{l}5.87 \mathrm{~J} \\
6.07 \mathrm{U} \\
6.67\end{array}$ & $\begin{array}{r}131.48 \\
203.77 \\
18.39\end{array}$ & $\begin{array}{r}159.12 \\
559.00 \\
27.80\end{array}$ & $\begin{array}{r}694.06 \\
1954.59 \\
289.45\end{array}$ & $\begin{array}{r}429.02 \\
3285.70 \\
134.34\end{array}$ \\
\hline $\begin{array}{l}\text { Comp L } \\
\text { Comp L } \\
\text { Comp L } \\
\text { Comp L } \\
\text { Comp L } \\
\text { Comp L } \\
\text { Comp L } \\
\text { Comp L } \\
\text { Comp F } \\
\text { Comp I } \\
\text { Comp II } \\
\text { Comp II } \\
\text { Comp O } \\
\text { C-SFBF } \\
\text { C-SFBC }\end{array}$ & $\begin{array}{l}\text { LC } \\
\text { LC-1 } \\
\text { LC-2 } \\
\text { LC-3 } \\
\text { LC-4 } \\
\text { LC-5 } \\
\text { LC-6 } \\
\text { USFC } \\
\text { FSFC } \\
\text { IHC-1 } \\
\text { IHC-2 } \\
\text { IHC-3 } \\
\text { (由) } \\
\text { F } \\
\text { I }\end{array}$ & $\begin{array}{l}1 \\
1 \\
1 \\
1 \\
1 \\
1 \\
1 \\
1 \\
1 \\
1 \\
1 \\
1 \\
1 \\
1 \\
1\end{array}$ & $\begin{array}{r}104.73 \\
117.34 \\
112.28 \\
78.91 \\
76.48 \\
183.51 \\
559.44 \\
507.10 \\
29.91 \\
15.22 \\
8.89 \mathrm{~J} \\
11.21 \\
6.00 \mathrm{~J} \\
7.62 \mathrm{~J} \\
5.18 \mathrm{U}\end{array}$ & $\begin{array}{r}84.63 \\
193.30 \\
70.32 \\
56.33 \\
168.27 \\
117.80 \\
238.52 \\
96.02 \\
19.30 \\
8.72 \mathrm{~J} \\
5.32 \mathrm{~J} \\
5.00 \mathrm{~J} \\
2.54 \mathrm{~J} \\
4.25 \mathrm{~J} \\
5.18 \mathrm{U}\end{array}$ & $\begin{array}{r}36.80 \\
75.21 \\
35.84 \\
27.25 \\
26.89 \\
63.85 \\
203.05 \\
83.09 \\
7.45 \\
4.79 \\
2.37 \\
4.15 \\
1.70 \\
2.20 \\
5.18\end{array}$ & & $\begin{array}{r}17.67 \\
17.54 \\
10.89 \\
10.11 \\
31.34 \\
14.92 \\
11.81 \\
60.95 \\
4.32 \mathrm{~J} \\
3.86 \mathrm{~J} \\
2.47 \mathrm{~J} \\
6.78 \mathrm{U} \\
7.91 \mathrm{U} \\
2.63 \mathrm{~J} \\
3.46 \mathrm{U}\end{array}$ & $\begin{array}{r}55.67 \\
32.01 \\
28.42 \\
26.25 \\
108.37 \\
105.77 \\
479.92 \\
353.87 \\
9.52 \\
3.98 \mathrm{~J} \\
2.79 \mathrm{~J} \\
8.80 \mathrm{U} \\
10.28 \mathrm{U} \\
3.08 \mathrm{~J} \\
4.49 \mathrm{U}\end{array}$ & $\begin{array}{r}76.02 \\
71.05 \\
66.58 \\
45.98 \\
298.35 \\
167.80 \\
690.42 \\
421.65 \\
12.41 \\
6.92 \\
4.11 \\
8.57 \\
10.00 \\
3.02 \\
4.38\end{array}$ & $\begin{array}{r}368.34 \\
432.32 \\
198.23 \\
194.74 \\
1489.13 \\
730.71 \\
1871.03 \\
1619.98 \\
80.57 \\
47.84 \\
34.97 \\
32.81 \\
15.21 \\
37.51 \\
0.37\end{array}$ & $\begin{array}{r}215.56 \\
211.43 \\
118.99 \\
105.36 \\
1455.57 \\
317.56 \\
440.70 \\
399.51 \\
36.91 \\
24.11 \\
12.94 \\
11.18 \\
7.39 \mathrm{~J} \\
9.86 \\
3.98 \mathrm{U}\end{array}$ \\
\hline $\begin{array}{l}\text { CBM Co } \\
\text { बBM Co }\end{array}$ & $\begin{array}{l}\text { omp - Fine } \\
\text { omp - Coarse }\end{array}$ & $\begin{array}{l}5 \\
5\end{array}$ & $\begin{array}{l}3.49 \mathrm{~J} \\
7.79\end{array}$ & $\begin{array}{l}1.39 \mathrm{~J} \\
8.96\end{array}$ & $\begin{array}{l}0.81 J \\
4.64\end{array}$ & & $\begin{array}{ll}3.43 & \mathrm{U} \\
0.63 \mathrm{~J}\end{array}$ & $\begin{array}{l}1.67 \mathrm{~J} \\
4.40 \mathrm{~J}\end{array}$ & $\begin{array}{l}1.40 \\
3.09\end{array}$ & $\begin{array}{r}5.10 \\
10.65\end{array}$ & $\begin{array}{ll}0.96 & \mathrm{~J} \\
2.02 & \mathrm{~J}\end{array}$ \\
\hline
\end{tabular}

(a) D Detection limit.

(b) Recoveries of all three surrogate compounds were below acceptable quality control range (40\%-120\%) in original and repeat analyses. Repeat anlysis data are reported here.

(c) J Analyte detected below method detection limit (MDL), but above instrument detection Limit (IDL).

(d) U Analyte was not present above the associated value. 
TABLE C. 15. High Molecular Weight Polynuclear Aromatic Hydrocarbons (HPAHs) in Younger Bay Mud from Selected Cores and Sediment Composites, United Heckathorn Remedial Investigation

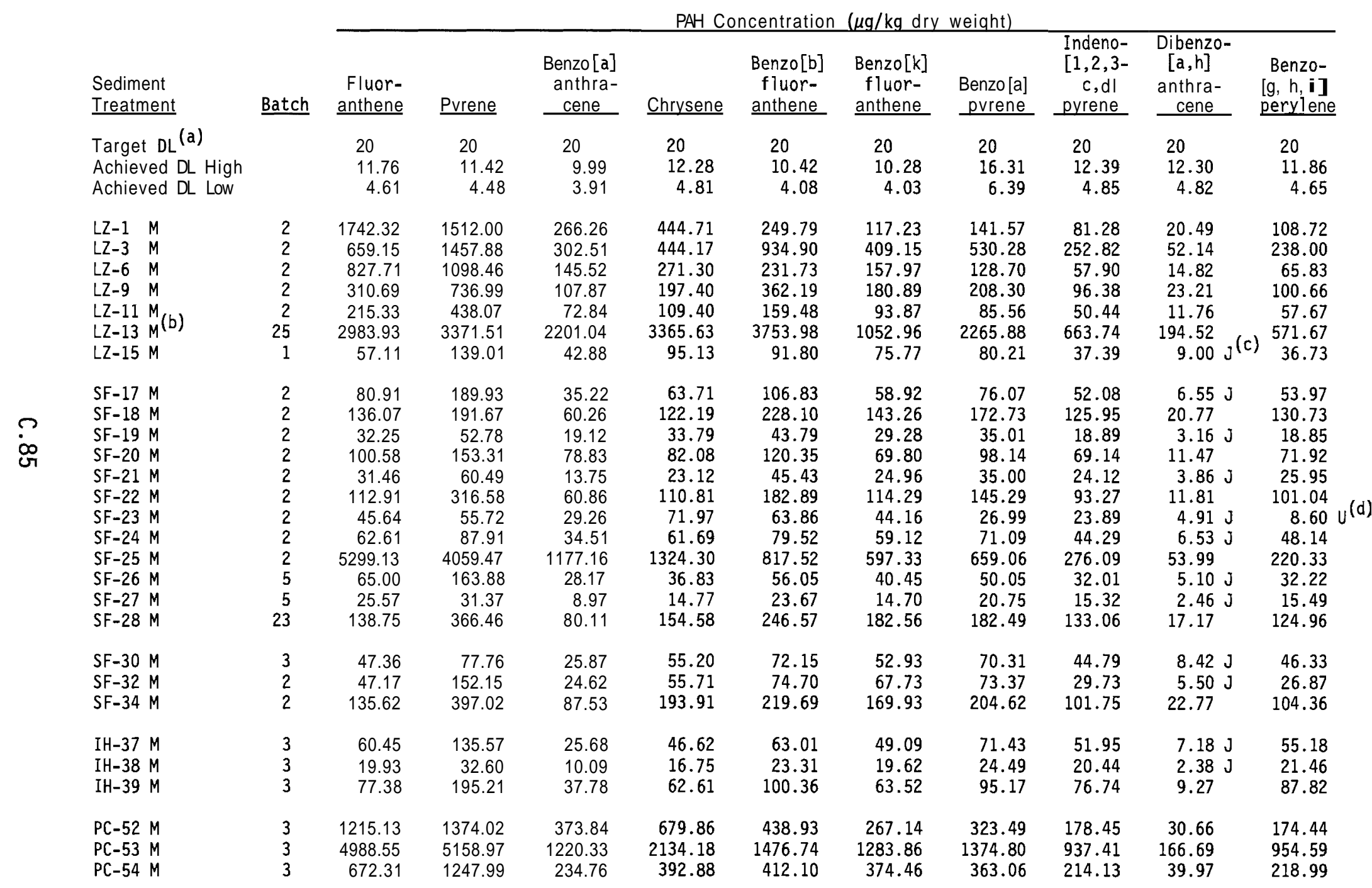


TABLE C.15. (contd)

\begin{tabular}{|c|c|c|c|c|c|c|c|c|c|c|c|}
\hline \multirow[b]{2}{*}{$\begin{array}{l}\text { Sediment } \\
\text { Treatment }\end{array}$} & \multirow[b]{2}{*}{ Batch } & \multicolumn{10}{|c|}{ PAH Concentration ( $\mu \mathrm{g} / \mathrm{kg}$ dry weight) } \\
\hline & & $\begin{array}{l}\text { Fluor- } \\
\text { anthene }\end{array}$ & Pyrene & $\begin{array}{c}\text { Benzo [a] } \\
\text { anthra- } \\
\text { cene } \\
\end{array}$ & Chrysene & $\begin{array}{c}\text { Benzo [b] } \\
\text { fluor- } \\
\text { anthene } \\
\end{array}$ & $\begin{array}{c}\text { Benzo }[\mathrm{k}] \\
\text { fluor- } \\
\text { anthene } \\
\end{array}$ & $\begin{array}{l}\text { Benzo[a] } \\
\text { pyrene }\end{array}$ & $\begin{array}{c}\text { Indeno- } \\
{[1,2,3-} \\
c, d] \\
\text { pyrene } \\
\end{array}$ & $\begin{array}{c}\text { Dibenzo- } \\
{[a, h]} \\
\text { anthra- } \\
\text { cene } \\
\end{array}$ & $\begin{array}{l}\text { Benzo- } \\
{[\mathrm{g}, \mathrm{h}, \mathbf{i}]} \\
\text { perylene }\end{array}$ \\
\hline Comp LC & 1 & 1204.53 & 1584.11 & 396.84 & 752.70 & 750.17 & 544.89 & 616.57 & 305.38 & 73.77 & 291.80 \\
\hline Comp LC-1 & $i$ & 1365.35 & 2199.33 & 666.45 & 1293.01 & 1304.37 & 1003.24 & 1006.88 & 659.20 & 184.07 & 674.69 \\
\hline Comp LC-2 & 1 & 371.85 & 900.83 & 243.20 & 454.75 & 669.84 & 424.10 & 519.83 & 319.45 & 74.44 & 332.97 \\
\hline Comp LC-3 & 1 & 425.73 & 1047.96 & 238.07 & 462.50 & 695.77 & 393.58 & 438.80 & 258.82 & 53.15 & 254.75 \\
\hline Comp LC-4 & 1 & 5333.03 & 4413.68 & 1353.55 & 2016.53 & 1566.33 & 1003.43 & 1183.49 & 510.83 & 110.03 & 421.28 \\
\hline Comp LC-5 & 1 & 1571.53 & 1999.02 & 507.91 & 929.97 & 774.38 & 860.57 & 599.55 & 239.85 & 55.64 & 223.20 \\
\hline Comp LC-6 & 1 & 1453.12 & 1266.50 & 356.52 & 573.89 & 401.21 & 242.70 & 260.37 & 119.68 & 32.86 & 122.09 \\
\hline Comp USFC & 1 & 1299.93 & 1401.28 & 389.61 & 516.67 & 533.67 & 505.71 & 451.46 & 279.46 & 52.70 & 260.97 \\
\hline Comp FSFC & 1 & 169.29 & 300.30 & 91.89 & 186.22 & 204.23 & 156.50 & 205.33 & 126.53 & 26.22 & 128.40 \\
\hline Comp IHC-1 & 1 & 95.82 & 175.51 & 55.31 & 103.31 & 101.33 & 84.44 & 135.14 & 93.42 & 12.73 & 95.41 \\
\hline Comp IHC-2 & 1 & 74.46 & 117.13 & 42.85 & 63.29 & 79.25 & 46.67 & 80.71 & 65.03 & $8.81 \mathrm{~J}$ & 70.97 \\
\hline Comp IHC-3 & 1 & 77.43 & 131.22 & 32.40 & 44.49 & 68.73 & 35.16 & 69.25 & 57.68 & $7.72 \mathrm{~J}$ & 62.90 \\
\hline Comp GD & 1 & 39.08 & 41.13 & 14.10 & 22.24 & 18.53 & 10.62 & 19.10 & 15.16 & $11.12 \mathrm{U}$ & 18.17 \\
\hline C-SFBF & 1 & 82.29 & 107.55 & 32.38 & 40.29 & 39.58 & 32.79 & 58.92 & 46.58 & $3.67 \mathrm{~J}$ & 53.38 \\
\hline C-SFBC & 1 & $1.51 \mathrm{~J}$ & $2.37 \mathrm{~J}$ & $0.99 \mathrm{~J}$ & $1.29 \mathrm{~J}$ & $4.12 \mathrm{U}$ & $4.06 \mathrm{U}$ & $6.45 \mathrm{U}$ & $4.90 \mathrm{U}$ & $4.86 \mathrm{U}$ & $4.69 \mathrm{U}$ \\
\hline $\begin{array}{l}\text { CBM Comp - Fine } \\
\text { CBM Comp - Coarse }\end{array}$ & $\begin{array}{l}3 \\
3\end{array}$ & $\begin{array}{l}4.51 \mathrm{~J} \\
27.07\end{array}$ & $\begin{array}{r}7.18 \\
28.44\end{array}$ & $\begin{array}{l}1.11 \mathrm{~J} \\
7.27\end{array}$ & $\begin{array}{r}1.28 \mathrm{~J} \\
13.29\end{array}$ & $\begin{array}{l}1.49 \mathrm{~J} \\
9.06\end{array}$ & $\begin{array}{l}1.49 \mathrm{~J} \\
5.44\end{array}$ & $\begin{array}{l}1.39 \mathrm{~J} \\
4.33 \mathrm{~J}\end{array}$ & $\begin{array}{l}0.93 \mathrm{~J} \\
2.71 \mathrm{~J}\end{array}$ & $\begin{array}{l}4.82 \mathrm{U} \\
0.51 \mathrm{~J}\end{array}$ & $\begin{array}{l}1.03 \mathrm{~J} \\
2.89 \mathrm{~J}\end{array}$ \\
\hline
\end{tabular}

(a) DL Detection limit.

(b) Recoveries of all three surrogate compounds were below acceptable quality control range (40\%-120\%) in original and repeat analyses Repeat analysis data are reported here.

(c) J Analyte detected below method detection limit (MDL), but above instrument detection limit (IDL).

(d) $U$ Analyte was not present above the associated value. 


\section{TABLE C. 16. Quality Control Data for Low Molecular Weight Polynuclear Aromatic Hydrocarbons (LPAHs) in Younger Bay Mud from Selected Cores and Sediment Composites, United Heckathorn Remedial Investigation}

Sediment

Treatment

Method Blanks

\begin{tabular}{|c|c|c|c|c|c|c|c|c|c|}
\hline $\begin{array}{l}\text { Blank } \\
\text { Blank } \\
\text { Blank } \\
\text { Blank } \\
\text { Blank }\end{array}$ & $\begin{array}{r}1 \\
2 \\
5 \\
23 \\
25\end{array}$ & $\begin{array}{l}9.17 \mathrm{U}^{(\mathrm{a})} \\
1.03 \mathrm{~J}^{(\mathrm{b})} \\
0.68 \mathrm{~J} \\
0.45 \mathrm{~J} \\
0.33 \mathrm{~J}\end{array}$ & $\begin{array}{l}9.17 \mathrm{U} \\
8.87 \mathrm{U} \\
8.27 \mathrm{U} \\
9.50 \mathrm{U} \\
8.98 \mathrm{U}\end{array}$ & $\begin{array}{l}9.17 \mathrm{U} \\
8.87 \mathrm{U} \\
8.27 \mathrm{U} \\
9.50 \mathrm{U} \\
8.98 \mathrm{U}\end{array}$ & $\begin{array}{l}6.13 \mathrm{U} \\
5.93 \mathrm{U} \\
5.53 \mathrm{U} \\
6.35 \mathrm{U} \\
6.00 \mathrm{U}\end{array}$ & $\begin{array}{l}7.96 \mathrm{U} \\
7.70 \mathrm{U} \\
7.19 \mathrm{U} \\
8.25 \mathrm{U} \\
7.80 \mathrm{U}\end{array}$ & $\begin{array}{l}7.75 \mathrm{U} \\
7.50 \mathrm{U} \\
6.99 \mathrm{U} \\
8.03 \mathrm{U} \\
7.59 \mathrm{U}\end{array}$ & $\begin{array}{l}8.12 \mathrm{U} \\
7.86 \mathrm{U} \\
0.81 \mathrm{~J} \\
8.41 \mathrm{U} \\
7.95 \mathrm{U}\end{array}$ & $\begin{array}{l}7.04 \mathrm{U} \\
6.82 \mathrm{U} \\
0.23 \mathrm{~J} \\
7.30 \mathrm{U} \\
6.90 \mathrm{U}\end{array}$ \\
\hline \multicolumn{10}{|l|}{ Matrix Spikes } \\
\hline $\begin{array}{l}\text { C-SFBC } \\
\text { C-SFBC MS } \\
\text { Concentration Recovere } \\
\text { Amount Spiked } \\
\text { Percent Recovery }\end{array}$ & $\begin{array}{r}1 \\
1 \\
\text { ed }\end{array}$ & $\begin{array}{c}5.18 \mathrm{U} \\
98.00 \\
98.00 \\
125.63 \\
78 \%\end{array}$ & $\begin{array}{l}\text { 5. } 18 \text { (U) } \\
N A \\
N A \\
N S \\
N A\end{array}$ & $\begin{array}{c}5.18 \mathrm{U} \\
\mathrm{NA} \\
\mathrm{NA} \\
\mathrm{NS} \\
\mathrm{NA}\end{array}$ & $\begin{array}{c}3.46 \mathrm{U} \\
95.82 \\
95.82 \\
125.63 \\
76 \%\end{array}$ & $\begin{array}{c}4.49 U \\
97.02 \\
97.02 \\
125.63 \\
77 \%\end{array}$ & $\begin{array}{c}4.38 \mathrm{U} \\
104.88 \\
104.88 \\
125.63 \\
83 \%\end{array}$ & $\begin{array}{r}0.37 \mathrm{~J} \\
111.98 \\
111.61 \\
125.63 \\
89 \%\end{array}$ & $\begin{array}{r}3.98 \mathrm{U} \\
106.24 \\
106.24 \\
125.63 \\
85 \%\end{array}$ \\
\hline $\begin{array}{l}\text { C-SFBC } \\
\text { C-SFBC MSD } \\
\text { Concentration Recovere } \\
\text { Amount Spiked } \\
\text { Percent Recovery }\end{array}$ & $\begin{array}{r}1 \\
1 \\
\text { ed }\end{array}$ & $\begin{array}{r}5.18 U \\
90.03 \\
90.03 \\
119.24 \\
76 \%\end{array}$ & $\begin{array}{l}5.18 \text { U } \\
\text { NA } \\
\text { NA } \\
\text { NS } \\
N A\end{array}$ & $\begin{array}{l}5.18 U \\
N A \\
N A \\
N S \\
N A\end{array}$ & $\begin{array}{c}3.46 \mathrm{U} \\
89.27 \\
89.27 \\
119.24 \\
75 \%\end{array}$ & $\begin{array}{c}4.49 \mathrm{U} \\
89.70 \\
89.70 \\
119.24 \\
75 \%\end{array}$ & $\begin{array}{c}4.38 U \\
94.73 \\
94.73 \\
119.24 \\
79 \%\end{array}$ & $\begin{array}{c}0.37 \mathrm{~J} \\
101.20 \\
100.83 \\
119.24 \\
85 \%\end{array}$ & $\begin{array}{c}3.98 \mathrm{U} \\
98.11 \\
98.11 \\
119.24 \\
82 \%\end{array}$ \\
\hline $\begin{array}{l}\text { RPD } \\
\text { I-Stat }\end{array}$ & & 0.02 & $\begin{array}{l}\text { NA } \\
\text { NA }\end{array}$ & $\begin{array}{l}\text { NA } \\
\text { NA }\end{array}$ & $0.01^{2 \%}$ & $0.01^{3 \%}$ & 0.02 & $0.02^{5 \%}$ & $0.01^{3 \%}$ \\
\hline $\begin{array}{l}\text { LZ-11 M } \\
\text { LZ-11 M MS } \\
\text { Concentration Recovere } \\
\text { Amount Spiked } \\
\text { Percent Recovery }\end{array}$ & $\begin{array}{r}2 \\
2 \\
\text { ed }\end{array}$ & $\begin{array}{r}208.48 \\
401.12 \\
192.64 \\
311.04 \\
62 \%\end{array}$ & $\begin{array}{l}51.73 \\
\text { NA } \\
\text { NA } \\
\text { NS } \\
\text { NA }\end{array}$ & $\begin{array}{r}40.47 \\
\text { NA } \\
\text { NA } \\
\text { NS } \\
\text { NA }\end{array}$ & $\begin{array}{r}4.90 \\
231.46 \\
226.56 \\
311.04 \\
73 \%\end{array}$ & $\begin{array}{r}54.83 \\
289.80 \\
234.97 \\
311.04 \\
76 \%\end{array}$ & $\begin{array}{r}49.16 \\
278.34 \\
229.18 \\
311.04 \\
74 \%\end{array}$ & $\begin{array}{r}129.31 \\
353.09 \\
223.78 \\
311.04 \\
72 \%\end{array}$ & $\begin{array}{r}67.09 \\
315.12 \\
248.03 \\
311.04 \\
80 \%\end{array}$ \\
\hline $\begin{array}{l}\text { LZ-11 M } \\
\text { LZ-11 M MSD } \\
\text { Concentration Recovere } \\
\text { Amount Spiked } \\
\text { Percent Recovery }\end{array}$ & $\begin{array}{r}2 \\
2 \\
\text { ed }\end{array}$ & $\begin{array}{r}208.48 \\
347.86 \\
139.38 \\
341.10 \\
41 \%\end{array}$ & $\begin{array}{r}51.73 \\
\text { NA } \\
\text { NA } \\
\text { NS } \\
\text { NA }\end{array}$ & $\begin{array}{r}40.47 \\
N A \\
N A \\
N S \\
N A\end{array}$ & $\begin{array}{r}4.90 \\
226.87 \\
221.97 \\
341.10 \\
65 \%\end{array}$ & $\begin{array}{r}54.83 \\
271.40 \\
216.57 \\
341.10 \\
63 \%\end{array}$ & $\begin{array}{r}49.16 \\
257.84 \\
208.68 \\
341.10 \\
61 \%\end{array}$ & $\begin{array}{r}129.31 \\
334.46 \\
205.15 \\
341.10 \\
60 \%\end{array}$ & $\begin{array}{r}67.09 \\
306.84 \\
239.75 \\
341.10 \\
70 \%\end{array}$ \\
\hline $\begin{array}{l}\text { RPD } \\
\text { I- St at }\end{array}$ & & $\begin{array}{l}41 \%(\mathrm{e}) \\
0.20\end{array}$ & $\begin{array}{l}\text { NA } \\
\text { NA }\end{array}$ & $\begin{array}{l}\text { NA } \\
\text { NA }\end{array}$ & $\begin{array}{l}11 \% \\
0.06\end{array}$ & $\begin{array}{l}17 \% \\
0.09\end{array}$ & $\begin{array}{l}19 \% \\
0.09\end{array}$ & $\begin{array}{l}18 \% \\
0.09\end{array}$ & $\begin{array}{l}13 \% \\
0.06\end{array}$ \\
\hline $\begin{array}{l}\text { OBM Comp - Coarse } \\
\text { OBM Comp - Coarse MS } \\
\text { Concentration Recovere } \\
\text { Amount Spiked } \\
\text { Percent Recovery }\end{array}$ & $\begin{array}{r}5 \\
5 \\
\text { ed }\end{array}$ & $\begin{array}{r}7.79 \\
94.21 \\
86.42 \\
125.10 \\
69 \%\end{array}$ & $\begin{array}{l}8.96 \\
\text { NA } \\
\text { NA } \\
\text { NS } \\
\text { NA }\end{array}$ & $\begin{array}{l}4.64 \mathrm{~J} \\
\text { NA } \\
\text { NA } \\
\text { NS } \\
\text { NA }\end{array}$ & $\begin{array}{r}0.63 \mathrm{~J} \\
91.89 \\
91.26 \\
125.10 \\
73 \%\end{array}$ & $\begin{array}{c}4.40 \mathrm{~J} \\
98.57 \\
94.17 \\
125.10 \\
75 \%\end{array}$ & $\begin{array}{c}3.09 \mathrm{~J} \\
82.42 \\
79.33 \\
125.10 \\
63 \%\end{array}$ & $\begin{array}{r}10.65 \\
95.79 \\
85.14 \\
125.10 \\
68 \%\end{array}$ & $\begin{array}{c}2.02 \mathrm{~J} \\
91.07 \\
89.05 \\
125.10 \\
71 \%\end{array}$ \\
\hline $\begin{array}{l}\text { CBM Comp - Coarse } \\
\text { CBM Comp - Coarse MSD } \\
\text { Concentration Recovere } \\
\text { Amount Spiked } \\
\text { Percent Recovery }\end{array}$ & $\begin{array}{r}5 \\
5 \\
\text { ed }\end{array}$ & $\begin{array}{r}7.79 \\
104.90 \\
97.11 \\
130.83 \\
74 \%\end{array}$ & $\begin{array}{r}8.96 \\
\text { NA } \\
\text { NA } \\
\text { NS } \\
\text { NA }\end{array}$ & $\begin{array}{l}4.64 \mathrm{~J} \\
\text { NA } \\
\text { NA } \\
\text { NS } \\
\text { NA }\end{array}$ & $\begin{array}{r}0.63 \mathrm{~J} \\
102.00 \\
101.37 \\
130.83 \\
77 \%\end{array}$ & $\begin{array}{c}4.40 \mathrm{~J} \\
108.84 \\
104.44 \\
130.83 \\
80 \%\end{array}$ & $\begin{array}{c}3.09 \mathrm{~J} \\
94.37 \\
91.28 \\
130.83 \\
70 \%\end{array}$ & $\begin{array}{r}10.65 \\
111.41 \\
100.76 \\
130.83 \\
77 \%\end{array}$ & $\begin{array}{r}2.02 \mathrm{~J} \\
101.55 \\
99.53 \\
130.83 \\
76 \%\end{array}$ \\
\hline $\begin{array}{l}\text { RPD } \\
\text { I-Stat }\end{array}$ & & 0.04 & $\begin{array}{l}\text { NA } \\
\text { NA }\end{array}$ & $\begin{array}{l}\text { NA } \\
\text { NA }\end{array}$ & 0.03 & 0.03 & $\begin{array}{l}10 \% \\
0.05\end{array}$ & $\begin{array}{l}12 \% \\
0.06\end{array}$ & 0.03 \\
\hline
\end{tabular}

$\mathrm{PAH}$ Concentration $(\mu \mathrm{g} / \mathrm{kg}$ dry weight)

\begin{tabular}{|c|c|c|c|c|c|c|c|c|}
\hline Batch & $\begin{array}{l}\text { Naphtha- } \\
\text { lene }\end{array}$ & $\begin{array}{l}\text { 2-Methyl- } \\
\text { naphtha- } \\
\text { lene }\end{array}$ & $\begin{array}{l}\text { 1-Methy1- } \\
\text { naphtha- } \\
\text { lene }\end{array}$ & $\begin{array}{l}\text { Acenaph- } \\
\text { thvlene }\end{array}$ & $\begin{array}{l}\text { Acenaph- } \\
\text { thene }\end{array}$ & Fluorene & $\begin{array}{l}\text { Phenan- } \\
\text { threne }\end{array}$ & $\begin{array}{l}\text { Anthra- } \\
\text { cene }\end{array}$ \\
\hline
\end{tabular}




\section{TABLE C.16. (contd)}

Sediment

$\underline{\text { Treatment }}$

ME73

ME73 NS

Amount Spiked

Percent Recovery

ME73

ME74 MSD

Amount Spiked

Percent Recovery

$\mathrm{RPD}$

I-Stat

MH37

MH37 MS

Amount Spiked

Percent Recovery

MH37

MH38 MSD

Amount Spiked

Percent Recovery

RPD

I-Stat
$\mathrm{PAH}$ Concentration $(\mu \mathrm{g} / \mathrm{kg}$ dry weight)

2-Methvl- 1-Methvl-

Naphtha- naphtha- naphtha- Acenaph- Acenaphlene thylene thene Fluorene threne cene

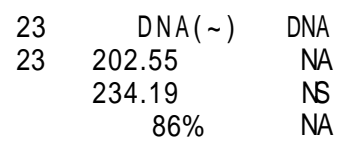

$\begin{array}{rrr}23 & \text { DNA } & \text { DNA } \\ 23 & 130.74 & \text { NA } \\ & 237.34 & \text { NS } \\ & 55 \% & \text { NA }\end{array}$

DNA DNA

DNA
148.46
237.34
$63 \%$

DNA
223.78
234.19
$96 \%$

DNA

$207.16-203.47$

$\begin{array}{llllll}\text { NS } & 234.19 & 234.19 & 234.19 & 234.19 & 234.19\end{array}$

$\begin{array}{llllll}\text { NA } & 100 \% & 96 \% & 88 \% & 87 \% & 83 \%\end{array}$

$\begin{array}{lllll}148.46 & 143.88 & 135.57 & 139.38 & 126.33\end{array}$

$\begin{array}{llllll}\text { NS } & 237.34 & 237.34 & 237.34 & 237.34 & 237.34\end{array}$

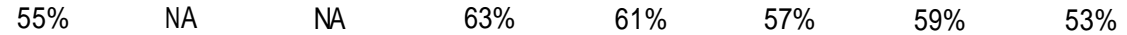

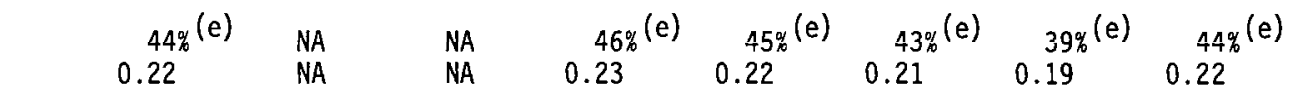

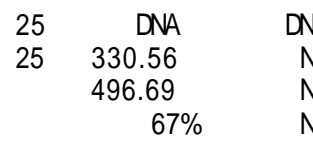

$\begin{array}{lllll}\text { DNA DNA DNA DNA DNA } & \text { DNA DNA }\end{array}$

$\begin{array}{llllll}\text { NA } & 346.27 & 330.52 & 331.38 & 329.87 & 313.28\end{array}$

NS $\quad 496.69 \quad 496.69 \quad 496.69 \quad 496.69 \quad 496.69$

$\begin{array}{rrrrrrrrr}25 & \text { DNA } & \text { DNA } & \text { DNA } & \text { DNA } & \text { DNA } & \text { DNA } & \text { DNA } & \text { DNA } \\ 25 & 355.32 & \text { NA } & \text { NA } & 369.80 & 349.02 & 353.70 & 350.70 & 327.84 \\ & 499.17 & \text { NS } & \text { NS } & 499.17 & 499.17 & 499.17 & 499.17 & 499.17 \\ & 71 \% & \text { NA } & \text { NA } & 74 \% & 70 \% & 71 \% & 70 \% & 66 \%\end{array}$

$\begin{array}{cccccccc}7 \% & \text { NA } & \text { NA } & 6 \% & 5 \% & 6 \% & 6 \% & 4 \% \\ 0.03 & \text { NA } & \text { NA } & 0.03 & 0.02 & 0.03 & 0.03 & 0.02\end{array}$

Analytical Duplicates

\begin{tabular}{|c|c|c|c|c|c|c|c|c|c|}
\hline $\begin{array}{l}\text { LZ-3 M } \\
\text { LZ-3 M Dupl icate } \\
\text { RPD } \\
\text { I-Stat }\end{array}$ & $\begin{array}{l}2 \\
2\end{array}$ & $\begin{array}{c}118.69 \\
130.98 \\
10 \% \\
0.05\end{array}$ & $\begin{array}{l}79.24 \\
89.93 \\
13 \% \\
0.06\end{array}$ & $\begin{array}{l}39.29 \\
45.91 \\
16 \% \\
0.08\end{array}$ & $\begin{array}{l}14.95 \\
16.17 \\
8 \% \\
0.04\end{array}$ & $\begin{array}{l}38.19 \\
51.57 \\
30 \% \\
0.15\end{array}$ & $\begin{array}{l}76.07 \\
84.05 \\
10 \% \\
0.05\end{array}$ & $\begin{array}{c}221.72 \\
274.39 \\
21 \% \\
0.11\end{array}$ & $\begin{array}{c}185.46 \\
251.61 \\
30 \% \\
0.15\end{array}$ \\
\hline $\begin{array}{l}\text { PC-52 M } \\
\text { PC-52 M Duplicate } \\
\text { RPD } \\
\text { I- Stat }\end{array}$ & $\begin{array}{l}5 \\
5\end{array}$ & $\begin{array}{l}105.05 \\
57.52 \\
58 \%(\mathrm{e}) \\
0.29\end{array}$ & $\begin{array}{l}104.06 \\
59.1 .6 \\
55 \% \\
0.28\end{array}$ & $\begin{array}{l}98.11 \\
57.07 \\
53 \%(\mathrm{e}) \\
0.26\end{array}$ & $\begin{array}{l}5.87 \mathrm{~J} \\
2.68 \mathrm{~J} \\
75 \% \\
0.37\end{array}$ & $\begin{array}{l}131.48 \\
72.59 \\
58 \%(\mathrm{e}) \\
0.29\end{array}$ & $\begin{array}{c}159.12 \\
85.98 \\
60 \% \\
0.30\end{array}$ & $\begin{array}{c}694.06 \\
366.13 \\
62 \%(e) \\
0.31\end{array}$ & $\begin{array}{c}429.02 \\
241.15 \\
56 \%(e) \\
0.28\end{array}$ \\
\hline $\begin{array}{l}\text { C-SFBF } \\
\text { C-SFBF Duplicate } \\
\text { RPD } \\
\text { I-Stat }\end{array}$ & $\begin{array}{l}1 \\
1\end{array}$ & $\begin{array}{l}7.62 \mathrm{~J} \\
6.22 \mathrm{~J} \\
20 \% \\
0.10\end{array}$ & $\begin{array}{l}4.25 \mathrm{~J} \\
2.80 \mathrm{~J} \\
\quad 41 \% \\
0.21\end{array}$ & $\begin{array}{l}2.20 \mathrm{~J} \\
2.17 \mathrm{~J} \\
1 \% \\
0.01\end{array}$ & $\begin{array}{l}2.63 \mathrm{~J} \\
3.04 \mathrm{~J} \\
14 \% \\
0.07\end{array}$ & $\begin{array}{l}3.08 \mathrm{~J} \\
6.86 \mathrm{U} \\
\mathrm{NA} \\
\mathrm{NA}\end{array}$ & $\begin{array}{l}3.02 \mathrm{~J} \\
3.45 \mathrm{~J} \\
13 \% \\
0.07\end{array}$ & $\begin{array}{l}37.51 \\
35.80 \\
5 \% \\
0.02\end{array}$ & $\begin{array}{c}9.86 \\
10.37 \\
5 \% \\
0.03\end{array}$ \\
\hline \multicolumn{10}{|c|}{ Compositing Duplicates } \\
\hline $\begin{array}{l}\text { SF-32 M } \\
\text { SF-32 M Cdup }(g) \\
\text { RPD } \\
\text { I- Stat }\end{array}$ & $\begin{array}{l}2 \\
2\end{array}$ & $\begin{array}{l}10.88 \\
14.68 \\
30 \% \\
0.15\end{array}$ & $\begin{array}{l}6.64 \mathrm{~J} \\
8.18 \\
\quad 21 \% \\
0.10\end{array}$ & $\begin{array}{l}2.50 \mathrm{~J} \\
3.49 \mathrm{~J} \\
33 \% \\
0.17\end{array}$ & $\begin{array}{l}2.14 \mathrm{~J} \\
4.84 \mathrm{~J} \\
77 \% \\
0.39\end{array}$ & $\begin{array}{l}3.61 \mathrm{~J} \\
4.30 \mathrm{~J} \\
17 \% \\
0.09\end{array}$ & $\begin{array}{l}6.44 \\
9.51 \\
38 \% \\
0.19\end{array}$ & $\begin{array}{l}30.31 \\
61.1 .5 \\
67 \%(e) \\
0.34\end{array}$ & $\begin{array}{l}25.08 \\
52.1 .3 \\
70 \% \\
0.35\end{array}$ \\
\hline $\begin{array}{l}\text { Comp LC } \\
\text { Comp LC Cdup } \\
\text { RPD } \\
\text { I- Stat }\end{array}$ & $\begin{array}{l}1 \\
1\end{array}$ & $\begin{array}{l}104.73 \\
11.54 \\
160 \% \\
0.80\end{array}$ & $\begin{array}{l}84.63 \\
6.97 \mathrm{~J} \\
170 \% \\
0.85\end{array}$ & $\begin{array}{c}36.80 \\
3.28 \mathrm{~J} \\
167 \% \\
0.84\end{array}$ & $\begin{array}{l}17.67 \\
2.47 \mathrm{~J} \\
151 \% \\
0.75\end{array}$ & $\begin{array}{l}55.67 \\
2.24 \\
185 \% \\
0.92\end{array}$ & $\begin{array}{l}76.02 \\
5.64 \\
172 \% \\
0.86\end{array}$ & $\begin{array}{c}368.34 \\
30.4 .7 \\
169 \%(e) \\
0.85\end{array}$ & $\begin{array}{l}215.56 \\
16.33 \\
172 \%(e) \\
0.86\end{array}$ \\
\hline
\end{tabular}




\section{TABLE C. $16 . \quad$ (contd)}

PAH Concentration $(\mu \mathrm{g} / \mathrm{kg}$ dry weight)

Sediment

Treatment

Comp IHC-2

Comp IHC-2 cdup

RPD

I-Stat
2-Methvl- 1-Methvl-

Naphtha- naphtha- naphtha- Acenaph- AcenaphBatch lene lene lene thylene thene Fluorene threne cene

Phenan- Anthra-

$\begin{array}{lrrrr}1 & 8.89 \mathrm{~J} & 5.32 \mathrm{~J} & 2.37 \\ 1 & 11.78 & 7.46 \mathrm{~J} & 2.97\end{array}$

$$
2.47 \mathrm{~J}
$$

2.79

$4.11 \mathrm{~J} \quad 34.97$

$5.55 \mathrm{~J} \quad 47.67$

$3.61 \mathrm{~J} \quad 3.63 \mathrm{~J}$

$26 \%$

0.14

0.17

0.11

0.19

0.13

$30 \%$

0.15

47.67

12.94
17.09

0.15

(a) U Analyte was not present above the associated value.

(b) J Analyte detected below method detection limit (MDL), but above instrument detection Iimit (IDL).

(c) NA Not applicable.

(d) NS Not spiked.

(e) Value exceeds relative precision goal of $\leq 30 \%$. For duplicates, one sample concentration must be $>10$ times the MDL.

(f) DNA Data not available.

(g) Compositing duplicate. 
TABLE C. 17. Qualit y Control Data for High Molecular Weight Polynuclear Aromatic Hydrocarbons (HPAHs) in Younger Bay Mud from Selected Cores and Sediment Composites, United Heckathorn

Remedial Investigation

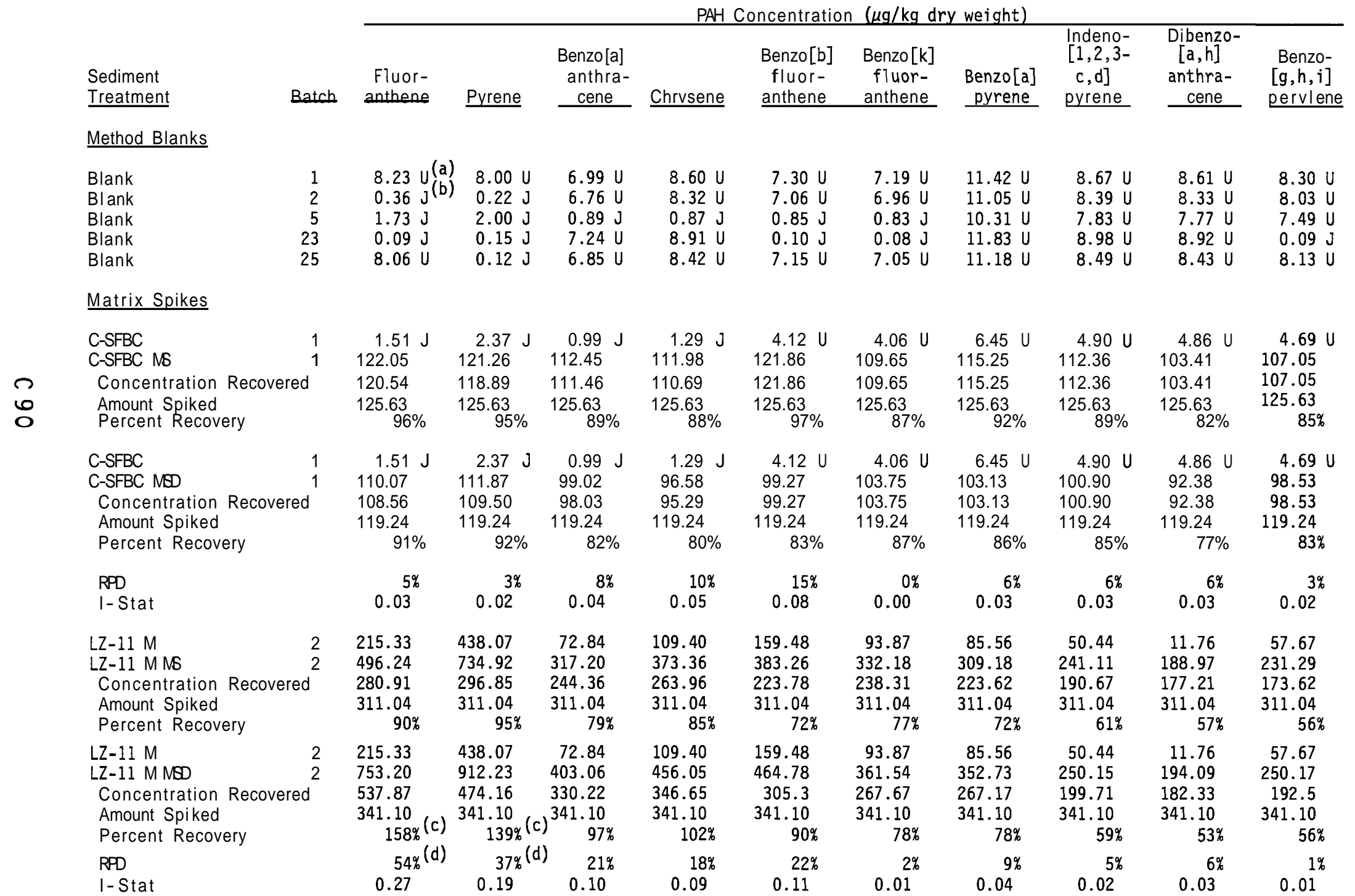


TABLE C. 17. (contd)

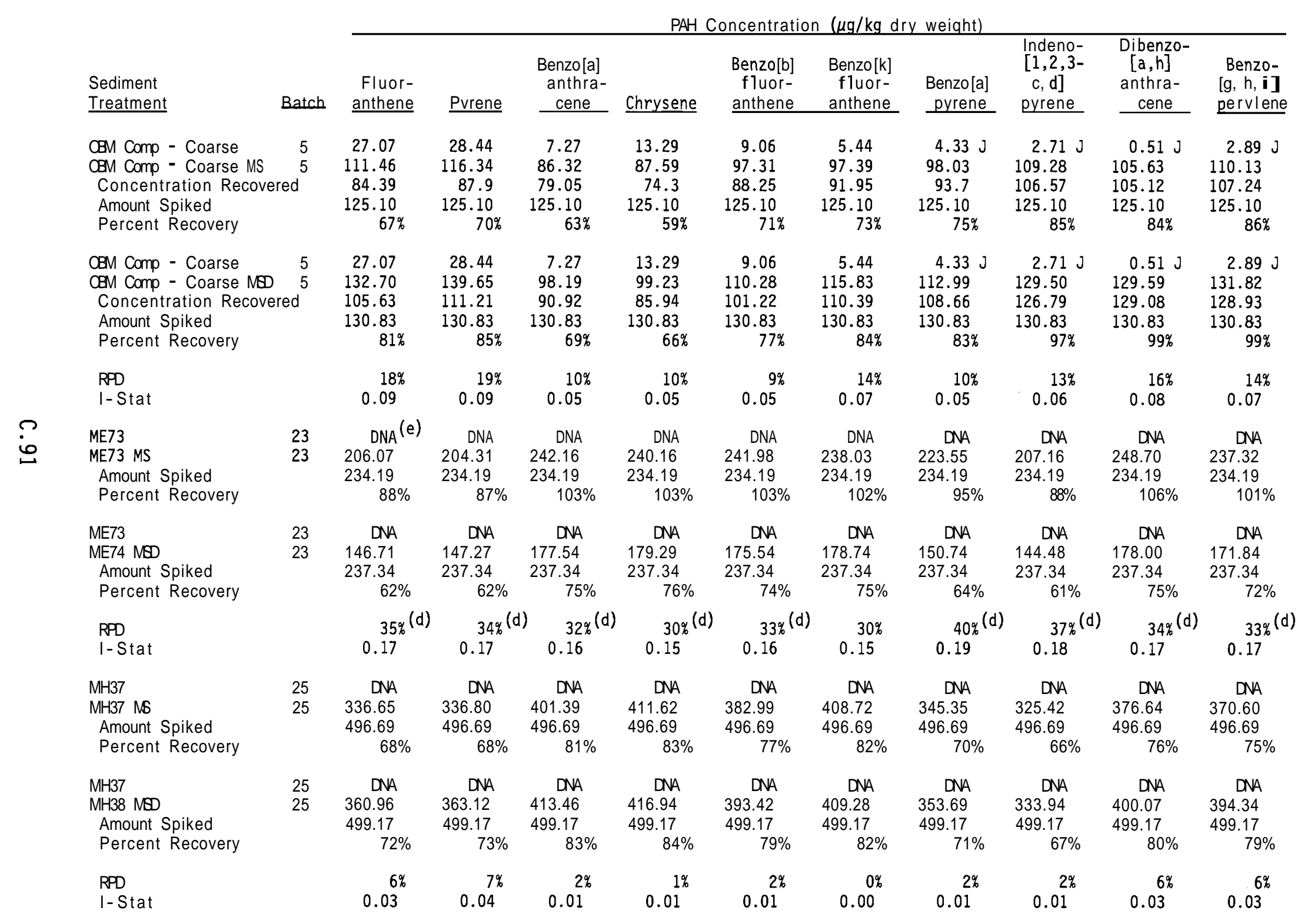




\section{TABLE C.17. (contd)}

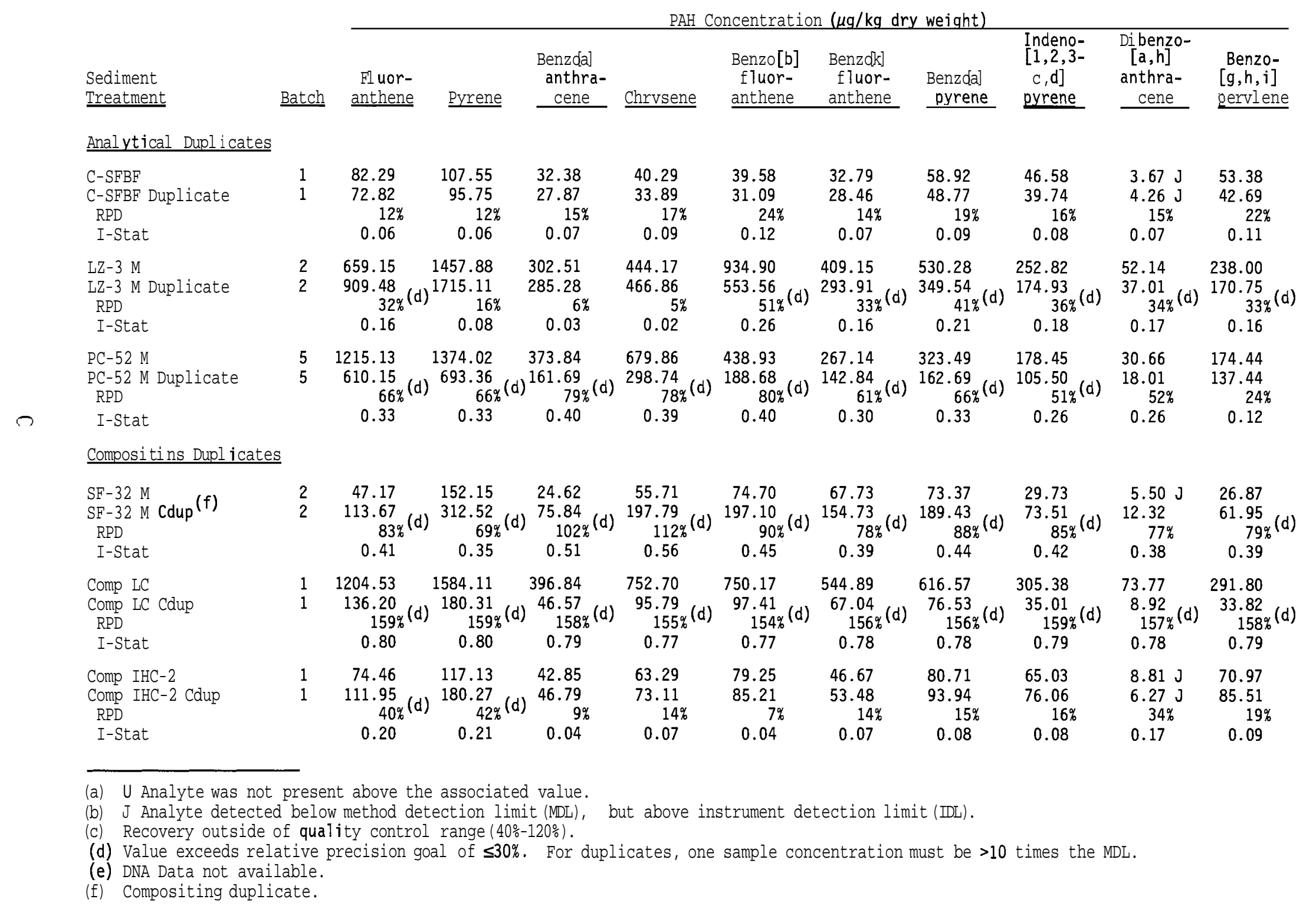


TABLE C. 18. Surrogate Recoveries for Polynuclear Aromatic Hydrocarbons (PAHs) in Younger Bay Mud from Selected Cores and Sediment Composites, United Heckathorn Remedial Investigation

\begin{tabular}{ll} 
Sediment \\
Treatment \\
\hline LZ-1 & $M$ \\
LZ-3 & $M$ \\
LZ-6 & $M$ \\
LZ-9 & $M$ \\
LZ-11 & $M$ \\
LZ-13 & $M$ \\
LZ-15 & $M$ \\
SF-17 & $M$ \\
SF-18 & $M$ \\
SF-19 & $M$ \\
SF-20 & $M$ \\
SF-21 & $M$ \\
SF-22 & $M$ \\
SF-23 & $M$ \\
SF-24 & $M$ \\
SF-25 & $M$ \\
SF-26 & $M$ \\
SF-27 & $M$ \\
SF-28 & $M$ \\
SF-30 & $M$ \\
SF-32 & $M$ \\
SF-34 & $M$ \\
IH-37 & $M$ \\
IH-38 & $M$ \\
IH-39 & $M$ \\
PC-52 & $M$ \\
PC-53 & $M$ \\
PC-54 & $M$ \\
Comp & LC \\
Comp & LC-1 \\
Comp & LC-2 \\
Comp & $L C-3$ \\
Comp & LC-4 \\
Comp & $L C-5$ \\
Comp & $L C-6$ \\
Comp & USFC \\
Comp & FSFC \\
Comp & IHC-1 \\
Comp & IHC-2 \\
Comp & IHC-3 \\
Comp & GD \\
\end{tabular}

Surrosate Percent Recoveries

\begin{tabular}{|c|c|c|}
\hline $\begin{array}{l}\text { Naphtha- } \\
\text { lene d8 }\end{array}$ & $\begin{array}{l}\text { Acenaph- } \\
\text { thene d10 }\end{array}$ & $\begin{array}{l}\text { Benzo[a] } \\
\text { pyrene d12 }\end{array}$ \\
\hline $\begin{array}{l}45.05 \\
42.93 \\
40.80 \\
43.42 \\
52.24 \\
29.93^{(a)} \\
45.70\end{array}$ & $\begin{array}{l}49.22 \\
50.70 \\
45.37 \\
52.35 \\
61.54 \\
38.89^{(\mathrm{a})} \\
52.86\end{array}$ & $\begin{array}{l}48.78 \\
48.40 \\
31.03^{(a)} \\
44.58 \\
62.55 \\
39.53^{(a)} \\
61.53\end{array}$ \\
\hline $\begin{array}{l}40.11 \\
43.81 \\
41.27 \\
42.07 \\
49.35 \\
47.22 \\
58.47 \\
42.10 \\
44.80 \\
58.07 \\
53.71 \\
48.05\end{array}$ & $\begin{array}{l}44.29 \\
49.05 \\
45.91 \\
46.76 \\
53.86 \\
53.17 \\
55.23 \\
47.78 \\
53.63 \\
56.72 \\
51.01 \\
57.20\end{array}$ & $\begin{array}{l}55.56 \\
59.65 \\
55.69 \\
62.62 \\
67.45 \\
61.54 \\
53.46 \\
65.23 \\
64.77 \\
75.38 \\
71.40 \\
55.96\end{array}$ \\
\hline $\begin{array}{l}43.83 \\
48.64 \\
47.88\end{array}$ & $\begin{array}{l}43.17 \\
49.89 \\
50.50\end{array}$ & $\begin{array}{l}63.03 \\
61.53 \\
61.94\end{array}$ \\
\hline $\begin{array}{l}58.72 \\
46.13 \\
45.72\end{array}$ & $\begin{array}{l}56.54 \\
44.30 \\
51.77\end{array}$ & $\begin{array}{l}78.45 \\
60.54 \\
69.31\end{array}$ \\
\hline $\begin{array}{l}53.93 \\
55.58 \\
39.57^{(a)}\end{array}$ & $\begin{array}{l}55.08 \\
64.14 \\
40.29\end{array}$ & $\begin{array}{l}66.84 \\
77.82 \\
51.92\end{array}$ \\
\hline $\begin{array}{l}64.74 \\
52.59 \\
52.56 \\
50.42 \\
55.26 \\
45.83 \\
56.33 \\
58.25 \\
50.67\end{array}$ & $\begin{array}{l}78.70 \\
67.39 \\
70.08 \\
60.42 \\
62.91 \\
57.82 \\
70.01 \\
70.11 \\
58.88\end{array}$ & $\begin{array}{l}78.94 \\
71.20 \\
67.85 \\
59.74 \\
75.25 \\
49.14 \\
54.14 \\
76.55 \\
67.79\end{array}$ \\
\hline $\begin{array}{l}51.71 \\
47.93 \\
50.72 \\
51.13\end{array}$ & $\begin{array}{l}63.94 \\
60.47 \\
56.86 \\
58.07\end{array}$ & $\begin{array}{l}81.26 \\
73.07 \\
62.57 \\
34.73^{(a)}\end{array}$ \\
\hline
\end{tabular}


TABLE C. $18 . \quad$ (contd)

Sediment

Treatment

C-SFBF

C-SFBC

CBM Comp - Fine

CBM Comp - Coarse

Qualit v Control Samples

Method Blanks

Bl ank

Blank

Blank

Blank

Blank

Matrix Spikes

C-SFBC MS

C-SFBC MSD

LZ-11 M MS

LZ-11 M MSD

CBM Comp - Coarse MS

CBM Comp - Coarse MSD

ME73 MS

ME74 MSD

MH37 MS

MH38 MSD

Analvtical Duplicates

C-SFBF Duplicate

LZ-3 M Duplicate

PC-52 M Dupl icate

Compositing Duplicates

SF-32 M Cdup ${ }^{(b)}$

Comp LC Cdup

Comp IHC-2 Cdup

\begin{tabular}{llc} 
& \multicolumn{3}{c}{ Naphtha- } & Acenaph- & Benzo[a] \\
Batch lene d8 & thene d10 & pvrene d12
\end{tabular}

$\begin{array}{llll}1 & 50.58 & 57.12 & 69.51\end{array}$

$\begin{array}{lll}58.83 & 65.00 & 73.45\end{array}$

$\begin{array}{llll}5 & 54.58 & 53.39 & 66.38\end{array}$

$\begin{array}{llll}5 & 69.12 & 65.79 & 79.51\end{array}$

$\begin{array}{rrrr}1 & 68.60 & 75.07 & 63.83 \\ 2 & 55.03 & 58.01 & 65.61 \\ 5 & 75.92 & 70.05 & 78.07 \\ 23 & 80.25 & 88.30 & 77.04 \\ 25 & 61.51 & 65.78 & 56.88\end{array}$

$1 \quad 67$

76

78

$1 \quad 66$

$2 \quad 54$

48

63

68

64

68

59

62

76

82

78

49

83

79

23

62

65

65

68

58

59

$\begin{array}{ll}1 & 46.19 \\ 2 & 57.04 \\ 5 & 52.55\end{array}$

52.55
54.43

70.25

51.80

54.63

71.57

59.82
66.93

70.41

68.13

(a) Recovery outside of quality control range (40\%-120\%).

(b) Compositing duplicate. 
TABLE C.19. Polychlorinated Biphenyls (PCBs) in Younger Bay Mud from Selected Cores and Sediment Composites, United Heckathorn Remedial Investigation

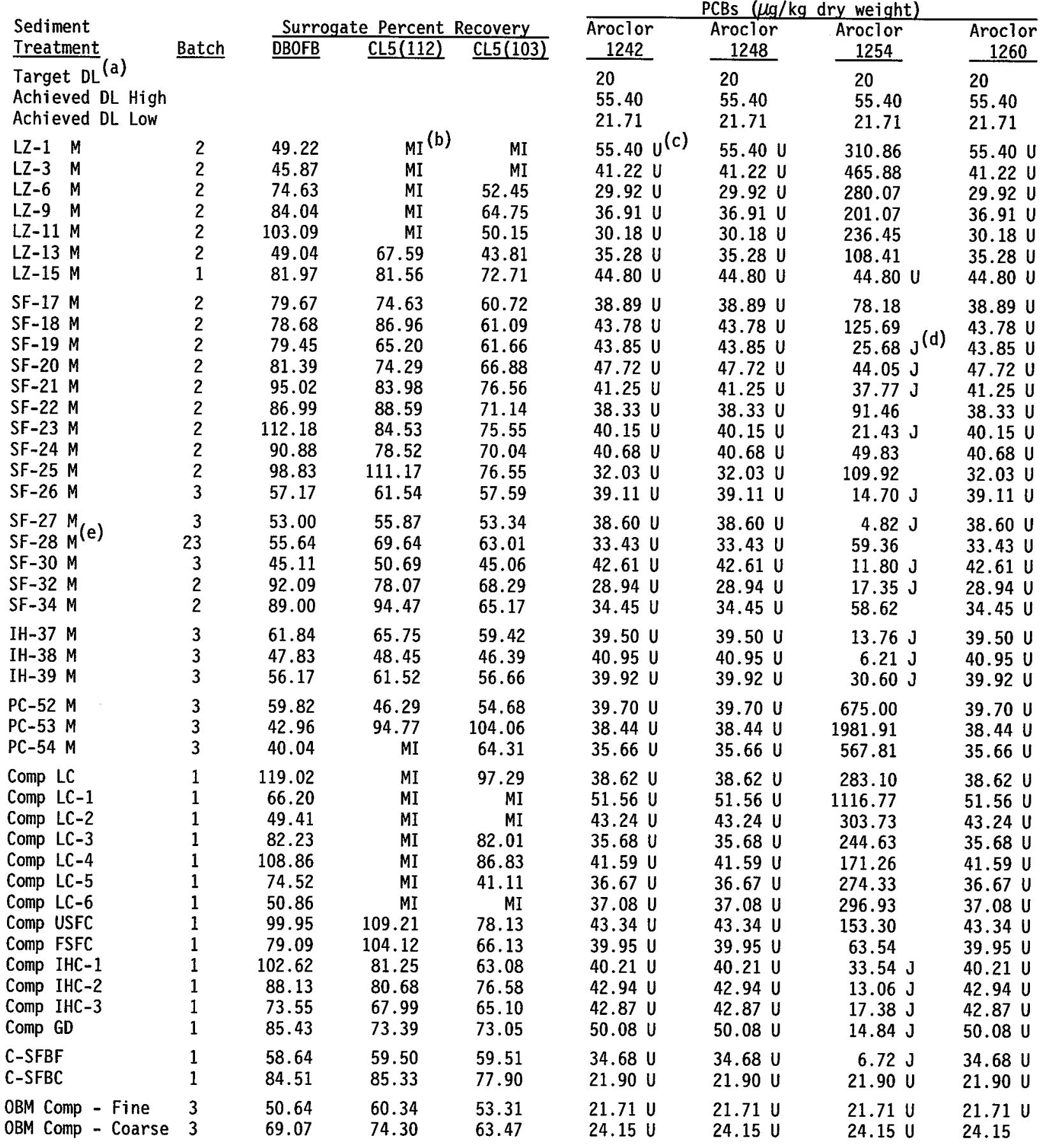

(a) DL Detection limit.

(b) MI Matrix interference.

(c) U Analyte was not present above the level of associated value.

(d) J Analyte detected below method detection limits (MDL), but above instrument detection limit (IDL).

(e) QC data are not applicable. 
TABLE C.20. Quality Control Data for Polychlorinated Biphenyls (PCBs) in Younger Bay Mud from Selected Cores and Sediment Composites, United Heckathorn Remedial Investigation

Sediment Treatment

Method Blanks

$\begin{array}{lrrrr}\text { Blank } & 1 & 108.92 & 80.37 & 88.02 \\ \text { Blank } & 2 & 92.26 & 83.35 & 75.31 \\ \text { Blank } & 3 & 74.26 & 65.12 & 69.78 \\ \text { Blank } & 23 & 92.44 & 81.29 & 59.02\end{array}$

Matrix Spikes

LZ-11 M
LZ-11 M MS

$\begin{array}{ll}\text { LZ-11 M } & 2 \\ \text { LZ-11 M MSD } & 2\end{array}$

Concentration Recovered Amount Spiked

Percent Recovery

RPD

I-Stat

C-SFBC

Concentration Recovered

Amount Spiked

Percent Recovery

C-SFBC

C-SFBC MSD

103.09

$\begin{array}{lll} & \mathrm{Ml} & 50.15\end{array}$

61

84.51

Concentration Recovered

Amount Spiked

Percent Recovery

RPD

I-Stat

CBM Comp - Coarse 3

CBM Comp - Coarse 3

Concentration Recovered Amount Spiked

Percent Recovery

CBM Comp - Coarse 3

CBM Comp - Coarse 3

Concentration Recovered

Amount Spiked

Percent Recovery

RPD

I-Stat

$\begin{array}{lll}84.51 & 85.33 & 77.90\end{array}$

88
$83 \quad 80$

$\begin{array}{rrr}55 & 60 & 58 \\ & 74.30 & 63.47\end{array}$

PCBs $(\mu \mathrm{g} / \mathrm{kg}$ drv weight)

\begin{tabular}{cccc}
\hline $\begin{array}{c}\text { Aroclor } \\
1242\end{array}$ & $\begin{array}{c}\text { Aroclor } \\
1248\end{array}$ & $\begin{array}{c}\text { Aroclor } \\
1254\end{array}$ & $\begin{array}{c}\text { Aroclor } \\
1260\end{array}$ \\
\hline
\end{tabular}

$\begin{array}{lll}38.79 U^{(a)} & 38.79 U \\ 37.53 & U & 37.53 U \\ 35.01 & U & 35.01 U \\ 40.18 U & 40.18 U\end{array}$

$38.79 \mathrm{U}$

$37.53 \mathrm{U}$

$35.01 \mathrm{U}$

$38.79 \mathrm{U}$

$40.18 \mathrm{U}$

$40.18 \mathrm{U}$

$40.18 \mathrm{U}$

$35.01 \mathrm{U}$

$40.18 \mathrm{U}$

$\begin{array}{cccc}30.18(\mathrm{c}) & 30.18 \mathrm{U} & 236.45 & 30.18 \mathrm{U} \\ \text { NA } & \text { NA } & 477.94 & \text { NA } \\ \text { NA } & \text { NA } & 241.49 & \text { NA } \\ \text { NS }(d) & \text { NS } & 248.83 & \text { NS } \\ \text { NA } & \text { NA } & 97 \% & \text { NA }\end{array}$

$\begin{array}{cccc}30.18 & 30.18 & 236.45 & 30.18 \mathrm{U} \\ \text { NA } & \text { NA } & 450.91 & \text { NA } \\ \text { NA } & \text { NA } & 214.46 & \text { NA } \\ \text { NS } & \text { NS } & 272.88 & \text { NS } \\ \text { NA } & \text { NA } & 79 \% & \text { NA } \\ \text { NA } & \text { NA } & 21 \% & \text { NA } \\ \text { NA } & \text { NA } & 0.11 & \text { NA }\end{array}$

21.90
NA
NA
NS
NA

$21.90 U$

NA

$21.90 \mathrm{U}$

78.97

78.97

100.50

$79 \%$

$21.90 \mathrm{U}$

NA

NA

NS

NA $\quad 79 \% \quad$ NA

21.90
NA
NA
NS
NA

$21.90 \mathrm{U}$

$21.90 \mathrm{U}$

72.01

72.01

NS $\quad 95.39 \quad$ NS

$75 \%$

$21.90 \mathrm{U}$

$\mathrm{NA}$

$\begin{array}{ll}\text { NA } & \text { NA } \\ \text { NA } & \text { NA }\end{array}$

0.02

NA

24.15
NA
NA
NS
NA

$24.15 U$

$24.15 \mathrm{U}$

53.47

53.47

100.08

$24.15 U$

NA
NA
NA

24.15
NA
NA
NS
NA
NA
NA

NA
NA
NS
NA
NA
NA

$24.15 \mathrm{~V}$

61.13

61.13

104.67

NA
NA

$9 \%$

0.04

$24.15 \mathrm{U}$

$24.15 U$ 


\section{TABLE C.20. (con $\mathrm{t} d$ )}

Sediment

$\underline{\text { Treatment }}$

Surrogate Percent Recovery

PCBs $(\mu \mathrm{g} / \mathrm{kg}$ dry weight)

\begin{tabular}{cccc}
\hline Aroclor & Aroclor & Aroclor & Aroclor \\
1242 & 1248 & 1254 & 1260 \\
\hline
\end{tabular}

$\underline{\text { Analytical Duplicates }}$

\begin{tabular}{|c|c|c|c|c|c|c|c|c|}
\hline $\begin{array}{l}\text { LZ-3 M } \\
\text { LZ-3 M Duplicate } \\
\text { RPD } \\
\text { I-Stat }\end{array}$ & $\begin{array}{l}2 \\
2\end{array}$ & $\begin{array}{l}45.87 \\
66.08\end{array}$ & $\begin{array}{l}\text { MI } \\
\text { MI }\end{array}$ & $\begin{array}{l}\text { MI } \\
\text { MI }\end{array}$ & $\begin{array}{c}41.22 \mathrm{U} \\
41.56 \mathrm{U} \\
\text { NA } \\
\text { NA }\end{array}$ & $\begin{array}{c}41.22 \mathrm{U} \\
41.56 \mathrm{U} \\
\text { NA } \\
\text { NA }\end{array}$ & $\begin{array}{c}465.88 \\
594.92 \\
24 \% \\
0.12\end{array}$ & $\begin{array}{c}41.22 \mathrm{U} \\
41.56 \mathrm{U} \\
\text { NA } \\
\text { NA }\end{array}$ \\
\hline $\begin{array}{l}\text { PC-52 M } \\
\text { PC-52 M Dupli cate } \\
\text { RPD } \\
\text { I-Stat }\end{array}$ & $\begin{array}{l}3 \\
3\end{array}$ & $\begin{array}{l}59.82 \\
51.99\end{array}$ & $\begin{array}{l}46.29 \\
54.70\end{array}$ & $\begin{array}{l}54.68 \\
55.40\end{array}$ & $\begin{array}{c}39.70 \mathrm{U} \\
39.53 \mathrm{U} \\
\text { NA } \\
\text { NA }\end{array}$ & $\begin{array}{c}39.70 \mathrm{U} \\
39.53 \mathrm{U} \\
\text { NA } \\
\text { NA }\end{array}$ & $\begin{array}{l}675.00 \\
450.35 \\
40 \% \\
0.20\end{array}$ & $\begin{array}{c}39.70 \mathrm{U} \\
39.53 \mathrm{U} \\
\text { NA } \\
\text { NA }\end{array}$ \\
\hline $\begin{array}{l}\text { C-SFBF } \\
\text { C-SFBF Duplicate } \\
\text { RPD } \\
\text { I-Stat }\end{array}$ & $\begin{array}{l}1 \\
1\end{array}$ & $\begin{array}{l}58.64 \\
69.04\end{array}$ & $\begin{array}{l}59.50 \\
69.54\end{array}$ & $\begin{array}{l}59.51 \\
63.94\end{array}$ & $\begin{array}{c}34.68 \mathrm{U} \\
33.43 \mathrm{U} \\
\text { NA } \\
\text { NA }\end{array}$ & $\begin{array}{c}34.68 \mathrm{U} \\
33.43 \mathrm{U} \\
\text { NA } \\
\text { NA }\end{array}$ & $\begin{array}{l}6.72 \mathrm{~J}^{(f)} \\
4.86 \mathrm{~J} \\
32 \% \\
0.16\end{array}$ & $\begin{array}{c}34.68 \mathrm{U} \\
33.43 \mathrm{U} \\
\text { NA } \\
\text { NA }\end{array}$ \\
\hline \multicolumn{9}{|c|}{ Compositing Duplicates } \\
\hline $\begin{array}{l}\text { SF-32 M } \\
\text { SF-32 M Cdup (g) } \\
\text { RPD } \\
\text { I-Stat }\end{array}$ & $\begin{array}{l}2 \\
2\end{array}$ & $\begin{array}{l}92.09 \\
91.04\end{array}$ & $\begin{array}{l}78.07 \\
85.23\end{array}$ & $\begin{array}{l}68.29 \\
67.77\end{array}$ & $\begin{array}{c}28.94 \mathrm{U} \\
32.96 \mathrm{U} \\
\text { NA } \\
\text { NA }\end{array}$ & $\begin{array}{c}28.94 \mathrm{U} \\
32.96 \mathrm{U} \\
\text { NA } \\
\text { NA }\end{array}$ & $\begin{array}{c}17.35 \mathrm{~J} \\
17.86 \mathrm{~J} \\
3 \% \\
0.01\end{array}$ & $\begin{array}{c}28.94 U \\
32.96 U \\
\text { NA } \\
\text { NA }\end{array}$ \\
\hline $\begin{array}{l}\text { Comp IHC-2 } \\
\text { Comp IHC-2 Cdup } \\
\text { RPD } \\
\text { I-Stat }\end{array}$ & $\begin{array}{l}1 \\
1\end{array}$ & $\begin{array}{l}88.13 \\
99.87\end{array}$ & $\begin{array}{l}80.68 \\
84.30\end{array}$ & $\begin{array}{l}76.58 \\
79.40\end{array}$ & $\begin{array}{c}42.94 \mathrm{U} \\
43.65 \mathrm{U} \\
\text { NA } \\
\text { NA }\end{array}$ & $\begin{array}{c}42.94 \mathrm{U} \\
43.65 \mathrm{U} \\
\text { NA } \\
\text { NA }\end{array}$ & $\begin{array}{c}13.06 \mathrm{~J} \\
21.77 \mathrm{~J} \\
50 \% \\
0.25\end{array}$ & $\begin{array}{c}42.94 U \\
43.65 U \\
\text { NA } \\
\text { NA }\end{array}$ \\
\hline $\begin{array}{l}\text { Comp LC } \\
\text { Comp LC Cdup } \\
\text { RPD } \\
\text { I-Stat }\end{array}$ & $\begin{array}{l}1 \\
1\end{array}$ & $\begin{array}{l}119.02 \\
112.72\end{array}$ & $\begin{array}{l}\text { MI } \\
\text { MI }\end{array}$ & $\begin{array}{l}97.29 \\
99.27\end{array}$ & $\begin{array}{c}38.62 \mathrm{U} \\
38.28 \mathrm{U} \\
\text { NA } \\
\text { NA }\end{array}$ & $\begin{array}{c}38.62 \mathrm{U} \\
38.28 \mathrm{U} \\
\text { NA } \\
\text { NA }\end{array}$ & $\begin{array}{c}283.10 \\
20.50 \mathrm{~J} \\
172 \% \\
0.86\end{array}$ & $\begin{array}{c}38.62 U \\
38.28 U \\
\text { NA } \\
\text { NA }\end{array}$ \\
\hline
\end{tabular}

\footnotetext{
(a) U Analyte was not present above the level of associated value.

(b) MI Matrix interference.

(c) NA Not applicable.

(d) NS Not spiked.

(e) Value exceeds relative precision goal of $\leq 30 \%$. For duplicates, one sample concentration must be $>10$ times the MDL.

(f) J Analyte detected below method detection limits (MDL), but above instrument detection Iimit (IDL).

(g) Compositing duplicate.
} 
TABLE C.21. Metals in Younger Bay Mud from Selected Cores and Sediment Composites, United Heckathorn Remedial Investigation

\begin{tabular}{|c|c|c|c|c|c|c|c|c|c|c|}
\hline \multirow{2}{*}{$\begin{array}{l}\text { Sediment } \\
\text { Treatment }\end{array}$} & \multicolumn{10}{|c|}{ Metals (mq/ $\mathrm{kg}$ dry weight) } \\
\hline & $\mathrm{Ag}$ & As & $\mathrm{Cd}$ & $\mathrm{Cr}$ & $\mathrm{Cu}$ & $\mathrm{Hg}$ & $\mathrm{Ni}$ & $\mathrm{Pb}$ & $\mathrm{Se}$ & $\mathrm{Zn}$ \\
\hline $\begin{array}{l}\text { Target DL (a) } \\
\text { Achieved DL High } \\
\text { Achieved DL Low }\end{array}$ & $\begin{array}{l}0.02 \\
0.01 \\
0.01\end{array}$ & $\begin{array}{l}2.5 \\
7.0 \\
4.6\end{array}$ & $\begin{array}{l}0.1 \\
0.01 \\
0.01\end{array}$ & $\begin{array}{l}33 \\
33 \\
33\end{array}$ & $\begin{array}{l}5.5 \\
5.5 \\
5.5\end{array}$ & $\begin{array}{l}0.01 \\
0.01 \\
0.006\end{array}$ & $\begin{array}{l}7.5 \\
7.5 \\
7.5\end{array}$ & $\begin{array}{l}6.2 \\
6.2 \\
6.2\end{array}$ & $\begin{array}{l}0.20 \\
0.10 \\
0.10\end{array}$ & $\begin{array}{l}7.8 \\
7.8 \\
7.8\end{array}$ \\
\hline $\begin{array}{ll}\text { LZ-1 } & M \\
\text { LZ-3 } & M \\
\text { LZ-6 } & M \\
\text { LZ-9 } & M \\
L Z-11 & M \\
L Z-13 & M \\
L Z-15 & M\end{array}$ & $\begin{array}{l}1.62 \\
1.27 \\
0.60 \\
0.59 \\
0.70 \\
0.42 \\
0.41\end{array}$ & $\begin{array}{l}16.4 \\
15.5 \\
15.7 \\
18.4 \\
15.1 \\
20.1 \\
15.6\end{array}$ & $\begin{array}{l}2.12 \\
1.87 \\
1.28 \\
1.04 \\
1.70 \\
1.02 \\
0.53\end{array}$ & $\begin{array}{r}177 \\
224 \\
237 \\
254 \\
235 \\
3990 \\
251\end{array}$ & $\begin{array}{c}138 \\
134 \\
113 \\
105 \\
99.3 \\
212 \\
155\end{array}$ & $\begin{array}{l}2.18 \\
1.70 \\
0.964 \\
0.779 \\
1.41 \\
0.554 \\
0.530\end{array}$ & $\begin{array}{c}91.4 \\
102 \\
105 \\
102 \\
93.4 \\
124 \\
122\end{array}$ & $\begin{array}{l}223 \\
222 \\
120 \\
78.8 \\
82.0 \\
102 \\
95.9\end{array}$ & $\begin{array}{l}0.60 \\
0.50 \\
0.30 \\
0.40 \\
0.60 \\
0.46 \\
0.40\end{array}$ & $\begin{array}{l}544 \\
378 \\
279 \\
262 \\
228 \\
360 \\
255\end{array}$ \\
\hline 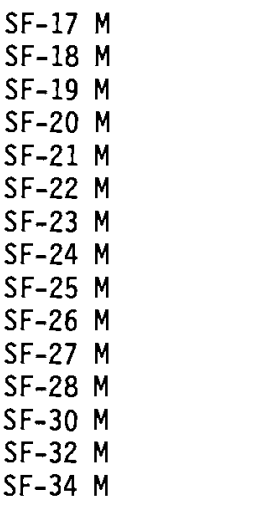 & $\begin{array}{l}0.57 \\
0.53 \\
0.62 \\
0.52 \\
0.55 \\
0.45 \\
0.48 \\
0.47 \\
0.39 \\
0.74 \\
0.51 \\
0.43 \\
0.51 \\
0.16 \\
0.34\end{array}$ & $\begin{array}{l}14.1 \\
15.0 \\
14.5 \\
14.5 \\
17.0 \\
26.6 \\
16.8 \\
17.4 \\
13.4 \\
17.6 \\
15.4 \\
11.6 \\
14.3 \\
14.8 \\
14.2\end{array}$ & $\begin{array}{l}0.92 \\
0.74 \\
0.73 \\
0.50 \\
0.60 \\
1.21 \\
0.54 \\
0.66 \\
0.78 \\
0.88 \\
0.67 \\
0.50 \\
0.47 \\
0.39 \\
0.77\end{array}$ & $\begin{array}{l}166 \\
176 \\
170 \\
168 \\
170 \\
173 \\
177 \\
180 \\
200 \\
196 \\
187 \\
181 \\
211 \\
199 \\
241\end{array}$ & $\begin{array}{c}104 \\
101 \\
104 \\
106 \\
94.9 \\
168 \\
88.5 \\
114 \\
64.9 \\
107 \\
86.2 \\
68.9 \\
100 \\
49.5 \\
61.5\end{array}$ & $\begin{array}{l}1.39 \\
1.13 \\
1.11 \\
0.758 \\
0.988 \\
1.18 \\
0.690 \\
1.01 \\
0.915 \\
1.25 \\
0.851 \\
0.611 \\
0.609 \\
0.308 \\
0.332\end{array}$ & $\begin{array}{c}97.8 \\
109 \\
103 \\
116 \\
116 \\
106 \\
104 \\
112 \\
90.5 \\
108 \\
104 \\
92.6 \\
110 \\
83.0 \\
96.9\end{array}$ & $\begin{array}{l}69.1 \\
75.2 \\
67.4 \\
58.6 \\
65.8 \\
65.9 \\
48.8 \\
60.4 \\
46.4 \\
70.6 \\
60.5 \\
42.7 \\
62.0 \\
23.4 \\
32.9\end{array}$ & $\begin{array}{l}0.45 \\
0.41 \\
0.41 \\
0.51 \\
0.45 \\
0.45 \\
0.45 \\
0.45 \\
0.45 \\
0.49 \\
0.36 \\
0.40 \\
0.40 \\
0.26 \\
0.40\end{array}$ & $\begin{array}{l}196 \\
223 \\
202 \\
209 \\
200 \\
396 \\
182 \\
206 \\
169 \\
226 \\
190 \\
157 \\
242 \\
105 \\
143\end{array}$ \\
\hline $\begin{array}{ll}I H-37 & M \\
I H-38 & M \\
I H-39 & M\end{array}$ & $\begin{array}{l}0.47 \\
0.48 \\
0.58\end{array}$ & $\begin{array}{l}13.0 \\
15.5 \\
15.7\end{array}$ & $\begin{array}{l}0.47 \\
0.50 \\
0.60\end{array}$ & $\begin{array}{l}183 \\
177 \\
192\end{array}$ & $\begin{array}{l}72.6 \\
74.8 \\
73.8\end{array}$ & $\begin{array}{l}0.519 \\
0.473 \\
0.532\end{array}$ & $\begin{array}{l}112 \\
117 \\
115\end{array}$ & $\begin{array}{l}55.5 \\
48.5 \\
54.7\end{array}$ & $\begin{array}{l}0.36 \\
0.40 \\
0.35\end{array}$ & $\begin{array}{l}181 \\
184 \\
192\end{array}$ \\
\hline $\begin{array}{l}P C-52 \\
P C-53 \\
P C-54\end{array}$ & $\begin{array}{l}0.98 \\
0.87 \\
0.60\end{array}$ & $\begin{array}{l}7.0 \mathrm{U}^{(\mathrm{b})} \\
6.8 \mathrm{U} \\
11.9\end{array}$ & $\begin{array}{l}3.17 \\
3.06 \\
1.99\end{array}$ & $\begin{array}{l}245 \\
233 \\
266\end{array}$ & $\begin{array}{l}138 \\
124 \\
98.1\end{array}$ & $\begin{array}{l}0.924 \\
0.800 \\
0.707\end{array}$ & $\begin{array}{l}86.0 \\
84.8 \\
86.3\end{array}$ & $\begin{array}{l}849 \\
807 \\
323\end{array}$ & $\begin{array}{l}0.45 \\
0.41 \\
0.40\end{array}$ & $\begin{array}{l}709 \\
707 \\
401\end{array}$ \\
\hline $\begin{array}{ll}\text { Comp LC } \\
\text { Comp LC-1 } \\
\text { Comp LC-2 } \\
\text { Comp LC-3 } \\
\text { Comp LC-4 } \\
\text { Comp LC-5 } \\
\text { Comp LC-6 } \\
\text { Comp USFC } \\
\text { Comp } & \text { FSFC } \\
\text { Comp IHC-1 } \\
\text { Comp IHC-2 } \\
\text { Comp IHC-3 } \\
\text { Comp GD }\end{array}$ & $\begin{array}{l}0.42 \\
0.67 \\
0.75 \\
0.40 \\
0.37 \\
0.60 \\
0.95 \\
0.66 \\
0.44 \\
0.43 \\
0.36 \\
0.37 \\
0.36\end{array}$ & $\begin{array}{l}4.6 \mathrm{U} \\
16.1 \\
19.1 \\
14.4 \\
14.4 \\
19.7 \\
12.1 \\
9.3 \\
15.9 \\
15.7 \\
17.0 \\
16.8 \\
13.9\end{array}$ & $\begin{array}{l}0.94 \\
2.06 \\
1.37 \\
0.90 \\
0.55 \\
1.25 \\
1.54 \\
1.02 \\
0.65 \\
0.42 \\
0.29 \\
0.36 \\
0.21\end{array}$ & $\begin{array}{r}273 \\
285 \\
273 \\
242 \\
248 \\
326 \\
1540 \\
143 \\
221 \\
200 \\
209 \\
203 \\
192\end{array}$ & $\begin{array}{l}96.6 \\
202 \\
171 \\
119 \\
118 \\
214 \\
100 \\
92.5 \\
91.3 \\
84.8 \\
75.8 \\
67.0 \\
71.5\end{array}$ & $\begin{array}{l}1.12 \\
1.27 \\
0.983 \\
0.691 \\
0.593 \\
0.826 \\
1.37 \\
1.48 \\
0.520 \\
0.543 \\
0.477 \\
0.461 \\
0.442\end{array}$ & $\begin{array}{c}93.4 \\
106 \\
103 \\
92.3 \\
99.7 \\
92.5 \\
101 \\
81.2 \\
113 \\
114 \\
130 \\
115 \\
106\end{array}$ & $\begin{array}{l}314 \\
225 \\
152 \\
119 \\
53.7 \\
92.1 \\
372 \\
65.6 \\
53.2 \\
46.3 \\
43.5 \\
41.9 \\
35.7\end{array}$ & $\begin{array}{l}0.50 \\
0.75 \\
0.55 \\
0.41 \\
0.45 \\
0.65 \\
0.51 \\
0.45 \\
0.35 \\
0.40 \\
0.40 \\
0.26 \\
0.31\end{array}$ & $\begin{array}{l}238 \\
517 \\
444 \\
313 \\
201 \\
244 \\
369 \\
213 \\
199 \\
194 \\
187 \\
171 \\
172\end{array}$ \\
\hline $\begin{array}{l}\text { C-SFBF } \\
\text { C-SFBC }\end{array}$ & $\begin{array}{l}0.20 \\
0.05\end{array}$ & $\begin{array}{r}13.7 \\
9.8\end{array}$ & $\begin{array}{l}0.25 \\
0.10\end{array}$ & $\begin{array}{l}191 \\
383\end{array}$ & $\begin{array}{l}36.0 \\
11.5\end{array}$ & $\begin{array}{l}0.249 \\
0.030\end{array}$ & $\begin{array}{l}90.5 \\
84.4\end{array}$ & $\begin{array}{l}20.5 \\
10.7\end{array}$ & $\begin{array}{l}0.26 \\
0.11\end{array}$ & $\begin{array}{l}108 \\
76.9\end{array}$ \\
\hline $\begin{array}{l}\text { CBM Comp - Fine } \\
\text { CBM Comp - Coarse }\end{array}$ & $\begin{array}{l}0.13 \\
0.10\end{array}$ & $\begin{array}{l}6.8 \\
9.4\end{array}$ & $\begin{array}{l}0.54 \\
0.39\end{array}$ & $\begin{array}{l}170 \\
267\end{array}$ & $\begin{array}{l}29.3 \\
16.2\end{array}$ & $\begin{array}{l}0.093 \\
0.077\end{array}$ & $\begin{array}{l}75.6 \\
63.5\end{array}$ & $\begin{array}{r}17.1 \\
9.0\end{array}$ & $\begin{array}{l}0.21 \\
0.10 \mathrm{U}\end{array}$ & $\begin{array}{l}79.9 \\
54.0\end{array}$ \\
\hline
\end{tabular}

(a) DL Detection limit

(b) $U$ Analyte was not present above the associated value. 
TABLE C.22. Quality Control Data for Metals in Younger Bay Mud from Selected Cores and Sediment Composites, United Heckathorn Remedial Investigation

Sediment

Treatment

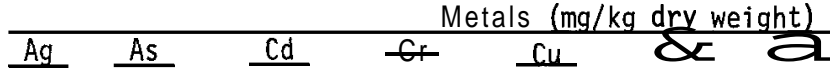

Method Blanks

\begin{tabular}{|c|c|c|c|c|c|c|c|c|c|c|}
\hline $\begin{array}{l}\text { Bl ank-1 } \\
\text { Bl ank-2 } \\
\text { Bl ank-3 } \\
\text { Bl ank-4 }\end{array}$ & $\begin{array}{l}0.01 \\
0.02 \\
0.02 \\
0.02\end{array}$ & $\begin{array}{l}\text { NA }(a) \\
\text { NA } \\
\text { NA } \\
\text { NA }\end{array}$ & $\begin{array}{l}0.01 U^{(b)} \\
0.01 \\
0.01 \\
0.01\end{array}$ & $\begin{array}{l}\text { NA } \\
\text { NA } \\
\text { NA } \\
\text { NA }\end{array}$ & $\begin{array}{l}\text { NA } \\
\text { NA } \\
\text { NA } \\
\text { NA }\end{array}$ & $\begin{array}{l}0.01 \\
0.01 \\
0.006 \\
0.006\end{array}$ & $\begin{array}{l}\text { NA } \\
\text { NA } \\
\text { NA } \\
\text { NA }\end{array}$ & $\begin{array}{l}\text { NA } \\
\text { NA } \\
\text { NA } \\
\text { NA }\end{array}$ & $\begin{array}{l}0.10 U \\
0.10 U \\
0.10 U \\
0.10 U\end{array}$ & $\begin{array}{l}\text { NA } \\
\text { NA } \\
\text { NA } \\
\text { NA }\end{array}$ \\
\hline \multicolumn{11}{|l|}{ Matrix Spikes } \\
\hline $\begin{array}{l}\text { Comp LC-5 } \\
\text { Comp LC-5 MS } \\
\text { Concentration Recovered } \\
\text { Amount Spiked } \\
\text { Percent Recovered }\end{array}$ & $\begin{array}{l}0.59 \\
2.31 \\
1.72 \\
2.00 \\
86 \%\end{array}$ & $\begin{array}{l}\text { NA } \\
\text { NA } \\
\text { NA } \\
\text { NS } \\
\text { NA }\end{array}$ & $\begin{array}{l}1.20 \\
2.92 \\
1.72 \\
2.00 \\
86 \%\end{array}$ & $\begin{array}{l}\text { NA } \\
\text { NA } \\
\text { NA } \\
\text { NS } \\
\text { NA }\end{array}$ & $\begin{array}{l}\text { NA } \\
\text { NA } \\
\text { NA } \\
\text { NS } \\
\text { NA }\end{array}$ & $\begin{array}{l}0.800 \\
2.65 \\
1.85 \\
2.00 \\
93 \%\end{array}$ & $\begin{array}{l}\text { NA } \\
\text { NA } \\
\text { NA } \\
\text { NS } \\
\text { NA }\end{array}$ & $\begin{array}{l}\text { NA } \\
\text { NA } \\
\text { NA } \\
\text { NS } \\
\text { NA }\end{array}$ & $\begin{array}{l}0.66 \\
2.81 \\
2.15 \\
2.00 \\
108 \%\end{array}$ & $\begin{array}{l}\text { NA } \\
\text { NA } \\
\text { NA } \\
\text { NS } \\
\text { NA }\end{array}$ \\
\hline $\begin{array}{l}\text { LZ-15 M(c) } \\
\text { LZ-15 M MS } \\
\text { Concentration Recovered } \\
\text { Amount Spiked } \\
\text { Percent Recovered }\end{array}$ & $\begin{array}{l}0.43 \\
2.10 \\
1.67 \\
2.00 \\
\quad 84 \%\end{array}$ & $\begin{array}{r}15.9 \\
N A \\
N A \\
N S \\
N A\end{array}$ & $\begin{array}{l}0.53 \\
2.19 \\
1.66 \\
2.00 \\
83 \%\end{array}$ & $\begin{array}{r}253 \\
N A \\
N A \\
N S \\
N A\end{array}$ & $\begin{array}{l}157 \\
N A \\
N A \\
N S \\
N A\end{array}$ & $\begin{array}{l}0.538 \\
2.69 \\
2.15 \\
2.00 \\
108 \%\end{array}$ & $\begin{array}{l}126 \\
N A \\
N A \\
N S \\
N A\end{array}$ & $\begin{array}{r}97.0 \\
\mathrm{NA} \\
\mathrm{NA} \\
\mathrm{NS} \\
\mathrm{NA}\end{array}$ & $\begin{array}{l}0.40 \\
2.08 \\
1.68 \\
2.00 \\
\quad 84 \%\end{array}$ & $\begin{array}{r}259 \\
\text { NA } \\
\text { NA } \\
\text { NS } \\
\text { NA }\end{array}$ \\
\hline $\begin{array}{l}\text { IH-37 M(c) } \\
\text { IH-37 M MS } \\
\text { Concentration Recovered } \\
\text { Amount Spiked } \\
\text { Percent Recovered }\end{array}$ & $\begin{array}{l}0.47 \\
2.35 \\
1.88 \\
2.00 \\
94 \%\end{array}$ & $\begin{array}{r}15.8 \\
N A \\
N A \\
N S \\
N A\end{array}$ & $\begin{array}{l}0.50 \\
2.09 \\
1.59 \\
2.00 \\
80 \%\end{array}$ & $\begin{array}{l}191 \\
\text { NA } \\
\text { NA } \\
\text { NS } \\
\text { NA }\end{array}$ & $\begin{array}{r}73.7 \\
N A \\
N A \\
N S \\
N A\end{array}$ & $\begin{array}{l}0.504 \\
2.47 \\
1.97 \\
2.00 \\
98 \%\end{array}$ & $\begin{array}{l}117 \\
\text { NA } \\
\text { NA } \\
\text { NS } \\
\text { NA }\end{array}$ & $\begin{array}{r}55.2 \\
N A \\
N A \\
N S \\
N A\end{array}$ & $\begin{array}{l}0.36 \\
1.96 \\
1.60 \\
2.00 \\
80 \%\end{array}$ & $\begin{array}{r}183 \\
\text { NA } \\
\text { NA } \\
\text { NS } \\
\text { NA }\end{array}$ \\
\hline
\end{tabular}

$\underline{\text { Standard Reference Material }}$

Certified

Value 1646

SPM 1646 Replicate

SRM 1646 Replicate

SPM 1646 Replicate

SPM 1646 Replicate

Analytical Duplicate

Comp LC-5

Comp LC-5 Duplicate

RPD

I- Stat

Comp LC-6

Comp LC-6 Duplicate

RPD

I-Stat

LZ-15 M

LZ-15 Duplicate

RPD

I-Stat

$\mathrm{IH}-37 \mathrm{M}$

IH-37 Duplicate

RPD

I-Stat

\begin{tabular}{rrr}
\multicolumn{2}{c}{${ }^{N C}{ }^{(e)} 11.6$} & 0.36 \\
$N C$ & \pm 1.3 & \pm 0.07 \\
& & \\
0.10 & 13.1 & 0.37 \\
0.10 & 10.6 & 0.38 \\
0.10 & 9.6 & 0.40 \\
0.11 & NA & 0.40
\end{tabular}

$\begin{array}{lll}19.7 & 1.25 \quad 326\end{array}$

$\begin{array}{cccc}5 \% & \mathrm{NA} & 1.14 & \mathrm{NA} \\ 0.03 & 9 \% & \mathrm{NA}\end{array}$

$0.03 \quad \mathrm{NA}$

0.05

$0.95 \quad 12$

NA 10.3

NA $\quad 16 \%$

NA $\quad 0.08$

1.54

1540

NA

1190

76
+3

18

0.063

$\pm 0.012$

32

28.2

NC

138

13.8

0.074

0.076

0.074

\section{0}

36.3

31.5

25.7

27.5

28.3

NA

NA

NA

214

$\begin{array}{ll}\text { NA } & 0.773 \\ \text { NA } & 7 \%\end{array}$

92.5
NA
NA
NA

92.1

NA

0.65

$0.66 \quad 244$

NA

0.03

NA

0.01

$\begin{array}{lll}1.37 & 101 & 372\end{array}$

0.51

NA $\quad 96.8 \quad 310$

NA $\quad 5 \% \quad 18 \%$

NA

$18 \%$ NA $\quad 7 \%$

$\begin{array}{lllll}0.41 & 15.6 & 0.53 & 251 & 155\end{array}$

$0.530 \quad 122$

0.09

NA

0.03

0.4416.

0.52

$254 \quad 159$

$0.545 \quad 129$

95.9

$0.40 \quad 255$

$\begin{array}{cccc}7 \% & 4 \% & 2 \% & 1 \% \\ 0.04 & 0.02 & 0.01 & 0.01\end{array}$

98.1

$0.40 \quad 262$

$\begin{array}{lllll}0.47 & 13.0 & 0.47 & 183 & 72.6\end{array}$

$0.46 \quad 18.6$

(f) $\begin{aligned} & 0.52 \\ & 10 \%\end{aligned}$

199

0.010 .18

0.05

0.04
0.01

0.01

0.03$$
0.519
$$

$\begin{array}{cc}0.519 & 112 \\ 0.488 & 121 \\ 6 \% & 8 \% \\ 0.03 & 0.04\end{array}$

0.01

0.00

$3 \%$

$0.01 \%$

55.5

$0.36 \quad 181$

$\begin{array}{rrr}54.9 & 0.36 & 184 \\ 1 \% & 0 \% & 2 \%\end{array}$

01

0.00

0.01 


\section{TABLE C.22. (contd)}

Sediment

$\underline{\text { Treatment }}$

Compositing Duplicates

SF-32 M

SF-32 M Cdup (g)

RPD

I-Stat

Comp LC

Comp LC Cdup

RPD

I-Stat

Comp IHC-2

Comp IHC-2 Cdup

RPD

I-Stat

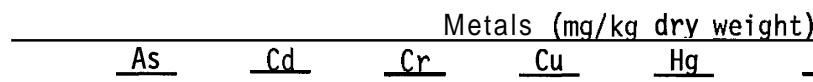

$\mathrm{Ni} \quad \mathrm{Ph} \quad \mathrm{Se} \quad \underline{\mathrm{Zn}}$

\begin{tabular}{|c|c|c|c|c|c|c|c|c|c|}
\hline 0.16 & 14.8 & 0.39 & 199 & 49.5 & 0.308 & 83.0 & 23.4 & 0.26 & 105 \\
\hline $\begin{array}{c}0.16 \\
0 \%\end{array}$ & 11.5 (f) & $\begin{array}{l}0.36 \\
8 \%\end{array}$ & $\begin{array}{c}205 \\
3 \%\end{array}$ & $38.1(f)$ & $\frac{0.397}{25 \%}(f)$ & 83.7 & $\begin{array}{r}25.7 \\
9 \%\end{array}$ & $\begin{array}{r}0.26 \\
0 \%\end{array}$ & $\begin{array}{r}104 \\
1 \%\end{array}$ \\
\hline 0.00 & 0.13 & 0.04 & 0.01 & 0.13 & 0.13 & 0.00 & 0.05 & 0.00 & 0.01 \\
\hline
\end{tabular}

$\begin{array}{llllllllll}0.42 & 4.6 \cup & 0.94 & 273 & 96.6 & 1.12 & 93.4 & 314 & 0.50 & 238\end{array}$

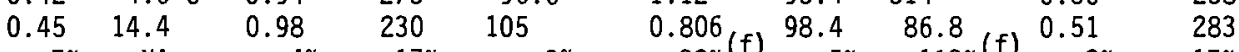

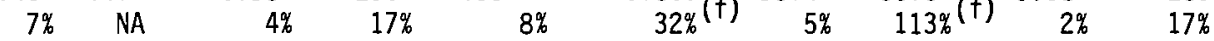

$\begin{array}{llllllllll}0.03 & \text { NA } & 0.02 & 0.09 & 0.04 & 0.16 & 0.03 & 0.57 & 0.01 & 0.09\end{array}$

$\begin{array}{llllllllll}0.36 & 17.0 & 0.29 & 209 & 75.8 & 0.477 & 130 & 43.5 & 0.40 & 187\end{array}$

$\begin{array}{cccccccccc}0.38 & 15.4 & 0.27 & 196 & 69.9 & 0.443 & 116 & 38.6 & 0.36 & 171\end{array}$

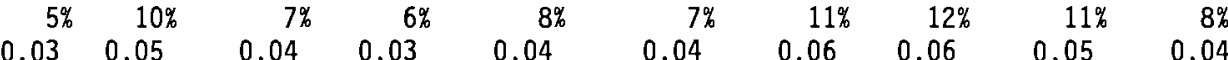

(a) NA Not applicable.

(b) $U$ Analyte was not present above the associated value.

(c) Mean of duplicated sample.

(d) NS Not spiked.

(e) NC Not certified.

(f) Value exceeds relative precision goal of $\leq 20 \%$.

(g) Compositing duplicate. 
TABLE C.23. Butyltins in Younger Bay Mud Sediment from Selected Cores and in Sediment Composites, United Heckathorn Remedial Investigation

Sediment

Treatment

Target $D^{(a)}$

Achieved DL
Tripentyltin

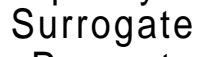

Percent

Batch

Recovery
Butyltins ( $\mu \mathrm{q} / \mathrm{kg}$ dry weight)

Tributvltin Dibutvltin

10

8

10

13.2

17.6

10.8

22.0

$5.3 \mathrm{~J}^{(\mathrm{c})}$

37.5

24.9

19.6

85.5

39.0

29.9

12.2

19.9

23.6

27.2

17.2

13.2

28.0

13.1

16.0

$7.9 \mathrm{~J}$

12.0

$5.1 \mathrm{~J}$

$7.4 \mathrm{~J}$

8.1

$28.0 \mathrm{Dl}^{(\mathrm{e})}$

20.2 D1

36.3

33.7

83.6

60.7

30.3

$209.6 D^{(\mathrm{g})}$

14.9

$6.0 \mathrm{~J}$
11.6

15.0

10.6

23.6

$4.5 \mathrm{~J}$

21.9

12.4

27.2

50.5

56.3

45.9

16.7

13.9

31.8

28.7

11.0

10.4

16.0

16.7

14.7

$3.6 \mathrm{~J}$

7.6

7.6

8.9

6.7

8.3 D1

15.9 D1

28.7

28.1

85.6

56.9

31.4

$55.9 \mathrm{D}$

13.0

5.3

70
71

Comp LC-5

1 
TABLE C.23. (contd)

Sediment

Treatment

Comp USFC

Comp FSFC

Comp IHC-1

Comp IHC-2

Comp IHC-3

Comp GD

C-SFBF

C-SFBC

CBM Comp-Fine

CBM Comp-Coarse
Tripentyltin

Surrogate

Percent

Recoverv

Batch

1

54

66

60

99

112

61

75

$1 \quad 93$

3

3

\section{6}

93
Butyltins

( $\mu \mathrm{g} / \mathrm{kg}$ drv weight)

Tributvltin Dibutvltin

39.3

18.0

37.4

12.3

13.3

8.7

$7.3 \mathrm{~J}$

7.6

$4.0 \mathrm{~J}$

$3.7 \mathrm{~J}$

16.6

5.7

$5.9 \mathrm{~J}$

19.6

$2.7 \mathrm{~J}$

$5.0 \mathrm{U}^{(\mathrm{h})}$

$2.8 \mathrm{~J}$

$5.0 \mathrm{U}$

$3.5 \mathrm{~J}$

(a) DL Detection limit. These detection limits represent quantitation limits (LOQ).

(b) Segment M: mudline to Younger Bay Mud/01der Bay Mud boundary.

(c) J Analyte detected below Limit of Quantitation (LOQ), but above method detection limit (MDL).

(d) ${ }^{* *}$ Surrogate internal standard not added; final internal standard used for quantitation.

(e) D1 Sample diluted 1:10.

(f) Recovery outside quality control range (40\%-120\%).

(g) D Sample diluted 1:2.

(h) $U$ Analyte was not present above the associated value. 
TABLE C.24. Quality Control Data for Butyltins in Younger Bay Mud Sediment from Selected Cores and in Sediment Composites, United Heckathorn Remedial Investigation

Sediment

$\underline{\text { Treatment }}$

Method Blanks

Blank 1

Blank 2

Blank 3

Blank 4

Matrix Spikes

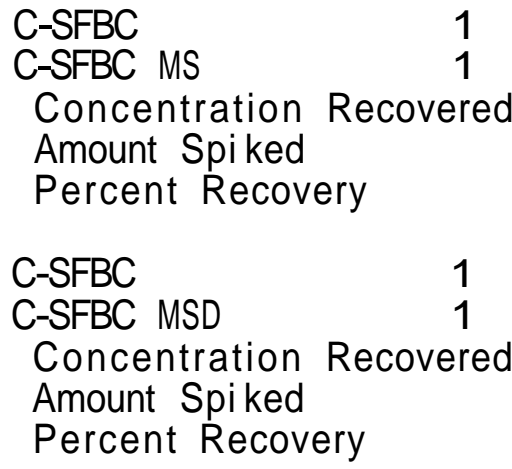

MS/MSD RPD

MS/MSD I-Stat

SF-17 $M^{(f)}$

SF-17 M MS

Concentration Recovered

Amount Spiked

Percent Recovery

SF-17 M

SF-17 M MSD

Concentration Recovered

Amount Spiked

Percent Recovery

MS/MSD RPD

MS/MSD I-Stat
Tripentyltin

Surrogate

Percent

Recoverv

82

97

99

$5.3 \mathrm{~J}^{(\mathrm{a})}$

$6.8 \mathrm{~J}$

$8.0 \mathrm{U}$

$8.0 \mathrm{U}$

$1.8 \mathrm{~J}^{(\mathrm{b})}$

$5.0 \mathrm{U}$

$5.0 \mathrm{U}$
Butyltins

( $\mu \mathrm{q} / \mathrm{kg}$ dry weight)

Tributvltin Dibutvltin
93

79

$N A^{(d)}$

$N S^{(e)}$

NA

93

79

NA

NS

NA

NA

NA

109

100

NA

NS

NA

109

108

NA

NS

NA

NA

NA
$2.7 \mathrm{~J}$

37.3

34.6

36.3

95\%

$2.7 \mathrm{~J}$

37.6

34.9

36.7

95\%

$0 \%$

0.00

19.6

62.7

43.1

50.6

$85 \%$

19.6

72.3

52.7

49.5

$106 \%$

$22 \%$

0.11
$5.0 \mathrm{U}$

31.8

31.8

36.3

$88 \%$

$5.0 \mathrm{U}$

31.2

31.2

36.7

$85 \%$

$0.02 \%$

27.2

61.6

34.4

50.6

$68 \%$

27.2

78.9

51.7

49.5

$104 \%$

$42 \%(\mathrm{~g})$ 
TABLE C.24. (contd)

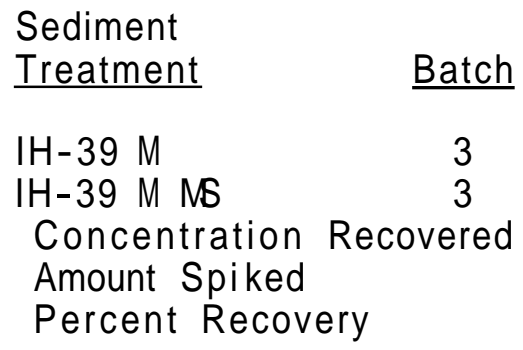

$\mathrm{IH}-39 \mathrm{M}$

IH-39 M MSD

3
3

Concentration Recovered Amount Spiked

Percent Recovery

MS/MSD RPD

MS/MSD I-Stat

Analvtical Duplicates
Tripentyltin Surrogate Percent Recovery

**

98

NA

NS

NA

**

100

NA

NS

NA

NA

NA

75

76

NA

NA

103

113

NA

NA

87

84

NA

NA

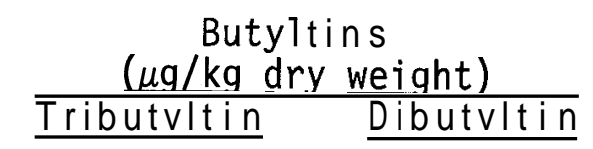

8.1

58.3

50.2

54.0

93\%

8.1

56.3

48.2

55.0

$88 \%$

6.7

36.9

30.2

54.0 $56 \%$

6.7

44.0

37.3

55.0

$68 \%$

$6 \%$

$19 \%$

0.10

$\begin{array}{ll}\text { PC-54 M } & 3 \\ \text { PC-54 M Duplicate } & 3\end{array}$

RPD

I-Stat

Compositing Duplicates

SF-32 M

SF-32 M Cdup ${ }^{(h)}$

RPD

I-Stat

Comp LC

Comp LC Cdup

RPD

I-Stat
$2 \quad 89$

113

NA

NA

70

80

NA

NA
$5.9 \mathrm{~J}$

$4.8 \mathrm{~J}$

$21 \%$

0.10

12.2

13.0

$6 \%$

0.03

36.3

38.2

0.03
19.6

23.4

$18 \%$

0.09

16.7

14.8

$12 \%$

0.06

28.7

30.8

0.04

C. 104 
TABLE C.24. (contd)

Sediment

Treatment

Comp IHC-2

Comp IHC-2 Cdup

$\mathrm{RPD}$

I-Stat

\section{Tripentylt in}

Surrogate

Percent

Batch

2

Recoverv

99
$126^{(i)}$
NA
NA

Butyltins

( $\mu \mathrm{q} / \mathrm{kg}$ drv weight)

Tributvltin Dibutvltin

8.7

8.3

$5 \%$

0.02
$4.0 \mathrm{~J}$

$3.7 \mathrm{~J}$

$8 \%$
0.04 
TABLE C.25. Chlorinated Pesticide Analyses of Older Bay Mud Samples, United Heckathorn Remedial Investigation

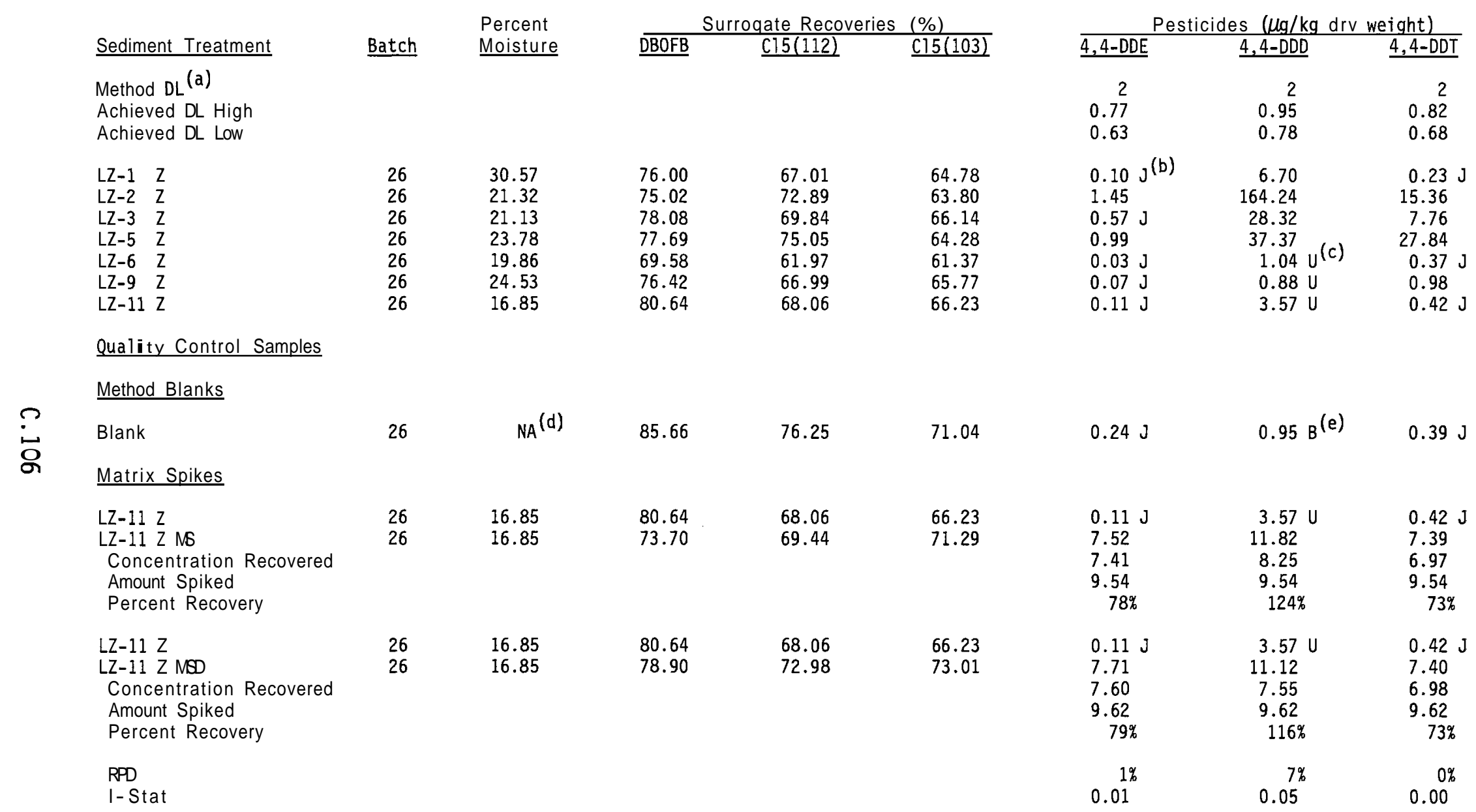


IABLE C.25. (contd)

\begin{tabular}{|c|c|c|c|c|c|c|c|c|}
\hline & & Percent & & sate $\operatorname{Recc}$ & $(\%)$ & & es (ug/k & ejght) \\
\hline Sediment Treatment & Batch & Moisture & DBOFB & C15(112) & C15(103) & $\overline{4,4-D D E}$ & $4,4-D D D$ & $4,4-D D T$ \\
\hline Analvtical Duplica & & & & & & & & \\
\hline LZ-2 Z & 26 & 21.32 & 75.02 & 72.89 & 63.80 & 1.45 & 164.24 & 15.36 \\
\hline LZ-2 Z Duplicate & 26 & 22.03 & 74.64 & 73.36 & 64.37 & 1.61 & 161.01 & 17.90 \\
\hline $\begin{array}{l}\text { RPD } \\
\text { I-Stat }\end{array}$ & & & & & & $\begin{array}{l}11 \% \\
0.05\end{array}$ & 0.01 & $\begin{array}{c}15 \% \\
0.08\end{array}$ \\
\hline
\end{tabular}




\section{QA/QC SUMMARY}

PROGRAM:

PARAMETER:

LABORATORY:

MATRIX:

SAMPLE NUMBER:
United Heckathorn Remedial Investigation

Grain Size

Soil Technology

Sediment

265

\section{QA/QC REQUIREMENTS}

Reference Method Range of Recovery Relative Precision Detection Limit
ASTM D2217 \&
Not applicable
$\pm 20 \%$
Not applicable

D422

\section{HOLDING TIMES}

The holding time of 6 months was met for all grain size analyses.

\section{DUPLICATES}

The precision criteria for analytical duplicates was exceeded in 4 of 56 measurements; all four exceedances were associated with fractions constituting $\leq 2 \%$ dry weight of the sample. Twelve of 52 RPD measurements exceeded the QC criteria in cornpositing duplicates. 


\section{QA/QC SUMMARY}

PROGRAM:

PARAMETER:

LABORATORY:

MATRIX:

SAMPLE NUMBER:

QA/QC REQUIREMENTS

$\begin{array}{cccc}\text { Reference Method } & \text { Ranae of Recovery } & \text { Relative Precision } & \text { Detection Limit } \\ \text { Modified } 9060 & \text { Not applicable } & \pm 10 \% & 0.1 \% \\ \text { HOLDING TIMES } & & & \end{array}$

The holding time of 6 months was met for all TOC analyses.

\section{PROCEDURAL BLANKS}

All procedural blanks contained less than $0.01 \%$ TOC. No QC criteria are designated for TOC procedural blanks.

\section{DUPLICATES}

Precision between analytical duplicates was good; only 2 of 27 RPD measurements exceeded the QC criteria. Five of 13 RPDs for compositing duplicates exceeded the QC criteria, probably due to sample inhomogeneity.

\section{DETECTION LIMITS}

The achieved detection limit met the detection limit specified in the Quality Assurance Project Plan (QAPP). 


\section{QA/QC SUMMARY}

PROGRAM:

PARAMETER:

LABORATORY:

MATRIX:

SAMPLE NUMBER: 265

\section{QA/QC REQUIREMENTS}

Reference Method Ranae of Recoven Relative Precision Detection Limit

Modified 8080

$40 \%-120 \%$

$\pm 30 \%$

Battelle Ocean Sciences Laboratory

Sediment

United Heckathorn Remedial Investigation

Chlorinated Pesticides

\section{HOLDING TIMES}

The following is a list of extraction and analysis dates for the 21 batches of sediment samples analyzed for pesticides:

\begin{tabular}{|c|c|c|c|c|}
\hline Batch 3 & $\begin{array}{l}\text { Date } \\
\text { Collected } \\
1 / 5-9 / 93\end{array}$ & $\begin{array}{l}\text { Date } \\
\text { Beceived } \\
1 / 19 / 93\end{array}$ & $\begin{array}{l}\text { Date } \\
\text { Extracted } \\
1 / 21 / 93\end{array}$ & $\begin{array}{l}\text { GC/ECD } \\
\frac{\text { Analvsis }}{2 / 25-26 / 93}\end{array}$ \\
\hline Batch 4 & $1 / 5-9 / 93$ & $1 / 19 / 93$ & $1 / 21 / 93$ & 2/26/93 \\
\hline Batch 6 & $1 / 5-9 / 93$ & $1 / 21 / 93$ & $1 / 25 / 93$ & 2/27/93 \\
\hline Batch 7 & $1 / 5-9 / 93$ & $1 / 19 / 93$ & $1 / 27 / 93$ & $2 / 27-28 / 93$ \\
\hline Batch 8 & $1 / 5-9 / 93$ & $1 / 19 / 93$ & 1127193 & 2/28/93 \\
\hline Batch 9 & $115-9193$ & $1 / 19 / 93$ & $1 / 29 / 93$ & $\begin{array}{l}2 / 28-3 / 1 \\
3 / 10-11 / 93\end{array}$ \\
\hline Batch 11 & $115-9 / 93$ & $1 / 19 / 93$ & $2 / 2 / 93$ & $\begin{array}{l}2 / 19-20 \\
3 / 9-10 / 93\end{array}$ \\
\hline Batch 12 & 1/5-9/93 & $1 / 19 / 93$ & 2/2/93 & $\begin{array}{l}2 / 22-24 \\
3 / 10 / 93\end{array}$ \\
\hline Batch 13 & $1 / 5-9 / 93$ & $1 / 19-20 / 93$ & 2/2/93 & $\begin{array}{l}3 / 3-5 \\
3 / 20-21193\end{array}$ \\
\hline
\end{tabular}




\begin{tabular}{|c|c|c|c|c|}
\hline & $\begin{array}{l}\text { Date } \\
\text { Collected }\end{array}$ & $\begin{array}{l}\text { Date } \\
\text { Received }\end{array}$ & $\begin{array}{l}\text { Date } \\
\text { Extracted }\end{array}$ & $\begin{array}{l}\text { GC/ECD } \\
\text { Analvsis }\end{array}$ \\
\hline Batch 14 & $1 / 5-9 / 93$ & $1 / 20 / 93$ & $2 / 2 / 93$ & $\begin{array}{l}3 / 5-6 \\
3 / 21 / 93\end{array}$ \\
\hline Batch 15 & $1 / 5-9 / 93$ & $1 / 20 / 93$ & $2 / 3 / 93$ & $\begin{array}{l}318-9, \\
3 / 22-23 / 93 \\
\text { (dilutions) }\end{array}$ \\
\hline Batch 16 & $1 / 5-9 / 93$ & $1 / 20-21 / 93$ & $2 / 3 / 93$ & $\begin{array}{l}3 / 9-11 \\
3 / 23 / 93 \\
\text { (dilutions) }\end{array}$ \\
\hline Batch 17 & $1 / 5-9 / 93$ & $1 / 20-21 / 93$ & $2 / 3 / 93$ & $3 / 16-17 / 93$ \\
\hline Batch 18 & $1 / 5-9 / 93$ & $1 / 21 / 93$ & $2 / 4 / 93$ & $3 / 18-19 / 93$ \\
\hline Batch 19 & $1 / 5-9193$ & $1 / 21 / 93$ & $2 / 4 / 93$ & $\begin{array}{l}3 / 15-16 \\
3 / 19 \& 25 / 93\end{array}$ \\
\hline Batch 20 & $1 / 5-9 / 93$ & $1 / 21 / 93$ & $2 / 4 / 93$ & $\begin{array}{l}3 / 17-18, \\
3123-24 \& \\
4 / 2 / 93 \\
\text { (dilutions) }\end{array}$ \\
\hline Batch 21 & $1 / 5-9 / 93$ & $1 / 19 / 93$ & $2 / 16 / 93$ & $\begin{array}{l}3120-21 \\
413-10193 \\
\text { (dilutions) }\end{array}$ \\
\hline Batch 22 & $1 / 5-9 / 93$ & $1 / 19 / 93$ & $2 / 16 / 93$ & $3 / 22-23 / 93$ \\
\hline Batch 23 & $1 / 5-9 / 93$ & $1 / 19 / 93$ & 2/19/93 & $\begin{array}{l}\text { 3/25-27, } \\
4 / 5 / 93 \\
\text { (dilutions) }\end{array}$ \\
\hline Batch 24 & $1 / 5-9 / 93$ & $1 / 19 / 93$ & $2 / 19 / 93$ & $\begin{array}{l}\text { 3/27-28, } \\
4 / 5-6 / 93 \\
\text { (dilutions) }\end{array}$ \\
\hline Batch 25 & 1/5-9193 & $1 / 19-21 / 93$ & $4 / 14 / 93$ & $\begin{array}{l}4 / 28-30, \\
5114-18 / 93 \\
\text { (dilutions) }\end{array}$ \\
\hline
\end{tabular}




$\begin{array}{lllll} & \begin{array}{l}\text { Date } \\ \text { Collected }\end{array} & \begin{array}{l}\text { Date } \\ \text { Received }\end{array} & \begin{array}{l}\text { Date } \\ \text { Extracted }\end{array} & \begin{array}{l}\text { GC/ECD } \\ \text { Analvsis }\end{array} \\ \text { Batch } 26 & 1 / 5-9 / 93 & 6 / 22 / 93 & 6 / 23 / 93 & \\ 7 / 1-2, \\ 7 / 10-11 / 93\end{array}$

The holding time of 30 days from the date of collection to sample extraction was met for all samples except those requiring re-extraction due to laboratory contamination attributed to highly contaminated sediment samples (Batches 21 through 24). The initial extractions for these samples were within the holding time. In addition, holding times were exceeded for samples requiring re-extraction and reanalysis due to poor surrogate recoveries (Batch 25). The 40-day holding time from extraction to analysis was exceeded for Batches 17 and 18 by one and two days, respectively because a severe winter storm caused a power outage at the laboratory. Batch 26 samples were archived sediments that required analysis after initial results were reviewed; they were stored frozen and analyzed after the holding time expired. The analytical results for these analyses are probably not affected because of the stability of pesticide compounds.

\section{PROCEDURAL BLANKS}

One procedural blank was processed with each batch of samples. Blanks for Batches $7,8,11$, and 13 had DDT concentrations above the method detection limit, and the blanks for Batches 11 and 26 had DDD concentrations above the method detection limit. Associated sample results for those compounds were flagged as undetected if the sample concentration was less than five times the concentration in the blank. The table below summarizes the concentrations of DDT and DDD in the blanks, the concentrations below which sample results were flagged as undetected, and the number of positive sample results subsequently flagged with a $U$.

\begin{tabular}{|c|c|c|c|c|}
\hline Batch & Analyte & $\begin{array}{c}\text { Blank } \\
\text { Concentration } \\
\underline{\mu g / k g d r y ~ w t}\end{array}$ & $\begin{array}{c}5 \text { X Blank } \\
\text { Concentration } \\
\mu \mathrm{g} / \mathrm{kg} \text { dry wt }\end{array}$ & $\begin{array}{c}\text { Number of } \\
\text { detections } \\
\text { flaaaed with U } \\
\end{array}$ \\
\hline 7 & DDT & 119.81 & 599.05 & $1^{*}$ \\
\hline 8 & DDT & 11.88 & 59.40 & 0 \\
\hline 11 & DDT & 4.10 & 20.50 & 14 \\
\hline 11 & DDD & 3.34 & 16.70 & 5 \\
\hline 13 & DDT & 1.52 & 7.60 & 6 \\
\hline 26 & DDD & 0.95 & 4.75 & 3 \\
\hline
\end{tabular}

*Sample LZ-14 A 
If the analyte was detected above the instrument detection limit but below the method detection limit, the "J" value was replaced with the detection limit for that sample.

\section{MATRIX SPIKES}

The recoveries of target pesticides in the matrix spike (MS) and matrix spike duplicate (MSD) samples were acceptable for all compounds except DDD and DDT. The recoveries of DDD were outside the Quality Control (QC) criteria of $40 \%$ to $120 \%$ in batches 11 and 18, and the recovery of DDT in the MSD sample was above the QC criteria of $120 \%$ in Batch 11 . The same sample (LZ-14 Y) was used for MS/MSD analysis in Batches 22, 23, and 24 because it was known to have low background concentrations of pesticides.

Greater than expected dilution ranges were necessary to quantify the concentrations of pesticides in six batches of highly contaminated samples. As a result, MS recoveries could not be calculated for Batches 3, 4, 6, 7, 8, and 9 because the MS compounds were diluted out.

\section{SURROGATES}

In general, surrogate recoveries were excellent. The recovery of 1 of 3 surrogate compounds was outside QC limits for 16 samples (including duplicates). The recoveries of two of three compounds were outside QC limits for one sample. The recoveries of all three compounds were outside QC limits for two samples. Surrogate recoveries could not be calculated for six batches of highly-contaminated samples because the surrogate compounds were diluted out. However, the excellent recoveries in the remaining batches indicate an efficient extraction procedure.

Eleven sediment samples required re-extraction due to unacceptable recoveries of the surrogate compounds. Data for these samples were provided with Batch 25. After the second extraction and analysis, two samples still showed unacceptable surrogate recoveries, indicating that the sample matrix may be interfering with the recovery of these compounds.

\section{DUPLICATES}

Duplicate precision between the MS and MSD was generally good. The relative percent difference (RPD) measurements exceeded the QC criteria for one pesticide in one batch, and two pesticides in two batches. The MS/MSD RPDs exceeded the QC criteria for all pesticides in Batch 23.

The QC criteria of $\pm 30 \%$ was exceeded numerous times for DDT, DDD, and DDE in analytical and compositing duplicates. The lack of precision is probably due to sample heterogeneity because the precision between MS/MSD samples is good. 


\section{DETECTION LIMITS}

Achieved detection limits were lower than the detection limits specified in the Quality Assurance Project Plan (QAPP) for all analyses that did not require dilutions. The detection limits for compounds in diluted samples were increased by the dilution factor. 


\section{QA/QC SUMMARY}

PROGRAM:

PARAMETER:

LABORATORY:

MATRIX:

SAMPLE NUMBER:
United Heckathorn Remedial Investigation

Total Petroleum Hydrocarbons (TPH)

Analytical Resources, Inc.

Sediment

45

\section{QA/QC REQUIREMENTS}

\begin{tabular}{cccc} 
Reference Method & Ranae of Recovery & Relative Precision & Detection Limit \\
\cline { 2 - 3 } & 518.1 & $\pm 20 \%$ & $\begin{array}{c}20 \mathrm{mg} / \mathrm{kg} \mathrm{dry} \\
\text { weight }\end{array}$
\end{tabular}

\section{HOLDING TIMES}

The following is a list of extraction and analysis dates for the three batches of sediment samples:

Date Collected

$1 / 5-9193$

Batch 1

Batch 2

Batch 3
$1 / 5-9 / 93$

$1 / 5-9 / 93$ pate Analyzed

7110193

$7 / 11 / 93$

$7112 / 93$

The samples were initially analyzed within the holding time of 28 days; however, they were reanalyzed 6 months later because the incorrect method was used for the corresponding oil and grease analyses. The samples were stored in a frozen state prior to reanalysis; therefore, the concentrations of petroleum hydrocarbons should not have significantly decreased during this time.

\section{PROCEDURAL BLANKS}

One procedural blank was processed with each batch of samples. No hydrocarbons were detected in the procedural blanks at concentrations above the detection limit.

\section{MATRIX SPIKES}

The matrix spike (MS) samples were spiked with vegetable oil and analyzed for total oil and grease. The vegetable oil would not be expected to carry over to the TPH fraction after silica gel cleanup; therefore, MS data for TPH analyses are not available. 


\section{DUPLICATES}

The relative percent difference (RPD) between analytical duplicates exceeded the QC criteria of $20 \%$ in two batches, and the RPD for one cornpositing duplicate exceeded $20 \%$.

\section{DETECTION LIMITS}

Achieved detection limits were 20 to $90 \mathrm{mg} / \mathrm{kg}$, which is higher than the detection limit specified in the Quality Assurance Project Plan (QAPP) for TPH analyses. TPH was detected in all but five samples. 


\section{QA/QC SUMMARY}
PROGRAM:
United Heckathorn Remedial Investigation
PARAMETER:
Oil and Grease
LABORATORY:
Analytical Resources, Inc.
MATRIX:
Sediment
SAMPLE NUMBER: 45

\section{QA/QC REQUIREMENTS}

Reference Method Ranae of Recovery Relative Precision Detection Limit

413.2

$50 \%-150 \%$

$\pm 20 \%$

$20 \mathrm{mg} / \mathrm{kg}$ dry

weight

\section{HOLDING TIMES}

The following is a list of analysis dates for the three batches of sediment samples:

\section{Date Collected $\quad$ Date Analvzed}

Batch 1

Batch 2

Batch 3
$1 / 5-9 / 93$

$1 / 5-9 / 93$

$1 / 5-9 / 93$
$7 / 10193$

$7111 / 93$

$7112 / 93$

The samples were initially analyzed within the holding time of 28 days; however, they were reanalyzed 6 months later because the incorrect method was used for the oil and grease analyses. The samples were stored in a frozen state prior to reanalysis; therefore, the concentrations of oil and grease should not have significantly decreased during this time.

\section{PROCEDURAL BLANKS}

One procedural blank was processed with each batch of samples. No hydrocarbons were detected in the procedural blanks at concentrations above the detection limit.

\section{MATRIX SPIKES}

Matrix spike recoveries ranged from $99 \%$ to $113 \%$, all within the acceptable range. 


\section{DUPLICATES}

The relative percent difference (RPD) between analytical duplicates and cornpositing duplicates exceed the quality control (QC) criteria of $20 \%$ in two batches.

\section{DETECTION LIMITS}

The achieved detection limits were between 20 and $30 \mathrm{mg} / \mathrm{kg}$ dry weight, which is higher than the detection limits specified in the Quality Assurance Project Plan (QAPP) for oil and grease analyses. Oil and grease was detected in all but two samples. 


\section{QA/QC SUMMARY}

PROGRAM:

PARAMETER:

LABORATORY:

MATRIX:

SAMPLE NUMBER:
United Heckathorn Remedial Investigation

Polynuclear Aromatic Hydrocarbons (PAH)

Battelle Ocean Sciences Laboratory

Sediment

45

\section{QA/QC REQUIREMENTS}

$\begin{array}{cccc}\text { Reference Method } & \text { Ranae of Recovery } & \text { Relative Precision } & \text { Detection Limit } \\ \text { Modified } 8270 & 40 \%-120 \% & \pm 30 \% & \begin{array}{c}20 \mu \mathrm{g} / \mathrm{kg} \mathrm{dry} \\ \text { weight }\end{array}\end{array}$

\section{HOLDING TIMES}

The following is a list of extraction and analysis dates for the three batches of sediment samples and two reanalyzed samples:

\begin{tabular}{lllll} 
Batch 1 & $\begin{array}{l}\text { Date } \\
\text { Collected } \\
1 / 5-9 / 93\end{array}$ & $\begin{array}{l}\text { Date } \\
\text { Received }\end{array}$ & $\begin{array}{l}\text { Date } \\
\text { Extracted } \\
1 / 19 / 93\end{array}$ & $\begin{array}{l}\text { GC/MS } \\
\text { Analysis } \\
1123-24 / 93, \\
1 / 28-29 / 93\end{array}$ \\
Batch 2 & $1 / 5-9 / 93$ & $1 / 19 / 93$ & $1 / 19 / 93$ & $1 / 30-2 / 1 / 93$ \\
Batch 5 & $1 / 5-9 / 93$ & $1 / 21 / 93$ & 1125193 & $2 / 3-4 / 93$ \\
$\begin{array}{l}\text { Batch 23 } \\
\text { (rerun) }\end{array}$ & $1 / 5-9 / 93$ & $1 / 21 / 93$ & $2119 / 93$ & $3 / 24 / 93$ \\
$\begin{array}{l}\text { Batch 25 } \\
\text { (rerun) }\end{array}$ & $1 / 5-9 / 93$ & $1 / 19 / 93$ & $4 / 14 / 93$ & $4 / 29 / 93$ \\
\hline
\end{tabular}

The holding times for all extractions and analyses were met, with the exception of the two samples that required re-extraction. The second extractions exceeded the holding time of 14 days.

\section{PROCEDURAL BLANKS}

One procedural blank was processed with each batch of samples. No PAHs were detected in the procedural blanks at concentrations above the method detection limit. 


\section{MATRIX SPIKES}

The recoveries of target PAHs in the MS and MSD were acceptable, with only two exceedances. In the Batch 2 MSD sample, the percent recoveries of fluoranthene and pyrene were $158 \%$ and $139 \%$, respectively. Recoveries were within limits for the corresponding MS sample.

The recovery of target PAHs in the MSIMSD samples for batches 23 and 25 (rerun samples) were not corrected for background levels because the spiked samples were analyzed for pesticides only. However, the MSIMSD sample was screened prior to analysis to ensure that a relatively uncontaminated sample was used.

\section{SURROGATES}

Two sediment samples required re-extraction due to unacceptable recoveries of the surrogate compounds. Data for these samples were provided with batches 23 and 25 .

The recovery of the PAH surrogate internal standard (SIS) compounds naphthalene$d_{8}$, acenapthene- $d_{10}$, and benzo[a]pyrene- $d_{12}$ were acceptable in all but three sediment samples. The recovery of benzo[a]pyrene- $d_{12}$ was $35 \%$ in one sample (Comp GD) and the recovery of naphthalene- $d_{8}$ was $39 \%$ in one sample (PC-54 M). The recoveries of all three surrogate compounds were unacceptable in one sample (LZ-13 M). The poor recoveries in this sample were confirmed after a second extraction and analysis, indicating that a matrix-related problem may be interfering with the recovery of the compounds.

\section{DUPLICATES}

Duplicate precision between the MS and MSD was excellent except for three compounds (naphthalene, fluoranthene, and pyrene) in Batch 2 and 15 compounds in Batch 23. The large relative percent difference (RPD) for two of the compounds in Batch 2 is due to the high percent recovery in the MSD sample. Replicate precision of the analytical and compositing duplicates exceeded the quality control (QC) criteria of $30 \%$ for 19 PAHs in Batch 1, 18 PAHs in Batch 2, and 15 PAHs in Batch 5. The elevated RPD values appear to be due to sample inhomogeneity rather than nonreproducible sample handling, because, as stated above, the RPDs between the MS and MSD samples were generally good.

\section{DETECTION LIMITS}

Achieved detection limits were lower than the detection limits specified in the Quality Assurance Project Plan (QAPP) for all analyses. 


\section{QA/QC SUMMARY}

PROGRAM:

PARAMETER:

LABORATORY:

MATRIX:

SAMPLE NUMBER:
United Heckathorn Remedial Investigation

Polychlorinated Biphenyls (PCB)

Battelle Ocean Sciences Laboratory

Sediment

45

\section{QA/QC REQUIREMENTS}

Reference Method Ranae of Recovery Relative Precision Detection Limit

$\begin{array}{cccc}\text { Modified } 8080 & 40 \%-120 \% & \pm 30 \% & \begin{array}{c}20 \mu \mathrm{g} / \mathrm{kg} \text { dry } \\ \text { weight }\end{array}\end{array}$

The following is a list of extraction and analysis dates for the three batches of sediment samples analyzed for PCBs:

\begin{tabular}{|c|c|c|c|c|}
\hline Batch 1 & $\begin{array}{l}\text { Date } \\
\text { Collected } \\
1 / 5-9193\end{array}$ & $\begin{array}{l}\text { Date } \\
\text { Received } \\
1 / 19 / 93\end{array}$ & $\begin{array}{l}\text { Date } \\
\text { Extracted } \\
\frac{1 / 19 / 93}{}\end{array}$ & $\begin{array}{l}\text { GC/ECD } \\
\text { Analysis } \\
1124-26193, \\
2 / 3 \& 11 / 93\end{array}$ \\
\hline Batch 2 & $1 / 5-9 / 93$ & $1 / 19 / 93$ & 1/19/93 & $\begin{array}{l}1 / 26-27 / 93, \\
2111193\end{array}$ \\
\hline Batch 5 & $1 / 5-9 / 93$ & $1 / 21 / 93$ & $1 / 25 / 93$ & $212-4193$ \\
\hline $\begin{array}{l}\text { Batch } 23 \\
\text { (rerun) }\end{array}$ & $1 / 5-9 / 93$ & $1 / 21 / 93$ & 2119/93 & $3 / 27 / 93$ \\
\hline
\end{tabular}

The holding times for all extractions and analyses were met, with the exception of one sample which required a second extraction and analysis due to poor surrogate recoveries. The re-extraction of this sample exceeded the 14 day holding time.

\section{PROCEDURAL BLANKS}

One procedural blank was processed with each batch of samples. No PCBs were detected in the procedural blanks. 


\section{MATRIX SPIKES}

The recoveries of Aroclor 1254 in the MS and MSD samples were acceptable. The MS/MSD samples analyzed with Batch 23 were not analyzed for Aroclor 1254.

\section{SURROGATES}

One sediment sample required re-extraction due to unacceptable recoveries of the surrogate compounds. Data for this sample was provided with Batch 23. Surrogate recoveries in the second analysis were acceptable.

The recoveries of the PCB surrogate internal standard (SIS) compounds DBOFB, $\mathrm{Cl}_{5}(103)$ and $\mathrm{Cl}_{5}(112)$ were acceptable; however, matrix interferences affected the recovery of one or more surrogate compounds in 15 samples (including duplicates).

Duplicate precision between the MS and MSD was good. Replicate precision of Aroclor 1254 in analytical and compositing duplicates exceeded the quality control (QC) criteria of $30 \%$ for one duplicate in Batch 1 and one in Batch 3. The elevated relative percent difference (RPD) values appear to be due to sample inhomogeneity rather than non-reproducible sample handling because, as stated above, the RPDs between the MS and MSD samples met QC criteria.

\section{DETECTION LIMITS}

Achieved detection limits of 30 to $50 \mu \mathrm{g} / \mathrm{kg}$ were higher than the detection limit specified in the Quality Assurance Project Plan (QAPP). The higher detection were the result of an uncommonly high moisture content. Detection limits are based on a sample dry weight of approximately $25 \mathrm{~g}$; the Heckathorn samples had a dry weight of approximately 10 to $15 \mathrm{~g}$. As a result, detection limits were affected proportionally. 


\section{QA/QC SUMMARY}

PROGRAM:

PARAMETER:

LABORATORY:

MATRIX:

SAMPLE NUMBER:
United Heckathorn Remedial Investigation

Metals

Battelle Marine Sciences Laboratory

Sediment

45

\section{QA/QC REQUIREMENTS}

\begin{tabular}{|c|c|c|c|}
\hline Reference Methoc & Banae of Recovery & Relative Precision & Detection Limit \\
\hline Varies by metal & $\begin{array}{c}75 \%-125 \%, \leq 30 \% \\
\text { from certified value } \\
\text { for SRM }\end{array}$ & $\pm 20 \%$ & Varies by met \\
\hline
\end{tabular}

\section{HOLDING TIMES}

The following table summarizes all analysis dates:

\section{Task}

Sample digestion

XRF analysis (As, $\mathrm{Cr}, \mathrm{Cu}, \mathrm{Ni}, \mathrm{Pb}, \mathrm{Zn}$ )

GFAA analysis $(\mathbf{A g})$

GFAA analysis $(\mathrm{Cd})$

GFAA analysis (Se)

CVAA analysis $(\mathrm{Hg})$

\section{Date Performed}

1125193

2113-19/93

$3117 / 93$

$3116 / 93$

$2 / 3 / 93$

$1128-29193$

The holding times for all analyses were met.

\section{PROCEDURAL BLANKS}

Four procedural blanks were analyzed for silver, cadmium, selenium, and mercury. Cadmium and silver were detected in the blanks at levels at or below the target detection limit. All metals data are blank corrected. Method blanks are not analyzed by $\mathrm{x}$-ray fluorescence (XRF), and no blank results are reported for XRF metals.

\section{MATRIX SPIKES}

Three MS samples were analyzed with the sediment samples analyzed by GFAA or CVAA. All MS recoveries were within QC limits. Samples analyzed by XRF are analyzed whole and cannot be spiked. 


\section{STANDARD REFERENCE MATERIALS}

The 1646 standard reference material (SRM) was analyzed for all metals with each batch. This SRM is an estuarine sediment obtained from the National Institute for Standards and Technology. All results were well within the QC range of $\pm 30 \%$ of the certified value.

\section{DUPLICATES}

Four analytical duplicates were analyzed with the sediment samples. Relative percent differences between the duplicates were within the QC limits for all metals except arsenic in one batch and chromium in one batch. These metals are both analyzed by XRF. Samples for XRF analysis are not processed, limiting the chance for contamination or loss due to handling; therefore, the difference is most likely due to sample inhomogeneity. The RPDs for compositing duplicates exceeded the QC criteria for three metals in one batch and two metals in another batch.

\section{DETECTION LIMITS}

Target detection limits were met for all metals except arsenic, with a target detection limit of $2.5 \mathrm{mg} / \mathrm{kg}$. Arsenic was detected in all but three samples, which had detection limits ranging from 4.6 to $7.0 \mathrm{mg} / \mathrm{kg}$. 


\section{QA/QC SUMMARY}

PROGRAM:

PARAMETER:

LABORATORY:

MATRIX:

SAMPLE NUMBER:
United Heckathorn Remedial Investigation

Butyltins

Battelle/Marine Sciences Laboratory

Sediment

45

\section{QA/QC REQUIREMENTS}

Reference Method Range of Recovery Relative Precision Detection Limit

Unger, et al.

$40 \%-120 \%$

$\pm 30 \%$

$10 \mu \mathrm{g} / \mathrm{kg}$ dry

weight

\section{HOLDING TIMES}

The following is a list of extraction and analysis dates for the three batches of sediment samples analyzed for butyltins:

\begin{tabular}{|c|c|c|c|c|}
\hline Batch 1 & $\begin{array}{l}\text { Date } \\
\frac{\text { Collected }}{115-9193}\end{array}$ & $\begin{array}{l}\text { Date } \\
\text { Received } \\
1 / 18 / 93\end{array}$ & $\begin{array}{l}\text { Date } \\
\text { Extracted } \\
1125-29193\end{array}$ & $\begin{array}{l}\text { GC/FPD } \\
\frac{\text { Analvsis }}{213-17 / 93}\end{array}$ \\
\hline Batch 2 & $1 / 5-9 / 93$ & 1/18/93 & $1 / 25-29 / 93$ & $1 / 30-2 / 1 / 93$ \\
\hline Batch 3 & $1 / 5-9 / 93$ & $1118 / 93$ & $1 / 25-29 / 93$ & $2 / 3-4 / 93$ \\
\hline $\begin{array}{l}\text { Batch } 4 \\
\text { (reruns) }\end{array}$ & $1 / 5-9 / 93$ & $1 / 18 / 93$ & $3 / 2 / 93$ & 3/10193 \\
\hline
\end{tabular}

The holding times for extractions and analyses for batches 1 through 3 were met. Five samples (Batch 4) were re-extracted on March 2 because the surrogate internal standard (SIS) was not added to the samples prior to the initial extraction. Extraction holding times for these samples were exceeded. These analyses were completed within the holding time.

\section{PROCEDURAL BLANKS}

One procedural blank was processed with each batch of samples. Tributyltin (TBT) was detected at concentrations below the limit of quantitation in the procedural blanks for batches 1 and 2. Dibutytlin (DBT) was detected below the limit of quantitation in the 
procedural blank for Batch 1. No butyltins were detected in the blanks for batches 3 and 4.

\section{MATRIX SPIKES}

The recoveries of tributyltin and dibutyltin in the matrix spike (MS) and matrix spike duplicate (MSD) samples for all batches were within the quality control (QC) limits.

\section{SURROGATES}

One surrogate internal standard (SIS), tripentyltin chloride, is added prior to extraction to assess the efficiency of the method. All sample data are corrected for the recovery of this compound. Surrogate recoveries for all but one sample were within the QC limits. One blank and one sample were not spiked with the SIS prior to extraction; these samples were quantified using a final internal standard, which was added just prior to gas chromatography.

\section{DUPLICATES}

Relative percent differences between the MS and MSD recoveries for butyltins were within the QC limits except dibutyltin in Batch 2. Replicate precision of the analytical and compositing duplicates met the QC criteria of $230 \%$.

\section{DETECTION LIMITS}

Target detection limits of $10 \mu \mathrm{g} / \mathrm{kg}$ dry weight were met for all butyltin compounds; achieved detection limits ranged form 5 to $8 \mu \mathrm{g} / \mathrm{kg}$.

\section{COMMENTS}

Matrix interferences affected the chromatography in terms of retention time drift and peak shape for a number of samples. Samples PC-52 M and PC-53 M were the most affected; dilution of these samples allowed for quantitation of the SIS and corresponding results were found to be acceptable. All sample data were reviewed and found to be acceptable; therefore, no sample data were qualified due to matrix effects. 


\section{APPENDIXD}

BIOASSAY RESULTS FOR 10-DAY SOLID-PHASE TEST

WITH Rheooxvnius abronius 

TABLE D. 1. Results for al1 Replicates in 10-Day R. abronius Solid-Phase Test, United Heckathorn Remedial Investigation

\begin{tabular}{|c|c|c|c|c|c|c|}
\hline \multirow[b]{2}{*}{$\begin{array}{l}\text { Sediment } \\
\text { Treatment } \\
\end{array}$} & \multirow[b]{2}{*}{$\underline{\text { Replicate }}$} & \multicolumn{2}{|c|}{$\begin{array}{l}\text { R. abronius } \\
\end{array}$} & \multirow[b]{2}{*}{$\begin{array}{l}\text { Proportion } \\
\text { Survival } \\
\end{array}$} & \multirow[b]{2}{*}{$\begin{array}{l}\text { Mean Proportion } \\
\text { Survival } \\
\end{array}$} & \multirow[b]{2}{*}{$\begin{array}{l}\text { Standard } \\
\text { Deviation }\end{array}$} \\
\hline & & $\begin{array}{l}\text { Number } \\
\text { Alive } \\
\end{array}$ & $\begin{array}{l}\text { Number Dead } \\
\text { or Missing }\end{array}$ & & & \\
\hline Comp LC-1 & 1 & 0 & 20 & 0.00 & & \\
\hline Comp LC-1 & 2 & 0 & 20 & 0.00 & & \\
\hline Comp LC-1 & 3 & 0 & 20 & 0.00 & & \\
\hline $\begin{array}{l}\text { Comp LC-1 } \\
\text { Comp LC-1 }\end{array}$ & $\begin{array}{l}4 \\
5\end{array}$ & $\begin{array}{l}0 \\
0\end{array}$ & $\begin{array}{l}20 \\
20\end{array}$ & $\begin{array}{l}0.00 \\
0.00\end{array}$ & 0.00 & 0.00 \\
\hline Comp LC-2 & 1 & 0 & 20 & 0.00 & & \\
\hline Comp LC-2 & 2 & 0 & 20 & 0.00 & & \\
\hline Comp LC-2 & 3 & 0 & 20 & 0.00 & & \\
\hline Comp LC-2 & 4 & 0 & 20 & 0.00 & & \\
\hline Comp LC-2 & 5 & 0 & 20 & 0.00 & 0.00 & 0.00 \\
\hline Comp LC-3 & 1 & 0 & 20 & 0.00 & & \\
\hline Comp LC-3 & 2 & 0 & 20 & 0.00 & & \\
\hline Comp LC-3 & 3 & 0 & 20 & 0.00 & & \\
\hline Comp LC-3 & 4 & 0 & 20 & 0.00 & & \\
\hline Comp LC-3 & 5 & 0 & 20 & 0.00 & 0.00 & 0.00 \\
\hline Comp LC-4 & 1 & 12 & 8 & 0.60 & & \\
\hline Comp LC-4 & 2 & 14 & 6 & 0.70 & & \\
\hline Comp LC-4 & 3 & 15 & 5 & 0.75 & & \\
\hline Comp LC-4 & 4 & 15 & 5 & 0.75 & & \\
\hline Comp LC-4 & 5 & 18 & 2 & 0.90 & 0.74 & 0.11 \\
\hline Comp LC-5 & 1 & 0 & 20 & 0.00 & & \\
\hline Comp LC-5 & 2 & 0 & 20 & 0.00 & & \\
\hline Comp LC-5 & 3 & 0 & 20 & 0.00 & & \\
\hline Comp LC-5 & 4 & 0 & 20 & 0.00 & & \\
\hline Comp LC-5 & 5 & 0 & 20 & 0.00 & 0.00 & 0.00 \\
\hline Comp USFC & 1 & 17 & 3 & 0.85 & & \\
\hline Comp USFC & 2 & 16 & 4 & 0.80 & & \\
\hline Comp USFC & 3 & 17 & 3 & 0.85 & & \\
\hline Comp USFC & 4 & 20 & 0 & 1.00 & & \\
\hline Comp USFC & 5 & 18 & 2 & 0.90 & 0.88 & 0.08 \\
\hline Comp FSFC & 1 & 16 & 4 & 0.80 & & \\
\hline Comp FSFC & 2 & 20 & 0 & 1.00 & & \\
\hline Comp FSFC & 3 & 19 & 1 & 0.95 & & \\
\hline Comp FSFC & 4 & 11 & 9 & 0.55 & & \\
\hline Comp FSFC & 5 & 8 & 12 & 0.40 & 0.74 & 0.26 \\
\hline Comp IHC-1 & 1 & 20 & 0 & 1.00 & & \\
\hline Comp IHC-1 & 2 & 19 & 1 & 0.95 & & \\
\hline Comp IHC-1 & 3 & 16 & 4 & 0.80 & & \\
\hline Comp IHC-1 & 4 & 15 & 5 & 0.75 & & \\
\hline Comp IHC-1 & 5 & 19 & 1 & 0.95 & 0.89 & 0.11 \\
\hline Comp IHC-2 & 1 & 17 & 3 & 0.85 & & \\
\hline Comp IHC-2 & 2 & 19 & 1 & 0.95 & & \\
\hline Comp IHC-2 & 3 & 17 & 3 & 0.85 & & \\
\hline Comp IHC-2 & 4 & 19 & 1 & 0.95 & & \\
\hline Comp IHC-2 & 5 & 17 & 3 & 0.85 & 0.89 & 0.05 \\
\hline
\end{tabular}

D. 1 
TABLE D.1. (contd)

Sediment

Treatment

Comp IHC-3

Comp IHC-3

Comp IHC-3

Comp IHC-3

Comp IHC-3

Comp GD

Comp (ד)

Comp (T)

Comp GD

Comp GD

CWB

CWB

CWB

CWB

CWB

CWB Rerun

CWB Rerun

CWB Rerun

CWB Rerun

CWBB Rerun

C-SFBF

C-SFBF

C-SFBF

C-SFBF

C-SFBF

C-SFBC

C-SFBC

C-SFBC

C-SFBC

C-SFBC

\section{Replicate}

1
2
3
4
5

1

2

3

5

1
2

3

5

2

3

4
5

2

3

4
5

2

3

4
5
R. abronius

\begin{tabular}{|c|c|c|c|}
\hline $\begin{array}{l}\text { Number } \\
\text { Ali ve }\end{array}$ & $\begin{array}{l}\text { Number Dead } \\
\text { or Missing }\end{array}$ & $\begin{array}{l}\text { Proportion } \\
\text { Survival }\end{array}$ & $\begin{array}{l}\text { Mean Proportion } \\
\text { Survival }\end{array}$ \\
\hline
\end{tabular}
0.85
0.09

0.95

0.70

0.85

0.95

0.80

0.95

1.00

0.90

0.92

0.08

1.00

0.95

1.00

0.95

0.90

0.96

0.04

1.00

0.95

1.00

1.00

1.00

$0.99 \quad 0.02$

0.85

0.95

1.00

0.90

0.90

0.92

0.06

1.00

1.00

1.00

1.00

1.00

1.00

0.00 
TABLE D.2. Water Quality Summary for 10-Day R. abronius Solid-Phase Test, United Heckathorn Remedial Investigation

\begin{tabular}{|c|c|c|c|c|c|c|c|c|}
\hline \multirow[t]{2}{*}{$\begin{array}{l}\text { Sediment } \\
\text { Treatment } \\
\end{array}$} & \multicolumn{2}{|c|}{$\begin{array}{c}\text { Temperature } \\
\left({ }^{\circ} \mathrm{C}\right)\end{array}$} & \multicolumn{2}{|c|}{$\mathrm{pH}(\mathrm{a})$} & \multicolumn{2}{|c|}{$\begin{array}{c}\text { Dissolved } \\
\text { Oxygen } \\
\text { (mg/L) }\end{array}$} & \multicolumn{2}{|c|}{$\begin{array}{c}\text { Salin ity } \\
(0 / 00)\end{array}$} \\
\hline & $\operatorname{Min}^{(b)}$ & $\underline{\operatorname{Max}}^{(\mathrm{b})}$ & Min & Max & Min & Max & Min & Max \\
\hline Acceptable Range & 13.0 & 17.0 & 7.60 & 8.60 & 6.0 & $N A^{(c)}$ & 28.0 & 32.0 \\
\hline $\begin{array}{l}\text { COMP LC-1 } \\
\text { COMP LC-2 } \\
\text { OOMP LC-3 } \\
\text { COMP LC-4 } \\
\text { OOMP LC-5 } \\
\text { COMP USFC } \\
\text { OOMP FSFC } \\
\text { OOMP IHC-1 } \\
\text { OOMP IHC-2 } \\
\text { OOMP IHC-3 } \\
\text { OOMP GD } \\
\text { C-WB } \\
\text { C-WB Rerun } \\
\text { C-SFBF } \\
\text { C-SFBC }\end{array}$ & $\begin{array}{l}15.5 \\
15.5 \\
15.5 \\
15.6 \\
15.6 \\
15.6 \\
15.6 \\
15.5 \\
15.5 \\
15.5 \\
15.6 \\
15.5 \\
15.6 \\
15.5 \\
15.5\end{array}$ & $\begin{array}{l}15.9 \\
16.0 \\
15.9 \\
15.9 \\
16.0 \\
15.9 \\
15.9 \\
15.9 \\
15.9 \\
15.9 \\
15.9 \\
15.9 \\
16.0 \\
15.9 \\
15.9\end{array}$ & $\begin{array}{l}7.94 \\
7.96 \\
7.82 \\
8.00 \\
8.01 \\
8.00 \\
7.93 \\
7.96 \\
7.93 \\
7.99 \\
7.81 \\
7.93 \\
7.90 \\
7.89 \\
8.01\end{array}$ & $\begin{array}{l}8.68^{(\mathrm{d})} \\
8.59 \\
8.23 \\
8.35 \\
8.24 \\
8.17 \\
8.15 \\
8.27 \\
8.16 \\
8.37 \\
8.12 \\
8.22 \\
8.33 \\
8.13 \\
8.16\end{array}$ & $\begin{array}{l}7.4 \\
7.4 \\
7.4 \\
7.4 \\
7.4 \\
7.3 \\
7.3 \\
7.5 \\
7.3 \\
7.3 \\
7.3 \\
7.5 \\
7.6 \\
7.2 \\
7.5\end{array}$ & $\begin{array}{l}8.2 \\
8.1 \\
8.0 \\
7.9 \\
8.1 \\
8.3 \\
8.4 \\
8.0 \\
8.1 \\
8.2 \\
8.0 \\
8.3 \\
8.5 \\
8.3 \\
8.2\end{array}$ & $\begin{array}{l}30.0 \\
30.0 \\
30.0 \\
30.0 \\
30.0 \\
30.0 \\
30.0 \\
30.0 \\
30.0 \\
30.0 \\
30.0 \\
30.0 \\
30.0 \\
30.0 \\
30.0\end{array}$ & $\begin{array}{l}31.5 \\
31.0 \\
31.5 \\
31.0 \\
31.0 \\
31.5 \\
32.0 \\
31.0 \\
31.5 \\
31.0 \\
31.5 \\
31.5 \\
31.0 \\
31.5 \\
31.0\end{array}$ \\
\hline
\end{tabular}

(a) Acceptable $\mathrm{pH}$ range is based on mean $\mathrm{pH}$ in al1 test chambers in 10-day test.

(b) Minimum and maximum values are derived from al1 replicates for each treatment.

(c) NA Not applicable.

(d) $\mathrm{pH}$ outside of acceptable range on Day 10 only, in three of five replicates. 
TABLE D.3. Results for all Replicates in 96- $h$ R. abronius Reference Toxicant Test, United Heckathorn Remedial Investigation

Cadmium

Concentration $(\mathrm{mg} / \mathrm{L})$

0.5

0.5

0.5

\begin{tabular}{ll} 
& R. abronius \\
\hline Number & Number Dead \\
Alive & or Missing
\end{tabular}

1
2
3

1
2
3

1

$$
2
$$

$$
\begin{aligned}
& 1 \\
& 2 \\
& 3
\end{aligned}
$$$$
1
$$$$
2
$$

18
18
19

18

17

14

\section{6}

8
7

2

1

0

0

2
2
1
2
3
6
6
14
12
13
18
19
17
20
20
20

Mean

Proportion Proportion Standard

Surviving Surviving Deviation

0.90

0.90

0.95

0.92

0.03

0.90

0.85

0.70

0.82

0.10

0.30

0.40

0.35

0.35

0.05

0.10

0.05

0.15

0.10

0.05

0.00

0.00

0.00

0.00 
TABLE D.4. Water Quality Summary for 96-h R. abronius Reference Toxicant Test, United Heckathorn Remedial Investigation

\begin{tabular}{|c|c|c|c|c|c|c|c|c|}
\hline \multirow[t]{2}{*}{$\begin{array}{c}\text { Cadmium } \\
\begin{array}{c}\text { Concentration } \\
(\mathrm{mq} / \mathrm{L})\end{array} \\
\end{array}$} & \multicolumn{2}{|c|}{$\begin{array}{c}\text { Temperature } \\
(\circ \mathrm{C})\end{array}$} & \multicolumn{2}{|c|}{$\mathrm{pH}^{(\mathrm{a})}$} & \multicolumn{2}{|c|}{$\begin{array}{l}\text { Dissolved } \\
\text { Oxygen } \\
\text { (mg/L) } \\
\end{array}$} & \multicolumn{2}{|c|}{$\begin{array}{l}\text { Salinity } \\
(0 / 00)\end{array}$} \\
\hline & $\underline{\operatorname{Min}}^{(b)}$ & $\operatorname{Max}^{(\mathrm{b})}$ & $\underline{\text { Min }}$ & Max & $\underline{\text { Min }}$ & Max & $\underline{\text { Min }}$ & Max \\
\hline Acceptable Range & 13.0 & 17.0 & 7.18 & 8.18 & 6.0 & $N A^{(c)}$ & 28.0 & 32.0 \\
\hline 0.0 & 15.6 & 15.9 & 8.01 & 8.14 & 7.4 & 8.1 & 30.0 & 31.0 \\
\hline 0.5 & 15.5 & 15.9 & 8.03 & 8.14 & 7.5 & 8.3 & 30.0 & 31.5 \\
\hline 1.0 & 15.6 & 15.8 & 7.99 & 8.12 & 7.5 & 8.2 & 30.0 & 31.0 \\
\hline 2.0 & 15.5 & 15.9 & 7.97 & 8.08 & 7.6 & 8.4 & 30.0 & 31.0 \\
\hline 4.0 & 15.5 & 15.9 & 7.80 & 8.00 & 7.4 & 8.1 & 30.0 & 31.0 \\
\hline
\end{tabular}

\footnotetext{
(a) Acceptable $\mathrm{pH}$ range is based on mean $\mathrm{pH}$ in all test chambers in 96-hour test.

(b) Minimum and maximum values are derived from all replicates for each concentration.

(c) NA Not applicable.
} 



\section{APPENDIXE}

\section{BIOASSAY RESULTS FOR 28-DAY SOLID-PHASE TEST}

WITH Macoma nasuta 

TABLE E.1. Results for all Replicates in 96-h M. nasuta Solid-Phase Test, United Heckathorn Remedial Investigation

\begin{tabular}{|c|c|c|c|c|c|c|}
\hline \multirow[b]{2}{*}{$\begin{array}{l}\text { Sediment } \\
\text { Treatment }\end{array}$} & \multirow[b]{2}{*}{ Replicate } & \multicolumn{2}{|c|}{ M. nasuta } & \multirow{2}{*}{$\begin{array}{l}\text { Mean } \\
\text { Proportion } \\
\text { Survival } \\
\end{array}$} & \multirow[b]{2}{*}{$\begin{array}{l}\text { Proportion } \\
\text { Survival }\end{array}$} & \multirow[b]{2}{*}{$\begin{array}{l}\text { Standard } \\
\text { Deviation }\end{array}$} \\
\hline & & $\begin{array}{l}\text { Number } \\
\text { Alive } \\
\end{array}$ & $\begin{array}{l}\text { Number Dead } \\
\text { or Missing }\end{array}$ & & & \\
\hline Comp LC & 1 & 24 & 1 & 0.96 & & \\
\hline Comp LC & 2 & 23 & 2 & 0.92 & & \\
\hline Comp LC & 3 & 24 & 1 & 0.96 & 0.94 & 0.02 \\
\hline Comp LC & 4 & 23 & 2 & 0.92 & & \\
\hline Comp LC & 5 & 24 & 1 & 0.96 & & \\
\hline Comp USFC & 1 & 25 & 0 & 1.00 & & \\
\hline Comp USFC & 2 & 25 & 0 & 1.00 & & \\
\hline Comp USFC & 3 & 25 & 0 & 1.00 & 0.95 & 0.07 \\
\hline Comp USFC & 4 & 23 & 2 & 0.92 & & \\
\hline Comp USFC & 5 & 21 & 4 & 0.84 & & \\
\hline Comp FSFC & 1 & 23 & 2 & 0.92 & & \\
\hline Comp FSFC & 2 & 25 & 0 & 1.00 & & \\
\hline Comp FSFC & 3 & 25 & 0 & 1.00 & 0.96 & 0.06 \\
\hline Comp FSFC & 4 & 25 & 0 & 1.00 & & \\
\hline Comp FSFC & 5 & 22 & 3 & 0.88 & & \\
\hline Comp IHC-1 & 1 & 24 & 1 & 0.96 & & \\
\hline Comp IHC-1 & 2 & 21 & 4 & 0.84 & & \\
\hline Comp IHC-1 & 3 & 24 & 1 & 0.96 & 0.94 & 0.05 \\
\hline Comp IHC-1 & 4 & 24 & 1 & 0.96 & & \\
\hline Comp IHC-1 & 5 & 24 & 1 & 0.96 & & \\
\hline Comp G & 1 & 24 & 1 & 0.96 & & \\
\hline Comp G & 2 & 23 & 2 & 0.92 & & \\
\hline Comp G & 3 & 22 & 3 & 0.88 & 0.94 & 0.05 \\
\hline Comp GD & 4 & 25 & 0 & 1.00 & & \\
\hline Comp G & 5 & 23 & 2 & 0.92 & & \\
\hline C-SB & 1 & 25 & 0 & 1.00 & & \\
\hline C-SB & 2 & 25 & 0 & 1.00 & & \\
\hline C-SB & 3 & 23 & 2 & 0.92 & 0.98 & 0.04 \\
\hline C-SB & 4 & 25 & 0 & 1.00 & & \\
\hline C-SB & 5 & 24 & 1 & 0.96 & & \\
\hline C-SFBF & 1 & 25 & 0 & 1.00 & & \\
\hline C-SFBF & 2 & 25 & 0 & 1.00 & & \\
\hline C-SFBF & 3 & 23 & 2 & 0.92 & 0.98 & 0.04 \\
\hline C-SFBF & 4 & 25 & 0 & 1.00 & & \\
\hline C-SFBF & 5 & 25 & 0 & 1.00 & & \\
\hline
\end{tabular}


TABLE E.2. Water Quality Summary for 28-Day M. nasuta Solid-Phase Test, United Heckathorn Remedial Investigation

\begin{tabular}{|c|c|c|c|c|c|c|c|c|c|c|}
\hline \multirow[t]{2}{*}{$\begin{array}{l}\text { Sediment } \\
\text { Treatment } \\
\end{array}$} & \multicolumn{2}{|c|}{$\begin{array}{c}\text { Temperature } \\
\left({ }^{\circ} \mathrm{C}\right) \\
\end{array}$} & \multicolumn{2}{|c|}{$\mathrm{pH}(\mathrm{a})$} & \multicolumn{2}{|c|}{$\begin{array}{c}\text { Dissolved } \\
\text { Oxygen } \\
(\mathrm{mg} / \mathrm{L})\end{array}$} & \multicolumn{2}{|c|}{$\begin{array}{c}\text { Salinity } \\
(0 / 00)\end{array}$} & \multicolumn{2}{|c|}{$\begin{array}{l}\text { Flow Rate } \\
(\mathrm{mL} / \mathrm{min})\end{array}$} \\
\hline & $\underline{\operatorname{Min}}^{(b)}$ & $\underline{\operatorname{Max}}^{(b)}$ & Min & $\underline{\text { Max }}$ & Min & $\underline{\text { Max }}$ & Min & $\underline{\text { Max }}$ & Min & Max \\
\hline Acceptable Range & 13.0 & 17.0 & 7.26 & 8.26 & 6.0 & $\mathrm{NA}^{(c)}$ & 28.0 & 32.0 & 115 & 135 \\
\hline Comp LC & 15.1 & 16.4 & 7.61 & 7.91 & 7.3 & 8.6 & 30.0 & 32.0 & 116 & 132 \\
\hline Comp USFC & 15.2 & 16.3 & 7.68 & 7.91 & 7.1 & 8.4 & 30.0 & 32.0 & 116 & 134 \\
\hline Comp FSFC & 15.1 & 16.3 & 7.62 & 8.01 & 7.1 & 8.6 & 30.0 & 32.0 & 116 & 132 \\
\hline Comp IHC-1 & 15.1 & 16.4 & 7.68 & 7.88 & 7.3 & 8.6 & 30.0 & 32.0 & 116 & 132 \\
\hline Comp GD & 15.1 & 16.4 & 7.65 & 7.89 & 7.2 & 8.6 & 30.0 & 31.5 & 116 & 132 \\
\hline C-SB & 15.1 & 16.4 & 7.68 & 7.86 & 7.0 & 8.4 & 30.0 & 32.0 & 116 & 132 \\
\hline C-SFBF & 15.1 & 16.4 & 7.66 & 7.87 & 7.3 & 8.5 & 30.0 & 32.0 & 116 & 134 \\
\hline
\end{tabular}

(a) Acceptable $\mathrm{pH}$ range is based on mean $\mathrm{pH}$ in all test chambers in 28-day test.

(b) Minimum and maximum values derived from all replicates for each treatment.

(c) Not applicable. 


\section{APPENDIX F}

\section{TISSUE CHEMISTRY AND QUALITY ASSURANCE DATA}

FOR Macoa nasuta 

TABLE F.1. Lipids in Tissues of M. nasuta, United Heckathorn Remedial Investigation

\begin{tabular}{|c|c|c|c|c|c|c|c|}
\hline $\begin{array}{l}\text { Sediment } \\
\text { Treatment } \\
\end{array}$ & Replicate & Batch & $\begin{array}{c}\text { Measured } \\
\text { Lipid Weight } \\
\text { (percent } \\
\text { wet weight) }\end{array}$ & $\begin{array}{c}\text { Bligh and Dyer } \\
\text { Equivalent } \\
\text { Weight } \\
\text { (percent } \\
\text { wet weight) } \\
\end{array}$ & $\begin{array}{c}\text { Percent } \\
\text { Dry } \\
\text { Weight }\end{array}$ & $\begin{array}{c}\text { Measured } \\
\text { Lipid Weight } \\
\text { (percent } \\
\text { dry weight) } \\
\end{array}$ & $\begin{array}{c}\text { Bligh and Dyer } \\
\text { Equivalent } \\
\text { Weight } \\
\text { (percent } \\
\text { dry weight) } \\
\end{array}$ \\
\hline \multicolumn{8}{|c|}{ Tissue Replicates } \\
\hline $\begin{array}{l}\text { Comp LC } \\
\text { Comp LC } \\
\text { Comp LC } \\
\text { Comp LC } \\
\text { Comp LC }\end{array}$ & $\begin{array}{l}1 \\
2 \\
3 \\
4 \\
5\end{array}$ & $\begin{array}{l}2 \\
2 \\
2 \\
1 \\
2\end{array}$ & $\begin{array}{l}0.64 \\
0.65 \\
0.81 \\
1.08 \\
0.59\end{array}$ & $\begin{array}{l}0.30 \\
0.30 \\
0.37 \\
0.49 \\
0.27\end{array}$ & $\begin{array}{l}20.75 \\
12.85 \\
11.83 \\
12.61 \\
15.15\end{array}$ & $\begin{array}{l}3.11 \\
5.04 \\
6.81 \\
8.53 \\
3.91\end{array}$ & $\begin{array}{l}1.43 \\
2.32 \\
3.13 \\
3.92 \\
1.80\end{array}$ \\
\hline $\begin{array}{l}\text { Comp USFC } \\
\text { Comp USFC } \\
\text { Comp USFC } \\
\text { Comp USFC } \\
\text { Comp USFC } \\
\text { Comp USFC }\end{array}$ & $\begin{array}{l}1 \\
1 \\
2 \\
3 \\
4 \\
5\end{array}$ & $\begin{array}{l}1 \\
1 \\
1 \\
1 \\
1 \\
1\end{array}$ & $\begin{array}{l}0.60 \\
0.60 \\
0.41 \\
0.65 \\
0.51 \\
0.45\end{array}$ & $\begin{array}{l}0.27 \\
0.28 \\
0.19 \\
0.30 \\
0.23 \\
0.21\end{array}$ & $\begin{array}{l}11.67 \\
11.67 \\
10.79 \\
11.59 \\
11.40 \\
10.90\end{array}$ & $\begin{array}{l}5.11 \\
5.16 \\
3.79 \\
5.64 \\
4.48 \\
4.15\end{array}$ & $\begin{array}{l}2.35 \\
2.37 \\
1.74 \\
2.59 \\
2.06 \\
1.91\end{array}$ \\
\hline $\begin{array}{ll}\text { Comp } & \text { FSFC } \\
\text { Comp } & \text { FSFC } \\
\text { Comp } & \text { FSFC } \\
\text { Comp } & \text { FSFC } \\
\text { Comp } & \text { FSFC } \\
\text { Comp } & \text { FSFC }\end{array}$ & $\begin{array}{l}1 \\
2 \\
3 \\
4 \\
5 \\
5\end{array}$ & $\begin{array}{l}1 \\
1 \\
1 \\
2 \\
2 \\
2\end{array}$ & $\begin{array}{l}1.07 \\
1.15 \\
0.55 \\
0.75 \\
0.48 \\
0.51\end{array}$ & $\begin{array}{l}0.49 \\
0.53 \\
0.25 \\
0.34 \\
0.22 \\
0.23\end{array}$ & $\begin{array}{r}9.79 \\
10.53 \\
10.91 \\
10.21 \\
10.95 \\
10.95\end{array}$ & $\begin{array}{r}10.94 \\
10.89 \\
5.07 \\
7.32 \\
4.38 \\
4.67\end{array}$ & $\begin{array}{l}5.03 \\
5.00 \\
2.33 \\
3.37 \\
2.01 \\
2.15\end{array}$ \\
\hline $\begin{array}{l}\text { Comp IHC-1 } \\
\text { Comp IHC-1 } \\
\text { Comp IHC-1 } \\
\text { Comp IHC-1 } \\
\text { Comp IHC-1 }\end{array}$ & $\begin{array}{l}1 \\
2 \\
3 \\
4 \\
5\end{array}$ & $\begin{array}{l}1 \\
1 \\
2 \\
1 \\
1\end{array}$ & $\begin{array}{l}2.70 \\
0.64 \\
0.66 \\
0.85 \\
0.63\end{array}$ & $\begin{array}{l}1.24 \\
0.29 \\
0.30 \\
0.39 \\
0.29\end{array}$ & $\begin{array}{l}17.41 \\
14.27 \\
16.58 \\
11.60 \\
14.66\end{array}$ & $\begin{array}{r}15.51 \\
4.48 \\
3.97 \\
7.30 \\
4.32\end{array}$ & $\begin{array}{l}7.13 \\
2.06 \\
1.82 \\
3.35 \\
1.99\end{array}$ \\
\hline $\begin{array}{l}\text { Comp GD } \\
\text { Comp GD } \\
\text { Comp GD } \\
\text { Comp GD } \\
\text { Comp GD }\end{array}$ & $\begin{array}{l}1 \\
2 \\
3 \\
4 \\
5\end{array}$ & $\begin{array}{l}2 \\
1 \\
2 \\
2 \\
1\end{array}$ & $\begin{array}{l}0.56 \\
0.47 \\
1.30 \\
0.61 \\
0.62\end{array}$ & $\begin{array}{l}0.26 \\
0.22 \\
0.60 \\
0.28 \\
0.28\end{array}$ & $\begin{array}{l}11.60 \\
10.84 \\
11.86 \\
12.38 \\
13.82\end{array}$ & $\begin{array}{r}4.86 \\
4.37 \\
10.93 \\
4.95 \\
4.46\end{array}$ & $\begin{array}{l}2.23 \\
2.01 \\
5.02 \\
2.27 \\
2.05\end{array}$ \\
\hline \multicolumn{8}{|c|}{ Tissue Composites } \\
\hline $\begin{array}{l}\text { Comp LC } \\
\text { Comp USFC } \\
\text { Comp FSFC } \\
\text { Comp IHC-1 } \\
\text { Comp GD }\end{array}$ & & $\begin{array}{l}2 \\
2 \\
2 \\
2 \\
2\end{array}$ & $\begin{array}{l}0.72 \\
1.26 \\
0.88 \\
1.01 \\
1.17\end{array}$ & $\begin{array}{l}0.33 \\
0.58 \\
0.41 \\
0.46 \\
0.54\end{array}$ & $\begin{array}{l}13.75 \\
24.06 \\
11.68 \\
13.51 \\
12.90\end{array}$ & $\begin{array}{l}5.25 \\
5.22 \\
7.57 \\
7.46 \\
9.11\end{array}$ & $\begin{array}{l}2.41 \\
2.40 \\
3.48 \\
3.43 \\
4.18\end{array}$ \\
\hline \multicolumn{8}{|c|}{ Analytical Duplicates } \\
\hline $\begin{array}{l}\text { Comp USFC } \\
\text { Comp USFC } \\
\text { RPD } \\
\text { I-Stat }\end{array}$ & $\begin{array}{l}1 \\
1\end{array}$ & $\begin{array}{l}1 \\
1\end{array}$ & $\begin{array}{l}0.60 \\
0.60 \\
1 \% \\
0.00\end{array}$ & $\begin{array}{l}0.27 \\
0.28 \\
1 \% \\
0.00\end{array}$ & & & \\
\hline $\begin{array}{l}\text { Comp FSFC } \\
\text { Comp FSFC } \\
\text { RPD } \\
\text { I-Stat }\end{array}$ & $\begin{array}{l}5 \\
5\end{array}$ & $\begin{array}{l}2 \\
2\end{array}$ & $\begin{array}{c}0.51 \\
0.48 \\
6 \% \\
0.03\end{array}$ & $\begin{array}{c}0.23 \\
0.22 \\
6 \% \\
0.03\end{array}$ & & & \\
\hline
\end{tabular}


TABLE F.2. Chlorinated Pesticides (elution order, Alpha-BHC to cis-Chlordane) in Tissues of M. nasuta, Wet Weight, United Heckathorn Remedial Investigation

\begin{tabular}{|c|c|c|c|c|c|c|c|c|c|c|c|c|}
\hline \multirow{2}{*}{$\begin{array}{l}\text { Sediment } \\
\text { Treatment }\end{array}$} & \multirow[b]{2}{*}{ Replicate } & \multirow[b]{2}{*}{ Batch } & \multicolumn{10}{|c|}{ Pesticides $(\mu \mathrm{q} / \mathrm{kq}$ wet weight $)$} \\
\hline & & & $\begin{array}{c}\text { Alpha } \\
\text { BHC } \\
\end{array}$ & $\begin{array}{r}\text { Beta } \\
\text { BHC } \\
\end{array}$ & Lindane & $\begin{array}{c}\text { Delta } \\
\text { BHC } \\
\end{array}$ & $\begin{array}{l}\text { Hepta- } \\
\text { chlor } \\
\end{array}$ & $\underline{\text { Aldrin }}$ & $\begin{array}{l}\text { Hepta- } \\
\text { chlor } \\
\text { epoxide }\end{array}$ & $\begin{array}{l}\text { trans- } \\
\text { Chlordane } \\
\end{array}$ & $\begin{array}{l}\text { Endo- } \\
\text { sulfan } 1\end{array}$ & $\begin{array}{c}\text { cis- } \\
\text { Chlordane }\end{array}$ \\
\hline $\begin{array}{l}\text { Target } \mathrm{DL}(\mathrm{a}) \\
\text { Achieved } \mathrm{DL} \\
\text { Achieved } \mathrm{DL}\end{array}$ & $\begin{array}{l}\text { High } \\
\text { Low }\end{array}$ & & $\begin{array}{l}2 \\
0.17 \\
0.08\end{array}$ & $\begin{array}{l}2 \\
0.17 \\
0.08\end{array}$ & $\begin{array}{l}2 \\
0.17 \\
0.08\end{array}$ & $\begin{array}{l}2 \\
0.17 \\
0.08\end{array}$ & $\begin{array}{l}2 \\
0.18 \\
0.08\end{array}$ & $\begin{array}{l}2 \\
0.11 \\
0.05\end{array}$ & $\begin{array}{l}2 \\
0.16 \\
0.07\end{array}$ & $\begin{array}{l}2 \\
0.33 \\
0.15\end{array}$ & $\begin{array}{l}2 \\
0.33 \\
0.15\end{array}$ & $\begin{array}{l}2 \\
0.19 \\
0.09\end{array}$ \\
\hline $\begin{array}{l}\text { Comp LC } \\
\text { Comp LC } \\
\text { Comp LC } \\
\text { Comp LC } \\
\text { Comp LC }\end{array}$ & $\begin{array}{l}1 \\
2 \\
3 \\
4 \\
5\end{array}$ & $\begin{array}{l}2 \\
2 \\
2 \\
1 \\
2\end{array}$ & $\begin{array}{l}0.63 \\
0.11 \\
0.75 \\
0.17 \\
0.13\end{array}$ & $\begin{array}{l}0.09 U^{(b)} \\
0.09 U \\
0.08 U \\
0.09 U \\
0.12 U\end{array}$ & $\begin{array}{l}0.34 \\
0.18 \\
0.29 \\
0.29 \\
0.25\end{array}$ & $\begin{array}{l}0.09 U \\
0.09 U \\
0.08 U \\
0.09 U \\
0.12 U\end{array}$ & $\begin{array}{l}0.09 \mathrm{U} \\
0.10 \mathrm{U} \\
0.08 \mathrm{U} \\
0.09 \mathrm{U} \\
0.13 \mathrm{U}\end{array}$ & $\begin{array}{l}1.59 \\
0.54 \\
1.31 \\
0.51 \\
0.79\end{array}$ & $\begin{array}{l}0.08 U \\
0.09 U \\
0.07 U \\
0.08 U \\
0.11 U\end{array}$ & $\begin{array}{r}226.50 \\
14.65 \\
250.50 \\
14.44 \\
14.89\end{array}$ & $\begin{array}{r}11.57 \\
8.62 \\
9.13 \\
7.82 \\
8.95\end{array}$ & $\begin{array}{r}10.35 \\
6.64 \\
9.05 \\
8.00 \\
7.09\end{array}$ \\
\hline $\begin{array}{l}\text { Comp USFC } \\
\text { Comp USFC } \\
\text { Comp USFC } \\
\text { Comp USFC } \\
\text { Comp USFC }\end{array}$ & $\begin{array}{l}1 \\
2 \\
3 \\
4 \\
5\end{array}$ & $\begin{array}{l}1 \\
1 \\
1 \\
1 \\
1\end{array}$ & $\begin{array}{l}0.11 \mathrm{~J}(\mathrm{c}) \\
0.06 \mathrm{~J} \\
0.11 \\
0.08 \mathrm{~J} \\
0.05 \mathrm{~J}\end{array}$ & $\begin{array}{l}0.12 \mathrm{U} \\
0.09 \mathrm{U} \\
0.09 \mathrm{U} \\
0.09 \mathrm{U} \\
0.09 \mathrm{U}\end{array}$ & $\begin{array}{l}0.12 \mathrm{U} \\
0.13 \\
0.09 \mathrm{U} \\
0.09 \mathrm{U} \\
0.16\end{array}$ & $\begin{array}{l}0.12 \mathrm{U} \\
0.09 \mathrm{U} \\
0.09 \mathrm{U} \\
0.09 \mathrm{U} \\
0.09 \mathrm{U}\end{array}$ & $\begin{array}{l}0.12 \mathrm{U} \\
0.09 \mathrm{U} \\
0.09 \mathrm{U} \\
0.09 \mathrm{U} \\
0.10 \mathrm{U}\end{array}$ & $\begin{array}{l}0.08 \mathrm{U} \\
0.06 \mathrm{U} \\
0.06 \mathrm{U} \\
0.06 \mathrm{U} \\
0.06 \mathrm{U}\end{array}$ & $\begin{array}{l}0.11 U \\
0.08 U \\
0.08 U \\
0.08 U \\
0.09 U\end{array}$ & $\begin{array}{l}0.30 \\
0.22 \\
0.33 \\
0.17 \mathrm{U} \\
0.18 \mathrm{~J}\end{array}$ & $\begin{array}{l}0.30 \\
0.20 \\
0.30 \\
0.18 \\
0.20\end{array}$ & $\begin{array}{l}0.25 \\
0.12 \\
0.21 \\
0.14 \\
0.14\end{array}$ \\
\hline $\begin{array}{l}\text { Comp FSFC } \\
\text { Comp FSFC } \\
\text { Comp FSFC } \\
\text { Comp FSFC } \\
\text { Comp FSFC }\end{array}$ & $\begin{array}{l}1 \\
2 \\
3 \\
4 \\
5\end{array}$ & $\begin{array}{l}1 \\
1 \\
1 \\
2 \\
3\end{array}$ & $\begin{array}{l}0.18 \\
0.13 \\
0.17 \\
0.12 \mathrm{~J} \\
0.08 \mathrm{U}\end{array}$ & $\begin{array}{l}0.09 \mathrm{U} \\
0.09 \mathrm{U} \\
0.13 \mathrm{U} \\
0.17 \mathrm{U} \\
0.08 \mathrm{U}\end{array}$ & $\begin{array}{l}0.22 \\
0.09 \mathrm{U} \\
0.13 \mathrm{U} \\
0.18 \\
0.08 \mathrm{U}\end{array}$ & $\begin{array}{l}0.09 \mathrm{U} \\
0.09 \mathrm{U} \\
0.13 \mathrm{U} \\
0.17 \mathrm{U} \\
0.08 \mathrm{U}\end{array}$ & $\begin{array}{l}0.10 \mathrm{U} \\
0.09 \mathrm{U} \\
0.14 \mathrm{U} \\
0.18 \mathrm{U} \\
0.09 \mathrm{U}\end{array}$ & $\begin{array}{l}0.06 \mathrm{U} \\
0.06 \mathrm{U} \\
0.08 \mathrm{U} \\
0.11 \mathrm{U} \\
0.05 \mathrm{U}\end{array}$ & $\begin{array}{l}0.09 \mathrm{U} \\
0.08 \mathrm{U} \\
0.12 \mathrm{U} \\
0.16 \mathrm{U} \\
0.08 \mathrm{U}\end{array}$ & $\begin{array}{l}0.56 \\
0.33 \\
0.25 U \\
0.51 \\
0.17 \mathrm{U}\end{array}$ & $\begin{array}{l}0.51 \\
0.40 \\
0.25 \mathrm{U} \\
0.26 \mathrm{~J} \\
0.17 \mathrm{U}\end{array}$ & $\begin{array}{l}0.30 \\
0.25 \\
0.15 \mathrm{U} \\
0.22 \\
0.10 \mathrm{U}\end{array}$ \\
\hline $\begin{array}{ll}\text { Comp IHC-1 } & \text { IHC-1 } \\
\text { Comp IHC-1 } \\
\text { Comp IHC-1 } \\
\text { Comp IHC-1 } \\
\text { Comp IHC-1 }\end{array}$ & $\begin{array}{l}1 \\
2 \\
3 \\
4 \\
5\end{array}$ & $\begin{array}{l}1 \\
1 \\
2 \\
1 \\
1\end{array}$ & $\begin{array}{l}0.11 \\
0.10 \\
0.08 \\
0.21 \\
0.16\end{array}$ & $\begin{array}{l}0.08 \mathrm{U} \\
0.09 \mathrm{U} \\
0.08 \mathrm{U} \\
0.09 \mathrm{U} \\
0.08 \mathrm{U}\end{array}$ & $\begin{array}{l}0.19 \\
0.14 \\
0.11 \\
0.09 \cup \\
0.08 \cup\end{array}$ & $\begin{array}{l}0.08 U \\
0.09 U \\
0.08 U \\
0.09 U \\
0.08 U\end{array}$ & $\begin{array}{l}0.09 U \\
0.09 U \\
0.08 U \\
0.09 U \\
0.09 U\end{array}$ & $\begin{array}{ll}0.05 & U \\
0.06 & U \\
0.05 & U \\
0.06 & U \\
0.05 & U\end{array}$ & $\begin{array}{l}0.08 U \\
0.08 U \\
0.07 U \\
0.08 U \\
0.08 U\end{array}$ & $\begin{array}{ll}0.17 & \\
0.22 & \\
0.11 & \mathrm{~J} \\
0.17 & \mathrm{U} \\
0.28 & \end{array}$ & $\begin{array}{ll}0.09 & \mathrm{~J} \\
0.09 & \mathrm{~J} \\
0.08 & \mathrm{~J} \\
0.15 \mathrm{~J} \\
0.10 \mathrm{~J}\end{array}$ & $\begin{array}{l}0.12 \\
0.16 \\
0.11 \\
0.15 \\
0.20\end{array}$ \\
\hline $\begin{array}{l}\text { Comp GD } \\
\text { Comp GD } \\
\text { Comp GD } \\
\text { Comp G } \\
\text { Comp GD }\end{array}$ & $\begin{array}{l}1 \\
2 \\
3 \\
4 \\
5\end{array}$ & $\begin{array}{l}2 \\
1 \\
2 \\
2 \\
1\end{array}$ & $\begin{array}{l}0.07 \mathrm{~J} \\
0.05 \mathrm{~J} \\
0.07 \mathrm{~J} \\
0.07 \mathrm{~J} \\
0.08\end{array}$ & $\begin{array}{l}0.09 \mathrm{U} \\
0.09 \mathrm{U} \\
0.09 \mathrm{U} \\
0.08 \mathrm{U} \\
0.08 \mathrm{U}\end{array}$ & $\begin{array}{l}0.09 \mathrm{U} \\
0.11 \\
0.12 \\
0.10 \\
0.08 \mathrm{U}\end{array}$ & $\begin{array}{l}0.09 U \\
0.09 U \\
0.09 U \\
0.08 U \\
0.08 U\end{array}$ & $\begin{array}{l}0.10 U \\
0.09 U \\
0.10 U \\
0.09 U \\
0.09 U\end{array}$ & $\begin{array}{l}0.06 U \\
0.06 U \\
0.06 U \\
0.05 U \\
0.05 U\end{array}$ & $\begin{array}{l}0.09 \mathrm{U} \\
0.08 \mathrm{U} \\
0.02 \mathrm{~J} \\
0.02 \mathrm{~J} \\
0.08 \mathrm{U}\end{array}$ & $\begin{array}{l}0.06 \mathrm{~J} \\
0.17 \mathrm{U} \\
0.06 \mathrm{~J} \\
0.06 \mathrm{~J} \\
0.16 \mathrm{U}\end{array}$ & $\begin{array}{l}0.01 \mathrm{~J} \\
0.08 \mathrm{~J} \\
0.01 \mathrm{~J} \\
0.16 \mathrm{U} \\
0.16 \mathrm{U}\end{array}$ & $\begin{array}{ll}0.06 & \mathrm{~J} \\
0.07 & \mathrm{~J} \\
0.06 & \mathrm{~J} \\
0.04 & \mathrm{~J} \\
0.08 \mathrm{~J}\end{array}$ \\
\hline
\end{tabular}

(a) DL Detection limit.

(b) $U$ Analyte was not present above the associated value.

(c) J Analyte detected below method detection limit (MDL), but above instrument detection limit (IDL). 
TABLE F.3. Chlorinated Pesticides (elution order, Dieldrin to Toxaphene) in Tissues of M. nasuta, Wet Weight, United Heckathorn Remedial Investigation

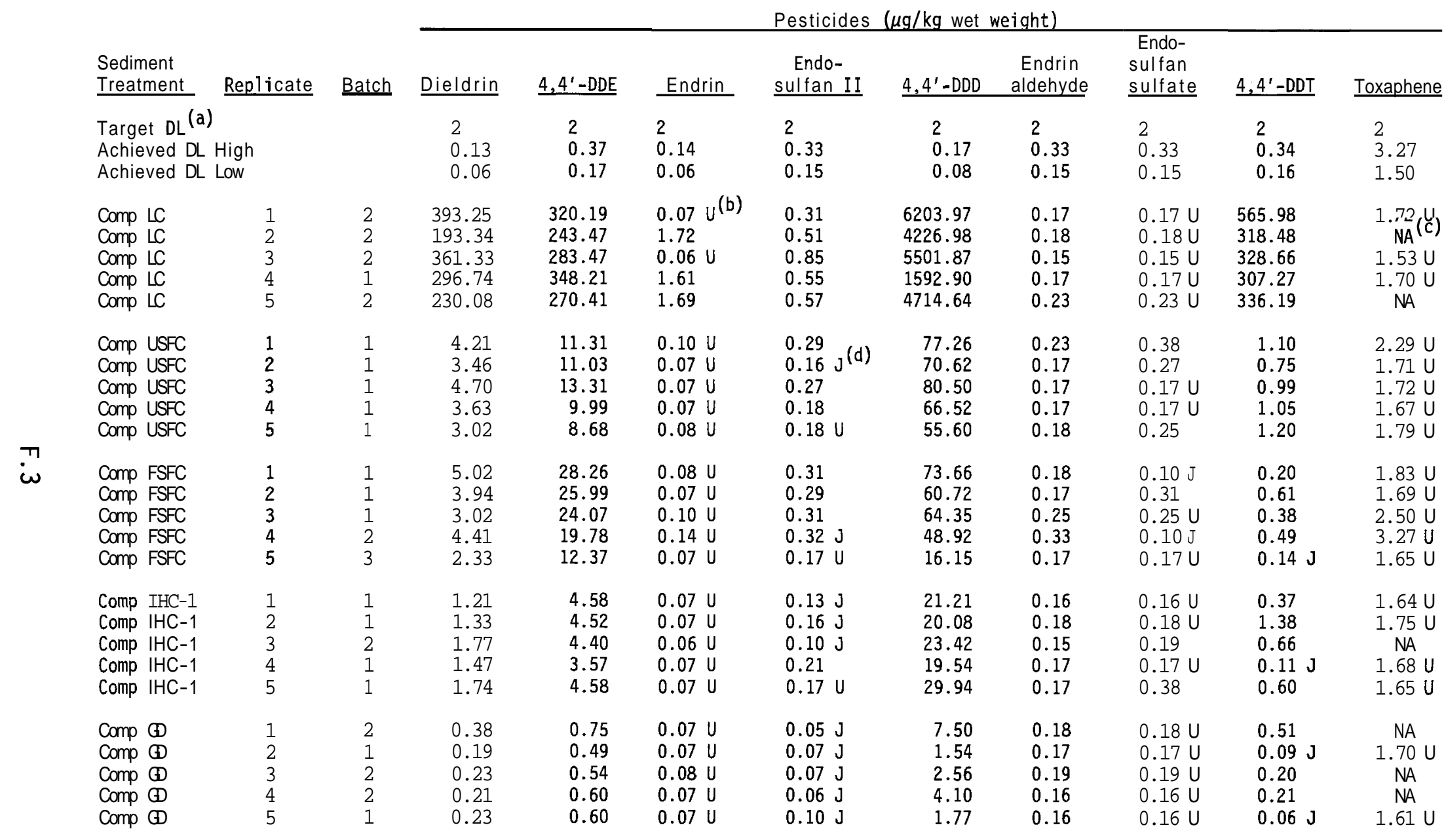

(a) DL Detection Iimit.

(b) U Analyte was not present above the associated value.

(c) NA Not analyzed.

(d) J Analyte detected below method detection limit (MDL), but above instrument detection limit (IDL). 
TABLE F.4. Chlorinated Pesticides (elution order, Alpha-BHC to cis-Chlordane) in Tissues of M. nasuta, Dry Weight, United Heckathorn Remedial Investigation

\begin{tabular}{|c|c|c|c|c|c|c|c|c|c|c|c|c|c|}
\hline \multirow{2}{*}{$\begin{array}{l}\text { Sediment } \\
\text { Treatment } \\
\end{array}$} & \multirow[b]{2}{*}{ Replicate } & \multirow[b]{2}{*}{ Batch } & \multirow[b]{2}{*}{$\begin{array}{c}\text { Percent } \\
\text { Dry } \\
\text { Weight } \\
\end{array}$} & \multicolumn{10}{|c|}{ Pesticides $(\mu \mathrm{g} / \mathrm{kg}$ dry weight) } \\
\hline & & & & $\begin{array}{c}\text { Alpha } \\
\text { Chn }\end{array}$ & $\begin{array}{l}\text { Beta } \\
\text { an }\end{array}$ & Lindane & $\begin{array}{c}\text { Delta } \\
\text { ac }\end{array}$ & $\begin{array}{l}\text { Hepta- } \\
\text { ehtor }\end{array}$ & Aldrin & $\begin{array}{l}\text { Hepta- } \\
\text { chlor } \\
\text { epoxide } \\
\end{array}$ & $\begin{array}{l}\text { trans- } \\
\text { Chlordane }\end{array}$ & $\begin{array}{c}\text { Endo- } \\
\text { sulfan I } \\
\end{array}$ & $\begin{array}{c}\text { cis- } \\
\text { Chlordane }\end{array}$ \\
\hline $\begin{array}{l}\text { Comp LC } \\
\text { Comp LC } \\
\text { Comp LC } \\
\text { Comp LC } \\
\text { Comp LC }\end{array}$ & $\begin{array}{l}1 \\
2 \\
3 \\
4 \\
5\end{array}$ & $\begin{array}{l}2 \\
2 \\
2 \\
1 \\
2\end{array}$ & $\begin{array}{l}20.75 \\
12.85 \\
11.83 \\
12.61 \\
15.15\end{array}$ & $\begin{array}{l}3.04 \\
0.86 \\
6.34 \\
1.35 \\
0.86\end{array}$ & $\begin{array}{l}0.43 U^{(a)} \\
0.70 U \\
0.68 U \\
0.71 U \\
0.79 U\end{array}$ & $\begin{array}{l}1.64 \\
1.40 \\
2.45 \\
2.30 \\
1.65\end{array}$ & $\begin{array}{l}0.43 \mathrm{U} \\
0.70 \mathrm{U} \\
0.68 \mathrm{U} \\
0.71 \mathrm{U} \\
0.79 \mathrm{U}\end{array}$ & $\begin{array}{l}0.43 \mathrm{U} \\
0.78 \mathrm{U} \\
0.68 \mathrm{U} \\
0.71 \mathrm{U} \\
0.86 \mathrm{U}\end{array}$ & $\begin{array}{r}7.66 \\
4.20 \\
11.07 \\
4.04 \\
5.21\end{array}$ & $\begin{array}{l}0.39 U \\
0.70 U \\
0.59 U \\
0.63 U \\
0.73 U\end{array}$ & $\begin{array}{r}1091.57 \\
114.01 \\
2117.50 \\
114.51 \\
98.28\end{array}$ & $\begin{array}{l}55.76 \\
67.08 \\
77.18 \\
62.01 \\
59.08\end{array}$ & $\begin{array}{l}49.88 \\
51.67 \\
76.50 \\
63.44 \\
46.80\end{array}$ \\
\hline $\begin{array}{l}\text { Comp USFC } \\
\text { Comp USFC } \\
\text { Comp USFC } \\
\text { Comp USFC } \\
\text { Comp USFC }\end{array}$ & $\begin{array}{l}1 \\
2 \\
3 \\
4 \\
5\end{array}$ & $\begin{array}{l}1 \\
1 \\
1 \\
1 \\
1\end{array}$ & $\begin{array}{l}11.67 \\
10.79 \\
11.59 \\
11.40 \\
10.90\end{array}$ & $\begin{array}{l}0.94 \mathrm{~J}^{(b)} \\
0.56 \mathrm{~J}^{(} \\
0.95 \\
0.70 \mathrm{~J} \\
0.46 \mathrm{~J}\end{array}$ & $\begin{array}{l}1.03 \mathrm{U} \\
0.83 \mathrm{U} \\
0.78 \mathrm{U} \\
0.79 \mathrm{U} \\
0.83 \mathrm{U}\end{array}$ & $\begin{array}{l}1.03 \mathrm{U} \\
1.20 \\
0.78 \mathrm{U} \\
0.79 \mathrm{U} \\
1.47\end{array}$ & $\begin{array}{l}1.03 \mathrm{U} \\
0.83 \mathrm{U} \\
0.78 \mathrm{U} \\
0.79 \mathrm{U} \\
0.83 \mathrm{U}\end{array}$ & $\begin{array}{l}1.03 \mathrm{U} \\
0.83 \mathrm{U} \\
0.78 \mathrm{U} \\
0.79 \mathrm{U} \\
0.92 \mathrm{U}\end{array}$ & $\begin{array}{l}0.69 \mathrm{U} \\
0.56 \mathrm{U} \\
0.52 \mathrm{U} \\
0.53 \mathrm{U} \\
0.55 \mathrm{U}\end{array}$ & $\begin{array}{l}0.94 U \\
0.74 U \\
0.69 U \\
0.70 U \\
0.83 U\end{array}$ & $\begin{array}{l}2.57 \\
2.04 \\
2.85 \\
1.49 \mathrm{U} \\
1.65 \mathrm{~J}\end{array}$ & $\begin{array}{l}2.57 \\
1.85 \\
2.59 \\
1.58 \\
1.83\end{array}$ & $\begin{array}{l}2.14 \\
1.11 \\
1.81 \\
1.23 \\
1.28\end{array}$ \\
\hline $\begin{array}{l}\text { Comp FSFC } \\
\text { Comp FSFC } \\
\text { Comp FSFC } \\
\text { Comp FSFC } \\
\text { Comp FSFC }\end{array}$ & $\begin{array}{l}1 \\
2 \\
3 \\
4 \\
5\end{array}$ & $\begin{array}{l}1 \\
1 \\
1 \\
2 \\
3\end{array}$ & $\begin{array}{r}9.79 \\
10.53 \\
10.91 \\
10.21 \\
10.95\end{array}$ & $\begin{array}{l}1.84 \\
1.23 \\
1.56 \\
1.18 \mathrm{~J} \\
0.73 \mathrm{U}\end{array}$ & $\begin{array}{l}0.92 U \\
0.85 U \\
1.19 U \\
1.67 U \\
0.73 U\end{array}$ & $\begin{array}{l}2.25 \\
0.85 \mathrm{U} \\
1.19 \mathrm{U} \\
1.76 \\
0.73 \mathrm{U}\end{array}$ & $\begin{array}{l}0.92 \mathrm{U} \\
0.85 \mathrm{U} \\
1.19 \mathrm{U} \\
1.67 \mathrm{U} \\
0.73 \mathrm{U}\end{array}$ & $\begin{array}{l}1.02 \mathrm{U} \\
0.85 \mathrm{U} \\
1.28 \mathrm{U} \\
1.76 \mathrm{U} \\
0.82 \mathrm{U}\end{array}$ & $\begin{array}{l}0.61 U \\
0.57 U \\
0.73 U \\
1.08 U \\
0.46 U\end{array}$ & $\begin{array}{l}0.92 U \\
0.76 U \\
1.10 U \\
1.57 U \\
0.73 U\end{array}$ & $\begin{array}{l}5.72 \\
3.13 \\
2.29 \mathrm{U} \\
5.00 \\
1.55 \mathrm{U}\end{array}$ & $\begin{array}{l}5.21 \\
3.80 \\
2.29 \mathrm{U} \\
2.55 \mathrm{~J} \\
1.55 \mathrm{U}\end{array}$ & $\begin{array}{l}3.06 \\
2.37 \\
1.37 \mathrm{U} \\
2.15 \\
0.91 \mathrm{U}\end{array}$ \\
\hline $\begin{array}{l}\text { Comp IHC-1 } \\
\text { Comp IHC-1 } \\
\text { Comp IHC-1 } \\
\text { Comp IHC-1 } \\
\text { Comp IHC-1 }\end{array}$ & $\begin{array}{l}1 \\
2 \\
3 \\
4 \\
5\end{array}$ & $\begin{array}{l}1 \\
1 \\
2 \\
1 \\
1\end{array}$ & $\begin{array}{l}17.41 \\
14.27 \\
16.58 \\
11.60 \\
14.66\end{array}$ & $\begin{array}{l}0.63 \\
0.70 \\
0.48 \\
1.81 \\
1.09\end{array}$ & $\begin{array}{l}0.46 \mathrm{U} \\
0.63 \mathrm{U} \\
0.48 \mathrm{U} \\
0.78 \mathrm{U} \\
0.55 \mathrm{U}\end{array}$ & $\begin{array}{l}1.09 \\
0.98 \\
0.66 \\
0.78 \mathrm{U} \\
0.55 \mathrm{U}\end{array}$ & $\begin{array}{l}0.46 \mathrm{U} \\
0.63 \mathrm{U} \\
0.48 \mathrm{U} \\
0.78 \mathrm{U} \\
0.55 \mathrm{U}\end{array}$ & $\begin{array}{l}0.52 U \\
0.63 U \\
0.48 U \\
0.78 U \\
0.61 U\end{array}$ & $\begin{array}{l}0.29 U \\
0.42 U \\
0.30 U \\
0.52 U \\
0.34 U\end{array}$ & $\begin{array}{l}0.46 U \\
0.56 U \\
0.42 U \\
0.69 U \\
0.55 U\end{array}$ & $\begin{array}{l}0.98 \\
1.54 \\
0.66 \mathrm{~J} \\
1.47 \mathrm{U} \\
1.91\end{array}$ & $\begin{array}{l}0.52 \mathrm{~J} \\
0.63 \mathrm{~J} \\
0.48 \mathrm{~J} \\
1.29 \mathrm{~J} \\
0.68 \mathrm{~J}\end{array}$ & $\begin{array}{l}0.69 \\
1.12 \\
0.66 \\
1.29 \\
1.36\end{array}$ \\
\hline $\begin{array}{l}\text { Comp G } \\
\text { Comp (1) } \\
\text { Comp G } \\
\text { Comp G } \\
\text { Comp G }\end{array}$ & $\begin{array}{l}1 \\
2 \\
3 \\
4 \\
5\end{array}$ & $\begin{array}{l}2 \\
1 \\
2 \\
2 \\
1\end{array}$ & $\begin{array}{l}11.60 \\
10.84 \\
11.86 \\
12.38 \\
13.82\end{array}$ & $\begin{array}{l}0.60 \mathrm{~J} \\
0.46 \mathrm{~J} \\
0.59 \mathrm{~J} \\
0.57 \mathrm{~J} \\
0.58\end{array}$ & $\begin{array}{l}0.78 \mathrm{U} \\
0.83 \mathrm{U} \\
0.76 \mathrm{U} \\
0.65 \mathrm{U} \\
0.58 \mathrm{U}\end{array}$ & $\begin{array}{l}0.78 \mathrm{U} \\
1.01 \\
1.01 \\
0.81 \\
0.58 \mathrm{U}\end{array}$ & $\begin{array}{l}0.78 U \\
0.83 U \\
0.76 U \\
0.65 U \\
0.58 U\end{array}$ & $\begin{array}{l}0.86 \mathrm{U} \\
0.83 \mathrm{U} \\
0.84 \mathrm{U} \\
0.73 \mathrm{U} \\
0.65 \mathrm{U}\end{array}$ & $\begin{array}{l}0.52 \mathrm{U} \\
0.55 \mathrm{U} \\
0.51 \mathrm{U} \\
0.40 \mathrm{U} \\
0.36 \mathrm{U}\end{array}$ & $\begin{array}{l}0.78 \mathrm{U} \\
0.74 \mathrm{U} \\
0.17 \mathrm{~J} \\
0.16 \mathrm{~J} \\
0.58 \mathrm{U}\end{array}$ & $\begin{array}{l}0.52 \mathrm{~J} \\
1.57 \mathrm{U} \\
0.51 \mathrm{~J} \\
0.48 \mathrm{~J} \\
1.16 \mathrm{U}\end{array}$ & $\begin{array}{l}0.09 \mathrm{~J} \\
0.74 \mathrm{~J} \\
0.08 \mathrm{~J} \\
1.29 \mathrm{U} \\
1.16 \mathrm{U}\end{array}$ & $\begin{array}{l}0.52 \mathrm{~J} \\
0.65 \mathrm{~J} \\
0.51 \mathrm{~J} \\
0.32 \mathrm{~J} \\
0.58 \mathrm{~J}\end{array}$ \\
\hline
\end{tabular}

(b) J Analyte detected below method detection limit (MDL), but above instrument detection Iimit (IDL) 
TABLE F.5. Chlorinated Pesticides (elution order, Dieldrin to Toxaphene) in Tissues of M. nasuta, Dry Weight, United Heckathorn Remedial Investigation

\begin{tabular}{|c|c|c|c|c|c|c|c|c|c|c|c|c|}
\hline \multirow{2}{*}{$\begin{array}{l}\text { Sediment } \\
\text { Treatment } \\
\end{array}$} & \multirow[b]{2}{*}{ Replicate } & \multirow[b]{2}{*}{ Batch } & \multirow[b]{2}{*}{$\begin{array}{c}\text { Percent } \\
\text { Dry } \\
\text { Weight } \\
\end{array}$} & \multicolumn{8}{|c|}{ Pesticides $(\mu \mathrm{q} / \mathrm{kg}$ dry weight) } & \multirow[b]{2}{*}{ Toxaphene } \\
\hline & & & & Dieldrin & $4,4^{\prime}-D D E$ & Endrin & $\begin{array}{l}\text { Endo- } \\
\text { sulfan II }\end{array}$ & $4.4^{\prime}-D D D$ & $\begin{array}{l}\text { Endrin } \\
\text { aldehyde }\end{array}$ & $\begin{array}{l}\text { Endo- } \\
\text { sulfan } \\
\text { sulfate }\end{array}$ & $\underline{4,4^{\prime}-D D T}$ & \\
\hline $\begin{array}{l}\text { Comp LC } \\
\text { Comp LC } \\
\text { Comp LC } \\
\text { Comp LC } \\
\text { Comp LC }\end{array}$ & $\begin{array}{l}1 \\
2 \\
3 \\
4 \\
5\end{array}$ & $\begin{array}{l}2 \\
2 \\
2 \\
1 \\
2\end{array}$ & $\begin{array}{l}20.75 \\
12.85 \\
11.83 \\
12.61 \\
15.15\end{array}$ & $\begin{array}{l}1895.18 \\
1504.59 \\
3054.35 \\
2353.21 \\
1518.68\end{array}$ & $\begin{array}{l}1543.08 \\
1894.71 \\
2396.20 \\
2761.38 \\
1784.88\end{array}$ & $\begin{array}{c}0.34 \mathrm{U}^{(\mathrm{a})} \\
13.39 \\
0.51 \mathrm{U} \\
12.77 \\
11.16\end{array}$ & $\begin{array}{l}1.49 \\
3.97 \\
7.19 \\
4.36 \\
3.76\end{array}$ & $\begin{array}{l}29898.65 \\
32894.79 \\
46507.78 \\
12632.04 \\
31119.74\end{array}$ & $\begin{array}{l}0.82 \mathrm{U} \\
1.40 \\
1.27 \\
1.35 \\
1.52\end{array}$ & $\begin{array}{l}0.82 \mathrm{U} \\
1.40 \mathrm{U} \\
1.27 \mathrm{U} \\
1.35 \mathrm{U} \\
1.52 \mathrm{U}\end{array}$ & $\begin{array}{l}2727.61 \\
2478.44 \\
2778.19 \\
2436.72 \\
2219.08\end{array}$ & $\begin{array}{r}8.29 \mathrm{U}) \\
\text { NA }(\mathrm{b}) \\
12.93 \mathrm{U} \\
13.48 \mathrm{U} \\
\text { NA }\end{array}$ \\
\hline $\begin{array}{l}\text { Comp USFC } \\
\text { Comp USFC } \\
\text { Comp USFC } \\
\text { Comp USFC } \\
\text { Comp USFC }\end{array}$ & $\begin{array}{l}1 \\
2 \\
3 \\
4 \\
5\end{array}$ & $\begin{array}{l}1 \\
1 \\
1 \\
1 \\
1\end{array}$ & $\begin{array}{l}11.67 \\
10.79 \\
11.59 \\
11.40 \\
10.90\end{array}$ & $\begin{array}{l}36.08 \\
32.07 \\
40.55 \\
31.84 \\
27.71\end{array}$ & $\begin{array}{r}96.92 \\
102.22 \\
114.84 \\
87.63 \\
79.63\end{array}$ & 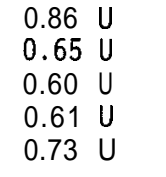 & $\begin{array}{l}2.49 \mathrm{~J}(\mathrm{c}) \\
1.48 \mathrm{~J} \\
2.33 \\
1.58 \\
1.65 \mathrm{U}\end{array}$ & $\begin{array}{l}662.04 \\
654.49 \\
694.56 \\
583.51 \\
510.09\end{array}$ & $\begin{array}{l}1.97 \\
1.58 \\
1.47 \\
1.49 \\
1.65\end{array}$ & $\begin{array}{l}3.26 \\
2.50 \\
1.47 \mathrm{U} \\
1.49 \mathrm{U} \\
2.29\end{array}$ & $\begin{array}{r}9.43 \\
6.95 \\
8.54 \\
9.21 \\
11.01\end{array}$ & $\begin{array}{l}19.62 \mathrm{U} \\
15.85 \mathrm{U} \\
14.84 \mathrm{U} \\
14.65 \mathrm{U} \\
16.42 \mathrm{U}\end{array}$ \\
\hline $\begin{array}{ll}\text { Comp } & \text { FSFC } \\
\text { Comp FSFC } \\
\text { Comp FSFC } \\
\text { Comp FSFC } \\
\text { Comp FSFC }\end{array}$ & $\begin{array}{l}1 \\
2 \\
3 \\
4 \\
5\end{array}$ & $\begin{array}{l}1 \\
1 \\
1 \\
2 \\
3\end{array}$ & $\begin{array}{r}9.79 \\
10.53 \\
10.91 \\
10.21 \\
10.95\end{array}$ & $\begin{array}{l}51.28 \\
37.42 \\
27.68 \\
43.19 \\
21.28\end{array}$ & $\begin{array}{l}288.66 \\
246.82 \\
220.62 \\
193.73 \\
112.97\end{array}$ & $\begin{array}{ll}0.82 & U \\
0.66 & U \\
0.92 & U \\
1.37 & U \\
0.64 & U\end{array}$ & $\begin{array}{l}3.17 \\
2.75 \\
2.84 \\
3.13 \quad \mathrm{~J} \\
1.55 \mathrm{U}\end{array}$ & $\begin{array}{l}752.40 \\
576.64 \\
589.83 \\
479.14 \\
147.49\end{array}$ & $\begin{array}{l}1.84 \\
1.61 \\
2.29 \\
3.23 \\
1.55\end{array}$ & $\begin{array}{l}1.02 \mathrm{~J} \\
2.94 \\
2.29 \mathrm{U} \\
0.98 \mathrm{~J} \\
1.55 \mathrm{U}\end{array}$ & $\begin{array}{l}2.04 \\
5.79 \\
3.48 \\
4.80 \\
1.28 \mathrm{~J}\end{array}$ & $\begin{array}{l}18.69 \mathrm{U} \\
16.05 \mathrm{U} \\
22.91 \mathrm{U} \\
32.03 \mathrm{U} \\
15.07 \mathrm{U}\end{array}$ \\
\hline 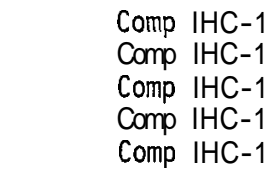 & $\begin{array}{l}1 \\
2 \\
3 \\
4 \\
5\end{array}$ & $\begin{array}{l}1 \\
1 \\
2 \\
1 \\
1\end{array}$ & $\begin{array}{l}17.41 \\
14.27 \\
16.58 \\
11.60 \\
14.66\end{array}$ & $\begin{array}{r}6.95 \\
9.32 \\
10.68 \\
12.67 \\
11.87\end{array}$ & $\begin{array}{l}26.31 \\
31.67 \\
26.54 \\
30.78 \\
31.24\end{array}$ & $\begin{array}{l}0.40 \mathrm{U} \\
0.49 \mathrm{U} \\
0.36 \mathrm{U} \\
0.60 \mathrm{U} \\
0.48 \mathrm{U}\end{array}$ & $\begin{array}{l}0.75 \mathrm{~J} \\
1.12 \mathrm{~J} \\
0.60 \mathrm{~J} \\
1.81 \mathrm{U} \\
1.16 \mathrm{U}\end{array}$ & $\begin{array}{l}121.83 \\
140.71 \\
141.25 \\
168.45 \\
204.23\end{array}$ & $\begin{array}{l}0.92 \\
1.26 \\
0.90 \mathrm{U} \\
1.47 \\
1.16\end{array}$ & $\begin{array}{l}0.92 \mathrm{U} \\
1.26 \mathrm{U} \\
1.15 \mathrm{U} \\
1.47 \mathrm{U} \\
2.59\end{array}$ & $\begin{array}{l}2.13 \\
9.67 \\
3.98 \\
0.95 \mathrm{~J} \\
4.09\end{array}$ & $\begin{array}{r}9.42 \mathrm{U} \\
12.26 \mathrm{U} \\
\mathrm{NA} \\
14.48 \mathrm{U} \\
11.26 \mathrm{U}\end{array}$ \\
\hline 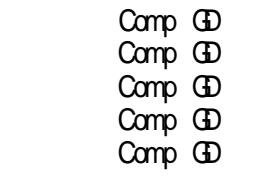 & $\begin{array}{l}1 \\
2 \\
3 \\
4 \\
5\end{array}$ & $\begin{array}{l}2 \\
1 \\
2 \\
2 \\
1\end{array}$ & $\begin{array}{l}11.60 \\
10.84 \\
11.86 \\
12.38 \\
13.82\end{array}$ & $\begin{array}{l}3.28 \\
1.75 \\
1.94 \\
1.70 \\
1.66\end{array}$ & $\begin{array}{l}6.47 \\
4.52 \\
4.55 \\
4.85 \\
4.34\end{array}$ & $\begin{array}{l}0.60 \mathrm{U} \\
0.65 \mathrm{U} \\
0.67 \mathrm{U} \\
0.57 \mathrm{U} \\
0.51 \mathrm{U}\end{array}$ & $\begin{array}{l}0.43 \mathrm{~J} \\
0.65 \mathrm{~J} \\
0.59 \mathrm{~J} \\
0.48 \mathrm{~J} \\
0.72 \mathrm{~J}\end{array}$ & $\begin{array}{l}64.66 \\
14.21 \\
21.59 \\
33.12 \\
12.81\end{array}$ & $\begin{array}{l}1.55 \\
1.57 \\
1.60 \\
1.29 \\
1.16\end{array}$ & $\begin{array}{l}1.55 U \\
1.57 \mathrm{U} \\
1.60 \mathrm{U} \\
1.29 \mathrm{U} \\
1.16 \mathrm{U}\end{array}$ & $\begin{array}{l}4.40 \\
0.83 \mathrm{~J} \\
1.69 \\
1.70 \\
0.43 \mathrm{~J}\end{array}$ & $\begin{array}{c}\text { NA } \\
15.68 \mathrm{U} \\
\text { NA } \\
\text { NA } \\
11.65 \mathrm{U}\end{array}$ \\
\hline
\end{tabular}

(a) U Analyte was not present above the associated value.

(b) NA Not analyzed.

(c) J Analyte detected below method detection Iimit (MDL), but above instrument detection Iimit (IDL). 
TABLE F.6. Quality Control Summary for Chlorinated Pesticides (elution order, Alpha-BHC to cisChlordane) in Tissues of M. nasuta, Wet Weight, United Heckathron Remedial Investigation

\begin{tabular}{|c|c|c|c|c|c|c|c|c|c|c|c|c|}
\hline & & & & & & & Pesticid & es $(\mu \mathrm{g} / \mathrm{k}$ & g wet wei & $g h t)$ & & \\
\hline Sediment Treatment & Replicate & Batch & $\begin{array}{l}\text { Alpha } \\
\text { BHC }\end{array}$ & $\begin{array}{l}\text { Beta } \\
\text { BHC }\end{array}$ & Lindane & $\begin{array}{c}\text { Delta } \\
\text { BHC }\end{array}$ & $\begin{array}{l}\text { Hepta- } \\
\text { chlor }\end{array}$ & Aldrin & $\begin{array}{l}\text { Hepta- } \\
\text { chlor } \\
\text { epoxide }\end{array}$ & $\begin{array}{c}\text { trans- } \\
\text { Chlordane }\end{array}$ & $\begin{array}{l}\text { Endo- } \\
\text { sulfan I }\end{array}$ & $\begin{array}{c}\text { cis- } \\
\text { Chlordane }\end{array}$ \\
\hline
\end{tabular}

\section{Procedural Blanks}

Blank

Blank

Blank

Matrix Spikes

Comp FSFC

Comp FSFC NS

Concentration Recovered

Amount Spiked

Percent Recovery

Comp FSFC

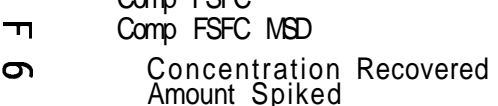

Percent Recovery

PPD

I-Stat

Comp FSFC

Comp FSFC NS

Concentration Recovered

Amount Spiked

Percent Recovery

\section{Comp FSFC}

Comp FSFC MSD

Concentration Recovered

Amount Spiked

Percent Recovery

RPD

I-Stat

\begin{tabular}{|c|c|c|c|c|c|c|c|c|c|c|c|}
\hline $\mathrm{NA}^{(\mathrm{a})}$ & 1 & $0.09 u^{(b)}$ & $0.09 \mathrm{U}$ & $0.09 \mathrm{U}$ & $0.09 \mathrm{U}$ & $0.10 \mathrm{U}$ & $0.06 U$ & $0.09 \mathrm{U}$ & $0.18 \mathrm{U}$ & $0.18 \mathrm{U}$ & $0.10 \mathrm{U}$ \\
\hline NA & 2 & $0.12 U$ & $0.12 \mathrm{U}$ & $0.12 \mathrm{U}$ & $0.12 \mathrm{U}$ & $0.13 U$ & $0.08 \mathrm{U}$ & $0.11 \mathrm{U}$ & $0.23 \mathrm{U}$ & $0.23 U$ & 0.14 \\
\hline NA & 3 & $0.09 \mathrm{U}$ & $0.09 \mathrm{U}$ & $0.09 \cup$ & $0.09 \mathrm{U}$ & $0.09 \cup$ & $0.06 U$ & $0.08 \mathrm{U}$ & $0.17 \mathrm{U}$ & $0.17 \cup$ & $0.10 \mathrm{U}$ \\
\hline
\end{tabular}

$0.14 \mathrm{U}$

$\begin{array}{llllllllllll}\text { NA } & 3 & 0.09 \cup & 0.09 \cup & 0.09 \cup & 0.09 \cup & 0.09 \cup & 0.06 \cup & 0.08 \cup & 0.17 \cup & 0.17\end{array}$

15

\begin{tabular}{|c|c|c|c|c|c|c|c|c|c|}
\hline $\begin{array}{l}0.17 \\
1.45 \\
1.28 \\
3.65 \\
35 \%(\mathrm{~d})\end{array}$ & $\begin{array}{l}0.13 \mathrm{U} \\
2.04 \\
2.04 \\
3.44 \\
59 \%\end{array}$ & $\begin{array}{l}0.13 \mathrm{U} \\
1.57 \\
1.57 \\
3.44 \\
46 \%\end{array}$ & $\begin{array}{l}0.13 \mathrm{U} \\
1.37 \\
1.37 \\
3.44 \\
40 \%\end{array}$ & $\begin{array}{l}0.14 U \\
2.26 \\
2.26 \\
3.44 \\
66 \%\end{array}$ & $\begin{array}{l}0.08 \mathrm{U} \\
1.82 \\
1.82 \\
3.44 \\
53 \%\end{array}$ & $\begin{array}{l}0.12 U \\
1.86 \\
1.86 \\
3.44 \\
54 \%\end{array}$ & $\begin{array}{l}0.25 \mathrm{U} \\
2.25 \\
2.25 \\
3.72 \\
\quad 60 \%\end{array}$ & $\begin{array}{l}0.25 \mathrm{U} \\
2.33 \\
2.33 \\
3.44 \\
\quad 68 \%\end{array}$ & $\begin{array}{l}0.15 U \\
\text { NA } \\
\text { NA } \\
\text { NS (c) } \\
\text { NA }\end{array}$ \\
\hline $\begin{array}{l}0.17 \\
1.52 \\
1.35 \\
3.88 \\
\quad 35 \% \text { (d) }\end{array}$ & $\begin{array}{l}0.13 \mathrm{U} \\
2.17 \\
2.17 \\
3.65 \\
59 \%\end{array}$ & $\begin{array}{l}0.13 \mathrm{U} \\
1.61 \\
1.61 \\
3.65 \\
44 \%\end{array}$ & $\begin{array}{l}0.13 \mathrm{U} \\
1.47 \\
1.47 \\
3.65 \\
40 \%\end{array}$ & $\begin{array}{l}0.14 U \\
2.62 \\
2.62 \\
3.65 \\
72 \%\end{array}$ & $\begin{array}{l}0.08 \mathrm{U} \\
1.61 \\
1.61 \\
3.65 \\
44 \%\end{array}$ & $\begin{array}{l}0.12 U \\
1.95 \\
1.95 \\
3.65 \\
53^{q}\end{array}$ & $\begin{array}{l}0.25 \mathrm{U} \\
2.24 \\
2.24 \\
3.96 \\
57 \%\end{array}$ & $\begin{array}{l}0.25 \mathrm{U} \\
2.29 \\
2.29 \\
3.65 \\
63 \%\end{array}$ & $\begin{array}{c}0.15 U \\
\text { NA } \\
\text { NA } \\
\text { NS } \\
\text { NA }\end{array}$ \\
\hline $\begin{array}{c}0 \% \\
0.00\end{array}$ & 0.00 & 0.02 & $0.01 \%$ & 0.04 & $\begin{array}{l}18 \% \\
0.09\end{array}$ & $0.01 \%$ & $\begin{array}{c}7 \% \\
0.03\end{array}$ & 0.04 & $\begin{array}{l}\text { NA } \\
\text { NA }\end{array}$ \\
\hline $\begin{array}{l}0.12 \mathrm{~J}(\mathrm{e}) \\
4.13 \\
4.01 \\
5.31 \\
76 \%\end{array}$ & $\begin{array}{l}0.17 \mathrm{U} \\
3.80 \\
3.80 \\
5.00 \\
76 \%\end{array}$ & $\begin{array}{l}0.18 \\
3.99 \\
3.81 \\
5.00 \\
76 \%\end{array}$ & $\begin{array}{l}0.17 \cup \\
4.28 \\
4.28 \\
5.00 \\
86 \%\end{array}$ & $\begin{array}{l}0.18 U \\
4.22 \\
4.22 \\
5.00 \\
84 \%\end{array}$ & $\begin{array}{l}0.11 U \\
3.95 \\
3.95 \\
5.00 \\
79 \%\end{array}$ & $\begin{array}{l}0.16 U \\
3.70 \\
3.70 \\
5.00 \\
74 \%\end{array}$ & $\begin{array}{l}0.51 \\
4.10 \\
3.59 \\
5.41 \\
66 \%\end{array}$ & $\begin{array}{l}0.26 \mathrm{~J} \\
4.20 \\
3.94 \\
5.00 \\
79 \%\end{array}$ & $\begin{array}{r}0.22 \\
\text { NA } \\
\text { NA } \\
\text { NS } \\
\text { NA }\end{array}$ \\
\hline $\begin{array}{l}0.12 \mathrm{~J} \\
3.61 \\
3.49 \\
5.06 \\
69 \%\end{array}$ & $\begin{array}{l}0.17 \quad U \\
3.56 \\
3.56 \\
4.76 \\
75 \%\end{array}$ & $\begin{array}{l}0.18 \\
3.70 \\
3.52 \\
4.76 \\
74 \%\end{array}$ & $\begin{array}{l}0.17 \mathrm{U} \\
3.74 \\
3.74 \\
4.76 \\
79 \%\end{array}$ & $\begin{array}{l}0.18 U \\
3.90 \\
3.90 \\
4.76 \\
82 \%\end{array}$ & $\begin{array}{l}0.11 \mathrm{U} \\
3.66 \\
3.66 \\
4.76 \\
77 \%\end{array}$ & $\begin{array}{l}0.16 \mathrm{U} \\
3.69 \\
3.69 \\
4.76 \\
78 \%\end{array}$ & $\begin{array}{l}0.51 \\
4.56 \\
4.05 \\
5.16 \\
78 \%\end{array}$ & $\begin{array}{l}0.26 \mathrm{~J} \\
3.99 \\
3.73 \\
4.76 \\
78 \%\end{array}$ & $\begin{array}{l}0.22 \\
N A \\
N A \\
N S \\
N A\end{array}$ \\
\hline $0.05^{9 \%}$ & 0.01 & 0.01 & 0.04 & 0.02 & 0.01 & $\begin{array}{c}5 \% \\
0.02\end{array}$ & $\begin{array}{l}17 \% \\
0.08\end{array}$ & $0.00^{1 \%}$ & $\begin{array}{l}\text { NA } \\
\text { NA }\end{array}$ \\
\hline
\end{tabular}


TABLE F.6. (contd)

\begin{tabular}{|c|c|c|c|c|c|c|c|c|c|c|c|c|}
\hline \multirow[b]{2}{*}{ Sediment Treatment } & \multirow[b]{2}{*}{ Replicate } & \multirow[b]{2}{*}{ Batch } & \multicolumn{10}{|c|}{ Pesticides $(\mu \mathrm{g} / \mathrm{kg}$ wet weight) } \\
\hline & & & $\begin{array}{l}\text { Alpha } \\
\text { BHC } \\
\end{array}$ & $\begin{array}{l}\text { Beta } \\
\mathrm{BHC} \\
\end{array}$ & Lindane & $\begin{array}{c}\text { Delta } \\
\text { BHC } \\
\end{array}$ & $\begin{array}{l}\text { Hepta- } \\
\text { chlor }\end{array}$ & Aldrin & $\begin{array}{l}\text { Hepta- } \\
\text { chlor } \\
\text { epoxide } \\
\end{array}$ & $\begin{array}{c}\text { trans- } \\
\text { Chlordane } \\
\end{array}$ & $\begin{array}{l}\text { Endo- } \\
\text { sulfan I } \\
\end{array}$ & $\begin{array}{c}\text { cis- } \\
\text { Chlordane } \\
\end{array}$ \\
\hline $\begin{array}{l}\text { MH32 } \\
\text { MH33 MBD } \\
\text { Amount Spiked } \\
\text { Percent Recovery }\end{array}$ & $\begin{array}{l}N A \\
N A\end{array}$ & $\begin{array}{l}3 \\
3\end{array}$ & $\begin{array}{l}\text { DNA } \\
\text { NA } \\
\text { NS } \\
\text { NA }\end{array}$ & $\begin{array}{l}\text { DNA } \\
\text { NA } \\
\text { NS } \\
\text { NA }\end{array}$ & $\begin{array}{l}\text { DNA } \\
1.06 \\
1.17 \\
90 \%\end{array}$ & $\begin{array}{l}\text { DNA } \\
\text { NA } \\
\text { NS } \\
\text { NA }\end{array}$ & $\begin{array}{l}\text { DNA } \\
1.05 \\
1.17 \\
90 \%\end{array}$ & $\begin{array}{l}\text { DNA } \\
0.81 \\
1.17 \\
69 \%\end{array}$ & $\begin{array}{l}\text { DNA } \\
1.03 \\
1.17 \\
88 \%\end{array}$ & $\begin{array}{l}\text { DNA } \\
\text { NA } \\
\text { NS } \\
\text { NA }\end{array}$ & $\begin{array}{l}\text { DNA } \\
\text { NA } \\
\text { NS } \\
\text { NA }\end{array}$ & $\begin{array}{l}\text { DNA } \\
0.99 \\
1.17 \\
84 \%\end{array}$ \\
\hline $\begin{array}{l}\text { RPD } \\
\text { I-Stat }\end{array}$ & & & $\begin{array}{l}\text { NA } \\
\text { NA }\end{array}$ & $\begin{array}{l}\text { NA } \\
\text { NA }\end{array}$ & 0.00 & $\begin{array}{l}\text { NA } \\
\text { NA }\end{array}$ & $0.01 \%$ & 0.01 & 0.02 & $\begin{array}{l}\text { NA } \\
\text { NA }\end{array}$ & $\begin{array}{l}\text { NA } \\
\text { NA }\end{array}$ & 0.01 \\
\hline Analytical Duplicat & & & & & & & & & & & & \\
\hline $\begin{array}{l}\text { Comp USFC } \\
\text { Comp USFC } \\
\text { RPD } \\
\text { I-Stat }\end{array}$ & $\begin{array}{l}1 \\
1\end{array}$ & $\begin{array}{l}1 \\
1\end{array}$ & $\begin{array}{l}0.11 \mathrm{~J} \\
0.12 \mathrm{~J} \\
9 \% \\
0.04\end{array}$ & $\begin{array}{l}0.12 U \\
0.13 U \\
\text { NA } \\
\text { NA }\end{array}$ & $\begin{array}{l}0.12 U \\
0.13 U \\
\text { NA } \\
\text { NA }\end{array}$ & $\begin{array}{l}0.12 U \\
0.13 U \\
\text { NA } \\
\text { NA }\end{array}$ & $\begin{array}{l}0.12 \mathrm{U} \\
0.13 \mathrm{U} \\
\mathrm{NA} \\
\mathrm{NA}\end{array}$ & $\begin{array}{l}0.08 U \\
0.08 \mathrm{U} \\
\text { NA } \\
\text { NA }\end{array}$ & $\begin{array}{l}0.11 U \\
0.12 U \\
\text { NA } \\
\text { NA }\end{array}$ & $\begin{array}{l}0.30 \\
0.51 \\
52 \%(\mathrm{~g}) \\
0.26\end{array}$ & $\begin{array}{l}0.30 \\
0.36 \\
18 \% \\
0.09\end{array}$ & $\begin{array}{l}0.25 \\
0.23 \\
8 \% \\
0.04\end{array}$ \\
\hline $\begin{array}{l}\text { Comp FSFC } \\
\text { Comp FSFC } \\
\text { RPD } \\
\text { I- Stat }\end{array}$ & $\begin{array}{l}5 \\
5\end{array}$ & $\begin{array}{l}2 \\
2\end{array}$ & $\begin{array}{l}0.08 \mathrm{U} \\
0.11 \mathrm{~J} \\
\text { NA } \\
\text { NA }\end{array}$ & $\begin{array}{l}0.08 U \\
0.16 U \\
\text { NA } \\
\text { NA }\end{array}$ & $\begin{array}{l}0.08 \mathrm{U} \\
0.13 \mathrm{~J} \\
\text { NA } \\
\text { NA }\end{array}$ & $\begin{array}{l}0.08 \mathrm{U} \\
0.16 \mathrm{U} \\
\text { NA } \\
\text { NA }\end{array}$ & $\begin{array}{l}0.09 \mathrm{U} \\
0.17 \mathrm{U} \\
\text { NA } \\
\text { NA }\end{array}$ & $\begin{array}{l}0.05 U \\
0.10 U \\
\text { NA } \\
\text { NA }\end{array}$ & $\begin{array}{l}0.08 \mathrm{U} \\
0.15 \mathrm{U} \\
\text { NA } \\
\text { NA }\end{array}$ & $\begin{array}{l}0.17 \mathrm{U} \\
0.30 \mathrm{~J} \\
\text { NA } \\
\text { NA }\end{array}$ & $\begin{array}{l}0.17 \mathrm{U} \\
0.20 \mathrm{~J} \\
\text { NA } \\
\text { NA }\end{array}$ & $\begin{array}{c}0.10 \mathrm{U} \\
0.19 \\
\text { NA } \\
\text { NA }\end{array}$ \\
\hline
\end{tabular}

(a) NA Not applicable

(b) U Analyte was not present above the associated value.

(c) NS Not spiked.

(d) Recovery outside of acceptable quality control range (40\%-120\%).

e) J Analyte detected below method detection limit (MDL), but above instrument detection limit (IDL)

(f) DNA Data not available.

(g) Precision criteria do not apply because sample results are less than 10 times the MDL. 
TABLE F.7. Quality Control Summary for Chlorinated Pesticides (elution order, Dieldrin to Toxaphene) in Tissues of M. nasuta, Wet Weight, United Heckathorn Remedial Investigation

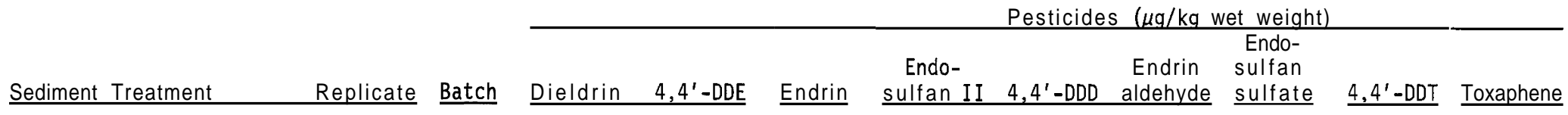
Procedural Blanks

Blank
Blank

Blank

Matrix Spikes

Comp FSFC

Comp FSFC MS

Concentration Recovered

Amount Spiked

Percent Recovery

$\begin{array}{ll} & \text { Comp FSFC } \\ \infty & \text { Comp FSFC MSD } \\ \infty & \text { Concentration Recovered }\end{array}$

Concentration

Percent Recovery

RPD

I-Stat

Comp FSFC

Comp FSFC NS

Concentration Recovered

Amount Spiked

Percent Recovery

\section{Comp FSFC}

Comp FSFC MSD

Concentration Recovered

Amount Spiked

Percent Recovery

RPD

I- Stat

$\begin{array}{llllllllllll}\text { NA } & (a) & 1 & 0.07 U^{(b)} & 0.20 U & 0.08 U & 0.18 U & 0.09 U & 0.18 & 0.18 U & 0.19 U & 1.80 U \\ \text { NA } & 2 & 0.10 U & 0.26 U & 0.10 U & 0.23 U & 0.12 U & 0.23 & 0.23 U & 0.24 U & 2.34 U \\ \text { NA } & 3 & 0.07 U & 0.20 U & 0.07 U & 0.17 U & 0.09 U & 0.17 & 0.17 U & 0.18 U & 1.75 U\end{array}$

\begin{tabular}{|c|c|c|c|c|c|c|}
\hline $\begin{array}{l}3 \\
3\end{array}$ & $\begin{array}{l}1 \\
1\end{array}$ & $\begin{array}{l}3.02 \\
6.12 \\
3.10 \\
3.44 \\
90 \%\end{array}$ & $\begin{array}{l}24.07 \\
23.87 \\
0.00 \\
3.44 \text { (d) }\end{array}$ & $\begin{array}{l}0.10 \mathrm{U} \\
2.10 \\
2.10 \\
3.51 \\
60 \%\end{array}$ & $\begin{array}{l}0.31 \\
2.71 \\
2.40 \\
3.44 \\
70 \%\end{array}$ & $\begin{array}{r}64.35 \\
49.55 \\
0.00 \\
3.44 \\
M\end{array}$ \\
\hline $\begin{array}{l}3 \\
3\end{array}$ & $\begin{array}{l}1 \\
1\end{array}$ & $\begin{array}{r}3.02 \\
5.76 \\
2.74 \\
3.65 \\
75 \%\end{array}$ & $\begin{array}{r}24.07 \\
22.70 \\
0.00 \\
3.65 \\
M\end{array}$ & $\begin{array}{l}0.10 \mathrm{U} \\
2.23 \\
2.23 \\
3.73 \\
60 \%\end{array}$ & $\begin{array}{r}0.31 \\
2.50 \\
2.19 \\
3.65 \\
60 \%\end{array}$ & $\begin{array}{r}64.35 \\
48.43 \\
0.00 \\
3.65 \\
M\end{array}$ \\
\hline & & $\begin{array}{l}18 \% \\
0.09\end{array}$ & $\begin{array}{l}N A \\
N A\end{array}$ & $0.0 \%$ & $\begin{array}{l}15 \% \\
0.08\end{array}$ & $\begin{array}{l}\text { NA } \\
\text { NA }\end{array}$ \\
\hline $\begin{array}{l}4 \\
4\end{array}$ & $\begin{array}{l}2 \\
2\end{array}$ & $\begin{array}{r}4.41 \\
\text { M } \\
\text { NA } \\
5.00 \\
\text { NA }\end{array}$ & $\begin{array}{r}19.78 \\
M \\
\text { NA } \\
5.00 \\
\text { NA }\end{array}$ & $\begin{array}{l}0.14 \mathrm{U} \\
3.89 \\
3.89 \\
5.10 \\
76 \%\end{array}$ & $\begin{array}{l}0.32 \mathrm{~J}^{(\mathrm{e})} \\
4.20 \\
3.88 \\
5.00 \\
\quad 78 \%\end{array}$ & $\begin{array}{r}48.92 \\
M \\
\text { NA } \\
5.00 \\
\text { NA }\end{array}$ \\
\hline $\begin{array}{l}4 \\
4\end{array}$ & $\begin{array}{l}2 \\
2\end{array}$ & $\begin{array}{r}4.41 \\
\text { M } \\
\text { NA } \\
4.76 \\
\text { NA }\end{array}$ & $\begin{array}{r}19.78 \\
M \\
\mathrm{NA} \\
4.76 \\
\mathrm{NA}\end{array}$ & $\begin{array}{l}0.14 \mathrm{U} \\
3.78 \\
3.78 \\
4.86 \\
78 \%\end{array}$ & $\begin{array}{l}0.32 \mathrm{~J} \\
4.44 \\
4.12 \\
4.76 \\
87 \%\end{array}$ & $\begin{array}{r}48.92 \\
\mathrm{M} \\
\mathrm{NA} \\
4.76 \\
\mathrm{NA}\end{array}$ \\
\hline & & $\begin{array}{l}N A \\
N A\end{array}$ & $\begin{array}{l}\text { NA } \\
\text { NA }\end{array}$ & 0.01 & $\begin{array}{c}11 \% \\
0.05\end{array}$ & $\begin{array}{l}\text { NA } \\
\text { NA }\end{array}$ \\
\hline
\end{tabular}

\begin{tabular}{|c|c|c|c|}
\hline $\begin{array}{l}0.25 \\
0.00 \\
0.00 \\
3.44\end{array}$ & $\begin{array}{l}0.25 \mathrm{U} \\
3.04 \\
3.04 \\
3.44\end{array}$ & $\begin{array}{l}0.38 \\
2.55 \\
2.17 \\
3.44\end{array}$ & $\begin{array}{l}2.50 U \\
N A \\
N A \\
N S(c)\end{array}$ \\
\hline M & $88 \%$ & $63 \%$ & NA \\
\hline $\begin{array}{r}0.25 \\
0.00 \\
0.00 \\
3.65 \\
M\end{array}$ & $\begin{array}{l}0.25 \mathrm{U} \\
3.13 \\
3.13 \\
3.65 \\
86 \%\end{array}$ & $\begin{array}{c}0.38 \\
3.46 \\
3.08 \\
3.65 \\
84 \%\end{array}$ & $\begin{array}{c}2.50 U \\
N A \\
N A \\
N S \\
N A\end{array}$ \\
\hline $\begin{array}{l}\text { NA } \\
\text { NA }\end{array}$ & $0.02^{3 \%}$ & $\begin{array}{l}29 \% \\
0.14\end{array}$ & $\begin{array}{l}\text { NA } \\
\text { NA }\end{array}$ \\
\hline $\begin{array}{r}0.33 \\
M \\
\text { NA } \\
5.00 \\
\text { NA }\end{array}$ & $\begin{array}{l}0.10 \mathrm{~J} \\
4.75 \\
4.65 \\
5.00 \\
93 \%\end{array}$ & $\begin{array}{c}0.49 \\
5.94 \\
5.45 \\
5.00 \\
109 \%\end{array}$ & $\begin{array}{c}3.27 \mathrm{U} \\
\mathrm{NA} \\
\mathrm{NA} \\
\mathrm{NS} \\
\mathrm{NA}\end{array}$ \\
\hline $\begin{array}{r}0.33 \\
M \\
\text { NA } \\
4.76 \\
\text { NA }\end{array}$ & $\begin{array}{l}0.10 \mathrm{~J} \\
4.38 \\
4.28 \\
4.76 \\
90 \%\end{array}$ & $\begin{array}{c}0.49 \\
6.02 \\
5.53 \\
4.76 \\
116 \%\end{array}$ & $\begin{array}{c}3.27 \mathrm{U} \\
\text { NA } \\
\text { NA } \\
\text { NS } \\
\text { NA }\end{array}$ \\
\hline $\begin{array}{l}\text { NA } \\
\text { NA }\end{array}$ & 0.02 & $\begin{array}{c}6 \% \\
0.03\end{array}$ & $\begin{array}{l}\text { NA } \\
\text { NA }\end{array}$ \\
\hline
\end{tabular}


TABLE F.7. (contd)

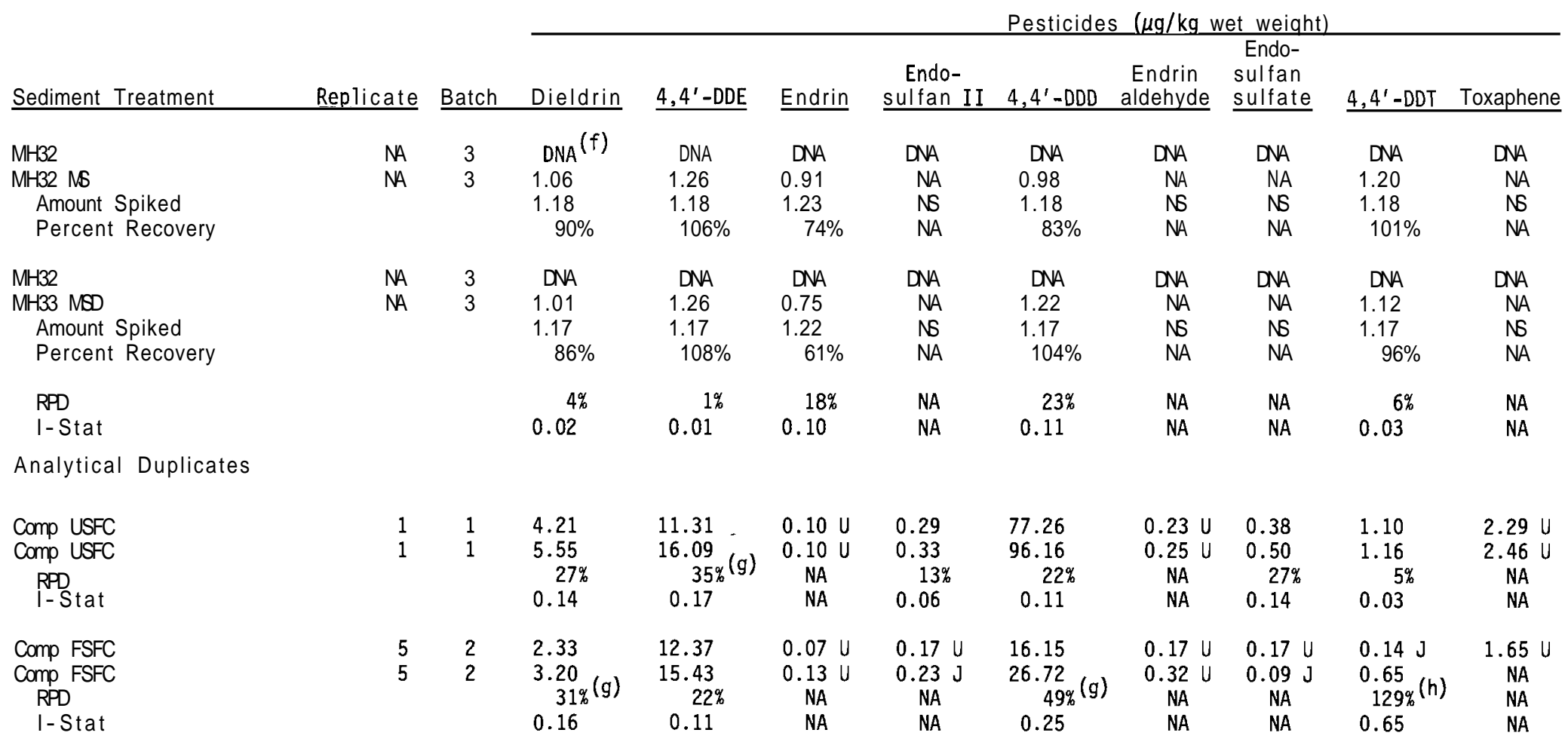

(a) NA Not applicable.

(b) $U$ Analyte was not present above the associated value.

(c) NS Not spiked.

(d) M Matrix interference. Recovery could not be calculated.

(e) J Analyte detected below method detection limit (MDL), but above instrument detection limit (IDL).

(f) DNA Data not available.

(g) Value exceeds relative precision goal of $\leq 30 \%$.

(h) Precision criteria do not apply because sample results are less than 10 times the MDL. 
TABLE F.8. Surrogate Recoveries for Chlorinated Pesticides in Tissues of M. nasuta, United Heckathorn Remedial Investigation

Sediment

Treatment

Comp LC

Comp LC

Comp LC

Comp LC

Comp LC

Comp USFC

Comp USFC

Comp USFC

Comp USFC

Comp USFC

Comp FSFC

Comp FSFC

Comp FSFC

Comp FSFC

Comp FSFC

Comp IHC-1

Comp IHC- 1

Comp IHC-1

Comp IHC-1

Comp IHC- 1

Comp GD

Comp GD

Comp GD

Comp GD

Comp GD

Rep 11
1
2
3
4
5$$
\begin{aligned}
& 1 \\
& 2 \\
& 3 \\
& 4 \\
& 5
\end{aligned}
$$

\section{1}

3

4
5

\section{1}

2

3

4

5

1
2
3
4
5

Qualitv Control Data

Procedural Blanks

Blank

Blank

Blank

Matrix Spikes

Comp FSFC NS

Comp FSFC MSD

Comp FSFC MS

Comp FSFC MSD

$\begin{array}{llc}N_{N A}{ }^{(c)} & 1 & 36.09^{(b)} \\ N A & 2 & 94.56 \\ N A & 3 & 72.20\end{array}$

$\begin{array}{ll}3 & 1 \\ 3 & 1\end{array}$

59

74

95

95
Surrogate Percent Recoveries $\underline{\mathrm{DBOFB}} \quad \underline{\mathrm{CL} 5(112)} \quad \underline{\mathrm{CL5}(103)}$

93.79

86.13

88.16

56.33

92.49

57.49

67.87

56.71

57.05

59.47

64.20

59.86

57.61

92.58

84.52

61.11

57.83

81.41

$36.06^{(b)}$

81.43

96.54

53.72

86.03

56.86
$M^{(a)}$
$M$
107.68
108.70
$M$

60.34

60.34

60.05

59.95

61.50

64.64

61.06

61.95

64.89

64.93

60.14

61.01

53.78

58.33

65.87

63.36

57.34

55.23

61.54

58.79
97.81

75.01

118.52

83.67

79.01

75.17

70.63

61.98

73.29

72.03

65.75

66.86

65.66

64.59

74.80

61.35

73.53

44.12

69.85

81.11

56.06

68.26

49.18

58.77

65.94

52.51

69.96

74.25

70.86

65.13

74.16

63

$64 \quad 63$

$75 \quad 64$

$68 \quad 65$ 
TABLE F.8. (contd)

Sediment

MH32 MS

MH33 MSD
Treatment

\begin{tabular}{|c|c|c|c|c|}
\hline & & Surr & Percent $\mathrm{R}$ & overies \\
\hline Replicate & Batch & DBOFB & CL5(112) & CL5 (103) \\
\hline $\begin{array}{l}\text { NA } \\
\text { NA }\end{array}$ & $\begin{array}{l}3 \\
3\end{array}$ & $\begin{array}{l}78 \\
89\end{array}$ & $\begin{array}{l}71 \\
83\end{array}$ & $\begin{array}{l}82 \\
95\end{array}$ \\
\hline
\end{tabular}

Analvtical Duplicates

Comp USFC Duplicate

Comp FSFC Duplicate

$\begin{array}{lll}1 & 1 & 59.76 \\ 5 & 2 & 87.92\end{array}$

87.92
62.08

65.10
64.15

60.19

(a) M Matrix interference. Recovery could not be calculated.

(b) Recovery outside of acceptable quality control range $(40 \%-120 \%$,

(c) NA Not applicable. 
TABLE F.9. Total Polynuclear Aromatic Hydrocarbons (PAHs) in Tissues of M. nasuta, United Heckathorn Remedial Investigation

\begin{tabular}{|c|c|c|c|c|c|c|}
\hline \multirow[b]{2}{*}{$\begin{array}{l}\text { Sediment } \\
\text { Treatment } \\
\end{array}$} & \multicolumn{3}{|c|}{$\begin{array}{l}\text { Concentration } \\
(\mu \mathrm{q} / \mathrm{kg} \text { wet weight })\end{array}$} & \multicolumn{3}{|c|}{$\begin{array}{l}\text { Concentration } \\
\text { ( } \mu \mathrm{g} / \mathrm{kg} \text { dry weight) }\end{array}$} \\
\hline & $\begin{array}{l}\text { Total } \\
\text { LPAH }\end{array}$ & $\begin{array}{l}\text { Total } \\
\text { HPAH } \\
\end{array}$ & $\begin{array}{l}\text { Total } \\
\text { PAH } \\
\end{array}$ & $\begin{array}{l}\text { Total } \\
\text { LPAH }\end{array}$ & $\begin{array}{l}\text { Total } \\
\text { HPAH }\end{array}$ & $\begin{array}{l}\text { Total } \\
\text { PAH } \\
\end{array}$ \\
\hline Comp LC & 8.8 & 738.1 & 747 & 63.9 & 5367.9 & 5432 \\
\hline Comp USFC & 263.3 & 1077.2 & 1340 & 1094.4 & 4476.9 & 5571 \\
\hline Comp FSFC & 17.4 & 194.7 & 212 & 149.1 & 1667.2 & 1816 \\
\hline Comp IHC- 1 & 3.2 & 74.4 & 78 & 23.9 & 550.9 & 575 \\
\hline Comp GD & 20.0 & 112.6 & 133 & 155.0 & 873.1 & 1028 \\
\hline
\end{tabular}


TABLE F. 10. Low Molecular Weight Polynuclear Aromatic Hydrocarbons (LPAHs) in the Tissues of M. nasuta, Wet Weight, United Heckathorn Remedial Investigation

Sediment

Treatment

Target $\mathrm{DL}(\mathrm{a})$

Achieved DL High

Achieved DL Low

Comp LC

Comp USFC

Comp FSFC

Comp IHC-1

Comp G

\begin{tabular}{|c|c|c|c|c|c|c|c|}
\hline $\begin{array}{c}\text { Naph- } \\
\text { thal ene }\end{array}$ & $\begin{array}{c}\text { 2-methvl } \\
\text { Naph- } \\
\text { thalene }\end{array}$ & $\begin{array}{c}\text { 1-methyl } \\
\text { Naph- } \\
\text { thalene } \\
\end{array}$ & $\begin{array}{l}\text { Acenaph- } \\
\text { thylene }\end{array}$ & $\begin{array}{l}\text { Acenaph- } \\
\text { thene }\end{array}$ & Fluorene & $\begin{array}{l}\text { Phenan- } \\
\text { threne }\end{array}$ & $\begin{array}{c}\text { Anthra- } \\
\text { cene }\end{array}$ \\
\hline $\begin{array}{r}20 \\
2.58 \\
1.76\end{array}$ & $\begin{array}{r}20 \\
1.31 \\
0.90\end{array}$ & $\begin{array}{r}20 \\
1.35 \\
0.93\end{array}$ & $\begin{array}{r}20 \\
2.38 \\
1.63\end{array}$ & $\begin{array}{r}20 \\
0.90 \\
0.62\end{array}$ & $\begin{array}{r}20 \\
1.52 \\
1.04\end{array}$ & $\begin{array}{r}20 \\
1.69 \\
1.15\end{array}$ & $\begin{array}{r}20 \\
1.30 \\
0.89\end{array}$ \\
\hline $\begin{array}{l}0.74 \mathrm{~J}^{(b)} \\
1.43 \mathrm{~J} \\
1.13 \mathrm{~J} \\
0.80 \mathrm{~J} \\
1.33 \mathrm{~J}\end{array}$ & $\begin{array}{l}0.53 \mathrm{~J} \\
0.78 \mathrm{~J} \\
0.69 \mathrm{~J} \\
0.38 \mathrm{~J} \\
0.54 \mathrm{~J}\end{array}$ & $\begin{array}{l}0.31 \mathrm{~J} \\
1.19 \mathrm{~J} \\
0.39 \mathrm{~J} \\
0.22 \mathrm{~J} \\
0.30 \mathrm{~J}\end{array}$ & $\begin{array}{l}0.41 \mathrm{~J} \\
1.13 \mathrm{~J} \\
0.30 \mathrm{~J} \\
1.68 \mathrm{U}(\mathrm{c}) \\
0.98 \mathrm{~J}\end{array}$ & $\begin{array}{c}0.17 \mathrm{~J} \\
14.68 \\
1.92 \\
0.64 \mathrm{U} \\
1.61\end{array}$ & $\begin{array}{c}0.27 \mathrm{~J} \\
20.90 \\
1.80 \\
0.19 \mathrm{~J} \\
2.05\end{array}$ & $\begin{array}{r}3.52 \\
183.54 \\
9.55 \\
1.24 \\
10.04\end{array}$ & $\begin{array}{c}2.84 \\
39.67 \\
1.63 \\
0.40 \mathrm{~J} \\
3.15\end{array}$ \\
\hline
\end{tabular}

(a) DL Detection Iimit.

(b) J Analyte detected below method detection limit (MDL), but above instrument detection Iimit (IDL).

(c) U Analyte was not present above the level of the associated value.

TABLE F.11. Low Molecular Weight Polynuclear Aromatic Hydrocarbons (PAHs) in the Tissues of M. nasuta, Dry Weight, United Heckathorn Remedial Investigation

\begin{tabular}{|c|c|c|c|c|c|c|c|c|c|}
\hline \multirow[b]{2}{*}{$\begin{array}{l}\text { Sediment } \\
\text { Treatment } \\
\end{array}$} & \multirow[b]{2}{*}{$\begin{array}{c}\text { Percent } \\
\text { Dry } \\
\text { Weight } \\
\end{array}$} & \multicolumn{8}{|c|}{ LPAHs $(\mu \mathrm{g} / \mathrm{kg}$ dry weight) } \\
\hline & & $\begin{array}{c}\text { Naph- } \\
\text { thalene } \\
\end{array}$ & $\begin{array}{c}\text { 2-methyl } \\
\text { Naph- } \\
\text { thalene } \\
\end{array}$ & $\begin{array}{c}\text { 1-methyl } \\
\text { Naph- } \\
\text { thalene } \\
\end{array}$ & $\begin{array}{l}\text { Acenaph- } \\
\text { thylene }\end{array}$ & $\begin{array}{l}\text { Acenaph- } \\
\text { thene }\end{array}$ & Fluorene & $\begin{array}{l}\text { Phenan- } \\
\text { threne }\end{array}$ & $\begin{array}{l}\text { Anthra- } \\
\text { cene }\end{array}$ \\
\hline $\begin{array}{l}\text { Comp LC } \\
\text { Comp USFC } \\
\text { Comp FSFC } \\
\text { Comp IHC-1 } \\
\text { Comp GD }\end{array}$ & $\begin{array}{l}13.75 \\
24.06 \\
11.68 \\
13.51 \\
12.90\end{array}$ & $\begin{array}{l}5.38 \mathrm{~J}^{(\mathrm{a})} \\
5.94 \mathrm{~J} \\
9.67 \mathrm{~J} \\
5.92 \mathrm{~J} \\
10.31 \mathrm{~J}\end{array}$ & $\begin{array}{l}3.85 \mathrm{~J} \\
3.24 \mathrm{~J} \\
5.91 \mathrm{~J} \\
2.81 \mathrm{~J} \\
4.19 \mathrm{~J}\end{array}$ & $\begin{array}{l}2.25 \mathrm{~J} \\
4.95 \mathrm{~J} \\
3.34 \mathrm{~J} \\
1.63 \mathrm{~J} \\
2.33 \mathrm{~J}\end{array}$ & $\begin{array}{r}2.98 \mathrm{~J} \\
4.70 \mathrm{~J} \\
2.57 \mathrm{~J} \\
12.44 \mathrm{U}^{(\mathrm{b})} \\
7.60 \mathrm{~J}\end{array}$ & $\begin{array}{c}1.24 \mathrm{~J} \\
61.01 \\
16.44 \\
4.74 \mathrm{U} \\
12.48\end{array}$ & $\begin{array}{r}1.96 \mathrm{~J} \\
86.87 \\
15.41 \\
1.41 \mathrm{~J} \\
15.89\end{array}$ & $\begin{array}{r}25.60 \\
762.84 \\
81.76 \\
9.18 \\
77.83\end{array}$ & $\begin{array}{r}20.65 \\
164.88 \\
13.96 \\
2.96 \mathrm{~J} \\
24.42\end{array}$ \\
\hline
\end{tabular}

(a) J Analyte detected below method detection limit (MDL), but above instrument detection Iimit (IDL).

(b) $U$ Analyte was not present above the level of the associated value. 
TABLE F. 12. High Molecular Weight Polynuclear Aromatic Hydrocarbons (HPAHs) in Tissues of M. nasuta, Wet Weight, United Heckathorn Remedial Investigation

\begin{tabular}{|c|c|c|c|c|c|c|c|c|c|c|}
\hline \multirow[b]{2}{*}{$\begin{array}{l}\text { Sediment } \\
\text { Treatment }\end{array}$} & \multicolumn{10}{|c|}{$\mathrm{HPAH}(\mu \mathrm{g} / \mathrm{kg}$ wet weight $)$} \\
\hline & $\begin{array}{r}\text { Fluor- } \\
\text { anthene }\end{array}$ & Pyrene & $\begin{array}{c}\text { Benzo }(\mathrm{a})- \\
\text { anthra- } \\
\text { cene } \\
\end{array}$ & Chrysene & $\begin{array}{l}\text { Benzo(b)- } \\
\text { fluor- } \\
\text { anthene }\end{array}$ & $\begin{array}{l}\text { Benzo }(k)- \\
\text { fluor- } \\
\text { anthene }\end{array}$ & $\begin{array}{l}\text { Benzo (a) - } \\
\text { pyrene }\end{array}$ & $\begin{array}{c}\text { Indeno- } \\
(1,2,3-c, d) \\
\text { pyrene } \\
\end{array}$ & $\begin{array}{c}\text { Dibenzo- } \\
(a, h) \\
\text { anthracene }\end{array}$ & $\begin{array}{c}\text { Benzo- } \\
(\mathrm{g}, \mathrm{h}, \mathrm{i}) \\
\text { perylene }\end{array}$ \\
\hline $\begin{array}{l}\text { Target DL (a) } \\
\text { Achieved DL High } \\
\text { Achieved DL Low }\end{array}$ & $\begin{array}{r}20 \\
2.25 \\
1.54\end{array}$ & $\begin{array}{r}20 \\
1.62 \\
1.11\end{array}$ & $\begin{array}{r}20 \\
2.05 \\
1.40\end{array}$ & $\begin{array}{r}20 \\
2.35 \\
1.60\end{array}$ & $\begin{array}{r}20 \\
2.32 \\
1.58\end{array}$ & $\begin{array}{r}20 \\
1.09 \\
0.74\end{array}$ & $\begin{array}{r}20 \\
0.86 \\
0.59\end{array}$ & $\begin{array}{r}20 \\
1.89 \\
1.29\end{array}$ & $\begin{array}{r}20 \\
1.70 \\
1.16\end{array}$ & $\begin{array}{r}20 \\
1.59 \\
1.09\end{array}$ \\
\hline $\begin{array}{l}\text { Comp LC } \\
\text { Comp USFC } \\
\text { Comp FSFC } \\
\text { Comp IHC-1 } \\
\text { Comp (1) }\end{array}$ & $\begin{array}{r}154.28 \\
387.63 \\
18.19 \\
3.58 \\
34.11\end{array}$ & $\begin{array}{r}279.02 \\
359.77 \\
75.45 \\
27.58 \\
31.95\end{array}$ & $\begin{array}{r}28.08 \\
69.28 \\
4.66 \\
2.24 \\
7.46\end{array}$ & $\begin{array}{r}39.14 \\
57.71 \\
7.53 \\
3.32 \\
9.00\end{array}$ & $\begin{array}{r}103.30 \\
89.50 \\
38.81 \\
15.39 \\
10.41\end{array}$ & $\begin{array}{r}52.82 \\
41.75 \\
17.97 \\
9.32 \\
5.21\end{array}$ & $\begin{array}{r}57.56 \\
46.52 \\
20.96 \\
8.05 \\
5.64\end{array}$ & $\begin{array}{r}11.61 \\
11.13 \\
4.66 \\
1.95 \\
3.43\end{array}$ & $\begin{array}{l}1.47 \mathrm{~J}(\mathrm{~b}) \\
1.38 \mathrm{~J} \\
0.81 \mathrm{~J}(\mathrm{c}) \\
1.20 \mathrm{U}(\mathrm{J} \\
1.14 \mathrm{~J}^{2}\end{array}$ & $\begin{array}{r}10.81 \\
12.48 \\
5.69 \\
3.00 \\
4.28\end{array}$ \\
\hline
\end{tabular}

(a) DL Detection limit.

(b) $\mathrm{J}$ Analyte detected below method detection limit (MDL), but above instrument detection limit (IDL)

$\check{x}$

TABLE F.13. High Molecular Weight Polynuclear Aromatic Hydrocarbons (HPAHs) in Tissues of M. nasuta, Dry Weight, United Heckathorn Remedial Investigation

\begin{tabular}{|c|c|c|c|c|c|c|c|c|c|c|c|}
\hline \multirow[b]{2}{*}{$\begin{array}{l}\text { Sediment } \\
\text { Treatment } \\
\end{array}$} & \multirow[b]{2}{*}{$\begin{array}{l}\text { Percent } \\
\text { Dry } \\
\text { Weight }\end{array}$} & \multicolumn{10}{|c|}{$\mathrm{HPAH}(\mu \mathrm{g} / \mathrm{kg}$ dry weight $)$} \\
\hline & & $\begin{array}{r}\text { Fluor- } \\
\text { anthene }\end{array}$ & Pvrene & $\begin{array}{c}\text { Benzo }(\mathrm{a})^{-} \\
\text {anthra- } \\
\text { cene } \\
\end{array}$ & Chrvsene & $\begin{array}{c}\text { Benzo (b) - } \\
\text { fluor- } \\
\text { anthene }\end{array}$ & $\begin{array}{l}\text { Benzo }(k)- \\
\text { fluor- } \\
\text { anthene }\end{array}$ & $\begin{array}{l}\text { Benzo (a) - } \\
\text { pyrene }\end{array}$ & $\begin{array}{c}\text { Indeno- } \\
(1,2,3-c, d) \\
\text { pyrene }\end{array}$ & $\begin{array}{c}\text { Dibenzo- } \\
(\mathrm{a}, \mathrm{h}) \\
\text { anthracene }\end{array}$ & $\begin{array}{c}\text { Benzo- } \\
\text { (g,h,i) } \\
\text { perylene }\end{array}$ \\
\hline $\begin{array}{l}\text { Comp LC } \\
\text { Comp USFC } \\
\text { Comp FSFC } \\
\text { CompIHC-1 } \\
\text { Comp (ه) }\end{array}$ & $\begin{array}{l}13.75 \\
24.06 \\
11.68 \\
13.51 \\
12.90\end{array}$ & $\begin{array}{r}1122.04 \\
1611.10 \\
155.74 \\
26.50 \\
264.42\end{array}$ & $\begin{array}{r}2029.24 \\
1495.30 \\
645.98 \\
204.15 \\
247.67\end{array}$ & $\begin{array}{r}204.22 \\
287.95 \\
39.90 \\
16.58 \\
57.83\end{array}$ & $\begin{array}{r}284.65 \\
239.86 \\
64.47 \\
24.57 \\
69.77\end{array}$ & $\begin{array}{r}751.27 \\
371.99 \\
332.28 \\
113.92 \\
80.70\end{array}$ & $\begin{array}{r}384.15 \\
173.52 \\
153.85 \\
68.99 \\
40.39\end{array}$ & $\begin{array}{r}418.62 \\
193.35 \\
179.45 \\
59.59 \\
43.72\end{array}$ & $\begin{array}{l}84.44 \\
46.26 \\
39.90 \\
14.43 \\
26.59\end{array}$ & $\begin{array}{r}10.69 \\
5.74 \mathrm{~J}(\mathrm{a}) \\
6.93 \mathrm{~J}(\mathrm{~b}) \\
8.88 \mathrm{U}^{(b)} \\
8.84 \mathrm{~J}\end{array}$ & $\begin{array}{l}78.62 \\
51.87 \\
48.72 \\
22.21 \\
33.18\end{array}$ \\
\hline
\end{tabular}

(a) J Analyte detected below method detection limit (MDL), but above instrument detection Iimit (IDL).

(b) $U$ Analyte was not present above the level of the associated value. 


\section{TABLE F. 14. Quality Control Summary for Low Molecular Weight Polynuclear Aromatic Hydrocarbons (LPAHs) in the Tissues of M. nasuta, Wet} Weight, United Heckathorn Remedial Investigation

Sediment

Treatment

Method Blank

Blank

Matrix Spikes

Comp FSFC Rep 4
Comp FSFC Rep $4 \mathrm{NS}$
Concentration Recovered
Amount Spiked
Percent Recovery
Comp FSFC Rep 4
Comp FSFC Rep $4 \mathrm{NSD}$
Concentration Recovered
Amount Spiked
Percent Recovery
RPD
I-Stat

\begin{tabular}{|c|c|c|c|c|c|c|c|}
\hline $\begin{array}{l}\text { Naph- } \\
\text { thalene }\end{array}$ & $\begin{array}{c}\text { 2-methyl } \\
\text { Naph- } \\
\text { thalene }\end{array}$ & $\begin{array}{c}\text { 1-methyl } \\
\text { Naph- } \\
\text { thalene }\end{array}$ & $\begin{array}{l}\text { Acenaph- } \\
\text { thylene }\end{array}$ & $\begin{array}{l}\text { Acenaph- } \\
\text { thene }\end{array}$ & Fluorene & $\begin{array}{l}\text { Phenan- } \\
\text { threne }\end{array}$ & $\begin{array}{l}\text { Anthra- } \\
\text { cene }\end{array}$ \\
\hline
\end{tabular}

$$
\begin{array}{lllllllll}
0.47 \mathrm{~J}(\mathrm{a}) & 0.23 \mathrm{~J} & 0.22 \mathrm{~J} & 0.18 \mathrm{~J} & 0.24 \mathrm{~J} & 0.26 \mathrm{~J} & 0.58 \mathrm{~J} & 0.31 \mathrm{~J}
\end{array}
$$

\begin{tabular}{|c|c|c|c|c|c|c|c|}
\hline $\begin{array}{r}1.01 \mathrm{~J} \\
88.68\end{array}$ & ${ }_{N A}^{0.3 Z}(b)^{\mathrm{J}}$ & $\begin{array}{l}1.05 \\
\text { NA }\end{array}$ & $\begin{array}{r}1.17 \mathrm{~J} \\
93.11\end{array}$ & $\begin{array}{r}15.58 \\
112.82\end{array}$ & $\begin{array}{r}20.30 \\
116.00\end{array}$ & $\begin{array}{l}163.64 \\
255.75\end{array}$ & $\begin{array}{r}36.90 \\
121.42\end{array}$ \\
\hline 87.67 & $N A$ & NA & 91.94 & 97.24 & 95.7 & 92.11 & 84.52 \\
\hline 104.09 & NS $(c)$ & NS & 104.09 & 104.09 & 104.09 & 104.09 & 104.09 \\
\hline $84 \%$ & $\mathrm{NA}$ & NA & $88 \%$ & $93 \%$ & $92 \%$ & $88 \%$ & $81 \%$ \\
\hline $1.01 \mathrm{~J}$ & $0.37 \mathrm{~J}$ & 1.05 & $1.17 \mathrm{~J}$ & 15.58 & 20.30 & 163.64 & 36.90 \\
\hline 85.90 & & NA & 89.39 & 116.59 & 116.02 & 361.47 & 150.69 \\
\hline 84.89 & NA & NA & 88.22 & 101.01 & 95.72 & 197.83 & 113.79 \\
\hline 99.14 & NS & NS & 99.14 & 99.14 & 99.14 & 99.14 & 99.14 \\
\hline $86 \%$ & NA & NA & $89 \%$ & $102 \%$ & $97 \%$ & $200 \%$ (d) & $115 \%$ \\
\hline $2 \%$ & NA & NA & $1 \%$ & $9 \%$ & $5 \%$ & $77 \%(\mathrm{e})$ & $34 \%(e)$ \\
\hline 0.01 & NA & NA & 0.00 & 0.04 & 0.02 & 0.39 & 0.17 \\
\hline
\end{tabular}

(a) J Analyte detected below method detection limit (MDL), but above instrument detection 1imit (IDL).

(b) NA Not applicable.

(c) NS Not spiked.

(d) Recovery outside of quality control range (40\%-120\%).

(e) Value exceeds relative precision goal of $\leq 30 \%$ 
TABLE F. 15. Quality Control Summary for High Molecular Weight Polynuclear Aromatic Hydrocarbons (HPAHs) in Tissues of M. nasuta, Wet Weight, United Heckathorn Remedial Investigation

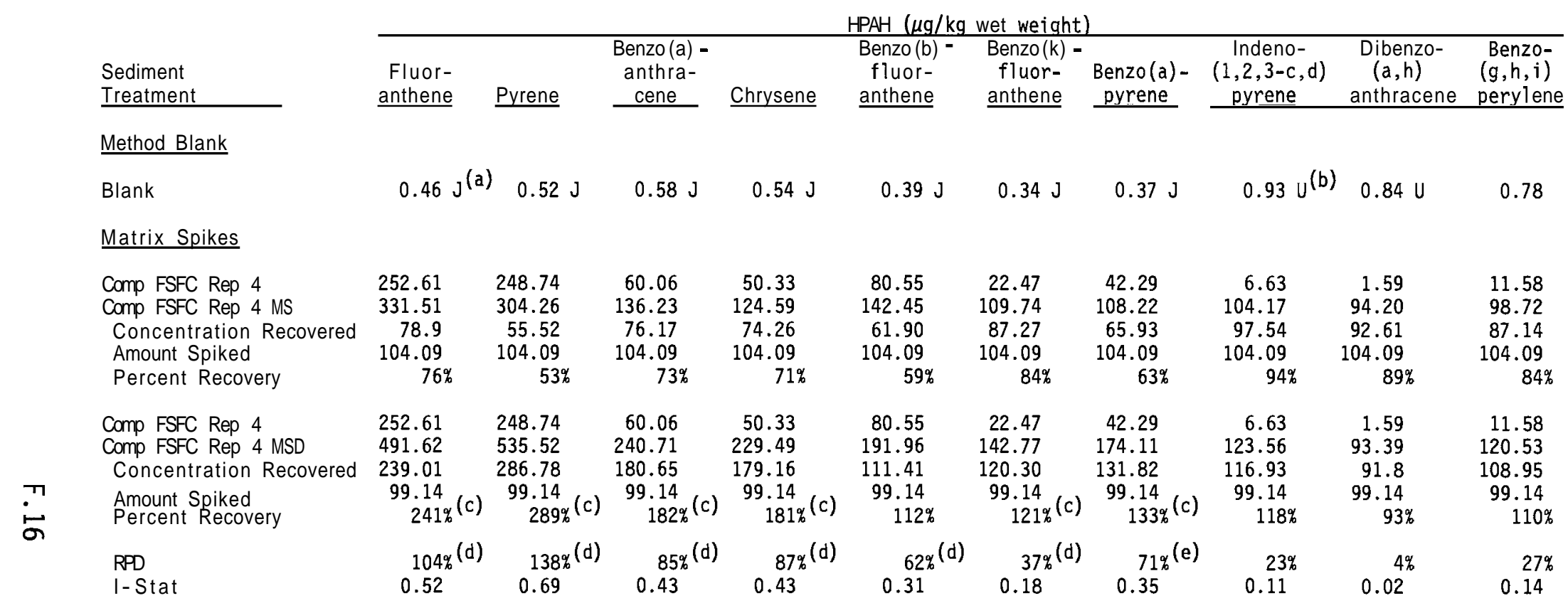

(a) J Analyte detected below method detection limit (MDL), but above instrument detection limit (IDL).

(b) $U$ Analyte was not present above the level of the associated value.

(c) Recovery outside of quality control range $(40 \%-120 \%)$

(d) Value exceeds relative precision goal of $\leq 30 \%$ 
TABLE F.16. Surrogate Recoveries for Analysis of Polynuclear Aromatic Hydrocarbons (PAHs) in Tissues of M. nasuta, United Heckathorn Remedial Investigation

Sediment

Treatment

Comp LC

Comp USFC

Comp FSFC

Comp IHC-1

Comp GD

\begin{tabular}{ccc}
\multicolumn{3}{c}{ Surroqate Percent Recoveries } \\
\cline { 1 - 2 } Naphthalene-d8 & Acenaphthene-d10 & Benzo[a]pyrene-d12 \\
\cline { 3 - 4 } 65.70 & 70.88 & 68.07 \\
66.89 & 70.36 & 65.68 \\
70.50 & 72.66 & 67.69 \\
70.71 & 73.77 & 64.95 \\
69.97 & 66.27 & 62.34
\end{tabular}

Qualitv Control Data

Blank

81.03

76.57

56.95

Comp FSFC Rep 4

Comp FSFC Rep 4 MS

66.13

Comp FSFC Rep 4 MSD

75

75

72.59

71

71

72.80

73

75 
TABLE F.17. Polychlorinated Biphenyls (PCBs) in Tissues of M. nasuta, Wet Weight, United Heckathorn Remedial Investigation

Sediment Treatment

Target DL (a)

Achieved DL High

Achieved DL Low

Comp LC

Comp USFC

Comp FSFC

Comp FSFC Rep 4

Comp IHC-1

Comp GD

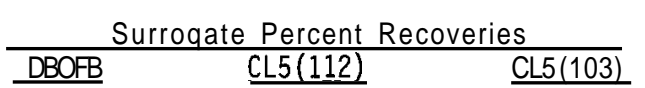

\section{NA $(b)$}

NA

NA

$\begin{array}{lll} & & \\ 89.36 & M(c) & 68.37 \\ 86.18 & 62.35 & 63.00 \\ 90.30 & 62.92 & 64.00 \\ 92.58 & 64.89 & 64.59 \\ 95.32 & 62.65 & 61.38 \\ 84.26 & 61.62 & 59.31\end{array}$

\begin{tabular}{|c|c|c|c|}
\hline \multicolumn{4}{|c|}{ PCBs $(\mu \mathrm{g} / \mathrm{kg}$ wet weight $)$} \\
\hline $\begin{array}{c}\text { Aroclor } \\
1242 \\
\end{array}$ & $\begin{array}{c}\text { Aroclor } \\
1248 \\
\end{array}$ & $\begin{array}{c}\text { Aroclor } \\
1254\end{array}$ & $\begin{array}{c}\text { Aroclor } \\
1260\end{array}$ \\
\hline $\begin{array}{l}20 \\
4.75 \\
3.24\end{array}$ & $\begin{array}{l}20 \\
4.75 \\
3.24\end{array}$ & $\begin{array}{l}20 \\
4.75 \\
3.24\end{array}$ & $\begin{array}{l}20 \\
4.75 \\
3.24\end{array}$ \\
\hline $\begin{array}{l}3.24 U^{(d)} \\
4.75 U \\
4.13 \mathrm{U} \\
3.27 \mathrm{U} \\
3.35 \mathrm{U} \\
4.52 \mathrm{U}\end{array}$ & $\begin{array}{l}3.24 U \\
4.75 U \\
4.13 U \\
3.27 U \\
3.35 U \\
4.52 U\end{array}$ & $\begin{array}{r}42.33 \\
43.64 \\
20.88 \\
28.95 \\
12.25 \\
7.09\end{array}$ & $\begin{array}{l}3.24 U \\
4.75 U \\
4.13 U \\
3.27 U \\
3.35 U \\
4.52 U\end{array}$ \\
\hline
\end{tabular}

(a) DL Detection limit.

(b) NA Not applicable.

(c) M Matrix interference.

(d) U Analyte not detected above the level of the associated value.

TABLE F.18. Polychlorinated Biphenyls (PCBs) in Tissues of M. nasuta, Dry Weight, United Heckathorn Remedial Investigation

Sediment Treatment

Comp LC

Comp USFC

Comp FSFC

Comp FSFC Rep 4

Comp IHC-1

Comp GD

\section{Percent Dry}

Weight

13.75
24.06
11.68
10.21
13.51
12.90

12.90

\begin{tabular}{|c|}
\hline $\begin{array}{l}\text { Aroclor } \\
1242 \\
\end{array}$ \\
\hline $\begin{array}{l}23.56 U^{(a)} \\
19.74 U^{(a)} \\
35.36 U \\
32.03 U \\
24.80 \mathrm{U} \\
35.04 \mathrm{U}\end{array}$ \\
\hline
\end{tabular}

PCBs $(\mu \mathrm{g} / \mathrm{kg} \mathrm{drv}$ weight $)$

Aroclor Aroclor

Aroclor

307.85

$23.56 \mathrm{U}$

$19.74 \mathrm{U}$

$35.36 \mathrm{U}$

$32.03 \mathrm{U}$

181.38

178.77

283.55

90.67

$35.04 \mathrm{U} \quad 54.96$
$23.56 \mathrm{U}$

$19.74 \mathrm{U}$

$35.36 \mathrm{U}$

$32.03 \mathrm{U}$

$24.80 \mathrm{U}$

$35.04 \mathrm{U}$

(a) U Analyte not detected above the level of the associated value. 
TABLE F. 19. Quality Control Summary for Polychlorinated Biphenyls (PCBs) in Tissues of M. nasuta, Wet Weight, United Heckathorn Remedial Investigation

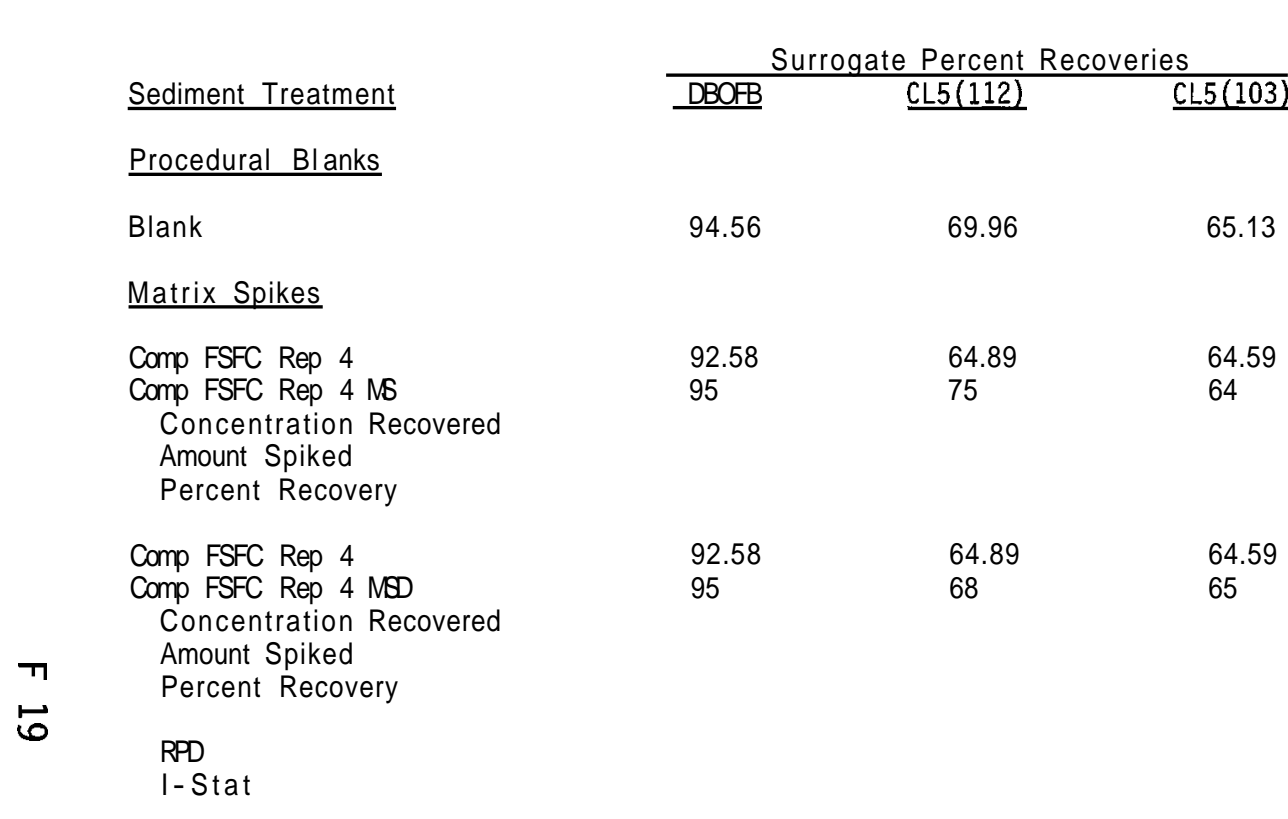

\begin{tabular}{|c|c|c|c|}
\hline \multicolumn{4}{|c|}{ PCBs $(\mu \mathrm{g} / \mathrm{kg}$ wet weight) } \\
\hline $\begin{array}{c}\text { Aroclor } \\
1242 \\
\end{array}$ & $\begin{array}{c}\text { Aroclor } \\
1248 \\
\end{array}$ & $\begin{array}{c}\text { Aroclor } \\
1254 \\
\end{array}$ & $\begin{array}{c}\text { Aroclor } \\
1260 \\
\end{array}$ \\
\hline $2.34 \mathrm{U}^{(\mathrm{a})}$ & $2.34 \mathrm{U}$ & $2.34 \mathrm{U}$ & $2.34 \mathrm{U}$ \\
\hline 3.27 & $3.27 \mathrm{U}$ & 28.95 & $3.27 \mathrm{U}$ \\
\hline$N A^{(b)}$ & NA & 69.93 & NA \\
\hline${ }^{N A}$ (c) & NA & 40.98 & NA \\
\hline$N S^{(C)}$ & NS & 83.28 & NS \\
\hline NA & NA & $49 \%$ & NA \\
\hline $3.27 \mathrm{U}$ & $3.27 \mathrm{U}$ & 28.95 & $3.27 \mathrm{U}$ \\
\hline NA & NA & 76.53 & NA \\
\hline NA & NA & 47.58 & NA \\
\hline NS & NS & 79.31 & NS \\
\hline NA & NA & $60 \%$ & NA \\
\hline NA & NA & $20 \%$ & NA \\
\hline NA & NA & 0.10 & NA \\
\hline
\end{tabular}

(a) U Analyte not detected above the level of the associated value.

(b) NA Not applicable.

(c) NS Not spiked. 
TABLE F.20. Metals in Tissues of M. nasuta, Wet Weight, United Heckathorn Remedial Investigation

\begin{tabular}{|c|c|c|c|c|c|c|c|c|c|c|c|}
\hline \multirow{2}{*}{$\begin{array}{l}\text { Sediment } \\
\text { Treatment } \\
\end{array}$} & \multirow{2}{*}{$\begin{array}{l}\% \text { Dry } \\
\text { Weight } \\
\end{array}$} & \multicolumn{10}{|c|}{ Metals (mg/kg wet weight) } \\
\hline & & $\mathrm{Ag}$ & As & $\mathrm{Cd}$ & $\mathrm{Cr}$ & CH & $\mathrm{Hg}$ & $\mathrm{Ni}$ & $\mathrm{Pb}$ & $\mathrm{Se}$ & $\mathrm{Zn}$ \\
\hline Comp LC & 12.90 & 0.08 & 3.6 & 0.05 & 0.22 & 3.2 & 0.017 & 0.5 & 0.36 & 0.24 & 13.3 \\
\hline Comp USFC & 14.62 & 0.10 & 4.4 & 0.04 & 0.30 & 3.5 & 0.020 & 0.7 & 0.34 & 0.27 & 14.4 \\
\hline Comp FSFC & 12.06 & 0.07 & 3.1 & 0.05 & 0.27 & 2.6 & 0.016 & 0.4 & 0.23 & 0.22 & 15.1 \\
\hline Comp IHC-1 & 12.39 & 0.06 & 4.1 & 0.06 & 0.33 & 2.5 & 0.017 & 0.6 & 0.31 & 0.18 & 12.0 \\
\hline Comp GD & 13.63 & 0.06 & 3.8 & 0.04 & 0.39 & 2.6 & 0.019 & 0.6 & 0.23 & 0.28 & 16.6 \\
\hline
\end{tabular}

TABLE F.21. Results and Quality Control Summary for Metals in Tissues of M. nasuta, Dry Weight, United Heckathorn Remedial Investigation

Sediment

Treatment

Target $\mathrm{DL}(\sim)$

Achieved DL

Comp LC

Comp USFC

Comp FSFC

Comp IHC- 1

Comp GD

\begin{tabular}{llll} 
& & & \multicolumn{2}{c}{ Ag } & As & Cd & $-\underline{C r}$ \\
0.10 & 2.0 & 0.10 & 1.00 \\
0.01 & 2.0 & 0.04 & 0.35 \\
& & & \\
0.63 & 28.1 & 0.40 & 1.69 \\
0.66 & 30.3 & 0.29 & 2.06 \\
0.59 & 25.5 & 0.39 & 2.20 \\
0.50 & 32.7 & 0.45 & 2.67 \\
0.47 & 28.2 & 0.33 & 2.85
\end{tabular}

Metals (mq $/ \mathrm{kg}$ dry weight)

\begin{tabular}{cccccr}
$\mathrm{Cu}$ & $\mathrm{Hg}$ & $\mathrm{Ni}$ & $\mathrm{Ph}$ & $\mathrm{Se}$ & $\mathrm{Zn}$ \\
\cline { 6 - 7 } & & & & & \\
4.3 & 0.010 & 1.0 & 1.00 & 1.00 & 35.0 \\
4.3 & 0.002 & 1.0 & 0.08 & 1.00 & 35.0 \\
24.6 & 0.131 & 3.7 & 2.82 & 1.84 & 103.0 \\
24.1 & 0.136 & 5.1 & 2.35 & 1.85 & 98.5 \\
21.8 & 0.131 & 3.1 & 1.88 & 1.80 & 125.0 \\
20.4 & 0.138 & 4.9 & 2.47 & 1.48 & 96.8 \\
18.9 & 0.138 & 4.1 & 1.66 & 2.06 & 122.0
\end{tabular}

Quality Control Data

Method Blank

Blank

$$
0.01 U^{(b)} \mathrm{NA}^{(c)} 0.04 \mathrm{U} 0.52
$$

NA

$0.002 U$

NA

$0.084 \mathrm{U}$

NA

NA

Matrix Spike

$\begin{array}{lllllllllll}\text { Comp GD(d) } & 0.46 & 28.0 & 0.33 & 2.79 & 18.9 & 0.140 & 4.0 & 1.77 & 1.98 & 121.5 \\ \text { Comp GD NS } & 1.30 & \text { NA } & 2.44 & 6.43 & \text { NA } & 1.010 & \text { NA } & 3.64 & \text { NA } & \text { NA } \\ \text { Concentration Recovered } & 0.84 & \text { NA } & 2.11 & 3.64 & \text { NA } & 0.871 & \text { NA } & 1.87 & \text { NA } & \text { NA } \\ \text { Amount Spiked } & 1.00 & \text { NS }(\mathrm{e}) & 2.00 & 4.00 & \text { NS } & 1.00 & \text { NS } & 2.00 & \text { NS } & \text { NS } \\ \text { Percent Recovered } & 84 \% & \text { NA } & 106 \% & 91 \% & \text { NA } & 87 \% & \text { NA } & 94 \% & \text { NA } & \text { NA }\end{array}$

$\underline{\text { Standard Reference Material }}$

\section{Certified}

Value 1566a

SRM1566a

Analytical Duplicate

Comp GD
Comp GD Duplicate
RPD
l-Stat

$$
\begin{array}{lllll}
\text { NA } & 14.0 & \text { NA } & \text { NA } & 66.3 \\
\text { NA } & \pm 1.2 & \text { NA } & \text { NA } & \pm 4.3
\end{array}
$$$$
\text { NA } 14.4
$$$$
\text { NA }
$$$$
\text { NA }
$$

65.6

\begin{abstract}
NA 2.3
\end{abstract}
NA 2.21

830

NA \pm 0.4

NA \pm 0.24

$\pm 57$

NA 2.2

NA 2.44

868

$\begin{array}{llllllllll}0.47 & 28.2 & 0.33 & 2.85 & 18.9 & 0.138 & 4.1 & 1.66 & 2.06 & 122.0 \\ 0.45 & 27.8 & 0.33 & 2.72 & 18.9 & 0.141 & 3.8 & 1.87 & 1.90 & 121.0 \\ 4 \% & 1 \% & 0 \% & 5 \% & 0 \% & 2 \% & 8 \% & 12 \% & 8 \% & 1 \% \\ 0.02 & 0.01 & 0.00 & 0.02 & 0.00 & 0.01 & 0.04 & 0.06 & 0.04 & 0.00\end{array}$
(a) DL Detection Iimit.
(b) U Analyte was not present above the associated value.
(c) NA Not applicable.
(d) Mean of replicated sample.
(e) NS Not spiked. 


\section{TABLE F.22. Results and Quality Control Summary for Butyltins in Tissues of M. nasuta, United Heckathorn Remedial Investigation}

Sediment

Treatment

Target $\mathrm{DL}^{(\mathrm{a})}$

Surrogate

Percent

Achieved DL

$$
\text { Recovery }
$$

Tripentyltin

\section{M. nasuta Butyltins}

$\frac{(\mu \mathrm{g} / \mathrm{kg} \text { dry weight })}{\text { Tri- }}$

butyltin

butyltin

$$
\begin{aligned}
& \text { NA } \\
& \text { NA }
\end{aligned}
$$

Comp LC

Comp USFC

Comp FSFC

Comp IHC-1

Comp GD

Quality Control Data

Method Blank

Blank

$111 \%$

$$
\begin{array}{r}
10 \\
0.5
\end{array}
$$

$106 \%$

$103 \%$

$104 \%$

$109 \%$

$101 \%$

$0.5 u^{(c)}$

$1.4 \mathrm{U}$

NA

Matrix Spikes

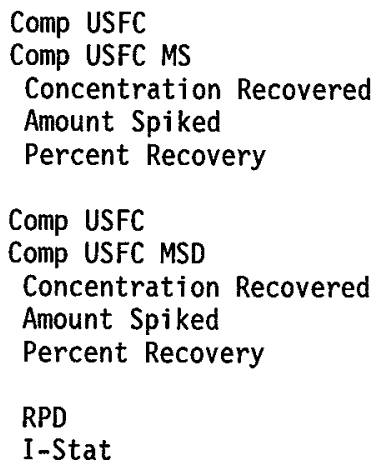

Analytical Duplicate

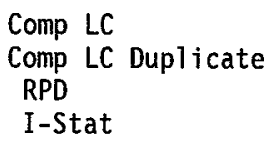

\begin{tabular}{|c|c|c|c|}
\hline $\begin{array}{r}103 \% \\
99 \%\end{array}$ & $\begin{array}{r}43.9 \\
377.7 \\
333.8 \\
354.6 \\
94 \%\end{array}$ & $\begin{array}{r}26.8 \\
386.6 \\
359.8 \\
354.6 \\
101 \%\end{array}$ & $\begin{array}{c}14.78 \\
\text { NA }\end{array}$ \\
\hline $\begin{array}{l}103 \% \\
100 \%\end{array}$ & $\begin{array}{c}43.9 \\
374.3 \\
330.4 \\
367.7 \\
90 \% \\
5 \% \\
0.02\end{array}$ & $\begin{array}{c}26.8 \\
397.9 \\
371.1 \\
367.7 \\
101 \% \\
1 \% \\
0.00\end{array}$ & $\begin{array}{c}14.78 \\
\text { NA }\end{array}$ \\
\hline $\begin{array}{r}106 \% \\
96 \%\end{array}$ & $\begin{array}{c}41.8 \\
39.4 \\
6 \% \\
0.03\end{array}$ & $\begin{array}{c}26.0 \\
29.0 \\
11 \% \\
0.05\end{array}$ & $\begin{array}{c}13.11 \\
\text { NA }\end{array}$ \\
\hline
\end{tabular}

\footnotetext{
(a) DL Detection limit.

(b) NA Not applicable.

(c) U Analyte was not present above the associated value.
} 


\section{QA/QC SUMMARY}

PROGRAM:

PARAMETER:

LABORATORY:

MATRIX:

SAMPLE NUMBER: 30

\section{QA/QC REQUIREMENTS}

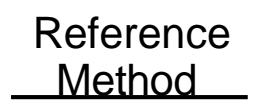

Bligh \& Dyer

$$
\begin{array}{r}
\text { Range of } \\
\text { Recovery } \\
\hline
\end{array}
$$

NA \begin{tabular}{l} 
Relative \\
Precision \\
\hline
\end{tabular}

$\pm 30 \%$

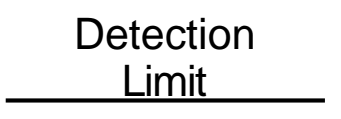

$0.1 \%$ wet weight

\section{HOLDING TIMES}

The following is a list of extraction and analysis dates for the 2 batches of tissue samples analyzed for lipids:

\begin{tabular}{cccc}
$\begin{array}{c}\text { Date } \\
\text { Collected }\end{array}$ & $\begin{array}{c}\text { Date } \\
\text { Received }\end{array}$ & $\begin{array}{c}\text { Date } \\
\text { Extracted }\end{array} \quad \begin{array}{c}\text { Lipid } \\
\text { Analvsis }\end{array}$ \\
\hline
\end{tabular}

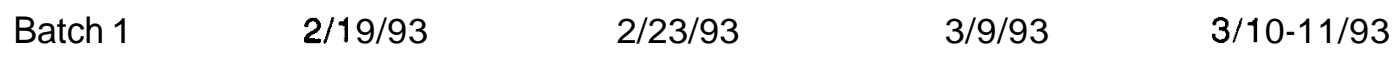

$\begin{array}{llll}\text { Batch } 2 & 2 / 19 / 93 & 3 / 23 / 93 & 3 / 11-15 / 93\end{array}$

Holding times for extractions and analyses were met.

\section{PROCEDURAL BLANKS}

Lipids were not measured in procedural blanks.

\section{MATRIX SPIKES}

Matrix spikes are not applicable to lipid analysis.

\section{SURROGATES}

Surrogates are not applicable to lipid analysis.

\section{DUPLICATES}

Two samples were analyzed in duplicate for lipids. Precision was acceptable (RPDs $1 \%$ and $6 \%$ ) in both sets of duplicates. 


\section{DETECTION LIMITS}

Target detection limits were met for lipid analysis. 


\section{QA/QC SUMMARY}

PROGRAM:

PARAMETER:

LABORATORY:

MATRIX:

SAMPLE NUMBER: 25

\section{QA/QC REQUIREMENTS}

\begin{tabular}{|c|c|c|c|}
\hline $\begin{array}{l}\text { Reference } \\
\text { Method }\end{array}$ & $\begin{array}{l}\text { Range of } \\
\text { Recovery }\end{array}$ & $\begin{array}{l}\text { Relative } \\
\text { Precision }\end{array}$ & $\begin{array}{c}\text { Detection } \\
\text { Limit }\end{array}$ \\
\hline Modified 8080 & $40 \%-120 \%$ & $\pm 30 \%$ & $\begin{array}{c}2 \mu \mathrm{g} / \mathrm{kg} \text { wet weight } \\
\text { (30 } \mu \mathrm{g} / \mathrm{kg} \text { for toxaphene) }\end{array}$ \\
\hline
\end{tabular}

United Heckathorn Remedial Investigation

Chlorinated Pesticides

Battelle Ocean Sciences Laboratory

$\mathrm{M}$ nasutatissue
(30 $\mu \mathrm{g} / \mathrm{kg}$ for toxaphene)

\section{HOLDING TIMES}

The following is a list of extraction and analysis dates for the two batches of tissue samples analyzed for pesticides:

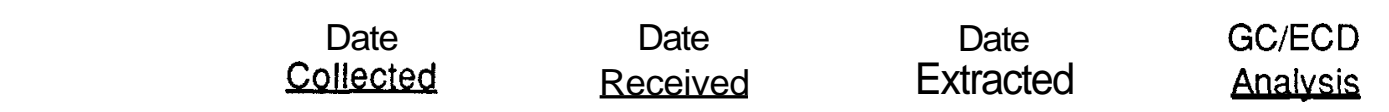

Batch 1

$2 / 19 / 93$

$2 / 23 / 93$

$3 / 9 / 93$

4/7-9/93, 4/10/93 (dilutions)

Batch 2

2/19/93

2/23/93

3/9/93

3/29-31/93, 4/10/93 (dilutions),

5/17/93 (reanalysis)

Batch 3

$2 / 19 / 93$

2/23/93

$4 / 28 / 93$

$5 / 17 / 93$

(rerun)

Holding times for extractions and analyses were met.

\section{PROCEDURAL BLANKS}

One procedural blank was processed with each batch of samples. Endrin aldehyde was detected above the method detection limit in the blanks for all three batches. Sample results less than five times the concentration in the associated blank were flagged as not detected. Affected samples were Comp LC, Replicate 1 and Comp IHC-1,Replicate 3. 


\section{MATRIX SPIKES}

The recoveries of target pesticides in the MS and MSD samples were acceptable for Batch 1 with the exception of low recoveries of alpha-BHC and delta-BHC $(35 \%$ and $40 \%$, respectively). In Batches 1 and 2, recoveries for DDE, DDD, and endrin aldehyde could not be quantified because of matrix interference. Dieldrin could not be quantified in Batch 2. The MS and MSD recoveries for all other compounds in Batch 2 were acceptable.

\section{SURROGATES}

The recovery of one surrogate compound (DBOFB) was less than $40 \%$ in one procedural blank and in one sample in Batch 1. In Batch 2, the recovery of another surrogate compound [CL5(112)], could not be determined in three samples because of matrix interferences. Surrogate recoveries for all other samples were acceptable.

\section{DUPLICATES}

Duplicate precision between the MS and MSD samples was very good for all compounds in all batches. Precision of laboratory duplicates could be evaluated for three compounds (dieldrin, 4,4'-DDE, and 4,4'-DDD) that had detected values greater than 10 times the achieved detection limit. RPDs ranged from $22 \%$ to $49 \%$, with three RPDs exceeding the $30 \%$ limit. The high RPDs were probably due to the relatively low values rather than sample inhomogeneity; the acceptable MS/MSD RPDs indicate acceptable analytical precision.

\section{DETECTION LIMITS}

Target detection limits were met for tissue pesticide analyses. 


\section{QA/QC SUMMARY}

PROGRAM:

PARAMETER:

LABORATORY:

MATRIX:

SAMPLE NUMBER:
United Heckathorn Remedial Investigation

Polynuclear Aromatic Hydrocarbons (PAH)

Battelle Ocean Sciences Laboratory

M. nasuta tissue

5

\section{QA/QC REQUIREMENTS}
Reference
Method
\begin{tabular}{l}
$\begin{array}{l}\text { Range of } \\
\text { Recovery }\end{array}$ \\
\hline
\end{tabular}
Relative
Precision
Detection
Limit
Modified 8270
$40 \%-120 \%$
$\pm 30 \%$
$20 \mu \mathrm{g} / \mathrm{kg}$ wet weight

\section{HOLDING TIMES}

Tissue samples for PAH analysis were extracted as part of pesticide Batch 2:

Batch 2

Date
Collected

$2 / 19 / 93$

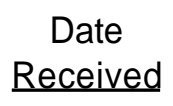

$2 / 23 / 93$

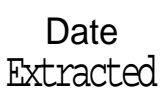

$3 / 9 / 93$
GC/MS

Analvsis

$3 / 23-24 / 93$

$4 / 28 / 93$

(MS background only)

The holding times for all extractions and analyses were met.

\section{PROCEDURAL BLANKS}

One procedural blank was processed with the batch of samples. No PAHs were detected above the method detection limit in the procedural blank.

\section{MATRIX SPIKES}

The recoveries of target PAHs in the MS were acceptable. Recoveries of 7 of $16 \mathrm{PAH}$ compounds exceeded quality control limits in the MSD: phenanthrene, fluoranthene, pyrene, benzo[a]anthracene, chrysene, benzo[k]fluoranthene, and benzo[a]pyrene. These seven compounds were present in the unspiked sample at relatively high concentrations. 


\section{SURROGATES}

All tissue PAH surrogate recoveries were acceptable.

\section{DUPLICATES}

The relative percent difference (RPD) between MS and MSD samples were acceptable except where the background sample had high levels of PAHs (the seven compounds with high MSD recoveries, plus anthracene and benzo[b]fluoranthene). A sample duplicate was not analyzed because of the small number of samples and limited sample volume.

\section{DETECTION LIMITS}

Achieved detection limits were acceptable ( $\leq 20 \mathrm{yg} / \mathrm{kg}$ wet weight). 


\section{QA/QC SUMMARY}

PROGRAM:

PARAMETER:

LABORATORY:

MATRIX:

SAMPLE NUMBER:
United Heckathorn Remedial Investigation

Polychlorinated Biphenyls (PCB)

Battelle Ocean Sciences Laboratory

M. nasutatissue

\section{QA/QC REQUIREMENTS}

\begin{tabular}{|c|c|c|c|}
\hline $\begin{array}{l}\text { Reference } \\
\text { Method }\end{array}$ & $\begin{array}{l}\text { Range of } \\
\text { Recovery }\end{array}$ & $\begin{array}{l}\text { Relative } \\
\text { Precision }\end{array}$ & $\begin{array}{l}\text { Detection } \\
\text { Limit }\end{array}$ \\
\hline Modified 8080 & $40 \%-120 \%$ & $\pm 30 \%$ & $20 \mu \mathrm{g} / \mathrm{kg} \mathrm{w}$ \\
\hline
\end{tabular}

\section{HOLDING TIMES}

Tissue samples analyzed for PCBs were extracted and analyzed with pesticide Batch 2 on these dates:

$\begin{array}{ccccc} & \begin{array}{c}\text { Date } \\ \text { Collected }\end{array} & \begin{array}{c}\text { Date } \\ \text { Received }\end{array} & \begin{array}{c}\text { Date } \\ \text { Extracted }\end{array} & \begin{array}{c}\text { GC/ECD } \\ \text { Analvsis }\end{array} \\ \text { Batch 2 } & 2 / 19 / 93 & 2 / 23 / 93 & 3 / 9 / 93 & \begin{array}{c}3 / 29-31 / 93, \\ 4 / 10 / 93 \text { (dilutions) }\end{array} \\ & & & & \end{array}$

Holding times for extractions and analyses were met.

\section{PROCEDURAL BLANKS}

One procedural blank was processed with the batch. No PCB compounds were detected in the blank.

\section{MATRIX SPIKES}

The recoveries of Aroclor 1254 in the MS and MSD samples were within quality control limits.

\section{SURROGATES}

The surrogate CL5(112) could not be measured in Comp GD tissue because of matrix interference; recoveries of the other two surrogates were acceptable in Comp GD. The recoveries of all three surrogate compounds were acceptable in all other samples. 


\section{DUPLICATES}

Duplicate precision between the MS and MSD samples was acceptable. Sample duplicates were not analyzed.

\section{DETECTION LIMITS}

Achieved detection limits for PCBs in tissues ranged from 3.35 to $4.75 \mathrm{yglkg}$ wet weight, well below the target detection limit of $20 \mathrm{yglkg}$. 


\section{QA/QC SUMMARY}

PROGRAM:

PARAMETER:

LABORATORY:

MATRIX:

SAMPLE NUMBER
United Heckathorn Remedial Investigation

Metals

Battelle Marine Sciences Laboratory

M. nasutatissue

5

\section{QA/QC REQUIREMENTS}

\begin{tabular}{|c|c|c|c|}
\hline $\begin{array}{l}\text { Reference } \\
\text { Method }\end{array}$ & $\begin{array}{l}\text { Range of } \\
\text { Recovery }\end{array}$ & $\begin{array}{l}\text { Relative } \\
\text { Precision }\end{array}$ & $\begin{array}{l}\text { Detection } \\
\text { Limit } \\
\end{array}$ \\
\hline $\begin{array}{c}\text { Varies by } \\
\text { metal }\end{array}$ & $\begin{array}{l}75 \%-125 \% \\
<30 \% \text { from } \\
\text { certified value } \\
\text { for SRM }\end{array}$ & $\pm 20 \%$ & $\begin{array}{c}\text { Varies by } \\
\text { metal }\end{array}$ \\
\hline
\end{tabular}

\section{HOLDING TIMES}

Tissue samples were received 2/19/93. The following table summarizes all analysis dates:

Task

Date Performed

APDC

GFAA analysis-silver

$3 / 5 / 93$

GFAA analysis-cadmium

$4 / 23 / 93$

GFAA analysis-chromium

$4 / 22 / 93$

GFAA analysis-lead

$4 / 23 / 93$

CVAA analysis-mercury

$4 / 23 / 93$

$3 / 11 / 93$

XRF analysis-arsenic, copper, nickel, selenium, zinc

$3 / 15 / 93$

The holding times were met for all analyses.

\section{PROCEDURAL BLANKS}

One procedural blank was analyzed with all metals analyzed by AA. Silver, cadmium, mercury, and lead were undetected in the blank. Chromium was detected in the blank but at a level less than the target detection limit. All GFAA metal values are blankcorrected. 


\section{MATRIX SPIKES}

One matrix spike sample was analyzed for all metals analyzed by AA. Matrix spike recoveries ranged from $84 \%$ to $106 \%$; all were within the QC limits of $75 \%$ to $125 \%$.

\section{DUPLICATES}

One sample was analyzed in duplicate. The relative percent difference (RPD) for all metals were 0 to $12 \%$, within the acceptable range of $\leq 20 \%$.

\section{DETECTION LIMITS}

Target detection limits were met for all metals. 


\section{QA/QC SUMMARY}

PROGRAM:

United Heckathorn Remedial Investigation

PARAMETER:

Butyltins

LABORATORY:

MATRIX:

Battelle Marine Sciences Laboratory

SAMPLE NUMBER:

$M$. nasuta tissue

\section{QA/QC REQUIREMENTS}

\begin{tabular}{lccc}
$\begin{array}{l}\text { Reference } \\
\text { Method }\end{array}$ & $\begin{array}{c}\text { Range of } \\
\text { Recovery }\end{array}$ & $\begin{array}{c}\text { Relative } \\
\text { Precision }\end{array}$ & $\begin{array}{c}\text { Detection } \\
\text { Limit }\end{array}$ \\
\cline { 5 - 5 } Unger, et. al & $40 \%-120 \%$ & $\pm 30 \%$ & $10 \mu \mathrm{g} / \mathrm{kg}$ dry weight
\end{tabular}

\section{HOLDING TIMES}

Extraction and analysis dates for the batch of tissue samples analyzed for butyltins were as follows:

\begin{tabular}{|c|c|c|c|c|}
\hline & Date & Date & Date & GC/FPD \\
\hline & Collected & $\underline{\text { Received }}$ & Extracted & Analvsis \\
\hline atch 1 & $2 / 19 / 93$ & 2/19/93 & $3 / 2 / 93$ & $3 / 10 / 93$ \\
\hline
\end{tabular}

The holding times for extractions and analyses were met.

\section{PROCEDURAL BLANKS}

One blank was processed with the batch of samples. No butyltins were detected in the blank.

\section{MATRIX SPIKES}

The recoveries of tributyltin and dibutyltin in the MS and MSD samples ranged from $90 \%$ to $101 \%$, with precision between the MS and MSD 5\% for tributyltin and $1 \%$ for dibutyltin. Both recoveries and RPDs were within acceptable limits.

\section{SURROGATES}

One SIS, tripentyltin chloride, is added prior to extraction to assess the efficiency of the method. All sample data are corrected for the recovery of this compound. Surrogate recoveries for all samples were within the QC limits. 


\section{DUPLICATES}

Relative percent differences between the analytical duplicates were within the QC limit of $30 \%$.

\section{DETECTION LIMITS}

Target detection limits of $10 \mu \mathrm{g} / \mathrm{kg}$ dry weight were met for all butyltin compounds. 

APPENDIX G

LIQUID-PHASE CHEMISTRY AND QUALITY ASSURANCE DATA 

TABLE G.1. Total Suspended Solids, United Heckathorn Remedial Investigation

\begin{tabular}{c} 
Sediment \\
Treatment \\
\hline
\end{tabular}

Site Water

Procedural Blank

Comp LC SPP

Comp LC ELUT

Comp LC-5 SPP

Comp LC-5 ELUT

Comp LC-6 SPP

Comp LC-6 ELUT

Comp USFC SPP

Comp USFC ELUT

Comp FSFC SPP

Comp FSFC ELUT

Comp IHC-1 SPP

Comp IHC-1 ELUT

Comp IHC-2 SPP

Comp IHC-2 ELUT

Comp IHC-3 SPP

Comp IHC-3 ELUT

\section{Batch}

Quality Control Samples

Method Blanks

Blank

Blank

Analytical Duplicates

Comp LC SPP

Comp LC SPP Duplicate

$\mathrm{RPD}$

I-Stat

Comp FSFC SPP

Comp FSFC SPP Duplicate

RPD

I-Stat
1

1

1

1

1

1

1

2

2

2

2

2

Solids $(\mathrm{mg} / \mathrm{L})$

14

8

41

8

57

20

59

36

62

8

42

34

3

52

0

40

2

1

3
3

1

41

46

$11 \%$

0.06

2

42

50

$17 \%$

0.09 
TABLE G.2. Chlorinated Pesticides (elution order, Alpha-BHC to Endosulfan I) in Liquid Phase Samples, United Heckathorn Remedial Investigation

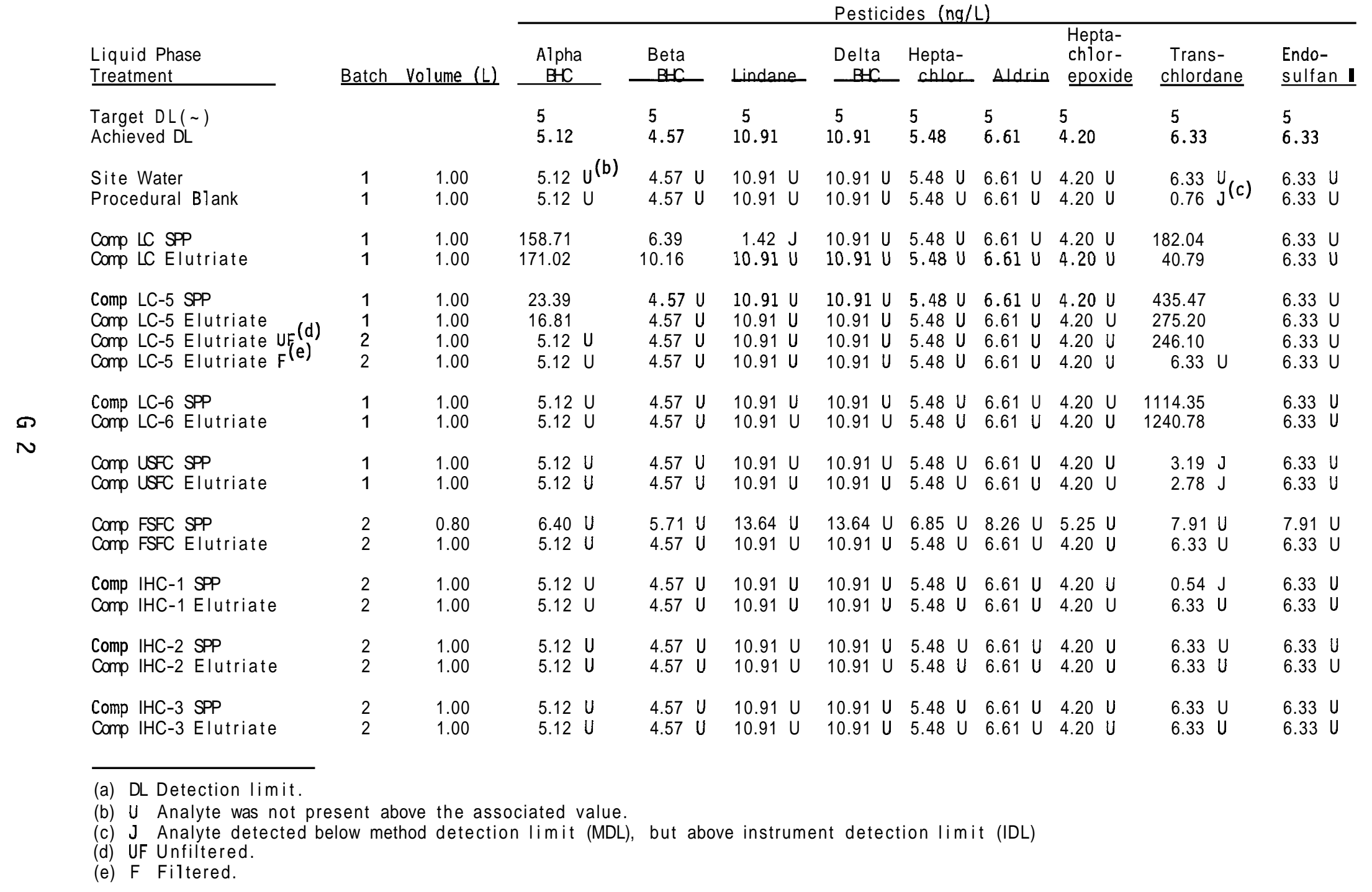


TABLE G.3. Chlorinated Pesticides (elution order, cis-Chlordane to Endosulfan II) in Liquid Phase Samples, United Heckathorn Remedia1 Investigation

\begin{tabular}{|c|c|c|c|c|c|c|c|}
\hline \multirow[b]{2}{*}{$\begin{array}{l}\text { Liquid Phase } \\
\text { Treatment }\end{array}$} & \multirow[b]{2}{*}{ Batch } & \multirow[b]{2}{*}{$\begin{array}{c}\text { Vol ume } \\
\text { (L) }\end{array}$} & \multicolumn{5}{|c|}{ Pesticides (nq/L) } \\
\hline & & & $\begin{array}{c}\text { cis- } \\
\text { Chlordane } \\
\end{array}$ & Dieldrin & $4,4^{\prime}-$ DDE & Endrin & $\begin{array}{c}\text { Endo- } \\
\text { sulfan II } \\
\end{array}$ \\
\hline $\begin{array}{l}\text { Target } D^{(a)} \\
\text { Achieved } D L\end{array}$ & & & $\begin{array}{l}5 \\
9.18\end{array}$ & $\begin{array}{l}5 \\
9.18\end{array}$ & $\begin{array}{l}5 \\
8.09\end{array}$ & $\begin{array}{l}5 \\
9.31\end{array}$ & $\begin{array}{l}5 \\
11.20\end{array}$ \\
\hline $\begin{array}{l}\text { Site Water } \\
\text { Procedural Blank }\end{array}$ & $\begin{array}{l}1 \\
1\end{array}$ & $\begin{array}{l}1.00 \\
1.00\end{array}$ & $\begin{array}{l}9.18 \mathrm{U}^{(\mathrm{b})} \\
0.16 \mathrm{~J}\end{array}$ & $\begin{array}{l}0.42 \mathrm{~J}^{(\mathrm{c})} \\
7.15 \mathrm{~J}\end{array}$ & $\begin{array}{l}8.09 \mathrm{U} \\
5.20 \mathrm{~J}\end{array}$ & $\begin{array}{l}9.31 \mathrm{U} \\
9.31 \mathrm{U}\end{array}$ & $\begin{array}{l}11.20 \mathrm{U} \\
11.20 \mathrm{U}\end{array}$ \\
\hline $\begin{array}{l}\text { Comp LC SPP } \\
\text { Comp LC Elutriate }\end{array}$ & $\begin{array}{l}1 \\
1\end{array}$ & $\begin{array}{l}1.00 \\
1.00\end{array}$ & $\begin{array}{l}46.96 \\
10.03\end{array}$ & $\begin{array}{l}447.81 \\
546.42\end{array}$ & $\begin{array}{l}610.58 \\
522.23\end{array}$ & $\begin{array}{r}15.53 \\
9.31 \mathrm{U}\end{array}$ & $\begin{array}{l}11.20 \mathrm{U} \\
11.20 \mathrm{U}\end{array}$ \\
\hline $\begin{array}{l}\text { Comp LC-5 SPP } \\
\text { Comp LC-5 Elutriate } \\
\text { Comp LC-5 Elutriate UF (d) } \\
\text { Comp LC-5 Elutriate F }\end{array}$ & $\begin{array}{l}1 \\
1 \\
2 \\
2\end{array}$ & $\begin{array}{l}1.00 \\
1.00 \\
1.00 \\
1.00\end{array}$ & $\begin{array}{r}189.15 \\
129.82 \\
70.60 \\
65.16\end{array}$ & $\begin{array}{l}4653.19 \\
3332.02 \\
2965.91 \\
2159.40\end{array}$ & $\begin{array}{l}7578.31 \\
4495.13 \\
3529.10 \\
2811.08\end{array}$ & $\begin{array}{l}9.31 \mathrm{U} \\
9.31 \mathrm{U} \\
9.31 \mathrm{U} \\
9.31 \mathrm{U}\end{array}$ & $\begin{array}{l}11.20 \mathrm{U} \\
11.20 \mathrm{U} \\
11.20 \mathrm{U} \\
11.20 \mathrm{U}\end{array}$ \\
\hline $\begin{array}{l}\text { Comp LC-6 SPP } \\
\text { Comp LC-6 Elutriate }\end{array}$ & $\begin{array}{l}1 \\
1\end{array}$ & $\begin{array}{l}1.00 \\
1.00\end{array}$ & $\begin{array}{l}710.01 \\
400.06\end{array}$ & $\begin{array}{l}5351.35 \\
9636.10\end{array}$ & $\begin{array}{r}4964.23 \\
10614.65\end{array}$ & $\begin{array}{l}9.31 \mathrm{U} \\
9.31 \mathrm{U}\end{array}$ & $\begin{array}{l}11.20 \mathrm{U} \\
11.20 \mathrm{U}\end{array}$ \\
\hline $\begin{array}{l}\text { Comp USFC SPP } \\
\text { Comp USFC Elutriate }\end{array}$ & $\begin{array}{l}1 \\
1\end{array}$ & $\begin{array}{l}1.00 \\
1.00\end{array}$ & $\begin{array}{l}9.18 \mathrm{U} \\
0.77 \mathrm{~J}\end{array}$ & $\begin{array}{r}8.31 \mathrm{~J} \\
22.89\end{array}$ & $\begin{array}{l}41.35 \\
29.93\end{array}$ & $\begin{array}{l}9.31 \mathrm{U} \\
9.31 \mathrm{U}\end{array}$ & $\begin{array}{l}11.20 \mathrm{U} \\
11.20 \mathrm{U}\end{array}$ \\
\hline $\begin{array}{l}\text { Comp FSFC SPP } \\
\text { Comp FSFC Elutriate }\end{array}$ & $\begin{array}{l}2 \\
2\end{array}$ & $\begin{array}{l}0.80 \\
1.00\end{array}$ & $\begin{aligned} 11.48 U \\
9.18 U\end{aligned}$ & $\begin{array}{r}11.28 \mathrm{~J} \\
5.43 \mathrm{~J}\end{array}$ & $\begin{array}{r}37.52 \\
4.09 \mathrm{~J}\end{array}$ & $\begin{aligned} 11.64 \mathrm{U} \\
9.31 \mathrm{U}\end{aligned}$ & $\begin{array}{l}14.00 \mathrm{U} \\
11.20 \mathrm{U}\end{array}$ \\
\hline $\begin{array}{l}\text { Comp IHC-1 SPP } \\
\text { Comp IHC-1 Elutriate }\end{array}$ & $\begin{array}{l}2 \\
2\end{array}$ & $\begin{array}{l}1.00 \\
1.00\end{array}$ & $\begin{array}{l}9.18 U \\
9.18 U\end{array}$ & $\begin{array}{l}1.81 \mathrm{~J} \\
1.12 \mathrm{~J}\end{array}$ & $\begin{array}{l}3.24 \mathrm{~J} \\
0.69 \mathrm{~J}\end{array}$ & $\begin{array}{l}9.31 \mathrm{U} \\
9.31 \mathrm{U}\end{array}$ & $\begin{array}{l}11.20 \mathrm{U} \\
11.20 \mathrm{U}\end{array}$ \\
\hline $\begin{array}{l}\text { Comp IHC-2 SPP } \\
\text { Comp IHC-2 Elutriate }\end{array}$ & $\begin{array}{l}2 \\
2\end{array}$ & $\begin{array}{l}1.00 \\
1.00\end{array}$ & $\begin{array}{l}9.18 \mathrm{U} \\
9.18 \mathrm{U}\end{array}$ & $\begin{array}{r}1.48 \mathrm{~J} \\
12.80\end{array}$ & $\begin{array}{r}2.62 \mathrm{~J} \\
20.29\end{array}$ & $\begin{array}{l}9.31 \mathrm{U} \\
9.31 \mathrm{U}\end{array}$ & $\begin{array}{l}11.20 \mathrm{U} \\
11.20 \mathrm{U}\end{array}$ \\
\hline $\begin{array}{l}\text { Comp IHC-3 SPP } \\
\text { Comp IHC-3 Elutriate }\end{array}$ & $\begin{array}{l}2 \\
2\end{array}$ & $\begin{array}{l}1.00 \\
1.00\end{array}$ & $\begin{array}{l}9.18 U \\
9.18 U\end{array}$ & $\begin{array}{l}1.20 \mathrm{~J} \\
1.17 \mathrm{~J}\end{array}$ & $\begin{array}{l}0.85 \mathrm{~J} \\
0.75 \mathrm{~J}\end{array}$ & $\begin{array}{l}9.31 \mathrm{U} \\
9.31 \mathrm{U}\end{array}$ & $\begin{array}{l}11.20 \mathrm{U} \\
11.20 \mathrm{U}\end{array}$ \\
\hline
\end{tabular}
(a) DL Detection limit.
(b) U Analyte was not present above the associated value.
(c) J Analyte detected below method detection limit (MDL), but above instrument detection Iimit (IDL).
(d) UF Unfiltered.
(e) F Filtered. 
TABLE 6.4. Chlorinated Pesticides (elution order, 4,4'-DDD to Toxaphene) in Liquid Phase Samples, United Heckathorn Remedial Investigation

\begin{tabular}{|c|c|c|c|c|c|c|c|}
\hline \multirow[b]{2}{*}{$\begin{array}{l}\text { Liquid Phase } \\
\text { Treatment }\end{array}$} & \multirow[b]{2}{*}{ Batch } & \multirow[b]{2}{*}{$\begin{array}{l}\text { Volume } \\
(L)\end{array}$} & \multicolumn{5}{|c|}{ Pesticides $(n q / L)$} \\
\hline & & & $4,4^{\prime}-D D D$ & $\begin{array}{c}\text { Endrin } \\
\text { Aldehyde } \\
\end{array}$ & $\begin{array}{l}\text { Endosulfan } \\
\text { Sulfate }\end{array}$ & $4,4^{\prime}-D D T$ & Toxaphene \\
\hline $\begin{array}{l}\text { Target } \mathrm{DL}(\mathrm{a}) \\
\text { Achieved } \mathrm{DL}\end{array}$ & & & $\begin{array}{c}5 \\
17.25\end{array}$ & $\begin{array}{l}5 \\
6.36\end{array}$ & $\begin{array}{l}5 \\
8.19\end{array}$ & $\begin{array}{c}5 \\
11.95\end{array}$ & $\begin{array}{c}5 \\
25.0\end{array}$ \\
\hline $\begin{array}{l}\text { Site Water } \\
\text { Procedural Blank }\end{array}$ & $\begin{array}{l}1 \\
1\end{array}$ & $\begin{array}{l}1.00 \\
1.00\end{array}$ & $\begin{array}{r}2.74 \mathrm{~J}^{(b)} \\
248.80\end{array}$ & $\begin{array}{l}6.36 \mathrm{U}^{(\mathrm{c})} \\
6.36 \mathrm{U}^{-}\end{array}$ & $\begin{array}{l}8.19 \mathrm{U} \\
8.19 \mathrm{U}\end{array}$ & $\begin{array}{l}0.76 \mathrm{~J} \\
6.33 \mathrm{~J}\end{array}$ & $\begin{array}{l}25.00 \mathrm{U} \\
25.00 \mathrm{U}\end{array}$ \\
\hline $\begin{array}{l}\text { Comp LC SPP } \\
\text { Comp LC Elutriate }\end{array}$ & $\begin{array}{l}1 \\
1\end{array}$ & $\begin{array}{l}1.00 \\
1.00\end{array}$ & $\begin{array}{l}9542.14 \\
2069.87\end{array}$ & $\begin{array}{l}6.36 \mathrm{U} \\
6.36 \mathrm{U}\end{array}$ & $\begin{array}{l}8.19 \mathrm{U} \\
8.19 \mathrm{U}\end{array}$ & $\begin{array}{l}700.84 \\
309.58\end{array}$ & $\begin{array}{l}25.00 \mathrm{U} \\
25.00 \mathrm{U}\end{array}$ \\
\hline $\begin{array}{l}\text { Comp LC-5 SPP } \\
\text { Comp LC-5 Elutriate } \\
\text { Comp LC-5 Elutriate UF (d) } \\
\text { Comp LC-5 Elutriate F (e) }\end{array}$ & $\begin{array}{l}1 \\
1 \\
2 \\
2\end{array}$ & $\begin{array}{l}1.00 \\
1.00 \\
1.00 \\
1.00\end{array}$ & $\begin{array}{l}78634.11 \\
54426.46 \\
42986.04 \\
32855.14\end{array}$ & $\begin{array}{l}6.36 \mathrm{U} \\
6.36 \mathrm{U} \\
6.36 \mathrm{U} \\
6.36 \mathrm{U}\end{array}$ & $\begin{array}{r}58.67 \\
94.81 \\
101.90 \\
8.04 \mathrm{~J}\end{array}$ & $\begin{array}{c}2228.04 \\
1419.21 \\
1087.98 \\
941.14\end{array}$ & $\begin{array}{l}25.00 \mathrm{U} \\
25.00 \mathrm{U} \\
25.00 \mathrm{U} \\
25.00 \mathrm{U}\end{array}$ \\
\hline $\begin{array}{l}\text { Comp LC-6 SPP } \\
\text { Comp LC-6 Elutriate }\end{array}$ & $\begin{array}{l}1 \\
1\end{array}$ & $\begin{array}{l}1.00 \\
1.00\end{array}$ & $\begin{array}{l}117168.80 \\
283065.07\end{array}$ & $\begin{array}{l}6.36 \mathrm{U} \\
6.36 \mathrm{U}\end{array}$ & $\begin{array}{l}8.19 \mathrm{U} \\
8.19 \mathrm{U}\end{array}$ & $\begin{array}{l}2764.24 \\
6801.44\end{array}$ & $\begin{array}{l}25.00 \mathrm{U} \\
25.00 \mathrm{U}\end{array}$ \\
\hline $\begin{array}{l}\text { Comp USFC SPP } \\
\text { Comp USFC Elutriate }\end{array}$ & $\begin{array}{l}1 \\
1\end{array}$ & $\begin{array}{l}1.00 \\
1.00\end{array}$ & $\begin{array}{l}101.44 \\
882.17\end{array}$ & $\begin{array}{l}6.36 \mathrm{U} \\
6.36 \mathrm{U}\end{array}$ & $\begin{array}{l}8.19 \mathrm{U} \\
8.19 \mathrm{U}\end{array}$ & $\begin{array}{r}4.75 \mathrm{~J} \\
18.45\end{array}$ & $\begin{array}{l}25.00 \mathrm{U} \\
25.00 \mathrm{U}\end{array}$ \\
\hline $\begin{array}{l}\text { Comp FSFC SPP } \\
\text { Comp FSFC Elutriate }\end{array}$ & $\begin{array}{l}2 \\
2\end{array}$ & $\begin{array}{l}0.80 \\
1.00\end{array}$ & $\begin{array}{r}203.86 \\
41.18\end{array}$ & $\begin{array}{l}7.95 \mathrm{U} \\
6.36 \mathrm{U}\end{array}$ & $\begin{array}{r}10.24 \mathrm{U} \\
8.19 \mathrm{U}\end{array}$ & $\begin{array}{l}9.33 \mathrm{~J} \\
1.53 \mathrm{~J}\end{array}$ & $\begin{array}{l}31.25 \mathrm{U} \\
25.00 \mathrm{U}\end{array}$ \\
\hline $\begin{array}{l}\text { Comp IHC- } 1 \text { SPP } \\
\text { Comp IHC-1 Elutriate }\end{array}$ & $\begin{array}{l}2 \\
2\end{array}$ & $\begin{array}{l}1.00 \\
1.00\end{array}$ & $\begin{array}{l}22.07 \\
17.00 \mathrm{~J}\end{array}$ & $\begin{array}{l}6.36 \mathrm{U} \\
6.36 \mathrm{U}\end{array}$ & $\begin{array}{l}8.19 \mathrm{U} \\
8.19 \mathrm{U}\end{array}$ & $\begin{array}{l}1.12 \mathrm{~J} \\
0.45 \mathrm{~J}\end{array}$ & $\begin{array}{l}25.00 \mathrm{U} \\
25.00 \mathrm{U}\end{array}$ \\
\hline $\begin{array}{l}\text { Comp IHC-2 SPP } \\
\text { Comp IHC-2 Elutriate }\end{array}$ & $\begin{array}{l}2 \\
2\end{array}$ & $\begin{array}{l}1.00 \\
1.00\end{array}$ & $\begin{array}{r}61.11 \\
663.67\end{array}$ & $\begin{array}{l}6.36 \mathrm{U} \\
6.36 \mathrm{U}\end{array}$ & $\begin{array}{l}8.19 \mathrm{U} \\
8.19 \mathrm{U}\end{array}$ & $\begin{array}{r}3.49 \mathrm{~J} \\
125.89\end{array}$ & $\begin{array}{l}25.00 \mathrm{U} \\
25.00 \mathrm{U}\end{array}$ \\
\hline $\begin{array}{l}\text { Comp IHC-3 SPP } \\
\text { Comp IHC-3 Elutriate }\end{array}$ & $\begin{array}{l}2 \\
2\end{array}$ & $\begin{array}{l}1.00 \\
1.00\end{array}$ & $\begin{array}{l}15.02 \\
18.94\end{array}$ & $\begin{array}{l}6.36 \mathrm{U} \\
6.36 \mathrm{U}\end{array}$ & $\begin{array}{l}8.19 \mathrm{U} \\
8.19 \mathrm{U}\end{array}$ & $\begin{array}{l}1.05 \mathrm{~J} \\
1.03 \mathrm{~J}\end{array}$ & $\begin{array}{l}25.00 \mathrm{U} \\
25.00 \mathrm{U}\end{array}$ \\
\hline
\end{tabular}

\footnotetext{
(a) DL Detection limit.

(b) J Analyte detected below method detection limit (MDL), but above instrument detection Iimit (IDL).

(c) U Analyte was not present above the associated value.

(d) UF Unfiltered.

(e) F Filtered.
} 
TABLE G.5. Qualit y Control Summary for Chlorinated Pesticides (elution order, Alpha-BHC to Endosulfan I) in Liquid Phase Samples, United Heckathorn Remedial Investigation

\begin{tabular}{|c|c|c|c|c|c|c|c|c|c|c|c|c|}
\hline \multirow{2}{*}{\multicolumn{2}{|c|}{$\begin{array}{l}\text { Liquid Phase } \\
\text { Treatment } \\
\end{array}$}} & \multirow[b]{2}{*}{ Batch } & \multirow[b]{2}{*}{$\begin{array}{c}\text { Volume } \\
\text { (L) }\end{array}$} & \multicolumn{8}{|c|}{ Pesticides (ng/L) } & \multirow[b]{2}{*}{$\begin{array}{c}\text { Endo- } \\
\text { sulfan I }\end{array}$} \\
\hline & & & & $\begin{array}{l}\text { Alpha } \\
\text { BHC }\end{array}$ & $\begin{array}{l}\text { Beta } \\
\mathrm{BHC}\end{array}$ & Lindane & $\begin{array}{l}\text { Delta } \\
\text { BHC }\end{array}$ & $\begin{array}{l}\text { Hepta- } \\
\text { chlor }\end{array}$ & Aldrin & $\begin{array}{l}\text { Hepta- } \\
\text { chlor- } \\
\text { epoxide } \\
\end{array}$ & $\begin{array}{c}\begin{array}{c}\text { Trans- } \\
\text { chlordane }\end{array} \\
\end{array}$ & \\
\hline & \multicolumn{12}{|l|}{ Method Blanks } \\
\hline & $\begin{array}{l}\text { Blank } \\
\text { Blank }\end{array}$ & $\begin{array}{l}1 \\
2\end{array}$ & $\begin{array}{l}1.00 \\
1.00\end{array}$ & $\begin{array}{l}5.12 U^{(a)} \\
5.12 U^{(a)}\end{array}$ & $\begin{array}{l}4.57 \mathrm{U} \\
4.57 \mathrm{U}\end{array}$ & $\begin{array}{l}10.91 \mathrm{U} \\
10.91 \mathrm{U}\end{array}$ & $\begin{array}{l}10.91 \mathrm{U} \\
10.91 \mathrm{U}\end{array}$ & $\begin{array}{l}5.48 \mathrm{U} \\
5.48 \mathrm{U}\end{array}$ & $\begin{array}{l}6.61 \mathrm{U} \\
6.61 \mathrm{U}\end{array}$ & $\begin{array}{l}4.20 \mathrm{U} \\
4.20 \mathrm{U}\end{array}$ & $\begin{array}{l}6.33 \mathrm{U} \\
6.33 \mathrm{U}\end{array}$ & $\begin{array}{l}6.33 \mathrm{U} \\
6.33 \mathrm{U}\end{array}$ \\
\hline & \multicolumn{12}{|l|}{ Matrix Spikes } \\
\hline & $\begin{array}{l}\text { Site Water } \\
\text { Site Water MS } \\
\text { Concentration Recovered } \\
\text { Amount Spiked } \\
\text { Percent Recovery }\end{array}$ & $\begin{array}{l}1 \\
1\end{array}$ & 1.00 & $\begin{array}{l}5.12 U \\
280.69 \\
280.69 \\
306.00 \\
92 \%\end{array}$ & $\begin{array}{r}4.57 \mathrm{U} \\
237.83 \\
237.83 \\
288.00 \\
83 \%\end{array}$ & $\begin{array}{l}10.91 U \\
292.41 \\
292.41 \\
288.00 \\
102 \%\end{array}$ & $\begin{array}{r}10.91 \text { U } \\
322.07 \\
322.07 \\
288.00 \\
112 \%\end{array}$ & $\begin{array}{r}5.48 U \\
226.31 \\
226.31 \\
288.00 \\
79 \%\end{array}$ & $\begin{array}{r}6.61 \mathrm{U} \\
271.20 \\
271.20 \\
288.00 \\
94 \%\end{array}$ & $\begin{array}{c}4.20 \mathrm{U} \\
247.63 \\
247.63 \\
288.00 \\
86 \%\end{array}$ & $\begin{array}{r}6.33 \mathrm{U} \\
211.42 \\
211.42 \\
306.00 \\
69 \%\end{array}$ & $\begin{array}{l}6.33 \mathrm{U} \\
233.03 \\
233.03 \\
288.00 \\
81 \%\end{array}$ \\
\hline $\begin{array}{l}\Omega \\
G\end{array}$ & $\begin{array}{l}\text { Site Water } \\
\text { Site Water NDD } \\
\text { Concentration Recovered } \\
\text { Amount Spiked } \\
\text { Percent Recovery }\end{array}$ & $\begin{array}{l}1 \\
1\end{array}$ & 1.00 & $\begin{array}{l}5.12 U \\
281.48 \\
281.48 \\
306.00 \\
92 \%\end{array}$ & $\begin{array}{r}4.57 \mathrm{U} \\
237.63 \\
237.63 \\
288.00 \\
83 \%\end{array}$ & $\begin{array}{l}10.91 \mathrm{U} \\
297.72 \\
297.72 \\
288.00 \\
103 \%\end{array}$ & $\begin{array}{r}10.91 \mathrm{U} \\
331.56 \\
331.56 \\
288.00 \\
115 \%\end{array}$ & $\begin{array}{r}5.48 U \\
234.14 \\
234.14 \\
288.00 \\
81 \%\end{array}$ & $\begin{array}{r}6.61 \mathrm{U} \\
270.63 \\
270.63 \\
288.00 \\
94 \%\end{array}$ & $\begin{array}{c}4.20 \mathrm{U} \\
253.40 \\
253.40 \\
288.00 \\
88 \%\end{array}$ & $\begin{array}{c}6.33 \mathrm{U} \\
212.49 \\
212.49 \\
306.00 \\
69 \%\end{array}$ & $\begin{array}{r}6.33 \mathrm{U} \\
235.98 \\
235.98 \\
288.00 \\
82 \%\end{array}$ \\
\hline & $\begin{array}{l}\text { RPD } \\
\text { I-Stat }\end{array}$ & & & $0.00 \%$ & 0.00 & 0.01 & 0.01 & $0.02^{3 \%}$ & $0.00 \%$ & 0.01 & $0.00^{1 \%}$ & 0.01 \\
\hline & $\begin{array}{l}\text { Comp FSFC SPP } \\
\text { Comp FSFC SPP NS } \\
\text { Concentration Recovered } \\
\text { Amount Spiked } \\
\text { Percent Recovery }\end{array}$ & $\begin{array}{l}2 \\
2\end{array}$ & 0.80 & $\begin{array}{l}6.40 \mathrm{U} \\
304.59 \\
304.59 \\
306.00 \\
100 \%\end{array}$ & $\begin{array}{r}5.71 \mathrm{U} \\
281.44 \\
281.44 \\
288.00 \\
98 \%\end{array}$ & $\begin{array}{l}13.64 \mathrm{U} \\
318.77 \\
318.77 \\
288.00 \\
\quad 111 \%\end{array}$ & $\begin{array}{c}13.64 \mathrm{U} \\
381.29 \\
381.29 \\
288.00 \\
132 \%(\mathrm{~b})\end{array}$ & $\begin{array}{r}6.85 U \\
270.40 \\
270.40 \\
288.00 \\
94 \%\end{array}$ & $\begin{array}{r}8.26 \mathrm{U} \\
270.88 \\
270.88 \\
288.00 \\
94 \%\end{array}$ & $\begin{array}{r}5.25 U \\
262.73 \\
262.73 \\
288.00 \\
91 \%\end{array}$ & $\begin{array}{r}7.91 \mathrm{U} \\
225.29 \\
225.29 \\
306.00 \\
74 \%\end{array}$ & $\begin{array}{r}7.91 \mathrm{U} \\
241.90 \\
241.90 \\
288.00 \\
84 \%\end{array}$ \\
\hline & $\begin{array}{l}\text { Comp FSFC SPP } \\
\text { Comp FSFC SPP MSD } \\
\text { Concentration Recovered } \\
\text { Amount Spiked } \\
\text { Percent Recovery }\end{array}$ & $\begin{array}{l}2 \\
2\end{array}$ & 0.80 & $\begin{array}{c}6.40 \mathrm{U} \\
340.67 \\
340.67 \\
306.00 \\
111 \%\end{array}$ & $\begin{array}{c}5.71 \mathrm{U} \\
314.63 \\
314.63 \\
288.00 \\
109 \%\end{array}$ & $\begin{array}{l}13.64 \mathrm{U} \\
362.16 \\
362.16 \\
288.00 \\
126 \%(b)\end{array}$ & $\begin{array}{c}13.64 \mathrm{U} \\
440.76 \\
440.76 \\
288.00 \\
153 \% \text { (b) }\end{array}$ & $\begin{array}{c}6.85 \mathrm{U} \\
314.20 \\
314.20 \\
288.00 \\
109 \%\end{array}$ & $\begin{array}{c}8.26 \mathrm{U} \\
306.30 \\
306.30 \\
288.00 \\
106 \%\end{array}$ & $\begin{array}{c}5.25 U \\
304.60 \\
304.60 \\
288.00 \\
106 \%\end{array}$ & $\begin{array}{c}7.91 U \\
258.29 \\
258.29 \\
306.00 \\
84 \%\end{array}$ & $\begin{array}{c}7.91 u \\
271.69 \\
271.69 \\
288.00 \\
94 \%\end{array}$ \\
\hline & $\begin{array}{l}\text { RPD } \\
\text { I-Stat }\end{array}$ & & & 0.06 & 0.06 & $\begin{array}{l}13 \% \\
0.06\end{array}$ & $\begin{array}{l}14 \% \\
0.07\end{array}$ & $\begin{array}{l}15 \% \\
0.07\end{array}$ & $\begin{array}{l}12 \% \\
0.06\end{array}$ & $\begin{array}{l}15 \% \\
0.07\end{array}$ & $\begin{array}{l}14 \% \\
0.07\end{array}$ & $\begin{array}{l}12 \% \\
0.06\end{array}$ \\
\hline
\end{tabular}


TABLE G.5. (contd)

\begin{tabular}{|c|c|c|c|c|c|c|c|c|c|c|c|}
\hline \multirow[b]{2}{*}{$\begin{array}{l}\text { Liquid Phase } \\
\text { Treatment }\end{array}$} & \multirow[b]{2}{*}{ Batch } & \multirow[b]{2}{*}{$\begin{array}{c}\text { Volume } \\
(\mathrm{L})\end{array}$} & \multicolumn{8}{|c|}{ Pesticides (ng/L) } & \multirow[b]{2}{*}{$\begin{array}{r}\text { Endo- } \\
\text { sulfan }\end{array}$} \\
\hline & & & $\begin{array}{l}\text { Alpha } \\
\text { BHC }\end{array}$ & $\begin{array}{l}\text { Beta } \\
\mathrm{BHC}\end{array}$ & Lindane & $\begin{array}{l}\text { Delta } \\
\text { BHC }\end{array}$ & $\begin{array}{l}\text { Hepta- } \\
\text { chlor }\end{array}$ & Aldrin & $\begin{array}{r}\text { Hepta- } \\
\text { chlor- } \\
\text { epoxide }\end{array}$ & $\begin{array}{c}\text { Trans- } \\
\text { chlordane }\end{array}$ & \\
\hline \multicolumn{12}{|l|}{ Analytical Duplicates } \\
\hline $\begin{array}{l}\text { Comp LC SPP } \\
\text { Comp LC SPP Duplicate } \\
\text { RPD } \\
\text { I-Stat }\end{array}$ & $\begin{array}{l}1 \\
1\end{array}$ & $\begin{array}{l}1.00 \\
1.00\end{array}$ & $\begin{array}{c}158.71 \\
212.98 \\
29 \% \\
0.15\end{array}$ & $\begin{array}{l}6.39 \\
9.09 \\
35 \% \\
0.17\end{array}$ & $\begin{array}{l}1.42 \mathrm{~J} \\
2.08 \mathrm{~J} \\
38 \%(\mathrm{c}) \\
0.19\end{array}$ & $\begin{array}{c}10.91 \mathrm{U} \\
10.91 \mathrm{U} \\
\text { NA } \\
\text { NA }\end{array}$ & $\begin{array}{l}5.48 \mathrm{U} \\
5.48 \mathrm{U} \\
\text { NA } \\
\text { NA }\end{array}$ & $\begin{array}{l}6.61 \mathrm{U} \\
6.61 \mathrm{U} \\
\mathrm{NA} \\
\mathrm{NA}\end{array}$ & $\begin{array}{l}4.20 \mathrm{U} \\
4.20 \mathrm{U} \\
\text { NA } \\
\text { NA }\end{array}$ & $\begin{array}{l}182.04 \\
257.33 \text { (d) } \\
34 \% \\
0.17\end{array}$ & $\begin{array}{l}6.330 \\
6.33 \\
\text { NA } \\
\text { NA }\end{array}$ \\
\hline $\begin{array}{l}\text { Comp IHC-2 SPP } \\
\text { Comp IHC-2 SPP Duplicate } \\
\text { RPD } \\
\text { l-Stat }\end{array}$ & $\begin{array}{l}2 \\
2\end{array}$ & $\begin{array}{l}1.00 \\
0.90\end{array}$ & $\begin{array}{l}5.12 U \\
5.69 \mathrm{U} \\
\text { NA } \\
\text { NA }\end{array}$ & $\begin{array}{l}4.57 \mathrm{U} \\
5.08 \mathrm{U} \\
\text { NA } \\
\text { NA }\end{array}$ & $\begin{array}{c}10.91 \mathrm{U} \\
12.12 \mathrm{U} \\
\text { NA } \\
\text { NA }\end{array}$ & $\begin{array}{c}10.91 \mathrm{U} \\
12.12 \mathrm{U} \\
\text { NA } \\
\text { NA }\end{array}$ & $\begin{array}{l}5.48 \mathrm{U} \\
6.09 \mathrm{U} \\
\text { NA } \\
\text { NA }\end{array}$ & $\begin{array}{l}6.61 \mathrm{U} \\
7.34 \mathrm{U} \\
\mathrm{NA} \\
\mathrm{NA}\end{array}$ & $\begin{array}{l}4.20 \mathrm{U} \\
4.67 \mathrm{U} \\
\text { NA } \\
\text { NA }\end{array}$ & $\begin{array}{l}6.33 \mathrm{U} \\
7.03 \mathrm{U} \\
\text { NA } \\
\text { NA }\end{array}$ & $\begin{array}{l}6.33 \\
7.03 \\
\text { NA } \\
\text { NA }\end{array}$ \\
\hline
\end{tabular}

(a) U Analyte was not present above the associated value.

(b) Recovery outside of quality control range (40\%- $120 \%)$.

(c) Precision criteria do not apply because sample results are less than 10 times the MDL 
TABLE G.6. Quality Control Summary for Chlorinated Pesticides (elution order, cis-Chl ordane to Endosulfan II) in Liquid Phase Samples, United Heckathorn Remedial Investigation

\begin{tabular}{|c|c|c|c|c|c|c|c|}
\hline \multirow[b]{2}{*}{$\begin{array}{l}\text { Liquid Phase } \\
\text { Treatment }\end{array}$} & \multirow[b]{2}{*}{ Batch } & \multirow[b]{2}{*}{$\begin{array}{l}\text { Volume } \\
\text { (L) } \\
\end{array}$} & \multicolumn{5}{|c|}{ Pesticides (ng/L) } \\
\hline & & & $\begin{array}{c}\text { cis- } \\
\text { Chlordane } \\
\end{array}$ & Dieldrin & $4,4^{\prime}-D D E$ & Endrin & $\begin{array}{c}\text { Endo- } \\
\text { sulfan II }\end{array}$ \\
\hline \multicolumn{8}{|l|}{ Method Blank } \\
\hline $\begin{array}{l}\text { Blank } \\
\text { Blank }\end{array}$ & $\begin{array}{l}1 \\
2\end{array}$ & $\begin{array}{l}1.00 \\
1.00\end{array}$ & $\begin{array}{l}9.18 U^{(a)} \\
9.18 U\end{array}$ & $\begin{array}{l}9.18 \mathrm{U} \\
9.18 \mathrm{U}\end{array}$ & $\begin{array}{l}8.09 \mathrm{U} \\
8.09 \mathrm{U}\end{array}$ & $\begin{array}{l}9.31 \mathrm{U} \\
9.31 \mathrm{U}\end{array}$ & $\begin{array}{l}11.20 \mathrm{U} \\
11.20 \mathrm{U}\end{array}$ \\
\hline \multicolumn{8}{|l|}{ Matrix Spike } \\
\hline $\begin{array}{l}\text { Site Water } \\
\text { Site Water NS } \\
\text { Concentration Recovered } \\
\text { Amount Spiked } \\
\text { Percent Recovery }\end{array}$ & $\begin{array}{l}1 \\
1\end{array}$ & 1.00 & $\begin{array}{l}9.18(\mathrm{U}) \\
\mathrm{NA} \\
\mathrm{NA} \\
\mathrm{NS} \\
\mathrm{NA}\end{array}$ & $\begin{array}{l}0.42 \mathrm{~J}^{(b)} \\
265.19 \\
264.77 \\
288.00 \\
92 \%\end{array}$ & $\begin{array}{c}8.09 \mathrm{U} \\
324.86 \\
324.86 \\
288.00 \\
113 \%\end{array}$ & $\begin{array}{r}9.31 U \\
281.69 \\
281.69 \\
294.00 \\
96 \%\end{array}$ & $\begin{array}{l}11.20 \mathrm{U} \\
275.32 \\
275.32 \\
288.00 \\
96 \%\end{array}$ \\
\hline $\begin{array}{l}\text { Site Water } \\
\text { Site Water MSD } \\
\text { Concentration Recovered } \\
\text { Amount Spiked } \\
\text { Percent Recovery }\end{array}$ & $\begin{array}{l}1 \\
1\end{array}$ & 1.00 & $\begin{array}{l}9.18 \mathrm{U} \\
\text { NA } \\
\text { NA } \\
\text { NS } \\
\text { NA }\end{array}$ & $\begin{array}{c}0.42 \mathrm{~J} \\
257.50 \\
257.08 \\
288.00 \\
89 \%\end{array}$ & $\begin{array}{c}8.09 \mathrm{U} \\
333.54 \\
333.54 \\
288.00 \\
116 \%\end{array}$ & $\begin{array}{c}9.31 \mathrm{U} \\
280.82 \\
280.82 \\
294.00 \\
96 \%\end{array}$ & $\begin{array}{l}11.20 \mathrm{U} \\
269.61 \\
269.61 \\
288.00 \\
94 \%\end{array}$ \\
\hline $\begin{array}{l}\text { RPD } \\
\text { I-Stat }\end{array}$ & & & $\begin{array}{l}\text { NA } \\
\text { NA }\end{array}$ & 0.01 & 0.01 & $0.00^{0 \%}$ & $0.01^{2 \%}$ \\
\hline $\begin{array}{l}\text { Comp FSFC SPP } \\
\text { Comp FSFC SPP NS } \\
\text { Concentration Recovered } \\
\text { Amount Spiked } \\
\text { Percent Recovery }\end{array}$ & $\begin{array}{l}2 \\
2\end{array}$ & 0.80 & $\begin{array}{c}11.48 \mathrm{U} \\
\mathrm{NA} \\
\mathrm{NA} \\
\mathrm{NS} \\
\mathrm{NA}\end{array}$ & $\begin{array}{c}11.28 \mathrm{~J} \\
253.40 \\
242.12 \\
288.00 \\
84 \%\end{array}$ & $\begin{array}{l}37.52 \\
356.03 \\
318.51 \\
288.00 \\
111 \%\end{array}$ & $\begin{array}{c}11.64 U \\
274.86 \\
274.86 \\
294.00 \\
93 \%\end{array}$ & $\begin{array}{l}14.00 \mathrm{U} \\
262.11 \\
262.11 \\
288.00 \\
91 \%\end{array}$ \\
\hline $\begin{array}{l}\text { Comp FSFC SPP } \\
\text { Comp FSFC SPP MSD } \\
\text { Concentration Recovered } \\
\text { Amount Spiked } \\
\text { Percent Recovery }\end{array}$ & $\begin{array}{l}2 \\
2\end{array}$ & 0.80 & $\begin{array}{c}11.48 \mathrm{U} \\
\text { NA } \\
\text { NA } \\
\text { NS } \\
\text { NA }\end{array}$ & $\begin{array}{c}11.28 \mathrm{~J} \\
289.81 \\
278.53 \\
288.00 \\
97 \%\end{array}$ & $\begin{array}{l}37.52 \\
387.20 \\
349.68 \\
288.00 \\
121 \%(e)\end{array}$ & $\begin{array}{c}11.64 U \\
313.40 \\
313.40 \\
294.00 \\
107 \%\end{array}$ & $\begin{array}{c}14.00 \mathrm{U} \\
291.24 \\
291.24 \\
288.00 \\
101 \%\end{array}$ \\
\hline $\begin{array}{l}\text { RPD } \\
\text { I-Stat }\end{array}$ & & & $\begin{array}{l}\text { NA } \\
\text { NA }\end{array}$ & $\begin{array}{l}14 \% \\
0.07\end{array}$ & $0.05^{9 \%}$ & 0.07 & $\begin{array}{l}11 \% \\
0.05\end{array}$ \\
\hline \multicolumn{8}{|l|}{ Analytical Duplicates } \\
\hline $\begin{array}{l}\text { Comp LC SPP } \\
\text { Comp LC SPP Duplicate } \\
\text { RPD } \\
\text { I-Stat }\end{array}$ & $\begin{array}{l}1 \\
1\end{array}$ & $\begin{array}{l}1.00 \\
1.00\end{array}$ & $\begin{array}{l}46.96 \\
87.09 \\
60 \%(f) \\
0.30\end{array}$ & $\begin{array}{l}447.81 \\
748.01 \\
50 \%(\mathrm{~g}) \\
0.25\end{array}$ & $\begin{array}{c}610.58 \\
1214.65 \\
66 \%(\mathrm{~g}) \\
0.33\end{array}$ & $\begin{array}{l}15.53 \\
25.83 \\
50 \% \\
0.25\end{array}$ & $\begin{array}{c}11.20 \mathrm{U} \\
11.20 \mathrm{U} \\
\mathrm{NA} \\
\mathrm{NA}\end{array}$ \\
\hline $\begin{array}{l}\text { Comp IHC-2 SPP } \\
\text { Comp IHC-2 SPP Duplicate } \\
\text { RPD } \\
\text { I-Stat }\end{array}$ & $\begin{array}{l}2 \\
2\end{array}$ & $\begin{array}{l}1.00 \\
0.90\end{array}$ & $\begin{array}{c}9.18 \mathrm{U} \\
10.20 \mathrm{U} \\
\mathrm{NA} \\
\mathrm{NA}\end{array}$ & $\begin{array}{l}1.48 \mathrm{~J} \\
0.85 \mathrm{~J} \\
54 \%(\mathrm{f}) \\
0.27\end{array}$ & $\begin{array}{l}2.62 \mathrm{~J} \\
1.50 \mathrm{~J} \\
54 \% \\
0.27\end{array}$ & $\begin{array}{c}9.31 \mathrm{U} \\
10.3 A \mathrm{U} \\
\mathrm{NA}\end{array}$ & $\begin{array}{c}11.20 \mathrm{U} \\
12.44 \mathrm{U} \\
\text { NA }\end{array}$ \\
\hline
\end{tabular}

(a) U Analyte was not present above the associated value.

(b) J Analyte detected below method detection limit (MDL), but above instrument detection Iimit (IDL).

(c) NA Not applicable.

(d) NS Not spiked.

(e) Recovery outside of quality control range $(40 \%-120 \%)$.

(f) Precision criteria do not apply because sample results are less than 10 times the MDL.

(g) Value exceeds relative precision goal of $\leq 30 \%$. 
TABLE 6.7. Quality Control Summary for Chlorinated Pesticides (elution order, 4,4'-DDD to Toxaphene) in Liquid Phase Samples, United Heckathorn Remedial Investigation

\begin{tabular}{|c|c|c|c|c|c|c|c|}
\hline \multirow[b]{2}{*}{$\begin{array}{l}\text { Liquid Phase } \\
\text { Treatment }\end{array}$} & \multirow[b]{2}{*}{ Batch } & \multirow[b]{2}{*}{$\begin{array}{l}\text { Volume } \\
\text { (L) }\end{array}$} & \multicolumn{5}{|c|}{ Pesticides (ng/L) } \\
\hline & & & $4,4^{\prime}-D D D$ & $\begin{array}{c}\text { Endrin } \\
\text { Aldehyde } \\
\end{array}$ & $\begin{array}{c}\text { Endosul fan } \\
\text { Sulfate }\end{array}$ & 4.4'-DDT & Toxaphene \\
\hline \multicolumn{8}{|l|}{ Method Blank } \\
\hline $\begin{array}{l}\text { Blank } \\
\text { Blank }\end{array}$ & $\begin{array}{l}1 \\
2\end{array}$ & $\begin{array}{l}1.00 \\
1.00\end{array}$ & $\begin{array}{r}17.25 \mathrm{U}_{(\mathrm{a})}^{(\mathrm{a})} \\
8.52 \mathrm{~b})\end{array}$ & $\begin{array}{l}6.36 \mathrm{U} \\
6.36 \mathrm{U}\end{array}$ & $\begin{array}{l}8.19 U \\
8.19 U\end{array}$ & $\begin{array}{l}11.95 \mathrm{U} \\
11.95 \mathrm{U}\end{array}$ & $\begin{array}{l}25.00 \mathrm{U} \\
25.00 \mathrm{U}\end{array}$ \\
\hline \multicolumn{8}{|l|}{ Matrix Spike } \\
\hline $\begin{array}{l}\text { Site Water } \\
\text { Site Water MS } \\
\text { Concentration Recovered } \\
\text { Amount Spiked } \\
\text { Percent Recovery }\end{array}$ & $\begin{array}{l}1 \\
1\end{array}$ & 1.00 & $\begin{array}{l}2.74 \mathrm{~J} \\
325.38 \\
322.64 \\
288.00 \\
112 \%\end{array}$ & $\begin{array}{l}6.36 U \\
289.66 \\
289.66 \\
288.00 \\
101 \%\end{array}$ & $\begin{array}{c}8.19 \mathrm{U} \\
275.65 \\
275.65 \\
288.00 \\
96 \%\end{array}$ & $\begin{array}{l}0.76 \mathrm{~J} \\
278.20 \\
277.44 \\
288.00 \\
96 \%\end{array}$ & $\begin{array}{l}25.00 \\
N A \\
N A \\
N A \\
N S \\
N A\end{array}$ \\
\hline $\begin{array}{l}\text { Site Water } \\
\text { Site Water NBD } \\
\text { Concentration Recovered } \\
\text { Amount Spiked } \\
\text { Percent Recovery }\end{array}$ & $\begin{array}{l}1 \\
1\end{array}$ & 1.00 & $\begin{array}{c}2.74 \mathrm{~J} \\
343.49 \\
340.75 \\
288.00 \\
118 \%\end{array}$ & $\begin{array}{l}6.36 \mathrm{U} \\
276.30 \\
276.30 \\
288.00 \\
96 \%\end{array}$ & $\begin{array}{l}8.19 \mathrm{U} \\
267.26 \\
267.26 \\
288.00 \\
93 \%\end{array}$ & $\begin{array}{l}0.76 \mathrm{~J} \\
294.81 \\
294.05 \\
288.00 \\
102 \%\end{array}$ & $\begin{array}{l}25.00 \mathrm{U} \\
\mathrm{NA} \\
\mathrm{NA} \\
\mathrm{NS} \\
\mathrm{NA}\end{array}$ \\
\hline $\begin{array}{l}\text { RPD } \\
\text { I-Stat }\end{array}$ & & & 0.03 & $0.02^{5 \%}$ & $0.02 \%$ & 0.03 & $\begin{array}{l}N A \\
N A\end{array}$ \\
\hline $\begin{array}{l}\text { Comp FSFC SPP } \\
\text { Comp FSFC SPP NS } \\
\text { Concentration Recovered } \\
\text { Amount Spiked } \\
\text { Percent Recovery }\end{array}$ & $\begin{array}{l}2 \\
2\end{array}$ & 0.80 & $\begin{array}{c}203.86 \\
M \\
\text { NA } \\
288.00 \\
\text { NA }\end{array}$ & $\begin{array}{c}7.95 \mathrm{U} \\
234.20 \\
234.20 \\
288.00 \\
81 \%\end{array}$ & $\begin{array}{c}10.24 U \\
258.98 \\
258.98 \\
288.00 \\
90 \%\end{array}$ & $\begin{array}{l}9.33 \mathrm{~J} \\
294.42 \\
285.09 \\
288.00 \\
99 \%\end{array}$ & $\begin{array}{l}31.25 U \\
\text { NA } \\
\text { NA } \\
\text { NS } \\
\text { NA }\end{array}$ \\
\hline $\begin{array}{l}\text { Comp FSFC SPP } \\
\text { Comp FSFC SPP MSD } \\
\text { Concentration Recovered } \\
\text { Amount Spiked } \\
\text { Percent Recovery }\end{array}$ & $\begin{array}{l}2 \\
2\end{array}$ & 0.80 & $\begin{array}{r}203.86 \\
M \\
\text { NA } \\
288.00 \\
\text { NA }\end{array}$ & $\begin{array}{c}7.95 U \\
298.32 \\
298.32 \\
288.00 \\
104 \%\end{array}$ & $\begin{array}{c}10.24 \mathrm{U} \\
293.25 \\
293.25 \\
288.00 \\
102 \%\end{array}$ & $\begin{array}{l}9.33 \mathrm{~J} \\
359.07 \\
349.74 \\
288.00 \\
121 \%(f)\end{array}$ & $\begin{array}{l}31.25 U \\
\text { NA } \\
\text { NA } \\
\text { NS } \\
\text { NA }\end{array}$ \\
\hline $\begin{array}{l}\text { RPD } \\
\text { I-Stat }\end{array}$ & & & $\begin{array}{l}\text { NA } \\
\text { NA }\end{array}$ & $\begin{array}{l}24 \% \\
0.12\end{array}$ & $\begin{array}{l}12 \% \\
0.06\end{array}$ & $\begin{array}{l}20 \% \\
0.10\end{array}$ & $\begin{array}{l}\text { NA } \\
\text { NA }\end{array}$ \\
\hline \multicolumn{8}{|l|}{ Analytical Duplicates } \\
\hline $\begin{array}{l}\text { Comp LC SPP } \\
\text { Comp LC SPP Duplicate } \\
\text { RPD } \\
\text { I-Stat }\end{array}$ & $\begin{array}{l}1 \\
1\end{array}$ & $\begin{array}{l}1.00 \\
1.00\end{array}$ & $\begin{array}{c}9542.14 \\
19611.03 \text { (g) } \\
69 \% \\
0.35\end{array}$ & $\begin{array}{l}6.36 \mathrm{U} \\
6.36 \mathrm{U} \\
\mathrm{NA} \\
\mathrm{NA}\end{array}$ & $\begin{array}{l}8.19 \mathrm{U} \\
8.19 \mathrm{U} \\
\text { NA } \\
\text { NA }\end{array}$ & $\begin{array}{c}700.84 \\
1940.75 \\
94 \%(\mathrm{~g}) \\
0.47\end{array}$ & $\begin{array}{l}25.00 \mathrm{U} \\
25.00 \mathrm{U} \\
\text { NA } \\
\text { NA }\end{array}$ \\
\hline $\begin{array}{l}\text { Comp IHC-2 SPP } \\
\text { Comp IHC-2 SPP Duplicate } \\
\text { RPD } \\
\text { I-Stat }\end{array}$ & $\begin{array}{r}2 \\
2\end{array}$ & $\begin{array}{l}1.00 \\
0.90\end{array}$ & $\begin{array}{l}61.11 \\
26.17 \\
80 \%(h) \\
0.40\end{array}$ & $\begin{array}{l}6.36 \mathrm{U} \\
7.07 \mathrm{U} \\
\text { NA } \\
\text { NA }\end{array}$ & $\begin{array}{l}8.19 \mathrm{U} \\
9.10 \mathrm{U} \\
\text { NA } \\
\text { NA }\end{array}$ & $\begin{array}{l}3.49 \mathrm{~J} \\
1.60 \mathrm{~J}(\mathrm{~h}) \\
74 \% \\
0.37\end{array}$ & $\begin{array}{l}25.00 \mathrm{U} \\
27.78 \mathrm{U} \\
\text { NA } \\
\text { NA }\end{array}$ \\
\hline
\end{tabular}

\footnotetext{
(a) U Analyte was not present above the associated value.

(b) J Analyte detected below method detection limit (MDL), but above instrument detection Iimit (IDL).

(c) NA Not applicable.

(d) NS Not spiked.

(e) M Matrix interference.

(f) Recovery outside of quality control range (40\%- $120 \%)$.

(g) Value exceeds relative precision goal of $\leq 30 \%$.

(h) Precision criteria do not apply because sample results are less than 10 times the MDL.
} 
TABLE G.8. Surrogate Percent Recoveries and Quality Control Summary for Chorinated Pesticides and Polychlorinated Biphenyls (PCBs) in Liquid Phase Samples, United Heckathorn Remedial Investigation

\begin{tabular}{|c|c|c|c|c|c|}
\hline Liquid Phase & & Volume & Surrog & Percent & ecoveries \\
\hline Treatment & Batch & $(L)$ & $\underline{\mathrm{DBOFB}}$ & $\underline{\text { CL5(112) }}$ & $\underline{\text { CL5 (103) }}$ \\
\hline $\begin{array}{l}\text { Site Water } \\
\text { Procedural Blank }\end{array}$ & $\begin{array}{l}1 \\
1\end{array}$ & $\begin{array}{l}1.00 \\
1.00\end{array}$ & $\begin{array}{l}75 \\
91\end{array}$ & $\begin{array}{l}61 \\
69\end{array}$ & $\begin{array}{l}55 \\
59\end{array}$ \\
\hline $\begin{array}{l}\text { Comp LC SPP } \\
\text { Comp LC Elutriate }\end{array}$ & $\begin{array}{l}1 \\
1\end{array}$ & $\begin{array}{l}1.00 \\
1.00\end{array}$ & $\begin{array}{l}86 \\
96\end{array}$ & $\begin{array}{l}101 \\
118\end{array}$ & $\begin{array}{l}57 \\
65\end{array}$ \\
\hline $\begin{array}{l}\text { Comp LC-5 SPP } \\
\text { Comp LC-5 Elutriate } \\
\text { Comp LC-5 Elutriate UF (a) } \\
\text { Comp LC-5 Elutriate F(c) }\end{array}$ & $\begin{array}{l}1 \\
1 \\
2 \\
2\end{array}$ & $\begin{array}{l}1.00 \\
1.00 \\
1.00 \\
1.00\end{array}$ & $\begin{array}{l}84 \\
99 \\
44 \\
94\end{array}$ & $\begin{array}{l}57 \\
63 \\
81 \\
87\end{array}$ & $\begin{array}{l}64 \\
42 \\
31(b) \\
58\end{array}$ \\
\hline $\begin{array}{l}\text { Comp LC-6 SPP } \\
\text { Comp LC-6 Elutriate }\end{array}$ & $\begin{array}{l}1 \\
1\end{array}$ & $\begin{array}{l}1.00 \\
1.00\end{array}$ & $\begin{array}{l}D^{(d)} \\
D\end{array}$ & $\begin{array}{l}D \\
D\end{array}$ & $\begin{array}{l}D \\
D\end{array}$ \\
\hline $\begin{array}{l}\text { Comp USFC SPP } \\
\text { Comp USFC Elutriate }\end{array}$ & $\begin{array}{l}1 \\
1\end{array}$ & $\begin{array}{l}1.00 \\
1.00\end{array}$ & $\begin{array}{r}90 \\
107\end{array}$ & $\begin{array}{l}68 \\
79\end{array}$ & $\begin{array}{l}58 \\
73\end{array}$ \\
\hline $\begin{array}{l}\text { Comp FSFC SPP } \\
\text { Comp FSFC Elutriate }\end{array}$ & $\begin{array}{l}2 \\
2\end{array}$ & $\begin{array}{l}0.80 \\
1.00\end{array}$ & $\begin{array}{l}94 \\
90\end{array}$ & $\begin{array}{l}72 \\
74\end{array}$ & $\begin{array}{l}60 \\
61\end{array}$ \\
\hline $\begin{array}{l}\text { Comp IHC-1 SPP } \\
\text { Comp IHC-1 Elutriate }\end{array}$ & $\begin{array}{l}2 \\
2\end{array}$ & $\begin{array}{l}1.00 \\
1.00\end{array}$ & $\begin{array}{l}88 \\
53\end{array}$ & $\begin{array}{l}70 \\
62\end{array}$ & $\begin{array}{l}58 \\
39^{(b)}\end{array}$ \\
\hline $\begin{array}{l}\text { Comp IHC-2 SPP } \\
\text { Comp IHC-2 Elutriate }\end{array}$ & $\begin{array}{l}2 \\
2\end{array}$ & $\begin{array}{l}1.00 \\
1.00\end{array}$ & $\begin{array}{r}71 \\
101\end{array}$ & $\begin{array}{l}56 \\
99\end{array}$ & $\begin{array}{l}49 \\
93\end{array}$ \\
\hline $\begin{array}{l}\text { Comp IHC-3 SPP } \\
\text { Comp IHC-3 Elutriate }\end{array}$ & $\begin{array}{l}2 \\
2\end{array}$ & $\begin{array}{l}1.00 \\
1.00\end{array}$ & $\begin{array}{l}83 \\
83\end{array}$ & $\begin{array}{l}65 \\
73\end{array}$ & $\begin{array}{l}57 \\
59\end{array}$ \\
\hline Quality Control Data & & & & & \\
\hline Method Blanks & & & & & \\
\hline $\begin{array}{l}\text { Blank } \\
\text { Blank }\end{array}$ & $\frac{1}{2}$ & $\begin{array}{l}1.00 \\
1.00\end{array}$ & $\begin{array}{l}92 \\
91\end{array}$ & $\begin{array}{l}85 \\
75\end{array}$ & $\begin{array}{l}63 \\
57\end{array}$ \\
\hline Matrix Spikes & & & & & \\
\hline $\begin{array}{l}\text { Site Water MS } \\
\text { Site Water MSD }\end{array}$ & $\begin{array}{l}1 \\
1\end{array}$ & & $\begin{array}{l}80 \\
77\end{array}$ & $\begin{array}{l}69 \\
64\end{array}$ & $\begin{array}{l}56 \\
53\end{array}$ \\
\hline $\begin{array}{lll}\text { Comp } & \text { FSFC SPP NS } \\
\text { Comp FSFC SPP MSD }\end{array}$ & $\begin{array}{l}2 \\
2\end{array}$ & & $\begin{array}{l}87 \\
93\end{array}$ & $\begin{array}{l}66 \\
69\end{array}$ & $\begin{array}{l}58 \\
63\end{array}$ \\
\hline
\end{tabular}


TABLE 6.8. (contd)

Liquid Phase

Treatment

Batch $\begin{gathered}\text { Volume } \\ (\mathrm{L})\end{gathered} \quad \underline{\text { SBOFB }} \underline{\mathrm{CL5}(112)} \underline{\mathrm{CL5}(103)}$

Analytical Duplicates

Comp LC SPP

Comp LC SPP Duplicate

$\begin{array}{lllll}1 & 1.00 & 86 & 101 & 57 \\ 1 & 1.00 & 91 & 104 & 59\end{array}$

Comp IHC-2 SPP

Comp IHC-2 SPP Duplicate

$2 \quad 1.00 \quad 71$

56

69

49

90

59
(a) UF Unfiltered.
(b) Recovery outside of quality control range (40\%-120\%).
(c) F Filtered.
(d) D Diluted out. 
TABLE G. 9. Total Polynuclear Aromatic Hydrocarbons (PAHs) in Liquid Phase Samples, United Heckathorn Remedial Investigation

\begin{tabular}{|c|c|c|c|c|}
\hline Liauid Phase Treatment & Batch & $\begin{array}{l}\text { Total Low } \\
\text { Mol ecular } \\
\text { Weight PAH } \\
\end{array}$ & $\begin{array}{l}\text { PAHs (ng/L) } \\
\text { Total High } \\
\text { Molecular } \\
\text { Weight PAH } \\
\end{array}$ & $\begin{array}{l}\text { Total } \\
\text { PAH } \\
\end{array}$ \\
\hline $\begin{array}{l}\text { Site Water } \\
\text { Procedural Blank }\end{array}$ & $\begin{array}{l}1 \\
1\end{array}$ & $\begin{array}{l}25.7 \\
40.8\end{array}$ & $\begin{array}{r}49.9 \\
119.5\end{array}$ & $\begin{array}{r}76 \\
160\end{array}$ \\
\hline $\begin{array}{l}\text { Comp LC SPP } \\
\text { Comp LC Elutriate }\end{array}$ & $\begin{array}{l}1 \\
1\end{array}$ & $\begin{array}{l}413.7 \\
311.4\end{array}$ & $\begin{array}{r}2829.5 \\
809.0\end{array}$ & $\begin{array}{l}3243 \\
1120\end{array}$ \\
\hline $\begin{array}{l}\text { Comp LC-5 SPP } \\
\text { Comp LC-5 Elutriate } \\
\text { Comp LC-5 Elutriate UF } \\
\text { Comp LC-5 Elutriate } \text { F }^{(\text {b) }}\end{array}$ & $\begin{array}{l}1 \\
1 \\
2 \\
2\end{array}$ & $\begin{array}{r}2516.3 \\
2676.9 \\
2503.2 \\
586.9\end{array}$ & $\begin{array}{l}9715.0 \\
7265.7 \\
7735.6 \\
4255.4\end{array}$ & $\begin{array}{r}12231 \\
9943 \\
10239 \\
4842\end{array}$ \\
\hline $\begin{array}{l}\text { Comp LC-6 SPP } \\
\text { Comp LC-6 Elutriate }\end{array}$ & $\begin{array}{l}1 \\
1\end{array}$ & $\begin{array}{r}9371.7 \\
19492.1\end{array}$ & $\begin{array}{l}11299.8 \\
21320.3\end{array}$ & $\begin{array}{l}20671 \\
40812\end{array}$ \\
\hline $\begin{array}{l}\text { Comp USFC SPP } \\
\text { Comp USFC Elutriate }\end{array}$ & $\begin{array}{l}1 \\
1\end{array}$ & $\begin{array}{l}7086.7 \\
7332.6\end{array}$ & $\begin{array}{l}3868.6 \\
1284.2\end{array}$ & $\begin{array}{r}10955 \\
8617\end{array}$ \\
\hline $\begin{array}{l}\text { Comp FSFC SPP } \\
\text { Comp FSFC Elutriate }\end{array}$ & $\begin{array}{l}2 \\
2\end{array}$ & $\begin{array}{r}110.3 \\
25.0\end{array}$ & $\begin{array}{l}572.9 \\
129.1\end{array}$ & $\begin{array}{l}683 \\
154\end{array}$ \\
\hline $\begin{array}{l}\text { Comp IHC-1 SPP } \\
\text { Comp IHC-1 Elutriate }\end{array}$ & $\begin{array}{l}2 \\
2\end{array}$ & $\begin{array}{l}48.7 \\
19.7\end{array}$ & $\begin{array}{r}176.6 \\
51.2\end{array}$ & $\begin{array}{r}225 \\
71\end{array}$ \\
\hline $\begin{array}{l}\text { Comp IHC-2 SPP } \\
\text { Comp IHC-2 Elutriate }\end{array}$ & $\begin{array}{l}2 \\
2\end{array}$ & $\begin{array}{r}26.4 \\
164.9\end{array}$ & $\begin{array}{l}168.6 \\
147.6\end{array}$ & $\begin{array}{l}195 \\
312\end{array}$ \\
\hline $\begin{array}{l}\text { Comp IHC-3 SPP } \\
\text { Comp IHC-3 Elutriate }\end{array}$ & $\begin{array}{l}2 \\
2\end{array}$ & $\begin{array}{l}68.3 \\
60.5\end{array}$ & $\begin{array}{l}182.0 \\
139.6\end{array}$ & $\begin{array}{l}250 \\
200\end{array}$ \\
\hline
\end{tabular}

(a) UF Unfiltered.

(b) F Filtered. 
TABLE G. 10. Low Molecular Weight Polynuclear Aromatic Hydrocarbons (LPAHs) in Liquid Phase Samples, United Heckathorn Remedial Investigation

\begin{tabular}{|c|c|c|c|c|c|c|c|c|c|c|}
\hline \multirow{2}{*}{\multicolumn{2}{|c|}{ Liquid Phase Treatment }} & \multirow[b]{2}{*}{ Batch } & \multicolumn{8}{|c|}{ LPAHs (ng/L) } \\
\hline & & & $\begin{array}{l}\text { Naphtha- } \\
\text { lene } \\
\end{array}$ & $\begin{array}{l}\text { 2-Methyl- } \\
\text { naphtha- } \\
\text { lene } \\
\end{array}$ & $\begin{array}{l}\text { 1-Methyl } \\
\text { naphtha- } \\
\text { lene } \\
\end{array}$ & $\begin{array}{l}\text { Acenaph- } \\
\text { thvlene }\end{array}$ & $\begin{array}{l}\text { Acenaph- } \\
\text { thene }\end{array}$ & Fluorene & $\begin{array}{l}\text { Phenan- } \\
\text { threne }\end{array}$ & $\begin{array}{l}\text { Anthra- } \\
\text { cene }\end{array}$ \\
\hline & $\begin{array}{l}\text { Target DL (a) } \\
\text { Achieved DL }\end{array}$ & & $\begin{array}{l}20 \\
29.87\end{array}$ & $\begin{array}{l}20 \\
29.87\end{array}$ & $\begin{array}{l}20 \\
29.87\end{array}$ & $\begin{array}{l}20 \\
31.60\end{array}$ & $\begin{array}{l}20 \\
27.37\end{array}$ & $\begin{array}{l}20 \\
36.06\end{array}$ & $\begin{array}{l}20 \\
23.16\end{array}$ & $\begin{array}{l}20 \\
23.96\end{array}$ \\
\hline & $\begin{array}{l}\text { Site Water } \\
\text { Procedural Blank }\end{array}$ & $\begin{array}{l}1 \\
1\end{array}$ & $\begin{array}{l}9.93 \mathrm{~J}^{(\mathrm{b})} \\
10.88 \mathrm{~J}^{-}\end{array}$ & $\begin{array}{l}3.82 \mathrm{~J} \\
4.03 \mathrm{~J}\end{array}$ & $\begin{array}{l}3.12 \mathrm{~J} \\
2.98 \mathrm{~J}\end{array}$ & $\begin{array}{l}1.83 \mathrm{~J} \\
4.35 \mathrm{~J}\end{array}$ & $\begin{array}{l}27.37 \mathrm{U}^{(\mathrm{c})} \\
5.61 \mathrm{~J}\end{array}$ & $\begin{array}{r}36.06 \mathrm{U} \\
4.57 \mathrm{~J}\end{array}$ & $\begin{array}{l}4.00 \mathrm{~J} \\
5.16 \mathrm{~J}\end{array}$ & $\begin{array}{l}3.01 \mathrm{~J} \\
3.25 \mathrm{~J}\end{array}$ \\
\hline & $\begin{array}{l}\text { Comp LC SPP } \\
\text { Comp LC Elutriate }\end{array}$ & $\begin{array}{l}1 \\
1\end{array}$ & $\begin{array}{l}15.38 \mathrm{~J} \\
16.19 \mathrm{~J}\end{array}$ & $\begin{array}{l}7.77 \mathrm{~J} \\
5.98 \mathrm{~J}\end{array}$ & $\begin{array}{l}6.42 \mathrm{~J} \\
6.01 \mathrm{~J}\end{array}$ & $\begin{array}{l}9.91 \mathrm{~J} \\
5.82 \mathrm{~J}\end{array}$ & $\begin{array}{l}140.49 \\
135.67\end{array}$ & $\begin{array}{l}33.78 \mathrm{~J} \\
32.62 \mathrm{~J}\end{array}$ & $\begin{array}{r}120.15 \\
87.93\end{array}$ & $\begin{array}{l}79.81 \\
21.14 \mathrm{~J}\end{array}$ \\
\hline & $\begin{array}{l}\text { Comp LC-5 SPP } \\
\text { Comp LC-5 Elutriate } \\
\text { Comp LC-5 Elutriate } U_{F}(d) \\
\text { Comp LC-5 Elutriate F(e) }\end{array}$ & $\begin{array}{l}1 \\
1 \\
2 \\
2\end{array}$ & $\begin{array}{r}281.08 \\
196.00 \\
180.49 \\
13.84 \mathrm{~J}\end{array}$ & $\begin{array}{r}170.61 \\
113.78 \\
94.72 \\
14.75 \mathrm{~J}\end{array}$ & $\begin{array}{r}183.43 \\
128.68 \\
115.73 \\
14.69 \mathrm{~J}\end{array}$ & $\begin{array}{l}64.78 \\
51.39 \\
45.32 \\
34.15\end{array}$ & $\begin{array}{r}443.07 \\
505.19 \\
436.42 \\
59.34\end{array}$ & $\begin{array}{r}280.19 \\
270.30 \\
254.74 \\
35.01 \mathrm{~J}\end{array}$ & $\begin{array}{r}683.49 \\
1065.38 \\
996.51 \\
221.39\end{array}$ & $\begin{array}{l}409.60 \\
346.16 \\
379.31 \\
193.76\end{array}$ \\
\hline 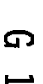 & $\begin{array}{l}\text { Comp LC-6 SPP } \\
\text { Comp LC-6 Elutriate }\end{array}$ & $\begin{array}{l}1 \\
1\end{array}$ & $\begin{array}{l}198.95 \\
317.77\end{array}$ & $\begin{array}{l}296.82 \\
548.14\end{array}$ & $\begin{array}{r}633.69 \\
1125.64\end{array}$ & $\begin{array}{r}35.16 \\
242.61\end{array}$ & $\begin{array}{l}2217.36 \\
4006.94\end{array}$ & $\begin{array}{l}1942.80 \\
4400.01\end{array}$ & $\begin{array}{l}3279.07 \\
7265.38\end{array}$ & $\begin{array}{r}767.81 \\
1585.58\end{array}$ \\
\hline & $\begin{array}{l}\text { Comp USFC SPP } \\
\text { Comp USFC Elutriate }\end{array}$ & $\begin{array}{l}1 \\
1\end{array}$ & $\begin{array}{l}15.52 \mathrm{~J} \\
10.96 \mathrm{~J}\end{array}$ & $\begin{array}{l}268.64 \\
387.15\end{array}$ & $\begin{array}{l}572.79 \\
788.98\end{array}$ & $\begin{array}{l}455.97 \\
447.66\end{array}$ & $\begin{array}{l}2573.43 \\
2377.41\end{array}$ & $\begin{array}{l}1437.89 \\
1398.82\end{array}$ & $\begin{array}{l}1522.41 \\
1724.51\end{array}$ & $\begin{array}{l}240.01 \\
197.12\end{array}$ \\
\hline & $\begin{array}{l}\text { Comp FSFC SPP } \\
\text { Comp FSFC Elutriate }\end{array}$ & $\begin{array}{l}2 \\
2\end{array}$ & $\begin{array}{r}18.85 \mathrm{~J} \\
7.02 \mathrm{~J}\end{array}$ & $\begin{array}{l}9.45 \mathrm{~J} \\
4.90 \mathrm{~J}\end{array}$ & $\begin{array}{l}7.74 \mathrm{~J} \\
3.40 \mathrm{u}\end{array}$ & $\begin{array}{l}5.36 \mathrm{~J} \\
3.15 \mathrm{~J}\end{array}$ & $\begin{array}{l}17.37 \mathrm{~J} \\
27.37 \mathrm{U}\end{array}$ & $\begin{array}{r}6.78 \mathrm{~J} \\
36.06 \mathrm{U}\end{array}$ & $\begin{array}{r}22.98 \mathrm{~J} \\
2.40 \mathrm{~J}\end{array}$ & $\begin{array}{r}21.78 \mathrm{~J} \\
4.11 \mathrm{~J}\end{array}$ \\
\hline & $\begin{array}{l}\text { Comp IHC-1 SPP } \\
\text { Comp IHC-1 Elutriate }\end{array}$ & $\begin{array}{l}2 \\
2\end{array}$ & $\begin{array}{r}10.15 \mathrm{~J} \\
5.82 \mathrm{~J}\end{array}$ & $\begin{array}{l}6.54 \mathrm{~J} \\
3.27 \mathrm{~J}\end{array}$ & $\begin{array}{l}5.53 \mathrm{~J} \\
3.28 \mathrm{~J}\end{array}$ & $\begin{array}{r}2.38 \mathrm{~J} \\
31.60 \mathrm{U}\end{array}$ & $\begin{array}{r}4.57 \mathrm{~J} \\
27.37 \mathrm{U}\end{array}$ & $\begin{array}{l}4.27 \mathrm{~J} \\
1.60 \mathrm{~J}\end{array}$ & $\begin{array}{l}8.16 \mathrm{~J} \\
3.21 \mathrm{~J}\end{array}$ & $\begin{array}{l}7.12 \mathrm{~J} \\
2.52 \mathrm{~J}\end{array}$ \\
\hline & $\begin{array}{l}\text { Comp IHC-2 SPP } \\
\text { Comp IHC-2 Elutriate }\end{array}$ & $\begin{array}{l}2 \\
2\end{array}$ & $\begin{array}{l}10.12 \mathrm{~J} \\
51.59 \mathrm{~J}\end{array}$ & $\begin{array}{r}4.92 \mathrm{~J} \\
43.96 \mathrm{~J}\end{array}$ & $\begin{array}{l}29.87 \mathrm{U} \\
33.29 \mathrm{~J}\end{array}$ & $\begin{array}{r}31.60 \mathrm{U} \\
5.99 \mathrm{~J}\end{array}$ & $\begin{array}{l}27.37 \mathrm{U} \\
27.37 \mathrm{U}\end{array}$ & $\begin{array}{r}36.06 \mathrm{U} \\
9.13 \mathrm{~J}\end{array}$ & $\begin{array}{r}5.73 \mathrm{~J} \\
12.90 \mathrm{~J}\end{array}$ & $\begin{array}{l}5.64 \mathrm{~J} \\
8.07 \mathrm{~J}\end{array}$ \\
\hline & $\begin{array}{l}\text { Comp IHC-3 SPP } \\
\text { Comp IHC-3 Elutriate }\end{array}$ & $\begin{array}{l}2 \\
2\end{array}$ & $\begin{array}{l}17.26 \mathrm{~J} \\
17.18 \mathrm{~J}\end{array}$ & $\begin{array}{l}4.98 \mathrm{~J} \\
5.89 \mathrm{~J}\end{array}$ & $\begin{array}{l}3.28 \mathrm{~J} \\
4.05 \mathrm{~J}\end{array}$ & $\begin{array}{l}6.66 \mathrm{~J} \\
5.14 \mathrm{~J}\end{array}$ & $\begin{array}{l}7.95 \mathrm{~J} \\
7.57 \mathrm{~J}\end{array}$ & $\begin{array}{l}8.23 \mathrm{~J} \\
6.28 \mathrm{~J}\end{array}$ & $\begin{array}{r}10.51 \mathrm{~J} \\
8.46 \mathrm{~J}\end{array}$ & $\begin{array}{l}9.42 \mathrm{~J} \\
5.88 \mathrm{~J}\end{array}$ \\
\hline
\end{tabular}

(a) DL Detection Iimit.

(b) J Analyte detected below method detection limit (MDL), but above instrument detection limit (IDL)

(c) U Analyte was not present above the associated value.

(d) UF Unfiltered.

(e) F Filtered. 
TABLE G. 11. High Molecular Weight Polynuclear Aromatic Hydrocarbons (HPAHs) in Liquid Phase Samples, United Heckathorn Remedial Investigation

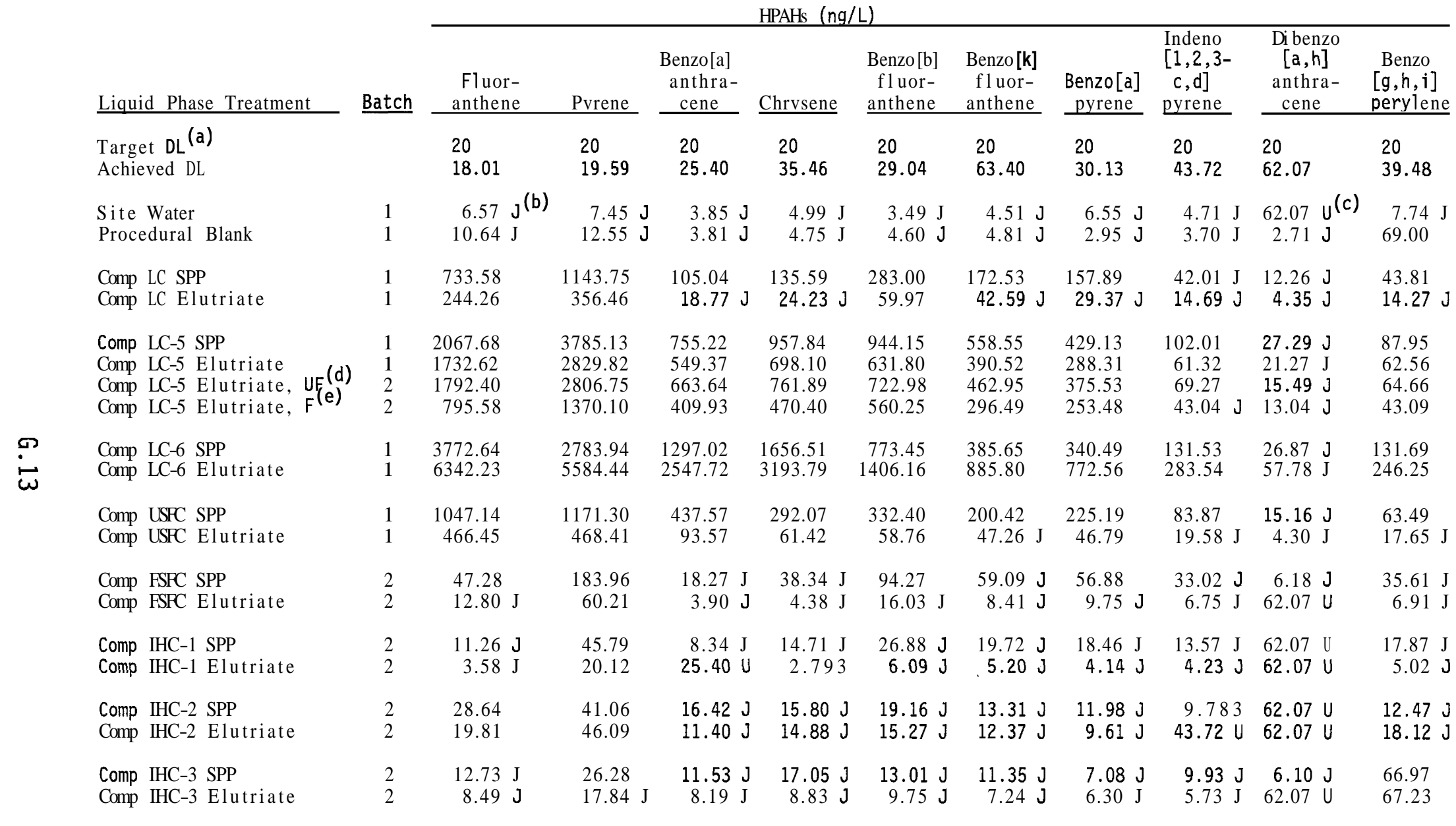

(a) DL Detection limit.

(b) J Analyte detected below method detection limit (MDL), but above instrument detection limit (IDL).

(c) $U$ Analyte was not present above the associated value.

(d) UF Unfi 1tered.

(e) F Filtered. 
TABLE 6.12. Quality Control Summary for Low Molecular Weight Polynuclear Aromatic Hydrocarbons (LPAHs) in Liquid Phase Samples, United Heckathorn Remedial Investigation

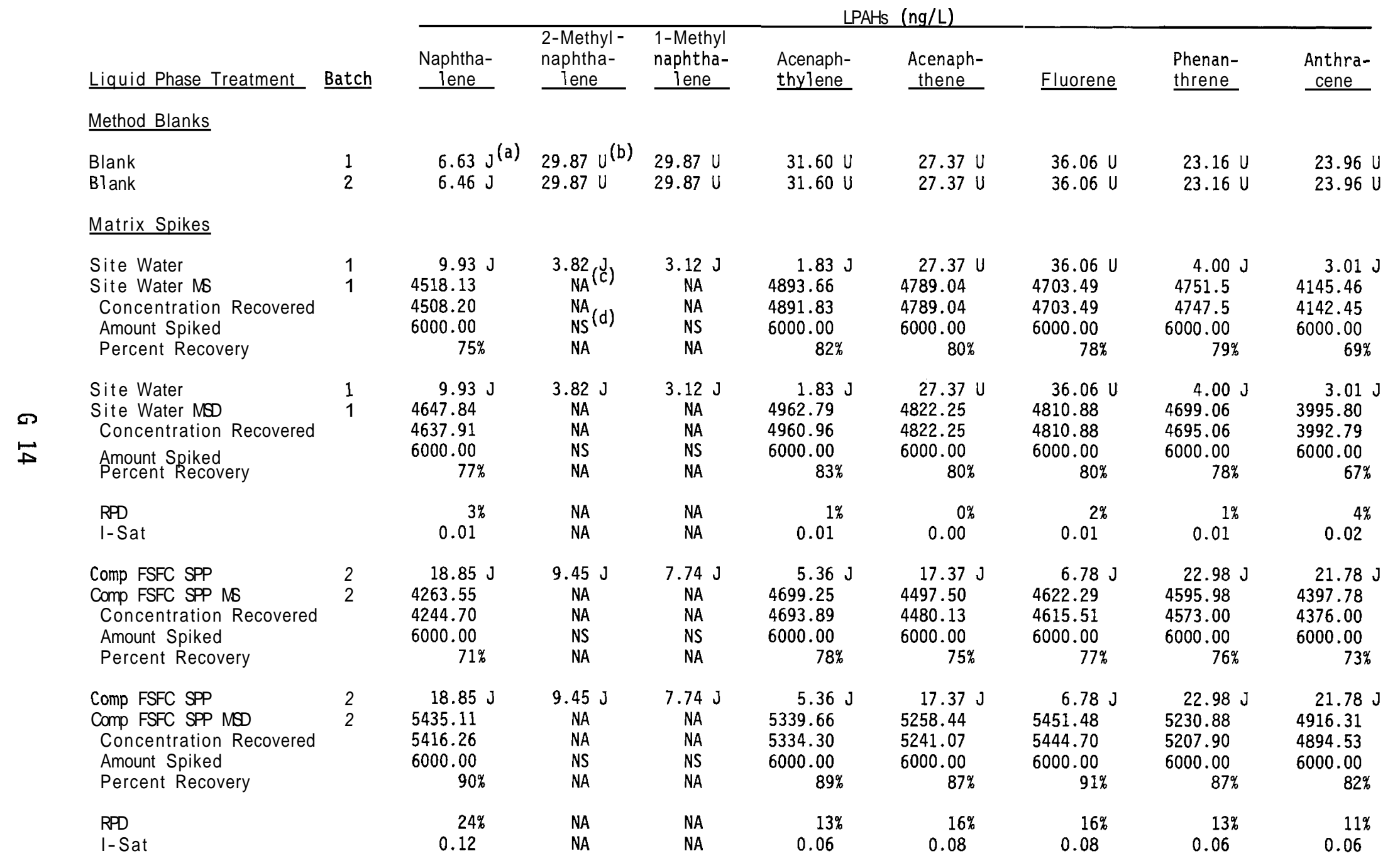


TABLE 6.12. (contd)

\begin{tabular}{|c|c|c|c|c|c|c|c|c|c|}
\hline \multirow[b]{2}{*}{ Liquid Phase Treatment } & \multirow[b]{2}{*}{ Batch } & \multicolumn{8}{|c|}{ LPAHs (ng/L) } \\
\hline & & $\begin{array}{l}\text { Naphtha- } \\
\text { lene } \\
\end{array}$ & $\begin{array}{l}\text { 2-Methyl- } \\
\text { naphtha- } \\
\text { lene } \\
\end{array}$ & $\begin{array}{c}\text { 1-Methyl } \\
\text { naphtha- } \\
\text { Tene } \\
\end{array}$ & $\begin{array}{l}\text { Acenaph- } \\
\text { thylene } \\
\end{array}$ & $\begin{array}{l}\text { Acenaph- } \\
\text { thene }\end{array}$ & Fluorene & $\begin{array}{l}\text { Phenan- } \\
\text { threne }\end{array}$ & $\begin{array}{l}\text { Anthra- } \\
\text { cene }\end{array}$ \\
\hline$\underline{\text { Analvtical Duplicates }}$ & & & & & & & & & \\
\hline $\begin{array}{l}\text { Comp LC SPP } \\
\text { Comp LC SPP Duplicate } \\
\text { RPD } \\
\text { I-Stat }\end{array}$ & $\begin{array}{l}1 \\
1\end{array}$ & $\begin{array}{c}15.38 \mathrm{~J} \\
14.72 \mathrm{~J} \\
4 \% \\
0.02\end{array}$ & $\begin{array}{l}7.77 \mathrm{~J} \\
9.24 \mathrm{~J} \\
17 \% \\
0.09\end{array}$ & $\begin{array}{l}6.42 \mathrm{~J} \\
6.54 \mathrm{~J} \\
2 \% \\
0.01\end{array}$ & $\begin{array}{l}9.91 \mathrm{~J} \\
19.33 \mathrm{~J} \\
64 \% \\
0.32\end{array}$ & $\begin{array}{r}140.49 \\
163.87 \\
15 \% \\
0.08\end{array}$ & $\begin{array}{l}33.78 \mathrm{~J} \\
56.63 \mathrm{e} \\
51 \% \\
0.25\end{array}$ & $\begin{array}{l}120.15 \\
254.83 \\
72 \%(f) \\
0.36\end{array}$ & $\begin{array}{c}79.81 \\
136.46 \\
52 \% \\
0.26\end{array}$ \\
\hline $\begin{array}{l}\text { Comp IHC-2 SPP } \\
\text { Comp IHC-2 SPP Duplicate } \\
\text { RPD } \\
\text { I-Stat }\end{array}$ & $\begin{array}{l}2 \\
2\end{array}$ & $\begin{array}{l}10.12 \mathrm{~J} \\
11.91 \mathrm{~J} \\
16 \% \\
0.08\end{array}$ & $\begin{array}{l}4.92 \mathrm{~J} \\
4.26 \mathrm{~J} \\
14 \% \\
0.07\end{array}$ & $\begin{array}{c}29.87 \mathrm{U} \\
2.43 \mathrm{~J} \\
\text { NA } \\
\text { NA }\end{array}$ & $\begin{array}{c}31.60 \mathrm{U} \\
1.92 \mathrm{~J} \\
\text { NA } \\
\text { NA }\end{array}$ & $\begin{array}{c}27.37 \mathrm{U} \\
30.41 \mathrm{U} \\
\text { NA } \\
\text { NA }\end{array}$ & $\begin{array}{l}36.06 \mathrm{U} \\
40.07 \mathrm{U} \\
\text { NA } \\
\text { NA }\end{array}$ & $\begin{array}{l}5.73 \mathrm{~J} \\
5.93 \mathrm{~J} \\
3 \% \\
0.02\end{array}$ & $\begin{array}{l}5.64 \mathrm{~J} \\
5.48 \mathrm{~J} \\
3 \% \\
0.01\end{array}$ \\
\hline
\end{tabular}

(a) J Analyte detected below method detection limit (MDL), but above instrument detection limit (IDL).

(b) $U$ Analyte was not present above the associated value.

(c) NA Not applicable.

$\vec{G} \quad($ e) Precision criteria do not apply because sample results are less than 10 times the MDL.

(f) Value exceeds relative precision goal of $\leq 30 \%$. 
TABLE 6.13. Qualit y Control Summary for High Molecular Weight Polynuclear Aromatic Hydrocarbons (HPAHs) in Liquid Phase Samples, United Heckathorn Remedial Investigation

\begin{tabular}{|c|c|c|c|c|c|c|c|c|c|c|c|}
\hline \multirow[b]{2}{*}{ Liquid Phase Treatment } & \multirow[b]{2}{*}{ Batch } & \multicolumn{10}{|c|}{ HPAHs (ng/L) } \\
\hline & & $\begin{array}{r}\text { Fluor- } \\
\text { anthene } \\
\end{array}$ & Pvrene & $\begin{array}{c}\text { Benzo [a] } \\
\text { anthra- } \\
\text { cene } \\
\end{array}$ & Chrysene & $\begin{array}{r}\text { Benzo [b] } \\
\text { fluor- } \\
\text { anthene } \\
\end{array}$ & $\begin{array}{r}\text { Benzo }[k] \\
\text { fluor- } \\
\text { anthene } \\
\end{array}$ & $\begin{array}{c}\text { Benzo [a] } \\
\text { pyrene }\end{array}$ & $\begin{array}{l}\text { Indeno } \\
{[1,2,3-} \\
c, d] \\
\text { pvrene } \\
\end{array}$ & $\begin{array}{l}\text { Dibenzo } \\
\text { [a, h] } \\
\text { anthra- } \\
\text { cene } \\
\end{array}$ & $\begin{array}{l}\text { Benzo } \\
{[g, h, i]} \\
\text { pervlene }\end{array}$ \\
\hline \multicolumn{12}{|l|}{ Method Blanks } \\
\hline $\begin{array}{l}\text { Blank } \\
\text { Blank }\end{array}$ & $\begin{array}{l}1 \\
2\end{array}$ & $\begin{array}{l}18.01 U^{(a} \\
18.01\end{array}$ & $\begin{array}{l}19.59 \mathrm{U} \\
19.59 \mathrm{U}\end{array}$ & $\begin{array}{l}25.40 \cup \\
25.40 \cup\end{array}$ & $\begin{array}{l}35.46 \mathrm{U} \\
35.46 \mathrm{U}\end{array}$ & $\begin{array}{l}29.04 \mathrm{U} \\
29.04 \mathrm{U}\end{array}$ & $\begin{array}{l}63.40 \mathrm{U} \\
63.40 \mathrm{U}\end{array}$ & $\begin{array}{r}9.88 \mathrm{~J}^{(\mathrm{b}} \\
30.13 \mathrm{U}\end{array}$ & $\begin{array}{l}43.72 \mathrm{U} \\
43.72 \mathrm{U}\end{array}$ & $\begin{array}{l}62.07 \mathrm{U} \\
62.07 \mathrm{U}\end{array}$ & $\begin{array}{l}39.48 \mathrm{U} \\
39.48 \mathrm{U}\end{array}$ \\
\hline \multicolumn{12}{|l|}{ Matrix Spikes } \\
\hline $\begin{array}{l}\text { Site Water } \\
\text { Site Water NS } \\
\text { Concentration Recovered } \\
\text { Amount Spiked } \\
\text { Percent Recovery }\end{array}$ & $\begin{array}{l}1 \\
1\end{array}$ & $\begin{array}{l}6.57 \mathrm{~J} \\
5084.17 \\
5077.60 \\
6000.00 \\
85 \%\end{array}$ & $\begin{array}{r}7.45 \mathrm{~J} \\
5007.11 \\
4999.66 \\
6000.00 \\
83 \%\end{array}$ & $\begin{array}{l}3.85 \mathrm{~J} \\
4908.70 \\
4904.85 \\
6000.00 \\
82 \%\end{array}$ & $\begin{array}{r}4.99 \mathrm{~J} \\
4915.16 \\
4910.17 \\
6000.00 \\
82 \%\end{array}$ & $\begin{array}{l}3.49 \mathrm{~J} \\
5182.08 \\
5178.59 \\
6000.00 \\
86 \%\end{array}$ & $\begin{array}{l}4.51 \mathrm{~J} \\
4996.91 \\
4992.40 \\
6000.00 \\
83 \%\end{array}$ & $\begin{array}{r}6.55 \mathrm{~J} \\
3517.57 \\
3511.02 \\
6000.00 \\
59 \%\end{array}$ & $\begin{array}{r}4.71 \mathrm{~J} \\
4442.04 \\
4437.33 \\
6000.00 \\
74 \%\end{array}$ & $\begin{array}{r}62.07 \mathrm{U} \\
4638.89 \\
4638.89 \\
6000.00 \\
77 \%\end{array}$ & $\begin{array}{r}7.74 \mathrm{~J} \\
4016.75 \\
4009.01 \\
6000.00 \\
\quad 67 \%\end{array}$ \\
\hline $\begin{array}{l}\text { Site Water } \\
\text { Site Water MSD } \\
\text { Concentration Recovered } \\
\text { Amount Spiked } \\
\text { Percent Recovery }\end{array}$ & $\begin{array}{l}1 \\
1\end{array}$ & $\begin{array}{l}\quad 6.57 \mathrm{~J} \\
5093.64 \\
5087.07 \\
6000.00 \\
85 \%\end{array}$ & $\begin{array}{r}7.45 \mathrm{~J} \\
4982.40 \\
4974.95 \\
6000.00 \\
83 \%\end{array}$ & $\begin{array}{l}3.85 \mathrm{~J} \\
4829.18 \\
4825.33 \\
6000.00 \\
\quad 80 \%\end{array}$ & $\begin{array}{r}4.99 \mathrm{~J} \\
4896.54 \\
4891.55 \\
6000.00 \\
82 \%\end{array}$ & $\begin{array}{r}3.49 \mathrm{~J} \\
5203.72 \\
5200.23 \\
6000.00 \\
87 \%\end{array}$ & $\begin{array}{l}4.51 \mathrm{~J} \\
5140.88 \\
5136.37 \\
6000.00 \\
86 \%\end{array}$ & $\begin{array}{r}6.55 \mathrm{~J} \\
3732.95 \\
3726.40 \\
6000.00 \\
62 \%\end{array}$ & $\begin{array}{r}4.71 \mathrm{~J} \\
4691.05 \\
4686.34 \\
6000.00 \\
78 \%\end{array}$ & $\begin{array}{r}62.07 \mathrm{U} \\
4885.10 \\
4885.10 \\
6000.00 \\
81 \%\end{array}$ & $\begin{array}{l}7.74 \mathrm{~J} \\
4384.41 \\
4376.67 \\
6000.00 \\
73 \%\end{array}$ \\
\hline $\begin{array}{l}\text { RPD } \\
\text { I-Stat }\end{array}$ & & 0.00 & 0.00 & 0.01 & 0.00 & $0.01 \%$ & 0.01 & 0.03 & 0.03 & 0.03 & 0.04 \\
\hline $\begin{array}{l}\text { Comp FSFC SPP } \\
\text { Comp FSFC SPP MS } \\
\text { Concentration Recovered } \\
\text { Amount Spiked } \\
\text { Percent Recovery }\end{array}$ & $\begin{array}{l}2 \\
2\end{array}$ & $\begin{array}{r}47.28 \\
5137.14 \\
5089.86 \\
6000.00 \\
85 \%\end{array}$ & $\begin{array}{r}183.96 \\
5155.04 \\
4971.08 \\
6000.00 \\
83 \%\end{array}$ & $\begin{array}{l}18.27 \mathrm{~J} \\
5662.65 \\
5644.38 \\
6000.00 \\
94 \%\end{array}$ & $\begin{array}{r}38.34 \mathrm{~J} \\
5563.09 \\
5524.75 \\
6000.00 \\
92 \%\end{array}$ & $\begin{array}{r}94.27 \\
5214.05 \\
5119.78 \\
6000.00 \\
85 \%\end{array}$ & $\begin{array}{r}59.09 \mathrm{~J} \\
5165.11 \\
5106.02 \\
6000.00 \\
85 \%\end{array}$ & $\begin{array}{r}56.88 \\
4439.42 \\
4382.54 \\
6000.00 \\
73 \%\end{array}$ & $\begin{array}{r}33.02 \mathrm{~J} \\
3640.15 \\
3607.13 \\
6000.00 \\
60 \%\end{array}$ & $\begin{array}{r}6.18 \mathrm{~J} \\
3920.97 \\
3914.79 \\
6000.00 \\
65 \%\end{array}$ & $\begin{array}{c}35.61 \mathrm{~J} \\
3239.66 \\
3204.05 \\
6000.00 \\
53 \%\end{array}$ \\
\hline $\begin{array}{l}\text { Comp FSFC SPP } \\
\text { Comp FSFC SPP MSD } \\
\text { Concentration Recovered } \\
\text { Amount Spiked }\end{array}$ & $\begin{array}{l}2 \\
2\end{array}$ & $\begin{array}{r}47.28 \\
5677.38 \\
5630.10 \\
6000.00\end{array}$ & $\begin{array}{r}183.96 \\
5679.57 \\
5495.61 \\
6000.00\end{array}$ & $\begin{array}{l}18.27 \mathrm{~J} \\
5790.00 \\
5771.73 \\
6000.00\end{array}$ & $\begin{array}{l}38.34 \mathrm{~J} \\
5701.23 \\
5662.89 \\
6000.00\end{array}$ & $\begin{array}{r}94.27 \\
5932.89 \\
5838.62 \\
6000.00\end{array}$ & $\begin{array}{l}59.09 \mathrm{~J} \\
5947.51 \\
5888.42 \\
6000.00\end{array}$ & $\begin{array}{r}56.88 \\
4925.53 \\
4868.65 \\
6000.00\end{array}$ & $\begin{array}{l}33.02 \mathrm{~J} \\
4884.41 \\
4851.39 \\
6000.00\end{array}$ & $\begin{array}{l}6.18 \mathrm{~J} \\
5082.85 \\
5076.67 \\
6000.00\end{array}$ & $\begin{array}{l}35.61 \mathrm{~J} \\
4444.20 \\
4408.59 \\
6000.00\end{array}$ \\
\hline Percent Recovery & & $94 \%$ & $92 \%$ & $96 \%$ & $94 \%$ & $97 \%$ & $98 \%$ & $81 \%$ & $81 \%$ & $85 \%$ & $73 \%$ \\
\hline $\begin{array}{l}\text { RPD } \\
\text { I-Stat }\end{array}$ & & $\begin{array}{l}10 \% \\
0.05\end{array}$ & $\begin{array}{l}10 \% \\
0.05\end{array}$ & 0.01 & 0.01 & $\begin{array}{l}13 \% \\
0.07\end{array}$ & $\begin{array}{l}14 \% \\
0.07\end{array}$ & $\begin{array}{l}11 \% \\
0.05\end{array}$ & $\begin{array}{l}29 \% \\
0.15\end{array}$ & $\begin{array}{l}26 \% \\
0.13\end{array}$ & $\begin{array}{l}32 \%(c) \\
0.16\end{array}$ \\
\hline
\end{tabular}


TABLE 6.13. (contd)

\begin{tabular}{|c|c|c|c|c|c|c|c|c|c|c|c|}
\hline \multirow[b]{2}{*}{ Liquid Phase Treatment } & \multirow[b]{2}{*}{ Batch } & \multicolumn{10}{|c|}{ HPAHs (ng/L) } \\
\hline & & $\begin{array}{r}\text { Fluor- } \\
\text { anthene }\end{array}$ & Pyrene & $\begin{array}{c}\text { Benzo[a] } \\
\text { anthra- } \\
\text { cene } \\
\end{array}$ & Chrysene & $\begin{array}{r}\text { Benzo [b] } \\
\text { fluor- } \\
\text { anthene } \\
\end{array}$ & $\begin{array}{r}\text { Benzo }[\mathrm{k}] \\
\text { fluor- } \\
\text { anthene } \\
\end{array}$ & $\begin{array}{l}\text { Benzo [a] } \\
\text { pyrene }\end{array}$ & $\begin{array}{l}\text { Indeno } \\
{[1,2,3-} \\
\mathrm{c}, \mathrm{d}] \\
\text { pyrene } \\
\end{array}$ & $\begin{array}{l}\text { Dibenzo } \\
{[a, h]} \\
\text { anthra- } \\
\text { cene } \\
\end{array}$ & $\begin{array}{c}\text { Benzo } \\
{[g, h, i]} \\
\text { perylene }\end{array}$ \\
\hline \multicolumn{12}{|l|}{ Anal vtical Duplicates } \\
\hline $\begin{array}{l}\text { Comp LC SPP } \\
\text { Comp LC SPP Duplicate } \\
\text { RPD } \\
\text { I-Stat }\end{array}$ & $\begin{array}{l}1 \\
1\end{array}$ & $\begin{array}{c}733.58 \\
1046.09 \\
35 \% \\
0.18\end{array}$ & $\begin{array}{c}1143.75 \\
1654.05 \\
36 \%(c) \\
0.18\end{array}$ & $\begin{array}{l}105.04 \\
204.78 \\
64 \% \\
0.32\end{array}$ & $\begin{array}{l}135.59 \\
287.17 \\
72 \%(\mathrm{~d}) \\
0.36\end{array}$ & $\begin{array}{l}283.00 \\
513.78 \text { (c) } \\
58 \%(c) \\
0.29\end{array}$ & $\begin{array}{l}172.53 \\
274.20 \\
46 \% \\
0.23\end{array}$ & $\begin{array}{c}157.89 \\
204.38 \\
26 \% \\
0.13\end{array}$ & $\begin{array}{l}42.01 \mathrm{~J} \\
67.47 \%(\mathrm{~d}) \\
0.23\end{array}$ & $\begin{array}{l}12.26 \mathrm{~J} \\
15.26 \% \mathrm{~J} \\
0.11\end{array}$ & $\begin{array}{c}57.629 \% \\
0.14\end{array}$ \\
\hline $\begin{array}{l}\text { Comp IHC-2 SPP } \\
\text { Comp IHC-2 SPP Duplicate } \\
\text { RPD } \\
\text { I-Stat }\end{array}$ & $\begin{array}{l}2 \\
2\end{array}$ & $\begin{array}{c}28.64 \\
28.60 \\
0 \% \\
0.00\end{array}$ & $\begin{array}{c}41.06 \\
43.54 \\
6 \% \\
0.03\end{array}$ & $\begin{array}{l}16.42 \mathrm{~J} \\
13.53 \mathrm{~J} \\
19 \% \\
0.10\end{array}$ & $\begin{array}{c}15.80 \mathrm{~J} \\
15.93 \mathrm{~J} \\
1 \% \\
0.00\end{array}$ & $\begin{array}{l}19.16 \mathrm{~J} \\
23.07 \mathrm{~J} \\
19 \% \\
0.09\end{array}$ & $\begin{array}{c}13.31 \mathrm{~J} \\
14.44 \mathrm{~J} \\
8 \% \\
0.04\end{array}$ & $\begin{array}{c}11.98 \mathrm{~J} \\
9.01 \mathrm{~J} \\
28 \% \\
0.14\end{array}$ & $\begin{array}{l}9.78 \mathrm{~J} \\
11.19 \mathrm{~J} \\
13 \% \\
0.07\end{array}$ & $\begin{array}{l}62.07 \mathrm{U} \\
4.26 \text { J } \\
\text { NA } \\
\text { NA }\end{array}$ & $\begin{array}{c}12.47 \mathrm{~J} \\
15.86 \mathrm{~J} \\
24 \% \\
0.12\end{array}$ \\
\hline
\end{tabular}

(a) U Analyte was not present above the associated value.

(b) J Analyte detected below method detection limit (MDL), but above instrument detection Iimit (IDL).

(c) Value exceeds relative precision goal of $\leq 30 \%$.

(d) Precision criteria do not apply because sample results are less than 10 times the MDL

(e) NA Not applicable. 
TABLE 6.14. Surrogate Percent Recoveries for Polynuclear Aromatic Hydrocarbons (PAHs) in Liquid Phase Samples, United Heckathorn Remedia1 Investigation

\begin{tabular}{|c|c|c|c|c|}
\hline \multirow{2}{*}{ Liquid Phase Treatment } & \multirow[b]{2}{*}{$\underline{B a t c h}$} & \multicolumn{3}{|c|}{ Surroqate Percent Recoveries } \\
\hline & & $\begin{array}{l}\text { Naphtha- } \\
\text { lene d8 }\end{array}$ & $\begin{array}{l}\text { Acenaph- } \\
\text { thene d10 }\end{array}$ & $\begin{array}{c}\text { Benzo [a] } \\
\text { pvrene d12 }\end{array}$ \\
\hline $\begin{array}{l}\text { Site Water } \\
\text { Procedural Blank }\end{array}$ & $\begin{array}{l}1 \\
1\end{array}$ & $\begin{array}{l}64 \\
78\end{array}$ & $\begin{array}{l}67 \\
83\end{array}$ & $\begin{array}{l}52 \\
47\end{array}$ \\
\hline $\begin{array}{l}\text { Comp LC SPP } \\
\text { Comp LC Elutriate }\end{array}$ & $\begin{array}{l}1 \\
1\end{array}$ & $\begin{array}{l}50 \\
71\end{array}$ & $\begin{array}{l}64 \\
76\end{array}$ & $\begin{array}{l}61 \\
58\end{array}$ \\
\hline $\begin{array}{l}\text { Comp LC-5 SPP } \\
\text { Comp LC-5 Elutriate } \\
\text { Comp LC-5 Elutriate UF(a) } \\
\text { Comp LC-5 Elutriate } F^{(b)}\end{array}$ & $\begin{array}{l}1 \\
1 \\
2 \\
2\end{array}$ & $\begin{array}{l}73 \\
61 \\
60 \\
68\end{array}$ & $\begin{array}{r}100 \\
81 \\
84 \\
91\end{array}$ & $\begin{array}{l}69 \\
60 \\
69 \\
75\end{array}$ \\
\hline $\begin{array}{l}\text { Comp LC-6 SPP } \\
\text { Comp LC-6 Elutriate }\end{array}$ & $\begin{array}{l}1 \\
1\end{array}$ & $\begin{array}{l}61 \\
79\end{array}$ & $\begin{array}{l}96 \\
154\end{array}$ & $\begin{array}{l}59 \\
64\end{array}$ \\
\hline $\begin{array}{l}\text { Comp USFC SPP } \\
\text { Comp USFC Elutriate }\end{array}$ & $\begin{array}{l}1 \\
1\end{array}$ & $\begin{array}{l}61 \\
72\end{array}$ & $\begin{array}{l}70 \\
76\end{array}$ & $\begin{array}{l}72 \\
77\end{array}$ \\
\hline $\begin{array}{l}\text { Comp FSFC SPP } \\
\text { Comp FSFC Elutriate }\end{array}$ & $\begin{array}{l}2 \\
2\end{array}$ & $\begin{array}{l}65 \\
75\end{array}$ & $\begin{array}{l}72 \\
80\end{array}$ & $\begin{array}{l}58 \\
76\end{array}$ \\
\hline $\begin{array}{l}\text { Comp IHC-1 SPP } \\
\text { Comp IHC-1 Elutriate }\end{array}$ & $\begin{array}{l}2 \\
2\end{array}$ & $\begin{array}{l}73 \\
47\end{array}$ & $\begin{array}{l}80 \\
60\end{array}$ & $\begin{array}{l}64 \\
51\end{array}$ \\
\hline $\begin{array}{l}\text { Comp IHC-2 SPP } \\
\text { Comp IHC-2 Elutriate }\end{array}$ & $\begin{array}{l}2 \\
2\end{array}$ & $\begin{array}{l}54 \\
61\end{array}$ & $\begin{array}{l}63 \\
66\end{array}$ & $\begin{array}{l}58 \\
71\end{array}$ \\
\hline $\begin{array}{l}\text { Comp IHC-3 SPP } \\
\text { Comp IHC-3 Elutriate }\end{array}$ & $\begin{array}{l}2 \\
2\end{array}$ & $\begin{array}{l}65 \\
68\end{array}$ & $\begin{array}{l}72 \\
74\end{array}$ & $\begin{array}{l}39^{(c)} \\
67\end{array}$ \\
\hline \multicolumn{5}{|l|}{ Qualit v Control Data } \\
\hline \multicolumn{5}{|l|}{ Method Blanks } \\
\hline $\begin{array}{l}\text { Blank } \\
\text { Blank }\end{array}$ & $\begin{array}{l}1 \\
2\end{array}$ & $\begin{array}{l}82 \\
81\end{array}$ & $\begin{array}{l}83 \\
87\end{array}$ & $\begin{array}{l}69 \\
66\end{array}$ \\
\hline \multicolumn{5}{|l|}{ Matrix Spikes } \\
\hline $\begin{array}{l}\text { Site Water MS } \\
\text { Site Water MSD }\end{array}$ & $\begin{array}{l}1 \\
1\end{array}$ & $\begin{array}{l}69 \\
70\end{array}$ & $\begin{array}{l}72 \\
71\end{array}$ & $\begin{array}{l}52 \\
54\end{array}$ \\
\hline $\begin{array}{l}\text { Comp FSFC SPP NS } \\
\text { Comp FSFC SPP MSD }\end{array}$ & $\begin{array}{l}2 \\
2\end{array}$ & $\begin{array}{l}65 \\
81\end{array}$ & $\begin{array}{l}69 \\
81\end{array}$ & $\begin{array}{l}69 \\
73\end{array}$ \\
\hline
\end{tabular}


TABLE 6.14. (contd)

Surrogate Percent Recoveries

Liquid Phase Treatment

Batch

Acenaph-

Benzo[a]

Naphtha-

thene $\mathrm{d} 10$

pvrene d12

Analvtical Duplicates

Comp LC SPP Duplicate

Comp IHC-2 SPP Duplicate

1
2

60

70

75

76

62

41

(a) UF Unfiltered.

(b) F Filtered.

(c) Recovery outside quality control range (40\%-120\%). 
TABLE 6.15. Polychlorinated Biphenyls (PCBs) in Liquid Phase Sarnples, United Heckathorn Rernedial Investigation

\begin{tabular}{|c|c|c|c|c|c|c|}
\hline \multirow[b]{2}{*}{$\begin{array}{l}\text { Liquid Phase } \\
\text { Treatment }\end{array}$} & \multirow[b]{2}{*}{ Batch } & \multirow[b]{2}{*}{ Volume (L) } & \\
\hline & & & $\begin{array}{l}\text { Aroclor } \\
1242 \\
\end{array}$ & $\begin{array}{c}\text { Aroclor } \\
1248 \\
\end{array}$ & $\begin{array}{c}\text { Aroclor } \\
1254 \\
\end{array}$ & $\begin{array}{c}\text { Aroclor } \\
1260 \\
\end{array}$ \\
\hline $\begin{array}{l}\text { Target } \mathrm{DL}(\mathrm{a}) \\
\text { Achieved } \mathrm{DL}\end{array}$ & & & $\begin{array}{l}50 \\
25.0\end{array}$ & $\begin{array}{l}50 \\
25.0\end{array}$ & $\begin{array}{l}50 \\
25.0\end{array}$ & $\begin{array}{l}50 \\
25.0\end{array}$ \\
\hline $\begin{array}{l}\text { Site Water } \\
\text { Procedural Blank }\end{array}$ & $\begin{array}{l}1 \\
1\end{array}$ & $\begin{array}{l}1.00 \\
1.00\end{array}$ & $\begin{array}{l}25.00 U^{(b)} \\
25.00 U^{(b)}\end{array}$ & $\begin{array}{l}25.00 \mathrm{U} \\
25.00 \mathrm{U}\end{array}$ & $\begin{array}{l}25.00 \mathrm{U} \\
25.00 \mathrm{U}\end{array}$ & $\begin{array}{l}25.00 \mathrm{U} \\
25.00 \mathrm{U}\end{array}$ \\
\hline $\begin{array}{l}\text { Comp LC SPP } \\
\text { Comp LC Elutriate }\end{array}$ & $\begin{array}{l}1 \\
1\end{array}$ & $\begin{array}{l}1.00 \\
1.00\end{array}$ & $\begin{array}{l}25.00 \mathrm{U} \\
25.00 \mathrm{U}\end{array}$ & $\begin{array}{l}25.00 \mathrm{U} \\
25.00 \mathrm{U}\end{array}$ & $\begin{array}{r}349.80 \\
25.00 \mathrm{U}\end{array}$ & $\begin{array}{l}25.00 \mathrm{U} \\
25.00 \mathrm{U}\end{array}$ \\
\hline $\begin{array}{l}\text { Comp LC-5 SPP (c) } \\
\text { Comp LC-5 Elutriate (c) } \\
\text { Comp LC-5 Elutriate UF (c) } \\
\text { Comp LC-5 Elutriate F(c) }\end{array}$ & $\begin{array}{l}1 \\
1 \\
2 \\
2\end{array}$ & $\begin{array}{l}1.00 \\
1.00 \\
1.00 \\
1.00\end{array}$ & $\begin{array}{l}25.00 \mathrm{U} \\
25.00 \mathrm{U} \\
25.00 \mathrm{U} \\
25.00 \mathrm{U}\end{array}$ & $\begin{array}{l}25.00 \mathrm{U} \\
25.00 \mathrm{U} \\
25.00 \mathrm{U} \\
25.00 \mathrm{U}\end{array}$ & $\begin{array}{l}25.00 \mathrm{U} \\
25.00 \mathrm{U} \\
25.00 \mathrm{U} \\
25.00 \mathrm{U}\end{array}$ & $\begin{array}{l}25.00 \cup \\
25.00 U \\
25.00 U \\
25.00 U\end{array}$ \\
\hline $\begin{array}{l}\text { Comp LC-6 SPP(c) } \\
\text { Comp LC-6 Elutriate (c) }\end{array}$ & $\begin{array}{l}1 \\
1\end{array}$ & $\begin{array}{l}1.00 \\
1.00\end{array}$ & $\begin{array}{l}25.00 \mathrm{U} \\
25.00 \mathrm{U}\end{array}$ & $\begin{array}{l}25.00 \mathrm{U} \\
25.00 \mathrm{U}\end{array}$ & $\begin{array}{l}25.00 \mathrm{U} \\
25.00 \mathrm{U}\end{array}$ & $\begin{array}{l}25.00 \mathrm{U} \\
25.00 \mathrm{U}\end{array}$ \\
\hline $\begin{array}{l}\text { Comp USFC SPP } \\
\text { Comp USFC Elutriate }\end{array}$ & $\begin{array}{l}1 \\
1\end{array}$ & $\begin{array}{l}1.00 \\
1.00\end{array}$ & $\begin{array}{l}25.00 \mathrm{U} \\
25.00 \mathrm{U}\end{array}$ & $\begin{array}{l}25.00 \mathrm{U} \\
25.00 \mathrm{U}\end{array}$ & $\begin{array}{r}223.62 \\
25.00 \mathrm{U}\end{array}$ & $\begin{array}{l}25.00 \mathrm{U} \\
25.00 \mathrm{U}\end{array}$ \\
\hline $\begin{array}{l}\text { Comp FSFC SPP } \\
\text { Comp FSFC Elutriate }\end{array}$ & $\begin{array}{l}2 \\
2\end{array}$ & $\begin{array}{l}0.80 \\
1.00\end{array}$ & $\begin{array}{l}31.25 \mathrm{U} \\
25.00 \mathrm{U}\end{array}$ & $\begin{array}{l}31.25 \mathrm{U} \\
25.00 \mathrm{U}\end{array}$ & $\begin{array}{r}124.21 \\
25.00 \mathrm{U}\end{array}$ & $\begin{array}{l}31.25 \mathrm{U} \\
25.00 \mathrm{U}\end{array}$ \\
\hline $\begin{array}{l}\text { Comp IHC-1 SPP } \\
\text { Comp IHC-1 Elutriate }\end{array}$ & $\begin{array}{l}2 \\
2\end{array}$ & $\begin{array}{l}1.00 \\
1.00\end{array}$ & $\begin{array}{l}25.00 \mathrm{U} \\
25.00 \mathrm{U}\end{array}$ & $\begin{array}{l}25.00 \mathrm{U} \\
25.00 \mathrm{U}\end{array}$ & $\begin{array}{l}63.69 \\
25.00 \mathrm{U}\end{array}$ & $\begin{array}{l}25.00 \mathrm{U} \\
25.00 \mathrm{U}\end{array}$ \\
\hline $\begin{array}{l}\text { Comp IHC-2 SPP } \\
\text { Comp IHC-2 Elutriate }\end{array}$ & $\begin{array}{l}2 \\
2\end{array}$ & $\begin{array}{l}1.00 \\
1.00\end{array}$ & $\begin{array}{l}25.00 \mathrm{U} \\
25.00 \mathrm{U}\end{array}$ & $\begin{array}{l}25.00 \mathrm{U} \\
25.00 \mathrm{U}\end{array}$ & $\begin{array}{l}25.00 \mathrm{U} \\
25.00 \mathrm{U}\end{array}$ & $\begin{array}{l}25.00 \mathrm{U} \\
25.00 \mathrm{U}\end{array}$ \\
\hline $\begin{array}{l}\text { Comp IHC-3 SPP } \\
\text { Comp IHC-3 Elutriate }\end{array}$ & $\begin{array}{l}2 \\
2\end{array}$ & $\begin{array}{l}1.00 \\
1.00\end{array}$ & $\begin{array}{l}25.00 \mathrm{U} \\
25.00 \mathrm{U}\end{array}$ & $\begin{array}{l}25.00 \mathrm{U} \\
25.00 \mathrm{U}\end{array}$ & $\begin{array}{l}25.00 \mathrm{U} \\
25.00 \mathrm{U}\end{array}$ & $\begin{array}{l}25.00 \mathrm{U} \\
25.00 \mathrm{U}\end{array}$ \\
\hline $\begin{array}{l}\text { (a) DL Detection limit. } \\
\text { (b) U Analyte was not pr } \\
\text { (c) These samples exhibit } \\
\text { the Aroclors. }\end{array}$ & it abo & $\begin{array}{l}\text { associate } \\
\text { rences: }\end{array}$ & not $i$ & antify & & \\
\hline
\end{tabular}

PCBs (ng/L)

(b) U Analyte was not present above the associated value. the Aroclors. 
TABLE G. 16. Quality Control Summary for Polychlorinated Biphenyls (PCBs) in Liquid Phase Samples, United Heckathorn Remedia1 Investigation

Liquid Phase

Treatment

Method Blanks

Blank

Blank

Matrix Spikes

$\begin{array}{lll}\text { Site Water } & 1 & 1.00 \\ \text { Site Water MS } & 1 & \\ \text { Concentration Recovered } & \\ \text { Amount Spiked } & \\ \text { Percent Recovery } & \\ \text { Site Water } & 1 & 1.00 \\ \text { Site Water MSD } & 1 & \\ \text { Concentration Recovered } & \\ \text { Amount Spiked } & \\ \text { Percent Recovery } & \\ \text { RPD } & \\ \text { I-Stat } & \\ \text { Comp FSFC SPP } & \\ \text { Comp FSFC SPP MS } & \\ \text { Concentration Recovered } & 2 & \\ \text { Amount Spiked } & \\ \text { Percent Recovery } & \\ \text { Comp FSFC SPP } & \\ \text { Comp FSFC SPP MSD } & \\ \text { Concentration Recovered } \\ \text { Amount Spiked } \\ \text { Percent Recovery } \\ \text { RPD }\end{array}$

Analvtical Duplicates

Comp LC SPP
Comp LC SPP Duplicate
RPD
I-Stat
Comp IHC-2 SPP
Comp IHC-2 SPP Duplicate
RPD
I-Stat

Batch Volume (L)

$\begin{array}{ll}1 & 1.00 \\ 2 & 1.00\end{array}$

1.00

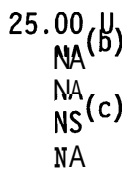

25.000
$N A$
$N A$
$N S$
$N A$

NA

NA
$25.00 \mathrm{U}$
NA
NA
NS
NA
$25.00 \mathrm{U}$
NA
NA
NS
NA
NA
NA

$\begin{array}{ll}1 & 1.00 \\ 1 & 1.00 \\ & \\ 2 & 1.00 \\ 2 & 0.90\end{array}$

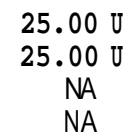
$25.00 \mathrm{U}$
$27.78 \mathrm{U}$ NA

PCBs (ng/L)

\begin{tabular}{cc}
$\begin{array}{c}\text { Aroclor } \\
1254\end{array}$ & Aroclor \\
1260 \\
\hline
\end{tabular}

$25.00 \mathrm{U}$

$25.00 \mathrm{U}$

$25.00 \mathrm{U}$

$25.00 \mathrm{U}$

$25.00 \mathrm{U}$

$25.00 \mathrm{U}$

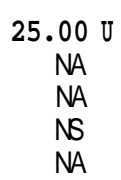

$25.00 \mathrm{U}$

$$
\begin{aligned}
& \text { NA } \\
& N A \\
& N S \\
& N A
\end{aligned}
$$

NA

NA

$$
\begin{gathered}
25.00 U \\
\text { NA } \\
\text { NA } \\
\text { NS } \\
\text { NA }
\end{gathered}
$$

$25.00 \mathrm{U}$

$$
\begin{aligned}
& \text { NA } \\
& \text { NA } \\
& \text { NS }
\end{aligned}
$$

NA

NA

NA
$25.00 \mathrm{U}$
$25.00 \mathrm{U}$
NA
$25.00 \mathrm{U}$
$27.78 \mathrm{U}$ NA
NA

$25.00 \mathrm{U}$
2867.87
2867.87
4800.00
$60 \%$

$25.00 \mathrm{U}$

2793.36

2793.36

4800.00

$58 \%$

$3 \%$

0.01

124.21

3534.48

3410.27

4800.00

$71 \%$

124.21

3918.20

3793.99

4800.00

$79 \%$

$11 \%$

0.05

$\begin{array}{cc}349.80 & 25.00 \mathrm{U} \\ 489.48 & 25.00 \mathrm{U} \\ & \text { NA } \\ 0.17 & \text { NA }\end{array}$

$25.00 \mathrm{U}$

$27.78 \mathrm{U}$

NA

NA
$25.00 \mathrm{U}$

NA

NA

$25.00 \mathrm{U}$

NA

NA

NS

NA

NA

$25.00 \mathrm{U}$

NA

NA

NS

NA

$25.00 \mathrm{U}$

NA

NA

NS

NA

NA

(a) U Analyte was not present above the associated value.

(b) NA Not applicable.

(c) NS Not spiked.

(d) Value exceeds relative precision goal of $\leq 30 \%$. 
TABLE 6.17. Metals in Liquid Phase Samples, United Heckathorn Remedial Investigation

\begin{tabular}{|c|c|c|c|c|c|c|c|c|c|c|}
\hline \multirow{2}{*}{$\begin{array}{l}\text { Liquid Phase } \\
\text { Treatment } \\
\end{array}$} & \multicolumn{10}{|c|}{ Metals $(\mu \mathrm{g} / \mathrm{L})$} \\
\hline & $\mathrm{Aq}$ & As & Cd & $\underline{\mathrm{Cr}}$ & لـلم & $\mathrm{Hg}$ & $\mathrm{Ni}$ & $\mathrm{Pb}$ & $\mathrm{Se}$ & $7 n$ \\
\hline $\begin{array}{l}\text { Target } \mathrm{DL}(\mathrm{a}) \\
\text { Achieved } \mathrm{DL}\end{array}$ & $\begin{array}{l}0.01 \\
0.02\end{array}$ & $\begin{array}{l}1.0 \\
0.01\end{array}$ & $\begin{array}{l}0.1 \\
0.02\end{array}$ & $\begin{array}{l}1.0 \\
0.05\end{array}$ & $\begin{array}{l}0.1 \\
0.006\end{array}$ & $\begin{array}{l}0.001 \\
0.001\end{array}$ & $\begin{array}{l}0.1 \\
0.01\end{array}$ & $\begin{array}{l}0.1 \\
0.02\end{array}$ & $\begin{array}{l}2.0 \\
2.3\end{array}$ & $\begin{array}{l}2.0 \\
0.4\end{array}$ \\
\hline $\begin{array}{l}\text { Site Water } \\
\text { Procedural Blank }\end{array}$ & $\begin{array}{l}0.02 U^{(b)} \\
0.02 U^{(b)}\end{array}$ & $\begin{array}{l}1.61 \\
0.99\end{array}$ & $\begin{array}{l}0.092 \\
0.103\end{array}$ & $\begin{array}{l}2.11 \\
0.33\end{array}$ & $\begin{array}{l}3.28 \\
2.40\end{array}$ & $\begin{array}{l}0.016 \\
0.005\end{array}$ & $\begin{array}{l}4.32 \\
3.56\end{array}$ & $\begin{array}{l}3.72 \\
0.250\end{array}$ & $\begin{array}{l}2.30 \mathrm{U} \\
2.30 \mathrm{U}\end{array}$ & $\begin{array}{l}21.4 \\
15.2\end{array}$ \\
\hline $\begin{array}{l}\text { Comp LC SPP } \\
\text { Comp LC SPP Duplicate } \\
\text { Comp LC Elutriate }\end{array}$ & $\begin{array}{l}0.02 \mathrm{U} \\
0.02 \mathrm{U} \\
0.02 \mathrm{U}\end{array}$ & $\begin{array}{l}7.48 \\
5.22 \\
3.96\end{array}$ & $\begin{array}{l}0.072 \\
0.068 \\
0.048\end{array}$ & $\begin{array}{l}1.31 \\
1.29 \\
0.62\end{array}$ & $\begin{array}{l}3.60 \\
3.38 \\
1.35\end{array}$ & $\begin{array}{l}0.036 \\
0.024 \\
0.010\end{array}$ & $\begin{array}{l}2.67 \\
2.49 \\
2.04\end{array}$ & $\begin{array}{l}3.45 \\
3.23 \\
0.790\end{array}$ & $\begin{array}{l}2.30 \mathrm{U} \\
2.30 \mathrm{U} \\
2.30 \mathrm{U}\end{array}$ & $\begin{array}{l}8.97 \\
9.24 \\
3.43\end{array}$ \\
\hline $\begin{array}{l}\text { Comp LC-5 SPP } \\
\text { Comp LC-5 Elutriate }\end{array}$ & $\begin{array}{l}0.022 \\
0.02 \mathrm{U}\end{array}$ & $\begin{array}{l}16.9 \\
19.1\end{array}$ & $\begin{array}{l}0.110 \\
0.067\end{array}$ & $\begin{array}{l}3.47 \\
0.98\end{array}$ & $\begin{array}{l}5.48 \\
1.84\end{array}$ & $\begin{array}{l}0.063 \\
0.018\end{array}$ & $\begin{array}{l}4.36 \\
3.33\end{array}$ & $\begin{array}{l}4.48 \\
1.92\end{array}$ & $\begin{array}{l}2.30 \mathrm{U} \\
2.30 \mathrm{U}\end{array}$ & $\begin{array}{l}17.3 \\
13.2\end{array}$ \\
\hline $\begin{array}{l}\text { Comp LC-6 SPP } \\
\text { Comp LC-6 Elutriate }\end{array}$ & $\begin{array}{l}0.160 \\
0.056\end{array}$ & $\begin{array}{l}10.9 \\
14.8\end{array}$ & $\begin{array}{l}0.121 \\
0.090\end{array}$ & $\begin{array}{l}1.75 \\
1.18\end{array}$ & $\begin{array}{l}5.28 \\
2.62\end{array}$ & $\begin{array}{l}0.148 \\
0.067\end{array}$ & $\begin{array}{l}2.80 \\
2.61\end{array}$ & $\begin{array}{l}3.01 \\
2.40\end{array}$ & $\begin{array}{l}2.30 \mathrm{U} \\
2.30 \mathrm{U}\end{array}$ & $\begin{array}{l}9.37 \\
5.54\end{array}$ \\
\hline $\begin{array}{l}\text { Comp USFC SPP } \\
\text { Comp USFC Elutriate } \\
\text { Comp FSFC SPP } \\
\text { Comp FSFC Elutriate }\end{array}$ & $\begin{array}{l}0.02 \mathrm{U} \\
0.02 \mathrm{U} \\
0.02 \mathrm{U} \\
0.02 \mathrm{U}\end{array}$ & $\begin{array}{l}7.47 \\
4.62 \\
4.26 \\
5.07\end{array}$ & $\begin{array}{l}0.042 \\
0.054 \\
0.179 \\
0.025\end{array}$ & $\begin{array}{l}1.34 \\
0.33 \\
1.18 \\
0.26\end{array}$ & $\begin{array}{l}2.66 \\
0.954 \\
2.94 \\
0.858\end{array}$ & $\begin{array}{l}0.033 \\
0.011 \\
0.024 \\
0.007\end{array}$ & $\begin{array}{l}1.58 \\
1.30 \\
2.16 \\
1.10\end{array}$ & $\begin{array}{l}1.92 \\
0.533 \\
1.44 \\
0.295\end{array}$ & $\begin{array}{l}2.30 \mathrm{U} \\
3.10 \mathrm{U} \\
2.30 \mathrm{U} \\
2.30 \mathrm{U}\end{array}$ & $\begin{array}{l}12.9 \\
2.11 \\
8.71 \\
3.96\end{array}$ \\
\hline $\begin{array}{l}\text { Comp IHC-1 SPP } \\
\text { Comp IHC-1 Elutriate }\end{array}$ & $\begin{array}{l}0.02 \mathrm{U} \\
0.02 \mathrm{U}\end{array}$ & $\begin{array}{l}8.17 \\
4.22\end{array}$ & $\begin{array}{l}0.035 \\
0.026\end{array}$ & $\begin{array}{l}1.08 \\
0.31\end{array}$ & $\begin{array}{l}2.52 \\
0.953\end{array}$ & $\begin{array}{l}0.021 \\
0.007\end{array}$ & $\begin{array}{l}2.36 \\
2.16\end{array}$ & $\begin{array}{l}2.11 \\
0.250\end{array}$ & $\begin{array}{l}2.30 \mathrm{U} \\
2.30 \mathrm{U}\end{array}$ & $\begin{array}{l}4.09 \\
5.28\end{array}$ \\
\hline $\begin{array}{l}\text { Comp IHC-2 SPP } \\
\text { Comp IHC-2 Elutriate }\end{array}$ & $\begin{array}{l}0.02 \mathrm{U} \\
0.02 \mathrm{U}\end{array}$ & $\begin{array}{l}7.99 \\
3.00\end{array}$ & $\begin{array}{l}0.02 \cup \\
0.02 U\end{array}$ & $\begin{array}{l}1.36 \\
0.08\end{array}$ & $\begin{array}{l}3.11 \\
0.757\end{array}$ & $\begin{array}{l}0.012 \\
0.004\end{array}$ & $\begin{array}{l}3.66 \\
1.41\end{array}$ & $\begin{array}{l}1.29 \\
0.162\end{array}$ & $\begin{array}{l}2.30 \mathrm{U} \\
2.30 \mathrm{U}\end{array}$ & $\begin{array}{l}4.49 \\
2.38\end{array}$ \\
\hline $\begin{array}{l}\text { Comp IHC-3 SPP } \\
\text { Comp IHC-3 Elutriate }\end{array}$ & $\begin{array}{l}0.02 \mathrm{U} \\
0.02 \mathrm{U}\end{array}$ & $\begin{array}{l}7.46 \\
3.33\end{array}$ & $\begin{array}{l}0.02 U \\
0.02 U\end{array}$ & $\begin{array}{l}1.03 \\
0.23\end{array}$ & $\begin{array}{l}1.99 \\
0.611\end{array}$ & $\begin{array}{l}0.015 \\
0.004\end{array}$ & $\begin{array}{l}2.97 \\
1.52\end{array}$ & $\begin{array}{l}0.915 \\
0.137\end{array}$ & $\begin{array}{l}2.30 \mathrm{U} \\
2.30 \mathrm{U}\end{array}$ & $\begin{array}{l}29.6 \\
1.45\end{array}$ \\
\hline
\end{tabular}

(a) DL Detection Iimit.

(b) U Analyte was not present above the associated value. 
TABLE 6.18. Quality Control Summary of Metals in Liquid Phase Samples, United Heckathorn Remedial Investigation

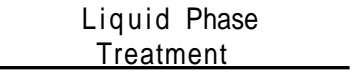

Method Blanks

Blank

Blank

Matrix Spikes

Comp LC-6 SPP

Comp LC-6 SPP MS

Concentration Recovered

Amount Spiked

Percent Recovered

Comp USFC Elutriate

Comp USFC Elutriate MS

Concentration Recovered

Amount Spiked

o Percent Recovered

$\tilde{\omega}$

Procedural Blan

Procedural Blank MS

Concentration Recovered

Amount Spiked

Percent Recovered

\begin{tabular}{|c|c|}
\hline $\mathrm{Aq}$ & As \\
\hline $0.02\left(\mathrm{NA}^{(\mathrm{a})}\right.$ & $\begin{array}{r}0.02 \\
\text { NA }\end{array}$ \\
\hline $\begin{array}{l}\text { NA } \\
\text { NA } \\
\text { NA } \\
\text { NS }(c) \\
\text { NA }\end{array}$ & $\begin{array}{l}10.9 \\
21.7 \\
10.8 \\
9.00 \\
120 \%\end{array}$ \\
\hline
\end{tabular}
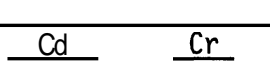

Metals $(\mu \mathrm{g} / \mathrm{L})$

Analytical Duplicates
Comp LC SPP
Comp LC SPP Duplicate
RPD
I-Stat

(a) Analyte was not

(a) U Analyte was not present above the associated value.

(b) NA Not applicable.

(c) NS Not spiked.

(d) Value exceeds relative precision goal of $\leq 20 \%$ 
TABLE G. 19. Butyltins in Liquid Phase Samples, United Heckathorn Remedial Investigation

\begin{tabular}{|c|c|c|c|c|c|}
\hline $\begin{array}{l}\text { Liquid Phase } \\
\text { Treatment }\end{array}$ & Batch & $\begin{array}{l}\text { Extraction } \\
\text { Volume (L) }\end{array}$ & $\begin{array}{c}\text { Tri- } \\
\text { butyltin } \\
\text { (ng/L) }\end{array}$ & $\begin{array}{c}\text { Di- } \\
\text { butylt in } \\
\text { (ng/L) }\end{array}$ & $\begin{array}{c}\text { Surrogate } \\
\text { Percent } \\
\text { Recovery } \\
\text { Tripentyltin } \\
\end{array}$ \\
\hline $\begin{array}{l}\text { Target } D L^{(a)} \\
\text { Achieved } D L\end{array}$ & & & $\begin{array}{l}10 \\
10\end{array}$ & $\begin{array}{l}10 \\
10\end{array}$ & \\
\hline $\begin{array}{l}\text { Site Water } \\
\text { Procedural Blank }\end{array}$ & $\begin{array}{l}1 \\
1\end{array}$ & $\begin{array}{l}1.060 \\
1.000\end{array}$ & $\begin{array}{l}27.2 \\
24.9\end{array}$ & $\begin{array}{l}11.4 \mathrm{~B}^{(\mathrm{b})} \\
20.2 \mathrm{~B}^{-1}\end{array}$ & $\begin{array}{r}107 \\
64\end{array}$ \\
\hline $\begin{array}{l}\text { Comp LC SPP } \\
\text { Comp LC ELUT }\end{array}$ & $\begin{array}{l}1 \\
1\end{array}$ & $\begin{array}{l}1.069 \\
1.037\end{array}$ & $\begin{array}{l}38.8 \\
29.8\end{array}$ & $\begin{array}{l}19.8 \mathrm{~B} \\
31.4 \mathrm{~B}\end{array}$ & $\begin{array}{l}91 \\
71\end{array}$ \\
\hline $\begin{array}{l}\text { Comp LC-5 SPP } \\
\text { Comp LC-5 ELUT }\end{array}$ & $\begin{array}{l}1 \\
1\end{array}$ & $\begin{array}{l}1.055 \\
1.055\end{array}$ & $\begin{array}{l}40.5 \\
28.3\end{array}$ & $\begin{array}{l}31.4 \mathrm{~B} \\
23.8 \mathrm{~B}\end{array}$ & $\begin{array}{r}118 \\
95\end{array}$ \\
\hline $\begin{array}{l}\text { Comp LC-6 SPP } \\
\text { Comp LC-6 ELUT }\end{array}$ & $\begin{array}{l}1 \\
1\end{array}$ & $\begin{array}{l}1.060 \\
1.030\end{array}$ & $\begin{array}{l}10.0 U^{(c)} \\
12.2\end{array}$ & $\begin{array}{l}10.5 \mathrm{BE}^{(\mathrm{d})} \\
31.3 \mathrm{~B}^{-}\end{array}$ & $\begin{array}{l}130^{(\mathrm{e})} \\
111\end{array}$ \\
\hline $\begin{array}{l}\text { Comp USFC SPP } \\
\text { Comp USFC ELUT }\end{array}$ & $\begin{array}{l}1 \\
1\end{array}$ & $\begin{array}{l}1.068 \\
1.009\end{array}$ & $\begin{array}{l}35.6 \\
24.6\end{array}$ & $\begin{array}{ll}22.6 & B \\
20.7 & B\end{array}$ & $\begin{array}{r}105 \\
97\end{array}$ \\
\hline $\begin{array}{l}\text { Comp FSFC SPP } \\
\text { Comp FSFC ELUT }\end{array}$ & $\begin{array}{l}2 \\
2\end{array}$ & $\begin{array}{l}1.063 \\
1.063\end{array}$ & $\begin{array}{l}17.1 \\
16.9\end{array}$ & $\begin{array}{l}18.9 \mathrm{~B} \\
18.7 \mathrm{~B}\end{array}$ & $\begin{array}{l}86 \\
88\end{array}$ \\
\hline 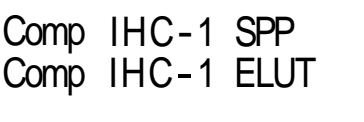 & $\begin{array}{l}2 \\
2\end{array}$ & $\begin{array}{l}1.067 \\
1.060\end{array}$ & $\begin{array}{l}13.9 \\
26.1\end{array}$ & $\begin{array}{l}15.8 \mathrm{~B} \\
18.3 \mathrm{~B}\end{array}$ & $\begin{array}{r}102 \\
69\end{array}$ \\
\hline $\begin{array}{lll}\text { Comp IHC-2 SPP } \\
\text { Comp IHC-2 ELUT }\end{array}$ & $\begin{array}{l}2 \\
2\end{array}$ & $\begin{array}{l}1.074 \\
1.061\end{array}$ & $\begin{array}{l}10.0 \mathrm{U} \\
13.4\end{array}$ & $\begin{array}{l}15.5 \mathrm{~B} \\
19.3 \mathrm{~B}\end{array}$ & $\begin{array}{r}105 \\
99\end{array}$ \\
\hline $\begin{array}{lll}\text { Comp } & \text { IHC-3 } & \text { SPP } \\
\text { Comp } & \text { IHC-3 } & \text { ELUT }\end{array}$ & $\begin{array}{l}2 \\
2\end{array}$ & $\begin{array}{l}1.067 \\
1.025\end{array}$ & $\begin{array}{l}12.7 \\
12.5\end{array}$ & $\begin{array}{l}17.5 \mathrm{~B} \\
18.6 \mathrm{~B}\end{array}$ & $\begin{array}{r}93 \\
102\end{array}$ \\
\hline
\end{tabular}
(a) DL Detection limit.
(b) B Analyte detected in blank associated with sample.
(c) $U$ Analyte was not present above the level of the associated value.
(d) $\mathrm{E}$ Quantitation is an estimate due to matrix interference.
(e) Recovery outside of quality control range $(40 \%-120 \%$, 
TABLE 6.20. Quality Control Summary for Butyltins in Liquid Phase Samples, United Heckathorn Remedial Investigation

\begin{tabular}{|c|c|c|c|c|c|}
\hline $\begin{array}{l}\text { Liquid Phase } \\
\text { Treatment }\end{array}$ & Batch & $\begin{array}{l}\text { Extraction } \\
\text { Volume (L) }\end{array}$ & $\begin{array}{c}\text { Tri- } \\
\text { butyltin } \\
\text { (ng/L) }\end{array}$ & $\begin{array}{c}\text { Di- } \\
\text { butylt in } \\
\text { (ng/L) }\end{array}$ & $\begin{array}{c}\text { Surrogate } \\
\text { Percent } \\
\text { Recovery } \\
\text { Tripentylti } \\
\end{array}$ \\
\hline \multicolumn{6}{|l|}{ Method Blanks } \\
\hline $\begin{array}{l}\text { Blank } \\
\text { Blank }\end{array}$ & $\begin{array}{l}1 \\
2\end{array}$ & $\begin{array}{l}1.000 \\
1.000\end{array}$ & $\begin{array}{l}60.0^{(\mathrm{a})} \\
10.0 \mathrm{U}^{(\mathrm{b})}\end{array}$ & $\begin{array}{l}14.1 \\
14.0\end{array}$ & $\begin{array}{l}94 \\
94\end{array}$ \\
\hline \multicolumn{6}{|l|}{ Matrix Spikes } \\
\hline $\begin{array}{l}\text { Site Water } \\
\text { Site Water MS } \\
\text { Concentration Recovered } \\
\text { Amount Spiked } \\
\text { Percent Recovery }\end{array}$ & $\begin{array}{l}1 \\
1\end{array}$ & $\begin{array}{l}1.060 \\
1.068\end{array}$ & $\begin{array}{r}27.2 \\
235.2 \\
208.0 \\
234.0 \\
89 \%\end{array}$ & $\begin{array}{l}11.4 \mathrm{~B}^{(\mathrm{c})} \\
243.0 \\
231.6 \\
234.0 \\
99 \%\end{array}$ & $\begin{array}{l}107 \\
100 \\
\text { NA } \\
\text { NA } \\
\text { NA }\end{array}$ \\
\hline $\begin{array}{l}\text { Site Water } \\
\text { Site Water MSD } \\
\text { Concentration Recovered } \\
\text { Amount Spiked } \\
\text { Percent Recovery }\end{array}$ & $\begin{array}{l}1 \\
1\end{array}$ & $\begin{array}{l}1.060 \\
1.070\end{array}$ & $\begin{array}{r}27.2 \\
238.4 \\
211.2 \\
234.0 \\
90 \%\end{array}$ & $\begin{array}{c}11.4 B \\
240.9 \\
229.5 \\
234.0 \\
98 \%\end{array}$ & $\begin{array}{r}107 \\
101 \\
\text { NA } \\
\text { NA } \\
\text { NA }\end{array}$ \\
\hline $\begin{array}{l}\text { RPD } \\
\text { I-Stat }\end{array}$ & & & $0.01^{2 \%}$ & $0.00^{1 \%}$ & $\begin{array}{l}\text { NA } \\
\text { NA }\end{array}$ \\
\hline $\begin{array}{l}\text { Comp FSFC SPP } \\
\text { Comp FSFC SPP MS } \\
\text { Concentrati on Recovered } \\
\text { Amount Spiked } \\
\text { Percent Recovery }\end{array}$ & $\begin{array}{l}2 \\
2\end{array}$ & $\begin{array}{l}1.063 \\
0.500\end{array}$ & $\begin{array}{r}17.1 \\
439.5 \\
422.4 \\
500.0 \\
84 \%\end{array}$ & $\begin{array}{l}18.9 \mathrm{~B} \\
524.2 \\
505.3 \\
500.0 \\
101 \%\end{array}$ & $\begin{array}{l}86 \\
82 \\
\text { NA } \\
\text { NA } \\
\text { NA }\end{array}$ \\
\hline $\begin{array}{l}\text { Comp FSFC SPP } \\
\text { Comp FSFC SPP MSD } \\
\text { Concentration Recovered } \\
\text { Amount Spiked } \\
\text { Percent Recovery }\end{array}$ & $\begin{array}{l}2 \\
2\end{array}$ & $\begin{array}{l}1.063 \\
0.560\end{array}$ & $\begin{array}{l}17.1 \\
447.1 \\
430.0 \\
446.0 \\
96 \%\end{array}$ & $\begin{array}{c}18.9 \text { B } \\
415.8 \\
396.9 \\
446.0 \\
89 \%\end{array}$ & $\begin{array}{l}86 \\
78 \\
\text { NA } \\
\text { NA } \\
\text { NA }\end{array}$ \\
\hline $\begin{array}{l}\text { RPD } \\
\text { I-Stat }\end{array}$ & & & $\begin{array}{c}13 \% \\
0.07\end{array}$ & $\begin{array}{l}13 \% \\
0.06\end{array}$ & $\begin{array}{l}\text { NA } \\
\text { NA }\end{array}$ \\
\hline
\end{tabular}


TABLE 6.20. (contd)

\begin{tabular}{|c|c|c|c|c|c|}
\hline $\begin{array}{c}\text { Liquid Phase } \\
\text { Treatment }\end{array}$ & Batch & $\begin{array}{l}\text { Extraction } \\
\text { Volume (L) }\end{array}$ & $\begin{array}{c}\text { Tri- } \\
\text { butylt in } \\
\text { (ng/L) }\end{array}$ & $\begin{array}{c}\text { Di- } \\
\text { butylt in } \\
(n q / L) \\
\end{array}$ & $\begin{array}{c}\text { Surrogate } \\
\text { Percent } \\
\text { Recovery } \\
\text { Tripentyltin } \\
\end{array}$ \\
\hline \multicolumn{6}{|l|}{ Analytical Duplicates } \\
\hline $\begin{array}{l}\text { Comp LC SPP } \\
\text { Comp LC SPP Duplicate } \\
\text { RPD } \\
\text { I-Stat }\end{array}$ & $\begin{array}{l}1 \\
1\end{array}$ & $\begin{array}{l}1.069 \\
1.045\end{array}$ & $\begin{array}{l}38.8 \\
71.4 \\
59 \%(\mathrm{e}) \\
0.30\end{array}$ & $\begin{array}{l}19.8 \mathrm{~B} \\
29.3 \mathrm{~B} \\
39 \%(\mathrm{e}) \\
0.19\end{array}$ & $\begin{array}{l}91 \\
75 \\
\text { NA } \\
\text { NA }\end{array}$ \\
\hline
\end{tabular}

(a) Blank contamination believed to be due to contamination of DI water used for blank; does not affect sample results.

(b) $U$ Analyte was not present above the level of the associated value.

(c) B Analyte detected in blank associated with sample.

(d) NA Not applicable.

(e) Precision criteria do not apply because sample results are less than 10 times the MDL. 


\section{QA/QC SUMMARY}

PROGRAM: United Heckathorn Remedial Investigation

PARAMETER: Total Suspended Solids (TSS)

LABORATORY: Battelle/Marine Sciences Laboratory

MATRIX: Water

SAMPLE NUMBER: 20

QA/QC REQUIREMENTS

Reference Method Ranae of Recovery Relative Precision Detection Limit

$\begin{array}{lll}\text { SOP MSL-M-39 Not applicable } \quad \pm 20 \% & \text { Not applicable }\end{array}$

HOLDING TIMES

The holding time of 7 days was met for all analyses.

\section{METHOD BLANKS}

Both method blanks contained $3 \mathrm{mg} / \mathrm{L}$ TSS. No QC criteria are designated for TSS procedural blanks.

\section{DUPLICATES}

Precision between both analytical duplicates met the QC criteria of $\pm 20 \%$. 


\section{QA/QC SUMMARY}

PROGRAM:

PARAMETER:

LABORATORY:

MATRIX:

SAMPLE NUMBER: 20

\section{QA/QC REQUIREMENTS}

$\begin{array}{cccc}\begin{array}{c}\text { Reference } \\ \text { Method }\end{array} & \begin{array}{c}\text { Range of } \\ \text { Recovery }\end{array} & \begin{array}{c}\text { Relative } \\ \text { Precision }\end{array} & \begin{array}{c}\text { Detection } \\ \text { Limit }\end{array} \\ 8080 & 40 \%-120 \% & \pm 30 \% & 5 \mathrm{ng} / \mathrm{L}\end{array}$

\section{HOLDING TIMES}

The following is a list of extraction and analysis dates for the two batches of water samples analyzed for pesticides and PCBs:

$\begin{array}{llll}\text { Date } & \text { Date } & \text { Date } & \text { GC/ECD } \\ \text { Collected } & \text { Received } & \text { Extracted } & \text { Analvsis }\end{array}$

Batch 1

$1 / 25-26 / 93$

$1 / 27 / 93$

2/4/93

3/5-7/93,

3121-22193

(dilutions)

Batch 2

2/1-2/93

2/3-4193

2/9/93

317-9193,

$3 / 22 / 93$

(dilutions)

Holding times for extractions and analyses were met.

\section{METHOD BLANKS}

One method blank was processed with each batch of samples. No pesticide or PCB compounds were detected above the method detection limit in the blanks. 


\section{MATRIX SPIKES}

The recoveries of target pesticides and $\mathrm{PCBs}$ in the MS and MSD samples were acceptable for Batch 1. Recoveries exceeded $120 \%$ for one pesticide in the MS and four pesticides in the MSD sample for Batch 2.

\section{SURROGATES}

The recoveries of surrogate compounds were acceptable in all samples in Batch 1. The recovery of one surrogate compound was less than $40 \%$ in two samples from Batch 2. Surrogate compounds were diluted out in two samples in Batch 1.

\section{DUPLICATES}

Duplicate precision between the MS and MSD samples was acceptable in both batches. The RPDs for sample duplicate results were greater than $30 \%$ for five pesticides and one Aroclor in Batch 1. The high RPDs were probably due to sample inhomogeneity; the acceptable MS/MSD RPDs indicate acceptable analytical precision.

\section{DETECTION LIMITS}

Achieved detection limits ranged from 4 to $17 \mathrm{ng} / \mathrm{L}$ for pesticides $(25 \mathrm{ng} / \mathrm{L}$ for toxaphene) and $25 \mathrm{ng} / \mathrm{L}$ for PCBs. Some of the detection limits were higher than those specified in the Quality Assurance Project Plan (QAPP) because a portion of the sample was archived in the event that the initial extractions or analyses were unsuccessful. 


\section{QA/QC SUMMARY}

PROGRAM:

PARAMETER:

\section{LABORATORY:}

MATRIX:

SAMPLE NUMBER:
United Heckathorn Remedial Investigation

Polynuclear Aromatic Hydrocarbons (PAH)

Battelle Ocean Sciences Laboratory

Water

20

\section{QA/QC REQUIREMENTS}

$\begin{array}{cccc}\begin{array}{c}\text { Reference } \\ \text { Method }\end{array} & \begin{array}{c}\text { Range of } \\ \text { Recoverv }\end{array} & \begin{array}{c}\text { Relative } \\ \text { Precision }\end{array} & \begin{array}{c}\text { Detection } \\ \text { Limit }\end{array} \\ 8270 & 40 \%-120 \% & \pm 30 \% & 20 \mathrm{ng} / \mathrm{L}\end{array}$

\section{HOLDING TIMES}

The following is a list of extraction and analysis dates for the two batches of water samples:

$\begin{array}{lccccc}\text { Batch 1 } & \begin{array}{c}\text { Date } \\ \text { Collected }\end{array} & \begin{array}{c}\text { Date } \\ \text { Received }\end{array} & \begin{array}{c}\text { Date } \\ \text { Extracted }\end{array} & \begin{array}{c}\text { GC/MS } \\ \text { Analysis }\end{array} \\ \text { Batch 2 } & 1125-26193 & 1 / 27 / 93 & 2 / 4 / 93 & 2 / 24-25 / 93 \\ & 211-2193 & 2 / 3-4 / 93 & 2 / 9 / 93 & 2126-27193\end{array}$

The holding times for all extractions and analyses were met.

\section{PROCEDURAL BLANKS}

One procedural blank was processed with each batch of samples. No PAHs were detected in the procedural blanks.

\section{MATRIX SPIKES}

The recoveries of target PAHs in the MS and MSD were acceptable in both batches.

\section{SURROGATES}

The recovery of one surrogate compound exceeded $120 \%$ in one sample from Batch 1 , and was slightly less than $40 \%$ in one sample from Batch 2 . The remaining surrogate recoveries were acceptable. 


\section{DUPLICATES}

The RPDs between MS and MSD samples slightly exceeded $30 \%$ for one compound in one sample. Replicate precision of the sample duplicates exceeded the QC criteria of $30 \%$ for two PAHs in Batch 1.

\section{DETECTION LIMITS}

Achieved detection limits ranged between 18 and $63 \mathrm{ng} / \mathrm{L}$. The detection limits for some compounds exceeded the requirements specified in the QAPP because a portion of the sample volume was archived in the event that initial extractions or analyses were unsuccessful. Higher detection limits were achieved because a smaller sample volume was extracted. 


\section{QA/QC SUMMARY}

PROGRAM:

PARAMETER:

LABORATORY:

MATRIX:

SAMPLE NUMBER: 20
United Heckathorn Remedial Investigation

Metals

Battelle/Marine Sciences Laboratory

Water

\section{QA/QC REQUIREMENTS}

$\begin{array}{clcc}\begin{array}{c}\text { Reference } \\ \text { Method }\end{array} & \begin{array}{l}\text { Range of } \\ \text { Recovery }\end{array} & \begin{array}{l}\text { Relative } \\ \text { Precision }\end{array} & \text { Detection } \\ \begin{array}{c}\text { Varies by } \\ \text { metal }\end{array} & \begin{array}{l}75-125 \%, \\ <30 \% \text { from } \\ \text { certified value } \\ \text { for SRM }\end{array} & \pm 20 \% & \begin{array}{c}\text { Varies by } \\ \text { metal }\end{array} \\ & & & \end{array}$

\section{HOLDING TIMES}

The following table summarizes all analysis dates:

Task

APDC

ICP/MS analysis (silver, cadmium, copper, nickel, lead)

HAA (arsenic)

GFAA analysis-chromium

GFAA analysis-selenium

GFAA analysis-zinc

CVAF analysis-mercury
Date Performed

$2 / 11 / 93$

$2 / 25 / 93$

$3 / 5 / 93$

$3 / 18 / 93$

$3 / 30 / 93$

$2 / 5 / 93$

$2 / 19$ and $3 / 1 / 93$

The holding times were met for all analyses.

\section{METHOD BLANKS}

One method blank was analyzed for all metals. Arsenic, chromium, copper, mercury and zinc were detected in the blanks at concentrations below the target detection limit. All metals data are blank corrected. 


\section{MATRIX SPIKES}

One MS sample was analyzed for all metals. Matrix spike recoveries ranged from $78 \%$ to $120 \%$; all were within the QC limits of $75 \%$ to $125 \%$.

\section{DUPLICATES}

One sample was analyzed in duplicate. The relative percent difference (RPD) for all but two metals were less than $20 \%$. The RPD was $40 \%$ for mercury and $36 \%$ for arsenic. A reanalysis of the same samples for arsenic confirmed a RPD of $36 \%$, indicating that the difference is probably due to sample inhomogeneity.

\section{DETECTION LIMITS}

Target detection limits were met for all metals except silver and selenium. The achieved detection limit for silver was $0.02 \mathrm{ug} / \mathrm{L}$ and $2.3 \mathrm{ug} / \mathrm{L}$ for selenium. 


\section{QA/QC SUMMARY}

PROGRAM:

PARAMETER:

LABORATORY:

MATRIX:

SAMPLE NUMBER:
United Heckathorn Remedial Investigation

Butyltins

Battelle/Marine Sciences Laboratory

Water

18

\section{QA/QC REQUIREMENTS}

$\begin{array}{llll}\begin{array}{l}\text { Reference } \\ \text { Method }\end{array} & \begin{array}{l}\text { Range of } \\ \text { Becoven }\end{array} & \begin{array}{l}\text { Relative } \\ \text { Precision }\end{array} & \begin{array}{c}\text { Detection } \\ \text { Limit }\end{array} \\ \text { Unger, et. al } & 40 \%-120 \% & \pm 30 \% & 10 \mathrm{ng} / \mathrm{L}\end{array}$

\section{HOLDING TIMES}

The following is a list of extraction and analysis dates for the two batches of water samples analyzed for butyltins:

$\begin{array}{lllll} & \begin{array}{l}\text { Date } \\ \text { Collected }\end{array} & \begin{array}{l}\text { Date } \\ \text { Received }\end{array} & \begin{array}{l}\text { Date } \\ \text { Extracted }\end{array} & \begin{array}{l}\text { GC/FPD } \\ \text { Analvsis }\end{array} \\ \text { Batch } 1 & 1 / 25-26 / 93 & 1 / 26 / 93 & 1 / 27 / 93 & 2 / 18-19 / 93 \\ \text { Batch } 2 & 2 / 1-2 / 93 & 2 / 3 / 93 & 2 / 3 / 93 & 2 / 18-19 / 93\end{array}$

The holding times for extractions and analyses were met.

\section{METHOD BLANKS}

One method blank was processed with each batch of samples. Tributyltin was detected in both blanks. Two analyses of the surrogate solution used in both batches indicate a TBT concentration of $15 \mathrm{ng} / \mathrm{L}$. Sample results were corrected by subtracting $15 \mathrm{ng} / \mathrm{L}$ because the surrogate solution was spiked into all samples, including the blanks. The blank for Batch 1 contained $60 \mathrm{ng} / \mathrm{L}$ of TBT in addition to the $15 \mathrm{ng} / \mathrm{L}$ contributed by the surrogate solution. The source of this TBT could not be confirmed although it is suspected that it is confined to the DI water used in the blank. The blank contamination does not appear to affect the samples because the sample results are less than the concentration in the blank. However, all sample results for this batch are flagged.

Dibutyltin was also detected in both method blanks at a concentration of $14 \mathrm{ng} / \mathrm{L}$. The source of the DBT is not known, and all sample results for DBT are flagged. 


\section{MATRIX SPIKES}

The recoveries of tributyltin and dibutyltin in the MS and MSD samples for all batches were within the QC limits.

\section{SURROGATES}

One SIS, tripentyltin chloride, is added prior to extraction to assess the efficiency of the method. All sample data are corrected for the recovery of this compound. Surrogate recoveries for all but one sample were within the QC limits. Matrix interferences resulted in poor chromatography for this sample; therefore, the results were flagged as estimated.

\section{DUPLICATES}

Relative percent differences between the analytical duplicates for butyltins exceeded the QC limit of $30 \%$. RPDs for matrix spike/matrix spike duplicate samples were very good, indicating that the poor precision in the sample duplicates may be due to sample inhomogeneity.

\section{DETECTION LIMITS}

Target detection limits of $10 \mathrm{ng} / \mathrm{L}$ were met for all butyltin compounds.

\section{COMMENTS}

Matrix interferences affected the chromatography in terms of retention time drift and peak shape for a number of samples. 



\section{APPENDIX H}

BIOASSAY RESULTS FOR 96-HOUR SUSPENDED-PARTICULATE-PHASE TEST AND 96-HOUR REFERENCE TOXICANT TEST FOR Holmesimvsis costata 

TABLE H.1. Results for all Replicates in 96-h H. costata SuspendedParticulate-Phase Test, United Heckathorn Remedial Investigation

\begin{tabular}{|c|c|c|c|c|c|c|c|}
\hline \multirow[b]{2}{*}{$\begin{array}{l}\text { Sediment } \\
\text { Treatment } \\
\end{array}$} & \multicolumn{2}{|l|}{ SPP } & \multicolumn{2}{|c|}{ H. costata } & \multicolumn{3}{|c|}{ Mean } \\
\hline & $\begin{array}{c}\text { Concentration } \\
\text { Percent } \\
\end{array}$ & Replicate & $\begin{array}{l}\text { Number } \\
\text { Alive } \\
\end{array}$ & $\begin{array}{l}\text { Number } \\
\text { Dead } \\
\end{array}$ & $\begin{array}{l}\text { Proportion } \\
\text { Surviving }\end{array}$ & $\begin{array}{l}\text { Proportion } \\
\text { Surviving }\end{array}$ & $\begin{array}{l}\text { Standard } \\
\text { Deviation }\end{array}$ \\
\hline Comp LC & 0 & 1 & 9 & 1 & 0.90 & & \\
\hline Comp LC & 0 & 2 & 10 & 0 & 1.00 & & \\
\hline Comp LC & 0 & 3 & 9 & 1 & 0.90 & 0.93 & 0.06 \\
\hline Comp LC & 10 & 1 & 0 & 10 & 0.00 & & \\
\hline Comp LC & 10 & 2 & 0 & 10 & 0.00 & & \\
\hline Comp LC & 10 & 3 & 0 & 10 & 0.00 & 0.00 & 0.00 \\
\hline Comp LC & 50 & 1 & 0 & 10 & 0.00 & & \\
\hline Comp LC & 50 & 2 & 0 & 10 & 0.00 & & \\
\hline Comp LC & 50 & 3 & 0 & 10 & 0.00 & 0.00 & 0.00 \\
\hline Comp LC & 100 & 1 & 0 & 10 & 0.00 & & \\
\hline Comp LC & 100 & 2 & 0 & 10 & 0.00 & & \\
\hline Comp LC & 100 & 3 & 0 & 10 & 0.00 & 0.00 & 0.00 \\
\hline $\begin{array}{l}\text { Comp LC-5R } \\
\text { Comp LC-5R }\end{array}$ & $\begin{array}{l}0 \\
0\end{array}$ & $\begin{array}{l}1 \\
2\end{array}$ & $\begin{array}{r}10 \\
8\end{array}$ & $\begin{array}{l}0 \\
2\end{array}$ & $\begin{array}{l}1.00 \\
0.80\end{array}$ & & \\
\hline Comp LC-5R & 0 & 3 & 10 & 0 & 1.00 & 0.93 & 0.12 \\
\hline Comp LC-5R & 0.01 & 1 & 9 & 1 & 0.90 & & \\
\hline Comp LC-5R & 0.01 & 2 & 10 & 0 & 1.00 & & \\
\hline Comp LC-5R & 0.01 & 3 & 10 & 0 & 1.00 & 0.97 & 0.06 \\
\hline Comp LC-5R & 0.1 & 1 & 8 & 2 & 0.80 & & \\
\hline Comp LC-5R & 0.1 & 2 & 8 & 2 & 0.80 & & \\
\hline Comp LC-5R & 0.1 & 3 & 9 & 1 & 0.90 & 0.83 & 0.06 \\
\hline Comp LC-5R & 1 & 1 & 2 & 8 & 0.20 & & \\
\hline Comp LC-5R & 1 & 2 & 1 & 9 & 0.10 & & \\
\hline Comp LC-5R & 1 & 3 & 3 & 7 & 0.30 & 0.20 & 0.10 \\
\hline Comp LC-5 & 0 & 1 & 10 & 0 & 1.00 & & \\
\hline Comp LC-5 & 0 & 2 & 9 & 1 & 0.90 & & \\
\hline Comp LC-5 & 0 & 3 & 9 & 1 & 0.90 & 0.93 & 0.06 \\
\hline Comp LC-5 & 10 & 1 & 0 & 10 & 0.00 & & \\
\hline Comp LC-5 & 10 & 2 & 0 & 10 & 0.00 & & \\
\hline Comp LC-5 & 10 & 3 & 0 & 10 & 0.00 & 0.00 & 0.00 \\
\hline Comp LC-5 & 50 & 1 & 0 & 10 & 0.00 & & \\
\hline Comp LC-5 & 50 & 2 & 0 & 10 & 0.00 & & \\
\hline Comp LC-5 & 50 & 3 & 0 & 10 & 0.00 & 0.00 & 0.00 \\
\hline Comp LC-5 & 100 & 1 & 0 & 10 & 0.00 & & \\
\hline Comp LC-5 & 100 & 2 & 0 & 10 & 0.00 & & \\
\hline Comp LC-5 & 100 & 3 & 0 & 10 & 0.00 & 0.00 & 0.00 \\
\hline Comp LC-6 & 0 & 1 & 9 & 1 & 0.90 & & \\
\hline Comp LC-6 & 0 & 2 & 9 & 1 & 0.90 & & \\
\hline Comp LC-6 & 0 & 3 & 9 & 1 & 0.90 & 0.90 & 0.00 \\
\hline Comp LC-6 & 10 & 1 & 0 & 10 & 0.00 & & \\
\hline Comp LC-6 & 10 & 2 & 0 & 10 & 0.00 & & \\
\hline Comp LC-6 & 10 & 3 & 0 & 10 & 0.00 & 0.00 & 0.00 \\
\hline Comp LC-6 & 50 & 1 & 0 & 10 & 0.00 & & \\
\hline Comp LC-6 & 50 & 2 & 0 & 10 & 0.00 & & \\
\hline Comp LC-6 & 50 & 3 & 0 & 10 & 0.00 & 0.00 & 0.00 \\
\hline Comp LC-6 & 100 & 1 & 0 & 10 & 0.00 & & \\
\hline Comp LC-6 & 100 & 2 & 0 & 10 & 0.00 & & \\
\hline Comp LC-6 & 100 & 3 & 0 & 10 & 0.00 & 0.00 & 0.00 \\
\hline Comp USFC & 0 & 1 & 10 & 0 & 1.00 & & \\
\hline Comp USFC & 0 & 2 & 9 & 1 & 0.90 & & \\
\hline Comp USFC & 0 & 3 & 9 & 1 & 0.90 & 0.93 & 0.06 \\
\hline Comp USFC & 10 & 1 & 8 & 2 & 0.80 & & \\
\hline Comp USFC & 10 & 2 & 6 & 4 & 0.60 & & \\
\hline Comp USFC & 10 & 3 & 6 & 4 & 0.60 & 0.67 & 0.12 \\
\hline Comp USFC & 50 & 1 & 3 & 7 & 0.30 & & \\
\hline
\end{tabular}

\section{H.1}


TABLE H.1. (contd)

\begin{tabular}{|c|c|c|c|c|c|c|c|}
\hline \multirow[b]{2}{*}{$\begin{array}{l}\text { Sediment } \\
\text { Treatment } \\
\end{array}$} & \multirow{2}{*}{$\begin{array}{c}\text { SPP } \\
\text { Concentration } \\
\text { Percent } \\
\end{array}$} & \multirow[b]{2}{*}{ Replicate } & \multicolumn{2}{|c|}{$\begin{array}{c}H . \text { costata } \\
\end{array}$} & \multicolumn{3}{|c|}{ Mean } \\
\hline & & & $\begin{array}{l}\text { Number } \\
\text { Alive } \\
\end{array}$ & $\begin{array}{l}\text { Number } \\
\text { Dead }\end{array}$ & $\begin{array}{l}\text { Proportion } \\
\text { Surviving }\end{array}$ & $\begin{array}{l}\text { Proportion } \\
\text { Surviving }\end{array}$ & $\begin{array}{l}\text { Standard } \\
\text { Deviation }\end{array}$ \\
\hline Comp USFC & 50 & 2 & 6 & 4 & 0.60 & & \\
\hline Comp USFC & 50 & 3 & 5 & 5 & 0.50 & 0.47 & 0.15 \\
\hline Comp USFC & 100 & 1 & 1 & 9 & 0.10 & & \\
\hline Comp USFC & 100 & 2 & 2 & 8 & 0.20 & & \\
\hline Comp USFC & 100 & 3 & 3 & 7 & 0.30 & 0.20 & 0.10 \\
\hline Comp FSFC & 0 & 1 & $\begin{array}{l}10 \\
10\end{array}$ & $\begin{array}{l}0 \\
0\end{array}$ & $\begin{array}{l}1.00 \\
1.00\end{array}$ & & \\
\hline $\begin{array}{l}\text { Comp FSFC } \\
\text { Comp FSFC }\end{array}$ & $\begin{array}{l}0 \\
0\end{array}$ & $\begin{array}{l}2 \\
3\end{array}$ & $\begin{array}{r}10 \\
9\end{array}$ & 0 & $\begin{array}{l}1.00 \\
0.90\end{array}$ & & \\
\hline $\begin{array}{l}\text { Comp FSFC } \\
\text { Comp FSFC }\end{array}$ & 10 & $\begin{array}{l}3 \\
1\end{array}$ & $\begin{array}{l}9 \\
9\end{array}$ & 1 & $\begin{array}{l}0.90 \\
0.90\end{array}$ & 0.97 & 0.06 \\
\hline $\begin{array}{l}\text { Comp FSFC } \\
\text { Comp FSFC }\end{array}$ & $\begin{array}{l}10 \\
10\end{array}$ & $\begin{array}{l}1 \\
2\end{array}$ & $\begin{array}{r}9 \\
10\end{array}$ & $\begin{array}{l}1 \\
0\end{array}$ & $\begin{array}{l}0.90 \\
1.00\end{array}$ & & \\
\hline Comp FSFC & 10 & 3 & 9 & 1 & 0.90 & 0.93 & 0.06 \\
\hline Comp FSFC & 50 & 1 & 8 & 2 & 0.80 & 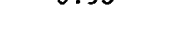 & \\
\hline Comp FSFC & 50 & 2 & 7 & 3 & 0.70 & & \\
\hline Comp FSFC & 50 & 3 & 8 & 2 & 0.80 & 0.77 & 0.06 \\
\hline Comp FSFC & 100 & 1 & 6 & 4 & 0.60 & & \\
\hline Comp FSFC & 100 & 2 & 6 & 4 & 0.60 & & \\
\hline Comp FSFC & 100 & 3 & 7 & 3 & 0.70 & 0.63 & 0.06 \\
\hline Comp IHC-1 & 0 & 1 & 9 & 1 & 0.90 & & \\
\hline Comp IHC-1 & 0 & 2 & 9 & 1 & 0.90 & & \\
\hline Comp IHC-1 & 0 & 3 & 10 & 0 & 1.00 & 0.93 & 0.06 \\
\hline Comp IHC-1 & 10 & 1 & 9 & 1 & 0.90 & & \\
\hline Comp IHC-1 & 10 & 2 & 8 & 2 & 0.80 & & \\
\hline Comp IHC-1 & 10 & 3 & 10 & 0 & 1.00 & 0.90 & 0.10 \\
\hline Comp IHC-1 & 50 & 1 & 8 & 2 & 0.80 & & \\
\hline Comp IHC-1 & 50 & 2 & 7 & 3 & 0.70 & & \\
\hline Comp IHC-1 & 50 & 3 & 9 & 1 & 0.90 & 0.80 & 0.10 \\
\hline Comp IHC-1 & 100 & 1 & 6 & 4 & 0.60 & & \\
\hline Comp IHC-1 & 100 & 2 & 7 & 3 & 0.70 & & \\
\hline Comp IHC-1 & 100 & 3 & 7 & 3 & 0.70 & 0.67 & 0.06 \\
\hline Comp IHC-2 & 0 & 1 & 8 & $\begin{array}{l}2 \\
0\end{array}$ & $\begin{array}{l}0.80 \\
1.00\end{array}$ & & \\
\hline $\begin{array}{l}\text { Comp IHC-2 } \\
\text { Comp IHC-2 }\end{array}$ & $\begin{array}{l}0 \\
0\end{array}$ & $\begin{array}{l}2 \\
3\end{array}$ & $\begin{array}{l}10 \\
10\end{array}$ & $\begin{array}{l}0 \\
0\end{array}$ & $\begin{array}{l}1.00 \\
1.00\end{array}$ & & \\
\hline $\begin{array}{l}\text { Comp IHC-2 } \\
\text { Comp IHC-2 }\end{array}$ & 10 & 1 & 10 & 0 & $\begin{array}{l}1.00 \\
1.00\end{array}$ & 0.93 & 0.12 \\
\hline Comp IHC-2 & 10 & 2 & 8 & 2 & 0.80 & & \\
\hline Comp IHC-2 & 10 & 3 & 8 & 2 & 0.80 & 0.87 & 0.12 \\
\hline Comp IHC-2 & 50 & 1 & 8 & 2 & 0.80 & & \\
\hline Comp IHC-2 & 50 & 2 & 7 & 3 & 0.70 & & \\
\hline Comp IHC-2 & 50 & 3 & 8 & 2 & 0.80 & 0.77 & 0.06 \\
\hline Comp IHC-2 & 100 & 1 & 7 & 3 & 0.70 & & \\
\hline Comp IHC-2 & 100 & 2 & 6 & 4 & 0.60 & & \\
\hline Comp IHC-2 & 100 & 3 & 7 & 3 & 0.70 & 0.67 & 0.06 \\
\hline Comp IHC-3 & 0 & 1 & 10 & 0 & 1.00 & & \\
\hline Comp IHC-3 & 0 & 2 & 9 & 1 & 0.90 & & \\
\hline Comp IHC-3 & 0 & 3 & 9 & 1 & 0.90 & 0.93 & 0.06 \\
\hline Comp IHC-3 & 10 & 1 & 9 & 1 & 0.90 & & \\
\hline Comp IHC-3 & 10 & 2 & 9 & 1 & 0.90 & & \\
\hline Comp IHC-3 & 10 & 3 & 10 & 0 & 1.00 & 0.93 & 0.06 \\
\hline Comp IHC-3 & 50 & 1 & 8 & 2 & 0.80 & & \\
\hline Comp IHC-3 & 50 & 2 & 7 & 3 & 0.70 & & \\
\hline Comp IHC-3 & 50 & 3 & 8 & 2 & 0.80 & 0.77 & 0.06 \\
\hline Comp IHC-3 & 100 & 1 & 7 & 3 & 0.70 & & \\
\hline Comp IHC-3 & 100 & 2 & 6 & 4 & 0.60 & & \\
\hline Comp IHC-3 & 100 & 3 & 4 & 6 & 0.40 & 0.57 & 0.15 \\
\hline
\end{tabular}

(a) Test of Comp LC-5 SPP at lower concentrations. 
TABLE H. 2. Water Quality Summary for 96-h H. costata Suspended-ParticulatePhase Test, United Heckathorn Remedial Investigation

\begin{tabular}{|c|c|c|c|c|c|c|c|c|c|}
\hline \multirow[t]{2}{*}{$\begin{array}{l}\text { Sediment } \\
\text { Treatment }\end{array}$} & \multirow[t]{2}{*}{$\begin{array}{c}\text { SPP } \\
\begin{array}{c}\text { Concentration } \\
\text { (Percent) }\end{array} \\
\end{array}$} & \multicolumn{2}{|c|}{$\begin{array}{c}\text { Temperature } \\
\left({ }^{\circ} \mathrm{C}\right) \\
\end{array}$} & 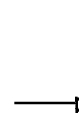 & & \multicolumn{2}{|c|}{$\begin{array}{c}\text { Dissolved } \\
\text { Oxygen } \\
\text { (mg/L) }\end{array}$} & \multicolumn{2}{|c|}{$\begin{array}{c}\text { Salinity } \\
(0 / 00)\end{array}$} \\
\hline & & $\underline{\operatorname{Min}}^{(b)}$ & $\underline{\operatorname{Max}}{ }^{(b)}$ & Min & $\operatorname{Max}$ & Min & Max & Min & Max \\
\hline Acceptable & Range & 13.0 & 17.0 & 7.46 & 8.46 & 4.0 & NA & 30.0 & 34.0 \\
\hline $\begin{array}{ll}\text { Comp } & \text { LC } \\
\text { Comp LC } \\
\text { Comp LC } \\
\text { Comp LC }\end{array}$ & $\begin{array}{r}0 \\
10 \\
50 \\
100\end{array}$ & $\begin{array}{l}16.3 \\
16.5 \\
16.5 \\
16.6\end{array}$ & $\begin{array}{l}16.7 \\
16.7 \\
16.7 \\
16.7\end{array}$ & $\begin{array}{l}7.71 \\
8.00 \\
8.05 \\
8.08\end{array}$ & $\begin{array}{l}7.98 \\
8.03 \\
8.29 \\
8.48(d)\end{array}$ & $\begin{array}{l}7.1 \\
7.2 \\
7.2 \\
6.2\end{array}$ & $\begin{array}{l}8.4 \\
8.2 \\
7.5 \\
7.0\end{array}$ & $\begin{array}{l}29.0^{(c)} \\
29.0^{(c)} \\
29.5^{(c)} \\
30.0^{(}\end{array}$ & $\begin{array}{l}30.0 \\
30.0 \\
30.0 \\
30.5\end{array}$ \\
\hline $\begin{array}{ll}\text { Comp } & \text { LC-5 } \\
\text { Comp LC-5 } \\
\text { Comp LC-5 } \\
\text { Comp LC-5 }\end{array}$ & $\begin{array}{r}0 \\
10 \\
50 \\
100\end{array}$ & $\begin{array}{l}16.2 \\
16.4 \\
16.5 \\
16.5\end{array}$ & $\begin{array}{l}16.7 \\
16.6 \\
16.7 \\
16.7\end{array}$ & $\begin{array}{l}7.48 \\
7.89 \\
7.86 \\
8.09\end{array}$ & $\begin{array}{l}7.91 \\
8.09 \\
8.60(d) \\
8.98\end{array}$ & $\begin{array}{l}6.7 \\
7.3 \\
6.0 \\
6.2\end{array}$ & $\begin{array}{l}8.6 \\
8.4 \\
7.5 \\
7.2\end{array}$ & $\begin{array}{l}28.0^{(c)}(c) \\
28.5^{(c)} \\
29.5^{(c)} \\
30.0^{(1)}\end{array}$ & $\begin{array}{l}30.0 \\
29.5(c) \\
30.0 \\
30.0\end{array}$ \\
\hline $\begin{array}{ll}\text { Comp } & \text { LC-5 } \\
\text { Comp LC-5 } \\
\text { Comp LC-5 } \\
\text { Comp LC-5 }\end{array}$ & $\begin{array}{r}0 \\
0.01 \\
0.1 \\
1\end{array}$ & $\begin{array}{l}15.8 \\
15.8 \\
15.7 \\
15.8\end{array}$ & $\begin{array}{l}16.4 \\
16.5 \\
16.4 \\
16.5\end{array}$ & $\begin{array}{l}7.81 \\
7.70 \\
7.76 \\
7.69\end{array}$ & $\begin{array}{l}8.01 \\
7.97 \\
7.98 \\
7.97\end{array}$ & $\begin{array}{l}6.9 \\
6.7 \\
7.0 \\
6.6\end{array}$ & $\begin{array}{l}8.8 \\
8.7 \\
8.9 \\
8.8\end{array}$ & $\begin{array}{l}29.5^{(c)} \\
29.5^{(c)} \\
30.0 \\
30.0\end{array}$ & $\begin{array}{l}30.0 \\
30.0 \\
30.0 \\
30.0\end{array}$ \\
\hline $\begin{array}{l}\text { Comp LC-6 } \\
\text { Comp LC-6 } \\
\text { Comp LC-6 } \\
\text { Comp LC-6 }\end{array}$ & $\begin{array}{r}0 \\
10 \\
50 \\
100\end{array}$ & $\begin{array}{l}16.2 \\
16.2 \\
16.3 \\
16.3\end{array}$ & $\begin{array}{l}16.4 \\
16.4 \\
16.5 \\
16.6\end{array}$ & $\begin{array}{l}7.70 \\
7.93 \\
7.96 \\
8.05\end{array}$ & $\begin{array}{l}7.95 \\
8.06 \\
8.4 .3 \\
8.73(d)\end{array}$ & $\begin{array}{l}6.6 \\
7.4 \\
7.2 \\
6.2\end{array}$ & $\begin{array}{l}7.9 \\
7.9 \\
7.5 \\
7.6\end{array}$ & $\begin{array}{l}28.5^{(c)}(c) \\
28.5^{(c)} \\
28.5^{(c)} \\
28.0^{(c)}\end{array}$ & $\begin{array}{l}30.0 \\
30.0 \\
30.0(c) \\
29.5\end{array}$ \\
\hline $\begin{array}{ll}\text { Comp } & \text { FSFC } \\
\text { Comp } & \text { FSFC } \\
\text { Comp } & \text { FSFC } \\
\text { Comp } & \text { FSFC }\end{array}$ & $\begin{array}{r}0 \\
10 \\
50 \\
100\end{array}$ & $\begin{array}{l}16.0 \\
16.1 \\
16.2 \\
16.1\end{array}$ & $\begin{array}{l}16.3 \\
16.3 \\
16.4 \\
16.4\end{array}$ & $\begin{array}{l}7.72 \\
7.76 \\
7.83 \\
7.93\end{array}$ & $\begin{array}{l}7.94 \\
7.94 \\
8.18 \\
8.16\end{array}$ & $\begin{array}{l}6.9 \\
7.0 \\
7.0 \\
5.6\end{array}$ & $\begin{array}{l}8.7 \\
8.5 \\
7.9 \\
7.6\end{array}$ & $\begin{array}{l}30.0 \\
30.0 \\
29.5(c) \\
29.0(c)\end{array}$ & $\begin{array}{l}30.5 \\
30.5 \\
30.5 \\
30.5\end{array}$ \\
\hline $\begin{array}{l}\text { Comp USFC } \\
\text { Comp USFC } \\
\text { Comp USFC } \\
\text { Comp USFC }\end{array}$ & $\begin{array}{r}0 \\
10 \\
50 \\
100\end{array}$ & $\begin{array}{l}16.1 \\
16.2 \\
16.2 \\
16.3\end{array}$ & $\begin{array}{l}16.6 \\
16.6 \\
16.6 \\
16.7\end{array}$ & $\begin{array}{l}7.76 \\
7.82 \\
7.87 \\
8.12\end{array}$ & $\begin{array}{l}7.92 \\
8.08 \\
8.13 \\
8.23\end{array}$ & $\begin{array}{l}7.1 \\
7.2 \\
6.7 \\
6.3\end{array}$ & $\begin{array}{l}8.0 \\
8.0 \\
7.9 \\
7.9\end{array}$ & $\begin{array}{l}29.0^{(\mathrm{c})} \\
29.5^{(\mathrm{c})} \\
30.0^{(\mathrm{c})} \\
29.5^{(\mathrm{c})}\end{array}$ & $\begin{array}{l}30.5 \\
30.5 \\
30.5 \\
30.5\end{array}$ \\
\hline $\begin{array}{ll}\text { Comp IHC-1 } \\
\text { Comp IHC-1 } \\
\text { Comp IHC-1 } \\
\text { Comp IHC-1 }\end{array}$ & $\begin{array}{r}0 \\
10 \\
50 \\
100\end{array}$ & $\begin{array}{l}16.0 \\
16.0 \\
16.0 \\
16.0\end{array}$ & $\begin{array}{l}16.2 \\
16.4 \\
16.4 \\
16.4\end{array}$ & $\begin{array}{l}7.72 \\
7.70 \\
7.70 \\
7.58\end{array}$ & $\begin{array}{l}7.97 \\
7.98 \\
8.10 \\
8.26\end{array}$ & $\begin{array}{l}7.0 \\
7.0 \\
6.6 \\
5.9\end{array}$ & $\begin{array}{l}8.5 \\
8.6 \\
8.0 \\
7.8\end{array}$ & $\begin{array}{l}30.0 \\
30.0 \\
29.5(c) \\
29.0^{(c)}\end{array}$ & $\begin{array}{l}30.5 \\
30.5 \\
30.0 \\
30.5\end{array}$ \\
\hline $\begin{array}{ll}\text { Comp } & \text { IHC-2 } \\
\text { Comp IHC-2 } & \text { IHC-2 } \\
\text { Comp IHC-2 } \\
\text { Comp IHC-2 }\end{array}$ & $\begin{array}{r}0 \\
10 \\
50 \\
100\end{array}$ & $\begin{array}{l}15.6 \\
15.6 \\
15.7 \\
15.6\end{array}$ & $\begin{array}{l}16.3 \\
16.3 \\
16.2 \\
16.4\end{array}$ & $\begin{array}{l}7.72 \\
7.71 \\
7.76 \\
7.65\end{array}$ & $\begin{array}{l}7.92 \\
7.96 \\
8.13 \\
8.15\end{array}$ & $\begin{array}{l}7.1 \\
7.0 \\
7.3 \\
6.8\end{array}$ & $\begin{array}{l}8.2 \\
8.2 \\
8.0 \\
7.7\end{array}$ & $\begin{array}{l}30.0 \\
30.0 \\
30.0 \\
29.5\end{array}$ & $\begin{array}{l}30.0 \\
30.0 \\
30.0 \\
30.0\end{array}$ \\
\hline $\begin{array}{ll}\text { Comp } & \mathrm{IHC}-3 \\
\text { Comp } & \mathrm{HHC}-3 \\
\text { Comp } & \mathrm{HHC}-3 \\
\text { Comp } & \mathrm{IHC}-3\end{array}$ & $\begin{array}{r}0 \\
10 \\
50 \\
100\end{array}$ & $\begin{array}{l}15.6 \\
15.6 \\
15.6 \\
15.6\end{array}$ & $\begin{array}{l}16.4 \\
16.3 \\
16.3 \\
16.3\end{array}$ & $\begin{array}{l}7.51 \\
7.72 \\
7.72 \\
7.62\end{array}$ & $\begin{array}{l}7.89 \\
7.88 \\
8.00 \\
8.30\end{array}$ & $\begin{array}{l}5.8 \\
6.4 \\
6.4 \\
6.2\end{array}$ & $\begin{array}{l}8.3 \\
8.3 \\
7.8 \\
7.3\end{array}$ & $\begin{array}{l}30.0 \\
30.0 \\
30.0 \\
30.0\end{array}$ & $\begin{array}{l}30.5 \\
30.5 \\
30.0 \\
30.0\end{array}$ \\
\hline
\end{tabular}

\footnotetext{
(a) Acceptable $\mathrm{pH}$ range is based on mean $\mathrm{pH}$ in all test chambers in $96-\mathrm{h}$ test.

(b) Minimum and maximum values are derived from all replicates for each treatment.

(c) The 96 -h test was conducted at a salinity of $30 \pm 2 \%$ instead of the $32 \pm 2 \%$ specified in the Quality Assurance Plan.

(d) Value exceeds acceptable range.
} 
TABLE H.3. Results for all Replicates in 96-h H. costata Elutriate Test, United Heckathorn Remedial Investigation

\begin{tabular}{|c|c|c|c|c|c|c|c|}
\hline & Elutriate & & & & & Mean & \\
\hline $\begin{array}{l}\text { Sediment } \\
\text { Treatment } \\
\end{array}$ & $\begin{array}{l}\text { Concentration } \\
\text { (Percent) }\end{array}$ & $\underline{\text { Replicate }}$ & $\begin{array}{l}\text { Number } \\
\text { Alive } \\
\end{array}$ & $\begin{array}{l}\text { Number } \\
\text { Dead }\end{array}$ & $\begin{array}{c}\text { Proportion } \\
\text { Survival } \\
\end{array}$ & $\begin{array}{l}\text { Proportion } \\
\text { Survival } \\
\end{array}$ & $\begin{array}{l}\text { Standard } \\
\text { Deviation }\end{array}$ \\
\hline Comp LC & 0 & 1 & 8 & 2 & 0.80 & & \\
\hline Comp LC & 0 & 2 & 10 & 0 & 1.00 & & \\
\hline Comp LC & 0 & 3 & 10 & 0 & 1.00 & 0.93 & 0.12 \\
\hline Comp LC & 10 & 1 & 0 & 10 & 0.00 & & \\
\hline Comp LC & 10 & 2 & 0 & 10 & 0.00 & & \\
\hline Comp LC & 10 & 3 & 0 & 10 & 0.00 & 0.00 & 0.00 \\
\hline Comp LC & 50 & 1 & 0 & 10 & 0.00 & & \\
\hline Comp LC & 50 & 2 & 0 & 10 & 0.00 & & \\
\hline Comp LC & 50 & 3 & 0 & 10 & 0.00 & 0.00 & 0.00 \\
\hline Comp LC & 100 & 1 & 0 & 10 & 0.00 & & \\
\hline Comp LC & 100 & 2 & 0 & 10 & 0.00 & & \\
\hline Comp LC & 100 & 3 & 0 & 10 & 0.00 & 0.00 & 0.00 \\
\hline Comp LC-5R ${ }^{(a)}$ & 0 & 1 & 9 & 1 & 0.90 & & \\
\hline Comp LC-5R & 0 & 2 & 10 & 0 & 1.00 & & \\
\hline Comp LC-5R & 0 & 3 & 10 & 0 & 1.00 & 0.97 & 0.06 \\
\hline Comp LC-5R & 0.01 & 1 & 9 & 1 & 0.90 & & \\
\hline Comp LC-5R & 0.01 & 2 & 10 & 0 & 1.00 & & \\
\hline Comp LC-5R & 0.01 & 3 & 10 & 0 & 1.00 & 0.97 & 0.06 \\
\hline Comp LC-5R & 0.1 & 1 & 8 & 2 & 0.80 & & \\
\hline Comp LC-5R & 0.1 & 2 & 10 & 0 & 1.00 & & \\
\hline Comp LC-5R & 0.1 & 3 & 9 & 1 & 0.90 & 0.90 & 0.10 \\
\hline Comp LC-5R & 1 & 1 & 3 & 7 & 0.30 & & \\
\hline Comp LC-5R & 1 & 2 & 5 & 5 & 0.50 & & \\
\hline Comp LC-5R & 1 & 3 & 5 & 5 & 0.50 & 0.43 & 0.12 \\
\hline Comp LC-5 & 0 & 1 & 10 & 0 & 1.00 & & \\
\hline Comp LC-5 & 0 & 2 & 10 & 0 & 1.00 & & \\
\hline Comp LC-5 & 0 & 3 & 9 & 1 & 0.90 & 0.97 & 0.06 \\
\hline Comp LC-5 & 10 & 1 & 0 & 10 & 0.00 & & \\
\hline Como LC-5 & 10 & 2 & 0 & 10 & 0.00 & & \\
\hline Comp LC-5 & 10 & 3 & 0 & 10 & 0.00 & 0.00 & 0.00 \\
\hline Comp LC-5 & 50 & 1 & 0 & 10 & 0.00 & & \\
\hline Comp LC-5 & 50 & 2 & 0 & 10 & 0.00 & & \\
\hline Comp LC-5 & 50 & 3 & 0 & 10 & 0.00 & 0.00 & 0.00 \\
\hline Comp LC-5 & 100 & 1 & 0 & 10 & 0.00 & & \\
\hline Comp LC-5 & 100 & 2 & 0 & 10 & 0.00 & & \\
\hline Comp LC-5 & 100 & 3 & 0 & 10 & 0.00 & 0.00 & 0.00 \\
\hline Comp LC-5 UF(b) & 0 & 1 & 9 & 1 & 0.90 & & \\
\hline Comp LC-5 UF & 0 & 2 & 10 & 0 & 1.00 & & \\
\hline Comp LC-5 UF & 0 & 3 & 10 & 0 & 1.00 & 0.97 & 0.06 \\
\hline Comp LC-5 UF & 100 & 1 & 0 & 10 & 0.00 & & \\
\hline Comp LC-5 UF & 100 & 2 & 0 & 10 & 0.00 & & \\
\hline Comp LC-5 LIF & 100 & 3 & 0 & 10 & 0.00 & 0.00 & 0.00 \\
\hline Comp LC-5 F (c) & 0 & 1 & 9 & 1 & 0.90 & & \\
\hline Comp LC-5 F & 0 & 2 & 10 & 0 & 1.00 & & \\
\hline Comp LC-5 F & 0 & 3 & 10 & 0 & 1.00 & 0.97 & 0.06 \\
\hline Comp LC-5 F & 100 & 1 & 0 & 10 & 0.00 & & \\
\hline Comp LC-5 F & 100 & 2 & 0 & 10 & 0.00 & & \\
\hline Comp LC-5 F & 100 & 3 & 0 & 10 & 0.00 & 0.00 & 0.00 \\
\hline
\end{tabular}


TABLE H.3. (contd)

\begin{tabular}{|c|c|c|c|c|c|c|c|}
\hline \multirow[b]{2}{*}{$\begin{array}{l}\text { Sediment } \\
\text { Treatment } \\
\end{array}$} & \multirow{2}{*}{$\begin{array}{c}\text { Elutriate } \\
\text { Concentration } \\
\text { (Percent) } \\
\end{array}$} & \multirow[b]{2}{*}{$\underline{\text { Replicate }}$} & \multicolumn{2}{|c|}{ H. costata } & \multirow[b]{2}{*}{$\begin{array}{l}\text { Proportion } \\
\text { Survival } \\
\end{array}$} & \multicolumn{2}{|l|}{ Mean } \\
\hline & & & $\begin{array}{l}\text { Number } \\
\text { Alive } \\
\end{array}$ & $\begin{array}{l}\text { Number } \\
\text { Dead } \\
\end{array}$ & & $\begin{array}{l}\text { Proportion } \\
\text { Survival } \\
\end{array}$ & $\begin{array}{l}\text { Standard } \\
\text { Deviation }\end{array}$ \\
\hline Comp LC-6 & 0 & 1 & 10 & 0 & 1.00 & & \\
\hline Comp LC-6 & 0 & 2 & 9 & 1 & 0.90 & & \\
\hline Comp LC-6 & 0 & 3 & 9 & 1 & 0.90 & 0.93 & 0.06 \\
\hline Comp LC-6 & 10 & 1 & 0 & 10 & 0.00 & & \\
\hline Comp LC-6 & 10 & 2 & 0 & 10 & 0.00 & & \\
\hline Comp LC-6 & 10 & 3 & 0 & 10 & 0.00 & 0.00 & 0.00 \\
\hline Comp LC-6 & 50 & 1 & 0 & 10 & 0.00 & & \\
\hline Comp LC-6 & 50 & 2 & 0 & 10 & 0.00 & & \\
\hline Comp LC-6 & 50 & 3 & 0 & 10 & 0.00 & 0.00 & 0.00 \\
\hline Comp LC-6 & 100 & 1 & 0 & 10 & 0.00 & & \\
\hline Comp LC-6 & 100 & 2 & 0 & 10 & 0.00 & & \\
\hline Comp LC-6 & 100 & 3 & 0 & 10 & 0.00 & 0.00 & 0.00 \\
\hline Comp FSFC & 0 & 1 & 10 & 0 & 1.00 & & \\
\hline Comp FSFC & 0 & 2 & 9 & 1 & 0.90 & & \\
\hline Comp FSFC & 0 & 3 & 9 & 1 & 0.90 & 0.93 & 0.06 \\
\hline Comp FSFC & 10 & 1 & 9 & 1 & 0.90 & & \\
\hline Comp FSFC & 10 & 2 & 10 & 0 & 1.00 & & \\
\hline Comp FSFC & 10 & 3 & 9 & 1 & 0.90 & 0.93 & 0.06 \\
\hline Comp FSFC & 50 & 1 & 7 & 3 & 0.70 & & \\
\hline Comp FSFC & 50 & 2 & 8 & 2 & 0.80 & & \\
\hline Comp FSFC & 50 & 3 & 9 & 1 & 0.90 & 0.80 & 0.10 \\
\hline Comp FSFC & 100 & 1 & 6 & 4 & 0.60 & & \\
\hline Comp FSFC & 100 & 2 & 8 & 2 & 0.80 & & \\
\hline Comp FSFC & 100 & 3 & 8 & 2 & 0.80 & 0.73 & 0.12 \\
\hline Comp USFC & 0 & 1 & 9 & 1 & 0.90 & & \\
\hline Comp USFC & 0 & 2 & 10 & 0 & 1.00 & & \\
\hline Comp USFC & 0 & 3 & 8 & 2 & 0.80 & 0.90 & 0.10 \\
\hline Comp USFC & 10 & 1 & 7 & 3 & 0.70 & & \\
\hline Comp USFC & 10 & 2 & 7 & 3 & 0.70 & & \\
\hline Comp USFC & 10 & 3 & 6 & 4 & 0.60 & 0.67 & 0.06 \\
\hline Comp USFC & 50 & 1 & 4 & 6 & 0.40 & & \\
\hline Comp USFC & 50 & 2 & 6 & 4 & 0.60 & & \\
\hline Comp USFC & 50 & 3 & 5 & 5 & 0.50 & 0.50 & 0.10 \\
\hline Comp USFC & 100 & 1 & 0 & 10 & 0.00 & & \\
\hline Comp USFC & 100 & 2 & 3 & 7 & 0.30 & & \\
\hline Comp USFC & 100 & 3 & 3 & 7 & 0.30 & 0.20 & 0.17 \\
\hline Comp IHC-1 & 0 & 1 & 10 & 0 & 1.00 & & \\
\hline Comp IHC-1 & 0 & 2 & 10 & 0 & 1.00 & & \\
\hline Comp IHC-1 & 0 & 3 & 10 & 0 & 1.00 & 1.00 & 0.00 \\
\hline Comp IHC-1 & 10 & 1 & 9 & 1 & 0.90 & & \\
\hline Comp IHC-1 & 10 & 2 & 8 & 2 & 0.80 & & \\
\hline Comp IHC-1 & 10 & 3 & 10 & 0 & 1.00 & 0.90 & 0.10 \\
\hline Comp IHC-1 & 50 & 1 & 9 & 1 & 0.90 & & \\
\hline Comp IHC-1 & 50 & 2 & 7 & 3 & 0.70 & & \\
\hline Comp IHC-1 & 50 & 3 & 9 & 1 & 0.90 & 0.83 & 0.12 \\
\hline Comp IHC-1 & 100 & 1 & 7 & 3 & 0.70 & & \\
\hline Comp IHC-1 & 100 & 2 & 6 & 4 & 0.60 & & \\
\hline Comp IHC-1 & 100 & 3 & 7 & 3 & 0.70 & 0.67 & 0.06 \\
\hline
\end{tabular}


TABLE H.3. (contd)

\begin{tabular}{|c|c|c|c|c|c|c|c|}
\hline \multirow[b]{2}{*}{$\begin{array}{l}\text { Sediment } \\
\text { Treatment } \\
\end{array}$} & \multirow{2}{*}{$\begin{array}{c}\text { Elutriate } \\
\text { Concentration } \\
\text { (Percent) } \\
\end{array}$} & \multirow[b]{2}{*}{ Replicate } & \multicolumn{2}{|c|}{ H. costata } & \multicolumn{3}{|c|}{ Mean } \\
\hline & & & $\begin{array}{l}\text { Number } \\
\text { Alive } \\
\end{array}$ & $\begin{array}{l}\text { Number } \\
\text { Dead } \\
\end{array}$ & $\begin{array}{l}\text { Proportion } \\
\text { Survival } \\
\end{array}$ & $\begin{array}{l}\text { Proportion } \\
\text { Survival } \\
\end{array}$ & $\begin{array}{l}\text { Standard } \\
\text { Deviation }\end{array}$ \\
\hline Comp IHC-2 & 0 & 1 & 9 & 1 & 0.90 & & \\
\hline Comp IHC-2 & 0 & 2 & 9 & 1 & 0.90 & & \\
\hline Comp IHC-2 & 0 & 3 & 10 & 0 & 1.00 & 0.93 & 0.06 \\
\hline Comp IHC-2 & 10 & 1 & 8 & 2 & 0.80 & & \\
\hline Comp IHC-2 & 10 & 2 & 9 & 1 & 0.90 & & \\
\hline Comp IHC-2 & 10 & 3 & 10 & 0 & 1.00 & 0.90 & 0.10 \\
\hline Comp IHC-2 & 50 & 1 & 7 & 3 & 0.70 & & \\
\hline Comp IHC-2 & 50 & 2 & 7 & 3 & 0.70 & & \\
\hline Comp IHC-2 & 50 & 3 & 8 & 2 & 0.80 & 0.73 & 0.06 \\
\hline Comp IHC-2 & 100 & 1 & 7 & 3 & 0.70 & & \\
\hline Comp IHC-2 & 100 & 2 & 6 & 4 & 0.60 & & \\
\hline Comp IHC-2 & 100 & 3 & 6 & 4 & 0.60 & 0.63 & 0.06 \\
\hline Comp IHC-3 & 0 & 1 & 10 & 0 & 1.00 & & \\
\hline Comp IHC-3 & 0 & 2 & 10 & 0 & 1.00 & & \\
\hline Comp IHC-3 & 0 & 3 & 9 & 1 & 0.90 & 0.97 & 0.06 \\
\hline Comp IHC-3 & 10 & 1 & 9 & 1 & 0.90 & & \\
\hline Comp IHC-3 & 10 & 2 & 8 & 2 & 0.80 & & \\
\hline Comp IHC-3 & 10 & 3 & 9 & 1 & 0.90 & 0.87 & 0.06 \\
\hline Comp IHC-3 & 50 & 1 & 7 & 3 & 0.70 & & \\
\hline Comp IHC-3 & 50 & 2 & 8 & 2 & 0.80 & & \\
\hline Comp IHC-3 & 50 & 3 & 8 & 2 & 0.80 & 0.77 & 0.06 \\
\hline Comp IHC-3 & 100 & 1 & 5 & 5 & 0.50 & & \\
\hline Comp IHC-3 & 100 & 2 & 5 & 5 & 0.50 & & \\
\hline Comp IHC-3 & 100 & 3 & 6 & 4 & 0.60 & 0.53 & 0.06 \\
\hline
\end{tabular}

(a) Test of Comp LC-5 elutriate at lower concentrations.

(b) UF Unfiltered.

(c) F Filtered through granular activated carbon.

H. 6 
TABLE H. 4. Water Quality Summary for $96-\mathrm{h} \mathrm{H}$. costata Elutriate Test, United Heckathorn Remedial Investigation

\begin{tabular}{|c|c|c|c|c|c|c|c|c|c|}
\hline \multirow[t]{2}{*}{$\begin{array}{l}\text { Sediment } \\
\text { Treatment } \\
\end{array}$} & \multirow[t]{2}{*}{$\begin{array}{c}\text { Elutriate } \\
\text { Concentration } \\
\text { (Percent) }\end{array}$} & \multicolumn{2}{|c|}{$\begin{array}{l}\text { Temperature } \\
\left({ }^{\circ} \mathrm{C}\right) \\
\end{array}$} & \multicolumn{2}{|c|}{$\mathrm{pH}^{(\mathrm{a})}$} & \multicolumn{2}{|c|}{$\begin{array}{c}\text { Dissolved } \\
\text { Oxygen } \\
\text { (mg/L) } \\
\end{array}$} & \multicolumn{2}{|c|}{$\begin{array}{c}\text { Salinity } \\
(0 / 00)\end{array}$} \\
\hline & & $\underline{\operatorname{Min}}^{(b)}$ & $\underline{\operatorname{Max}}^{(\mathrm{b})}$ & $\underline{\text { Min }}$ & Max & $\underline{\text { Min }}$ & $\underline{\text { Max }}$ & $\operatorname{Min}$ & Max \\
\hline Acceptable Range & & 13.0 & 17.0 & 7.45 & 8.45 & 4.0 & NA & 30.0 & 34.0 \\
\hline $\begin{array}{l}\text { Comp LC } \\
\text { Comp LC } \\
\text { Comp LC } \\
\text { Comp LC }\end{array}$ & $\begin{array}{r}0 \\
10 \\
50 \\
100\end{array}$ & $\begin{array}{l}16.5 \\
16.6 \\
16.6 \\
16.6\end{array}$ & $\begin{array}{l}16.8 \\
16.8 \\
16.7 \\
16.8\end{array}$ & $\begin{array}{l}7.42(c) \\
7.88 \\
8.02 \\
7.92\end{array}$ & $\begin{array}{l}7.99 \\
8.03 \\
8.28(c) \\
8.47\end{array}$ & $\begin{array}{l}6.0 \\
6.9 \\
7.1 \\
6.4\end{array}$ & $\begin{array}{l}8.3 \\
8.0 \\
7.9 \\
7.4\end{array}$ & $\begin{array}{l}30.0 \\
30.0 \\
30.0 \\
30.0\end{array}$ & $\begin{array}{l}30.0 \\
30.5 \\
30.5 \\
30.5\end{array}$ \\
\hline $\begin{array}{l}\text { Comp LC-5 } \\
\text { Comp LC-5 } \\
\text { Comp LC-5 } \\
\text { Comp LC-5 }\end{array}$ & $\begin{array}{r}0 \\
10 \\
50 \\
100\end{array}$ & $\begin{array}{l}16.4 \\
16.6 \\
16.7 \\
16.6\end{array}$ & $\begin{array}{l}16.7 \\
16.9 \\
16.9 \\
16.9\end{array}$ & $\begin{array}{l}7.74 \\
7.86 \\
7.99 \\
8.04\end{array}$ & $\begin{array}{l}7.99 \\
8.12(c) \\
8.60(c) \\
8.97(c)\end{array}$ & $\begin{array}{l}6.8 \\
7.1 \\
6.2 \\
6.0\end{array}$ & $\begin{array}{l}8.1 \\
8.1 \\
8.0 \\
7.6\end{array}$ & $\begin{array}{l}28.0 \text { (d) } \\
29.0 \text { (d) } \\
29.0 \text { (d) } \\
29.5^{(d)}\end{array}$ & $\begin{array}{l}30.0 \\
30.0 \\
30.0 \\
30.5\end{array}$ \\
\hline $\begin{array}{l}\text { Comp LC-5 } \\
\text { Comp LC-5 } \\
\text { Comp LC-5 } \\
\text { Comp LC-5 }\end{array}$ & $\begin{array}{r}0 \\
0.01 \\
0.1 \\
1\end{array}$ & $\begin{array}{l}16.1 \\
16.2 \\
16.1 \\
16.1\end{array}$ & $\begin{array}{l}16.5 \\
16.5 \\
16.5 \\
16.5\end{array}$ & $\begin{array}{l}7.73 \\
7.65 \\
7.66 \\
7.76\end{array}$ & $\begin{array}{l}7.96 \\
7.97 \\
7.94 \\
7.90\end{array}$ & $\begin{array}{l}7.0 \\
6.6 \\
6.5 \\
6.9\end{array}$ & $\begin{array}{l}8.7 \\
8.8 \\
8.9 \\
8.7\end{array}$ & $\begin{array}{l}30.0 \\
30.0 \\
30.0 \text { (d) } \\
29.5\end{array}$ & $\begin{array}{l}30.5 \\
30.5 \\
30.5 \\
30.5\end{array}$ \\
\hline $\begin{array}{l}\text { Comp LC-5 } \\
\text { Comp LC-5 UE (e) } \\
\text { Comp LC-5 F(f) }\end{array}$ & $\begin{array}{r}0 \\
100 \\
100\end{array}$ & $\begin{array}{l}16.0 \\
16.1 \\
16.1\end{array}$ & $\begin{array}{l}16.3 \\
16.4 \\
16.4\end{array}$ & $\begin{array}{l}7.72 \\
8.26 \\
8.05\end{array}$ & $\begin{array}{l}7.91(c) \\
8.92(c) \\
8.65(c)\end{array}$ & $\begin{array}{l}6.8 \\
7.1 \\
7.1\end{array}$ & $\begin{array}{l}8.2 \\
8.0 \\
8.0\end{array}$ & $\begin{array}{l}29.0 \text { (d) } \\
29.0 \text { (d) } \\
28.5^{(d)}\end{array}$ & $\begin{array}{l}30.0 \\
29.5(d) \\
30.0\end{array}$ \\
\hline $\begin{array}{l}\text { Comp LC-6 } \\
\text { Comp LC-6 } \\
\text { Comp LC-6 } \\
\text { Comp LC-6 }\end{array}$ & $\begin{array}{r}0 \\
10 \\
50 \\
100\end{array}$ & $\begin{array}{l}16.5 \\
16.5 \\
16.5 \\
16.5\end{array}$ & $\begin{array}{l}16.7 \\
16.8 \\
16.6 \\
16.7\end{array}$ & $\begin{array}{l}7.74 \\
7.95 \\
7.97 \\
8.04\end{array}$ & $\begin{array}{l}7.93 \\
8.02 \\
8.42 \\
8.70(c)\end{array}$ & $\begin{array}{l}7.0 \\
7.6 \\
7.6 \\
7.1\end{array}$ & $\begin{array}{l}7.9 \\
7.9 \\
7.7 \\
7.5\end{array}$ & $\begin{array}{l}29.5^{(d)} \\
29.0 \text { (d) } \\
29.0 \text { (d) } \\
29.5 \text { (d) }\end{array}$ & $\begin{array}{l}30.0 \\
30.0 \\
30.0 \\
30.0\end{array}$ \\
\hline $\begin{array}{ll}\text { Comp } & \text { FSFC } \\
\text { Comp FSFC } \\
\text { Comp FSFC } \\
\text { Comp FSFC }\end{array}$ & $\begin{array}{r}0 \\
10 \\
50 \\
100\end{array}$ & $\begin{array}{l}15.9 \\
16.0 \\
15.9 \\
15.9\end{array}$ & $\begin{array}{l}16.4 \\
16.4 \\
16.4 \\
16.5\end{array}$ & $\begin{array}{l}7.63 \\
7.78 \\
7.79 \\
7.86\end{array}$ & $\begin{array}{l}7.91 \\
7.94 \\
8.00 \\
8.17\end{array}$ & $\begin{array}{l}6.6 \\
6.7 \\
7.0 \\
6.9\end{array}$ & $\begin{array}{l}8.7 \\
8.6 \\
8.3 \\
8.1\end{array}$ & $\begin{array}{l}30.0 \\
30.0 \\
30.0 \\
30.0\end{array}$ & $\begin{array}{l}30.0 \\
30.0 \\
30.0 \\
30.0\end{array}$ \\
\hline $\begin{array}{l}\text { Comp USFC } \\
\text { Comp USFC } \\
\text { Comp USFC } \\
\text { Comp USFC }\end{array}$ & $\begin{array}{r}0 \\
10 \\
50 \\
100\end{array}$ & $\begin{array}{l}16.5 \\
16.4 \\
16.3 \\
16.4\end{array}$ & $\begin{array}{l}16.7 \\
16.8 \\
16.8 \\
16.8\end{array}$ & $\begin{array}{l}7.85 \\
7.75 \\
7.99 \\
8.00\end{array}$ & $\begin{array}{l}8.02 \\
8.01 \\
8.14 \\
8.28\end{array}$ & $\begin{array}{l}7.1 \\
6.9 \\
6.9 \\
6.7\end{array}$ & $\begin{array}{l}8.2 \\
8.0 \\
7.8 \\
7.8\end{array}$ & $\begin{array}{l}29.5^{(d)} \\
30.0 \\
29.5 \\
30.0\end{array}$ & $\begin{array}{l}30.0 \\
30.5 \\
31.0 \\
30.5\end{array}$ \\
\hline $\begin{array}{l}\text { Comp IHC-1 } \\
\text { Comp IHC-1 } \\
\text { Comp IHC-1 } \\
\text { Comp IHC-1 }\end{array}$ & $\begin{array}{r}0 \\
10 \\
50 \\
100\end{array}$ & $\begin{array}{l}16.0 \\
16.0 \\
16.0 \\
16.0\end{array}$ & $\begin{array}{l}16.3 \\
16.3 \\
16.4 \\
16.4\end{array}$ & $\begin{array}{l}7.62 \\
7.82 \\
7.85 \\
7.88\end{array}$ & $\begin{array}{l}7.86 \\
7.92 \\
8.09 \\
8.23\end{array}$ & $\begin{array}{l}6.7 \\
6.9 \\
7.0 \\
6.9\end{array}$ & $\begin{array}{l}8.6 \\
8.6 \\
8.3 \\
7.9\end{array}$ & $\begin{array}{l}30.0 \\
30.0 \\
30.0 \\
30.0\end{array}$ & $\begin{array}{l}30.0 \\
30.0 \\
30.0 \\
30.0\end{array}$ \\
\hline $\begin{array}{l}\text { Comp IHC-2 } \\
\text { Comp IHC-2 } \\
\text { Comp IHC-2 } \\
\text { Comp IHC-2 }\end{array}$ & $\begin{array}{r}0 \\
10 \\
50 \\
100\end{array}$ & $\begin{array}{l}15.9 \\
15.9 \\
16.0 \\
16.0\end{array}$ & $\begin{array}{l}16.4 \\
16.4 \\
16.4 \\
16.5\end{array}$ & $\begin{array}{l}7.61 \\
7.55 \\
7.75 \\
7.66\end{array}$ & $\begin{array}{l}7.88 \\
7.93 \\
8.01 \\
8.06\end{array}$ & $\begin{array}{l}6.7 \\
6.0 \\
6.5 \\
6.7\end{array}$ & $\begin{array}{l}8.3 \\
8.3 \\
8.1 \\
7.9\end{array}$ & $\begin{array}{l}30.0 \\
30.0 \\
30.0 \\
30.0\end{array}$ & $\begin{array}{l}30.0 \\
30.0 \\
30.0 \\
30.0\end{array}$ \\
\hline $\begin{array}{l}\text { Comp IHC-3 } \\
\text { Comp IHC-3 } \\
\text { Comp IHC-3 } \\
\text { Comp IHC-3 }\end{array}$ & $\begin{array}{r}0 \\
10 \\
50 \\
100\end{array}$ & $\begin{array}{l}15.7 \\
15.8 \\
15.9 \\
15.9\end{array}$ & $\begin{array}{l}16.4 \\
16.5 \\
16.5 \\
16.4\end{array}$ & $\begin{array}{l}7.73 \\
7.55 \\
7.75 \\
7.76\end{array}$ & $\begin{array}{l}7.90 \\
7.86 \\
8.09 \\
8.28\end{array}$ & $\begin{array}{l}6.9 \\
6.3 \\
6.0 \\
6.7\end{array}$ & $\begin{array}{l}8.4 \\
8.4 \\
8.1 \\
7.7\end{array}$ & $\begin{array}{l}30.0 \\
30.0 \\
30.0 \text { (d) } \\
29.0\end{array}$ & $\begin{array}{l}30.5 \\
30.0 \\
30.0 \\
30.0\end{array}$ \\
\hline
\end{tabular}

\footnotetext{
(a) Acceptable $\mathrm{pH}$ range is based on mean $\mathrm{pH}$ in all test chambers in 10-day test.

(b) Minimum and maximum values are derived from all replicates for each treatment.

(c) Value exceeds acceptable range.

(d) The $96-\mathrm{h}$ test was conducted at a salinity of $30 \pm 2 \%$ instead of the $32 \pm 2 \%$ specified in the Quality Assurance Plan.

(e) UF Unfiltered.

(f) F Filtered.
} 
TABLE H.5. Results for all Replicates in 96-h H. costata Reference Toxicant Tests, United Heckathorn Remedial Investigation

Copper

Concentration $(\mathrm{mg} / \mathrm{L})$
Number

\section{Mean}

Number Proportion Proportion Standard Dead Surviving Surviving Deviation

Test 1: H. costata used for testing Comps LC, LC-5, LC-6, and USFC SPP and Elutriate

$\begin{array}{rrrrrrr}0.00 & 1 & 10 & 0 & 1.00 & & \\ 0.00 & 2 & 9 & 1 & 0.90 & & \\ 0.00 & 3 & 10 & 0 & 1.00 & 0.97 & 0.06 \\ 0.05 & 1 & 7 & 3 & 0.70 & & \\ 0.05 & 2 & 8 & 2 & 0.80 & & \\ 0.05 & 3 & 7 & 3 & 0.70 & 0.73 & 0.06 \\ 0.10 & 1 & 3 & 7 & 0.30 & & \\ 0.10 & 2 & 6 & 4 & 0.60 & & \\ 0.10 & 3 & 5 & 5 & 0.50 & 0.47 & 0.15 \\ 0.20 & 1 & 0 & 10 & 0.00 & & \\ 0.20 & 2 & 0 & 10 & 0.00 & & \\ 0.20 & 3 & 0 & 10 & 0.00 & 0.00 & 0.00 \\ 0.40 & 1 & 0 & 10 & 0.00 & & \\ 0.40 & 2 & 0 & 10 & 0.00 & & \\ 0.40 & 3 & 0 & 10 & 0.00 & 0.00 & 0.00\end{array}$

Test 2: H. costata used for testing Comps FSFC, IHC-1, IHC-2, IHC-3 SPP and Elutriate; Comp LC-5 SPP and Elutriate at Lower Concentrations and Comp LC-5 Elutriate Filtered and Unfiltered

0.00

0.00

0.00

0.05

0.05

0.05

0.10

0.10

0.10

0.20

0.20

0.20

0.40

0.40

0.40

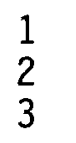

1
2
3

1
2
3

1
2
3

1
2
3
9
10
9

9
8
8

5
7
5

0

0
0

0
0
0

1
0
1

0.90

1.00

0.90

0.93

0.06

1
2
2

0.90

0.80

0.80

0.83

0.06

5
3
5

0.50

0.70

0.50

0.57

0.12

10

10

0.00

0.00

0.00

0.00

0.00

10

10

0.00

10

0.00

0.00

0.00

0.00 
TABLE H.6. Water Quality Summary for $96-\mathrm{h} \mathrm{H}$. costata Reference Toxicant Tests, United Heckathorn Remedial Investigation

\section{Copper}

Concentration

(mq/L)

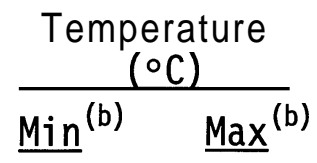

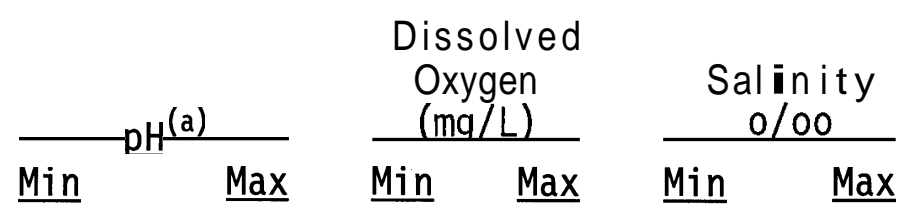

Acceptable

Range

7.32

8.32

4.0

$\mathrm{NA} \quad 30.0 \quad 34.0$

Test 1: H. Costata used for testing Comps LC, LC-5, LC-6, and USFC SPP and Elutriate

$\begin{array}{lllllllll}0.00 & 16.0 & 16.7 & 7.73 & 7.95 & 7.2 & 8.6 & 30.0 & 31.5 \\ 0.05 & 16.1 & 16.6 & 7.71 & 7.99 & 7.2 & 8.2 & 30.0 & 31.5 \\ 0.1 & 16.2 & 16.5 & 7.75 & 8.01 & 7.2 & 8.2 & 30.0 & 31.0 \\ 0.2 & 16.2 & 16.5 & 7.74 & 8.02 & 7.5 & 8.2 & 30.0 & 31.0 \\ 0.4 & 16.2 & 16.5 & 7.74 & 8.04 & 7.7 & 8.2 & 30.0 & 30.5\end{array}$

Test 2: H. costata used for testing Comps FSFC, IHC-1, IHC-2, IHC-3 SPP and Elutriate; Comp LC-5 SPP and Elutriate at Lower Concentrations and Comp LC-5 Elutriate Filtered and Unfiltered

$\begin{array}{lllllllll}0.00 & 16.1 & 16.5 & 7.44 & 7.82 & 6.2 & 8.2 & 30.5 & 31.0 \\ 0.05 & 16.0 & 16.4 & 7.54 & 7.83 & 6.6 & 8.3 & 30.5 & 31.0 \\ 0.1 & 16.1 & 16.5 & 7.66 & 7.95 & 7.1 & 8.2 & 30.5 & 31.0 \\ 0.2 & 16.2 & 16.6 & 7.77 & 7.96 & 7.2 & 8.3 & 30.0 & 31.0 \\ 0.4 & 16.3 & 16.6 & 7.80 & 7.89 & 7.8 & 8.2 & 30.0 & 31.0\end{array}$

(a) Acceptable $\mathrm{pH}$ range is based on mean $\mathrm{pH}$ in all test chambers in $96-\mathrm{h}$ test.

(b) Minimum and maximum values are derived from al1 replicates for each concentration. 


\section{APPENDIX I}

BIOASSAY RESULTS FOR 48-HOUR SUSPENDED-PARTICULATE-PHASE TEST AND 48-HOUR REFERENCE TOXICANT TEST FOR Mytilus galloprovincialis 
TABLE I.1. Results for all Replicates in 48-h M. galloprovincial is Suspended-Particulate-Phase Test, United Heckathorn Remedial Investigation

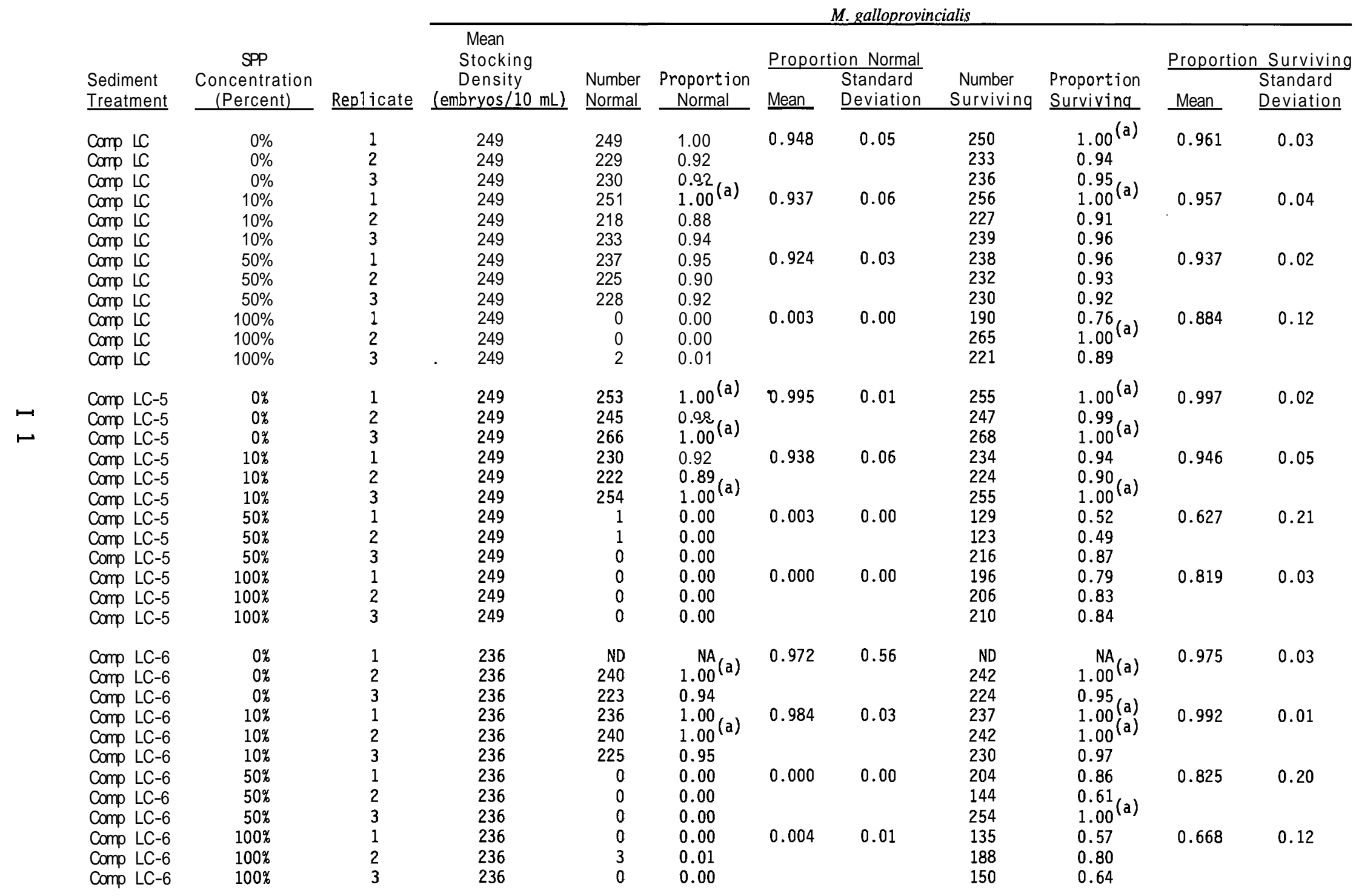


TABLE 1.1. (contd)

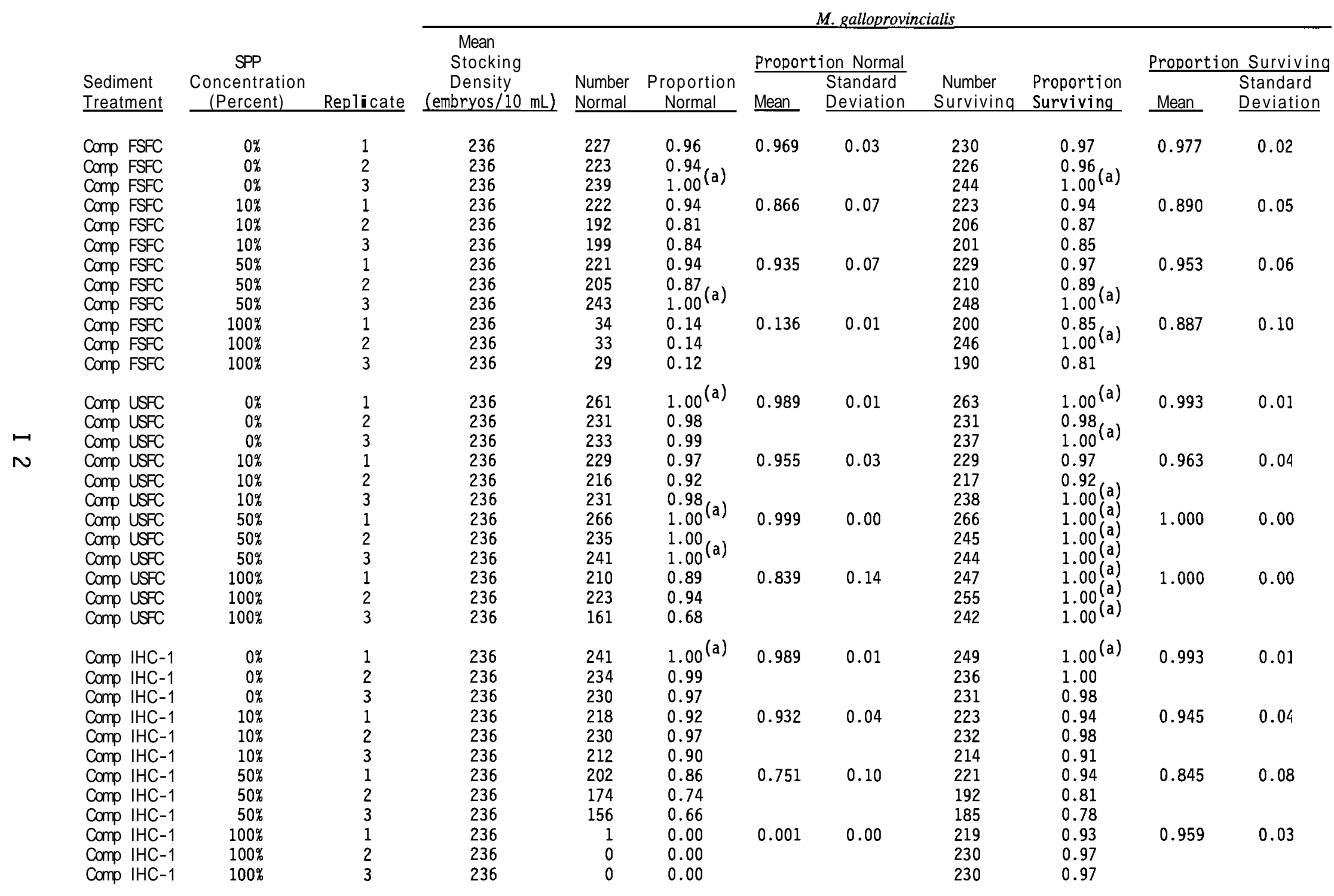


TABLE 1.1. (contd)

\begin{tabular}{|c|c|c|c|c|c|c|c|c|c|c|c|}
\hline \multirow[b]{3}{*}{$\begin{array}{l}\text { Sediment } \\
\text { Treatment } \\
\end{array}$} & \multirow{3}{*}{$\begin{array}{c}\text { SPP } \\
\begin{array}{c}\text { Concentration } \\
\text { (Percent) }\end{array} \\
\end{array}$} & \multirow[b]{3}{*}{ Replicate } & \multicolumn{9}{|c|}{ M. galloprovincialis } \\
\hline & & & $\begin{array}{l}\text { Mean } \\
\text { Stocking }\end{array}$ & & & \multicolumn{2}{|c|}{ Proportion Normal } & \multirow[b]{2}{*}{$\begin{array}{l}\text { Number } \\
\text { Surviving }\end{array}$} & \multirow[b]{2}{*}{$\begin{array}{l}\text { Proportion } \\
\text { Surviving }\end{array}$} & \multicolumn{2}{|c|}{ Proportion Surviving } \\
\hline & & & $\begin{array}{c}\text { Density } \\
\text { (embryos } / 10 \mathrm{~mL} \text { ) } \\
\end{array}$ & $\begin{array}{l}\text { Number } \\
\text { Normal } \\
\end{array}$ & $\begin{array}{c}\text { Proportion } \\
\text { Normal } \\
\end{array}$ & Mean & $\begin{array}{l}\text { Standard } \\
\text { Deviation }\end{array}$ & & & Mean & $\begin{array}{l}\text { Standard } \\
\text { Deviation }\end{array}$ \\
\hline Comp IHC-2 & $0 \%$ & 1 & 279 & 298 & $1.00(\mathrm{a})$ & 0.975 & 0.04 & 301 & $1.00^{(a)}$ & 0.980 & 0.04 \\
\hline Comp IHC-2 & $0 \%$ & 2 & 279 & 293 & $1.00^{(a)}$ & & & 297 & $1.00^{(\mathrm{a})}$ & & \\
\hline Comp IHC-2 & $0 \%$ & 3 & 279 & 258 & 0.92 & & & 262 & 0.94 & & \\
\hline Comp IHC-2 & $10 \%$ & 1 & 279 & 220 & 0.79 & 0.901 & 0.11 & 223 & 0.80 & 0.909 & 0.10 \\
\hline Comp IHC-2 & $10 \%$ & 2 & 279 & 255 & 0.91 & & & 259 & 0.93 & & \\
\hline Comp IHC-2 & $10 \%$ & 3 & 279 & 288 & $1.00^{(\mathrm{a})}$ & & & 294 & $1.00^{(\mathrm{a})}$ & & \\
\hline Comp IHC-2 & $50 \%$ & 1 & 279 & 239 & 0.86 & 0.805 & 0.13 & 258 & 0.92 & 0.841 & 0.14 \\
\hline Comp IHC-2 & $50 \%$ & 2 & 279 & 184 & 0.66 & & & 191 & 0.68 & & \\
\hline Comp IHC-2 & $50 \%$ & 3 & 279 & 251 & 0.90 & & & 255 & 0.91 & & \\
\hline Comp IHC-2 & $100 \%$ & 1 & 279 & 0 & 0.00 & 0.002 & 0.00 & 253 & 0.91 & 0.940 & 0.05 \\
\hline Comp IHC-2 & $100 \%$ & 2 & 279 & 0 & 0.00 & & & 283 & $1.00^{(a)}$ & & \\
\hline Comp IHC-2 & $100 \%$ & 3 & 279 & 2 & 0.01 & & & 255 & 0.91 & & \\
\hline Comp IHC-3 & $0 \%$ & 1 & 279 & 271 & $0.97(a)$ & 0.940 & 0.08 & 274 & 0.98 & 0.953 & 0.07 \\
\hline Comp IHC-3 & $0 \%$ & 2 & 279 & 298 & $1.00^{(a)}$ & & & 299 & $1.00^{(a)}$ & & \\
\hline Comp IHC-3 & $0 \%$ & 3 & 279 & 237 & 0.85 & & & 245 & 0.88 & & \\
\hline Comp IHC-3 & $10 \%$ & 1 & 279 & 336 & $1.00^{(a)}$ & 0.908 & 0.11 & 342 & $1.00^{(a)}$ & 0.919 & 0.11 \\
\hline Comp IHC-3 & $10 \%$ & 2 & 279 & 263 & 0.94 & & & 269 & 0.96 & & \\
\hline Comp IHC-3 & $10 \%$ & 3 & 279 & 218 & 0.78 & & & 221 & 0.79 & & \\
\hline Comp IHC-3 & $50 \%$ & 1 & 279 & 0 & 0.00 & 0.001 & 0.00 & 288 & $1.00^{(a)}$ & 0.953 & 0.07 \\
\hline Comp IHC-3 & $50 \%$ & 2 & 279 & 0 & 0.00 & & & 276 & 0.99 & & \\
\hline Comp IHC-3 & $50 \%$ & 3 & 279 & 1 & 0.00 & & & 243 & 0.87 & & \\
\hline Comp IHC-3 & $100 \%$ & 1 & 279 & 0 & 0.00 & 0.000 & 0.00 & 200 & 0.72 & 0.849 & 0.12 \\
\hline Comp IHC-3 & $100 \%$ & 2 & 279 & 0 & 0.00 & & & 261 & 0.94 & & \\
\hline Comp IHC-3 & $100 \%$ & 3 & 279 & 0 & 0.00 & & & 250 & 0.90 & & \\
\hline
\end{tabular}

(a) When number normal or number surviving exceeded the stocking density, a proportion normal and/or proportion survival of 1.00 was used for mean calculations and statistical analysis. 
TABLE I.2. Water Qualit y Summary for 48-h M. galloprovincial is Suspended-Particulate-Phase Test, United Heckathorn Remedial Investigation

\begin{tabular}{|c|c|c|c|c|c|c|c|c|c|}
\hline \multirow[t]{2}{*}{$\begin{array}{l}\text { Sediment } \\
\text { Treatment } \\
\end{array}$} & \multirow[t]{2}{*}{$\begin{array}{c}\text { SPP } \\
\text { Concentration } \\
\text { (Percent) }\end{array}$} & \multicolumn{2}{|c|}{$\begin{array}{c}\text { Temperature } \\
\left({ }^{\circ} \mathrm{C}\right) \\
\end{array}$} & \multicolumn{2}{|c|}{$\mathrm{pH}$} & \multicolumn{2}{|c|}{$\begin{array}{c}\text { Dissolved } \\
\text { Oxygen } \\
\text { (mg/L) } \\
\end{array}$} & \multicolumn{2}{|c|}{$\begin{array}{c}\text { Salinity } \\
(0 / 00)\end{array}$} \\
\hline & & $\underline{\operatorname{Min}}^{(b)}$ & $\underline{\operatorname{Max}}{ }^{(b)}$ & Min & Max & Min & Max & $\underline{\text { Min }}$ & Max \\
\hline Acceptable & nge & 14.0 & 18.0 & 7.63 & 8.63 & 4.0 & NA & 28.0 & 32.0 \\
\hline $\begin{array}{l}\text { Comp LC } \\
\text { Comp LC } \\
\text { Comp LC } \\
\text { Comp LC }\end{array}$ & $\begin{array}{r}0 \\
10 \\
50 \\
100\end{array}$ & $\begin{array}{l}15.7 \\
15.8 \\
15.8 \\
15.8\end{array}$ & $\begin{array}{l}16.0 \\
16.0 \\
16.0 \\
16.0\end{array}$ & $\begin{array}{l}8.03 \\
8.04 \\
8.14 \\
8.23\end{array}$ & $\begin{array}{l}8.07 \\
8.09 \\
8.28 \\
8.46\end{array}$ & $\begin{array}{l}7.5 \\
7.5 \\
7.6 \\
7.5\end{array}$ & $\begin{array}{l}7.9 \\
7.9 \\
7.9 \\
7.9\end{array}$ & $\begin{array}{l}29.5 \\
29.0 \\
29.5 \\
29.5\end{array}$ & $\begin{array}{l}30.0 \\
30.5 \\
30.5 \\
31.0\end{array}$ \\
\hline $\begin{array}{l}\text { Comp LC-5 } \\
\text { Comp LC-5 } \\
\text { Comp LC-5 } \\
\text { Comp LC-5 }\end{array}$ & $\begin{array}{r}0 \\
10 \\
50 \\
100\end{array}$ & $\begin{array}{l}15.8 \\
15.8 \\
15.7 \\
15.8\end{array}$ & $\begin{array}{l}16.0 \\
16.1 \\
16.0 \\
16.1\end{array}$ & $\begin{array}{l}7.97 \\
8.04 \\
8.08 \\
8.14\end{array}$ & $\begin{array}{l}8.12 \\
8.11 \\
8.58 \\
8.97(c)\end{array}$ & $\begin{array}{l}7.5 \\
7.4 \\
7.5 \\
7.5\end{array}$ & $\begin{array}{l}7.9 \\
8.0 \\
7.9 \\
7.9\end{array}$ & $\begin{array}{l}29.0 \\
29.5 \\
29.0 \\
29.5\end{array}$ & $\begin{array}{l}30.0 \\
30.0 \\
30.0 \\
30.5\end{array}$ \\
\hline $\begin{array}{l}\text { Comp LC-6 } \\
\text { Comp LC-6 } \\
\text { Comp LC-6 } \\
\text { Comp LC-6 }\end{array}$ & $\begin{array}{r}0 \\
10 \\
50 \\
100\end{array}$ & $\begin{array}{l}16.2 \\
16.2 \\
16.2 \\
16.2\end{array}$ & $\begin{array}{l}16.4 \\
16.4 \\
16.4 \\
16.4 \\
\end{array}$ & $\begin{array}{l}7.88 \\
7.99 \\
8.04 \\
8.12\end{array}$ & $\begin{array}{l}8.08 \\
8.10 \\
8.41(c) \\
8.74\end{array}$ & $\begin{array}{l}7.4 \\
7.6 \\
7.4 \\
7.3\end{array}$ & $\begin{array}{l}8.0 \\
8.3 \\
8.2 \\
8.1\end{array}$ & $\begin{array}{l}30.0 \\
29.5 \\
29.0 \\
28.5\end{array}$ & $\begin{array}{l}30.0 \\
30.0 \\
30.0 \\
30.0\end{array}$ \\
\hline $\begin{array}{l}\text { Comp USFC } \\
\text { Comp USFC } \\
\text { Comp USFC } \\
\text { Comp USFC }\end{array}$ & $\begin{array}{r}0 \\
10 \\
50 \\
100\end{array}$ & $\begin{array}{l}16.2 \\
16.2 \\
16.2 \\
16.2\end{array}$ & $\begin{array}{l}16.3 \\
16.3 \\
16.4 \\
16.3\end{array}$ & $\begin{array}{l}7.95 \\
7.93 \\
8.12 \\
8.20\end{array}$ & $\begin{array}{l}8.06 \\
8.06 \\
8.16 \\
8.27\end{array}$ & $\begin{array}{l}7.5 \\
7.5 \\
7.4 \\
7.2\end{array}$ & $\begin{array}{l}8.2 \\
8.2 \\
8.1 \\
8.3\end{array}$ & $\begin{array}{l}30.0 \\
30.0 \\
30.0 \\
30.0\end{array}$ & $\begin{array}{l}30.0 \\
30.0 \\
30.5 \\
31.0\end{array}$ \\
\hline $\begin{array}{ll}\text { Comp } & \text { FSFC } \\
\text { Comp } & \text { FSFC } \\
\text { Comp } & \text { FSFC } \\
\text { Comp } & \text { FSFC }\end{array}$ & $\begin{array}{r}0 \\
10 \\
50 \\
100\end{array}$ & $\begin{array}{l}15.5 \\
15.5 \\
15.5 \\
15.6\end{array}$ & $\begin{array}{l}15.8 \\
15.8 \\
15.9 \\
15.8\end{array}$ & $\begin{array}{l}7.95 \\
7.93 \\
8.05 \\
8.16\end{array}$ & $\begin{array}{l}8.05 \\
8.15 \\
8.23 \\
8.33\end{array}$ & $\begin{array}{l}7.5 \\
7.5 \\
7.6 \\
7.4\end{array}$ & $\begin{array}{l}8.1 \\
8.2 \\
8.2 \\
8.4\end{array}$ & $\begin{array}{l}30.0 \\
30.0 \\
30.0 \\
30.0\end{array}$ & $\begin{array}{l}30.0 \\
30.0 \\
30.0 \\
30.0\end{array}$ \\
\hline $\begin{array}{ll}\text { Comp } & \text { HHC- } 1 \\
\text { Comp IHC-1 } \\
\text { Comp IHC-1 } \\
\text { Comp IHC-1 }\end{array}$ & $\begin{array}{r}0 \\
10 \\
50 \\
100\end{array}$ & $\begin{array}{l}15.6 \\
15.5 \\
15.5 \\
15.6\end{array}$ & $\begin{array}{l}15.8 \\
15.8 \\
15.8 \\
15.8\end{array}$ & $\begin{array}{l}7.96 \\
7.80 \\
7.91 \\
7.96\end{array}$ & $\begin{array}{l}8.13 \\
8.16 \\
8.29 \\
8.44\end{array}$ & $\begin{array}{l}7.5 \\
7.6 \\
7.6 \\
7.6\end{array}$ & $\begin{array}{l}8.3 \\
8.3 \\
8.3 \\
8.1\end{array}$ & $\begin{array}{l}30.0 \\
30.0 \\
30.0 \\
30.0\end{array}$ & $\begin{array}{l}30.0 \\
30.0 \\
30.0 \\
30.0\end{array}$ \\
\hline $\begin{array}{ll}\text { Comp } & \text { IHC-2 } \\
\text { Comp } & \text { IHC-2 } \\
\text { Comp } & \text { HC-2 } \\
\text { Comp } & \text { IHC-2 }\end{array}$ & $\begin{array}{r}0 \\
10 \\
50 \\
100\end{array}$ & $\begin{array}{l}16.1 \\
16.1 \\
16.1 \\
16.1\end{array}$ & $\begin{array}{l}16.2 \\
16.2 \\
16.2 \\
16.2\end{array}$ & $\begin{array}{l}7.96 \\
7.96 \\
7.85 \\
7.69\end{array}$ & $\begin{array}{l}8.09 \\
8.11 \\
8.25 \\
8.38\end{array}$ & $\begin{array}{l}7.6 \\
7.7 \\
7.7 \\
7.1 \\
7.1\end{array}$ & $\begin{array}{l}7.9 \\
8.0 \\
8.0 \\
8.0\end{array}$ & $\begin{array}{l}30.0 \\
30.0 \\
30.0 \\
30.0\end{array}$ & $\begin{array}{l}30.0 \\
30.0 \\
30.0 \\
30.0\end{array}$ \\
\hline $\begin{array}{ll}\text { Comp IHC-3 } \\
\text { Comp IHC-3 } \\
\text { Comp IHC-3 } \\
\text { Comp IHC-3 }\end{array}$ & $\begin{array}{r}0 \\
10 \\
50 \\
100\end{array}$ & $\begin{array}{l}16.1 \\
16.1 \\
16.1 \\
16.1\end{array}$ & $\begin{array}{l}16.2 \\
16.3 \\
16.2 \\
16.3 \\
\end{array}$ & $\begin{array}{l}7.95 \\
7.93 \\
7.90 \\
7.77 \\
\end{array}$ & $\begin{array}{l}8.07 \\
8.15 \\
8.34 \\
8.48\end{array}$ & $\begin{array}{l}7.6 \\
7.5 \\
7.7 \\
7.0\end{array}$ & $\begin{array}{l}8.3 \\
8.0 \\
8.0 \\
8.1\end{array}$ & $\begin{array}{l}30.0 \\
30.0 \\
30.0 \\
30.0\end{array}$ & $\begin{array}{l}30.5 \\
30.5 \\
30.0 \\
30.0\end{array}$ \\
\hline
\end{tabular}

(a) Acceptable $\mathrm{pH}$ range is based on mean $\mathrm{pH}$ in all test chambers in 48-h test.

(b) Minimum and maximum values are derived from all replicates for each treatment.

(c) Value exceeds acceptable range. 
TABLE 1.3. Results for a11 Replicates in 48-h M. galloprovincialis Elutriate Test, United Heckathorn Remedial Investigation

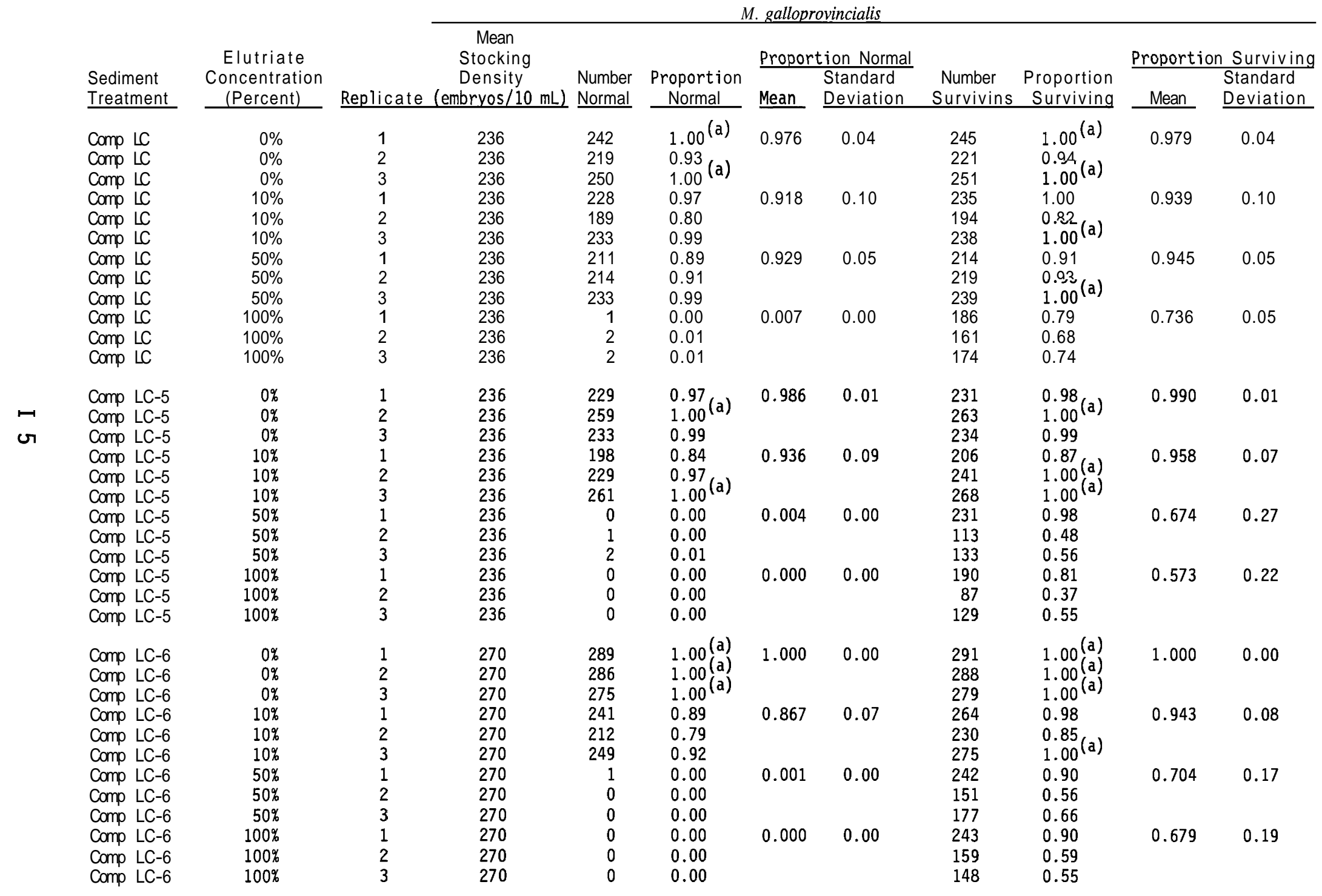


TABLE 1.3. (contd)

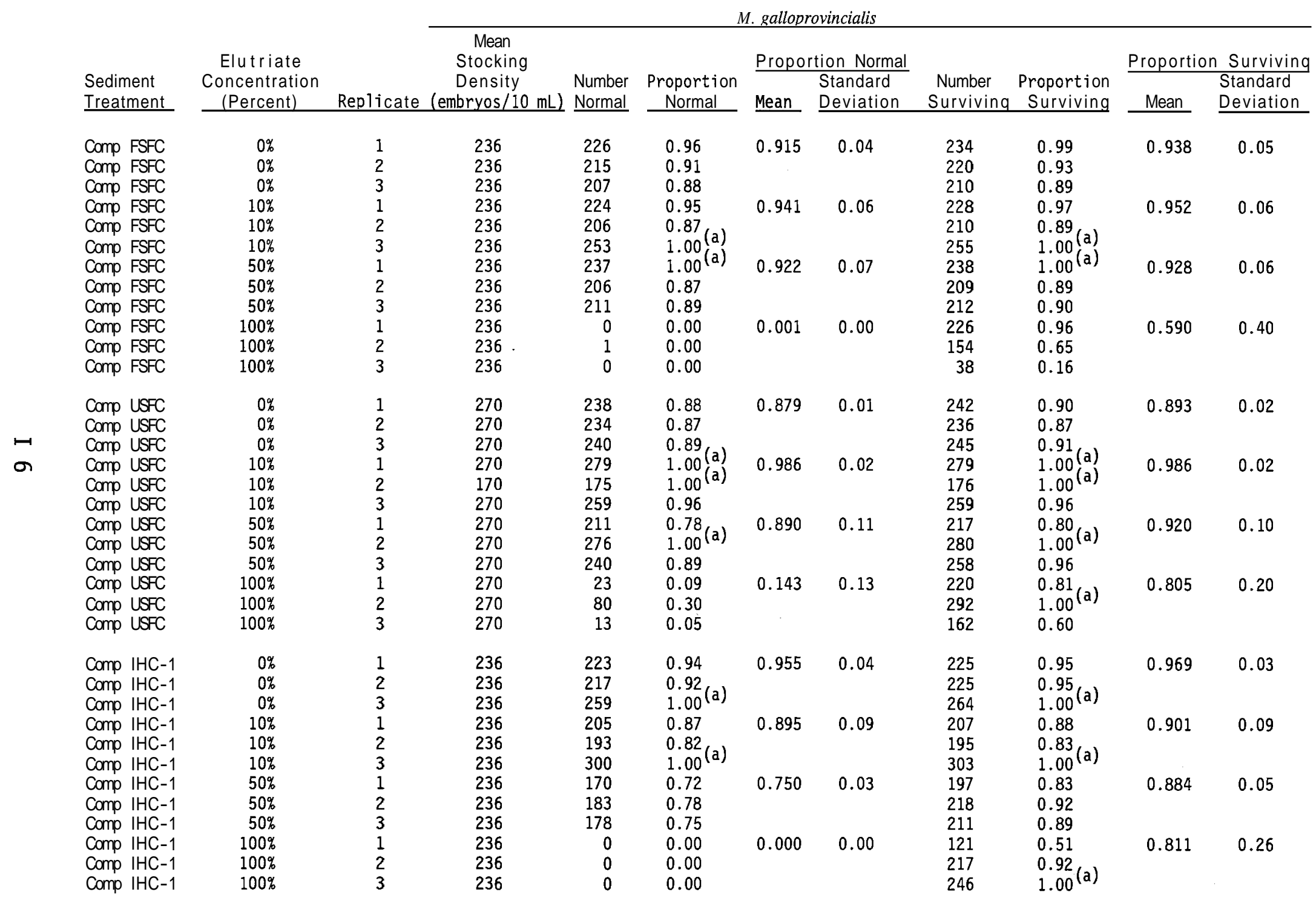


TABLE I. 3. (contd)

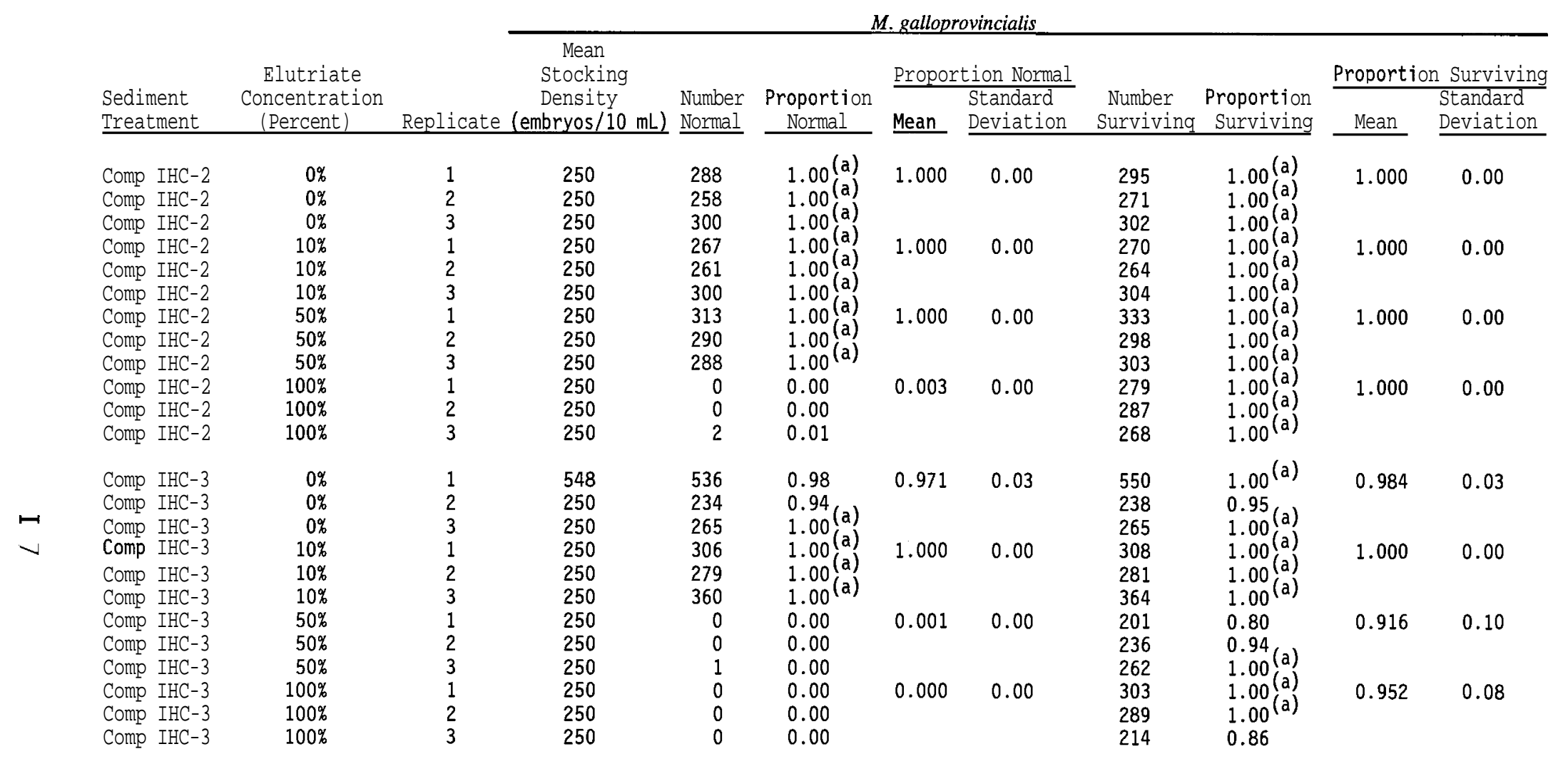

(a) When number normal or number surviving exceeded the stocking density, a proportion normal and/or proportion survival of 1.00 was used for mean calculations and statistical analysis. 
TABLE 1.4. Water Quality Summary for 48-h M. galloprovincialis Elutriate Test, United Heckathorn Remedial Investigation

\begin{tabular}{|c|c|c|c|c|c|c|c|c|c|}
\hline \multirow[t]{2}{*}{$\begin{array}{l}\text { Sediment } \\
\text { Treatment } \\
\end{array}$} & \multirow[t]{2}{*}{$\begin{array}{c}\text { Elutriate } \\
\text { Concentration } \\
\text { (Percent) }\end{array}$} & \multicolumn{2}{|c|}{$\begin{array}{c}\text { Temperature } \\
\left({ }^{\circ} \mathrm{C}\right)\end{array}$} & \multicolumn{2}{|c|}{$\mathrm{pH}(\mathrm{a})$} & \multicolumn{2}{|c|}{$\begin{array}{l}\text { Dissolved } \\
\text { Oxygen } \\
(\mathrm{mg} / \mathrm{L}) \\
\end{array}$} & \multicolumn{2}{|c|}{$\begin{array}{c}\text { Salinity } \\
(0 / 00)\end{array}$} \\
\hline & & $\operatorname{Min}(b)$ & $\operatorname{Max}(b)$ & $\operatorname{Min}$ & Max & Min & Max & $\underline{\text { Min }}$ & $\underline{\text { Max }}$ \\
\hline Acceptable Range & & 14.0 & 18.0 & 7.63 & 8.63 & 4.0 & NA & 28.0 & 32.0 \\
\hline $\begin{array}{l}\text { Comp LC } \\
\text { Comp LC } \\
\text { Comp LC } \\
\text { Comp LC }\end{array}$ & $\begin{array}{r}0 \\
10 \\
50 \\
100\end{array}$ & $\begin{array}{l}15.8 \\
15.8 \\
15.8 \\
15.8\end{array}$ & $\begin{array}{l}16.0 \\
16.1 \\
16.0 \\
16.0\end{array}$ & $\begin{array}{l}8.03 \\
8.00 \\
8.13 \\
8.21\end{array}$ & $\begin{array}{l}8.08 \\
8.09 \\
8.29 \\
8.45\end{array}$ & $\begin{array}{l}7.6 \\
7.5 \\
7.6 \\
7.6\end{array}$ & $\begin{array}{l}8.0 \\
8.5 \\
8.0 \\
7.9\end{array}$ & $\begin{array}{l}28.5 \\
28.5 \\
29.0 \\
29.5\end{array}$ & $\begin{array}{l}30.0 \\
30.5 \\
30.5 \\
30.0\end{array}$ \\
\hline $\begin{array}{l}\text { Comp LC-5 } \\
\text { Comp LC-5 } \\
\text { Comp LC-5 } \\
\text { Comp LC-5 }\end{array}$ & $\begin{array}{r}0 \\
10 \\
50 \\
100\end{array}$ & $\begin{array}{l}15.8 \\
15.8 \\
15.8 \\
15.8\end{array}$ & $\begin{array}{l}16.0 \\
16.0 \\
16.0 \\
16.0\end{array}$ & $\begin{array}{l}8.02 \\
8.03 \\
8.08 \\
8.06\end{array}$ & $\begin{array}{l}8.09 \\
8.12 \\
8.53 \\
8.94\end{array}$ & $\begin{array}{l}7.6 \\
7.6 \\
7.6 \\
7.5 \\
\end{array}$ & $\begin{array}{l}7.9 \\
7.8 \\
7.9 \\
7.8\end{array}$ & $\begin{array}{l}29.0 \\
29.0 \\
29.0 \\
29.0\end{array}$ & $\begin{array}{l}30.0 \\
30.0 \\
30.5 \\
30.5\end{array}$ \\
\hline $\begin{array}{l}\text { Comp LC-6 } \\
\text { Comp LC-6 } \\
\text { Comp LC-6 } \\
\text { Comp LC-6 }\end{array}$ & $\begin{array}{r}0 \\
10 \\
50 \\
100\end{array}$ & $\begin{array}{l}16.2 \\
16.2 \\
16.3 \\
16.2\end{array}$ & $\begin{array}{l}16.3 \\
16.4 \\
16.4 \\
16.4\end{array}$ & $\begin{array}{l}7.77 \\
8.02 \\
8.07 \\
8.12\end{array}$ & $\begin{array}{l}8.06 \\
8.09 \\
8.39 \\
8.73\end{array}$ & $\begin{array}{l}7.4 \\
7.5 \\
7.4 \\
7.5\end{array}$ & $\begin{array}{l}8.1 \\
8.1 \\
8.2 \\
8.1\end{array}$ & $\begin{array}{l}30.0 \\
30.0 \\
29.5 \\
29.0\end{array}$ & $\begin{array}{l}30.5 \\
30.5 \\
30.0 \\
30.5\end{array}$ \\
\hline $\begin{array}{l}\text { Comp USFC } \\
\text { Comp USFC } \\
\text { Comp USFC } \\
\text { Comp USFC }\end{array}$ & $\begin{array}{r}0 \\
10 \\
50 \\
100\end{array}$ & $\begin{array}{l}16.2 \\
16.2 \\
16.2 \\
16.3\end{array}$ & $\begin{array}{l}16.4 \\
16.4 \\
16.3 \\
16.3\end{array}$ & $\begin{array}{l}8.00 \\
8.02 \\
8.11 \\
8.23\end{array}$ & $\begin{array}{l}8.05 \\
8.10 \\
8.21 \\
8.34\end{array}$ & $\begin{array}{l}7.4 \\
7.5 \\
7.5 \\
7.5\end{array}$ & $\begin{array}{l}7.9 \\
7.9 \\
8.4 \\
8.1\end{array}$ & $\begin{array}{l}30.0 \\
30.0 \\
30.0 \\
30.0\end{array}$ & $\begin{array}{l}30.5 \\
30.5 \\
30.5 \\
30.5\end{array}$ \\
\hline $\begin{array}{ll}\text { Comp } & \text { FSFC } \\
\text { Comp } & \text { FSFC } \\
\text { Comp } & \text { FSFC } \\
\text { Comp } & \text { FSFC }\end{array}$ & $\begin{array}{r}0 \\
10 \\
50 \\
100\end{array}$ & $\begin{array}{l}15.6 \\
15.6 \\
15.5 \\
15.5\end{array}$ & $\begin{array}{l}15.8 \\
15.8 \\
15.8 \\
15.8 \\
\end{array}$ & $\begin{array}{l}7.94 \\
7.96 \\
8.04 \\
8.10\end{array}$ & $\begin{array}{l}8.10 \\
8.13 \\
8.24 \\
8.35\end{array}$ & $\begin{array}{l}7.6 \\
7.8 \\
7.3 \\
7.5\end{array}$ & $\begin{array}{l}8.2 \\
8.2 \\
8.2 \\
8.2\end{array}$ & $\begin{array}{l}30.0 \\
30.0 \\
30.0 \\
30.0\end{array}$ & $\begin{array}{l}30.0 \\
30.0 \\
30.0 \\
30.0\end{array}$ \\
\hline $\begin{array}{ll}\text { Comp IHC-1 } & \text { IHC-1 } \\
\text { Comp IHC-1 } \\
\text { Comp IHC-1 } \\
\text { Comp IHC-1 }\end{array}$ & $\begin{array}{r}0 \\
10 \\
50 \\
100\end{array}$ & $\begin{array}{l}15.6 \\
15.6 \\
15.6 \\
15.6\end{array}$ & $\begin{array}{l}15.7 \\
15.8 \\
15.8 \\
15.8\end{array}$ & $\begin{array}{l}7.80 \\
7.94 \\
7.96 \\
7.96\end{array}$ & $\begin{array}{l}8.06 \\
8.09 \\
8.25 \\
8.37\end{array}$ & $\begin{array}{l}7.6 \\
7.5 \\
7.5 \\
7.4\end{array}$ & $\begin{array}{l}8.2 \\
8.2 \\
8.4 \\
8.2\end{array}$ & $\begin{array}{l}29.5 \\
29.5 \\
29.5 \\
29.5\end{array}$ & $\begin{array}{l}30.0 \\
30.0 \\
30.0 \\
30.0\end{array}$ \\
\hline $\begin{array}{ll}\text { Comp } & \text { IHC-2 } \\
\text { Comp } & \text { IHC-2 } \\
\text { Comp } & \text { IHC-2 } \\
\text { Comp } & \text { IHC-2 }\end{array}$ & $\begin{array}{r}0 \\
10 \\
50 \\
100\end{array}$ & $\begin{array}{l}16.1 \\
16.1 \\
16.1 \\
16.1\end{array}$ & $\begin{array}{l}16.3 \\
16.3 \\
16.2 \\
16.3 \\
\end{array}$ & $\begin{array}{l}7.99 \\
7.97 \\
7.87 \\
7.91\end{array}$ & $\begin{array}{l}8.10 \\
8.15 \\
8.26 \\
8.40\end{array}$ & $\begin{array}{l}7.8 \\
7.7 \\
7.7 \\
7.7\end{array}$ & $\begin{array}{l}8.4 \\
8.2 \\
8.2 \\
8.1\end{array}$ & $\begin{array}{l}30.0 \\
30.0 \\
30.0 \\
30.0\end{array}$ & $\begin{array}{l}30.0 \\
30.0 \\
30.0 \\
30.0\end{array}$ \\
\hline $\begin{array}{l}\text { Comp IHC-3 } \\
\text { Comp IHC-3 } \\
\text { Comp IHC-3 } \\
\text { Comp IHC-3 }\end{array}$ & $\begin{array}{r}0 \\
10 \\
50 \\
100\end{array}$ & $\begin{array}{l}16.1 \\
16.1 \\
16.1 \\
16.1\end{array}$ & $\begin{array}{l}16.3 \\
16.3 \\
16.2 \\
16.3\end{array}$ & $\begin{array}{l}7.94 \\
7.97 \\
7.94 \\
7.91\end{array}$ & $\begin{array}{l}8.09 \\
8.17 \\
8.35 \\
8.48\end{array}$ & $\begin{array}{l}7.7 \\
7.6 \\
7.7 \\
7.6\end{array}$ & $\begin{array}{l}8.2 \\
8.1 \\
8.1 \\
8.1\end{array}$ & $\begin{array}{l}30.0 \\
30.0 \\
30.0 \\
30.0\end{array}$ & $\begin{array}{l}30.0 \\
30.0 \\
30.0 \\
30.0\end{array}$ \\
\hline
\end{tabular}

(a) Aceptable $\mathrm{pH}$ range is based on mean $\mathrm{pH}$ in all test chambers in 48 -h test.

(b) Minimum and maximum values are derived from all replicates for each concentration. 
TABLE 1.5. Results for al1 Replicates in 48-h M. galloprovincialis Reference Toxicant Test, United Heckathorn Remedial Investigation

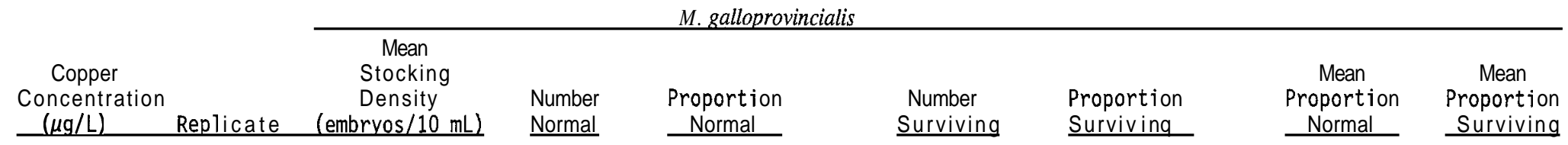

Batch 1: Organisms for Comp LC and Comp LC-5, SPP and Elutriate Testing

\begin{tabular}{|c|c|c|c|c|c|c|c|c|}
\hline $\begin{array}{l}0 \\
0 \\
0\end{array}$ & $\begin{array}{l}1 \\
2 \\
3\end{array}$ & $\begin{array}{l}249 \\
249 \\
249\end{array}$ & $\begin{array}{l}248 \\
268 \\
263\end{array}$ & $\begin{array}{l}1.00 \\
1.00(a) \\
1.00\end{array}$ & $\begin{array}{l}251 \\
278 \\
267\end{array}$ & $\begin{array}{l}1.00 \text { (a) } \\
1.00 \text { (a) } \\
1.00 \text { (a) }\end{array}$ & 1.00 & 1.00 \\
\hline $\begin{array}{l}1 \\
1 \\
1\end{array}$ & $\begin{array}{l}1 \\
2 \\
3\end{array}$ & $\begin{array}{l}249 \\
249 \\
249\end{array}$ & $\begin{array}{l}236 \\
244 \\
228\end{array}$ & $\begin{array}{l}0.95 \\
0.98 \\
0.92\end{array}$ & $\begin{array}{l}237 \\
244 \\
232\end{array}$ & $\begin{array}{l}0.95 \\
0.98 \\
0.93\end{array}$ & 0.95 & 0.95 \\
\hline $\begin{array}{l}4 \\
4 \\
4\end{array}$ & $\begin{array}{l}1 \\
2 \\
3\end{array}$ & $\begin{array}{l}249 \\
249 \\
249\end{array}$ & $\begin{array}{l}261 \\
237 \\
250\end{array}$ & $\begin{array}{l}1.00^{(\mathrm{a})} \\
0.95^{(1.00}\end{array}$ & $\begin{array}{l}267 \\
239 \\
254\end{array}$ & $\begin{array}{l}1.00(a) \\
0.96 \\
1.00\end{array}$ & 0.99 & 0.99 \\
\hline $\begin{array}{l}16 \\
16 \\
16\end{array}$ & $\begin{array}{l}1 \\
2 \\
3\end{array}$ & $\begin{array}{l}249 \\
249 \\
249\end{array}$ & $\begin{array}{l}0 \\
0 \\
0\end{array}$ & $\begin{array}{l}0.00 \\
0.00 \\
0.00\end{array}$ & $\begin{array}{l}98 \\
50 \\
34\end{array}$ & $\begin{array}{l}0.39 \\
0.20 \\
0.14\end{array}$ & 0.00 & 0.24 \\
\hline $\begin{array}{l}64 \\
64 \\
64\end{array}$ & $\begin{array}{l}1 \\
2 \\
3\end{array}$ & $\begin{array}{l}249 \\
249 \\
249\end{array}$ & $\begin{array}{l}0 \\
0 \\
0\end{array}$ & $\begin{array}{l}0.00 \\
0.00 \\
0.00\end{array}$ & $\begin{array}{r}0 \\
10 \\
14\end{array}$ & $\begin{array}{l}0.00 \\
0.04 \\
0.06\end{array}$ & 0.00 & 0.03 \\
\hline $\begin{array}{l}256 \\
256 \\
256\end{array}$ & $\begin{array}{l}1 \\
2 \\
3\end{array}$ & $\begin{array}{l}249 \\
249 \\
249\end{array}$ & $\begin{array}{l}0 \\
0 \\
0\end{array}$ & $\begin{array}{l}0.00 \\
0.00 \\
0.00\end{array}$ & $\begin{array}{l}0 \\
0 \\
0\end{array}$ & $\begin{array}{l}0.00 \\
0.00 \\
0.00\end{array}$ & 0.00 & 0.00 \\
\hline $\begin{array}{l}\text { Brine } \\
\text { Brine } \\
\text { Brine }\end{array}$ & $\begin{array}{l}1 \\
2 \\
3\end{array}$ & $\begin{array}{l}249 \\
249 \\
249\end{array}$ & $\begin{array}{l}317 \\
287 \\
278\end{array}$ & $\begin{array}{l}1.00(\mathrm{a}) \\
1.00(\mathrm{a}) \\
1.00^{(\mathrm{a})}\end{array}$ & $\begin{array}{l}324 \\
290 \\
281\end{array}$ & $\begin{array}{l}1.00(\mathrm{a}) \\
1.00(\mathrm{a}) \\
1.00^{(\mathrm{a})}\end{array}$ & 1.00 & 1.00 \\
\hline
\end{tabular}


TABLE I.5. (contd)

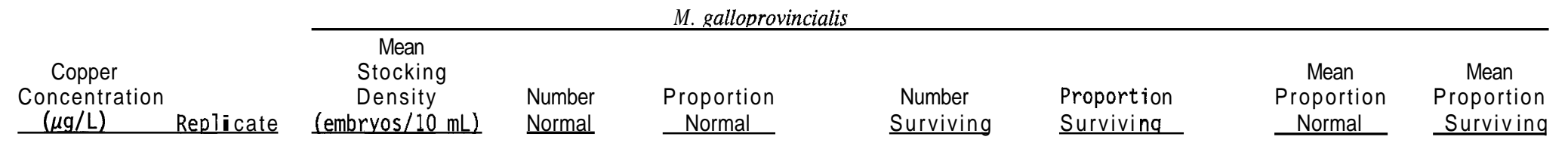

Batch 2: Organisms for Comp LC-6 and Comp USFC, SPP and Elutriate Testing

\begin{tabular}{|c|c|c|c|c|c|c|c|c|}
\hline $\begin{array}{l}0 \\
0 \\
0\end{array}$ & $\begin{array}{l}1 \\
2 \\
3\end{array}$ & $\begin{array}{l}335 \\
335 \\
335\end{array}$ & $\begin{array}{l}277 \\
299 \\
285\end{array}$ & $\begin{array}{l}0.83 \\
0.89 \\
0.85\end{array}$ & $\begin{array}{l}280 \\
292 \\
299\end{array}$ & $\begin{array}{l}0.84 \\
0.87 \\
0.89\end{array}$ & 0.86 & 0.87 \\
\hline $\begin{array}{l}1 \\
1 \\
1\end{array}$ & $\begin{array}{l}1 \\
2 \\
3\end{array}$ & $\begin{array}{l}335 \\
335 \\
335\end{array}$ & $\begin{array}{l}278 \\
317 \\
291\end{array}$ & $\begin{array}{l}0.83 \\
0.95 \\
0.87\end{array}$ & $\begin{array}{l}282 \\
322 \\
293\end{array}$ & $\begin{array}{l}0.84 \\
0.96 \\
0.87\end{array}$ & 0.88 & 0.89 \\
\hline $\begin{array}{l}4 \\
4 \\
4\end{array}$ & $\begin{array}{l}1 \\
2 \\
3\end{array}$ & $\begin{array}{l}335 \\
335 \\
335\end{array}$ & $\begin{array}{l}322 \\
313 \\
265\end{array}$ & $\begin{array}{l}0.96 \\
0.93 \\
0.79\end{array}$ & $\begin{array}{l}326 \\
323 \\
268\end{array}$ & $\begin{array}{l}0.97 \\
0.96 \\
0.80\end{array}$ & 0.90 & 0.91 \\
\hline $\begin{array}{l}16 \\
16 \\
16\end{array}$ & $\begin{array}{l}1 \\
2 \\
3\end{array}$ & $\begin{array}{l}335 \\
335 \\
335\end{array}$ & $\begin{array}{l}0 \\
0 \\
1\end{array}$ & $\begin{array}{l}0.00 \\
0.00 \\
0.00\end{array}$ & $\begin{array}{r}97 \\
182 \\
138\end{array}$ & $\begin{array}{l}0.29 \\
0.54 \\
0.41\end{array}$ & 0.00 & 0.41 \\
\hline $\begin{array}{l}64 \\
64 \\
64\end{array}$ & $\begin{array}{l}1 \\
2 \\
3\end{array}$ & $\begin{array}{l}335 \\
335 \\
335\end{array}$ & $\begin{array}{l}0 \\
0 \\
0\end{array}$ & $\begin{array}{l}0.00 \\
0.00 \\
0.00\end{array}$ & $\begin{array}{l}0 \\
0 \\
6\end{array}$ & $\begin{array}{l}0.00 \\
0.00 \\
0.02\end{array}$ & 0.00 & 0.01 \\
\hline $\begin{array}{l}256 \\
256 \\
256\end{array}$ & $\begin{array}{l}1 \\
2 \\
3\end{array}$ & $\begin{array}{l}335 \\
335 \\
335\end{array}$ & $\begin{array}{l}0 \\
0 \\
0\end{array}$ & $\begin{array}{l}0.00 \\
0.00 \\
0.00\end{array}$ & $\begin{array}{l}0 \\
0 \\
1\end{array}$ & $\begin{array}{l}0.00 \\
0.00 \\
0.00\end{array}$ & 0.00 & 0.00 \\
\hline $\begin{array}{l}\text { Brine } \\
\text { Brine } \\
\text { Brine }\end{array}$ & $\begin{array}{l}1 \\
2 \\
3\end{array}$ & $\begin{array}{l}335 \\
335 \\
335\end{array}$ & $\begin{array}{l}314 \\
304 \\
342\end{array}$ & $\begin{array}{l}0.94 \\
0.91 \\
1.00\end{array}$ & $\begin{array}{l}322 \\
310 \\
348\end{array}$ & $\begin{array}{l}0.96 \\
0.93 \\
1.00\end{array}$ & 0.95 & 0.96 \\
\hline
\end{tabular}


TABLE 1.5. (contd)

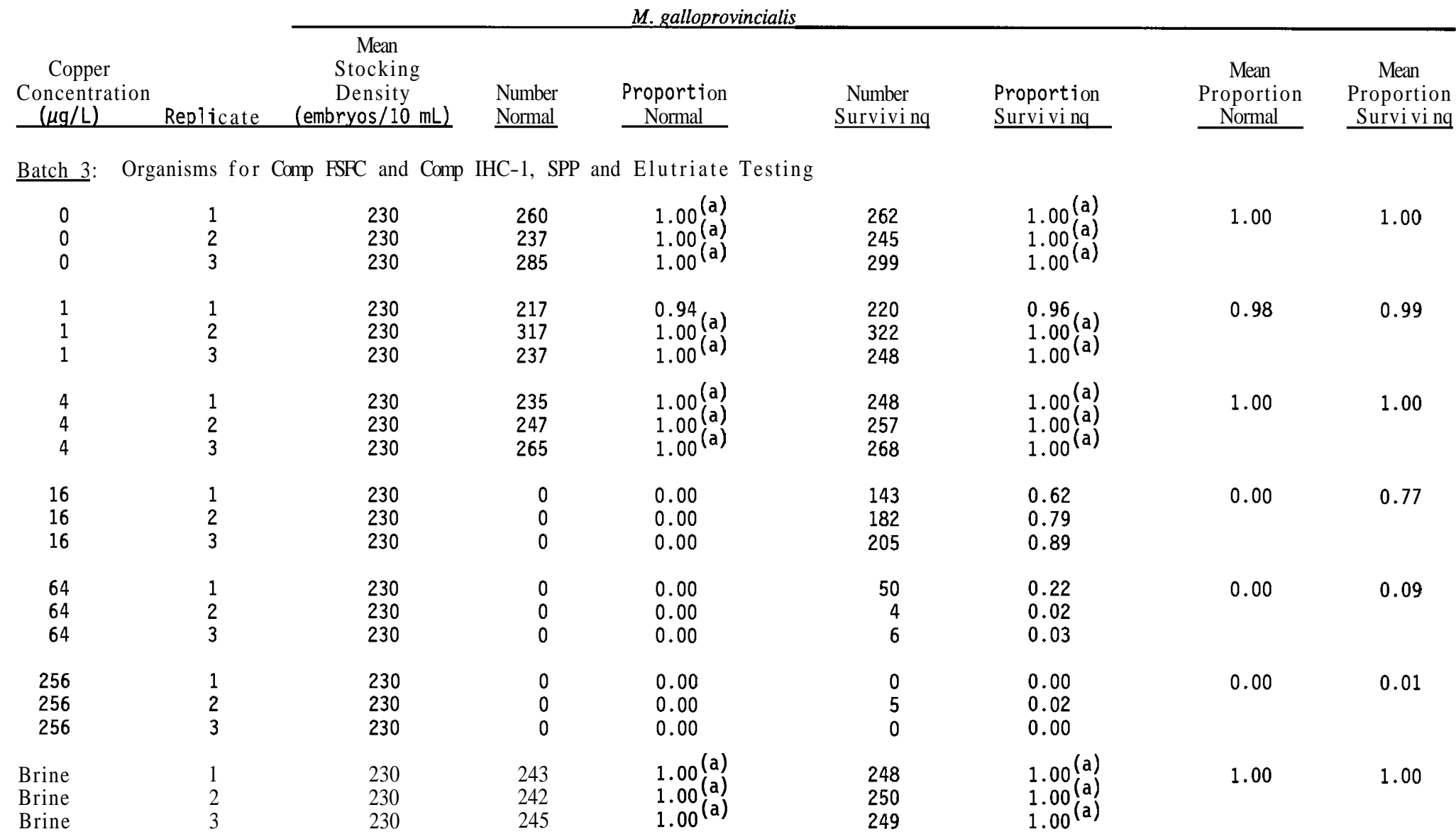


TABLE I.5. (contd)

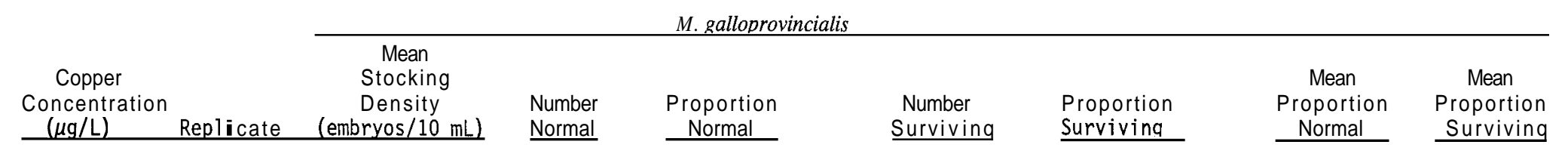

Batch 4: Organisms for Comp IHC-2 and Comp IHC-3, SPP and Elutriate Testing

\begin{tabular}{|c|c|c|c|c|c|c|c|c|}
\hline $\begin{array}{l}0 \\
0 \\
0\end{array}$ & $\begin{array}{l}1 \\
2 \\
3\end{array}$ & $\begin{array}{l}286 \\
286 \\
286\end{array}$ & $\begin{array}{l}256 \\
282 \\
280\end{array}$ & $\begin{array}{l}0.90 \\
0.99 \\
0.98\end{array}$ & $\begin{array}{l}257 \\
285 \\
282\end{array}$ & $\begin{array}{l}0.90 \\
1.00 \\
0.99\end{array}$ & 0.95 & 0.96 \\
\hline $\begin{array}{l}1 \\
1 \\
1\end{array}$ & $\begin{array}{l}1 \\
2 \\
3\end{array}$ & $\begin{array}{l}286 \\
286 \\
286\end{array}$ & $\begin{array}{l}278 \\
243 \\
262\end{array}$ & $\begin{array}{l}0.97 \\
0.85 \\
0.92\end{array}$ & $\begin{array}{l}285 \\
251 \\
264\end{array}$ & $\begin{array}{l}1.00 \\
0.88 \\
0.92\end{array}$ & 0.91 & 0.93 \\
\hline $\begin{array}{l}4 \\
4 \\
4\end{array}$ & $\begin{array}{l}1 \\
2 \\
3\end{array}$ & $\begin{array}{l}286 \\
286 \\
286\end{array}$ & $\begin{array}{l}222 \\
277 \\
271\end{array}$ & $\begin{array}{l}0.78 \\
0.97 \\
0.95\end{array}$ & $\begin{array}{l}236 \\
283 \\
276\end{array}$ & $\begin{array}{l}0.83 \\
0.99 \\
0.97\end{array}$ & 0.90 & 0.93 \\
\hline$\ddot{n}$ & $\begin{array}{l}1 \\
2 \\
3\end{array}$ & $\begin{array}{l}286 \\
286 \\
286\end{array}$ & $\begin{array}{l}0 \\
0 \\
0\end{array}$ & $\begin{array}{l}0.00 \\
0.00 \\
0.00\end{array}$ & $\begin{array}{r}208 \\
58 \\
253\end{array}$ & $\begin{array}{l}0.73 \\
0.20 \\
0.88\end{array}$ & 0.00 & 0.60 \\
\hline $\begin{array}{l}64 \\
64 \\
64\end{array}$ & $\begin{array}{l}1 \\
2 \\
3\end{array}$ & $\begin{array}{l}286 \\
286 \\
286\end{array}$ & $\begin{array}{l}0 \\
0 \\
0\end{array}$ & $\begin{array}{l}0.00 \\
0.00 \\
0.00\end{array}$ & $\begin{array}{r}93 \\
0 \\
56\end{array}$ & $\begin{array}{l}0.33 \\
0.00 \\
0.20\end{array}$ & 0.00 & 0.17 \\
\hline $\begin{array}{l}256 \\
256 \\
256\end{array}$ & $\begin{array}{l}1 \\
2 \\
3\end{array}$ & $\begin{array}{l}286 \\
286 \\
286\end{array}$ & $\begin{array}{l}0 \\
0 \\
0\end{array}$ & $\begin{array}{l}0.00 \\
0.00 \\
0.00\end{array}$ & $\begin{array}{l}0 \\
0 \\
0\end{array}$ & $\begin{array}{l}0.00 \\
0.00 \\
0.00\end{array}$ & 0.00 & 0.00 \\
\hline $\begin{array}{l}\text { Brine } \\
\text { Brine } \\
\text { Brine }\end{array}$ & $\begin{array}{l}1 \\
2 \\
3\end{array}$ & $\begin{array}{l}286 \\
286 \\
286\end{array}$ & $\begin{array}{l}296 \\
304 \\
244\end{array}$ & $\begin{array}{l}1.00(\mathrm{a}) \\
1.00 \\
0.85\end{array}$ & $\begin{array}{l}302 \\
310 \\
250\end{array}$ & $\begin{array}{l}1.00(\mathrm{a}) \\
1.00(\mathrm{a}) \\
0.87\end{array}$ & 0.95 & 0.96 \\
\hline
\end{tabular}

(a) When number normal or number surviving exceeded the stocking density, a proportion normal and/or proportion survival of 1.00 was used for mean calculations and statistical analysis. 


\section{TABLE 1.6. Water Quality Summary for 48-h M. galloprovincial is}

Reference Toxicant Test. United Heckathorn Remedial Investigation

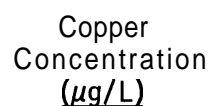

Acceptable Range
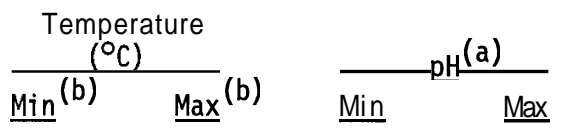

$14.0 \quad 18.0$

$7.48 \quad 8.48$

Batch 1: Organisms for Comp LC and Comp LC-5, SPP and Elutriate Testing

0
1
4
16
64
256
Brine

15.8
15.8
15.8
15.9
15.8
15.8
15.8

$\begin{array}{ll}16.0 & 7.93 \\ 16.1 & 7.95 \\ 16.1 & 7.95 \\ 16.1 & 8.00 \\ 16.1 & 8.00 \\ 16.0 & 7.99 \\ 16.0 & 8.01\end{array}$

8.01
8.00
8.00
8.02
8.02
8.02
8.11

7.5
7.6
7.5
7.6
7.5
7.7
7.6

$\begin{array}{lll}7.9 & 30.0 & 31.5 \\ 7.9 & 30.0 & 31.5 \\ 7.9 & 30.0 & 31.5 \\ 7.9 & 30.0 & 31.5 \\ 7.9 & 30.0 & 31.5 \\ 7.9 & 30.0 & 31.5 \\ 7.9 & 30.0 & 31.0\end{array}$

Batch 2: Organisms for Comp LC-6 and Comp USFC, SPP and Elutriate Testing

\begin{tabular}{|c|c|c|c|c|c|c|c|c|}
\hline 0 & 16.3 & 16.3 & 7.88 & 8.03 & 7.4 & 7.7 & 30.0 & 31.0 \\
\hline 1 & 16.2 & 16.4 & 7.84 & 8.05 & 7.5 & 7.7 & 30.0 & 31.0 \\
\hline 4 & 16.2 & 16.4 & 7.90 & 7.98 & 7.6 & 7.7 & 30.0 & 31.0 \\
\hline 16 & 16.2 & 16.4 & 7.97 & 8.06 & 7.4 & 7.7 & 30.0 & 31.5 \\
\hline 64 & 16.3 & 16.4 & 7.93 & 8.04 & 7.5 & 7.8 & 30.0 & 31.5 \\
\hline 256 & 16.2 & 16.3 & 7.90 & 8.02 & 7.4 & 7.8 & 30.0 & 30.5 \\
\hline Brine & 16.3 & 16.4 & 7.95 & 8.06 & 7.4 & 7.9 & 30.5 & 31.5 \\
\hline
\end{tabular}

Batch 3: Organisms for Comp FSFC and Comp IHC-1, SPP and Elutriate Testing

$\begin{array}{rllllllll}0 & 15.6 & 15.9 & 7.92 & 8.11 & 7.5 & 8.1 & 30.0 & 30.5 \\ 1 & 15.5 & 15.8 & 7.85 & 8.10 & 7.5 & 8.1 & 30.0 & 30.5 \\ 4 & 15.5 & 15.9 & 7.89 & 8.11 & 7.5 & 8.2 & 30.0 & 30.5 \\ 16 & 15.5 & 15.9 & 7.88 & 8.11 & 7.6 & 8.1 & 30.0 & 30.5 \\ 64 & 15.6 & 15.9 & 7.84 & 8.11 & 7.7 & 8.1 & 30.0 & 30.5 \\ 256 & 15.5 & 15.8 & 7.85 & 8.11 & 7.6 & 8.1 & 30.0 & 30.0 \\ \text { Brine } & 15.6 & 15.9 & 7.86 & 8.10 & 7.7 & 8.2 & 29.5 & 30.0\end{array}$

Batch 4: Organisms for Comp IHC-2 and Comp IHC-3, SPP and Elutriate Testing

$\begin{array}{rllllllll}0 & 16.1 & 16.3 & 7.92 & 8.09 & 7.7 & 8.0 & 30.0 & 30.0 \\ 1 & 16.1 & 16.3 & 7.97 & 8.07 & 7.5 & 8.0 & 30.0 & 30.5 \\ 4 & 16.1 & 16.3 & 7.99 & 8.07 & 7.6 & 8.0 & 30.0 & 30.5 \\ 16 & 16.0 & 16.4 & 7.92 & 8.02 & 7.7 & 8.0 & 30.0 & 30.0 \\ 64 & 16.0 & 16.3 & 7.94 & 8.04 & 7.6 & 8.0 & 30.0 & 30.0 \\ 256 & 16.0 & 16.3 & 7.94 & 8.03 & 7.5 & 8.1 & 30.0 & 30.0 \\ \text { Brine } & 15.9 & 16.4 & 7.96 & 8.09 & 7.6 & 8.0 & 30.0 & 31.0\end{array}$

(a) Acceptable $\mathrm{pH}$ range is based on mean $\mathrm{pH}$ in all test chambers in 48 -h test.

(b) Minimum and maximum values are derived from a11 replicates for each treatment. 

APPENDIX J

\section{FISH TISSUE CHEMISTRY AND QUALITY ASSURANCE DATA}



TABLE J.1. Lipids in Tissues of C. aggregata, United Heckathorn Remedial Investigation

$\begin{array}{lcc}\text { Sample } & \begin{array}{c}\text { Percent } \\ \text { Dry } \\ \text { Weight }\end{array} & \begin{array}{c}\text { Lipid Weight } \\ \text { (percent wet) }\end{array} \\ \text { S1CHT-206/11 } & 26.44 & 5.89 \\ \text { S1CHT-206/12 } & 26.98 & 6.63 \\ \text { S1CHT-206/13 } & 27.32 & 6.83 \\ \text { S1CHT-206/14 } & 26.44 & 4.36 \\ \text { S1CHT-206/15 } & 28.72 & 10.13 \\ \text { S1CHT-206/16 } & 30.44 & 12.63 \\ \text { S1CHT-206/17 } & 29.36 & 8.30 \\ \text { S1CHT-206/18 } & 26.35 & 8.78 \\ \text { S1CHT-206/19 } & 30.39 & 10.54 \\ \text { S1CHT-206/20 } & 30.13 & 10.14 \\ \text { Analytical Duplicate } & & \\ \text { S1CHT-206/20 } & & \\ \text { S1CHT-206/20 Duplicate } & 30.13 & 10.14 \\ \text { RPD } & 29.62 & 10.75 \\ \text { I- Stat } & 2 \% & 6 \%\end{array}$


TABLE J.2. Chlorinated Pesticides (elution order, Alpha-BHC to cis-Chlordane) in Tissues of C. aggregata, Wet Weight, United Heckathorn Remedial Investigation

\begin{tabular}{|c|c|c|c|c|c|c|c|c|c|c|}
\hline \multirow[b]{2}{*}{ Sample } & \multicolumn{10}{|c|}{ Pesticides $(\mu \mathrm{g} / \mathrm{kg}$ wet weight) } \\
\hline & $\begin{array}{c}\text { Alpha } \\
\text { BHC }\end{array}$ & $\begin{array}{r}\text { Beta } \\
\text { BHC } \\
\end{array}$ & Lindane & $\begin{array}{c}\text { Delta } \\
\text { BHC }\end{array}$ & $\begin{array}{l}\text { Hepta- } \\
\text { chlor }\end{array}$ & Aldrin & $\begin{array}{l}\text { Heptachior } \\
\text { Epoxide }\end{array}$ & $\begin{array}{c}\text { trans- } \\
\text { Chlordane }\end{array}$ & $\begin{array}{c}\text { Endo- } \\
\text { sulfan I }\end{array}$ & $\begin{array}{c}\text { cis- } \\
\text { Chlordane }\end{array}$ \\
\hline $\begin{array}{l}\text { Target DL (a) } \\
\text { Achieved DL High } \\
\text { Achieved DL Low }\end{array}$ & $\begin{array}{l}2 \\
16.03 \\
5.50 \mathrm{U}\end{array}$ & $\begin{array}{l}2 \\
16.03 \\
5.50 \mathrm{U}\end{array}$ & $\begin{array}{l}2 \\
16.03 \\
5.50 \mathrm{U}\end{array}$ & $\begin{array}{l}2 \\
16.03 \\
5.50 \mathrm{U}\end{array}$ & $\begin{array}{l}2 \\
17.04 \\
5.85 \mathrm{U}\end{array}$ & $\begin{array}{l}2 \\
10.39 \\
3.57 \mathrm{U}\end{array}$ & $\begin{array}{c}2 \\
15.14 \\
5.20 \mathrm{U}\end{array}$ & $\begin{array}{l}2 \\
31.49 \\
10.81 \mathrm{U}\end{array}$ & $\begin{array}{l}2 \\
31.49 \\
10.81 \mathrm{U}\end{array}$ & $\begin{array}{l}2 \\
18.31 \\
6.29 \mathrm{U}\end{array}$ \\
\hline $\begin{array}{l}\text { S1CHT-206/11 } \\
\text { S1CHT-206/12 } \\
\text { S1CHT-206/13 } \\
\text { S1CHT-206/14 } \\
\text { S1CHT-206/15 } \\
\text { S1CHT-206/16 } \\
\text { S1CHT-206/17 } \\
\text { S1CHT-206/18 } \\
\text { SICHT-206/19 } \\
\text { S1CHT-206/20 }\end{array}$ & $\begin{array}{r}7.65 \mathrm{U}^{(\mathrm{b})} \\
9.07 \mathrm{U} \\
6.17 \mathrm{U} \\
6.82 \mathrm{U} \\
12.38 \mathrm{U} \\
5.90 \mathrm{U} \\
5.50 \mathrm{U} \\
10.27 \mathrm{U} \\
16.03 \mathrm{U} \\
12.55 \mathrm{U}\end{array}$ & $\begin{array}{r}7.65 \mathrm{U} \\
9.07 \mathrm{U} \\
6.17 \mathrm{U} \\
6.82 \mathrm{U} \\
12.38 \mathrm{U} \\
5.90 \mathrm{U} \\
5.50 \mathrm{U} \\
10.27 \mathrm{U} \\
16.03 \mathrm{U} \\
12.55 \mathrm{U}\end{array}$ & $\begin{array}{r}7.65 \mathrm{U} \\
9.07 \mathrm{U} \\
6.17 \mathrm{U} \\
6.82 \mathrm{U} \\
12.38 \mathrm{U} \\
5.90 \mathrm{U} \\
5.50 \mathrm{U} \\
10.27 \mathrm{U} \\
16.03 \mathrm{U} \\
12.55 \mathrm{U}\end{array}$ & $\begin{array}{r}7.65 \mathrm{U} \\
9.07 \mathrm{U} \\
6.17 \mathrm{U} \\
6.82 \mathrm{U} \\
12.38 \mathrm{U} \\
5.90 \mathrm{U} \\
5.50 \mathrm{U} \\
10.27 \mathrm{U} \\
16.03 \mathrm{U} \\
12.55 \mathrm{U}\end{array}$ & $\begin{array}{r}8.13 \mathrm{U} \\
9.65 \mathrm{U} \\
6.56 \mathrm{U} \\
7.25 \mathrm{U} \\
13.16 \mathrm{U} \\
6.27 \mathrm{U} \\
5.85 \mathrm{U} \\
10.92 \mathrm{U} \\
17.04 \mathrm{U} \\
13.34 \mathrm{U}\end{array}$ & $\begin{array}{r}4.96 \mathrm{U} \\
5.88 \mathrm{U} \\
4.00 \mathrm{U} \\
4.42 \mathrm{U} \\
8.03 \mathrm{U} \\
3.82 \mathrm{U} \\
3.57 \mathrm{U} \\
6.65 \mathrm{U} \\
10.39 \mathrm{U} \\
8.13 \mathrm{U}\end{array}$ & $\begin{array}{r}7.22 \mathrm{U} \\
8.57 \mathrm{U} \\
5.83 \mathrm{U} \\
6.44 \mathrm{U} \\
11.70 \mathrm{U} \\
5.57 \mathrm{U} \\
5.20 \mathrm{U} \\
9.70 \mathrm{U} \\
15.14 \mathrm{U} \\
11.86 \mathrm{U}\end{array}$ & $\begin{array}{l}15.02 \mathrm{U} \\
17.83 \mathrm{U} \\
12.12 \mathrm{U} \\
13.39 \mathrm{U} \\
24.32 \mathrm{U} \\
11.58 \mathrm{U} \\
10.81 \mathrm{U} \\
20.17 \mathrm{U} \\
31.49 \mathrm{U} \\
24.65 \mathrm{U}\end{array}$ & $\begin{array}{l}15.02 \mathrm{U} \\
17.83 \mathrm{U} \\
12.12 \mathrm{U} \\
13.39 \mathrm{U} \\
24.32 \mathrm{U} \\
11.58 \mathrm{U} \\
10.81 \mathrm{U} \\
20.17 \mathrm{U} \\
31.49 \mathrm{U} \\
24.65 \mathrm{U}\end{array}$ & $\begin{array}{r}8.74 \mathrm{U} \\
10.37 \mathrm{U} \\
7.05 \mathrm{U} \\
7.79 \mathrm{U} \\
14.14 \mathrm{U} \\
6.73 \mathrm{U} \\
6.29 \mathrm{U} \\
11.73 \mathrm{U} \\
18.31 \mathrm{U} \\
14.34 \mathrm{U}\end{array}$ \\
\hline
\end{tabular}

C. (a) DL Detection limit.

iv (b) U Analyte was not present above the associated value. 
TABLE J.3. Chlorinated Pesticides (elution order, Dieldrin to Toxaphene) in Tissues of C. aggregata, Wet Weight, United Heckathorn Remedial Investigation

\begin{tabular}{|c|c|c|c|c|c|c|c|c|c|}
\hline \multirow[b]{2}{*}{ Sample } & \multicolumn{9}{|c|}{ Pesticides $(\mu \mathrm{g} / \mathrm{kg}$ wet weight $)$} \\
\hline & Dieldrin & 4.4'-DDE & Endrin & $\begin{array}{c}\text { Endo- } \\
\text { sulfan II } \\
\end{array}$ & $\underline{4,4^{\prime}-D D D}$ & $\begin{array}{c}\text { Endrin } \\
\text { aldehyde } \\
\end{array}$ & $\begin{array}{l}\text { Endosul fan } \\
\text { sulfate } \\
\end{array}$ & $\underline{4,4^{\prime}-\mathrm{DDT}}$ & Toxaphene \\
\hline Target $D_{L}(a)$ & 2 & 2 & 2 & 2 & 2 & 2 & 2 & 2 & 2 \\
\hline Achieved DL High & 12.86 & 163.83 & $13.18 \mathrm{U}$ & $31.49 \mathrm{U}$ & 73.99 & $31.49 \mathrm{U}$ & $31.49 \mathrm{U}$ & 32.94 & $314.56 \mathrm{U}$ \\
\hline Achieved DL Low & 4.41 & 15.03 & $4.52 \mathrm{U}$ & $10.81 \mathrm{U}$ & 9.04 & $10.81 \mathrm{U}$ & $10.81 \mathrm{U}$ & 11.31 & $107.98 \mathrm{U}$ \\
\hline S1CHT-206/11 & 172.47 & 401.84 & $6.29 \mathrm{U}^{(\mathrm{b})}$ & $15.02 \mathrm{U}$ & 1365.46 & $15.02 \mathrm{U}$ & $15.02 \mathrm{U}$ & 1123.41 & $150.09 \mathrm{U}$ \\
\hline S1CHT-206/12 & 270.95 & 829.11 & $7.46 \mathrm{U}$ & $17.83 \mathrm{U}$ & 1170.11 & $17.83 \mathrm{U}$ & $17.83 \mathrm{U}$ & 459.02 & $178.08 \mathrm{U}$ \\
\hline S1CHT-206/13 & 132.85 & 355.05 & $5.07 \mathrm{U}$ & $12.12 \mathrm{U}$ & 1371.57 & $12.12 \mathrm{U}$ & $12.12 \mathrm{U}$ & 207.86 & $121.06 \mathrm{U}$ \\
\hline S1CHT-206/14 & 99.70 & 597.54 & $5.60 \mathrm{U}$ & $13.39 \mathrm{U}$ & 952.42 & $13.39 \mathrm{U}$ & $13.39 \mathrm{U}$ & 374.84 & $133.76 \mathrm{U}$ \\
\hline S1CHT-206/15 & 311.85 & 2220.06 & $10.18 \mathrm{U}$ & $24.32 \mathrm{U}$ & 3128.46 & $24.32 \mathrm{U}$ & $24.32 \mathrm{U}$ & 1624.77 & $242.95 \mathrm{U}$ \\
\hline S1CHT-206/16 & 155.46 & 396.75 & $4.85 \mathrm{U}$ & $11.58 \mathrm{U}$ & 711.35 & $11.58 \mathrm{U}$ & $11.58 \mathrm{U}$ & 190.18 & $115.69 \mathrm{U}$ \\
\hline S1CHT-206/17 & 137.53 & 342.69 & $4.52 \mathrm{U}$ & $10.81 \mathrm{U}$ & 1682.63 & $10.81 \mathrm{U}$ & $10.81 \mathrm{U}$ & 275.54 & $107.98 \mathrm{U}$ \\
\hline S1CHT-206/18 & 156.97 & 761.73 & $8.44 \mathrm{U}$ & $20.17 \mathrm{U}$ & 1807.78 & $20.17 \mathrm{U}$ & $20.17 \mathrm{U}$ & 410.60 & $201.47 \mathrm{U}$ \\
\hline S1CHT-206/19 & 180.14 & 1170.42 & $13.18 \mathrm{U}$ & $31.49 \mathrm{U}$ & 2177.06 & $31.49 \mathrm{U}$ & $31.49 \mathrm{U}$ & 515.18 & $314.56 \mathrm{U}$ \\
\hline S1CHT-206/20 & 175.88 & 957.71 & $10.32 \mathrm{U}$ & $24.65 \mathrm{U}$ & 2007.63 & $24.65 \mathrm{U}$ & $24.65 \mathrm{U}$ & 301.13 & $246.28 U$ \\
\hline
\end{tabular}

c. (a) DL Detection limit.

$\omega$ (b) U Analyte was not present above the associated value. 
TABLE J.4. Quality Control Summary for Chlorinated Pesticides (elution order, Alpha-BHC to ci s-Chl ordane) in Tissues of C. aggregata, Wet Weight, United Heckathorn

Remedial Investigation

\begin{tabular}{|c|c|c|c|c|c|c|c|c|c|c|}
\hline & & & & & Pesticide & $(\mu \mathrm{g} / \mathrm{kg}$ we & weight) & & & \\
\hline$\underline{\text { Sample }}$ & $\begin{array}{l}\text { Alpha } \\
\text { De }\end{array}$ & Beta & Lindane & $\begin{array}{c}\text { Delta } \\
\text { BHC } \\
\end{array}$ & $\begin{array}{l}\text { Hepta- } \\
\text { chlor } \\
\end{array}$ & Aldrin & $\begin{array}{l}\text { Hepta- } \\
\text { chlor } \\
\text { epoxide } \\
\end{array}$ & $\begin{array}{c}\text { trans- } \\
\text { Chlordane } \\
\end{array}$ & $\begin{array}{c}\begin{array}{c}\text { Endo- } \\
\text { sulfan I }\end{array} \\
\end{array}$ & $\begin{array}{c}\text { cis- } \\
\text { Chlordane } \\
\end{array}$ \\
\hline Method Blank & & & & & & & & & & \\
\hline Bl ank & $4.10 u^{(a)}$ & $4.10 \mathrm{U}$ & $4.10 \mathrm{U}$ & $4.10 \mathrm{U}$ & $4.35 \mathrm{U}$ & $2.65 \mathrm{U}$ & $3.87 \mathrm{U}$ & $8.05 U$ & $8.05 \mathrm{U}$ & $4.68 U$ \\
\hline Matrix Spikes & & & & & & & & & & \\
\hline $\begin{array}{l}\text { S1CHT-206/19 } \\
\text { S1CHT-206/19 NS } \\
\text { Concentration Recovered } \\
\text { Amount Spiked } \\
\text { Percent Recovery }\end{array}$ & $\begin{array}{l}16.03 \mathrm{U} \\
10.47 \\
10.47 \\
10.39 \\
101 \%\end{array}$ & $\begin{array}{c}16.03 \mathrm{U} \\
7.76 \\
7.76 \\
9.78 \\
79 \%\end{array}$ & $\begin{array}{c}16.03 \mathrm{U} \\
7.15 \\
7.15 \\
9.78 \\
73 \%\end{array}$ & $\begin{array}{c}16.03 \mathrm{U} \\
8.65 \\
8.65 \\
9.78 \\
88 \%\end{array}$ & $\begin{array}{c}17.04 \mathrm{U} \\
7.06 \\
7.06 \\
9.78 \\
72 \%\end{array}$ & $\begin{array}{c}10.39 \mathrm{U} \\
7.36 \\
7.36 \\
9.78 \\
75 \%\end{array}$ & $\begin{array}{l}15.14 \mathrm{U} \\
6.80 \\
6.80 \\
9.78 \\
70 \%\end{array}$ & $\begin{array}{r}31.49(\mathrm{~b}) \\
M(\mathrm{~b}) \\
N A \\
10.60 \\
N A\end{array}$ & $\begin{array}{r}31.49 \mathrm{U} \\
\mathrm{M} \\
\mathrm{NA} \\
9.78 \\
\mathrm{NA}\end{array}$ & $\begin{array}{l}18.31 \mathrm{U} \\
\mathrm{M} \\
\mathrm{NA} \\
\mathrm{NS} \\
\mathrm{NA}\end{array}$ \\
\hline $\begin{array}{l}\text { S1CHT-206/19 } \\
\text { S1CHT-206/19 MBD } \\
\text { Concentration Recovered } \\
\text { Amount Spiked } \\
\text { Percent Recovery }\end{array}$ & $\begin{array}{l}16.03 \mathrm{U} \\
15.83 \\
15.83 \\
18.61 \\
85 \%\end{array}$ & $\begin{array}{l}16.03 \mathrm{U} \\
13.57 \\
13.57 \\
17.52 \\
77 \%\end{array}$ & $\begin{array}{l}16.03 \mathrm{U} \\
13.00 \\
13.00 \\
17.52 \\
74 \%\end{array}$ & $\begin{array}{l}16.03 \mathrm{U} \\
14.13 \\
14.13 \\
17.52 \\
\quad 81 \%\end{array}$ & $\begin{array}{l}17.04 \mathrm{U} \\
12.46 \\
12.46 \\
17.52 \\
71 \%\end{array}$ & $\begin{array}{l}10.39 \mathrm{U} \\
12.40 \\
12.40 \\
17.52 \\
71 \%\end{array}$ & $\begin{array}{l}15.14 \mathrm{U} \\
12.53 \\
12.53 \\
17.52 \\
72 \%\end{array}$ & $\begin{array}{r}31.49 \mathrm{U} \\
\mathrm{M} \\
\mathrm{NA} \\
18.98 \\
\mathrm{NA}\end{array}$ & $\begin{array}{r}31.49 \mathrm{U} \\
\mathrm{M} \\
\mathrm{NA} \\
17.52 \\
\mathrm{NA}\end{array}$ & $\begin{array}{r}18.31 \mathrm{U} \\
\mathrm{M} \\
\mathrm{NA} \\
\mathrm{NS} \\
\mathrm{NA}\end{array}$ \\
\hline $\begin{array}{l}\text { RPD } \\
\text { I-Stat }\end{array}$ & $\begin{array}{l}17 \% \\
0.08\end{array}$ & 0.01 & 0.01 & 0.05 & 0.01 & 0.03 & 0.02 & $\begin{array}{l}\text { NA } \\
\text { NA }\end{array}$ & $\begin{array}{l}\text { NA } \\
\text { NA }\end{array}$ & $\begin{array}{l}\text { NA } \\
\text { NA }\end{array}$ \\
\hline Analytical Duplicate & & & & & & & & & & \\
\hline $\begin{array}{l}\text { S1CHT-206/20 } \\
\text { S1CHT-206/20 Dupl icate } \\
\text { RPD } \\
\text { I- Stat }\end{array}$ & $\begin{array}{c}12.55 \mathrm{U} \\
9.14 \mathrm{U} \\
\mathrm{NA} \\
\mathrm{NA}\end{array}$ & $\begin{array}{c}12.55 U \\
9.14 \mathrm{U} \\
\mathrm{NA} \\
\mathrm{NA}\end{array}$ & $\begin{array}{c}12.55 \cup \\
9.14 \mathrm{U} \\
\mathrm{NA} \\
\mathrm{NA}\end{array}$ & $\begin{array}{c}12.55 \mathrm{U} \\
9.14 \mathrm{U} \\
\mathrm{NA} \\
\mathrm{NA}\end{array}$ & $\begin{array}{c}13.34 U \\
9.72 U \\
N A \\
N A\end{array}$ & $\begin{array}{l}8.13 U \\
5.93 U \\
\text { NA } \\
\text { NA }\end{array}$ & $\begin{array}{c}11.86 U \\
8.64 U \\
\mathrm{NA} \\
\mathrm{NA}\end{array}$ & $\begin{array}{c}24.65 U \\
17.96 U \\
\text { NA } \\
\text { NA }\end{array}$ & $\begin{array}{c}24.65 \mathrm{U} \\
17.96 \mathrm{U} \\
\mathrm{NA} \\
\mathrm{NA}\end{array}$ & $\begin{array}{c}14.34 \mathrm{U} \\
10.44 \mathrm{U} \\
\mathrm{NA} \\
\mathrm{NA}\end{array}$ \\
\hline
\end{tabular}

(a) $U$ Analyte was not present above the associated value.

(b) M Matrix interference. Recovery could not be calculated.

(c) NA Not applicable.

(d) NS Not spiked. 
TABLE J.5. Quality Control Summary for Chlorinated Pesticides (elution order, Dieldrin to Toxaphene) in Tissues of C. aggregata, Wet Weight, United Heckathorn Remedial Investigation

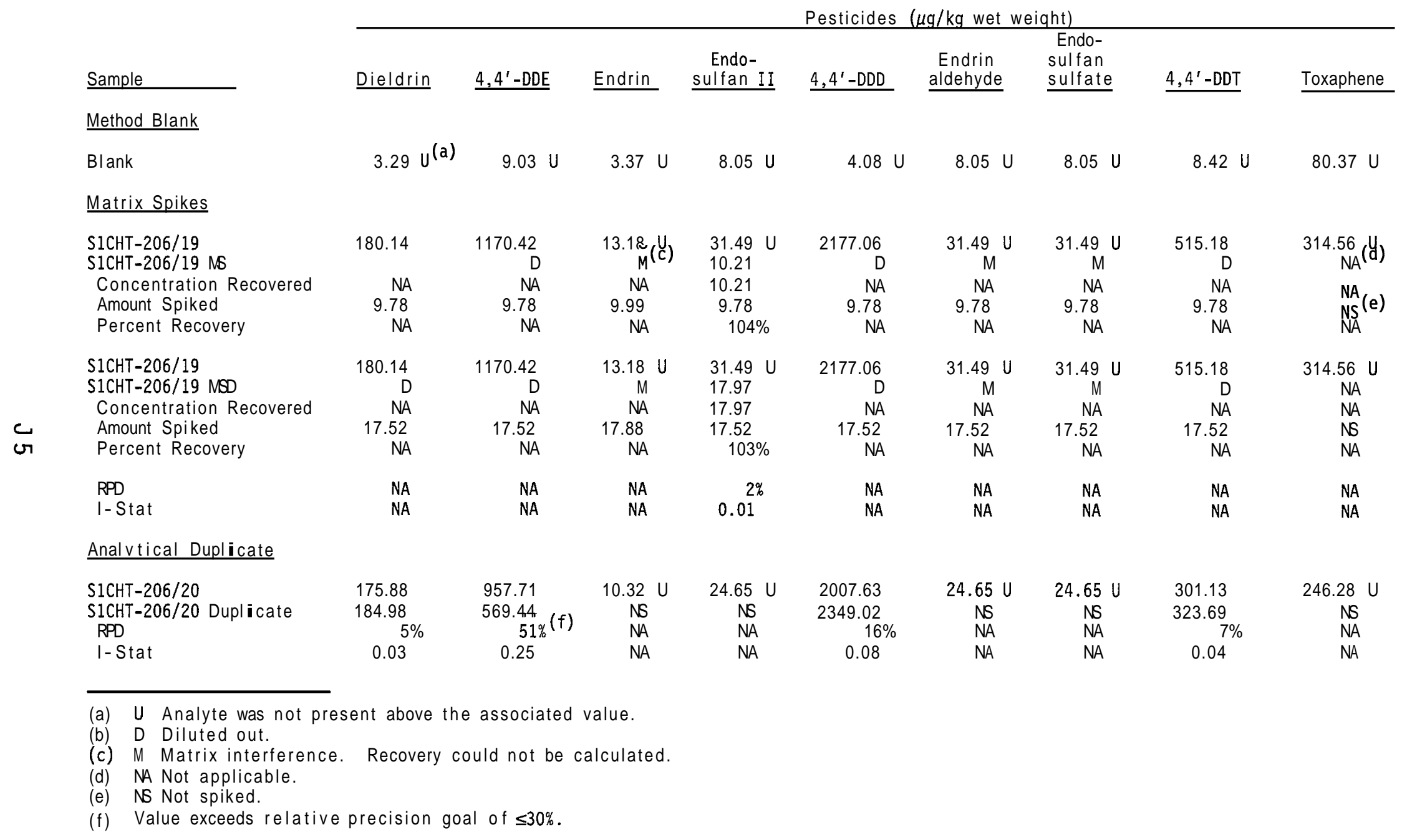


TABLE 5.6. Surrogate Recoveries for Chlorinated Pesticides in Tissues of C. aggregata, United Heckathorn Remedial Investigation

Sample
S1CHT-206/11
S1CHT-206/12
S1CHT-206/13
S1CHT-206/14
S1CHT-206/15
S1CHT-206/16
S1CHT-206/17
S1CHT-206/18
S1CHT-206/19
S1CHT-206/20

Quality Control Data

Method Blank

Blank

Matrix Spikes

S1CHT-206/19 NS

S1CHT-206/19 MSD

Analytical Duplicate

S1CHT-206/20 Duplicate

\begin{tabular}{lll}
\multicolumn{3}{c}{ Surrogate Percent Recoveries } \\
\hline$\underline{\mathrm{DBOFB}}$ & $\underline{\mathrm{CL5}(112)}$ & $\underline{\mathrm{CL5}(103)}$
\end{tabular}

74.99

77.44

78.91

80.27

71.68

69.18

66.04

73.94

77.42

76.11

74.52

67.95

70.63

68.90

78.63

80.68

81.72

77.21

72.42

74.83

76.87

89.08

77.64

74.86

93.20

85.11

57.15

68.09

73.51

71.51
78.59
77.76
71.24

72.37

69.19

74.62

76.69

71.69

76.14

73.41

77.11

70.64 
TABLE 5.7. Polychlorinated Biphenyls (PCBs) in Tissues of C. aggregata, Wet Weight, United Heckathorn Remedial Investigation

Surrogate Percent Recoveries

Sample

Target $\mathrm{DL}^{(\mathrm{a})}$

Achieved DL High

Achieved DL Low

\begin{tabular}{l}
\hline DBOFB \\
\hline NA $(b)$ \\
NA \\
NA \\
74.99 \\
77.44 \\
78.91 \\
80.27 \\
71.68 \\
69.18 \\
66.04 \\
73.94 \\
77.42 \\
76.11
\end{tabular}

CL5(112)
NA
$N A$
$N A$

74.52
67.95
70.63
68.90
78.63
80.68
81.72
77.21
72.42
74.83

CL5(103)
NA
$N A$
$N A$
76.87
89.08
77.64
74.86
93.20
85.11
57.15
68.09
73.51
71.51

\begin{tabular}{|c|c|c|c|}
\hline $\begin{array}{c}\text { Aroclor } \\
1242 \\
\end{array}$ & $\begin{array}{c}\text { Aroclor } \\
1248 \\
\end{array}$ & $\begin{array}{c}\text { Aroclor } \\
1254 \\
\end{array}$ & $\begin{array}{c}\text { Aroclor } \\
1260 \\
\end{array}$ \\
\hline $\begin{array}{l}20 \\
246.28 \mathrm{U} \\
107.98 \mathrm{U}\end{array}$ & $\begin{array}{l}20 \\
246.28 \mathrm{U} \\
107.98 \mathrm{U}\end{array}$ & $\begin{array}{r}20 \\
242.97 \\
4.84\end{array}$ & $\begin{array}{l}20 \\
246.28 \mathrm{U} \\
107.98 \mathrm{U}\end{array}$ \\
\hline $\begin{array}{l}150.09 U^{(c)} \\
178.08 U \\
121.06 U \\
133.76 U \\
242.95 U \\
115.69 U \\
107.98 U \\
201.47 U \\
314.56 U \\
246.28 U\end{array}$ & $\begin{array}{l}150.09 \mathrm{U} \\
178.08 \mathrm{U} \\
121.06 \mathrm{U} \\
133.76 \mathrm{U} \\
242.95 \mathrm{U} \\
115.69 \mathrm{U} \\
107.98 \mathrm{U} \\
201.47 \mathrm{U} \\
314.56 \mathrm{U} \\
246.28 \mathrm{U}\end{array}$ & $\begin{array}{l}657.50 \\
602.56 \mathrm{~J}(\mathrm{~d}) \\
740.01 \\
497.23 \mathrm{~J} \\
787.71 \\
349.63 \\
224.16 \\
458.23 \\
419.34 \mathrm{~J} \\
332.07 \mathrm{~J}\end{array}$ & $\begin{array}{l}150.09 \mathrm{U} \\
178.08 \mathrm{U} \\
121.06 \mathrm{U} \\
133.76 \mathrm{U} \\
242.95 \mathrm{U} \\
115.69 \mathrm{U} \\
107.98 \mathrm{U} \\
201.47 \mathrm{U} \\
314.56 \mathrm{U} \\
246.28 \mathrm{U}\end{array}$ \\
\hline
\end{tabular}

$c$
(a) DL Detection limit.
(b) NA Not applicable.
(c) U Analyte not detected above the level of the associated value.
(d) J Analyte detected below detection limit (MDL), but above instrument detection limit (IDL). 
TABLE J.8. Quality Control Summary for Polychlorinated Biphenyls (PCBs) in Tissues of C. aggregata, Wet Weight, United Heckathorn Remedial Investigation

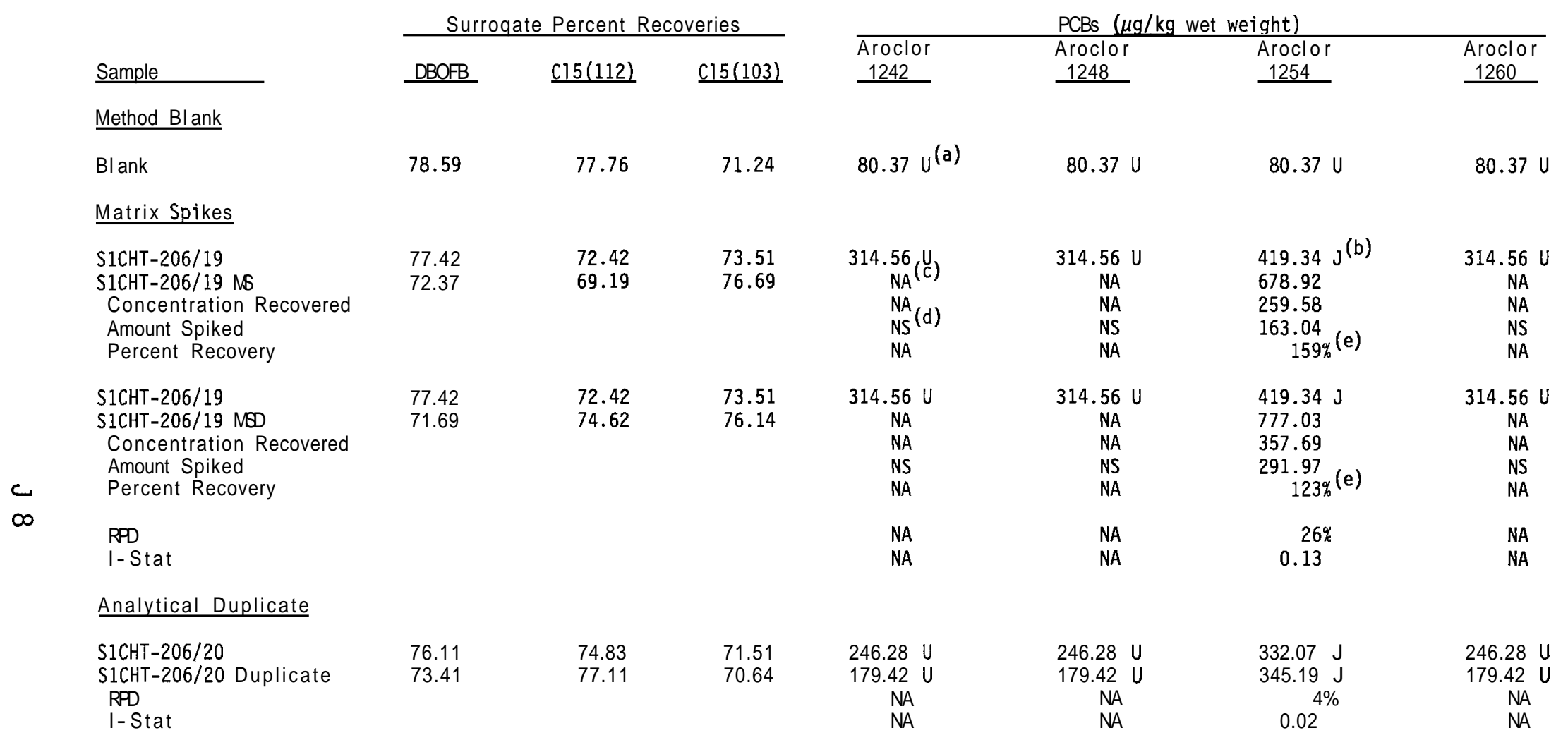

\footnotetext{
(a) $U$ Analyte not detected above the level of the associated value.

(b) J Analyte detected below detection limit (MDL), but above instrument detection limit (IDL).

(c) NA Not applicable.

(d) NS Not spiked.

(e) Recovery outside of quality control range (40\%-120\%).
} 
Table J.9. Low Molecular Weight Polynuclear Aromatic Hydrocarbons (LPAHs) in the Tissues of C. aggregata, Wet Weight, United Heckathorn

Remedial Investigation

Sample

Target $\mathrm{DL}(\sim)$

Achieved DL High

Achieved DL Low

S1CHT-206/11

SICHT-206/12

S1CHT-206/13

S1CHT-206/14

S1CHT-206/15

S1CHT-206/16

S1CHT-206/17

S1CHT-206/18

S1CHT-206/19

S1CHT-206/20

\begin{tabular}{|c|c|c|c|c|c|c|c|}
\hline $\begin{array}{l}\text { Naph- } \\
\text { thalone }\end{array}$ & $\begin{array}{c}\text { 2-methyl } \\
\text { Naph- } \\
\end{array}$ & $\begin{array}{c}\text { 1-methyl } \\
\text { Naph- } \\
\text { thalone }\end{array}$ & $\begin{array}{l}\text { Acenaph- } \\
\text { thylene }\end{array}$ & $\begin{array}{l}\text { Acenaph- } \\
\text { thene }\end{array}$ & Fluorene & $\begin{array}{l}\text { Phenan- } \\
\text { threne }\end{array}$ & $\begin{array}{l}\text { Anthra- } \\
\text { cene } \\
\end{array}$ \\
\hline $\begin{array}{l}20 \\
6.84 \\
2.35\end{array}$ & $\begin{array}{l}20 \\
3.48 \\
1.19\end{array}$ & $\begin{array}{r}20 \\
3.59 \\
1.23\end{array}$ & $\begin{array}{l}20 \\
6.31 \\
2.17\end{array}$ & $\begin{array}{l}20 \\
2.39 \\
0.82\end{array}$ & $\begin{array}{l}20 \\
4.03 \\
1.38\end{array}$ & $\begin{array}{l}20 \\
4.47 \\
1.54\end{array}$ & $\begin{array}{l}20 \\
3.43 \\
1.18\end{array}$ \\
\hline $\begin{array}{l}21.70 \\
25.25 \\
34.44 \\
37.74 \\
25.12 \\
33.62 \\
21.65 \\
35.78 \\
31.48 \\
28.07\end{array}$ & $\begin{array}{l}4.23 \\
5.76 \\
5.60 \\
5.45 \\
5.33 \\
7.70 \\
3.54 \\
4.24 \\
4.08 \\
3.94\end{array}$ & $\begin{array}{l}2.80 \\
4.52 \\
3.58 \\
4.03 \\
3.88 \\
5.84 \\
2.58 \\
2.78 \\
2.99 \mathrm{~J} \\
2.73 \mathrm{~J}\end{array}$ & $\begin{array}{l}3.25 \mathrm{~J}(\mathrm{~b}) \\
2.92 \mathrm{~J} \\
4.16 \\
4.55 \mathrm{~J} \\
6.40 \\
3.91 \\
5.18 \\
3.24 \mathrm{~J} \\
3.86 \mathrm{~J} \\
4.49 \mathrm{~J}\end{array}$ & $\begin{array}{r}42.83 \\
63.85 \\
47.07 \\
34.61 \\
46.38 \\
100.08 \\
44.07 \\
40.23 \\
45.89 \\
41.35\end{array}$ & $\begin{array}{l}17.19 \\
23.38 \\
18.89 \\
11.39 \\
17.31 \\
45.97 \\
17.22 \\
14.07 \\
17.83 \\
15.31\end{array}$ & $\begin{array}{l}15.33 \\
15.94 \\
16.56 \\
12.77 \\
11.15 \\
28.89 \\
13.58 \\
10.60 \\
17.27 \\
12.39\end{array}$ & $\begin{array}{r}7.66 \\
7.27 \\
10.79 \\
7.75 \\
11.88 \\
11.09 \\
12.26 \\
6.82 \\
9.70 \\
9.68\end{array}$ \\
\hline
\end{tabular}

(a) DL Detection limit.

(b) J Analyte detected below method detection limit (MDL), but above instrument detection Iimit (IDL). 
TABLE J.10. High Molecular Weight Polynuclear Aromatic Hydrocarbons (HPAHs) in Tissues of C. aggregata, Wet Weight, United Heckathorn Remedial Investigation

\begin{tabular}{|c|c|c|c|c|c|c|c|c|c|c|}
\hline \multirow[b]{2}{*}{ Sample } & \multicolumn{10}{|c|}{$\mathrm{HPAH}(\mu \mathrm{g} / \mathrm{kg}$ wet weight $)$} \\
\hline & $\begin{array}{r}\text { Fluor- } \\
\text { anthene }\end{array}$ & Pyrene & $\begin{array}{c}\text { Benzo }(\mathrm{a})^{-} \\
\text {anthra- } \\
\text { cene } \\
\end{array}$ & $\underline{\text { Chrvsene }}$ & $\begin{array}{l}\text { Benzo(b) - } \\
\text { fluor- } \\
\text { anthene } \\
\end{array}$ & $\begin{array}{l}\text { Benzo(k)- } \\
\text { fluor- } \\
\text { anthene } \\
\end{array}$ & $\begin{array}{l}\text { Benzo (a) - } \\
\text { pyrene }\end{array}$ & $\begin{array}{c}\text { Indeno } \\
(1,2,3,-c, d) \\
\text { pyrene } \\
\end{array}$ & $\begin{array}{c}\text { Dibenzo- } \\
(\mathrm{a}, \mathrm{h}) \\
\text { anthracene } \\
\end{array}$ & $\begin{array}{c}\text { Benzo- } \\
(\mathrm{g}, \mathrm{h}, \mathrm{i}) \\
\text { perylene }\end{array}$ \\
\hline $\begin{array}{l}\text { Target DL (a) } \\
\text { Achieved DL High } \\
\text { Achieved DL Low }\end{array}$ & $\begin{array}{l}20 \\
5.95 \\
2.05\end{array}$ & $\begin{array}{l}20 \\
4.28 \\
1.47\end{array}$ & $\begin{array}{l}20 \\
5.44 \\
1.87\end{array}$ & $\begin{array}{l}20 \\
6.22 \\
2.14\end{array}$ & $\begin{array}{l}20 \\
6.14 \\
2.11\end{array}$ & $\begin{array}{l}20 \\
2.87 \\
0.99\end{array}$ & $\begin{array}{l}20 \\
2.29 \\
0.79\end{array}$ & $\begin{array}{l}20 \\
5.01 \\
1.72\end{array}$ & $\begin{array}{l}20 \\
4.51 \\
1.55\end{array}$ & $\begin{array}{l}20 \\
4.21 \\
1.45\end{array}$ \\
\hline $\begin{array}{l}\text { S1CHT-206/11 } \\
\text { S1CHT-206/12 } \\
\text { S1CHT-206/13 } \\
\text { S1CHT-206/14 } \\
\text { S1CHT-206/15 } \\
\text { S1CHT-206/16 } \\
\text { S1CHT-206/17 } \\
\text { S1CHT-206/18 } \\
\text { S1CHT-206/19 } \\
\text { S1CHT-206/20 }\end{array}$ & $\begin{array}{l}24.77 \\
20.89 \\
34.01 \\
14.59 \\
22.74 \\
35.92 \\
26.87 \\
16.03 \\
24.43 \\
22.71\end{array}$ & $\begin{array}{r}7.04 \\
4.40 \\
11.25 \\
4.10 \\
7.36 \\
8.08 \\
7.97 \\
3.66 \\
6.14 \\
6.70\end{array}$ & $\begin{array}{l}2.83 \\
0.63 \mathrm{~J} \\
4.66 \\
2.37 \mathrm{~J} \\
2.39 \\
1.86 \mathrm{~J} \\
2.79 \\
0.76 \mathrm{~J} \\
1.66 \mathrm{~J} \\
2.25 \mathrm{~J}\end{array}$ & $\begin{array}{c}7.53 \\
2.28 \mathrm{~J} \\
10.97 \\
4.29 \mathrm{~J} \\
4.15 \\
4.92 \\
6.74 \\
2.49 \mathrm{~J} \\
4.27 \mathrm{~J} \\
4.90\end{array}$ & $\begin{array}{l}4.87 \\
0.67 \mathrm{~J} \\
6.31 \\
3.02 \mathrm{~J} \\
2.54 \\
2.00 \mathrm{~J} \\
4.18 \mathrm{~J} \\
0.92 \mathrm{~J} \\
1.91 \mathrm{~J} \\
2.75 \mathrm{~J}\end{array}$ & $\begin{array}{l}2.15 \\
0.24 \mathrm{~J} \\
2.80 \\
1.55 \mathrm{~J} \\
1.13 \\
1.10 \\
1.61 \\
0.36 \mathrm{~J} \\
0.76 \mathrm{~J} \\
0.94 \mathrm{~J}\end{array}$ & $\begin{array}{l}2.66 \\
0.31 \mathrm{~J} \\
2.84 \\
1.76 \mathrm{~J} \\
1.67 \\
1.41 \\
2.22 \\
0.40 \mathrm{~J} \\
0.94 \mathrm{~J} \\
1.67 \mathrm{~J}\end{array}$ & $\begin{array}{l}2.46 \\
0.39 \mathrm{~J} \\
2.39 \\
1.74 \mathrm{~J} \\
1.41 \mathrm{~J} \\
1.13 \mathrm{~J} \\
1.83 \mathrm{~J} \\
0.45 \mathrm{~J} \\
1.03 \mathrm{~J} \\
1.56 \mathrm{~J}\end{array}$ & $\begin{array}{l}0.90 \mathrm{~J}(\mathrm{~b}) \\
0.15 \mathrm{~J} \\
0.78 \mathrm{~J} \\
0.89 \mathrm{~J} \\
0.38 \mathrm{~J} \\
0.45 \mathrm{~J} \\
0.48 \mathrm{~J} \\
0.23 \mathrm{~J} \\
0.39 \mathrm{~J} \\
0.36 \mathrm{~J}\end{array}$ & $\begin{array}{l}2.54 \\
0.65 \mathrm{~J} \\
2.36 \\
2.00 \mathrm{~J} \\
1.80 \\
1.46 \mathrm{~J} \\
1.69 \\
0.73 \mathrm{~J} \\
1.57 \mathrm{~J} \\
1.83 \mathrm{~J}\end{array}$ \\
\hline
\end{tabular}

c

(a) DL Detection limit.

(b) J Analyte detected below method detection limit (MDL), but above instrument detection Iimit (IDL). 
TABLE J.11. Quality Control Summary for Low Molecular Weight Polynuclear Aromatic Hydrocarbons (LPAHs) in the Tissues of C. aggregata, Wet Weight, United Heckathorn Remedial Investigation

\begin{tabular}{|c|c|c|c|c|c|c|c|c|}
\hline \multirow[b]{2}{*}{ Sample } & \multicolumn{8}{|c|}{ LPAHs $(\mu \mathrm{g} / \mathrm{kg}$ wet weight $)$} \\
\hline & $\begin{array}{c}\text { Naph- } \\
\text { thalene } \\
\end{array}$ & $\begin{array}{l}\text { 2-methyl } \\
\text { Naph- } \\
\text { thalene } \\
\end{array}$ & $\begin{array}{l}\text { 1-methyl } \\
\text { Naph- } \\
\text { thalene } \\
\end{array}$ & $\begin{array}{l}\text { Acenaph- } \\
\text { thrlene }\end{array}$ & $\begin{array}{l}\text { Acenaph- } \\
\text { thene }\end{array}$ & Fluorene & $\begin{array}{l}\text { Phenan- } \\
\text { threne }\end{array}$ & $\begin{array}{c}\text { Anthra- } \\
\text { cene }\end{array}$ \\
\hline \multicolumn{9}{|l|}{ Method Blank } \\
\hline Blank & 9.15 & $0.45 \mathrm{~J}^{(\mathrm{a})}$ & $0.23 \mathrm{~J}$ & $3.23 u^{(b)}$ & $1.22 \mathrm{U}$ & $0.11 \mathrm{~J}$ & $2.11 \mathrm{~J}$ & $1.76 \mathrm{U}$ \\
\hline \multicolumn{9}{|l|}{ Matrix Spike } \\
\hline $\begin{array}{l}\text { S1CHT-206/19 } \\
\text { S1CHT-206/19 NS } \\
\text { Concentration Recovered } \\
\text { Amount Spiked } \\
\text { Percent Recovery }\end{array}$ & $\begin{array}{r}31.48 \\
165.74 \\
134.26 \\
203.80 \\
66 \%\end{array}$ & $\begin{array}{l}4.08 \\
N A \\
N A \\
N S \\
N A \\
N A\end{array}$ & $\begin{array}{l}2.99 \mathrm{~J} \\
\text { NA } \\
\text { NA } \\
\text { NS } \\
\text { NA }\end{array}$ & $\begin{array}{r}3.86 \mathrm{~J} \\
155.55 \\
151.69 \\
203.80 \\
74 \%\end{array}$ & $\begin{array}{r}45.89 \\
194.08 \\
148.19 \\
203.80 \\
73 \%\end{array}$ & $\begin{array}{r}17.83 \\
164.57 \\
146.74 \\
203.80 \\
72 \%\end{array}$ & $\begin{array}{r}17.27 \\
159.19 \\
141.92 \\
203.80 \\
70 \%\end{array}$ & $\begin{array}{r}9.70 \\
148.31 \\
138.61 \\
203.80 \\
68 \%\end{array}$ \\
\hline $\begin{array}{l}\text { S1CHT-206/19 } \\
\text { S1CHT-206/19 MSD } \\
\text { Concentration Recovered } \\
\text { Amount Spiked } \\
\text { Percent Recovery }\end{array}$ & $\begin{array}{r}31.48 \\
305.67 \\
274.19 \\
364.96 \\
75 \%\end{array}$ & $\begin{array}{r}4.08 \\
\text { NA } \\
\text { NA } \\
\text { NS } \\
\text { NA }\end{array}$ & $\begin{array}{l}2.99 \mathrm{~J} \\
\text { NA } \\
\text { NA } \\
\text { NS } \\
\text { NA }\end{array}$ & $\begin{array}{r}3.86 \mathrm{~J} \\
287.08 \\
283.22 \\
364.96 \\
78 \%\end{array}$ & $\begin{array}{r}45.89 \\
317.48 \\
271.59 \\
364.96 \\
74 \%\end{array}$ & $\begin{array}{r}17.83 \\
290.90 \\
273.07 \\
364.96 \\
75 \%\end{array}$ & $\begin{array}{r}17.27 \\
285.98 \\
268.71 \\
364.96 \\
74 \%\end{array}$ & $\begin{array}{r}9.70 \\
275.86 \\
266.17 \\
364.96 \\
73 \%\end{array}$ \\
\hline $\begin{array}{l}\text { RPD } \\
\text { I- St at }\end{array}$ & $\begin{array}{l}13 \% \\
0.07\end{array}$ & $\begin{array}{l}\text { NA } \\
\text { NA }\end{array}$ & $\begin{array}{l}\text { NA } \\
\text { NA }\end{array}$ & $0.02^{4 \%}$ & 0.01 & 0.02 & 0.03 & $\begin{array}{r}7 \% \\
0.03\end{array}$ \\
\hline \multicolumn{9}{|l|}{ Analytical Duplicate } \\
\hline $\begin{array}{l}\text { \$1CHT-206/20 } \\
\text { S1CHT-206/20 Duplicate } \\
\text { RPD } \\
\text { I-Stat }\end{array}$ & $\begin{array}{l}28.07 \\
22.64 \\
21 \% \\
0.11\end{array}$ & $\begin{array}{l}3.94 \\
3.47 \\
13 \% \\
0.06\end{array}$ & $\begin{array}{l}2.73 \mathrm{~J} \\
2.54 \\
7 \% \\
0.04\end{array}$ & $\begin{array}{l}4.49 \mathrm{~J} \\
4.72 \\
5 \% \\
0.02\end{array}$ & $\begin{array}{c}41.35 \\
43.72 \\
6 \% \\
0.03\end{array}$ & $\begin{array}{c}15.31 \\
16.58 \\
8 \% \\
0.04\end{array}$ & $\begin{array}{c}12.39 \\
12.81 \\
3 \% \\
0.02\end{array}$ & $\begin{array}{l}9.68 \\
9.88 \\
2 \% \\
0.01\end{array}$ \\
\hline
\end{tabular}

\footnotetext{
(a) J Analyte detected below detection limit (MDL), but above instrument detection limit (IDL).

(b) $U$ Analyte was not present above the level of the associated value.

(c) NA Not applicable.

(d) NS Not spiked.
} 
TABLE 5.12. Quality Control Summary for High Molecular Weight Polynuclear Aromatic Hydrocarbons (HPAHs) in Tissues of C. aggregata, Wet Weight, United Heckathorn Remedial Investigation

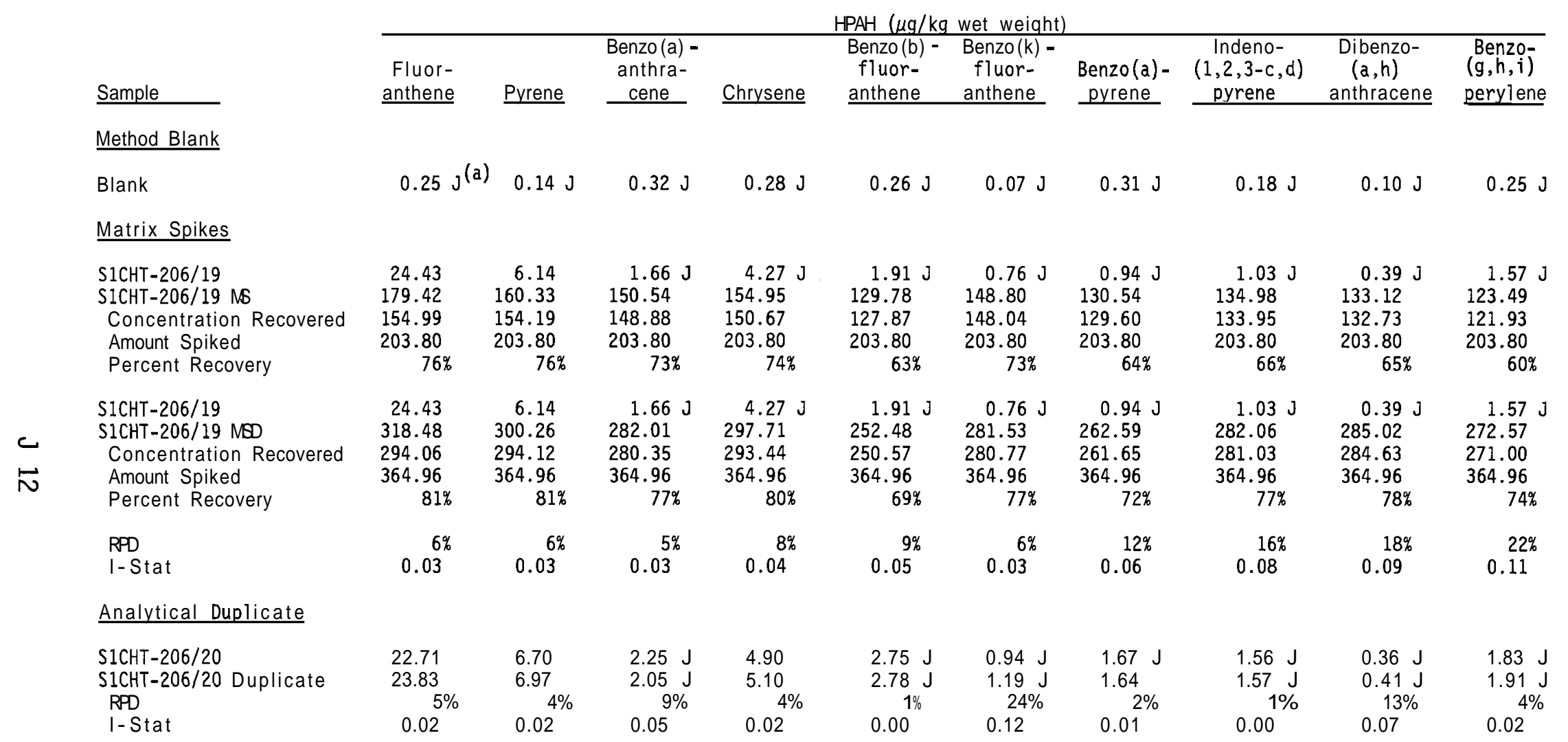

(a) J Analyte detected below detection limit (MDL), but above instrument detection limit (IDL). 
TABLE 5.13. Surrogate Recoveries for Analysis of Polynuclear Aromatic Hydrocarbons (PAHs) in Tissues of C. aggregata, United Heckathorn Remedial Investigation

Sample

S1CHT-206/11

S1CHT $-206 / 12$

S1CHT $-206 / 13$

S1CHT-206/14

S1CHT-206/15

S1CHT-206/16

S1CHT-206/17

S1CHT $-206 / 18$

S1CHT-206/19

S1CHT-206/20

Quality Control Data

Method Blank

Blank

Matrix Spikes

S1CHT-206/19

S1CHT-206/19 NS

SICHT-206/19 MSD
Surrogate Percent Recoveries

Naphthalene-d8 Acenaphthene-d10 Benzo「a]pvrene-d12

73.36

72.99

70.67

71.19

73.80

70.77

68.21

67.30

69.66

72.66

72.68

57.83

60.26

54.76

64.98

51.86

47.88

49.41

53.38

60.58

60.64
84.40

72.45

68.68

74.22
72.66

71.24

74.78
60.58

62.38

68.14 
TABLE 5.14. Phthalate Esters in Tissues of C. aggregata, Wet Weight, United Heckathorn Remedial Investigation

\begin{tabular}{|c|c|c|c|c|c|c|}
\hline \multirow[b]{2}{*}{ Sample } & \multicolumn{6}{|c|}{ Phthalate Esters $(\mu \mathrm{g} / \mathrm{kg}$ wet weight $)$} \\
\hline & $\begin{array}{l}\text { Dimethyl- } \\
\text { phthalate }\end{array}$ & $\begin{array}{r}\text { Diethyl- } \\
\text { phthalate }\end{array}$ & $\begin{array}{l}\text { Di-n-butyl- } \\
\text { phthalate }\end{array}$ & $\begin{array}{l}\text { Di-n-octyl- } \\
\text { phthalate }\end{array}$ & $\begin{array}{c}\text { Butyl } \\
\text { benzyl- } \\
\text { phthalate }\end{array}$ & $\begin{array}{c}\text { Bis } \\
\text { (2-ethylhexy1)- } \\
\text { phthalate } \\
\end{array}$ \\
\hline $\begin{array}{l}\text { Target DL (a) } \\
\text { Achieved DL High } \\
\text { Achieved DL Low }\end{array}$ & $\begin{array}{r}75 \\
189.87 \\
65.22\end{array}$ & $\begin{array}{r}75 \\
189.87 \\
65.22\end{array}$ & $\begin{array}{r}75 \\
189.87 \\
65.22\end{array}$ & $\begin{array}{r}75 \\
189.87 \\
65.22\end{array}$ & $\begin{array}{r}75 \\
189.87 \\
65.22\end{array}$ & $\begin{array}{r}75 \\
189.87 \\
65.22\end{array}$ \\
\hline $\begin{array}{l}\text { S1CHT-206/11 } \\
\text { S1CHT-206/12 } \\
\text { S1CHT-206/13 } \\
\text { S1CHT-206/14 } \\
\text { S1CHT-206/15 } \\
\text { S1CHT-206/16 } \\
\text { S1CHT-206/17 } \\
\text { S1CHT-206/18 } \\
\text { S1CHT-206/19 } \\
\text { S1CHT-206/20 }\end{array}$ & $\begin{array}{l}1.52 \mathrm{~J}^{(b)} \\
1.53 \mathrm{~J} \\
1.94 \mathrm{~J} \\
2.02 \mathrm{~J} \\
1.61 \mathrm{~J} \\
1.52 \mathrm{~J} \\
0.63 \mathrm{~J} \\
2.52 \mathrm{~J} \\
1.08 \mathrm{~J} \\
1.35 \mathrm{~J}\end{array}$ & $\begin{array}{r}17.19 \mathrm{~J} \\
22.67 \mathrm{~J} \\
59.22 \mathrm{~J} \\
68.77 \mathrm{~J} \\
15.22 \mathrm{~J} \\
18.97 \mathrm{~J} \\
9.53 \mathrm{~J} \\
25.20 \mathrm{~J} \\
24.32 \mathrm{~J} \\
30.66 \mathrm{~J}\end{array}$ & $\begin{array}{r}24.88 \mathrm{~J} \\
17.73 \mathrm{~J} \\
11.93 \mathrm{~J} \\
30.88 \mathrm{~J} \\
15.89 \mathrm{~J} \\
125.68 \\
12.07 \mathrm{~J} \\
76.20 \mathrm{~J} \\
34.19 \mathrm{~J} \\
24.36 \mathrm{~J}\end{array}$ & $\begin{array}{r}28.55 \mathrm{~J} \\
0.69 \mathrm{~J} \\
0.82 \mathrm{~J} \\
1.29 \mathrm{~J} \\
1.77 \mathrm{~J} \\
1.59 \mathrm{~J} \\
1.87 \mathrm{~J} \\
15.17 \mathrm{~J} \\
6.44 \mathrm{~J} \\
1.17 \mathrm{~J}\end{array}$ & $\begin{array}{r}334.90 \\
4.26 \mathrm{~J} \\
3.37 \mathrm{~J} \\
5.09 \mathrm{~J} \\
25.73 \mathrm{~J} \\
29.55 \mathrm{~J} \\
23.01 \mathrm{~J} \\
262.95 \\
291.13 \\
6.84 \mathrm{~J}\end{array}$ & $\begin{array}{r}478.42 \\
7.53 \mathrm{~J} \\
9.92 \mathrm{~J} \\
31.04 \mathrm{~J} \\
14.32 \mathrm{~J} \\
19.38 \mathrm{~J} \\
11.01 \mathrm{~J} \\
1438.23 \\
25.57 \mathrm{~J} \\
16.22 \mathrm{~J}\end{array}$ \\
\hline
\end{tabular}

(a) DL Detection Iimit.

(b) J Analyte detected below method detection limit (MDL), but above instrument detection Iimit (IDL).

TABLE 5.15. Quality Control Summary for Phthalate Esters in Tissues of C. aggregata, Wet Weight, United Heckathorn Remedial Investigation

\begin{tabular}{|c|c|c|c|c|c|}
\hline $\begin{array}{l}\text { Dimethyl- } \\
\text { phthalate }\end{array}$ & $\begin{array}{l}\text { Diethyl- } \\
\text { phthalate }\end{array}$ & $\begin{array}{c}\text { Di-n-butyl- } \\
\text { phthalate }\end{array}$ & $\begin{array}{c}\text { Di-n-octyl- } \\
\text { phthalate }\end{array}$ & $\begin{array}{c}\text { Butyl } \\
\text { benzyl- } \\
\text { phthalate }\end{array}$ & $\begin{array}{c}\text { Bis } \\
\text { (2-ethylhexyl)- } \\
\text { phthal ate }\end{array}$ \\
\hline
\end{tabular}

Method Blank

Blank

$$
0.29 \mathrm{~J}(\mathrm{a}) \quad 3.80 \mathrm{~J}
$$

$19.98 \mathrm{~J}$

$0.26 \mathrm{~J}$

$4.27 \mathrm{~J}$

$6.96 \mathrm{~J}$

Blank Spike

Blank Spike
Amount Spiked
Percent Recovery

$\begin{array}{rrr}2660.79 & 2954.84 & 3291.89 \\ 3750.00 & 3846.00 & 3750.00 \\ 71 \% & 77 \% & 88 \%\end{array}$

956.99
3750.00

(308

Analytical Duplicate
S1CHT-206/20
S1CHT-206/20 Duplicate RPD
I-Stat

$\begin{array}{cc}1.35 \mathrm{~J} & 30.66 \mathrm{~J} \\ 1.23 \mathrm{~J} & 18.48 \mathrm{~J} \\ 9 \% & 50 \% \\ 0.04 & 0.25\end{array}$

$24.36 \mathrm{~J}$
$23.15 \mathrm{~J}$
$5 \%$
0.03

$1.17 \mathrm{~J}$
$1.07 \mathrm{~J}$
$9 \%$
0.04

$6.84 \mathrm{~J}$
$5.17 \mathrm{~J}$
$28 \%$
0.14

$16.22 \mathrm{~J}$

$9.07 \mathrm{~J}$ $57 \%$

0.28

(a) J Analyte detected below method detection limit (MDL), but above instrument detection limit (IDL). (b) Recovery outside of quality control range $(40 \%-120 \%)$. 


\section{QAVQC SUMMARY}

PROGRAM:

PARAMETER:

LABORATORY:

MATRIX:

SAMPLE NUMBER:

QA/QC REQUIREMENTS
United Heckathorn Remedial Investigation

Total Lipids

Battelle Ocean Sciences Laboratory

C. aggregata tissue

\begin{tabular}{l} 
Reference \\
Method \\
\hline
\end{tabular}

$$
\begin{aligned}
& \text { Range of } \\
& \text { Recovery }
\end{aligned}
$$

NA

$$
\begin{aligned}
& \text { Relative } \\
& \text { Precision }
\end{aligned}
$$

$\pm 30 \%$
Detection

Limit

$0.1 \%$ wet weight

\section{HOLDING TIMES}

The holding time for lipid analysis has not been specified.

\section{MATRIX SPIKES}

Matrix spikes are not applicable to lipid analyses.

\section{SURROGATES}

Surrogates are not applicable to lipid analyses.

\section{DUPLICATES}

The precision of duplicate measurements was within QC criteria.

\section{DETECTION LIMITS}

Target detection limits were met for lipid analyses. 


\section{QAVQC SUMMARY}

PROGRAM: United Heckathorn Remedial Investigation

PARAMETER: Chlorinated Pesticides

LABORATORY: $\quad$ Battelle Ocean Sciences Laboratory

MATRIX:

C. aggregatatissue

SAMPLE NUMBER: 10

QA/QC REQUIREMENTS

\begin{tabular}{|c|c|c|c|}
\hline $\begin{array}{l}\text { Reference } \\
\text { Method }\end{array}$ & $\begin{array}{l}\text { Range of } \\
\text { Recoverv }\end{array}$ & $\begin{array}{l}\text { Relative } \\
\text { Precision }\end{array}$ & $\begin{array}{l}\text { Detection } \\
\text { Limit }\end{array}$ \\
\hline Modified 8080 & $40 \%-120 \%$ & $\pm 30 \%$ & $\begin{array}{c}2 \mu \mathrm{g} / \mathrm{kg} \text { wet weight } \\
\text { (30 } \mu \mathrm{g} / \mathrm{kg} \text { for toxaphene) }\end{array}$ \\
\hline
\end{tabular}

\section{HOLDING TIMES}

The following is a list of extraction and analysis dates for the tissue samples:

$\begin{array}{cccc}\begin{array}{c}\text { Date } \\ \text { Collected }\end{array} & \begin{array}{c}\text { Date } \\ \text { Received }\end{array} & \begin{array}{c}\text { Date } \\ \text { Extracted }\end{array} & \begin{array}{c}\text { GC/ECD } \\ \text { Analvsis }\end{array} \\ & 5 / 25 / 93 & 6 / 11 / 93 & \begin{array}{c}6 / 19-22 / 93 \\ 6 / 25-26 / 93,7 / 1 / 93\end{array}\end{array}$

Holding times for extractions were exceeded; however, samples were stored in frozen state from the time of collection to extraction. The holding time from extraction to analysis was met.

\section{METHOD BLANKS}

Pesticides were not detected in the method blank.

\section{MATRIX SPIKES}

The recoveries of target pesticides in the MS and MSD samples were acceptable for all compounds.

\section{SURROGATES}

Surrogate recoveries for all samples were acceptable. 


\section{DUPLICATES}

Duplicate precision between the MS and MSD samples was good for all compounds. Precision of laboratory duplicates was acceptable for all compounds except 4,4'-DDE, with a RPD of $51 \%$.

\section{DETECTION LIMITS}

Achieved detection limits were higher than the target detection limits because sample dilution was required. 


\section{QA/QC SUMMARY}

PROGRAM:

PARAMETER:

LABORATORY:

MATRIX:

SAMPLE NUMBER:
United Heckathorn Remedial Investigation

Polychlorinated Biphenyls (PCB)

Battelle Ocean Sciences Laboratory

C. aggregata tissue

10

QA/QC REQUIREMENTS

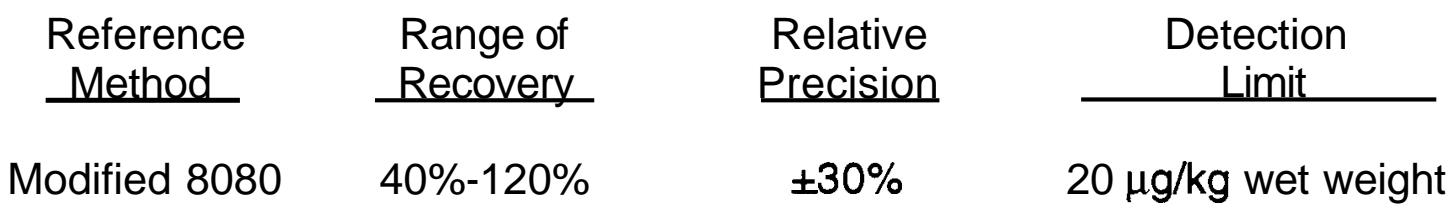

\section{HOLDING TIMES}

The following is a list of extraction and analysis dates for the tissue samples:

\begin{tabular}{|c|c|c|c|}
\hline Date & Date & Date & GC/ECD \\
\hline Collected & Received & Extracted & Analvsis \\
\hline $10 / 10 / 91$ & $5 / 25 / 93$ & $6 / 11 / 93$ & $\begin{array}{c}6 / 19-22 / 93 \\
6 / 25-26 / 93,7 / 1 / 93\end{array}$ \\
\hline
\end{tabular}

Holding times for extractions were exceeded; however, samples were stored in frozen state from the time of collection to extraction. The holding time from extraction to analysis was met.

\section{METHOD BLANKS}

No PCB compounds were detected in the method blank.

\section{MATRIX SPIKES}

The recoveries of Aroclor 1254 in the MS and MSD samples exceeded the quality control limits of $40 \%-120 \%$.

\section{SURROGATES}

The recoveries of all three surrogate compounds were acceptable in the samples. 
DUPLICATES

Duplicate precision between the MS and MSD samples was acceptable. Precision of analytical duplicate measurements was also acceptable.

\section{DETECTION LIMITS}

Achieved detection limits for PCBs in tissues were higher than target detection limits because sample dilution was required. 


\section{QA/QC SUMMARY}

PROGRAM:

United Heckathorn Remedial Investigation

PARAMETER:

Polynuclear Aromatic Hydrocarbons (PAH)

LABORATORY: $\quad$ Battelle Ocean Sciences Laboratory

MATRIX:

SAMPLE NUMBER:

C. aggregata tissue

QA/QC REQUIREMENTS

\begin{tabular}{|c|c|c|c|}
\hline $\begin{array}{l}\text { Reference } \\
\text { Method }\end{array}$ & $\begin{array}{l}\text { Range of } \\
\text { Recover? }\end{array}$ & $\begin{array}{l}\text { Relative } \\
\text { Precision }\end{array}$ & $\begin{array}{l}\text { Detection } \\
\text { Limit }\end{array}$ \\
\hline & & & \\
\hline
\end{tabular}

\section{HOLDING TIMES}

The following is a list of extraction and analysis dates for the tissue samples:

$\begin{array}{cccc}\begin{array}{c}\text { Date } \\ \text { Collected }\end{array} & \begin{array}{c}\text { Date } \\ \text { Received }\end{array} & \begin{array}{c}\text { Date } \\ \text { Extracted }\end{array} & \begin{array}{c}\text { GC/MS } \\ \text { Analvsis }\end{array} \\ 10 / 10 / 91 & 5 / 25 / 93 & 6 / 11 / 93 & \begin{array}{c}6 / 21-22 / 93 \\ 6 / 24-25 / 93\end{array}\end{array}$

Holding times for extractions were exceeded; however, samples were stored in frozen state from the time of collection to extraction. The holding time from extraction to analysis was met.

\section{METHOD BLANKS}

Naphthalene was detected in the method blank at a concentration greater than the method detection limit (MDL) but lower than the quality control criteria of five times the MDL. Fourteen PAHs were detected at concentrations below the MDL.

\section{MATRIX SPIKES}

The recoveries of target PAHs in the MS and MSD were acceptable.

\section{SURROGATES}

All tissue PAH surrogate recoveries were acceptable. 


\section{DUPLICATES}

The RPDs between MS and MSD samples and analytical duplicates were acceptable.

\section{DETECTION LIMITS}

Achieved detection limits were acceptable ( $<20 \mu \mathrm{g} / \mathrm{kg}$ wet weight). 


\section{QA/QC SUMMARY}

PROGRAM:

PARAMETER:

LABORATORY:

MATRIX:

SAMPLE NUMBER:
United Heckathorn Remedial Investigation

Phthalate Esters

Battelle Ocean Sciences Laboratory

C. aggregata tissue

\section{QA/QC REQUIREMENTS}

\begin{tabular}{|c|c|c|c|}
\hline $\begin{array}{l}\text { Reference } \\
\text { Method }\end{array}$ & $\begin{array}{l}\text { Range of } \\
\text { Recover? }\end{array}$ & $\begin{array}{l}\text { Relative } \\
\text { Precision }\end{array}$ & $\begin{array}{l}\text { Detection } \\
\text { Limit }\end{array}$ \\
\hline 1odified 8270 & $40 \%-120 \%$ & $\pm 30 \%$ & $5 \mu \mathrm{g} / \mathrm{kg}$ wet weight \\
\hline
\end{tabular}

\section{HOLDING TIMES}

The following is a list of extraction and analysis dates for the tissue samples:

\begin{tabular}{cccc}
$\begin{array}{c}\text { Date } \\
\text { Collected }\end{array}$ & $\begin{array}{c}\text { Date } \\
\text { Received }\end{array}$ & $\begin{array}{c}\text { Date } \\
\text { Extracted }\end{array}$ & $\begin{array}{c}\text { GC/MS } \\
\text { Analvsis }\end{array}$ \\
\cline { 5 - 5 } & & & \\
$10 / 10 / 91$ & $5 / 25 / 93$ & $6 / 11 / 93$ & $6 / 21-22 / 93$, \\
& & & $6 / 24-25 / 93$
\end{tabular}

Holding times for extractions were exceeded; however, samples were stored in frozen state from the time of collection to extraction. The holding time from extraction to analysis was met.

\section{METHOD BLANKS}

Phthalate esters were detected at concentrations below the MDL in the method blank.

\section{BLANK SPIKES}

One blank spike sample was analyzed. The recovery of di-n-octyl phthalate was less than the minimum QC requirement of $40 \%$. All other recoveries were acceptable.

\section{SURROGATES}

Surrogate recoveries (reported in Table J.13) were acceptable. 


\section{DUPLICATES}

The concentrations of phthalate esters in the duplicate samples were less than the method detection limit; therefore, QC criteria do not apply.

\section{DETECTION LIMITS}

Achieved detection limits for some analyses exceeded the target detection limit of $75 \mu \mathrm{g} / \mathrm{kg}$ wet weight because of sample dilution. 



\section{DISTRIBUTION}

No. of

Copies

12 DOE/Office of Scientific and Technical Information

8 A. Lincoff U.S. Environmental Protection Agency Mail Code 86-3

75 Hawthorne Street

San Francisco, CA 94105

R. Chisholm

U.S. Army Corps of Engineers

San Francisco District

211 Main Street

San Francisco, CA 94105

P. Finley

Pillsbury, Madison \& Sutro

225 Bush Street

San Francisco, CA 94104

S. Gladstone

Regional Water Quality Control Board 2101 Webster Street, Suite 500

Oakland, CA 94612

S. Goldbeck

Bay Conservation and Development Commission

30 Van Ness Avenue, Suite 2011

San Francisco, CA 94102-6080

J. Haas

U.S. Fish and Wildlife Service

2800 Cottaga Way

Sacramento, CA 95825

M. Herz

Baykeeper

Fort Mason, Building A

San Francisco, CA 94123

K. Howard

Cooper, White \& Cooper

1333 N. California Blvd., \#450

Walnut Creek, CA 94596
No. of

Copies

D. Klimas

National Oceanic and Atmospheric

Administration

75 Hawthorne Street $(\mathrm{H}-1-2)$

San Francisco, CA 94105

L. Lee

Save the Bay

1736 Franklin Street, 3rd Floor

Oakland, CA 94612

S. Luoma

U.S. Geological Survey

Mail Stop 465

345 Middlefield Road

Menlo Park, CA 94025

M. Martin

California Department of Fish and

Game

20 Lower Ragsdale Drive

Monterey, CA 93940

P. Maynard

Sierra Club

6014 College Avenue

Oakland, CA 94618

M. Montgomery

Battelle/PNL

2701 Prospect Park Dr., Suite 110

Rancho Cordova, CA 95670

J. Ratcliff

Thatcher, Albrecht \& Ratcliff

300 Montgomery Street, Suite 700

San Francisco, CA 94104

M. Robson

Littler, Mendelson, Fastiff \& Tichy

2175 North California Blvd., Suite 835

Walnut Creek, CA 94596-3548

Distr.1 
No. of

Copies

E. Serex

Port of Richmond

P.O. Box 4046

Richmond, CA 94804

J. Soto

Department of Toxic Substances Control

700 Heinz Avenue, Building $F$

Berkeley, CA 94710
A. Ujihara
Department of Health Services
5900 Hollis Street, Suite E
Emeryville, CA 94608

No. of

Copies

ONSITE

DOE Richland Operations Office

P. W. Kruger

A5-90

Pacific Northwest Laboratory

12 P. J. White

N. P. Kohn

W. W. Gardiner

J. Q. Word

L. M. Gully

Publishing Coordination

Technical Report Files (5)

SEQUI

SEQUI

SEQUI

SEQUI

SEQUI

K1-06

Routing

R. M. Ecker
M. J. Graham
P. M. Irving
C. S. Sloane
P. C. Hays (last)

SEQUI

$\mathrm{K} 6-78$

$\mathrm{K} 6-98$

K6-04

K6-86 